Universidade de São Paulo

Faculdade de Filosofia, Letras e Ciências Humanas

Departamento de História

\title{
CINTURÃO PAULISTANO \\ economia e demografia nas vizinhanças \\ da capital de São Paulo (c. 1798 - c. 1830)
}

Déborah Oliveira Martins dos Reis

Orientador: Prof. Dr. José Flávio Motta

Tese apresentada ao Programa de Pósgraduação em História Econômica da Faculdade de Filosofia, Letras e Ciências Humanas da Universidade de São Paulo, para obtenção do título de doutor.

Exemplar revisado

São Paulo

2010 
Para o Fred com quem aprendi muito mais do que dividir e a viver sem ter a vergonha de feliz

Para o pequeno Théo que por um instante iluminou minha vida 


\section{AGRADECIMENTOS}

Estranha a sensação que sinto ao escrever estes agradecimentos como encerramento do trabalho que ora vai apresentado: alívio e saudade. O presente trabalho representa mais do que requisito para a obtenção de um título, mas um conjunto de escolhas, certas e erradas, e de vivencias que, em alguma medida, deixarão de existir ou ao menos mudarão sua feição.

Agora, do outro lado, sei quão árdua, mas gratificante é a transmissão do conhecimento. Desde as primeiras aulas de formação econômica do Brasil ainda no início da graduação, nos idos da década de 1990, o Prof. José Flávio foi presença constante. Não me resta, portanto, nada além de agradecê-lo, imensamente, pelo muito que me ofereceu ao longo desses anos. Muito obrigada! Fica aqui meu reconhecimento. Sem sua paciência e confiança este trabalho não estaria sendo finalizado. E se errei foi tentando acertar, e se até decepcionei foi por minha inteira deficiência.

Ao Prof.Dr.Iraci Costa pela troca de emails que acabaram por nortear meu projeto de pesquisa, e aos membros da banca de qualificação, Profs. Drs. Nelson Nozoe e Horacio Gutierrez, pelas críticas e sugestões ao projeto naquele momento apresentado, minha gratidão.

Ao CNpq agradeço pelo período em que fui agraciada com bolsa de pesquisa.

E como em nenhum sentido andaria este trabalho sem a documentação consultada, agradeço aos funcionários do Arquivo Público do Estado de São Paulo, não só por sua indispensável função na disponibilização da fontes manuscritas, mas pela simpatia e companhia nas inúmeras manhãs, tardes e finais de semana que ali estive em meio aos "papéis velhos".

Nesse processo pela busca de dados, especial menção a minha mãe Angélica, que num gesto de que só as mães são capazes, aprendeu a lidar com o passado e foi meu socorro na incursão pelas fontes, sem o qual muito teria se tonado inviável.

Entre o muito que passou por baixo da ponte nos últimos anos, decerto o mais difícil foi perder a companhia do irmão Frederico, que se faz presente neste trabalho, afinal como aqui estariam os inúmeros gráficos e tabelas que o compõem, se não fosse a sua total paciência em me convencer que o tal do computador não era o monstro que eu imaginava? Se o Fred não pôde me acompanhar até este momento, agradeço ao cunhado Hugo, que em meio aos seus softwares foi de importante ajuda na confecção dos mapas aqui colocados. 
Aos amigos de sempre, Raphael, Kátia, Rejane, Liliane, Karina, tia Sheila e Jacque, pelos muitos momentos, pelo muito que torceram por mim e pelos sorrisos futuros. $E$ aos novos amigos, Tharsila e Carlos, por partilharem dos mesmos sentimentos.

Aos meus pais pelo amor incondicional.

E ao Bráulio, com amor, pela paciência e por saber esperar. Agora já podemos terminar nossa volta ao mundo. 


\title{
RESUMO
}

Desde que se iniciaram no Brasil há cerca de quatro décadas, os estudos dedicados à demografia histórica, mormente caracterizados por trabalhos monográficos, têm avançado de maneira significativa em seus aspectos quantitativos e qualitativos, especialmente no que tange à interdisciplinaridade. Paralelamente à continuidade desses estudos, o trabalho desenvolvido nessa tese analisa o processo de ocupação agrícola e o evolver demográfico-econômico das localidades paulistas de Jundiaí, Atibaia, Bragança Paulista, Nazaré, Jacareí e Mogi das Cruzes, que compunham o que denominamos de "cinturão paulistano", contempladas para o período c.1798 a c.1830. O caminho seguido em nosso trabalho envolveu a busca de padrões e regularidades para referidas localidades, área que ao longo de todo o período estudado esteve vinculada à produção de gêneros de subsistência, em maior ou menor intensidade - distanciando-as em alguns de seus caracteres, mas as aproximando em outros, levando aos padrões encontrados para as características demográficas de sua população, para a produção levada a cabo e para as estruturas fundiárias ali existentes.

\begin{abstract}
Since it began in Brazil almost four decades ago, studies devoted to historical demographics, especially characterized by monographs, have advanced significantly in their quantitative and qualitative aspects, especially with respect to the interdisciplinarity. Parallel to the continuity of such work, we analyze the process of agricultural occupation and the demographic-economic development in São Paulo sites of Jundiaí, Atibaia, Bragança Paulista, Nazaré, Jacareí and Mogi das Cruzes, who comprised what we call "paulistano belt", referred to the period c.1798 to c.1830. We search for patterns and regularities to those localities, area that throughout the period studied was linked to the production of genres of subsistence, to a greater or lesser intensity - distancing them in some of their characters, but approaching them in other ones, leading to the patterns found for the demographic characteristics of its population, to the production carried out and to the land use structure existing there.
\end{abstract}




\section{SUMÁRIO}

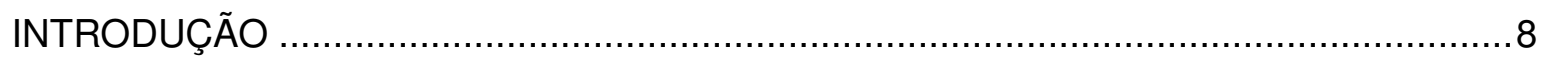

Capítulo I - POPULAÇÃO: EVOLVER, CARACTERES DEMOGRÁFICOS, POSSE DE

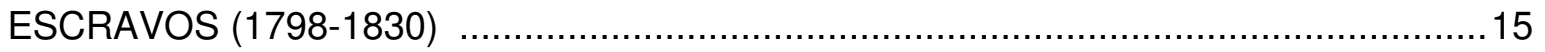

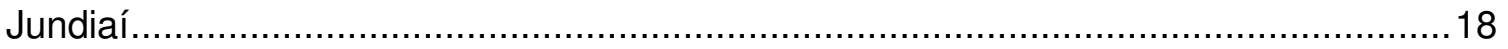

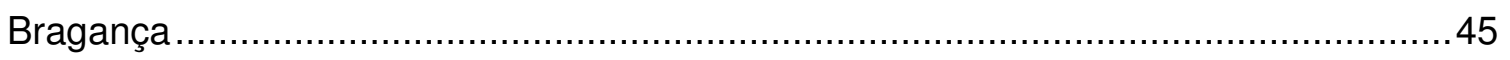

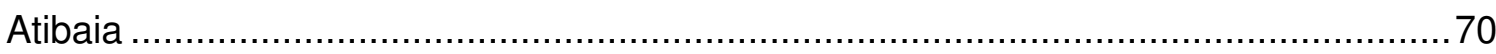

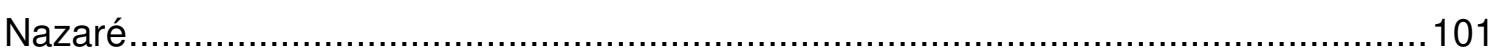

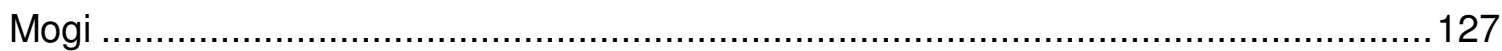

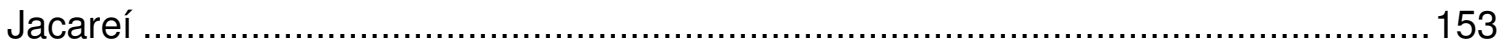

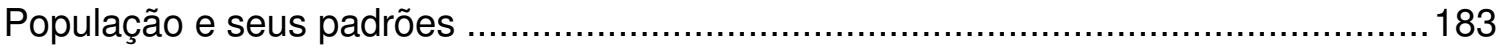

Capítulo II - ECONOMIA: ATIVIDADES ECONÔMICAS, PRODUÇÃO E COMÉRCIO

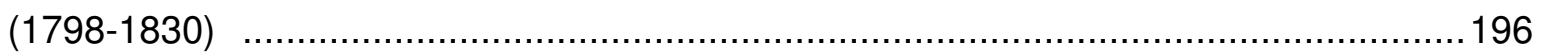

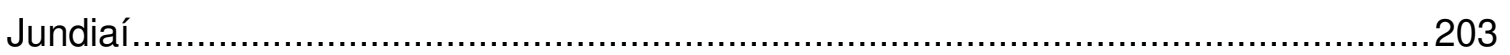

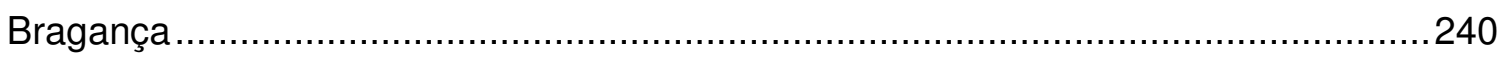

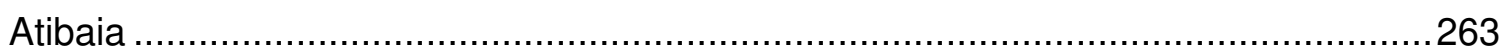

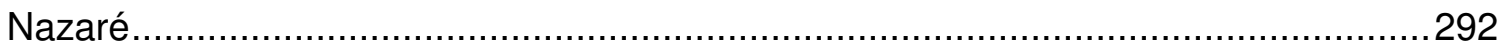

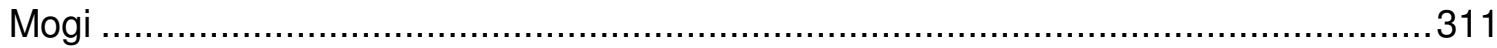

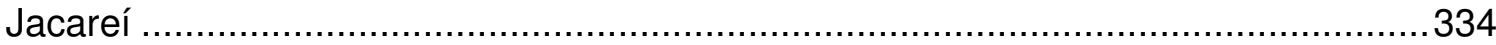

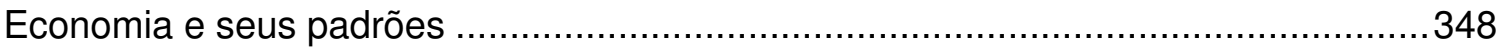

Capítulo III - ESTRUTURA FUNDIÁRIA: FORMAÇÃO E CARACTERÍSTICAS EM

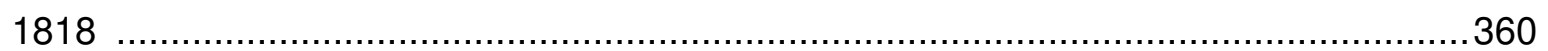

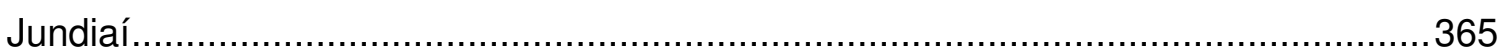

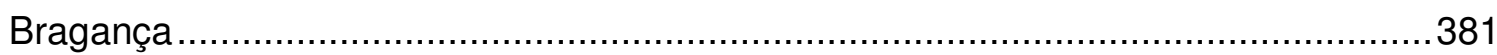

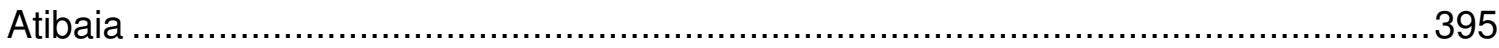

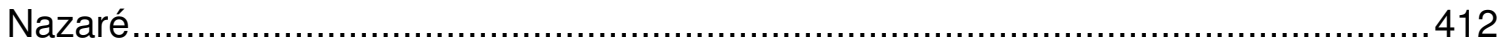

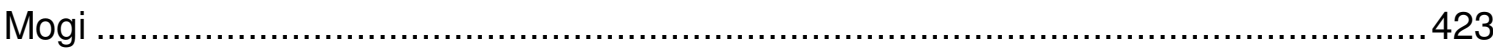

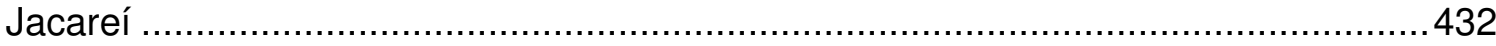

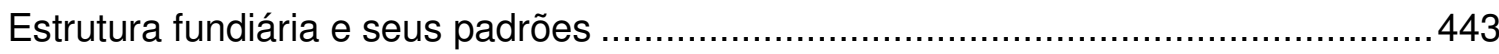


Apêndice 1 - EVOLUÇÃO ADMINISTRATIVA E TERRITORIAL: BREVE HISTÓRICO 462 Jundiaí. 468

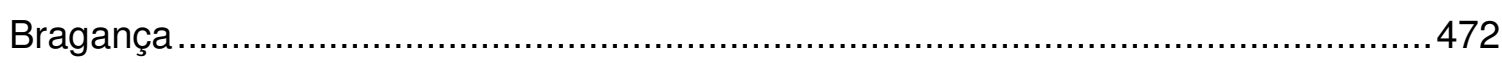

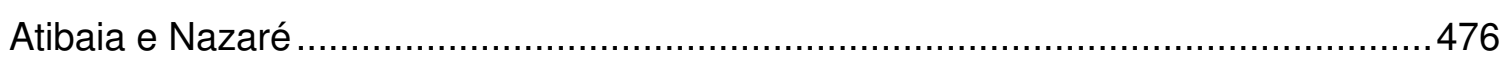

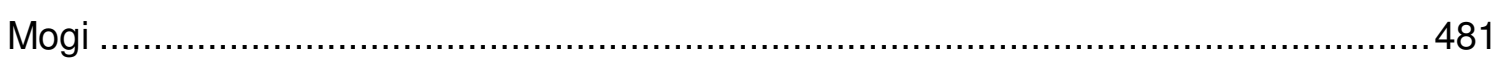

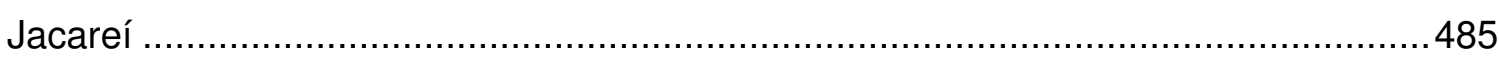

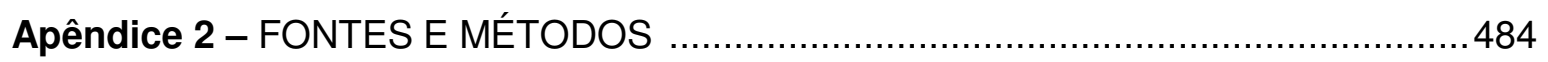

Tombamento de bens rústicos......................................................................... 484

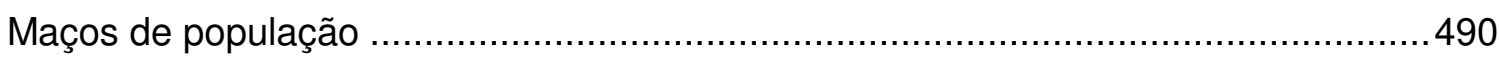

Mapas de produção e comércio...................................................................... 500

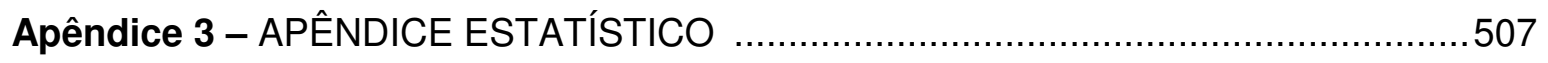

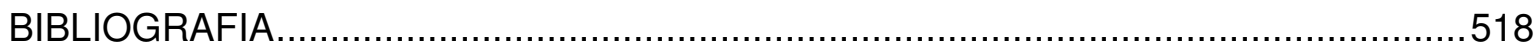

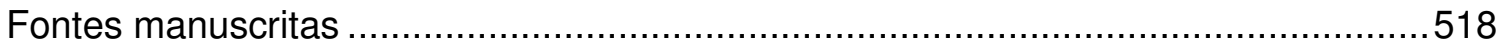

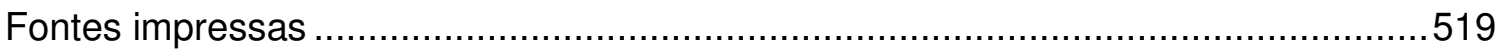




\section{INTRODUÇÃO}

Pouco mais de quatro décadas atrás Maria Luíza Marcílio escrevia a introdução à edição francesa de seu La Ville de São Paulo: Peuplement et Population, 1750-1850, publicado em português, alguns anos mais tarde, numa co-edição da Pioneira com a Editora da Universidade de São Paulo (MARCÍLIO, 1973). Essa tese de doutoramento, orientada em Paris pelos professores Michel Fleury e Louis Henry, foi um dos marcos inicias da produção acadêmica brasileira dedicada aos estudos de demografia histórica.

Como se sabe, esses cerca de 40 anos têm sido extremamente profícuos no que respeita a esses estudos. Mormente se perfilharmos a definição de demografia histórica proposta por Iraci del Nero da Costa, ${ }^{1}$ os trabalhos desenvolvidos nessa área contam-se às centenas. E, para além dessa expressividade quantitativa, não há como negar o impacto qualitativo dos estudos realizados pelos demógrafos-historiadores. Em um dos diversos textos elaborados com vistas à feitura de um balanço daquela produção, ${ }^{2}$ o autor assevera "inequivocamente o muito que a Demografia Histórica tem contribuído, mediante uma contundente e, sobretudo, proveitosa intromissão em um alentado universo temático, para o conhecimento da economia e da sociedade no passado brasileiro" (MOTTA, 1995, p. 146).

Uma das características presente em grande parte desses estudos é seu caráter monográfico. Em boa medida ligada à utilização - mediante o cruzamento das informações disponíveis - de amplo leque de fontes documentais primárias, essa característica traduz-se em análises, amiúde, de localidades isoladas, possuindo menor freqüência aquelas dedicadas a conjuntos de localidades. No que diz respeito aos limites temporais, estas últimas análises, regra geral, restringem-se a períodos mais curtos,

\footnotetext{
1 "A demografia histórica, que tem como objeto precípuo de estudo as populações humanas do período précensitário (o qual engloba os períodos pré e proto-estatísticos), é o campo da Ciência Social que, estabelecendo, in totum ou parcialmente, o estado e os movimentos daquelas populações, procura identificar as causas e conseqüências dos mesmos, bem como explicitar as inter-relações destes com outros elementos da vida em sociedade. Para tanto, lança mão, também, das técnicas e dos conhecimentos das demais ciências e desenvolve técnicas e modelos próprios utilizando, além dos dados tradicionalmente considerados pela Demografia, todas e quaisquer fontes que possam servir ao seu escopo. Presentes estas fontes e aquelas técnicas e modelos, a Demografia Histórica estende-se ao período censitário. Cumpre observar, ademais, que os resultados propiciados pela Demografia Histórica não se limitam ao campo estrito dos fenômenos tidos como puramente demográficos, pois também dizem respeito aos demais campos da Ciência Social" (COSTA, 1994, p. 1). Para uma definição alternativa ver, por exemplo, Nadalin (2004).

${ }^{2}$ Escritos a partir de meados dos anos de 1990, ao mesmo tempo em que realizavam tal balanço, em ditos textos se reflete sobre a demografia histórica brasileira e se lançam propostas em termos dos caminhos a serem por ela trilhados. Ver, por exemplo, Costa (1994), Motta (1995 e 1999), Motta \& Costa (1997), Bacellar, Scott \& Bassanezi (2005).
} 
sendo maiores as possibilidades de trabalhos sobre povoações específicas atingirem ou ultrapassarem o intervalo de um século.

Não é à toa, portanto, que Motta \& Costa, em seu "Demografia histórica: da semeadura à colheita", finalizem o texto com a seguinte indicação:

\begin{abstract}
Assim sendo, acreditamos que, pari passu à continuidade das linhas de pesquisa em que temos trabalhado com tanto êxito, continuidade na qual a ênfase deve radicar nas tentativas de utilização conjunta de múltiplas fontes documentais; pari passu ao esforço no sentido do alargamento sempre crescente, em termos espaciais e temporais, da vasta temática por nós privilegiada, deverão os pesquisadores, sobretudo, [...] preocupar-se com a integração dos resultados alcançados no decurso dos últimos lustros em modelos mais gerais, interpretativos de nosso evolver histórico. Aí está, assim entendemos, o mais rico filão que se abre ao futuro da demografia histórica brasileira. (Motta \& Costa, 1997, p.156)
\end{abstract}

A pesquisa que segue a estas notas introdutórias insere-se nesse esforço visando à integração acima mencionada. Não temos a pretensão de formular um modelo interpretativo de natureza totalizante, a exemplo dos elaborados por Caio Prado Júnior, Jacob Gorender, entre outros. Afinal, não tem sido por acaso o emprego, em muitos dos estudos de nossa demografia histórica, das abordagens da micro-história ou da história regional. Nosso foco estará centrado numa etapa que entendemos como intermediária, na qual a análise das localidades ver-se-á marcada pela procura de padrões e suas regularidades e tendências. ${ }^{3}$

O esforço direcionado ao estudo das regularidades e padrões pode desdobrar-se em inúmeras vertentes de análise. Em nossa pesquisa, optamos por desenvolver um estudo centrado em localidades ligadas, em especial, à atividade de subsistência, no período iniciado nos anos finais do Setecentos (1798/99) até as três primeiras décadas do século XIX (1829/1830). Tais localidades, todas situadas na capitania, depois província, de São Paulo, compunham o que denominamos de "cinturão paulistano". São elas: Jundiaí, Bragança Paulista (antes Jaguari), Atibaia, Nazaré, Jacareí e Mogi das Cruzes. (cf. Figura 1).

\footnotetext{
${ }^{3}$ Vale dizer, sem abandonar aquelas abordagens, mas ao contrário, aproveitando-nos de sua riqueza, a identificação desses padrões e dos fatores que os causam apresenta-se como um primeiro passo no sentido da formulação daqueles modelos interpretativos mais gerais de nosso evolver histórico.
} 
Figura 1

Localidades estudadas

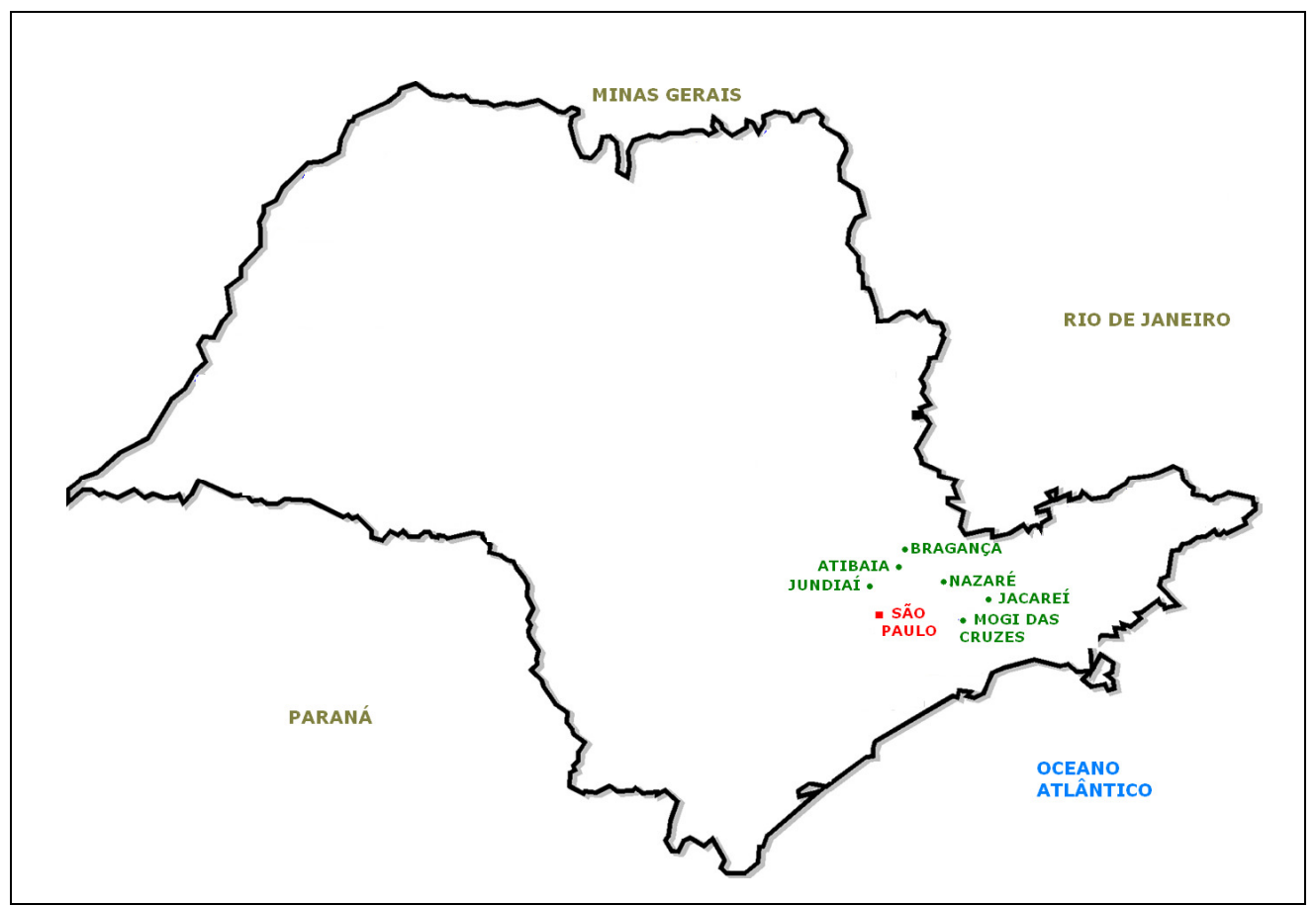

Nosso foco recai no processo de ocupação agrícola e no evolver demo-econômico de tais localidades. Investigamos o evolver e os caracteres econômicos e populacionais das localidades consideradas, norteados por temas inter-relacionados, e ao mesmo tempo passíveis de análises específicas, quais sejam: caracteres demográficos e crescimento da população livre e cativa; produção e mercado (possibilidade/necessidade/interesse na produção e comercialização de diferentes bens); estrutura fundiária.

Nesse contexto, o padrão aqui entendido define-se como uma característica ou um conjunto delas, associadas ou não, que de tão amplamente ou repetidamente encontrada(s) na observação individual e sucessiva de cada localidade serve como referência ou modelo para a definição de caracteres gerais do conjunto da área estudada.

Ao passo que entendemos por atividade ou produção de subsistência aquela cujo resultado final característico tem como finalidade o suprimento de necessidades básicas de sobrevivência da população internamente à colônia; em seu âmbito há convivência de atividades para suprir as necessidades diretas das próprias unidades domiciliares/produtivas, o autoconsumo, e de atividades de mais amplo espectro, voltadas, em diferentes medidas, ao suprimento de mercados regionais. ${ }^{4}$

\footnotetext{
${ }^{4}$ Assim, produtos como açúcar ou café, por exemplo, podem ser considerados produtos de subsistência, na medida em que também eram consumidos nas próprias unidades produtivas, que muitas vezes os produziam
} 
Inúmeras pesquisas têm-se ocupado do estudo da economia interna. Ainda que seja inegável a relevância das atividades de exportação para o passado colonial e imperial brasileiro, a historiografia mais recente tem sido capaz de revelar um mercado de víveres bem desenvolvido, com considerável grau de mercantilização e dinamização através do comércio local e/ou das articulações entre diferentes regiões. Tem sido destacada a importância da parcela da população envolvida em atividades de subsistência, em especial, o elevado contingente de pequenos e médios lavradores. Esses agricultores, além da mão-de-obra familiar, em muitos casos utilizavam regularmente o trabalho escravo (mormente em pequenos plantéis) e produziam visando ao comércio ou, mesmo na ausência desse objetivo precípuo, obtendo excedentes substanciais capazes de abastecer o mercado. ${ }^{5}$ Esses trabalhos, muitos dos quais inseridos no campo da demografia histórica, evidenciam, em suma, as grandes possibilidades postas pelo estudo de espaços e populações marcados pela produção de gêneros de primeira necessidade.

Nesse horizonte, a região periférica à cidade de São Paulo estudada, apresenta-se como lócus privilegiado para pesquisa. Diferentemente do núcleo central paulistano, importante centro comercial e administrativo, essas localidades eram parte do que podemos considerar um verdadeiro "cinturão de área verde". A proximidade com a cidade de São Paulo fez com que se tornassem indispensáveis centros abastecedores da capital, que necessitava da produção das localidades periféricas para seu abastecimento. Ademais, em alguns momentos, destacam-se as fortes ligações das localidades em foco com outras regiões vizinhas, como Rio de Janeiro, Minas Gerais, ou outras mais distantes como as áreas mais ao sul da colônia ou Goiás, como fica evidenciado ao longo do texto apresentado.

Desde o início as localidades em tela foram agrícolas, produzindo essencialmente produtos de subsistência. Havia plantações de feijão, algodão, cana, amendoim, milho, arroz etc. Desenvolvia-se certa criação de gado vacum e, especialmente, porcos, cujo toucinho foi importante na dinâmica econômica desta área.. Havia também produção artesanal de tecidos. Além de produzir para consumo próprio, essas localidades beneficiaram-se do comércio com outras regiões e da influência dessas, e algumas produziram produtos de interesse no mercado internacional, como café ou açúcar.

em pequena medida, sendo esta a característica inicial de implantação da produção desses gêneros mais comumente verificada. A esse respeito ver Nozoe \& Motta (1999), Godoy (2004).

${ }^{5}$ Ver, entre outros, Linhares e Silva (1981), Schwartz (2001), Barickman (2003), Fragoso e Florentino (2001). 
As localidades de Atibaia - desmembrada de São Paulo em 1765, sendo Nazaré seu distrito até 1850 - e Bragança, que se tornou vila em 1789, ${ }^{6}$ foram importantes abastecedoras das Minas Gerais (em especial no século XVIII) e do Rio de Janeiro, além da capital paulista relações estreitas com o porto de Santos.

Encontramos na periferia do Grande São Paulo uma área típica de economia de subsistência; suas colheitas de feijão, de milho vendiam-se diariamente no mercado paulistano, complementadas com o toucinho, a aguardente, o tecido de algodão feito no recinto doméstico, a farinha de mandioca. Estes produtos constituíam cerca de $95 \%$ do valor da exportação global das vilas de Atibaia e Bragança (com sua freguesia de Nazaré), no conjunto do termo, 24,55\%. (CANABRAVA, 1972b, p.85)

Em regra, utilizou-se o trabalho escravo em pequenas posses. A população dessas localidades não sofreu grandes mudanças desde o fim do século XVIII e primeiras décadas do século XIX, demonstrando baixo crescimento (cf. CANABRAVA, 1972 e LUNA, 2009b): "A participação dos escravos na população manteve-se estável e baixa, sendo de apenas 17,3\% em 1829; a porcentagem de fogos com escravos manteve-se também estável ao redor de $20 \%$, variando a média de escravo por fogo ao redor de 1,0.” (LUNA, 2009b, p.343)

As características mencionadas, no que respeita ao desenvolvimento populacional, importância dos cativos e atividades agrícolas desenvolvidas, estendem-se a Mogi das Cruzes, também limítrofe com a capital e desmembrada desta em 1611. Distingue-se Mogi das Cruzes, no entanto, pela proximidade com o Vale do Paraíba - sendo, mesmo, considerada parte dele por alguns autores. O Vale do Paraíba caracterizou-se, a partir dos primeiros anos do século XIX, pelo desenvolvimento, em várias de suas vilas, do café.

Embora em meados do século [XIX - DOMR] Mogi figurasse com destaque entre os municípios cafeicultores — com 100000@ é o terceiro em 1855 — a verdade é que se a cultura do café efetuou uma rápida marcha passando pelo Vale, mais rápido ainda deixaria a área mogiana do Vale do Tietê. Por isso, Mogi não atingiu o fastígio e a riqueza de outras cidades valeparaíbanas. (CAMPOS, 1978, p.45)

Por seu turno, Jacareí (vila em 1657), não obstante localizada efetivamente no Vale do Paraíba, não chegou a apresentar produção cafeeira em tão larga escala, ainda que lá a rubiácea tenha sido também importante.

A produção no Vale do Paraíba era diversificada, com a lavoura cafeeira crescendo com ímpeto - principalmente nas localidades mais próximas ao Rio de Janeiro

\footnotetext{
${ }^{6}$ Durante o período considerado ocorreram modificações de natureza administrativa, com a criação de novas vilas e segmentação territorial das existentes. Com o intuito de preservar a comparabilidade, no tempo, dos espaços contemplados pelas análises desenvolvidas, esse assunto é devidamente tratado no apêndice 1.
} 
-, conquistando terras à anterior lavoura de cana-de-açúcar, dominando quase toda a região já na década de 1830. Sendo que anteriormente, em 1818, nas exportações "o café participava nesse ano com 24,80\%, o açúcar e os produtos pecuários com o mesmo percentual (32,00\%) e os gêneros da lavoura de subsistência com 5,0\%)" (CANABRAVA, 1972, p.88).

A região constituía a zona paulista mais dinâmica em termos populacionais, com taxa média anual de crescimento de $2,4 \%$ nas primeiras décadas do Oitocentos. Foi significativa a expansão do número de livres e, principalmente, dos escravos $(3,5 \%$ ao ano a partir de 1804), devida à introdução do café em inícios do século XIX, refletindo-se em um aumento da participação dos escravos na população de 22,1\% em 1777 para $33,1 \%$ em 1829 sendo, sendo cerca $28 \%$ o percentual de fogos com escravos. (cf. LUNA, 2009b).

Em Jundiaí (vila desde 1655), por sua vez, encontramos, além das atividades típicas de subsistência, a lavoura de cana e ligações com a feira de animais de Sorocaba: "[...] a grande lavoura canavieira mantém a produção de açúcar $(21,91 \%$ do valor da exportação da área, um centro de reexportação do muar adquirido na feira de Sorocaba (49,00\%), e a mais importante organização do serviço de transportes da Capitania com as tropas de carga." (CANABRAVA, 1972, p.85). Ainda que a produção de açúcar fosse relevante, não era comparável em Jundiaí às das principais localidades produtoras da região oeste (Itu, Porto Feliz, Campinas), onde se situa a própria Jundiaí.

Comparados Vale do Paraíba e Oeste Paulista, notam-se influências diferentes provocadas pelo café e pelo açúcar. Nas duas áreas manteve-se elevado o percentual de fogos com escravos que, em combinação com um alto número médio de escravos por fogo, resultou expressivo peso dos escravos no total da população, acima de $33 \%$ nas duas regiões. Esse processo foi acompanhado por intenso crescimento no tamanho médio do plantel de escravos, particularmente no Oeste Paulista, fruto da atividade açucareira, com nível de concentração maior nessa atividade do que na cafeeira. Isso explica a elevada média de escravos por fogo, de 2,9, nessa região. (LUNA, 2009b, pp.342-343).

Essas, portanto, de forma sucinta, as características das localidades estudadas e ponto de partida para a análise dos referidos padrões, regularidades e tendências.

Para observar o cinturão paulistano dos anos finais do Setecentos até 1829/30, apoiamo-nos em uma gama de fontes documentais manuscritas. O principal e maior corpus documental consultado é constituído pelas listas nominativas de habitantes, 
arquivadas sob a rubrica "maços de população" no AESP (Arquivo Público do Estado de São Paulo). Acrescem a elas mapas comparativos de produção e comércio, o inventário de bens rústicos e, de maneira mais pontual, registros de sesmarias. As características atinentes a cada uma das fontes, bem como dos procedimentos adotados em seu tratamento são apresentadas no apêndice 2.

Ademais, o trabalho está estruturado em três capítulos e outros dois apêndices. O apêndice 1 Evolução administrativa e territorial, apresenta um breve histórico do delineamento da unidade territorial das localidades objeto de análise, a partir da chegada dos primeiros povoadores até a ereção de cada uma das localidades à condição de vila ou freguesia. O terceiro e último apêndice é estatístico e nele apresentamos alguns dados de maneira complementar.

Em seu cerne, o trabalho inicia-se com capítulo dedicado à análise do evolver populacional em seu conjunto e da observação das características demográficas (tais como condição, sexo, idade, estado conjugal, cor) da parcela livre da sociedade, além de trazer análise acerca das características que envolvem a posse dos escravos ligados a esta parcela livre da sociedade.

No segundo capítulo apresentamos um apanhado sobre aspectos econômicos atinentes às atividades produtivas levadas a cabo no entorno paulistano, à produção e ao comércio em que estavam envolvidas as distintas localidades.

O terceiro e último capítulo é dedicado ao acompanhamento da estrutura fundiária e dos processos de repartição, concentração e utilização das terras, cujas características são fundamentais para o entendimento dos limites da ocupação e do potencial de desenvolvimento da área em tela.

A forma como se estrutura cada um dos capítulos busca, através do recurso a recortes o mais possível semelhantes - marcados que foram, como ficará evidenciado ao longo do texto, por consideráveis diferenças quantitativas e qualitativas entre os vários documentos para as diferentes localidades -, observar os caracteres demográficos, econômicos e fundiários atinentes a cada uma das vilas observadas individualmente. $E$, na comparação dos resultados apurados para cada uma delas, chegar aos referidos padrões e tendências que, como adiantado, são caracteres que de tão amplamente ou repetidamente apresentados servem como referência e podem ser generalizados para todo o cinturão paulistano. 


\section{Capítulo I \\ POPULAÇÃO: EVOLVER, CARACTERES DEMOGRÁFICOS, POSSE DE ESCRAVOS \\ $1798-1830$}

A área que hoje conforma o estado de São Paulo surgiu, ou seja, começou a receber população, ainda no século XVI, sendo uma das primeiras áreas ocupadas pelos portugueses no Brasil. A este tempo, São Paulo ainda caracterizava-se como uma área de fronteira e por uma população dispersa em povoações costeiras e outras poucas vilas planalto acima.

Depois de colonizarem de maneira superficial a costa, com as povoações litorâneas de Santos e São Vicente, ainda no século XVI, os portugueses seguiram planalto adentro, instalando outros povoados. São Paulo de Piratininga foi a primeira área planaltina colonizada após a ocupação de Santo André, cujo povoamento se redirecionou para São Paulo. Formado o núcleo paulistano - em região usualmente habitada por distintas tribos indígenas - este se tornou ponto de partida para a sistemática exploração do território paulista (e para as demais áreas interioranas brasileiras) até meados do Setecentos.

Essa exploração do interior esteve diretamente ligada ao apresamento do indígena, "nenhum colono existe, por mais miserável, que não explore uma criatura do gentio" (MACHADO,1980), pois "este oferecia mão-de-obra fácil e barata para o estabelecimento de uma agricultura local de subsistência" (MARCíLIO, 1973, p.17). As bandeiras de apresamento, que percorreram distâncias consideráveis, foram o meio pelo qual se processou a expansão rumo ao sertão desconhecido, durante todo o século XVII e parte do XVIII.

Assim, o indígena esteve ligado à formação da população paulista desde seus primórdios, sendo suas diversas tribos incorporadas ao "mundo" dos colonizadores na medida em que eram conquistadas, conferindo à sociedade um aspecto miscigenado.

Aqui no Brasil tratou-se desde o início de aproveitar o índio, não apenas para obtenção dele, pelo tráfico mercantil, de produtos nativos, ou simplesmente como aliado, mas sim como elemento participante da colonização. Os colonos viam nele um trabalhador aproveitável; a metrópole, um povoador para a área imensa que tinha que ocupar, muito além de sua capacidade demográfica. (PRADO Jr,1996, p.91, grifo do autor) 
Durante os dois primeiros séculos de colonização os indígenas, certamente, eram maior parte da população; população esta que em pequena medida vivia nos núcleos urbanos das povoações, sede administrativa das localidades. "Provavelmente, em nenhuma outra região das Américas escravos índios e trabalhadores livres, fossem índios ou mestiços, integraram-se tão plenamente em um regime colonial dominado por brancos." (LUNA \& KLEIN, 2006, p.25) Já em meados do Setecentos o número de indígenas havia diminuído, forçando o declínio das bandeiras de apresamento e a sua penetração a locais cada vez mais distantes.

As bandeiras voltaram-se, então, para outro objetivo, qual seja, a busca por pedras e metais preciosos. Foram, ao final do século XVII, concedidos incentivos e privilégios pela Coroa para aqueles dispostos a dedicar-se à busca de metais; e "Com a descoberta do ouro, uma página da história local de São Paulo fora virada." (MARCÍLIO, 1973, pp.1718)

As descobertas auríferas, assim como, em menor medida, o declínio do apresamento indígena, forneceram subsídios para a dispersão da população por que passaram, então, as populações seiscentistas paulistas rumo àquelas áreas, que já apontavam o sentido das novas regiões a serem exploradas; e que o foram mormente por paulistas. Se inicialmente os paulistas eram maioria na Minas,

Superados numericamente, os paulistas perderam o controle das jazidas auríferas e alguns deles abandonaram estas regiões interioranas para retornar a São Paulo. Embora a abertura das jazidas auríferas acabasse provocando um grande impacto positivo sobre a província, nos primeiros anos da corrida do ouro talvez tenha ocorrido uma redução na população residente em São Paulo. Embora a população possa ter crescido depois dessas perdas iniciais, o crescimento parece ter sido limitado, pois não foram fundadas novas vilas na capitania no período de 1705 a 1767. (LUNA \& KLEIN, 2006, p.38).

Mas, a população da região das minas cresceu rapidamente e a capitania paulista aproveitou-se desse avanço, que serviu de estímulo econômico (mercado consumidor crescente), "para as profundas mudanças efetuadas, por reflexo e interação na região de São Paulo" (MARCÍLIO, 2000, p.18), entre elas um grande crescimento demográfico. Como fornecedora de diversos gêneros: "São Paulo que no início da mineração não possuía fontes organizadas de produção em larga escala, nem efetivos humanos para abastecer as Gerais, improvisou produção e população" (ZEMELLA, 1990, p.65).

Dois problemas cruciais apresentaram-se aos paulistas do inicio do século XVIII, como resposta à emulação econômica criada com a descoberta do ouro nas Gerais: a carência de mão-de-obra e a precária rede de caminhos [...] Para ambos o ouro 
permitiu as bases materiais necessárias para as soluções rápidas. No primeiro caso, as soluções foram encontradas na importação de negros africanos, na entrada contínua de contingentes brancos na região, além do prosseguimento da prática tradicional [...] transformando o índio em escravo disfarçado (MARCILIO, 2000, p.19)

Desta feita, durante a primeira metade do século XVIII, introduziu-se a mão-deobra do escravo africano negro, em detrimento ao indígena. Brancos livres e africanos negros passaram a dominar a posição que antes era devida, principalmente, ao gentio da terra. Ao final do Setecentos "concentrava-se em São Paulo uma população escrava considerável, a maioria nascida no Brasil [...] $O$ ingresso de cativos em grande quantidade, principalmente homens adultos, africanos ou nacionais, destruiu o relativo equilíbrio existente na população, tanto na proporção entre os sexos como na estrutura etária." (LUNA, 2009c, p.94)

Assim, foi contínuo e crescente, após iniciado, o afluxo de escravos africanos, acarretando em grande mudança na estrutura demográfica de São Paulo, pois antes o crescimento da população havia sido lento, "o que permitiu, no século XVIII, com a maior entrada de europeus e africanos, a rápida modificação da mestiçagem inicial." (MARCILIO, 2000, p.69)

Foi possível, então,

"[...] em território paulista um incremento demográfico resultante de fatores artificiais: entrada crescente de escravos na área desde os primórdios do século XVIII e de habitantes livres, sobras das Minas; elevadas e inusitadas taxas de crescimento natural [...] e mortalidade constantemente alta, mas sem a presença de flutuações ocasionadas por grandes crises demográficas" (MARCíLIO, 2000, p.192)

Assim, a fase iniciada no começo do século XVIII e que se estendeu por mais de um século representou importante fase de povoamento e de "movimentos espaciais humanos" em São Paulo, que viveu no período um crescimento em ritmo acelerado de sua população. "A região paulista do século XVIII e inícios do XIX estava em desbravamento, e processo de ocupação e de disseminação de homens sobre seu território, de organização de forma de vida e de subsistência." (Marcilio, 2000, p.18)

Todo o processo de exploração, ocupação e conseqüente povoamento, viu-se refletido nas características da população a viver em São Paulo, que aqui observamos nos caracteres encontrados nos arrolamento populacionais das localidades de Jundiaí, Bragança, Atibaia, Nazaré, Mogi das Cruzes e Jacareí, em período de grande dinâmica demográfica, representado pelo final do século XVIII e primeiras décadas da centúria subseqüente 


\section{Jundiaí}

Podemos traçar um perfil da população de Jundiaí no período 1799 a 1830 utilizando os dados contidos nos maços de população dos referidos anos e em outros intermediários $^{7}$ (Gráfico I.1 e Tabela I.1). Em 1799 existiam ali 3876 habitantes, entre livres e escravos, espraiados por 735 fogos. Entre os livres estão considerados, nesse e nos demais anos, também os libertos. Os forros, embora formalmente livres, estavam próximos ao passado cativo e aos laços que criaram e que muitas vezes mantinham. Mas, por aparecerem explicitados em número bastante diminuto, apontando certamente para uma omissão nas declarações (eram 23 em 1799, quatro em 1803, seis em 1808 e 1830, dois em 1822), foram computados entre os livres.

Já em 1830 eram 5713 habitantes, resultantes do crescimento populacional ocorrido a uma taxa anual de 1,3\% no decorrer do período. Os pouco mais de 30 anos observados responderam por uma variação positiva da população jundiaense em 47,4\%, valor inferior ao observado para a capitania/província como um todo, que teve sua população total ampliada em $77,2 \%$ em período semelhante (1798 a 1828).

Apesar da média positiva, as mudanças no número total de habitantes foi bastante variável ao longo dos anos considerados. O maior boom populacional ocorreu entre 1822 e 1826, quando o número de indivíduos descritos viu-se aumentado em $23,8 \%$, sendo que no período imediatamente anterior, entre 1816 e 1822, houve um decréscimo na população total $(-10,9 \%)$, que passou de 4979 a 4438 pessoas (nesse intervalo, os resumos que acompanham as listas nominativas apontam para 1817 uma população de 4894 indivíduos, número ampliado a 4952 no ano seguinte). Redução no número total de habitantes ocorreu também entre 1803 e 1808, -7,4\%, logo após um crescimento de 18,3\% entre 1799 e 1803 (anteriormente, em 1798, haviam sido segundo os mapas com resumos populacionais, 3332 habitantes, valor que subiu a 4692 em 1804, caindo a 4729 em 1805).

Essa variação na população total reflete em boa medida o ocorrido com a população livre, em sendo os indivíduos não cativos maioria da população - mínimo de $64,4 \%$ em 1830. Os livres tiveram seu maior crescimento também entre 1822 e 1825 (18,9\%), assim como crescimentos consideráveis entre 1808 e 1812 (13,7\%) e entre 1799 e 1803 quando se ampliou o número desses indivíduos de 3197 pessoas para 3739, 17\%; para também passar por um decréscimo no período seguinte, 1803-1808, desta feita de $10,4 \%$

\footnotetext{
${ }^{7}$ Para uma análise das fontes utilizadas neste trabalho ver Apêndice 2: fontes e métodos.
} 


\section{Gráfico I.1}

Evolução (em valores absolutos) da população total, população livre e escravos

$$
\text { (Jundiaí - } 1799 \text { a 1830) }
$$

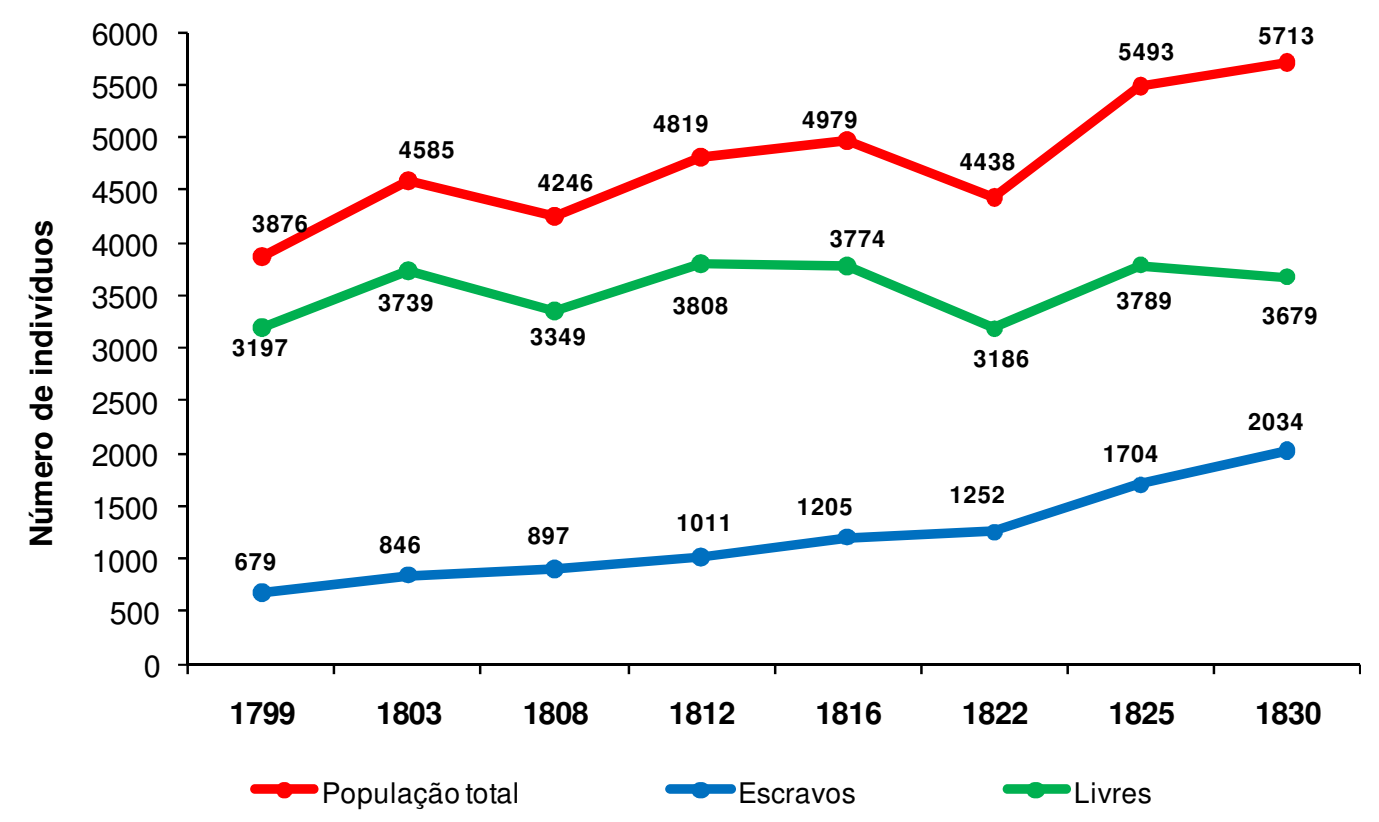

Tabela I.1

Variação da população total, população livre e escravos (Jundiaí - 1799 a 1830, São Paulo - 1798 a 1828)

\begin{tabular}{|c|c|c|c|c|c|c|}
\hline \multirow[b]{2}{*}{ Anos } & \multicolumn{4}{|c|}{ Jundiaí ** } & \multicolumn{2}{|c|}{$\begin{array}{l}\text { Capitania/Província } \\
\text { de São Paulo* }\end{array}$} \\
\hline & $\begin{array}{c}\text { Variação \% } \\
\text { da } \\
\text { população } \\
\text { total }\end{array}$ & $\begin{array}{l}\text { Variação \% } \\
\text { da } \\
\text { população } \\
\text { livre }\end{array}$ & $\begin{array}{c}\text { Variação \% } \\
\text { da } \\
\text { população } \\
\text { cativa }\end{array}$ & $\begin{array}{l}\text { Variação \% } \\
\text { do número } \\
\text { de fogos }\end{array}$ & Anos & $\begin{array}{c}\text { Variação \% } \\
\text { da } \\
\text { população } \\
\text { total }\end{array}$ \\
\hline $1799-1803$ & 18,3 & 17,0 & 24,6 & 1,1 & $1798-1800$ & 4,4 \\
\hline $1803-1808$ & $-7,4$ & $-10,4$ & 6,0 & $-1,6$ & $1800-1808$ & 15,7 \\
\hline $1808-1812$ & 13,5 & 13,7 & 12,7 & 14,6 & $1808-1818$ & 13,0 \\
\hline $1812-1816$ & 3,3 & $-0,9$ & 19,2 & 3,0 & $1818-1822$ & 10,3 \\
\hline $1816-1822$ & $-10,9$ & $-15,6$ & 3,9 & $-11,4$ & 1822-1828 & 17,7 \\
\hline $1822-1825$ & 23,8 & 18,9 & 36,1 & 14,4 & 1798-1818 & 36,5 \\
\hline $1825-1830$ & 4,0 & $-2,9$ & 19,4 & 4,0 & 1818-1828 & 29,8 \\
\hline $1799-1816$ & 28,5 & 18,0 & 77,5 & 17,4 & $1798-1828$ & 77,2 \\
\hline $1816-1830$ & 14,7 & $-2,5$ & 68,8 & 5,4 & & \\
\hline $1799-1830$ & 47,4 & 15,1 & 199,6 & 23,8 & & \\
\hline
\end{tabular}

*Valores calculados a partir dos dados apresentados por M arcílio (2000, p.71), inclui Paraná

**Fonte: AESP, M aços de População, Jundiaí: anos selecionados 


\section{Gráfico 1.2}

Participação de livres e escravos na população

$$
\text { (Jundiaí - } 1799 \text { a 1830) }
$$

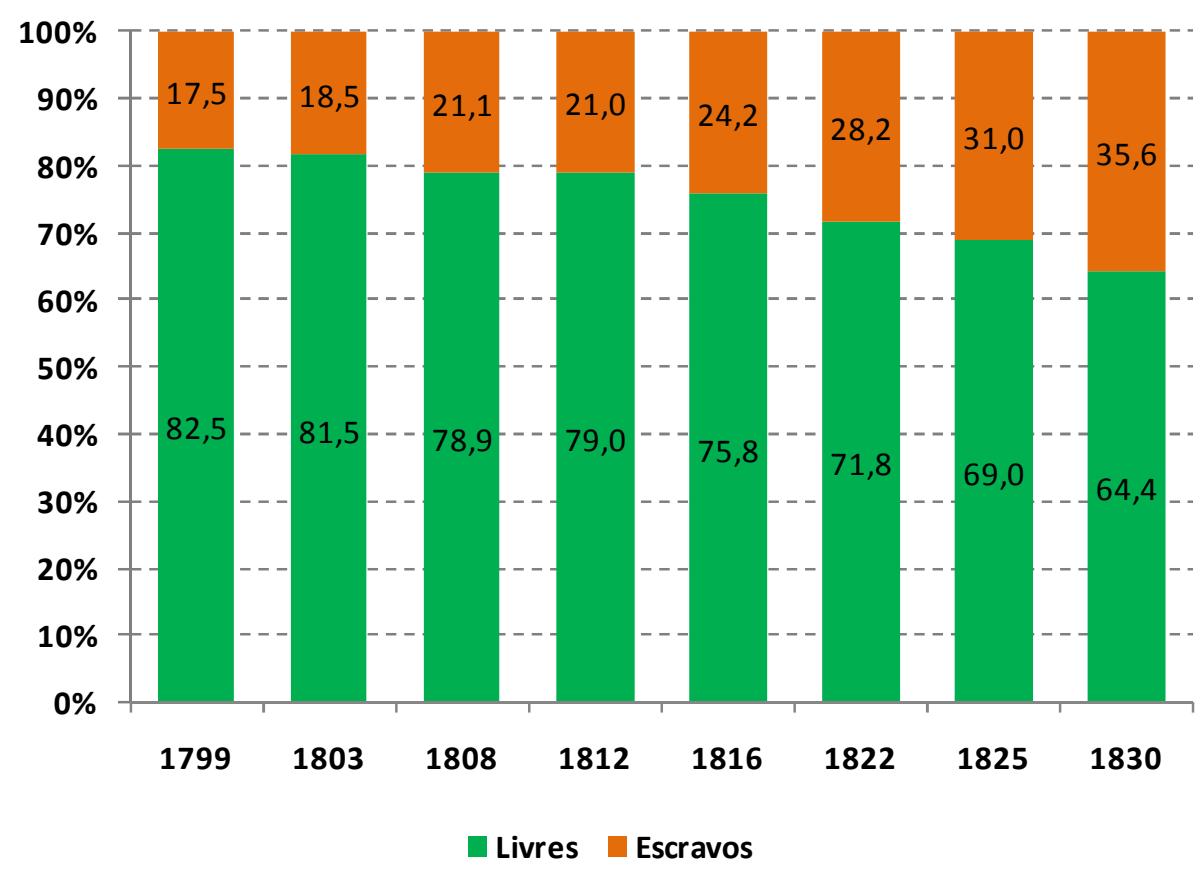

Notamos que a população livre teve um crescimento numérico relativamente pouco significativo entre 1799 e 1830, 15,1\% - a população total, como adiantado, cresceu acima de $47 \%$ e os escravos tiveram seu número triplicado entre 1799 e 1830 - e proporcionalmente em constante declínio em relação à população cativa, que respondia por $17,5 \%$ do total de habitantes arrolados na lista nominativa jundiaense no final do Setecentos, chegando a 35,6\% da população da vila após três décadas.

Eram 679 escravos no nosso ano inicial, ultrapassando os mil indivíduos em 1812 e chegando a 1704 (31\%) em 1825; ao final do período, 1830, estavam registrados no censo 2034 cativos, que correspondiam a $35,6 \%$ de todos os jundiaenses arrolados na lista nominativa daquele ano.

Os períodos de maior crescimento da população livre correspondem também à maior variação percentual no número de cativos na localidade que entre 1799 e 1803 tiveram seu número elevado em 24,6\% e entre 1822 e 1825 se viram aumentados em $36,1 \%$. Apesar de momentos de redução da população livre, os mancípios mantiveram sempre uma variação positiva ainda que, comparativamente aos demais períodos, o crescimento de 6\% ocorrido entre 1803 e 1808 e os 3,9\% de variação entre 1816 e 1822 
possam ser considerados pequenos. Entre 1812 e 1816 enquanto a população livre decresceu cerca de $1 \%$ a população escrava cresceu $19,2 \%$.

Ao longo das três décadas que separam 1799 de 1830 o número de cativos na localidade aumentou praticamente $200 \%$. Efeito, ao que parece, da expansão do setor agro-açucareiro ligado à exportação, que viu aumentado o número de cativos em seus engenhos (vide capítulo II). Processo coincidente ao verificado no Oeste paulista, região com a qual Jundiaí mantinha estreitos vínculos, senão pertencente a ela ${ }^{8}$ : em nota, Bacellar (2001, pp. 38-39) informa que

A introdução maciça de escravos nas áreas de grande lavoura sempre resultou na elevação de seu contingente. Deste modo, as vilas do Oeste paulista contavam, em 1836, escravos em proporções bastante contrastantes frente a Sorocaba: $35,4 \% \mathrm{em}$ Piracicaba, $42,2 \%$ em Itu, 58,6\% em Campinas, contra 23,3\% de Sorocaba e 23,5\% em Itapetininga, também afastada do grande circuito exportador.

Para o ano de 1836 temos o Ensaio d'um quadro estatístico da província de São Paulo, de Daniel Pedro Müller, que aponta que 34,9\% da população jundiaense naquele momento era composta por cativos. E segundo Luna (2009, p.339), entre 1804 e 1809, a população do Oeste Paulista cresceu a taxas de 2,07\% entre 1804 e 1829, sendo de $3,31 \%$ a taxa anual de crescimento para o número de escravos no período.

Apenas entre 1808 e 1812 o aumento da população cativa foi inferior àquele calculado para a população livre. Todavia, esse período correspondeu àquele com maior elevação no número de fogos, que de 731 em 1808 foram encontrados em número de 838 no ano de 1812, um aumento de 14,6\% nos domicílios jundiaense. Entre os referidos anos a média de indivíduos livres por domicílio manteve-se $(4,5 / 4,6)$, enquanto o número médio de cativos por fogo manteve-se em 1,2. Assim, o número médio de habitantes livres por fogo esconde o processo de queda na participação percentual dos indivíduos livres na vila de Jundiaí anteriormente identificado, diferentemente do número médio de cativos que passou de 0,8 em 1799 a 2,2 em 1830. (cf. Tabela I.2)

\footnotetext{
8 Jundiaí está situada em área limítrofe à região da capital e o oeste paulista, apresentando características de ambas as regiões, como se verá ao longo do presente trabalho. Assim, alguns autores a estudam vinculada à região da capital, a exemplo Canabrava (1972), Marcílio (2000) e Nozoe (2008); outros entendem como pertencentes à região açucareira do Oeste Paulista, como Bacellar (1997) e Luna (2009).
} 
Tabela I.2

Variação do número de fogos,

presença de livres e escravos nos domicílios

$$
\text { (Jundiaí - } 1799 \text { a 1830) }
$$

\begin{tabular}{|c|c|c|c|c|c|c|c|c|c|c|c|c|}
\hline \multirow{2}{*}{ Ano } & \multirow{2}{*}{$\begin{array}{l}\text { № de } \\
\text { fogos }\end{array}$} & \multirow{2}{*}{$\begin{array}{l}\text { Variação } \\
\text { \% do } \\
\text { número de } \\
\text { fogos }\end{array}$} & \multicolumn{3}{|c|}{ Indivíduos } & \multicolumn{3}{|c|}{ Livres } & \multicolumn{3}{|c|}{ Escravos } & \multirow{2}{*}{$\begin{array}{c}\text { Relação } \\
\text { escravos/livres }\end{array}$} \\
\hline & & & Média & Mediana & Moda & Média & Mediana & Moda & Média & Mediana & Moda & \\
\hline 1799 & 735 & & 5,3 & 5,0 & 3,0 & 4,3 & 7,0 & 4,0 & 0,9 & 0,0 & 0,0 & 0,21 \\
\hline 1803 & 743 & 1,1 & 6,2 & 5,0 & 3,0 & 5,0 & 5,0 & 3,0 & 1,1 & 0,0 & 0,0 & 0,23 \\
\hline 1808 & 731 & $-1,6$ & 5,8 & 5,0 & 3,0 & 4,6 & 5,0 & 2,0 & 1,2 & 0,0 & 0,0 & 0,27 \\
\hline 1812 & 838 & 14,6 & 5,8 & 5,0 & 3,0 & 4,5 & 4,0 & 3,0 & 1,2 & 0,0 & 0,0 & 0,27 \\
\hline 1816 & 863 & 3,0 & 5,8 & 5,0 & 3,0 & 4,4 & 5,0 & 3,0 & 1,4 & 0,0 & 0,0 & 0,32 \\
\hline 1822 & 765 & $-11,4$ & 5,8 & 5,0 & 3,0 & 4,2 & 4,0 & 2,0 & 1,6 & 0,0 & 0,0 & 0,39 \\
\hline 1825 & 875 & 14,4 & 6,3 & 5,0 & 3,0 & 4,3 & 4,0 & 3,0 & 1,9 & 0,0 & 0,0 & 0,45 \\
\hline 1830 & 910 & 4,0 & 6,3 & 5,0 & 3,0 & 4,0 & 4,0 & 2,0 & 2,2 & 0,0 & 0,0 & 0,55 \\
\hline
\end{tabular}

Fonte: AESP, M aços de População, Jundiaí: anos selecionados

Tabela I.3

Peso dos domicílios com e sem escravos na população

(Jundiaí - 1799 a 1830)

\begin{tabular}{|c|c|c|c|c|c|c|c|}
\hline \multirow[b]{2}{*}{ Anos } & \multicolumn{3}{|c|}{ Fogos sem escravos } & \multicolumn{4}{|c|}{ Fogos com escravos } \\
\hline & $\begin{array}{c}\% \text { da } \\
\text { população } \\
\text { total }\end{array}$ & $\begin{array}{c}\text { \% da } \\
\text { população } \\
\text { livre }\end{array}$ & $\begin{array}{l}\text { Média de } \\
\text { indivíduos }\end{array}$ & $\begin{array}{c}\text { \% da } \\
\text { população } \\
\text { total }\end{array}$ & $\begin{array}{l}\text { \% da } \\
\text { população } \\
\text { livre }\end{array}$ & $\begin{array}{l}\text { Média de } \\
\text { indivíduos }\end{array}$ & $\begin{array}{l}\text { Média de } \\
\text { livres }\end{array}$ \\
\hline 1799 & 67,1 & 81,4 & 4,4 & 32,9 & 18,6 & 9,1 & 4,3 \\
\hline 1803 & 62,8 & 76,9 & 5,0 & 37,2 & 23,1 & 10,2 & 5,1 \\
\hline 1808 & 62,0 & 78,7 & 4,6 & 38,0 & 21,3 & 10,5 & 4,6 \\
\hline 1812 & 61,4 & 77,5 & 4,4 & 38,6 & 22,5 & 10,6 & 4,8 \\
\hline 1816 & 59,8 & 77,6 & 4,3 & 40,2 & 22,4 & 11,0 & 4,7 \\
\hline 1822 & 54,7 & 75,2 & 4,1 & 45,3 & 24,8 & 11,0 & 4,3 \\
\hline 1825 & 50,5 & 73,5 & 4,3 & 49,5 & 26,5 & 12,4 & 4,6 \\
\hline 1830 & 45,1 & 69,3 & 3,8 & 54,9 & 30,7 & 13,0 & 4,7 \\
\hline
\end{tabular}

Fonte: AESP, M aços de População, Jundiaí: anos selecio nados

A estrutura desses fogos, observada de acordo com a presença ou não de cativos (Tabela I.3) mostra uma população, entre livres mais escravos, vivendo em fogos com mancípios cada vez maior - 32,9\% da população estava diretamente ligada a plantéis em 1799, percentual alçado a 40,2\% em 1816 e 54,9\% em 1830 -, em grande medida reflexo 
do considerável crescimento e, por conseguinte, da alteração da participação da população cativa verificada. A sua vez, a parcela livre da população também ampliou seu peso entre aqueles fogos com escravos, ainda que essa mudança tenha sido menos gradual: 18,6\% em 1799, ao redor de $22 \%$ nos anos de 1808 a 1816, 30,7\% em 1830 .

Conforme se vê no Gráfico I.3, os fogos com cativos eram 19,2\% dos 735 fogos arrolados em 1799. Nos anos seguintes, entre 1803 e 1816, os percentuais variaram ao redor de 20,8\% (1812) a 22,3\% (1803); e na década de 1820 passou a 24\% em 1822 e $26,6 \%$ era o percentual de fogos escravistas em 1830 . Verificamos um aumento de pouco mais de oito pontos percentuais na participação de fogos com escravos na localidade entre anos limítrofes do lapso estudado, variação importante, correspondente proporcionalmente a uma mudança de $38,7 \%$ nos fogos com presença de escravos.

\section{Gráfico I.3}

\section{Fogos com e sem escravos}

\section{(Jundiaí - 1799 a 1830)}

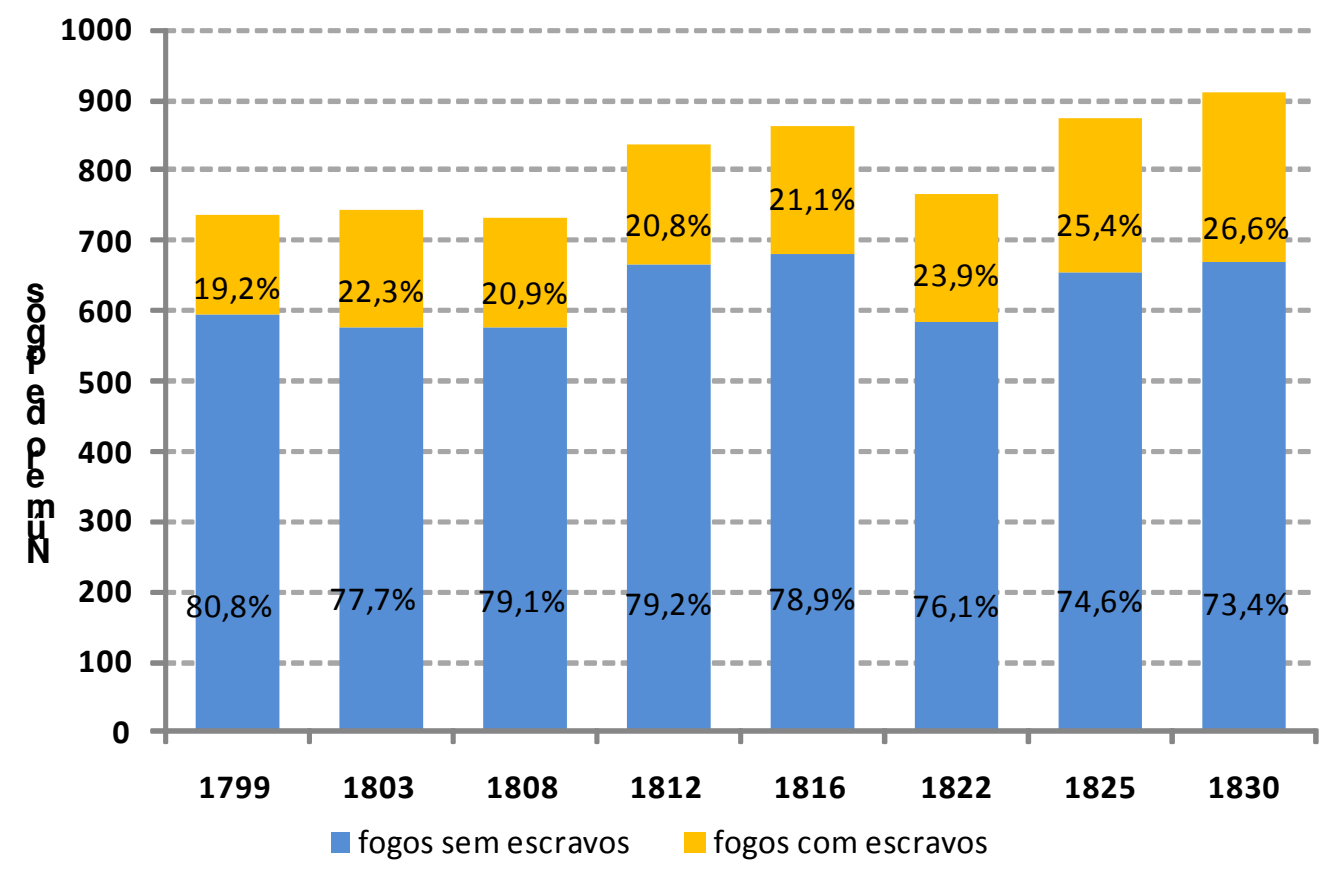

Contudo, as mudanças observadas para os fogos apresentam menor monta que aquelas anteriormente identificadas para a parcela de escravos a compor o total da população da vila de Jundiaí, implicando necessariamente em um maior número de cativos presentes naqueles fogos em que se encontram, como se viu. Doravante, o conjunto de cativos presentes nos fogos será denominado, em regra, plantel. 
Tabela I.4

Indicadores estatísticos para a posse de escravos

(Jundiaí - 1799 a 1830)

\begin{tabular}{|c|c|c|c|c|c|c|c|c|}
\hline \multirow[b]{2}{*}{ Estatísticas } & \multicolumn{2}{|c|}{1799} & \multicolumn{2}{|c|}{1803} & \multicolumn{2}{|c|}{1808} & \multicolumn{2}{|c|}{1812} \\
\hline & $\begin{array}{l}\text { Total de } \\
\text { fogos }\end{array}$ & $\begin{array}{c}\text { Fogos com } \\
\text { escravos }\end{array}$ & $\begin{array}{l}\text { Total de } \\
\text { fogos }\end{array}$ & $\begin{array}{l}\text { Fogos com } \\
\text { escravos }\end{array}$ & $\begin{array}{l}\text { Total de } \\
\text { fogos }\end{array}$ & $\begin{array}{l}\text { Fogos com } \\
\text { escravos }\end{array}$ & $\begin{array}{l}\text { Total de } \\
\text { fogos }\end{array}$ & $\begin{array}{c}\text { Fogos com } \\
\text { escravos }\end{array}$ \\
\hline Média & 0,9 & 4,8 & 1,2 & 5,3 & 1,2 & 5,9 & 1,2 & 5,8 \\
\hline Moda & 0,0 & 1,0 & 0,0 & 1,0 & 0,0 & 1,0 & 0,0 & 1,0 \\
\hline Mediana & 0,0 & 2,0 & 0,0 & 3,0 & 0,0 & 3,0 & 0,0 & 2,0 \\
\hline Desvio padrão & 3,1 & 5,6 & 3,7 & 6,4 & 4,4 & 7,9 & 4,7 & 8,8 \\
\hline Variância & 9,5 & 30,8 & 13,9 & 40,8 & 19,0 & 63,1 & 21,6 & 77,6 \\
\hline Índice de Gini & 0,909 & 0,525 & 0,897 & 0,537 & 0,912 & 0,581 & 0,918 & 0,606 \\
\hline Máximo & \multicolumn{2}{|c|}{29,0} & \multicolumn{2}{|c|}{37,0} & \multicolumn{2}{|c|}{50,0} & \multicolumn{2}{|c|}{60,0} \\
\hline \multirow[b]{2}{*}{ Estatísticas } & \multicolumn{2}{|c|}{1816} & \multicolumn{2}{|c|}{1822} & \multicolumn{2}{|c|}{1825} & \multicolumn{2}{|c|}{1830} \\
\hline & $\begin{array}{l}\text { Total de } \\
\text { fogos }\end{array}$ & $\begin{array}{c}\text { Fogos com } \\
\text { escravos }\end{array}$ & $\begin{array}{l}\text { Total de } \\
\text { fogos }\end{array}$ & $\begin{array}{l}\text { Fogos com } \\
\text { escravos }\end{array}$ & $\begin{array}{l}\text { Total de } \\
\text { fogos }\end{array}$ & $\begin{array}{l}\text { Fogos com } \\
\text { escravos }\end{array}$ & $\begin{array}{l}\text { Total de } \\
\text { fogos }\end{array}$ & $\begin{array}{c}\text { Fogos com } \\
\text { escravos }\end{array}$ \\
\hline Média & 1,4 & 6,4 & 1,6 & 6,7 & 2,0 & 7,7 & 2,2 & 8,3 \\
\hline Moda & 0,0 & 1,0 & 0,0 & 1,0 & 0,0 & 1,0 & 0,0 & 1,0 \\
\hline Mediana & 0,0 & 2,0 & 0,0 & 3,0 & 0,0 & 3,0 & 0,0 & 3,0 \\
\hline Desvio padrão & 5,3 & 10,0 & 5,6 & 9,9 & 7,1 & 12,4 & 8,7 & 15,4 \\
\hline Variância & 27,7 & 99,6 & 31,3 & 98,2 & 50,1 & 153,3 & 76,0 & 237,2 \\
\hline Índice de Gini & 0,921 & 0,624 & 0,905 & 0,602 & 0,903 & 0,620 & 0,911 & 0,665 \\
\hline Máximo & \multicolumn{2}{|c|}{72,0} & \multicolumn{2}{|c|}{78,0} & \multicolumn{2}{|c|}{88,0} & \multicolumn{2}{|c|}{89,0} \\
\hline
\end{tabular}

Fonte: AESP, Maços de População, Jundiaí: anos selecionados

Se considerados apenas os fogos em que os cativos estavam presentes, de fato, a média para os chefes/proprietários de escravos elevou-se: eram 4,8 cativos por domicilio em 1799, 5,9 e 5,8 e 1808 e 1812, no ano de 1816 o número médio chegou a 6,7 escravos e em 1830 encontramos, em média, 8,3 mancípios por fogo escravista. Estes dados são apresentado na Tabela I.4. ${ }^{9}$

O número médio de escravos calculado para os proprietários de cativos apresentou-se, em todo o lapso em tela, acima da mediana e da moda, evidenciando que poucos proprietários possuíam muitos escravos, mantendo elevada a média encontrada com relação às outras estatísticas de posição: a moda foi invariavelmente igual a 1 e a

\footnotetext{
${ }^{9}$ Os dados apresentados, assim como o faremos para as demais localidades, são referentes aos escravos encontrados no domicilio, podendo incluir cativos pertencentes a agregados não aparentados ou outros membros do fogo. A posse aqui aparece sob um mesmo conjunto por acreditarmos estarem suas tarefas ligadas dentro daquilo que era a atividade principal (e suas subsidiárias não identificadas) do fogo em que viviam e trabalhavam. Todos os indivíduos considerados escravistas são chefes de domicílio, ou seja, denominamos escravistas aqueles jundiaenses chefes de fogos onde foram localizados cativos. Tal procedimento poderia sofrer pequena influencia se considerássemos as estatísticas apresentadas por indivíduos efetivamente proprietários de escravo. Iraci Costa em sua Breve nota sobre o termo plantel aponta que "Se o termo for usado sem qualquer especificação refere-se ao conjunto de escravos pertencente a um proprietário tomado individualmente ou a um grupo de proprietários desde que o fossem, com respeito a um especifico grupo de cativos, na condição de sócios." Os indivíduos envolvidos na questão em tela podem ser considerados sócios, afinal ao habitarem um mesmo domicilio estavam ligados por algum tipo de contrato social.
} 
mediana oscilou entre 2 e 3 cativos. O índice de Gini, explicado pela dinâmica dos menores e maiores plantéis, aponta para concentração média nos primeiros anos, iniciado com índice de 0,525 , tendente a forte com o passar dos anos, quando foi calculado em 0,665 em 1830.

Tabela $\mathbf{I . 5}$

Distribuição de escravos e escravistas de acordo com faixas de tamanho dos plantéis (Jundiaí - 1799 a 1830)

\begin{tabular}{|c|c|c|c|c|c|c|c|c|c|c|c|c|}
\hline \multirow{3}{*}{ FTP } & \multicolumn{4}{|c|}{1799} & \multicolumn{4}{|c|}{1803} & \multicolumn{4}{|c|}{1808} \\
\hline & \multicolumn{2}{|c|}{ Escravistas } & \multicolumn{2}{|c|}{ Escravos } & \multicolumn{2}{|c|}{ Escravistas } & \multicolumn{2}{|c|}{ Escravos } & \multicolumn{2}{|c|}{ Escravistas } & \multicolumn{2}{|c|}{ Escravos } \\
\hline & № & $\%$ & № & $\%$ & № & $\%$ & № & $\%$ & № & $\%$ & № & $\%$ \\
\hline 1 a 5 & 103 & 73,0 & 212 & 31,2 & 122 & 73,5 & 277 & 32,7 & 113 & 73,9 & 257 & 28,7 \\
\hline 6 a 10 & 17 & 12,1 & 129 & 19,0 & 21 & 12,7 & 155 & 18,3 & 14 & 9,2 & 105 & 11,7 \\
\hline 11 a 20 & 16 & 11,3 & 213 & 31,4 & 16 & 9,6 & 231 & 27,3 & 16 & 10,5 & 241 & 26,9 \\
\hline Acima 20 & 5 & 3,5 & 125 & 18,4 & 7 & 4,2 & 183 & 21,6 & 10 & 6,5 & 294 & 32,8 \\
\hline \multirow[t]{2}{*}{ Total } & 141 & 100,0 & 679 & 100,0 & 166 & 100,0 & 846 & 100,0 & 153 & 100,0 & 897 & 100,0 \\
\hline & \multicolumn{4}{|c|}{1812} & \multicolumn{4}{|c|}{1816} & \multicolumn{4}{|c|}{1822} \\
\hline \multirow{2}{*}{ FTP } & \multicolumn{2}{|c|}{ Escravistas } & \multicolumn{2}{|c|}{ Escravos } & \multicolumn{2}{|c|}{ Escravistas } & \multicolumn{2}{|c|}{ Escravos } & \multicolumn{2}{|c|}{ Escravistas } & \multicolumn{2}{|c|}{ Escravos } \\
\hline & № & $\%$ & № & $\%$ & № & $\%$ & № & $\%$ & № & $\%$ & № & $\%$ \\
\hline 1 a 5 & 127 & 73,0 & 261 & 25,8 & 129 & 70,9 & 260 & 21,6 & 127 & 69,4 & 275 & 22,0 \\
\hline 6 a 10 & 23 & 13,2 & 175 & 17,3 & 19 & 10,4 & 152 & 12,6 & 25 & 13,7 & 191 & 15,3 \\
\hline 11 a 20 & 12 & 6,9 & 183 & 18,1 & 17 & 9,3 & 222 & 18,4 & 13 & 7,1 & 207 & 16,5 \\
\hline Acima 20 & 12 & 6,9 & 392 & 38,8 & 17 & 9,3 & 571 & 47,4 & 18 & 9,8 & 579 & 46,2 \\
\hline Total & 174 & 100,0 & 1011 & 100,0 & 182 & 100,0 & 1205 & 100,0 & 183 & 100,0 & 1252 & 100,0 \\
\hline \multirow{3}{*}{ FTP } & \multicolumn{4}{|c|}{1825} & \multicolumn{4}{|c|}{1830} & & & & \\
\hline & \multicolumn{2}{|c|}{ Escravistas } & \multicolumn{2}{|c|}{ Escravos } & \multicolumn{2}{|c|}{ Escravistas } & \multicolumn{2}{|c|}{ Escravos } & & & & \\
\hline & № & $\%$ & № & $\%$ & № & $\%$ & № & $\%$ & & & & \\
\hline 1 a 5 & 152 & 68,5 & 354 & 20,8 & 168 & 69,4 & 382 & 18,8 & & & & \\
\hline 6 a 10 & 24 & 10,8 & 190 & 11,2 & 28 & 11,6 & 209 & 10,3 & & & & \\
\hline 11 a 20 & 27 & 12,2 & 378 & 22,2 & 23 & 9,5 & 343 & 16,9 & & & & \\
\hline Acima 20 & 19 & 8,6 & 782 & 45,9 & 23 & 9,5 & 1100 & 54,1 & & & & \\
\hline Total & 222 & 100,0 & 1704 & 100,0 & 242 & 100,0 & 2034 & 100,0 & & & & \\
\hline
\end{tabular}

Ao verificar o peso dos segmentos de plantéis pequenos (considerados aqueles plantéis com a 1 a 5 cativos), médios ( 6 a 10), grandes (11 a 20) e muito grandes (acima de 20), percebemos o predomínio, na Jundiaí de 1799 a 1830, de um escravismo de pequenos e médios proprietários, com os dados das listas nominativas de habitantes apontando um percentual pouco variável, devido aos pequenos plantéis: entre $73 \%$ e $74 \%$ esteve o percentual daqueles fogos com 1 a 5 cativos até 1812, em 1816 esse percentual 
foi $70,9 \%$ e na década de 1820 foi de $68,5 \%$ em 1825 e $69,4 \%$ nos outros dois anos (cf. Tabela 1.5).

Contudo, o número de escravos nas mãos destes chefes foi, proporcionalmente, diminuindo. Eram 32,7\% em 1803, 25,8\% decorrida quase uma década e atingiu seu mínimo em 1830, quando $18,8 \%$ dos cativos viviam em fogos com até cinco pessoas a compor seus plantéis. Esta modificação ocorreu inversamente ao movimento identificado para o extremo oposto da distribuição, ou seja, aqueles chefes/domicílios com ao menos 20 escravos descritos.

Tomando os senhores de cativos com os maiores plantéis, temos evidenciada sua reduzida participação, entre os detentores de escravos não mais de 9,8\% (em 1822). Apesar de sua reduzida participação no total de domicílios com cativos, nota-se que de cinco indivíduos em 1799, essa faixa de tamanho de plantel passou a 23 pessoas após três décadas, um aumento de $360 \%$ - o aumento dos domicílios no período foi de $23,7 \%$ e o de fogos com escravos de $71 \%$. Assim, houve uma significativa variação no percentual por eles representado: eram apenas 3,5\% dos fogos escravistas em 1799, $4,2 \%$ no ano de 1803, percentual alçado a cerca de 6,5\%-7\% em 1808 e 1812, e que esteve ao redor de 9\% nos momentos observados a partir de 1816.

A estes grandes escravistas cabia $18,4 \%$ dos mancípios arrolados para a vila e seu termo em 1799 e 54\% em 1830, ou seja, 1100 indivíduos, uma média de 47,8 cativos por fogo. Em 1799 eram apenas 125 escravos anotados nos cinco plantéis muito grandes (25 por fogo) e em 1816 chegavam a 33,6 em média por domicílio.

Foi, então, claramente crescente o número de escravos ligados a esses plantéis de maior monta, refletindo o aumento do número desses plantéis e, para além desse aumento, o número mais elevado de escravos em cada um deles, que de um máximo de 29 pessoas em 1799 chegou 88 escravos em 1825, pertencentes a José Castanho de Morais o maior número verificado até então. No ano seguinte observado encontramos plantel semelhante: 89 pessoas.

Os referidos 89 cativos foram descritos no fogo do alferes reformado Clemente da Costa Alves, natural do Porto e que em 1830, aos 54 anos e solteiro, encontrava-se vivendo em Jundiaí com a irmã Joaquina Maria de Jesus, quatro sobrinhos e ainda a agregada Anna Gertrudes, viúva e natural de Sorocaba que possuía seis entre os 89 escravos arrolados no fogo. Restavam, portanto, 83 escravos a Clemente, que ainda era detentor de um dos cinco maiores grupos de cativos da Jundiaí de 1830. Manuel Soares Ferraz, assim como Roza Delfina de Camargo, também era senhor de 83 escravos e Antonio de Queiroz Telles e Jose Pereira de Queirós arrolaram 87 mancípios cada. Em 
comum todos declararam ser senhores de engenho e agricultores, produzindo não menos de 990 arrobas de açúcar cada um, destinado ao mercado de Santos.

No que respeita ao número de indivíduos por domicílio, considerados apenas os livres, os dois segmentos de fogo, com e sem escravos, apresentam valores bastante próximos, em torno de 4-5 indivíduos, sem grandes variações (apenas em 1830 quando a média de pessoas livres em fogos escravistas mantém-se nos padrões anteriores, 4,7, e o número médio de livres em fogos sem escravos cai levemente a 3,8, amplia-se a diferença para quase um indivíduo). Assim, as modificações no peso relativo de domicílios com e sem escravos entre a população total deve-se à ampliação da participação do número de fogos com cativos.

Em suma, ao longo do período 1799-1830 o número de habitantes da vila de Jundiaí cresceu - a menores taxas que a capitania/província de São Paulo em sua totalidade -, sendo o aumento da população livre intermitente, ainda que positiva entre os anos limítrofes considerados, enquanto a população cativa variou positivamente durante todos os momentos analisados, ampliando ao longo do tempo sua participação entre os habitantes da vila de Jundiaí, assim como o peso dos livres a eles diretamente ligados via presença de plantéis nos domicílios.

Dentre os livres, nos domicílios da localidade encontramos importante participação dos agregados, cuja presença é mostrada na Tabela I.6.

Em 1799 foi registrado o menor número deles, 275, verificados em 143 fogos $(19,5 \%)$ e respondendo naquele momento por $7,1 \%$ da população total e $8,6 \%$ dos livres em Jundiaí. Nos próximos dois anos observados, 1803 e 1808, o percentual alçou-se a mais de 9\% da população total, devido à sua variação que chegou a 79\% entre $1799 \mathrm{e}$ 1803, enquanto a população livre e, por conseguinte, a total decresceu, como observado.

Assim, nesse momento a média de agregados por fogo chegou a 2,3 (0,67 em se considerando o total de fogos em 1803), a maior verificada - ainda que a evolução ao longo do tempo não tenha mostrado grande variação, existindo ao menos 1,9 agregado por fogo (1799) ao longo dos 31 anos estudados - sendo no início do Oitocentos 29,1\% dos domicílios possuidores desses indivíduos entre seus membros. Em 1822 a presença de agregados foi a menos significativa, com $17,1 \%$ dos fogos, $5,8 \%$ da população total e $8 \%$ entre os livres, tendo o número de agregados, assim como a população livre, sofrido uma queda importante comparativamente a 1816. Parte dos fogos com agregados estavam também vinculados à posse de escravos, tendo seu percentual de participação, assim como para o total de fogos, atingido maior participação em 1803, 9,8\%, e a menor vinte anos depois (1822), 5,6\%. 
Tabela 1.6

Peso dos domicílios com e sem agregados não aparentados na população (Jundiaí - 1799 a 1830)

\begin{tabular}{|c|c|c|c|c|c|c|c|}
\hline Anos & $\begin{array}{l}\text { \% de fogos } \\
\text { com } \\
\text { agregados }\end{array}$ & $\begin{array}{c}\text { № de } \\
\text { agregados }\end{array}$ & $\begin{array}{c}\text { \% de } \\
\text { agregados } \\
\text { na } \\
\text { população } \\
\text { total }\end{array}$ & $\begin{array}{c}\% \text { de } \\
\text { agregados } \\
\text { na } \\
\text { população } \\
\text { livre }\end{array}$ & $\begin{array}{l}\text { Média de } \\
\text { agregados } \\
\text { (fogos com } \\
\text { agregados) }\end{array}$ & $\begin{array}{l}\text { Média de } \\
\text { agregados } \\
\text { (total de } \\
\text { fogos) }\end{array}$ & $\begin{array}{c}\% \text { de fogos } \\
\text { com agregados } \\
\text { e escravos }\end{array}$ \\
\hline 1799 & 19,5 & 275 & 7,1 & 8,6 & 1,9 & 0,37 & 4,4 \\
\hline 1803 & 29,1 & 497 & 10,8 & 13,3 & 2,3 & 0,67 & 9,8 \\
\hline 1808 & 24,9 & 408 & 9,6 & 12,2 & 2,2 & 0,56 & 7,1 \\
\hline 1812 & 22,3 & 405 & 8,4 & 10,6 & 2,2 & 0,48 & 8,4 \\
\hline 1816 & 21,6 & 393 & 7,9 & 10,4 & 2,1 & 0,46 & 7,6 \\
\hline 1822 & 17,1 & 256 & 5,8 & 8,0 & 2,0 & 0,33 & 5,6 \\
\hline 1825 & 18,9 & 351 & 6,4 & 9,3 & 2,1 & 0,40 & 8,3 \\
\hline 1830 & 18,1 & 341 & 6,0 & 9,3 & 2,1 & 0,37 & 7,4 \\
\hline
\end{tabular}

Fonte: AESP, M aços de População, Jundiaí: anos selecionados

Esses indivíduos agregados parecem ter tido importante mobilidade, pois expressões como "acresceu seu(a) agregada(o)", "acréscimo o(a) agregado(a)" agregado(a) saiu de sua companhia", "agregada mudou para outra casa", "saíram seus agregados" "agregado foi assentar praça na tropa de linha", "casou agregada" foram bastante comuns entre as observações para diferentes fogos a partir de 1803. (Listas Nominativa de Jundiaí, 1799 a 1830 - AESP, Maços de População/rolos diversos)

Por exemplo, em 1812, 41 fogos mencionaram movimentação de agregados (excluídas duas mortes), sendo 20 (48,8\%) de acréscimo, 18 de baixa (inclusive casamentos) e dois de acréscimo e saída. Assim, Francisco de Paula Pedroso declarou o "acréscimo de seus agregados com seus criolos"; o fogo de Joaquim dos Santos Braz foi acrescido das agregadas Rita e Generosa e dele saiu o agregado Rafael; Manoel de Queirós observou o acréscimo de quatro agregados. (cf. Lista Nominativa de Jundiaí, 1812 - AESP, Maços de População/rolo 109)

Os registros postos na Tabela I.7 mostram que, entre os livres, agregados ou não, o número de mulheres foi sempre superior ao de homens na Jundiaí do final do século XVIII e primeiras décadas da centúria seguinte, ainda que o percentual devido a cada um dos sexos não seja muito dispare. Nos anos de 1808 e 1812 verificamos a maior diferença 
entre a participação masculina, respectivamente $46 \%$ e 46,7\%, e a participação feminina, $54 \%$ e 53,3\%, em sequência, respondendo pelas menores razões de sexo calculadas: 85 e 87,5 homens para cada grupo de 100 mulheres.

\section{Tabela $\mathbf{I . 7}$}

\section{Composição da população livre por sexo}

$$
\text { (Jundiaí - } 1799 \text { a 1830) }
$$

\begin{tabular}{|c|c|c|c|c|c|c|c|c|}
\hline \multirow{3}{*}{ Anos } & \multicolumn{5}{|c|}{ População Livre } & \multicolumn{3}{|c|}{ Chefes de fogo } \\
\hline & \multicolumn{2}{|c|}{ Homens } & \multicolumn{2}{|c|}{ Mulheres } & \multirow{2}{*}{$\begin{array}{l}\text { Razão de } \\
\text { sexo }\end{array}$} & \multirow{2}{*}{$\begin{array}{c}\text { Homens } \\
\text { \% (№) }\end{array}$} & \multirow{2}{*}{$\begin{array}{c}\text { Mulheres } \\
\text { \% (№) }\end{array}$} & \multirow{2}{*}{$\begin{array}{l}\text { Razão de } \\
\text { sexo }\end{array}$} \\
\hline & \% (№) & $\begin{array}{c}\text { Variação } \\
\%\end{array}$ & \% (№) & $\begin{array}{c}\text { Variação } \\
\%\end{array}$ & & & & \\
\hline 1799 & $48,8(1560)$ & & $51,2(1636)$ & & 95,4 & $79,9 \quad(587)$ & $20,1 \quad(148)$ & 396,6 \\
\hline 1803 & $48,0(1796)$ & 15,1 & $52,0(1943)$ & 18,8 & 92,4 & $80,1 \quad(596)$ & 19,9 (149) & 402,0 \\
\hline 1808 & $46,0(1538)$ & $-14,4$ & $54,0(1809)$ & $-6,9$ & 85,0 & $79,3 \quad(577)$ & $20,7 \quad(151)$ & 382,1 \\
\hline 1812 & $46,7(1777)$ & 15,5 & $53,3(2031)$ & 12,3 & 87,5 & $80,8 \quad(677)$ & $19,2(161)$ & 420,5 \\
\hline 1816 & $47,6(1797)$ & 1,1 & $52,4(1977)$ & $-2,7$ & 90,9 & $79,6 \quad(686)$ & $20,4 \quad(177)$ & 389,2 \\
\hline 1822 & $47,6(1518)$ & $-15,5$ & $52,4(1668)$ & $-15,6$ & 91,0 & $79,4 \quad(606)$ & $20,6 \quad(158)$ & 385,4 \\
\hline 1825 & $48,2(1825)$ & 20,2 & $51,8(1960)$ & 17,5 & 93,1 & $77,9 \quad(681)$ & $22,1 \quad(193)$ & 352,8 \\
\hline 1830 & $47,7(1751)$ & $-4,1$ & 52,3 (1919) & $-2,1$ & 91,2 & $78,0 \quad(710)$ & $22,0 \quad(200)$ & 354,5 \\
\hline
\end{tabular}

Fonte: AESP, Maços de População, Jundiaí: anos selecionados

Todavia, o percentual de homens era bastante superior ao de mulheres, sendo a razão entre os sexos multiplicada por cerca de quatro quando consideramos apenas os chefes de fogo, mantendo-se bastante elevada, como esperado, com o passar dos anos e sem consideráveis variações. Destacamos 1812, ano em que razão de sexo chegou a 420,5 , observamos, como adiantado, uma das maiores participações femininas entre a população livre total. ${ }^{10}$

Pensando-se o crescimento da população feminina e masculina verificamos que apresentaram, de um recenseamento para outro, acentuadas flutuações, sugestão de importantes migrações, como se verá. Em regra, a população masculina e feminina, ainda que com alguma pequena diferença no montante, principalmente ente 1799 e 1803, flutuaram no mesmo sentido.

No que respeita à mobilidade, a origem dos indivíduos que viviam em Jundiaí pode nos dar uma aproximação (Tabela I.8). Nada foi mencionado para a origem daqueles ali residentes em 1799, mas em 1803 os habitantes com origem declarada eram, em sua

\footnotetext{
${ }^{10}$ Se considerados apenas os indivíduos a chefiar domicílios em que foi verificada a presença de cativos, obtemos uma razão de sexo ainda mais elevada que esta colocada para os chefes de fogo em sua totalidade.
} 
maioria $(56,3 \%)$, vindos de outras diversas localidades paulistas, sendo de $41,1 \% 0$ percentual daqueles dali originários. Atibaia, naturalidade de $17,2 \%$ dos residentes na vila em análise, era a maior "exportadora" de pessoas para a vila vizinha. Em segundo lugar em importância encontramos Parnaíba (9,3\%) e a cidade de São Paulo (8,7\%), e em terceiro as também vizinhas Bragança e Nazaré (2,4\% cada), Juqueri - atual Mairiporã $(2,6 \%)$, Itu (2,8\%), além de outras capitanias (2,2\%).

A lista nominativa mostra uma fotografia daquilo que deveria ser a população da localidade em 1803, mas a chegada desses indivíduos de outras áreas não foi estática e ocorreu ao longo do tempo, certamente com início ainda no século XVIII, sendo importante relembramos o crescimento populacional observado no período 1799 -1803, $17 \%$ entre os livres, sem sombra de dúvidas o maior entre os calculados para todo o lapso considerado.

Ainda que pudéssemos pensar, dada a abrangência das declarações - 43,8\% da população livre -, nessa elevada participação de forasteiros como sendo, em grande medida, resultado de elevada omissão de informações relativa aos locais, não foi este o caso posto repetir-se, com um certo incremento na intensidade, entre os chefes de domicilio cuja abrangência de declarações foi de 96,3\%, a elevada participação de paulistas: $61,7 \%$, sendo atibaienses $29,3 \%$ deles. $^{11}$

Mesmo decrescente, manteve-se importante o percentual devido aos paulistas entre a população livre total até 1812, 46,9\% e 34,1\%, respectivamente. Em 1816 e 1822 o percentual manteve-se ao redor de 17\%, caindo a 14,5\% em 1825 e 13,8\% em 1830, sempre com maior participação dos habitantes originários de Atibaia. Para os chefes de fogo, a participação de "estrangeiros" foi ainda mais acentuada até 1830, sendo a menor participação verificada para $1825,34,8 \%$ e a maior em $1812,53 \%$.

É dizer, houve um grande fluxo migratório em direção a Jundiaí, com auge possivelmente no século XVIII - período de importante para o açúcar -, sendo esse fluxo proporcionalmente decrescente com o passar dos anos, ainda que positivo (vide origem por números absolutos), não sendo suficiente para repor sua participação e superar o crescimento vegetativo positivo da população.

\footnotetext{
A menor delas, encontrada em 1816 foi de 417,1 e a maior foi de 451,5 , calculada para o ano de 1822 . Vide Tabela no apêndice estatístico.

${ }^{11} \mathrm{Em} 1803$ encontramos 128 fogos chefiados por atibaienses em Jundiaí. Neste mesmo ano havia em Atibaia 575 fogos, ou seja, os domicílios transportados para Jundiaí correspondiam a quase um quarto dos domicílios efetivamente existente em Atibaia naquele ano. Se comparados ao número verificado para 1799, 622, esse percentual seria de 20,6\%. Entre 1799 e 1803 a população de Atibaia, como se verá mais adiante, caiu 2,4\% e o número de fogos $7,6 \%$.
} 
Tabela $\mathbf{I . 8}$

Origem da população livre

(Jundiaí - 1799 a 1830)

\begin{tabular}{|c|c|c|c|c|c|c|c|}
\hline \multirow{3}{*}{ Origem } & \multicolumn{7}{|c|}{ População livre } \\
\hline & 1803 & 1808 & 1812 & 1816 & 1822 & 1825 & 1830 \\
\hline & \% (№) & \% (№) & \% (№) & \% (№) & \% (№) & \% (№) & \% (№) \\
\hline Jundiaí & $41,1(576)$ & $48,8(360)$ & $64,8(1981)$ & $81,3(3025)$ & $81,4(2586)$ & $83,9(3122)$ & $85,2(3100)$ \\
\hline Atibaia & $17,2(241)$ & $16,3(120)$ & $12,6(385)$ & 3,7 (139) & $7,3(231)$ & $5,4(201)$ & $4,8(174)$ \\
\hline Nazaré & 2,4 (34) & $2,8(21)$ & $1,0(32)$ & $0,5(19)$ & $0,4(14)$ & $0,5(18)$ & $0,3(10)$ \\
\hline Bragança & 2,4 (33) & $6,0(44)$ & $4,8(148)$ & $1,2(46)$ & $2,3(74)$ & $2,5(92)$ & $1,8(64)$ \\
\hline Mogi das Cruzes & $1,1(15)$ & $1,1(8)$ & $0,4(11)$ & $0,6(21)$ & $0,2(7)$ & $0,1 \quad(4)$ & $0,1(3)$ \\
\hline Jacareí & $0,1(1)$ & - & - & - & - & $0,1(2)$ & - \\
\hline Itu & $2,8(39)$ & $1,6(12)$ & $2,5(77)$ & $2,1(78)$ & $1,2(39)$ & $0,8(31)$ & $1,0(36)$ \\
\hline Juqueri & $2,6(36)$ & $2,0(15)$ & $1,5(45)$ & $1,0(36)$ & $0,6(18)$ & $0,8(28)$ & 1,3 (48) \\
\hline Parnaíba & $9,3(130)$ & 4,7 (35) & $5,0(152)$ & $3,9(144)$ & $2,2(70)$ & $1,5(57)$ & $1,6(59)$ \\
\hline São Paulo & $8,7(122)$ & $5,1 \quad(38)$ & $2,2(68)$ & $1,6(58)$ & $1,5(49)$ & $1,7(62)$ & $1,9(69)$ \\
\hline $\begin{array}{l}\text { Outras localidades da } \\
\text { capitania/província }\end{array}$ & $9,8(137)$ & $7,2(53)$ & $4,1(124)$ & $2,8(103)$ & $1,7(54)$ & $1,2(44)$ & $1,1(41)$ \\
\hline $\begin{array}{l}\text { TOTAL da } \\
\text { capitania/província } \\
\text { (exclusive Jundiaí) }\end{array}$ & $56,3(788)$ & $46,9(346)$ & $34,1(1042)$ & $17,3(644)$ & $17,5(556)$ & 14,5 (539) & $13,8(504)$ \\
\hline $\begin{array}{l}\text { Outras } \\
\text { capitanias/províncias }\end{array}$ & $2,2(31)$ & $2,6(19)$ & $0,9(29)$ & $1,1 \quad(41)$ & $0,8(26)$ & $1,1(40)$ & $0,8(28)$ \\
\hline Outros países & $0,4(5)$ & $1,8(13)$ & $0,2(6)$ & $0,2(9)$ & $0,3(10)$ & $0,5(19)$ & $0,2(8)$ \\
\hline TOTAL & $100,0(1400)$ & $100,0(738)$ & $100,0(3058)$ & $100,0(3719)$ & $100,0(3178)$ & $100,0(3720)$ & $100,0(3640)$ \\
\hline \multirow[t]{2}{*}{$\begin{array}{l}\text { Abrangência das } \\
\text { declarações }\end{array}$} & $43,8 \%$ & $19,7 \%$ & $80,3 \%$ & $98,5 \%$ & $99,7 \%$ & $98,2 \%$ & $98,9 \%$ \\
\hline & \multicolumn{7}{|c|}{ Chefes de fogo } \\
\hline \multirow[t]{2}{*}{ Origem } & 1803 & 1808 & 1812 & 1816 & 1822 & 1825 & 1830 \\
\hline & \% (№) & \% (№) & \% (№) & \% (№) & \% (№) & \% (№) & \% (№) \\
\hline Jundiaí & $34,5(244)$ & $55,1(360)$ & 44,1 (358) & $45,9(390)$ & $59,9(456)$ & $61,5(530)$ & $60,6(547)$ \\
\hline Atibaia & $18,1(128)$ & $13,0(85)$ & $17,3(140)$ & $13,8(117)$ & 13,5 (103) & $12,6(109)$ & $12,1(109)$ \\
\hline Nazaré & $2,8(20)$ & $1,8(12)$ & $2,0(16)$ & $2,1(18)$ & 1,3 (10) & $1,4(12)$ & $0,9(8)$ \\
\hline Bragança & $2,0(14)$ & $4,9(32)$ & $6,8(55)$ & $4,4(37)$ & $4,5(34)$ & $6,1(53)$ & $1,0(9)$ \\
\hline Mogi das Cruzes & $1,3(9)$ & $1,1(7)$ & $1,2(10)$ & $2,4(20)$ & $0,8(6)$ & $0,3(3)$ & $0,2(2)$ \\
\hline Jacareí & $0,1(1)$ & - & - & - & - & $0,2(2)$ & - \\
\hline Itu & $3,2(23)$ & $1,5(10)$ & $3,7(30)$ & 4,0 (34) & $2,2(17)$ & $2,0(17)$ & $2,1(19)$ \\
\hline Juqueri & $3,1 \quad(22)$ & $2,1(14)$ & $3,0(24)$ & $2,9(25)$ & $1,3(10)$ & $1,2(10)$ & $3,0(27)$ \\
\hline Parnaíba & $9,7(69)$ & $4,4(29)$ & $7,9(64)$ & $9,2(78)$ & $6,4(49)$ & $4,3(37)$ & $4,5(41)$ \\
\hline São Paulo & $9,7(69)$ & $4,6(30)$ & $4,2(34)$ & $4,5(38)$ & $3,0(23)$ & $3,5(30)$ & $4,9(44)$ \\
\hline $\begin{array}{l}\text { Outras localidades da } \\
\text { capitania/província }\end{array}$ & $11,6(82)$ & $6,4(42)$ & $7,0(57)$ & $6,0(51)$ & $3,4(26)$ & $3,1 \quad(27)$ & $7,6(69)$ \\
\hline $\begin{array}{l}\text { TOTAL da } \\
\text { capitania/província } \\
\text { (exclusive Jundiaí) }\end{array}$ & $34,5(244)$ & $53,0(346)$ & $53,0(430)$ & $49,2(418)$ & $36,5(278)$ & $34,8(300)$ & 36,3 (328) \\
\hline $\begin{array}{l}\text { Outras } \\
\text { capitanias/províncias }\end{array}$ & $3,0(21)$ & $2,9(19)$ & $2,1(17)$ & 3,9 (33) & $2,2(17)$ & $2,6(22)$ & $2,2(20)$ \\
\hline Outros países & $0,8(6)$ & $2,0(13)$ & $0,7(6)$ & $1,1(9)$ & $1,3(10)$ & $1,2(10)$ & $0,9(8)$ \\
\hline TOTAL & $100,0(708)$ & $100,0(653)$ & $100,0(811)$ & $100,0(850)$ & $100,0(761)$ & $100,0(862)$ & $100,0(903)$ \\
\hline $\begin{array}{l}\text { Abrangência das } \\
\text { declarações }\end{array}$ & $96,3 \%$ & $87,2 \%$ & $96,8 \%$ & $98,5 \%$ & $99,5 \%$ & $98,5 \%$ & $99,2 \%$ \\
\hline
\end{tabular}

Fonte: AESP, M aços de População, Jundiaí: anos selecionados

Exclusive indivíduos com naturalidade não identificada 
Entre os casados, a origem do cônjuge seguia proporções próximas àquelas verificadas para o total da população em 1803: 41\% eram da própria localidade, sendo esse percentual um pouco superior àquele verificado para os chefes de fogo. Nos anos seguintes, 1808 e 1812, o percentual devido aos cônjuges naturais de Jundiaí eram menores que os verificados para os chefes de fogo. E entre 1816 e 1830 esse percentual manteve-se em torno de $81 \%$ a $85 \%$, sempre superior aos $46 \%-60 \%$ dos chefes de fogo. ${ }^{12}$

Ou seja, ao que parece, em um primeiro momento (aproximadamente até 1812) a migração era feita por famílias, com casais que provavelmente se casaram fora de Jundiaí e para lá se dirigiram. Posteriormente, os desequilíbrios na razão de sexo deveriam justificar a união entre migrantes e jundiaenses natos.

Para além das variáveis demográficas até o momento consideradas, podemos observar o estado conjugal da população não cativa de Jundiaí, conforme explicitado na Tabela I.9.

\section{Tabela 1.9}

Composição da população livre de acordo com estado conjugal e sexo - exclusive indivíduos de até 14 anos (Jundiaí - 1799 a 1830)

\begin{tabular}{|c|c|c|c|c|c|c|c|c|c|}
\hline \multirow{2}{*}{ Anos } & \multicolumn{3}{|c|}{ Homens } & \multicolumn{3}{|c|}{ Mulheres } & \multicolumn{3}{|c|}{ Homens + Mulheres } \\
\hline & $\begin{array}{c}\text { Casados } \\
\%\end{array}$ & $\begin{array}{c}\text { Solteiros } \\
\%\end{array}$ & $\begin{array}{c}\text { Viúvos } \\
\%\end{array}$ & $\begin{array}{c}\text { Casadas } \\
\%\end{array}$ & $\begin{array}{c}\text { Solteiras } \\
\%\end{array}$ & $\begin{array}{c}\text { Viúvas } \\
\%\end{array}$ & $\begin{array}{c}\text { Casados } \\
\%\end{array}$ & $\begin{array}{c}\text { Solteiros } \\
\%\end{array}$ & $\begin{array}{c}\text { Viúvos } \\
\%\end{array}$ \\
\hline 1799 & 58,1 & 37,4 & 4,5 & 52,9 & 33,6 & 13,4 & 55,4 & 35,4 & 9,2 \\
\hline 1803 & 57,7 & 37,3 & 5,0 & 50,6 & 35,8 & 13,6 & 53,8 & 36,5 & 9,7 \\
\hline 1808 & 63,3 & 31,2 & 5,5 & 53,2 & 33,6 & 13,2 & 57,8 & 32,5 & 9,7 \\
\hline 1812 & 65,3 & 30,8 & 3,9 & 55,2 & 34,2 & 10,5 & 59,7 & 32,6 & 7,7 \\
\hline 1816 & 63,0 & 32,2 & 4,8 & 55,4 & 32,5 & 12,2 & 58,9 & 32,3 & 8,7 \\
\hline 1822 & 65,7 & 30,1 & 4,2 & 56,1 & 31,5 & 12,4 & 60,5 & 30,9 & 8,7 \\
\hline 1825 & 64,8 & 30,8 & 4,4 & 55,6 & 33,0 & 11,4 & 59,8 & 32,0 & 8,2 \\
\hline 1830 & 65,2 & 30,5 & 4,3 & 58,7 & 29,1 & 12,3 & 61,6 & 29,8 & 8,6 \\
\hline
\end{tabular}

Fonte: AESP, M aços de População, Jundiaí: ano s selecionado s

Exclusive indivíduo s com estado conjugal e/ou sexo não identificado

Exclui individuos de 0 a 14 anos

\footnotetext{
${ }^{12}$ A comparação foi feita com os chefes de fogo pois, conforme exposto na Tabela I.10, a participação dos não casados entre os chefes de fogo foi pequena, sendo insignificante a mudança dos resultados com a exclusão de tais indivíduos.
} 
Dentre os livres com ao menos 15 anos de idade, sem considerarmos qualquer outra variável, os casados eram maioria, com percentuais que variaram entre o máximo de $61,6 \%$ em 1830 e o mínimo de 53,8\% em 1803, ano em que perdeu participação para os solteiros, que atingiram sua participação máxima com $36,5 \%$ no referido ano. Os viúvos mantiveram participação pouco variável, entre 7,7\% (1812) e 9,7\% (1803 e 1808).

No entanto o estado conjugal apresenta uma variação entre homens e mulheres, especialmente no que respeita à presença de viúvos, que não passou dos 5,5\% entre os homens, e não foi inferior a 10,5\% entre as mulheres que, em maiores proporções que os homens, tendiam a permanecer nessa condição, consideradas taxas de mortalidade semelhantes para os sexos. Ou, há ainda a possibilidade de os homens estarem envolvidos em atividades mais periculosas, que implicassem em longas viagens ou serviços militares - que apresentam grande importância na composição das ocupações jundiaenses, conforme anotado no capítulo II -, falecendo assim em maior medida.

Em se considerando os chefes de fogo, as diferenças são ainda mais marcantes (Tabela I.10). Enquanto os homens eram majoritariamente casados, com percentuais bem mais elevados que aqueles verificados para o total da população livre masculina, as mulheres assumiam a condição de chefes de domicilio quando viúvas, situação que correspondia a 73,7\% delas em 1799, entorno de 60\% em 1812-1816 e 57,5\% em 1830.

As solteiras eram o segundo grupo mais importante, com participação entre $22,6 \%$ (1803) e $30 \%$ (1812 e 1830). A sua vez, as casadas eram apenas 3,6\% em 1799, atingindo percentuais consideráveis entre 1812 e 1822 e em 1830. No censo de 1816 eram $17 \%$ das mulheres que chefiavam seus domicílios. Independente do ano, o fato de grande parte das casadas chefiarem seus fogos e não os maridos se deve à ausência destes, o que parece ter sido comum.

Dentre outros casos, encontramos Leonor Pereira que, aos 50 anos em 1808, vivia com um filho e uma agregada e entre as observações ligadas a seu fogo encontramos "marido ausente há 15 anos". No mesmo ano Escolástica Maria de 30 anos declarou ser "moradora nova" e estar seu "marido ausente"(cf. Lista Nominativa de Jundiaí, 1808 - AESP, Maços de População/rolo 108), assim como ainda acontecia em 1812 em que a dita fiandeira Escolástica Maria, natural de Bragança, declarou novamente marido ausente. Já em 1822 encontramos o fogo em que Maria Antonia, de 30 anos de idade, dividia com o filho Manoel (seis anos) e declarou "vive encostada com seu pai marido ausente". (Lista Nominativa de Jundiaí, 1822 - AESP, Maços de População/rolo 110) 
Tabela $\mathbf{l . 1 0}$

Composição dos chefes de fogo de acordo com estado conjugal e sexo - exclusive indivíduos de até 14 anos (Jundiaí - 1799 a 1830)

\begin{tabular}{|c|c|c|c|c|c|c|c|c|c|}
\hline \multirow{2}{*}{ Anos } & \multicolumn{3}{|c|}{ Homens } & \multicolumn{3}{|c|}{ Mulheres } & \multicolumn{3}{|c|}{ Homens + Mulheres } \\
\hline & $\begin{array}{c}\text { Casados } \\
\%\end{array}$ & $\begin{array}{c}\text { Solteiros } \\
\%\end{array}$ & $\begin{array}{c}\text { Viúvos } \\
\%\end{array}$ & $\begin{array}{c}\text { Casadas } \\
\%\end{array}$ & $\begin{array}{c}\text { Solteiras } \\
\%\end{array}$ & $\begin{array}{c}\text { Viúvas } \\
\%\end{array}$ & $\begin{array}{c}\text { Casados } \\
\%\end{array}$ & $\begin{array}{c}\text { Solteiros } \\
\%\end{array}$ & $\begin{array}{c}\text { Viúvos } \\
\%\end{array}$ \\
\hline 1799 & 86,3 & 7,5 & 6,1 & 3,6 & 22,6 & 73,7 & 70,3 & 10,5 & 19,2 \\
\hline 1803 & 86,1 & 7,4 & 6,4 & 8,2 & 24,5 & 67,3 & 70,6 & 10,8 & 18,5 \\
\hline 1808 & 87,5 & 5,2 & 7,3 & 8,6 & 27,8 & 63,6 & 71,2 & 9,9 & 18,9 \\
\hline 1812 & 90,2 & 5,1 & 4,7 & 10,9 & 30,1 & 59,0 & 75,1 & 9,9 & 15,0 \\
\hline 1816 & 87,7 & 6,1 & 6,1 & 17,0 & 22,2 & 60,8 & 73,2 & 9,4 & 17,3 \\
\hline 1822 & 86,9 & 7,6 & 5,5 & 13,5 & 19,9 & 66,7 & 71,8 & 10,1 & 18,1 \\
\hline 1825 & 33,9 & 33,9 & 32,2 & 7,0 & 33,3 & 59,7 & 17,4 & 33,6 & 49,0 \\
\hline 1830 & 87,1 & 7,4 & 5,5 & 12,5 & 30,0 & 57,5 & 70,6 & 12,4 & 17,0 \\
\hline
\end{tabular}

Consideradas para os livres as idades de acordo com o estado conjugal, acrescendo também a característica sexo temos um percentual bastante reduzido daqueles que com 50 ou mais anos de idade eram solteiros (vide Tabela I.11), ou seja, atingiram esta idade sem jamais terem se casado, estando numa situação que podemos considerar como de celibato definitivo, em que pese a possibilidade de algumas deles viverem em uniões estáveis não legalmente reconhecidas. Entre 1799 e 1830 o percentual devido a estes indivíduos esteve sempre ao redor de $3 \%$, tendo as mulheres apresentado um percentual pouco superior ao calculado para os homens. Eles alçaram ao limite de 2,3\% (1803) e elas 4,5\% (1825), nesta sociedade em que as razões de sexo sempre foram favoráveis às mulheres.

Os homens casados tinham média de idade em torno de 40 anos - menor média 38,5 (1816) e maior média 41,7 (1803) -, ao passo que para as mulheres esta idade era um pouco mais baixa: entre 31,4 (1830) e 34,1, assim como para os homens, em 1803. Uma diferença etária que se manteve em torno de cinco anos. Modas e medianas não apresentaram uma tendência clara ao longo do tempo, tampouco entre homens e mulheres. 
Tabela I.11

Estatísticas para a idade dos livres de acordo com o estado conjugal e sexo (Jundiaí - 1799 a 1830)

\begin{tabular}{|c|c|c|c|c|c|c|c|c|c|c|c|c|}
\hline \multirow[b]{3}{*}{ Idade } & \multicolumn{3}{|c|}{1799} & \multicolumn{3}{|c|}{1803} & \multicolumn{3}{|c|}{1808} & \multicolumn{3}{|c|}{1812} \\
\hline & \multicolumn{3}{|c|}{ Solteiros } & \multicolumn{3}{|c|}{ Solteiros } & \multicolumn{3}{|c|}{ Solteiros } & \multicolumn{3}{|c|}{ Solteiros } \\
\hline & Homens & Mulheres & $\begin{array}{l}\text { Homens + } \\
\text { Mulheres }\end{array}$ & Homens & Mulheres & $\begin{array}{l}\text { Homens + } \\
\text { Mulheres }\end{array}$ & Homens & Mulheres & $\begin{array}{l}\text { Homens + } \\
\text { Mulheres }\end{array}$ & Homens & Mulheres & $\begin{array}{l}\text { Homens + } \\
\text { Mulheres }\end{array}$ \\
\hline$\% 15$ ou mais anos & 32,9 & 34,1 & 33,5 & 29,0 & 32,0 & 30,6 & 28,1 & 31,1 & 29,8 & 27,6 & 32,9 & 30,5 \\
\hline$\% 50$ ou mais anos & 1,9 & 3,3 & 2,6 & 2,3 & 3,8 & 3,1 & 2,1 & 4,0 & 3,2 & 1,9 & 3,5 & 2,8 \\
\hline $\begin{array}{l}\text { Estatísticas para } \\
\text { idade }\end{array}$ & \multicolumn{3}{|c|}{ Casados } & \multicolumn{3}{|c|}{ Casados } & \multicolumn{3}{|c|}{ Casados } & \multicolumn{3}{|c|}{ Casados } \\
\hline Média & 41,4 & 33,0 & 37,2 & 41,7 & 34,1 & 37,9 & 40,0 & 32,9 & 36,4 & 39,1 & 32,1 & 35,5 \\
\hline Moda & 40,0 & 30,0 & 25 e 30 & $25 \mathrm{e}$ & 28,0 & 28,0 & 40,0 & 30,0 & 30,0 & $40 \mathrm{e}$ & 20,0 & 20,0 \\
\hline Mediana & 40,0 & 30,0 & 35,0 & 39,0 & 32,0 & 35,0 & 38,0 & 30,0 & 34,0 & 38,0 & 30,0 & 33,0 \\
\hline \multirow[t]{2}{*}{$\% 50$ ou mais anos } & 30,3 & 11,9 & 21,0 & 29,8 & 13,4 & 21,5 & 23,4 & 12,5 & 17,9 & 24,9 & 12,4 & 18,6 \\
\hline & \multicolumn{3}{|c|}{1816} & \multicolumn{3}{|c|}{1822} & \multicolumn{3}{|c|}{1825} & \multicolumn{3}{|c|}{1830} \\
\hline$\% 15$ ou mais anos & 30,2 & 33,7 & 32,0 & 26,8 & 32,0 & 29,5 & 25,7 & 31,2 & 28,5 & 28,7 & 29,7 & 29,3 \\
\hline$\% 50$ ou mais anos & 1,5 & 3,0 & 2,3 & 2,0 & 3,0 & 2,5 & 1,9 & 4,5 & 3,2 & 2,0 & 3,2 & 2,6 \\
\hline \multirow{2}{*}{$\begin{array}{l}\text { Estatísticas para } \\
\text { idade }\end{array}$} & \multicolumn{3}{|c|}{ Casados } & \multicolumn{3}{|c|}{ Casados } & \multicolumn{3}{|c|}{ Casados } & \multicolumn{3}{|c|}{ Casados } \\
\hline & Homens & Mulheres & $\begin{array}{l}\text { Homens + } \\
\text { Mulheres }\end{array}$ & Homens & Mulheres & $\begin{array}{l}\text { Homens + } \\
\text { Mulheres }\end{array}$ & Homens & Mulheres & $\begin{array}{l}\text { Homens + } \\
\text { Mulheres }\end{array}$ & Homens & Mulheres & $\begin{array}{l}\text { Homens + } \\
\text { Mulheres }\end{array}$ \\
\hline Média & 38,5 & 3,9 & 35,2 & 39,0 & 31,8 & 36,1 & 39,0 & 31,8 & 35,4 & 38,5 & 31,4 & 34,9 \\
\hline Moda & 25,0 & 23,0 & 25,0 & 30,0 & 30,0 & 40,0 & 30,0 & 30,0 & 30,0 & 40,0 & 30,0 & 40,0 \\
\hline Mediana & 37,0 & 29,0 & 32,0 & 37,5 & 30,0 & 34,0 & 37,5 & 30,0 & 32,0 & 38,0 & 30,0 & 33,0 \\
\hline$\% 50$ ou mais anos & 22,5 & 9,2 & 15,8 & 25,2 & 12,1 & 18,6 & 24,0 & 10,8 & 17,4 & 20,8 & 8,4 & 14,5 \\
\hline
\end{tabular}

Fonte: AESP, M aços de População, Jundiaí: anos selecionados 
Consideradas somente as variáveis sexo e idade, temos o Gráfico 1.4 correspondente às pirâmides etárias para os livres da vila de Jundiaí, nos anos selecionados de 1799 a 1830, segundo faixas qüinqüenais de idade. Vê-se, de imediato, que ao longo de todo o período a base da pirâmide é bastante alargada, ou seja, estavam, homens e mulheres, em grande medida em idades de até 10 anos, sendo o retângulo representativo da população de 5 a 9 anos inicialmente mais pronunciado, passando, a partir de 1816 e até 1825 a ter maior representatividade a faixa etária anterior. A cúspide da pirâmide, referente à população com 70 ou mais anos de idade, apresenta um ligeiro alargamento em seu topo relativo à população de mais de 60 anos.

\section{Gráfico 1.4}

\section{Pirâmides etárias da população livre}

\section{(Jundiaí - 1799 a 1830)}

\section{9}
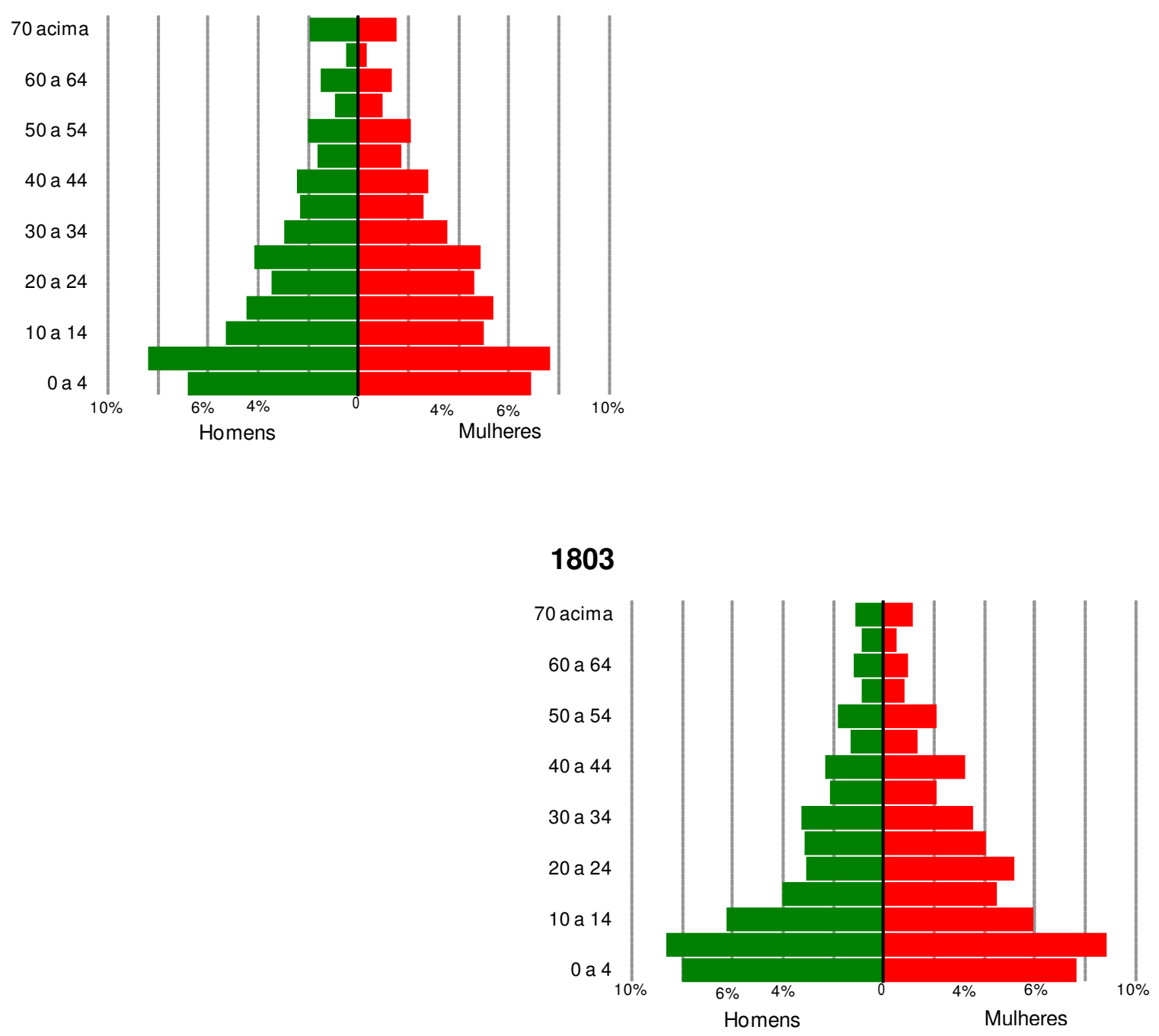
1808
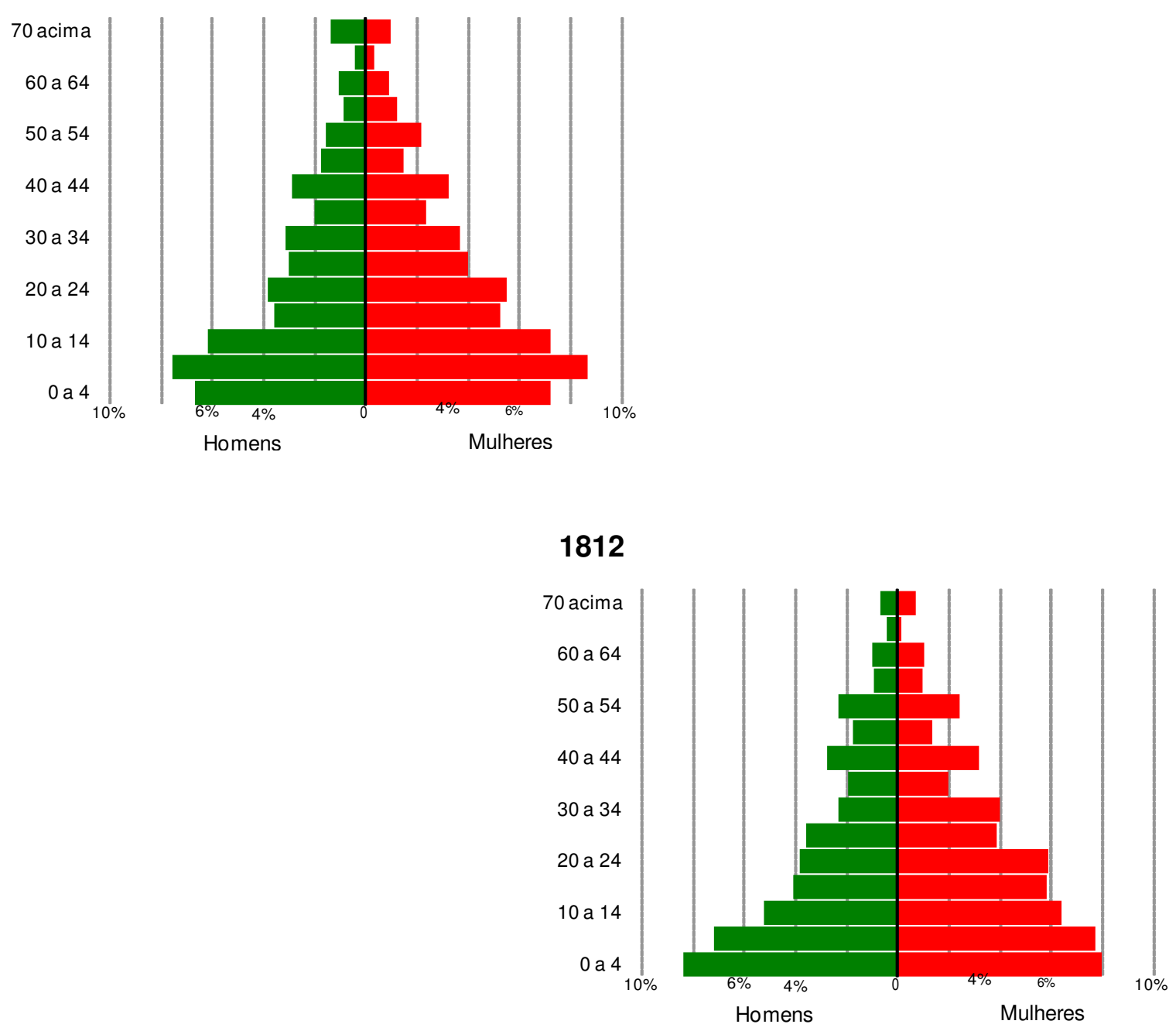

1816

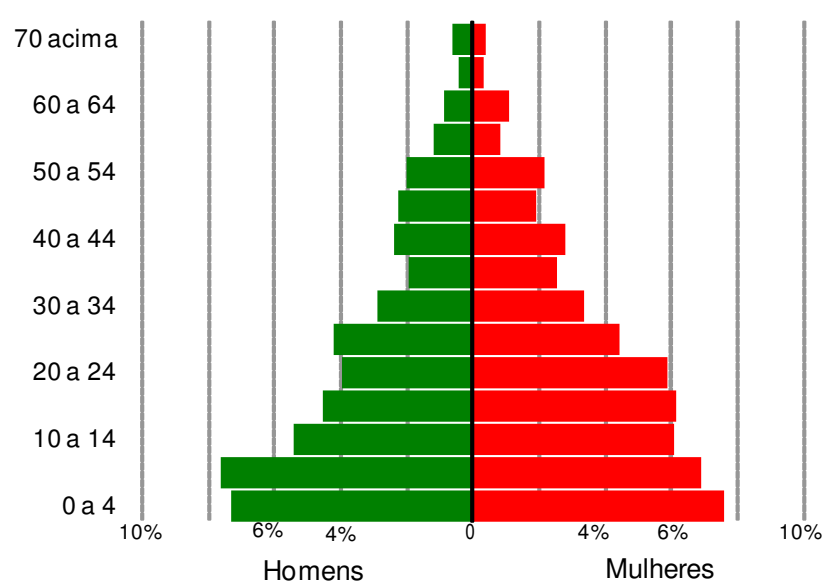


1822

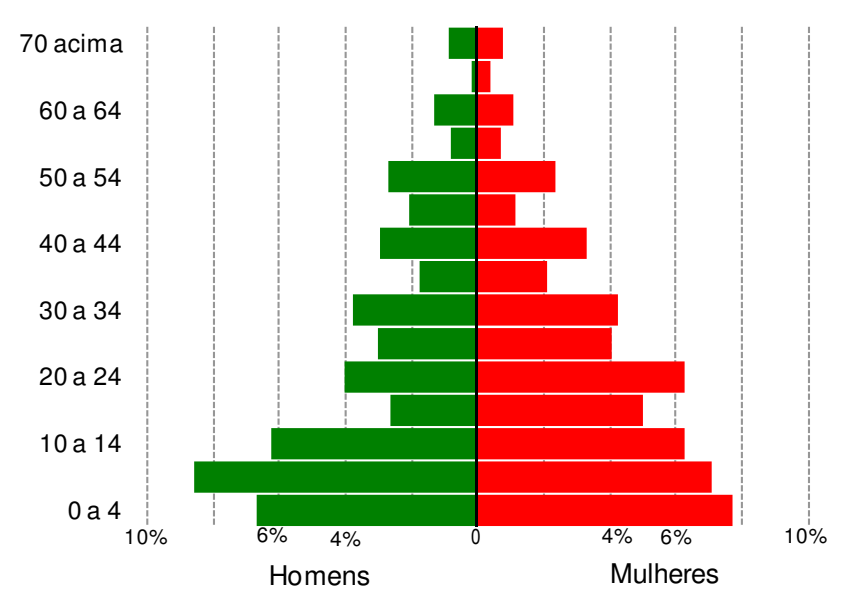

1825

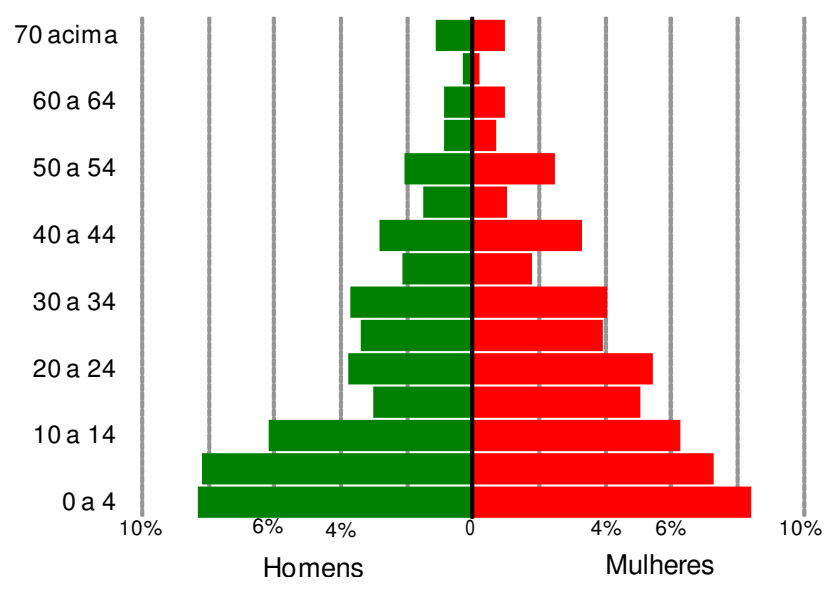

1830

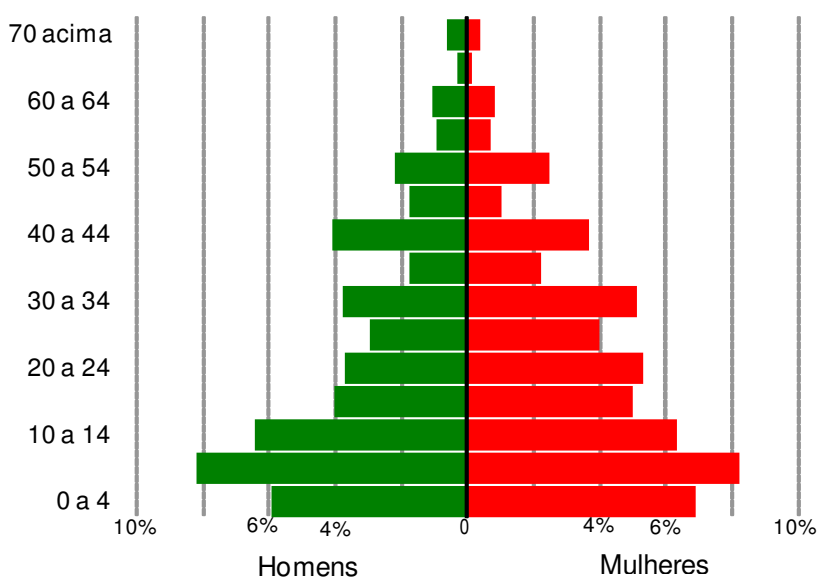


Em regra as pirâmides apresentaram participação decrescente ao longo das faixas etárias, mas a parcela da população entre 40 e 44 anos foi sempre bastante pronunciada, especialmente em detrimento à faixa imediatamente anterior; apenas em 1830 a razão de sexo entre esses indivíduos foi favorável aos homens, 112, 8 , tendo sempre se mantido abaixo dos 90 nos demais anos. A faixa etária 45-49 anos, a sua vez, apresentou razão de sexo favorável aos homens (exceção 1779, 94,4\%) e crescente no período: em 1803 era de 102, 134 em 1812 e 171,1 em 1830.

As pirâmides etárias dos livres de Jundiaí parecem apontar, então, para uma população com consideráveis índices de natalidade ${ }^{13}$ e elevada mobilidade, uma vez que a interpretação de pirâmides etárias não pode desconsiderar a migração que se ocorrer com uma especificidade etária ou sexual afetará consideravelmente sua forma, corroborando os dados apresentados para a origem da população anteriormente considerados.

Características atinentes a sexo e idade apresentadas para os livres não se repetiam entre a parcela não-livre da população, que, ao ver-se em grande medida afetada pela migração - qual seja, a entrada maciça de cativos caracterizados, tipicamente, por serem homens jovens - sofreu menor influência de sua capacidade de crescimento natural na determinação dessas características.

Foram claramente disformes as pirâmides etárias dos cativos em Jundiaí ao longo de todo o lapso 1799-1830. A base estreita aponta para uma possível, porém não muito significativa reprodução natural da população cativa. Por outro lado, chama atenção a grande presença indivíduos homens, especialmente entre 15 e 30 anos, idades em que podemos considerar os cativos bastante produtivos. Essa ampliação ocorreu especialmente a partir de 1803, quando os homens de 15 a 24 anos eram quase $19 \%$ de toda a massa cativa encontrada na vila. Tal presença acentuou-se com o passar dos anos e em 1822, chegou a $25 \%$ (14,7\% entre 20 e 24 anos), ou seja, um quarto da escravaria jundiaense era composta por homens jovens, com idades entre 15 e 24 anos.

\footnotetext{
${ }^{13}$ Não é confiável verificar o número exato de filhos por mulher, uma vez que em elevado número de fogos os filhos descritos eram de outros casamentos ou os filhos mencionados não eram a totalidade deles, pois alguns já teriam deixado o domicílio paterno/materno, mas podemos criar uma proxy utilizando a razão criança/mulher, apresentada em tabela no apêndice estatístico. A razão entre o número de crianças (0-4 ou 0-9 anos) e o número de mulheres em idade reprodutiva, que aqui consideramos 15-39 ou 15-44 anos, tem sido amplamente utilizada pela historiografia como indicador para o nível reprodutivo de determinadas populações, e se refere ao número de crianças para cada 1000 mulheres. As razões calculadas para Jundiaí foram bastante variáveis ao longo do tempo e consideráveis: entre as razões 0-9/15-44, temos um mínimo de 1154,9 em 1830 e no outro extremo 1460,4 em 1803.
} 


\section{Gráfico I.5}

Pirâmides etárias da população escrava

$$
\text { (Jundiaí - } 1799 \text { a 1830) }
$$

1799

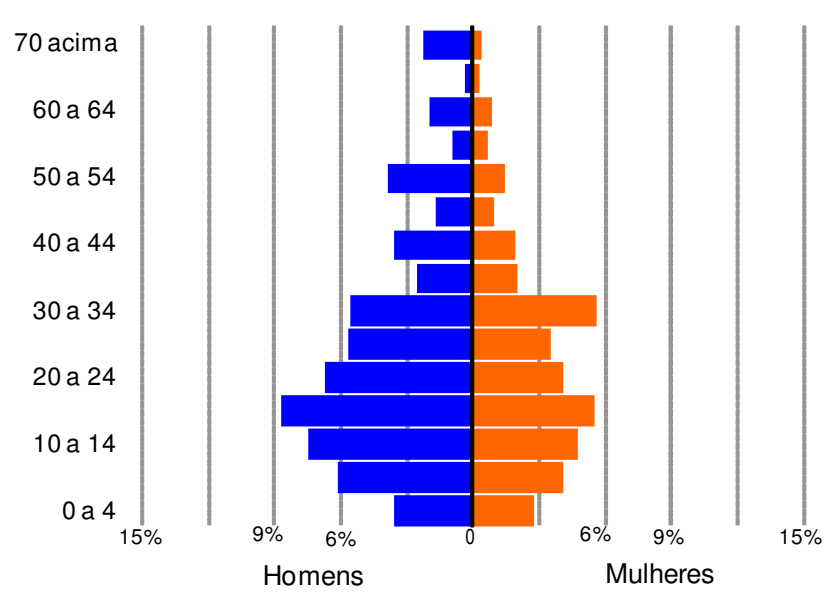

1803

70 acima
60 a 64
50 a 54
40 a 44
30 a 34
20 a 24
10 a 14
0 a 4

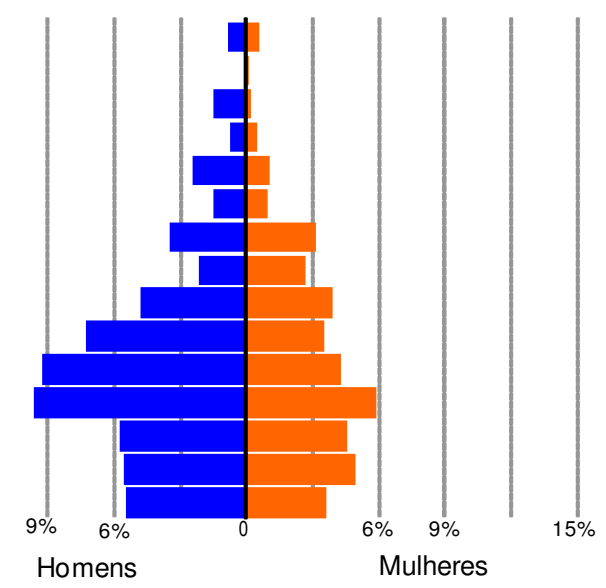

1808

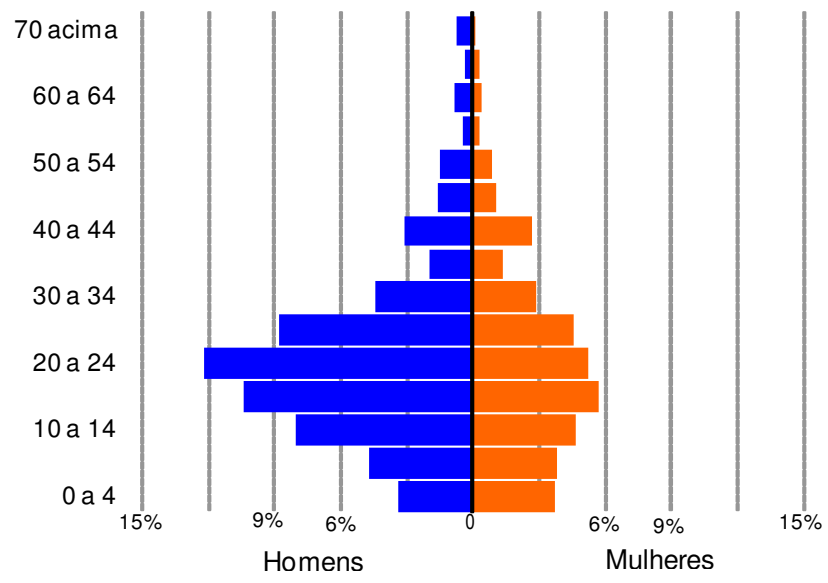


1812

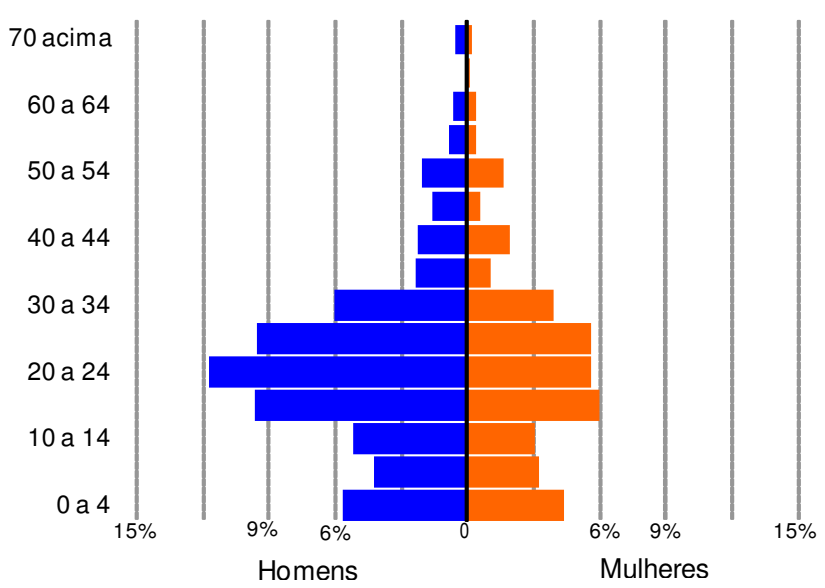

\section{6}

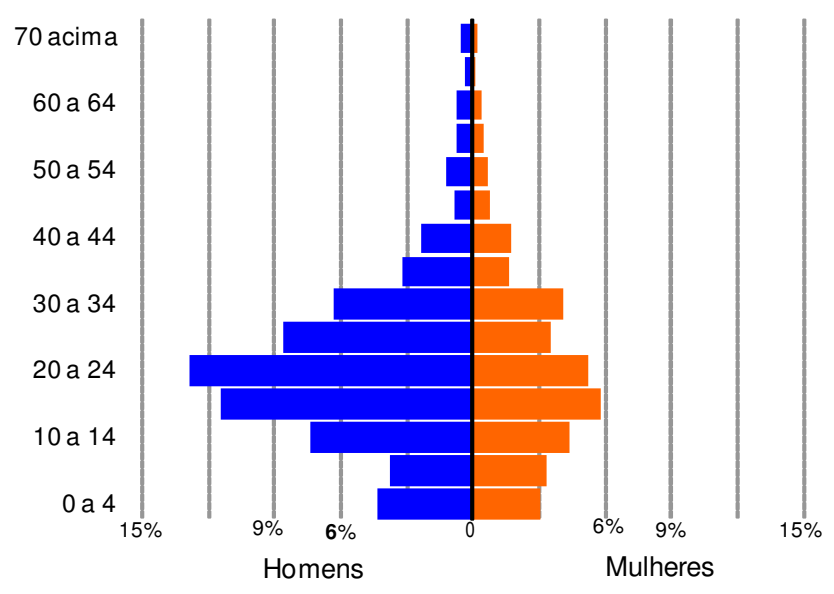

1820

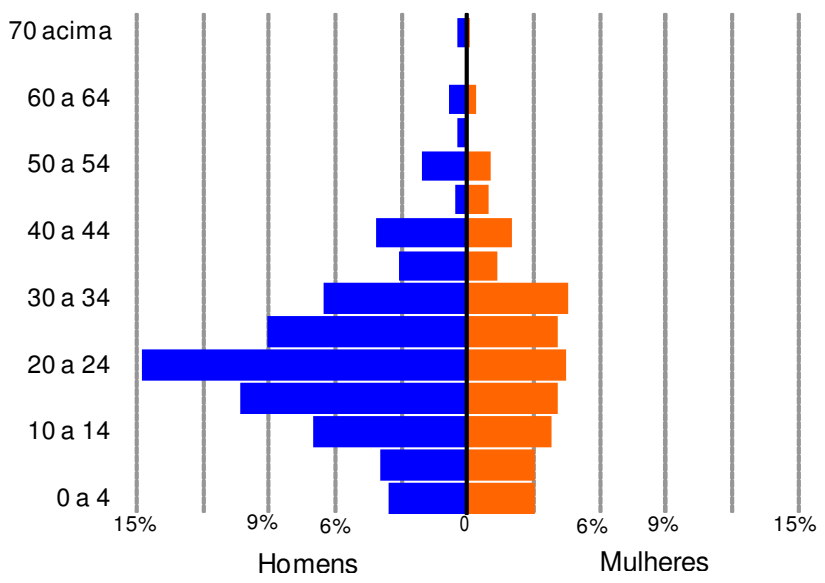


1825

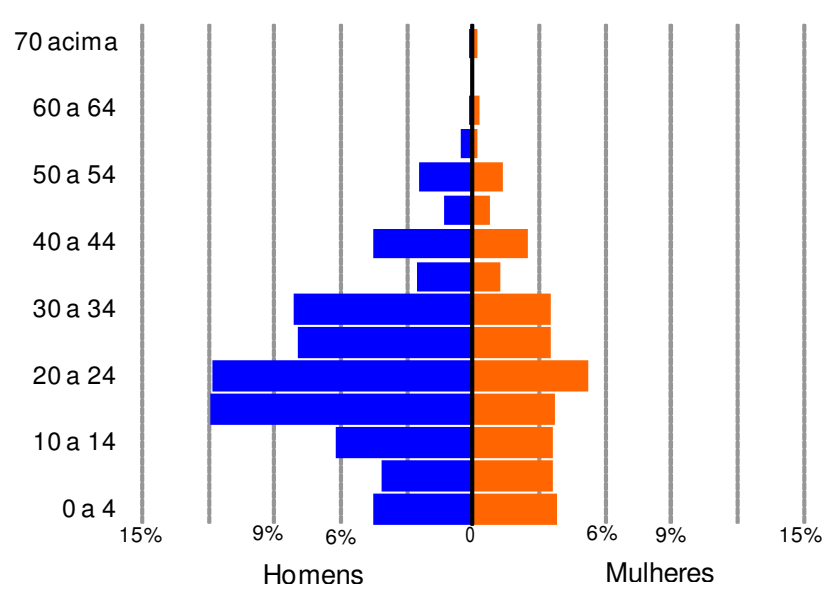

1830

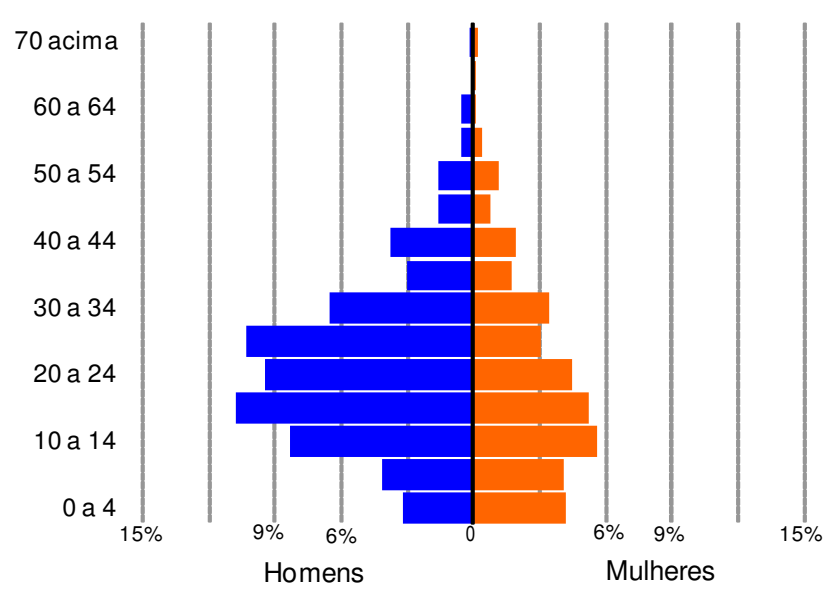

Transportando os dados atinentes ao gênero das pirâmides etárias para o Gráfico I.6, obtemos as diferentes razões entre os sexos dos cativos de Jundiaí, observados também de acordo com o tamanho da massa cativa encontrada nos fogos, pequena ( 1 a 5 escravos) ou muito grande (acima de 20 pessoas).

Para o total de escravos com sexo identificado, observamos elevadas proporções favoráveis aos homens, acentuadas com passar dos anos. Em 1799 eram 152,4 homens para cada grupo de 100 mulheres, ao final do período eram 173,7 homens para 100 mulheres, após um pico de 198,1 naquele ano de 1822. 


\section{Gráfico 1.6}

Razão de sexo dos cativos de acordo com faixas

de tamanho dos plantéis

$$
\text { (Jundiaí - } 1799 \text { a 1829) }
$$

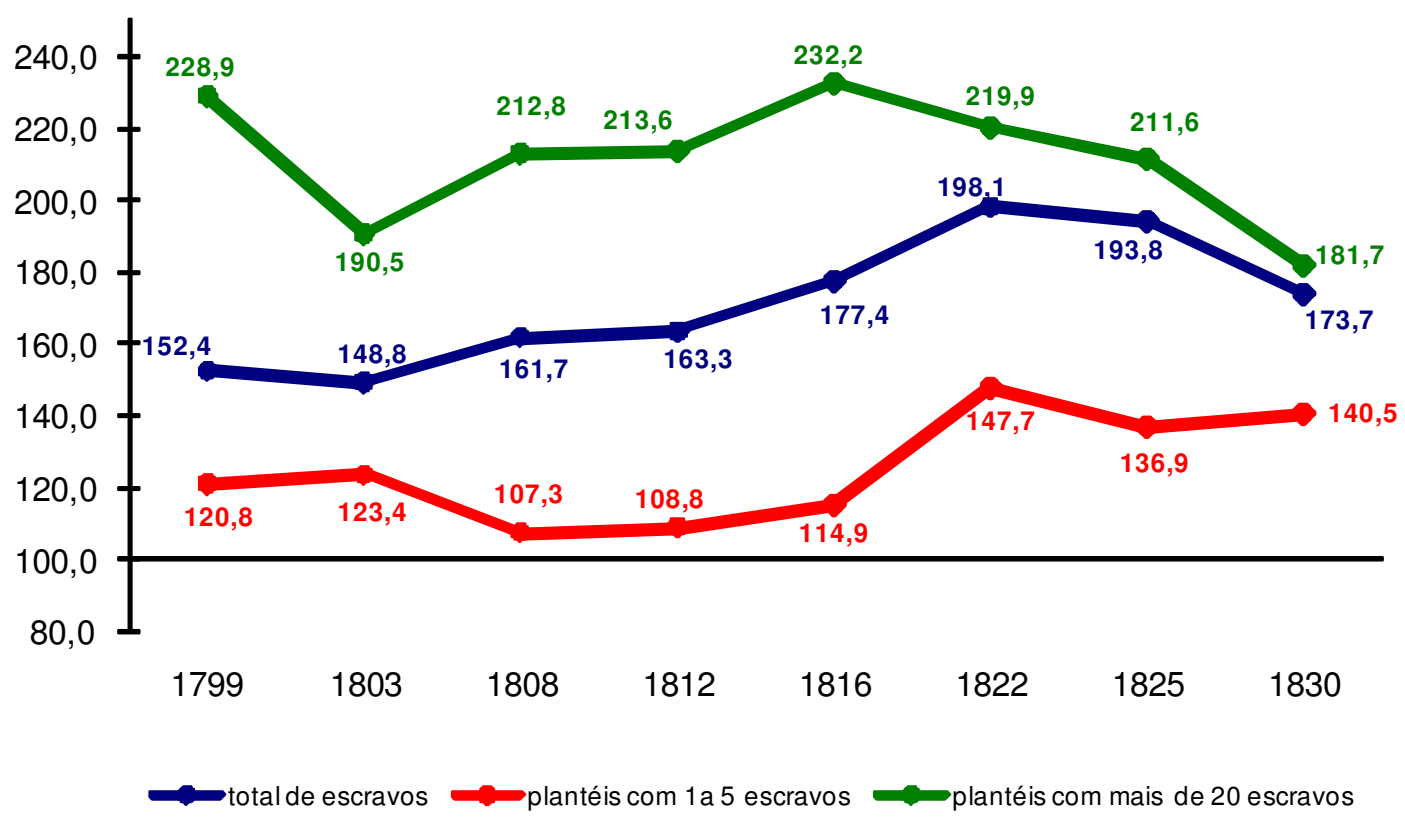

Essa proporção via-se ainda mais acentuada entre cativos sitos em plantéis muito grandes que apresentaram, diferente do verificado para a população cativa em seu conjunto, proporção entre os sexos tendente à queda ao longo do tempo. Era de 229,8 a razão entre os sexos em 1799, 232,2 em 1816 e ao final do lapso considerado a razão, 181,7 , foi próxima àquela apontada para os indivíduos em foco no seu conjunto. A sua vez, os escravos em companhia de outros poucos, também mostraram proporções favoráveis aos homens, todavia, com máximo em 147,7, inferior ao mínimo das outras duas séries apresentadas.

Por fim, resta-nos tecer comentários acerca da cor dos habitantes livres da Jundiaí Setecentista/Oitocentista (análise que, obviamente, não se estende ao escravos por serem sempre de origem africana negra). Em 1799 e 1825 encontramos a população dividida entre brancos, mulatos e pretos, nos demais anos a especificação apresentada era brancos, pardos e negros (Tabela I.12). De acordo com Marcílio (2000, p.118):

Nas estatísticas demográficas da época, bem como nos censos nominativos, distinguiam-se fundamentalmente três grupos étnicos: o branco, o negro e o pardo. Por várias evidências, posso supor que o caboclo - descendente de índio e português - era declarado no grupo dos brancos. Como "pardos" eram tomados apenas os indivíduos mesclados, em alguma graduação, sendo predominante 0 
"mulato". Pardo e mulato são quase sinônimos. Insignificantes eram as proporções de indivíduos frutos de cruzamentos de índios com negros.

As listas nominativas apontam para todos os anos maior parte da população constituída por brancos. Mas a parcela a eles devida foi variável ao longo dos anos: em $1799,77 \%$ dos livres foram anotados como brancos, percentual que se manteve entre $46 \%-48 \%$ entre os anos 1803 e 1816 , voltando a crescer nos momentos seguintes, em que se situou entre $54,2 \%$ (1825) e praticamente 60\% (1822 e 1830), sendo sabida a grande entrada de africanos em São Paulo entre 1808 e 1836. Ainda no Setecentos, notese, foram arrolados 126 carijós - ao que parece, últimos remanescentes da utilização da mão-de-obra dos negos da terra -, não considerados na construção da Tabela; se anotados entre os não brancos, reduziriam a participação dos brancos a $72,7 \%$, percentual ainda bastante elevado, especialmente se considerados os demais anos.

Tabela I.12

Distribuição da população livre entre brancos e não brancos (Jundiaí - 1799 a 1830)

\begin{tabular}{|c|c|c|c|c|c|}
\hline \multirow{3}{*}{ Anos } & \multirow{3}{*}{$\begin{array}{l}\text { Brancos } \\
\text { \% (№) }\end{array}$} & \multicolumn{3}{|c|}{ Não Brancos } & \multirow{3}{*}{$\begin{array}{c}\text { Total: Brancos } \\
\text { + Não brancos } \\
\text { \% (№) }\end{array}$} \\
\hline & & Pardos/Mulatos & Negros/Pretos & Total & \\
\hline & & \% (№) & \% (№) & \% (№) & \\
\hline $1799^{*}$ & $77,0(1627)$ & 65,8 (320) & 34,2 (166) & $23,0(486)$ & $100,0(2113)$ \\
\hline 1803 & $46,0(1721)$ & $97,8(1976)$ & $2,2(44)$ & $54,0(2020)$ & $100,0(3741)$ \\
\hline 1808 & $45,0(1507)$ & 97,7 (1797) & $2,3(43)$ & $55,0(1840)$ & $100,0(3347)$ \\
\hline 1812 & $46,6(1767)$ & 97,8 (1978) & $2,2(45)$ & $53,4(2023)$ & $100,0(3790)$ \\
\hline 1816 & $48,1(1815)$ & $96,3(1886)$ & $3,7(72)$ & $51,9(1958)$ & 100,0 (3773) \\
\hline 1822 & $60,1(1915)$ & $99,0(1258)$ & $1,0(13)$ & $39,9(1271)$ & $100,0(3186)$ \\
\hline 1825 & $54,2(2043)$ & $97,6(1682)$ & $2,4(42)$ & 45,8 (1724) & $100,0(3767)$ \\
\hline 1830 & 60,2 (2215) & $96,6(1413)$ & $3,4(50)$ & $39,8(1463)$ & $100,0(3678)$ \\
\hline
\end{tabular}

É notável o clareamento dos não brancos a partir de 1803, cuja participação dos negros entre eles passa a ser de ínfimos $2,2 \%$, não chegando a $4 \%$ nas décadas seguintes, enquanto havia sido de consideráveis 34,2\% em 1799. Decerto, essa mudança não foi efetiva, tendo sido mais padrão social, especialmente de estratificação (julgandose o pardo/mulato melhor que o negro/preto), do que fato. 


\section{Bragança}

As listas nominativas da Vila Nova de Bragança, consideradas aqui aquelas datadas de 1799 a 1830, fornecem informações detalhadas sobre a população bragantina em cada um dos momentos e sua análise conjunta nos leva às flutuações e mudanças ocorridas nas características demográficas desta sociedade.

Conforme exposto no Gráfico I.7 e na Tabela I.13, no intervalo entre 1799 e 1830 a população total de Bragança viu-se bastante ampliada, saltando de 5600 habitantes naquele primeiro ano para 10272 indivíduos cerca de 30 anos depois, um crescimento de $83,4 \%$, correspondente a uma mudança média de $2 \%$ ao ano. O contingente populacional bragantino apresentou alta acentuada até 1811, ano ao qual chegou composto por 8702 pessoas, já um crescimento da ordem de $55,4 \%$ em se detendo no ano inicial. Após uma considerável redução de $14,5 \%$ entre 1811 e 1816, a tendência ao crescimento foi retomada, voltando a população a um número próximo ao de 1811 em 1826 (8667 almas), ultrapassando, como supracitado, os dez mil indivíduos em 1830, sendo o crescimento registrado de $32,4 \%$ entre os anos 1816 e $1830 .{ }^{14}$ Essa mudança de longo prazo foi superior àquela verificada para a capitania/província de São Paulo em período semelhante: $77,2 \%$ entre 1798 e 1828 .

O crescimento verificado foi em boa medida devido ao avanço da população cativa que saltou de 439 pessoas em 1799, para mais mil em 1816, 1714 em 1826 e 2127 em 1830, incremento de $385 \%$. Em nenhum momento a população cativa decresceu tendo, inclusive, crescido 20,9\% quando da redução da população total entre 1811 e 1816.

Considerada em separado, a população livre mostrou evolução ao longo do tempo bastante semelhante à verificada para a população total, apresentando as curvas exatamente o mesmo formato, mas com variações percentuais ocorrendo em menores proporções - vale notar, assim como o fizemos anteriormente para Jundiaí, sendo a

\footnotetext{
${ }^{14}$ Os dados encontrados nos resumos que acompanham as listas nominativas eram, para todos os anos em que foram encontrados, bastante distintos daqueles apurados com a leitura da lista em sua totalidade; em regra, os resumos apresentam montantes superiores para a população total. Os números absolutos encontrados nos resumos foram colocados na tabela a seguir.

\begin{tabular}{l|l|l|l|l|l|l|l|l|l|l|l|l|l|l}
\hline \hline $\mathbf{1 7 9 8}$ & $\mathbf{1 7 9 9}$ & $\mathbf{1 8 0 7}$ & $\mathbf{1 8 1 0}$ & $\mathbf{1 8 1 1}$ & $\mathbf{1 8 1 2}$ & $\mathbf{1 8 1 8}$ & $\mathbf{1 8 2 0}$ & $\mathbf{1 8 2 2}$ & $\mathbf{1 8 2 5}$ & $\mathbf{1 8 2 6}$ & $\mathbf{1 8 2 7}$ & $\mathbf{1 8 2 8}$ & $\mathbf{1 8 2 9}$ & $\mathbf{1 8 3 0}$ \\
\hline 6044 & 6319 & 8865 & 9509 & 9078 & 9613 & 10239 & 10615 & 11287 & 11875 & 11580 & 13569 & 13033 & 13607 & 13589 \\
\hline \hline
\end{tabular}

Fonte:AESP, M aços de População, Bragança - Resumos

Ainda que distintos, os números corroboram a observação posta acerca da evolução numérica dos habitantes de Bragança, qual seja, o grande crescimento da população total ao longo do lapso estudado. Os resumos apontam um aumento muitíssimo elevado, 225\% entre 1798 e 1830, estando a população em torno de 6 mil habitantes no Setecentos, chegando aos 10 mil na década de 1810 e superando os onze mil indivíduos na primeira metade da década seguinte e alcançando cerca de 13500 ao final do período, quando subiu acima de $17 \%$ em um lustro.
} 
observação válida também para as demais localidades a serem estudadas, que os forros, ainda que representassem parcela com características específicas dentre os livres, estão sendo considerados sem nenhuma distinção, posto serem explicitados de maneira diminuta, ou melhor, ser praticamente ignorada sua referência: contamos 23 declarações em 1799, sendo quatro observações em 1803, três em 1808, 1811 (5), 1816 (6), 1820 (5), 1826 (4) e 1829 (1).

Assim, em Bragança era comparativamente pequena a influência da população cativa nos movimentos ao longo dos anos dos habitantes em sua totalidade. Ou seja, a população foi crescente ao longo dos anos, sendo sua variação determinada especialmente pelas mudanças na população livre. As grandezas da população total e livre, no entanto, foram se distanciando ao longo do tempo, pois o crescimento do número de escravos foi muitas vezes superior ao verificado para não cativos.

\section{Gráfico 1.7}

\section{Evolução (em valores absolutos) da população total,} população livre e escravos

\section{(Bragança - 1799 a 1830)}

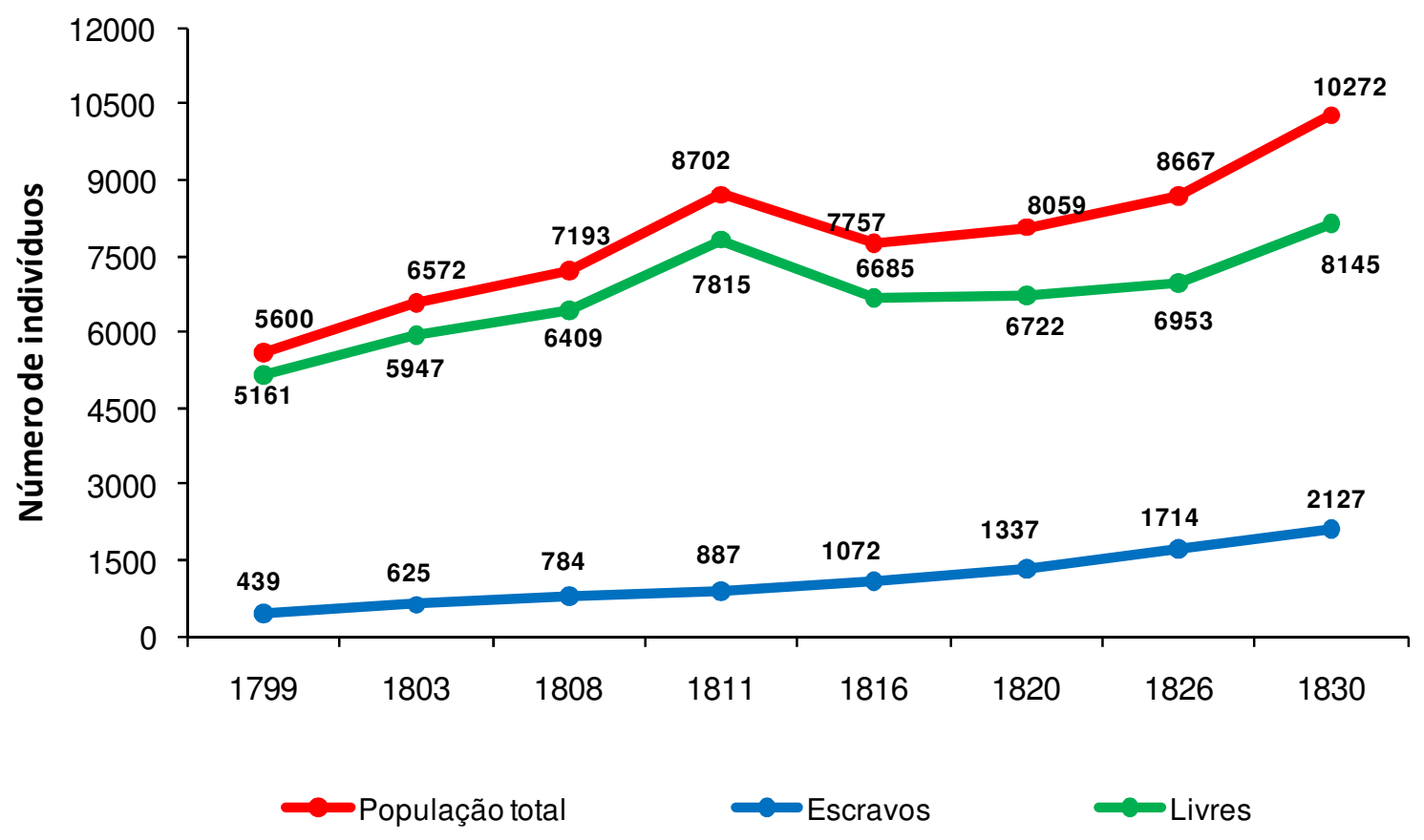


Tabela I.13

Variação da população total, população livre e escravos

(Bragança - 1799 a 1830, São Paulo - 1798 a 1828)

\begin{tabular}{|c|c|c|c|c|c|}
\hline \multicolumn{4}{|c|}{ Bragança Paulista } & \multicolumn{2}{|c|}{ Província São Paulo* } \\
\hline Anos & $\begin{array}{l}\text { Variação \% da } \\
\text { população total }\end{array}$ & $\begin{array}{l}\text { Variação \% da } \\
\text { população livre }\end{array}$ & $\begin{array}{l}\text { Variação \% da } \\
\text { população } \\
\text { cativa }\end{array}$ & Anos & $\begin{array}{l}\text { Variação \% da } \\
\text { população total }\end{array}$ \\
\hline $1799-1803$ & 17,4 & 15,2 & 42,4 & $1798-1800$ & 4,4 \\
\hline $1803-1808$ & 9,4 & 7,8 & 25,4 & $1800-1808$ & 15,7 \\
\hline $1808-1811$ & 21,0 & 21,9 & 13,1 & $1808-1818$ & 13,0 \\
\hline $1811-1816$ & $-10,9$ & $-14,5$ & 20,9 & $1818-1822$ & 10,3 \\
\hline $1816-1820$ & 3,9 & 0,6 & 24,7 & $1822-1828$ & 17,7 \\
\hline $1820-1826$ & 7,5 & 3,4 & 28,2 & $1798-1818$ & 36,5 \\
\hline $1826-1830$ & 18,5 & 17,1 & 24,1 & $1818-1828$ & 29,8 \\
\hline $1799-1816$ & 38,5 & 29,5 & 144,2 & $1798-1828$ & 77,2 \\
\hline $1816-1830$ & 32,4 & 21,8 & 98,4 & & \\
\hline $1799-1830$ & 83,4 & 57,8 & 384,5 & & \\
\hline
\end{tabular}

*Valores calculados a partir dos dados apresentados por M arcílio (2000, p.71), inclui Paraná

*^Fonte: AESP, M aços de População, Bragança: anos selecionados

\section{Gráfico I.8}

Participação de livres e escravos na população

(Bragança - 1799 a 1830)

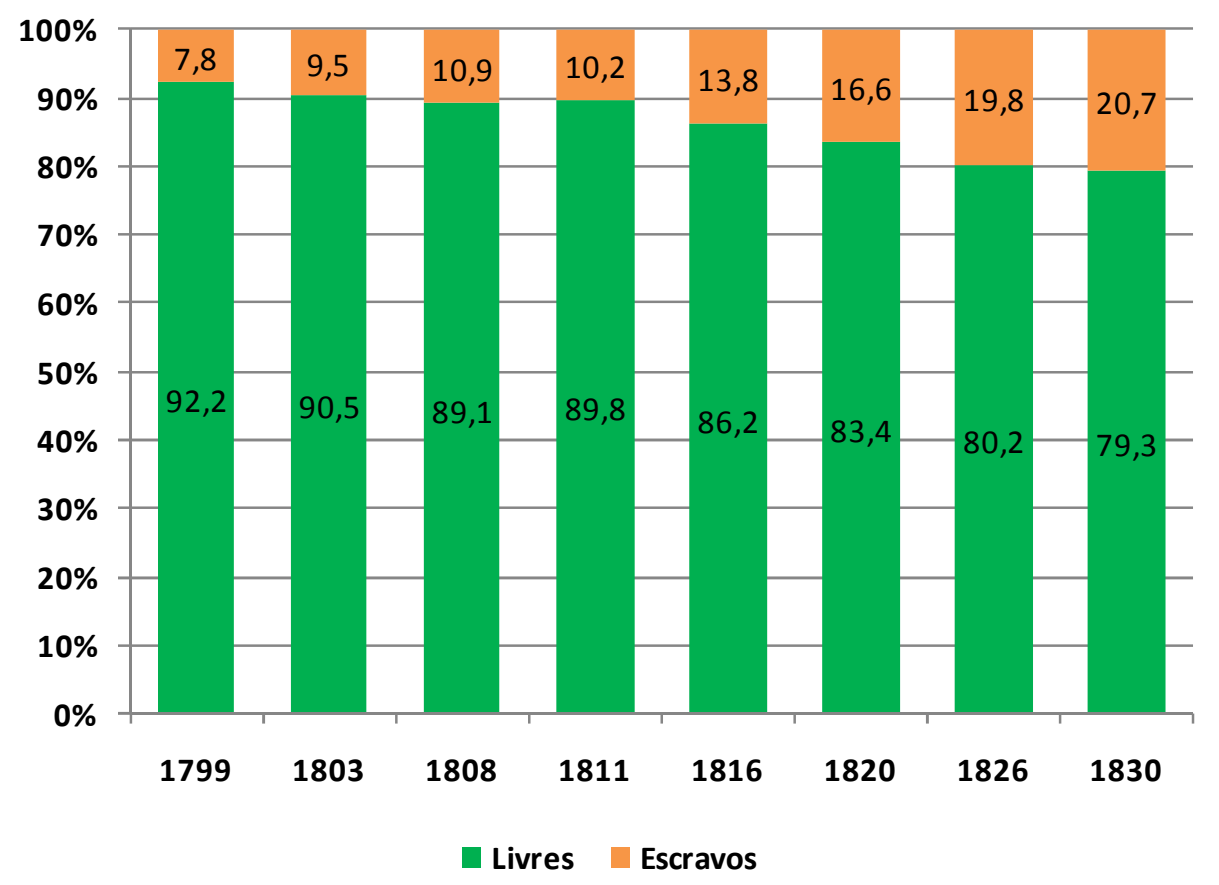


Esse crescimento diferenciado entre livres e cativos modificou a participação devida a cada grupo na população (Gráfico I.8). Em 1799 os livres eram 92,2\% dos habitantes da Vila Nova de Bragança, percentual mantido ao redor de 90\% entre 1803 e 1811, chegando a 83,4\% em 1820 e 79,3\% uma década depois. É dizer, os cativos eram em 1799 7,8\% da população, foram aumentando paulatinamente sua participação e, ao fim do período considerado, 1830, haviam ampliado consideravelmente presença a pouco mais de um quinto dos habitantes (20,7\%).

Como a população, o número de fogos (916 no primeiro momento) apresentou alta acentuada ao longo do tempo tendo dobrado seu número até 1830, com destaque para o crescimento verificado entre 1799 e 1811: 73,5\%, elevando a quantidade de domicílios a 1589. Observados os intervalos entre os anos considerados, 1808-1811 apresentou a maior elevação do número de fogos, 26,5\%. À exceção de 1816-20 e 1820-26, a quantidade de domicílios oscilou de maneira similar, porém mais acentuada que a população total e livre tendo, inclusive, decrescido entre 1811 e 1816 . O aumento do número dos fogos ocorreu, todavia, de forma bem menos marcante que os escravos (exceto entre 1808-1811).

Tabela 1.14

Variação do número de fogos, presença de livres e escravos nos domicílios

\section{(Bragança - 1799 a 1830)}

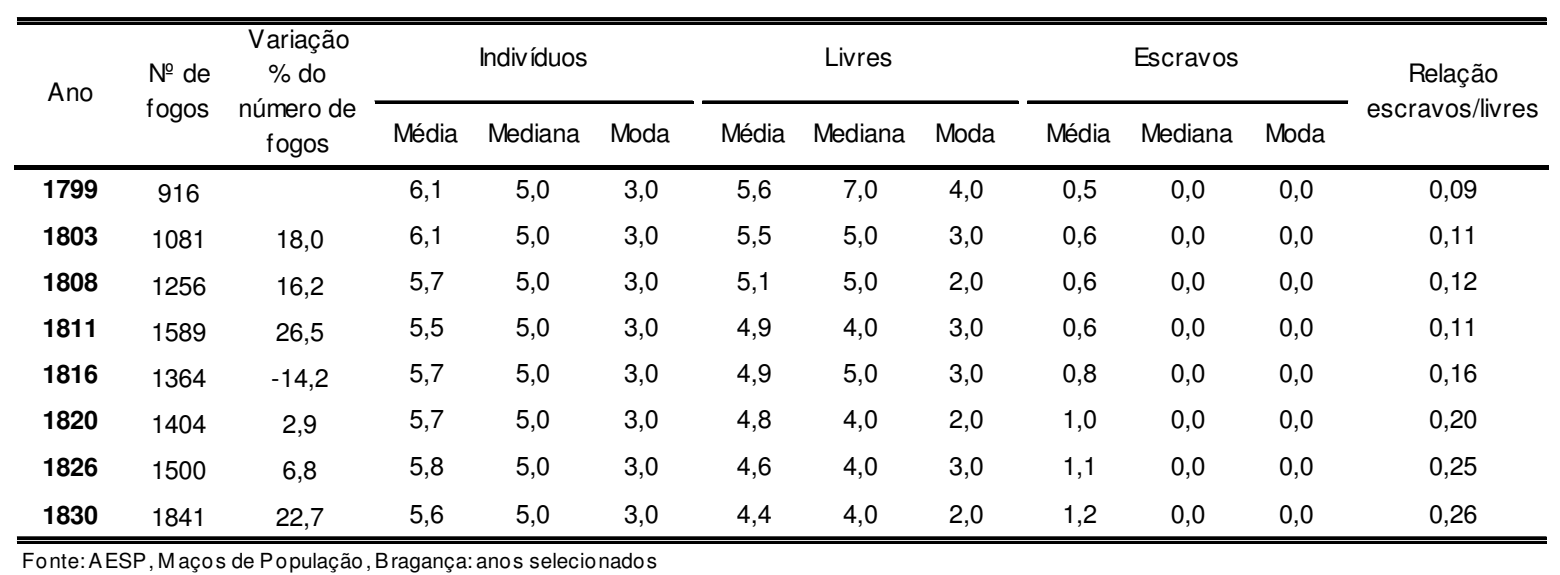

Assim, em 1799 encontramos uma média de 6,1 indivíduos por fogo, estatística sutilmente reduzida ao longo do tempo, chegando a 5,6 em 1830, não representando propriamente uma mudança no padrão verificado para o tamanho dos domicílios. 0 
mesmo ocorreu com a média de livres que caiu de 5,6 para 4,4 entre os extremos analisados, pouco mais acentuada que a mudança da população. Os cativos, a sua vez, eram 0,5 por domicilio em 1799, chegando a 1 em 1820 e 1,2 uma década depois. Esses dados são apresentados na Tabela I.14.

A tendência ao crescimento da população parece ter continuado na década seguinte, uma vez que Müller (1923, p.138) aponta para Bragança em 1816 uma população total de 11618 pessoas, sendo mantida a composição verificada ao início da década: $20,8 \%$ escravos e $79,2 \%$ livres. Comparando-se os dados apresentados por Müller àqueles por nós levantados, encontramos crescimento de 12,7\% para os livres e $14,7 \%$ para os cativos entre 1830 e 1836. De maneira diversa ao observado até então, estes bragantinos de 1836 estariam distribuídos por apenas 969 fogos, número correspondente ao verificado ao fim do Setecentos e a uma elevada média de 12 pessoas por domicílio.

Os escravos tiveram aumentada não só sua participação entre a população ao longo do tempo, como também o número de fogos a eles vinculados, como se nota na análise de escravistas e seus plantéis que segue. Observados os dados apresentados nos arrolamentos populacionais bragantinos, observamos que eles englobam informações a respeito de uma população cativa em constante crescimento entre anos de 1799 e 1830, como adiantado.

\section{Gráfico 1.9}

Fogos com e sem escravos

(Bragança - 1799 a 1830)

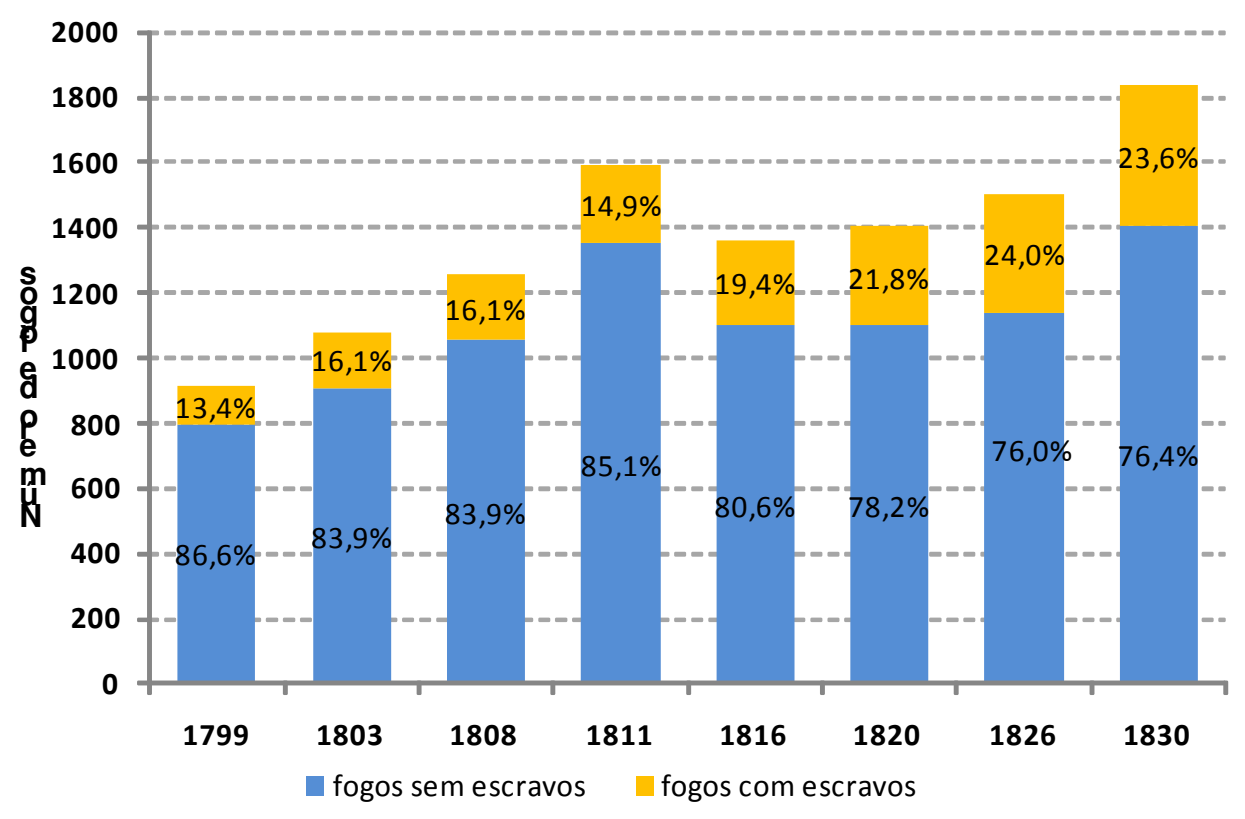


Conforme se vê no Gráfico I.9, em que os fogos descritos em Bragança são apresentados de acordo com a presença ou ausência de escravos, a ampliação do número total de escravos nesta sociedade deu-se, também, com o aumento percentual daqueles fogos em que estes mancípios viviam. Cativos foram encontrados em 13,4\% dos domicílios bragantinos arrolados em 1799; nos anos observados para a primeira década do Oitocentos o percentual foi calculado em $16,1 \%$, estando ao redor de $20-21 \%$ em 1816 e 1820, e nos dois anos finais considerados o percentual havia se elevado $24 \%$ (1826) e 23,6\% (1829), uma variação de dez pontos percentuais. ${ }^{15}$

Seguindo tendência encontrada para a totalidade dos domicílios, eram majoritariamente chefiados por homens os fogos com cativos em Bragança. A participação devida a cada sexo variou dentro de pequeno intervalo entre 1799 e 1826: o menor percentual devido aos homens foi de $88,1 \%$ calculado para 1812 e 1826, enquanto os indivíduos do sexo masculino tiveram sua maior participação ainda no Setecentos, 91,9\%. Esses percentuais correspondem a razões de sexo consideravelmente altas e bastante acima daquelas que conhecemos para as unidades domiciliares em seu conjunto. Em 1799, nos fogos diretamente vinculados à escravidão, encontramos razão de 1130, sendo de 661,7 a proporção para os fogos em seu conjunto; em 1811 e 1820, a diferença foi semelhante, 575,5 e 578,3 para o conjunto dos chefes, e 815,4 e 827,3 para as amostras mais reduzidas, em sequência nos anos de 1811 e 1820.

Ou seja, era essencialmente masculina a parcela de indivíduos detentores de cativos, ainda que entre os chefes do sexo masculino tenhamos percentual de escravistas crescente ao longo dos anos, assim como aconteceu com as mulheres. Entre eles, 23,8\% dos chefes haviam declarado escravos em 1799, 28,6\% em 1803, 30-31\% nos dois anos seguinte considerados, 42,2\% passados cinco anos, 53,9\% (1820), 64,2\% (1825) e 65,6\% em 1830. Para o sexo oposto, os escravos apareceram em $27,5 \%$ dos fogos por elas chefiados em 1799, e, 33,5\% não ano de 1803, 36,3\% em 1811, 29,2\% (1816), 42,6\% (1816), 48,5\% (1820), 58,1\% (1825) e 58,7\% em 1830.

No que respeita à quantidade de escravos possuídos, verifica-se, de imediato, a significativa representatividade dos indivíduos com pequeno número deles. De modo geral, até 1811 , entre $80 \%$ (1808) e $85 \%$ (1803) dos escravistas possuía massa cativa composta por um a cinco indivíduos. Esses percentuais foram sendo reduzidos

\footnotetext{
15 Esses fogos nos quais cativos eram encontrados estavam sendo chefiados por indivíduos com idades médias constantemente em torno de 45 anos. No ano inicial observado, assim como no ano final observado e em 1816, a média foi de 43,4-43,8 anos, e em 1803 e 1811 foram encontrados chefes escravistas com idades de 45,8 anos em média. (Os dados mencionados encontram-se em tabela no apêndice estatístico). Todas estas idades médias são superiores àquelas apuradas, mais adiante, para o conjunto dos bragantinos a chefiar domicílios.
} 
gradativamente, chegando a 75,2\% em 1820, 72,8\% em 1825 e, por fim, em 1830 encontramos $68,7 \%$ dos senhores de escravos com plantéis considerados pequenos. (Tabela I.15)

No extremo oposto, os proprietários de 20 ou mais escravos eram representados apenas por Aleixo Correia da Costa com 24 cativos declarados em 1799. A ele somaramse outros dois chefes em 1803. Em 1820 eram sete os indivíduos com escravaria muito grande, número que em 1816 era de 16 indivíduos. Tal variação nominal corresponde a uma ampliação de $1500 \%$ desses indivíduos, que de 0,8\% em 1799 passaram a 3,7\% dos escravistas em 1830.

Tabela I.15

Distribuição de escravistas e escravos de acordo com faixas de tamanho dos plantéis

(Bragança - 1799 a 1830)

\begin{tabular}{|c|c|c|c|c|c|c|c|c|c|c|c|c|}
\hline \multirow{3}{*}{ FTP } & \multicolumn{4}{|c|}{1799} & \multicolumn{4}{|c|}{1803} & \multicolumn{4}{|c|}{1808} \\
\hline & \multicolumn{2}{|c|}{ Escravistas } & \multicolumn{2}{|c|}{ Escravos } & \multicolumn{2}{|c|}{ Escravistas } & \multicolumn{2}{|c|}{ Escravos } & \multicolumn{2}{|c|}{ Escravistas } & \multicolumn{2}{|c|}{ Escravos } \\
\hline & № & $\%$ & № & $\%$ & № & $\%$ & № & $\%$ & № & $\%$ & № & $\%$ \\
\hline 1 a 5 & 102 & 82,9 & 219 & 49,9 & 148 & 85,1 & 341 & 54,6 & 162 & 80,2 & 337 & 43,0 \\
\hline 6 a 10 & 14 & 11,4 & 105 & 23,9 & 18 & 10,3 & 139 & 22,2 & 26 & 12,9 & 191 & 24,4 \\
\hline 11 a 20 & 6 & 4,9 & 91 & 20,7 & 7 & 4,0 & 114 & 18,2 & 11 & 5,4 & 144 & 18,4 \\
\hline Acima 20 & 1 & 0,8 & 24 & 5,5 & 1 & 0,6 & 31 & 5,0 & 3 & 1,5 & 112 & 14,3 \\
\hline Total & 123 & 100,0 & 439 & 100,0 & 174 & 100,0 & 625 & 100,0 & 202 & 100,0 & 784 & 100,0 \\
\hline \multirow{3}{*}{ FTP } & \multicolumn{4}{|c|}{1811} & \multicolumn{4}{|c|}{1816} & \multicolumn{4}{|c|}{1820} \\
\hline & \multicolumn{2}{|c|}{ Escravistas } & \multicolumn{2}{|c|}{ Escravos } & \multicolumn{2}{|c|}{ Escravistas } & \multicolumn{2}{|c|}{ Escravos } & \multicolumn{2}{|c|}{ Escravistas } & \multicolumn{2}{|c|}{ Escravos } \\
\hline & № & $\%$ & № & $\%$ & № & $\%$ & № & $\%$ & № & $\%$ & № & $\%$ \\
\hline 1 a 5 & 193 & 81,4 & 422 & 47,6 & 207 & 78,1 & 428 & 40,0 & 230 & 75,2 & 493 & 36,9 \\
\hline 6 a 10 & 30 & 12,7 & 228 & 25,7 & 36 & 13,6 & 279 & 26,1 & 50 & 16,3 & 367 & 27,4 \\
\hline 11 a 20 & 11 & 4,6 & 153 & 17,2 & 19 & 7,2 & 274 & 25,6 & 19 & 6,2 & 268 & 20,0 \\
\hline Acima 20 & 3 & 1,3 & 84 & 9,5 & 3 & 1,1 & 90 & 8,4 & 7 & 2,3 & 209 & 15,6 \\
\hline Total & 237 & 100,0 & 887 & 100,0 & 265 & 100,0 & 1071 & 100,0 & 306 & 100,0 & 1337 & 100,0 \\
\hline \multirow{3}{*}{ FTP } & \multicolumn{4}{|c|}{1826} & \multicolumn{4}{|c|}{1830} & & & & \\
\hline & \multicolumn{2}{|c|}{ Escravistas } & \multicolumn{2}{|c|}{ Escravos } & \multicolumn{2}{|c|}{ Escravistas } & \multicolumn{2}{|c|}{ Escravos } & & & & \\
\hline & № & $\%$ & № & $\%$ & № & $\%$ & № & $\%$ & & & & \\
\hline 1 a 5 & 262 & 72,8 & 617 & 36,0 & 299 & 68,7 & 696 & 32,7 & & & & \\
\hline 6 a 10 & 63 & 17,5 & 468 & 27,3 & 73 & 16,8 & 541 & 25,4 & & & & \\
\hline 11 a 20 & 27 & 7,5 & 391 & 22,8 & 47 & 10,8 & 477 & 22,4 & & & & \\
\hline Acima 20 & 8 & 2,2 & 238 & 13,9 & 16 & 3,7 & 413 & 19,4 & & & & \\
\hline Total & 360 & 100,0 & 1714 & 100,0 & 435 & 100,0 & 2127 & 100,0 & & & & \\
\hline
\end{tabular}

Fonte:AESP, M aços de População, Bragança: anos selecionados 
As escravarias intermediárias (as médias com 6 a 10 escravos e as grandes, com 11 a 20 pessoas) também ampliaram sua participação. Os plantéis de tamanho médio, sempre o segundo grupo mais representativo, eram 11,4\% em 1799, 13,6\% em 1816 e $17,5 \%$ em 1826. Já os grandes plantéis ampliaram sua presença de $4,9 \%$ no Setecentos a $10,8 \%$ em 1830.

Acompanhando as modificações apontadas para a presença na localidade das diferentes faixas de tamanho de plantel, encontramos a distribuição do número de cativos entre estas faixas, ou seja, decrescente para as menores escravarias e crescente para as demais FTP com o passar dos anos. Parcela majoritária dos cativos sempre esteve nas mãos dos pequenos escravistas, mas em menores medidas que a presença destes chefes e senhores de cativos: em 1803 estavam nesse grupo 54,6\% dos mancípios arrolados, em 1816 eram $40 \%$ deles e ao final do período $32,7 \%$. Nas duas FTP seguintes a variação da participação ainda que crescente foi de pouca monta. E a participação dos plantéis muito grandes na composição da massa cativa bragantina, que havia sido de 5\% nos dois primeiros anos, chegou ao final do período estudado em 19,4\%: um total de 413 escravos, distribuídos por 16 unidades produtivas, implicando em média de 25,8 pessoas em cada uma dessas unidades.

Viram-se, então, modificadas as características de distribuição de escravistas e escravos na Vila de Bragança entre 1799 e 1830, com ampliação do número de proprietários de 6 ou mais mancípios e da representatividade dos cativos por eles possuídos, em detrimento ao menores proprietários; mesmo majoritários, aqueles com até 5 cativos reduziram sua presença percentual e a representatividade numérica de seus cativos.

Tais modificações refletem-se nas estatísticas de posição e concentração encontradas nos diferentes anos para a localidade em tela, conforme apresentado na Tabela I.16.

O primeiro indicador a refletir tal distribuição é o índice de Gini. Seus valores para os anos em apreço estão compreendidos entre 0,466 (1803) e 0,515 (1820), que podem ser considerados indicativos de concentração média dos cativos entre os seus senhores. A média de escravos por proprietário foi de 3,5 em 1799 e 1803, 3,8 nos dois anos seguintes, 4,5 em 1816 e 5,2 em 1830, resultado da ampliação da participação de plantéis maiores. A moda predominante situou-se invariavelmente em um. E quanto à mediana, os números situaram-se em dois ou três; medianas iguais a dois foram encontradas até 1816 e medianas três são características dos anos de 1820, 1825 e 1830. As maiores 
escravarias da localidade tinham, em seu limite, 44 escravos em 1826, número equivalente aos 43 indivíduos encontrados em 1820.

\section{Tabela I.16}

\section{Indicadores estatísticos para a posse de escravos}

(Bragança - 1799 a 1830)

\begin{tabular}{|c|c|c|c|c|c|c|c|c|}
\hline \multirow[b]{2}{*}{ Estatísticas } & \multicolumn{2}{|c|}{1799} & \multicolumn{2}{|c|}{1803} & \multicolumn{2}{|c|}{1808} & \multicolumn{2}{|c|}{1811} \\
\hline & $\begin{array}{c}\text { Total de } \\
\text { fogos }\end{array}$ & Escravistas & $\begin{array}{l}\text { Total de } \\
\text { fogos }\end{array}$ & Escravistas & $\begin{array}{c}\text { Total de } \\
\text { fogos }\end{array}$ & Escravistas & $\begin{array}{c}\text { Total de } \\
\text { fogos }\end{array}$ & Escravistas \\
\hline Média & 0,5 & 3,5 & 0,6 & 3,5 & 0,6 & 3,8 & 0,6 & 3,8 \\
\hline Moda & 0,0 & 1,0 & 0,0 & 1,0 & 0,0 & 1,0 & 0,0 & 1,0 \\
\hline Mediana & 0,0 & 2,0 & 0,0 & 2,0 & 0,0 & 2,0 & 0,0 & 2,0 \\
\hline Desvio padrão & 1,9 & 3,9 & 2,0 & 4,0 & 2,3 & 4,6 & 2,1 & 4,3 \\
\hline Variância & 3,5 & 15,4 & 4,2 & 15,8 & 5,4 & 21,4 & 4,6 & 18,5 \\
\hline Índice de Gini & 0,931 & 0,486 & 0,914 & 0,466 & 0,920 & 0,505 & 0,923 & 0,484 \\
\hline Máximo & \multicolumn{2}{|c|}{24,0} & \multicolumn{2}{|c|}{31,0} & \multicolumn{2}{|c|}{37,0} & \multicolumn{2}{|c|}{36,0} \\
\hline \multirow[b]{2}{*}{ Estatísticas } & \multicolumn{2}{|c|}{1816} & \multicolumn{2}{|c|}{1820} & \multicolumn{2}{|c|}{1826} & \multicolumn{2}{|c|}{1830} \\
\hline & $\begin{array}{c}\text { Total de } \\
\text { fogos }\end{array}$ & Escravistas & $\begin{array}{c}\text { Total de } \\
\text { fogos }\end{array}$ & Escravistas & $\begin{array}{c}\text { Total de } \\
\text { fogos }\end{array}$ & Escravistas & $\begin{array}{c}\text { Total de } \\
\text { fogos }\end{array}$ & Escravistas \\
\hline Média & 0,8 & 4,0 & 1,0 & 4,5 & 1,1 & 4,7 & 1,2 & 5,2 \\
\hline Moda & 0,0 & 1,0 & 0,0 & 1,0 & 0,0 & 1,0 & 0,0 & 1,0 \\
\hline Mediana & 0,0 & 2,0 & 0,0 & 3,0 & 0,0 & 3,0 & 0,0 & 3,0 \\
\hline Desvio padrão & 2,6 & 4,7 & 3,2 & 5,5 & 3,4 & 5,5 & 3,6 & 5,8 \\
\hline Variância & 6,8 & 21,9 & 10,1 & 30,6 & 11,3 & 30,1 & 12,9 & 33,8 \\
\hline Índice de Gini & 0,905 & 0,500 & 0,894 & 0,515 & 0,880 & 0,499 & 0,883 & 0,506 \\
\hline Máximo & \multicolumn{2}{|c|}{35,0} & \multicolumn{2}{|c|}{43,0} & \multicolumn{2}{|c|}{44,0} & \multicolumn{2}{|c|}{38,0} \\
\hline
\end{tabular}

Fonte: AESP, M aços de População, Bragança: anos selecio nados

Não ocorreram variações muito grandes nas estatísticas relacionadas aos cativos nos fogos, mas o número de domicílios escravistas que, como vimos, passou de 123 $(13,4 \%)$ em 1799 a $(23,6 \%)$ em 1830, levou ao concomitante incremento do número e da participação de livres ligados a estes indivíduos, como mostrado na Tabela I.17: em 1799 $16,4 \%$, percentual que, especialmente a partir de 1816 foi sempre superior a $20 \%$, chegando ao máximo de 25,3\% em 1825.

A presença de cativos elevou a média de pessoas por fogo que se manteve em torno de $9-10 \%$ superior ao verificado anteriormente para o total de fogos e ao calculado para os fogos compostos apenas por livres, que teve seu mínimo em 1830 (4,4 pessoas) e máximo em 1799-1803 (5,4 pessoas). Considerados apenas os livres, fogos com e sem a presença de escravos apresentaram número de indivíduos decrescente e mais próximo com o passar dos anos. Em 1799 eram 5,4 habitantes em domicílios sem escravos e 6,9 naqueles com algum plantel, médias que passaram, respectivamente, a 4,8 e 5,3 em 1816 , sendo praticamente coincidentes em torno de 4,5 ao término do período. 
Tabela 1.17

Peso dos domicílios com e sem escravos na população

(Bragança - 1799 a 1830)

\begin{tabular}{|c|c|c|c|c|c|c|c|}
\hline \multirow[b]{2}{*}{ Anos } & \multicolumn{3}{|c|}{ "Fogos sem escravos } & \multicolumn{4}{|c|}{ Fogos com escravos } \\
\hline & $\begin{array}{c}\% \text { da } \\
\text { população } \\
\text { total }\end{array}$ & $\begin{array}{c}\% \text { da } \\
\text { população } \\
\text { livre }\end{array}$ & $\begin{array}{l}\text { Média de } \\
\text { indivíduos }\end{array}$ & $\begin{array}{c}\% \text { da } \\
\text { população } \\
\text { total }\end{array}$ & $\begin{array}{c}\% \text { da } \\
\text { população } \\
\text { livre }\end{array}$ & $\begin{array}{l}\text { Média de } \\
\text { indivíduos }\end{array}$ & $\begin{array}{l}\text { Média de } \\
\text { livres }\end{array}$ \\
\hline 1799 & 77,1 & 83,6 & 5,4 & 22,9 & 16,4 & 10,4 & 6,9 \\
\hline 1803 & 74,0 & 81,8 & 5,4 & 26,0 & 18,2 & 9,8 & 6,2 \\
\hline 1808 & 73,3 & 82,3 & 5,0 & 26,7 & 17,7 & 9,5 & 5,6 \\
\hline 1811 & 74,6 & 83,0 & 4,8 & 25,4 & 17,0 & 9,3 & 5,6 \\
\hline 1816 & 68,4 & 79,3 & 4,8 & 31,6 & 20,7 & 9,3 & 5,3 \\
\hline 1820 & 63,3 & 75,9 & 4,6 & 36,7 & 24,1 & 9,7 & 5,3 \\
\hline 1826 & 59,9 & 74,7 & 4,6 & 40,1 & 25,3 & 9,6 & 4,9 \\
\hline 1830 & 59,6 & 75,2 & 4,4 & 40,4 & 24,8 & 9,5 & 4,6 \\
\hline
\end{tabular}

Fonte: AESP, M aços de População, Bragança: anos selecionados

Entre o total de fogos cerca de 3,5\% (1816) a 5\% (1808) tinham, além de cativos, agregados não aparentados entre seus habitantes livres. (vide Tabela I.18) Os fogos com presença de indivíduos agregados eram percentual significativo, ainda que decrescente entre 1799 e 1816, passando de 16,9\% a 10,9\%, voltando a crescer até 1830, ano em que encontramos agregados em 13\% dos domicílios da vila de Bragança.

Tabela 1.18

Peso dos domicílios com e sem agregados não aparentados na população

(Bragança - 1799 a 1830)

\begin{tabular}{|c|c|c|c|c|c|c|c|}
\hline Anos & $\begin{array}{l}\% \text { de fogos } \\
\text { com } \\
\text { agregados }\end{array}$ & $\begin{array}{c}\text { № de } \\
\text { agregados }\end{array}$ & $\begin{array}{c}\% \text { de } \\
\text { agregados } \\
\text { na } \\
\text { população } \\
\text { total }\end{array}$ & $\begin{array}{c}\% \text { de } \\
\text { agregados } \\
\text { na } \\
\text { população } \\
\text { livre }\end{array}$ & $\begin{array}{c}\text { Média de } \\
\text { agregados } \\
\text { (fogos com } \\
\text { agregados) }\end{array}$ & $\begin{array}{l}\text { Média de } \\
\text { agregados } \\
\text { (total de } \\
\text { fogos) }\end{array}$ & $\begin{array}{c}\% \text { de fogos } \\
\text { com agregados } \\
\text { e escravos }\end{array}$ \\
\hline 1799 & 16,9 & 272 & 4,9 & 5,3 & 1,8 & 0,30 & 4,4 \\
\hline 1803 & 16,4 & 368 & 5,6 & 6,2 & 2,1 & 0,34 & 4,3 \\
\hline 1808 & 14,5 & 334 & 4,6 & 5,2 & 1,8 & 0,27 & 5,1 \\
\hline 1811 & 12,2 & 336 & 3,9 & 4,3 & 1,7 & 0,21 & 3,7 \\
\hline 1816 & 10,9 & 254 & 3,3 & 3,8 & 1,7 & 0,19 & 3,5 \\
\hline 1820 & 12,0 & 302 & 3,7 & 4,5 & 1,8 & 0,22 & 4,6 \\
\hline 1826 & 13,1 & 372 & 4,3 & 5,4 & 1,9 & 0,25 & 4,3 \\
\hline 1830 & 13,0 & 474 & 4,6 & 5,8 & 2,0 & 0,26 & 3,8 \\
\hline
\end{tabular}

Fonte:AESP, Maços de População, Bragança: anos selecionados 
Assim como a sua presença nos domicílios, o número de agregados variou ao longo do tempo, estando justamente em 1816, ano com menor percentual de fogos com estes bragantinos o seu menor número, 254, que correspondia a tão somente 3,3\% da população total e $3,8 \%$ da população livre. Em 1830 foram encontrados em termos absolutos em maior número, 474, sendo a principal participação encontrada em 1803: $5,6 \%$ entre todos os habitantes da localidade e $6,2 \%$ daqueles não cativos; anos para os quais foram verificados as maiores médias, respectivamente 2,1 e 2 agregados em 1803 e 1830.

A população livre, agregada ou não, era composta basicamente por brancos, pardos e mulatos, sendo o número de negros bastante reduzido, com o máximo 41 bragantinos que correspondiam a apenas $0,6 \%$ dos livres e $2,6 \%$ dos não brancos em 1826. Indubitavelmente brancos eram maior parte da população, mas com participação variável com o passar dos anos: em 1799 eram 98,4\% dos não cativos, em 1811 o percentual devido a estes indivíduos reduziu-se a 74,5\%, e viu-se alçado a 85\% em 1820 .

Tabela I.19

Distribuição da população livre entre brancos e não brancos

(Bragança - 1799 a 1830)

\begin{tabular}{|c|c|c|c|c|c|}
\hline \multirow{3}{*}{ Anos } & \multirow{3}{*}{$\begin{array}{c}\text { Brancos } \\
\text { \% (№) }\end{array}$} & \multicolumn{3}{|c|}{ Não Brancos } & \multirow{3}{*}{$\begin{array}{c}\text { Total: Brancos } \\
\text { + Não brancos } \\
\% \text { (№) }\end{array}$} \\
\hline & & Pardos/Mulatos & Negros & Total & \\
\hline & & \% (№) & \% (№) & \% (№) & \\
\hline 1799 & $98,4(4911)$ & $96,3(79)$ & 3,7 (3) & $1,6(82)$ & $100,0(4993)$ \\
\hline 1803 & $78,5(4666)$ & $99,6(1270)$ & $0,4(5)$ & $21,5(1275)$ & $100,0(5941)$ \\
\hline 1808 & $83,6(5359)$ & $99,7(1045)$ & $0,3(3)$ & $16,4(1048)$ & $100,0(6407)$ \\
\hline 1811 & 74,5 (5819) & $99,8(1991)$ & $0,2(3)$ & 25,5 (1994) & $100,0(7813)$ \\
\hline 1816 & $80,6(5382)$ & $99,8(1292)$ & $0,2(3)$ & $19,4(1295)$ & $100,0(6677)$ \\
\hline 1820 & $85,0(5698)$ & $98,3(990)$ & $1,7(17)$ & $15,0(1007)$ & $100,0(6705)$ \\
\hline 1826 & $79,6(5534)$ & $97,1(1377)$ & $2,9(41)$ & $20,4(1418)$ & $100,0(6952)$ \\
\hline 1830 & 78,6 (6382) & $98,2(1707)$ & 1,8 (32) & 21,4 (1739) & $100,0(8121)$ \\
\hline
\end{tabular}

Exclusive indivíduos com cor não identificada

Fonte:AESP, Maços de População, Bragança: anos selecionados

Tal variação é compreensível, pois 'Sabe-se que a determinação de 'cor' no momento do levantamento dos habitantes sofria injunções de ordem econômica, social e cultural em nossa terra, sendo o 'branqueamento' dos indivíduos padrão de domínio ou ascensão social." (MARCíLIO, 200, p.117).

A composição dos sexos encontrada para a população livre em seu conjunto aponta razões de sexo em pequena medida favoráveis às mulheres em todo o período. As 
mulheres foram ao longo do tempo ao redor de $50,2 \%$ a $52,6 \%$ da população livre da Vila Nova de Bragança. Em 1799, apesar da superioridade feminina, esta diferença era insignificante, tendo se ampliado nos demais anos. Especialmente em 1808 e 1811 as razões encontradas foram de 90 e 92,2, resultado da maior variação da população feminina bragantina comparativamente ao crescimento da parcela masculina da população: as mulheres tiveram seu número aumentado em 21\% entre 1803 e 1808, e $35,8 \%$ entre 1808 e 1811, contra uma variação de homens da ordem de $15,5 \%$ e $25 \%$ respectivamente nos mesmos intervalos.

Tabela 1.20

Composição da população livre por sexo (Bragança - 1799 a 1830)

\begin{tabular}{|c|c|c|c|c|c|c|c|c|}
\hline \multirow{3}{*}{ Anos } & \multicolumn{5}{|c|}{ População Livre } & \multicolumn{3}{|c|}{ Chefes de fogo } \\
\hline & \multicolumn{2}{|c|}{ Homens } & \multicolumn{2}{|c|}{ Mulheres } & \multirow{2}{*}{$\begin{array}{l}\text { Razão de } \\
\text { sexo }\end{array}$} & \multirow{2}{*}{$\begin{array}{c}\text { Homens } \\
\text { \% (№) }\end{array}$} & \multirow{2}{*}{$\begin{array}{c}\text { Mulheres } \\
\text { \% (№) }\end{array}$} & \multirow{2}{*}{$\begin{array}{l}\text { Razão de } \\
\text { sexo }\end{array}$} \\
\hline & \% (№) & $\begin{array}{c}\text { Variação } \\
\%\end{array}$ & \% (№) & $\begin{array}{c}\text { Variação } \\
\%\end{array}$ & & & & \\
\hline 1799 & $49,8(2565)$ & & $50,2(2585)$ & & 99,2 & $86,8(916)$ & $13,2(795)$ & 661,7 \\
\hline 1803 & $49,1(2921)$ & 18,0 & $50,9(3024)$ & 18,2 & 96,6 & $86,8(1081)$ & $13,2(938)$ & 655,9 \\
\hline 1808 & $47,4(3035)$ & 15,5 & $52,6(3374)$ & 21,0 & 90,0 & $86,2(1256)$ & $13,8(1083)$ & 626,0 \\
\hline 1811 & $48,0(3751)$ & 25,0 & $52,0(4060)$ & 35,8 & 92,5 & 85,2 (1589) & $14,8(1354)$ & 575,5 \\
\hline 1816 & $49,0(3278)$ & $-14,1$ & $51,0(3406)$ & $-14,5$ & 96,2 & $85,3(1364)$ & $14,7(1163)$ & 578,6 \\
\hline 1820 & $49,4(3322)$ & 2,9 & $50,6(3400)$ & 3,0 & 97,7 & $85,3(1404)$ & $14,7(1197)$ & 578,3 \\
\hline 1826 & $48,8(3393)$ & 7,9 & $51,2(3558)$ & 0,5 & 95,4 & $86,1(1500)$ & 13,9 (1292) & 621,2 \\
\hline 1830 & 49,0 (3991) & 21,2 & $51,0(4152)$ & 32,2 & 96,1 & $85,1(1841)$ & $14,9(1566)$ & 569,5 \\
\hline
\end{tabular}

Exclusive indivíduos com sexo não identificado

Fonte: AESP, Maços de População, Bragança: anos selecionados

A evolução dessa estrutura pode ser visualizada nas pirâmides etárias construídas em números relativos para livres nos diferentes anos considerados entre 1799 e 1830, apresentadas no Gráfico I.10. 


\section{Gráfico I.10}

\section{Pirâmides etárias da população livre}

(Bragança - 1799 a 1830)

\section{9}
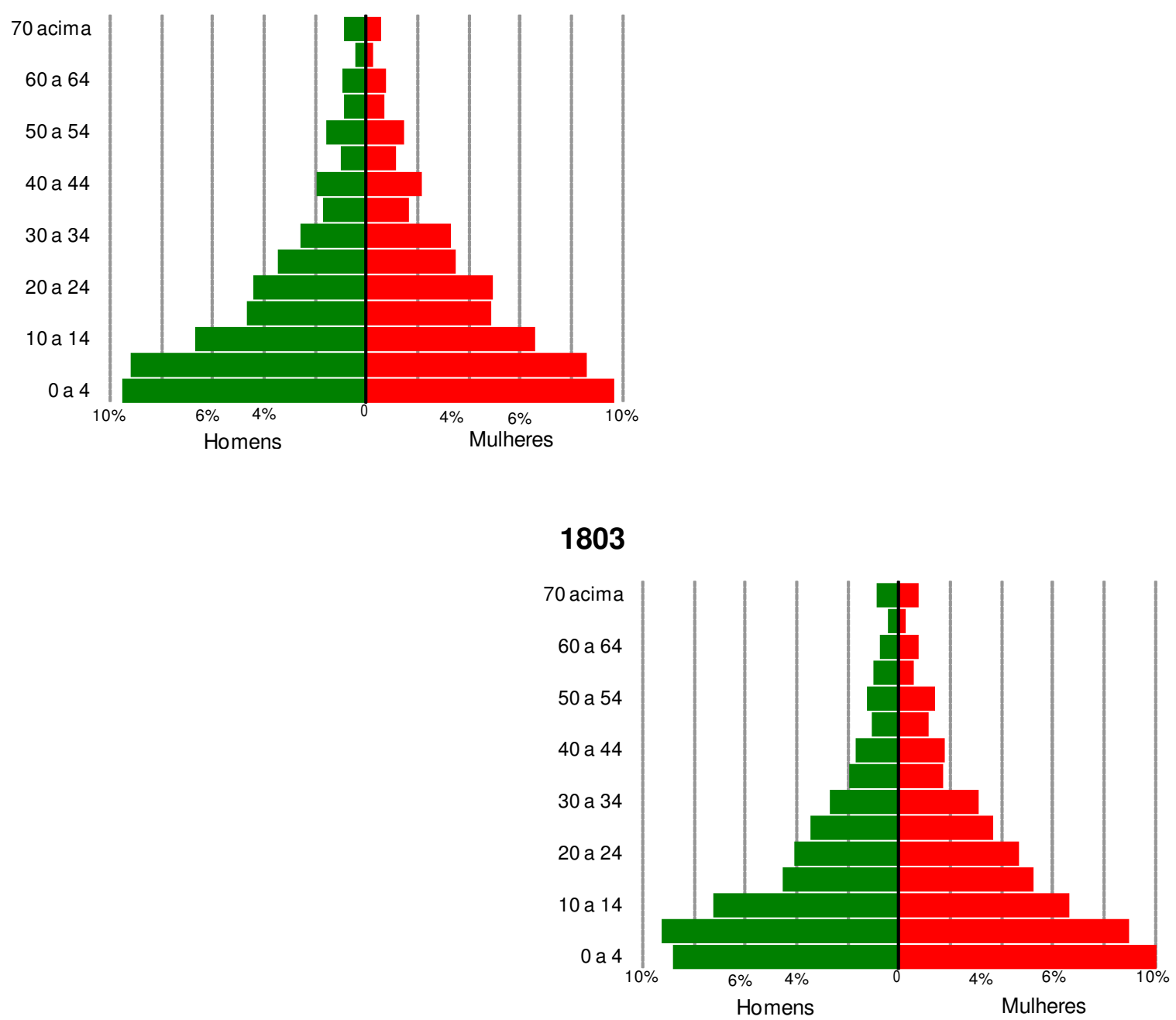

1808

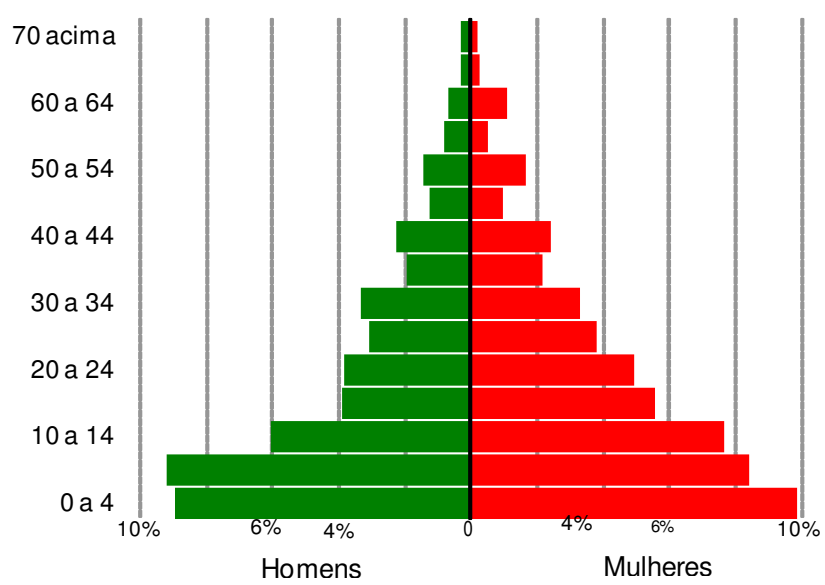




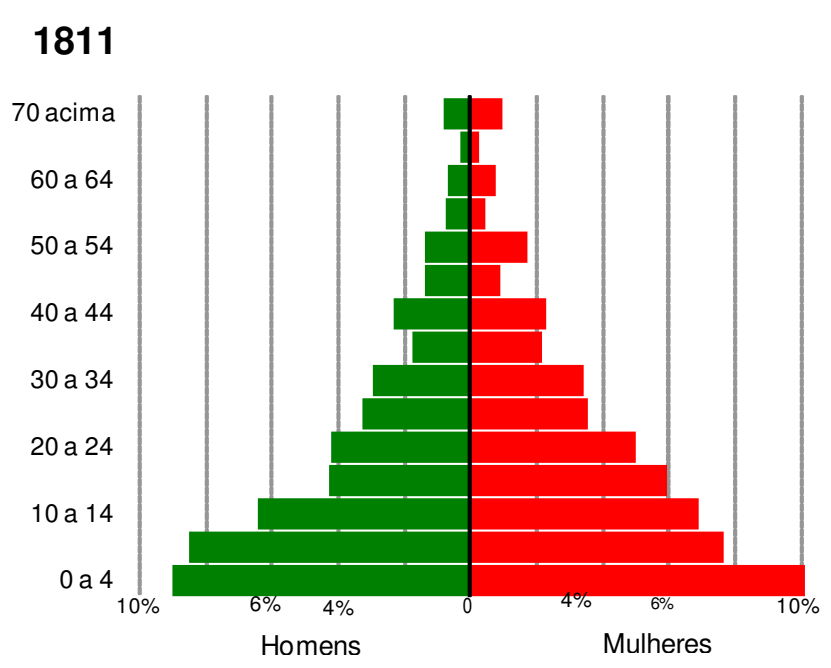

\section{6}

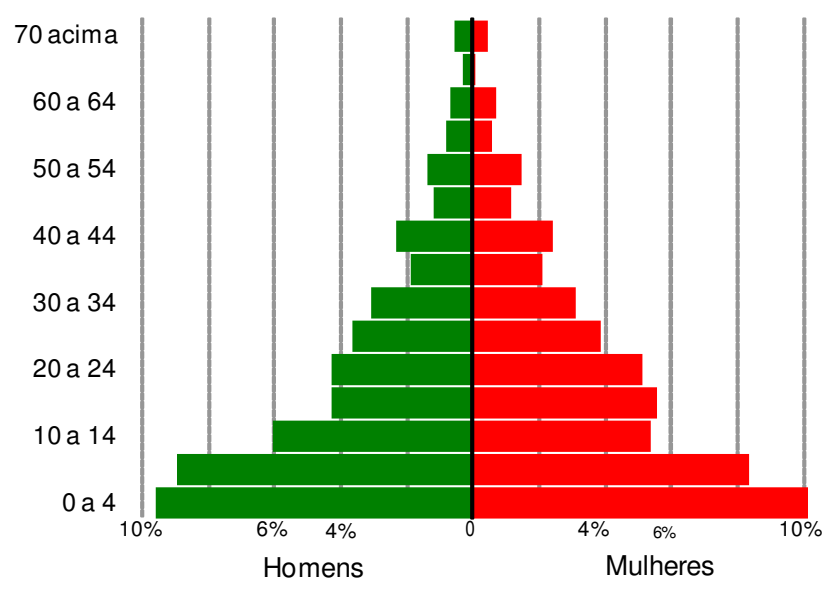

1820

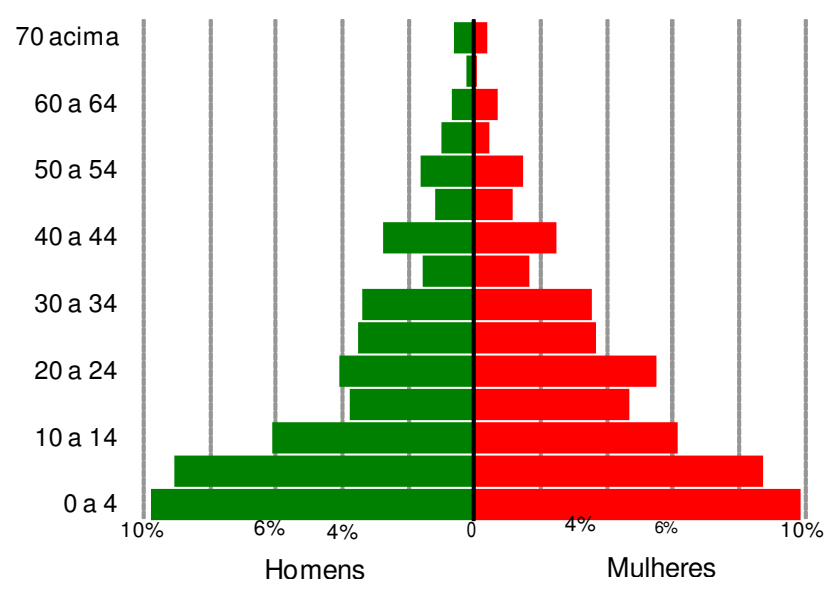


1826

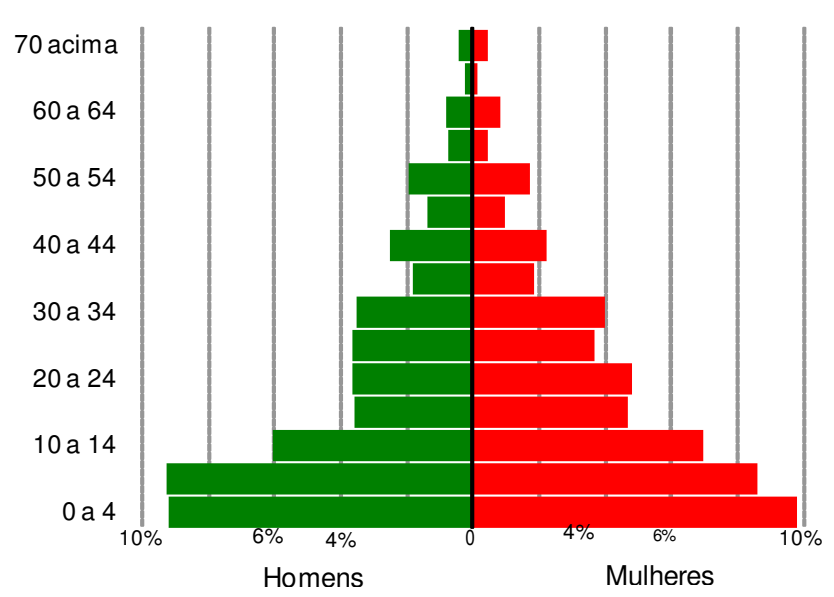

1830

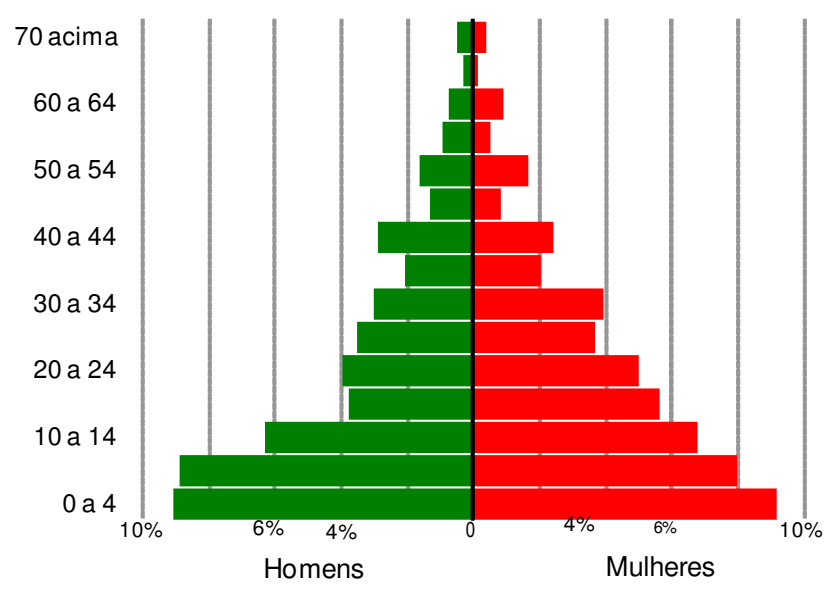

Todas as pirâmides apresentam manutenção de suas bases, que permanecem com o mesmo tamanho, variando somente nas proporções de cada sexo, sempre tendendo a maiores proporções de mulheres. A estrutura etária mantém-se jovem no período observado devido, ao que parece, a níveis de natalidade razoavelmente constantes no período, posto serem aqueles indivíduos com até quatro anos de idade sempre em torno de $19-20 \%$ dos livres. Em regra, a estrutura assume contornos regulares e desenho compatível com o de populações jovens.

O padrão etário caracterizado pela manutenção de uma estrutura jovem confirmase no exame da distribuição da população por grandes grupos etários. Entre 1799 e 1830, a proporção da população com idades de até 14 anos se manteve estável, variando de a $51 \%$ (1803) a 48,2\% (1830), assim como a população entre 15 e 34 anos, correspondente 
a percentuais que atingiram um mínimo de 31,5\% (1803 e 1826) e o máximo de 33\% (1811), entre estes a proporção de mulheres era mais elevada que a verificada para a totalidade dos livres, saindo de 90,9 no primeiro ano considerado, para 82 em 1811 e 78,8 em 1830. Temos, então, uma população livre cuja média de idade era de pouco mais de 19 anos, sendo o mínimo de 19,2 em 1816 e o máximo de 19,9 anos de idade em 1811.

Já a população cativa, de maneira diversa à parcela livre da sociedade jundiaense, apresentou razões de sexo favoráveis aos homens. Essa constatação é especialmente válida para o total da população, ou, em análise mais específica, para aqueles indivíduos vivendo em grupos de ao menos 20 escravos. (Gráfico I.11, no apêndice apresentamos tabela em que constam razões de sexo para todas as faixas de tamanho de plantel que compõem nosso recorte)

\section{Gráfico I.11}

\section{Razão de sexo dos cativos de acordo com faixas}

de tamanho dos plantéis

(Bragança - 1799 a 1829)

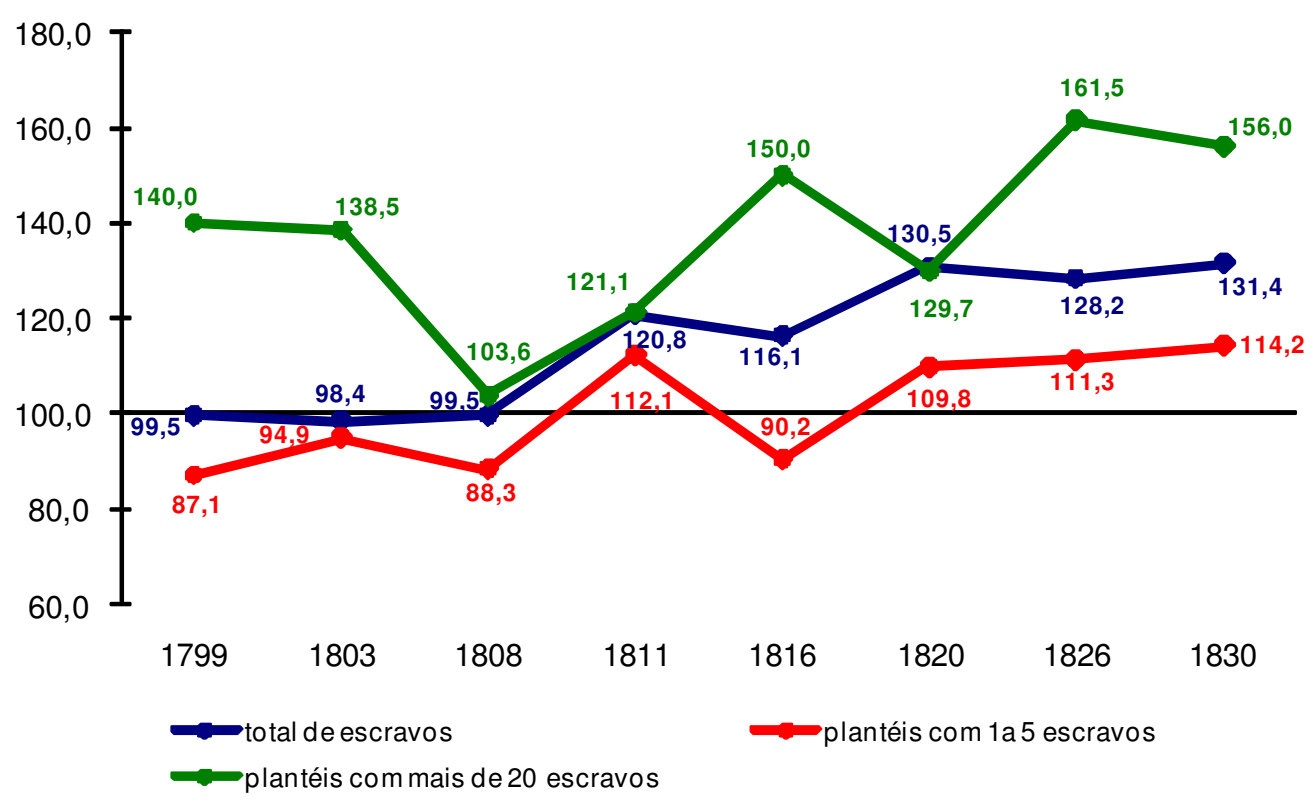

O total da população cativa apresentou razões levemente favoráveis às mulheres no Setecentos e nos primeiros anos observados para a século seguinte. Foram 99,5 cativos para cada grupo de 100 cativas (91,2\% mulheres) em 1799, proporção repetida em 1808. A partir daí a participação de homens viu-se ampliada, tendo a razão passado a 120,8 já em 1811; apresentando variação positiva desde então, chegando em 1830 à 
proporção de 131,4 homens para cada grupo de 100 mulheres. Variações diversas apresentaram os maiores contingentes mancípios, favoráveis aos homens em todo o lapso considerado, com mínimo de 103,6 em 1808, seguida por 121,1 (aproximadamente $55 \%$ homens) em 1811. As variações na composição por sexo das menores escravarias seguiram aquelas apresentadas para a população cativa em seu conjunto, mas com valores inferiores, sendo o mínimo de 87,1 homens para cada 100 mulheres no primeiro ano observado, e máximo de 114,3 ao final do período.

Nas pirâmides etárias as desproporções entre os sexos também podem ser observadas, sendo acrescidas da variável faixa etária. (Gráfico I.12)

\section{Gráfico I.12}

\section{Pirâmides etárias da população escrava}

(Bragança - 1799 a 1830)

1799

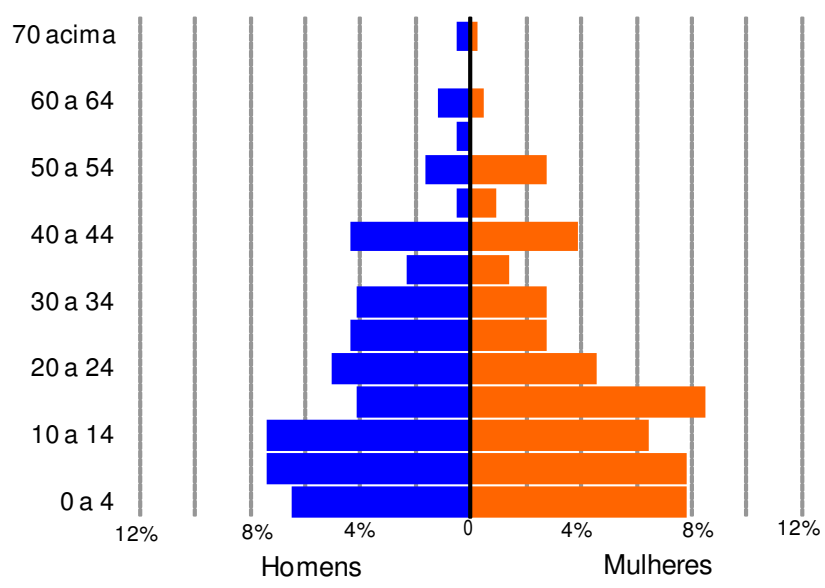

1803

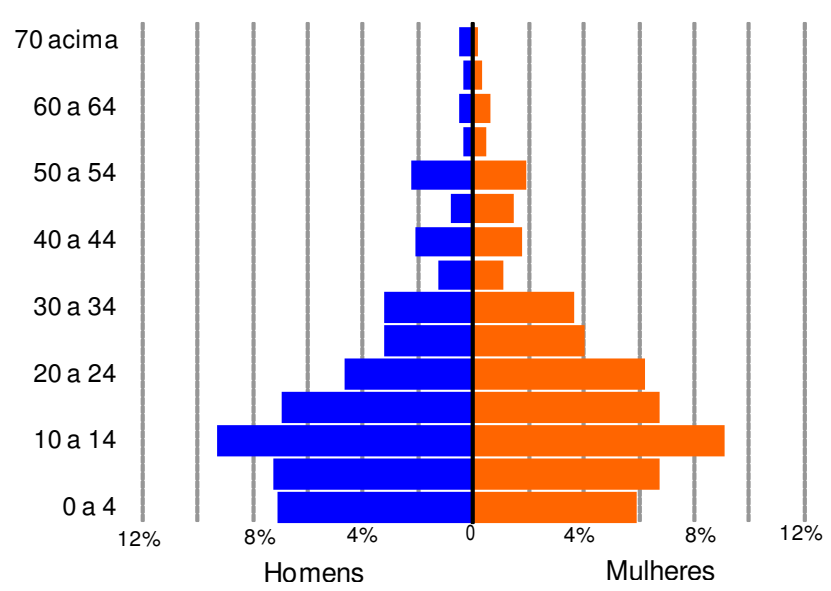


1808

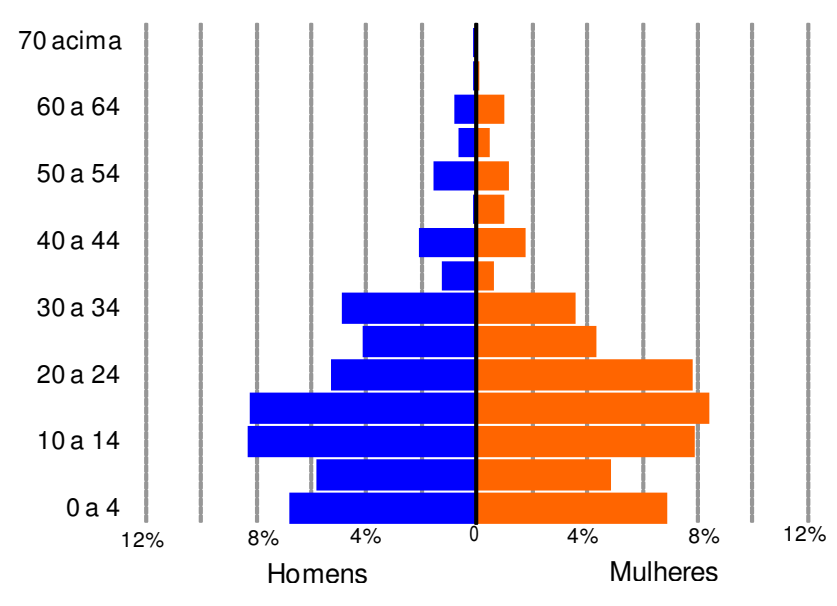

1811

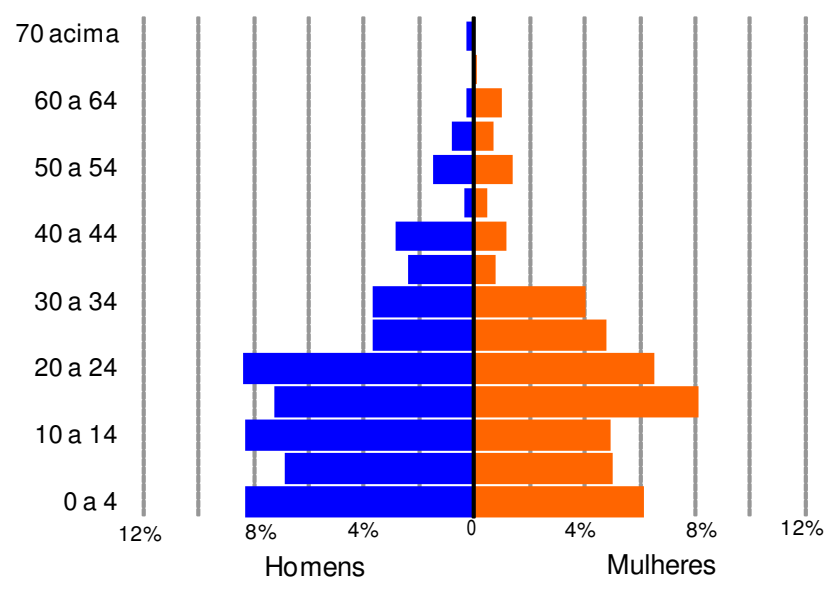

1816

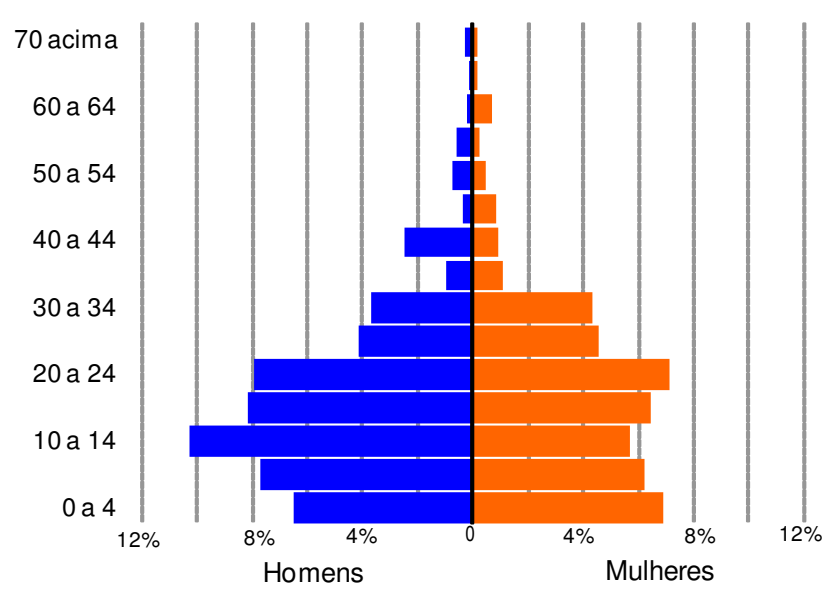


1820

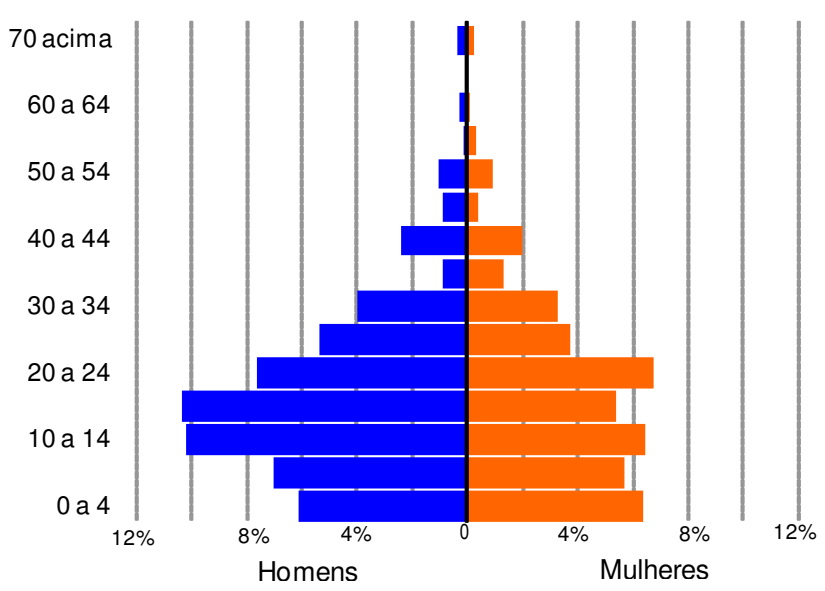

\section{6}

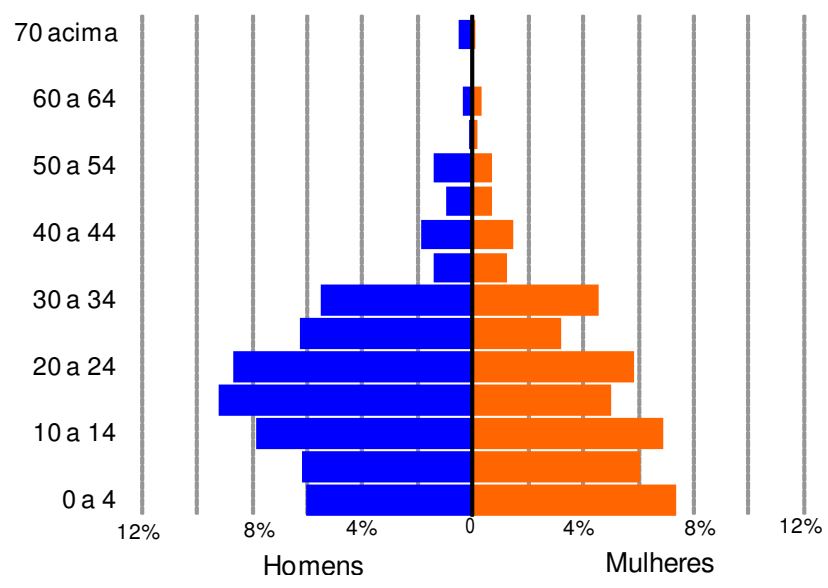

\section{0}

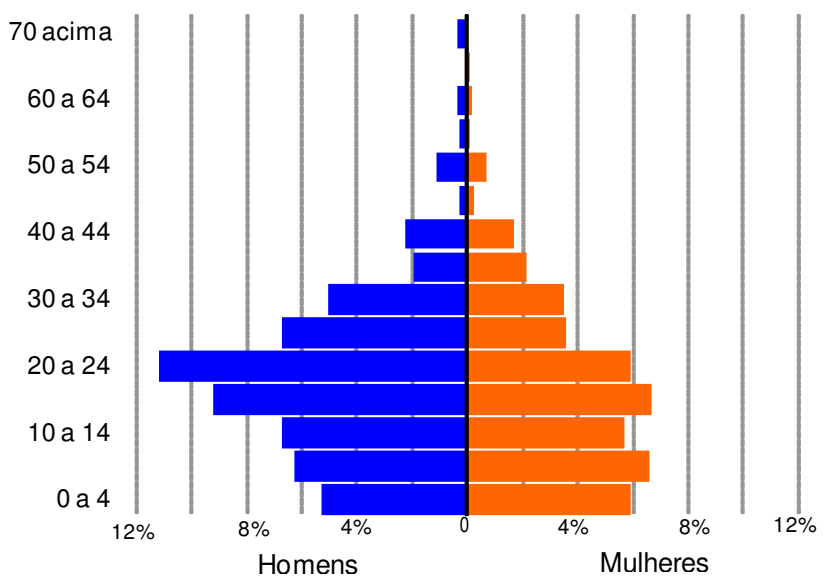


Não é observável um movimento contínuo de envelhecimento ou rejuvenescimento da população mancípia em Bragança, ainda que os intervalos entre os anos sejam próximos às faixas de tamanho dos plantéis. Os escravos de determinada faixa em um ano, são os possíveis escravos encontrados na faixa seguinte no próximo ano para o qual buscamos dados. Mantiveram-se em grande proporção, homens e mulheres jovens, especialmente aqueles com idades entre 15 e 14 anos, estes últimos com destaque em 1830, quando sua participação é de mais de $11 \%$ do total da população escrava do município.

Voltando à população livre, temos na baixa idade média da população, anteriormente anotada, implicância no fato de que grande parte dela seja solteira, ainda que em percentual decrescente: eram 68,4\% em 1803, 63,9\% em 1811, 63,3\% em 1811 e 1816, e $60,2 \%$ em 1830. (cf. tabela no apêndice estatístico)

Excluindo-se destes os indivíduos de até 14 anos, observamos os dados da Tabela I.21, que apontam para uma maioria de casados na população livre, tendente ao crescimento ao longo dos anos. Em 1799, 58,3\% dos não cativos vivendo em Bragança eram casados, percentual alçado a 63-64\% em 1811 -1816, chegando à casa dos 70\% no último lustro da década de 1820. Esse aumento no percentual de casados correspondeu a um decréscimo da participação devida aos solteiros que de $35,6 \%$ dos livres com 15 ou mais anos de idade em 1799 caíram a 23,8\% deste mesmo grupo passados 30 anos.

\section{Tabela I.21}

Composição da população livre de acordo com estado conjugal e sexo - exclusive indivíduos de até 14 anos (Bragança - 1799 a 1830)

\begin{tabular}{|c|c|c|c|c|c|c|c|c|c|}
\hline \multirow{2}{*}{ Anos } & \multicolumn{3}{|c|}{ Homens } & \multicolumn{3}{|c|}{ Mulheres } & \multicolumn{3}{|c|}{ Homens + Mulheres } \\
\hline & $\begin{array}{c}\text { Casados } \\
\%\end{array}$ & $\begin{array}{c}\text { Solteiros } \\
\%\end{array}$ & $\begin{array}{c}\text { Viúvos } \\
\%\end{array}$ & $\begin{array}{c}\text { Casadas } \\
\%\end{array}$ & $\begin{array}{c}\text { Solteiras } \\
\%\end{array}$ & $\begin{array}{c}\text { Viúvas } \\
\%\end{array}$ & $\begin{array}{c}\text { Casados } \\
\%\end{array}$ & $\begin{array}{c}\text { Solteiros } \\
\%\end{array}$ & $\begin{array}{c}\text { Viúvos } \\
\%\end{array}$ \\
\hline 1799 & 58,6 & 38,4 & 3,1 & 57,0 & 33,7 & 9,3 & 58,3 & 35,6 & 6,1 \\
\hline 1803 & 59,9 & 37,1 & 3,0 & 56,4 & 34,8 & 8,8 & 58,3 & 35,7 & 6,0 \\
\hline 1808 & 66,0 & 30,8 & 3,3 & 58,0 & 33,1 & 8,9 & 62,1 & 31,6 & 6,3 \\
\hline 1811 & 67,4 & 30,3 & 2,3 & 58,8 & 31,8 & 9,3 & 63,3 & 30,7 & 6,0 \\
\hline 1816 & 67,5 & 29,3 & 3,2 & 61,3 & 29,6 & 9,2 & 64,5 & 29,2 & 6,3 \\
\hline 1820 & 67,9 & 30,1 & 2,0 & 64,3 & 27,7 & 8,0 & 66,4 & 28,6 & 5,1 \\
\hline 1826 & 73,0 & 24,6 & 2,4 & 66,8 & 24,1 & 9,1 & 70,2 & 24,0 & 5,8 \\
\hline 1830 & 72,9 & 24,6 & 2,4 & 66,3 & 23,4 & 10,3 & 69,7 & 23,8 & 6,5 \\
\hline
\end{tabular}

Fonte: AESP, M aços de População, Bragança: anos selecionados

Exclusive indivíduos com estado conjugal e/ou sexo não identificado Exclui individuos de 0 a 14 anos 
Os viúvos variaram ao redor dos $6 \%$ nos oito anos para os quais levantamos dados, sendo que para as mulheres esse percentual foi sempre superior ao verificado para os homens, estando ao redor de $8 \%$ para elas e 2-3\% para eles. Entre os homens o número de casados era maior que o valor calculado para as mulheres - diferença que chegou a 8,6 pontos percentuais em 1811 -, o que não surpreende posta a predominância feminina na população.

Unindo as características de sexo, idade e estados conjugal (Tabela I.22), verificamos que aqueles indivíduos em celibato definitivo, ou seja, solteiros acima de 50 anos, era bastante diminuta, independente do sexo: entre 1799 e 1830 o percentual devido a estes indivíduos esteve sempre ao redor de $2 \%$, tendo as mulheres apresentado um percentual pouquíssimo superior ao calculado para os homens, com limites de 1,4\% e $2,4 \%$, tendo os homens limites de $0,9 \%$ e $2,2 \%$, lembrando mais uma vez, apresentar esta sociedade razões de sexo sempre favoráveis às mulheres.

As idades médias para homens e mulheres casados eram distintas, sendo que os indivíduos do sexo masculino tinham média de idade em torno de 36-37 anos, com menor média encontrada em 1830, 35,9, e maior verificado em 1799: 37,7. A sua vez, encontramos para as mulheres casadas idades médias em torno de 5,5 anos mais baixas - apenas em 1820 a diferença atingiu 6,7 anos e no ano de 1830 foi 6,3 anos de idade -, sendo as mais baixas médias de 29,6 e 29,9 anos de idade em 1825 e 1830 e as maiores calculadas em 32,1 em nosso ano inicial. Modas e medianas, assim como as médias foram superiores para os homens, mantendo-se a mediana em 34 para os homens até 18811, sendo praticamente a mesma nos anos seguintes, 32 em 1816 e 33 nos demais anos.

Diferente do que foi observado para o total da população livre, entre os chefes de domicílio a predominância masculina era absoluta e pode ser considerada constante ao longo dos anos: entre $85 \%$ e $87 \%$ dos chefes de fogo eram do sexo masculino, implicando em razões de sexo de ao menos 575, encontrada para o ano de 1811 (vide Tabela I.20). 
Tabela 1.22

Estatísticas para a idade dos livres de acordo com o estado conjugal e sexo (Bragança - 1799 a 1830)

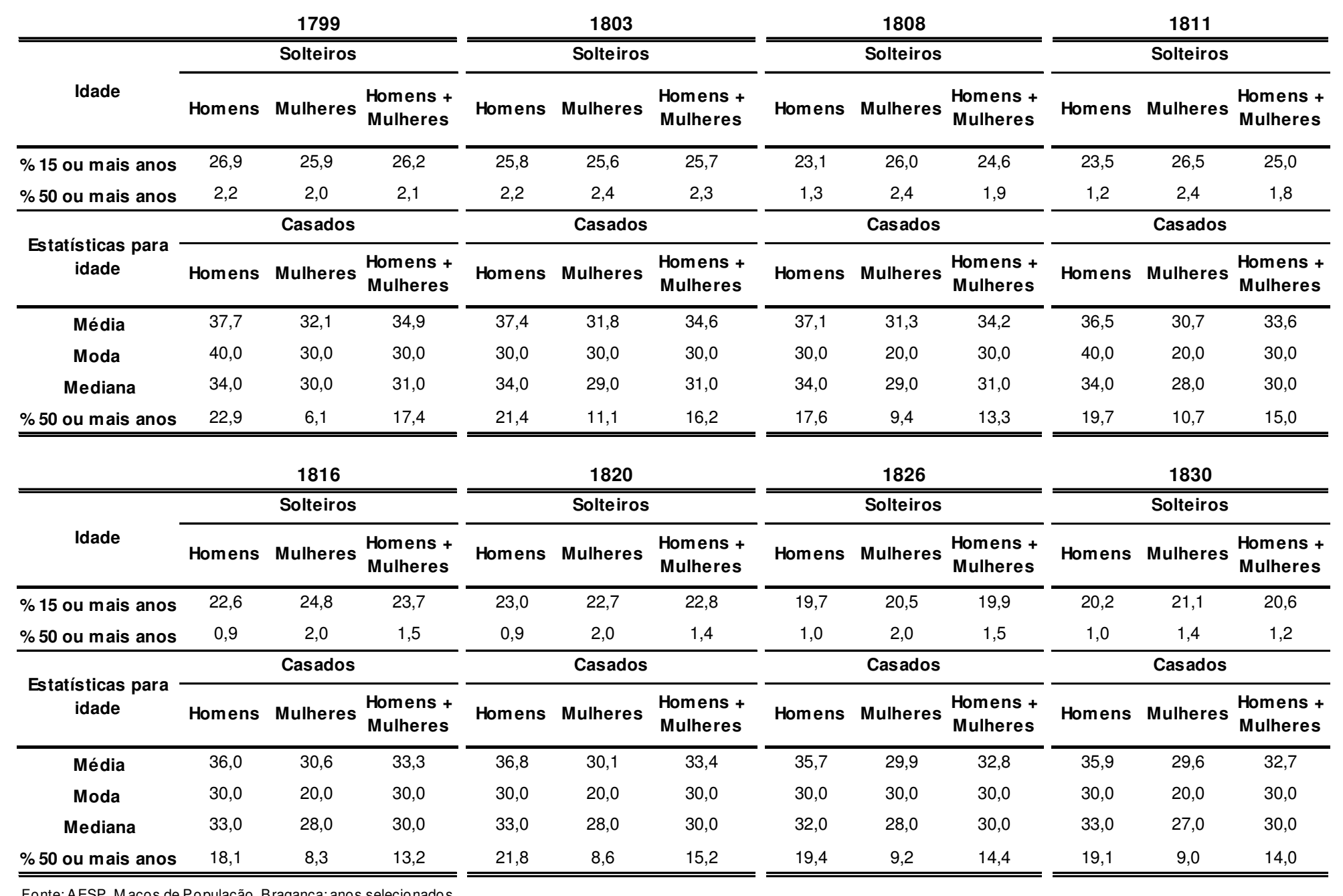


Da mesma maneira, a composição por estado conjugal deste grupo aponta para uma diferenciação grande entre os indivíduos de cada um dos sexos. A Tabela I.23 mostra a composição dos chefes de fogo de acordo com estado conjugal e sexo.

\section{Tabela I.23}

Composição dos chefes de fogo de acordo com estado conjugal e sexo - exclusive indivíduos de até 14 anos -

(Bragança - 1799 a 1830)

\begin{tabular}{|c|c|c|c|c|c|c|c|c|c|}
\hline \multirow{2}{*}{ Anos } & \multicolumn{3}{|c|}{ Homens } & \multicolumn{3}{|c|}{ Mulheres } & \multicolumn{3}{|c|}{ Homens + Mulheres } \\
\hline & $\begin{array}{c}\text { Casados } \\
\%\end{array}$ & $\begin{array}{c}\text { Solteiros } \\
\%\end{array}$ & $\begin{array}{c}\text { Viúvos } \\
\%\end{array}$ & $\begin{array}{c}\text { Casadas } \\
\%\end{array}$ & $\begin{array}{c}\text { Solteiras } \\
\%\end{array}$ & $\begin{array}{c}\text { Viúvas } \\
\%\end{array}$ & $\begin{array}{c}\text { Casados } \\
\%\end{array}$ & $\begin{array}{c}\text { Solteiros } \\
\%\end{array}$ & $\begin{array}{c}\text { Viúvos } \\
\%\end{array}$ \\
\hline 1799 & 91,0 & 4,6 & 4,4 & 10,9 & 21,0 & 68,1 & 80,4 & 6,8 & 12,8 \\
\hline 1803 & 88,5 & 7,9 & 3,5 & 13,4 & 26,8 & 59,9 & 78,6 & 10,4 & 11,0 \\
\hline 1808 & 90,2 & 5,6 & 4,3 & 13,5 & 25,9 & 60,6 & 79,7 & 8,3 & 11,9 \\
\hline 1811 & 92,5 & 4,8 & 2,7 & 13,6 & 28,1 & 58,3 & 80,9 & 8,2 & 10,9 \\
\hline 1816 & 93,1 & 2,9 & 4,0 & 10,4 & 25,4 & 64,2 & 80,9 & 6,2 & 12,8 \\
\hline 1820 & 92,0 & 5,8 & 2,3 & 18,4 & 28,6 & 52,9 & 81,2 & 9,1 & 9,7 \\
\hline 1826 & 93,0 & 4,1 & 2,9 & 12,5 & 28,8 & 58,7 & 81,8 & 7,5 & 10,7 \\
\hline 1830 & 92,1 & 5,2 & 2,7 & 12,4 & 23,6 & 64,0 & 80,2 & 7,9 & 11,9 \\
\hline
\end{tabular}

Fonte: AESP, M aços de População, Bragança: anos selecionados

Exclusive indivíduos com estado conjugal e/ou sexo não identificado

Exclui individuos de 0 a 14 anos

Se por um lado os homens eram majoritariamente casados, com percentuais bem mais elevados que aqueles verificados para o total da população livre masculina, chegando a mais de 90\% entre 1799 e 1830 (exceção para 1803: 88,8\%), as mulheres encontradas sob a condição de chefes de domicilio eram majoritariamente viúvas, situação que correspondia ao 68,1\% delas em 1799, esteve ao redor de $60 \%$ em $1803-$ 1808, chegando ao mínimo de 52,9\% em 1820 e sendo alçada a 64\% em 1830.

Apenas 2,9\% dos chefes de domicilio do sexo masculino eram solteiros em 1816, com máximo de $7,9 \%$ em 1803 , estando em torno de $5 \%$ nos demais anos. Percentuais correspondentes à quarta parte daqueles observados para as mulheres: 21\% em $1799 \mathrm{e}$ acima de $28 \%$ em 1811, 1820 e 1826.

Estes chefes de fogo em grande medida eram vindos de outras localidades, conforme apresentado na Tabela I.24. 
Tabela I.24

Origem dos chefes de fogo

(Bragança - 1799 a 1830)

\begin{tabular}{|c|c|c|c|c|c|c|c|}
\hline \multirow{3}{*}{ Origem } & \multicolumn{7}{|c|}{ Chefes de fogo } \\
\hline & 1803 & 1808 & 1811 & 1816 & 1820 & 1826 & 1830 \\
\hline & \% (№) & \% (№) & \% (№) & \% (№) & \% (№) & \% (№) & \% (№) \\
\hline Bragança & $40,9(401)$ & $41,0(435)$ & $52,1(743)$ & $53,8(683)$ & $55,0(663)$ & $69,0(966)$ & $68,9(1131)$ \\
\hline Atibaia & $31,0(304)$ & $30,2(321)$ & $24,0(342)$ & $23,5(298)$ & $19,7(237)$ & $13,8(193)$ & 13,0 \\
\hline Nazaré & $7,0(69)$ & $7,3(78)$ & $5,9(84)$ & $6,5(82)$ & $4,0(48)$ & $2,3(32)$ & $2,7(45)$ \\
\hline Mogi das Cruzes & $2,8(27)$ & $2,5(27)$ & $1,9(27)$ & $1,6(20)$ & $2,2(26)$ & $1,1(16)$ & $1,0(16)$ \\
\hline Jundiaí & $0,4(4)$ & $0,5(5)$ & $0,4(5)$ & $0,4(5)$ & $0,3(4)$ & $0,2(3)$ & $0,6(10)$ \\
\hline Jacareí & $0,5(5)$ & $0,2(2)$ & - & $0,1(1)$ & $0,2(2)$ & $0,4(5)$ & $0,2(4)$ \\
\hline São Paulo & $3,9(38)$ & $2,9(31)$ & $3,5(50)$ & $3,2(41)$ & $4,4(53)$ & $3,2(45)$ & $2,5(41)$ \\
\hline Santo Amaro & $1,3(13)$ & $0,8(8)$ & $0,7(10)$ & $0,3(4)$ & $0,4(5)$ & $0,2(3)$ & $0,4(7)$ \\
\hline Conceição & $3,4(33)$ & $2,9(31)$ & $2,5(36)$ & $1,6(20)$ & $1,7(21)$ & $0,9(13)$ & $1,0(17)$ \\
\hline Juqueri & $1,5(15)$ & $3,0(32)$ & $1,6(23)$ & $2,0(25)$ & $2,2(26)$ & $1,5(21)$ & $1,0(17)$ \\
\hline $\begin{array}{l}\text { Outras localidades da } \\
\text { capitania/província }\end{array}$ & $3,7(36)$ & $5,0(53)$ & $4,2(60)$ & $4,2(54)$ & $5,5(63)$ & $3,0(42)$ & $4,0(65)$ \\
\hline $\begin{array}{l}\text { TOTAL da } \\
\text { capitania/província } \\
\text { (exclusive Bragança) }\end{array}$ & $57,9(544)$ & $55,4(588)$ & $44,7(637)$ & $43,3(550)$ & $40,5(488)$ & 26,6 (373) & $26,5(435)$ \\
\hline $\begin{array}{l}\text { Outras } \\
\text { capitanias/províncias }\end{array}$ & $3,1(30)$ & $2,3(24)$ & $1,9(27)$ & $1,3(17)$ & $2,9(35)$ & $2,2(31)$ & $2,6(43)$ \\
\hline Outros países & $0,6(6)$ & $1,4(15)$ & $1,3(18)$ & $1,6(20)$ & $1,7(20)$ & $2,2(31)$ & $2,0(32)$ \\
\hline TOTAL & $100,0(981)$ & $100,0(1062)$ & $100,0(1425)$ & $100,0(1270)$ & 100,0 (1203) & $100,0(1401)$ & $100,0(1641)$ \\
\hline $\begin{array}{l}\text { Abrangência das } \\
\text { declarações }\end{array}$ & $90,7 \%$ & $84,6 \%$ & $89,7 \%$ & $93,1 \%$ & $85,7 \%$ & $93,4 \%$ & $89,1 \%$ \\
\hline
\end{tabular}

Fonte: AESP, M aços de População, B ragança: anos selecionados

Exclusive chefes de fogo com naturalidade não identificada

Ainda que a maioria deles fosse efetivamente natural da Vila de Bragança; importante percentual era devido a indivíduos chegados de outras localidades da capitania e depois província de São Paulo. Considerando que as listas apresentam movimentos populacionais ocorridos em momentos anteriores, parece ter havido importante migração com destino a Bragança ainda no século XVII, tendo sido proporcionalmente menos importante na virada do século e decrescente ao longo do século XIX na composição dos fogos bragantinos, não sendo, portanto, suficiente para repor sua participação frente crescimento natural da população.

Ao final do Setecentos, $41 \%$ dos domicílios da localidade eram chefiados por pessoas nascidas na própria vila, percentual que foi crescente ao longo do lapso até 1830, sendo de 52,1\% em 1811, 55\% em 1820 e 69\% em 1826 e 1830. Ou seja, o percentual devido a "estrangeiros" foi decrescente, partindo de 59\% em 1799 para 31\% passadas três dedadas. Entre os forasteiros a maior participação era daqueles vindos da vizinha Atibaia - em que pese o fato de Bragança ter sido freguesia judiciária e 
administrativamente ligada a Atibaia até 1797 - que respondia pela origem de 304 (31\%) dos chefes de domicilio habitantes de Bragança em 1799. Em 1830 esse percentual era de apenas 13\% (213 fogos). Merecem menção ainda, nessa ordem, a freguesia de Nazaré, a cidade de São Paulo, a vila de Conceição e a vila de Mogi das Cruzes, à exceção de São Paulo, todas com participações decrescentes.

Ao contrário, aqueles vindos de terras realmente distantes, de fora das fronteiras brasileiras, ampliaram sua participação. Mas apesar de passar de 0,6\% em 1799 a 2,2\% em 1826, o percentual a eles devido ainda era pequeno. 


\section{Atibaia}

As informações sobre a população contidas nas listas nominativas de habitantes de Atibaia revelam com clareza as transformações demográficas ocorridas ao longo das três primeiras décadas do século XIX, ainda que o efeito destas transformações tenha reverberado na população local posteriormente a 1830 e a própria população por nós observada seja em alguns de seus caracteres reflexo do ocorrido anteriormente.

Nosso ponto de partida para a observação das características e das mudanças ocorridas na população - especialmente a livre - da Vila de Atibaia é o ano de 1799. A esse tempo, após quase 150 anos do povoamento inicial de suas terras, Atibaia havia passado por progressiva modificação no conjunto de atribuições ligadas à sua organização, já sendo reconhecida como vila. Ao longo desse período as bases das suas atividades produtivas já estavam plenamente estabelecidas e eram responsáveis pela fixação na localidade de um contingente populacional de 4162 indivíduos entre livres e cativos, vivendo em 622 fogos, conforme se observa no Gráfico I.13, na Tabela I.25 e seguintes. A partir daí a população passou por modificações atingindo o máximo de 4233 pessoas em 1816, posteriormente decrescendo para chegar ao final da segunda década do Oitocentos com uma população reduzida a 3310 pessoas, distribuídas por 532 domicílios.

No período 1799 a 1829, são identificados quatro momentos de mudanças na população total de Atibaia, verdadeiros ciclos de população: entre 1799 a 1808 houve uma queda de 6,4\% no número de habitantes da localidade; de 1808 a 1816 o movimento foi diverso, havendo um crescimento da ordem de $8,6 \%$, do ano 1816 ao de 1826 a população voltou a retrair-se, desta monta em $24,5 \%$; para posteriormente elevar-se em $3,6 \%$ até $1830 .^{16}$

\footnotetext{
${ }^{16}$ Importa ressaltar, conforme explicitamos no apêndice metodológico, a ausência para 1826 dos bairros de Itapetinga, Rio Acima e Cachoeira, e para 1829 dos bairros Mato Dentro, Itajoapira e Boa Vista. Esta ausência certamente justifica em boa medida a queda considerável da população - note-se, em 1820 houve queda na população, sem haver sido excluído algum bairro - que seria, na realidade, devida a ausência do arrolamento dos referidos bairros.
} 


\section{Gráfico I.13}

Evolução (em valores absolutos) da população total, população livre e escravos

(Atibaia - 1799 a 1829)

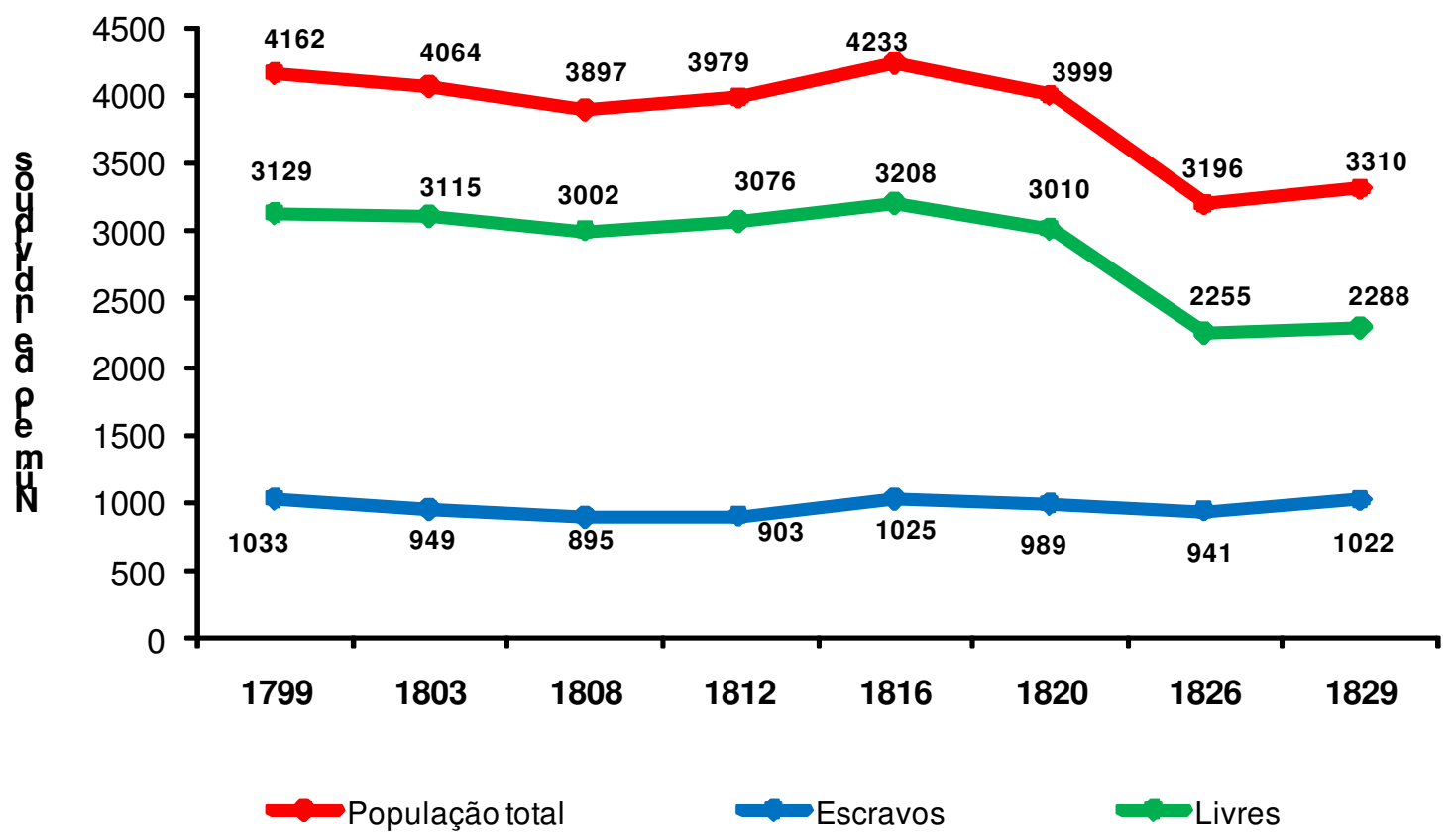

Tabela 1.25

Variação da população total, população livre e escravos

(Atibaia - 1799 a 1829, São Paulo - 1798 a 1828)

\begin{tabular}{|c|c|c|c|c|c|}
\hline \multicolumn{4}{|c|}{ Atibaia $^{\star *}$} & \multicolumn{2}{|c|}{ Província São Paulo* } \\
\hline Anos & $\begin{array}{l}\text { Variação \% da } \\
\text { população total }\end{array}$ & $\begin{array}{c}\text { Variação \% da } \\
\text { população livre }\end{array}$ & $\begin{array}{l}\text { Variação \% da } \\
\text { população } \\
\text { cativa }\end{array}$ & Anos & $\begin{array}{c}\text { Variação \% da } \\
\text { população total }\end{array}$ \\
\hline $1799-1803$ & $-2,4$ & $-0,4$ & $-8,1$ & $1798-1800$ & 4,4 \\
\hline $1803-1808$ & $-4,1$ & $-3,6$ & $-5,7$ & $1800-1808$ & 15,7 \\
\hline $1808-1812$ & 2,1 & 2,5 & 0,9 & $1808-1818$ & 13,0 \\
\hline $1812-1816$ & 6,4 & 4,3 & 13,5 & $1818-1822$ & 10,3 \\
\hline $1816-1820$ & $-5,5$ & $-6,2$ & $-3,5$ & $1822-1828$ & 17,7 \\
\hline $1820-1826$ & $-20,1$ & $-25,1$ & $-4,9$ & $1798-1818$ & 36,5 \\
\hline $1826-1829$ & 3,6 & 1,5 & 8,6 & $1818-1828$ & 29,8 \\
\hline $1799-1816$ & 1,7 & 5,6 & $-0,8$ & $1798-1828$ & 77,2 \\
\hline $1816-1829$ & $-21,8$ & $-28,7$ & $-0,3$ & & \\
\hline $1799-1829$ & $-20,5$ & $-24,7$ & $-1,1$ & & \\
\hline
\end{tabular}

*Valores calculados a partir dos dados apresentados por M arcílio (2000, p.71), inclui Paraná.

**Fonte: AESP, M aços de População, Atibaia: anos selecionados 
Tabela 1.26

Variação do número de fogos

(Atibaia - 1799 a 1829)

\begin{tabular}{ccc}
\hline \hline Ano & № de fogos & $\begin{array}{c}\text { Variação \% do } \\
\text { número de fogos }\end{array}$ \\
\hline $\mathbf{1 7 9 9}$ & 622 & \\
$\mathbf{1 8 0 3}$ & 575 & $-7,6$ \\
$\mathbf{1 8 0 8}$ & 590 & 2,6 \\
$\mathbf{1 8 1 2}$ & 619 & 4,9 \\
$\mathbf{1 8 1 6}$ & 667 & 7,8 \\
$\mathbf{1 8 2 0}$ & 658 & $-1,3$ \\
$\mathbf{1 8 2 6}$ & 494 & $-24,9$ \\
$\mathbf{1 8 2 9}$ & 532 & 7,7 \\
\hline \hline
\end{tabular}

Fonte: AESP, M aços de População, A tibaia: anos selecionados

Essas variações foram bastante diversas àquelas encontradas para a capitania/província como um todo, cuja população total cresceu de maneira notável, como já observamos em outros momentos, tendo sido ampliada em cerca dos já conhecidos $77 \%$, comparados os anos 1798 e $1828 .^{17}$

Com exceção do período entre 1803 e 1808, quando ocorreu uma ampliação do número de fogos $(2,6 \%)$ frente a uma redução da população total $(4,1 \%)$ e livre $(3,6 \%)$, a variação do número de fogos e do número de habitantes variou no mesmo sentido, tendo nos momentos de ampliação da população livre o número de fogos aumentado em maior proporção, possivelmente devido ao desmembramento dos fogos e famílias chegando a Atibaia.

Em 1808 encontramos apenas treze chefes de fogo (2,2\%) que declararam ser "morador novo", ou seja, terem estabelecido seu domicílio na vila e seu termo naquele ano - entre estes, quatro mencionaram ser naturais da própria Atibaia; Joze Cardoso de Siqueira e Joze Pedroso eram naturais de Conceição, Antonio de Oliveira era da vizinha

\footnotetext{
17 Para a década de 1830 Daniel Pedro Müller apresenta dados para a população de Atibaia em que são considerados também os habitantes da freguesia de Nazaré, que teriam em conjunto 10211 indivíduos em1836. Proporcionalmente, em momento anterior, o número total de habitantes de Nazaré foi crescente com relação a Atibaia, sendo de 60,5\% destes em 1799, ao redor de $85 \%-95 \%$ nos anos entre 1803 e 1816 , tendo superado o número de moradores da vila já em 1820, chegando a ser $142 \%$ deles em 1826, com média para o período $1776-1829$ de $98,7 \%$ (vide dados apresentados em seção relativa a Nazaré). Considerando que metade dos moradores de Atibaia mais Nazaré habitavam a área correspondente a vila, estes seriam mais de 5100 pessoas, apontando para um novo período de crescimento populacional em Atibaia.
} 
Bragança, Joze Marianno de São Paulo e Francisco Antonio de Juqueri. Outros oito jovens chefes de fogo (idade média de 24,8 anos) mencionaram ser "casado de novo".

Sendo estes números aproximados também para os anos 1804 a 1807, certamente representariam um aumento considerável no número de fogos, mas não necessariamente da população, uma vez que famílias formadas por novos casais eram pequenas (média inferior a três, ou seja, eram fogos compostos basicamente pelo casal e um filho pequeno ou escravo), enquanto os fogos de moradores novos apresentavam características relativas ao número de moradores - média 4,8, moda 3 , mediana 4 inferiores ao verificado para a totalidade dos domicílios (discutidos mais adiante).

Já entre 1803 e 1808 o número de fogos chefiados por indivíduos vindos de outras localidades da capitania de São Paulo passou de 93 a 115, sendo proporcionalmente de $17 \%$ em 1803 e $28,2 \%$ após um lustro, em que pese a menor representatividade dos dados verificados para 1808 (69,2\%) comparativamente aos verificados para 1803 que foram próximos à totalidade dos fogos atibaienses $(95,1 \%)$. Como se pode notar na Tabela I.23, em Atibaia os indivíduos vindos de outras localidades nunca chegaram a ser maioria entre os chefes de fogo, assim como entre a população total - exceção para 1812 quando a representativamente dos dados para os chefes de fogos é bastante discrepante daquela encontrada para os demais anos, apontando para uma "preferência" da menção a forasteiros.

Em que pesem problemas com as fontes, em especial o menor número de declarações para alguns anos, a ampla maioria dos indivíduos livres com naturalidade/origem declarada havia nascido na capitania/província de São Paulo se incluídos aqueles originários da própria localidade de Atibaia. Para 1799 não existiam dados sobre naturalidade. Os dados para 1808 e 1812 apontam nesse período uma queda significativa da participação de atibaienses na população, com um aumento da participação de outros paulistanos. E nos demais anos encontramos participação maciça dos atibaienses, que variou entre $80 \%$ e $83 \%$, superando os $90 \%$ em 1829 , quando a representatividade das declarações chegou a quase $79 \%$ dos livres. 
Tabela I.27

Origem da população livre

(Atibaia - 1799 a 1829)

\begin{tabular}{|c|c|c|c|c|c|c|c|}
\hline \multirow{2}{*}{ Origem } & \multicolumn{7}{|c|}{ População livre } \\
\hline & \% (№) & \% (№) & \% (№) & \% (№) & \% (№) & \% (№) & \% (№) \\
\hline Atibaia & $80,5(965)$ & $58,6(465)$ & $51,7(281)$ & $83,6(592)$ & 80,5 (537) & $83,2(966)$ & $93,6(1687)$ \\
\hline Nazaré & 1,8 (22) & 4,3 (34) & 4,1 (22) & $1,3(9)$ & $1,2(8)$ & $0,3(3)$ & $1,1(20)$ \\
\hline Bragança & 2,7 (32) & $6,2(49)$ & $9,6(52)$ & $2,8(20)$ & $3,1(21)$ & $4,7(55)$ & $0,3(5)$ \\
\hline Jundiaí & $0,9(11)$ & $2,6(21)$ & $2,9(16)$ & $0,1(1)$ & 1,3 (9) & $0,5(6)$ & $0,8(14)$ \\
\hline Jacareí & $0,1(1)$ & - & $0,2(1)$ & & - & - & - \\
\hline São Paulo & $2,8(34)$ & $5,3(42)$ & $4,2(23)$ & $2,1(15)$ & $2,5(17)$ & $1,8(21)$ & $0,9(17)$ \\
\hline Santos & $0,3(4)$ & $0,6(5)$ & $1,5(8)$ & 0,1 (1) & 0,1 & $0,2(2)$ & 0,1 (1) \\
\hline $\begin{array}{l}\text { Outras localidades da } \\
\text { capitania/província }\end{array}$ & $2,0(24)$ & $3,6(29)$ & $3,5(19)$ & $0,6(4)$ & $2,0(13)$ & $2,4(28)$ & $0,4(7)$ \\
\hline $\begin{array}{l}\text { TOTAL da } \\
\text { capitania/província } \\
\text { (exclusive Atibaia) } \\
\end{array}$ & $17,9(215)$ & $38,5(306)$ & $45,5(247)$ & $13,3(94)$ & $16,5(110)$ & $13,9(161)$ & $5,4(97)$ \\
\hline $\begin{array}{l}\text { Outras } \\
\text { capitanias/províncias }\end{array}$ & $1,4(17)$ & $1,8(14)$ & $1,7(9)$ & $2,0(14)$ & $2,1(14)$ & $1,7(20)$ & $0,3(6)$ \\
\hline Outros países & $0,2(2)$ & $1,1(9)$ & $1,1(6)$ & $1,1(8)$ & $0,9(6)$ & $1,2(14)$ & $0,7(13)$ \\
\hline TOTAL & 100,0 (1199) & $100,0(794)$ & $100,0(543)$ & $100,0(708)$ & $100,0(667)$ & $100,0(1161)$ & $100,0(1803)$ \\
\hline $\begin{array}{l}\text { Abrangência das } \\
\text { declarações }\end{array}$ & $38,5 \%$ & $26,4 \%$ & $17,7 \%$ & $22,1 \%$ & $22,2 \%$ & $51,5 \%$ & $78,8 \%$ \\
\hline Nazaré & 2,7 (15) & $3,9(16)$ & $9,2(13)$ & $1,4(9)$ & $1,2(8)$ & $0,3(1)$ & $1,7(9)$ \\
\hline Bragança & $2,4(13)$ & $3,7(15)$ & $8,5(12)$ & $2,4(15)$ & $3,1(20)$ & $3,1(9)$ & $0,8(4)$ \\
\hline Mogi das Cruzes & $1,5(8)$ & $2,0(8)$ & $2,1(3)$ & $0,9(6)$ & $0,9(6)$ & $1,4(4)$ & $0,6(3)$ \\
\hline Jundiaí & $0,7(4)$ & $1,5(6)$ & $4,3(6)$ & $0,2(1)$ & $1,4(9)$ & $1,0(3)$ & $1,5(8)$ \\
\hline Jacareí & $0,2(1)$ & - & $0,7(1)$ & - & - & - & - \\
\hline São Paulo & $3,1(17)$ & $4,9(20)$ & $5,7(8)$ & $1,7(11)$ & $2,1(14)$ & $2,0(6)$ & $0,9(5)$ \\
\hline Santos & $0,4(2)$ & $1,0(4)$ & $3,5(5)$ & $0,2(1)$ & $0,2(1)$ & $0,7(2)$ & $0,2(1)$ \\
\hline Conceição & $0,7(4)$ & $2,9(12)$ & $5,7(8)$ & $0,9(6)$ & $1,4(9)$ & $1,7(5)$ & $1,7(9)$ \\
\hline Juqueri & $3,3(18)$ & $4,9(20)$ & $12,1(17)$ & $3,3(21)$ & $3,1(20)$ & $5,8(17)$ & $0,2(1)$ \\
\hline Parnaíba & $0,4(2)$ & 1,2 (5) & $2,8(4)$ & $1,1(7)$ & $0,6(4)$ & $1,0(3)$ & - \\
\hline $\begin{array}{l}\text { Outras localidades da } \\
\text { capitania/província }\end{array}$ & $2,6(9)$ & $2,2(9)$ & $7,1(10)$ & $0,6(4)$ & $1,9(12)$ & $4,1(12)$ & $0,9(5)$ \\
\hline $\begin{array}{l}\text { TOTAL da } \\
\text { capitania/província } \\
\text { (exclusive Atibaia) }\end{array}$ & $17,0(93)$ & $28,2(115)$ & $61,7(87)$ & $12,8(81)$ & $15,8(103)$ & $21,2(62)$ & $8,5(45)$ \\
\hline $\begin{array}{l}\text { Outras } \\
\text { capitanias/províncias }\end{array}$ & $2,2(12)$ & $1,5(6)$ & $5,0(7)$ & $1,7(11)$ & $1,2(8)$ & $3,4(10)$ & $0,6(3)$ \\
\hline Outros países & $0,4(2)$ & $1,7(7)$ & $3,5(5)$ & $0,3(2)$ & $0,8(5)$ & $3,4(10)$ & $1,7(9)$ \\
\hline TOTAL & $100,0(547)$ & $100,0(408)$ & $100,0(141)$ & $100,0(632)$ & $100,0(653)$ & $100,0(293)$ & $100,0(527)$ \\
\hline
\end{tabular}


O maior número de indivíduos chegou a Atibaia vindo das vizinhas Nazaré, Bragança, São Paulo e Juqueri e, nos anos iniciais, Parnaíba. Apesar dessa chegada de migrantes, a se ter em conta o decréscimo na população e os dados apontados anteriormente para Jundiaí e Bragança, cujos fogos eram chefiados em importante medida por atibaienses em inícios do Oitocentos - havia tantos atibaienses chefiando fogos nessas localidades como na própria Atibaia, eram, por exemplo, 432 em 1803 ( $75 \%$ do total de fogos da vila de Atibaia e 98,2\% daqueles explicitamente chefiados por indivíduos naturais da própria localidade) -, temos que os indivíduos naturais de Atibaia migraram mais para as cidades vizinhas, que receberam este fluxo. A historiografia local aponta que "Entre 1801 e 1810, vários atibaianos das mais tradicionais famílias deixam sua terra natal para morar na nova Vila de São Carlos." (BEDORE, 2000, p.13), atual Campinas, erigida em vila desmembrada em 1797 de Jundiaí.

Os dados apresentados na tabela de naturalidades dizem respeito somente à população livre e liberta, que manteve evolução semelhante, no que refere ao sentido das variações, à verificada para a parcela cativa da população. A população livre e a cativa variaram no mesmo sentido - compreensível em se supondo que escravos deveriam seguir os senhores - com algumas diferenças mais acentuadas entre os percentuais.

Entre 1812-16, por exemplo, os livres apresentaram uma expansão de 4,3\%, enquanto os escravos tiveram seu número ampliado em 13,5\%. Já entre os anos de 1820 e 1826, a população livre perdeu um quarto de seu contingente enquanto a redução do contingente mancípio foi de $5 \%$. Assim, embora a população livre tenha decrescido a taxas médias anuais de $-1 \%$, a população cativa manteve uma variação média nula, mantendo-se praticamente inalterada em 30 anos: em 1799 eram 1033 escravos em Atibaia, em 1816 eram 1025 e em 1830 havia ali 1022 desses indivíduos, ou seja, uma variação nada significativa de tão somente $1,1 \%$.

A sua vez, a população livre reduziu-se em $24,7 \%$ entre os extremos observados, fazendo com que a composição da população local entre livres e cativos fosse alterada (Gráfico I.14), assim como a representatividade dos livres diretamente ligados aos escravos (Tabela I.28). Em 1799 os escravos respondiam por 24,8\% da população atibaiense, percentual que se viu diminuído a 22,7\% em 1812, sendo de 29,4\% em 1826 e 30,9\% em 1829 apontando assim, em uma análise de longo prazo, para uma maior representatividade dos cativos na sociedade atibaiense.

Esse aumento foi seguido por grande variação no percentual da população habitando fogos com escravos: $45,5 \%$ da população total em 1799 , cerca de $52-55 \%$ nos anos de 1803 a 1820, chegando a quase 74\% em 1826 e 1830, enquanto o percentual foi 
mais variável, porém também ascendente no longo prazo para a parcela livre dos moradores de Atibaia (33,9\% em 1799, cerca de 45\% em 1803,62,1\% em 1826).

Ou seja, quase dobrou o percentual de livres vivendo em fogos com cativos na Atibaia das três primeiras décadas do Oitocentos, tendo aumentado também o número médio desses indivíduos nos referidos fogos entre 1799 e 1829, sendo a evolução dessa estatística bastante variável, tendo crescido e decrescido sucessivamente entre cada um dos anos considerados. Em 1799 eram 6,1 livres por fogo com escravos, em 1803 eram 9,$4 ; 6,2$ em 1820 e 13,2 ao final do período analisado. As médias verificadas para o número de livres em fogos com escravos era superior à média verificada para os livres em fogos sem cativos, que apresentou tendência decrescente ao longo dos 30 anos que separam 1799 e 1829, sendo de 4,8 em 1799 e 5,2 em 1803, tendo caído a 4,3 em 1820 e 1826 e 4,1 moradores livres por fogo em que não foi verificada presença de mancípios.

\section{Gráfico I.14}

\section{Participação de livres e escravos na população}

(Atibaia - 1799 a 1829)

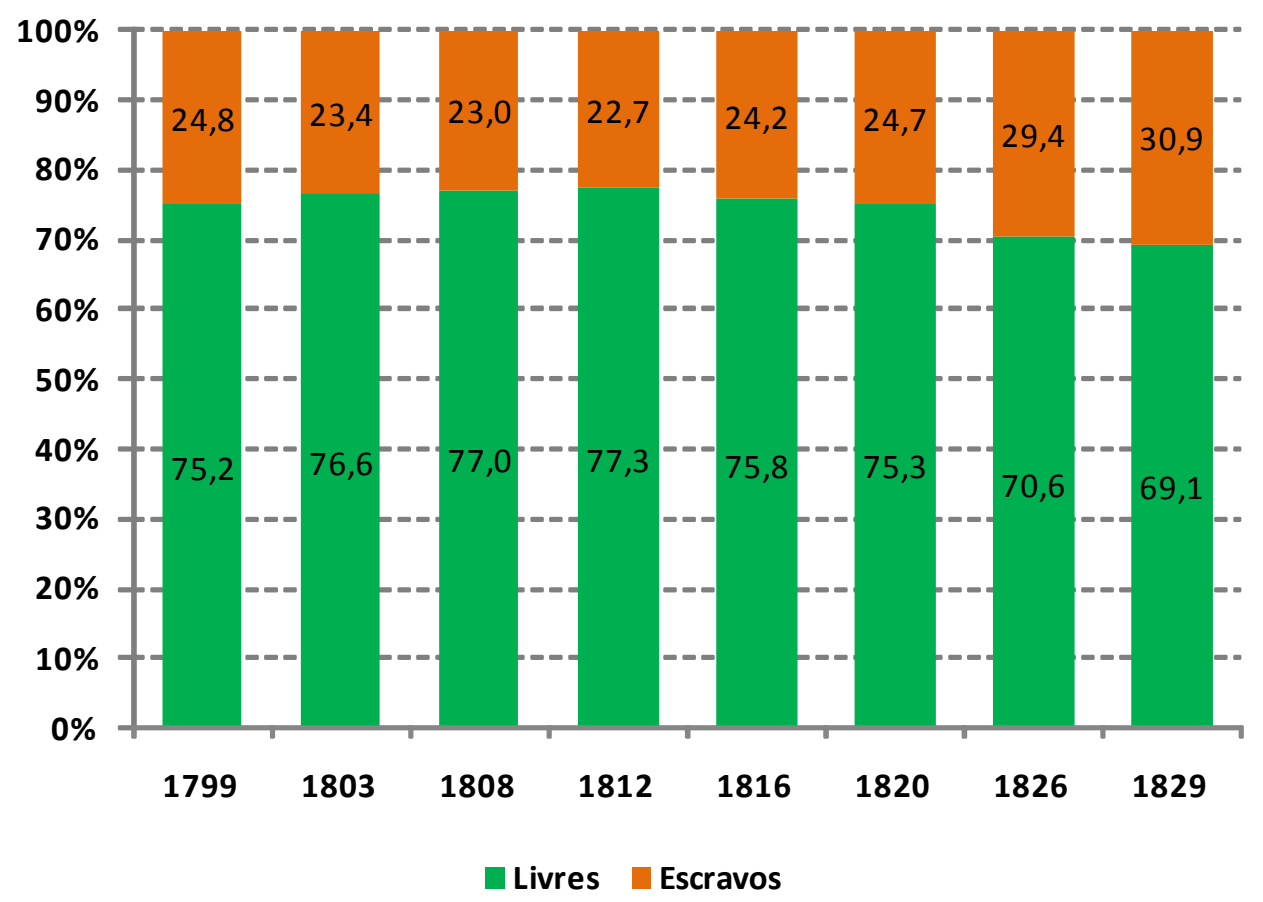


Tabela 1.28

Peso dos domicílios com e sem escravos na população

(Atibaia - 1799 a 1829)

\begin{tabular}{|c|c|c|c|c|c|c|c|}
\hline \multirow[b]{2}{*}{ Anos } & \multicolumn{3}{|c|}{ Fogos sem escravos } & \multicolumn{4}{|c|}{ Fogos com escravos } \\
\hline & $\begin{array}{c}\text { \% da } \\
\text { população } \\
\text { total }\end{array}$ & $\begin{array}{l}\text { \% da } \\
\text { população } \\
\text { livre }\end{array}$ & $\begin{array}{l}\text { Média de } \\
\text { indivíduos }\end{array}$ & $\begin{array}{c}\text { \% da } \\
\text { população } \\
\text { total }\end{array}$ & $\begin{array}{l}\text { \% da } \\
\text { população } \\
\text { livre }\end{array}$ & $\begin{array}{l}\text { Média de } \\
\text { indivíduos }\end{array}$ & $\begin{array}{l}\text { Média de } \\
\text { livres }\end{array}$ \\
\hline 1799 & 54,5 & 66,1 & 4,8 & 45,5 & 33,9 & 10,0 & 6,1 \\
\hline 1803 & 44,7 & 54,8 & 5,2 & 55,3 & 45,2 & 14,2 & 9,4 \\
\hline 1808 & 48,0 & 60,8 & 4,9 & 52,0 & 39,2 & 13,0 & 7,7 \\
\hline 1812 & 44,5 & 56,4 & 4,8 & 55,5 & 43,6 & 15,6 & 9,7 \\
\hline 1816 & 45,5 & 60,0 & 4,7 & 54,5 & 40,0 & 14,9 & 8,3 \\
\hline 1820 & 46,7 & 65,1 & 4,3 & 53,3 & 34,9 & 13,2 & 6,2 \\
\hline 1826 & 26,2 & 37,9 & 4,3 & 73,8 & 62,1 & 26,0 & 15,1 \\
\hline 1829 & 26,3 & 40,9 & 4,1 & 73,7 & 59,1 & 25,5 & 13,2 \\
\hline
\end{tabular}

Para o total da população livre a média de indivíduos por fogo foi próxima a verificada para aqueles não diretamente vinculados aos cativos, posto serem em maior número os fogos nessas condições. Em 1799, 72,3\% dos domicílios da localidade não eram escravistas, em 1812 estes constituíam 74\% e oito anos depois 68,1\% dos chefes de fogo que declararam possuir cativos, como se observa no Gráfico I.15.

Os dados para presença de livres e escravos nos domicílios atibaienses são apresentados na Tabela I.29.

No que respeita ao número de indivíduos por domicílio, considerados todos os viventes em Atibaia, basta acrescermos às médias verificadas para os livres aquelas verificadas para os cativos, bastante próximas ao longo de todo o período, ainda que superior ao final dele. Eram 1,7 escravos por fogo em 1799 e 1803, caindo a 1,5 nos cinco seguintes anos observados e atingindo 1,9 em 1826 e 1829; levando assim a uma média variável entre 6-7 habitantes por domicílio, com modas sempre inferiores às medianas e estas sempre inferires às médias. 
Gráfico 1.15

Fogos com e sem escravos

(Atibaia - 1799 a 1829)

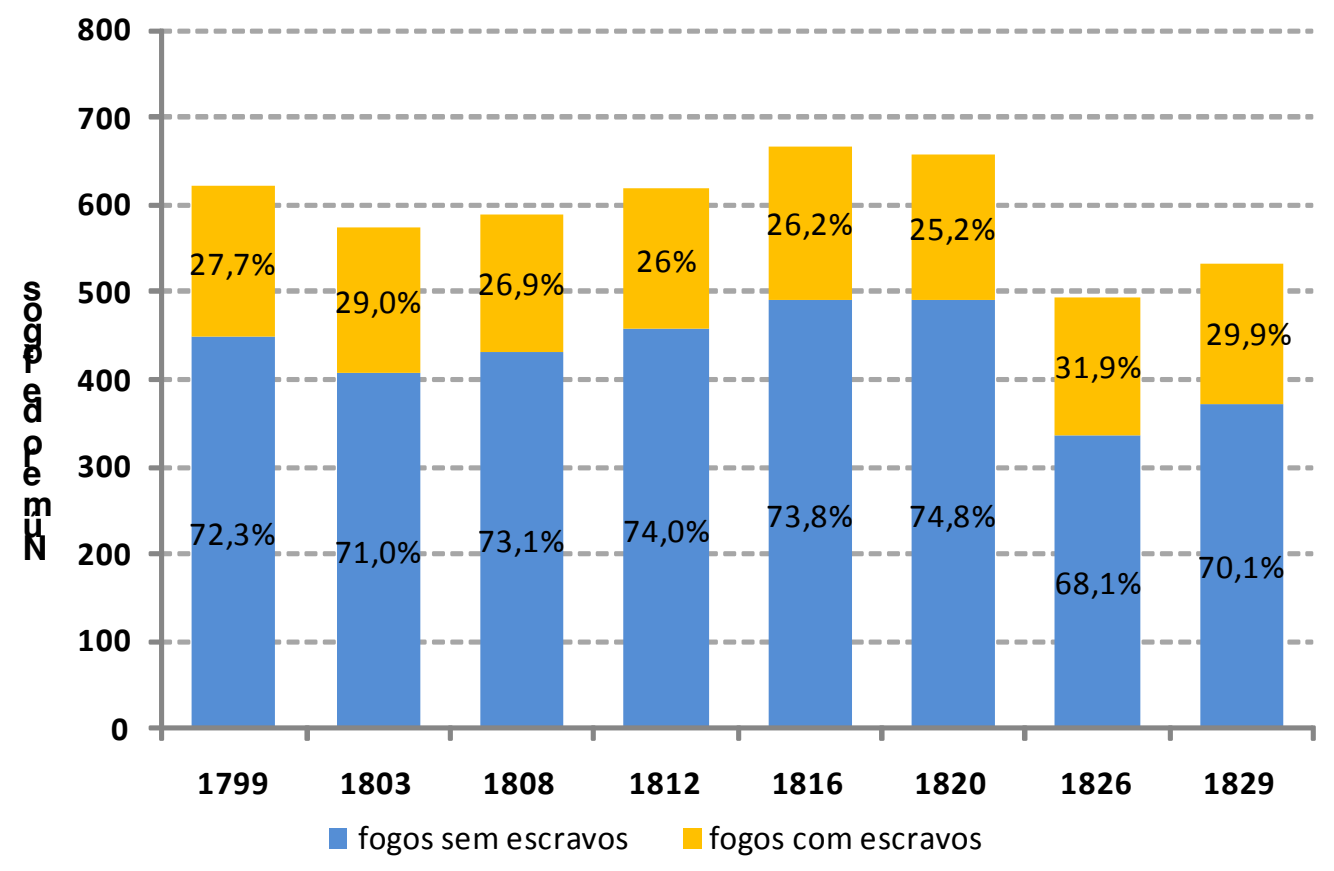

Tabela I.29

Presença de livres e escravos nos domicílios

(Atibaia - 1799 a 1829)

\begin{tabular}{|c|c|c|c|c|c|c|c|c|c|c|}
\hline \multirow{2}{*}{ Ano } & \multicolumn{3}{|c|}{ Indivíduos } & \multicolumn{3}{|c|}{ Livres } & \multicolumn{3}{|c|}{ Escravos } & \multirow{2}{*}{$\begin{array}{c}\text { Relação } \\
\text { escravos/livres }\end{array}$} \\
\hline & Média & Mediana & Moda & Média & Mediana & Moda & Média & Mediana & Moda & \\
\hline 1799 & 6,7 & 5,0 & 3,0 & 5,0 & 5,0 & 3,0 & 1,7 & 0,0 & 0,0 & 0,33 \\
\hline 1803 & 7,1 & 6,0 & 4,0 & 5,4 & 5,0 & 4,0 & 1,7 & 0,0 & 0,0 & 0,30 \\
\hline 1808 & 6,6 & 5,0 & 4,0 & 5,1 & 5,0 & 3,0 & 1,5 & 0,0 & 0,0 & 0,30 \\
\hline 1812 & 6,4 & 5,0 & 3,0 & 5,0 & 4,0 & 3,0 & 1,5 & 0,0 & 0,0 & 0,29 \\
\hline 1816 & 6,3 & 5,0 & 3,0 & 4,8 & 4,0 & 3,0 & 1,5 & 0,0 & 0,0 & 0,32 \\
\hline 1820 & 6,1 & 5,0 & 3,0 & 4,6 & 4,0 & 2,0 & 1,5 & 0,0 & 0,0 & 0,33 \\
\hline 1826 & 6,5 & 5,0 & 2,0 & 4,6 & 4,0 & 2,0 & 1,9 & 0,0 & 0,0 & 0,42 \\
\hline 1829 & 6,2 & 4,5 & 4,0 & 4,3 & 4,0 & 2,0 & 1,9 & 0,0 & 0,0 & 0,45 \\
\hline
\end{tabular}

Fonte: AESP, M aços de População, Atibaia: anos selecio nados

Considerados apenas os fogos em que os cativos estiveram presentes temos 0 número médio de escravos calculado para os proprietários de cativos sempre acima da mediana e da moda. As menores médias de escravos por proprietário ocorreram entre 
1803 e $1812(5,6)$; a maior média foi encontrada em $1829(6,4)$. A moda predominante situou-se em 4 , e a mediana foi 1 , valores que caem a 0 , considerados todos os chefes de fogo.

Tabela I.30

Indicadores estatísticos para a posse de escravos

(Atibaia - 1799 a 1829)

\begin{tabular}{|c|c|c|c|c|c|c|c|c|}
\hline \multirow[b]{2}{*}{ Estatísticas } & \multicolumn{2}{|c|}{1799} & \multicolumn{2}{|c|}{1803} & \multicolumn{2}{|c|}{1808} & \multicolumn{2}{|c|}{1812} \\
\hline & $\begin{array}{l}\text { Total de } \\
\text { fogos }\end{array}$ & $\begin{array}{c}\text { Fogos com } \\
\text { escravos }\end{array}$ & $\begin{array}{l}\text { Total de } \\
\text { fogos }\end{array}$ & $\begin{array}{c}\text { Fogos com } \\
\text { escravos }\end{array}$ & $\begin{array}{l}\text { Total de } \\
\text { fogos }\end{array}$ & $\begin{array}{c}\text { Fogos com } \\
\text { escravos }\end{array}$ & $\begin{array}{l}\text { Total de } \\
\text { fogos }\end{array}$ & $\begin{array}{c}\text { Fogos com } \\
\text { escravos }\end{array}$ \\
\hline Média & 1,7 & 6,1 & 1,7 & 5,7 & 1,5 & 5,6 & 1,5 & 5,6 \\
\hline Mediana & 0,00 & 4,00 & 0,00 & 4,00 & 0,00 & 4,00 & 0,00 & 4,00 \\
\hline Moda & 0,00 & 1,00 & 0,00 & 1,00 & 0,00 & 1,00 & 0,00 & 1,00 \\
\hline Desvio padrão & 4,34 & 6,46 & 4,10 & 5,92 & 4,29 & 6,73 & 4,04 & 6,29 \\
\hline Variância & 18,84 & 41,73 & 16,79 & 35,00 & 18,41 & 45,34 & 16,29 & 39,50 \\
\hline Índice de Gini & 0,865 & 0,544 & 0,851 & 0,488 & 0,869 & 0,514 & 0,871 & 0,504 \\
\hline \multirow[t]{2}{*}{ Máximo } & \multicolumn{2}{|c|}{44,00} & \multicolumn{2}{|c|}{35,00} & \multicolumn{2}{|c|}{53,00} & \multicolumn{2}{|c|}{43,00} \\
\hline & \multicolumn{2}{|c|}{1816} & \multicolumn{2}{|c|}{1820} & \multicolumn{2}{|c|}{1826} & \multicolumn{2}{|c|}{1829} \\
\hline Estatísticas & $\begin{array}{l}\text { Total de } \\
\text { fogos }\end{array}$ & $\begin{array}{c}\text { Fogos com } \\
\text { escravos }\end{array}$ & $\begin{array}{l}\text { Total de } \\
\text { fogos }\end{array}$ & $\begin{array}{c}\text { Fogos com } \\
\text { escravos }\end{array}$ & $\begin{array}{l}\text { Total de } \\
\text { fogos }\end{array}$ & $\begin{array}{c}\text { Fogos com } \\
\text { escravos }\end{array}$ & $\begin{array}{l}\text { Total de } \\
\text { fogos }\end{array}$ & $\begin{array}{c}\text { Fogos com } \\
\text { escravos }\end{array}$ \\
\hline Média & 1,5 & 5,9 & 1,5 & 6,0 & 1,9 & 6,0 & 1,9 & 6,4 \\
\hline Moda & 0,00 & 4,00 & 0,00 & 4,00 & 0,00 & 4,00 & 0,00 & 4,00 \\
\hline Mediana & 0,00 & 1,00 & 0,00 & 1,00 & 0,00 & 1,00 & 0,00 & 1,00 \\
\hline Desvio padrão & 4,11 & 6,26 & 4,03 & 6,17 & 5,02 & 7,41 & 5,08 & 7,60 \\
\hline Variância & 16,89 & 39,19 & 16,27 & 38,07 & 25,16 & 54,84 & 25,85 & 57,73 \\
\hline Índice de Gini & 0,866 & 0,490 & 0,869 & 0,482 & 0,846 & 0,516 & 0,851 & 0,502 \\
\hline Máximo & \multicolumn{2}{|c|}{43,00} & \multicolumn{2}{|c|}{42,00} & \multicolumn{2}{|c|}{55,00} & \multicolumn{2}{|c|}{62,00} \\
\hline
\end{tabular}

Fonte: AESP, M aços de População, A tibaia: anos selecionados

A Tabela I.31 mostra o padrão de distribuição de escravos e senhores de acordo com faixas de tamanho dos plantéis. Verificamos a presença majoritária de pequenos plantéis (até 5 cativos) para a totalidade dos anos observados. A distribuição não mostra uma mudança significativa durante as décadas. Passou-se, segundo os dados apresentados, de 61,6\% de plantéis de até cinco escravos, no ano de 1799, para cerca de $67,3 \%$ em 1808, ano com maior participação desse segmento.

A sua vez, os cativos estavam em grande proporção vivendo em pequenos e médios plantéis. Em 1799 e nas décadas inicias do Oitocentos, à exceção de 1829 - em que $54,5 \%$ dos escravos estavam em plantéis considerados grandes ou muito grandes, possivelmente devido ao fato de um único domicílio arrolar 62 escravos, representando $6,1 \%$ do total dos cativos arrolados nesse ano - não menos de $50 \%$ dos cativos estavam em pequenas e médias posses consideradas conjuntamente. 
Esse maior plantel pertencia a João Franco Dutra, sendo o segundo principal proprietário de cativos o capitão Lucas de Siqueira Franco, que manteve importante plantel durante deferentes anos.

\section{Tabela I.31}

Distribuição de escravistas e escravos de acordo com faixas de tamanho dos plantéis

(Atibaia - 1799 a 1829)

\begin{tabular}{|c|c|c|c|c|c|c|c|c|c|c|c|c|}
\hline \multirow{3}{*}{ FTP } & \multicolumn{4}{|c|}{1799} & \multicolumn{4}{|c|}{1803} & \multicolumn{4}{|c|}{1808} \\
\hline & \multicolumn{2}{|c|}{ Escravistas } & \multicolumn{2}{|c|}{ Escravos } & \multicolumn{2}{|c|}{ Escravistas } & \multicolumn{2}{|c|}{ Escravos } & \multicolumn{2}{|c|}{ Escravistas } & \multicolumn{2}{|c|}{ Escravos } \\
\hline & № & $\%$ & № & $\%$ & № & $\%$ & № & $\%$ & № & $\%$ & № & $\%$ \\
\hline 1 a 5 & 106 & 61,6 & 275 & 24,5 & 105 & 62,9 & 259 & 27,3 & 107 & 67,3 & 260 & 29,1 \\
\hline 6 a 10 & 39 & 22,7 & 298 & 26,5 & 41 & 24,6 & 312 & 32,9 & 30 & 18,9 & 230 & 25,7 \\
\hline 11 a 20 & 19 & 11,0 & 263 & 23,4 & 16 & 9,6 & 232 & 24,4 & 17 & 10,7 & 242 & 27,0 \\
\hline Acima 20 & 8 & 4,7 & 288 & 25,6 & 5 & 3,0 & 146 & 15,4 & 5 & 3,1 & 163 & 18,2 \\
\hline Total & 172 & 100,0 & 1124 & 100,0 & 167 & 100,0 & 949 & 100,0 & 159 & 100,0 & 895 & 100,0 \\
\hline \multirow{3}{*}{ FTP } & \multicolumn{4}{|c|}{1812} & \multicolumn{4}{|c|}{1816} & \multicolumn{4}{|c|}{1820} \\
\hline & \multicolumn{2}{|c|}{ Escravistas } & \multicolumn{2}{|c|}{ Escravos } & \multicolumn{2}{|c|}{ Escravistas } & \multicolumn{2}{|c|}{ Escravos } & \multicolumn{2}{|c|}{ Escravistas } & \multicolumn{2}{|c|}{ Escravos } \\
\hline & № & $\%$ & № & $\%$ & № & $\%$ & № & $\%$ & № & $\%$ & № & $\%$ \\
\hline 1 a 5 & 102 & 63,4 & 239 & 26,5 & 112 & 64,0 & 283 & 27,6 & 100 & 60,2 & 247 & 25,0 \\
\hline 6 a 10 & 38 & 23,6 & 283 & 31,3 & 36 & 20,6 & 268 & 26,1 & 41 & 24,7 & 304 & 30,7 \\
\hline 11 a 20 & 16 & 9,9 & 227 & 25,1 & 22 & 12,6 & 321 & 31,3 & 19 & 11,4 & 266 & 26,9 \\
\hline Acima 20 & 5 & 3,1 & 154 & 17,1 & 5 & 2,9 & 153 & 14,9 & 6 & 3,6 & 172 & 17,4 \\
\hline Total & 161 & 100,0 & 903 & 100,0 & 175 & 100,0 & 1025 & 100,0 & 166 & 100,0 & 989 & 100,0 \\
\hline \multirow{3}{*}{ FTP } & \multicolumn{4}{|c|}{1826} & \multicolumn{4}{|c|}{1829} & & & & \\
\hline & \multicolumn{2}{|c|}{ Escravistas } & \multicolumn{2}{|c|}{ Escravos } & \multicolumn{2}{|c|}{ Escravistas } & \multicolumn{2}{|c|}{ Escravos } & & & & \\
\hline & № & $\%$ & № & $\%$ & № & $\%$ & № & $\%$ & & & & \\
\hline 1 a 5 & 101 & 63,9 & 248 & 26,4 & 96 & 60,4 & 242 & 23,7 & & & & \\
\hline 6 a 10 & 33 & 20,9 & 255 & 24,4 & 31 & 19,5 & 223 & 21,8 & & & & \\
\hline 11 a 20 & 17 & 10,8 & 234 & 22,4 & 28 & 17,6 & 403 & 39,4 & & & & \\
\hline Acima 20 & 6 & 3,8 & 204 & 19,5 & 4 & 2,5 & 154 & 15,1 & & & & \\
\hline Total & 157 & 100,0 & 941 & 100,0 & 159 & 100,0 & 1022 & 100,0 & & & & \\
\hline
\end{tabular}

Essa constatação implica em uma concentração não muito acentuada dos escravos encontrados na localidade ao longo das décadas entre os escravistas. O índice de Gini (que mede a concentração da escravaria) considerado apenas para os domicílios com cativos foi de 0,54 em 1799, a partir de então, tal índice estabilizou-se no período 1803-1829, em torno do patamar de 0,50. Abarcando todos os fogos, o Gini também se apresenta estável ao longo do tempo, porém com valores em torno de 0,80 , indicando 
uma elevada concentração dos cativos na sociedade como um todo e evidenciando certa rigidez da concentração desses escravos entre os atibaienses. (Tabela I.30)

Até 1812, os escravos encontrados na listagem populacional de Atibaia, considerados em sua totalidade, apresentaram relativo equilíbrio entre os sexos, típico de economias vinculadas aos cultivos e à mercantilização de gêneros exclusivamente de subsistência interna. (Gráfico I.16) A razão de sexos foi de 102,4 (50,6\% eram escravos do sexo masculino) em 1799, 105,3 (51,3\% homens) em 1808 e de 100 homens para cada grupo de 100 mulheres no ano de 1812. A partir de 1816, a razão entre os sexos acentuou-se favoravelmente aos homens e no limite máximo, identificado com o ano de 1826, encontramos $54,5 \%$ da população cativa composta por homens, contra $45,5 \%$ devidos ao sexo oposto, ou seja, uma razão de 119,9 homens para cada grupo de 100 mulheres.

\section{Gráfico I.16}

\section{Razão de sexo dos cativos de acordo com faixas} de tamanho dos plantéis

(Atibaia - 1799 a 1829)

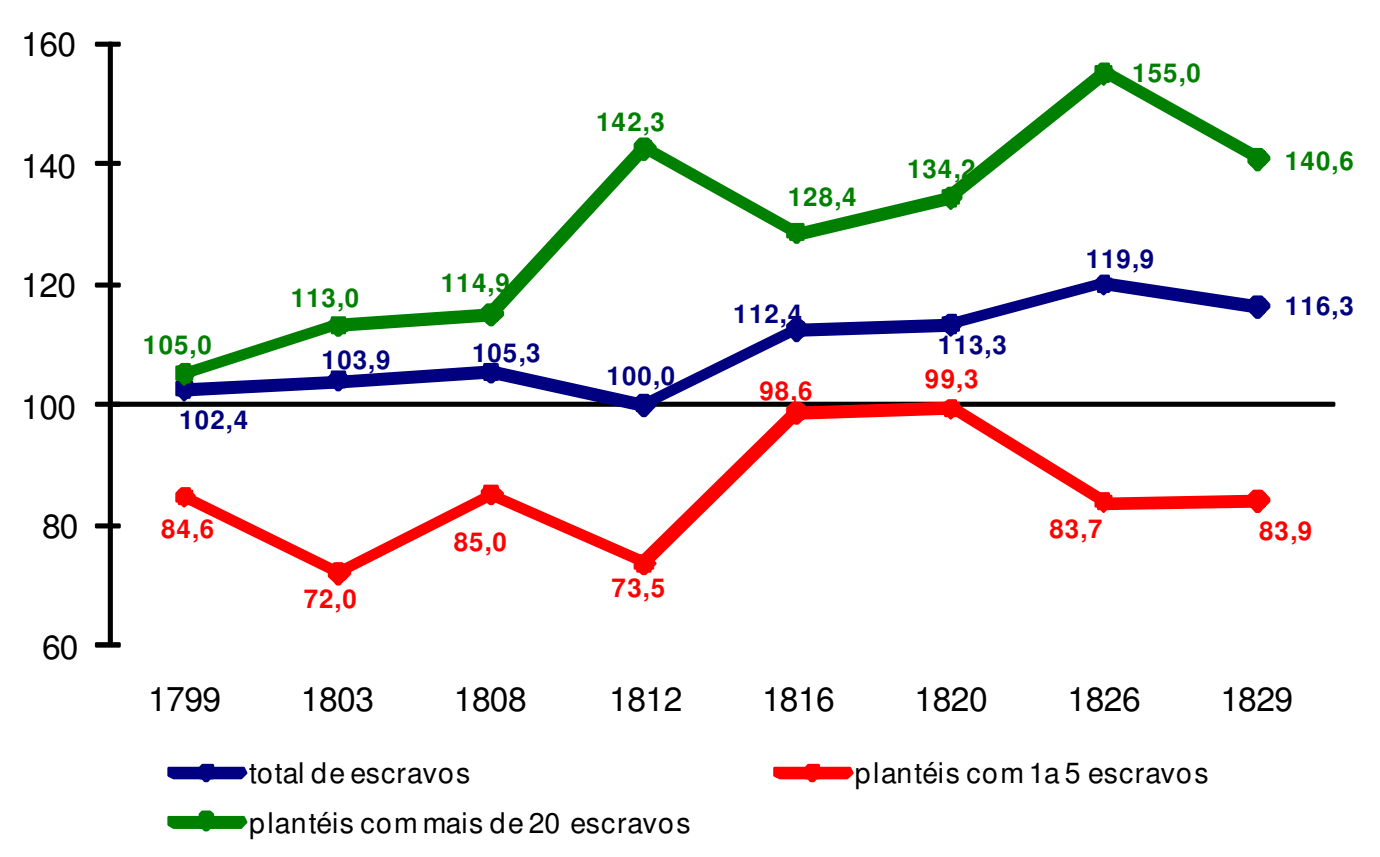

A se considerar no cálculo das razões de sexo as diferentes faixas de tamanho dos plantéis, observamos que o percentual de homens e mulheres a compor os plantéis acentuou-se com aumento da faixa de tamanho da escravaria. Nos pequenos plantéis é 
marcante a presença majoritária de cativas. Já os plantéis grandes e muito grandes apresentaram as maiores razões de sexo. (Gráfico l.16 e Tabela em apêndice estatístico)

As pequenas posses, assim como as muito grandes apresentaram evolver errático ao longo do tempo, mas independente desta variação, de maior monta entre os maiores conjuntos cativos, a diferenciação entre elas é sempre marcante.

Os grandes plantéis foram aqueles para os quais verificamos nos anos iniciais do século XIX razões de sexos indicativas da presença de 113(1803) a 115(1808) homens para cada grupo de 100 mulheres, razão que atingiu um de seus mais altos valores em 1812: 142,3 homens por 100 mulheres, correspondente a um percentual de 58,7\% homens e de $41,3 \%$ de mulheres entre aqueles a conviver em fogos com ao menos outros 19 indivíduos na mesma condição cativa. O cume dessa série de razões de sexo ocorreu em 1826, quando foram computados 155 homens para 110 mulheres, ou seja, $60,8 \%$ dos escravos aí colocados eram do sexo masculino.

Nestes anos de 1812 e 1826, as razões calculadas para plantéis compostos por 1 a 5 escravos apresentou valores, respectivamente, de 73,5 e 83,7. É dizer, as mulheres representavam $57,6 \%$ da população cativa em pequenos plantéis no início da década de 1810 e 54,4\% passados quase exatamente três lustros.

Encontramos diferenciação entre os cativos quando consideramos também as idades. Características de sexo e idade para a parcela da população em tela podem ser observadas nas pirâmides etárias, aqui apresentadas como Gráfico I.17.

\section{Gráfico I.17}

\section{Pirâmides etárias da população cativa}

\section{(Atibaia - 1799 a 1829)}

1799

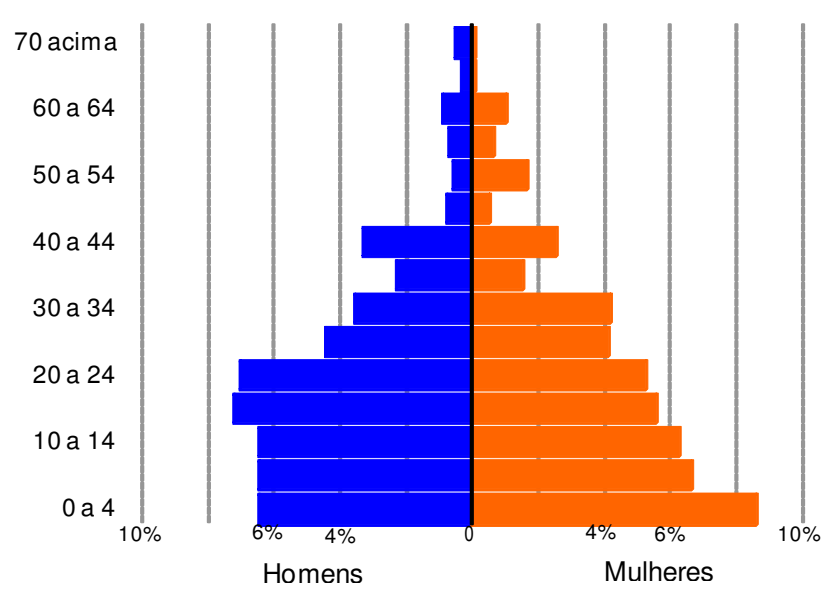




\section{3}

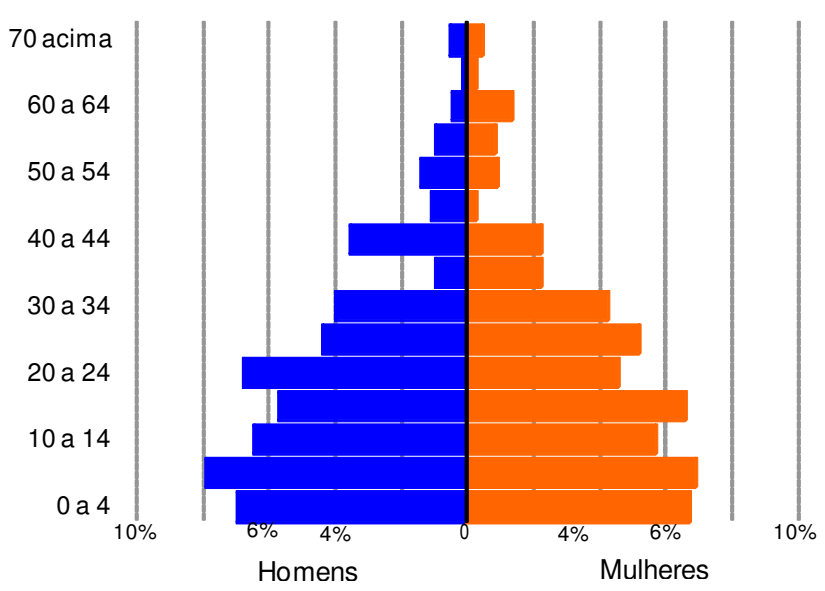

\section{8}

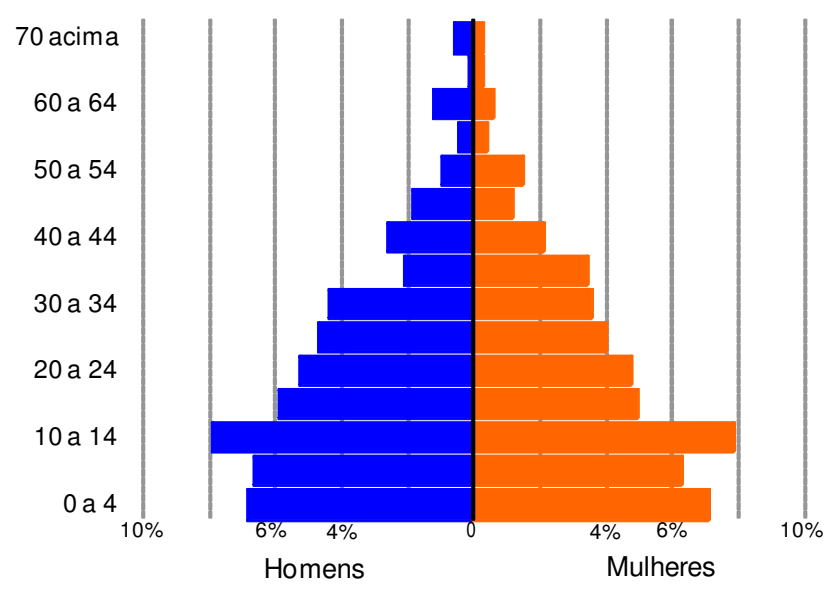

1812

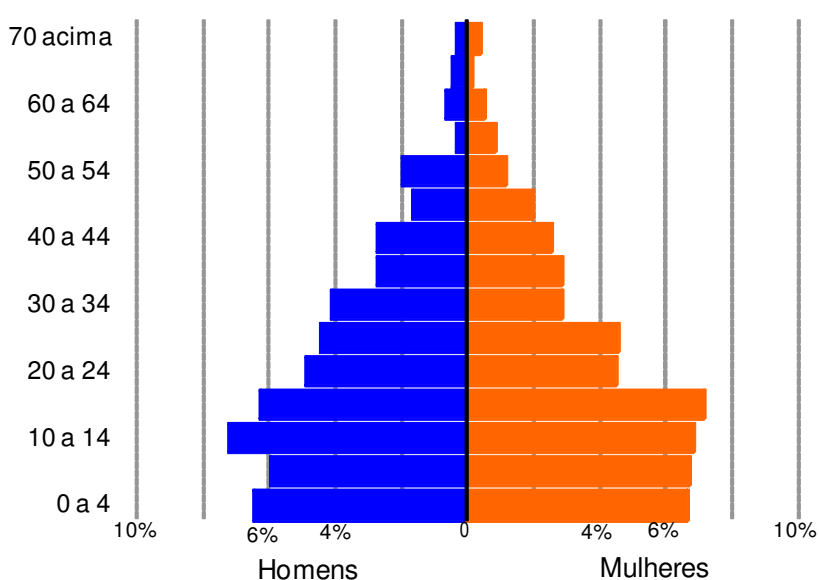


1816

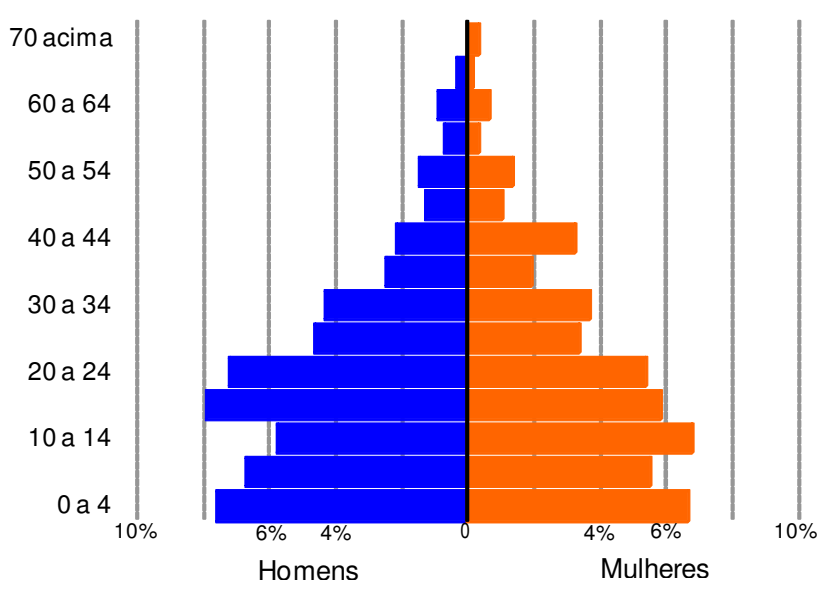

1820

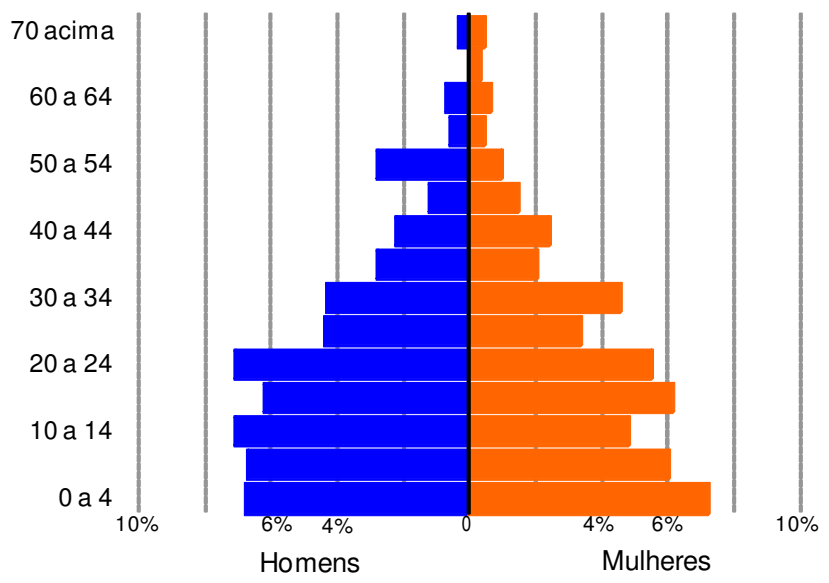

\section{6}

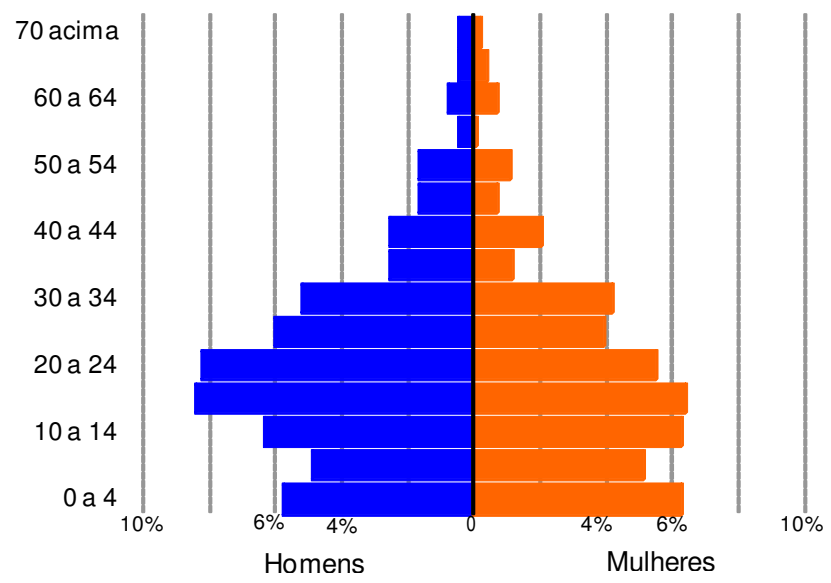


1829

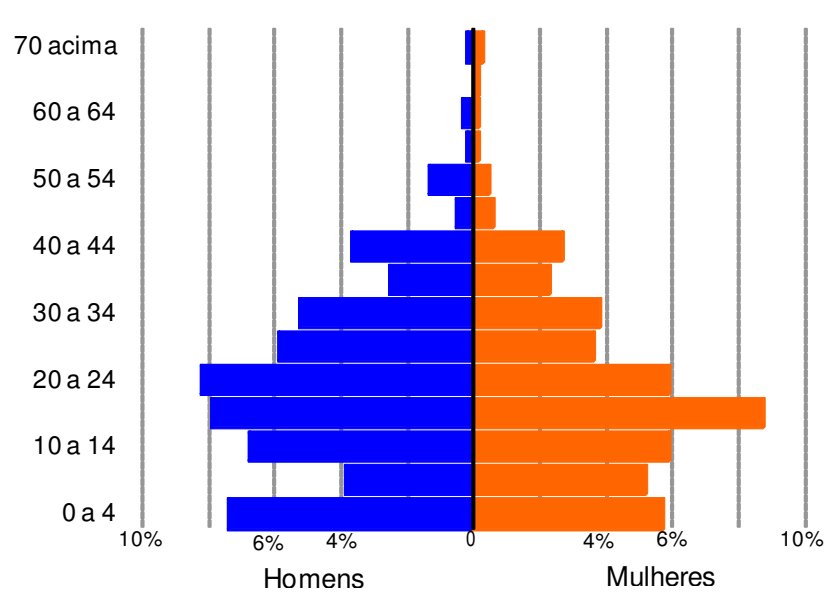

As pirâmides etárias construídas para os cativos demonstram a superioridade numérica masculina e a maior concentração de pessoas entre os 15 e os 24 anos de idade, com participação de escravos de até 14 anos também bastante representativa, mas como base, apresenta-se mais estreita que aquela observada para sociedades com crescimento natural positivo e menores volumes de migração.

Não é observável um movimento contínuo de envelhecimento ou rejuvenescimento da população mancípia em Atibaia, ainda que os intervalos entre os anos sejam próximos às faixas de tamanho dos plantéis. Os escravos de determinada faixa em um ano, são os possíveis escravos encontrados na faixa seguinte no próximo ano para o qual buscamos dados.

Especialmente em 1826 a faixa etária dos 15 aos 19 anos e a seguinte foi bastante favorável aos homens, com percentual de $17 \%$ do total de cativos devidos a eles e $12 \%$ devido a elas.

Considerando a razão de sexo de acordo com a idade dos escravos (Gráfico I.18) observamos, como era de se esperar que, comparativamente ao valor calculado para a totalidade dos escravos os cativos em idade mais produtiva apresentavam razões de sexo mais elevadas. Mesmo em posses de pequena monta, os cativos constituíam importantes braços na produção e na execução de diferentes atividades, sendo sua presença parte fundamental da mão-de-obra no cerne da economia atibaiense. Nesse contexto, crianças e idosos teriam papéis menos significativos em termos da capacidade de trabalho apresentada. 


\section{Gráfico I.18}

Razão de sexo dos cativos de acordo idades

e suas possibilidade de produção

(Atibaia - 1799 a 1829)

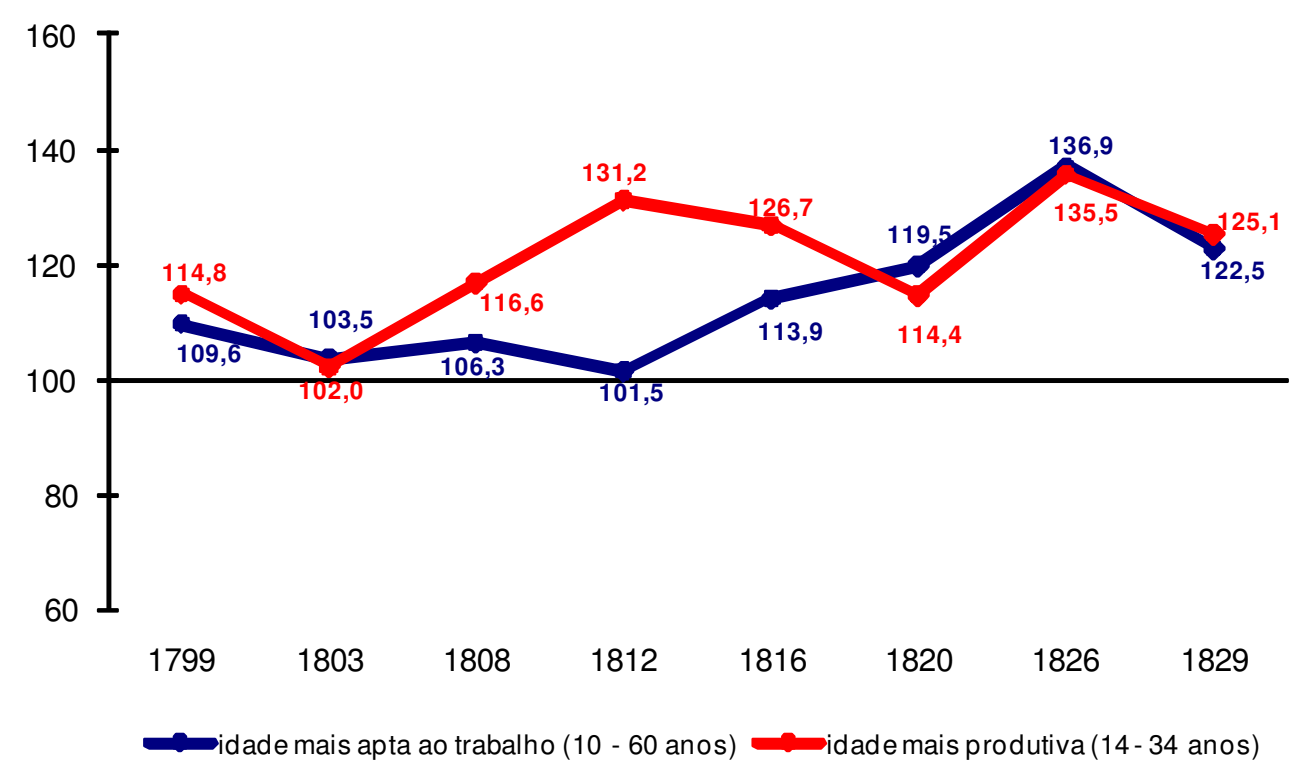

Observamos, então, escravos em idade que consideramos mais apta ao trabalho (10 aos 59 anos de idade) e em idade mais produtiva (14 aos 34 anos de idade). As variações das curvas relativas às respectivas razões de sexo apresentam evolução errática. Nos diferentes anos observados dentro dos 30 anos estudados, encontramos razões entre os sexos tendendo à superioridade masculina, com os anos até 1812 para a faixa em que a proporção calculada foi bastante próxima à igualdade entre os sexos: em 1803, por exemplo, observamos 102 homens para cada grupo de 100 mulheres. Para a outra faixa etária no momento considerada, encontramos esta proximidade neste mesmo ano de 1803: 103,5.

Comparando-se a razão de sexos para os cativos na idade em que podemos considerá-los a apresentar maior produtividade do trabalho e expandindo esta faixa etária para o que consideramos a já citada idade mais apta ao trabalho, verificamos que há um deslocamento de ambas as curvas em 1808, 1812 e 1816, que mesmo em diferentes medidas caminham no mesmo sentido e/ou patamares semelhantes. Em 1812, a referidas razões foram, respectivamente de 101,5 e 131,2 escravos homens para 100 escravas. 
Essas modificações deveriam acompanhar as modificações abertas à economia local nos diferentes momentos observados, ou seja, captam com sensibilidade os momentos de maior dinâmica econômica. ${ }^{18}$

Em suma, a população total atibaiense decresceu entre 1799 e 1820 passando, ao longo desse período, por momentos diversos de expansão e declínio, ou seja, apresentou-se bastante instável. Ainda que a população total tenha caído em $20 \%$, a parcela cativa dos habitantes da localidade manteve seu número aproximado, seguindo em diferentes medidas os mesmos sentidos de variação verificados para o total da população e da população livre que representou ao longo dos 30 anos observados ao menos $69 \%$ daqueles a viver em Atibaia, ao fim do período, quando houve uma queda em sua participação. Esses movimentos foram os mesmos identificados para o número de fogos, mas, ressalte-se, em momentos de crescimento da população livre o número de fogos foi ampliado em maior proporção.

Isto posto, ao longo das primeiras décadas Oitocentistas foi multiplicada por quase dois a parcela dos livres vivendo em domicílios nos quais escravos foram encontrados. Para fogos com e sem escravos verificamos ser os domicílios chefiados majoritariamente por atibaienses, com alguma presença de indivíduos vindos de outras áreas, especialmente vizinhas. Considerados em sua totalidade, os habitantes de Atibaia eram, ainda em maior medida, nascidos ali mesmo tendo Atibaia, ao que parece, enviado mais pessoas a outras que áreas que recebido indivíduos destas nos anos cuja movimentação influenciaram os anos de 1799 a 1829 aqui considerados.

Observando outros caracteres demográficos, especialmente atinentes ao sexo, idade e estado conjugal dos habitantes de Atibaia, observamos não ser o movimento populacional generalizado, atingindo grupos específicos entre momentos específicos.

\footnotetext{
${ }^{18}$ Conforme se verá no capítulo II, no ano de 1812 a produção média de milho principal gênero mais amplamente difundido em Atibaia, foi a maior verificada para o período 1799 e 1829, 251,4 alqueires, sendo $12,9 \%$ da produção total do grão explicitamente comercializada (percentual comparativamente elevado, como se verá). Não obtivemos dados para preço do milho em 1812, mas em ano próximo, 1814, o mantimento apresentou seu pico de preço, puxado especialmente pelas transações levada a cabo com e/ou em Santos, importante porto escoadouro da produção paulista naquele momento. Entre 1806 e 1814 houve grande recuperação da balança comercial da localidade. E houve também, em comparação a 1808, redução significativa do número de pobres na localidade, para níveis em que se manteriam no restante dos anos estudados. Lembrando haver ocorrido, ente 1808 e 1816 os maiores avanços populacionais da localidade livre e cativa atibaiense. Tudo isso, justificava a necessidade de maior mão-de-obra e, ao mesmo tempo permitia, acreditamos, reservas para a compra e/ou crédito para a compra de maior número de escravo que, como sabemos, eram comercializados em um mercado onde majoritariamente circulavam jovens homens. Dotes, heranças, doações também modificavam a estrutura de sexo das escavarias, representando transferências entre plantéis que poderiam ver seu tamanho modificado, ou a própria razão entre os sexos em questão poderia ser mudada. Em sendo parcela da população oriunda de outras áreas, é possível que daí também tenham chegado cativos por estes meios adquiridos.
} 
O Gráfico I.19 corresponde às pirâmides etárias para a população livre, ou seja, o percentual devido a cada sexo em cada grupo etário de cinco anos para a composição da população total da vila nos oito diferentes anos em tela.

No que respeita às idades do total da população livre, até 1816 as pirâmides etárias possuem uma forma em alguma medida próxima a um triângulo - em que pese ser sobressalente a faixa etárias dos 40 aos 44 anos -, indicando uma grande quantidade de crianças e jovens e baixa percentagem de pessoas mais velhas, principalmente acima dos 55 anos. A base alargada das figuras e o respectivo percentual de pessoas com até 14 anos de idade, bastante elevado em todo o período de 1799 a 1829, estando estável entre $42,5 \%$ (1812) e 45,2\% (1808), são indicativos de taxas de natalidade positivas nessa população.

\section{Gráfico I.19}

\section{Pirâmides etárias da população livre}

(Atibaia - 1799 a 1829)

1799

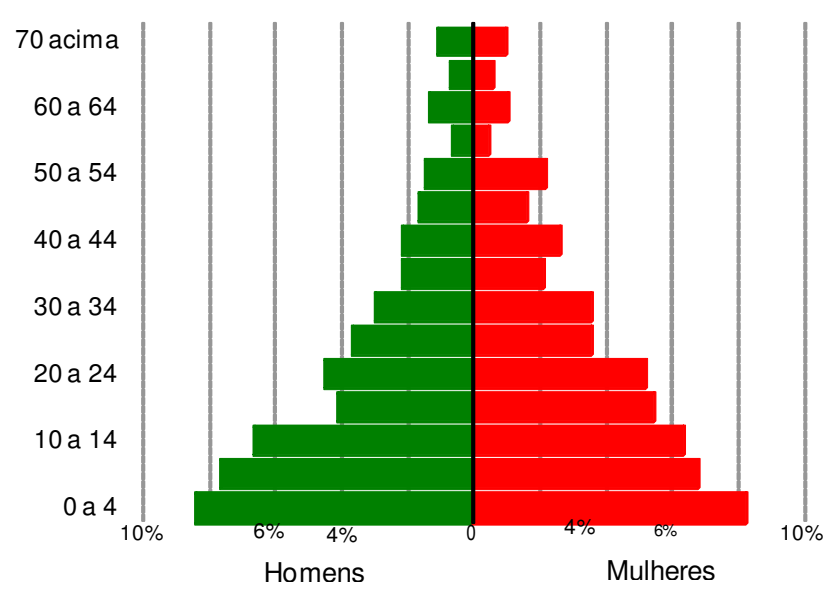




\section{3}

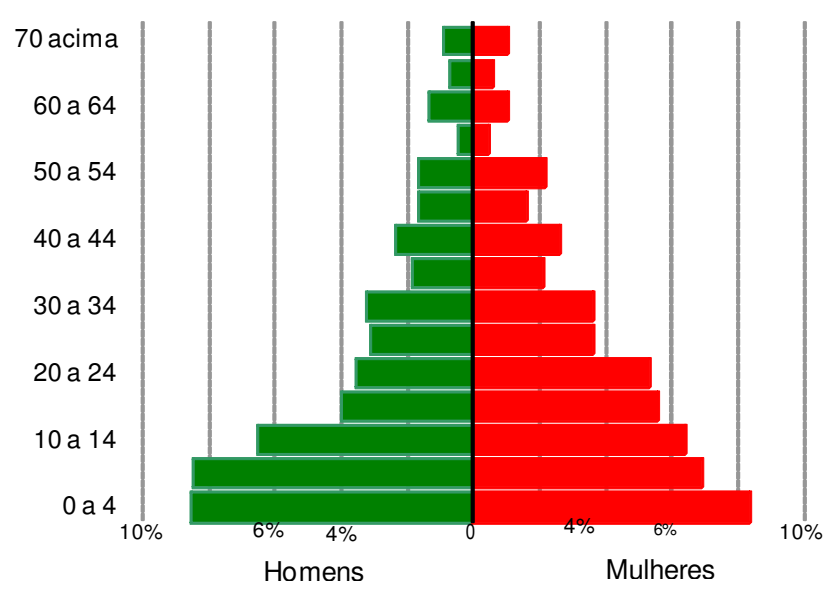

\section{8}

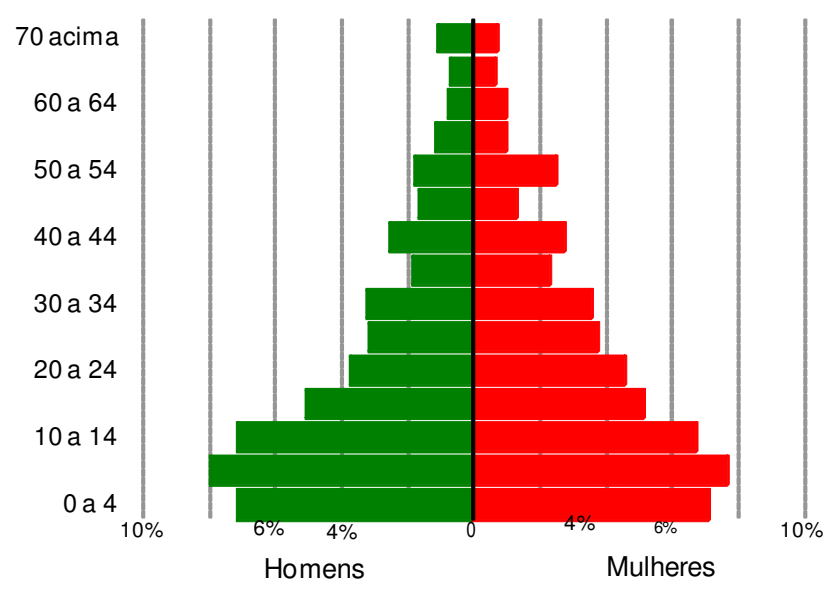

1812

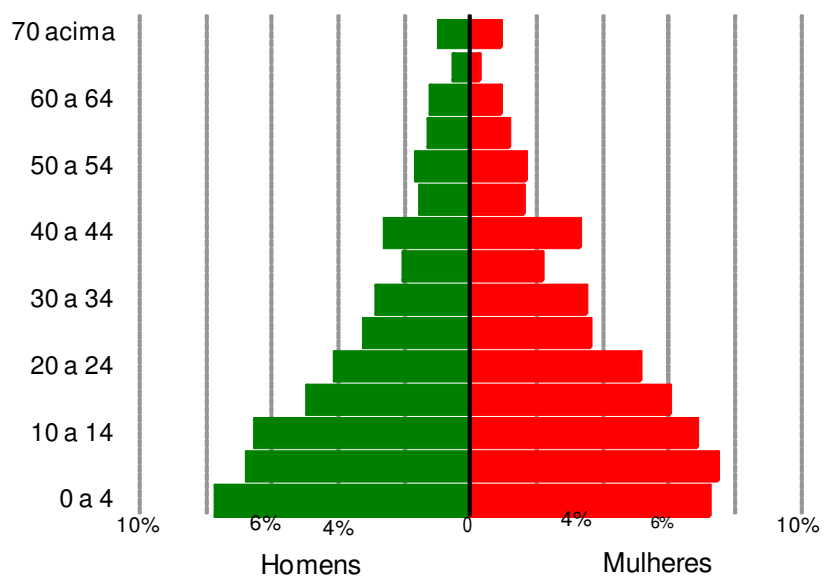


1816

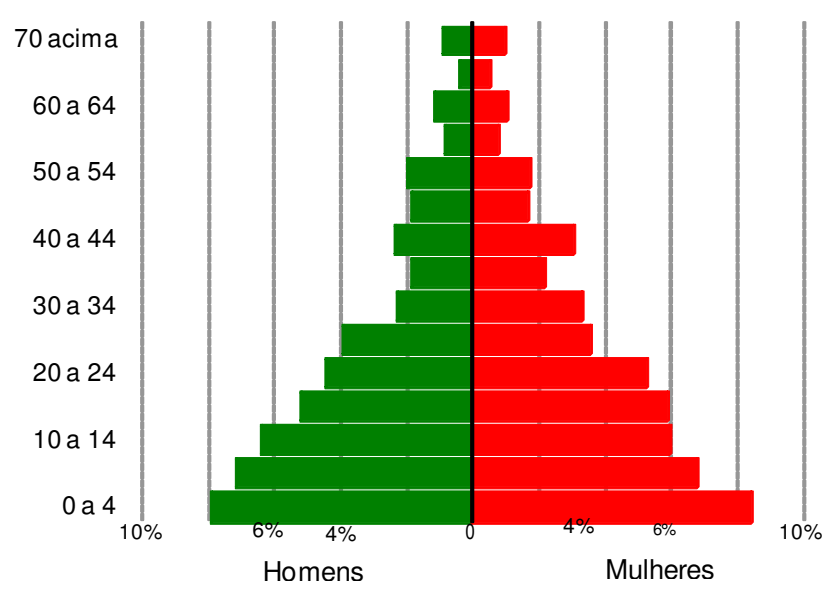

1820

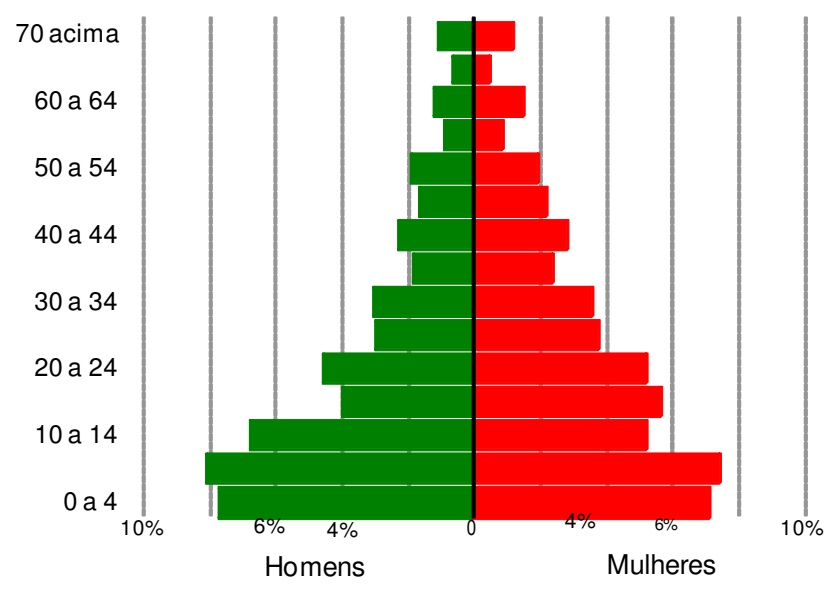

1826

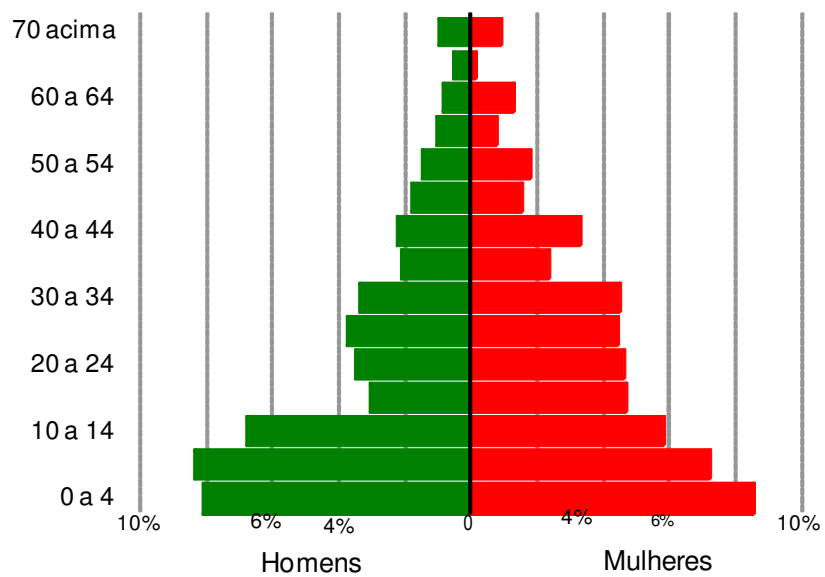




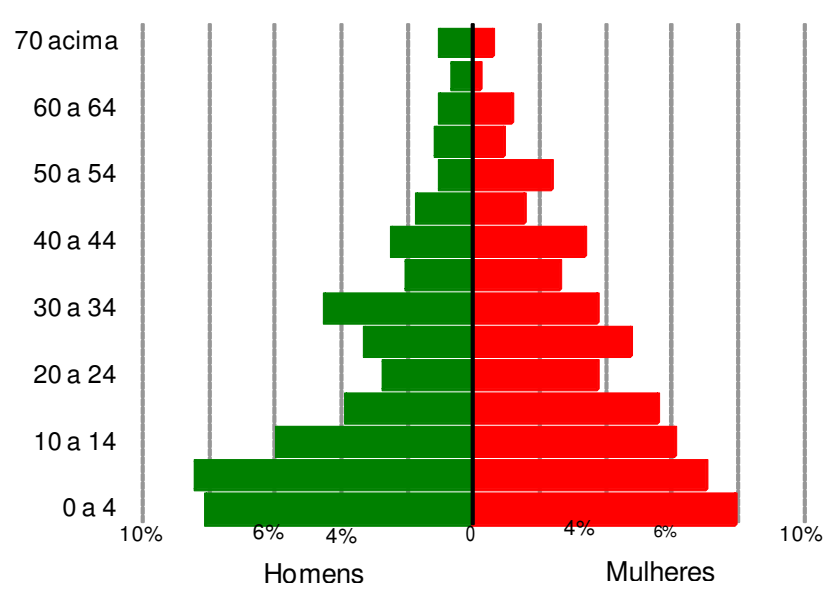

A partir de 1820 a composição dos habitantes de Atibaia por idade e sexo mostra uma diferenciação com redução da participação de homens entre 15 e 29 anos. Nesse período houve as guerras nas fronteiras do sul do Brasil, culminando com a guerra da Cisplatina, iniciada em 1825. Dado o grande contingente atibaiense ligado às milícias ${ }^{19}$ associado à já adiantada constatação de que nos anos de 1820, 26 e 29 houve uma modificação na forma da pirâmides etárias, com a redução no número de homens entre 15 anos - idade da maioridade, já sendo possível alistar-se - e 29 anos, é possível que tenha havido grande número de indivíduos deslocados para as frentes de batalha. Ou ainda, a guerra eminente e a obrigatoriedade do recrutamento, podem ter sido motivos para a ocultação desses indivíduos das listas nominativas.

Identificar o efetivo volume dessa movimentação nos documentos censitários é bastante difícil, mas a sua ocorrência pode ser anotada, pois observações pontuais neste sentido foram encontradas. Em 1820, Maria Carolina Justiniana chefiava seu fogo pois "seu marido sargento mor Feliz Jose da Cunha foi para o sul na tropa miliciana de cavalaria"; Gertrudes Maria e Paula Maria também anotaram "marido foi para o sul", da mesma forma aconteceu no fogo onde uma certa Maria Francisca, de 34 anos, vivia somente na companhia de quatro filhos menores, posto ter sido seu "marido destacado para o sul". (Lista Nominativa de Atibaia, 1820 - AESP, Maços de População/rolo 17)

Em 1826 no fogo em que Maria Buena vivia com dois filhos "falta seu marido que foi na expedição para o sul" e nas observações do domicílio da supracitada Maria Carolina ainda se mencionava, passados seis anos, ser ela "mulher do sargento mor Feliz Joze da

\footnotetext{
${ }^{19}$ Conforme o exposto no capítulo II, os militares de diversas patentes representavam $23 \%$ dos chefes de domicílio em 1808, 19,3\% no ano seguinte considerado, decrescendo a cerca de 15\% nos anos 1820 , lembrando que apenas homens poderiam estar ligados a essas atividades, ou seja, pelo menos 15\% (1799) dos fogos considerados não teriam possibilidade de ter esse setor militar como ou entre os principais, percentual que circunda os $20 \%$ a partir de 1816 .
} 
Cunha destacado para o sul". (Lista Nominativa de Atibaia, 1820 - AESP, Maços de População/rolo 19).

Considerados conjuntamente os indivíduos dos 15 aos 29 anos de idade, temos razões de sexo favoráveis às mulheres calculadas em 90,6 para 1816, 78,1 para 1820, 73,4 (1826) e finalmente 69,2 (1829), ou seja, os homens eram $48 \%$ desses jovens em 1816, passando a $40 \%$ em 1829, uma redução de 17,6\%. Apesar dessa queda verificada na década de 1820, as razões de sexo sempre foram extremamente mais favoráveis às mulheres nas faixas etárias dos 15 aos 19 e dos 20 aos 24 anos, tendo se expandido essa maioridade feminina para algumas faixas etárias seguintes, conforme Tabela I.32.

Tabela 1.32

Razão de sexo da população livre de acordo faixas etárias

(Atibaia - 1799 a 1829)

\begin{tabular}{ccccccccc}
\hline \hline $\begin{array}{c}\text { Faixas } \\
\text { etárias }\end{array}$ & $\mathbf{1 7 9 9}$ & $\mathbf{1 8 0 3}$ & $\mathbf{1 8 0 8}$ & $\mathbf{1 8 1 2}$ & $\mathbf{1 8 1 6}$ & $\mathbf{1 8 2 0}$ & $\mathbf{1 8 2 6}$ & $\mathbf{1 8 2 9}$ \\
\hline $\mathbf{0}$ a $\mathbf{4}$ & 101,6 & 101,6 & 99,5 & 106,5 & 93,2 & 107,9 & 93,9 & 101,1 \\
$\mathbf{5}$ a $\mathbf{9}$ & 112,7 & 122,2 & 103,5 & 90,1 & 104,2 & 108,5 & 115,1 & 118,4 \\
$\mathbf{1 0}$ a $\mathbf{1 4}$ & 104,5 & 100,5 & 105,0 & 94,6 & 106,9 & 128,0 & 115,7 & 97,2 \\
$\mathbf{1 5}$ a $\mathbf{1 9}$ & 74,4 & 70,3 & 96,7 & 81,7 & 87,2 & 70,4 & 63,3 & 68,5 \\
$\mathbf{2 0}$ a $\mathbf{2 4}$ & 85,4 & 65,9 & 80,7 & 79,2 & 82,6 & 86,5 & 74,8 & 72,4 \\
$\mathbf{2 5}$ a $\mathbf{2 9}$ & 101,8 & 84,8 & 83,0 & 87,2 & 107,9 & 78,1 & 82,5 & 67,6 \\
$\mathbf{3 0}$ a $\mathbf{3 4}$ & 83,0 & 87,5 & 89,6 & 80,2 & 68,6 & 84,1 & 73,1 & 118,2 \\
$\mathbf{3 5}$ a $\mathbf{3 9}$ & 100,0 & 84,8 & 78,3 & 93,8 & 82,9 & 77,5 & 85,5 & 75,4 \\
$\mathbf{4 0}$ a $\mathbf{4 4}$ & 80,5 & 86,6 & 91,5 & 77,8 & 75,3 & 81,0 & 65,8 & 72,2 \\
$\mathbf{4 5}$ a $\mathbf{4 9}$ & 100,0 & 98,0 & 125,6 & 93,8 & 107,5 & 74,2 & 113,9 & 111,1 \\
$\mathbf{5 0}$ a $\mathbf{5 4}$ & 66,2 & 75,0 & 70,7 & 96,0 & 110,7 & 94,9 & 78,6 & 43,6 \\
$\mathbf{5 5}$ a $\mathbf{5 9}$ & 133,3 & 93,3 & 113,8 & 102,8 & 104,0 & 103,8 & 121,1 & 118,2 \\
$\mathbf{6 0}$ a $\mathbf{6 4}$ & 127,3 & 124,2 & 79,3 & 120,7 & 102,9 & 77,8 & 61,3 & 85,7 \\
$\mathbf{6 5}$ a $\mathbf{6 9}$ & 110,0 & 110,0 & 105,0 & 150,0 & 70,6 & 112,5 & 220,0 & 233,3 \\
$\mathbf{7 0}$ acima & 103,1 & 87,5 & 139,1 & 100,0 & 90,3 & 91,4 & 104,8 & 164,3 \\
\hline \hline
\end{tabular}

Fonte: AESP, M aços de População, Atibaia: anos selecionados

Exclusive indivíduos com idade e/ou sexo não identificado

Note-se, todavia, que as faixas de idade de até 14 anos apresentam, ainda que inconstantes ao longo do tempo, razões comparativamente menos acentuadas e, na maioria das faixas e anos, favoráveis aos homens. Assim, por exemplo, em 1816 os atibaienses de 10 a 14 anos eram em número de 107 homens para cada grupo de 100 mulheres; em sendo este grupo aquele que em grande medida irá compor a faixa etária 
seguinte (15 a 19 anos) passados quatro anos, seria de se esperar um valor não tão favorável às mulheres como o efetivamente verificado em 1820: 70,4 indivíduos do sexo masculino para cada grupo de 100 mulheres. Certamente podemos aventar a "fuga" dos atibaienses a partir dos 15 anos. Fato este que pode ser verificado para todos os demais anos, com exceção de 1803 a 1808 períodos no qual a variação foi bem menos marcante: razão de 100,5 para os livres com idades entre 10 e 14 anos em 1803 e 96,7 para aqueles com 15 a 19 anos de idade no ano de 1808.

Considerada a população livre como um todo (Tabela I.33) temos também, como não surpreende, razões de sexo favoráveis às mulheres. Mas as atibaienses em seu conjunto nunca chegaram a responder por mais de $53,5 \%$ dos livres que compunham o arrolamento populacional da vila; percentual este, encontrado para 1803, 1812, 1826 e 1829, próximo ao verificado para os anos de 1808, 1816 e 1820: cerca de 51,5\%.

\section{Tabela I.33}

\section{Composição da população livre por sexo}

(Atibaia - 1799 a 1829)

\begin{tabular}{|c|c|c|c|c|c|c|c|c|}
\hline \multirow{3}{*}{ Anos } & \multicolumn{5}{|c|}{ População Livre } & \multicolumn{3}{|c|}{ Chefes de fogo } \\
\hline & \multicolumn{2}{|c|}{ Homens } & \multicolumn{2}{|c|}{ Mulheres } & \multirow{2}{*}{$\begin{array}{l}\text { Razão de } \\
\text { sexo }\end{array}$} & \multirow{2}{*}{$\begin{array}{l}\text { Homens } \\
\text { \% (№) }\end{array}$} & \multirow{2}{*}{$\begin{array}{c}\text { Mulheres } \\
\text { \% (№) }\end{array}$} & \multirow{2}{*}{$\begin{array}{l}\text { Razão de } \\
\text { sexo }\end{array}$} \\
\hline & \% (№) & $\begin{array}{c}\text { Variação } \\
\% \\
\end{array}$ & \% (№) & $\begin{array}{c}\text { Variação } \\
\% \\
\end{array}$ & & & & \\
\hline 1799 & 49,8 (1527) & & $50,2(1537)$ & & 99,3 & $80,5(501)$ & $19,5(121)$ & 414,0 \\
\hline 1803 & $47,7(1478)$ & $-3,2$ & $52,3(1623)$ & 5,6 & 91,1 & $81,1(468)$ & $18,9(109)$ & 429,4 \\
\hline 1808 & 48,3 (1423) & $-3,7$ & $51,7(1521)$ & $-6,3$ & 93,6 & $81,0(478)$ & $19,0(112)$ & 426,8 \\
\hline 1812 & $47,7(1426)$ & 0,2 & $52,3(1563)$ & 2,8 & 91,2 & $81,9(508)$ & $18,1(112)$ & 453,6 \\
\hline 1816 & $48,4(1530)$ & 7,3 & $51,6(1631)$ & 4,4 & 93,8 & $78,6(525)$ & $21,4(143)$ & 367,1 \\
\hline 1820 & $48,4(1441)$ & $-5,8$ & $51,6(1539)$ & $-5,6$ & 93,6 & $77,4(509)$ & $22,6(149)$ & 341,6 \\
\hline 1826 & $47,6(1071)$ & $-25,7$ & $52,4(1179)$ & $-23,4$ & 90,8 & $77,5(382)$ & $22,5(111)$ & 344,1 \\
\hline 1829 & $47,6(1087)$ & 1,5 & $52,4(1198)$ & 1,6 & 90,7 & $77,6(413)$ & 22,4 (119) & 347,1 \\
\hline
\end{tabular}

Exclusive indivíduos com sexo não identificado

Fonte:AESP, M aços de População, A tibaia: anos selecionados

Como esperado, considerados apenas os chefes de domicílio, o percentual de homens era bastante superior ao de mulheres. O número de homens ultrapassa os 340 para o número de 100 mulheres, correspondendo a não menos de $77,5 \%$ de homens entre os chefes de fogo. Com o passar dos anos, todavia, houve um decréscimo nessa participação masculina que variou de 80,5\% em 1799 para 78,6\% em 1816 e 77,6\% em 1829. É dizer, a razão de sexo caiu de 414 em 1799 a 347,1 em 1829. Nos anos 1820, 1826 e 1829 - coincidentes com a queda da participação de homens com ao menos 15 
anos de idade - o percentual de homens e mulheres na população foi o mesmo e, como adiantado, corresponderam à menor participação de indivíduos do sexo masculino.

Dentre os chefes de domicilio, para o grupo de escravistas, mostrados na Tabela I.34, encontramos maioria de homens, seguindo tendência esperada e encontrada para a totalidade dos chefes de fogo, cuja grande maioria era composta por indivíduos do sexo masculino (cabendo às mulheres esse posto, majoritariamente, quando viúvas, recorde-se uma vez mais ou, em menor medida, solteiras). Mas note-se, a proporção de sexos para os senhores de escravos era ainda mais acentuada que para o total dos chefes de fogo. Em 1799 a razão de sexo calculada foi de 440 homens para cada 100 mulheres entre os chefes de domicílio, enquanto esse indicador era alçado a 612,5 entre os escravistas; encontramos ao final do período (1829) uma relação de sexos menos acentuada, no entanto, com a mesma tendência: razão de sexo de 347,1 para chefes de fogo e 468,2 para escravistas.

Ou seja, era essencialmente masculina a parcela da população possuidora de cativos - embora as mulheres tivessem, como filhas e/ou casadas, acesso a serviços prestados por esses indivíduos.

Tabela 1.34

Sexo e idade dos chefes de fogo com escravos

(Atibaia - 1799 a 1829)

\begin{tabular}{ccccccccc}
\hline \hline & 1799 & 1803 & 1808 & 1812 & 1816 & 1820 & 1826 & 1829 \\
\hline Homens (\%) & 86,0 & 83,2 & 79,2 & 82,6 & 84,0 & 79,5 & 82,9 & 82,4 \\
Mulheres (\%) & 14,0 & 16,8 & 20,8 & 17,4 & 16,0 & 20,5 & 17,1 & 17,6 \\
Razão de sexo & 612,5 & 495,2 & 380,8 & 474,7 & 525,0 & 387,8 & 484,8 & 468,2 \\
\hline Idade média & 45,9 & 44,6 & 44,5 & 46,1 & 43,2 & 50,1 & 45,2 & 45,3 \\
Idade mínima & 19 & 18 & 18 & 18 & 17 & 21 & 15 & 17 \\
Idade máxima & 90 & 89 & 81 & 84 & 84 & 85 & 96 & 83 \\
\hline \hline Fonte: AESP, Maços de População, Atibaia: anos selecionados
\end{tabular}

Fonte: AESP, M aços de População, Atibaia: anos selecionados

Assim como a composição por sexos, a idade dos donos de cativos não sofreu alterações importantes ao longo do tempo. Merece destaque o ano de 1826, quando 0 calculo das idades apontou média de 50,1 anos, enquanto nos demais anos havia estado sempre próxima aos 45 anos.

$\mathrm{Na}$ população total, para homens mais mulheres livres acima de 14 anos encontramos uma maioria, crescente, de casados: eram 55,5\% em 1799 passando a $57,9 \%$ em 1820 e ultrapassando os $60 \%$ a partir de 1826 . Para os homens o percentual 
de indivíduos que haviam contraído matrimônio subiu 10 pontos percentuais após três décadas, passando de 57,7\% em 1799 a 63,9\% em 1820, chegando a 68,6\% em 1829, correspondendo a uma redução dos atibaienses do sexo masculino de 37\% (1799) para $28,2 \%$ (1829) e dos viúvos de 5,2\% (1799) a 2,8\% (1826). As mulheres, a sua vez, apresentaram percentual de viúvas bem mais considerável, variando entre o mínimo de 9\% em 1812 ao máximo de $12 \%$ no último ano considerado. Para elas, o percentual de casadas flutuou em menor medida que para eles no longo prazo, subiu de 53,7\% em 1799 para $56,3 \%$ em 1829, sendo o percentual relativo a 1803, 48,7\%. (vide Tabela I.35)

Por outro lado, a composição por estado conjugal do grupo que chefiava os domicílios da vila aponta para uma diferenciação grande entre os gêneros. Entre os chefes do sexo masculino era absoluta, ao longo dos anos, a presença de casados, sendo o percentual, assim como ocorria para todos os homens, crescente, subindo de $86,1 \%$ a $91,7 \%$ em trinta anos. Entre as mulheres encontradas sob a condição de chefes de fogo a predominância era das viúvas, com percentual flutuante, situação que correspondia ao estado conjugal de 70,9\% delas em sua maior participação datada de 1799 e 55,5\% delas quando de sua menor participação em 1826. (vide Tabela I.36)

\section{Tabela $\mathbf{I . 3 5}$}

Composição da população livre de acordo com estado conjugal e sexo - exclusive indivíduos de até 14 anos (Atibaia - 1799 a 1829)

\begin{tabular}{|c|c|c|c|c|c|c|c|c|c|}
\hline \multirow{2}{*}{ Anos } & \multicolumn{3}{|c|}{ Homens } & \multicolumn{3}{|c|}{ Mulheres } & \multicolumn{3}{|c|}{ Homens + Mulheres } \\
\hline & $\begin{array}{c}\text { Casados } \\
\%\end{array}$ & $\begin{array}{c}\text { Solteiros } \\
\%\end{array}$ & $\begin{array}{c}\text { Viúvos } \\
\%\end{array}$ & $\begin{array}{c}\text { Casadas } \\
\%\end{array}$ & $\begin{array}{c}\text { Solteiras } \\
\%\end{array}$ & $\begin{array}{c}\text { Viúvas } \\
\%\end{array}$ & $\begin{array}{c}\text { Casados } \\
\%\end{array}$ & $\begin{array}{c}\text { Solteiros } \\
\%\end{array}$ & $\begin{array}{c}\text { Viúvos } \\
\%\end{array}$ \\
\hline 1799 & 57,7 & 37,0 & 5,2 & 53,7 & 35,9 & 10,3 & 55,5 & 36,6 & 7,9 \\
\hline 1803 & 59,3 & 35,7 & 5,1 & 48,7 & 42,1 & 9,3 & 53,3 & 39,4 & 7,3 \\
\hline 1808 & 57,8 & 38,3 & 3,9 & 51,3 & 38,6 & 10,2 & 53,9 & 38,9 & 7,2 \\
\hline 1812 & 60,5 & 34,9 & 4,6 & 52,7 & 38,4 & 9,0 & 56,3 & 36,7 & 7,0 \\
\hline 1816 & 59,0 & 36,8 & 4,2 & 51,4 & 37,4 & 11,2 & 54,9 & 37,4 & 7,7 \\
\hline 1820 & 63,9 & 32,5 & 4,6 & 53,0 & 36,0 & 11,0 & 57,9 & 34,0 & 8,1 \\
\hline 1826 & 68,2 & 29,0 & 2,8 & 54,4 & 34,2 & 11,4 & 60,8 & 31,6 & 7,6 \\
\hline 1829 & 68,6 & 28,2 & 3,1 & 56,3 & 31,5 & 12,1 & 60,5 & 31,6 & 7,9 \\
\hline
\end{tabular}

Fonte: AESP, M aços de População, A tibaia: anos selecio nados 
Tabela I.36

Composição dos chefes de fogo de acordo com estado conjugal e sexo

- exclusive indivíduos de até 14 anos -

(Atibaia - 1799 a 1829)

\begin{tabular}{|c|c|c|c|c|c|c|c|c|c|}
\hline \multirow{2}{*}{ Anos } & \multicolumn{3}{|c|}{ Homens } & \multicolumn{3}{|c|}{ Mulheres } & \multicolumn{3}{|c|}{ Homens + Mulheres } \\
\hline & $\begin{array}{c}\text { Casados } \\
\%\end{array}$ & $\begin{array}{c}\text { Solteiros } \\
\%\end{array}$ & $\begin{array}{c}\text { Viúvos } \\
\%\end{array}$ & $\begin{array}{c}\text { Casadas } \\
\%\end{array}$ & $\begin{array}{c}\text { Solteiras } \\
\%\end{array}$ & $\begin{array}{c}\text { Viúvas } \\
\%\end{array}$ & $\begin{array}{c}\text { Casados } \\
\%\end{array}$ & $\begin{array}{c}\text { Solteiros } \\
\%\end{array}$ & $\begin{array}{c}\text { Viúvos } \\
\%\end{array}$ \\
\hline 1799 & 86,1 & 6,5 & 7,4 & 7,8 & 21,4 & 70,9 & 72,5 & 9,1 & 18,4 \\
\hline 1803 & 88,1 & 5,8 & 6,0 & 6,4 & 37,6 & 56,0 & 72,6 & 11,9 & 15,5 \\
\hline 1808 & 89,1 & 6,3 & 4,6 & 11,7 & 28,8 & 59,5 & 74,4 & 10,6 & 15,0 \\
\hline 1812 & 87,3 & 6,0 & 6,6 & 7,3 & 33,9 & 58,7 & 73,0 & 11,0 & 16,0 \\
\hline 1816 & 89,2 & 4,2 & 6,6 & 8,5 & 28,9 & 62,7 & 71,9 & 9,5 & 18,6 \\
\hline 1820 & 89,1 & 5,0 & 6,0 & 10,9 & 32,0 & 57,1 & 71,4 & 11,1 & 17,5 \\
\hline 1826 & 91,0 & 5,5 & 3,4 & 10,0 & 34,5 & 55,5 & 72,8 & 12,1 & 15,1 \\
\hline 1829 & 91,7 & 4,4 & 3,9 & 14,3 & 24,4 & 61,3 & 74,3 & 8,9 & 16,8 \\
\hline
\end{tabular}

Assim como anotamos para Jundiaí e Bragança, as mulheres casadas deveriam ser chefes de fogo na ausência do marido. Para Atibaia também conseguimos identificar casos pontuais em que a ausência do marido foi explicitada, a exemplo, as referidas mulheres cujos maridos foram destacados para o sul na década na década de 1820 . Ou, claramente anos antes, ainda no Setecentos, quando na descrição de cinco dos oito domicílios chefiados por mulheres encontramos explicitamente maridos ausentes, podendo esta se prolongar, como atesta Maria Bicuda, que aos 43 anos em 1808 declarou "marido ausente a 9 anos" (Lista Nominativa de Atibaia, 1820 - AESP, Maços de População/rolo 15)

A Tabela 1.37 apresenta valores estatísticos para a idade dos não cativos de acordo com o estado conjugal e sexo. De imediato percebemos ser a idade média dos indivíduos casados pouco variável ao longo dos anos, mantendo-se em torno de 36-37 anos, com uma diferenciação média de cinco pontos percentuais entre a média de idade para mulheres e homens, sendo as mulheres casadas mais jovens. Atibaienses do sexo masculino e casados tinham, aproximadamente, idades em torno de 39 anos; para mulheres esta média era aproximadamente de 33,5 anos. 
Tabela 1.37

Estatísticas para a idade dos livres de acordo com o estado conjugal e sexo (Atibaia - 1799 a 1829)

\begin{tabular}{|c|c|c|c|c|c|c|c|c|c|c|c|c|}
\hline \multirow[b]{3}{*}{$\begin{array}{l}\text { Estatísticas para } \\
\text { idade }\end{array}$} & \multicolumn{3}{|c|}{1799} & \multicolumn{3}{|c|}{1803} & \multicolumn{3}{|c|}{1808} & \multicolumn{3}{|c|}{1812} \\
\hline & \multicolumn{3}{|c|}{ Solteiros } & \multicolumn{3}{|c|}{ Solteiros } & \multicolumn{3}{|c|}{ Solteiros } & \multicolumn{3}{|c|}{ Solteiros } \\
\hline & Homens & Mulheres & $\begin{array}{l}\text { Homens + } \\
\text { Mulheres }\end{array}$ & Homens & Mulheres & $\begin{array}{l}\text { Homens + } \\
\text { Mulheres }\end{array}$ & Homens & Mulheres & $\begin{array}{l}\text { Homens + } \\
\text { Mulheres }\end{array}$ & Homens & Mulheres & $\begin{array}{l}\text { Homens + } \\
\text { Mulheres }\end{array}$ \\
\hline$\% 15$ ou mais anos & 28,7 & 31,3 & 30,1 & 27,4 & 35,3 & 31,2 & 31,4 & 35,1 & 33,4 & 30,2 & 35,2 & 32,8 \\
\hline$\% 50$ ou mais anos & 1,8 & 3,0 & 2,5 & 2,0 & 5,1 & 3,6 & 2,7 & 4,4 & 3,6 & 2,0 & 4,2 & 3,2 \\
\hline \multirow{2}{*}{$\begin{array}{l}\text { Estatísticas para } \\
\text { idade }\end{array}$} & \multicolumn{3}{|c|}{ Casados } & \multicolumn{3}{|c|}{ Casados } & \multicolumn{3}{|c|}{ Casados } & \multicolumn{3}{|c|}{ Casados } \\
\hline & Homens & Mulheres & $\begin{array}{l}\text { Homens + } \\
\text { Mulheres }\end{array}$ & Homens & Mulheres & $\begin{array}{l}\text { Homens + } \\
\text { Mulheres }\end{array}$ & Homens & Mulheres & $\begin{array}{l}\text { Homens + } \\
\text { Mulheres }\end{array}$ & Homens & Mulheres & $\begin{array}{l}\text { Homens + } \\
\text { Mulheres }\end{array}$ \\
\hline Média & 39,4 & 33,4 & 36,3 & 39,4 & 33,5 & 36,4 & 40,3 & 34,6 & 37,4 & 39,2 & 33,6 & 36,4 \\
\hline Moda & 25,0 & 31,0 & 25,0 & 24,0 & 28,0 & 24,0 & 31,0 & 30,0 & 30,0 & 24,0 & 18,0 & 20,0 \\
\hline Mediana & 37,0 & 31,0 & 33,0 & 37,0 & 31,0 & 34,0 & 38,0 & 32,0 & 35,0 & 37,0 & 32,0 & 34,0 \\
\hline \multirow[t]{2}{*}{$\% 50$ ou mais anos } & 24,8 & 12,3 & 18,5 & 24,0 & 12,9 & 18,5 & 26,0 & 15,9 & 21,0 & 24,8 & 13,3 & 18,9 \\
\hline & \multicolumn{3}{|c|}{1816} & \multicolumn{3}{|c|}{1820} & \multicolumn{3}{|c|}{1826} & \multicolumn{3}{|c|}{1829} \\
\hline \multirow{2}{*}{$\begin{array}{l}\text { Estatísticas para } \\
\text { idade }\end{array}$} & \multicolumn{3}{|c|}{ Solteiros } & \multicolumn{3}{|c|}{ Solteiros } & \multicolumn{3}{|c|}{ Solteiros } & \multicolumn{3}{|c|}{ Solteiros } \\
\hline & Homens & Mulheres & $\begin{array}{l}\text { Homens + } \\
\text { Mulheres }\end{array}$ & Homens & Mulheres & $\begin{array}{l}\text { Homens + } \\
\text { Mulheres }\end{array}$ & Homens & Mulheres & $\begin{array}{l}\text { Homens + } \\
\text { Mulheres }\end{array}$ & Homens & Mulheres & $\begin{array}{l}\text { Homens + } \\
\text { Mulheres }\end{array}$ \\
\hline$\% 15$ ou mais anos & 31,7 & 35,5 & 33,9 & 26,0 & 34,7 & 30,4 & 23,0 & 33,0 & 28,2 & 24,1 & 32,0 & 28,2 \\
\hline$\% 50$ ou mais anos & 1,7 & 3,7 & 2,8 & 1,8 & 4,6 & 3,2 & 1,7 & 4,6 & 3,2 & 1,8 & 4,8 & 3,4 \\
\hline \multirow{2}{*}{$\begin{array}{l}\text { Estatísticas para } \\
\text { idade }\end{array}$} & \multicolumn{3}{|c|}{ Casados } & \multicolumn{3}{|c|}{ Casados } & \multicolumn{3}{|c|}{ Casados } & \multicolumn{3}{|c|}{ Casados } \\
\hline & Homens & Mulheres & $\begin{array}{l}\text { Homens + } \\
\text { Mulheres }\end{array}$ & Homens & Mulheres & $\begin{array}{l}\text { Homens + } \\
\text { Mulheres }\end{array}$ & Homens & Mulheres & $\begin{array}{l}\text { Homens + } \\
\text { Mulheres }\end{array}$ & Homens & Mulheres & $\begin{array}{l}\text { Homens + } \\
\text { Mulheres }\end{array}$ \\
\hline Média & 39,2 & 33,3 & 36,2 & 38,9 & 33,2 & 36,0 & 38,7 & 32,4 & 35,5 & 39,2 & 32,6 & 35,9 \\
\hline Moda & 40,0 & 20,0 & 40,0 & 30,0 & 20,0 & 30,0 & 28,0 & 26,0 & 30,0 & 31,0 & 30,0 & 25,0 \\
\hline Mediana & 38,0 & 30,0 & 34,0 & 37,0 & 30,0 & 33,0 & 36,0 & 30,0 & 33,0 & 36,0 & 25,0 & 33,0 \\
\hline$\% 50$ ou mais anos & 25,1 & 13,8 & 19,4 & 24,5 & 13,1 & 18,7 & 11,9 & 22,1 & 16,7 & 22,0 & 11,9 & 16,9 \\
\hline
\end{tabular}

Fonte: AESP, Maços de População, Atibaia: anos selecionados 
Para os casados, cerca de um quarto dos homens tinham 50 ou mais anos de idade, enquanto para as mulheres o percentual foi inferior, situando-se entre $12 \%$ (1826) e $15,9 \%$ (1808). Indivíduos solteiros acima dos 50 anos (celibato definitivo) eram presença bastante diminuta nas listas nominativas, para ambos os sexos: entre 1799 e 1830 o percentual devido a esta fatia da população de Atibaia variou entre 2,5\% e 3,6\%, com mulheres apresentado um percentual em pouco superior ao verificado para o sexo oposto, com limites de $3 \%$ e $5,1 \%$ para elas mantendo-se em todos os anos em $1,7 \%-2 \%$ para eles, em que pesem as razões de sexo anteriormente apontadas.

Para além da presença de livres e escravos (e suas características) em fogos com e sem escravos, podemos observar a parcela agregada dessa população livre, que teve importante participação na composição dos fogos da Atibaia nos séculos XVIII e XIX. A tabela 1.38 apresenta dados para os agregados livres não aparentados na população.

O menor número absoluto deles foi arrolado em 1829, quando eram 195 indivíduos que respondiam por apenas 5,3\% da população total e 3,4\% da população livre de Atibaia ao habitarem $21,6 \%$ das unidades familiares locais (115 fogos). Nesse ano, a média de agregados por fogo foi de 1,7, a menor verificada e coincidente com aquela calculada para o ano de 1816, quando eram 205 os agregados encontrados em $18 \%$ dos fogos.

Tabela 1.38

Peso dos domicílios com e sem agregados não aparentados na população (Atibaia - 1799 a 1829)

\begin{tabular}{|c|c|c|c|c|c|c|c|}
\hline Anos & $\begin{array}{l}\% \text { de fogos } \\
\text { com } \\
\text { agregados }\end{array}$ & $\begin{array}{c}\text { № de } \\
\text { agregados }\end{array}$ & $\begin{array}{c}\% \text { de } \\
\text { agregados } \\
\text { na } \\
\text { população } \\
\text { total }\end{array}$ & $\begin{array}{c}\text { \% de } \\
\text { agregados } \\
\text { na } \\
\text { população } \\
\text { livre }\end{array}$ & $\begin{array}{c}\text { Média de } \\
\text { agregados } \\
\text { (fogos com } \\
\text { agregados) }\end{array}$ & $\begin{array}{l}\text { Média de } \\
\text { agregados } \\
\text { (total de } \\
\text { fogos) }\end{array}$ & $\begin{array}{c}\% \text { de fogos } \\
\text { com agregados } \\
\text { e escravos }\end{array}$ \\
\hline 1799 & 18,2 & 267 & 6,9 & 8,4 & 2,4 & 0,43 & 7,6 \\
\hline 1803 & 26,8 & 343 & 7,5 & 9,2 & 2,2 & 0,60 & 10,6 \\
\hline 1808 & 21,0 & 243 & 5,7 & 7,3 & 2,0 & 0,41 & 8,6 \\
\hline 1812 & 18,6 & 227 & 4,7 & 6,0 & 2,0 & 0,37 & 10,3 \\
\hline 1816 & 18,0 & 205 & 4,1 & 5,4 & 1,7 & 0,31 & 7,9 \\
\hline 1820 & 21,0 & 279 & 6,3 & 8,8 & 2,0 & 0,42 & 10,6 \\
\hline 1826 & 25,7 & 276 & 5,0 & 7,3 & 2,2 & 0,56 & 13,4 \\
\hline 1829 & 21,6 & 195 & 3,4 & 5,3 & 1,7 & 0,37 & 11,3 \\
\hline
\end{tabular}

Fonte: AESP, M aços de População, A tibaia: anos selecionados 
Assim como outras variáveis observadas para a população da Vila de São João de Atibaia, houve sempre variação nos caracteres representativos da presença de agregados, tendo sido encontrados em $18,2 \%$ dos fogos em 1799 , subido ao máximo para o período em $1803,26,8 \%$, caindo posteriormente a $21 \%$ e $18 \%$, subindo a $25,7 \%$ em 1826 antes de atingir as características observadas para o ano de 1829, nunca ultrapassando o máximo de $7,5 \%$ da população total naquele ano em que estavam em maior número de domicílios, mesmo ano em que eram $9,2 \%$ da população livre.

Agregados eram encontrados em fogos com e sem a presença de plantéis cativos, tendo seu percentual de participação em conjunto nos fogos atingido maior participação em 1826, 13,4\% e os menores uma e três décadas antes (1816 e 1799), 7,9\% e 7,6\%, sendo que apenas entre 1808 e 1812 o percentual de fogos com agregados e o percentual de fogos com agregados e escravos variou em sentidos opostos.

Por fim, a Tabela 1.39 apresenta uma última variável: cor.

Apesar de em todas as listas os brancos constituírem maior parte da população livre, é perceptível, ao longo dos anos, um escurecimento dessa população; Diferentemente do que se poderia imaginar, a opção por um branqueamento da população ao ser esta arrolada na lista, pois, como discutido em seções anteriores, é sabido que $o$ arrolamento de cor dos habitantes sofria influências de ordem social e econômica, sendo o branqueamento ali colocado padrão de ascensão social.

\section{Tabela 1.39}

Distribuição da população livre entre brancos e não brancos

(Atibaia - 1799 a 1829)

\begin{tabular}{|c|c|c|c|c|c|}
\hline \multirow{3}{*}{ Anos } & \multirow{3}{*}{$\begin{array}{l}\text { Brancos } \\
\text { \% (№) }\end{array}$} & \multicolumn{3}{|c|}{ Não Brancos } & \multirow{3}{*}{$\begin{array}{c}\text { Total: Brancos } \\
\text { + Não brancos } \\
\text { \% (№) }\end{array}$} \\
\hline & & Pardos/Mulatos & Negros/Pretos & Total & \\
\hline & & \% (№) & \% (№) & \% (№) & \\
\hline 1799 & $89,5(1594)$ & 74,3 (139) & $25,7(48)$ & $10,5(187)$ & $100,0(1781)$ \\
\hline 1803 & $74,5(2310)$ & 92,7 (732) & 7,3 (58) & $25,5(790)$ & $100,0(3100)$ \\
\hline 1808 & $77,3(2276)$ & $93,4(625)$ & $6,6(44)$ & 22,7 (669) & $100,0(2945)$ \\
\hline 1812 & $73,5(2197)$ & $93,6(743)$ & $6,4(51)$ & $26,5(794)$ & $100,0(2991)$ \\
\hline 1816 & 71,7 (2257) & 94,7 (844) & $5,3(47)$ & $28,3(891)$ & $100,0(3148)$ \\
\hline 1820 & $68,3(2024)$ & $93,4(879)$ & $6,6(62)$ & 31,7 (941) & $100,0(2965)$ \\
\hline 1826 & $64,5(1448)$ & $92,2(736)$ & $7,8(62)$ & $35,5(798)$ & $100,0(2246)$ \\
\hline 1829 & $54,0(1234)$ & 95,0 (999) & $5,0(53)$ & $46,0(1052)$ & $100,0(2286)$ \\
\hline
\end{tabular}


Compunham a população livre da vila de Atibaia basicamente brancos em 1799: $89,5 \%$ dos indivíduos com cor identificada assim foram arrolados, sendo 10,5\% não brancos, dos quais $74,3 \%$ eram mulatos e $25,7 \%$ pretos. Em 1812 os brancos eram $73,5 \%$ e em 1826 os 1234 brancos descritos representavam 64,5\% da população, percentual que se reduziu ainda mais até 1829 , quando $54 \%$ da população era declaradamente branca, sendo os $46 \%$ de não brancos compostos por pardos (95\%) e negros (5\%).

Essas mudanças não acompanham a variação do número de cativos na população total da localidade. A correlação entre cor e número de escravos é positiva, porém não muito significativa $(0,561)$, implicando em uma maior miscigenação entre os habitantes da localidade. 


\section{Nazaré}

Entre 1799 e 1829, a freguesia de Nazaré apresentou acentuado crescimento, que pode ser demonstrado pela evolução do número de fogos, número de livres e escravos nessa sociedade. A população nazareana arrolada nas listas nominativas (Gráfico I.20 e Tabela I.40) cresceu 56,9\% nesses 30 anos. Contudo, este crescimento não foi o mesmo em todos os momentos, variando ao longo do tempo, passando também por momentos de declínio, todavia pouco significativos diante da tendência de longo prazo ao incremento da população total. Entre 1799 e 1803 a população cresceu vertiginosos 35,9\% voltando a crescer (8,5\%) entre 1803 e 1808. Já no momento seguinte, 1808 a 1812, houve queda de 3,2\% no número de habitantes arrolados em Nazaré. Apesar dessa redução, a população que era de 2519 indivíduos em 1799 passou a 3595 pessoas em 1812, um crescimento de $42,7 \%$. A partir daí houve outro intenso crescimento até 1826 , quando a população nazareana atingiu os 4537 indivíduos, sendo $26,2 \%$ maior do que havia sido três lustros antes. Considerado o período entre 1799 e 1826, o crescimento populacional da localidade chegou a $80 \%$.

Esse crescimento supera os elevados $77,2 \%$ de expansão da população paulista entre 1798 e 1828, e apresentou maior dinamismo até 1808, crescendo a taxas consideravelmente maiores que a média da província de São Paulo. E, apesar de haverem diminuído, as taxas de crescimento positivas dos habitantes de Nazaré permaneceram se consideramos o período analisado até $1816 .^{20}$

\footnotetext{
${ }^{20}$ Uma observação deve ser feita, as curvas de evolução populacional de Nazaré seguem sentido oposto às curvas analisadas para Atibaia. Em sendo as duas localidades ligadas administrativamente e as listas nominativas apresentadas em conjunto, é possível que parte dessa grande mudança apresentada por Nazaré seja devida a problemas na alocação dos diferentes bairros entre Atibaia e Nazaré. O gráfico abaixo ilustra a evolução das respectivas populações totais e da população consideradas vila e freguesia em conjunto.
}

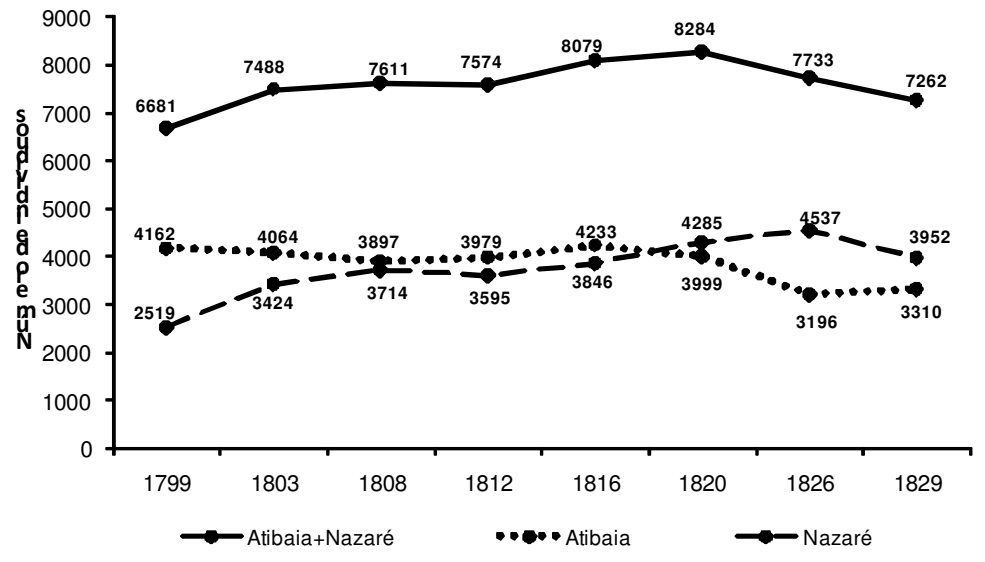




\section{Gráfico I.20}

\section{Evolução (em valores absolutos) da população total,}

população livre e escravos

(Nazaré - 1799 a 1829)

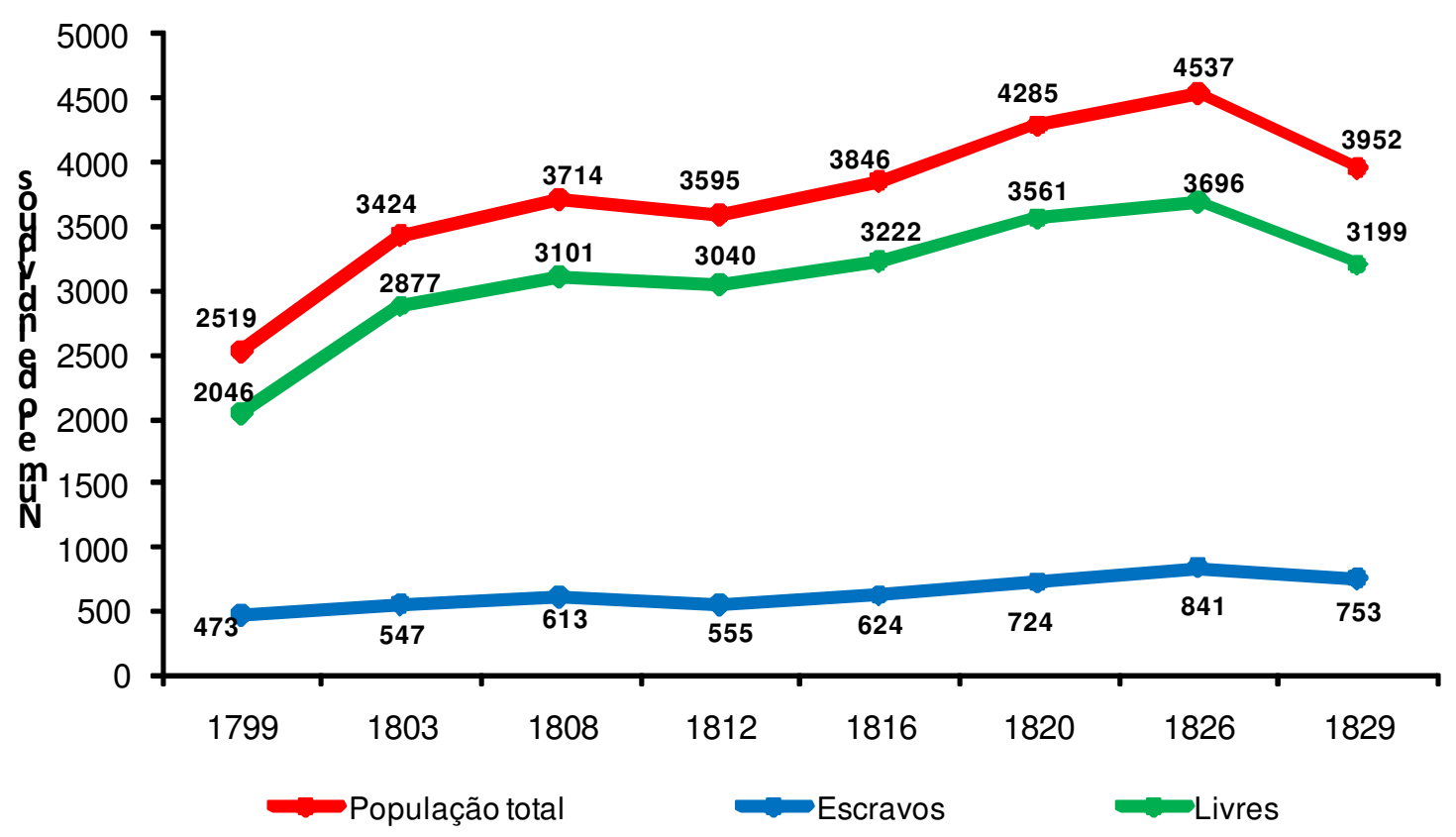

Ademais, note-se que, em 1803, comparativamente a 1799, houve, no arrolamento populacional da localidade, acréscimo do bairro do Rio do Peixe, presente em todos os demais anos. Este bairro respondia por $24 \%$ da população em 1803, ou seja, 823 indivíduos. Se desconsiderado tal bairro, a população nazareana seria de 2601 indivíduos em 1803, ou seja, haveria sido incrementada em tão somente 3,3\% entre 1799 e 1803. O referido bairro, não existia em 1797 e em 1798 apareceu no arrolamento daquele ano sendo descrita em sua introdução: "Lista todos os habitantes do Bairro do Rio do Peixe e seus anexos conforme as partições dos bairros da Freguesia de Nazaré, termo da Vila de São João de Atibaia, pertencente a ordenança do Capitão Fernando Dias Paes Leme e Cintra feito por ordem do llustríssimo e Excelentíssimo senhor Dom Antonio Manuel de Melo Castro e Mendonça governador e capitão general desta capitania de São Paulo" (Lista Nominativa de Nazaré, 1798 - AESP, Maços de População/rolo 21). Não foram localizadas listas nominativas para 1800 a 1802 que pudessem fornecer um indicativo acerca do arrolamento do bairro a posterior a 1799. Naquele primeiro ano, de acordo com os resumos populacionais que acompanhavam a lista, Nazaré teria 2685 habitantes, número próximo ao que encontramos no ano seguinte, indicando entre 1798 e 1803 um crescimento de 27,5 . 
Tabela 1.40

Variação da população total, população livre e escravos (Nazaré - 1799 a 1829, São Paulo - 1798 a 1828)

\begin{tabular}{|c|c|c|c|c|c|}
\hline \multicolumn{4}{|c|}{ Nazaré } & \multicolumn{2}{|c|}{ Província São Paulo* } \\
\hline Anos & $\begin{array}{l}\text { Variação \% da } \\
\text { população total }\end{array}$ & $\begin{array}{c}\text { Variação \% da } \\
\text { população livre }\end{array}$ & $\begin{array}{l}\text { Variação \% da } \\
\text { população } \\
\text { cativa }\end{array}$ & Anos & $\begin{array}{r}\text { Variação \% da } \\
\text { população tota }\end{array}$ \\
\hline $1799-1803$ & 35,9 & 40,6 & 15,6 & $1798-1800$ & 4,4 \\
\hline $1803-1808$ & 8,5 & 7,8 & 12,1 & $1800-1808$ & 15,7 \\
\hline $1808-1812$ & $-3,2$ & $-2,0$ & $-9,5$ & $1808-1818$ & 13,0 \\
\hline $1812-1816$ & 7,0 & 6,0 & 12,4 & $1818-1822$ & 10,3 \\
\hline $1816-1820$ & 11,4 & 10,5 & 16,0 & $1822-1828$ & 17,7 \\
\hline $1820-1826$ & 5,9 & 3,8 & 16,2 & $1798-1818$ & 36,5 \\
\hline $1826-1829$ & $-12,9$ & $-13,4$ & $-10,5$ & $1818-1828$ & 29,8 \\
\hline $1799-1816$ & 52,7 & 57,5 & 31,9 & $1798-1828$ & 77,2 \\
\hline $1816-1829$ & 2,8 & $-0,7$ & 20,7 & & \\
\hline $1799-1829$ & 56,9 & 56,4 & 59,2 & & \\
\hline
\end{tabular}

*Valores calculados a partir dos dados apresentados por M arcílio (2000, p.71), inclui Paraná.

Fonte: AESP, Maços de População, Nazaré: anos selecio nados

Os mesmos documentos censitários de Nazaré apontam, com exceção do período entre 1808 e 1812, a variação do número de fogos (Tabela I.41) e do número de habitantes sempre no mesmo sentido. Se até 1816, nos momentos em que houve aumento da população livre o número de fogos aumentou em maior proporção indicando que poderia haver famílias chegando a Nazaré e principalmente desmembramento dos fogos, visto que migração representa em aumento populacional maior que o número de fogos, em especial em se tratando de famílias, o que o corroborase, como se verá, com a naturalidade da população nazareana - entre 1816 e 1820 enquanto a população livre cresceu 10,5\%, o número de fogos subiu 5\%. Eram 380 fogos ao final do Setecentos, alçados a 792 em 1826, uma ampliação de mais de 108\%, um pouco menor seria se considerássemos o período em sua totalidade: $87,4 \%$. 0 boom populacional verificado entre 1799 e 1803 foi ainda maior consideradas as unidades familiares, cujo crescimento entre os referidos anos foi de $49,7 \%$, em que pese o eventual problema decorrente da ausência do Bairro do Rio do Peixe em 1799. 
Tabela $\mathbf{l . 4 1}$

Variação do número de fogos,

presença de livres e escravos nos domicílios

(Nazaré - 1799 a 1829)

\begin{tabular}{|c|c|c|c|c|c|c|c|c|c|c|c|c|}
\hline \multirow{2}{*}{ Ano } & \multirow{2}{*}{$\begin{array}{l}\text { № de } \\
\text { fogos }\end{array}$} & \multirow{2}{*}{$\begin{array}{c}\text { Variação } \\
\% \text { do } \\
\text { número de } \\
\text { fogos }\end{array}$} & \multicolumn{3}{|c|}{ Indivíduos } & \multicolumn{3}{|c|}{ Livres } & \multicolumn{3}{|c|}{ Escravos } & \multirow{2}{*}{$\begin{array}{c}\text { Relação } \\
\text { escravos/livres }\end{array}$} \\
\hline & & & Média & Mediana & Moda & Média & Mediana & Moda & Média & Mediana & Moda & \\
\hline 1799 & 380 & & 6,6 & 6,0 & 6,0 & 5,4 & 5,0 & 6,0 & 1,2 & 0,0 & 0,0 & 0,23 \\
\hline 1803 & 569 & 49,7 & 6,0 & 5,0 & 3,0 & 5,1 & 5,0 & 3,0 & 1,0 & 0,0 & 0,0 & 0,19 \\
\hline 1808 & 637 & 12,0 & 5,8 & 5,0 & 5,0 & 4,9 & 5,0 & 3,0 & 1,0 & 0,0 & 0,0 & 0,20 \\
\hline 1811 & 647 & 1,6 & 5,6 & 5,0 & 5,0 & 4,7 & 4,0 & 3,0 & 0,9 & 0,0 & 0,0 & 0,18 \\
\hline 1816 & 715 & 10,5 & 6,2 & 5,0 & 3,0 & 5,2 & 4,0 & 4,0 & 1,0 & 0,0 & 0,0 & 0,19 \\
\hline 1820 & 751 & 5,0 & 5,7 & 5,0 & 3,0 & 4,7 & 4,0 & 4,0 & 1,0 & 0,0 & 0,0 & 0,20 \\
\hline 1826 & 792 & 5,5 & 5,7 & 5,0 & 3,0 & 4,7 & 4,0 & 3,0 & 1,1 & 0,0 & 0,0 & 0,23 \\
\hline 1830 & 712 & $-10,1$ & 5,6 & 5,0 & 3,0 & 4,5 & 4,0 & 2,0 & 1,1 & 0,0 & 0,0 & 0,24 \\
\hline
\end{tabular}

Fonte: AESP, M aços de População, Nazaré: anos selecionados

Dentre estes fogos, foi percentualmente decrescente aqueles nos quais foram encontrados escravos. Em 1799 eram $26,6 \%$ do total de fogos declarados, percentual que caiu a 22,3\% em 1803, 20,9\% em 1808 e esteve sempre abaixo de 20\% nos demais anos, chegando ao final do período em $18,5 \%$.

\section{Gráfico I.21}

Fogos com e sem escravos

(Nazaré - 1799 a 1829)

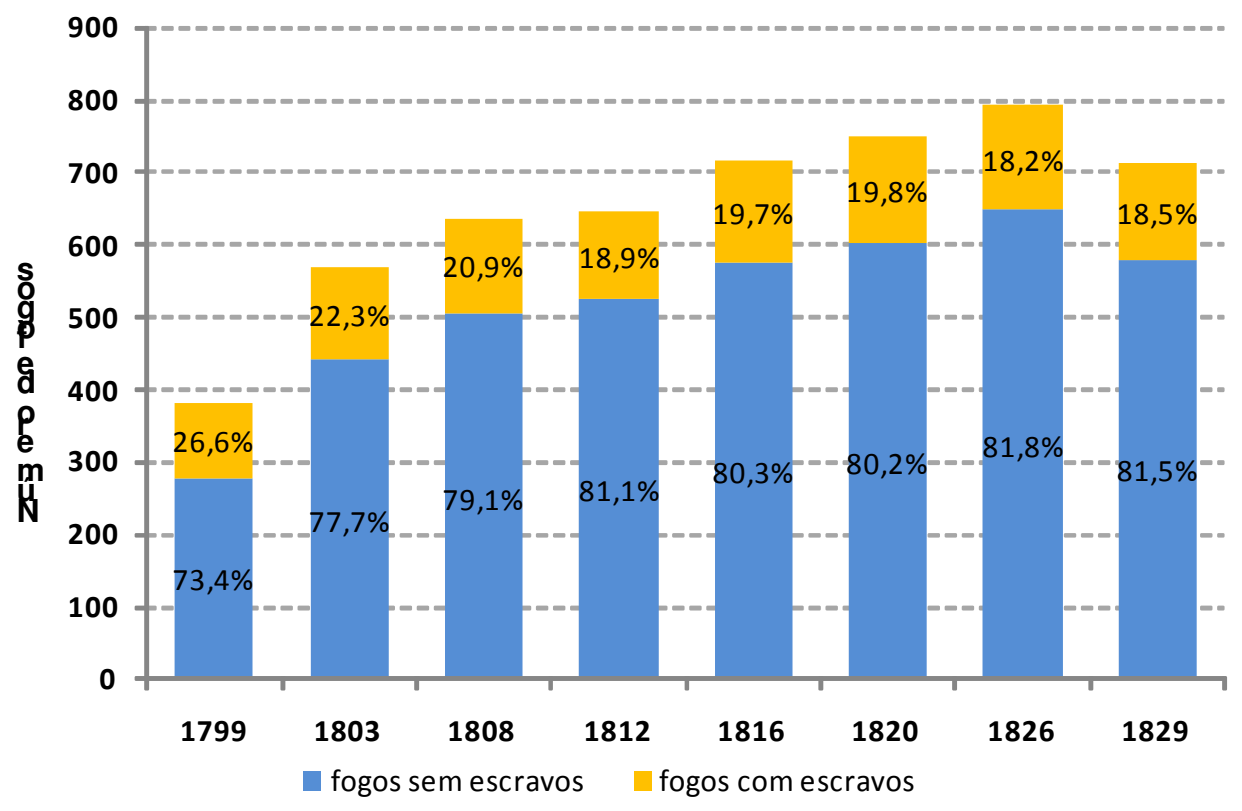


Os escravos que representavam 18,7\% da população em 1799 (cf. Gráfico I.22) chegaram ao final da década de 1820 com presença equivalente, 19,2\% (essa, sua maior participação ao longo dos anos). Mas observada sua participação para anos com que temos trabalhado, houve entre 1803 e 1820 um percentual cerca de três pontos percentual menor, chegando a $15,5 \%$ em 1812. A população cativa variou no mesmo sentido anotado para a população livre, com algumas diferenças mais acentuadas entre os percentuais, sendo que a variável do número de cativos foi mais "constante" que a dos livres. Assim, 1799 a 1808 e 1812 a 1826 representaram expansão do número de escravos em Nazaré (foi de $51,5 \%$ a expansão ocorrida nesse segundo momento), e entre 1808-1812 e 1826-1829 houve queda no número desses indivíduos na localidade.

\section{Gráfico I.22}

\section{Participação de livres e escravos na população}

(Nazaré - 1799 a 1829)

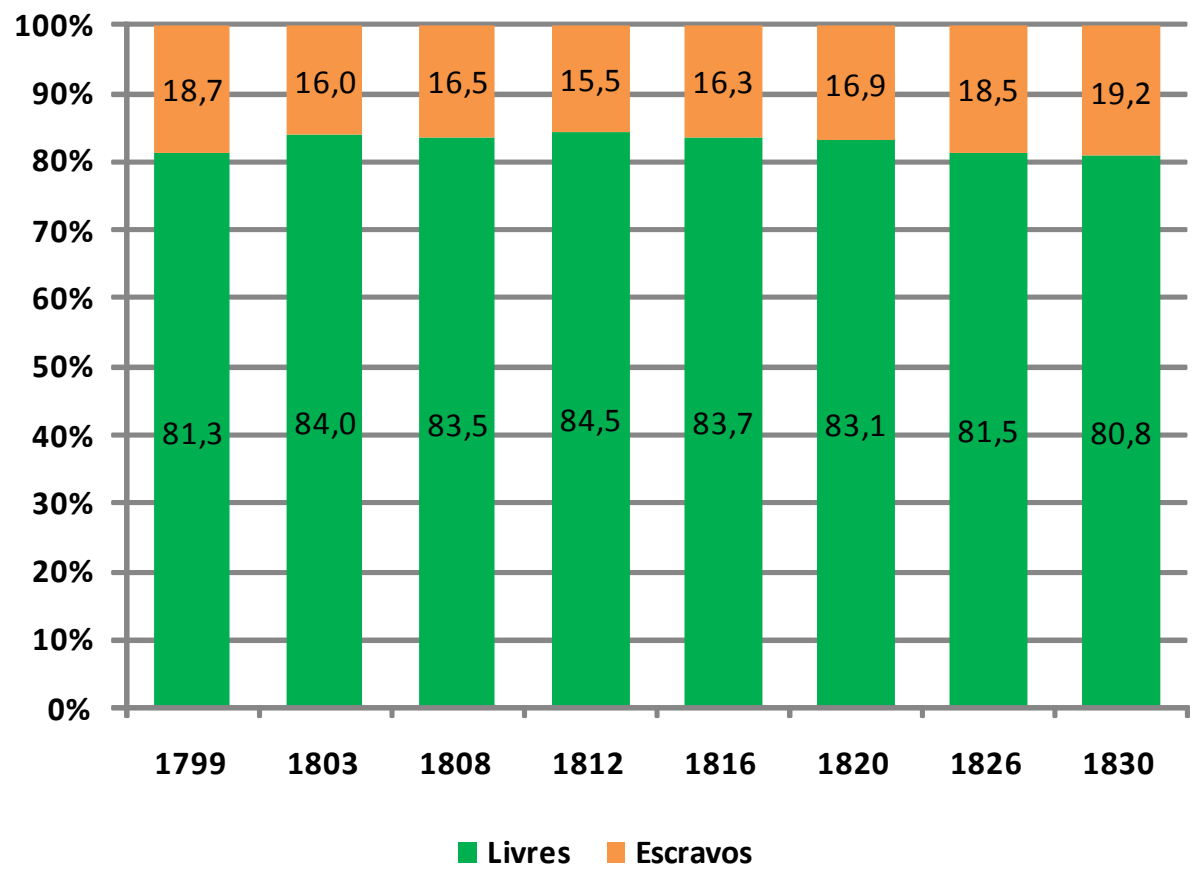

Essa queda ocorrida na participação do número de escravos em 1812, como se vê no Gráfico I.22, implicou em uma variação imperceptível em sua presença média nas unidades familiares da freguesia neste ano, 0,9, enquanto para dois anos antes ou depois foi constante em 1 escravo por fogo, passando a 1,1 em 1826 e 1829.

A concentração desses cativos nos domicílios, no entanto, era bastante elevada: 0 índice de Gini que permite analisar o grau de concentração da posse de escravos, aparece com o valor de 0,920 , concentração quase absoluta, em 1829, ano em que se 
manifesta o maior grau de concentração dos escravos entre o total de fogos, seguida de perto pelos demais anos, sendo a menor concentração encontrada em 1799: 0,871.(Tabela I.42)

A sua vez, os indivíduos livres encontrados caíram de 5,4 em 1799 a 4,5 em 1830, com um período de pequeno pico neste intervalo, no ano de 1816, quando o número médio de não cativos por fogo foi de 5,1 , uma pequena diferença frente aos valores mais comumente verificados 4,7 (nos anos de 1812, 182 e 1826). Ou seja, podem ser considerados constantes, ao longo dos anos, o número médio de escravos e livres nos domicílios: em torno de 1 era a presença dos escravos por fogo e situou-se ao redor de 5 o número médio de livres.

Tabela I.42

Indicadores estatísticos para a posse de escravos (Nazaré - 1799 a 1829)

\begin{tabular}{|c|c|c|c|c|c|c|c|c|}
\hline \multirow[b]{2}{*}{ Estatísticas } & \multicolumn{2}{|c|}{1799} & \multicolumn{2}{|c|}{1803} & \multicolumn{2}{|c|}{1808} & \multicolumn{2}{|c|}{1812} \\
\hline & $\begin{array}{c}\text { Total de } \\
\text { fogos }\end{array}$ & Escravistas & $\begin{array}{c}\text { Total de } \\
\text { fogos }\end{array}$ & Escravistas & $\begin{array}{c}\text { Total de } \\
\text { fogos }\end{array}$ & Escravistas & $\begin{array}{c}\text { Total de } \\
\text { fogos }\end{array}$ & Escravistas \\
\hline Média & 1,2 & 4,7 & 1,0 & 4,4 & 1,0 & 4,7 & 0,9 & 4,6 \\
\hline Moda & 0,0 & 1,0 & 0,0 & 1,0 & 0,0 & 1,0 & 0,0 & 1,0 \\
\hline Mediana & 0,0 & 3,0 & 0,0 & 3,0 & 0,0 & 3,0 & 0,0 & 2,0 \\
\hline Desvio padrão & 3,5 & 5,5 & 2,9 & 4,9 & 3,0 & 5,2 & 2,8 & 5,0 \\
\hline Variância & 12,2 & 30,3 & 8,7 & 23,6 & 9,3 & 27,5 & 7,9 & 25,2 \\
\hline Índice de Gini & 0,871 & 0,513 & 0,887 & 0,498 & 0,899 & 0,508 & 0,909 & 0,518 \\
\hline Máximo & \multicolumn{2}{|c|}{29,0} & \multicolumn{2}{|c|}{26,0} & \multicolumn{2}{|c|}{33,0} & \multicolumn{2}{|c|}{23,0} \\
\hline \multirow[b]{2}{*}{ Estatísticas } & \multicolumn{2}{|c|}{1816} & \multicolumn{2}{|c|}{1820} & \multicolumn{2}{|c|}{1826} & \multicolumn{2}{|c|}{1829} \\
\hline & $\begin{array}{c}\text { Total de } \\
\text { fogos }\end{array}$ & Escravistas & $\begin{array}{c}\text { Total de } \\
\text { fogos }\end{array}$ & Escravistas & $\begin{array}{c}\text { Total de } \\
\text { fogos }\end{array}$ & Escravistas & $\begin{array}{c}\text { Total de } \\
\text { fogos }\end{array}$ & Escravistas \\
\hline Média & 0,9 & 4,6 & 1,0 & 5,1 & 1,1 & 6,0 & 1,1 & 6,2 \\
\hline Moda & 0,0 & 1,0 & 0,0 & 1,0 & 0,0 & 1,0 & 0,0 & 2,0 \\
\hline Mediana & 0,0 & 3,0 & 0,0 & 3,0 & 0,0 & 3,0 & 0,0 & 4,0 \\
\hline Desvio padrão & 2,8 & 4,8 & 3,3 & 5,9 & 1,4 & 8,1 & 4,5 & 9,2 \\
\hline Variância & 7,6 & 22,6 & 11,0 & 35,3 & 17,2 & 65,8 & 20,1 & 85,3 \\
\hline Índice de Gini & 0,903 & 0,491 & 0,904 & 0,510 & 0,918 & 0,547 & 0,920 & 0,538 \\
\hline Máximo & \multicolumn{2}{|c|}{25,0} & \multicolumn{2}{|c|}{41,0} & \multicolumn{2}{|c|}{63,0} & \multicolumn{2}{|c|}{80,0} \\
\hline
\end{tabular}

Fonte:AESP, M aços de População, Nazaré: anos selecionados

Considerados apenas aqueles fogos em que cativos estiveram presentes, a média para a presença destas pessoas foi mais elevada, 4,7 escravos por fogo até 1816, subindo a partir de então a 5,1 escravos por proprietário em 1820, seis em 1826 e 6,2 no ano de 1829. A moda foi invariavelmente igual a um até 1826 , subindo a dois em 1829. A sua vez, a mediana manteve-se pouco acima da moda: dois em 1812, quatro em 1829 e 
três nos demais anos. A concentração dos escravos apenas entre os fogos em que estiveram presentes foi média: em torno de 0,5 em todo lapso considerado.

Esteve em torno de $35 \%$ o percentual de cativos nas mãos daqueles chefes de domicilio que podiam contar com até cinco escravos, e cerca de $2 \%$ entre aqueles com 6 a 10 escravos. Em 1829 estes escravos estavam relativamente bem distribuídos entre os diferentes tamanhos de plantel. Eram $26,6 \%$ sitos nas escravarias mais diminutas, $21,2 \%$ nos médios plantéis, $23,1 \%$ naqueles plantéis de tamanho grande, e o restante $(29,1 \%)$ em fogos com 20 ou mais escravos.

Tabela 1.43

Distribuição de escravistas e escravos

de acordo com faixas de tamanho dos plantéis

(Nazaré - 1799 a 1829)

\begin{tabular}{|c|c|c|c|c|c|c|c|c|c|c|c|c|}
\hline \multirow{3}{*}{ FTP } & \multicolumn{4}{|c|}{1799} & \multicolumn{4}{|c|}{1803} & \multicolumn{4}{|c|}{1808} \\
\hline & \multicolumn{2}{|c|}{ Escravistas } & \multicolumn{2}{|c|}{ Escravos } & \multicolumn{2}{|c|}{ Escravistas } & \multicolumn{2}{|c|}{ Escravos } & \multicolumn{2}{|c|}{ Escravistas } & \multicolumn{2}{|c|}{ Escravos } \\
\hline & № & $\%$ & № & $\%$ & № & $\%$ & № & $\%$ & № & $\%$ & № & $\%$ \\
\hline 1 a 5 & 76 & 75,2 & 179 & 37,9 & 93 & 73,2 & 207 & 37,8 & 96 & 72,2 & 219 & 35,7 \\
\hline 6 a 10 & 17 & 16,8 & 130 & 27,5 & 22 & 17,3 & 142 & 26,0 & 20 & 15,0 & 148 & 24,1 \\
\hline 11 a 20 & 4 & 4,0 & 58 & 12,3 & 9 & 7,1 & 127 & 23,2 & 12 & 9,0 & 174 & 28,4 \\
\hline Acima 20 & 4 & 4,0 & 105 & 22,2 & 3 & 2,4 & 71 & 13,0 & 5 & 3,8 & 72 & 11,7 \\
\hline Total & 101 & 100,0 & 472 & 100,0 & 127 & 100,0 & 547 & 100,0 & 133 & 100,0 & 613 & 100,0 \\
\hline \multirow{3}{*}{ FTP } & \multicolumn{4}{|c|}{1812} & \multicolumn{4}{|c|}{1816} & \multicolumn{4}{|c|}{1820} \\
\hline & \multicolumn{2}{|c|}{ Escravistas } & \multicolumn{2}{|c|}{ Escravos } & \multicolumn{2}{|c|}{ Escravistas } & \multicolumn{2}{|c|}{ Escravos } & \multicolumn{2}{|c|}{ Escravistas } & \multicolumn{2}{|c|}{ Escravos } \\
\hline & № & $\%$ & № & $\%$ & № & $\%$ & № & $\%$ & № & $\%$ & № & $\%$ \\
\hline 1 a 5 & 90 & 73,8 & 187 & 33,7 & 97 & 68,8 & 217 & 34,8 & 105 & 70,5 & 248 & 34,3 \\
\hline 6 a 10 & 18 & 14,8 & 142 & 25,6 & 26 & 18,4 & 187 & 30,0 & 27 & 18,1 & 206 & 28,5 \\
\hline 11 a 20 & 12 & 9,8 & 182 & 32,8 & 11 & 7,8 & 148 & 23,7 & 9 & 6,0 & 135 & 18,6 \\
\hline Acima 20 & 2 & 1,6 & 44 & 7,9 & 7 & 5,0 & 72 & 11,5 & 8 & 5,4 & 135 & 18,6 \\
\hline Total & 122 & 100,0 & 555 & 100,0 & 141 & 100,0 & 624 & 100,0 & 149 & 100,0 & 724 & 100,0 \\
\hline
\end{tabular}

\begin{tabular}{|c|c|c|c|c|c|c|c|c|}
\hline \multirow{3}{*}{ FTP } & \multicolumn{4}{|c|}{1826} & \multicolumn{4}{|c|}{1829} \\
\hline & \multicolumn{2}{|c|}{ Escravistas } & \multicolumn{2}{|c|}{ Escravos } & \multicolumn{2}{|c|}{ Escravistas } & \multicolumn{2}{|c|}{ Escravos } \\
\hline & № & $\%$ & № & $\%$ & № & $\%$ & № & $\%$ \\
\hline 1 a 5 & 97 & 67,4 & 237 & 28,2 & 82 & 62,1 & 200 & 26,6 \\
\hline 6 a 10 & 29 & 20,1 & 229 & 27,2 & 22 & 16,7 & 160 & 21,2 \\
\hline 11 a 20 & 9 & 6,3 & 144 & 17,1 & 13 & 9,8 & 174 & 23,1 \\
\hline Acima 20 & 9 & 6,3 & 231 & 27,5 & 15 & 11,4 & 219 & 29,1 \\
\hline Total & 144 & 100,0 & 841 & 100,0 & 132 & 100,0 & 753 & 100,0 \\
\hline
\end{tabular}

Fonte: AESP, Maços de População, Nazaré: anos selecionados

Contudo, o percentual de fogos incluídos nestas diferentes faixas de tamanho de plantel era bastante superior ao percentual indicado para os cativos a viver ali. Assim, em 
1829 os cativos em pequenos plantéis dividiam-se por $62,1 \%$ do total de fogos com descrição de cescravos. Esta participação havia sido maior em 1820, 70\% e em outros anos, iniciando o período estudado em $75,2 \%$.

Observada a população de acordo com a presença ou não de escravos nos fogos (Tabela I.44), encontramos livres mais escravos vivendo em fogos com mancípios em proporções variáveis: $58,1 \%$ da população estava diretamente ligada a plantéis em 1799, percentual alçado a 67,9\% em 1812 e caindo pouco, a aproximadamente 66\% em 1826 e 1829. A sua vez, a parcela livre da população ligada diretamente ao trabalho compulsório teve seu peso reduzido com o passar dos anos. Eram 28,4\% em 1799, 24,1\% em 1803, $19,7 \%$ de 1812 a 1820 e aproximadamente $18,5 \%$ nos últimos anos observados.

O número médio de indivíduos nos dois segmentos de domicílio, considerados apenas os livres, mostra valores bastante próximos e decrescentes. Os fogos sem escravos tinham em 1799, em média, 5,2 livres, percentual que esteve entre 4,5-4,7 entre 1808 e 1826, chegando a 1829 em 4,4. De forma semelhante, os livres em fogos com cativos eram 5,8 em 1799, valor reduzido a 4,8 no último ano analisado.

\section{Tabela 1.44}

Peso dos domicílios com e sem escravos na população

(Nazaré - 1799 a 1829)

\begin{tabular}{|c|c|c|c|c|c|c|c|}
\hline \multirow[b]{2}{*}{ Anos } & \multicolumn{3}{|c|}{ "Fogos sem escravos } & \multicolumn{4}{|c|}{ "Fogos com escravos } \\
\hline & $\begin{array}{c}\text { \% da } \\
\text { população } \\
\text { total }\end{array}$ & $\begin{array}{l}\text { \% da } \\
\text { população } \\
\text { livre }\end{array}$ & $\begin{array}{l}\text { Média de } \\
\text { indivíduos }\end{array}$ & $\begin{array}{c}\text { \% da } \\
\text { população } \\
\text { total }\end{array}$ & $\begin{array}{c}\text { \% da } \\
\text { população } \\
\text { livre }\end{array}$ & $\begin{array}{l}\text { Média de } \\
\text { indivíduos }\end{array}$ & $\begin{array}{l}\text { Média de } \\
\text { livres }\end{array}$ \\
\hline 1799 & 58,1 & 71,6 & 5,2 & 41,9 & 28,4 & 10,4 & 5,8 \\
\hline 1803 & 63,8 & 75,9 & 5,0 & 36,2 & 24,1 & 9,7 & 5,4 \\
\hline 1808 & 66,0 & 79,0 & 4,8 & 34,0 & 21,0 & 9,6 & 5,0 \\
\hline 1812 & 67,9 & 80,3 & 4,7 & 32,1 & 19,7 & 9,5 & 4,9 \\
\hline 1816 & 67,3 & 80,3 & 4,5 & 32,7 & 19,7 & 9,2 & 4,6 \\
\hline 1820 & 66,7 & 80,2 & 4,7 & 33,3 & 19,8 & 9,9 & 4,9 \\
\hline 1826 & 66,2 & 81,2 & 4,6 & 33,8 & 18,8 & 10,7 & 4,9 \\
\hline 1829 & 65,9 & 81,5 & 4,4 & 34,1 & 18,5 & 10,9 & 4,8 \\
\hline
\end{tabular}

Fonte:AESP, M aços de População, Nazaré: anos selecionados

Parte dessa população livre encontrada em Nazaré era composta por um grupo de agregados que não tinham parentesco com o núcleo principal dos domicílios. Dados para os agregados são apresentados na Tabela I.45. 
Tabela 1.45

Peso dos domicílios com e sem agregados

não aparentados na população

(Nazaré - 1799 a 1829)

\begin{tabular}{cccccccc}
\hline \hline Anos & $\begin{array}{c}\text { \% de fogos } \\
\text { com } \\
\text { agregados }\end{array}$ & $\begin{array}{c}\text { \% de } \\
\text { agregados }\end{array}$ & $\begin{array}{c}\text { \% de } \\
\text { agregados } \\
\text { na } \\
\text { população } \\
\text { total }\end{array}$ & $\begin{array}{c}\text { agregados } \\
\text { na } \\
\text { população } \\
\text { livre }\end{array}$ & $\begin{array}{c}\text { Média de } \\
\text { agregados } \\
\text { (fogos com } \\
\text { agregados) }\end{array}$ & $\begin{array}{c}\text { Média de } \\
\text { agregados } \\
\text { (total de } \\
\text { fogos) }\end{array}$ & $\begin{array}{c}\text { \% de fogos } \\
\text { com agregados } \\
\text { e escravos }\end{array}$ \\
\hline $\mathbf{1 7 9 9}$ & 14,2 & 97 & 3,9 & 4,7 & 1,8 & 0,3 & 8,4 \\
$\mathbf{1 8 0 3}$ & 12,0 & 113 & 3,3 & 3,9 & 1,7 & 0,2 & 5,8 \\
$\mathbf{1 8 0 8}$ & 9,9 & 108 & 2,9 & 3,5 & 1,7 & 0,2 & 4,4 \\
$\mathbf{1 8 1 2}$ & 10,8 & 107 & 3,0 & 3,5 & 1,5 & 0,2 & 4,6 \\
$\mathbf{1 8 1 6}$ & 8,5 & 106 & 2,8 & 3,3 & 1,7 & 0,1 & 4,6 \\
$\mathbf{1 8 2 0}$ & 10,7 & 149 & 3,5 & 4,2 & 1,9 & 0,2 & 3,6 \\
$\mathbf{1 8 2 6}$ & 11,1 & 165 & 3,6 & 4,5 & 1,9 & 0,2 & 3,4 \\
$\mathbf{1 8 2 9}$ & 10,8 & 133 & 3,4 & 4,2 & 1,7 & 0,2 & 3,1 \\
\hline \hline
\end{tabular}

Fonte: AESP, Maços de População, Nazaré: anos selecionados

Estes indivíduos, espraiados por $14,2 \%$ das unidades familiares nazareanas, contava-se em número de 97 em 1799, equivalentes a 4,7\% da população livre e 3,9\% da população total neste ano, no qual foi registrado o menor número deles. Apesar serem arrolados em menor número, sua participação na composição da população total e livre em 1799 foi a maior verificada ao longo dos trinta anos estudados. Entre os livres, o percentual devido aos agregados caiu a cerca de 3,5\% em 1808, 1812 e 1816 voltando, já na década de 1820, a valores próximos àqueles verificados nos idos do século XVIII, 4,2\%-4,5\%. Pensados com relação à população total, a partir de 1803 os valores foram variáveis dentro de um limite restrito que teve como mínimo o ano de 1816, quando os agregados estavam espraiados por $8,5 \%$ dos fogos nazareanos e respondiam por $2,8 \%$ dos moradores da freguesia, e cujo limite máximo foi de 3,6\%, registrado em 1826. Assim, a média de agregados por fogo não mostrou variação significativa, existindo ao menos 1,5 agregados por fogo (1812), considerados os fogos em que foram computados ao longo dos anos, sendo a maior média calculada em 1,9 agregados por domicilio nos anos de 1820 e 1826.

Note-se, ademais, que parte dos domicílios com agregados estavam também ligados a plantéis, sendo decrescente a participação de fogos com presença concomitante de cativos e agregados na composição dos fogos da localidade: de 8,4\% em 1799 caiu a $5,8 \%$ no ano de 1803 , em torno de $4,5 \%$ entre 1808 e 1816 , caindo ainda mais nos três 
últimos anos observados, quando não passou de 3,6\% o percentual daqueles em que habitavam escravos e agregados sem parentesco com o núcleo familiar principal.

Agregados ou não, a população livre de Nazaré era composta em sua maioria por brancos (Tabela I.46). A parcela a eles devida entre o final do Setecentos e as primeiras décadas no Oitocentos flutuou: em 1799 foram anotados como brancos no recenseamento $79,1 \%$, percentual que subiu a $84,7 \%$ em 1803 . Considerado o próximo ano para o qual levantamos dados (1803), esse percentual havia caído a $83,1 \%$, sendo de $81 \%$ decorridos dez anos, 75,6\% em 1820 e 74,1\% ao final dos anos 1820 .

Os não brancos (pardos/mulatos e negros/pretos), passaram de 15,3\% em 1803 a $25,9 \%$ dos livres da freguesia, sendo contados em 268 naquele primeiro ano e 882 em 1825 , um crescimento de $229 \%$, incomparavelmente superior ao da população total e a qualquer um de seus grupos, livres ou escravos. Flutuações marcantes, no entanto, são apresentadas na divisão dos não brancos entre pardos/mulatos e negros/pretos, decerto não efetivas - entre 1812 os 33 pretos (6,3\%) passaram a $169(30,2 \%)$ e os mulatos foram de $491(93,7 \%)$ a 391 indivíduos (69,8\%).

\section{Tabela 1.46}

Distribuição da população livre entre brancos e não brancos

(Nazaré - 1799 a 1829)

\begin{tabular}{|c|c|c|c|c|c|}
\hline \multirow{3}{*}{ Anos } & \multirow{3}{*}{$\begin{array}{c}\text { Brancos } \\
\text { \% (№) }\end{array}$} & \multicolumn{3}{|c|}{ Não Brancos } & \multirow{3}{*}{$\begin{array}{c}\text { Total: Brancos } \\
\text { + Não brancos } \\
\% \text { (№) }\end{array}$} \\
\hline & & Pardos/Mulatos & Negros/Pretos & Total & \\
\hline & & \% (№) & \% (№) & \% (№) & \\
\hline 1799 & $79,1(1012)$ & $86,9(233)$ & 13,1 (35) & $20,9(268)$ & $100,0(1280)$ \\
\hline 1803 & 84,7 (2436) & $94,8(418)$ & $5,2(23)$ & $15,3(441)$ & $100,0(2877)$ \\
\hline 1808 & $83,1(2574)$ & $93,7(491)$ & $6,3(33)$ & $16,9(524)$ & 100,0 (3098) \\
\hline 1812 & 81,5 (2474) & $69,8(391)$ & 30,2 (169) & $18,5(560)$ & $100,0(3034)$ \\
\hline 1816 & $81,0(2607)$ & $88,7(544)$ & $11,3(69)$ & $19,0(613)$ & 100,0 (3220) \\
\hline 1820 & 75,6 (2692) & $92,9(807)$ & $7,1(62)$ & $24,4(869)$ & $100,0(3561)$ \\
\hline 1826 & 76,1 (2814) & $90,9(802)$ & $9,1(80)$ & $23,9(882)$ & $100,0(3696)$ \\
\hline 1829 & 74,1 (2369) & 91,7 (759) & $8,3(69)$ & 25,9 (828) & 100,0 (3197) \\
\hline
\end{tabular}

Fonte: AESP, M aços de População, Nazaré: anos selecionados

Desconsiderada qualquer outra variável, a proporção entre homens e mulheres livres na sociedade nazareana era favorável ao sexo feminino, como mostram os registros postos na Tabela 1.47 
Tabela 1.47

Composição da população livre por sexo

(Nazaré - 1799 a 1829)

\begin{tabular}{|c|c|c|c|c|c|}
\hline \multirow{3}{*}{ Anos } & \multicolumn{5}{|c|}{ População Livre } \\
\hline & \multicolumn{2}{|c|}{ Homens } & \multicolumn{2}{|c|}{ Mulheres } & \multirow{2}{*}{$\begin{array}{l}\text { Razão de } \\
\text { sexo }\end{array}$} \\
\hline & \% (№) & $\begin{array}{c}\text { Variação } \\
\%\end{array}$ & \% (№) & $\begin{array}{c}\text { Variação } \\
\%\end{array}$ & \\
\hline 1799 & 46,4 (932) & & $53,6(1075)$ & & 86,7 \\
\hline 1803 & $47,2(1353)$ & 45,2 & $52,8(1515)$ & 40,9 & 89,3 \\
\hline 1808 & $46,9(1449)$ & 7,1 & 53,1 (1639) & 8,2 & 88,4 \\
\hline 1812 & $47,3(1432)$ & $-1,2$ & $52,7(1598)$ & $-2,5$ & 89,6 \\
\hline 1816 & $48,0(1546)$ & 8,0 & $52,0(1673)$ & 4,7 & 92,4 \\
\hline 1820 & $47,5(1687)$ & 9,1 & $52,5(1863)$ & 11,4 & 90,6 \\
\hline 1826 & $47,3(1744)$ & 3,4 & 52,7 (1942) & 4,2 & 89,8 \\
\hline 1829 & 47,5 (1509) & $-13,5$ & $52,5(1668)$ & $-14,1$ & 90,5 \\
\hline
\end{tabular}

Exclusive indivíduos com sexo não identificado

Fonte: AESP, M aços de População, Nazaré: anos selecio nados

A maior diferença entre a participação masculina e feminina nesta população verificamos em 1799, 46,3\% e 53,6\% respectivamente para homens e mulheres, respondendo pela mais reduzida razão de sexo encontrada em Nazaré: 86,7 homens para um grupo de 100 mulheres. Homens e mulheres tiveram suas populações variando sempre no mesmo sentido e em medidas relativamente próximas, levando ao longo do período 1799-1829 a diferenças não muito díspares entre homens e mulheres, sendo a maior razão entre os sexos calculada para 1820: 90,6 homens para 100 mulheres.

Conforme a Tabela I.48, dentre as mulheres não cativas com mais de 14 anos de idade, as casadas respondiam por percentuais crescentes com o passar do tempo, que variaram entre o mínimo de 52,9\% em 1803 e o máximo de 60,3\% em 1826 e 1829 nestes anos, apesar dos números absolutos distintos, em sequência, 616 e 545 casadas, os percentuais foram os mesmos, assim como foram coincidentes para solteiras e viúvas. Eram, em grande medida, também solteiras as nazareanas, que correspondiam a $35,7 \%$ da população feminina em tela em 1803 , caindo a $28,9 \%$ no último lustro estudado. As viúvas eram entre $10 \%$ e $11 \%$ das mulheres, pouco menor percentual em $1812,9,3 \%$. 
Tabela 1.48

Composição da população livre de acordo com estado conjugal e sexo - exclusive indivíduos de até 14 anos (Nazaré - 1799 a 1829)

\begin{tabular}{|c|c|c|c|c|c|c|c|c|c|}
\hline \multirow{2}{*}{ Anos } & \multicolumn{3}{|c|}{ Homens } & \multicolumn{3}{|c|}{ Mulheres } & \multicolumn{3}{|c|}{ Homens + Mulheres } \\
\hline & $\begin{array}{c}\text { Casados } \\
\%\end{array}$ & $\begin{array}{c}\text { Solteiros } \\
\%\end{array}$ & $\begin{array}{c}\text { Viúvos } \\
\%\end{array}$ & $\begin{array}{c}\text { Casadas } \\
\%\end{array}$ & $\begin{array}{c}\text { Solteiras } \\
\%\end{array}$ & $\begin{array}{c}\text { Viúvas } \\
\%\end{array}$ & $\begin{array}{c}\text { Casados } \\
\%\end{array}$ & $\begin{array}{c}\text { Solteiros } \\
\%\end{array}$ & $\begin{array}{c}\text { Viúvos } \\
\%\end{array}$ \\
\hline 1799 & 62,1 & 35,1 & 2,7 & 54,5 & 33,7 & 11,8 & 58,2 & 34,4 & 7,4 \\
\hline 1803 & 55,3 & 42,0 & 2,7 & 52,9 & 35,7 & 11,4 & 54,2 & 38,7 & 7,1 \\
\hline 1808 & 64,0 & 32,8 & 3,2 & 54,9 & 35,1 & 10,0 & 59,3 & 33,9 & 6,8 \\
\hline 1812 & 67,5 & 29,3 & 3,1 & 56,9 & 33,8 & 9,3 & 62,2 & 31,2 & 6,5 \\
\hline 1816 & 67,5 & 28,5 & 4,1 & 56,9 & 31,6 & 11,4 & 62,2 & 29,9 & 7,9 \\
\hline 1820 & 65,6 & 29,5 & 4,9 & 56,8 & 32,0 & 11,2 & 61,1 & 30,7 & 8,3 \\
\hline 1826 & 66,6 & 28,5 & 5,0 & 60,3 & 28,9 & 10,8 & 63,5 & 28,6 & 7,9 \\
\hline 1829 & 66,2 & 28,8 & 5,0 & 60,3 & 28,9 & 10,8 & 63,3 & 28,6 & 8,1 \\
\hline
\end{tabular}

Fonte: AESP, M aços de População, Nazaré: ano s selecio nados

Exclusive indivíduos com estado conjugal e/ou sexo não identificado

Exclui individuos de 0 a 14 anos

Comparativamente aos homens, é bastante significativa a presença de viúvas, pois entre eles o percentual dos viúvos não ultrapassou os 5\% verificados em 1820, 1826 e 1829 , e que havia sido de $2,7 \%$ três décadas antes (1799 e 1803). Mais uma vez notamos que, em maiores proporções que indivíduos do sexo masculino, mulheres tendiam a permanecer na condição de viúvas, consideradas taxas de mortalidade semelhantes para ambos os sexos. Homens casados apresentam, em pouca medida, maior participação que mulheres, compreensível, posto serem descritos em menor número.

Considerados em seu conjunto, homens mais mulheres eram principalmente casados, entre aqueles com idades superiores aos 14 anos, em percentuais que de $54,2 \%$ em 1803 viram-se alçados a 63,5\% em 1826. Decerto, para a população total independente da idade a maior parcela era devida aos solteiros, pois os nazareanos de pouca idade, ou seja, não casadoiros, eram base alargada nas pirâmides etárias da freguesia como se verá. Em regra, era de um terço dos solteiros os que efetivamente possuíam idades acima de 14 anos, podendo casar não o tendo ainda feito. (cf. Tabela I.49).

Estatísticas relativas à idade dos nazareanos de acordo com sexo e estado conjugal são apresentadas na Tabela I.49 a seguir: 
Tabela I.49

Estatísticas para a idade dos livres de acordo com o estado conjugal e sexo (Nazaré - 1799 a 1829)

\begin{tabular}{|c|c|c|c|c|c|c|c|c|c|c|c|c|}
\hline \multirow[b]{3}{*}{ Idade } & \multicolumn{3}{|c|}{1799} & \multicolumn{3}{|c|}{1803} & \multicolumn{3}{|c|}{1808} & \multicolumn{3}{|c|}{1812} \\
\hline & \multicolumn{3}{|c|}{ Solteiros } & \multicolumn{3}{|c|}{ Solteiros } & \multicolumn{3}{|c|}{ Solteiros } & \multicolumn{3}{|c|}{ Solteiros } \\
\hline & Homens & Mulheres & $\begin{array}{l}\text { Homens + } \\
\text { Mulheres }\end{array}$ & Homens & Mulheres & $\begin{array}{l}\text { Homens + } \\
\text { Mulheres }\end{array}$ & Homens & Mulheres & $\begin{array}{l}\text { Homens + } \\
\text { Mulheres }\end{array}$ & Homens & Mulheres & $\begin{array}{l}\text { Homens + } \\
\text { Mulheres }\end{array}$ \\
\hline$\% 15$ ou mais anos & 30,9 & 29,5 & 30,2 & 36,1 & 29,8 & 32,8 & 29,0 & 31,2 & 30,2 & 43,4 & 28,5 & 26,2 \\
\hline$\% 50$ ou mais anos & 1,2 & 2,7 & 2,0 & 1,6 & 1,9 & 1,8 & 0,7 & 2,6 & 1,7 & 1,5 & 2,5 & 1,8 \\
\hline \multirow{2}{*}{$\begin{array}{l}\text { Estatísticas para } \\
\text { idade }\end{array}$} & \multicolumn{3}{|c|}{ Casados } & \multicolumn{3}{|c|}{ Casados } & \multicolumn{3}{|c|}{ Casados } & \multicolumn{3}{|c|}{ Casados } \\
\hline & Homens & Mulheres & $\begin{array}{l}\text { Homens + } \\
\text { Mulheres }\end{array}$ & Homens & Mulheres & $\begin{array}{l}\text { Homens + } \\
\text { Mulheres }\end{array}$ & Homens & Mulheres & $\begin{array}{l}\text { Homens + } \\
\text { Mulheres }\end{array}$ & Homens & Mulheres & $\begin{array}{l}\text { Homens + } \\
\text { Mulheres }\end{array}$ \\
\hline Média & 39,0 & 34,1 & 36,6 & 39,3 & 33,5 & 36,4 & 38,3 & 32,6 & 35,4 & 37,3 & 31,1 & 34,2 \\
\hline Moda & 25,0 & 23,0 & 31,0 & 35,0 & 27,0 & 27,0 & 31,0 & 27,0 & 30,0 & 33,0 & 21,0 & 31,0 \\
\hline Mediana & 36,0 & 32,0 & 34,0 & 36,0 & 31,0 & 33,0 & 35,0 & 30,0 & 32,0 & 35,0 & 30,0 & 32,0 \\
\hline \multirow[t]{2}{*}{$\% 50$ ou mais anos } & 22,2 & 12,6 & 17,6 & 23,3 & 13,3 & 18,2 & 22,2 & 11,5 & 16,8 & 20,2 & 8,6 & 14,4 \\
\hline & \multicolumn{3}{|c|}{1816} & \multicolumn{3}{|c|}{1820} & \multicolumn{3}{|c|}{1826} & \multicolumn{3}{|c|}{1829} \\
\hline & \multicolumn{3}{|c|}{ Solteiros } & \multicolumn{3}{|c|}{ Solteiros } & \multicolumn{3}{|c|}{ Solteiros } & \multicolumn{3}{|c|}{ Solteiros } \\
\hline Idade & Homens & Mulheres & $\begin{array}{l}\text { Homens + } \\
\text { Mulheres }\end{array}$ & Homens & Mulheres & $\begin{array}{l}\text { Homens + } \\
\text { Mulheres }\end{array}$ & Homens & Mulheres & $\begin{array}{l}\text { Homens + } \\
\text { Mulheres }\end{array}$ & Homens & Mulheres & $\begin{array}{l}\text { Homens + } \\
\text { Mulheres }\end{array}$ \\
\hline$\% 15$ ou mais anos & 23,9 & 28,7 & 26,4 & 25,2 & 28,3 & 26,8 & 24,4 & 24,5 & 24,5 & 26,1 & 25,8 & 25,9 \\
\hline$\% 50$ ou mais anos & 0,9 & 2,9 & 1,8 & 0,9 & 2,2 & 1,6 & 1,4 & 2,6 & 2,0 & 0,4 & 2,1 & 1,3 \\
\hline \multirow[b]{2}{*}{$\begin{array}{c}\text { Estatísticas para } \\
\text { idade }\end{array}$} & \multicolumn{3}{|c|}{ Casados } & \multicolumn{3}{|c|}{ Casados } & \multicolumn{3}{|c|}{ Casados } & \multicolumn{3}{|c|}{ Casados } \\
\hline & Homens & Mulheres & $\begin{array}{l}\text { Homens + } \\
\text { Mulheres }\end{array}$ & Homens & Mulheres & $\begin{array}{l}\text { Homens + } \\
\text { Mulheres }\end{array}$ & Homens & Mulheres & $\begin{array}{l}\text { Homens + } \\
\text { Mulheres }\end{array}$ & Homens & Mulheres & $\begin{array}{l}\text { Homens + } \\
\text { Mulheres }\end{array}$ \\
\hline Média & 37,0 & 31,1 & 34,1 & 37,3 & 30,9 & 34,2 & 38,0 & 31,4 & 34,7 & 38,6 & 31,9 & 35,2 \\
\hline Moda & 28,0 & 20,0 & 25,0 & 26,0 & 25,0 & 25,0 & 30,0 & 30,0 & 30,0 & 30,0 & 20,0 & 30,0 \\
\hline Mediana & 34,0 & 29,0 & 31,0 & 34,0 & 28,0 & 31,0 & 36,0 & 30,0 & 32,0 & 36,0 & 30,0 & 33,0 \\
\hline$\% 50$ ou mais anos & 18,3 & 8,5 & 13,4 & 19,6 & 7,8 & 13,7 & 19,9 & 8,8 & 14,4 & 20,6 & 8,1 & 14,3 \\
\hline
\end{tabular}


Os indivíduos do sexo masculino e casados tinham idades médias que não alcançavam 40 anos, com menor média, 37 anos, verificada em 1816 e a maior, 39,3 anos calculada para 1803. Para o sexo oposto a idade manteve-se, em média, 5 anos e meio menor: entre 30,9 (1820) e 34,1 (1799) anos de idade. Em diferentes medidas, modas e medianas foram sempre inferiores às médias evidenciando que um número menor de pessoas possuíam idade mais avançada, mantendo elevada a média encontrada com relação às outras estatísticas de posição.

Sem nunca terem conhecido legalmente o matrimônio ultrapassaram os 50 anos percentual diminuto: Entre 1799 e 1829 o percentual devido a estes indivíduos esteve sempre ao redor de 1,8\%. Para o sexo feminino essa medida esteve em 2,9\% (1816) em sua maior medida e em $1,9 \%$ na menor. Para os homens não observamos valor superior a $1,6 \%$.

As anteriormente referidas pirâmides etárias são apresentadas a seguir, de acordo com faixas etárias qüinqüenais (Gráfico I.23).

\section{Gráfico I.23}

\section{Pirâmides etárias da população livre}

(Nazaré - 1799 a 1829)

\section{9}

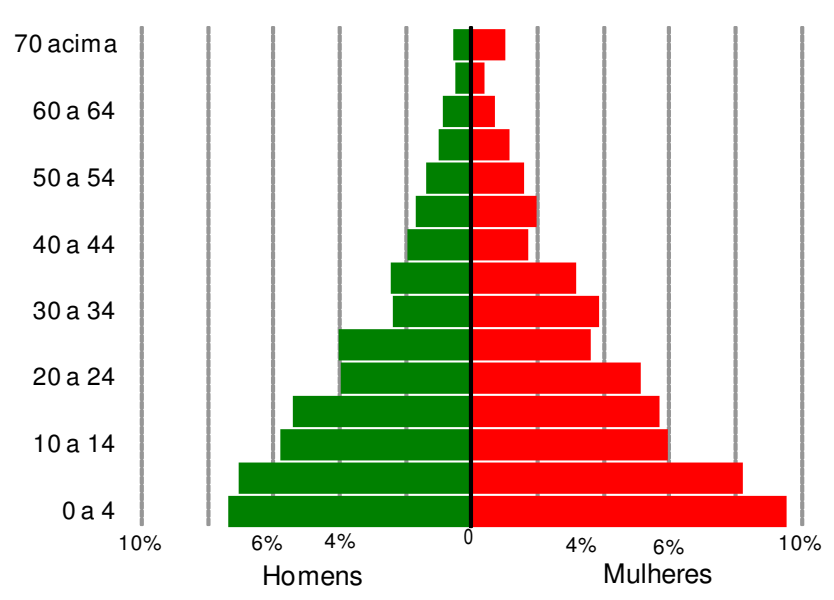


1803

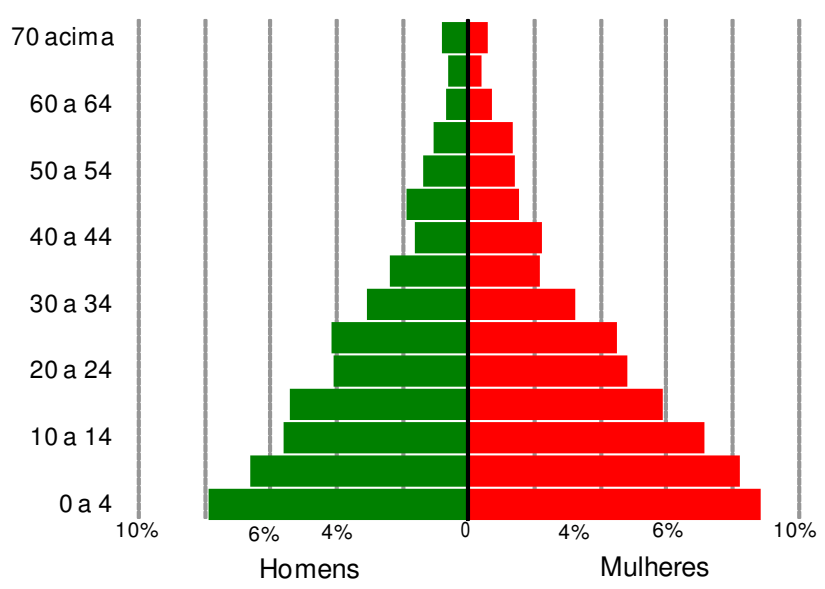

\section{8}

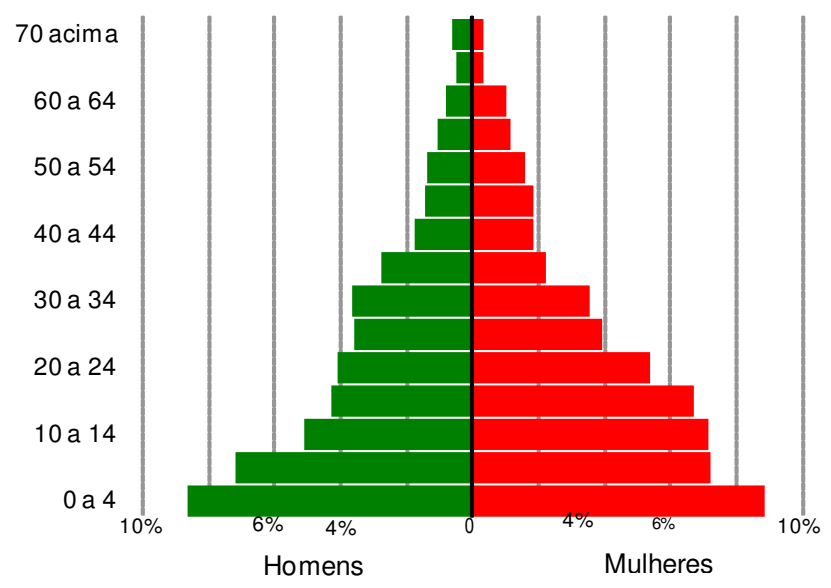

1812

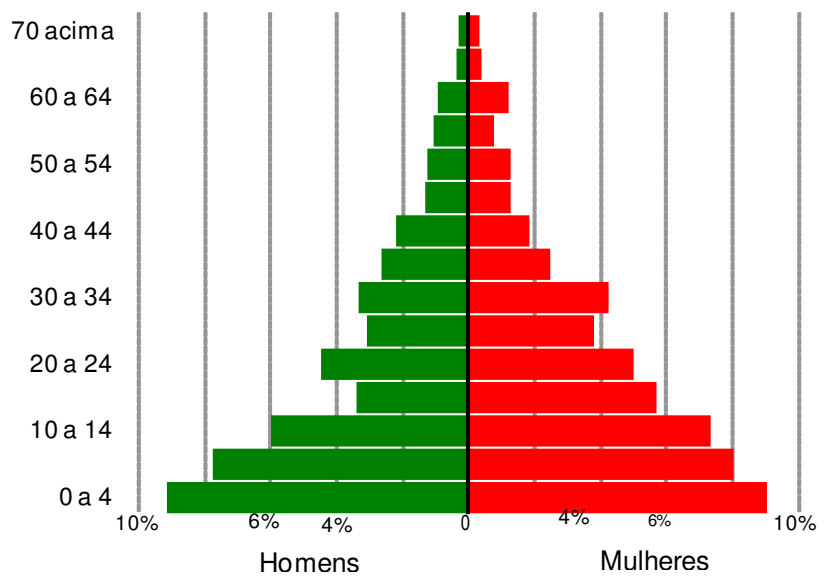


1816

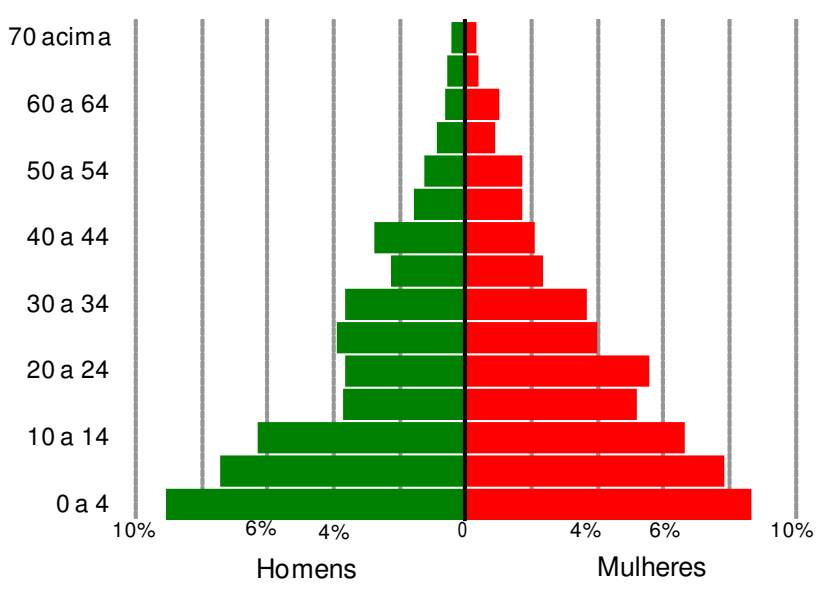

1820

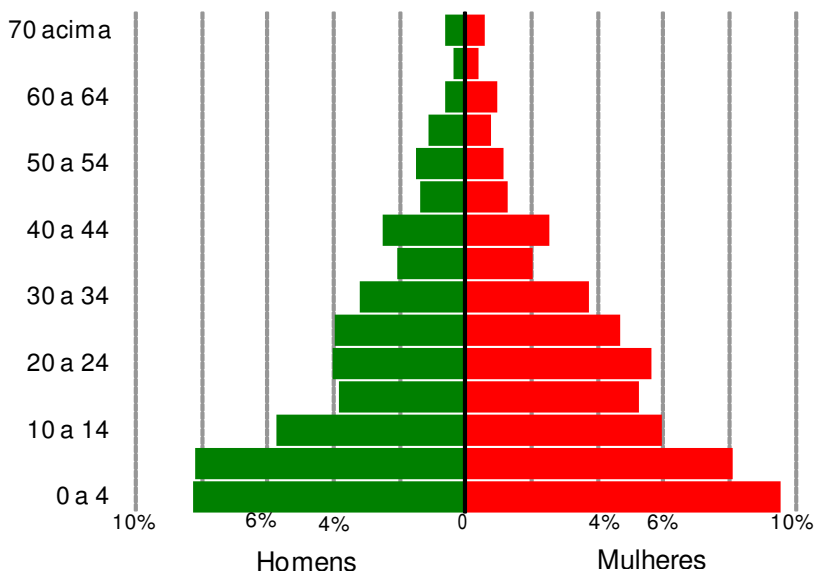

1826

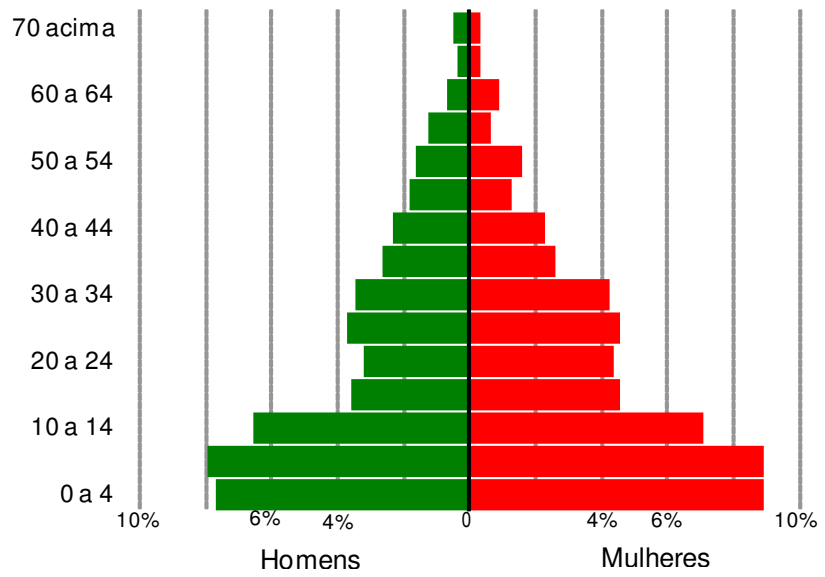


1829

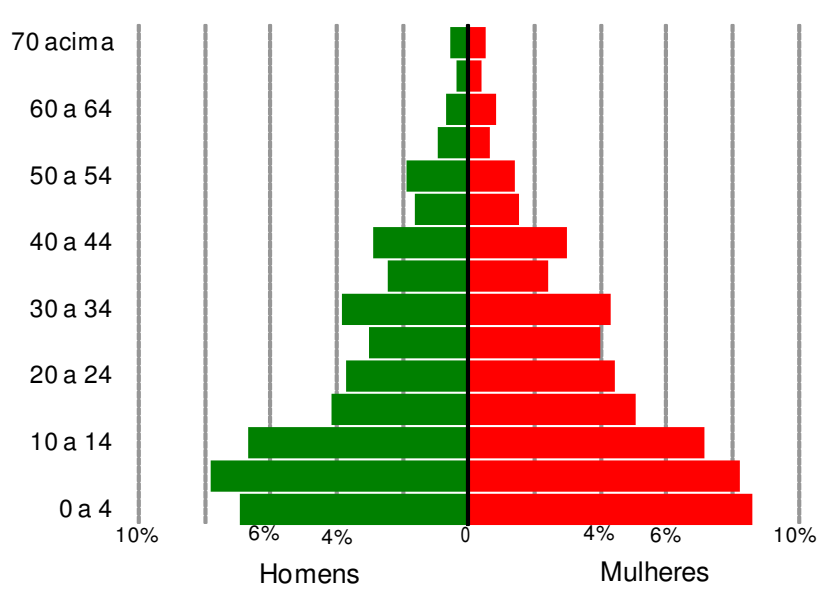

De imediato, percebe-se, como adiantado, que ao longo de todo o período a base da pirâmide é bastante alargada - é dizer, estavam homens e mulheres, em sua maioria, com idades de até 14 anos - e parece apontar, então, para uma população com consideráveis índices de natalidade. Em se desconsiderando algumas pequenas variações (classes ocas) até 1812, a aparência das pirâmides etárias da freguesia de Nazaré era a da forma tipicamente crescente: pessoas com zero a 14 anos constituíam em média $45 \%$ da população e os indivíduos com mais de 60 anos tinham participação diminuta (em média 3,5\%), ou seja, o topo era estreito. Ainda que, em regra, base larga e topo estreito sejam características de todo o lapso 1799-1830, no ano de 1816 e seguintes há, para os homens, pequena diferenciação entre os jovens nas faixas etárias qüinqüenais dos 15 aos 29 anos. As mulheres parecem acompanhar essa redução em 1826.

Observando as variáveis sexo e estado conjugal em um recorte que leva em consideração o fato do indivíduo ser considerado chefe de fogo, verificamos serem esta variáveis bastante afetadas: o grupo dos chefes de fogo é caracteristicamente composto por homens casados (Tabelas 1.50 e I.51).

Entre os chefes de domicílio o percentual de homens era muito superior ao de mulheres, sendo a razão entre os sexos multiplicada por cerca de seis quando comparada à anteriormente verificada para o livres, mantendo-se bastante elevada, durante todo o lapso estudado. A razão de sexo apresentou variações que merecem nota em 1816, quando atingiu seu menor valor, 445,8, equivalente a $81,7 \%$ de homens e $18,3 \%$ mulheres; e uma década depois quando alçou-se a 606,3 homens para 100 mulheres (ou seja, $85,5 \%$ indivíduos do sexo masculino). 
Tabela 1.50

Composição dos chefes de fogo por sexo

(Nazaré - 1799 a 1829)

\begin{tabular}{cccc}
\hline \hline & \multicolumn{3}{c}{ Chefes de fogo } \\
\cline { 2 - 4 } Anos & Homens & Mulheres & Razão de \\
& $\%$ sexo \\
\hline $\mathbf{1 7 9 9}$ & $84,2(314)$ & $15,8(59)$ & 532,2 \\
$\mathbf{1 8 0 3}$ & $84,5(479)$ & $15,5(88)$ & 544,3 \\
$\mathbf{1 8 0 8}$ & $84,7(538)$ & $15,3(97)$ & 554,6 \\
$\mathbf{1 8 1 2}$ & $84,0(540)$ & $16,0(103)$ & 524,3 \\
$\mathbf{1 8 1 6}$ & $81,7(584)$ & $18,3(131)$ & 445,8 \\
$\mathbf{1 8 2 0}$ & $84,3(632)$ & $15,7(118)$ & 535,6 \\
$\mathbf{1 8 2 6}$ & $85,8(679)$ & $14,2(112)$ & 606,3 \\
$\mathbf{1 8 2 9}$ & 83,5 (592) & $16,5(117)$ & 506,0 \\
\hline \hline
\end{tabular}

Exclusive indivíduos com sexo não identificado

Fonte: AESP, M aços de População, Nazaré: anos selecio nados

\section{Tabela $\mathbf{1 . 5 1}$}

Composição dos chefes de fogo de acordo com estado conjugal e sexo - exclusive indivíduos de até 14 anos -

(Nazaré - 1799 a 1829)

\begin{tabular}{|c|c|c|c|c|c|c|c|c|c|}
\hline \multirow{2}{*}{ Anos } & \multicolumn{3}{|c|}{ Homens } & \multicolumn{3}{|c|}{ Mulheres } & \multicolumn{3}{|c|}{ Homens + Mulheres } \\
\hline & $\begin{array}{c}\text { Casados } \\
\%\end{array}$ & $\begin{array}{c}\text { Solteiros } \\
\%\end{array}$ & $\begin{array}{c}\text { Viúvos } \\
\%\end{array}$ & $\begin{array}{c}\text { Casadas } \\
\%\end{array}$ & $\begin{array}{c}\text { Solteiras } \\
\%\end{array}$ & $\begin{array}{c}\text { Viúvas } \\
\%\end{array}$ & $\begin{array}{c}\text { Casados } \\
\%\end{array}$ & $\begin{array}{c}\text { Solteiros } \\
\%\end{array}$ & $\begin{array}{c}\text { Viúvos } \\
\%\end{array}$ \\
\hline 1799 & 91,7 & 5,1 & 3,2 & 11,9 & 22,0 & 66,1 & 79,2 & 7,9 & 12,9 \\
\hline 1803 & 88,3 & 7,7 & 4,0 & 6,8 & 21,6 & 71,6 & 75,7 & 9,9 & 14,4 \\
\hline 1808 & 90,9 & 4,8 & 4,3 & 11,5 & 20,8 & 67,7 & 78,9 & 7,2 & 13,8 \\
\hline 1812 & 89,7 & 6,0 & 4,3 & 7,8 & 29,1 & 76,4 & 76,4 & 15,1 & 8,6 \\
\hline 1816 & 90,7 & 3,8 & 5,5 & 7,6 & 24,4 & 67,9 & 75,4 & 7,6 & 17,0 \\
\hline 1820 & 90,5 & 3,3 & 6,2 & 7,6 & 16,1 & 76,3 & 77,4 & 5,3 & 17,2 \\
\hline 1826 & 89,7 & 4,1 & 6,2 & 8,0 & 17,9 & 74,1 & 78,1 & 6,1 & 15,8 \\
\hline 1829 & 91,0 & 2,7 & 6,3 & 10,3 & 21,6 & 68,1 & 77,5 & 5,9 & 16,6 \\
\hline
\end{tabular}

Fonte:AESP, M aços de População, Nazaré: ano s selecionados

Exclusive indivíduos com estado conjugal e/ou sexo não identificado

Exclui individuos de 0 a 14 anos 
Os dados acerca do estado conjugal, a sua vez, apontam diferenças marcantes entre homens e mulheres. Os chefes do sexo masculino eram, como adiantado, majoritariamente casados, sendo os valores a eles devidos cerca de 25 pontos percentuais acima do verificado para os nazareanos livres com ao menos 15 anos de idade. Em 1799 eram casados 91,7\% dos homens, passado menos de um lustro o percentual havia caído a $88,3 \%$ (o menor encontrado), estando sempre variando entre $90 \%$ e $91 \%$ nos anos que seguem partindo de 1808. O percentual de solteiros foi inconstante, com mínimo de 3,3\% em 1808 e máximo de 7,7\% em 1803. Para os viúvos, cuja participação foi sempre minoritária, é identificável um incremento na participação que, de $3,2 \%$ ao final do Setecentos passou a 4,3\% em 1808-12, 5,5\% no próximo ano em análise, tendo superado os 6\% na década de 1820 .

Por outro lado, mulheres casadas conformavam o menor grupo entre as chefes de domicílio, com percentuais variáveis ao longo dos anos. Em 1799 as mulheres que estavam em matrimônio eram 11,9\%, percentual que viu-se reduzido a $6,8 \%$ em 1803 , voltou a superar os $11 \%$ em 1808 passando por certa estabilidade em 7,8\% na década seguinte, chegando a 10,3\% em 1829. Essas modificações acompanharam as variações apresentadas pelo principal grupo feminino: as viúvas. Tornar-se viúva era, certamente, o meio principal de ascensão à condição de chefe de domicílio e este certamente o caso em 1799 quando anotada a menor parcela delas, 66,1\% e em 1820, ano em que sua participação atingiu o máximo por nós registrado: 76,3\%.

Em existindo chefes do sexo masculino em maior número, estes determinam a composição por estado conjugal considerados ambos os sexos, qual seja, maioria de casados, em percentuais situados entre 75,4\% (1820) e 79,2\% (1799).

Havia, dentre os grupo dos chefes de domicilio, especificidade devida àqueles cujos fogos descreviam cativos. Tais aspectos podem ser verificados através da participação dos proprietários de escravos segundo o sexo (Tabela I.52). Vê-se que a participação feminina no total dos detentores de escravos foi constante e baixa, com mínimo de 13,3\% em 1825 e o máximo de 16,8\% (1808 e 1816). Nestes anos as razões de sexo haviam sido, respectivamente, de 652,6 e 512,5. Para estes mesmos anos, como adiantado, para o total dos chefes de domicilio encontramos valores de 532,2 e 506 . 
Tabela 1.52

Sexo e idade dos chefes de fogo com escravos

(Nazaré - 1799 a 1829)

\begin{tabular}{ccccccccc}
\hline \hline & $\mathbf{1 7 9 9}$ & $\mathbf{1 8 0 3}$ & $\mathbf{1 8 0 8}$ & $\mathbf{1 8 1 2}$ & $\mathbf{1 8 1 6}$ & $\mathbf{1 8 2 2}$ & $\mathbf{1 8 2 5}$ & $\mathbf{1 8 3 0}$ \\
\hline Homens (\%) & 83,7 & 85,9 & 83,2 & 86,1 & 83,2 & 83,6 & 86,7 & 84,3 \\
Mulheres (\%) & 16,3 & 14,1 & 16,8 & 13,9 & 16,8 & 16,4 & 13,3 & 15,7 \\
Razão de sexo & 512,5 & 611,1 & 495,5 & 617,6 & 495,7 & 508,3 & 652,6 & 536,8 \\
\hline Idade média & 45,3 & 44,5 & 45,3 & 44,1 & 45,8 & 44,9 & 45,8 & 46,3 \\
Idade mínima & 21 & 17 & 17 & 18 & 18 & 18 & 16 & 23 \\
Idade máxima & 79 & 98 & 99 & 93 & 96 & 90 & 84 & 83 \\
\hline \hline
\end{tabular}

Fonte: AESP, M aços de População, Nazaré: anos selecionados

Diferenciação entre chefes de fogo e a totalidade dos livres encontramos também na naturalidade descrita pra os habitantes de Nazaré. Os dados levantados, dispostos na Tabela I.53, destacam ser a grande maioria daqueles que vivam na freguesia nascidos ali mesmo. Até 1816 a representatividade dos nazareanos propriamente variou dentro de um intervalo curto de um mínimo de 85,1\% verificado em 1799 e um máximo de 89,7\% anotado em 1812 (incluídos aí os anos de 1816 e 1820, em que a representatividade para esta informação na documentação viu-se reduzida a $76 \%$ e $71 \%$, enquanto havia sido superior aos $97 \%$ nos demais anos). Em 1829 o percentual alçou-se a 92,5\%.

Os migrantes chegados de locais mais distantes, quais sejam, outras capitanias e outros países, foram encontrados em pequeno número na Nazaré Oitocentista, não somando, em seu conjunto, mais que $1,2 \%$ (1816) da população com naturalidade explicitada. Os não nazareanos haviam migrado, principalmente, de outras áreas da capitania depois província de São Paulo, em especial das localidades vizinhas de Bragança, Mogi da Cruzes, Conceição e São Paulo, que mantiveram alguma participação ao longo de todo o lapso 1799-1829.

Estranhamente, em 1826 haviam 243 indivíduos descritos como oriundos de Santa Isabel. Entre eles, 237 (97,5\%) encontravam-se no Bairro do Rio do peixe - capitaneado por Joze Joaquim de Oliveira -, e todos apresentavam filiação como relação com os respectivos chefe de domicílio. Foram declarados nos referidos fogos, em regra o nome do chefe ao qual estava acrescido "natural desta", seguido pelo cônjuge e na seqüência por "seus filhos naturais da Freguesia de Santa Izabel", listados imediatamente abaixo. (Lista Nominativa de Nazaré, 1826 - AESP, Maços de População/rolo 29) 
Tabela 1.53

Origem da população livre

(Nazaré - 1799 a 1829)

\begin{tabular}{|c|c|c|c|c|c|c|c|}
\hline \multirow{3}{*}{ Origem } & \multicolumn{7}{|c|}{ População livre } \\
\hline & 1803 & 1808 & 1812 & 1816 & 1820 & 1826 & 1829 \\
\hline & \% (№) & \% (№) & \% (№) & \% (№) & \% (№) & \% (№) & \% (№) \\
\hline Nazaré & $85,1(2418)$ & $88,3(2664)$ & $89,7(2665)$ & $87,9(2155)$ & $86,6(2191)$ & $86,0(3118)$ & $92,5(2887)$ \\
\hline Atibaia & $0,4(12)$ & $0,3(9)$ & $0,8(24)$ & $0,7(17)$ & $0,8(21)$ & $0,8(30)$ & $0,9(28)$ \\
\hline Bragança & $0,5(15)$ & $0,5(15)$ & $1,8(53)$ & $1,5(38)$ & $2,0(51)$ & $0,4(16)$ & $0,7(23)$ \\
\hline Mogi das Cruzes & $1,6(46)$ & $1,5(46)$ & $0,7(21)$ & 1,2 (29) & $0,4(11)$ & $0,5(18)$ & $0,2(7)$ \\
\hline Jundiaí & $0,0(1)$ & - & - & - & $0,0(1)$ & - & $0,0(1)$ \\
\hline Jacareí & $0,8(22)$ & $0,1(4)$ & $0,3(8)$ & $0,2(4)$ & $0,1(3)$ & $0,1(3)$ & $0,0(1)$ \\
\hline São Paulo & $2,1 \quad(59)$ & $1,4(43)$ & $0,9(26)$ & $1,4(35)$ & $1,1(29)$ & $0,9(33)$ & $1,0(30)$ \\
\hline Conceição & $5,8(166)$ & $5,0(151)$ & $2,8(82)$ & $4,0(97)$ & $3,6(91)$ & $2,5(91)$ & 2,7 (85) \\
\hline Juqueri & 1,3 (38) & $1,1(34)$ & $1,1(33)$ & $0,9(22)$ & $0,6(14)$ & $0,2(8)$ & $0,4(12)$ \\
\hline Mogi mirim & - & - & $0,3(8)$ & $0,2(4)$ & $1,0(26)$ & $0,7(27)$ & $0,7(21)$ \\
\hline Santa Izabel & - & - & - & - & $1,2(31)$ & $6,7(243)$ & - \\
\hline $\begin{array}{l}\text { Outras localidades da } \\
\text { capitania/província }\end{array}$ & 1,2 (34) & $0,7(21)$ & (22) & $0,9(23)$ & 1,3 (33) & $0,4(13)$ & $0,2(6)$ \\
\hline $\begin{array}{l}\text { TOTAL da } \\
\text { capitania/província } \\
\text { (exclusive Nazaré) }\end{array}$ & $13,8(393)$ & $10,7(323)$ & $9,4(277)$ & $11,0(269)$ & $12,3(311)$ & $13,3(482)$ & $6,9(214)$ \\
\hline $\begin{array}{l}\text { Outras } \\
\text { capitanias/províncias }\end{array}$ & $0,8(23)$ & $0,7(21)$ & $0,8(23)$ & $0,7(16)$ & $0,7(17)$ & $0,4(13)$ & $0,4(11)$ \\
\hline Outros países & $0,3(8)$ & $0,3(9)$ & $0,2(6)$ & $0,5(13)$ & $0,4(10)$ & $0,3(12)$ & $0,3(9)$ \\
\hline TOTAL & $100,0(2842)$ & $100,0(3017)$ & $100,0(2971)$ & $100,0(2453)$ & $100,0(2529)$ & $100,0(3625)$ & $100,0(3121)$ \\
\hline \multirow[t]{2}{*}{$\begin{array}{l}\text { Abrangência das } \\
\text { declarações }\end{array}$} & $98,8 \%$ & $97,3 \%$ & $97,7 \%$ & $76,1 \%$ & $71,0 \%$ & $98,1 \%$ & $97,6 \%$ \\
\hline & \multicolumn{7}{|c|}{ Chefes de fogo } \\
\hline \multirow[t]{2}{*}{ Origem } & 1803 & 1808 & 1812 & 1816 & 1820 & 1826 & 1829 \\
\hline & \% (№) & \% (№) & \% (№) & \% (№) & \% (№) & \% (№) & \% (№) \\
\hline Nazaré & $65,1(369)$ & $70,4(443)$ & $74,2(477)$ & $74,4(530)$ & $75,0(558)$ & $80,3(628)$ & $80,3(565)$ \\
\hline Atibaia & $1,8(10)$ & $0,6(4)$ & $1,9(12)$ & $1,7(12)$ & $2,0(15)$ & $2,0(16)$ & $2,7(19)$ \\
\hline Bragança & $1,1(6)$ & $1,3(8)$ & $4,2(27)$ & $3,4(24)$ & $4,3(32)$ & $1,7(13)$ & $1,3(9)$ \\
\hline Mogi das Cruzes & $5,3(30)$ & $5,2(33)$ & $2,0(13)$ & $2,2(16)$ & $1,2(9)$ & $1,2(9)$ & $0,6(4)$ \\
\hline Jundiaí & - & - & - & - & - & - & $0,1(1)$ \\
\hline Jacareí & $1,2(7)$ & $0,6(4)$ & $0,6(4)$ & $0,1(1)$ & $0,3(2)$ & - & $0,1(1)$ \\
\hline São Paulo & $4,8(27)$ & $3,8(24)$ & $2,8(18)$ & $2,8(20)$ & $2,8(21)$ & $3,3(26)$ & $3,6(25)$ \\
\hline Conceição & $10,9(62)$ & $9,2(58)$ & $6,2(40)$ & 7,7 (55) & $6,2(46)$ & $6,0(47)$ & $5,7(40)$ \\
\hline Juqueri & $3,2(18)$ & 2,7 (17) & $1,9(12)$ & $1,8(13)$ & $1,2(9)$ & $0,8(6)$ & $1,4(10)$ \\
\hline Mogi mirim & - & - & $0,8(5)$ & $0,4(3)$ & $2,2(16)$ & $1,0(8)$ & $1,3(9)$ \\
\hline $\begin{array}{l}\text { Outras localidades da } \\
\text { capitania/província }\end{array}$ & 3,4 (19) & $2,2(14)$ & $2,0(13)$ & $2,1(15)$ & $2,2(16)$ & $1,5(12)$ & $0,9(6)$ \\
\hline $\begin{array}{l}\text { TOTAL da } \\
\text { capitania/província } \\
\text { (exclusive Nazaré) }\end{array}$ & 31,6 (179) & $25,8(162)$ & $22,4(144)$ & 22,3 (159) & $22,3(166)$ & $17,5(137)$ & $17,6(124)$ \\
\hline $\begin{array}{l}\text { Outras } \\
\text { capitanias/províncias }\end{array}$ & $2,3(13)$ & 2,7 (17) & $2,5(16)$ & $1,4(10)$ & $1,5(11)$ & $1,0(8)$ & $1,0(7)$ \\
\hline Outros países & $1,1(6)$ & $1,1(7)$ & $0,9(6)$ & $1,8(13)$ & $1,2(9)$ & $1,2(9)$ & $1,1(8)$ \\
\hline TOTAL & $100,0(567)$ & $100,0(629)$ & $100,0(643)$ & $100,0(712)$ & $100,0(744)$ & $100,0(782)$ & $100,0(704)$ \\
\hline $\begin{array}{l}\text { Abrangência das } \\
\text { declarações }\end{array}$ & $99,6 \%$ & $98,7 \%$ & $99,4 \%$ & $99,6 \%$ & $99,1 \%$ & $98,7 \%$ & $98,9 \%$ \\
\hline
\end{tabular}

Fonte: A ESP, M aços de População, Nazaré: anos selecionados

Exclusive indivíduos com naturalidade não identificada 
A diferenciação com relação aos chefes de fogo se dá no percentual em que indivíduos vindos de outras áreas aparecem. Em 1799, enquanto para o total da população livre citamos $85,1 \%$ da própria freguesia, sendo próxima a $14 \%$ a participação de outras localidades da capitania, para os chefes de domicilio os naturais da própria terra são $65 \%$ contra $31,6 \%$ dos naturais de outras paragens, ou seja, há proporcionalmente duas vezes mais forasteiros chefiando fogos em Nazaré do que estes indivíduos estão presentes, como livres ou libertos, nesta sociedade.

A participação de forasteiros foi nitidamente decrescente entre os indivíduos a chefiar unidades domiciliares: caiu a $25,8 \%$ em 1803 , estando em $22 \%$ entre os anos 1812 e 1820 e em um terceiro momento, 1826-1829, eram 17,5\%. Ainda que em visível retração, este percentual foi sempre superior ao anotado para o total dos livres. São Paulo, Atibaia, Juqueri estavam entre as localidades originárias de alguns chefes de fogo, mas destacam-se Conceição e Mogi das Cruzes, em especial em 1799 e 1803 quando responderam, respectivamente, cada uma delas por $10 \%$ e $5 \%$ da chefia dos domicílios na freguesia.

Oriundos da freguesia ou não, parte destes chefes de domicílios, como sabemos, contavam com a mão-de-obra cativa em seus fogos, indivíduos estes para os quais também podemos anotar algumas características demográficas.

As pirâmides etárias para os cativos (Gráfico I.24) diferenciam-se daquelas em momento anterior apresentadas para os nazareanos livres, por sua inconstância entre faixas de idade e entre os sexos. De um modo geral, a base permanece alargada. Mas, com áreas intermediárias também alargadas, especialmente nos anos a partir de 1820, sendo quase tão largas quanto as bases, apontando para relativo envelhecimento da população cativa da Freguesia de Nazaré.

Em tal população, em 1803 e 1812, havia se destacado as mulheres com 15 a 19 anos de idade, a responder por $10 \%$ dos escravos anotados em ambos os anos referidos; nestas mesmas faixas etárias os homens responderam por 7,5\% e 6,1\% da população em questão. Em 1808 os homens com 20 a 24 anos destacaram-se, ao responder por quase $8 \%$ dos escravos nazareanos. 


\section{Gráfico I.24}

Pirâmides etárias da população escrava

(Nazaré - 1799 a 1829)

\section{9}
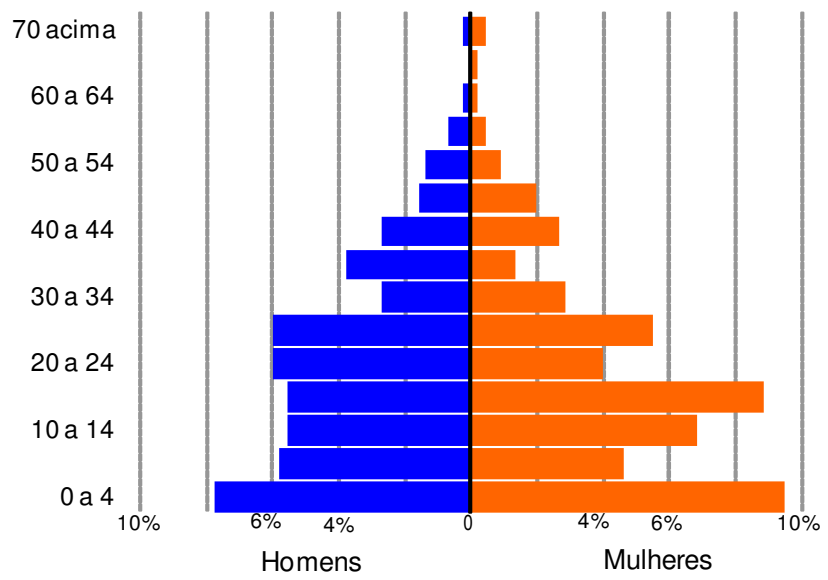

1803
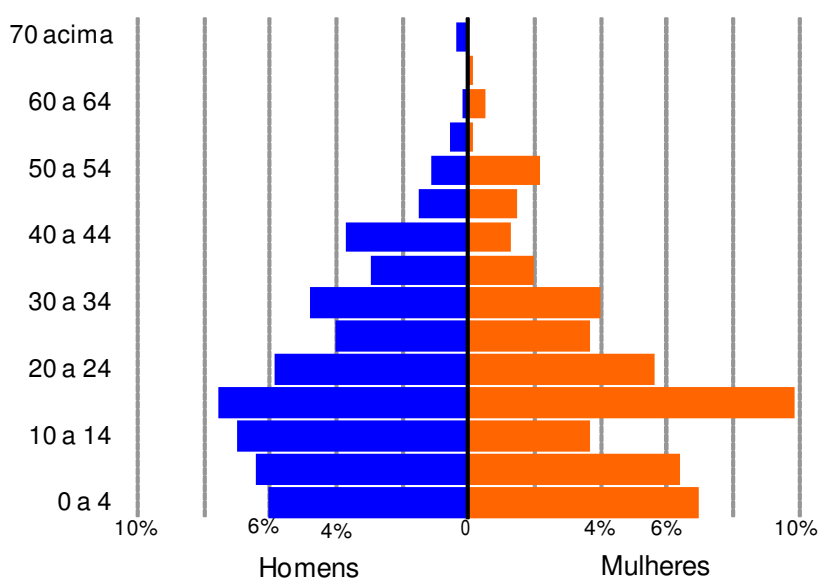

1808

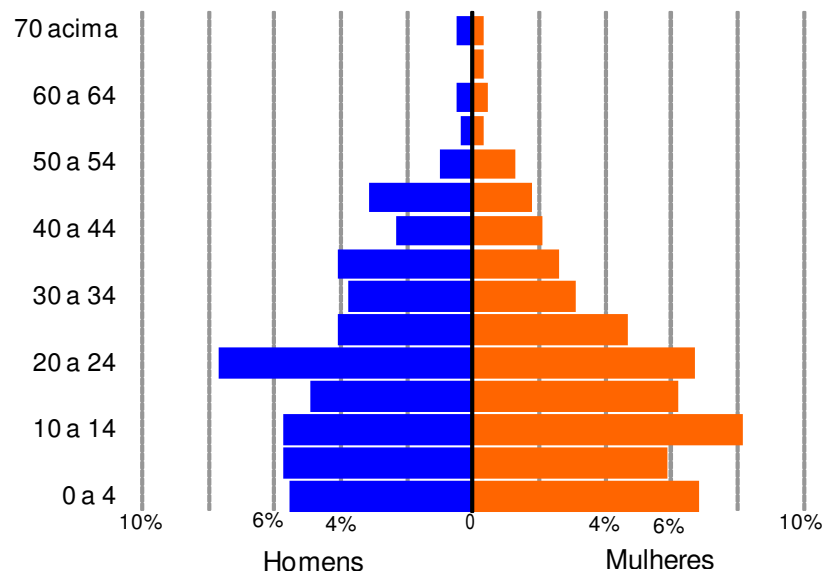


1812

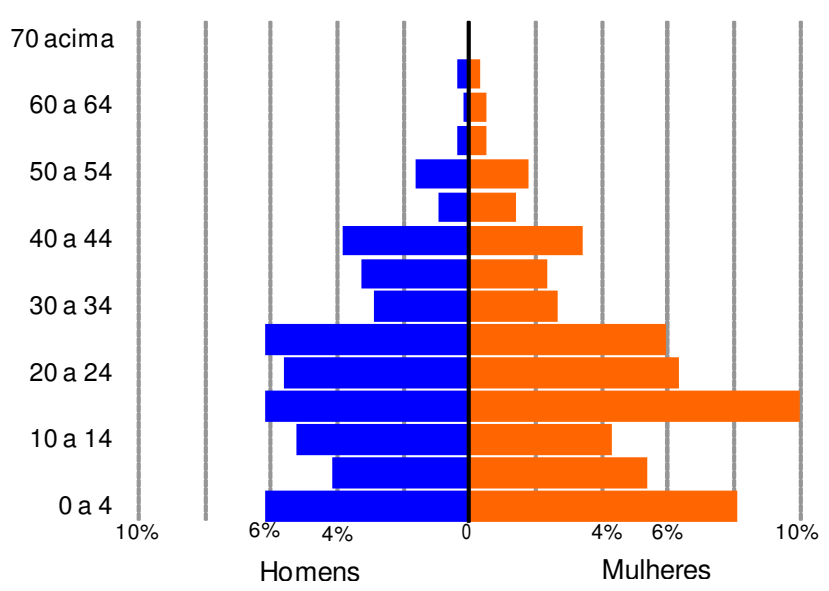

1816

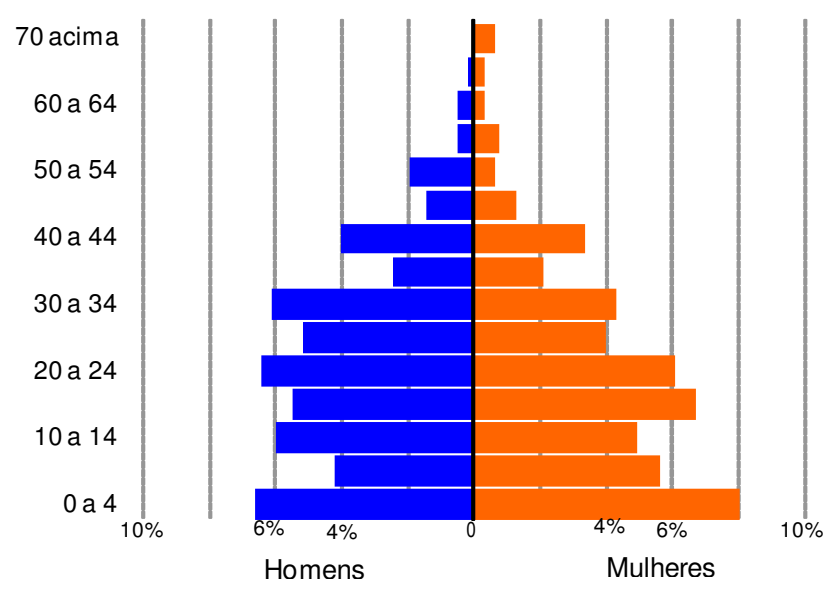

1820

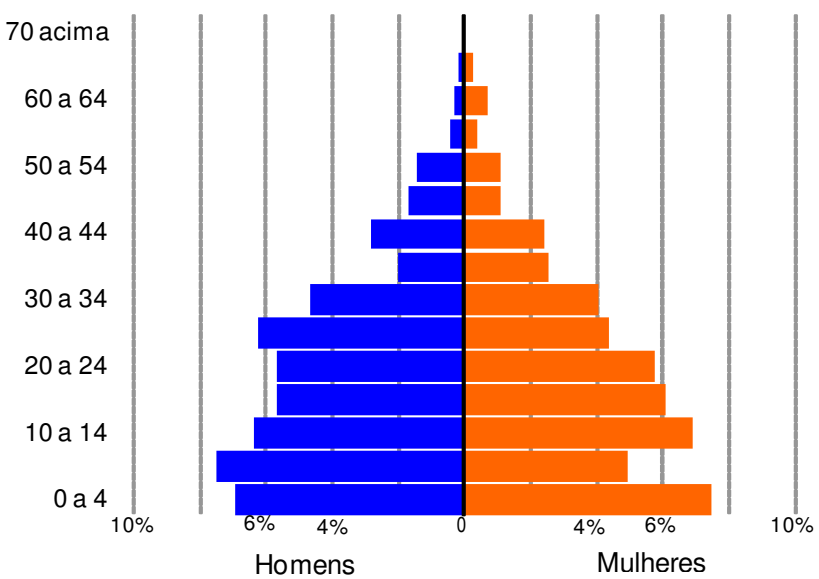


1826

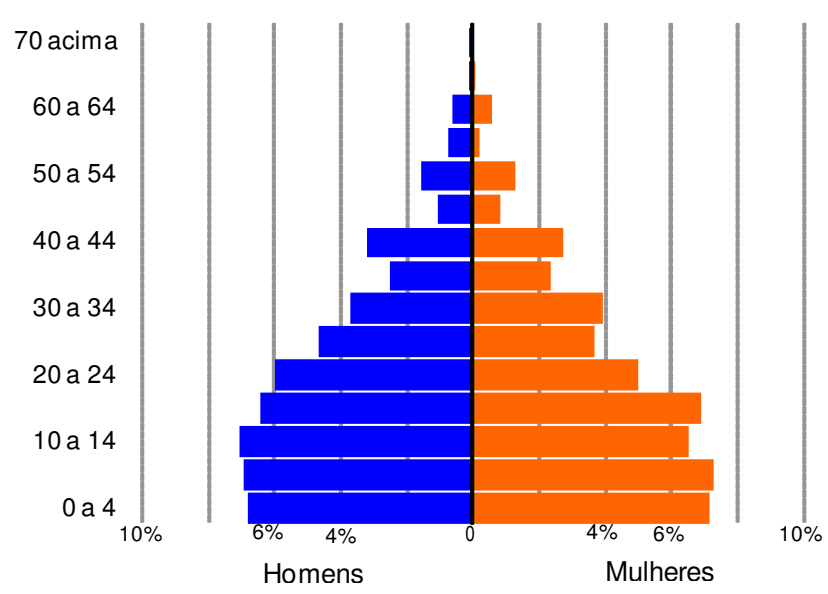

1829

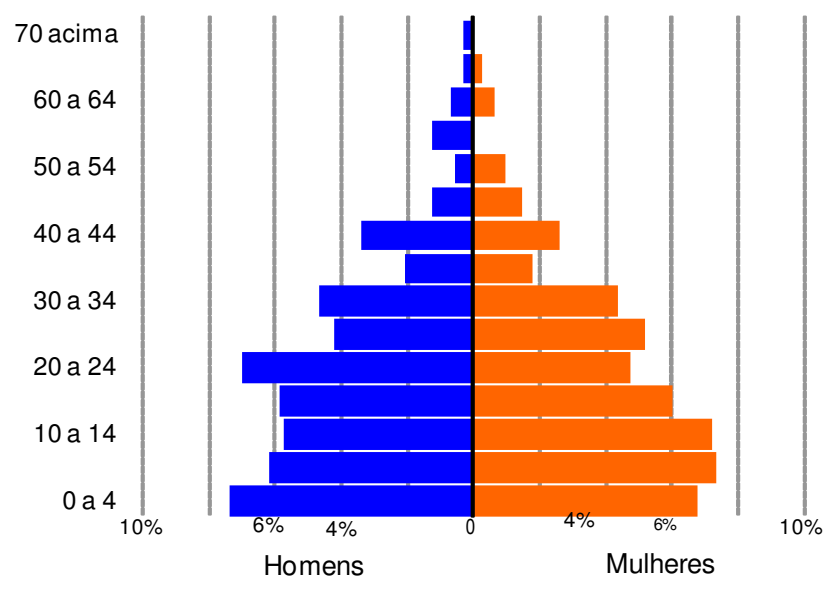

As razões entre os sexos podem ser melhor observadas no Gráfico 1.25. A curva apresentada para a totalidade dos escravos, não obstante a presença de um ponto de mínimo pouco distanciado em 1812 - razão entre os sexos de 87,8, equivalente à presença de $53,2 \%$ de mulheres e $46,8 \%$ de homens entre os escravos - flutuou ao redor da igualdade entre os sexos em todos os anos, sendo assim, ora favorável aos escravos ora favorável às escravas.

Variação bastante errática encontramos ao longo dos anos para a proporção entre os sexos dos indivíduos em plantéis muito grandes, que de 153,7 (60,6\% homens) em 1803 caiu a 91,3 (47,7\% homens) em menos de uma década, uma diferença de 20 pontos percentuais, passada da participação masculina à feminina. 
Gráfico I.25

Razão de sexo dos cativos de acordo com faixas

de tamanho dos plantéis

(Nazaré - 1799 a 1829)

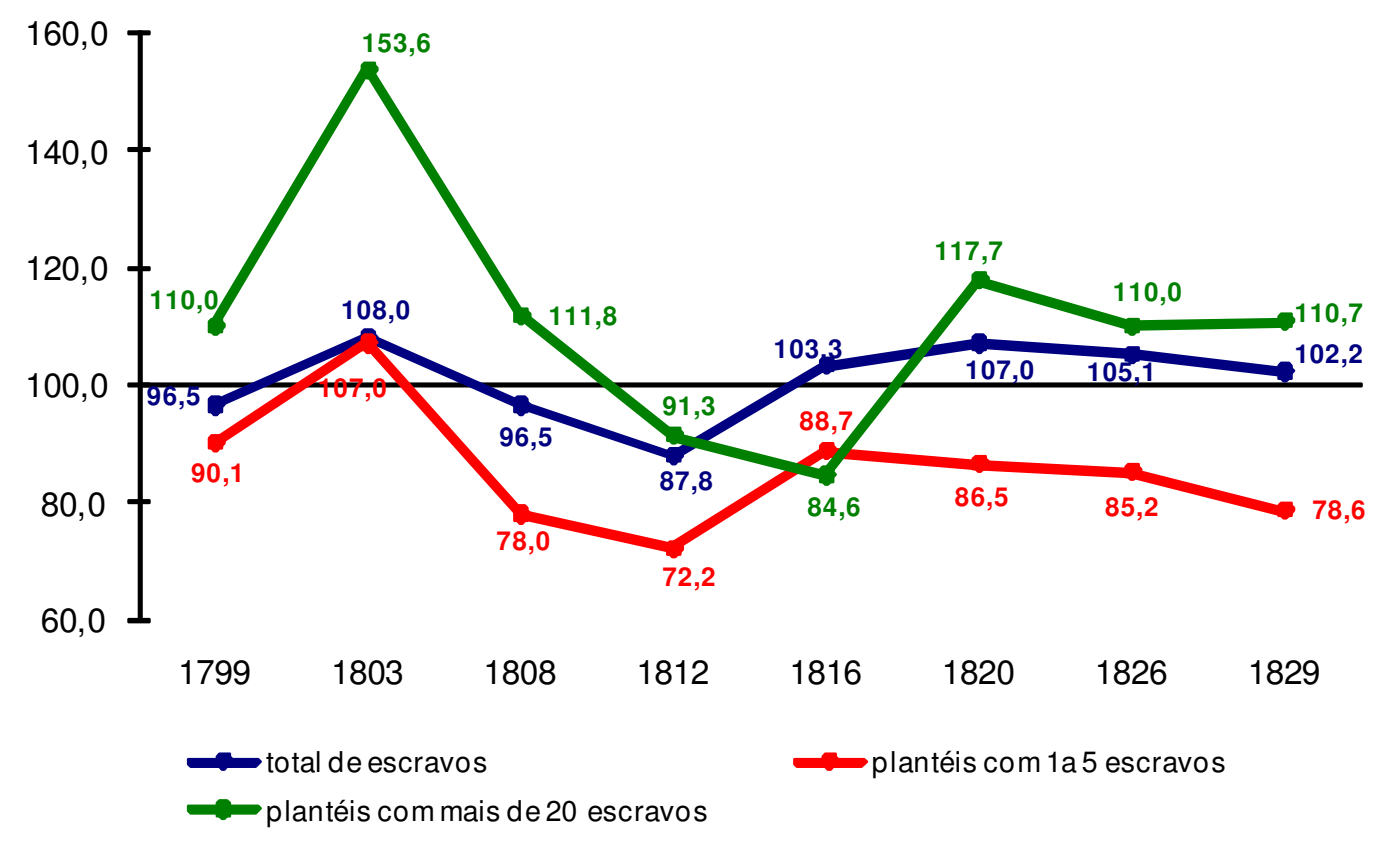




\section{Mogi da Cruzes}

Os dados populacionais para a vila de Santana das Cruzes de Mogi indicam, claramente, um crescimento considerável entre 1799 e 1829. A população de Mogi - que havia sido "[...] composta de 4844 pessoas em 1777, 6895 em 1801, 9364 em 1818" (SANTOS, 2004) - contava, em 1799, com 6982 indivíduos de acordo com nossos levantamentos.

Se em 1799 foram computados quase 7000 indivíduos na população total da localidade vivendo em 1142 fogos, para 1829, data da última lista nominativa mogiana que observamos em detalhe, dispomos de dados que indicam uma população total de pouco menos de 10800 indivíduos, distribuídos por cerca de 1940 fogos. ${ }^{21}$ Diante de tais dados, revela-se um grande crescimento populacional, que elevou o número de moradores na vila de Mogi da Cruzes em 54,6\%, enquanto os domicílios foram acrescidos em 69,5\%. (cf. Gráfico I.26 e Tabelas I.54 e I.55)

Contudo, incluídos os recenseamentos para outros anos, há indicação de três períodos nesse crescimento. De 1799 até 1803 estima-se uma expansão populacional de 18\%, acompanhada de uma elevação de 18,2\% no número de domicílios. Entre 1803 e 1820 parece ter havido uma relativa imobilidade populacional, com flutuações que não atingiram $4,5 \%$ entre os anos considerados, sendo registrada uma população total de 8056 habitantes em 1820, algo como 500 indivíduos a menos que o pico populacional no período, registrado em 1812: 8525 pessoas (se considerado o crescimento datado entre 1799 e 1816, este seria da ordem de 17\%). Entre 1820 e 1829 a população cresceu a olhos vistos, foram mais de 2700 indivíduos (34\%) incorporados à vila de Mogi em menos de uma década, ligados a um crescimento das unidades familiares semelhante, $32 \%{ }^{22}$

${ }^{21}$ Também para Mogi há divergências entre os totais para a população calculados através da relação de habitantes e dos mapas de população. Os números dos resumos para a população total de Mogi está listada no quadro que segue:

\begin{tabular}{c|c|c|c|c|c|c|c|c|c|c|c|c|c|c}
\hline \hline $\mathbf{1 7 9 8}$ & $\mathbf{1 7 9 9}$ & $\mathbf{1 8 0 3}$ & $\mathbf{1 8 0 5}$ & $\mathbf{1 8 0 6}$ & $\mathbf{1 8 0 8}$ & $\mathbf{1 8 1 0}$ & $\mathbf{1 8 1 2}$ & $\mathbf{1 8 1 4}$ & $\mathbf{1 8 1 6}$ & $\mathbf{1 8 1 8}$ & $\mathbf{1 8 2 0}$ & $\mathbf{1 8 2 2}$ & $\mathbf{1 8 2 6}$ & $\mathbf{1 8 2 9}$ \\
\hline 7017 & 7175 & 7907 & 8228 & 7983 & 8014 & 7832 & 8178 & 7935 & 7703 & 9294 & 8984 & 9231 & 9405 & 10550 \\
\hline
\end{tabular}

As diferenças ao longo do lapso considerado são da mesma proporção daquelas arroladas no corpo do texto: de 7000 habitantes em 1798 a 10500 em 1829 (50,3\%)

${ }_{22}$ Em se considerando os números colocados por Jonas Santos (2004) e apresentados no primeiro parágrafo, a população mogiana em 1818, de 9364 indivíduos (número também distinto ao encontrado nos mapas de população), seria superior em 14,6\% àquela que registramos em 1816; em se considerando apenas os resumos, temos uma variação de $20,7 \%$ entre 1816 e 1818 . Indícios, eventualmente, de um considerável incremento populacional ocorrido anteriormente ao período por nós identificado. Utilizando a mesma fonte a que recorremos o autor aponta, para 1829, uma população de 10762 indivíduos (8624 livres e 138 escravos), 29 pessoas a menos do que computamos. Essas pequenas divergências nos totais apresentados (cerca de $0,4 \%$ para todos os segmentos) são devidas, certamente, às dificuldades naturais na leitura dos documentos. 
Em período pouco menor, 1822 a 1828, a população total da província expandiu-se em $17,7 \%$.

Os mesmos arrolamentos indicam certa diferenciação na dinâmica apresentada pelas parcelas livre e cativa daquela sociedade, referente ao segundo momento, quando o número de cativos decresceu mantendo relativa estabilidade a população livre (esta, a determinante dos movimentos observados para o total de mogianos). Entre 1799 e 1803, assim como ocorreu com a população total, livres e cativos apresentaram considerável avanço, $19,8 \%$ para os livres e $11,4 \%$ para os mancípios. Entre os escravos, a população diminuiu 15\% no intervalo que separa 1803 e 1820, passando de 1762 a 1497 indivíduos; por outro lado, os não cativos foram de 6471 a 6559 indivíduos no mesmo período (avanço de 1,5\%) após terem sido 6824 pessoas em 1812. Ambos os contingentes populacionais cresceram de maneira importante desde então, avançando $22,4 \%$ e $28,4 \%$, respectivamente livres e escravos entre 1820 e 1825; percentuais calculados em 7,9\% e $10,7 \%$ entre 1825 e 1829.

Os dados apresentados incluem a freguesia de Santa Isabel, ${ }^{23}$ explicitada na documentação a partir de 1825, quando a ela eram devidos 1741 indivíduos (17,5\%), sendo 288 escravos, e 311 fogos (17,4\%). Em 1829 estavam distribuídos, pelas três companhias componentes da freguesia naquele ano, 2124 habitantes livres e 497 escravos, eram 2621 indivíduos (24,3\%) em 446 domicílios (23\%).

Temos, então, para a população de Mogi/Santa Isabel um crescimento a taxas anuais médias de 1,5\% nas três décadas que separam 1799 e 1829, sendo de 1,6\% ao ano a expansão dos livres e $1 \%$ a taxa referente aos cativos; crescimento este devido às consideráveis variações ocorridas na virada para o Oitocentos e na década de 1820.

Vinculando as variações demográficas às características econômicas da localidade, Jonas Santos (2004, p.5) aponta que

O crescimento significativo de escravos no primeiro período [1777 a 1801 - DOMR] está ligado a um dinamismo provocado principalmente, pela introdução do cultivo e manufatura do algodão e ao aumento da produção de aguardente. Porém, no segundo período [1801 a 1818 - DOMR] a reduzida taxa de crescimento vinculavase principalmente à extinção das peças de panos de algodão das receitas de exportação, que até o final do século XVIII representava o principal produto de exportação. No terceiro período [1818 a 1829 - DOMR], retomou-se o aumento significativo no número de escravos em função principalmente da introdução e cultivo do café.

\footnotetext{
${ }^{23}$ Para referências acerca da relação territorial-administrativa entre Mogi das Cruzes e Santa Isabel, ver apêndice 1: evolução administrativa e territorial.
} 


\section{Gráfico I.26}

Evolução (em valores absolutos) da população total, população livre e escravos

(Mogi - 1799 a 1829)

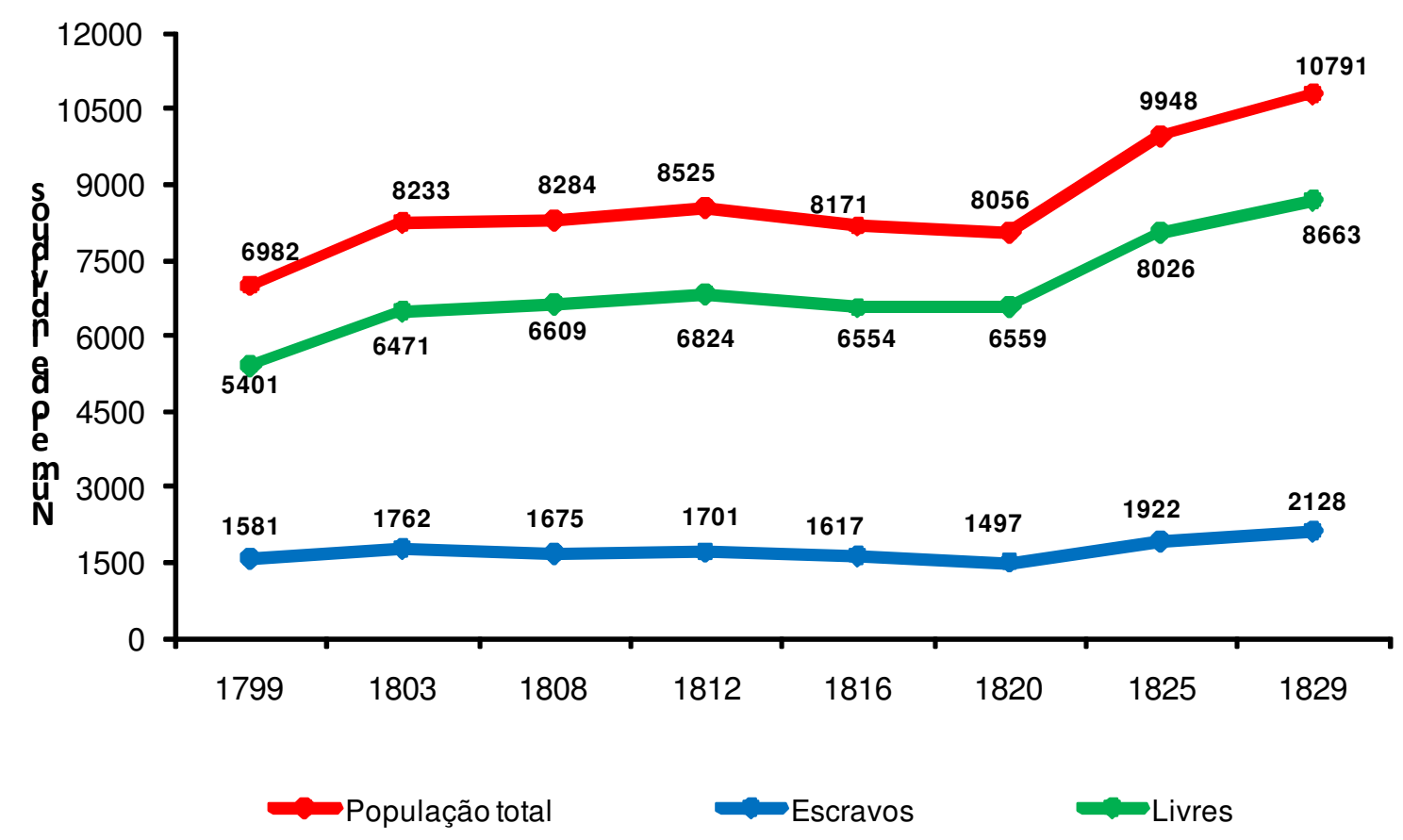

Tabela I.54

Variação da população total, população livre e escravos

(Mogi - 1799 a 1829, São Paulo - 1798 a 1828)

\begin{tabular}{|c|c|c|c|c|c|}
\hline \multicolumn{4}{|c|}{ Bragança Paulista } & \multicolumn{2}{|c|}{ Província São Paulo* } \\
\hline Anos & $\begin{array}{l}\text { Variação \% da } \\
\text { população total }\end{array}$ & $\begin{array}{c}\text { Variação \% da } \\
\text { população livre }\end{array}$ & $\begin{array}{l}\text { Variação \% da } \\
\text { população } \\
\text { cativa }\end{array}$ & Anos & $\begin{array}{c}\text { Variação \% da } \\
\text { população total }\end{array}$ \\
\hline $1799-1803$ & 17,9 & 19,8 & 11,4 & $1798-1800$ & 4,4 \\
\hline $1803-1808$ & 0,6 & 2,1 & $-4,9$ & $1800-1808$ & 15,7 \\
\hline $1808-1812$ & 2,9 & 3,3 & 1,6 & $1808-1818$ & 13,0 \\
\hline $1812-1816$ & $-4,2$ & $-4,0$ & $-4,9$ & $1818-1822$ & 10,3 \\
\hline $1816-1820$ & $-1,4$ & 0,1 & $-7,4$ & $1822-1828$ & 17,7 \\
\hline $1820-1825$ & 23,5 & 22,4 & 28,4 & $1798-1818$ & 36,5 \\
\hline $1825-1829$ & 8,5 & 7,9 & 10,7 & $1818-1828$ & 29,8 \\
\hline $1799-1816$ & 17,0 & 21,3 & 2,3 & $1798-1828$ & 77,2 \\
\hline $1816-1829$ & 32,1 & 32,2 & 31,6 & & \\
\hline $1799-1829$ & 54,6 & 60,4 & 34,6 & & \\
\hline
\end{tabular}

*Valores calculados a partir dos dados apresentados por M arcílio (2000, p.71), inclui Paraná

*^Fonte: AESP, M aços de População, Mogi das Cruzes: anos selecionados 


\section{Tabela 1.55}

Variação do número de fogos

$$
\text { (Mogi - } 1799 \text { a 1829) }
$$

\begin{tabular}{ccc}
\hline \hline Ano & № de fogos & $\begin{array}{c}\text { Variação \% } \\
\text { do número de } \\
\text { fogos }\end{array}$ \\
\hline 1799 & 1142 & \\
1803 & 1350 & 18,2 \\
1808 & 1490 & 10,4 \\
1812 & 1552 & 4,2 \\
1816 & 1402 & $-9,7$ \\
1820 & 1467 & 4,6 \\
1825 & 1789 & 21,9 \\
1829 & 1936 & 8,2 \\
\hline \hline Fonte: AESP, Maços de População, Mogi das Cruzes: \\
anos selecionados
\end{tabular}

\section{Gráfico I.27}

\section{Participação de livres e escravos na população}

(Mogi - 1799 a 1829)

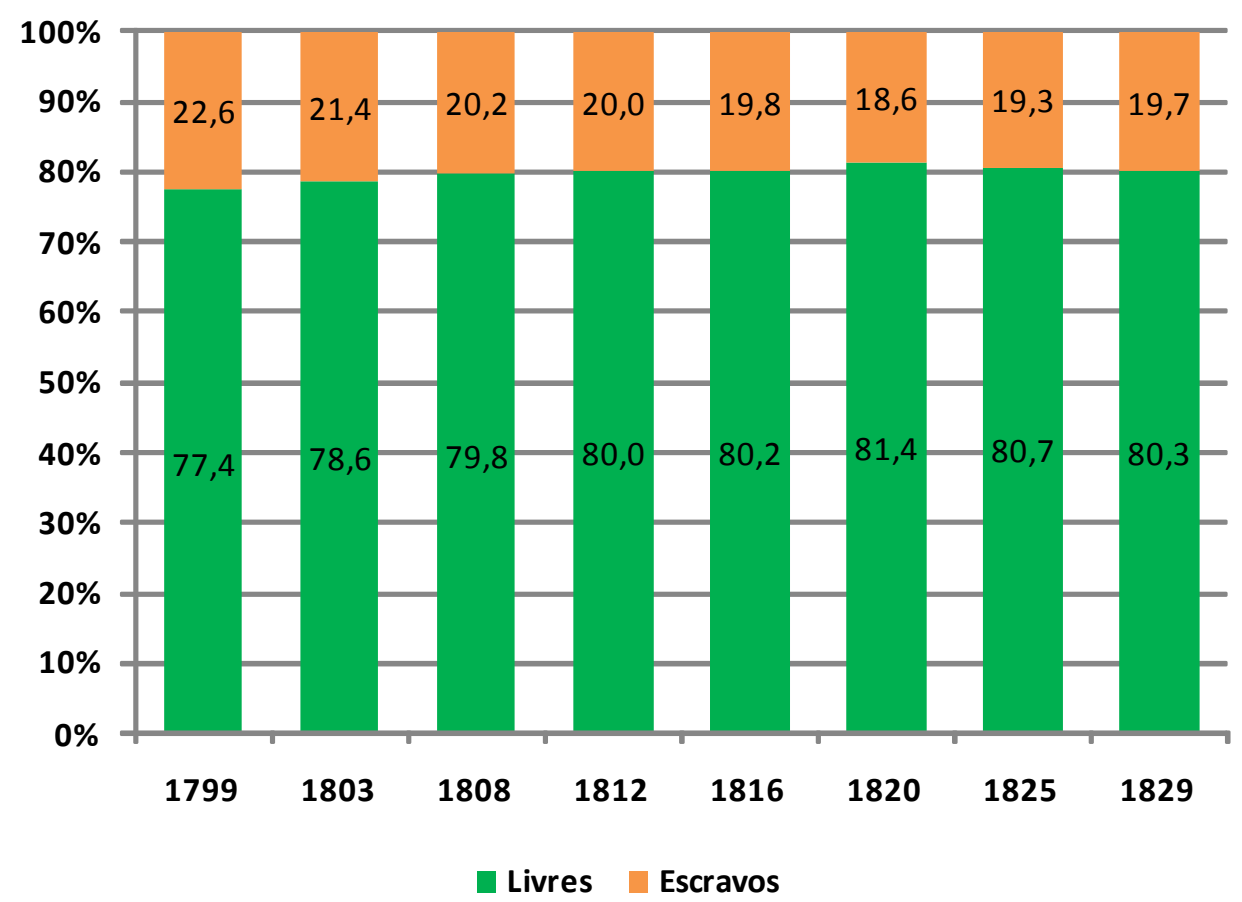

$\mathrm{Na}$ Mogi das Cruzes de 1799 a população cativa representava 22,6\% dos habitantes, passando a 21,4\% em 1803. A partir de 1808 a participação dos cativos revela 
relativa constância em torno de 20\%, um mínimo de 18,6\% em 1820 e um máximo de 20,2\% em 1808, com uma média geral de 19,6\%. (Gráfico I.27)

Essa relativa constância foi característica também do percentual atinente ao número de fogos em que estes indivíduos não livres foram encontrados. (Gráfico I.28) A participação de domicílios escravistas era pouco superior à participação de escravos na população, contudo apresentou também uma queda entre 1799 e 1803, mantendo-se em um mesmo patamar desde então. Foram identificados, 329 fogos com escravos na Mogi Setecentista, correspondentes a $28,8 \%$ do total deles, percentual que caiu a $25,3 \%$ (341 fogos) em 1803, e manteve-se entre $23,4 \%$ (1808 e 1820) e 24\% (1816 e 1825); sendo em número absoluto maior apenas na segunda metade da década de 1820 - 430 e 452 , nos anos de 1825 e 1829 em seqüência -, nos anos correspondentes ao incremento populacional descrito.

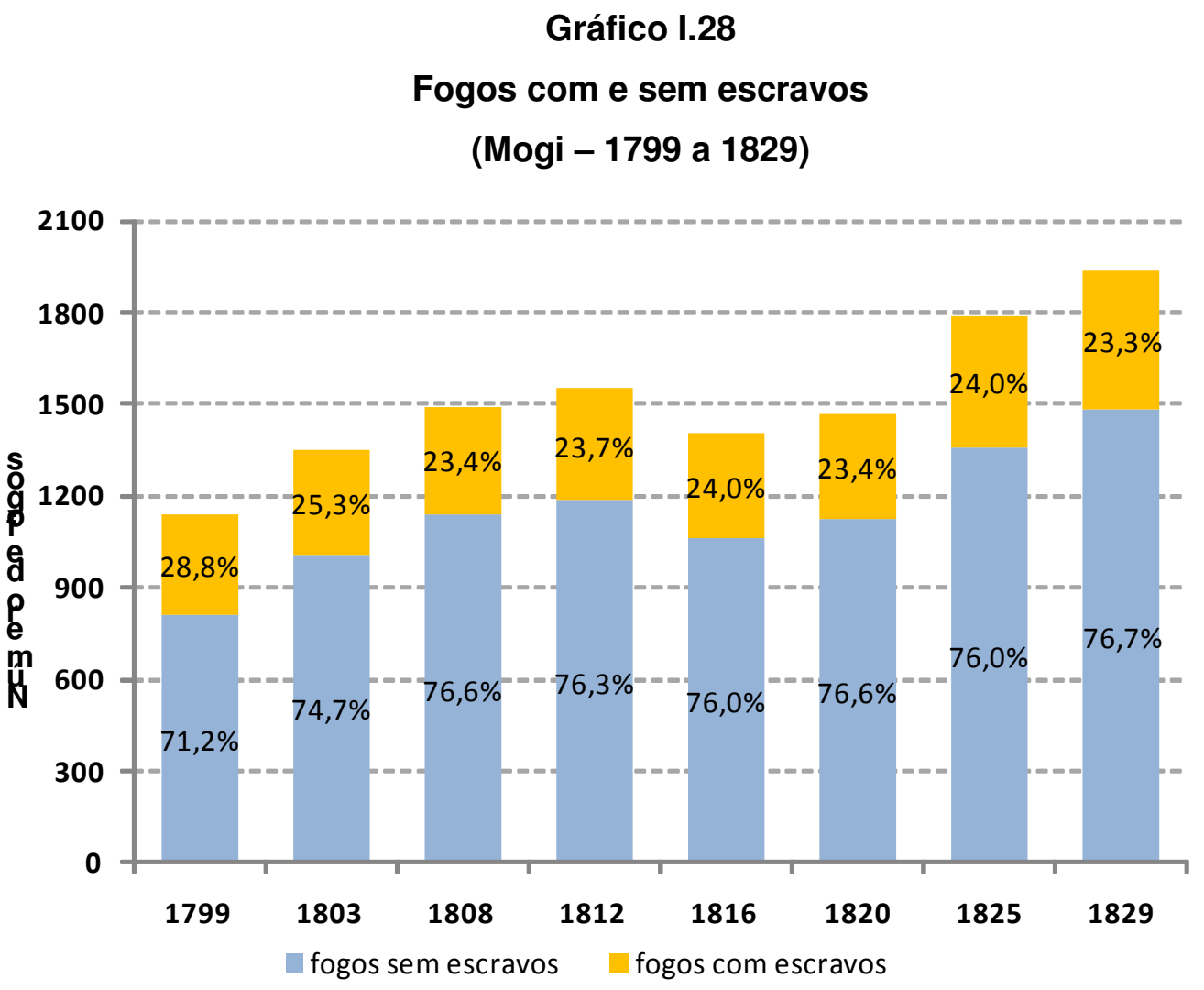

Havia entre 0,2 e 0,3 escravos por livre em Mogi e seu termo nas três décadas iniciais do século XIX, sendo a média de livres por domicílio constante em torno de 4,5 indivíduos. A unidade familiar típica era bem pouco menor, tinha entre 3 e 4 livres e metade dos fogos era composto por até 4 pessoas livres (exceção para 1803, quando este número sobe a 5). Uma vez que a média de cativos entre o total de fogos foi de 1,4 
(1799) a 1,0 (1820), incluindo-se os cativos, em 1799 encontramos uma média de 6,1 moradores por fogo, que foi sutilmente reduzida a 5,5 - 5,8 a parir de 1808, com mediana invariavelmente 5 e moda inferior, igual a 3 ou 4 indivíduos. (cf. Tabela I.56)

O número médio de escravos por domicílio altera-se sob a consideração de fogos/chefes escravistas apenas. A observação dos dados inscritos na tabela 1.57 impõem, desde logo, a observação de que os cativos existiam, em média, em pouco mais de 4 indivíduos por plantel, mesmo diante da expansão populacional havida na vila e seu termo. Tomado o ano de 1803, no qual este valor médio apresentou seu máximo, revelase uma média de 4,9 escravos por unidade domiciliar em que estiveram presentes; valores superiores à moda, ou seja, o número de escravos mais tipicamente encontrado: dois, em 1799 e 1816, e um nos demais anos considerados.

Acompanhando a redução da participação dos mancípios na população, houve retração no percentual de indivíduos livres diretamente ligados a plantéis cativos, ou seja, habitando o mesmo fogo, mantendo, conforme mostrado na Tabela I.58, proporções semelhantes àquelas apontadas para os fogos com escravos. Em 1799 29,8\% da população livre vivia em fogos com escravos, eram 26,8\% em 1803 percentual que especialmente a partir de 1808 foi mantido em cerca de $24 \%$. Apesar dessa queda de cinco pontos percentuais, fato é que um quarto da população convivia diretamente com escravos em seu próprio domicilio, percentual bastante considerável.

Tabela 1.56

Presença de livres e escravos nos domicílios

(Mogi - 1799 a 1829)

\begin{tabular}{|c|c|c|c|c|c|c|c|c|c|c|}
\hline \multirow{2}{*}{ Ano } & \multicolumn{3}{|c|}{ Indivíduos } & \multicolumn{3}{|c|}{ Livres } & \multicolumn{3}{|c|}{ Escravos } & \multirow{2}{*}{$\begin{array}{c}\text { Relação } \\
\text { escravos/livres }\end{array}$} \\
\hline & Média & Mediana & Moda & Média & Mediana & Moda & Média & Mediana & Moda & \\
\hline 1799 & 6,1 & 5,0 & 3,0 & 4,7 & 4,0 & 2 e 3 & 1,4 & 0,0 & 0,0 & 0,29 \\
\hline 1803 & 6,1 & 5,0 & 4,0 & 4,8 & 5,0 & 3,0 & 1,3 & 0,0 & 0,0 & 0,29 \\
\hline 1808 & 5,6 & 5,0 & 3,0 & 4,4 & 4,0 & 3,0 & 1,1 & 0,0 & 0,0 & 0,27 \\
\hline 1812 & 5,5 & 5,0 & 3,0 & 4,4 & 4,0 & 4,0 & 1,1 & 0,0 & 0,0 & 0,25 \\
\hline 1816 & 5,8 & 5,0 & 4,0 & 4,7 & 4,0 & 3,0 & 1,2 & 0,0 & 0,0 & 0,25 \\
\hline 1820 & 5,5 & 5,0 & 3,0 & 4,5 & 4,0 & 3,0 & 1,0 & 0,0 & 0,0 & 0,25 \\
\hline 1825 & 5,6 & 5,0 & 3,0 & 4,5 & 4,0 & 3,0 & 1,1 & 0,0 & 0,0 & 0,23 \\
\hline 1829 & 5,6 & 5,0 & 4,0 & 4,5 & 4,0 & 3,0 & 1,1 & 0,0 & 0,0 & 0,24 \\
\hline
\end{tabular}

Fonte: AESP, Maços de População, Mogi das Cruzes: anos selecionados 
Tabela 1.57

Indicadores estatísticos para a posse de escravos

(Mogi - 1799 a 1829)

\begin{tabular}{|c|c|c|c|c|c|c|c|c|}
\hline \multirow[b]{2}{*}{ Estatísticas } & \multicolumn{2}{|c|}{1799} & \multicolumn{2}{|c|}{1803} & \multicolumn{2}{|c|}{1808} & \multicolumn{2}{|c|}{1812} \\
\hline & $\begin{array}{c}\text { Total de } \\
\text { fogos }\end{array}$ & $\begin{array}{c}\text { Fogos com } \\
\text { escravos }\end{array}$ & $\begin{array}{c}\text { Total de } \\
\text { fogos }\end{array}$ & $\begin{array}{c}\text { Fogos com } \\
\text { escravos }\end{array}$ & $\begin{array}{c}\text { Total de } \\
\text { fogos }\end{array}$ & $\begin{array}{l}\text { Fogos com } \\
\text { escravos }\end{array}$ & $\begin{array}{l}\text { Total de } \\
\text { fogos }\end{array}$ & $\begin{array}{c}\text { Fogos com } \\
\text { escravos }\end{array}$ \\
\hline Média & 1,4 & 4,3 & 1,3 & 4,9 & 1,1 & 4,7 & 1,1 & 4,5 \\
\hline Mediana & 0,0 & 3,0 & 0,0 & 3,0 & 0,0 & 3,0 & 0,0 & 3,0 \\
\hline Moda & 0,0 & 2,0 & 0,0 & 1,0 & 0,0 & 1,0 & 0,0 & 1,0 \\
\hline Desvio padrão & 3,1 & 4,5 & 3,5 & 5,6 & 3,4 & 5,7 & 3,2 & 5,2 \\
\hline Variância & 9,7 & 20,5 & 12,5 & 31,8 & 11,5 & 32,6 & 10,0 & 27,1 \\
\hline Índice de Gini & 0,849 & 0,477 & 0,870 & 0,486 & 0,880 & 0,486 & 0,875 & 0,473 \\
\hline Máximo & \multicolumn{2}{|c|}{31,0} & \multicolumn{2}{|c|}{63,0} & \multicolumn{2}{|c|}{71,0} & \multicolumn{2}{|c|}{66,0} \\
\hline \multirow[b]{2}{*}{ Estatísticas } & \multicolumn{2}{|c|}{1816} & \multicolumn{2}{|c|}{1820} & \multicolumn{2}{|c|}{1825} & \multicolumn{2}{|c|}{1829} \\
\hline & $\begin{array}{c}\text { Total de } \\
\text { fogos }\end{array}$ & $\begin{array}{c}\text { Fogos com } \\
\text { escravos }\end{array}$ & $\begin{array}{c}\text { Total de } \\
\text { fogos }\end{array}$ & $\begin{array}{l}\text { Fogos com } \\
\text { escravos }\end{array}$ & $\begin{array}{c}\text { Total de } \\
\text { fogos }\end{array}$ & $\begin{array}{l}\text { Fogos com } \\
\text { escravos }\end{array}$ & $\begin{array}{c}\begin{array}{c}\text { Total de } \\
\text { fogos }\end{array}\end{array}$ & $\begin{array}{c}\text { Fogos com } \\
\text { escravos }\end{array}$ \\
\hline Média & 1,2 & 4,6 & 1,0 & 4,4 & 1,1 & 4,5 & 1,1 & 4,6 \\
\hline Mediana & 0,0 & 3,0 & 0,0 & 3,0 & 0,0 & 3,0 & 0,0 & 3,0 \\
\hline Moda & 0,0 & 2,0 & 0,0 & 2,0 & 0,0 & 1,0 & 0,0 & 1,0 \\
\hline Desvio padrão & 3,3 & 5,4 & 3,4 & 5,8 & 3,6 & 6,1 & 3,7 & 6,5 \\
\hline Variância & 10,8 & 29,1 & 11,3 & 33,6 & 12,6 & 37,5 & 13,5 & 41,8 \\
\hline Índice de Gini & 0,871 & 0,465 & 0,880 & 0,487 & 0,879 & 0,498 & 0,887 & 0,516 \\
\hline Máximo & \multicolumn{2}{|c|}{69,0} & \multicolumn{2}{|c|}{79,0} & \multicolumn{2}{|c|}{90,0} & \multicolumn{2}{|c|}{89,0} \\
\hline
\end{tabular}

Fonte: AESP, M aços de População, M ogi das Cruzes: anos selecionados

A presença de cativos em nada elevou a média de pessoas por fogo, mantida em torno de 4,5, com maior diferença em 1803 e em 1820, quando os fogos com cativos tinham 0,4 pessoas a mais que os fogos sem a presença de trabalho compulsório.

\section{Tabela $\mathbf{I . 5 8}$}

Peso dos domicílios com e sem escravos na população (Mogi - 1799 a 1829)

\begin{tabular}{ccccccccc}
\hline \hline & \multicolumn{3}{c}{ Fogos sem escravos } & & \multicolumn{4}{c}{ Fogos com escravos } \\
\cline { 2 - 3 } Anos & $\begin{array}{c}\text { \% da } \\
\text { população } \\
\text { total }\end{array}$ & $\begin{array}{c}\text { \% da } \\
\text { população } \\
\text { livre }\end{array}$ & $\begin{array}{c}\text { Média de } \\
\text { indivíduos }\end{array}$ & & $\begin{array}{c}\text { \% da } \\
\text { população } \\
\text { total }\end{array}$ & $\begin{array}{c}\text { \% da } \\
\text { população } \\
\text { livre }\end{array}$ & $\begin{array}{c}\text { Média de } \\
\text { indivíduos }\end{array}$ & $\begin{array}{c}\text { Média de } \\
\text { livres }\end{array}$ \\
\hline $\mathbf{1 7 9 9}$ & 54,2 & 70,2 & 4,7 & & 45,8 & 29,8 & 9,6 & 4,8 \\
$\mathbf{1 8 0 3}$ & 57,5 & 73,2 & 4,7 & & 42,5 & 26,8 & 10,2 & 5,1 \\
$\mathbf{1 8 0 8}$ & 60,6 & 76,1 & 4,4 & & 39,4 & 23,9 & 9,4 & 4,6 \\
$\mathbf{1 8 1 2}$ & 60,5 & 75,7 & 4,4 & & 39,5 & 24,3 & 9,1 & 4,5 \\
$\mathbf{1 8 1 6}$ & 61,1 & 76,4 & 4,7 & & 38,9 & 23,6 & 9,4 & 4,6 \\
$\mathbf{1 8 2 0}$ & 61,2 & 75,2 & 4,4 & & 38,8 & 24,8 & 9,1 & 4,8 \\
$\mathbf{1 8 2 5}$ & 61,1 & 75,7 & 4,5 & & 38,9 & 24,3 & 9,0 & 4,5 \\
$\mathbf{1 8 2 9}$ & 61,2 & 76,3 & 4,5 & & 38,8 & 23,7 & 9,2 & 4,5 \\
\hline \hline
\end{tabular}

Fonte:AESP, M aços de População, Mogi das Cruzes: anos selecionados 
Parte dos livres ligados a cativos nas unidades familiares de Mogi/Santa Isabel eram indivíduos não aparentados com os efetivos membros das famílias, identificados nas próprias listas nominativas sob a denominação de agregados. Existiam em pequeno número fogos com a presença de agregados e escravos que, ademais de reduzido, viram cair sua participação na composição dos domicílios na localidade. Eram 7,2\% dos fogos em 1799, 6,6-6,8\% em 1812 e 1820, chegando ao último ano considerado (1829) respondendo por tão somente $4,2 \%$ dos fogos mogianos junto com sua freguesia de Santa Isabel. A Tabela I.59 apresenta estes valores.

Tabela 1.59

Peso dos domicílios com e sem agregados não aparentados na população (Mogi - 1799 a 1829)

\begin{tabular}{cccccccc}
\hline \hline Anos & $\begin{array}{c}\text { \% de fogos } \\
\text { com } \\
\text { agregados }\end{array}$ & $\begin{array}{c}\text { \% de } \\
\text { agregados } \\
\text { agregados } \\
\text { na } \\
\text { população } \\
\text { total }\end{array}$ & $\begin{array}{c}\text { \% de } \\
\text { agregados } \\
\text { na } \\
\text { população } \\
\text { livre }\end{array}$ & $\begin{array}{c}\text { Média de } \\
\text { agregados } \\
\text { (fogos com } \\
\text { agregados) }\end{array}$ & $\begin{array}{c}\text { Média de } \\
\text { agregados } \\
\text { (total de } \\
\text { fogos) }\end{array}$ & $\begin{array}{c}\text { \% de fogos } \\
\text { comagregados } \\
\text { e escravos }\end{array}$ \\
\hline $\mathbf{1 7 9 9}$ & 25,7 & 635 & 9,1 & 11,8 & 2,2 & 0,6 & 7,2 \\
$\mathbf{1 8 0 3}$ & 23,3 & 749 & 9,1 & 11,6 & 2,4 & 0,6 & 6,8 \\
$\mathbf{1 8 0 8}$ & 20,8 & 655 & 7,9 & 9,9 & 2,1 & 0,4 & 5,9 \\
$\mathbf{1 8 1 2}$ & 20,6 & 746 & 8,8 & 10,9 & 2,3 & 0,5 & 6,6 \\
$\mathbf{1 8 1 6}$ & 24,3 & 793 & 9,7 & 12,1 & 2,3 & 0,6 & 6,8 \\
$\mathbf{1 8 2 0}$ & 21,1 & 654 & 8,1 & 10,0 & 2,1 & 0,4 & 5,3 \\
$\mathbf{1 8 2 5}$ & 18,1 & 740 & 7,4 & 9,2 & 2,3 & 0,4 & 5,1 \\
$\mathbf{1 8 2 9}$ & 18,9 & 859 & 8,0 & 9,9 & 2,4 & 0,4 & 4,2 \\
\hline \hline
\end{tabular}

Fonte: AESP, M aços de População, Mogi da Cruzes: anos selecio nados

Os fogos com agregados não aparentados (independentemente da concomitante presença ou não de escravos) foram encontrados em proporções significativas, ainda que declinantes entre 1799 e 1829, passando de 25,7\% naquele primeiro ano a 18,9\% no último. Nesse longo prazo a mudança foi gradual e variável, havendo $23,3 \%$ desses fogos em 1803 , pouco mais de $20,5 \%$ nos anos seguintes considerados, superando os $24 \%$ em 1816 e, então, efetivamente caindo a menos de $19 \%$.

Assim como o percentual de domicílios com estes indivíduos entre seus habitantes, o número de agregados variou ao longo do tempo (mesmo tendo a média sido conservada em 2,1-2,4 por fogo) estando, destarte, justamente em 1829 (ano com um dos menores percentuais de fogos com estes indivíduos, como adiantado) o seu maior 
número: 859 , relativo a $8 \%$ da população total e $10 \%$ da população livre da vila de Mogi e seu termo. Esse número havia sido de 635 pessoas em 1799, mas respondia por 9,1\% da população total e $11,8 \%$ dos habitantes livres da localidade naquele momento. Sua maior participação verificamos em 1816, quando os 793 agregados arrolados responderam por $12,1 \%$ da população livre e $9,7 \%$ se somados os cativos.

Proporcionalmente estes agregados estavam concentrados em maior medida em Santa Isabel, onde foram encontrados em número de 544 e 590, respondendo 14,7\% e $12,7 \%$ dos livres respectivamente em 1825 e 1829. Para a vila de Mogi propriamente, a presença de agregados nestes anos foi calculada em $8 \%$ e $9 \%$, em sequência.

Os agregados eram, ao longo de todo o período 1799-1829, majoritariamente mulheres. O menor percentual devido a elas foi de 61,8\% em 1799 e 1803, e o maior de $65,4 \%$ no ano de 1812. Essas participações favoráveis às mulheres conferem, ainda que mais acentuadas para os agregados, com o anotado para o total dos moradores de Mogi, apresentados na Tabela I.60: Composição da população livre por sexo.

\section{Tabela 1.60}

\section{Composição da população livre por sexo}

(Mogi - 1799 a 1829)

\begin{tabular}{|c|c|c|c|c|c|c|c|c|}
\hline \multirow{3}{*}{ Anos } & \multicolumn{5}{|c|}{ População Livre } & \multicolumn{3}{|c|}{ Chefes de fogo } \\
\hline & \multicolumn{2}{|c|}{ Homens } & \multicolumn{2}{|c|}{ Mulheres } & \multirow{2}{*}{$\begin{array}{l}\text { Razão de } \\
\text { sexo }\end{array}$} & \multirow{2}{*}{$\begin{array}{c}\text { Homens } \\
\text { \% (№) }\end{array}$} & \multirow{2}{*}{$\begin{array}{c}\text { Mulheres } \\
\text { \% (№) }\end{array}$} & \multirow{2}{*}{$\begin{array}{l}\text { Razão de } \\
\text { sexo }\end{array}$} \\
\hline & \% (№) & $\begin{array}{c}\text { Variação } \\
\%\end{array}$ & \% (№) & $\begin{array}{c}\text { Variação } \\
\%\end{array}$ & & & & \\
\hline 1799 & $46,5(2509)$ & & $53,5(2892)$ & & 86,8 & 80,3 (912) & $19,7(224)$ & 407,1 \\
\hline 1803 & 46,3 (2995) & 19,4 & $53,7(3471)$ & 20,0 & 86,3 & $78,6(1059)$ & $21,4(289)$ & 366,4 \\
\hline 1808 & $45,2(2981)$ & $-0,5$ & $54,8(3611)$ & 4,0 & 82,6 & $77,4(1151)$ & $22,6(337)$ & 341,5 \\
\hline 1812 & $45,2(3074)$ & 3,1 & $54,8(3726)$ & 3,2 & 82,5 & $77,2(1197)$ & $22,8(354)$ & 338,1 \\
\hline 1816 & $46,0(3017)$ & $-1,9$ & $54,0(3535)$ & $-5,1$ & 85,3 & $80,3(1124)$ & $19,7(276)$ & 407,2 \\
\hline 1820 & $46,1(3018)$ & 0,0 & $53,9(3531)$ & $-0,1$ & 85,5 & 81,7 (1199) & $18,3(268)$ & 447,4 \\
\hline 1825 & $46,4(3725)$ & 23,4 & $53,6(4299)$ & 21,8 & 86,6 & $81,9(1466)$ & $18,1(323)$ & 453,9 \\
\hline 1829 & $47,7(4118)$ & 10,6 & $52,3(4507)$ & 4,8 & 91,4 & $82,6(1597)$ & $17,4(337)$ & 473,9 \\
\hline
\end{tabular}

Exclusive indivíduos com sexo não identificado e fogos com chefe não residente em Mogi e/ou não identificado Fonte:AESP, Maços de População, Mogi das Cruzes: anos selecionados

A composição por sexos da totalidade da população livre de Mogi/Santa Isabel mostra-se favorável às mulheres em todo o lapso estudado. As mulheres responderam ao longo dos anos por ao menos $52,3 \%$ dos livres (em 1829) e no máximo por $54,8 \%$ nos anos de 1808 e 1812, correspondentes as razões de sexo calculadas dentro do intervalo 82,5 e 91,4 homens para cada grupo de 100 mulheres. 
Mas se restringimos os livres apenas àqueles indivíduos a chefiar domicílios, o intervalo para as razões de sexo passa a de 338,1 homens para 100 mulheres (em 1812) a 473,9 (1829), correspondendo, os chefes de fogo do sexo masculino, a não menos de $77 \%$ entre todos dos fogos arrolados, ou seja, era predominantemente masculina a parcela de indivíduos a chefiar fogos na Mogi do início do Oitocentos.

Assim como eram majoritariamente homens, em diferentes proporções, aqueles chefes de domicílios possuidores de cativos. A proporção de homens entre os escravistas chegou a em $83,3 \%$ em 1803 , correspondente a uma razão entre os sexos de 520 , ano em que encontramos razão de 366,4 homens para cada grupo de 100 mulheres a chefiar domicílios em Mogi/Santa Isabel. Nos anos observados nas décadas de 1810 e seguinte, a proporção esteve entre $77,7 \%$ de homens em 1812 (razão de 348,8, equivalente à assumida pela totalidade dos domicílios: 338,1 ) e $80,8 \%$ (1830), equivalente a 419,5 como razão entre os sexos, neste caso, pouco inferior aos 473,9 identificados para o conjunto de chefes de fogo.

\section{Tabela $\mathbf{I . 6 1}$}

Sexo e idade dos chefes de fogo com escravos

(Mogi - 1799 a 1829)

\begin{tabular}{ccccccccc}
\hline \hline & $\mathbf{1 7 9 9}$ & $\mathbf{1 8 0 3}$ & $\mathbf{1 8 0 8}$ & $\mathbf{1 8 1 2}$ & $\mathbf{1 8 1 6}$ & $\mathbf{1 8 2 0}$ & $\mathbf{1 8 2 5}$ & $\mathbf{1 8 2 9}$ \\
\hline Homens (\%) & 81,8 & 83,9 & 81,3 & 77,7 & 77,8 & 79,0 & 77,7 & 80,8 \\
Mulheres (\%) & 18,2 & 16,1 & 18,7 & 22,3 & 22,2 & 21,0 & 22,3 & 19,2 \\
Razão de sexo & 448,3 & 520,0 & 435,4 & 348,8 & 349,3 & 376,4 & 347,9 & 419,5 \\
\hline ldade média & 48,2 & 48,9 & 48,2 & 49,6 & 48,7 & 46,6 & 47,0 & 47,1 \\
Idade mínima & 18 & 18 & 14 & 16 & 17 & 19 & 15 & 20 \\
Idade máxima & 98 & 93 & 98 & 85 & 87 & 92 & 90 & 95 \\
\hline \hline
\end{tabular}

Fonte: AESP, M aços de População, Jundiaí: anos selecionados

Acompanhando característica verificada para a população livre em seu conjunto, assim como para parte destes indivíduos a compor os domicílios como agregados, a parcela da população composta por cativos, analisada sob a variável sexo, apresentou números favoráveis à presença de mulheres, ao menos até o início da década de 1820.

Para a totalidade dos cativos encontramos razões entre os sexos que foram, até 1822, em seu menor valor, igual a 85,7 homens para cada grupo de 100 mulheres no ano de 1803, razão equivalente a um percentual de 54\% mulheres na composição da escravaria por sexos; e em seu maior valor, 98,4 (50,5\% mulheres) em 1816. 
Em 1825 a participação dos homens passou a ser majoritária, razão calculada em 102,9, subindo ainda mais, encerrando o período em 116 (53,6\% homens). Observada a curva para a evolução desses valores (Gráfico I.29), observamos que a razão de sexo dos cativos mogianos foi crescente, tendendo à ampliação da participação masculina nesta população a partir de 1812.

\section{Gráfico I.29}

Razão de sexo dos cativos de acordo com faixas

de tamanho dos plantéis

(Mogi - 1799 a 1829)

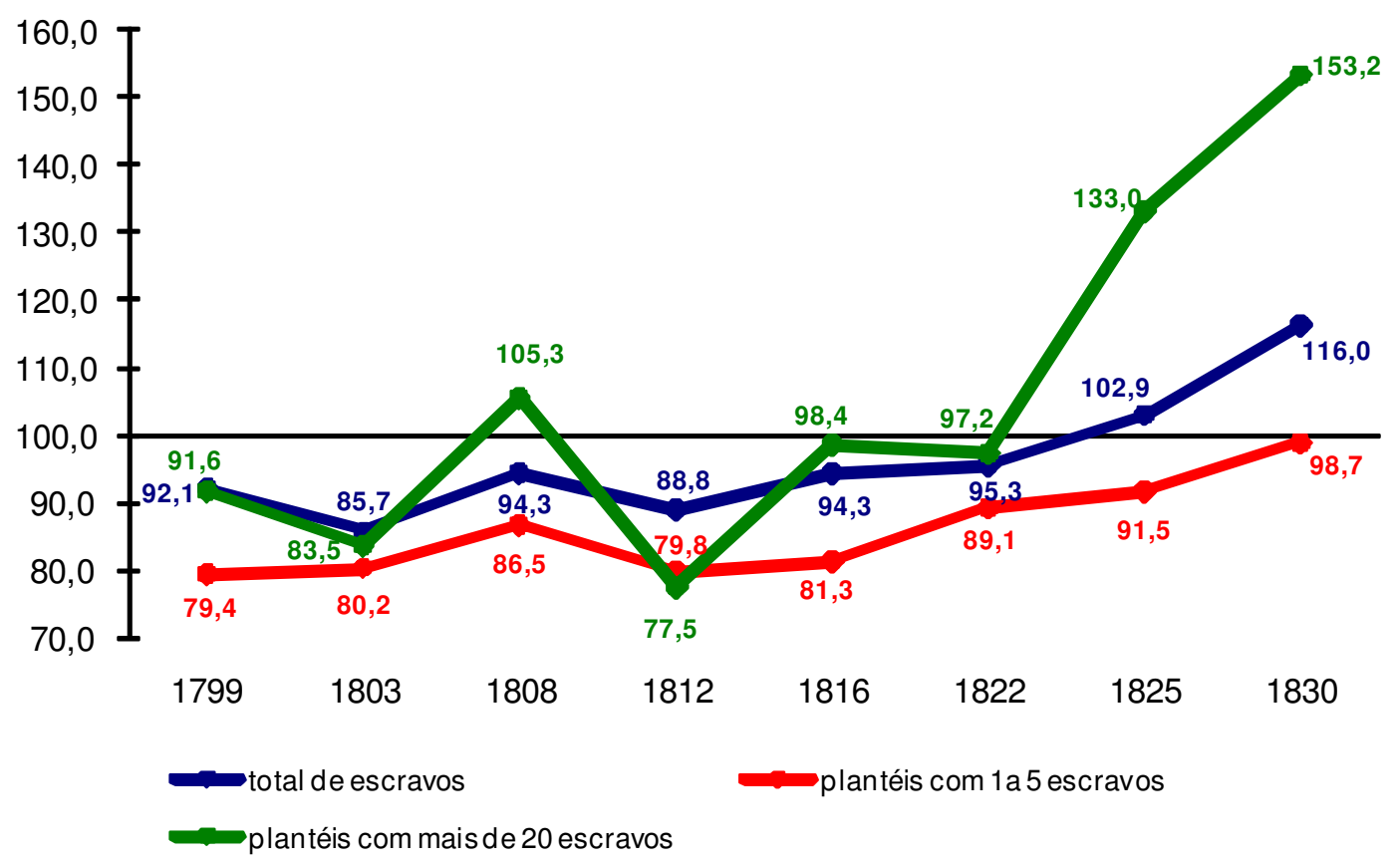

Esta mudança ocorreu pois as características atinentes ao tamanho dos grupos de escravos nos fogos viu-se modificada com o aparecimento nos arrolamentos de escravarias de maior monta (chegando a 90 pessoas) que, como sabido, apresentavam, de modo geral, razões de sexo favoráveis aos homens. Voltando à Tabela 1.57 verificamos que de um máximo de 31 cativos encontrados em um único fogo em 1799, passou-se a 90 escravos nas mãos de um único chefe em 1825.

Os plantéis muito grandes, acima de 20 escravos, foram em todo o lapso estudado cerca de $2 \%$ do total, mas nestes grupos eram encontrados perto de $20 \%$ de todos os mancípios na Vila de Mogi e seu termo. (cf. Tabela I.62) Por outro lado, nos menores plantéis, com até 5 pessoas, majoritários em todo o período - estavam entre eles 0 
mínimo de 70,7\% (1803) dos fogos com cativos, e o máximo de $77,8 \%$ ao final do Oitocentos -, foram encontrados não mais de 39,5\% (1816) da escravaria mogiana. 0 índice de concentração de Gini foi, então, médio, sempre ao redor de 0,5.

Estes menores plantéis apresentaram presença de mulheres em proporção pouco variável, em torno de 55,5\%, até 1816, caindo a 52\% em 1822 e 1825, havendo equilíbrio entre os sexos em 1830. As razões de sexo relativas a estas proporções pertencem ao intervalo 77,5 (1812) a 98,7 (1830).

Tabela 1.62

Distribuição de escravistas e escravos

de acordo com faixas de tamanho dos plantéis

(Mogi - 1799 a 1829)

\begin{tabular}{|c|c|c|c|c|c|c|c|c|}
\hline \multirow{3}{*}{ FTP } & \multicolumn{4}{|c|}{1799} & \multicolumn{4}{|c|}{1803} \\
\hline & \multicolumn{2}{|c|}{ Escravistas } & \multicolumn{2}{|c|}{ Escravos } & \multicolumn{2}{|c|}{ Escravistas } & \multicolumn{2}{|c|}{ Escravos } \\
\hline & № & $\%$ & № & $\%$ & № & $\%$ & № & $\%$ \\
\hline 1 a 5 & 256 & 77,8 & 611 & 38,6 & 241 & 70,7 & 584 & 33,1 \\
\hline 6 a 10 & 46 & 14,0 & 354 & 22,4 & 65 & 19,1 & 470 & 26,7 \\
\hline 11 a 20 & 21 & 6,4 & 298 & 18,8 & 28 & 8,2 & 396 & 22,5 \\
\hline Acima 20 & 6 & 1,8 & 318 & 20,1 & 7 & 2,1 & 312 & 17,7 \\
\hline Total & 329 & 100,0 & 1581 & 100,0 & 341 & 100,0 & 1762 & 100,0 \\
\hline \multirow{3}{*}{ FTP } & \multicolumn{4}{|c|}{1812} & \multicolumn{4}{|c|}{1816} \\
\hline & \multicolumn{2}{|c|}{ Escravistas } & \multicolumn{2}{|c|}{ Escravos } & \multicolumn{2}{|c|}{ Escravistas } & \multicolumn{2}{|c|}{ Escravos } \\
\hline & № & $\%$ & № & $\%$ & № & $\%$ & № & $\%$ \\
\hline 1 a 5 & 270 & 73,4 & 661 & 38,9 & 251 & 74,5 & 639 & 39,5 \\
\hline 6 a 10 & 73 & 19,8 & 534 & 31,4 & 58 & 17,2 & 440 & 27,2 \\
\hline 11 a 20 & 21 & 5,7 & 323 & 19,0 & 22 & 6,5 & 288 & 17,8 \\
\hline Acima 20 & 4 & 1,1 & 181 & 10,7 & 6 & 1,8 & 250 & 15,5 \\
\hline Total & 368 & 100,0 & 1699 & 100,0 & 337 & 100,0 & 1617 & 100,0 \\
\hline \multirow{3}{*}{ FTP } & \multicolumn{4}{|c|}{1825} & \multicolumn{4}{|c|}{1829} \\
\hline & \multicolumn{2}{|c|}{ Escravistas } & \multicolumn{2}{|c|}{ Escravos } & \multicolumn{2}{|c|}{ Escravistas } & \multicolumn{2}{|c|}{ Escravos } \\
\hline & № & $\%$ & № & $\%$ & № & $\%$ & № & $\%$ \\
\hline 1 a 5 & 323 & 75,1 & 742 & 38,6 & 338 & 74,8 & 776 & 36,5 \\
\hline 6 a 10 & 76 & 17,7 & 575 & 29,9 & 75 & 16,6 & 545 & 25,6 \\
\hline 11 a 20 & 24 & 5,6 & 358 & 18,6 & 29 & 6,4 & 405 & 19,0 \\
\hline Acima 20 & 7 & 1,6 & 247 & 12,9 & 10 & 2,2 & 402 & 18,9 \\
\hline Total & 430 & 100,0 & 1922 & 100,0 & 452 & 100,0 & 2128 & 100,0 \\
\hline
\end{tabular}

Para além do sexo, outras variáveis demográficas podem ser observadas para a população mogiana. Observado estado conjugal, temos homens, assim como as 
mulheres, em sua maioria casados, considerados aqueles com 15 ou mais anos de idade. Se os homens casados apresentaram percentuais de ao menos $61 \%-62 \%$ nos primeiros anos considerados, chegando ao máximo de $68,3 \%$ em 1820 , quando cairam a $66,6 \%$ (1826) e 64,9\% (1829); as mulheres que conheceram o matrimônio foram encontradas em menor medida e em maioria absoluta apenas a partir de 1816 , quando subiram de $52 \%$ a $56,5 \%$ (1829). Antes, as casadas eram $49 \%$ a $50 \%$ dos indivíduos do sexo feminino. Considerados os livres com ao menos 15 anos de idade, sem distinção de qualquer outra variável, os casados eram maioria, correspondendo a uma ponderação dos resultados apontados para os sexos: aproximadamente $55 \%$ até 1808 , chegando a $57,8 \%$ em 1816 e crescendo a $60 \%-61 \%$ a partir de 1820 .

\section{Tabela 1.63}

Composição da população livre de acordo com estado conjugal e sexo - exclusive indivíduos de até 14 anos (Mogi - 1799 a 1829)

\begin{tabular}{|c|c|c|c|c|c|c|c|c|c|}
\hline \multirow{2}{*}{ Anos } & \multicolumn{3}{|c|}{ Homens } & \multicolumn{3}{|c|}{ Mulheres } & \multicolumn{3}{|c|}{ Homens + Mulheres } \\
\hline & $\begin{array}{c}\text { Casados } \\
\%\end{array}$ & $\begin{array}{c}\text { Solteiros } \\
\%\end{array}$ & $\begin{array}{c}\text { Viúvos } \\
\%\end{array}$ & $\begin{array}{c}\text { Casadas } \\
\%\end{array}$ & $\begin{array}{c}\text { Solteiras } \\
\%\end{array}$ & $\begin{array}{c}\text { Viúvas } \\
\%\end{array}$ & $\begin{array}{c}\text { Casados } \\
\%\end{array}$ & $\begin{array}{c}\text { Solteiros } \\
\%\end{array}$ & $\begin{array}{c}\text { Viúvos } \\
\%\end{array}$ \\
\hline 1799 & 61,1 & 34,8 & 4,2 & 49,7 & 41,4 & 8,9 & 54,8 & 38,5 & 6,8 \\
\hline 1803 & 61,8 & 32,9 & 5,3 & 49,4 & 38,9 & 11,8 & 54,8 & 36,2 & 8,9 \\
\hline 1808 & 62,9 & 31,2 & 5,9 & 49,0 & 38,7 & 12,3 & 55,0 & 35,5 & 9,5 \\
\hline 1812 & 64,4 & 30,9 & 4,7 & 49,9 & 38,2 & 11,9 & 56,1 & 35,1 & 8,8 \\
\hline 1816 & 64,2 & 32,6 & 3,3 & 52,7 & 36,2 & 11,1 & 57,8 & 34,6 & 7,6 \\
\hline 1820 & 68,3 & 27,8 & 3,9 & 55,2 & 34,1 & 10,7 & 60,9 & 31,4 & 7,7 \\
\hline 1825 & 66,6 & 29,2 & 4,2 & 54,5 & 34,1 & 11,4 & 59,9 & 31,9 & 8,2 \\
\hline 1829 & 64,9 & 30,5 & 4,6 & 56,5 & 31,9 & 11,6 & 60,4 & 31,3 & 8,3 \\
\hline
\end{tabular}

Exclusive indivíduos com estado conjugal e/ou sexo não identificado Exclui individuos de 0 a 14 anos

A principal diferença entre homens e mulheres respeita à presença de viúvos, que não passou dos 5,9\% (1808) entre os homens e não foi menor que 8,9\% entre as mulheres, percentual referente a 1799, seguido pelas 10,7\% de mulheres viúvas em 1820, meio ponto percentual abaixo do maior valor calculado, 12,3\% em 1812. Ao que parece, consideradas taxas de mortalidade semelhantes para os sexos, maiores proporções de mulheres tenderiam a permanecer nessa condição, não contraindo novas núpcias.

Resumido o grupo àqueles chefes de fogo, exclusive indivíduos com idades de até 14 anos (Tabela I.64), o que se esboça é um quadro bastante diferente daquele 
observado acima. As viúvas, importantes partícipes da parcela feminina da população, superaram em quatro vezes o percentual anteriormente apontado, sendo de $57,5 \% \mathrm{em}$ 1799 , valor alçado a $65,6 \%$ em 1816 , superando os $70 \%$ a partir de 1825 (74\% neste ano e $71,9 \%$ em 1829). Em bem menor número eram encontrados viúvos entre os homens a chefiar domicílios - percentual mínimo de 3,8\% em 1816 e máximo de 7,4\% em 1808 -, mormente casados. Em 1808, ano no qual comparativamente menos homens eram casados, eles eram $85,9 \%$, e era de $91,4 \%$ o percentual devido a eles passados oito anos.

Tabela 1.64

Composição dos chefes de fogo de acordo com estado conjugal e sexo - exclusive indivíduos de até 14 anos (Mogi - 1799 a 1829)

\begin{tabular}{|c|c|c|c|c|c|c|c|c|c|}
\hline \multirow{2}{*}{ Anos } & \multicolumn{3}{|c|}{ Homens } & \multicolumn{3}{|c|}{ Mulheres } & \multicolumn{3}{|c|}{ Homens + Mulheres } \\
\hline & $\begin{array}{c}\text { Casados } \\
\%\end{array}$ & $\begin{array}{c}\text { Solteiros } \\
\%\end{array}$ & $\begin{array}{c}\text { Viúvos } \\
\%\end{array}$ & $\begin{array}{c}\text { Casadas } \\
\%\end{array}$ & $\begin{array}{c}\text { Solteiras } \\
\%\end{array}$ & $\begin{array}{c}\text { Viúvas } \\
\%\end{array}$ & $\begin{array}{c}\text { Casados } \\
\%\end{array}$ & $\begin{array}{c}\text { Solteiros } \\
\%\end{array}$ & $\begin{array}{c}\text { Viúvos } \\
\%\end{array}$ \\
\hline 1799 & 88,3 & 5,7 & 6,0 & 7,1 & 35,4 & 57,5 & 72,8 & 11,4 & 15,9 \\
\hline 1803 & 86,9 & 6,5 & 6,6 & 8,7 & 26,7 & 64,6 & 70,1 & 10,8 & 19,1 \\
\hline 1808 & 85,9 & 6,6 & 7,4 & 10,1 & 25,7 & 64,2 & 68,8 & 10,9 & 20,3 \\
\hline 1812 & 88,5 & 5,2 & 6,3 & 9,1 & 27,3 & 63,6 & 70,4 & 10,2 & 19,3 \\
\hline 1816 & 91,4 & 4,7 & 3,8 & 8,7 & 25,7 & 65,6 & 75,1 & 8,9 & 16,0 \\
\hline 1820 & 89,0 & 6,4 & 4,6 & 10,5 & 28,5 & 61,0 & 74,6 & 10,5 & 14,9 \\
\hline 1825 & 89,4 & 5,1 & 5,5 & 5,6 & 20,4 & 74,0 & 74,3 & 7,8 & 17,9 \\
\hline 1829 & 88,8 & 5,2 & 6,0 & 7,5 & 20,6 & 71,9 & 74,5 & 7,9 & 17,6 \\
\hline
\end{tabular}

A composição por estado conjugal apresentada abordou não menos de 55,8\% da população, posto ter a distribuição por idade apontado serem os mogianos de até 14 anos, em sua maior participação, $44,2 \%$ em 1803, passando ao mínimo de $38,8 \%$ em 1816, voltando a variar nos anos seguintes considerados, chegando ao fim do período estudado (1825 e 1829) em 41,1\%. Certamente era positiva a taxa de natalidade desta população, haja visto a mencionada elevada participação nas listas nominativas desses mogianos de até 14 anos de idade.

A distribuição etária da população livre, observada também por sexos pode ser melhor observada através das pirâmides etárias para a população em tela, apresentadas como Gráfico I.30. 
Gráfico I.30

Pirâmides etárias da população livre

(Mogi - 1799 a 1829)

1799

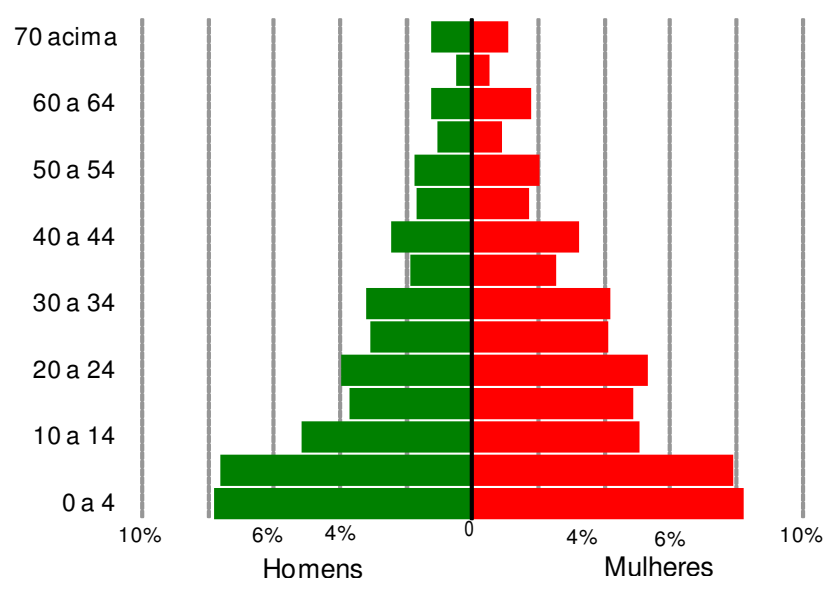

1803

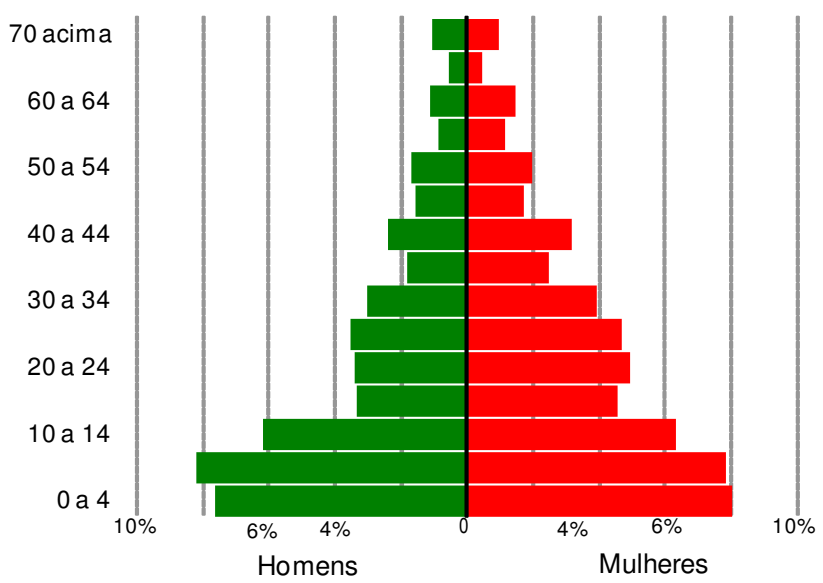


1808

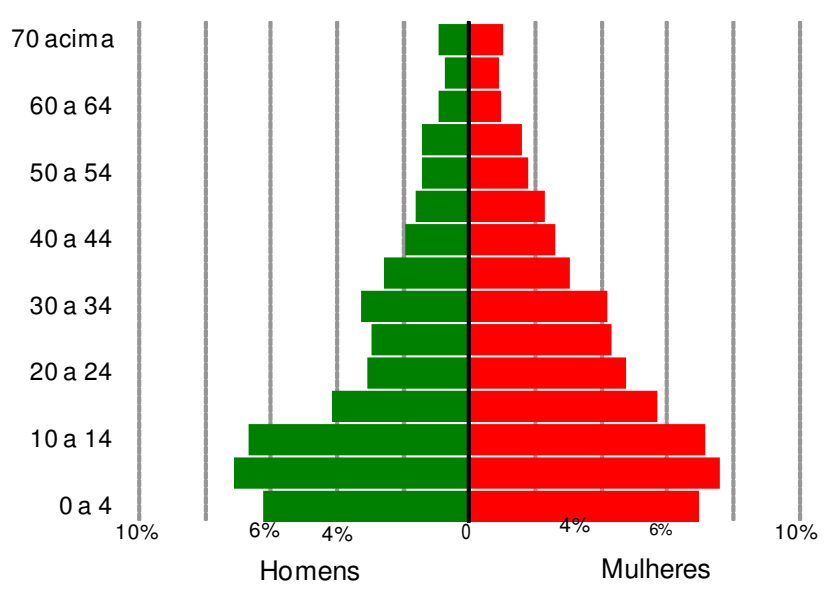

1812

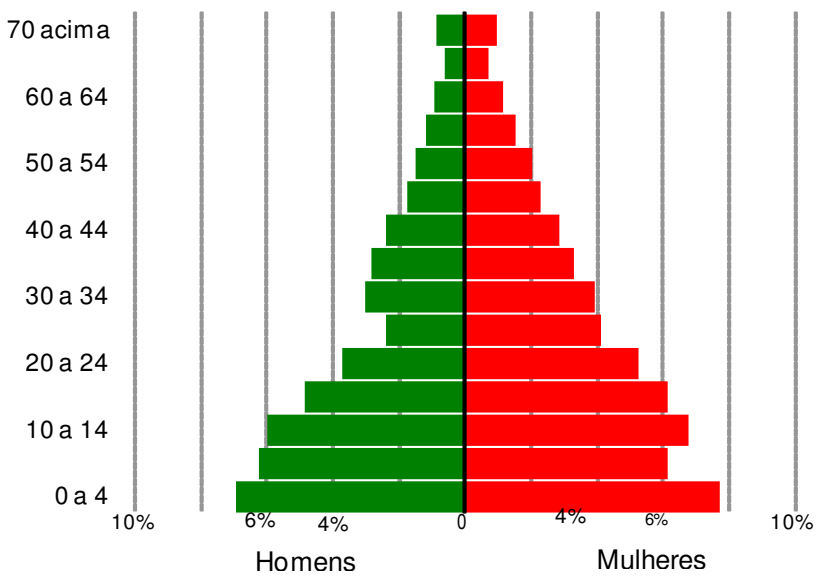

\section{6}

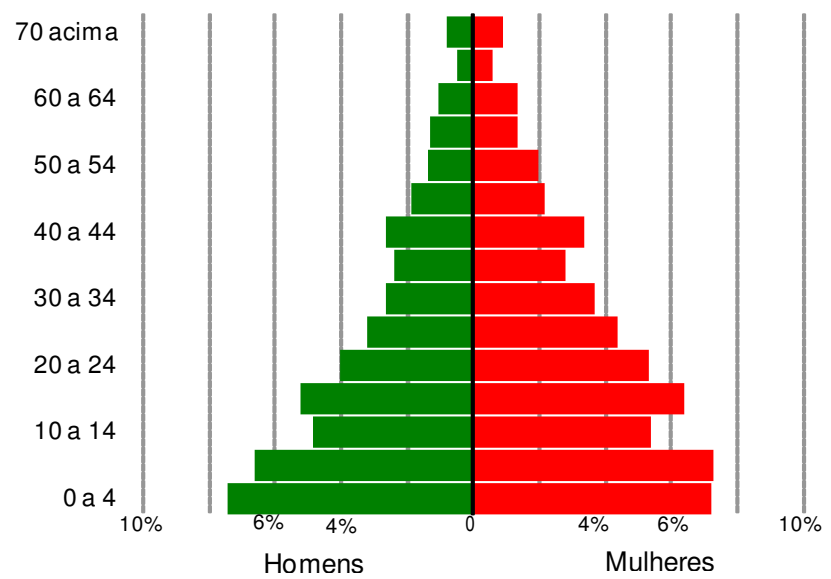


1820

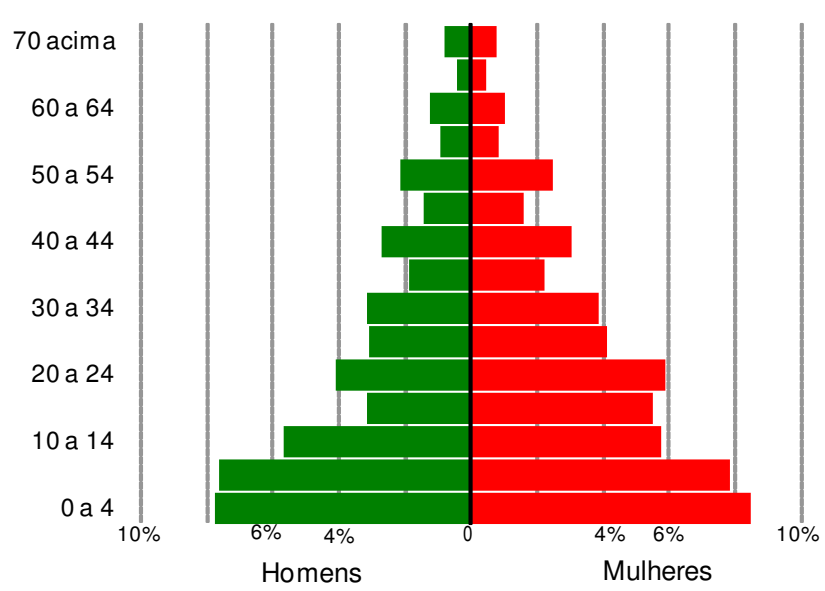

1825

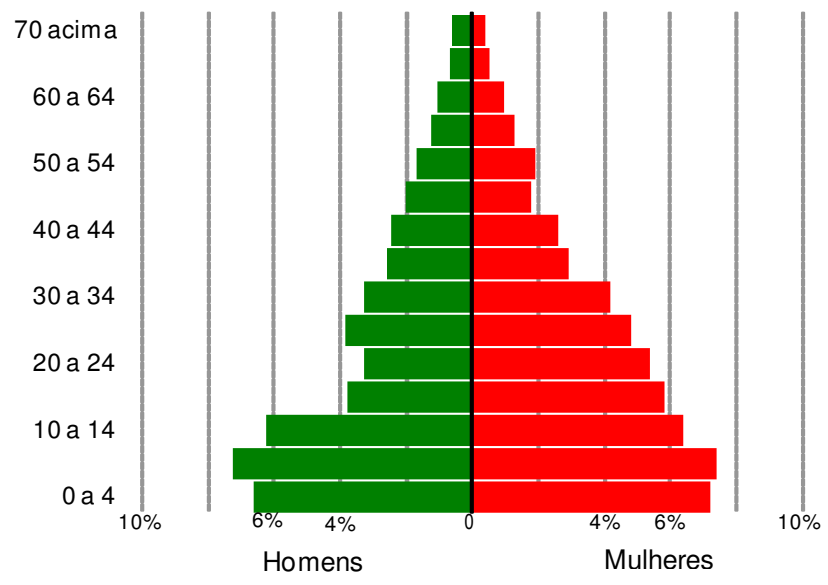

1829

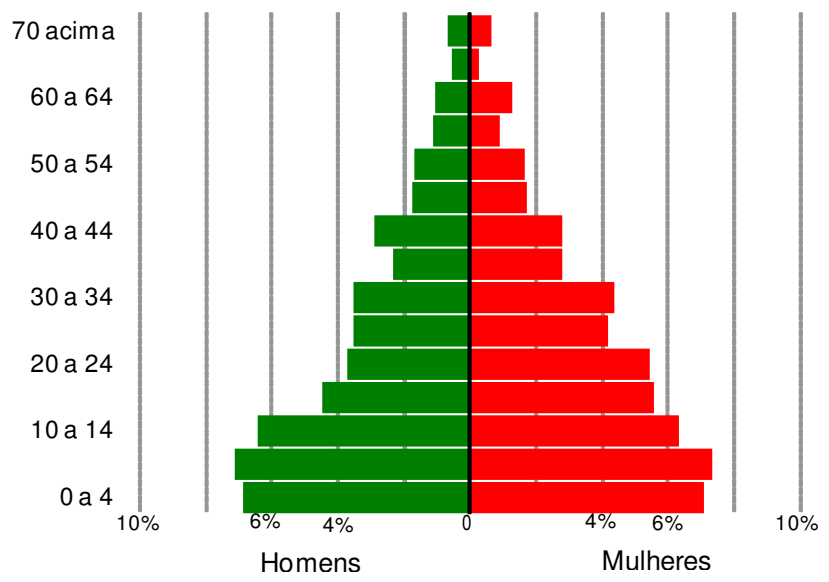


Nota-se - ainda que as bases das pirâmides sejam alargadas, indicando, como adiantado, importantes taxas de natalidade -, que a zona central de algumas figuras, especialmente a partir de 1812, são quase tão largas quanto as bases, apontando para relativo envelhecimento dessa população pela base causado pelo decréscimo da população de crianças de até quatro anos de idade, destacando-se, da mesma maneira, o prolongamento da cúspide, demonstrando alguma longevidade dos mogianos ao longo dos anos.

Com poucas exceções - com destaque para 1829, quando as faixas a partir de 40 anos e em 1825, em que as faixas a partir dos 45 anos costumaram ser favoráveis aos homens - nas diferentes faixas etárias houve superioridade numérica feminina, mesmo entre as crianças. Para as menores idades que, em regra, apresentam equilíbrio entre os sexos, encontramos também valores favoráveis às mulheres, ainda que com razões de sexo superiores àquelas calculadas para as faixas dos 15 aos 39 anos de idade, que estiveram ao redor dos 70 homens para cada 100 mulheres, sendo as razões para as crianças variáveis em torno de 90-95 homens para cada 100 mulheres.

Unindo as variáveis sexo, estado conjugal e idade, temos as observações colocadas na Tabela I.65.

Homens mais mulheres casados tinham, de maneira estável, em média 36-37 anos de idade. As médias correspondentes às mulheres, no entanto, apresentaram-se inferiores às verificadas para o sexo oposto: aproximadamente entre $32,4(1820)$ e 34,3 (1799) para elas, contra 39-40 anos para eles, diferença em torno de sete anos. Modas e, mormente, medianas, assim como anotado para as médias, foram superiores para os homens, mantendo-se a mediana entre 37 e 39 para indivíduos do sexo masculino e entre 32 e 35 anos de idade para as mulheres.

Para os indivíduo acima de 50 anos e solteiros - que temos identificado como em celibato definitivo - era reduzida, independente se falamos de homens ou mulheres: entre 1799 e 1820 o percentual devido a estes indivíduos esteve sempre ao redor de 3,5\%, caindo a 2,2\% em 1829, tendo as mulheres apresentado um percentual superior aos dos homens: cerca de $5 \%$ até 1816 contra $1,5 \%$ a $2 \%$ dos homens, lembrando, serem as razões de sexo anteriormente calculadas sempre favoráveis às mulheres, para indistintas faixas etárias. Já entre os casados, os homens apresentaram-se com maior percentual acima dos 50 anos, em torno de um quarto deles, sendo somente entre 10,3\% (1829) e $15,1 \%$ (1799) das mulheres casadas as que haviam completado 50 ou mais anos de vida. 
Tabela 1.65

Estatísticas para a idade dos livres de acordo com o estado conjugal e sexo (Mogi - 1799 a 1829)

\begin{tabular}{|c|c|c|c|c|c|c|c|c|c|c|c|c|}
\hline \multirow[b]{3}{*}{ Idade } & \multicolumn{3}{|c|}{1799} & \multicolumn{3}{|c|}{1803} & \multicolumn{3}{|c|}{1808} & \multicolumn{3}{|c|}{1812} \\
\hline & \multicolumn{3}{|c|}{ Solteiros } & \multicolumn{3}{|c|}{ Solteiros } & \multicolumn{3}{|c|}{ Solteiros } & \multicolumn{3}{|c|}{ Solteiros } \\
\hline & Homens & Mulheres & $\begin{array}{l}\text { Homens + } \\
\text { Mulheres }\end{array}$ & Homens & Mulheres & $\begin{array}{l}\text { Homens + } \\
\text { Mulheres }\end{array}$ & Homens & Mulheres & $\begin{array}{l}\text { Homens + } \\
\text { Mulheres }\end{array}$ & Homens & Mulheres & $\begin{array}{l}\text { Homens + } \\
\text { Mulheres }\end{array}$ \\
\hline$\% 15$ ou mais anos & 30,1 & 38,4 & 34,6 & 26,7 & 35,7 & 31,5 & 28,2 & 37,4 & 33,2 & 29,5 & 39,1 & 34,8 \\
\hline$\% 50$ ou mais anos & 2,1 & 5,1 & 3,7 & 2,0 & 4,8 & 3,5 & 2,3 & 5,4 & 4,0 & 1,5 & 5,2 & 3,5 \\
\hline \multirow{2}{*}{$\begin{array}{l}\text { Estatísticas para } \\
\text { idade }\end{array}$} & \multicolumn{3}{|c|}{ Casados } & \multicolumn{3}{|c|}{ Casados } & \multicolumn{3}{|c|}{ Casados } & \multicolumn{3}{|c|}{ Casados } \\
\hline & Homens & Mulheres & $\begin{array}{l}\text { Homens + } \\
\text { Mulheres }\end{array}$ & Homens & Mulheres & $\begin{array}{l}\text { Homens + } \\
\text { Mulheres }\end{array}$ & Homens & Mulheres & $\begin{array}{l}\text { Homens + } \\
\text { Mulheres }\end{array}$ & Homens & Mulheres & $\begin{array}{l}\text { Homens + } \\
\text { Mulheres }\end{array}$ \\
\hline Média & 40,4 & 34,3 & 37,3 & 40,5 & 33,8 & 37,1 & 39,5 & 33,5 & 36,5 & 39,3 & 33,5 & 36,3 \\
\hline Moda & 30,0 & 30,0 & 30,0 & 28,0 & 29,0 & 28,0 & 33,0 & 30,0 & 33,0 & $30 \mathrm{e}$ & 24,0 & 30,0 \\
\hline Mediana & 39,0 & 32,0 & 35,0 & 39,0 & 31,0 & 34,0 & 37,0 & 32,0 & 34,0 & 37,0 & 31,0 & 34,0 \\
\hline \multirow[t]{2}{*}{$\% 50$ ou mais anos } & 26,8 & 15,1 & 20,9 & 26,1 & 12,7 & 19,3 & 24,8 & 11,2 & 17,9 & 23,4 & 11,3 & 17,3 \\
\hline & \multicolumn{3}{|c|}{1816} & \multicolumn{3}{|c|}{1820} & \multicolumn{3}{|c|}{1825} & \multicolumn{3}{|c|}{1829} \\
\hline \multirow[b]{2}{*}{ Idade } & \multicolumn{3}{|c|}{ Solteiros } & \multicolumn{3}{|c|}{ Solteiros } & \multicolumn{3}{|c|}{ Solteiros } & \multicolumn{3}{|c|}{ Solteiros } \\
\hline & Homens & Mulheres & $\begin{array}{l}\text { Homens + } \\
\text { Mulheres }\end{array}$ & Homens & Mulheres & $\begin{array}{l}\text { Homens + } \\
\text { Mulheres }\end{array}$ & Homens & Mulheres & $\begin{array}{l}\text { Homens + } \\
\text { Mulheres }\end{array}$ & Homens & Mulheres & $\begin{array}{l}\text { Homens + } \\
\text { Mulheres }\end{array}$ \\
\hline$\% 15$ ou mais anos & 31,7 & 38,5 & 35,4 & 24,8 & 33,1 & 29,3 & 27,2 & 34,7 & 31,5 & 29,1 & 33,0 & 31,1 \\
\hline$\% 50$ ou mais anos & 1,3 & 4,9 & 3,3 & 2,2 & 4,5 & 3,5 & 1,7 & 3,0 & 2,4 & 1,6 & 2,8 & 2,2 \\
\hline \multirow{2}{*}{$\begin{array}{l}\text { Estatísticas para } \\
\text { idade }\end{array}$} & \multicolumn{3}{|c|}{ Casados } & \multicolumn{3}{|c|}{ Casados } & \multicolumn{3}{|c|}{ Casados } & \multicolumn{3}{|c|}{ Casados } \\
\hline & Homens & Mulheres & $\begin{array}{l}\text { Homens + } \\
\text { Mulheres }\end{array}$ & Homens & Mulheres & $\begin{array}{l}\text { Homens + } \\
\text { Mulheres }\end{array}$ & Homens & Mulheres & $\begin{array}{l}\text { Homens + } \\
\text { Mulheres }\end{array}$ & Homens & Mulheres & $\begin{array}{l}\text { Homens + } \\
\text { Mulheres }\end{array}$ \\
\hline Média & 39,4 & 33,8 & 36,6 & 39,1 & 32,4 & 35,7 & 39,7 & 33,2 & 36,4 & 38,8 & 32,7 & 35,8 \\
\hline Moda & 40,0 & 22,0 & 40,0 & 42,0 & 22,0 & 22,0 & 25,0 & 27,0 & 25,0 & 30,0 & 20,0 & 30,0 \\
\hline Mediana & 38,0 & 32,0 & 35,0 & 37,0 & 30,0 & 32,0 & 38,0 & 31,0 & 34,0 & 37,0 & 31,0 & 33,0 \\
\hline$\% 50$ ou mais anos & 23,3 & 11,9 & 18,0 & 25,9 & 11,3 & 18,4 & 23,9 & 11,9 & 17,8 & 22,1 & 10,3 & 16,1 \\
\hline
\end{tabular}

Fonte: AESP, Maços de População, Mogi das Cruzes: anos selecionados 
A sua vez, para a parcela cativa da população, a observação dos caracteres atinentes a idade, observados para faixas e separadamente para homens e mulheres através das pirâmides etárias, apontam uma grande concentração dos indivíduos nas faixas etárias dos 15 aos 19 anos e dos 20 aos 24, como predominante em todo 0 período. Em alguns momentos, a exemplo 1825, os cativos ainda mais jovens, 10 a 14 anos, aparecem de maneira também importante, sendo mais generalizada a importância daqueles com 25 a 34 anos, também com participações próximas às daquelas faixas etárias citadas. Como se verificou para os cativos em sua totalidade, consideradas as faixas etárias também encontramos ampliação da participação masculina comparativamente à presença de mulheres mais ao final do período e mais marcada para os cativos jovens.

\section{Gráfico I.31}

\section{Pirâmides etárias da população escrava}

(Mogi - 1799 a 1829)

1799

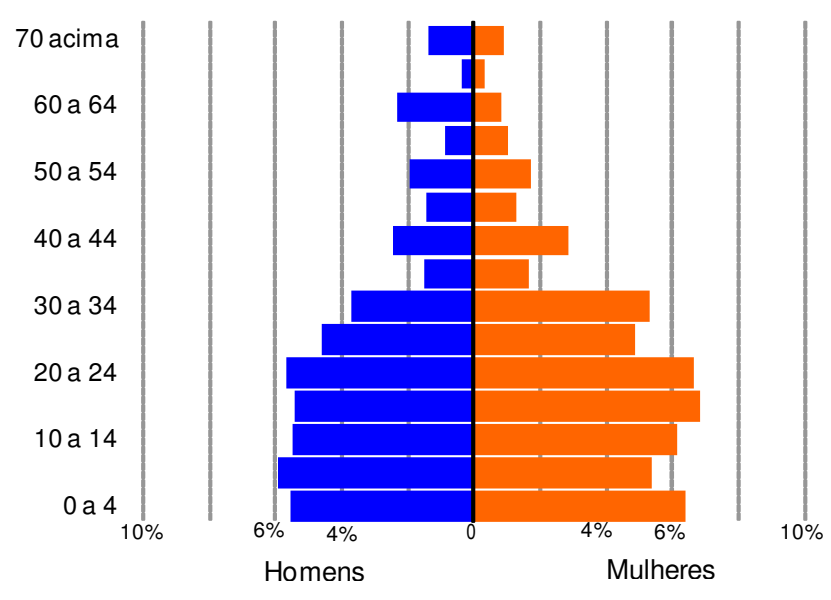




\section{3}

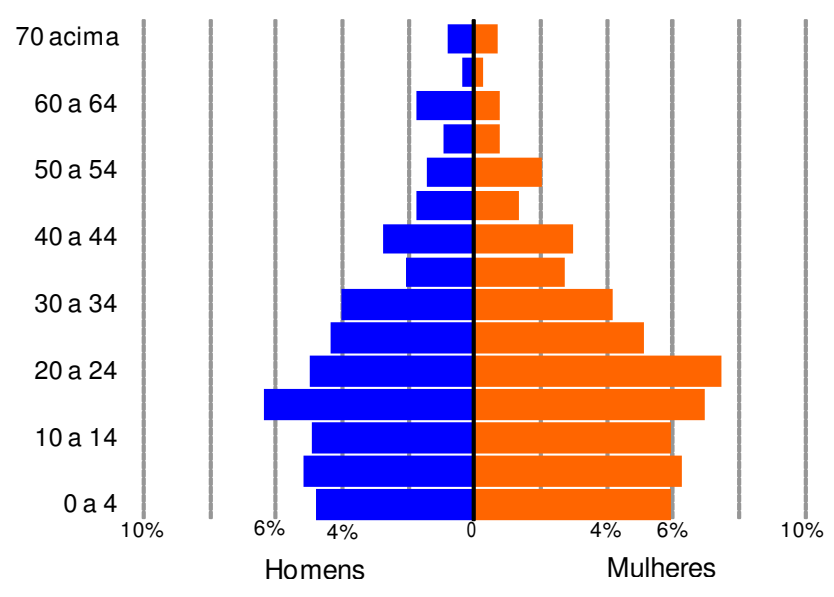

1808

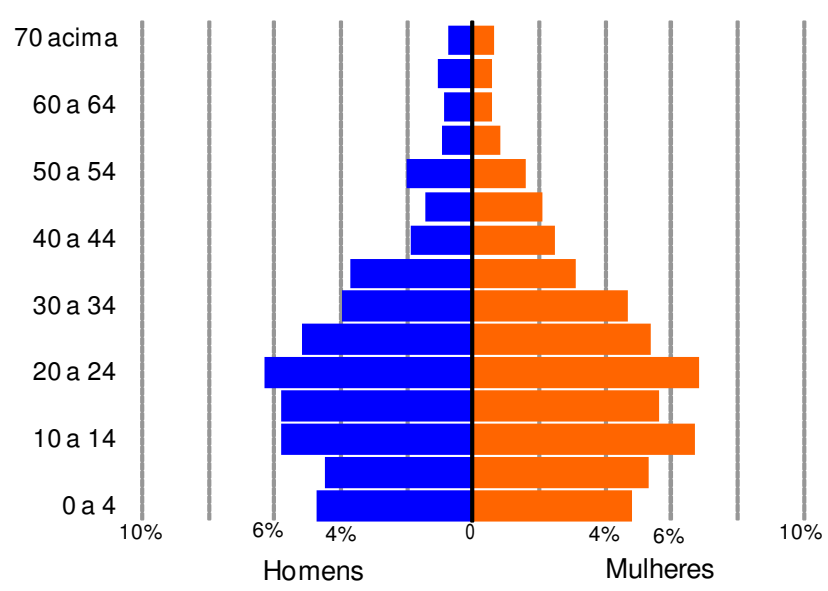

1812

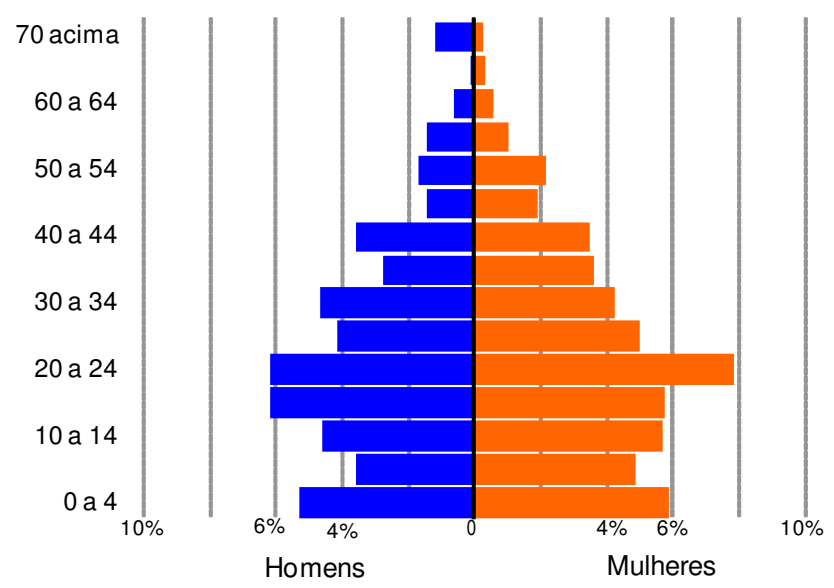




\section{6}

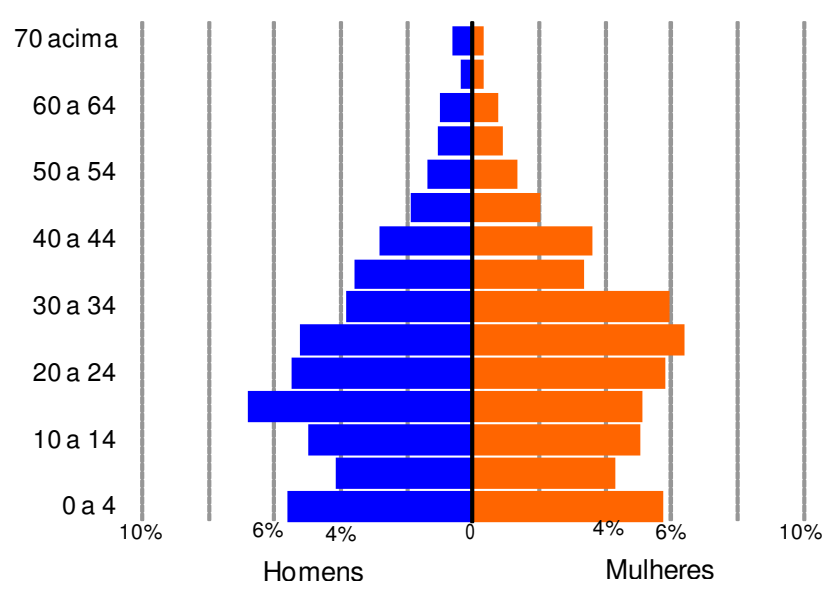

\section{0}

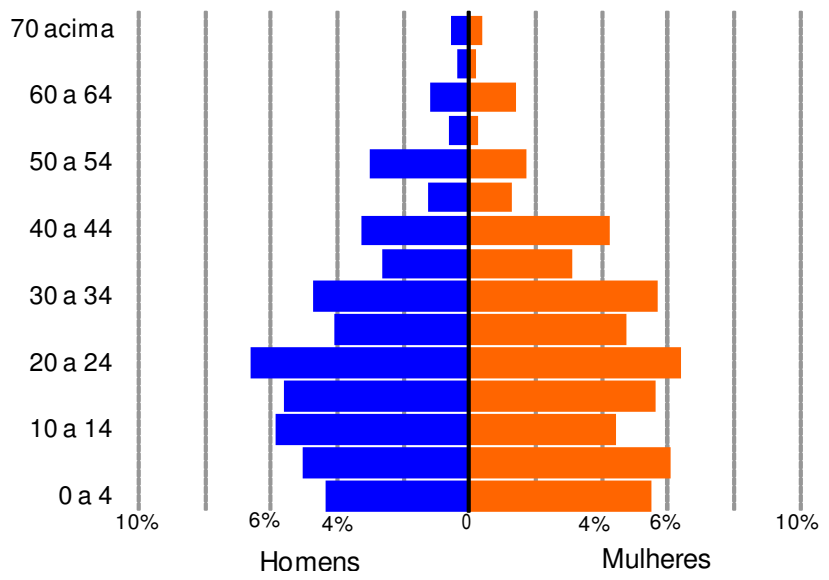

1825

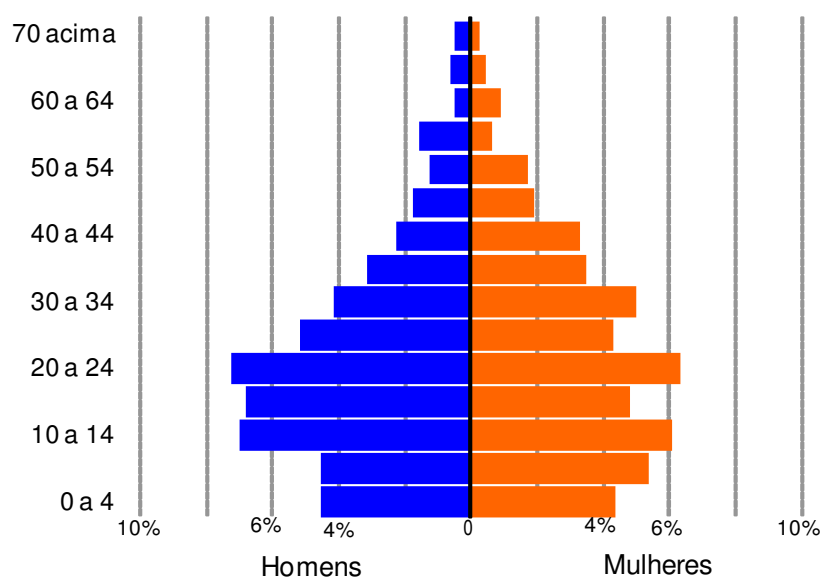


1830

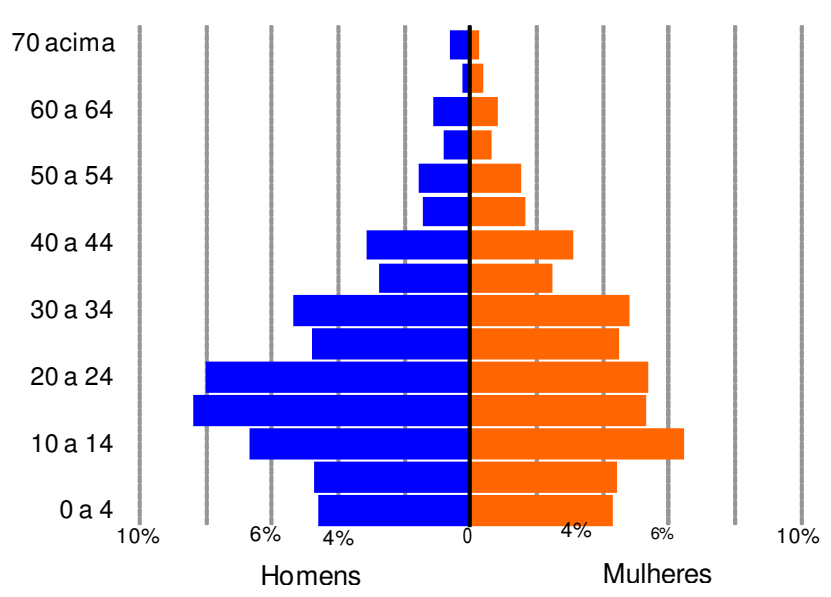

Ademais das variáveis demográficas colocadas até o momento, podemos considerar, para os livres, a cor, apresentada para brancos e não brancos (estes últimos arrolados como pardos ou mulatos) que consideramos sob a mesma cor, e negros (Tabela I.66). A descrição de mulatos foi comumente encontrada apenas nos anos 1799 e 1803.

Tabela 1.66

Distribuição da população livre entre brancos e não brancos (Mogi - 1799 a 1829)

\begin{tabular}{|c|c|c|c|c|c|}
\hline \multirow{3}{*}{ Anos } & \multirow{3}{*}{$\begin{array}{c}\text { Brancos } \\
\text { \% (№) }\end{array}$} & \multicolumn{3}{|c|}{ Não Brancos } & \multirow{3}{*}{$\begin{array}{c}\text { Total: Brancos } \\
\text { + Não brancos } \\
\text { \% (№) }\end{array}$} \\
\hline & & Pardos/Mulatos & Negros & Total & \\
\hline & & \% (№) & \% (№) & \% (№) & \\
\hline 1799 & $72,6(3870)$ & $95,8(1402)$ & $4,2(61)$ & $27,4(1463)$ & $100,0(5333)$ \\
\hline 1803 & $66,9(4325)$ & $97,0(2078)$ & $3,0(64)$ & $33,1(2142)$ & $100,0(6467)$ \\
\hline 1808 & $69,3(4576)$ & $94,1(1908)$ & $5,9(120)$ & 30,7 (2028) & $100,0(6604)$ \\
\hline 1812 & $72,0(4907)$ & $95,1(1819)$ & $4,9(93)$ & $28,0(1912)$ & $100,0(6819)$ \\
\hline 1816 & $75,2(4930)$ & $93,6(1519)$ & $6,4(104)$ & $24,8(1623)$ & $100,0(6553)$ \\
\hline 1820 & $72,1(4723)$ & $94,9(1734)$ & $5,1(94)$ & $27,9(1828)$ & $100,0(6551)$ \\
\hline 1825 & $70,4(5646)$ & 94,7 (2252) & $5,3(127)$ & $29,6(2379)$ & $100,0(8025)$ \\
\hline 1829 & $67,9(5883)$ & $95,9(2660)$ & $4,1(115)$ & $32,1(2775)$ & $100,0(8658)$ \\
\hline
\end{tabular}

Fonte: AESP, M aços de População, Mogi das Cruzes: anos selecionados

Como esperado, a maioria da população foi declarada branca ao longo de todo o lapso estudado, com percentuais dispostos em um intervalo cujo mínimo e máximo distam entre si pouco mais de oito pontos percentuais. Em 1803 67\% da população da vila e seu termo era branca, percentual que se viu aumentado ao longo de cada um dos anos 
considerados até atingir seu máximo de $75,2 \%$ em 1816, voltando a cair a partir daí: $70,4 \%$ em 1825 e 67,9\% em 1829. O ano em que encontramos o maior percentual de brancos destaca-se, ademais, por participação pouco mais elevada de negros entre os não brancos: 6,4\% (1,6\% da totalidade de livres). Comumente os não brancos livres eram pardos ou mulatos, com participação média ao redor dos $95 \%$ e percentual máximo de 97\% (1803).

E, por fim, resta-nos observar a naturalidade dos indivíduos a viver na Mogi das Cruzes dos Setecentos/Oitocentos. A observação da naturalidade dos moradores livres de Mogi das Cruzes em seu conjunto apresenta-se bastante prejudicada, uma vez que a abrangência das declarações foi bastante restrita, em sua melhor apresentação chegou a ser registrada para $46,9 \%$ dos indivíduos listados no recenseamento de 1829 , o que correspondia a 337 indivíduos. Em 1820 eram apenas 85 descrições (5,6\%) e em 1799 e 1816 eram praticamente inexistes. (Tabela I.67)

Em 1799 havia um índio (não incluído na Tabela I.66) da Aldeia Senhora da Ajuda, Antonio Jose Fernandes era natural de Jacareí, assim como era jacareiense o capitão e dizimeiro Joze Joaquim de Godois. Manoel da Costa de 33 anos a viver de seu negócio de fazenda seca era natural de Sorocaba. E em 1816, além de 20 indivíduos terem declarado serem naturais da própria localidade, havia três outros naturais da capital da capitania; Jose Pires de Almeida, 60 anos, era lavrador originário de Juquiri e havia ainda o sargento chegado porto João da Silva. A sua vez, os informes atinentes aos chefes de domicílio apresentaram maior qualidade, ao menos em três momentos, 1803, 08 e 12, em que abrangeram ao menos $92,4 \%$ dos chefes de fogo, percentual este referente ao primeiro ano citado. E em 1820 foram mencionadas naturalidades para $74,1 \%$ dos chefes. Entre 1803 e 1812 nota-se participação principal devida às pessoas nascidas na própria vila de Mogi das Cruzes e seu termo, com percentuais crescentes que foram de $74,9 \%$ a $86,5 \%$. Essa variação ocorreu em detrimento aos migrantes de outras áreas da capitania, que tiveram sua participação reduzida à metade em pouco menos de uma década.

Entre os forasteiros, importante participação era a dos jacareienses, a chefiar 59 fogos (4,7\%) na Mogi de 1803 e daqueles naturais da capital provincial, 73 (5,8\%) e 75 $(5,5 \%)$ em 1803 e 08. Mais expressiva era a participação devida àqueles vindos de Conceição: $5,4 \%, 5,7 \%$ e 4\%, respectivamente nos anos 1803 a 1812. Ainda que a análise para 1829 fique prejudicada especialmente pela ausência quase total dos indivíduos naturais de Mogi, vale mencionar que neste ano foram encontrados 182 domicílios com chefes oriundos de Conceição, número que havia sido de 165 no ano anterior, e somente vinte em 1820. 
Tabela 1.67

Origem da população livre

(Mogi - 1799 a 1829)

\begin{tabular}{|c|c|c|c|c|c|c|}
\hline \multirow{3}{*}{ Origem } & \multicolumn{6}{|c|}{ População livre } \\
\hline & 1803 & 1808 & 1812 & 1820 & 1825 & 1829 \\
\hline & \% (№) & \% (№) & \% (№) & \% (№) & \% (№) & \% (№) \\
\hline Mogi das Cruzes & 75,4 (1572) & 78,2 (1589) & 84,5 (2068) & $93,8(1414)$ & $69,9(638)$ & $50,8(365)$ \\
\hline Atibaia & $0,7(14)$ & $0,2(4)$ & $0,2(4)$ & - & - & $0,1(1)$ \\
\hline Nazaré & $0,6(12)$ & $0,6(12)$ & $0,4(9)$ & $0,1(1)$ & $1,5(14)$ & $8,3(60)$ \\
\hline Bragança & $0,2(4)$ & $0,0(1)$ & $0,0(1)$ & $0,1(1)$ & - & - \\
\hline Jundiaí & $0,0(1)$ & - & - & - & - & - \\
\hline Jacareí & 4,7 (97) & 4,7 (95) & $3,9(95)$ & $1,4(21)$ & $2,4(22)$ & $6,1(44)$ \\
\hline São Paulo & $6,2(130)$ & $4,9(100)$ & $3,3(82)$ & $0,8(12)$ & $2,8(26)$ & $3,9(28)$ \\
\hline Santos & $0,5(10)$ & $0,4(8)$ & $0,2(4)$ & - & - & - \\
\hline Conceição & $6,1(127)$ & $6,3(127)$ & 3,9 (95) & $1,7(25)$ & $18,6(170)$ & $25,5(183)$ \\
\hline São Luiz & - & - & $0,0(1)$ & $0,5(7)$ & $0,9(8)$ & $1,3(9)$ \\
\hline Taubaté & $1,2(26)$ & $0,8(17)$ & $1,0(25)$ & $0,4(6)$ & $0,8(7)$ & - \\
\hline Parnaíba & $0,2(5)$ & $0,2(5)$ & - & - & $0,5(5)$ & - \\
\hline $\begin{array}{l}\text { Outras localidades da } \\
\text { capitania/província }\end{array}$ & $1,5(31)$ & $1,3(27)$ & $0,5(12)$ & $0,8(12)$ & $1,1(10)$ & $1,7(12)$ \\
\hline $\begin{array}{l}\text { TOTAL da } \\
\text { capitania/província } \\
\text { (exclusive Mogi) }\end{array}$ & $21,9(457)$ & $19,5(396)$ & $13,4(328)$ & $5,6(85)$ & $28,7(262)$ & $46,9(337)$ \\
\hline $\begin{array}{l}\text { Outras } \\
\text { capitanias/províncias }\end{array}$ & $1,7(36)$ & $0,9(19)$ & $1,3(31)$ & $0,2(3)$ & $0,8(7)$ & $1,7(12)$ \\
\hline Outros países & $0,9(19)$ & $1,4(28)$ & $0,9(21)$ & $0,3(5)$ & $0,7(6)$ & $0,7(5)$ \\
\hline TOTAL & $100,0(2084)$ & $100,0(2032)$ & $100,0(2448)$ & $100,0(1507)$ & $100,0(913)$ & $100,0(719)$ \\
\hline \multirow[t]{2}{*}{$\begin{array}{l}\text { Abrangência das } \\
\text { declarações }\end{array}$} & $32,2 \%$ & $30,7 \%$ & $35,9 \%$ & $23,0 \%$ & $11,4 \%$ & $8,3 \%$ \\
\hline & \multicolumn{6}{|c|}{ Chefes de fogo } \\
\hline \multirow[t]{2}{*}{ Origem } & 1803 & 1808 & 1812 & 1820 & 1826 & 1829 \\
\hline & \% (№) & \% (№) & \% (№) & \% (№) & \% (№) & \% (№) \\
\hline Mogi das Cruzes & 74,9 (935) & $81,1(1105)$ & $86,5(1274)$ & 92,7 (1008) & $69,4(603)$ & $21,8(98)$ \\
\hline Atibaia & $0,4(5)$ & - & - & - & - & $0,2(1)$ \\
\hline Nazaré & $0,8(10)$ & $0,7(10)$ & $0,4(6)$ & - & $1,6(14)$ & $13,3(60)$ \\
\hline Bragança & $0,2(3)$ & $0,1(1)$ & $0,1(1)$ & $0,1(1)$ & - & - \\
\hline Jundiaí & $0,1(1)$ & - & - & - & - & - \\
\hline Jacareí & $4,7(59)$ & $4,2(57)$ & $3,7(54)$ & 1,7 (19) & $2,5(22)$ & $8,9(40)$ \\
\hline São Paulo & $5,8(73)$ & $5,5(75)$ & $0,5(7)$ & $0,8(9)$ & $3,0(26)$ & $7,1 \quad(32)$ \\
\hline Santos & $0,6(8)$ & $0,4(6)$ & $0,2(3)$ & - & - & - \\
\hline Conceição & $5,4(67)$ & $5,7(78)$ & 4,0 (59) & $1,8(20)$ & $19,0(165)$ & $40,4(182)$ \\
\hline São Luiz & & - & 0,1 (1) & $0,6(7)$ & $0,9(8)$ & $2,0(9)$ \\
\hline Taubaté & $0,9(11)$ & $0,9(12)$ & $1,2(18)$ & $0,5(5)$ & $0,8(7)$ & $0,2(1)$ \\
\hline Parnaíba & $0,3(4)$ & - & - & - & $0,6(5)$ & $1,1(5)$ \\
\hline $\begin{array}{l}\text { Outras localidades da } \\
\text { capitania/província }\end{array}$ & $1,4(17)$ & 1,3 (18) & $0,7(10)$ & $0,9(10)$ & $0,7(6)$ & $1,6(7)$ \\
\hline $\begin{array}{l}\text { TOTAL da } \\
\text { capitania/província } \\
\text { (exclusive Mogi) }\end{array}$ & 20,7 (258) & $18,9(257)$ & $10,8(159)$ & $6,5(71)$ & 29,1 (253) & 74,9 (337) \\
\hline $\begin{array}{l}\text { Outras } \\
\text { capitanias/províncias }\end{array}$ & $2,9(36)$ & $1,2(17)$ & $1,7(25)$ & $0,3(3)$ & $0,8(7)$ & $2,4(11)$ \\
\hline Outros países & $1,5(19)$ & $1,0(13)$ & $1,0(15)$ & $0,5(5)$ & $0,7(6)$ & $0,9(4)$ \\
\hline TOTAL & $100,0(1248)$ & $102,2(1392)$ & $100,0(1473)$ & $100,0(1087)$ & $100,0(869)$ & $100,0(450)$ \\
\hline $\begin{array}{l}\text { Abrangência das } \\
\text { declarações }\end{array}$ & $92,4 \%$ & $93,4 \%$ & $94,9 \%$ & $74,1 \%$ & $48,6 \%$ & $23,2 \%$ \\
\hline
\end{tabular}

Fonte: AESP, M aços de População, Mogi: anos selecionados

Exclusive indivíduos co $m$ naturalidade não identificada 
É dizer, houve movimento populacional no sentido Conceição-Mogi, localidades vizinhas, na década de 1820. Da mesma maneira os chefes de fogo naturais de Nazaré que contados em número de 10 ao início do século XIX, estavam a chefiar 60 unidades familiares ao final da década de 1820.

Os chefes de fogo oriundos de Conceição, em que pese a influência daqueles chegados à localidade há mais tempo, eram, em 1825, 80,6\% homens, $14 \%$ deles tinham cativos, $75 \%$ eram casados e 18,8\% viúvos, possuíam idade média de 44 anos (com moda 45 e mediana 44,5). Mais de metade deles declararam ser lavradores, 57\% e 8,5\% se disseram pobres. $\mathrm{E}$ em apenas sete situações encontramos referência explicita a fogo novo. 


\section{Jacareí}

Os números da população de Jacareí, obtidos através das listas nominativas dos habitantes da localidade em diferentes anos entre 1798 e 1829, apresentados na Tabela I.68 e no Gráfico I.32, possibilitam perceber o grande crescimento demográfico vivido pela localidade nesse período: 49,3\%; crescimento que seria de $79,7 \%$ em se considerando o ano anterior. Observamos que, de 4670 indivíduos em 1798, primeiro ano considerado neste trabalho, passadas quase três décadas, em 1825 a população jacareiense alcançou 7972 indivíduos - entre 1798 e 1825 o crescimento médio anual da população total foi de $2 \%$-, sendo de 6973 a população registrada em 1829, em que pese a deficiência do documento para esta data. ${ }^{24}$

\section{Gráfico I.32}

\section{Evolução (em valores absolutos) da população total, população livre e escravos

$$
\text { (Jacareí - } 1798 \text { a 1829) }
$$

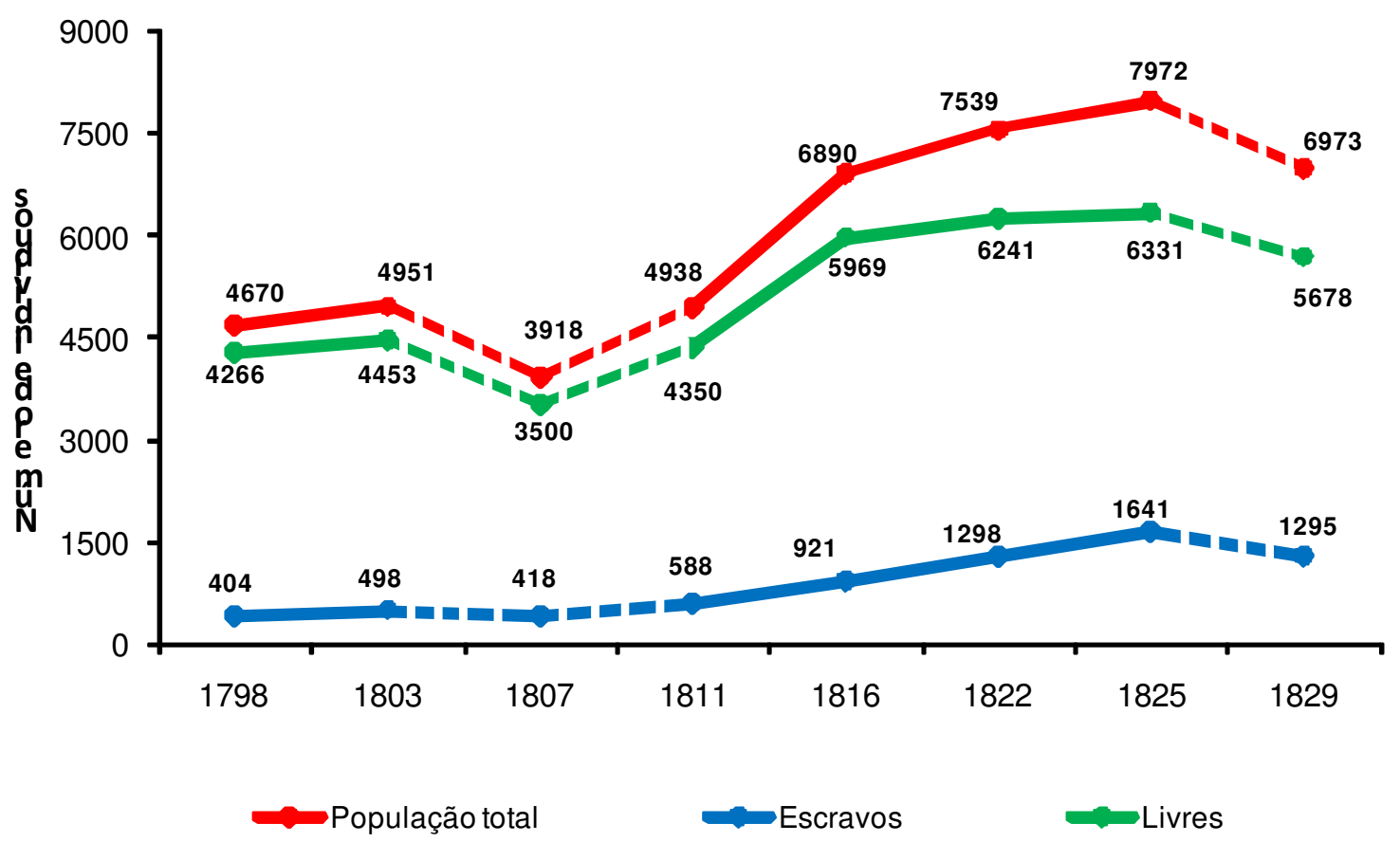

\footnotetext{
${ }^{24}$ Ver apêndice 2 para informações sobre as listas nominativas consideradas.
} 
Tabela 1.68

Variação da população total, população livre e escravos

(Jacareí - 1798 a 1825, São Paulo - 1798 a 1828)

\begin{tabular}{ccccccc}
\hline \hline & \multicolumn{2}{c}{ Jacareí } & & \multicolumn{2}{c}{ Província São Paulo* $^{*}$ Anos } \\
\cline { 1 - 3 } \cline { 5 - 6 } & $\begin{array}{c}\text { Variação \% da } \\
\text { população total }\end{array}$ & $\begin{array}{c}\text { Variação \% da } \\
\text { população livre }\end{array}$ & $\begin{array}{c}\text { Variação \% da } \\
\text { população } \\
\text { cativa }\end{array}$ & & Anos & $\begin{array}{c}\text { Variação \% da } \\
\text { população total }\end{array}$ \\
\hline $1798-1803$ & 6,0 & 4,4 & 23,3 & & $1798-1800$ & 4,4 \\
$1803-1811$ & $-0,3$ & $-2,3$ & 18,1 & & $1800-1808$ & 15,7 \\
$1811-1816$ & 42,4 & 40,4 & 56,6 & & $1808-1818$ & 13,0 \\
$1816-1822$ & 38,4 & 28,4 & 121,9 & & $1818-1822$ & 10,3 \\
$1822-1825$ & 5,8 & 1,5 & 26,4 & & $1822-1828$ & 17,7 \\
\hline $1799-1816$ & 47,5 & 39,9 & 128,0 & & $1798-1818$ & 36,5 \\
$1816-1825$ & 15,7 & 6,1 & 78,2 & & $1818-1828$ & 29,8 \\
$1799-1825$ & 49,3 & 33,1 & 220,5 & & $1798-1828$ & 77,2 \\
\hline \hline
\end{tabular}

*Valores calculados a partir dos dados apresentados por M arcílio (2000, p.71), inclui Paraná

**Fonte: AESP, M aços de População, Jacareí: anos selecionados

Esse crescimento inclui a partir de 1816, explicitamente, companhias relativas à Paraibuna, que havia sido elevada à condição de freguesia poucos anos antes, ao final de 1812. Paraibuna contava com duas companhias de ordenança, sendo que a ausência da segunda delas em 1829 justifica a redução da população descrita naquele ano - 833, 1177 e 1272 indivíduos foram arrolados nessa companhia em 1816, 1822 e 1825. Assim, nos anos de 1816, 1822, 25 e 29, respectivamente 20,9\%, 27,1\%, 29,7\% e 16,3\% da população declarada o foi em Paraibuna.

Da mesma maneira ao verificado em 1829, o aparente decréscimo da população ocorrido entre 1803 e 1807 na realidade é reflexo, fundamentalmente, da ausência do arrolamento para a primeira companhia, correspondente à área mais urbana da vila, neste ano de 1807. Excluída a primeira companhia das listas de 1803 e 1811 teríamos, respectivamente, 3811 e 3960 indivíduos. O que implicaria em uma variação positiva de $2,8 \%$ entre 1803 e 1807 e de $1,1 \%$ entre 1807 e 1811 . Entre 1803 e 1811 a mudança na população, desconsiderada a primeira companhia teria sido de 3,9\%, enquanto consideradas as companhias em sua totalidade houve um decréscimo de 2,3\% no número total de habitantes em Jundiaí, implicando, no período 1803-1811, em um crescimento havido, especialmente, nos bairros mais rurais da vila.

Ainda que com referência ao aumento do total da população ao longo de 30 anos pareça ter havido duas fases, é preciso sopesar essas observações, uma vez que não conseguimos identificar se houve e qual foi a participação de Paraibuna nas listas anteriores a 1816. De qualquer maneira, a primeira fase de crescimento teria acorrido até 
1811, quando a população passou por um período de estabilidade, sendo acrescida em apenas $3,6 \%$, correspondendo a somente 168 pessoas e a um crescimento de $0,3 \%$ ao ano. Nesse período a população foi de 4670 indivíduos (1798) a 4951 em 1803, caindo um pouco nos anos seguintes, chegando a 1811 com 4838 pessoas. A segunda fase ocorreu quando, em um salto, a partir de 1811 a população ampliou-se em 42,4\% até 1816 e $64,8 \%$ se considerado o ano de 1825 (crescimento anual de 3,6\%).

No Gráfico I.33 apresentamos versão para o Gráfico I.32, com alguns ajustes que respeitam à exclusão da primeira companhia de Jacareí propriamente e a separação dos números de Paraibuna para 1816, 1822, 1825 e 1829, descontados destes a segunda companhia. Tarefa que, todavia, também não se mostra livre de incorreções, pois, dada a ampliação do número de companhias visualizada na década de 1820, não sabemos ser a área da primeira companhia até aquele momento correspondente, nas listas consultadas a partir de 1822, somente à área da primeira ou da primeira e mais companhias. Sendo a segunda opção a mais provável, o número de indivíduos de 1822 a 1829 deveria ser menor que o disposto no gráfico.

Em um primeiro momento, descontada a primeira companhia de Jacareí, os novos dados parecem corroborar a análise anterior: ainda que existam flutuações, pode-se dizer que a população pouco variou, manteve-se entre o mínimo de 3811 em 1803 e 4032 indivíduos em 1798. Já o salto ocorrido entre 1816 e 1822 foi bastante grande, tendo a população saído de 3994 habitantes para 5615 porém ocorrido em um período posterior que engloba, justamente, a ampliação do número de companhias. Assim, vale observar que se houvéssemos descontado a freguesia de Paraibuna e mantido a primeira companhia, em nada teria avançado o número total de habitantes de Jacareí passados cerca de seis anos (1816-1822): seriam apenas 48 pessoas $0,9 \%$; sendo de 108 pessoas, $2 \%$, o crescimento entre 1822 e 1825 e de 4,2\% o avanço populacional entre 1825 e 1829, ou seja, muito provavelmente houve o desmembramento das companhias e o desconto a que procedemos deveria ter sido feito não somente com a primeira, a partir de 1822.

A sua vez, a primeira companhia de Paraibuna cresceu vertiginosamente entre 1822 e 1825, passando de 867 a 1135 indivíduos, 26,5\%. Bem mais modesto o crescimento verificado para a mesma companhia entre 1825 e 1829, 3,5\% e, anteriormente, 1816-1822: 4,1\%. Consideradas em conjunto, as duas companhias componentes da freguesia tiveram sua população aumentada em 15,9\% entre os últimos anos considerados (1822 e 1825); crescimento que havia sido de elevados $41,6 \%$ entre 1816 e 1822, equivalente a uma expansão demográfica de impressionantes $6 \%$ ao ano. 


\section{Gráfico I.33}

Evolução (em valores absolutos) da população total, população livre e escravos modificada

- exclusive $1^{\mathrm{a}}$ cia da vila e $2^{\mathrm{a}}$ cia da freguesia (Jacareí - 1798 a 1829)

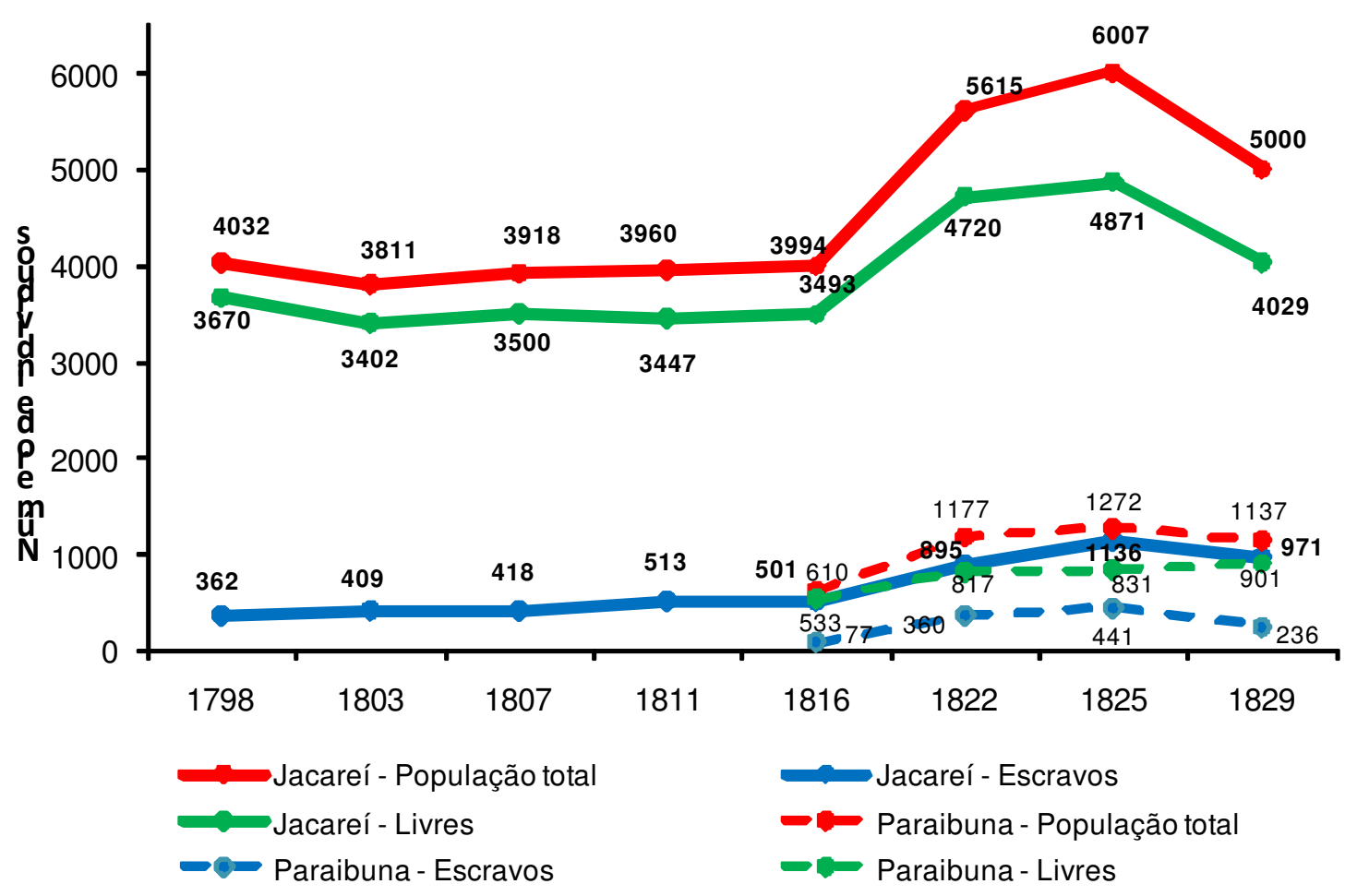

Em suma, a vila de Jacareí (e seu termo) apresentou um crescimento mais modesto até 1816. Já a partir daí a população total cresceu em grande medida, crescimento este devido, especialmente, ao grande avanço populacional vivido pela freguesia de Paraibuna.

Em se considerando que na segunda metade do século XVIII o povoamento de Paraibuna era ainda incipiente, um pequeno povoado em seu início - haja visto a Ordem para ser fundada a Povoação de Paraibuna, expedida em 1773 pelo Morgado de Mateus, tendo em vista "as ordens de Sua Majestade de aumentar as povoações desta Capitania e tenho notícia que na paragem chamada Santo Antônio da Barra do Paraibuna, entre as Vilas de Sam Sebastião, Jacareí e Sam Luiz de Paraitinga há terras suficientes para estabelecer uma boa povoação" (apud CALDEIRA, 1932), vide apêndice 1 e capítulo III e que em um prazo de 60 anos (em 1833) o aglomerado urbano inicial se tornou vila instalada e independente de Jacareí, cuja criação resulta de uma série de modificações 
no que tange ao crescimento da localidade e suas necessidades, corrobora-se o grande crescimento da localidade. Contava a vila, três anos após sua efetiva instalação, com 3169 moradores, entre livres e cativos, de acordo com dados apresentados por Müller (1923, p.136), uma avanço de 33,8\% em uma década (crescimento anual médio de 6\%, semelhante ao verificado desde que foi explicita a freguesia pela primeira até 1822 , como se viu).

O avanço populacional apresentado por Jacareí com sua freguesia de Paraibuna foi distinto, no que respeita aos montantes das variações, se observados em separado livres e cativos. Os escravos passaram de 404 em 1798 a 1295 em 1829, expansão de mais de 220\%; se considerado como referência o ano anteriormente observado - em 1825 havia uma companhia a mais, como sabido - a expansão seria ainda maior: $306,2 \%$. Certamente este crescimento acompanhou os momentos anteriormente observados: entre 1798 e 1816 o crescimento foi calculado em 128\%, e havia sido reduzido no Setecentos em sendo os cativos de Jacareí apenas 305 indivíduos em 1777 (cf. LUNA, 1988, p.24). A comparação ente 1816 e 1825 resultou em uma variação de $78,2 \%{ }^{25}$

Em 1822 a participação dos escravos sitos na freguesia era de 41,4\% contra $58,6 \%$ dos indivíduos arrolados em Jacareí propriamente. Em 1825 o peso dos cativos listados em Paraibuna foi de 39\%, próximo ao encontrado para 1816, 36,5\%, e em 1829 esse peso caiu a $18,2 \%$.

Assim, vale observar que do crescimento ocorrido entre 1811 e $1816,16,2 \%$ foi devido aos cativos. Para o avanço populacional do período posterior, 1816-22, esse percentual foi de $58,4 \%$, sendo de $54,9 \%$ devido aos cativos da vila propriamente e $45,1 \%$ para aqueles sitos na freguesia.

Numericamente, encontramos 1,1 vezes mais livres em 1816 que em 1798 e 1,3 vezes mais em 1822 que em 1816. O crescimento entre os mais de quinze anos que separam 1798 e 1816 foi de 13,9\%, superado quatro anos depois, quando o avanço dos jacareienses não cativos foi de $28,4 \%$.

\footnotetext{
${ }^{25}$ LUNA (1988) apresenta para Jacareí, respectivamente em 1777, 1804 e 1829, anos estudado pelo autor via listas nominativas, população cativa de 305, 494 e 1298 indivíduos. O número apontado para 1804 é bastante próximo àquele por nós levantado para o ano anterior - 498 seria o número de escravos na Jacareí de 1803 . Em 1829, os nossos números indicam três cativos a menos, diferença insignificante $(0,2 \%)$, como apontamos em outras oportunidades devido, certamente, às dificuldades próprias da leitura desses documentos manuscritos.
} 


\section{Gráfico I.34}

Participação de livres e escravos na população

(Jacareí - 1798 a 1829)

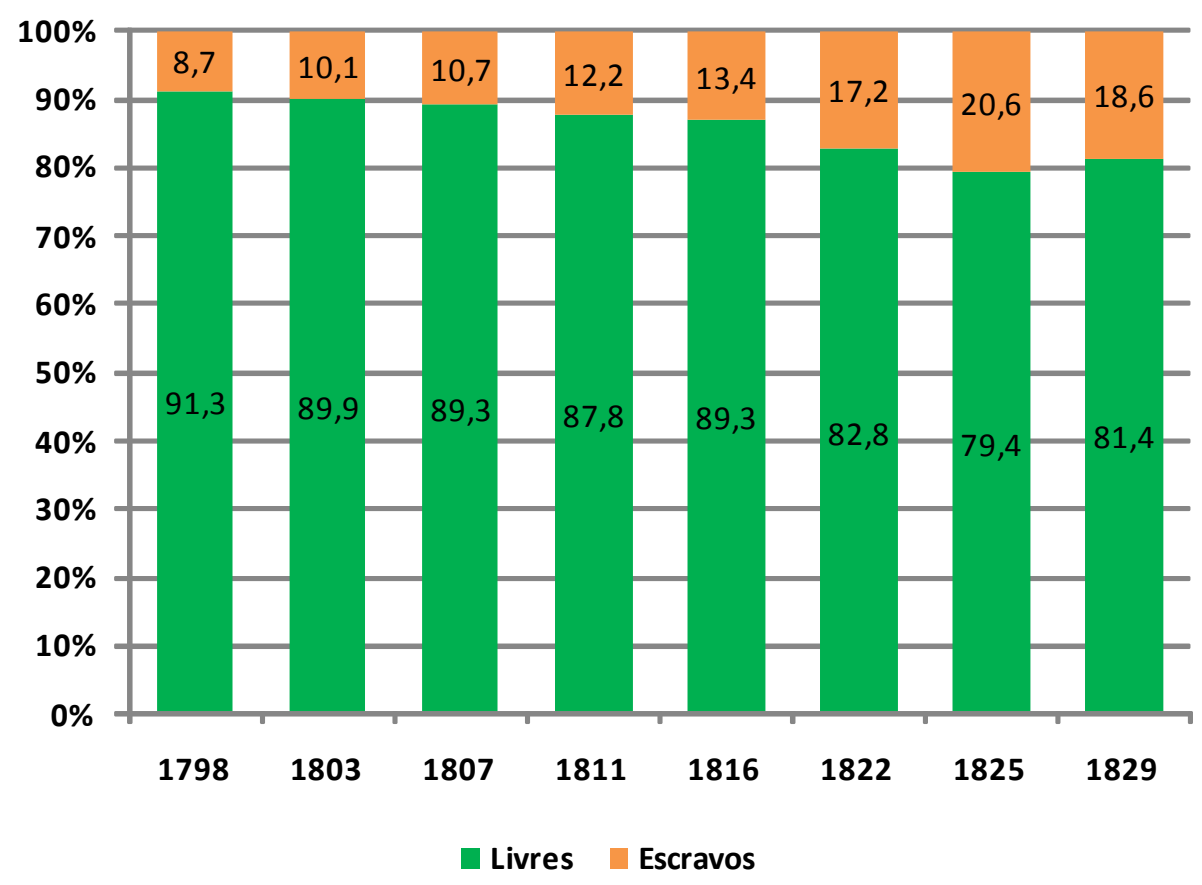

O aumento em maior medida da população cativa levou a uma visível mudança ao longo dos anos do seu peso na composição da população de Jacareí, observada no Gráfico I.34. Em 1798 eram 8,7\% da população, variando cerca de 10\% a 12\% nos anos de 1803 a 1807, saltando a 17,2\% em 1822 e 20,6\% em 1825. Assim, os cativos eram em 1798 8,7\% da população, tiveram sua participação paulatinamente aumentada e, ao final do período considerado haviam ampliado sua participação a cerca de $20 \%$.

Ocorreu, outrossim, um incremento no percentual de fogos em que cativos eram encontrados (Gráfico I.35), assim como na população vivendo em fogos onde também viviam escravos (Tabela I.69) .

Os jacareienses estavam distribuídos, em 1798, por 902 fogos, número 24\% menor que o verificado em 1816, com destaque, durante este período (1798 a 1816), para os $41,3 \%$ de ampliação ocorrida entre 1811 e 1816 (em que pese a explicitação dos fogos de Paraibuna); até 1811, com o dobro o tempo, o crescimento havia sido inferior a um quarto deste: 9,9\%. Em 1825 este número tinha atingido pouco menos de 1500 domicílios, correspondente a um acréscimo de $22,1 \%$ entre 1816 e 1822 e 2,2\% entre 1822 e 1825 . À exceção de 1811-1816, a quantidade de fogos flutuou de maneira menos acentuada que a população total, livres e escravos. 
Já a presença de chefes com escravos, em 1799 foi de 11,5\%, correspondente a 104 fogos. Entre 1803 e 1816 o percentual observado esteve entre 13\% (1807) e 14,5\% (1816). Em 1822 15,2\% dos fogos de Jacareí/Paraibuna descreveram escravos e em 1825 o percentual de chefes diretamente ligados a estes indivíduos foi de 17,5\%. Dentre este percentual em 1822 28,1\% (62 fogos) eram relativos à freguesia, assim como 29,7\% em 1825 (77 fogos) - Paraibuna tinha 19,9\% de seus fogos com escravos em 1816, $201,1 \%$ em 1822, 21,1\% em 1825 e 19,3\% em 1829.

Quanto ao incremento da população convivendo em fogos com cativos, observamos em $179821 \%$ da população total em fogos com escravos, em torno de $23 \%$ nos anos de 1803 a 1811, e superior a 32\% de 1822 em diante: 32,3\% em 1822, 35,1\% em 1825 e 33,4\% em 1829. A parcela livre da população também ampliou seu peso entre aqueles fogos com escravos, ainda que essa mudança tenha sido de menor monta: foi de 4,7 pontos percentuais (35\%) entre 1798 e 1829 para estes - de 13,5\% em no Setecentos a $18,2 \%$ ao fim da década de 20 do Oitocentos - e de 12,4 pontos percentuais (59\%) para aqueles.

\section{Gráfico I.35}

Fogos com e sem escravos

$$
\text { (Jacareí - } 1799 \text { a 1829) }
$$

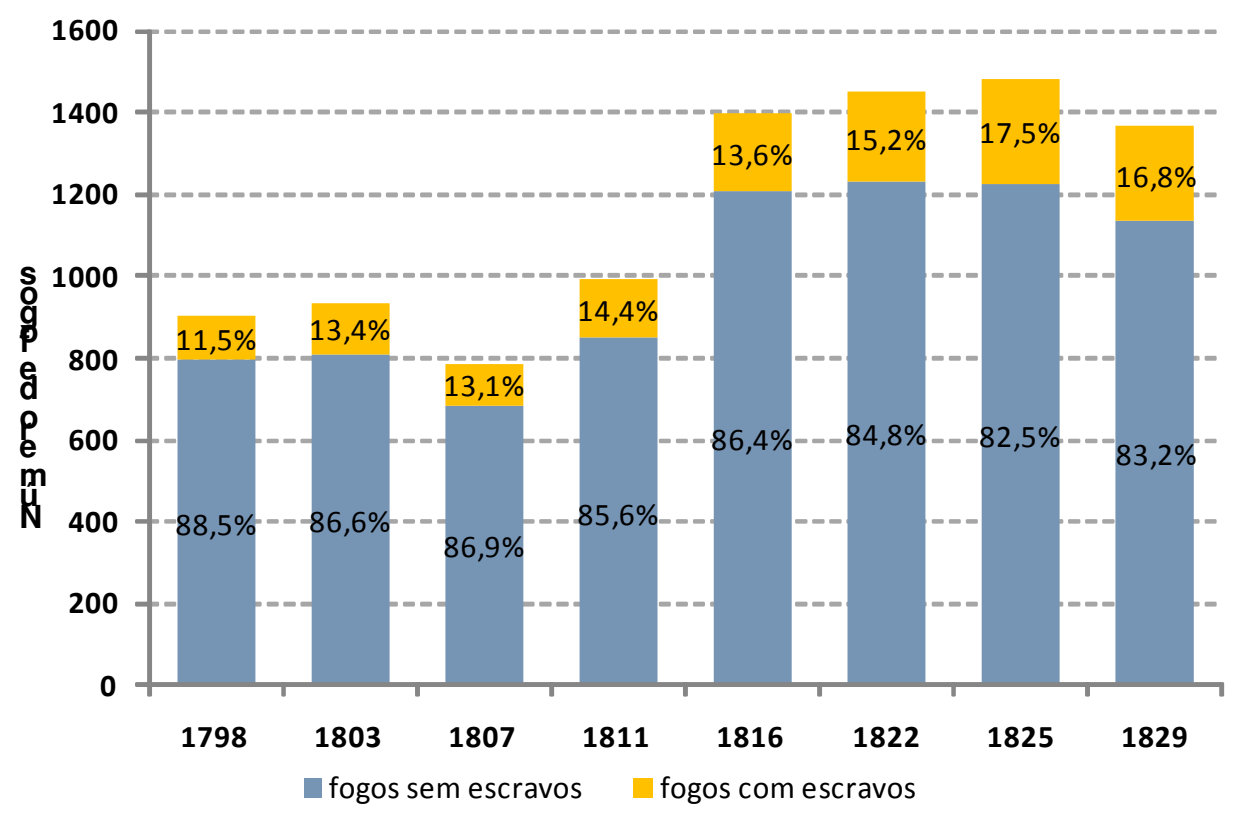


Tabela 1.69

Peso dos domicílios com e sem escravos na população (Jacareí - 1798 a 1829)

\begin{tabular}{|c|c|c|c|c|c|c|c|}
\hline \multirow[b]{2}{*}{ Anos } & \multicolumn{3}{|c|}{ Fogos sem escravos } & \multicolumn{4}{|c|}{ Fogos com escravos } \\
\hline & $\begin{array}{c}\text { \% da } \\
\text { população } \\
\text { total }\end{array}$ & $\begin{array}{c}\text { \% da } \\
\text { população } \\
\text { livre }\end{array}$ & $\begin{array}{l}\text { Média de } \\
\text { indivíduos }\end{array}$ & $\begin{array}{c}\text { \% da } \\
\text { população } \\
\text { total }\end{array}$ & $\begin{array}{c}\text { \% da } \\
\text { população } \\
\text { livre }\end{array}$ & $\begin{array}{l}\text { Média de } \\
\text { indivíduos }\end{array}$ & $\begin{array}{l}\text { Média de } \\
\text { livres }\end{array}$ \\
\hline 1798 & 79,0 & 86,5 & 4,6 & 21,0 & 13,5 & 9,4 & 5,5 \\
\hline 1803 & 77,2 & 85,8 & 4,7 & 22,8 & 14,2 & 9,0 & 5,1 \\
\hline 1807 & 76,6 & 85,7 & 4,4 & 23,4 & 14,3 & 8,9 & 4,9 \\
\hline 1811 & 76,7 & 87,4 & 4,4 & 23,3 & 12,6 & 7,9 & 3,8 \\
\hline 1816 & 72,8 & 83,3 & 4,1 & 27,2 & 16,7 & 10,1 & 5,2 \\
\hline 1822 & 67,7 & 81,8 & 4,1 & 32,3 & 18,2 & 11,1 & 5,2 \\
\hline 1825 & 64,9 & 81,7 & 4,2 & 35,1 & 18,3 & 10,8 & 4,5 \\
\hline 1829 & 66,6 & 81,8 & 4,1 & 33,4 & 18,2 & 10,1 & 4,5 \\
\hline
\end{tabular}

Fonte: AESP, M aços de População, Jacareí: anos selecionados

Os fogos com cativos apresentaram, em média, livres em maior quantidade que o verificado para os fogos em que escravos não foram arrolados. Eram no mínimo 4,1 indivíduos por domicilio sem escravos (1816, 22 e 29) e no máximo 4,7 em 1803 - ano em que a diferença entre fogos esteve em tão somente 0,3 pessoas. Nestes mesmos anos os fogos com cativos apresentaram médias de livres de 5,1 e 4,6, em sequência. A maior diferença entre os dois segmentos foi anotada em 1816 e 1822: 1,1 indivíduo. Notese, também, o incremento no número médio de indivíduos por fogo, dado o grande aumento da parcela cativa da população: de 9,4 em 1798 foi decrescente a 7,9 em 1812, voltando a subir a partir de 1816, chegando próximo a 11 em 1822 e 1825.

Adicionalmente, assim como o aumento da sua participação na população e dos livres a eles vinculados, o grande crescimento dos escravos expandiu a média desses indivíduos por fogo ao longo dos anos. Eram 0,4 indivíduos por domicilio em 1798, em 2011 a média era de 0,6, 0,9 em 1822 e 1829 e em 1825 foram registrados 1,1 escravos por fogo; mas os cativos ainda estavam ausentes da maioria dos domicílios, sendo padrão a ausência de plantéis (moda e mediana iguais a zero).

Desconsiderados os fogos em que os mancípios estavam ausentes, as médias para os escravos seriam superiores e apresentando claro aumento ao longo do tempo. Eram 3,9 cativos por proprietário em 1798, 4,9 destes indivíduos em 1816 e seis escravos por fogo em 1829 (moda sempre um e mediana igual a dois até 1816 e três nos anos finais anotados). 
Tal aumento ocorreu como reflexo da ampliação na Vila de Jacareí e seu termo da participação de plantéis de maior vulto: em 1798 estavam ausentes da localidade plantéis com mais de 20 escravos, sendo o máximo anotado para o lavrador e dono de engenho Miguel Moreira, que possuía ao final do século XVIII tão somente 19 cativos.

Após 30 anos havia na localidade 11 plantéis muito grandes, respondendo por quase 5\% das unidades domiciliares jacareienses: o maior deles tinha, neste ano 65 escravos e pertencia a João de Souza de Carvalho. Comparativamente aos anos de 1816, 1822 e 1829, esse plantel é ainda reduzido. Destacava-se nestes dois últimos anos o padre Valério de Alvarenga com 105 escravos em 1822 - primeira vez em que aparece no arrolamento populacional, mas já presente na localidade desde ao menos 1818, quando apareceu no tombamento de bens rústicos com 111 escravos - e 121 escravos em 1825. Essas maiores escravarias estavam todas na Freguesia de Paraibuna.

Em sentido inverso, os pequenos plantéis diminuíram sua participação entre o total de escravistas, passando de 78,8\% em 1798 a 69,5\% em 1825. Os chefes a compor as demais faixas de tamanho do plantel mostraram percentual de participação relativamente constante nos diferentes anos tratados.

Essa mudança na composição das FTP levou a mudança significativa no percentual de cativos encontrados em cada uma delas: até 1811 o percentual máximo observado para os escravos a viver em plantéis muito grandes havia sido de $78,2 \%$ do total deles calculado para o ao de 1807, a partir de 1816, o percentual de cativos nessas maiores escravarias cresceu a olhos visto, sendo sempre superior a $31 \%$. Em 1822, cinco indivíduos tinham em suas mãos mais de um terço $(34,1 \%)$ de toda a população mancípia do município. Tais constatações apontam para uma concentração que podemos considerar forte, medida pelo índice de Gini que foi de 0,58 em 1825 e 1829.

Por outro lado, os livres eram encontrados em número médio de 4,8 por fogo em 1803, 4,1 em 1816, chegando ao final do período com média de 4,3 (1822-25) e 4,2 pessoas por unidade familiar (1829). A média de habitantes livres mais cativos por fogo foi variável entre o mínimo de 4,6 em 1816 e 5,4 dez anos depois. (Tabela I.70) 
Tabela $\mathbf{l . 7 0}$

Variação do número de fogos,

presença de livres e escravos nos domicílios

(Jacareí - 1798 a 1829)

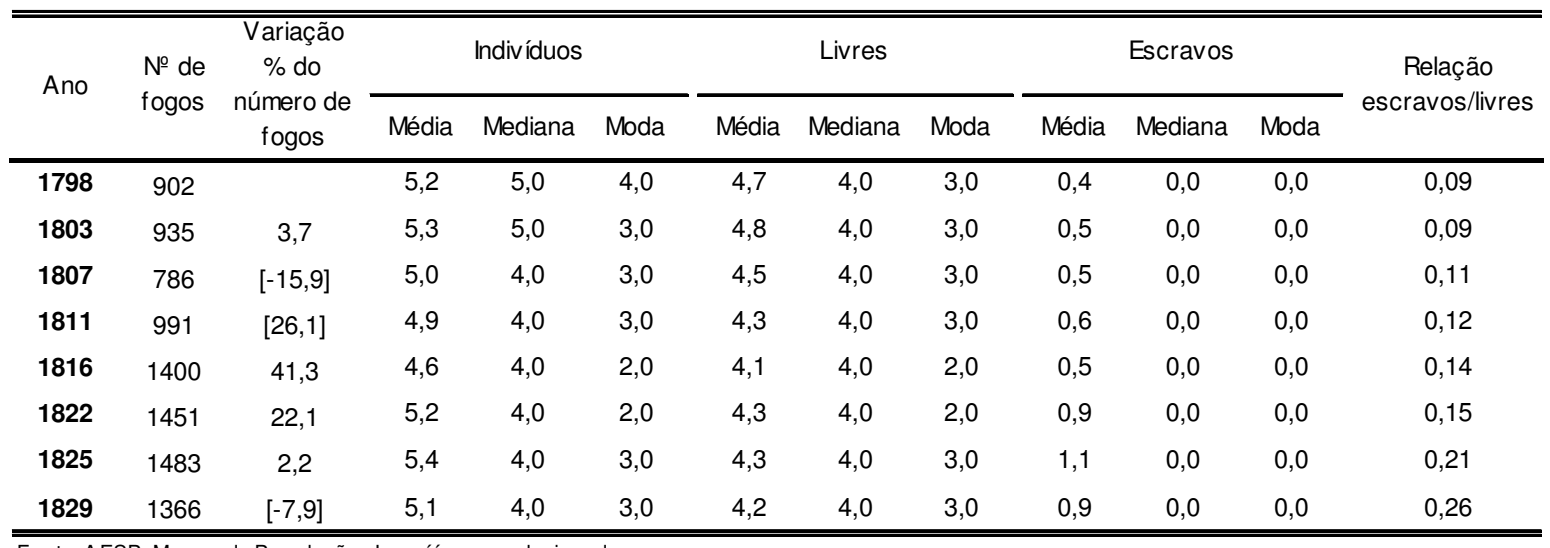

Fonte: AESP, M aços de População, Jacaréí: anos selecionados

Tabela I.71

Indicadores estatísticos para a posse de escravos

(Jacareí - 1798 a 1829)

\begin{tabular}{|c|c|c|c|c|c|c|c|c|}
\hline \multirow[b]{2}{*}{ Estatísticas } & \multicolumn{2}{|c|}{1798} & \multicolumn{2}{|c|}{1803} & \multicolumn{2}{|c|}{1807} & \multicolumn{2}{|c|}{1811} \\
\hline & $\begin{array}{c}\text { Total de } \\
\text { fogos }\end{array}$ & $\begin{array}{c}\text { Fogos com } \\
\text { escravos }\end{array}$ & $\begin{array}{c}\text { Total de } \\
\text { fogos }\end{array}$ & $\begin{array}{c}\text { Fogos com } \\
\text { escravos }\end{array}$ & $\begin{array}{c}\text { Total de } \\
\text { fogos }\end{array}$ & $\begin{array}{c}\text { Fogos com } \\
\text { escravos }\end{array}$ & $\begin{array}{c}\begin{array}{c}\text { Total de } \\
\text { fogos }\end{array} \\
\end{array}$ & $\begin{array}{l}\text { Fogos com } \\
\text { escravos }\end{array}$ \\
\hline Média & 0,4 & 3,9 & 0,5 & 4,0 & 0,5 & 4,1 & 0,6 & 4,1 \\
\hline Median & 0,0 & 2,0 & 0,0 & 2,0 & 0,0 & 2,0 & 0,0 & 2,0 \\
\hline Moda & 0,0 & 1,0 & 0,0 & 1,0 & 0,0 & 1,0 & 0,0 & 1,0 \\
\hline Desvio padrão & 1,8 & 4,0 & 2,1 & 4,5 & 2,1 & 4,2 & 2,2 & 4,4 \\
\hline Variância & 3,3 & 15,6 & 4,5 & 19,9 & 4,2 & 18,0 & 4,9 & 19,5 \\
\hline Índice de Gini & 0,951 & 0,417 & 0,932 & 0,489 & 0,931 & 0,475 & 0,928 & 0,504 \\
\hline Máximo & \multicolumn{2}{|c|}{19,0} & \multicolumn{2}{|c|}{34,0} & \multicolumn{2}{|c|}{30,0} & \multicolumn{2}{|c|}{25,0} \\
\hline \multirow[b]{2}{*}{ Estatísticas } & \multicolumn{2}{|c|}{1816} & \multicolumn{2}{|c|}{1822} & \multicolumn{2}{|c|}{1825} & \multicolumn{2}{|c|}{1829} \\
\hline & $\begin{array}{c}\text { Total de } \\
\text { fogos }\end{array}$ & $\begin{array}{c}\text { Fogos com } \\
\text { escravos }\end{array}$ & $\begin{array}{c}\text { Total de } \\
\text { fogos }\end{array}$ & $\begin{array}{c}\text { Fogos com } \\
\text { escravos }\end{array}$ & $\begin{array}{c}\text { Total de } \\
\text { fogos }\end{array}$ & $\begin{array}{c}\text { Fogos com } \\
\text { escravos }\end{array}$ & $\begin{array}{c}\text { Total de } \\
\text { fogos }\end{array}$ & $\begin{array}{l}\text { Fogos com } \\
\text { escravos }\end{array}$ \\
\hline Média & 0,7 & 4,9 & 0,9 & 5,9 & 1,1 & 6,2 & 1,0 & 6,0 \\
\hline Moda & 0,0 & 2,0 & 0,0 & 3,0 & 0,0 & 3,0 & 0,0 & 3,0 \\
\hline Mediana & 0,0 & 1,0 & 0,0 & 1,0 & 0,0 & 1,0 & 0,0 & 1,0 \\
\hline Desvio padrão & 3,8 & 9,4 & 4,4 & 10,0 & 5,4 & 11,6 & 4,6 & 9,9 \\
\hline Variância & 14,7 & 88,0 & 19,6 & 100,1 & 29,1 & 135,2 & 21,3 & 97,7 \\
\hline Índice de Gini & 0,941 & 0,567 & 0,932 & 0,565 & 0,927 & 0,583 & 0,930 & 0,585 \\
\hline Máximo & \multicolumn{2}{|c|}{108,0} & \multicolumn{2}{|c|}{105,0} & \multicolumn{2}{|c|}{121,0} & \multicolumn{2}{|c|}{66,0} \\
\hline
\end{tabular}

Fonte: AESP, M aços de População, Jacareí: anos selecionados 
Tabela $\mathbf{I . 7 2}$

Distribuição de escravistas e escravos

de acordo com faixas de tamanho dos plantéis

(Jacareí - 1799 a 1829)

\begin{tabular}{|c|c|c|c|c|c|c|c|c|}
\hline \multirow{3}{*}{ FTP } & \multicolumn{4}{|c|}{1798} & \multicolumn{4}{|c|}{1803} \\
\hline & \multicolumn{2}{|c|}{ Escravistas } & \multicolumn{2}{|c|}{ Escravos } & \multicolumn{2}{|c|}{ Escravistas } & \multicolumn{2}{|c|}{ Escravos } \\
\hline & № & $\%$ & № & $\%$ & № & $\%$ & № & $\%$ \\
\hline 1 a 5 & 82 & 78,8 & 176 & 43,6 & 95 & 76,0 & 196 & 39,4 \\
\hline 6 a 10 & 14 & 13,5 & 111 & 27,5 & 24 & 19,2 & 186 & 37,3 \\
\hline 11 a 20 & 8 & 7,7 & 117 & 29,0 & 5 & 4,0 & 82 & 16,5 \\
\hline Acima 20 & - & - & - & - & 1 & 0,8 & 34 & 6,8 \\
\hline \multirow[t]{2}{*}{ Total } & 104 & 100,0 & 404 & 100,0 & 125 & 100,0 & 498 & 100,0 \\
\hline & \multicolumn{4}{|c|}{1811} & \multicolumn{4}{|c|}{1816} \\
\hline \multirow[t]{2}{*}{ FTP } & \multicolumn{2}{|c|}{ Escravistas } & \multicolumn{2}{|c|}{ Escravos } & \multicolumn{2}{|c|}{ Escravistas } & \multicolumn{2}{|c|}{ Escravos } \\
\hline & № & $\%$ & № & $\%$ & № & $\%$ & № & $\%$ \\
\hline 1 a 5 & 110 & 76,9 & 235 & 40,0 & 149 & 78,0 & 331 & 35,9 \\
\hline 6 a 10 & 21 & 14,7 & 163 & 27,7 & 27 & 14,1 & 201 & 21,8 \\
\hline 11 a 20 & 11 & 7,7 & 165 & 28,1 & 8 & 4,2 & 102 & 11,1 \\
\hline Acima 20 & 1 & 0,7 & 25 & 4,3 & 7 & 3,7 & 287 & 31,2 \\
\hline Total & 143 & 100,0 & 588 & 100,0 & 191 & 100,0 & 921 & 100,0 \\
\hline \multirow{3}{*}{ FTP } & \multicolumn{4}{|c|}{1825} & \multicolumn{4}{|c|}{1829} \\
\hline & \multicolumn{2}{|c|}{ Escravistas } & \multicolumn{2}{|c|}{ Escravos } & \multicolumn{2}{|c|}{ Escravistas } & \multicolumn{2}{|c|}{ Escravos } \\
\hline & № & $\%$ & № & $\%$ & № & $\%$ & № & $\%$ \\
\hline 1 a 5 & 180 & 69,5 & 420 & 25,6 & 163 & 71,2 & 376 & 29,0 \\
\hline 6 a 10 & 44 & 17,0 & 333 & 20,3 & 39 & 17,0 & 284 & 21,9 \\
\hline 11 a 20 & 24 & 9,3 & 328 & 20,0 & 16 & 7,0 & 224 & 17,3 \\
\hline Acima 20 & 11 & 4,2 & 560 & 34,1 & 11 & 4,8 & 411 & 31,7 \\
\hline Total & 259 & 100,0 & 1641 & 100,0 & 229 & 100,0 & 1295 & 100,0 \\
\hline
\end{tabular}

Fonte: AESP, M aços de População, Jacareí: anos selecionados

De maneira flutuante, assim como anteriormente apontado para a totalidade dos fogos, alguns desses fogos possuíam, entre seus habitantes livres, agregados. Os fogos com presença de indivíduos agregados eram percentual bastante significativo, tendente em suas flutuações à queda no longo prazo (variação de 25 pontos percentuais em 26 anos): em 1803 44,3\% dos fogos possuíam agregados entre seus membros, percentual que esteve em 30-32\% ente 1807 e 1816, caiu a 24\% em 1822 e a $19 \%$ ao final do período, ainda bastante considerável. 
Tabela 1.73

Peso dos domicílios com e sem agregados não aparentados na população (Jacareí - 1798 a 1829)

\begin{tabular}{cccccccc}
\hline \hline Anos & $\begin{array}{c}\text { \% de fogos } \\
\text { com } \\
\text { agregados }\end{array}$ & $\begin{array}{c}\text { \% de de } \\
\text { agregados }\end{array}$ & $\begin{array}{c}\text { agregados } \\
\text { na } \\
\text { população } \\
\text { total }\end{array}$ & $\begin{array}{c}\text { agregados } \\
\text { na } \\
\text { população } \\
\text { livre }\end{array}$ & $\begin{array}{c}\text { Média de } \\
\text { agregados } \\
\text { (fogos com } \\
\text { agregados) }\end{array}$ & $\begin{array}{c}\text { Média de } \\
\text { agregados } \\
\text { (total de } \\
\text { fogos) }\end{array}$ & $\begin{array}{c}\text { \% de fogos } \\
\text { com agregados } \\
\text { e escravos }\end{array}$ \\
\hline $\mathbf{1 7 9 8}$ & 30,7 & 277 & 5,9 & 6,5 & 1,7 & 0,31 & 4,4 \\
$\mathbf{1 8 0 3}$ & 44,3 & 414 & 8,4 & 9,3 & 2,0 & 0,44 & 5,9 \\
$\mathbf{1 8 0 7}$ & 31,8 & 250 & 6,4 & 7,1 & 1,9 & 0,32 & 4,6 \\
$\mathbf{1 8 1 1}$ & 30,1 & 298 & 6,0 & 6,9 & 1,9 & 0,30 & 4,8 \\
$\mathbf{1 8 1 6}$ & 31,1 & 436 & 6,3 & 7,3 & 2,0 & 0,31 & 4,1 \\
$\mathbf{1 8 2 2}$ & 24,0 & 348 & 4,6 & 5,6 & 1,9 & 0,24 & 4,5 \\
$\mathbf{1 8 2 5}$ & 19,1 & 283 & 3,5 & 4,5 & 1,7 & 0,19 & 3,3 \\
$\mathbf{1 8 2 9}$ & 18,9 & 258 & 3,7 & 4,5 & 1,8 & 0,19 & 4,2 \\
\hline \hline
\end{tabular}

Fonte: AESP, M aços de População, Jacareí: anos selecionados

Assim como a sua presença nos domicílios, o número de agregados variou ao longo do tempo, refletindo essa mudança na participação desses jacareienses na população total e livre da localidade: em 1803, ano em que aparecem em maior medida nos fogos, seu número foi também um dos mais elevados, 443 indivíduos, cuja participação foi de $8,4 \%$ na população total e $9,3 \%$ entre os livres recenseados naquele ano. Já nos anos 1825 e 29, a menor presença de agregados nos fogos e de seu número reduziu sua presença a 3,5-7\% dos habitantes e 4,5\% dos livres em Jacareí.

Apesar destas diferenças, como fogos e número de agregados variaram na mesma direção, a presença deles nos domicílios foi característica e manteve-se, ao longo do período 1798-1829, entre 1,7 (1798 e 1825) e 2 (1803 e 1816) agregados por unidade domiciliar.

Uma maior flutuação da população frente a uma menor flutuação do número de fogos é resultado, em regra, de crescimento natural positivo e migrações de grupos domiciliares com mais de um indivíduo. A observação da origem dos jacareienses pode nos fornecer uma aproximação para aspectos migratórios dessa população. Esses dados, para o total dos livres e para os chefes de fogo, são apresentados na Tabela 1.74 que considera a freguesia de Paraibuna, sendo esta observada em separado na Tabela I.75. 
Tabela $\mathbf{I . 7 4}$

Origem da população livre

(Jacareí - 1798 a 1829)

\begin{tabular}{|c|c|c|c|c|c|c|c|}
\hline \multirow{3}{*}{ Origem } & \multicolumn{7}{|c|}{ População livre } \\
\hline & 1803 & 1807 & 1811 & 1816 & 1822 & 1825 & 1829 \\
\hline & \% (№) & \% (№) & \% (№) & \% (№) & \% (№) & \% (№) & \% (№) \\
\hline Jacareí & $83,6(3034)$ & 96,9 (3336) & $98,6(4228)$ & $85,3(4766)$ & $82,4(5034)$ & 83,1 (5199) & $88,1 \quad(4971)$ \\
\hline Atibaia & $0,0(1)$ & - & - & - & $0,0(2)$ & $0,0(3)$ & - \\
\hline Nazaré & $0,1(4)$ & 0,1 (3) & - & $0,0(2)$ & $0,3(20)$ & $0,0(2)$ & $0,1(8)$ \\
\hline Bragança & $0,0(1)$ & - & - & 0,1 (3) & $0,0(3)$ & 0,0 & - \\
\hline Mogi das Cruzes & $4,0(144)$ & $1,1(38)$ & $0,4(17)$ & $1,8(102)$ & $3,5(213)$ & $3,3(207)$ & $2,4(134)$ \\
\hline Jundiaí & $0,1(2)$ & 0,1 (2) & - & $0,0(2)$ & 0,0 & $0,0(1)$ & $0,0(1)$ \\
\hline São Paulo & $0,5(19)$ & $0,3(9)$ & $0,2(7)$ & $0,4(21)$ & 0,0 & $0,4(22)$ & $0,5(29)$ \\
\hline Taubaté & $0,8(30)$ & $0,3(9)$ & $0,2(7)$ & $5,5(305)$ & $6,5(397)$ & $6,2(386)$ & $3,8(213)$ \\
\hline Cunha & $0,0(1)$ & - & - & $0,2(9)$ & $0,6(34)$ & $0,4(24)$ & $0,3(17)$ \\
\hline Guaratinguetá & $0,1(4)$ & - & - & $0,4(24)$ & $0,4(26)$ & $0,3(16)$ & $0,1(8)$ \\
\hline Pindam onhangaba & $0,1(4)$ & $0,0(1)$ & $0,0(1)$ & $0,4(22)$ & $0,5(28)$ & $0,2(11)$ & $0,1(8)$ \\
\hline São José & $0,4(14)$ & 0,1 (3) & $0,0(1)$ & $0,3(16)$ & 0,0 & $0,6(38)$ & $0,5(27)$ \\
\hline São Luiz & $0,1(5)$ & - & - & $4,1(230)$ & 3,9 (239) & $3,7(230)$ & $2,2(122)$ \\
\hline São Sebastião & - & - & $0,0(2)$ & $0,1(5)$ & 0,0 & $0,2(13)$ & 0,1 (3) \\
\hline $\begin{array}{l}\text { Outras localidades da } \\
\text { capitania/província }\end{array}$ & $1,2(43)$ & $0,3(11)$ & $0,1 \quad(5)$ & $0,2(13)$ & $0,5(29)$ & $0,4(25)$ & $0,5(31)$ \\
\hline $\begin{array}{l}\text { TOTAL da } \\
\text { capitania/província } \\
\text { (exclusive Jacareí) }\end{array}$ & $7,5(272)$ & $2,2(76)$ & $0,9(40)$ & $13,5(754)$ & 16,3 (994) & $15,6(978)$ & $10,7(601)$ \\
\hline $\begin{array}{l}\text { Outras } \\
\text { capitanias/províncias }\end{array}$ & $1,3(46)$ & $0,7(23)$ & $0,3(15)$ & $0,9(50)$ & $1,0(63)$ & $0,9(59)$ & $0,9(51)$ \\
\hline Outros países & $0,2(6)$ & $0,2(6)$ & $0,1(6)$ & $0,3(17)$ & $0,3(20)$ & $0,3(20)$ & $0,3(17)$ \\
\hline TOTAL & $100,0(3630)$ & $100,0(3441)$ & $100,0(4289)$ & $100,0(5587)$ & $100,0(6111)$ & $100,0(6256)$ & $100,0(5640)$ \\
\hline \multirow[t]{2}{*}{$\begin{array}{l}\text { Abrangência das } \\
\text { declarações }\end{array}$} & $75,4 \%$ & $98,3 \%$ & $98,6 \%$ & $93,6 \%$ & $97,9 \%$ & $98,8 \%$ & $99,3 \%$ \\
\hline & \multicolumn{7}{|c|}{ Chefes de fogo } \\
\hline \multirow[t]{2}{*}{ Origem } & 1803 & 1807 & 1811 & 1816 & 1822 & 1825 & 1829 \\
\hline & \% (№) & \% (№) & \% (№) & \% (№) & \% (№) & \% (№) & \% (№) \\
\hline Jacareí & $80,5(728)$ & $89,7(691)$ & $95,7(941)$ & $81,6(1095)$ & $71,4(1044)$ & $73,2(1068)$ & $77,4(1080)$ \\
\hline Atibaia & - & - & - & $0,0(0)$ & $0,1(1)$ & $0,1(2)$ & - \\
\hline Nazaré & $0,3(3)$ & $0,4(3)$ & - & $0,0(0)$ & $0,1(2)$ & - & $0,2(3)$ \\
\hline Bragança & $0,1(1)$ & - & - & $0,1(1)$ & $0,2(3)$ & - & - \\
\hline Mogi das Cruzes & $9,1 \quad(82)$ & $3,8(29)$ & $1,3(13)$ & $3,3(44)$ & $6,0(87)$ & $7,1(103)$ & $4,9(69)$ \\
\hline Jundiaí & $0,1(1)$ & $0,3(2)$ & - & $0,1(2)$ & - & 0,1 (1) & $0,1(1)$ \\
\hline São Paulo & $1,4(13)$ & $0,9(7)$ & $0,4(4)$ & $0,9(12)$ & $1,1(16)$ & $0,8(12)$ & $0,9(13)$ \\
\hline Taubaté & $1,5(14)$ & $0,8(6)$ & $0,2(2)$ & $6,3(85)$ & $7,1(104)$ & 7,7 (113) & $5,5(77)$ \\
\hline Cunha & $0,1(1)$ & - & $0,1(1)$ & $0,4(5)$ & $0,8(12)$ & $0,6(9)$ & $0,2(3)$ \\
\hline Guaratinguetá & $0,3(3)$ & - & - & $0,5(7)$ & $0,6(9)$ & $0,6(9)$ & $0,4(5)$ \\
\hline Pindam onhangaba & $0,4(4)$ & $0,1(1)$ & $0,1(1)$ & $0,8(11)$ & $1,0(15)$ & $0,4(6)$ & $0,4(6)$ \\
\hline São José & - & - & - & $0,1(2)$ & (18) & - & $(10)$ \\
\hline São Luiz & $0,2(2)$ & - & - & $1,9(26)$ & $3,2(47)$ & $3,8(56)$ & 2,3 (32) \\
\hline São Sebastião & 0,0 & - & 0,1 (1) & $0,4(5)$ & $0,8(11)$ & $0,8(11)$ & $0,2(3)$ \\
\hline $\begin{array}{l}\text { Outras localidades da } \\
\text { capitania/província }\end{array}$ & $3,0(27)$ & $1,0(8)$ & $0,3(3)$ & $1,0(14)$ & $1,6(24)$ & $2,0 \quad(29)$ & $0,9(12)$ \\
\hline $\begin{array}{l}\text { TOTAL da } \\
\text { capitania/província } \\
\text { (exclusive Jacareí) }\end{array}$ & $16,7(151)$ & $7,3(56)$ & $2,5(25)$ & $15,9(214)$ & 23,9 (349) & $24,0(351)$ & $16,8(234)$ \\
\hline $\begin{array}{l}\text { Outras } \\
\text { capitanias/províncias }\end{array}$ & $2,2(20)$ & 2,2 (17) & $0,9(9)$ & $1,9(25)$ & $2,7(40)$ & $2,1 \quad(31)$ & 2,3 (32) \\
\hline Outros países & $0,6(5)$ & $0,8(6)$ & $0,8(8)$ & $0,6(8)$ & $1,0(15)$ & $0,7(10)$ & $0,8(11)$ \\
\hline TOTAL & $100,0(904)$ & $100,0(770)$ & $100,0(983)$ & $100,0(1342)$ & $99,0(1448)$ & $100,0(1460)$ & $97,2(1357)$ \\
\hline $\begin{array}{l}\text { Abrangência das } \\
\text { declarações }\end{array}$ & $96,7 \%$ & $98,0 \%$ & $99,2 \%$ & $95,9 \%$ & $99,8 \%$ & $98,4 \%$ & $99,3 \%$ \\
\hline
\end{tabular}


Tabela 1.75

Origem da população livre

(Paraibuna - 1798 a 1829)

\begin{tabular}{|c|c|c|c|c|c|c|c|c|}
\hline \multirow{3}{*}{ Origem } & \multicolumn{4}{|c|}{ População livre } & \multicolumn{4}{|c|}{ Chefes de fogo } \\
\hline & 1816 & 1822 & 1825 & 1829 & 1816 & 1822 & 1825 & 1829 \\
\hline & \% (№) & \% (№) & \% (№) & \% (№) & \% (№) & \% (№) & \% (№) & \% (№) \\
\hline Paraibuna & $27,5(303)$ & $32,8(505)$ & $38,1(637)$ & $35,4(315)$ & $1,9(4)$ & $2,0(6)$ & $5,8(21)$ & - \\
\hline Jacareí & $8,0(88)$ & $7,3(113)$ & $8,2(137)$ & $12,1(108)$ & $12,4(26)$ & $9,5(29)$ & $11,9(43)$ & $18,8(41)$ \\
\hline Atibaia & - & - & $0,1(1)$ & - & - & - & - & - \\
\hline Nazaré & - & $0,1(1)$ & - & - & - & - & - & - \\
\hline Bragança & - & $0,1(1)$ & - & - & - & $0,3(1)$ & - & - \\
\hline Mogi das Cruzes & $8,3(91)$ & $7,2(110)$ & $8,3(139)$ & $6,6(59)$ & $13,3(28)$ & $12,1(37)$ & $15,2(55)$ & $12,4(27)$ \\
\hline Jundiaí & - & - & - & - & - & - & - & - \\
\hline São Paulo & $0,5(5)$ & $1,1(17)$ & $0,9(15)$ & $1,6(14)$ & $1,0(2)$ & $1,6(5)$ & $1,7(6)$ & $2,8(6)$ \\
\hline Taubaté & $25,9(285)$ & $23,9(367)$ & 22,2 (372) & $21,6(192)$ & $35,7(75)$ & $29,7(91)$ & $30,5(110)$ & $30,7(67)$ \\
\hline Cunha & $0,6(7)$ & $2,1(32)$ & 1,3 (22) & $1,9(17)$ & $1,9(4)$ & $3,6(11)$ & $2,2(8)$ & $1,4(3)$ \\
\hline Guaratinguetá & $1,9(21)$ & $1,5(23)$ & $0,8(13)$ & $0,9(8)$ & $3,3(7)$ & $2,3(7)$ & $1,9(7)$ & $2,3(5)$ \\
\hline Pindamonhangaba & $1,9(21)$ & $1,7(26)$ & $0,5(9)$ & $0,6(5)$ & $4,8(10)$ & $4,2(13)$ & $1,1(4)$ & $1,8(4)$ \\
\hline São José & $0,6(7)$ & $2,2(34)$ & $1,8(30)$ & $1,8(16)$ & $1,0(2)$ & $4,2(13)$ & $2,5(9)$ & $2,3(5)$ \\
\hline São Luiz & 20,8 (229) & $15,3(235)$ & $13,4(225)$ & $12,7(113)$ & $12,4(26)$ & $14,4(44)$ & $15,5(56)$ & $13,3(29)$ \\
\hline São Sebastião & $0,4(4)$ & $0,4(6)$ & $0,5(9)$ & $0,3(3)$ & $1,9(4)$ & $1,6(5)$ & $2,2(8)$ & $1,4(3)$ \\
\hline $\begin{array}{l}\text { Outras localidades da } \\
\text { capitania/província }\end{array}$ & $0,6(7)$ & $1,3(20)$ & $1,5(25)$ & $2,1(19)$ & $1,9(4)$ & $3,3(10)$ & $3,3(12)$ & $5,0(11)$ \\
\hline $\begin{array}{l}\text { TOTAL da } \\
\text { capitania/província } \\
\text { (exclusive Jacareí) }\end{array}$ & $61,5(677)$ & $56,7(872)$ & $51,4(860)$ & $50,1(446)$ & $77,1(162)$ & 77,5 (237) & $76,2(275)$ & $73,4(160)$ \\
\hline $\begin{array}{l}\text { Outras } \\
\text { capitanias/províncias }\end{array}$ & $2,1(23)$ & $2,7(42)$ & $2,2(36)$ & $2,1(19)$ & $7,1(15)$ & $9,8(30)$ & $5,3(19)$ & $7,3(16)$ \\
\hline Outros países & $0,8(9)$ & $0,4(6)$ & $0,2(4)$ & $0,2(2)$ & $1,4(3)$ & $1,3(4)$ & $0,8(3)$ & $0,5(1)$ \\
\hline TOTAL & $100,0(1100)$ & $100,0(1538)$ & $100,0(1674)$ & $100,0(890)$ & $100,0(210)$ & $100,0(306)$ & $100,0(361)$ & $100,0(218)$ \\
\hline $\begin{array}{l}\text { Abrangência das } \\
\text { declarações }\end{array}$ & $99,4 \%$ & $100,0 \%$ & $99,1 \%$ & $98,8 \%$ & $98,6 \%$ & $99,7 \%$ & $99,4 \%$ & $100,0 \%$ \\
\hline
\end{tabular}

Fonte: AESP, M aços de População, Jacareí (Paraibuna): anos selecionados

Exclusive indivíduos com naturalidade não identificada

Como já não é novidade, nada foi mencionado a respeito da naturalidade dos indivíduos residentes na Jacareí de 1799, mas para 1803 sabemos que a maioria daqueles com alguma declaração de origem havia nascido ali mesmo, eram 83,6\%. Esse percentual foi variável, tendo decrescido em 1816 e 1825. Em 1811, chegou a 98,9\% (o mesmo percentual da abrangência das declarações neste ano), ou seja, havia poucos forasteiros em Jacareí naquele momento, assim como proporcionalmente poucos havia em 1829, quando 98,8\% declaram serem naturais da própria localidade.

Entre os forasteiros destacam-se os naturais da vizinha Taubaté, cuja participação na composição da população jacareiense saltou de 0,2\% em 1811 para 5,5\% (305 pessoas) após cinco anos e 6,5\% (397 indivíduos) passados seis anos mais. Ao final do período os taubateanos eram 3,8\% dos habitantes de Jacareí com a freguesia de Paraibuna. Esses dados estariam indicando importante migração no sentido Taubaté - 
Jacareí ocorrida, especialmente, entre 1811 e 1816. Esse afluxo populacional coincide com a criação de Paraibuna como freguesia, e incentivos como a existência de terras devolutas ainda no Oitocentos para aquela região (cf. capítulo III), entre outros, deveriam ser atrativo para a mudança para aquelas paragens. Eram em número de 285 (93,4\%) os taubateanos descritos na lista de Paraibuna, o que corresponde a 25,7\% dos livres com declaração de origem na localidade.

Em 1816, maior participação em Paraibuna era devida apenas aos naturais da própria freguesia que eram tão somente $27 \%$. Outros $20,7 \%$ dos livres em Paraibuna eram vindos de São Luiz do Paraitinga, outra das divisas da localidade. Considerada Jacareí com Paraibuna a participação dos naturais de São Luiz havia passado de inexistente em 1811 a $4,1 \%$ dos moradores livres da vila e seu termo em 1816, um acréscimo de 230 indivíduos, à exceção de um, todos encontrados em Paraibuna.

Uma terceira vila parece ter seguido o mesmo caminho: Mogi das Cruzes, igualmente vizinha. Entre 1811 e 1822, sua participação foi de 0,4\% a 3,9\%. Esta, uma migração mais "tradicional", posto terem sido os mogianos $4 \%$ dos habitantes com origem arrolada em Jacareí no ano de 1803.

Considerados somente os chefes de fogo, observamos serem estes em maior medida que o total da população livre oriundos de outras localidades, mas seguindo o mesmo movimento, com ampliação da participação a partir de 1816, quando os habitantes com declaração de naturalidade relativa a outras partes da capitania depois província de São Paulo chegaram a 15,9\% conta 2,5\% verificados para 1811, subindo a $24 \%$ em 1822 e 1825. Entre eles, acompanhando o observado para a população livre em seu conjunto, temos maior participação de migrantes de Taubaté, Mogi das Cruzes e São Luiz, nesta ordem, novamente a partir de 1816.

Parte majoritária desses forasteiros estava em Paraibuna, onde apenas 1,9\% dos fogos em 1816 e 5,8\% em 1825 eram cabeceados por indivíduos declarados naturais de Paraibuna, acrescidos a eles aqueles declarados jacareienses, esse percentual eleva-se a $14,3 \%$ em 1816 e 17,7\% em 1825, ainda uma participação bastante reduzida, mas compreensível, posto ser bastante recente, como sabemos, a ocupação da área relativa a Paraibuna.

Somados, os chefes provenientes de Taubaté, Mogi e Paraitinga eram 61\% daqueles identificados em Paraibuna em 1816 e 1825 (em 1822 o percentual foi calculado em $56 \%$ ); o que corresponde a $9,6 \%$ dos chefes considerada Jacareí mais Paraibuna naquele primeiro ano de 1816. Neste ano, 19 indivíduos chefes de domicilio oriundos de Taubaté a viver em Paraibuna declaram ser "morador novo", número que correspondia a 
$9 \%$ dos fogos arrolados e a $25,3 \%$ daqueles chefiados por taubateanos na freguesia naquele ano. Habitavam estas unidades domiciliares 45 livres e nenhum cativo.

Para Paraibuna, também merece realce o percentual de indivíduos de outras províncias como chefes de fogo, que a partir do quarto lustro do Oitocentos elevaram sua participação a 7,1\% (1816) e 9,8\%(1822).

A sua vez, podemos aventar através da observação das idades, características de possíveis crescimentos naturais positivos, especialmente através de faixas etárias jovens, indicativas, em sendo elevadas, de altas taxas de natalidade. Este o caso de Jacareí/Paraibuna, como se pode observar nas pirâmides etárias da localidade que, como sabido, ademais das faixas etárias apresenta proporções para os sexos.

\section{Gráfico I.36}

\section{Pirâmides etárias da população livre}

(Jacareí - 1798 a 1829)

1798

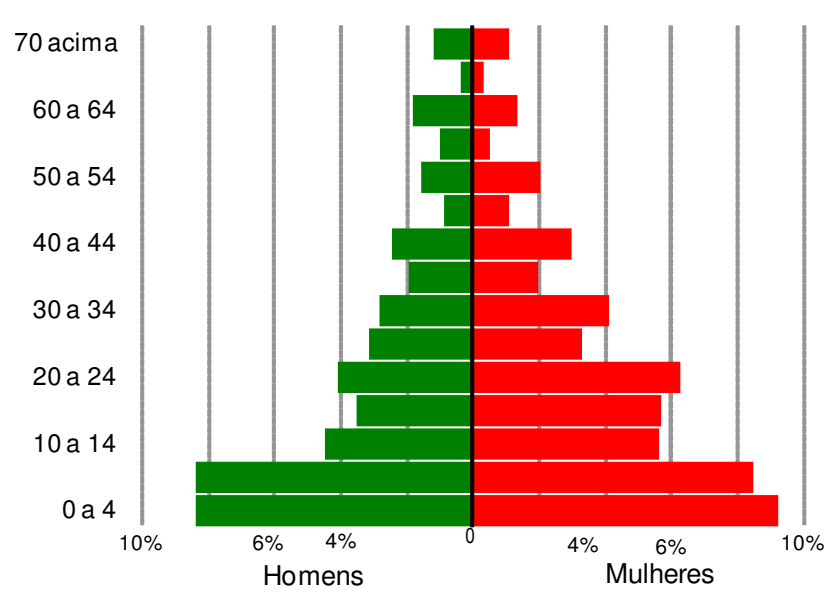




\section{3}

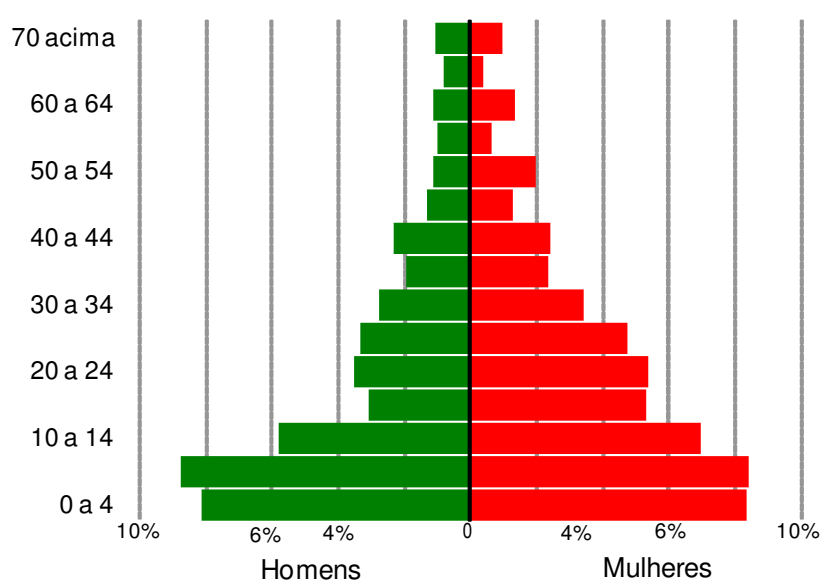

1807

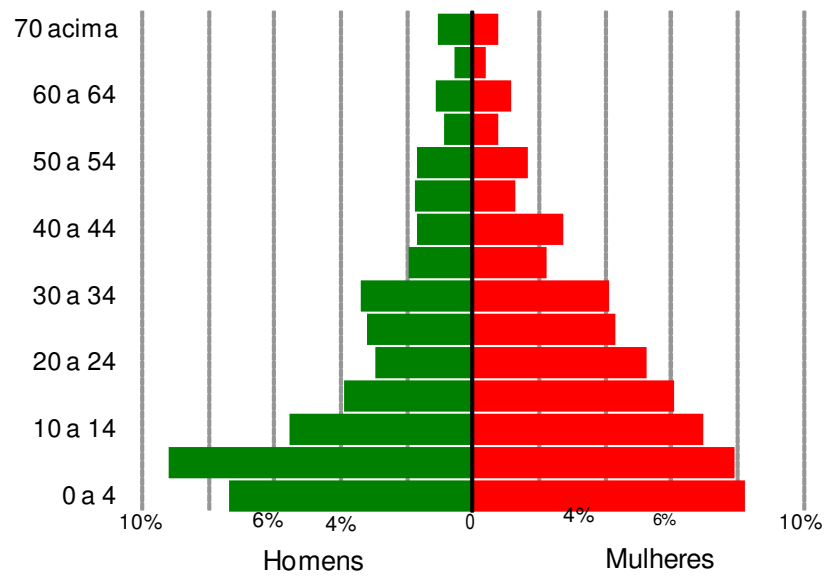

1811

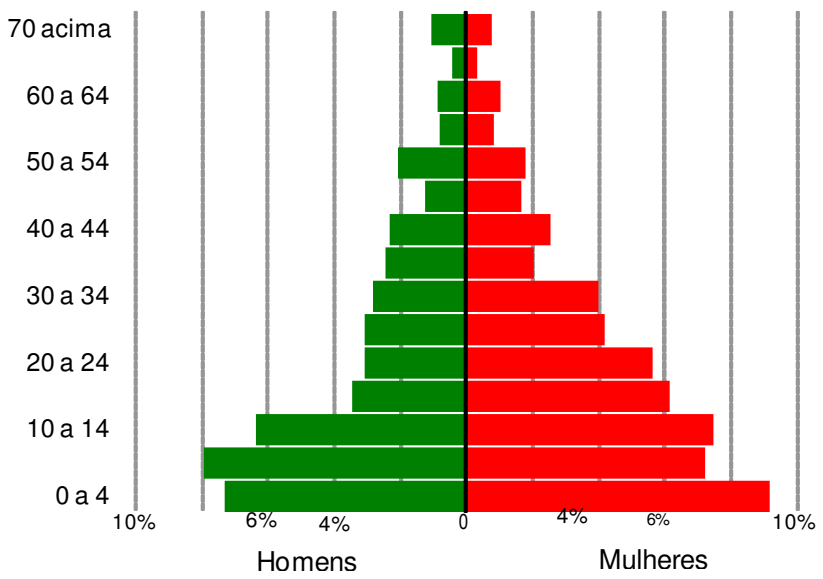


1816

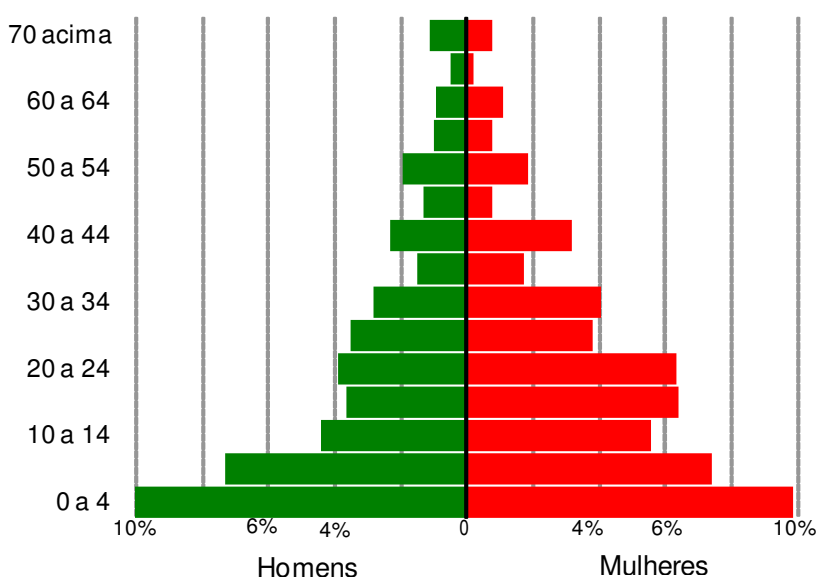

1822

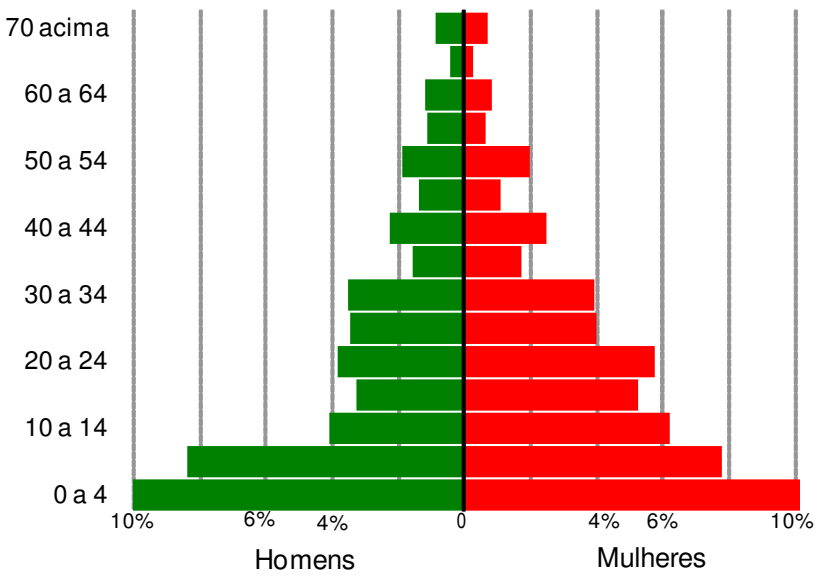

1825

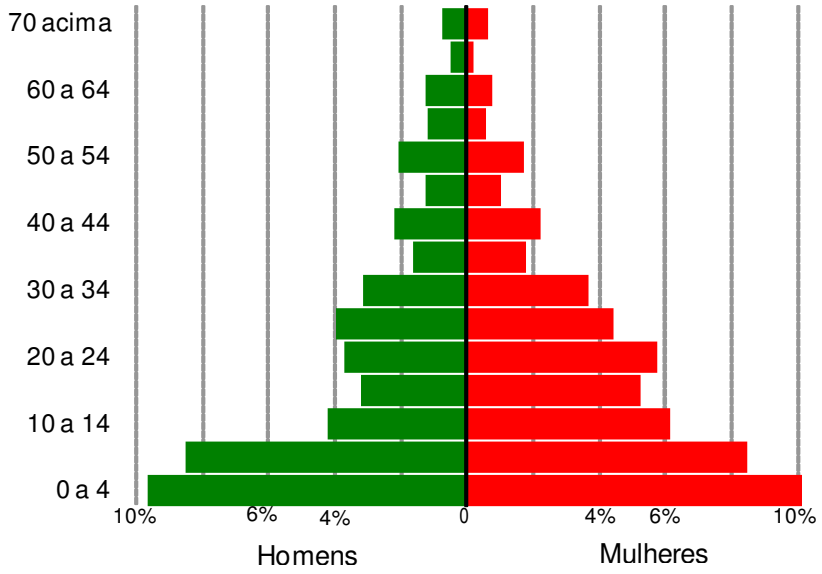




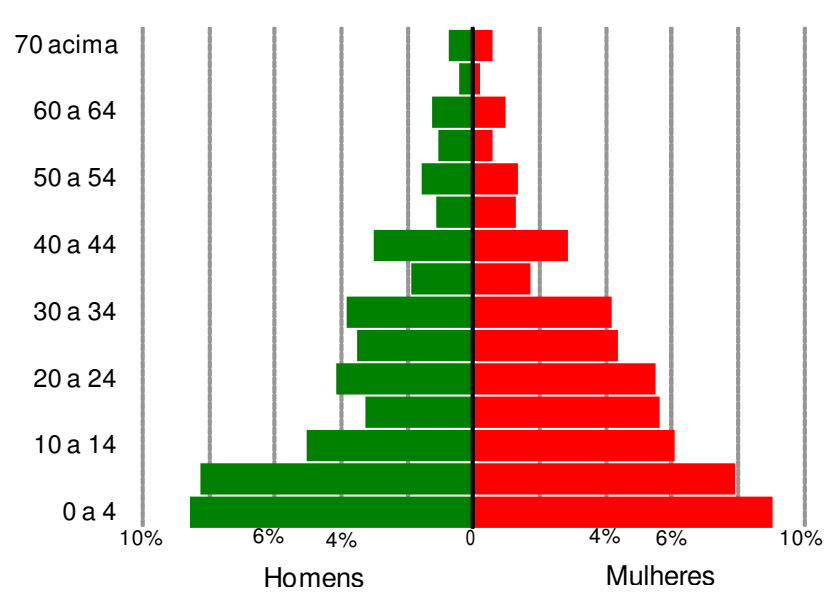

Como destacado, as pirâmides entre 1798 e 1829 mostram alargadas bases, com percentuais de indivíduos de até nove anos de idade apresentando menores percentuais em 1807 e 1811 (32,7\% e 31,6\%) e os maiores percentuais em 1816 e 1822 (36,\% e $36,8 \%$ ). Se considerada também a faixa etária seguinte, o percentual sobe ao mínimo de $44,5 \%$ em 1798, equivalente ao calculado para $1811(44,6 \%)$ e 1829 (44,9\%), sendo o menor percentual encontrado em 1825: 47,1\% dos jacareienses com até 14 anos de idade. No outro extremo o cume apresenta-se estreito caracterizando, junto com uma grande base, uma pirâmide típica de populações jovens.

Para Jacareí encontramos, em alguns anos, faixas etárias mais pronunciadas que a faixa etária imediatamente anterior. Esta situação foi mais válida para idades a partir dos 30 anos, sendo sempre mais consideráveis as faixas etárias que incluem idades com final zero $(30,40,50,60$ anos). Ao que parece, houve preferência por parte dos responsáveis pela feitura dos arrolamentos populacionais por estas idades, como já haviam anotado, em análise de listas nominativas Nozoe e Costa (1991): "Por ocasião da feitura do levantamento, ou da inclusão de moradores na lista, explicitava-se uma visível preferência por idades com terminação 0".

Chama atenção a pirâmide construída a partir dos dados levantados para 1811, ano em que as razões de sexo são bastante favoráveis às mulheres, consideradas as crianças de até quatro anos (razão de 79,6), idade em que esperávamos encontrar equilíbrio entre os sexos. Neste mesmo ano há uma clara redução na população masculina de 15 a 34 anos, cujas faixas qüinqüenais apresentam percentuais próximos e têm os seguintes números para homens considerados para cem mulheres: 56,4 para a 
faixa de 15 a 19 anos, 54,3 para indivíduos de 20 a 24 anos, subido a 73,5\% para aqueles com 25 a 29 anos e 70,5 na faixa etária seguinte.

Para os demais anos, as razões de sexo nas faixas etárias a partir dos 15 e até os 35-39 anos foram aquelas que apresentaram menores razões de sexo, sendo assim sempre superior o número de mulheres ao número de homens, ainda que a proporção fosse bem mais igualitária para aqueles de até 14 anos.

Ainda que em diferentes medidas, a superioridade numérica apontada para faixas etárias específicas refletem o ocorrido em Jacareí e seu termo: maioria feminina, vide Tabela I.76. Os jacareienses sempre apresentaram razão entre os sexos favorável às mulheres e em proporções não muito variáveis. Elas responderam por percentuais calculados entre $52,3 \%$ (1829) e 54,8\% (1811), diferença de 2,5 pontos percentuais devida às distintas taxas de variação dos dois sexos que ocorreu, todavia, sempre no mesmo sentido. A menor proporção de mulheres correspondia à relação 91,1 homens para cada grupo de cem mulheres, e a maior correspondia a 82,6 homens para cem mulheres.

\section{Tabela $\mathbf{I . 7 6}$}

Composição da população livre por sexo

(Jacareí - 1798 a 1829)

\begin{tabular}{|c|c|c|c|c|c|c|c|c|}
\hline \multirow{3}{*}{ Anos } & \multicolumn{5}{|c|}{ População Livre } & \multicolumn{3}{|c|}{ Chefes de fogo } \\
\hline & \multicolumn{2}{|c|}{ Homens } & \multicolumn{2}{|c|}{ Mulheres } & \multirow{2}{*}{$\begin{array}{l}\text { Razão de } \\
\text { sexo }\end{array}$} & \multirow{2}{*}{$\begin{array}{c}\text { Homens } \\
\text { \% (№) }\end{array}$} & \multirow{2}{*}{$\begin{array}{c}\text { Mulheres } \\
\text { \% (№) }\end{array}$} & \multirow{2}{*}{$\begin{array}{l}\text { Razão de } \\
\text { sexo }\end{array}$} \\
\hline & \% (№) & $\begin{array}{c}\text { Variação } \\
\%\end{array}$ & \% (№) & $\begin{array}{c}\text { Variação } \\
\%\end{array}$ & & & & \\
\hline 1798 & $46,0(1958)$ & & $54,0(2303)$ & & 85,0 & $85,3(768)$ & $14,7(132)$ & 581,8 \\
\hline 1803 & $46,1(2047)$ & 4,5 & $53,9(2390)$ & 3,8 & 85,6 & $85,3(796)$ & $14,7(137)$ & 581,0 \\
\hline 1807 & $46,3(1619)$ & {$[-20,9]$} & $53,7(1875)$ & {$[-21,5]$} & 86,3 & $81,0(637)$ & $19,0(149)$ & 427,5 \\
\hline 1811 & $45,2(1965)$ & {$[21,4]$} & $54,8(2379)$ & {$[26,9]$} & 82,6 & $87,0(861)$ & $13,0(129)$ & 667,4 \\
\hline 1816 & $46,6(2782)$ & 41,6 & $53,4(3186)$ & 33,9 & 87,3 & $87,5(1225)$ & $12,5(175)$ & 700,0 \\
\hline 1822 & $47,4(2951)$ & 6,1 & $52,6(3281)$ & 3,0 & 89,9 & $87,4(1264)$ & $12,6(183)$ & 690,7 \\
\hline 1825 & $47,1(2979)$ & 0,9 & $52,9(3340)$ & 1,8 & 89,2 & $87,5(1296)$ & $12,5(185)$ & 700,5 \\
\hline 1829 & $47,7(2686)$ & {$[-9,8]$} & $52,3(2947)$ & {$[-11,8]$} & 91,1 & $86,9(1184)$ & $13,1(179)$ & 661,5 \\
\hline
\end{tabular}

Exclusive indivíduos com sexo não identificado e fogos com chefe não residente em Jacareí e/ou não identificado Fonte: AESP, Maços de População, Jacareí: anos selecionados

Por outro lado, diferenciação de grande monta ocorria entre o número de homens e mulheres que assumiram a condição de chefes de domicílio, apresentados na Tabela I.77. A maioria absoluta dos fogos era encabeçada, como já não nos é novidade, por homens. Em 1807 eles responderam por 81\% dos chefes de domicílio (razão de 427,5), 
nos anos anteriores haviam sido 85,3\% (razão aproximada de 581) e entre 1811 e 1829 estavam perto de $87 \%$ (intervalo de $86,9 \%$ a $87,5 \%$ ).

Também era majoritariamente masculina, como era de se esperar, a parcela dentre esses chefes de domicílios composta por indivíduos donos de escravos. 0 percentual devido aos homens variou dentro do intervalo de $82,2 \%$ (1825) e $86,4 \%$ (1807), correspondente, respectivamente, a razões de sexo de 463 a 635,7. Nestes anos de 1807 e 1825, para o total dos chefes de fogos foram apuradas razões de 427,5 e 690,7 . Já a idade para os chefes em fogos com presença mancípia foi pouco variável e esteve ao redor dos 45 anos.

Tabela 1.77

Sexo e idade dos chefes de fogo com escravos (Jacareí - 1799 a 1829)

\begin{tabular}{ccccccccc}
\hline \hline & $\mathbf{1 7 9 8}$ & $\mathbf{1 8 0 3}$ & $\mathbf{1 8 0 7}$ & $\mathbf{1 8 1 1}$ & $\mathbf{1 8 1 6}$ & $\mathbf{1 8 2 2}$ & $\mathbf{1 8 2 5}$ & $\mathbf{1 8 2 9}$ \\
\hline Homens (\%) & 82,7 & 83,1 & 86,4 & 84,6 & 84,8 & 86,0 & 82,2 & 83,8 \\
Mulheres (\%) & 17,3 & 16,9 & 13,6 & 15,4 & 15,2 & 14,0 & 17,8 & 16,2 \\
Razão de sexo & 477,8 & 490,5 & 635,7 & 550,0 & 558,6 & 612,9 & 463,0 & 516,2 \\
\hline Idade média & 47,4 & 45,7 & 46,3 & 45,7 & 44,5 & 47,2 & 45,6 & 45,6 \\
Idade mínima & 19 & 18 & 20 & 20 & 12 & 19 & 15 & 20 \\
Idade máxima & 102 & 83 & 83 & 88 & 97 & 94 & 90 & 88 \\
\hline \hline
\end{tabular}

Fonte: AESP, M aços de População, Jacareí: anos selecionados

Como se pode notar na Tabela I.78, as mulheres assumiam a condição de chefiar seu núcleo doméstico, mormente, quando viúvas. Os mais baixos percentuais para viúvas foram encontrados nos anos de 1807 a 1816, em que foram 60,1\%, 56,6\% e 50,3\%, respectivamente em cada um deles. Anteriormente, 1803, sua participação havia sido bem mais elevada, $69,3 \%$.

Se não menos de $86,3 \%$ (1807) dos chefes do sexo masculino eram casados, para o sexo oposto este valor, em seu máximo, atingiu 16,0\% (1816 e 1829). Assim como era bastante diferente entre os sexos a participação de solteiros; enquanto para elas 0 percentual foi de ao menos $21 \%$ (1829) - bastante variável ao longo do tempo, chegando aos $35,8 \%$ em 1807 - para eles não chegou a tingir os $8 \%$, tendo chegado perto disto apenas em 1807, quando foi calculado em $7,6 \%$. 


\section{Tabela I.78}

Composição dos chefes de fogo de acordo com estado conjugal e sexo

- exclusive indivíduos de até 14 anos -

(Jacareí - 1798 a 1829)

\begin{tabular}{|c|c|c|c|c|c|c|c|c|c|}
\hline \multirow{2}{*}{ Anos } & \multicolumn{3}{|c|}{ Homens } & \multicolumn{3}{|c|}{ Mulheres } & \multicolumn{3}{|c|}{ Homens + Mulheres } \\
\hline & $\begin{array}{c}\text { Casados } \\
\%\end{array}$ & $\begin{array}{c}\text { Solteiros } \\
\%\end{array}$ & $\begin{array}{c}\text { Viúvos } \\
\%\end{array}$ & $\begin{array}{c}\text { Casadas } \\
\%\end{array}$ & $\begin{array}{c}\text { Solteiras } \\
\%\end{array}$ & $\begin{array}{c}\text { Viúvas } \\
\%\end{array}$ & $\begin{array}{c}\text { Casados } \\
\%\end{array}$ & $\begin{array}{c}\text { Solteiros } \\
\%\end{array}$ & $\begin{array}{c}\text { Viúvos } \\
\%\end{array}$ \\
\hline 1798 & 90,4 & 5,5 & 4,1 & 11,5 & 26,7 & 61,8 & 78,7 & 8,8 & 12,6 \\
\hline 1803 & 91,0 & 4,7 & 4,3 & 5,8 & 24,8 & 69,3 & 78,5 & 7,6 & 13,9 \\
\hline 1807 & 86,3 & 7,6 & 6,2 & 4,1 & 35,8 & 60,1 & 70,7 & 12,9 & 16,4 \\
\hline 1811 & 92,9 & 3,9 & 3,3 & 12,4 & 31,0 & 56,6 & 82,3 & 7,4 & 10,3 \\
\hline 1816 & 92,0 & 4,3 & 3,7 & 16,0 & 33,7 & 50,3 & 82,1 & 7,8 & 10,1 \\
\hline 1822 & 90,4 & 6,0 & 3,6 & 10,5 & 27,1 & 62,4 & 80,3 & 8,8 & 11,0 \\
\hline 1825 & 93,0 & 4,0 & 3,0 & 12,0 & 26,6 & 61,4 & 82,9 & 6,9 & 10,3 \\
\hline 1829 & 92,7 & 3,9 & 3,4 & 15,9 & 21,0 & 63,1 & 82,6 & 6,1 & 11,3 \\
\hline
\end{tabular}

A grande diferenciação ente os sexos no que refere ao estado conjugal dos chefes de domicilio é característica desse grupo específico e não representa a realidade da localidade para a totalidade daqueles com ao menos 15 anos de idade, cujos dados são apresentados na Tabela I.79. Ainda que o caractere estado conjugal apareça de maneira diversa entre indivíduos do sexo masculino e feminino, essa diferença encontra-se no nível de importância dos valores e não na ordem de sua representatividade. Assim, havia maioria de casados(as), seguido por solteiros(as) e por último, com pequena representatividade na população observada, os viúvos(as). Considerados homens e mulheres casados em seu conjunto temos percentual crescente ao longo dos anos, tendo saído de $59,7 \%$ em 1798 , chegado a $66,6 \%$ em 1811 e superado os $70 \%$ desde 1816 : destaque para $1825,72,9 \%$.

As mulheres apresentaram percentuais para solteiras e viúvas maiores que os correspondentes para os homens. As jacareienses eram, como adiantado, em sua maior parcela casadas, tendo saído seu percentual de 53,9\% em 1798 para 60,4\% em 1811 e $68,5 \%$ nos dois últimos anos considerados. Esses valores foram entre 13-15 pontos percentuais menores que os apurados para o sexo oposto nos dois primeiro anos em questão, chegou a mais de 18 pontos percentuais de diferença em 1811 (ano, note-se, em que houve a menor participação masculina na população), caindo pela metade na década de 1820. 
Tabela 1.79

Composição da população livre de acordo com estado conjugal e sexo

- exclusive indivíduos de até 14 anos -

(Jacareí - 1798 a 1829)

\begin{tabular}{|c|c|c|c|c|c|c|c|c|c|}
\hline \multirow{2}{*}{ Anos } & \multicolumn{3}{|c|}{ Homens } & \multicolumn{3}{|c|}{ Mulheres } & \multicolumn{3}{|c|}{ Homens + Mulheres } \\
\hline & $\begin{array}{c}\text { Casados } \\
\%\end{array}$ & $\begin{array}{c}\text { Solteiros } \\
\%\end{array}$ & $\begin{array}{c}\text { Viúvos } \\
\%\end{array}$ & $\begin{array}{c}\text { Casadas } \\
\%\end{array}$ & $\begin{array}{c}\text { Solteiras } \\
\%\end{array}$ & $\begin{array}{c}\text { Viúvas } \\
\%\end{array}$ & $\begin{array}{c}\text { Casados } \\
\%\end{array}$ & $\begin{array}{c}\text { Solteiros } \\
\%\end{array}$ & $\begin{array}{c}\text { Viúvos } \\
\%\end{array}$ \\
\hline 1798 & 67,0 & 30,0 & 3,0 & 53,9 & 38,8 & 7,3 & 59,7 & 34,9 & 5,4 \\
\hline 1803 & 70,4 & 25,6 & 4,1 & 55,3 & 35,0 & 9,7 & 61,8 & 30,9 & 7,2 \\
\hline 1807 & 65,2 & 29,9 & 5,0 & 51,4 & 38,5 & 10,1 & 57,5 & 34,7 & 7,9 \\
\hline 1811 & 78,8 & 18,2 & 3,0 & 60,4 & 31,1 & 8,5 & 66,6 & 27,2 & 6,2 \\
\hline 1816 & 78,9 & 17,5 & 3,5 & 64,2 & 27,4 & 8,3 & 71,4 & 21,9 & 6,7 \\
\hline 1822 & 75,2 & 21,8 & 3,0 & 66,3 & 25,2 & 8,5 & 70,4 & 23,7 & 5,9 \\
\hline 1825 & 77,8 & 19,4 & 2,8 & 68,6 & 23,1 & 8,2 & 72,9 & 21,4 & 5,7 \\
\hline 1829 & 76,9 & 20,2 & 2,9 & 68,5 & 22,1 & 9,4 & 72,4 & 21,3 & 6,4 \\
\hline
\end{tabular}

Fonte: AESP, M aços de População, Jacareí: anos selecionados

Exclusive indivíduos com estado conjugal e/ou sexo não identificado

Exclui individuos de 0 a 14 anos

Diferente das mulheres que tiveram o percentual de casadas aumentado paulatinamente, para os homens este percentual não mostrou flutuação clara ao longo dos anos - eram 67\% inicialmente, 65,2\% em 1807, praticamente 79\% em 1811 e 1816 e $76,9 \%$ ao final do período. Conseqüentemente, mulheres solteiras e viúvas superavam os homens nestas condições: solteiras foram de 38,8\% em 1798 a 22,1\% após três décadas e viúvas eram, em seu mínimo, 7,3\% (1798); homens solteiros estavam entre 17,5\% (1816) e 30\% (1798), e os viúvos atingiram sua maior participação com um 5\% em 1807.

Observando, para a população livre, as idades de acordo com sexo e estado conjugal, temos as estatísticas apresentadas na Tabela I.80. Homens mais mulheres casados apresentaram idades médias em pequena medida decrescentes que foram de $36,5 \%$ em 1798 a 33,9 em 1829, sendo que na composição desses valores mulheres entraram com idades, em regra, inferiores, sendo em média não superior aos 33,5 anos (1798), enquanto os jacareienses do sexo masculino tinham idades que variaram entre 36,4 anos (1816) e 39,6 anos (1798), diferença entre seis e sete anos. Modas e medianas estiveram sempre abaixo da média. 
Tabela 1.80

Estatísticas para a idade dos livres de acordo com o estado conjugal e sexo (Jacareí - 1798 a 1829)

\begin{tabular}{|c|c|c|c|c|c|c|c|c|c|c|c|c|}
\hline \multirow[b]{3}{*}{ Idade } & \multicolumn{3}{|c|}{1798} & \multicolumn{3}{|c|}{1803} & \multicolumn{3}{|c|}{1807} & \multicolumn{3}{|c|}{1811} \\
\hline & \multicolumn{3}{|c|}{ Solteiros } & \multicolumn{3}{|c|}{ Solteiros } & \multicolumn{3}{|c|}{ Solteiros } & \multicolumn{3}{|c|}{ Solteiros } \\
\hline & Homens & Mulheres & $\begin{array}{l}\text { Homens + } \\
\text { Mulheres }\end{array}$ & Homens & Mulheres & $\begin{array}{l}\text { Homens + } \\
\text { Mulheres }\end{array}$ & Homens & Mulheres & $\begin{array}{l}\text { Homens + } \\
\text { Mulheres }\end{array}$ & Homens & Mulheres & $\begin{array}{l}\text { Homens + } \\
\text { Mulheres }\end{array}$ \\
\hline$\% 15$ ou mais anos & 25,6 & 34,0 & 30,2 & 20,9 & 31,3 & 26,4 & 24,7 & 34,0 & 29,6 & 16,8 & 29,1 & 23,7 \\
\hline$\% 50$ ou mais anos & 1,7 & 3,4 & 2,7 & 1,4 & 3,3 & 2,4 & 2,5 & 3,8 & 3,2 & 1,5 & 2,8 & 2,2 \\
\hline \multirow{2}{*}{$\begin{array}{l}\text { Estatísticas para } \\
\text { idade }\end{array}$} & \multicolumn{3}{|c|}{ Casados } & \multicolumn{3}{|c|}{ Casados } & \multicolumn{3}{|c|}{ Casados } & \multicolumn{3}{|c|}{ Casados } \\
\hline & Homens & Mulheres & $\begin{array}{l}\text { Homens + } \\
\text { Mulheres }\end{array}$ & Homens & Mulheres & $\begin{array}{l}\text { Homens + } \\
\text { Mulheres }\end{array}$ & Homens & Mulheres & $\begin{array}{l}\text { Homens + } \\
\text { Mulheres }\end{array}$ & Homens & Mulheres & $\begin{array}{l}\text { Homens + } \\
\text { Mulheres }\end{array}$ \\
\hline Média & 39,6 & 33,5 & 36,5 & 39,2 & 32,9 & 36,0 & 38,7 & 32,1 & 35,4 & 37,7 & 31,4 & 34,5 \\
\hline Moda & 30,0 & 30,0 & 30,0 & 24,25 e 41 & 26,0 & 24,0 & 31,0 & 30,0 & 30,0 & 30,0 & 20,0 & 30,0 \\
\hline Mediana & 36,5 & 30,0 & 33,0 & 36,0 & 29,5 & 32,0 & 35,0 & 30,0 & 32,0 & 35,0 & 29,0 & 31,0 \\
\hline \multirow[t]{2}{*}{$\% 50$ ou mais anos } & 28,5 & 14,9 & 21,5 & 24,7 & 13,3 & 18,9 & 23,4 & 10,0 & 16,7 & 23,5 & 10,5 & 16,9 \\
\hline & \multicolumn{3}{|c|}{1816} & \multicolumn{3}{|c|}{1822} & \multicolumn{3}{|c|}{1825} & \multicolumn{3}{|c|}{1829} \\
\hline \multirow[b]{2}{*}{ Idade } & \multicolumn{3}{|c|}{ Solteiros } & \multicolumn{3}{|c|}{ Solteiros } & \multicolumn{3}{|c|}{ Solteiros } & \multicolumn{3}{|c|}{ Solteiros } \\
\hline & Homens & Mulheres & $\begin{array}{l}\text { Homens + } \\
\text { Mulheres }\end{array}$ & Homens & Mulheres & $\begin{array}{l}\text { Homens + } \\
\text { Mulheres }\end{array}$ & Homens & Mulheres & $\begin{array}{l}\text { Homens + } \\
\text { Mulheres }\end{array}$ & Homens & Mulheres & $\begin{array}{l}\text { Homens + } \\
\text { Mulheres }\end{array}$ \\
\hline$\% 15$ ou mais anos & 16,1 & 26,6 & 21,5 & 19,2 & 23,1 & 21,3 & 17,6 & 20,9 & 19,3 & 19,1 & 21,8 & 20,3 \\
\hline$\% 50$ ou mais anos & 1,3 & 2,9 & 2,2 & 1,6 & 2,3 & 1,9 & 1,2 & 1,6 & 1,4 & 1,1 & 1,2 & 1,2 \\
\hline \multirow{2}{*}{$\begin{array}{l}\text { Estatísticas para } \\
\text { idade }\end{array}$} & \multicolumn{3}{|c|}{ Casados } & \multicolumn{3}{|c|}{ Casados } & \multicolumn{3}{|c|}{ Casados } & \multicolumn{3}{|c|}{ Casados } \\
\hline & Homens & Mulheres & $\begin{array}{l}\text { Homens + } \\
\text { Mulheres }\end{array}$ & Homens & Mulheres & $\begin{array}{l}\text { Homens + } \\
\text { Mulheres }\end{array}$ & Homens & Mulheres & $\begin{array}{l}\text { Homens + } \\
\text { Mulheres }\end{array}$ & Homens & Mulheres & $\begin{array}{l}\text { Homens + } \\
\text { Mulheres }\end{array}$ \\
\hline Média & 36,4 & 29,9 & 33,1 & 37,5 & 31,0 & 34,2 & 37,7 & 30,7 & 34,2 & 37,2 & 30,6 & 33,9 \\
\hline Moda & 30,0 & 20,0 & 30,0 & 30,0 & 20,0 & 30,0 & 30,0 & 20,0 & 30,0 & 40,0 & 20,0 & 30,0 \\
\hline Mediana & 32,0 & 27,0 & 30,0 & 33,0 & 28,0 & 30,0 & 34,0 & 27,0 & 30,0 & 34,0 & 28,0 & 30,0 \\
\hline$\% 50$ ou mais anos & 22,5 & 10,5 & 16,5 & 24,5 & 11,9 & 18,1 & 25,6 & 11,7 & 18,5 & 21,8 & 9,6 & 15,5 \\
\hline
\end{tabular}


As estatísticas mencionadas refletem uma estrutura etária em que homens com 50 ou mais anos correspondiam a percentuais entre os homens casados que iam de $21,8 \%$ (1829) a $28,5 \%$ (1799), enquanto as mulheres acima dos 50 anos entre aquelas casadas tiveram sua maior presença identificada em 1799, quando somaram 14,9\%, mais de 13 pontos percentuais ao equivalente masculino. Por outro lado, para os indivíduos acima de 50 anos e solteiros era reduzida a participação, para ambos os sexos, pouco superior, neste caso, para elas: homens apresentaram percentuais entre 1,1\% (1829) e 2,5\% (1807) e para mulheres os percentuais estiveram entre 1,2\% (1829) e 3,8\% (1807).

Por fim, resta-nos verificar a cor dos habitantes livres da vila de Jacareí e sua freguesia do Setecentos às primeiras décadas do século XIX: "Os habitantes de Jacareí podem se dividir em duas classes: os cafuzos, mestiços de negros com índios, e os mamelucos, mestiços de índios com brancos." (D’ORBIGNY, 1976, p.174)

$\mathrm{Na}$ vila em tela, diferentemente do que temos observado para outras localidades em estudo, a flutuação de participação de brancos e não brancos na composição dessa sociedade foi bastante grande. Os não brancos chegaram a superar a participação dos brancos nos dois primeiros lustros do Oitocentos, quando responderam por $66,3 \%$ da população em 1803 e 57-57,5\% em 1807 e 1811; em 1816 caíram a 33,6\%, foram encontrados ao redor de $26,6 \%$ em $1822-25$ e ao final do período foram registrados em percentual inferior a $20 \%$. (cf. Tabela I.81) Decerto as variações na cor da população decorriam das anotações nas listas, não necessariamente da real distribuição de cor da população, afinal o papel aceita aquilo que ali é colocado.

\section{Tabela I.81}

Distribuição da população livre entre brancos e não brancos (Jacareí - 1798 a 1829)

\begin{tabular}{|c|c|c|c|c|c|}
\hline \multirow{3}{*}{ Anos } & \multirow{3}{*}{$\begin{array}{c}\text { Brancos } \\
\text { \% (№) }\end{array}$} & \multicolumn{3}{|c|}{ Não Brancos } & \multirow{3}{*}{$\begin{array}{c}\text { Total: Brancos } \\
\text { + Não brancos } \\
\% \text { (№) }\end{array}$} \\
\hline & & \multirow{2}{*}{$\begin{array}{c}\text { Pardos/Mulatos } \\
\% \text { (№) }\end{array}$} & \multirow{2}{*}{$\begin{array}{c}\text { Negros } \\
\text { \% (№) }\end{array}$} & \multirow{2}{*}{$\begin{array}{l}\text { Total } \\
\text { \% (№) }\end{array}$} & \\
\hline & & & & & \\
\hline 1798 & 78,9 (2908) & $100,0(776)$ & $0,0(0)$ & $21,1(776)$ & $100,0(3684)$ \\
\hline 1803 & 33,7 (1499) & $98,1(2889)$ & $1,9(57)$ & $66,3(2946)$ & $100,0(4445)$ \\
\hline 1807 & 43,0 (1502) & 99,0 (1969) & $1,0(20)$ & $57,0(1989)$ & $100,0(3491)$ \\
\hline 1811 & 42,5 (2229) & $99,4(3002)$ & $0,6(19)$ & $57,5(3021)$ & $100,0(5250)$ \\
\hline 1816 & 66,4 (3961) & $97,9(1965)$ & 2,1 (42) & $33,6(2007)$ & $100,0(5968)$ \\
\hline 1822 & $73,4(4575)$ & $97,5(1620)$ & $2,5(41)$ & $26,6(1661)$ & $100,0(6236)$ \\
\hline 1825 & 73,7 (4666) & $97,6(1623)$ & $2,4(40)$ & $26,3(1663)$ & 100,0 (6329) \\
\hline 1829 & 80,5 (4571) & $95,8(1060)$ & $4,2(46)$ & $19,5(1106)$ & $100,0(5677)$ \\
\hline
\end{tabular}

Fonte: AESP, Maços de População, Jacareí: anos selecionados 
Os negros ou pretos eram praticamente inexistentes nos documentos censitários de Jacareí/Paraibuna em todo o lapso em tela, inclusive naqueles anos em que os não brancos foram mencionados em maior proporção. O maior número deles foi verificado em 1803, 57 indivíduos (1,9\% dos não brancos e 1,3\% do total dos não cativos com cor explicitada) e o maior percentual encontramos em 1829, 4,2\% dos não brancos (correspondente a 46 indivíduos e $0,8 \%$ do total dos livres na localidade). Em 1799 existiam, ainda, seis índios que deixaram de compor a Tabela I.81.

Características demográficas apresentadas para os livres, especialmente aquelas atinentes à composição por sexos e a idade, não se repetiam na mesma medida entre a parcela cativa da população jacareiense.

\section{Gráfico I.37}

\section{Razão de sexo dos cativos de acordo com faixas}

de tamanho dos plantéis

\section{(Jacareí - 1799 a 1829)}

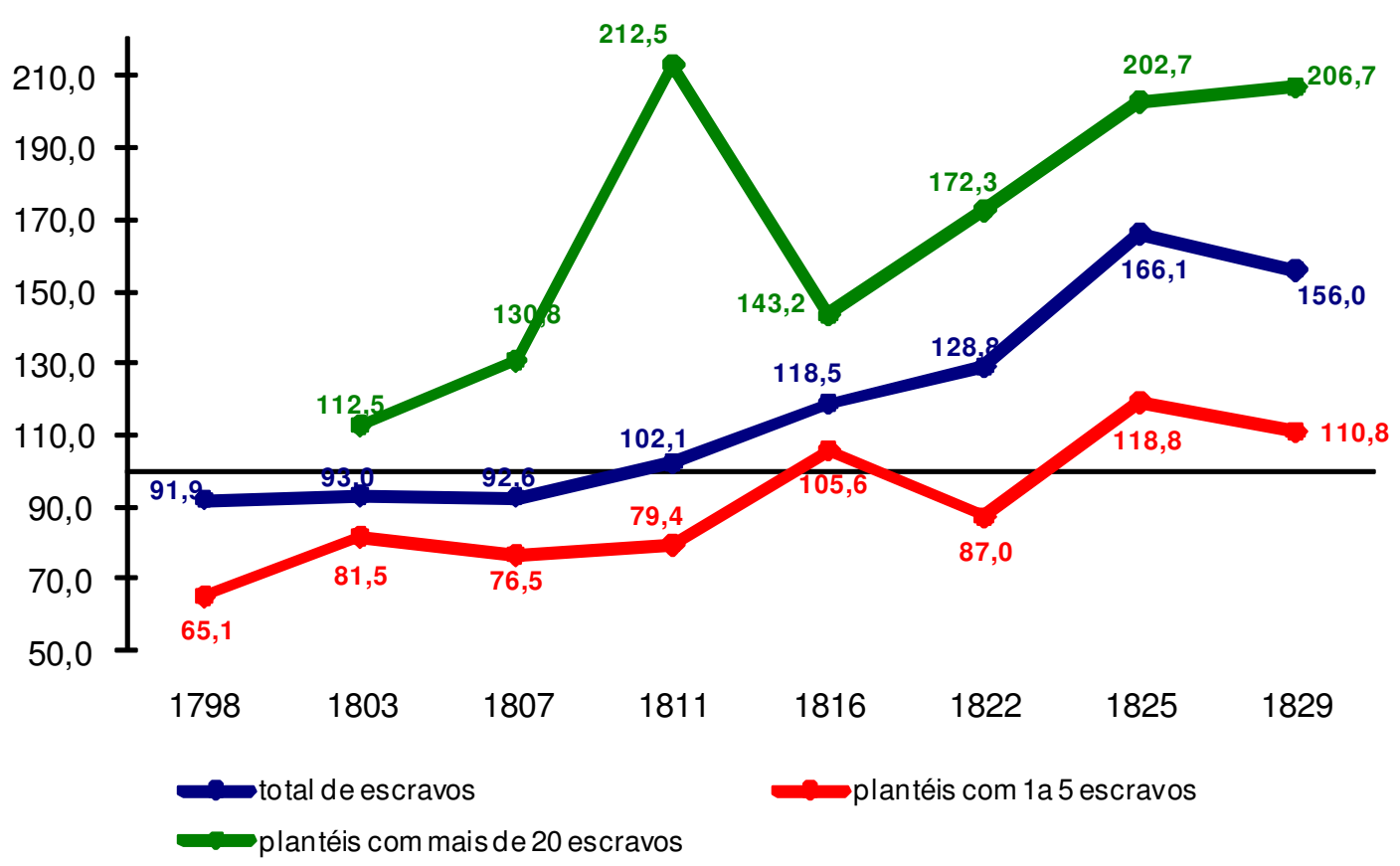

A população cativa, apenas nos primeiros anos considerados apresentou maior número de mulheres comparativamente aos homens, mas em medida que em quase nada se afastava do equilíbrio entre os sexos: 91,9 em 1799, 93 em 1803 e 92,6 em 1803. Em constante crescimento rumo à maior presença proporcional de homens, já em 1811 o número deles havia superado o delas, e em 1816 era de 118,5 o número de homens para 
cada grupo de 100 mulheres, razão alçada a 166,1 em 1825 e 156 no ano seguinte observado, ou seja, era de cerca de $62,5 \%$ e $61 \%$ a participação dos homens entre a população cativa vivendo na Vila de Jacareí e seu termo. (cf. Gráfico I.37)

As mulheres aparecem mais representadas entre os cativos em plantéis com até cinco deles. Para estas pessoas, até 1811 as razões de sexo foram bastante favoráveis às mulheres, ainda que crescentes, saindo de 65,1 em 1798 a 79,4 indivíduos do sexo masculino para cada grupo de 100 escravos do sexo oposto em 1811; em 1825 a proporção situou-se em 118,8, já com maioria masculina, e em 1829 a razão foi de 110,8.

De forma bastante diversa apresentaram-se as razões para os maiores grupos mancípios da localidade; sempre bastante favoráveis aos homens as razões estiveram em ao menos 112,5 (ainda no Setecentos), e em seu limite máximo foi calculada em 212, 5 (1811), ou seja, naquele momento a massa cativa jacareiense era composta por homens na medida de $68 \%$ e mulheres $32 \%$.

As razões de sexo apresentadas para os cativos podem ser visualizadas também nas pirâmides de idades dessa população (Gráfico I.38). A superioridade numérica masculina constatada para as décadas de 1810 e 1820 pode facilmente ser auferida pelo maior volume apresentado pelo lado esquerdo, referente aos homens, em seus gráficos.

\section{Gráfico I.38}

\section{Pirâmides etárias da população escrava}

(Jacareí - 1798 a 1829)

\section{8}

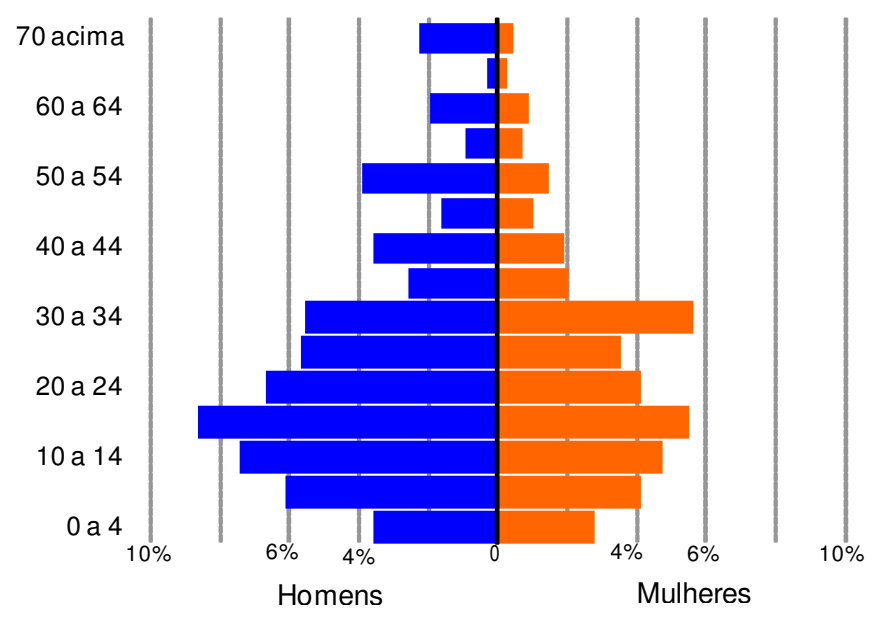


1803

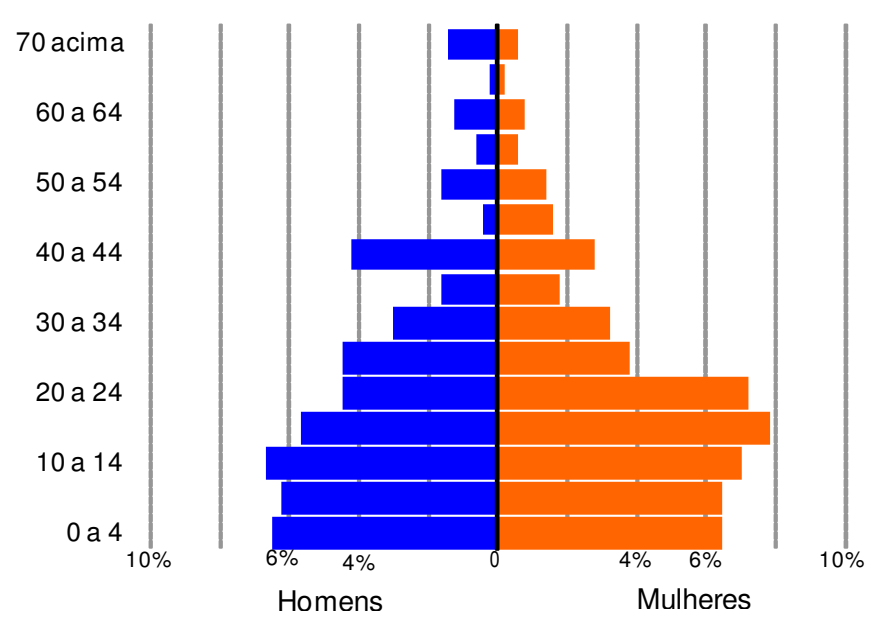

1807

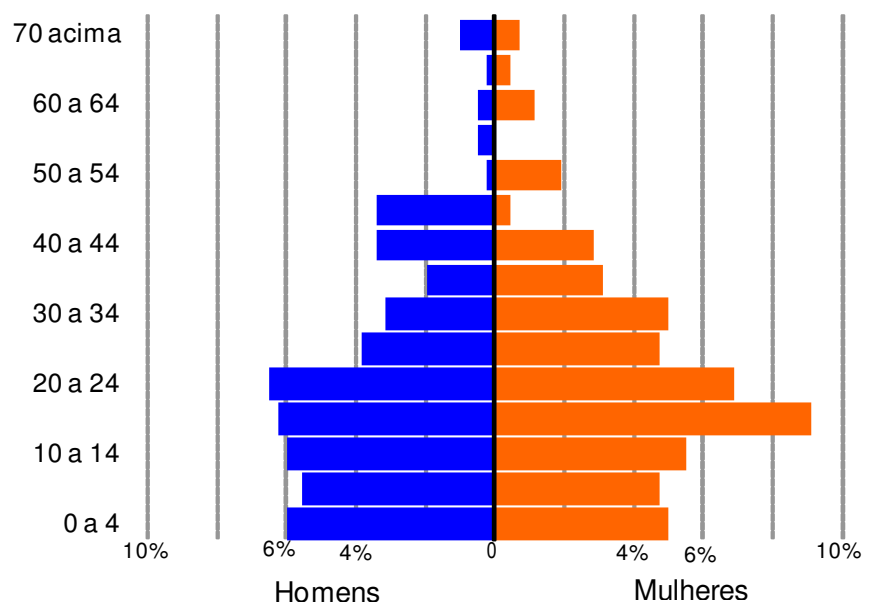

\section{1}

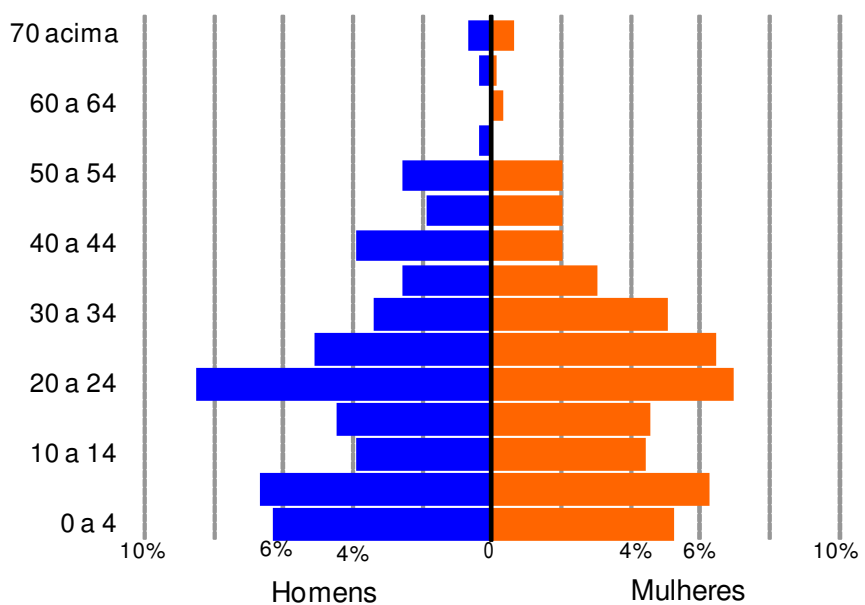




\section{6}

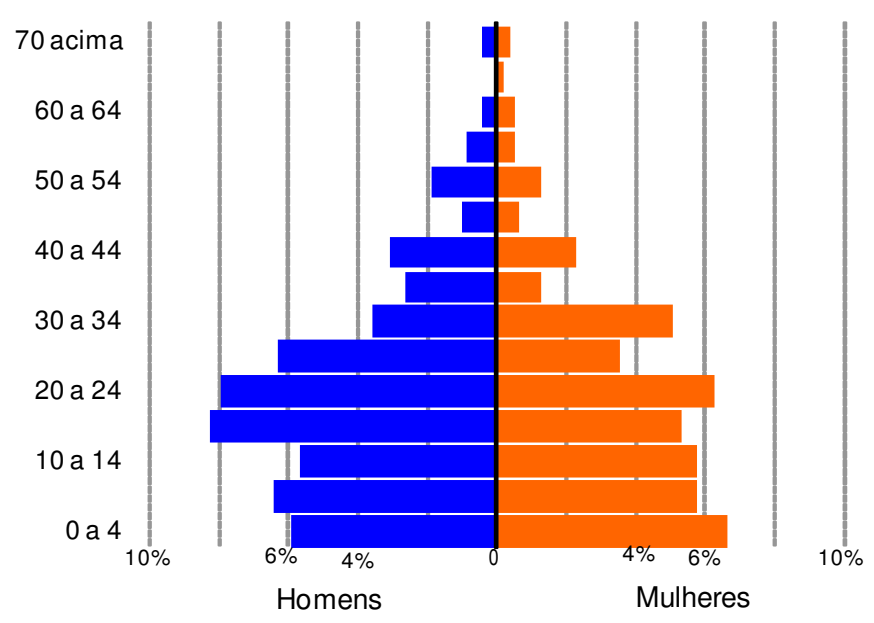

1822

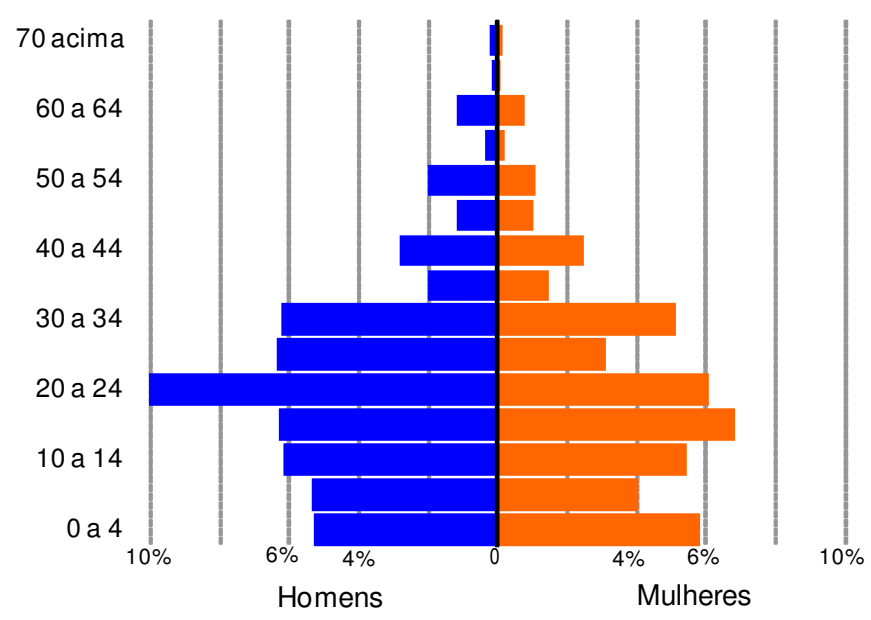

1825

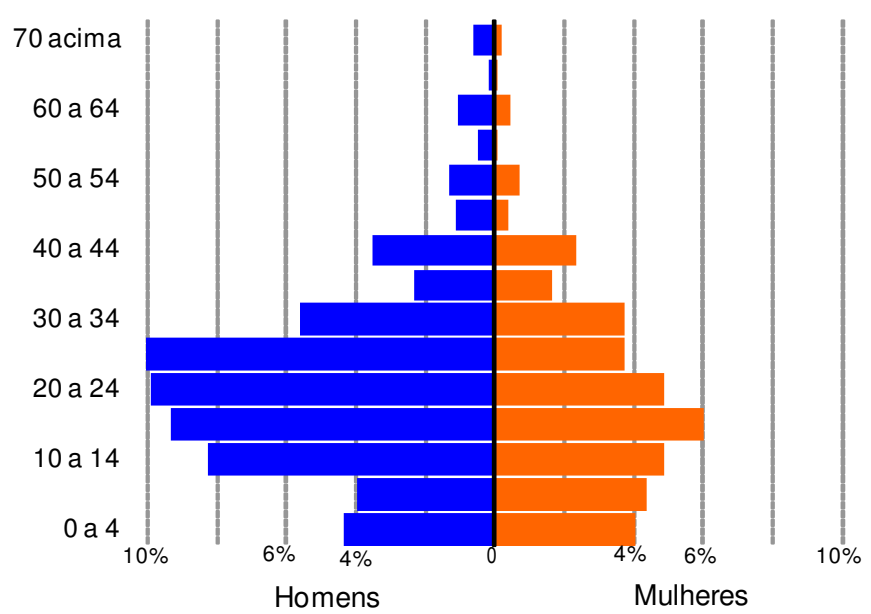


1829

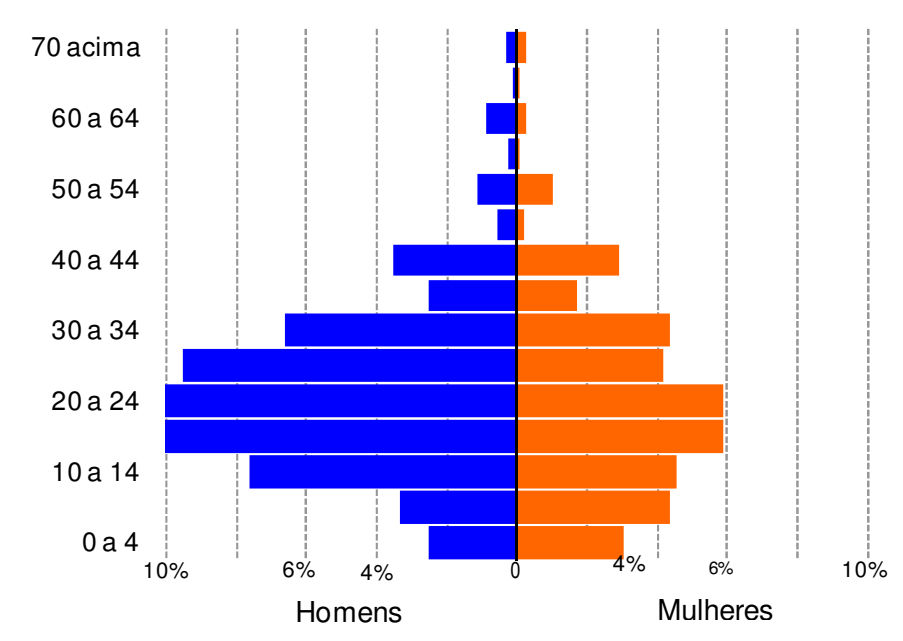

Destaca-se o ano de 1822 quando os homens de 20 a 24 anos apresentaram participação maior que qualquer outro grupo. Participação que se repete no ano de 1825, quando é importante também a presença de escravos do sexo masculino com idades entre 10 e 14 e 15 e 20 anos; assim como aconteceu em 1829, em que aos grupos citados são acrescidos os mancípios com 25 a 29 anos de idade. 


\section{População e seus padrões}

Na passagem do século XVIII para a centúria seguinte e em suas primeiras décadas, a capitania depois província de São Paulo apresentou expressiva ampliação de sua população que cresceu a taxas anuais médias de 1,55\% ao ano entre 1777 e 1829 (cf. LUNA, 2009b, p.397), entre 1765 e 1808 a população paulista teria crescido 148\% (MARCÍLIO, 2000, p.71). Já na segunda década do Oitocentos os habitantes da capitania

incluindo as paróquias que dela dependem, foi calculada, recentemente, em 30.000 almas, metade das quais forma a chamada população branca, ou supostamente branca, sendo a outra metade gente de cor. A população total da capitania de São Paulo era, em 1815, de 215.000 almas. Nesse número, devia ser incluída uma certa quantidade de negros escravos que chegavam todos os anos, à província. (D'ORBIGNY, 1976, p.177)

Decerto as localidades do entorno paulistano que observamos contribuíram para este crescimento populacional, pois, à exceção de Atibaia, todas viram expandir de maneira considerável o número de seus habitantes com o passar dos anos, a contar de 1798/99. Ao todo foram registrados 27911 indivíduos em 1798-99, número que chegou a 41011 pessoas em 1829-30, consideradas as localidades em seu conjunto (em que pese os apontados problemas pontuais com os arrolamentos): um crescimento anual médio da ordem de $1,2 \%$, que resultou em um avanço de $46,9 \%$ no número de habitantes dessa área em três décadas. ${ }^{26}$

Tais variações para a população de Jundiaí, Nazaré, Mogi das Cruzes/Santa Isabel e Jacareí/Paraibuna foram as mesmas, $1,3 \%$ ou $1,4 \%$ ao ano, como apontado em momentos anteriores. O maior crescimento médio anual foi verificado para Bragança, que cresceu a taxas de $2 \%$ ao ano - percentual igual ao de Jacareí, se considerado o ano final 1825 para esta vila -; e, como sabido, a população de Atibaia decresceu, o que ocorreu a uma taxa média de $0,7 \%$ ao ano.

Independentemente da dinâmica de suas economias e das conseqüentes mudanças populacionais em que poderiam implicar, as variações positivas apontadas representam tendências de longo prazo, posto ter sido comumente encontradas flutuações diversas, ao longo de todo o período 1798-29 e 1829-30. Assim, comparandose os extremos do lapso estudado houve crescimento generalizado nas populações específicas, mas em períodos mais curtos todas as localidades passaram por momentos, não coincidentes, de expansão e declínio de sua população. 
Gráfico I.20

População total por localidade

(1798-99 e 1829-30)
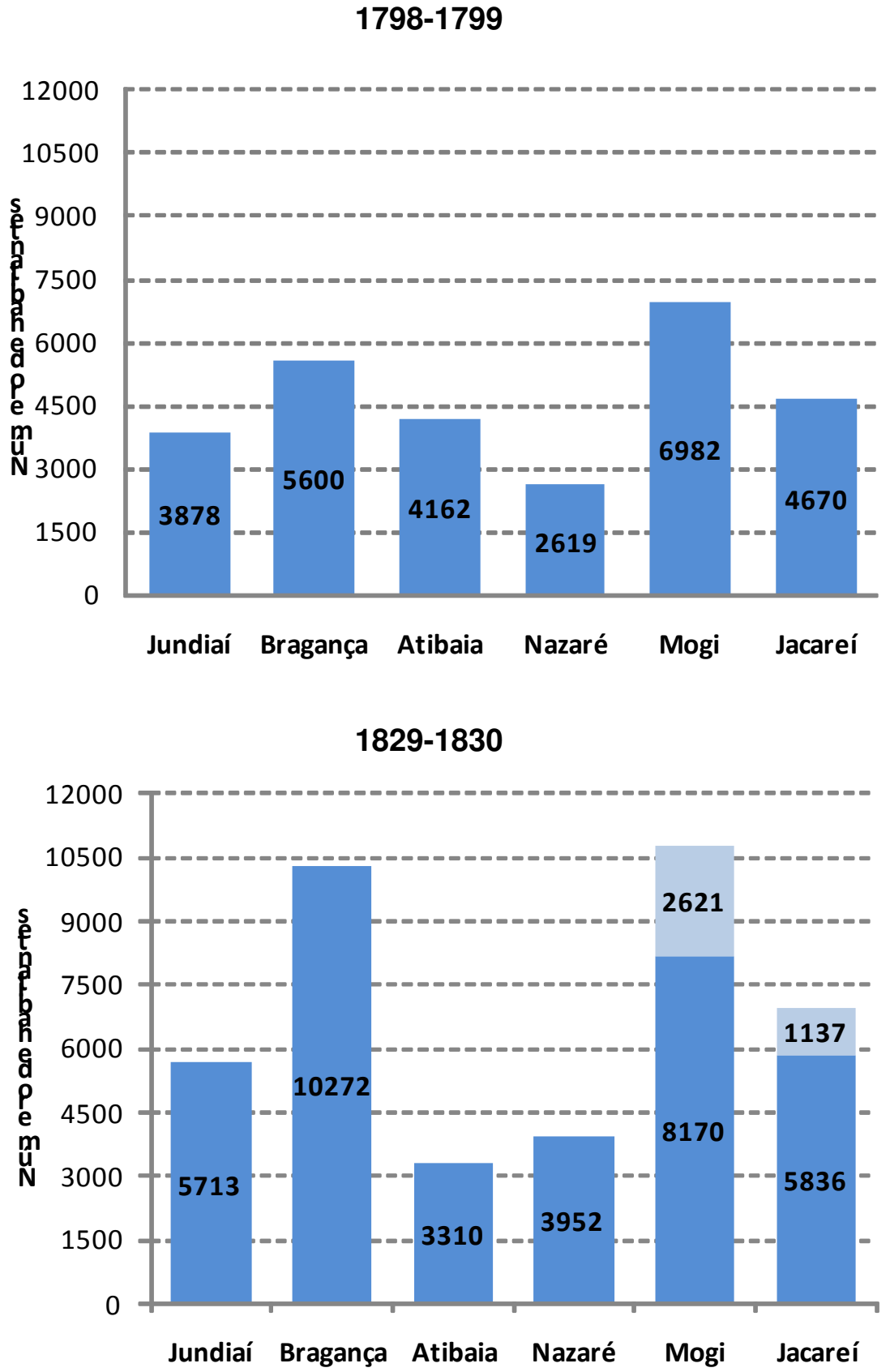

${ }^{26}$ Para dados sobre o crescimento regionalizado da população de São Paulo ver o rico trabalho de Francisco Vidal Luna (2009b): São Paulo: população, atividades e posse de escravos em vinte e cinco localidades (1777-1829). 
Ainda que Atibaia seja uma exceção, tendo decrescido entre 1799 e 1829, a população da localidade variou para cima entre 1799 e 1816, período em que foi acrescida em pouco mais de $6 \%$ do seu número ao final do Setecentos; o que nos permite, em alguma medida, atribuir à década de 1820 coincidência com o período de declínio em seu ciclo populacional.

Desconsideradas epidemias ou fome, que não foram muito comuns na capitania ${ }^{27}$ - as vilas em tela sempre apresentaram produção exportável e uma parcela mais pobre da população produzindo para seu sustento -, caracteres econômicos, migrações, entrada de escravos, crescimento natural, estão entre os fatores que podem, cada um a sua maneira e medida, justificar os diferentes momentos do evolver da população nas diversas localidades.

Entre os escravos, é possível que tenha ocorrido, em diferentes medidas, crescimento natural dessa população, como tem sido discutido para outros grupos mancípios. Alguns estudos têm mostrado evidências significativas da possibilidade de crescimento natural positivo dos cativos. Essa possibilidade foi aventada para diferentes regiões e momentos, em áreas voltadas para o mercado interno ou para exportação, tanto em anos anteriores como posteriores ao final do tráfico africano de escravos. ${ }^{28}$

As bases das pirâmides etárias das populações cativas, comparativamente menos alargadas, são indicativas da presença de crianças entre não livres (com idades, inclusive, inferiores a um ano). Em sendo crianças pouco traficadas - "Os estudos do tráfico comprovam uma constante predisposição contra mulheres e crianças" (KLEIN, 1989, p.16) - $^{29}$, parte desta população mancípia deveria se reproduzir naturalmente. Não à toa encontrarmos, em momentos nos quais as listas mostraram-se mais detalhadas, referências a "nasceu a escrava Maria" ou "acresceu o escravo João que nasceu".

Contudo, ainda que podendo ser positivas, as taxas de ampliação natural da população cativa não se mostraram suficientes para impor suas características às

\footnotetext{
${ }^{27}$ Mesmo devendo-se considerar fatores como epidemias na análise de dinâmicas populacionais, não mencionamos em nenhum momento pois "[...] em todo o curso do Seiscentos andaram longe os surtos epidêmicos de assumir nesses lugares de serra-acima as proporções calamitosas que atingiram em outras partes do Brasil e do continente americano." (HOLANDA, 1966, p. 74); e, para os séculos seguintes termos tomado como verdade haverem sido, os surtos epidêmicos em São Paulo, "de caráter local e atingiram de preferência núcleos do litoral mais exposto ao contágio trazido dos navios. [...] Sarampo, 'bexigas'(varíola), difterias atemorizavam as populações da capitania/província de São Paulo. Eles voltavam com certa freqüência e em épocas diversas, mas sem apresentarem a brusca e acentuada elevação na curva das morte, desequilibrando as taxas de crescimento." (MARCíLIO, 2000, p.75)

${ }_{28}$ A esse respeito ver, entre outros, Costa, Slenes e Schwartz (1987), Paiva e Klein (1992), Luna (2009c), Paiva e Libby (1995), Bergad (1994 e 2004), Marcondes e Garavazo (2002).

${ }^{29}$ Gutiérrez (1989, p.60), aponta que "[...] fato é que os alegados baixos índices de crianças traficadas foram aparentemente uma realidade em certas épocas do comércio negreiro brasileiro, principalmente durante o século dezenove. Contudo, para períodos anteriores a essa data, a importação de crianças parece não ter sido completamente desprezível e em certos momentos pôde ter atingido mesmo níveis equivalentes a10\% do total dos negros transportados."
} 
variáveis sexo ou idade dessa parcela da população do entorno paulistano e/ou assumir papel primordial em sua expansão. Os "viéses de idade e sexo dos africanos que migraram tinham impacto direto no crescimento e declínio das populações escravas americanas." (KLEIN, 1989, p. 17).

De forma mais efetiva, sabemos que o período que observamos representou grande afluxo de escravos negros africanos para São Paulo ${ }^{30}$, devendo ser sopesada essa entrada maciça de escravos negros africanos com os caracteres econômicos atinentes a cada uma das localidades, especialmente no que respeita à capacidade de absorção destes indivíduos nas diferentes atividades produtivas.

A crescente entrada de africanos, iniciada na capitania de São Paulo em grande monta no século XVIII, como descrito em outro momento, foi responsável por uma miscigenação na população, inclusive livre (incluídos aí os libertos, recorde-se), que apresentou parcela composta por pardos ou mulatos e negros (em alguns momentos e locais importante, senão majoritária). Os "indígenas foram eliminados, mas, da aliança e suas filhas com os primeiros colonos, nasceram mestiços, que são confundidos com os indivíduos da raça verdadeiramente caucásica" (SAINT-HILAIRE, 1976) Mais difícil encontrar aqui algum padrão.

Jundiaí apresentou, durante todos os anos que separam 1803 e 1816, participação majoritária dos livres devida a estes indivíduos não brancos, sendo notável a partir de 1803 o seu clareamento, cuja participação dos negros reduziu-se consideravelmente. Já em Atibaia, em todas as listas os brancos constituíram maior parte da população livre, mas houve nítida tendência a um escurecimento dessa população (de 89,5\% 54\% de branco, entre 1799 e 1829). Brancos foram maioria dos indivíduos arrolados também nas vilas de Bragança - com evolver bastante errático, sem tendência de longo prazo (em 1803, assim como em 1830 os brancos eram 78,5\% dos livres) -, Mogi das Cruzes, e Nazaré, que entre 1803 e 1825 apresentou um crescimento bastante superior ao da população total e a qualquer um de seus grupos, livres ou escravos. Em Jacareí e seu termo, a cor teve variação também errática com momentos de maior participação de brancos e outros de mulatos e negros. ${ }^{31}$

\footnotetext{
${ }^{30}$ A década de 1820 "[...] testemunhou os maiores desembarques na história do tráfico negreiro para o centro sul do Brasil (a melhor estimativa é de que o número de escravos importados era de 296.000), volume este ultrapassado, e mesmo assim por pouco, apenas na famigerada década de 1840." (PAIVA \& LIBBY, 1995, p.217)

${ }^{31}$ Para a também paulista localidade de Ubatuba temos dados que apontam que "No seio da população livre de Ubatuba, em 1798, 83,6\% eram brancos, 1,3\%, pretos e 15,1\%, pardos. Estas proporções alteram-se ligeiramente, com relativo enriquecimento do município, aumentando a proporção de brancos em detrimento dos mulatos. Em 1828, os brancos subiam a $86,5 \%$ da população livre, os negros permaneciam em $1,8 \%$ e os mulatos eram, agora, 11,7\%. (MARCÍLIO, 2006, p.118) Segundo Klein e Luna (2009, p.469) em 1829-30 "Os livres de cor estavam bem distribuídos pela população da província. Apesar de representarem $21 \%$ da população total, somavam um quarto de todos os chefes de domicilio. Além disso estavam igualmente bem
} 
O arrolamento de cor dos habitantes sofria influências de ordem social e econômica, como adiantado, sendo o branqueamento padrão de ascensão social, também apontando para condições econômicas diversas que possibilitassem aos indivíduos melhoria em suas condições e conseqüente possibilidade de "mudar" sua cor. Como bem observou Maria Luisa Marcilio:

No Brasil tradicional, freqüentemente a pobreza estava associada à mestiçagem, à cor. Ser 'branco' necessariamente não significava um descendente de europeu apenas, pois a cor não estava associada apenas à pigmentação da pele. Em muitos casos o 'branco' é o proprietário, o homem importante da localidade, o senhor de escravos e exportador da produção, aquele que pertence à categoria dos letrados ou do clero, mesmo tendo evidentes misturas de sangue com o índio ou com o africano.[...] Podia ocorrer variação de cor em um mesmo indivíduo. Bastava que ele subisse na escala social, fosse bem sucedido, passasse para a categoria dos abastados, para deixar de ser pardo. (MARCÍLIO, 2006, pp.117-118)

Entre os cativos aspectos econômicos justificavam sua absorção crescente e em diferentes medidas; estes mesmos elementos representavam para parcela da população livre incentivos à fixação ou abandono de suas localidades de origem. Os momentos de maior crescimento da população deveriam estar inter-relacionados com mudanças econômicas, que pressionavam um novo desenvolvimento da agropecuária do entorno paulistano, mormente daquela agropecuária ligada a produtos típicos de subsistência, (característica marcante de todas as localidades, como se verá) em que os produtos eram relativamente homogêneos, e havia muitos produtores posto não haverem grandes barreiras ao mercado - ainda que presença de terras devolutas fosse importante atrativo populacional, a ausência destas poderia ser suprida com o trabalho em terras alheias, como notado no capítulo III.

Se cada fogo representa uma unidade produtiva, um "lucro econômico" menor que zero no setor justificaria a mudança desta unidade de produção a um baixo custo de oportunidade, ou seja, haveria migração para outras áreas, ao contrário, um "lucro econômico" positivo atrairia população, processo que por si só seria capaz de influenciar os mercados locais, inclusive na determinação de volume e preço da produção. ${ }^{32}$

distribuídos pelos municípios. lam de $12 \%$ de todos os domicílios, no caso de algumas cidades menores, a um terço ou mais do domicílios no caso de municípios maiores com Santos, São Paulo e Curitiba. Chegavam mesmo a somar três quartos da população na cidade litorânea de Guaratuba [...]"

${ }^{32}$ Ver considerações econômicas para as localidades no capítulo II. 
O sentido do deslocamento dos livres, ainda que em caráter intra-regional pôde ser auferido. Mesmo sendo possível apontar e encontrar indivíduos oriundos de locais mais distantes, inclusive de áreas além mar, o grosso da mobilidade, capaz de afetar os caracteres demográficos das localidades - e por conseguinte econômicos -, era devido a fluxos em menores distâncias, entre vilas vizinhas, que acabavam por ter suas fronteiras fluidas, permitindo movimento de consideráveis volumes populacionais, que não tinham um sentido único.

É dizer, todas as vilas/freguesias tanto recebiam quanto enviavam indivíduos a outras áreas sendo as principais relações verificadas entre localidades fronteiriças, como se nota na composição das populações locais por naturalidade de seus indivíduos livres e especialmente dos chefes de fogo. "A migração no Brasil durante todo o período colônia, sempre foi expressiva. Em determinados momentos, entretanto, algumas áreas tiveram o fluxo aumentado" (FARIA, 1998, p. 170), o que aconteceu com Jundiaí no Setecentos e/ou nos primeiros anos do Oitocentos e em Paraibuna na década de 1810.

Os chefes de fogo ao apresentarem forasteiros em maiores proporções que a totalidade dos habitantes livres apontam, para diferentes momentos entre as localidades, a possibilidade de movimentos de indivíduos que vieram a contrair matrimônio em outra localidade, que não a sua de origem. E "Nos segmentos mais enriquecidos da população, a busca de parceiros para a formação de casais chegava a ser incentivada, promovendo a aliança entre grupos familiares de localidades distintas e estabelecendo mais um lance no complexo jogo de concentração e transmissão de fortunas" (BACELLAR, 2001, p. 47)

A sua vez, ainda que superficialmente abordada, taxas de natalidade positivas para livres eram característica extensiva a todas as localidades do entorno paulistano em tela, em todo o período 1798-9 e 1829-30: entre 50 e 55 nascimentos por ano, para cada mil habitantes livres, explicada "por uma fecundidade legítima acentuada somada às taxas elevadas de concubinato e ilegitimidade" (cf. MARCíLIO, 2000).

O estudo das pirâmides etárias apontou para todas elas figuras do tipo crescente tipicamente com base larga e estreitamento rumo ao cume - com alguns períodos em que foram identificadas faixas etárias podendo ser classificadas como classes ocas (classe menor do que aquela que representa o escalão etário superior, corroborando a possibilidade e migração de grupos específicos, como demonstrado para Atibaia na década de 1820).

Assim, como padrão temos populações livres com elevada taxa de natalidade, grande proporção de jovens, baixa participação de idosos (devido à baixa expectativa de vida daquele tempo, especialmente devida, entre outras possibilidades, às precárias 
condições sanitárias e higiênicas daquele tempo) ${ }^{33}$ e em crescimento (como havíamos apresentado anteriormente à apresentação das pirâmides etárias), característicos da forma apresentada pelas figuras.

Ademais, as pirâmides etárias apontam para diferenciação entre os sexos, outra característica observada para a população livre: não fugiu ao modelo de superioridade numérica feminina nenhuma localidade em nenhum momento, sendo esta superioridade encontrada, no mais das vezes, em pequena medida e com pequenas variações ao longo do tempo, decorrentes de flutuações em montantes diferentes do número de indivíduos de cada um dos sexos, ainda que, em regra, homens e mulheres tivessem suas populações variando no mesmo sentido e em proporções relativamente próximas. ${ }^{34}$ A parcela da população feminina manteve-se entre $51 \%$ e $55 \%$ em todas as localidades. Ou seja, temos como padrão a superioridade numérica feminina, aspecto apurado sem alterações importantes no tempo e no espaço. ${ }^{35}$

Migrações na busca de novas oportunidades em áreas em fase de ocupação; estímulos governamentais para a efetiva ocupação do sul da colônia; grande contingente de tropas recrutadas em São Paulo e mobilizadas nas guerras com os espanhóis, que também ocasionavam sistemática fuga de homens adultos desse odiado recrutamento; todas são causas geralmente apontados (sic!) para o desequilíbrio quantitativo entre os sexos. Possivelmente ocorria uma combinação daqueles fatores, todos influenciando no mesmo sentido, talvez com diferentes pesos, a depender do período estudado e da região. Essa maioridade feminina entre os livres em São Paulo, permanecerá como uma característica importante dessa população no século XVIII e parte do XIX. (LUNA \& KLEIN, 2009, p.170) ${ }^{36}$

Soma-se à superioridade numérica feminina ser recorrente, ou seja, podermos igualmente considerar um padrão, a existência em quantidade majoritária, em todos os casos, de parcela da população livre com ao menos 15 anos de idade sendo casada,

\footnotetext{
${ }^{33}$ Para observação sobre taxas de mortalidade em algumas localidades ver, entre outros, Teixeira (2006) e Marcilio (2000).

${ }^{34}$ Para a população da capitania de São Paulo temos que "As porcentagens de crescimento médio anual intercensitários para a população total foram: para os homens - de 1798 a 1808 de 1,82\%; e 1808 a 1818 de $1,76 \%$ e de 1818 a 1828 de 2,95\%. Para as mulheres, as taxas obtidas variaram: de 1,98\%, 1,26\% e 2,35\% respectivamente para os mesmos intervalos censitários. Se se considerar apenas a parcela livre da população, as taxas obtidas foram: para os homens entre 1798-1808 de 1,85\%, entre 1808 e 1818 de $1,04 \%$ e de 1818 a 1828 , de 2,20\%. Para as mulheres, respectivamente no mesmo intervalo elas foram de: $2,16 \%$, $1,20 \%$ e 1,91\%" (MARCílIO, 2000, p.87)

${ }^{35}$ O padrão apontado não surpreende posto já ter sido verificado para outras localidades e regiões e momentos, a exemplo de Vila Rica em 1804: "Para os livres a razão de masculinidade correspondia, apenas, a 80,80 - vale dizer contávamos 80,8 homens para cada grupo de cem mulheres. Esses resultados rompem o relativo equilíbrio existente entre os sexos se considerada a população total, na qual computamos 95,56 homens para cem indivíduos do sexo oposto. Infere-se, do acima exposto, ter predominado, no processo de excisão populacional por que passava a área, o elemento masculino". (LUNA \& COSTA, 2009, p.49)

${ }^{36}$ Por exemplo, para a cidade de São Paulo em 1827 e 1836 encontramos em Samara (2006, p.35): "Como hipótese para o menor número de homens livres na população, podemos apontar a ausência de grandes oportunidades econômicas na região, aliada a numerosa quantidade de territórios ainda disponíveis para a abertura de nova zonas agrícolas, levando parte dos homens a migrar sozinha em busca de melhores condições."
} 
seguida por solteiros(as) e por último, com pequena representatividade na população livre observada, os viúvos(as), ${ }^{37}$ sendo o percentual devido aos homens sempre superior aquele verificado para as mulheres entre os solteiros e casados - o desequilíbrio entre os sexos favorecia os homens no "mercado matrimonial", ampliando suas possibilidades de encontrar uma parceira. As mulheres, a sua vez, em maior proporção que os indivíduos do sexo masculino eram viúvas. Observações estas válidas, novamente, sem grandes distinções no tempo e no espaço.

Ainda que exista a possibilidade de que os homens, ao estarem envolvidos em atividades mais perigosas, que implicassem em longas viagens ou serviços militares faleciam em maior medida; parece-nos mais correto afirmar que em maiores proporções que indivíduos do sexo masculino mulheres tendiam a permanecer nessa condição de viúvas:

Os homens tinham maiores dificuldades de se manterem sós, sem companheiras, e procuravam, pois, buscar logo o casamento [...]

As viúvas encontravam maiores dificuldades para encontrar um segundo marido. Muito poucos eram os solteiros que se dispunham a casar-se com elas. Preconceito social mas também pressão de uma sociedade em que as moças em idades casadouras eram sempre em maior número do que os rapazes. Por isso, a comunidade não podia permitir, com facilidade, a concorrência aos jovens solteiros que as viúvas pudessem Ihes fazer. (MARCíLIO, 2006, p.175)

Do mesmo modo, tendo atingindo os 50 ou mais anos de idade, as mulheres, mais que os homens, eram solteiras, ao menos oficialmente pois é preciso, de um lado, lembrar que boa porcentagem delas viviam em uniões estáveis, não legalmente estabelecidas, em que pese as possíveis dificuldades para conseguir a realização de um casamento religioso, a ausência de cabedais que justifiquem uma união formal e outras dificuldades (como a conhecida desproporções entre os sexos) para se conseguir um casamento. Em sendo as mulheres sistematicamente em maior número que os homens, essas mulheres em celibato definitivo representavam percentuais cerca de dois pontos superiores aos dos homens ao longo do tempo e nas diferentes localidades, mesmo sendo para ambos os sexos o percentual desses indivíduos reduzido, não tendo ultrapassado os 5,2\% verificado para as mulheres na vila de Mogi no ano de 1812. Homens casados possuíam idades médias superiores às encontradas para as mulheres em 5 a 7 anos, sendo a idade média

\footnotetext{
${ }^{37}$ Costa e Gutierréz (2009, p. 511) apontam para São Paulo, em 1830, uma população livre acima de 10 anos de idade em que, respectivamente, $40,8 \%, 52,2 \%$ e $7 \%$ eram solteiros, casados e viúvos; para o Paraná são apontados, para cada estados conjugal, $43,6 \%, 49,4 \%$ e $7 \%$.
} 
calculada para eles sempre na casa dos 30 anos de idade, novamente sem grandes variações ao longo do lapso estudado ou entre as vilas estudadas.

Parece-nos, então, que caracteres demográficos dos livres, tais como gênero, idade, estado conjugal e cor apresentaram padrões em cada uma das localidades e entre as distintas localidades do entorno paulistano observadas. Nas vilas/freguesia apresentaram flutuações mantidas dentro de determinados intervalos cujos mínimos e máximos não estavam à grande distância. Da mesma maneira estas observações postas podem ser estendidas para a totalidade das povoações, apontando para aspecto comum e recorrente entre elas. Assim, justifica-se havermos indicado algumas vezes terem certos caracteres deixado de apresentar variações significativas no tempo e no espaço.

Por outro lado, vista em seu conjunto, as populações das vilas apresentaram características comuns no que respeita, ao longo do tempo, a grandes flutuações, que passados momentos de expansão e recuo populacional, representam tendência de crescimento de longo prazo. Crescimento este, ao que parece, influenciado por natalidades positivas e aspectos migratórios - que dadas as condições da época ocorriam especialmente entre vilas vizinhas, sempre aptas a receber, assim como enviar indivíduos a outras áreas, seguindo flutuações em sua dinâmica econômica ou determinadas até mesmo pelas próprias características demográficas dos livres em cada uma da vilas. 0 que implicou em não coincidência entre períodos e montantes nas flutuações observadas, que estavam vinculadas, também, às condições de absorção de cativos em cada sociedade.

A participação de fogos com escravos foi diversa, em seus níveis e flutuações, entre as localidades. Jundiaí, Bragança e Jacareí, apresentaram ampliação do número percentual de fogos com presença de cativos acontecida, verdade, paralelamente ao incremento de atividades a dinamizar suas economias, capazes que eram gerar efeitos multiplicadores. Quais sejam estas atividades, em sequência para cada uma das localidades anotadas: ampliação do número do número e da atividade açucareira dos engenhos; incremento da criação comercial de porcos e da mercantilização do toucinho; aparecimento e instalação da lavoura comercial do café (cf. capítulo II).

A sua vez, Mogi manteve a participação de fogos com cativos em proporções relativamente constantes, entre $23 \%$ e $25 \%$, ao longo dos anos. Nazaré viu reduzida a parcela de seus domicílios de aproximadamente $26 \%$ a $18 \%$, enquanto Atibaia não mostrou flutuações claras ao longo do tempo, mas manteve os mais altos valores encontrados para o percentual de chefes/domicílios diretamente ligados à escravidão. 
A se ter em conta a parcela de escravos encontrada nestes fogos, foi padrão verificado de maneira constante entre localidades e anos, concentração média a forte dos cativos entre seus donos, concentração que foi de forte a muito forte e, eventualmente quase absoluta, tomadas as unidades domiciliares em sua totalidade. ${ }^{38}$

Entre os livres o grupo dos chefes de fogo apresentou características atinentes a sexo e estado conjugal apartadas daquelas verificadas para os livres em seu conjunto. Era majoritariamente masculina a parcela dos livres a chefiar domicílios, nunca sendo encontradas razões de sexo inferiores a 340. Os chefes de domicilio escravistas apresentavam proporção de homens ainda mais acentuada, e apartada daquilo que havia sido a composição sexual da população livre.

Ainda que o percentual possa ter variado entre as localidades, fato é que as mulheres assumiam a condição de chefiar seu núcleo doméstico, mormente, quando viúvas. O que não ocorria com os homens, que em sua maioria eram casados ao apresentarem-se como chefes de fogo, com percentuais bem mais elevados que aqueles verificados para o total da população livre masculina. Decerto mulheres tinham maiores dificuldades em iniciar ou manter sozinhas uma escravaria.

O número de fogos chefiados por estes indivíduos escravistas variaram sem flutuações claras em períodos curtos, não necessariamente acompanhando as variações apresentadas pela população total ou livre, mas mantendo tendência a grande ampliação no longo prazo, novamente com exceção de Atibaia, em se considerando todo o lapso 1799-1829.

Essas flutuações, somadas às flutuações da população levaram a pequenas mudanças no número médio de indivíduos por domicílio, cujos menores valores encontramos em Jacareí, onde havia entre 4,6 e 5,3 indivíduos por fogo, sendo os livres entre 4,1 e 4,8 pessoas em média; e os maiores em Atibaia onde existiam entre 6,1 e 7,1 indivíduos por fogo, sendo entre eles de 4,3 a 5,4 livres. "Não se pode esquecer que 0 regime demográfico de alta mortalidade, em especial de alta mortalidade infantil, como 0 era o da capitania paulista, sendo então a esperança de vida ao nascer curta, não comporta a prevalência de famílias extensas, com a presença de três gerações." (MARCÍLIO, 2000, p.99) Apesar das diferenças, parece característico haver ao redor de seis indivíduos, entre livres e cativos, por unidade domiciliar, com variação em torno de

\footnotetext{
${ }^{38}$ Para fins de padronização convencionamos, ao proceder a tal afirmação, que o índice de Gini de 0,000 a 0,100 apresenta uma concentração considerada nula, de 0,101 a 0,250 uma concentração de nula a fraca, de 0,251 a 0,500 concentração fraca a média, de 0,501 a 0,700 concentração média a forte, de 0,701 a 0,900 concentração forte a muito forte e de 0,901 a 1,000 concentração muito forte a absoluta.
} 
um para mais ou para menos, indicativos de que a distribuição dos mancípios pelos domicílios era bem dispersa, à parte de alguns fogos com elevados plantéis.

Os cativos, considerados apenas em fogos nos quais estavam presentes, apresentaram médias, crescentes ou não, que se não dentro do que podemos considerar pequenos plantéis, estavam bem próximas a eles, como foi o caso de Atibaia. As modas, ou seja, o tamanho de plantel mais comumente encontrado, foram bastante reduzidas: igual a dois ou, majoritariamente, novamente sem diferenças no tempo ou no espaço, igual a um.

Constatação esta, próxima às verificadas para várias regiões por diferentes autores, ou seja, era em grande medida semelhante, no que respeita à predominância de pequenos plantéis, à distribuição encontrada em outras localidades. ${ }^{39}$ Os estudos empíricos sobre o tema têm apontado para uma predominância numérica de proprietários de pequenos plantéis entre o total de senhores e para uma posse difundida em economias regionais voltadas para a produção de subsistência, como ocorre na área que observamos:

Enfim se, como sabido, panos de fundo socioeconômicos distintos podem dar suporte a populações cujas estruturas demográficas apresentam perfis estatísticos em boa medida semelhantes, este é o caso do padrão de distribuição da propriedade escrava no Brasil dos séculos XVIII e XIX. Nesse padrão figuravam, de forma inequívoca, vale a pena repisar, como escravista majoritário, o que possuía poucos cativos, e, como escravo típico, o que vivia fora do ambiente característico da plantation. Estes os traços delineadores da estrutura da posse de escravos mais saliente do escravismo brasileiro. (MOTTA, NOZOE \& COSTA, 2004, pp.209-210)

Para estes escravos encontramos algum padrão, mas com algumas variações para composição por sexos, consideradas as massas cativas em seu conjunto. ${ }^{40}$ Não à toa llana Rocha (2009, p.19), menciona "[...] a dificuldade em estabelecer uma padronização para a escravidão brasileira." Todavia, foram comumente encontradas mudanças nas razões de sexo observadas para diferentes tamanhos de plantéis: a razão

\footnotetext{
${ }^{39}$ Para dados e análise comparativa de estatísticas relativas à posse de cativos em diversas localidades e regiões e brasileiras, ver Às vésperas da abolição de Motta, Nozoe \& Costa (2004).

${ }^{40} \mathrm{De}$ acordo com comparações de diferentes trabalhos que versaram sobre o sexo dos cativos, especialmente em 1829, Ilana Rocha aponta que: "O tipo de atividade econômica predominante mostrou uma influência importante da razão de masculinidade. Dava-se maior peso masculino naquelas áreas dedicadas ao cultivo de produtos destinados ao mercado externo, como café e o açúcar. Itu, Jundiaí, Areias, Cunha, Lorena, Jacareí e Guaratinguetá apresentaram tal característica. Nas áreas mais intensamente dedicadas ao cultivo de gêneros de subsistência ou pecuária (Curitiba, São Sebastião, Iguape e Mogi das Cruzes) ou ao comércio, artesanato e serviço (São Paulo) mantinha-se relativo equilíbrio quantitativo entre os sexos, embora com leve maioria masculina, exceto em Curitiba, única localidade onde encontrou-se peso majoritário feminino." (ROCHA, 2009, p.23)
} 
muda favoravelmente aos homens na medida em que se amplia a faixa de tamanho de plantel considerada.

É dizer, em plantéis muito grandes (utilizados nas diferentes seções para comparação ao longo do tempo), a razão de sexos foi sempre superior àquela encontrada nos menores grupos de cativos. Observação válida para situações verificadas em que ambas as faixas apresentam razões abaixo de 100 (perfeito equilíbrio entre os sexos), sendo assim com maior participação feminina; situações em que pequenos e grandes plantéis são caracterizados pela superioridade numérica masculina; ou ainda diante da possibilidade de uma das razões se encontrar acima e outra abaixo da razão correspondente ao equilíbrio sexual. ${ }^{41}$

A sua vez, as já citadas pirâmides etárias para as populações não livres apontam, de maneira característica, para um centro comparativamente mais alargado, indicando um relativo "envelhecimento" da população, com concentração desses cativos em faixas etárias mais jovens (não crianças): 15-19, 20-24 e 25-30 anos de idade e, em maior medida, para homens, tipicamente resultado de efeitos migratórios, que em se tratando de escravos, traduz-se no tráfico que, como anteriormente anotado, favorecia homens jovens. $^{42}$

Note-se, por fim, que entre os livres, sob a forma de agregados, "Ao contrário do que se poderia esperar, a maioria de indivíduos e núcleos familiares que viviam sob a dependência do chefe de domicilio não era de parentes, mas de pessoas sem vínculo de parentesco." (MARCÍLIO, 2000, p.103) Ou seja, estavam a viver entre os livres nos domicílios, indivíduos agregados sem nenhum grau de parentesco com o núcleo familiar principal. ${ }^{43}$

${ }^{41}$ Bergad (1994, p.502) encontrou para a região de Mariana, por exemplo, razões de sexo que chegaram a 329 durante o auge da mineração. Mas algumas regiões específicas, principalmente em áreas onde a atividade principal não se relacionava ao comércio exterior, apresentam um quadro algo diferente: relativo equilíbrio entre os sexos. Horacio Gutierrez (1987) encontrou uma proporção de homens e mulheres bastante próxima para o conjunto de plantéis escravos paranaenses nas primeiras décadas do século XIX, chamando a atenção para o provável peso do trabalho feminino. Em diversas localidades de São Paulo este equilíbrio também se verificou em 1804 (LUNA \& COSTA, 2009). Para Sorocaba, Bacellar (2000) observou uma igualdade na presença de escravos e escravas especificamente em plantéis com até 5 cativos.

$42 \mathrm{O}$ tráfico interno também caracterizou-se, amiúde, por maior contingente masculino. Estudando o tráfico de escravos na Província de São Paulo (Areias, Silveiras, Guaratinguetá e Casa Branca) entre 1861 e 1887, Motta (2001) encontrou, à exceção de Silveiras, predomínio masculino entre os escravos transacionados, sendo a razão de sexo dos cativos comercializados em Guaratinguetá 139,2 e em Casa Branca, 174.

${ }^{43}$ Entre outros autores que se depararam com presença de considerável percentual de agregados temos Luna e Costa (2009, p.48): Na mineira Vila Rica em 1804 "Os agregados correspondiam a 16,14\% dos livres." Em trabalho em que considera estruturas demo-econômicas para alguma localidades mineiras em 1804, Iraci Costa (2009, p.77) aponta que "O peso dos agregados entre a população livre variou de $99 \%$ a $55 \%$. A divergência mais significativa deu-se entre a estrutura rural-mineradora (55\%) e as demais: 9,9\% na rural de autoconsumo, $13,6 \%$ na intermédia e de $15,3 \%$ na urbana. Parece-nos sintomático que a menor participação se tenha dado na estrutura rural de autoconsumo, justamente a que menos condições oferecia para 'suportar' ou 'exigir' número avultado de agregados. A existência de parcela significativa de agregados na estrutura urbana pode ser explicada pelas condições econômicas adversas defrontadas pelos núcleos urbanos da área ao abrir-se o século XIX. A grande parcela de agregados na estrutura rural-mineradora pode ser explicada, ao 
Grupo este a apresentar grande mobilidade sendo que, a se ter em conta o verificado por Marcílio (2006, p.118) para a localidade paulista de Ubatuba, deveria ocorrer "Na maior parte dos casos, sobretudo em se tratando de casais ou mães solteiras, são estes os indivíduos de maior mobilidade espacial na comunidade, permanecendo um ou poucos anos em companhia de uma mesma família".

que parece, pelo fato de existirem, nos centros estudados, umas poucas propriedades de porte relativamente grande, propriedades estas que 'exigiam' e podiam 'suportar' o contingente representado pela numerosa parcela de agregados, os quais não raramente faziam-se acompanhar de seus escravos." Já na capitania paulista "A ocorrência dos agregados mostrou alguma significância em Areias, correspondendo a cerca de 5\% do total da população e $7 \%$ dos livres, com presença em aproximadamente $15 \%$ dos fogos. Os agregados mostravam maior importância relativa nos fogos com escravos. Assim, em um quinto dos fogos escravistas identificaram-se agregados; nos fogos sem escravos a ocorrência mostrou-se bastante variável, oscilando entre $17 \%$ em 1817 e $6,4 \%$ em 1829. (LUNA, 2009a, p.136) 


\section{Capítulo II \\ ECONOMIA: ATIVIDADES ECONÔMICAS, PRODUÇÃO E COMÉRCIO}

O inicio da ocupação e exploração produtiva do território brasileiro foi baseado na organização de empresas comerciais para exploração dos recursos naturais aqui existentes e na sequência pelo estabelecimento de um sistema produtivo de caráter exportacionista. Antes de tudo, o interesse estava em aplicar recursos de maneira lucrativa, constituindo-se a colônia num mero instrumento de valorização dos capitais mercantis e enriquecimento da metrópole. (cf. PRADO Jr., 1996; NOVAES, 2001). Assim, "De simples empresa espoliativa e extrativa [...] a América passa a constituir parte integrante da economia reprodutiva européia, cuja técnica e capitais nela se aplicam para criar de forma permanente um fluxo de bens destinados ao mercado europeu." (FURTADO, 1998, p.8)

A faixa litorânea do nordeste ("norte") representou o primeiro centro de colonização e urbanização do Brasil e concentrou, até meados do século XVIII, as principais atividades econômicas da colônia e fatia importante de sua a população - Salvador foi capital e cidade mais importante do Brasil até 1763. Neste período o "sul" era uma área periférica e bem menos urbanizada, pois não representava área de interesse mercantil além mar.

A ativação sócio-econômica do nordeste ocorreu em função da empresa do açúcar, produto demandado e valorizado no mercado internacional. Combinando fatores como boa qualidade do solo e clima favorável, foi exitosa a organização da indústria açucareira no nordeste brasileiro, especialmente em Pernambuco e no Recôncavo Baiano - com portos importantes instalados em Recife e Salvador, possuíam relativa facilidade de escoamento da produção e recepção de mão-de-obra negra africana - onde se estabeleceram os centros principais da administração colonial portuguesa na América.

Neste contexto, como área ao sul, São Paulo apresentou papel secundário (ainda que tenha sido uma das primeiras áreas ocupadas pelos portugueses no Brasil). Sua inserção no complexo exportador foi inviável nos séculos iniciais da colonização e sua escassa população dedicou-se à economia de subsistência. "Embora desde o início se produzisse algum açúcar e aguardente na província de São Paulo, essas atividades atendiam apenas às necessidades locais, devido às dificuldades de transporte e à falta de mercados, e só foram adquirir importância na segunda metade do século XVIII" (LUNA \& KLEIN, 2006, p.26). 
Na então capitania de São Vicente, ainda no Quinhentos, "Martim Afonso foi sócio, com portugueses e estrangeiros, de um engenho que talvez tenha sido o maior do sul do país - o São Jorge dos Erasmos" (FAUSTO, 2009, p.78) Contudo, a fabricação de açúcar vicentina não resistiu diante da robustez da produção nordestina: "Em 1580, apontava-se aí a presença de apenas quatro engenhos enquanto na Bahia haveria 36 e em Pernambuco 66." (RANGEL, 1990, p.2)

A quase ausência de cabedais apreciáveis foi uma constante para São Paulo em seus séculos iniciais, pois "Ora, a fortuna que vem da agricultura é lenta e difícil. Aos povoadores do Piratininga o clima recusa o açúcar naquela fartura que enriquece os cultivadores do nordeste. Entre as lavouras e o mar se levanta, dificultando o transporte, a serra tumultuosa." (MACHADO, 1980, p.38)

Os paulistas dedicaram-se, então, naqueles primeiros momentos, à produção de gêneros de subsistência baseada em lavouras de alimentos levadas a cabo de forma rudimentar, sem grandes técnicas, em uma região com grandes áreas de fronteira ainda inexploradas e povoações ainda esparsas.

É certo que na São Vicente/São Paulo existiam atividades como plantações de mandioca, feijão, milho, arroz, trigo, cana, frutas (em especial "de espinho"). Além disso, plantava-se algodão e eram criadas ovelhas para serem utilizadas na fiação e tecelagem, permitindo uma pequena manufatura de tecidos mais grosseiros. Criavam-se, em alguma medida, também bois e principalmente porcos (carne, toucinho). Existiam ainda pessoas exercendo ofícios como ferreiro, serralheiro, sapateiro - atividades, em regra, paralelas, mas com variações: áreas mais ou menos ligadas a determinado cultivo e períodos em que determinada atividade foi mais intensa que em outros. Mas,

[...] não ocorrendo nenhum artigo valioso de exportação não permitia esta circunstância a acumulação de capitais. E não nos esqueçamos de quanto as ásperas condições geográficas não permitiam vultosa saída dos gêneros de Serra Acima, impossibilitados de escoarem abundantes pelas agruras da Paranapiacaba. Ilhada como se achava, supria-se São Paulo largamente a si própria, produzindo cereais em grande escala - sobretudo trigo, milho e feijão - algodão, lã, um pouco de açúcar, marmelos. Como indústria só oferecia rústicos panos de algodão, grosseiros tecidos de lã, chapéus de feltro, rudimentar cerâmica. A pecuária ainda não estava muito desenvolvida, os rebanhos bovinos, as manadas eqüinas, os plantéis de ovinos não apresentam proporções avantajadas. (TAUNAY, 2004, p.95) Terra sem açúcar, sem um produto de forte utilidade mundial, teria São Paulo de viver na pobreza quando os outros núcleos principais do Brasil, Bahia e Pernambuco, sobretudo, dispunham de muito maiores cabedais. (TAUNAY, 2004, p.113) 
Tem-se, então, até o século XVII a imagem de São Paulo (seja a capitania, a cidade, ou a capitania refletida na cidade) pobre, ligada a uma "mera" economia de subsistência.

Já na segunda metade do Seiscentos, a capitania (assim como sua capital, a vila de São Paulo), apresentava-se de maneira diversa. Sua especificidade deriva de sua própria dinâmica interna, qual seja, através de todo um processo de mercantilização São Paulo constituiu-se em pólo de abastecimento interno, articulando-se com as demais áreas e capitanias, principalmente as exportadoras (cf. BLAJ, 1995).

Essas mudanças processaram-se, em grande medida, a partir da última década do século XVII, com a descoberta e exploração do ouro nas Minas Gerais. A crescente concorrência do açúcar antilhano levou ao declínio da produção e comercialização do produto brasileiro afetando, esta decadente economia, a metrópole. Portugal passou, então, a estimular a busca por metais como forma de recuperar sua economia.

Com a descoberta do ouro, as transformações sofridas pela colônia foram profundas e incluíram a concentração de esforços econômicos e político-administrativos na região da mineração e o deslocamento maciço de população para as Minas - "houve um abandono generalizado da agricultura despovoando-se as demais capitanias e concentrando-se, em um curto espaço de tempo, considerável massa populacional nas Gerais”. (RANGEL, 1990, p.5) Por conseguinte, a vizinha capitania de São Paulo viu-se afetada, pois foi a partir da ascensão da economia mineratória que se desenvolveram "as primeiras formas efetivas de integração da Capitania de São Paulo ao restante do Brasilcolônia", que passou a fornecer e gêneros diversos para as regiões mineiras.

Ainda que parte do abastecimento alimentar das Minas fosse feito a partir da própria região - outras atividades econômicas se desenvolveram paralelamente e muitas das vezes com igual relevância -, parte substancial das necessidades da região era suprida com produtos importados, "[...] logo se fizeram estalagens e logo começaram os mercadores a mandar às minas o melhor que chega nos navios do Reino e de outras partes [...] de todas as partes do Brasil se começou a enviar tudo o que dá a terra, com lucro não somente grande, mas excessivo", produtos estes vendidos a elevados preços "E estes preços, tão altos e tão correntes na mina, foram causa de subirem tanto os preços de todas as coisas como se experimenta nos portos das cidades e vilas do Brasil" (ANTONIL, 1997, pp.160-171) 
Nesse rendoso comércio de abastecimento destacou-se São Paulo:

[...] a princípio, os habitantes de Piratininga limitaram-se a mandar para as Gerais as sobras de sua minguada produção. Depois, atraídos pelos gordos lucros, intensificaram esta produção, com o fito de vender cada vez mais, ainda que fosse com sacrifício dos consumidores locais. Em seguida, não contentes com isso, foram buscar, em regiões por vezes distanciadas, tudo aquilo que os mineiros careciam e que eles mesmos não podiam produzir. (ZEMELLA, 1990, p.60)

Desfrutando de posição geograficamente privilegiada com relação às Minas Gerais; com caminhos que para lá seguiam, além de outros que ligavam a capitania a diversas regiões, pôde ser "retaguarda econômica da minas", tendo em Santos importante porta de entrada para os produtos europeus (incluindo diversas manufaturas até então com fabricação proibida no Brasil), e escravos para trabalharem nas minas, além de escoadouro da riqueza mineira:

A região Planaltina transformou-se, nessa época recente dos descobrimentos, na verdadeira retaguarda econômica da minas, privilegiada com relação ao Rio de Janeiro, já que esta capitania não dispunha de caminho direto para manter o intercâmbio com o hinterland aurífero, e também privilegiada com relação à Bahia porque esta fora proibida de negociar com as Minas. (ZEMELLA, 1990, p.62)

Todavia, essa posição privilegiada de São Paulo foi sobrepujada pelo Rio de Janeiro, quando da abertura do Caminho Novo das Minas, ou Caminho Novo do Rio de Janeiro no início do século XVIII. As atividades comerciais, antes realizadas via São Paulo, passaram a ser, preferencialmente, feitas pelo caminho fluminense que, mais curto, representava maiores facilidades e menores custos no transporte de mercadorias, o que dinamizou a região fluminense, justificando, provavelmente, a perda da autonomia administrativa de São Paulo na década de 1740 (e a posterior transferência da capital da colônia para o Rio de Janeiro). (cf. LUNA \& KLEIN, 2006, p.40) "Se a região Planaltina não experimentou uma decadência total e rápida com a abertura do 'caminho novo', foi por ter-se tornado o caminho necessário para as minas que se descobriram em Goiás e Mato Grosso, e também por ser região de passagem das tropas que vinham do sul." (ZEMELLA, 1990, p.63) 
Figura II.1

Principais caminhos paulistas

(século XVIII)

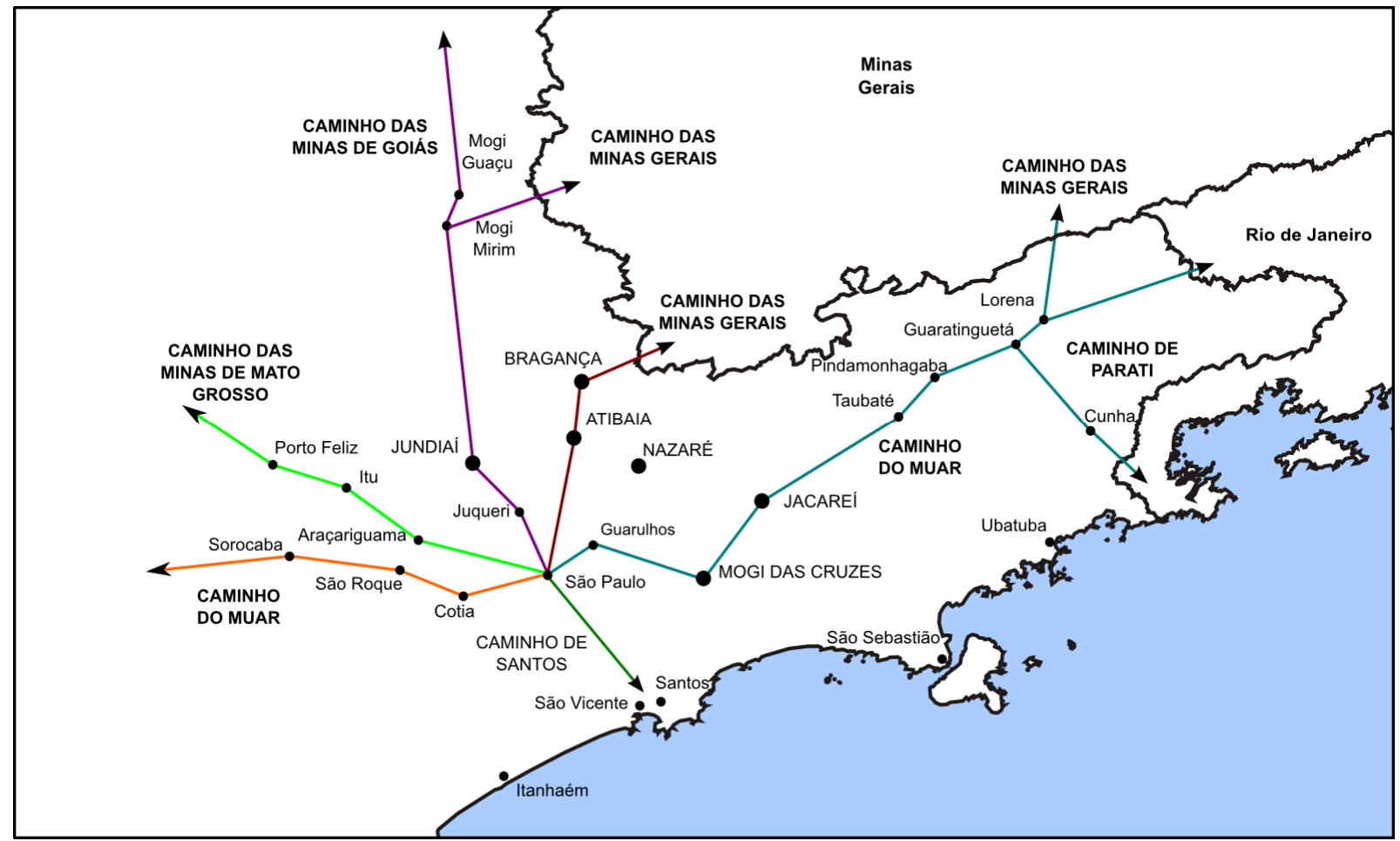

Fonte: RANGEL, 1990, p. 49

Mesmo assim, não deve ter-se excluído de todo o comércio paulista com as Minas Gerais, o surgimento de outra área de abastecimento importante não exclui a possibilidade de continuidade da anteriormente existente, pois

[...] a ampliação da oferta, ao provocar um reajustamento do mercado a níveis inferiores de preços, deveria ter inviabilizado somente as regiões mais distantes. Relativamente à Baixada fluminense, cujos custos de transporte deveriam ser menores, as vilas paulistas operariam com menor lucratividade a partir dos preços vigentes nas Gerais. Entretanto, para as vilas paulistas localizadas próximas às Gerais, como as do norte do Vale do Paraíba e mesmo as do Oeste Paulista, que atendiam ao sudoeste das Minas Gerais, o mercado mineiro parece ter tido alguma significância.

[...] E mais provável, portanto, que o comércio com as Gerais não se tenha arrefecido totalmente com a abertura do Caminho Novo. Provavelmente, estabeleceu-se um fluxo de abastecimento das Gerais através de terras paulistas de artigos de menor significação como pano de algodão, fumo de qualidade inferior, mantimentos e mesmo algum açúcar. (RANGEL, 1990, p.8)

Destarte, o comércio com as minas de Goiás e do Mato Grosso, assim como a intermediação no comércio de muares e o enfraquecido comércio com as Minas Gerais, representavam a mercantilização da capitania paulista na primeira metade do século 
XVIII. Já na segunda metade do Setecentos, ainda que continuada, esta mercantilização viu-se diminuída frente à contínua decadência das minas das Gerais - os depósitos superficiais já estavam praticamente esgotados, e não existiam recursos locais, devido ao sistema tributário que possibilitassem a reestruturação do sistema mineratório -, assim como dos novos descobertos, bem mais efêmeros.

A economia colonial e, a sua vez, paulista teria se voltado, então, de forma generalizada a atividades agropecuárias, passando por um "renascimento agrícola", com ampliação, mormente, da produção de algodão e de açúcar para outros mercados. (cf. PRADO Jr.,1996) - impulsionadas, também, pelas mudanças no mercado europeu, especialmente com a revolução industrial, com a revolução francesa e com a independência de outras colônias na América não portuguesa.

Uma nova política de estímulo à produção foi implementada pela metrópole e, tornando-se novamente capitania autônoma (1765), São Paulo passou a partir do primeiro governo da capitania restaurada, devido à Morgado de Mateus, por sucessivas administrações até o início do século XIX, que buscaram "modernizar" a agricultura paulista, com a necessidade de "[...] apegarem-se à cultura das terras com arado, gados e estrumes, como se pratica nas nações mais polidas e bem governadas". Foram promovidas melhorias nas redes de transporte paulistas, com o estabelecimento de uma melhor estrutura portuária e dos caminhos de ligação, preparando uma infra-estrutura que facilitaria a exportação de diversos produtos.

Ademais, o final do Setecentos foi um período de importantes transformações no que tange à administração da colônia: a mudança da capital colonial para o Rio de Janeiro em 1763 anteriormente citada e a chegada e instalação da corte portuguesa na capital, já nos primórdios do século XIX (1808), estimularam atividades ligadas ao abastecimento interno, criando novas demandas por produtos de subsistência.

Paralelamente, as questões fronteiriças, com a necessidade de manutenção das fronteiras portuguesas na região do rio da Prata (que se estenderam por décadas) fizeram com que esforços militares fossem levados a cabo, justificando a preocupação com o transporte e com a concentração e estabilidade de povoações, então dispersas, capazes de manter uma produção sólida.

Sem abandonar as culturas de auto-subsistência e abastecimento interno características de sua economia desde os primeiros tempos, boa parte deste processo refletiu-se no açúcar, tornando-se São Paulo um exportador do produto para além mar, produto que "era muito insignificante em meados do século XVIII", ainda que nunca tenha "desaparecido por completo das terras da capitania de São Paulo", visou ao mercado 
mundial apenas a partir do governo de Morgado de Mateus, tendo sua produção aumentado gradativamente no correr dos anos: eram 483 engenhos conhecidos na capitania em 1798, número elevado a 574 no ano seguinte. "Os paulistas resolveram dedicar-se intensivamente à cultura da cana que, por período de mais de meio século, vai ser produto chave da economia paulista." (cf. PETRONE, 1968).

Nas primeiras décadas do Oitocentos, o açúcar concentrava-se, especialmente no Oeste da capitania, e a

[...] cidade de São Paulo, pelas funções de capital e localização privilegiada, representava o núcleo mais importante e densamente povoado; concentrava inúmeras atividades não agrícolas, ligadas ao comércio, ao artesanato e às profissões liberais. Ao seu redor espalhavam-se várias localidades, essencialmente agrícolas, cuja produção abastecia a capital. (LUNA \& KLEIN, 2009a, p.165).

Na virada do século XVIII para o XIX, começou a aparecer em São Paulo a cultura do café:

Diante do desenvolvimento da produção cafeeira comercial na província vizinha do Rio de Janeiro, do íntimo contato dos paulistas com esta economia e da nova riqueza gerada localmente pelas exportações açucareiras de São Paulo, foi inevitável a penetração do café na província, vindo do Rio de Janeiro no primeiro quartel do século XIX. (LUNA \& KLEIN, 2006, p.250)

O café passou a ser a nova cultura de exportação do Oitocentos, fixada de forma efetiva nas décadas de 1820 e a partir da década de 1830, ocupando, em especial, a área do Vale do Paraíba. 


\title{
Jundiaí
}

Segundo os maços de população analisados para o período 1799 a 1830 para a então vila de Jundiaí e seu termo, a sociedade jundiaense era acentuadamente rural, mas com importante participação de domicílios cujas atividades econômicas principais estavam ligadas a setores como artesanato, transporte ou comércio, serviços básicos também para quem se dedicava à agropecuária.

$\mathrm{Na}$ Tabela II.1, são mostrados os principais setores em que podemos classificar as atividades econômicas arroladas para os chefes de fogo da localidade ao longo dos anos. No apêndice estatístico a tabela é apresentada com maiores detalhes, pois os setores aparecem subdivididos em ramos e ocupações específicas. A divisão das ocupações apresentada é uma adaptação baseada na classificação proposta por Costa e Nozoe (1987), em artigo intitulado Economia colonial brasileira: classificação das ocupações segundo ramos e setores, em "que o termo economia colonial denota a estrutura econômica, não se prendendo ao marco político a contar do qual foram rompidos os liames que nos atavam a Portugal." ${ }^{44} \mathrm{Na}$ definição dos próprios autores:

\begin{abstract}
Ocupação econômica ou atividade econômica - é o atributo do indivíduo ao qual se pode imputar o fato de o mesmo auferir (ou possibilitar que outrem o faça) ganhos pecuniários ou em espécie e que o vincula, mediata ou imediatamente, à produção de bens e serviços. [...] Ramo de atividade econômica - é a designação genérica atribuída a um conjunto de ocupações afins, as quais, isolada ou conjuntamente, propiciam a produção de determinados bens ou serviços que apresentam características básicas comuns. [...] Setor econômico - é a denominação sob a qual agrupam-se determinados ramos econômicos cuja afinidade é dada por características comuns. [...] O primeiro nível, ocupações, fica mais próximo do concreto e refere-se, imediatamente, às pessoas. Toda ocupação enquadra-se em um ramo e cada um destes integra um setor. [...] ramos e setores são categorias mais abstratas e só se referem mediatamente às pessoas, pois dizem respeito à estrutura econômica das comunidades, a qual expressa a divisão social do trabalho, a distribuição da riqueza e as estruturas de poder. (COSTA \& NOZOE, 1987, pp.7273, grifo nosso)
\end{abstract}

Destarte, incluímos entre as distintas atividades econômicas, e por conseguinte, em seus ramos e setores, ocupações não necessariamente ligadas à produção de bens ou serviços com mercantilização direta. Declarações de atividades como "planta para seu sustento", "colheu mantimentos para gasto" ou "vive de suas lavouras" estão incluídas entre as atividades produtivas/econômicas locais, assim como as distintas patentes

\footnotetext{
44 Essa classificação será adotada também para as demais localidades estudadas. Para uma proposta alternativa ver, por exemplo, BOTELHO et. al. (2006).
} 
militares, ainda que não identificadas diretamente como tropa paga, cuja determinação mostrou-se difícil.

Cabe notar também que observamos em separado pessoas descritas como pobres, mendigas, vadias ou a viver de esmolas, assim como aquelas declaradas como "vive de andar passeando" ou "vive de andar e passear", referências que não se enquadram nas ocupações econômicas no sentido apontado anteriormente, mas cuja observação revela-se importante para o entendimento dos processos de integração econômica nos diversos momentos pesquisados e ao longo deles.

Estão colocados na tabela apenas os chefes de fogo para os quais pudemos identificar a atividade desenvolvida. Não menos de $80,6 \%$ dos fogos (1808) foram contemplados. E consideramos a ocupação realizada pelo chefe como a atividade principal do fogo, mesmo sabendo que, muito provavelmente, atividades diversas eram desenvolvidas concomitantemente por outros membros do domicílio, em especial mulheres, bastante ligadas ao artesanato, em atividades como fiação e costura e ainda outros serviços domésticos diversos. Em regra, as mulheres cujas atividades produtivas foram declaradas eram chefes de fogo que se encontravam nessa situação por serem viúvas. Como sabemos, o percentual chefes de fogo do sexo feminino esteve ao redor $20 \%$, sendo viúvas não menos de $58 \%$ ou mais delas. Isso subestima consideravelmente a importância de fiandeiras, tecedeiras, rendeiras, costureiras entre outras, na divisão do trabalho.

Os demais membros dos fogos praticamente não tiveram suas ocupações arroladas, exceção dos parentes, melhor dizendo, filhos, militares. Em 1799 foram descritos, para além de chefes de fogo apenas 29 militares. Em 1803, para as 57 descrições, encontramos 50 relativas às distintas patentes militares, sendo que do total dessas declarações cinco eram dos filhos do capitão mor e senhor de engenho Antonio de Siqueira de Morais, sendo três de seus filhos militares das ordenanças, Joaquim de 31 anos clérigo de menores e Maria, religiosa no convento da Conceição em São Paulo aos 31 anos de idade. Em 1808 essas declarações correspondiam a 52 militares e dois clérigos. Já em 1812 e 1816 encontramos perto de 90\% de militares. Foram 33 militares entre as 36 declarações de 1822, no seguinte ano observado eram 11 milicianos em não mais de 15 ocupações arroladas e em 1830 encontramos apenas 8 declarações desse tipo: tropeiro, administrador de engenho - este, vivendo no fogo somente na companhia dos escravos, pois trata-se de Domingos Lemes de Sampaio, administrador do engenho do capitão Vicente de Sampaio - três feitores e quatro soldados milicianos. 
Tabela II.1

Distribuição dos fogos por setores de atividade econômica

(Jundiaí - 1799 a 1830)

\begin{tabular}{|c|c|c|c|c|c|c|c|c|}
\hline Setor & $\begin{array}{l}1799 \\
\% \text { (№) }\end{array}$ & $\begin{array}{c}1803 \\
\% \text { (№) }\end{array}$ & $\begin{array}{c}1808 \\
\% \text { (№) }\end{array}$ & $\begin{array}{c}1812 \\
\% \text { (№) }\end{array}$ & $\begin{array}{r}1816 \\
\% \text { (№) }\end{array}$ & $\begin{array}{c}1822 \\
\% \text { (№) }\end{array}$ & $\begin{array}{r}1825 \\
\% \text { (№) }\end{array}$ & $\begin{array}{r}1830 \\
\% \text { (№) }\end{array}$ \\
\hline Agricultura & $71,6(442)$ & $50,6(316)$ & $55,9(329)$ & $53,1(391)$ & $48,9(370)$ & $45,3(315)$ & $50,3(406)$ & $47,5(406)$ \\
\hline Artesanato & $6,3(39)$ & $10,9(68)$ & $12,4(73)$ & $12,2(90)$ & $14,9(113)$ & $15,2(106)$ & $16,7(135)$ & $17,2(147)$ \\
\hline Igreja & $0,5(3)$ & $0,6(4)$ & $0,7(4)$ & $0,5(4)$ & $0,4(3)$ & $0,3(2)$ & $0,2(2)$ & $0,4(3)$ \\
\hline Magistratura & $0,2(1)$ & $0,5(3)$ & $0,8(5)$ & $0,4(3)$ & $0,1(1)$ & $0,3(2)$ & $0,2(2)$ & $0,5(4)$ \\
\hline Profissões liberais & $0,2(1)$ & $0,2(1)$ & $0,3(2)$ & $0,0(0)$ & $0,0(0)$ & $0,1(1)$ & $0,1(1)$ & $0,2(2)$ \\
\hline Rentistas & $0,2(1)$ & $0,2(1)$ & $0,7(4)$ & $0,5(4)$ & $0,3(2)$ & $0,6(4)$ & $0,2(2)$ & $0,2(2)$ \\
\hline Comércio & $2,4(15)$ & $1,9(12)$ & $1,7(10)$ & $1,4(10)$ & $2,2(17)$ & $3,9(27)$ & $3,8(31)$ & $7,0(60)$ \\
\hline Transporte & $2,9(18)$ & $8,0(50)$ & $6,3(37)$ & $3,3(24)$ & $7,4(56)$ & $5,7(40)$ & $6,2(50)$ & $5,7(49)$ \\
\hline Serviços em geral & $0,2(1)$ & $0,0(0)$ & $0,0(0)$ & $0,0(0)$ & $0,0(0)$ & $0,1(1)$ & $0,1(1)$ & $0,5(4)$ \\
\hline Corpo militar & $1,9(12)$ & $0,3(2)$ & $1,4(8)$ & $0,9(7)$ & $0,7(5)$ & $0,3(2)$ & $0,1(1)$ & $0,2(2)$ \\
\hline Jornaleiros & $4,2(26)$ & $3,0(19)$ & $1,2(7)$ & $3,4(25)$ & $1,3(10)$ & $5,2(36)$ & $2,7(22)$ & $6,9(59)$ \\
\hline Não classificadas & $0,5(3)$ & $3,5(22)$ & $0,0(0)$ & $1,8(13)$ & $3,7(28)$ & $0,1(1)$ & $0,1(1)$ & $0,1(1)$ \\
\hline Múltiplos setores & $8,9(55)$ & $20,3(127)$ & $18,7(110)$ & $22,5(166)$ & $20,1(152)$ & $22,8(159)$ & $19,0(153)$ & $13,6(116)$ \\
\hline Total & $100,0(617)$ & $100,0(625)$ & $100,0(589)$ & $100,0(737)$ & $100,0(757)$ & $100,0(696)$ & 100,0 (807) & 100,0 \\
\hline
\end{tabular}

Especialmente entre 1803 e 1825, merecem destaque entre os domicílios jundiaenses aqueles ligados a múltiplos setores, ou seja, aqueles fogos em que o chefe declarou realizar duas ou mais atividades econômicas. O percentual devido a esses fogos variou em torno dos $20 \%$ ao longo dos referidos anos, sendo a menor participação identificada em 1808 (18,7\%) e a maior em 1822 (22,8\%). Nesse sentido, a especialização não aparece de forma totalitária.

O corpo militar apresentou participação significativa na conjugação com outros setores, não menos de 79,3\% das múltiplas ocupações correspondia, entre as ocupações declaradas, a militares, independentemente da patente considerada, sendo que não mais de 1,9\% das ocupações declaradas (correspondente a 12 indivíduos em 1799) eram exclusivamente de chefes de domicílio componentes do corpo militar.

A atividade conjugada ao setor militar deveria ser a mais representativa das atividades produtivas dos domicílios. Assim, a Tabela II.2 apresenta também a divisão por ramos e setores desconsiderando-se o corpo militar caso ele aparecesse conjugado a uma outra atividade. Tal procedimento diminui sobremaneira a participação dos múltiplos setores ao longo dos anos, que, no limite, identificado no ano de 1812, passa de 116 chefes de domicílio (22,5\% do total), para 11 indivíduos (1,5\% do total), ou seja, 155 fogos tinham um chefe militar que se ocupava primordialmente de uma outra atividade. 
Considerado sem distinção de patentes (de ajudante a capitão), o corpo militar esteve ligado à totalidade dos demais setores. Assim, por exemplo, encontramos em 1808 Francisco de Paula, então com 34 anos, cabo que também declarou que "vive de andar com seus animais no caminho de Santos" (Lista Nominativa de Jundiaí - AESP, Maços de População/rolo 108) ou quatro anos depois o soldado Inacio Dias "vive de ganhar jornais", assim como os soldados Manuel e Salvador de Oliveira enquanto o soldado Joaquim Alvares era carpinteiro, o miliciano Jose dos Santos Reis era alfaiate e taberneiro, e o sargento Manoel Dias apenas colheu para gasto; entre dezenas de outras possibilidades encontrados ao longo dos anos. (cf. Lista Nominativa de Jundiaí, 1812 AESP, Maços de População/rolo 109)

Embora tenhamos agrupado sob a rubrica "militar" indivíduos de diferentes patentes, podemos identificar algumas diferenças entre elas. As atividades ligadas ao setor artesanato aparecem, basicamente, entre os soldados, cabos ou milicianos, ou seja, o piso do serviço militar. Decerto, mesmo capazes de prover seu próprio sustento, indivíduos ligados a atividades manuais, ainda que especializadas, não apresentavam nenhum "nobreza", indispensável para ascensão aos melhores postos militares. É também entre os soldados, que encontramos os militares com indicativo de produção de gêneros apenas para seu sustento e jornaleiros, certamente camadas menos abastadas da população, ainda que os primeiros tivessem alguma ligação com a terra (cf. referida tabela em apêndice).

Por outro lado, os postos mais altos apresentam outra especificidade: a ligação com engenhos e a produção comercial de açúcar, discutida mais adiante. Os engenhos foram descritos (também ligados à "pinga") nos fogos de alguns alferes, tenentes e capitães, que deveriam controlar a produção desse bem.

Grosso modo, podemos afirmar que os fogos jundiaenses dividiam-se entre aqueles chefiados por indivíduos ligados às atividades agropastoris, e chefes ligados a outros setores de atividade, que por sua vez poderiam ser militares ou não. Em sendo militares, tenderia a acompanhar os de alta patente a agropecuária de produtos de agrícolas com vistas ao mercado, especialmente o açúcar; enquanto a baixa patente dedicar-se-ia exclusivamente à produção para o consumo próprio e eventuais negociações e atividades manuais. 
Tabela II.2

Distribuição dos fogos por setores de atividade econômica

- exclusive militares em múltiplas ocupações (Jundiaí - 1799 a 1830)

\begin{tabular}{|c|c|c|c|c|c|c|c|c|}
\hline Setor & $\begin{array}{l}1799 \\
\% \text { (№) }\end{array}$ & $\begin{array}{r}1803 \\
\% \text { (№) }\end{array}$ & $\begin{array}{c}1808 \\
\% \text { (№) }\end{array}$ & $\begin{array}{c}1812 \\
\% \text { (№) }\end{array}$ & $\begin{array}{c}1816 \\
\% \text { (№) }\end{array}$ & $\begin{array}{c}1822 \\
\% \text { (№) }\end{array}$ & $\begin{array}{l}1825 \\
\% \text { (№) }\end{array}$ & $\begin{array}{l}1830 \\
\% \text { (№) }\end{array}$ \\
\hline Agricultura & $78,4(484)$ & $64,2(401)$ & $70,3(414)$ & $69,1(509)$ & $63,0(477)$ & $60,1(418)$ & $63,4(512)$ & $54,9(469)$ \\
\hline Artesanato & $6,3(39)$ & $11,7(73)$ & $13,9(82)$ & $13,4(99)$ & 14,9 (113) & $15,2(106)$ & $17,3(140)$ & $18,0(154)$ \\
\hline Igreja & $0,5(3)$ & $0,6(4)$ & $0,7(4)$ & $0,5(4)$ & $0,4(3)$ & $0,3(2)$ & $0,2(2)$ & $0,4(3)$ \\
\hline Magistratura & $0,2(1)$ & $0,5(3)$ & $0,8(5)$ & $0,4(3)$ & $0,3(2)$ & $0,3(2)$ & $0,2(2)$ & $0,5(4)$ \\
\hline Profissões liberais & $0,2(1)$ & $0,2(1)$ & $0,3(2)$ & $0,0(0)$ & $0,0(0)$ & $0,1(1)$ & $0,1(1)$ & $0,2(2)$ \\
\hline Rentistas & $0,2(1)$ & $0,2(1)$ & $0,7(4)$ & $0,7(5)$ & $0,3(2)$ & $0,6(4)$ & $0,5(4)$ & $0,2(2)$ \\
\hline Comércio & $2,9(18)$ & $2,1(13)$ & $1,9(11)$ & $2,6(19)$ & $2,6(20)$ & $5,9(41)$ & $4,6(37)$ & $8,5(73)$ \\
\hline Transporte & $3,4(21)$ & $10,1(63)$ & $7,5(44)$ & $4,5(33)$ & $9,2(70)$ & $9,2(64)$ & $7,9(64)$ & $6,8(58)$ \\
\hline Serviços em geral & $0,2(1)$ & $0,0(0)$ & $0,0(0)$ & $0,0(0)$ & $0,0(0)$ & $0,1(1)$ & $0,1(1)$ & $0,5(4)$ \\
\hline Corpo militar & $1,9(12)$ & $0,3(2)$ & $1,4(8)$ & $0,9(7)$ & $0,7(5)$ & $0,3(2)$ & $0,1(1)$ & $0,2(2)$ \\
\hline Jornaleiros & $4,4(27)$ & $3,0(19)$ & $1,2(7)$ & $4,6(34)$ & $1,7(13)$ & $5,6(39)$ & $2,9(23)$ & $6,9(59)$ \\
\hline Não classificadas & $0,5(3)$ & $3,5(22)$ & $0,0(0)$ & $1,8(13)$ & $4,0(30)$ & $0,1(1)$ & (1) & $0,1(1)$ \\
\hline Múltiplos setores & $1,0(6)$ & $3,7(23)$ & $1,4(8)$ & $1,5(11)$ & 2,9 (22) & 2,2 (15) & $2,4(19)$ & $2,8(24)$ \\
\hline Total & $100,0(617)$ & $100,0(625)$ & $100,0(589)$ & $100,0(737)$ & $100,0(757)$ & $100,0(696)$ & $100,0(807)$ & $100,0(855)$ \\
\hline
\end{tabular}

Exclusıve pobres, vadıos, indıgentes e chetes de togo sem ocupaçao declarada, que declararam "nao da nada" e ılegıveıs

Fontes: AESP, Maços de População, Jundiai: anos selecionados

O corpo militar era composto por três linhas - tropa regular (paga), os auxiliares (para segurança interna) e as ordenanças (segurança local, serviços gratuitos) - com um "estado maior", efetivamente os "militares de patente" e a este estado maior podendo estar subordinadas várias companhias, compostas por militares (oficiais inferiores) exercendo diferentes funções, sendo que à exceção de soldados, que se contavam às dezenas, cabos (5), sargentos (2), existiam em número de 1 os demais cargos em cada companhia.

Aproximadamente, para as três linhas, temos a hierarquia: coronel, capitão-mor, sargento-mor, capitão, tenente, alferes, sargento, furriel, cabo, anspeçada, soldado. Soldados - maior parcela dos indivíduos ligados ao corpo militar -, não estavam ligados a engenhos, havia um único cabo produzindo açúcar em 1799, era o mulato João Fernandes que produzia apenas $2,6 \%$ do açúcar arrolado pelos oito produtores na lista nominativa daquele ano. Em 1803 e 1812 os produtores de açúcar com patentes explicitamente ligadas ao corpo militar eram ao menos alferes, sendo nos demais anos os menores percentuais encontrados em 1822 (75\%) quando o soldado miliciano Ignacio Bueno declarou engenho e açúcar, e em 1825 (68,2\%), quando dois soldados milicianos, entre o total de 22 com patente, produziram o bem. 
A propriedade de engenhos e a produção de açúcar estavam incluídas entre as ocupações do setor agricultura e manufatura rural e representava, certamente, a atividade mais representativa desse setor em termos de possibilidades mercantis da produção, sendo o açúcar produto de importante presença na pauta exportacionista da colônia e do município.

Junto aos declarados "senhor de engenho", "possui engenho", estão postos no setor agricultura aqueles indivíduos que se declaram "agricultor", planta ou colhe "para o gasto", "vive de suas lavouras", "planta", "cria", "lavrador". As mais comumente encontradas variaram de acordo com o ano da lista e, ao longo do tempo, não havia uma única situação em que os indivíduos se encontravam, ou seja, em um momento certo chefe de fogo poderia se definido como agricultor, em outro como colheu para gasto e na próxima lista considerada ser encontrado como criador. Só para ilustrarmos com algumas poucas situações, temos Anna de Lima do Prado que em 1799 declarou plantar para gasto e viver de lavoura, já em 1803 encontramos arrolado para mesma Anna "planta e cria". Antonio Fernandes de Freitas era plantador para gasto em 1808 e agricultor em 1812; Bernardo Moraes Passos plantava para gasto e vivia de sua lavoura em 1799 e em 1803 era cabo e "não plantou". (cf. Lista Nominativa de Jundiaí,1799, 1803, 1808 e 1812 - AESP, Maços de População/rolos 106 a109)

Essa variação nas definições dificulta uma avaliação das distintas possibilidades vinculadas ao setor agropecuário, pois certo é que embora agrupados sob diferentes ocupações dentro do grupo em questão - assim como deveria ocorrer com outros grupos como aquele relativo aos comerciantes - havia indivíduos em situações distintas, podendo existir alguns tendentes aos pobres, enquanto outros desenvolviam atividades de maior monta.

Todavia, importa notar que chefes de fogo ligados ao setor agricultura e manufatura rural representavam, como não poderia deixar de ser, parcela majoritária daqueles com ocupação declarada ao longo do período aqui observado, ainda que com uma tendência de longo prazo decrescente. Em $183047,5 \%$ de todas as ocupações listadas eram agropecuárias, percentual quase 30 pontos inferior ao observado no início do período, 1799 , em que as atividades rurais responderam por $71,6 \%$ de todas aquelas anotadas. O fim do Setecentos destaca-se por apresentar participação do referido setor bastante superior àquela verificada para os demais anos, que não ultrapassou os $55,9 \%$ registrados em 1808.

Em sentido diverso ao setor agropecuário, encontramos o setor artesanato - em que estão arroladas, em especial, ocupações como pedreiro, louceiro, ferreiro, 
cangalheiro, carpinteiro/carapina, fiadeira, tecedeira, sapateiro, alfaiate, costureira, entre outras -, sempre como segundo maior empregador de chefes jundiaenses e com participação constantemente crescente ao longo do tempo. Eram 6,3\% dos fogos cuja atividade principal era o artesanato em 1799, $11 \%$ em 1803, cerca de $12 \%$ nos anos 1808-12, perto de 15\% nos dois períodos que seguem, atingindo cerca de 17\% em 1825 e 1830. Ou seja, a participação do setor foi aumentada em mais de $170 \%$ ao longo dos 30 anos observados, sendo a variação de $58 \%$ ao longo das primeiras décadas oitocentistas.

Em que pese a participação das mulheres viúvas entre os chefes de domicílio (cf. capítulo anterior) e sua ausência entre os múltiplos setores onde, como vimos, era contundente a predominância de militares, a elevação das propriedades vinculadas ao artesanato deve-se em sua maior monta à presença das atividades femininas ligadas à fiação e à tecelagem: declaradas em número de 21 em 1799 (2,1\% do total), fiadeiras, tecedeiras e costureiras alçaram-se a 97 em 1825 (12\%) e 106 no ano de 1830, número correspondente a $12,4 \%$ das atividades encontradas para os fogos da vila. Nos últimos anos, a participação desses fogos respondia por $72 \%$ do total do setor artesanal.

Participação importante também era devida ao setor comércio. Vendeiros, taberneiros, negociantes que não ultrapassaram os $2,4 \%$ dos chefes de domicílio até 1816, chegaram a 60 indivíduos em 1830, ou seja, 7\% dos domicílios do período. Entre eles destacam-se os taberneiros, que de nenhuma declaração até a primeira década do século XIX, chegavam a 30 chefes de domicílio em 1830, superando os vendeiros e negociante de fazenda seca, mais comuns até então. Se considerados os indivíduos que além a comerciantes eram também parte do corpo militar, o percentual devido a comerciantes eleva-se em alguma medida, chegando a 8,5\% em 1830.

Em se considerando o incremento no setor comercial da localidade e, tendo-se como dada a dinâmica populacional local (observada no capítulo I), observamos que houve um incremento considerável no setor comércio entre 1799 e 1830, 305,6\% contra $47,4 \%$ da população. Observados dentro do setor apenas os negociantes e vendeiros, a variação no período seria de $114,3 \%$. Sendo uma casa comercial capaz de atender a inúmeras unidades familiares podemos aventar, como primeira hipótese, o incremento da circulação de bens e serviços e conseguintemente da dinâmica da economia local.

Diferentemente das atividades agrícolas e artesanais que, facilmente, espraiavamse pelas diferentes companhias que conformavam o território de Jundiaí, as casas de comércio predominavam na área mais "urbana" da vila, mormente na primeira companhia, em especial ao bairro da vila, ou seja, a área mais "urbanizada" do município. Ao menos $62,5 \%$ (1803 e 1825) dos negócios do município, ali estavam. 
Outro setor merecedor de menção é o setor relativo aos serviços de transporte. De acordo com Saint-Hilaire, em escrito da década de 1830: "Jundiaí fornece às tropas que vão a Goiás e Mato Grosso um número de camaradas ainda maior do que Moji-Mirim, e segundo me afirmaram, eles são os melhores dentre todos os distritos vizinhos. (SAINTHILAIRE, 1976, p.114) O setor apresentou participação, bastante variável ao longo do tempo, saindo de um mínimo de $2,9 \%$ em 1799 , chegou a $8 \%$ dos fogos com atividade principal declarada em 1803 e 7,4\% em 1816, percentuais que elevam-se a 3,4\%, 10,1\% e $9,2 \%$, respectivamente, se acrescemos aqueles que também exerciam atividades militares. Esses maiores percentuais são inferiores apenas aos verificados para o setor agricultura e artesanato.

Resta-nos, então, estudar mais de perto cada uma dessas possibilidades consideradas. Para tal, observamos inicialmente os diversos produtos cultivados, cuja produção foi mencionada nas várias listas nominativas de Jundiaí consultadas e que estão apresentados na Tabela II.3 e no Gráfico II.1.

Tabela II.3

Gêneros plantados e presença concomitante dos diferentes gêneros nos fogos

(Jundiaí - 1799 a 1830)

\begin{tabular}{lccccccc}
\hline \hline \multicolumn{1}{c}{ CULTURAS } & $\mathbf{1 7 9 9}$ & $\mathbf{1 8 0 3}$ & $\mathbf{1 8 0 8}$ & $\mathbf{1 8 1 6}$ & $\mathbf{1 8 2 2}$ & $\mathbf{1 8 2 5}$ & $\mathbf{1 8 2 9}$ \\
\hline MILHO & $90,0 \%$ & $99,8 \%$ & $94,4 \%$ & $99,0 \%$ & $99,8 \%$ & $99,6 \%$ & $99,5 \%$ \\
FEIJÃO & $54,9 \%$ & $70,2 \%$ & $81,1 \%$ & $66,7 \%$ & $62,4 \%$ & $77,9 \%$ & $66,5 \%$ \\
ALGODÃO & $15,6 \%$ & $14,7 \%$ & $24,0 \%$ & $13,6 \%$ & $7,9 \%$ & $2,8 \%$ & $3,3 \%$ \\
ARROZ & $4,7 \%$ & $22,1 \%$ & $14,2 \%$ & $12,6 \%$ & $12,9 \%$ & $11,8 \%$ & $15,9 \%$ \\
AMENDOIM & - & $2,6 \%$ & $0,4 \%$ & $5,2 \%$ & $0,5 \%$ & $0,2 \%$ & - \\
TRIGO & - & - & - & $0,6 \%$ & - & - & - \\
CANA & $6,2 \%$ & $4,2 \%$ & $9,0 \%$ & $3,8 \%$ & $7,2 \%$ & $6,0 \%$ & $4,1 \%$ \\
MANDIOCA & - & - & $0,4 \%$ & $0,2 \%$ & - & - & - \\
CAFÉ & - & - & - & - & - & - & $0,3 \%$ \\
MAMONA & - & - & - & $0,2 \%$ & - & - & - \\
FUMO & $0,3 \%$ & - & - & $0,4 \%$ & - & $0,2 \%$ & - \\
\hline \hline
\end{tabular}

Fonte: AESP, M aços de População, jundiaí: anos selecio nados, exclusive 1812 


\section{Gráfico II.1}

Percentual de fogos com presença dos diversos gêneros cultivados

\section{(Jundiaí - 1799 a 1830)}

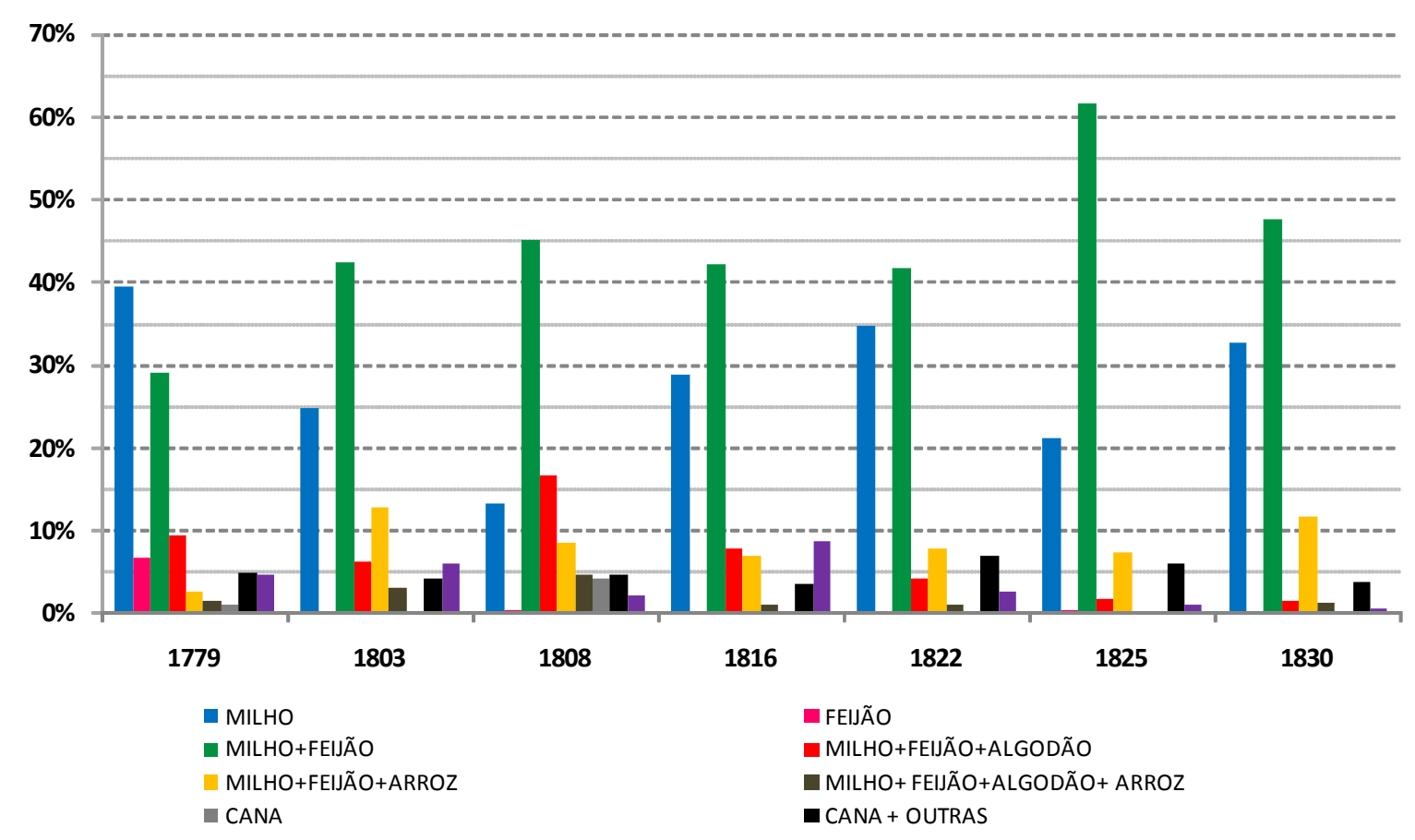

Vale observar que o cultivo da cana foi auferido a partir da presença do açúcar e/ou da aguardente. O ano de 1812 foi excluído dos números apresentados, pois apresentou apenas 21 domicílios com algum tipo de menção ao cultivo levado a cabo, sendo que em 17 deles encontramos produto da atividade de engenhos, o que certamente não é representativo da realidade produtiva da vila naquele momento. A representatividade verificada para os demais anos foi considerável, sendo no mínimo $31,9 \%$ em 1808 e no máximo de $61,1 \%$ em 1825, considerados todos os fogos jundiaenses. Em se considerando apenas aqueles explicitamente ligados à agricultura e manufatura rural e/ou setores incluindo agricultura, (conforme explicitado na tabela II.1), temos uma representatividade que chegou a $70 \%$ em 1803, 55\% em 1808, 80\% em 1830 e praticamente $100 \%$ nos demais anos (exceto 1812).

De maneira clara, em termos de abrangência e presença nos domicílios, encontramos total supremacia do milho, espraiado por $90 \%$ das declarações em 1799 , $94,4 \%$ em 1808 e estando praticamente na totalidade dos fogos com algum tipo de produção mencionada em 1830. Todavia, o cereal apareceu como cultura exclusiva em comparativamente pequena fatia dos fogos: máximo de 35,3\% em 1799, o que 
correspondia a 134 domicílios, e o mínimo de 13,3\% no ano de 1808, quando 31 chefes arrolaram apenas o milho em suas declarações.

Ou seja, ao menos $56,1 \%$ dos plantadores de milho (1799), mantiveram concomitantemente ao longo dos anos, outro tipo de cultivo que merecesse algum destaque a ponto de ser referido, percentual este que foi máximo em 1808, 85,9\%. O principal deles foi o feijão, que participando como segundo principal produto pensado em termos de presença nos fogos - variou entre $54,9 \%$ e $81,1 \%$ - viu-se como principal complementar do milho.

Ambos os produtos apresentaram grande variação ao longo do tempo no que respeita ao número de vezes em que aparecem mencionados nas listas. Mas ainda assim, o lugar que ocupam como primeiro e segundo principais cultivos manteve-se e, conjugados, foram certamente o padrão de produção jundiaense na medida em que essa associação respondeu por mais de $40 \%$ desde os primeiros anos do Oitocentos, saltando ao olhos sua representatividade no Gráfico II.1.

A conjugação milho mais feijão apareceu, ao longo do tempo, em diferentes medidas e momentos e com certa representatividade ligada também ao arroz e a algodão e ainda em menor proporção ligada ao trigo, amendoim, mamona, mandioca, café e cana (vide tabela em apêndice). Entre os produtos citados, algodão, arroz e cana foram os mais recorrentes entre os fogos.

À exceção da cana, que para além dos derivados mais grosseiros e baratos, rapadura e aguardente, sabidamente participava do comércio intra-regional e para além mar, todos os demais produtos estavam entre aqueles que designamos como de subsistência, ainda que não necessariamente auto-subsistência. Um maior número de plantações torna, para aqueles as praticam, a especialização mais difícil indicando, possivelmente, maior autoconsumo, ou seja, produção em quantidades limitadas que atendessem às necessidades das próprias unidades produtivas. Este foi certamente 0 caso daqueles que mencionaram grande número de gêneros.

Importante notar que mesmo naquelas unidades ligadas ao cultivo da cana para beneficiamento, ou seja, nas propriedades em que existiam engenhos, o cultivo dos demais gêneros esteve presente: $81 \%$ dos senhores de engenho declararam também outros produtos em 1799, 50\% em 1808, e ao menos 95\% nos demais anos, chegando à totalidade em 1803 e 1825. Facilmente compreensível, posto ser a atividade açucareira bastante intensiva em mão-de-obra, ou seja, em trabalho de cativos - aí estava empregada parcela elevada dos escravos da vila de Jundiaí entre 1799 e 1830 - que 
precisavam alimentar-se, mesmo sendo de difícil mensuração para nós o montante efetivamente necessário para consumo próprio nos diversos fogos.

Ademais de plantações, faz-se mister considerar no "sistema agrário" do município de Jundiaí as criações. Em 1816, por exemplo, 40,3\% das ocupações do setor agropecuário e 19,7\% do total das ocupações declaradas correspondiam àqueles que explicitamente criavam e plantavam, mesmo apresentando a proximidade de tais atividades, algumas das vezes, problemas: em 1803 Francisco Garcia "nada colheu porque o gado do vizinho comeu" (Lista Nominativa de Jundiaí, 1803 - AESP, Maços de População/rolo 107)

A criação de suínos estava mais disseminada comparativamente à de gado vacum. Em 1830 94,2\% dos fogos ligados a algum animal descreviam exclusivamente esses animais; apenas em 1803 os criadores de porcos eram menos da metade dos fogos (cf. Tabela II.4), ano em que as vacas/bezerros apresentaram seu maior percentual, consideradas como únicos animais presentes nos domicílios: 45,8\%. Nos demais anos esse percentual não chegou a 24\% e em 1830 apenas dois chefes declararam ter tido, como criação, naquele ano exclusivamente vacas.

O percentual de vacuns vê-se elevado nos anos de 1799, 1816 e seguintes, quando considerados aqueles criadores de capados e bois, percentual correspondente a $18,3 \%$ das criações (48 fogos) mencionadas em 1816.

\section{Tabela II.4}

\section{Criações e presença concomitante dos diferentes animais nos fogos}

(Jundiaí - 1799 a 1830)

\begin{tabular}{|c|c|c|c|c|c|c|c|}
\hline CRIAÇÕES & $\begin{array}{l}1779 \\
\% \text { (№) }\end{array}$ & $\begin{array}{l}1803 \\
\% \text { (№) }\end{array}$ & $\begin{array}{l}1808 \\
\% \text { (№) }\end{array}$ & $\begin{array}{l}1816 \\
\% \text { (№) }\end{array}$ & $\begin{array}{l}1822 \\
\% \text { (№) }\end{array}$ & $\begin{array}{l}1825 \\
\% \text { (№) }\end{array}$ & $\begin{array}{l}1830 \\
\% \text { (№) }\end{array}$ \\
\hline VACABEZZERRO & $23,3(24)$ & $45,8(44)$ & $21,3(13)$ & $18,3(48)$ & $21,8(17)$ & $19,8(22)$ & $1,0(2)$ \\
\hline PORCO/CAPADO & $55,3(57)$ & $44,8(43)$ & $77,0(47)$ & $53,6(141)$ & $70,5(55)$ & $71,2(79)$ & $94,2(195)$ \\
\hline BESTABURRO/MULA & $1,9(2)$ & $2,1(2)$ & $1,6(1)$ & $1,1(3)$ & $2,6(2)$ & - & - \\
\hline VACA+CAPADO & $11,7(12)$ & - & - & $18,3(48)$ & $5,1(4)$ & $7,2(8)$ & $1,0(2)$ \\
\hline VACA+BESTA & $3,9(4)$ & $6,3(6)$ & - & $4,6(12)$ & - & $1,8(2)$ & $1,0(2)$ \\
\hline VACA+CAPADO+BESTA & $1,9(2)$ & $1,0(1)$ & - & $2,7(7)$ & - & - & $1,4(3)$ \\
\hline CAPADO+CAVALO & $1,9(2)$ & - & - & $1,5(4)$ & - & - & - \\
\hline CAVALO & - & - & - & - & - & - & $0,5(1)$ \\
\hline VACA+CAPADO+CARNEIRO & - & - & - & - & - & - & $0,5(1)$ \\
\hline VACA+CAPADO+CABRITO & - & - & - & - & - & - & $0,5(1)$ \\
\hline TOTAL & $100,0(103)$ & $100,0(96)$ & $100,0(61)$ & $100,0(263)$ & $100,0(78)$ & $100,0(111)$ & $100,0(207)$ \\
\hline
\end{tabular}


Apesar do crescente número de fogos verificados no setor transporte, ligados ao transporte, os cavalares e muares apareceram em quantidade quase nada significativa. Os cavalos deveriam estar ligados ao transporte humano, entre os bairros e localidades, por exemplo; enquanto as bestas e burros deveriam transportar carga, tendo para inúmeros indivíduos ao longo dos anos aparecido a descrição "tem sua tropa", que implicaria em possuir animais.

Os carneiros e cabritos apareceram apenas em 1830, sempre em pequena quantidade e em tão somente um fogo cada, ambos com criação conjunta de porcos e vacas, indicando a ligação desses animais somente a restritas necessidades domésticas.

Decerto as poucas menções a criações ocorrem por serem elas referentes, nas listas nominativas jundiaenses, provavelmente, aos animais nascidos nos domicílios no período considerado na documentação, uma vez que comumente encontramos expressão "teve" na descrição de algumas delas.

Parte da criação, como adiantado, era realizada de forma concomitante à plantação, tendo sido mencionadas em conjunto em 48,5\% dos 103 casos de criação de 1799, 82\% dos casos em 1808 e sempre acima de 96,5\% nos demais anos, exceto 1812.

Para além da produção primária apresentada até o momento, esses gêneros foram também consumidos de maneira intermediária, possibilitando que fizesse parte do produto local a farinha de milho, mandioca ou trigo, o açúcar, a aguardente e o tabaco. Para a observação dessa produção recorremos, além das listas nominativas propriamente ditas até agora utilizadas, aos mapas de comércio para os anos em que estavam disponíveis.

Consideradas as diferentes medidas (volume, peso ou unidades) para os distintos bens, utilizamos a moeda como unidade de mensuração. Os resultados do processo produtivo da vila e seu termo, tomando-se os "bens finais" produzidos, observada através do valor total do produto ao longo do tempo ${ }^{45}$, mostrado na Tabela II.5, levam a interessantes considerações.

Sendo amplamente disseminado, o milho apresenta participação incontestável ao se precificar os bens. Ao lado do açúcar, manufaturado que tem, via de regra, elevados preços no mercado, como se verá, o cereal em tela foi um dos principais representantes da composição do produto jundiaense durante as mais de três décadas consideradas.

Milho e açúcar (principalmente o açúcar fino ou branco) foram os dois principais produtos locais em valor e oscilaram ao longo do tempo no primeiro e segundo postos.

45 Devido às características dos Mapas de produção, comércio e preços consultados e os próprios arrolamentos populacionais, o valor de cada bem foi calculado multiplicando-se a quantidade pelo preço médio para consumo na vila, sendo o preço médio considerado como $P M e=\frac{(\text { preçomínimo }+ \text { preçomáximo })}{2}$. 
Assim, não houve uma tendência clara de variação ao longo do tempo ou algum patamar padrão de valor em que houvesse se estabelecido cada um dos bens.

Tabela II.5

Participação percentual dos diversos gêneros

no valor do produto

(Jundiaí - 1798 a 1830)

\begin{tabular}{|c|c|c|c|c|c|c|c|c|c|c|}
\hline Produtos & $1798^{*}$ & $1799^{*}$ & $1799^{\star \star}$ & $1803^{\star \star}$ & $1808^{\star \star}$ & $1814^{\star}$ & $1815^{\star}$ & $1816^{\star}$ & $1816^{\star \star}$ & $1817^{\star}$ \\
\hline Milho & 36,9 & 35,0 & 29,4 & 55,5 & 55,5 & 33,4 & 32,3 & 29,0 & 29,6 & 22,0 \\
\hline Feijão & 4,4 & 9,4 & 10,5 & 10,5 & 9,1 & 16,2 & 0,4 & 7,4 & 8,1 & 22,0 \\
\hline Algodão & 0,7 & 3,8 & 3,5 & 2,1 & 2,4 & 1,7 & 0,7 & 1,2 & 1,0 & 1,4 \\
\hline Açúcar branco & 37,5 & 20,0 & 24,3 & 11,7 & 16,3 & 24,8 & 30,4 & 29,5 & 30,3 & 26,0 \\
\hline Açúcar redondo & 13,5 & 6,0 & 10,7 & 4,4 & 2,9 & 9,8 & 8,0 & 11,2 & 10,1 & 7,9 \\
\hline Açúcar mascavo & 2,6 & 0,9 & 2,0 & 1,7 & 0,9 & 2,7 & 3,1 & 3,6 & 3,0 & 1,9 \\
\hline Aguardente & 3,4 & 0,9 & 3,4 & 6,7 & 4,6 & 5,0 & 3,8 & 2,8 & 3,0 & 3,7 \\
\hline Rapadura & - & - & $* * * *$ & 0,0 & - & - & - & 3,0 & - & 2,3 \\
\hline Álcool & - & - & - & 1,5 & - & - & - & - & - & - \\
\hline Fumo & - & - & 0,1 & - & - & 0,1 & $* \star \star *$ & 0,1 & 0,1 & 0,1 \\
\hline Toucinho & - & 21,8 & - & - & - & 0,0 & - & - & - & - \\
\hline Capados & - & - & 6,1 & 5,8 & 7,0 & 4,3 & 19,3 & 10,0 & 13,7 & 10,3 \\
\hline Bois & - & 1,8 & 9,7 & $* * * *$ & - & 0,7 & 0,8 & 1,1 & - & 1,3 \\
\hline Burros & - & - & - & - & - & - & - & - & - & - \\
\hline Cavalos/Potros & - & 0,4 & 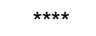 & 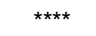 & - & 0,3 & 0,3 & 0,4 & $* \star \star \star *$ & 0,2 \\
\hline TOTAL & 100,0 & 100,0 & 100,0 & 100,0 & 100,0 & 100,0 & 100,0 & 100,0 & 100,0 & 100,0 \\
\hline Produtos & $1818^{*}$ & $1822^{*}$ & $1822^{\star \star}$ & $1825^{\star \star}$ & $1825^{\star}$ & $1827^{\star}$ & $1828^{\star}$ & $1829^{\star}$ & $1830^{\star}$ & $1830^{\star \prime}$ \\
\hline Milho & 17,2 & 45,6 & 36,9 & 38,5 & 41,4 & 40,5 & 39,6 & 40,0 & 34,0 & 45,2 \\
\hline Feijão & 8,6 & 10,0 & 12,2 & 7,2 & 7,3 & 7,8 & 11,4 & 10,6 & 6,7 & 9,0 \\
\hline Algodão & 0,8 & - & $* * *$ & 0,2 & - & - & - & - & - & $* * * *$ \\
\hline Arroz & 0,4 & 0,6 & 0,7 & - & 0,8 & 0,4 & 0,5 & 0,7 & 0,5 & 0,9 \\
\hline Café & - & - & - & $* * * *$ & - & - & $* \star \star *$ & $\star \star \star \star *$ & $\star \star \star * \star$ & $* * * *$ \\
\hline Amendoim & 0,1 & - & $* \star \star \star$ & - & $\star \star \star \star *$ & - & - & - & - & - \\
\hline Açucar & - & 28,8 & - & - & 40,9 & 41,0 & 38,6 & 26,2 & 43,3 & - \\
\hline Açúcar branco & 37,9 & - & 25,6 & 22,9 & - & - & - & - & - & 16,2 \\
\hline Açúcar redondo & 14,1 & - & 7,4 & 7,4 & - & - & - & - & - & 4,8 \\
\hline Açúcar mascavo & 3,5 & - & 1,7 & 1,3 & - & - & - & - & - & 1,5 \\
\hline Farinha & 0,0 & - & - & - & - & - & - & - & - & $* * * *$ \\
\hline Aguardente & 2,1 & 2,5 & 3,1 & 3,1 & 3,3 & 2,7 & 2,4 & 2,6 & 3,3 & 4,5 \\
\hline Rapadura & 3,5 & - & 1,0 & 11,0 & - & - & - & - & - & 0,1 \\
\hline Álcool & - & - & - & - & - & - & - & - & - & - \\
\hline Fumo & 0,1 & - & - & 0,1 & - & - & - & - & - & - \\
\hline Toucinho & - & 5,1 & - & - & - & - & - & - & - & - \\
\hline Capados & 11,0 & 6,2 & 10,3 & 8,4 & 6,2 & 7,6 & 7,4 & 19,9 & 12,1 & 18,0 \\
\hline Bois & 0,7 & 0,9 & 0,9 & $* * * *$ & $* * * *$ & $* * * *$ & $* \star \star *$ & $* \star \star *$ & $* \star \star \star *$ & 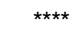 \\
\hline Burros & - & $* * * *$ & - & - & - & $* * * *$ & $* * * *$ & - & $* * * *$ & - \\
\hline Cavalos/Potros & 0,1 & - & $* * * *$ & - & $* * * *$ & - & - & $* * * *$ & - & $* * * *$ \\
\hline Galinhas & - & 0,3 & - & - & 0,1 & 0,1 & - & 0,1 & - & - \\
\hline TOTAL & 100,0 & 100,0 & 100,0 & 100,0 & 100,0 & 100,0 & 100,0 & 100,0 & 100,0 & 100,0 \\
\hline
\end{tabular}


Em que pesem as diferenças encontradas entre os dados obtidos através das observações atinentes ao diferentes fogos no arrolamento populacional dos anos por nós considerados, e os montantes retirados dos mapas de produção, chama a atenção os anos 1803-1808, em que o percentual devido ao milho atingiu cerca de $55 \%$, seu mais alto valor, enquanto o açúcar nestes mesmos anos esteve ao redor de 18 a $20 \%$ todavia, há que mencionar que em 1808 o preço do milho atingiu seu maiores valores, como exposto mais adiante. Por outro lado, a partir de 1814 a participação do açúcar cresceu consideravelmente atingindo seu máximo em 1818, com 55,4\% do produto daquele ano. A sua vez, a participação do milho viu-se gradativamente reduzida, de $33,4 \%$ em 1814 a $17,2 \%$ naquele mesmo ano de 1818 , em que se verificou sua menor participação considerado todo o período de 1798 a 1830.

Os demais gêneros produzidos localmente também não tiveram tendência identificável no longo prazo, mas aguardente, feijão e capados merecem ser citados. A aguardente teve uma participação média ao redor de 3\%, sendo seu máximo identificado na lista nominativa de 1803: 6,7\%. O feijão, apesar de sua participação insignificante nos mapas de $1815(0,4 \%)$, no ano anterior havia respondido por $16,2 \%$ e no ano seguinte por $7-8 \%$, percentual que se repetiu em meados da década de 1820, e que foi seguido por consideráveis $22 \%$ em 1817. Os capados apareceram na documentação desde 1799 , certamente em detrimento ao toucinho que, terceiro principal responsável pelo valor do produto jundiaense em 1799, 21,8\% de acordo com o mapa de comércio, desapareceu definitivamente da relação de bens produzidos já no arrolamento populacional do mesmo 1799. Os capados atingiram seu pico em 1815 como 19,3\% e 1829 com 19,9\%, percentual pouco alterado no ano seguinte: $18 \%$.

O milho e o açúcar - os dois principais gêneros produzidos localmente ao longo do período 1798 a 1836 - merecem uma análise mais específica. Os dois eram utilizados para consumo na própria vila e seu termo e faziam parte da pauta de exportações jundiaenses (que compunham em diferentes proporções, postas na Tabela II.6, e com vistas a diferentes destinos), assim como distintos eram os aspectos diversos de seu cultivo/criação. 
Tabela II.6

Percentual exportado e participação percentual dos diversos gêneros

no valor do produto exportado

(Jundiaí - 1798 a 1830)

\begin{tabular}{|c|c|c|c|c|c|c|c|c|c|c|}
\hline \multirow[b]{2}{*}{ Produtos } & \multicolumn{2}{|c|}{1798} & \multicolumn{2}{|c|}{1799} & \multicolumn{2}{|c|}{1814} & \multicolumn{2}{|c|}{1815} & \multicolumn{2}{|c|}{1816} \\
\hline & $\begin{array}{c}\% \text { da } \\
\text { produção } \\
\text { do bem } \\
\text { exportada }\end{array}$ & $\begin{array}{c}\% \text { do valor } \\
\text { total } \\
\text { exportado }\end{array}$ & $\begin{array}{c}\text { \% da } \\
\text { produção } \\
\text { do bem } \\
\text { exportada }\end{array}$ & $\begin{array}{c}\% \text { do valor } \\
\text { total } \\
\text { exportado }\end{array}$ & $\begin{array}{c}\text { \% da } \\
\text { produção } \\
\text { do bem } \\
\text { exportada }\end{array}$ & $\begin{array}{c}\% \text { do valor } \\
\text { total } \\
\text { exportado }\end{array}$ & $\begin{array}{c}\text { \% da } \\
\text { produção } \\
\text { do bem } \\
\text { exportada }\end{array}$ & $\begin{array}{c}\% \text { do valor } \\
\text { total } \\
\text { exportado }\end{array}$ & $\begin{array}{c}\% \text { da } \\
\text { produção } \\
\text { do bem } \\
\text { exportada }\end{array}$ & $\begin{array}{c}\% \text { do valor } \\
\text { total } \\
\text { exportado }\end{array}$ \\
\hline Milho & 3,3 & 2,2 & 2,0 & 2,0 & 0,04 & 0,04 & 0,1 & 0,1 & 0,7 & 0,6 \\
\hline Feijão & 23,1 & 1,8 & 16,5 & 4,5 & - & - & 19,6 & 0,2 & 1,3 & 0,2 \\
\hline Algodão & - & - & 21,2 & 2,3 & - & - & - & - & - & - \\
\hline Arroz & 1,0 & 0,1 & 100,0 & 0,2 & - & - & - & - & - & - \\
\hline Açúcar branco & 100,0 & 66,9 & 100,0 & 58,0 & 42,6 & 30,8 & 53,1 & 39,9 & 47,2 & 36,3 \\
\hline Açúcar redondo & 100,0 & 24,1 & 100,0 & 17,3 & 37,9 & 10,9 & 70,2 & 13,8 & 36,4 & 10,7 \\
\hline Açúcar mascavo & 100,0 & 4,6 & 100,0 & 2,7 & 40,4 & 3,2 & 53,0 & 4,1 & 43,2 & 4,0 \\
\hline Farinha & 100,0 & 0,4 & - & - & - & - & - & - & - & - \\
\hline Aguardente & - & - & 100,0 & 2,7 & 37,6 & 5,5 & 23,2 & 2,2 & 26,6 & 1,9 \\
\hline Toucinho & - & - & 10,4 & 6,6 & - & - & - & - & - & - \\
\hline Capados & - & - & - & - & 13,0 & 1,6 & 23,2 & 11,1 & 32,9 & 8,6 \\
\hline Bois & - & - & 45,7 & 2,4 & - & - & - & - & - & - \\
\hline Burros/Bestas & - & - & - & - & - & 48,0 & - & 28,7 & - & 37,3 \\
\hline Cavalos/Potros & - & - & 100,0 & 1,3 & - & - & - & - & - & - \\
\hline \multirow[t]{3}{*}{ TOTAL } & 56,1 & 100,0 & 31,7 & 100,0 & 32,1 & 100,0 & 38,8 & 100,0 & 36,1 & 100,0 \\
\hline & \multicolumn{2}{|c|}{1817} & \multicolumn{2}{|c|}{1818} & \multicolumn{2}{|c|}{1822} & \multicolumn{2}{|c|}{1825} & \multicolumn{2}{|c|}{1827} \\
\hline & $\begin{array}{c}\% \text { da } \\
\text { produção } \\
\text { do bem } \\
\text { exportada }\end{array}$ & $\begin{array}{c}\% \text { do valor } \\
\text { total } \\
\text { exportado }\end{array}$ & $\begin{array}{c}\text { \% da } \\
\text { produção } \\
\text { do bem } \\
\text { exportada }\end{array}$ & $\begin{array}{c}\% \text { do valor } \\
\text { total } \\
\text { exportado }\end{array}$ & $\begin{array}{c}\text { \% da } \\
\text { produção } \\
\text { do bem } \\
\text { exportada }\end{array}$ & $\begin{array}{c}\% \text { do valor } \\
\text { total } \\
\text { exportado }\end{array}$ & $\begin{array}{c}\text { \% da } \\
\text { produção } \\
\text { do bem } \\
\text { exportada }\end{array}$ & $\begin{array}{c}\% \text { do valor } \\
\text { total } \\
\text { exportado }\end{array}$ & $\begin{array}{c}\% \text { da } \\
\text { produção } \\
\text { do bem } \\
\text { exportada }\end{array}$ & $\begin{array}{c}\% \text { do valor } \\
\text { total } \\
\text { exportado }\end{array}$ \\
\hline Milho & 0,3 & 0,3 & 0,4 & 0,1 & 1,0 & 1,4 & 0,8 & 0,8 & 4,1 & 3,7 \\
\hline Feijão & - & - & - & - & - & - & 2,7 & 0,4 & 1,0 & 0,2 \\
\hline Açucar & - & - & - & - & 98,3 & 84,5 & 95,1 & 88,0 & 91,2 & 82,6 \\
\hline Açúcar branco & 95,3 & 48,7 & 82,6 & 41,3 & - & - & - & - & - & - \\
\hline Açúcar redondo & 92,5 & 14,4 & 82,9 & 15,4 & - & - & - & - & - & - \\
\hline Açúcar mascavo & 100,0 & 3,8 & 76,3 & 3,5 & - & - & - & - & - & - \\
\hline Farinha & - & - & - & - & - & - & - & - & - & - \\
\hline Aguardente & 4,2 & 3,0 & 60,6 & 1,7 & 48,1 & 3,6 & 58,6 & 4,3 & 62,3 & 3,7 \\
\hline Rapadura & - & - & 33,2 & 1,6 & - & - & - & - & - & - \\
\hline Toucinho & - & - & - & - & 66,3 & 10,1 & - & - & - & - \\
\hline Capados & 32,5 & 6,6 & 40,9 & 5,9 & - & - & 45,1 & 6,3 & 58,1 & 9,8 \\
\hline Bois & - & - & - & - & - & - & - & - & - & - \\
\hline Burros/Bestas & - & 23,3 & - & 30,6 & - & - & - & - & - & - \\
\hline Galinhas & - & - & - & - & 38,8 & 0,3 & 33,3 & 0,1 & 52,4 & 0,1 \\
\hline \multirow[t]{2}{*}{ TOTAL } & 37,1 & 100,0 & 72,8 & 100,0 & 31,8 & 100,0 & 44,2 & 100,0 & 44,2 & 100,0 \\
\hline & \multicolumn{2}{|c|}{1828} & \multicolumn{2}{|c|}{1829} & \multicolumn{2}{|c|}{1830} & & & & \\
\hline Produtos & $\begin{array}{c}\text { \% da } \\
\text { produção } \\
\text { do bem } \\
\text { exportada }\end{array}$ & $\begin{array}{c}\% \text { do valor } \\
\text { total } \\
\text { exportado }\end{array}$ & $\begin{array}{c}\text { \% da } \\
\text { produção } \\
\text { do bem } \\
\text { exportada }\end{array}$ & $\begin{array}{c}\% \text { do valor } \\
\text { total } \\
\text { exportado }\end{array}$ & $\begin{array}{c}\text { \% da } \\
\text { produção } \\
\text { do bem } \\
\text { exportada }\end{array}$ & $\begin{array}{c}\% \text { do valor } \\
\text { total } \\
\text { exportado }\end{array}$ & & & & \\
\hline Milho & 4,7 & 4,5 & 5,5 & 6,7 & - & - & & & & \\
\hline Feijão & 1,8 & 0,5 & 13,8 & 4,5 & - & - & & & & \\
\hline Arroz & 5,7 & 0,1 & - & - & - & - & & & & \\
\hline Café & - & - & 66,7 & * & 62,5 & * & & & & \\
\hline Açucar & 91,2 & 84,7 & 91,3 & 73,2 & 91,5 & 92,5 & & & & \\
\hline Aguardente & 54,6 & 3,1 & 31,2 & 2,4 & 31,9 & 2,5 & & & & \\
\hline Capados & 40,0 & 7,1 & 21,4 & 13,1 & 17,8 & 5,0 & & & & \\
\hline Galinhas & 50,0 & 0,1 & 40,0 & 0,1 & - & - & & & & \\
\hline TOTAL & 40,5 & 100,0 & 31,9 & 100,0 & 41,4 & 100,0 & & & & \\
\hline
\end{tabular}


A produção de milho, a mais espraiada delas, era levada a cabo em propriedades que mencionaram ao menos um alqueire do cereal e que respondiam por não mais de $2,2 \%$ do valor total exportado ao longo dos anos que seguiram 1798 até 1825 , chegando a 3,5\% em $1827,4,5 \%$ no ano seguinte e seu máximo, $6,7 \%$ em 1829 , reflexo da pequena parcela da produção que participava do mercado para além das fronteiras do município, especialmente para um produto que se manteve como importante em valor, assim como em volume, ao longo de todo o período em tela, tendo sua produção chegado a superar os 60 mil alqueires nos anos finais estudados, que correspondem ao período com maior percentual de sua produção levada a outros mercados: 4,1\% (1827), 4,7\% (1828) e 5,5\% (1829), conforme Tabela II.6

Conforme exposto nas Tabelas II.7 a II.10 (ainda que o significado efetivo das produções nas listas nominativas seja de difícil compreensão, havendo declarações apenas do montante vendido, outros com menção ao o montante produzido e a parte dele levado ao comércio e ainda aqueles nos quais foi apenas dito "colheu") fato é que para atingir esse montante produzido e vendido o grupo dos produtores de milho teve sua "colheita" média aumentada de 59,3 alqueires por unidade produtiva em 1799 para 109,8 em 1816, e de 88,2 alqueires em 1822 para 144,2 alqueires em 1830, com destaque para os produtores de 100,1 a 300 alqueires, pois foram de 6\% dos cultivadores em 1799 para $17,2 \%$ pouco mais de 25 anos depois e para 19,5\% passado mais um lustro, quando se destacam também os maiores produtores locais do grão (com mais de 500 alqueires arrolados), contados em número de 16 em 1825 e 12 em 1830, quando em 1799 eram apenas três.

Todavia, independente do momento, as produções mais representativas da realidade produtiva na vila eram aquelas produzindo entre 10,1 e 50 alqueires de milho que responderam por não menos de 46,5\% dos domicílios (1830) - sendo esta última a produção mais comumente encontrada (moda) em três dos sete anos cujo cálculo foi possível (em 1816, a moda foi 100, com 52 fogos, sendo este número praticamente igual aos 51 fogos correspondentes às produções de 50 alqueires), e os 20 alqueires em outros dois anos.

Em decorrência de tais caracteres, observamos relativa concentração entre os produtores de acordo com os índices de Gini calculados, mantidos entre 0,560 (1822)/ 0,570 (1799), quando o limite da produção foi de 1000 alqueires, e 0,651 (1830), quando o capitão mor Jose Vicente Ferreira declarou 11000 alqueires de milho (valor bastante apartado daquele verificado em todos os demais documentos analisados, levando-nos a crer em erro na descrição, posto inclusive ter o referido capitão mor produzido 800 
alqueires de milho em 1825). Se expandida para os demais fogos, a concentração chega a superar os 0,8 em alguns momentos, sendo nunca inferior a 0,742 (1825).

Apesar da presença de produtores responsáveis pela colheita de consideráveis volumes de milho, estes não eram necessariamente aqueles responsáveis pela comercialização do cereal. Entre os poucos fogos explicitamente vendedores de milho encontramos, ao longo do tempo, aqueles enquadrados em todas as faixas produtivas.

Em 1799, os menores plantadores venderam 13,3\% da sua produção e deixaram de registrar tal destino para ela a partir de então, quando recorrentemente a faixa dos 100,1 aos 300 alqueires respondeu pelos maiores percentuais vendidos, sendo superada em 1830 pela faixa seguinte, o que afirmamos com certa reticência devido ao pequeno número de observações para análises estatísticas mais apuradas. Observada a participação de cada faixa de produção no volume total vendido verificamos, em regra, serem os principais vendedores os que produziam/colhiam entre 10 e 300 alqueires; apenas em 1822, ano para o qual temos somente cinco observações de venda, estas concentraram-se nos domicílios com mais de 100 alqueires do cereal declarados.

Tabela II.7

Estatísticas para a produção de milho

(Jundiaí - 1799 a 1830)

\begin{tabular}{|c|c|c|c|c|c|c|c|c|}
\hline \multirow[b]{2}{*}{ Estatísticas } & \multicolumn{2}{|c|}{1799} & \multicolumn{2}{|c|}{1803} & \multicolumn{2}{|c|}{1808} & \multicolumn{2}{|c|}{1816} \\
\hline & $\begin{array}{c}\text { Total de } \\
\text { fogos }\end{array}$ & $\begin{array}{l}\text { Fogos com } \\
\text { milho }\end{array}$ & $\begin{array}{c}\text { Total de } \\
\text { fogos }\end{array}$ & $\begin{array}{l}\text { Fogos com } \\
\text { milho }\end{array}$ & $\begin{array}{c}\text { Total de } \\
\text { fogos }\end{array}$ & $\begin{array}{c}\text { Fogos com } \\
\text { milho }\end{array}$ & $\begin{array}{c}\text { Total de } \\
\text { fogos }\end{array}$ & $\begin{array}{c}\text { Fogos com } \\
\text { milho }\end{array}$ \\
\hline Média & 25,5 & 59,3 & 49,1 & 84,9 & 26,2 & 86,8 & 63,1 & 109,8 \\
\hline Moda & 0,0 & 50,0 & 0,0 & 50,0 & 0,0 & 20,0 & 0,0 & 100,0 \\
\hline Mediana & 0,0 & 30,0 & 15,0 & 45,0 & 0,0 & 40,0 & 20,0 & 50,0 \\
\hline Desvio padrão & 73,0 & 102,0 & 134,9 & 168,0 & 128,6 & 222,6 & 145,1 & 177,1 \\
\hline Variância & 5328,0 & 10407,0 & 18201,5 & 28228,2 & 16525,4 & 49553,0 & 21060,3 & 31362,6 \\
\hline Índice de Gini & 0,828 & 0,570 & 0,763 & 0,586 & 0,886 & 0,620 & 0,756 & 0,576 \\
\hline Mínimo & 0,0 & 4,0 & 0,0 & 1,0 & 0,0 & 4,0 & 0,0 & 1,0 \\
\hline Máximo & \multicolumn{2}{|c|}{1000,0} & \multicolumn{2}{|c|}{2580,0} & \multicolumn{2}{|c|}{3000,0} & \multicolumn{2}{|c|}{1800,0} \\
\hline \multirow[b]{2}{*}{ Estatísticas } & \multicolumn{2}{|c|}{1822} & \multicolumn{2}{|c|}{1825} & \multicolumn{2}{|c|}{1830} & & \\
\hline & $\begin{array}{c}\text { Total de } \\
\text { fogos }\end{array}$ & $\begin{array}{l}\text { Fogos com } \\
\text { milho }\end{array}$ & $\begin{array}{c}\text { Total de } \\
\text { fogos }\end{array}$ & $\begin{array}{l}\text { Fogos com } \\
\text { milho }\end{array}$ & $\begin{array}{c}\text { Total de } \\
\text { fogos }\end{array}$ & $\begin{array}{c}\text { Fogos com } \\
\text { milho }\end{array}$ & & \\
\hline Média & 48,4 & 88,2 & 68,5 & 113,3 & 60,4 & 144,2 & & \\
\hline Moda & 0,0 & 20,0 & 0,0 & 50,0 & 0,0 & 100,0 & & \\
\hline Mediana & 20,0 & 50,0 & 24,0 & 50,0 & 0,0 & 50,0 & & \\
\hline Desvio padrão & 103,0 & 126,6 & 139,1 & 164,3 & 381,6 & 577,0 & & \\
\hline Variância & 10612,6 & 16034,0 & 19345,5 & 27003,3 & 145641,7 & 332943,0 & & \\
\hline Índice de Gini & 0,754 & 0,560 & 0,742 & 0,576 & 0,853 & 0,651 & & \\
\hline Mínimo & 0,0 & 5,0 & 0,0 & 2,0 & 0,0 & 5,0 & & \\
\hline Máximo & \multicolumn{2}{|c|}{1000,0} & \multicolumn{2}{|c|}{1600,0} & \multicolumn{2}{|c|}{11000,0} & & \\
\hline
\end{tabular}


Tabela II.8

Distribuição de produtores e produção de milho

de acordo com faixas de alqueires

(Jundiaí - 1799 a 1830)

\begin{tabular}{|c|c|c|c|c|c|c|c|c|c|c|c|c|}
\hline \multirow{3}{*}{$\begin{array}{l}\text { Faixas de } \\
\text { alqueires }\end{array}$} & \multicolumn{4}{|c|}{1799} & \multicolumn{4}{|c|}{1803} & \multicolumn{4}{|c|}{1808} \\
\hline & Produtores & Volume & \multicolumn{2}{|c|}{ Venda } & Produtores & Volume & \multicolumn{2}{|c|}{ Venda } & Produtores & Volume & \multicolumn{2}{|c|}{ Venda } \\
\hline & № (\%) & Alq. (\%) & & $\begin{array}{l}\% \\
\text { Alq. }\end{array}$ & № (\%) & Alq. (\%) & № & $\begin{array}{l}\% \\
\text { Alq. }\end{array}$ & № (\%) & Alq. (\%) & & $\begin{array}{l}\% \\
\text { Alq. }\end{array}$ \\
\hline Até 10 & $40(12,7)$ & $345(1,8)$ & 8 & 13,3 & $30(6,9)$ & $265(0,7)$ & - & - & $20(9,0)$ & $194(1,0)$ & $\overline{-}$ & - \\
\hline 10,1 a 50 & $207(65,5)$ & $6374(34,0)$ & 26 & 8,3 & $241(55,7)$ & $7455(20,3)$ & 4 & 1,5 & $123(55,7)$ & $3623(18,9)$ & 5 & 1,0 \\
\hline 50,1 a 100 & $41(13,0)$ & $3425(18,3)$ & 13 & 10,9 & $91(21,0)$ & $7409(20,2)$ & 6 & 4,1 & $45(20,4)$ & $3770(19,6)$ & 10 & 10,8 \\
\hline 100,1 a 300 & $19(6,0)$ & $3615(19,3)$ & 8 & 18,3 & $55(12,7)$ & $10181(27,7)$ & 14 & 22,8 & $23(10,4)$ & $4051(21,1)$ & 7 & 14,4 \\
\hline 300,1 a 500 & $6(1,9)$ & $2600(13,9)$ & 2 & 17,3 & $7(1,6)$ & $3025(8,2)$ & 2 & 8,8 & $4(1,8)$ & $1730(9,0)$ & - & - \\
\hline 500,1 ou mais & $3(0,9)$ & $2370(12,7)$ & 1 & 8,4 & $9(2,1)$ & $8430(22,9)$ & 3 & 29,1 & $6(2,7)$ & $5820(30,3)$ & 2 & 14,2 \\
\hline Total & $316(100,0)$ & $18729(100,0)$ & 58 & 12 & $433(100,0)$ & $36765(100,0)$ & 29 & 11 & $221(100,0)$ & $19188(100,0)$ & 24 & 6,9 \\
\hline \multirow{2}{*}{$\begin{array}{l}\text { Faixas de } \\
\text { alqueires }\end{array}$} & Produtores & $\begin{array}{l}1816 \\
\text { Volume }\end{array}$ & \multicolumn{2}{|c|}{ Venda } & Produtores & $\begin{array}{l}1822 \\
\text { Volume }\end{array}$ & \multicolumn{2}{|c|}{ Venda } & Produtores & $\begin{array}{l}1825 \\
\text { Volume }\end{array}$ & \multicolumn{2}{|c|}{ Venda } \\
\hline & № (\%) & Alq. (\%) & № & $\begin{array}{l}\% \\
\text { Alq. }\end{array}$ & № (\%) & Alq. (\%) & № & $\begin{array}{l}\% \% \\
\text { Alq. }\end{array}$ & № (\%) & Alq. (\%) & № & $\begin{array}{l}\% \\
\text { Alq. }\end{array}$ \\
\hline Até 10 & $19(3,8)$ & $162(0,3)$ & - & - & $18(4,2)$ & $136(0,4)$ & - & - & $21(3,9)$ & $166(0,3)$ & - & - \\
\hline 10,1 a 50 & $244(48,7)$ & $7954(14,5)$ & 3 & 1,6 & $261(60,8)$ & $8704(23,0)$ & - & - & $270(50,4)$ & $9103(15,0)$ & 2 & 0,6 \\
\hline 50,1 a 100 & $114(22,8)$ & $9634(17,5)$ & 3 & 1,6 & $75(17,5)$ & $6660(17,6)$ & - & - & $113(21,1)$ & $9562(15,7)$ & 8 & 6,0 \\
\hline 100,1 a 300 & $92(18,4)$ & $17054(31,0)$ & 7 & 16,8 & $53(12,4)$ & $10540(27,9)$ & 2 & 2,6 & $92(17,2)$ & $18644(30,7)$ & 10 & 14,1 \\
\hline 300,1 a 500 & $23(4,6)$ & $10180(18,5)$ & - & - & $14(3,3)$ & $5900(15,6)$ & 2 & 6,9 & $24(4,5)$ & $10318(17,0)$ & 2 & 5,4 \\
\hline 500,1 ou mais & $9(1,8)$ & $10025(18,2)$ & 2 & 16,9 & $8(1,9)$ & $5900(15,6)$ & 1 & 8,4 & $16(3,0)$ & $12950(21,3)$ & - & - \\
\hline Total & $501(100,0)$ & 55009100,0 & 15 & 6,2 & $429(100,0)$ & $37840 \quad 100,0$ & 5 & 2,5 & $536(100,0)$ & $60743 \quad 100,0$ & 22 & 4,8 \\
\hline
\end{tabular}

\begin{tabular}{|c|c|c|c|c|}
\hline \multirow{3}{*}{$\begin{array}{l}\text { Faixas de } \\
\text { alqueires }\end{array}$} & \multicolumn{4}{|c|}{1830} \\
\hline & Produtores & \multirow{2}{*}{$\frac{\text { Volume }}{\text { Alq. (\%) }}$} & \multicolumn{2}{|c|}{ Venda } \\
\hline & № (\%) & & № & $\begin{array}{l}\% \\
\text { Alq. }\end{array}$ \\
\hline Até 10 & $14(3,6)$ & $129(0,3)$ & - & - \\
\hline 10,1 a 50 & $179(46,5)$ & $5777(11,7)$ & 1 & 0,5 \\
\hline 50,1 a 100 & $85(22,1)$ & $1083(2,2)$ & 2 & 2,3 \\
\hline 100,1 a 300 & $75(19,5)$ & $14447(29,2)$ & 4 & 8,9 \\
\hline 300,1 a 500 & $20(5,2)$ & $8281(16,7)$ & 4 & 17,3 \\
\hline 500,1 ou mais & $\leqslant 12(3,1)$ & $19812(40,0)$ & - & - \\
\hline Total & $385(100,0)$ & 49529100,0 & 11 & 4,7 \\
\hline
\end{tabular}


Tabela II.9

Participação das faixas de alqueires

no volume de milho vendido

(Jundiaí - 1799 a 1830)

\begin{tabular}{cccccccc}
\hline \hline $\begin{array}{c}\text { Faixas de } \\
\text { alqueires }\end{array}$ & 1799 & 1803 & 1808 & 1816 & 1822 & 1825 & 1830 \\
\hline Até 10 & 13,8 & - & - & - & - & & - \\
10,1 a 50 & 44,8 & 13,8 & 20,8 & 20,0 & - & 9,1 & 9,1 \\
50,1 a 100 & 22,4 & 20,7 & 41,7 & 20,0 & - & 36,4 & 18,2 \\
100,1 a 300 & 13,8 & 48,3 & 29,2 & 46,7 & 40,0 & 45,5 & 36,4 \\
300,1 a 500 & 3,4 & 6,9 & - & - & 40,0 & 9,1 & 36,4 \\
500,1 ou mais & 1,7 & 10,3 & 8,3 & 13,3 & 20,0 & - & - \\
\hline Total & 100,0 & 100,0 & 100,0 & 100,0 & 100,0 & 100,0 & 100,0 \\
\hline \hline
\end{tabular}

Fonte: AESP, M aços de População, Jundiaí: anos selecio nados

Tabela II.10

Local de venda do milho

(Jundiaí - 1799 a 1830)

\begin{tabular}{|c|c|c|c|c|c|c|c|c|}
\hline \multirow{2}{*}{ Anos } & \multicolumn{2}{|c|}{ Terra } & \multicolumn{2}{|c|}{ Vila } & \multicolumn{2}{|c|}{ São Paulo } & \multicolumn{2}{|c|}{ Total } \\
\hline & № (\%) & Alq. (\%) & № (\%) & Alq. (\%) & № (\%) & Alq. (\%) & № (\%) & Alq. (\%) \\
\hline 1799 & $13(52,0)$ & $571(57,3)$ & $10(40,0)$ & $378(38,0)$ & $2(8,0)$ & $47(4,7)$ & $25(100,0)$ & $996(100,0)$ \\
\hline 1803 & $24(92,3)$ & $1054(95,9)$ & - & - & $2(7,7)$ & $45(4,1)$ & $26(100,0)$ & $1099(100,0)$ \\
\hline 1808 & $18(81,8)$ & $922(80,7)$ & $2(9,1)$ & $100(8,8)$ & $2(9,1)$ & $120(10,5)$ & $22(100,0)$ & $1142(100,0)$ \\
\hline 1816 & $1(7,7)$ & $300(29,0)$ & $9(69,2)$ & $466(45,1)$ & $3(23,1)$ & $268(25,9)$ & $13(100,0)$ & $1034(100,0)$ \\
\hline 1822 & $4(80,0)$ & $450(94,7)$ & $1(20,0)$ & $25(5,3)$ & - & - & $5(100,0)$ & $475(100,0)$ \\
\hline 1825 & - & - & $3(100,0)$ & $120(100,0)$ & - & - & $3(100,0)$ & $120(100,0)$ \\
\hline 1830 & $9(100,0)$ & $660(100,0)$ & - & - & - & - & $9(100,0)$ & $660(100,0)$ \\
\hline
\end{tabular}

Fonte: AESP, M aços de População, Jundiaí: anos selecio nados

Essas operações de venda envolviam locais diferentes, quais sejam, a vila, a "terra", entendida como o próprio local de produção, e a cidade de São Paulo. Sem dúvida, percentual mais importante para número de transações e volume transacionado foi declarado na lista para vendas na terra, sendo que diretamente para São Paulo (local a que atribuímos também aquelas declarações menos explícitas: "vendeu na cidade") seria encaminhada uma pequena parcela da produção. Decerto parte desse comércio estava ligado a outros indivíduos da localidade que não agricultores, ou até mesmo agricultores que além de produzir necessitavam dirigir-se o mercado como consumidores, pois "o que colheu não deu para o gasto" - eis o caso de Bento Barboza Pires que em 1808 "plantou 
para gasto e ainda comprou mantimentos" (Lista Nominativa de Jundiaí, 1808 - AESP, Maços de População/rolo 108) Ademais, poderia haver intermediários indo até as unidades produtivas com suas tropas em busca da produção.

Como já observamos ao verificar os gêneros plantados e a presença concomitante dos diferentes gêneros nos fogos, o milho era cultivado tanto em unidades produtivas nas quais apenas o cereal foi identificado, assim como em outras dedicadas a distintos produtos, entre eles açúcar e capados. Foi justamente nesses últimos fogos que encontramos os grandes plantadores locais, que necessitavam do milho não só para consumo próprio de sua família, mas também para alimentar animais e escravos (intensivos na produção canavieira e seus derivados).

Em 1825 nenhum dos 16 produtores com safra superior a 500 alqueires declarou vender ao menos parte do que foi produzido, assim como ocorreu em 1830: 12 domicílios com produção acima de 500 alqueires e nenhuma referência à comercialização de tal produção. Neste último ano, entre os chefes considerados encontramos sete senhores de engenho, com plantéis cativos que iam de 20 a 89 indivíduos. Antonio Pires Pimentel produziu 700 alqueires de milho e declarou ter sua tropa. Dez indivíduos criavam porcos, com especial atenção para o alferes Thome Joaquim de Passo que declarou naquele ano 100 capados, que a se considerar os números apresentados por Mawe e Schewege citados por Luna (2006, p.129), deveriam consumir cada um, em períodos de criação de oito a doze meses, entre 200 e 250 quilos de milho (aproximadamente 6,6 a 8,3 alqueires), totalizando, para a criação de tais animais cerca de 660 a 830 alqueires, algo compatível com os 800 alqueires declarados pelo alferes, cujo fogo compunha-se ainda de sua mulher, seis filhos e 47 escravos. Decrescendo a faixa de produção pra 300,1 alqueires, em 1830 encontramos 84,4\% (27 em 32) dos produtores também como criadores de porcos - percentual idêntico encontramos em 1816.

Assim as grandes colheitas do cereal estavam ligadas a fogos com grande número de indivíduos e/ou animais, que apesar do elevado montante produzido tendiam a consumi-los na própria unidade produtiva não sendo, de forma considerável, transacionados por esses produtores. Especialmente ao final do período quando se vê aumentada a população cativa e o número de engenhos na vila de Jundiaí. Ao que parece, aqueles que produziam entre 10,1 e 300 alqueires eram os maiores responsáveis pela comercialização do milho jundiaense. 
O milho levado ao mercado apresentou preços reais ${ }^{46}$ bastante variáveis ao longo dos anos, como se vê no Gráfico II.2. Entre os anos para os quais obtivemos a informação de preço constatamos o pico em 1808, quando o preço real médio do milho praticado na localidade superou os $\$ 400$ por alqueire, sendo esse elevado valor coincidente com a menor produção total do gênero em tela. Apenas a partir de 1814 conseguimos observar novamente o preço do milho no mercado jundiaense, ano em que o preço foi inferior aos $\$ 200$, tendo caído a pouco mais de $\$ 130$ já em 1816, não chegando ao preço médio de 1814 até 1818. Já em 1822 e até 1827 o preço do milho cresceu, tendo sua produção (disponibilidade) seguido o aumento verificado para os preços. Em 1828 a produção do milho foi a maior verificada, tendo o preço respondido negativamente, e caído em mais de $\$ 50$ por alqueire (queda de $28 \%$ ), tendo a produção caído já no ano seguinte. Vale lembrar que o período 1827-29 foi aquele em ampliou-se a participação do milho no valor das exportações da vila de Jundiaí e ainda o percentual do bem enviado para fora das fronteiras da localidade.

\section{Gráfico II.2}

Evolução do volume total produzido

e do preço real médio do milho

(Jundiaí - 1798 a 1830)

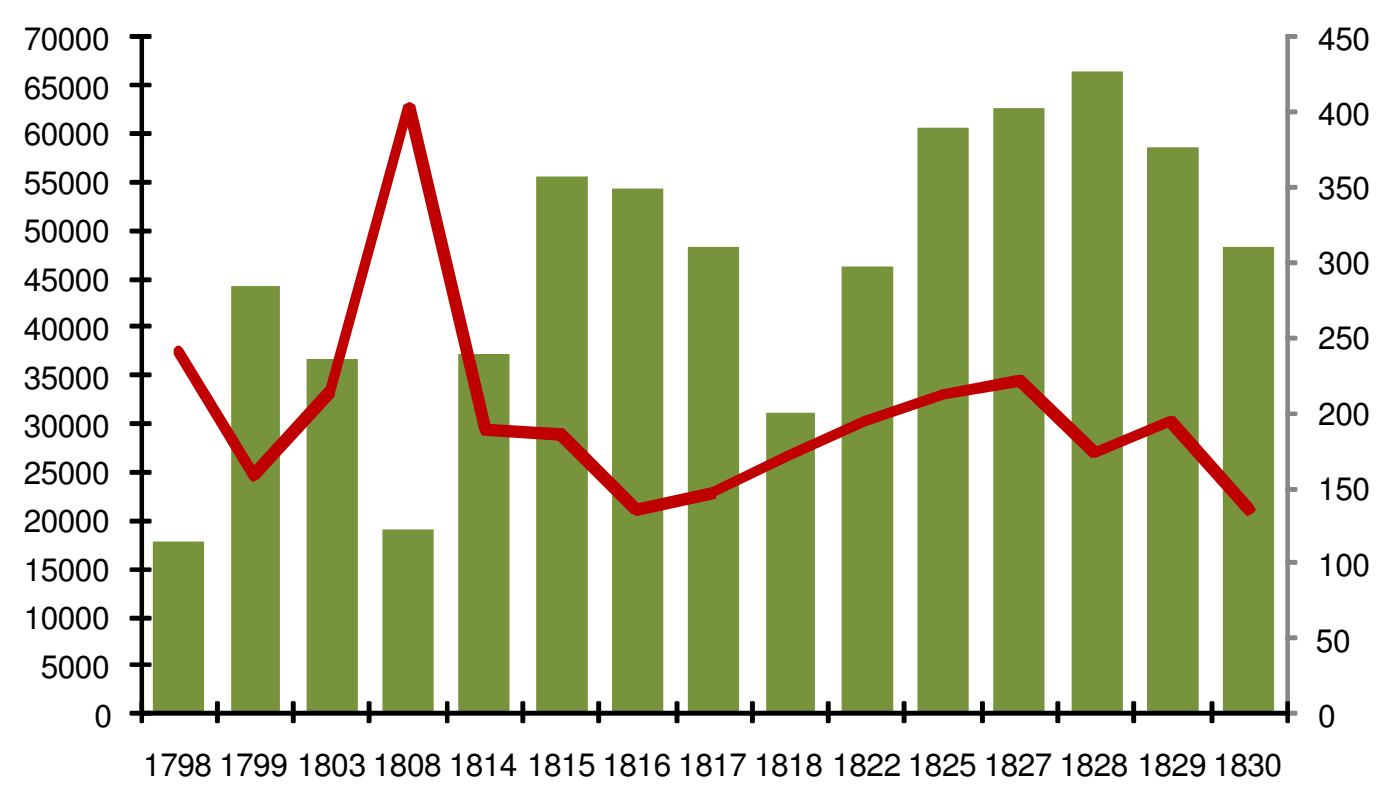

produção total (alqueires - eixo esquerdo)

preço real médio (réis - eixo direito)

\footnotetext{
${ }^{46}$ Para uma discussão sobre deflacionamento e índice usado no cálculo do preço real, ver apêndice 2: fontes e métodos.
} 
Diferente do milho, o açúcar possuía um destino bem definido: o mercado externo via porto de Santos (ou Santos - Rio de Janeiro). Como se verá, a cidade de São Paulo recebeu parte do açúcar jundiaense, mas certamente maior parcela da produção era enviada àquela vila portuária.

Apesar da sua importância inegável na produção local, longe de se espalhar por uma vasta gama de domicílios, o açúcar e seus montantes produzidos e/ou comercializados foram arrolados em poucos fogos (Tabela II. 11). Entre 1799 e 1808 o número variou entre 14 e 17, caiu para nove em 1812, subiu a 22 em 1816, chegando a 33 produtores em 1822-25. Parece clara, então, a grande ampliação do número de indivíduos envolvidos no mercado do açúcar; mercado este que viu ampliado não só o número de seus produtores/vendedores, como também o volume devido a cada um deles e, por conseguinte, do volume total de açúcar produzido em Jundiaí, observação que acompanha o ocorrido com a produção da capitania/província e, seu conjunto:

Segundo o 'Mapa dos Engenhos de açúcar' elaborado por Melo Castro e Mendonça, pode-se calcular, para o ano de 1798 a média de 314,3 arrobas por engenho e, para 1799, 345,7 arrobas. Em 1836m usando os dados de D. P. Müller, a média por engenho seria de 977,6 arrobas. Para 1854, portanto no fim do ciclo do açúcar, a média calculada com elementos fornecidos por Machado d'Oliveira é de 1388 arrobas por engenho. Houve, portanto, aumento gradativo no rendimento médio de um engenho em São Paulo. (Petrone, 1968, p.106)

Em Jundiaí, na virada do século XVIII para o XIX foram anotados, em média, 333 arrobas por produtor, montante que ao final do período estudado (1830) já havia atingido mais de 775 arrobas de açúcar, entre fino, redondo e mascavo. O mínimo havia sido de 40 arrobas em 1799, em 1830 era três vezes maior: 120 arrobas. Da mesma maneira, o extremo superior da produção situava-se em 1200 arrobas ao final do Setecentos, tendo dobrado passados 30 anos: Escolástica Joaquina de Barros produziu 2400 arrobas. Neste ano a moda foi 1000 arrobas com mediana 700 arrobas. Variações ocorreram nos valores apurados com destaque para 1803, quando o maior senhor de engenho açucareiro produziu tão somente 530 arrobas; e em 1812 Francisco Xavier Vaz produziu 130 arrobas, sendo o menor volume declarado naquele ano, mas $115 \%$ maior do que o correspondente poucos anos antes, $1808 .{ }^{47}$

\footnotetext{
${ }^{47}$ Havia importante concentração dos escravos nos fogos com presença da produção comercial do açúcar. Como temos mostrado o açúcar esteve presente em pequeno, mas crescente número de fogos. A ampliação ocorreu não somente no número observado de unidades produtivas, mas também no montante de produto saído destes fogos. Em Jundiaí, as estatísticas observadas para os produtores de açúcar apresentam-se sempre em valor superior àquelas anteriormente observadas para a totalidade dos detentores de escravos. $O$ número de escravos em domicílios com a presença de engenhos e produção de açúcar subiu de 223 indivíduos em 16 fogos em 1799 a 1082 indivíduos em 29 fogos em 1830, um aumento nominal de 385\%. Essa mudança respondeu por médias flutuantes e elevadas, correspondentes a escravarias de tamanho
} 
Tabela II.11

Estatística para a produção de açúcar

(Jundiaí - 1799 a 1830)

\begin{tabular}{ccccccccc}
\hline \hline $\begin{array}{l}\text { Estatísticas } \\
\begin{array}{l}\text { (Fogos com } \\
\text { açúcar) }\end{array}\end{array}$ & 1799 & 1803 & 1808 & 1812 & 1816 & 1822 & 1825 & 1830 \\
\hline № de fogos & 16 & 14 & 17 & 9 & 22 & 33 & 33 & 29 \\
Média & 333,6 & 208,2 & 384,9 & 510,0 & 433,4 & 587,0 & 609,1 & 775,8 \\
Moda & 400,0 & 208,0 & 150,0 & 400,0 & 600,0 & 100 e 900 & 200,0 & 1000,0 \\
Mediana & 325,0 & 155,0 & 200,0 & 400,0 & 345,0 & 480,0 & 500,0 & 700,0 \\
Desvio padrão & 270,4 & 154,9 & 298,5 & 313,0 & 316,3 & 420,6 & 414,2 & 567,9 \\
Variância & 73095,6 & 23990,8 & 89091,9 & 97975,0 & 100020,3 & 176904,4 & 171521,0 & 322562,4 \\
Índice de Gini & 0,366 & 0,390 & 0,412 & 0,315 & 0,361 & 0,396 & 0,374 & 0,373 \\
Mínimo & 40,0 & 35,0 & 60,0 & 130,0 & 40,0 & 80,0 & 90,0 & 120,0 \\
Máximo & 1200,0 & 550,0 & 1000,0 & 1010,0 & 1500,0 & 1500,0 & 1500,0 & 2400,0 \\
\hline \hline
\end{tabular}

Fonte: AESP, M aços de População, Jundiaí: anos selecio nados

Apesar de elevados para alguns senhores, os volumes médios da produção açucareira em Jundiaí eram inferiores aos verificados para outras regiões (especialmente o nordeste do Brasil) e períodos. De acordo com Petrone (1968, pp.106-7):

Com os dados que Antonil (1710) nos fornece, pode-se calcular uma média de 2450 arrobas de açúcar para os engenhos dos Brasil. A média para os engenhos da Bahia era de 2791 arrobas, para os de Pernambuco 1750 arrobas e para os do Rio de Janeiro, 2630 arrobas. Manuel Ferreira da Câmara, descrevendo a capitania de Ilhéus, em 1789, afirmava que o senhor de engenho, que em qualquer parte do Brasil fazia 1000 pães de três arrobas, podia ser considerado grande lavrador. Pizzarro e Araújo afirma que nos campos dos Goitacazes poucas fábricas faziam anualmente mais que 40 caixas de açúcar e 'de ordinário chegam a menos de 30'. Calculando 35 arrobas para uma caixa, a produção de um engenho seria de 1050 a 1400 arrobas.

grande a muito grande: em 1799 a média observada foi de 13,9 cativos por fogo, em 1812 eram 22,5 escravos em cada unidade produtiva, número próximo aos 21,9 encontrados em 1822 e inferior à maior média calculada para 1830, 37,3 escravos; ano em que a mediana esteve em 25 - igual àquela calculada para 1816 e próximas às de 1808, 22,5, e 1825, 23 escravos - ou seja, ao menos 15 entre os produtores de açúcar em 1830 possuíam 25 ou mais escravos. Assim, não estranha termos nos deparado com percentual bastante elevado dos escravos em Jundiaí na produção de açúcar. No Setecentos 32,8\% dos cativos tinham vínculo direto com o açúcar (na medida em eram encontrados nos mesmos fogos) e, especialmente na a partir de 1816, quando vê-se aumentado o número de produtores, o percentual atinge $48,3 \%$ em 1816 , finalizando o período em $53,2 \%$, após haver sido de $57,7 \%$ em 1822 . Ou seja, nas décadas finais observadas quase dois terços dos escravos encontrados no recenseamento jundiaense foram anotados junto a chefes produtores de açúcar. Vide tabelas no apêndice estatístico. 
Tabela II.12

Distribuição de produtores e produção de açúcar

de acordo com faixas de arrobas

(Jundiaí - 1799 a 1830)

\begin{tabular}{|c|c|c|c|c|c|c|}
\hline \multirow{3}{*}{$\begin{array}{c}\text { Faixas de } \\
\text { arrobas }\end{array}$} & \multicolumn{2}{|c|}{1799} & \multicolumn{2}{|c|}{1803} & \multicolumn{2}{|c|}{1808} \\
\hline & Produtores & Volume & Produtores & Volume & Produtores & Volume \\
\hline & № (\%) & Arrobas (\%) & № (\%) & Arrobas (\%) & № (\%) & Arrobas (\%) \\
\hline Até 50 & $2(12,5)$ & $90(1,7)$ & $3(21,4)$ & $135(4,6)$ & $(0,0)$ & $(0,0)$ \\
\hline 50,1 a 100 & $2(12,5)$ & $180(3,4)$ & $2(14,3)$ & $180(6,2)$ & $2(11,8)$ & $159(2,4)$ \\
\hline 100,1 a 500 & $11(68,8)$ & $3868(72,5)$ & $8(57,1)$ & $2050(70,3)$ & $8(47,1)$ & $1525(23,3)$ \\
\hline 500,1 a 1000 & $(0,0)$ & $(0,0)$ & $1(7,1)$ & $550(18,9)$ & $7(41,2)$ & $4860(74,3)$ \\
\hline 1000,1 ou mais & $1(6,3)$ & $1200(22,5)$ & $(0,0)$ & $(0,0)$ & $(0,0)$ & $(0,0)$ \\
\hline Total & $16(100,0)$ & $5338 \quad(100,0)$ & $14(100,0)$ & $2915(100,0)$ & $17(100,0)$ & $6544 \quad(100,0)$ \\
\hline \multirow{3}{*}{$\begin{array}{l}\text { Faixas de } \\
\text { alqueires }\end{array}$} & \multicolumn{2}{|c|}{1812} & \multicolumn{2}{|c|}{1816} & \multicolumn{2}{|c|}{1822} \\
\hline & Produtores & Volume & Produtores & Volume & Produtores & Volume \\
\hline & № (\%) & Arrobas (\%) & № (\%) & Arrobas (\%) & № (\%) & Arrobas (\%) \\
\hline Até 50 & $(0,0)$ & $(0,0)$ & $1(4,5)$ & $40(0,4)$ & $(0,0)$ & $(0,0)$ \\
\hline 50,1 a 100 & $(0,0)$ & $(0,0)$ & $1(4,5)$ & $81(0,8)$ & $5(15,2)$ & $471(2,4)$ \\
\hline 100,1 a 500 & $5(55,6)$ & $1470(32,0)$ & $13(59,1)$ & $4014(42,1)$ & $13(39,4)$ & $4281(22,1)$ \\
\hline 500,1 a 1000 & $3(33,3)$ & $2110(46,0)$ & $6(27,3)$ & $3900(40,9)$ & $9(27,3)$ & $6950(35,9)$ \\
\hline 1000,1 ou mais & $1(11,1)$ & $1010(22,0)$ & $1(4,5)$ & $1500(15,7)$ & $6(18,2)$ & $7670(39,6)$ \\
\hline Total & $9(100,0)$ & $4590 \quad(100,0)$ & $22(100,0)$ & $9535(100,0)$ & $33(100,0)$ & $19372(100,0)$ \\
\hline \multirow{3}{*}{$\begin{array}{c}\text { Faixas de } \\
\text { alqueires }\end{array}$} & \multicolumn{2}{|c|}{1825} & \multicolumn{2}{|c|}{1830} & & \\
\hline & Produtores & Volume & Produtores & Volume & & \\
\hline & № (\%) & Arrobas (\%) & № $(\%)$ & Arrobas (\%) & & \\
\hline Até 50 & $(0,0)$ & $(0,0)$ & $(0,0)$ & $(0,0)$ & & \\
\hline 50,1 a 100 & $2(6,1)$ & $190(0,9)$ & $(0,0)$ & $(0,0)$ & & \\
\hline 100,1 a 500 & $17(51,5)$ & $5570(27,7)$ & $12(41,4)$ & $3640(16,2)$ & & \\
\hline 500,1 a 1000 & $9(27,3)$ & $7850(39,1)$ & $13(44,8)$ & $11357(50,5)$ & & \\
\hline 1000,1 ou mais & $5(15,2)$ & $6490(32,3)$ & $4(13,8)$ & $7500(33,3)$ & & \\
\hline Total & $33(100,0)$ & $20100(100,0)$ & $29(100,0)$ & $22497(100,0)$ & & \\
\hline
\end{tabular}

Parcela majoritária dos engenheiros situava-se na faixa de produção de 100 a 500 arrobas faixa que, apenas em 1799 e 1803, respondeu à maior parcela da produção: $72,5 \%$ e 70,3\%, respectivamente. A partir daí avançou o número e o volume produzido por aqueles declarantes de 500 a 1000 arrobas, que de um único declarante em 1803 (7\%) - Domingos Pinheiro de Oliveira, com 550 arrobas declaradas -, encontramos sete em $1808(41,2 \%)$ e $13(44,8 \%)$ em 1830. A partir de 1822, avançou o número e a participação daqueles de cujo engenho saiu mais de 100 arrobas de açúcar. Apenas 
Pedro Ferraz de Arruda (4,5\%) havia produzido 1500 arrobas em 1816, a ele somaram-se outros cinco indivíduos em 1822, fazendo com que neste ano 18,2\% dos produtores houvesse refinado açúcar em grandes quantidades. Corrobora-se, portanto, por outro ângulo, a expansão da produção açucareira jundiaense.

Mesmo tendo identificado o avanço no número de produtores e na produção da localidade, sabemos que diferentemente da cultura do milho em que era fácil a mobilidade no mercado, o mercado açucareiro era bastante restritivo, pois "[...] o açúcar foi, desde o início um produto que, mesmo em sua fase de consumo apenas local, exigiu muito mais capital para o ingresso na atividade, e sua produção atraiu uma parcela menor dos agricultores." (LUNA \& KLEIN, 2006, p.82). Ainda assim, alguns indivíduos chegaram à vila e seu termo com o intuito de serem ali senhores de engenho, ou ainda constatamos a criação de engenhos novos, como bem se entende com o aumento do número de fogos produtores do gênero e de algumas descrições mais explícitas: em 1808 Manoel Jose Fonseca, natural de São Pedro e aos 31 anos, não apareceu como produtor pois possuía "engenho novo ainda não produziu" (Lista Nominativa de Jundiaí, 1808 - AESP, Maços de População/rolo 108).

A elevação do volume produzido, todavia, ao que parece não representou para os senhores de engenho vantagem no que tange ao preço. O auge da produção jundiaense dentro do período 1799-1830 correspondeu aos menores preços reais médios do produto no mercado (Gráfico II. 3). No final do século XVII o preço real do açúcar chegou a superar os $3 \$ 000$; na década de 1820 , flutuava em torno de $\$ 500$, em média. Assim, ainda que o açúcar possa ser considerado uma commodity, cujo preço era influenciado internacionalmente, fato é que os preços do açúcar "na paróquia" encontraram relação com o volume produzido, apontando para alguma influência local no preço de comercialização do produto, ao menos para intermediários internos.

Apenas em 1799 três indivíduos declararam haver vendido parte de sua produção na própria propriedade, eram Salvador Pedroso Alvarenga (40 arrobas), Francisco Vaz Paes (200 arrobas) e Antonio Jose da Cruz (1200 arrobas, o maior volume declarado). No ano seguinte observado, Francisco não apareceu na lista, Salvador declarou "planta para gasto" e no fogo Antonio havia menção à produção de 330 arrobas sem qualquer menção ao destino da produção. 


\section{Gráfico II.3}

Evolução do volume total produzido

e do preço real médio do açúcar

(Jundiaí - 1798 a 1830)

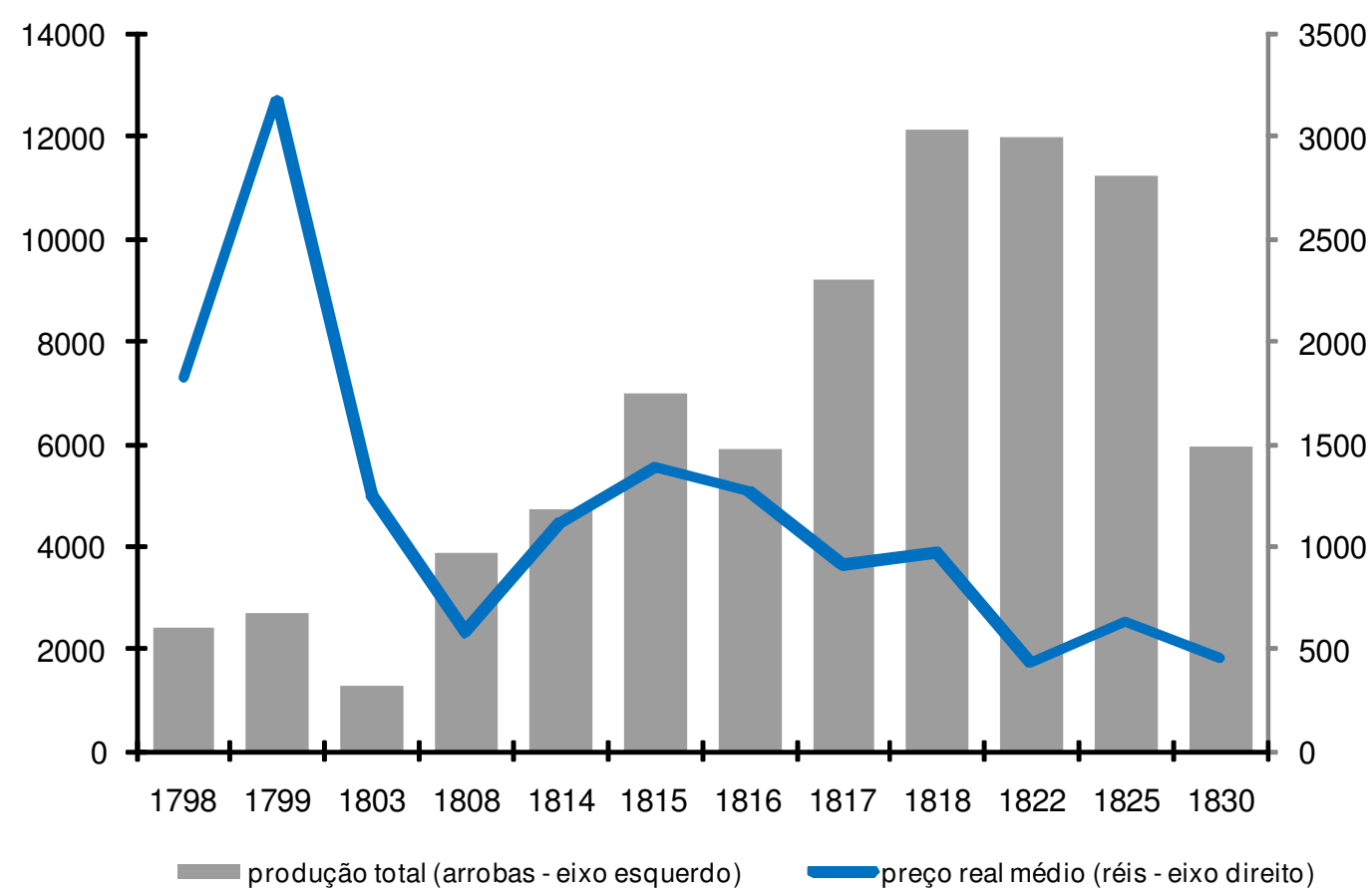

Há que sopesar, no entanto, tais considerações com o baixo número de observações disponíveis para a variável local de venda da produção (Tabela II.13). Ainda que grande parte dos produtores tenham declarado o comércio de açúcar, apenas pequena parcela das declarações era acompanhada do local onde foi realizada a transação. De todo modo, Santos apareceu como o principal destino da produção, na maioria dos anos, exceção para 1803 e 1816 quando a capital de São Paulo foi mais citada.

Ademais, a expansão da produção levou não somente à queda do preço, como também à dificuldade no escoamento do açúcar. Ao menos é o que se percebe tendo-se em conta a declaração de Escolástica Joaquina que em 1825 "o açúcar vendeu pelo que comer em Santos" (Lista Nominativa de Jundiaí, 1825 - AESP, Maços de População/rolo 110). Já Jose Gomes de Oliveira, em 1808 havia produzido 150 arrobas, mas tinha em suas observações declaração mais enfática: "não vendeu porque não achou quem compra" (Lista Nominativa de Jundiaí, 1808 - AESP, Maços de População/rolo 108). 
Tabela II.13

Local de venda do açúcar

(Jundiaí - 1799 a 1830)

\begin{tabular}{|c|c|c|c|c|}
\hline \multirow{2}{*}{ Anos } & Terra/Vila & Santos & São Paulo & Total \\
\hline & № (\%) & № (\%) & № (\%) & № $(\%)$ \\
\hline 1799 & $3(25,0)$ & $6(50,0)$ & $3(25,0)$ & $12(100,0)$ \\
\hline 1803 & - & $1(25,0)$ & $3(75,0)$ & $4(100,0)$ \\
\hline 1808 & - & $3(100,0)$ & - & $3(100,0)$ \\
\hline 1816 & - & $1(20,0)$ & $4(80,0)$ & $5(100,0)$ \\
\hline 1822 & - & $8(72,7)$ & $3(27,3)$ & $11(100,0)$ \\
\hline 1825 & - & $15(100,0)$ & - & $15(100,0)$ \\
\hline 1830 & - & $12(92,3)$ & $1(7,7)$ & $13(100,0)$ \\
\hline
\end{tabular}

Fonte: AESP, M aços de População, Jundiaí: anos selecionados

Como vimos anteriormente, milho, capados e açúcar fizeram parte da pauta de exportações da vila de Jundiaí. No entanto, o destino de tais gêneros, assim como já havíamos verificado para as características de cada produção, foram distintos, como mostra a Tabela II.14. De acordo com os mapas de comércio jundiaense, ao fim do Setecentos e da década de 1810 o milho era enviado exclusivamente para São Paulo, para onde seguiam também feijão, farinha, aguardente, e ainda toucinho/capados e o açúcar. Especialmente a partir de 1814 aqueles eram enviados ademais para a vila de Parnaíba e estes, foram, em todos os anos observados, enviados para a vila de Santos, ou melhor dizendo, para o porto de Santos de onde deveria sair do Brasil.

Em 1799, entre o destino das exportações encontramos a própria vila, fato devido, imaginamos, à comercialização de parte dos gêneros ocorrer em Jundiaí, porém para consumo final fora do município. ${ }^{48}$ Em 1814 Cuiabá importou capados.

O açúcar, por representar parcela principal das exportações e por ser enviado principalmente para Santos, foi o responsável pela participação majoritária da localidade na composição percentual do destino dos bens saídos de Jundiaí (Gráfico II.4). Em 1799 a participação de Santos foi de $37,6 \%$, devido à grande participação da paróquia nas transações. Já entre 1814 e 1818, Santos foi responsável por importar ao menos 43,4\% do valor total exportado por Jundiaí, chegando a mais de $65 \%$ em 1817, enquanto verificamos a participação máxima para a cidade de São Paulo em 1815 (30,1\%), logo após a cidade apresentar percentual muito pequeno, não atingindo os $3 \%$. Parcela 
considerável do valor das exportações era devido às Minas de Goiás, ao menos $21 \%$ entre 1814 e 1818. Independente destas grandes variações é possível observar que entre meados e o final da década de 1810, Santos foi o principal destino dos gêneros exportados por Jundiaí, sendo seguido especialmente por Goiás e depois pela cidade de São Paulo.

Tabela II.14

Gêneros exportados de acordo com o destino

(Jundiaí - 1798 a 1818)

\begin{tabular}{|c|c|c|c|c|c|c|c|}
\hline Anos & São Paulo & Santos & Parnaíba & Goiás & Cuiabá & Bahia & Jundiaí \\
\hline 1798 & $\begin{array}{c}\text { açúcar fino, redondo e } \\
\text { mascavo, milho, feijão, } \\
\text { farinha de trigo, } \\
\text { toucinho }\end{array}$ & $\begin{array}{c}\text { açúcar fino, redondo e } \\
\text { mascavo }\end{array}$ & & & & & \\
\hline 1799 & $\begin{array}{c}\text { açúcar fino, redondo e } \\
\text { mascavo, toucinho }\end{array}$ & $\begin{array}{c}\text { açúcar fino, redondo e } \\
\text { mascavo }\end{array}$ & & & & & $\begin{array}{c}\text { açúcar fino, } \\
\text { redondo, mascavo, } \\
\text { aguardente, milho, } \\
\text { feijão, algodão, } \\
\text { toucinho, potros } \\
\end{array}$ \\
\hline 1814 & $\begin{array}{l}\text { aguardente, milho, } \\
\text { capados }\end{array}$ & $\begin{array}{l}\text { açúcar fino, redondo e } \\
\text { mascavo, aguardente }\end{array}$ & capados & bestas & capados & bestas & \\
\hline 1815 & $\begin{array}{l}\text { açúcar fino, redondo e } \\
\text { mascavo, aguardente, } \\
\text { milho, feijão, capados }\end{array}$ & $\begin{array}{l}\text { açúcar fino, redondo e } \\
\text { mascavo, aguardente }\end{array}$ & capados & bestas & & & \\
\hline 1816 & $\begin{array}{l}\text { aguardente, milho, } \\
\text { feijão, capados }\end{array}$ & $\begin{array}{l}\text { açúcar fino, redondo e } \\
\text { mascavo, aguardente }\end{array}$ & & muares & & & \\
\hline 1817 & $\begin{array}{l}\text { açúcar fino, redondo, } \\
\text { aguardente, rapadura, } \\
\text { milho, capados }\end{array}$ & $\begin{array}{c}\text { açúcar fino, redondo e } \\
\text { mascavo }\end{array}$ & capados & muares & & & \\
\hline 1818 & $\begin{array}{c}\text { açúcar } \\
\text { branco,redondo e } \\
\text { mascavo, rapadura, } \\
\text { milho, capados }\end{array}$ & $\begin{array}{l}\text { açúcar fino, redondo e } \\
\text { mascavo, aguardente }\end{array}$ & capados & muares & & & \\
\hline
\end{tabular}

Fonte: AESP, Maços de População - Mapas de produção e comércio, Jundiaí

\footnotetext{
${ }^{48}$ Ver seções atinentes a Atibaia e Nazaré.
} 


\section{Gráfico II.4}

\section{Participação das diferentes localidades nas exportações (Jundiaí - 1799 e 1814 a 1818)}

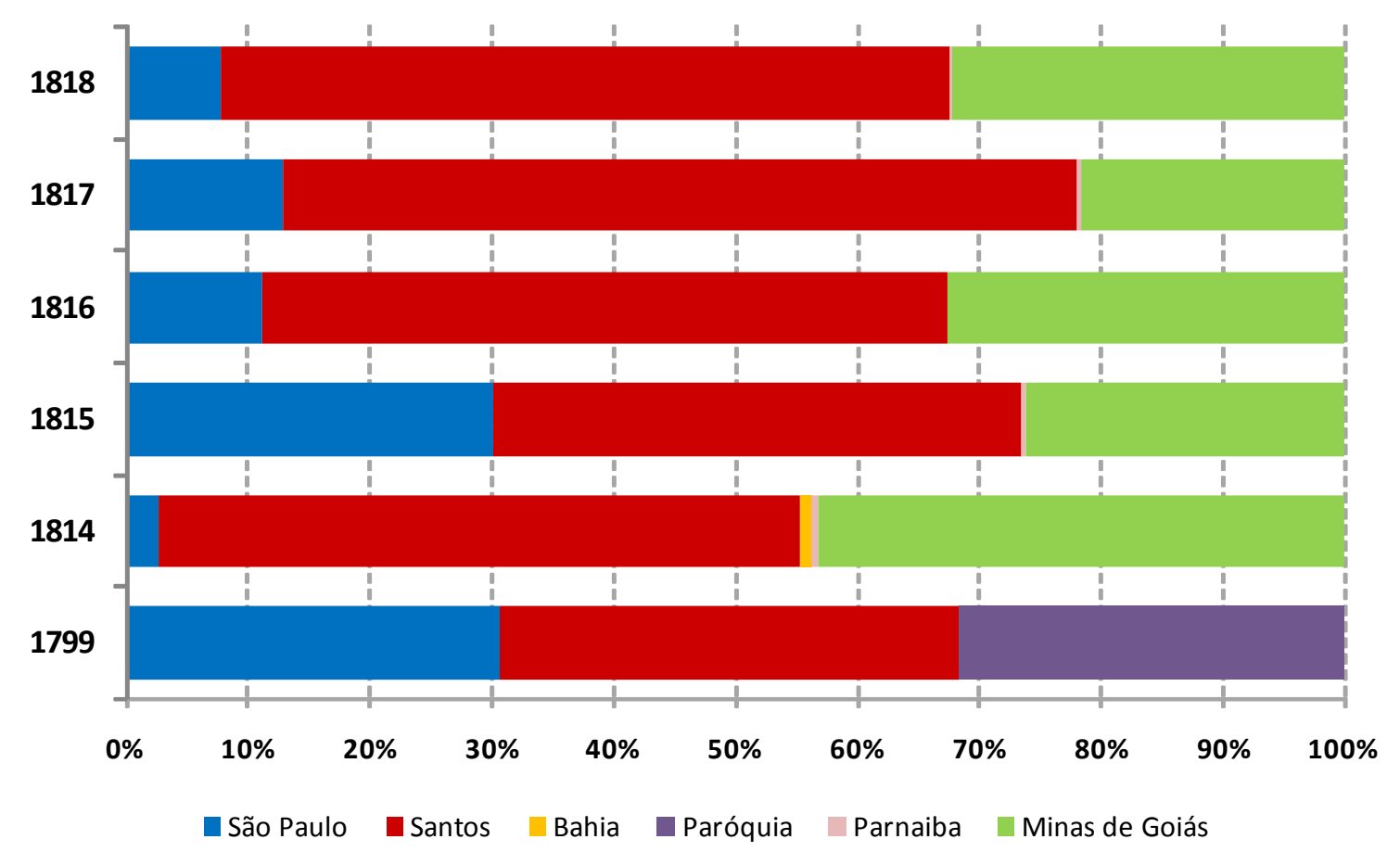

Conforme a Tabela II.14, para Goiás eram mandados exclusivamente bestas e muares, cujo comércio encontrava facilidade na localização de Jundiaí nas junto à rota que de São Paulo para lá seguia (vide Figura II.1). Mas, de maneira diversa ao verificado para os demais produtos exportados, bestas não apareceram de maneira significativa entre as produções da localidade, sendo encontradas em apenas um ou outro fogo ao longo de todo o lapso 1799-1830 (vide Tabela II.4 e II.5). Negociadas por jundiaenses, bestas e muares eram provenientes, ao princípio do Oitocentos, do Sul, das feiras de Curitiba e Viamão.

Já nos anos dez do Oitocentos, Sorocaba era a origem dos muares reexportados de São Paulo para Goiás. Conhecida sua feira desde meados do século XVIII, Sorocaba transformou-se com o passar dos anos em importante centro de comercialização de tropas, reunindo vendedores e compradores que vinham ao encontro de seu mercado. A proximidade com Jundiaí possibilitou que parte desses compradores fossem habitantes da nossa vila em tela, o que possivelmente representou, com relação à feira de Curitiba, freqüentada anteriormente, ganhos com relação a tempo e custos de transportes para esses comerciantes de animais da vila, e a conseqüente entrada de novos indivíduos nesse mercado. 
Tabela II.15

Gêneros importados de acordo com a origem

(Jundiaí - 1798 a 1825)

\begin{tabular}{|c|c|c|c|c|c|c|}
\hline Anos & São Paulo & Santos & Rio de Janeiro & Bahia & $\begin{array}{c}\text { Curitiba (e } \\
\text { Viamão) }\end{array}$ & Sorocaba \\
\hline 1799 & sal, ferro, aço & sal,vinho & $\begin{array}{c}\text { panos e tecidos, } \\
\text { chapéus }\end{array}$ & - & potros, bestas & - \\
\hline 1800 & - & sal,vinho & panos e tecidos & chapéus & potros, bestas & - \\
\hline 1801 & $\begin{array}{c}\text { fazendas secas: } \\
\text { vários gêneros, } \\
\text { sal }\end{array}$ & $\begin{array}{r}\text { fazendas secas } \\
\text { vários gêneros }\end{array}$ & $\begin{array}{l}\text { fazendas secas: } \\
\text { vários gêneros }\end{array}$ & $\begin{array}{l}\text { fazendas secas: } \\
\text { vários gêneros }\end{array}$ & potros, bestas & - \\
\hline 1802 & - & panos, sal & panos & - & - & - \\
\hline 1809 & - & sal, vinho & $\begin{array}{c}\text { fazendas secas: } \\
\text { vários gêneros, } \\
\text { molhados }\end{array}$ & - & potros, bestas & - \\
\hline 1810 & tecidos & sal & $\begin{array}{l}\text { panos, chapéus, } \\
\text { meias, ferro, aço }\end{array}$ & - & potros, bestas & - \\
\hline 1811 & - & sal & $\begin{array}{l}\text { panos e tecidos, } \\
\text { chapéus, ferro, } \\
\text { aço, sal }\end{array}$ & - & - & - \\
\hline 1812 & - & sal & $\begin{array}{l}\text { panos, chapéus, } \\
\text { meias, ferro, aço, } \\
\text { chumbo, pólvora }\end{array}$ & - & - & bestas \\
\hline 1814 & - & $\begin{array}{l}\text { sal, vinho, } \\
\text { vinagre }\end{array}$ & $\begin{array}{c}\text { panos, chapéus, } \\
\text { ferro, aço, } \\
\text { chumbo, pólvora }\end{array}$ & - & - & bestas \\
\hline 1816 & - & $\begin{array}{c}\text { sal,vinho, } \\
\text { vinagre, } \\
\text { aguardente de } \\
\text { quina }\end{array}$ & $\begin{array}{c}\text { panos e tecidos, } \\
\text { chapéus, meias, } \\
\text { ferro, aço, } \\
\text { pólvora }\end{array}$ & - & - & muares \\
\hline 1817 & - & $\begin{array}{c}\text { sal,vinho, } \\
\text { vinagre, } \\
\text { aguardente de } \\
\text { quina }\end{array}$ & $\begin{array}{l}\text { panos e tecidos, } \\
\text { chapéus, meias, } \\
\text { ferro, aço }\end{array}$ & - & - & muares \\
\hline 1818 & - & $\begin{array}{c}\text { sal,vinho, } \\
\text { vinagre, } \\
\text { aguardente de } \\
\text { quina }\end{array}$ & $\begin{array}{l}\text { panos e tecidos, } \\
\text { meias, chapéus }\end{array}$ & - & - & bestas \\
\hline 1822 & - & $\begin{array}{l}\text { vinho, } \\
\text { aguardente, } \\
\text { vinagre }\end{array}$ & $\begin{array}{l}\text { panos e tecidos, } \\
\text { meias, chapéus, } \\
\text { papel, retrós }\end{array}$ & - & - & - \\
\hline 1825 & - & $\begin{array}{l}\text { vinho, } \\
\text { aguardente, } \\
\text { vinagre, } \\
\text { bacalhau }\end{array}$ & $\begin{array}{l}\text { panos e tecidos, } \\
\text { meias, chapéus, } \\
\text { papel, retrós }\end{array}$ & - & - & - \\
\hline
\end{tabular}


Esse comércio de compra e venda de muares era bastante significativo para a economia local, posto ser o segundo principal gerador de divisas externas da Vila de Jundiaí, perdendo em valor apenas para o açúcar. Os valores conjuntos para importação e exportação desses animais foram encontrados apenas para 1816,1817 e 1818. Nesses asnos haviam sido importados de Sorocaba, respectivamente, 300, 325 e 630 bestas. Este número corresponde exatamente àquele exportado para Goiás nos referidos anos. Nominalmente, os preços de importação eram de $11 \$ 000$ em 1817 e $12 \$ 000$ em 1816 e 1818, enquanto os valores nominais de exportação foram de $16 \$ 000$ nos três anos. Assim, temos em 1816 importações que nominalmente foram de 3:600 $\$ 000$, contra 4:800\$000 para as exportações, sendo o líquido de 1:200\$000. No ano seguinte as exportações nominais líquidas alçaram-se a 1:625\$000, para 3:575\$000 de importações e 5:200\$000 em importações. Já em 1818 o número de muares transacionados dobrou com relação aos anos anteriores, movimentando em compras 7:560\$000 e em vendas 10:080\$000, uma diferença de 2:520\$000, ou seja, cerca de $33 \%$.

Apesar de produzir alguns gêneros de subsistência em grande monta, diferentes gêneros mais sofisticados chegavam a Jundiaí vindos de outros mercados. Ao longo do período 1799 a 1825, para os anos em os mapas de comércio apresentavam este dados, encontramos presença de Santos e Rio de Janeiro, portos onde desembarcavam uma série destes produtos vindos, inclusive, de além mar. Em alguns momentos temos menção à cidade de São Paulo e em 1800 e 1801 gêneros haviam chegado da Bahia.

Como adiantado, entre o final do Setecentos e 1818 encontramos intenso mercado de muares em Jundiaí. Nos anos em que estiveram presentes, responderam pelo percentual majoritário do valor das importações locais; apenas em 1809 o Rio de Janeiro apareceu como ponto de partida de mercadorias de valor superior, $41,2 \%$, enquanto os potros e bestas oriundos de Curitiba responderam por $37,9 \%$ das importações jundiaenses. Nos demais anos, apesar de majoritários os percentuais foram bastante variáveis: $60,5 \%$ em 1800 e $82,6 \%$ já no ano seguinte, por exemplo. O mesmo ocorreu quando a origem dos animais era Sorocaba, entre 1812 e 1818: 84,2\% no primeiro ano, caindo a $57,3 \%$ no ano seguinte e subindo a $72,4 \%$ passados outros dois anos. 
Tabela II.16

Percentual do valor importado de acordo com a origem

(Jundiaí - 1799 a 1830)

\begin{tabular}{|c|c|c|c|c|c|c|c|}
\hline Anos & $\begin{array}{c}\text { São Paulo } \\
\%\end{array}$ & $\begin{array}{c}\text { Rio de } \\
\text { Janeiro } \\
\%\end{array}$ & $\begin{array}{c}\text { Santos } \\
\%\end{array}$ & $\begin{array}{c}\text { Bahia } \\
\%\end{array}$ & $\begin{array}{c}\text { Curitiba (e } \\
\text { Viamão) } \\
\%\end{array}$ & $\begin{array}{c}\text { Sorocaba } \\
\%\end{array}$ & $\begin{array}{r}\text { Total } \\
\%\end{array}$ \\
\hline 1799 & 13,9 & 7,4 & 10,7 & - & 67,9 & - & 100,0 \\
\hline 1800 & - & 7,8 & 9,5 & 22,2 & 60,5 & - & 100,0 \\
\hline 1801 & 2,5 & 2,6 & 8,5 & 3,8 & 82,6 & - & 100,0 \\
\hline 1802 & - & 16,1 & 7,3 & - & 76,6 & - & 100,0 \\
\hline 1809 & 1,9 & 41,2 & 18,9 & - & 37,9 & - & 100,0 \\
\hline 1810 & 5,8 & 20,6 & 8,2 & - & 65,4 & - & 100,0 \\
\hline 1811 & - & 99,0 & 1,0 & - & - & - & 100,0 \\
\hline 1812 & - & 12,4 & 3,4 & - & - & 84,2 & 100,0 \\
\hline 1814 & 8,8 & 25,1 & 8,8 & - & - & 57,3 & 100,0 \\
\hline 1816 & - & 21,9 & 5,7 & - & - & 72,4 & 100,0 \\
\hline 1817 & - & 20,1 & 3,4 & - & - & 76,6 & 100,0 \\
\hline 1818 & - & 16,2 & 3,1 & - & - & 80,7 & 100,0 \\
\hline 1822 & - & 88,5 & 11,5 & - & - & - & 100,0 \\
\hline 1825 & - & 91,0 & 9,0 & - & - & - & 100,0 \\
\hline 1827 & - & 85,4 & 14,6 & - & - & - & 100,0 \\
\hline 1828 & - & 69,4 & 30,6 & - & - & - & 100,0 \\
\hline 1829 & - & 73,8 & 26,2 & - & - & - & 100,0 \\
\hline 1830 & - & 53,7 & 46,3 & - & - & - & 100,0 \\
\hline
\end{tabular}

Fonte:AESP, M aços de População - M apas de produção e comércio, Jundiaí

Entre as demais localidades vendedoras de gêneros para Jundiaí, também não houve nenhum sentido claro nas flutuações, além daquele que aponta para a importância assumida pelo Rio de Janeiro a partir da segunda década do Oitocentos, mas perdendo algum espaço para Santos nos anos finais da década de 1820, especialmente já no ano de 1830 , em que $53,7 \%$ das importações eram devidas ao Rio de Janeiro e $46,3 \%$ a Santos.

Comparando as importações com as exportações obtemos dados relativos à balança comercial da localidade ao longo do tempo de acordo com os mapas de comércio, conforme vai colocado no Gráfico II.5. 


\section{Gráfico II.5}

\section{Saldo do balanço comercial}

\section{(Jundiaí - 1799 a 1830)}

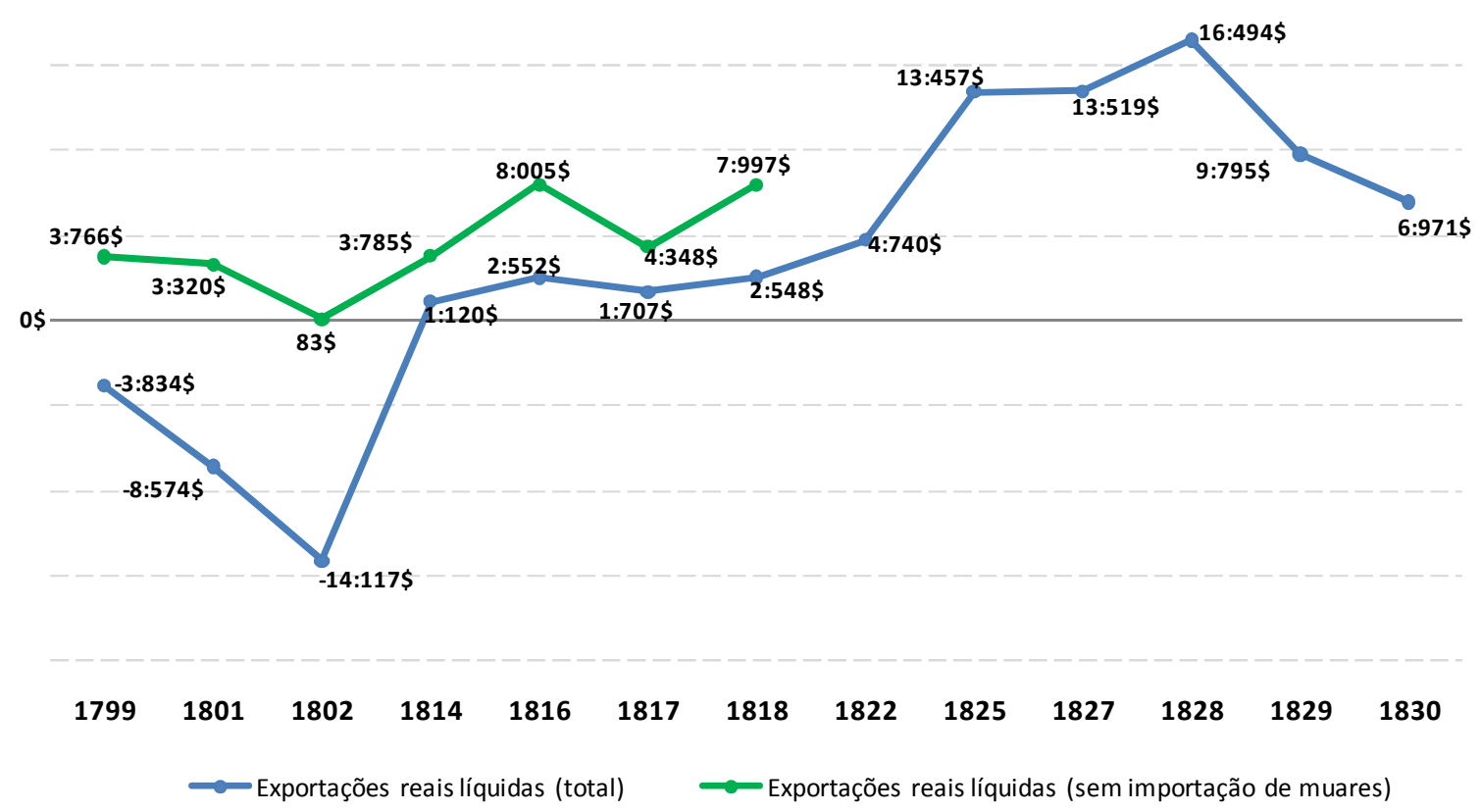

Os resultados comerciais de Jundiaí apontam três períodos distintos: até 1802 houve déficit, que passou a superávit a partir de 1814; essa diferença positiva foi crescente até 1818 e nos dois anos seguintes, apesar do elevado superávit que chegou, em termos reais, a 9:794\$969 (1828) e 6:971\$313 (1830), este foi decrescente com relação a 1828, sendo ao final do período considerado (1830), o saldo comercial da localidade pouco menos de 58\% abaixo daquele observado dois anos antes.

Chama a atenção o ano de 1802, no qual a diferença entre exportações e importações foi negativa em 14:117\$199, montante bastante próximo aos computado para os animais chegados do sul: 14:199\$714

É dizer, o comércio exportacionista jundiaense (regional e internacional), nas décadas de 1810 e 1820 foi capaz de suprir, com folga, as necessidades da vila de gêneros, secos e molhados, vindos de outras regiões brasileiras e de outras áreas mais afastadas, fora da colônia/império, em muito devido ao comércio de açúcar e de muares. 
Tabela II.17

Coeficientes de exportação e importação

(Jundiaí - 1798 a 1818)

\begin{tabular}{ccc}
\hline \hline Anos & $\begin{array}{c}\text { Coeficiente de } \\
\text { exportação* }\end{array}$ & $\begin{array}{c}\text { Penetração das } \\
\text { importações ** }\end{array}$ \\
\hline 1798 & 0,56 & - \\
1799 & 0,32 & 0,73 \\
1814 & 0,32 & 0,30 \\
1815 & 0,39 & - \\
1816 & 0,36 & 0,44 \\
1817 & 0,37 & 0,12 \\
1818 & 0,73 & 0,76 \\
1822 & 0,32 & 0,20 \\
1827 & 0,44 & 0,07 \\
1828 & 0,41 & 0,04 \\
1829 & 0,32 & 0,06 \\
1830 & 0,41 & 0,07 \\
1825 & 0,44 & 0,10 \\
\hline \hline *valor das exportações/valor da produção & \\
**valor das importações/valor do consumo & \\
Fonte: AESP, Maços de População - Mapas de produção e comércio, \\
Jundiaí:anos selecionados
\end{tabular}

Este comércio com outras regiões era dinamizado especialmente pela comercialização do açúcar produzido localmente e pela intermediação na venda dos muares, os dois principais componentes da pauta exportacionista de Jundiaí. Decerto a importância assumida por estes gêneros e as modificações mercantis que para eles observamos, fizeram com que se mostrassem mais ou menos atrativos os distintos setores econômicos, justificando as modificações na composição das ocupações da localidade anteriormente apresentadas.

Entre eles, em especial, o setor de transportes, em grande medida ligado ao escoamento da produção, como fica claro em algumas situações como as verificadas no arrolamento de 1799 em que Pedro Vaz de Lima, Vitorino de Godois e Joaquim dos Reis tinham anotado em suas observações: "vive de conduzir açúcar para Santos". (Lista Nominativa de Jundiaí, 1799 - AESP, Maços de População/rolo 106) Ademais, o serviço de transportes deveria abrir outras possibilidades correlatas como encontramos em 1808 o caso de Manoel de Arruda que aos 76 anos "vive de arrancar capim e vender para as tropas". (Lista Nominativa de Jundiaí, 1808 - AESP, Maços de População/rolo 108) 
Deveriam sofrer mais diretamente com as flutuações do mercado também os jornaleiros, que por viverem se seu jornal, ou seja, pelo pagamento de um dia de trabalho, dependiam das condições de seus possíveis pagadores, que a sua vez dependiam da dinâmica econômica local. Em 1799 o percentual desses chefes de fogo atingiu 4,2\% em 1808 e 1816 caiu a pouco mais de $1 \%$, em 1822 foi de 5,2\% e ao fim do período, 1830, chegou a 6,9\% (cf. Tabela II.1). Por exemplo, Domingos da Cruz vivia de seus jornais em 1799 e foi encontrado como plantador para gasto nos anos seguintes (1803 e 1808), o mesmo acontecendo, por exemplo, com Eleutério Pires. Ou ainda apodemos citar Angelo de Lima, que em 1799 vivia de seus jornais, em 1803 vivia de suas lavouras, cinco anos depois foi encontrado novamente como jornaleiro e, passado outro lustro declarou plantar para gasto.

Assim, acreditamos ter ocorrido em Jundiaí um efeito multiplicador, à la Keynes, nos moldes daquele identificado por Robert Slenes (1988) para a economia mineira no século XIX, a partir de seu centro dinâmico exportador:

\begin{abstract}
Este setor exportador, por sua vez, teve um impacto sobre a economia interna. As pessoas nele envolvidas precisavam comer e provavelmente compravam pelo menos uma parte de seus mantimentos. Além disso, o transporte de produtos de algodão para as regiões cafeeiras criava empregos para tropeiros, livres e escravos, que, por sua vez, estimulavam o mercado doméstico para milho, ferraduras, pregos - e também para pano de algodão. A produção de queijo, gado e toucinho para as áreas cafeeiras e seus centros urbanos também tinha ligações primárias e secundárias com a economia interna, aumentando a procura de mantimentos, ferragens e têxteis e estimulando o emprego de pessoas nesses setores e no transporte, o que por sua vez dava mais um incentivo ao mercado interno para produtos agrícolas e manufaturados. E havia ainda ligações terciárias: o abastecimento dos tropeiros e dos condutores de gado bovino e suíno no setor exportador e o suprimento dos fazendeiros e sitiantes (que produziam mantimentos para estes trabalhadores e seus animais) criavam mais empregos nos transportes, 0 que estimulava mais uma vez a procura no mercado interno. (SLENES, 1988, pp.460-461)
\end{abstract}

É dizer, Jundiaí possuía um setor exportador capaz de gerar importantes divisas e que possuía razoável importância. Em que pese a parcela devida ao setor ligado ao comércio para além das fronteiras coloniais, essas atividades exportacionistas causavam impacto sobre o já estabelecido setor agrícola de abastecimento interno, estimulando ainda mais sua veia comercial e incentivando ainda outras atividades diversas, espraiando e ampliando atividades comerciais e manufatureiras, assim como intensificando a importância dos indivíduos ligados ao transporte.

Mesmo com distintas possibilidades abertas pelo mercado em diferentes momentos, havia uma parcela da sociedade jundiaense à margem de todo esse processo, 
ou que ao menos assim se reconheciam, imaginamos, ao se declararem despossuídos nos arrolamentos populacionais, conforme dados expostos no Gráfico II.6

\section{Gráfico II.6}

Número absoluto de chefes despossuídos e sua participação percentual no número total de domicílios

(Jundiaí - 1799 a 1830)

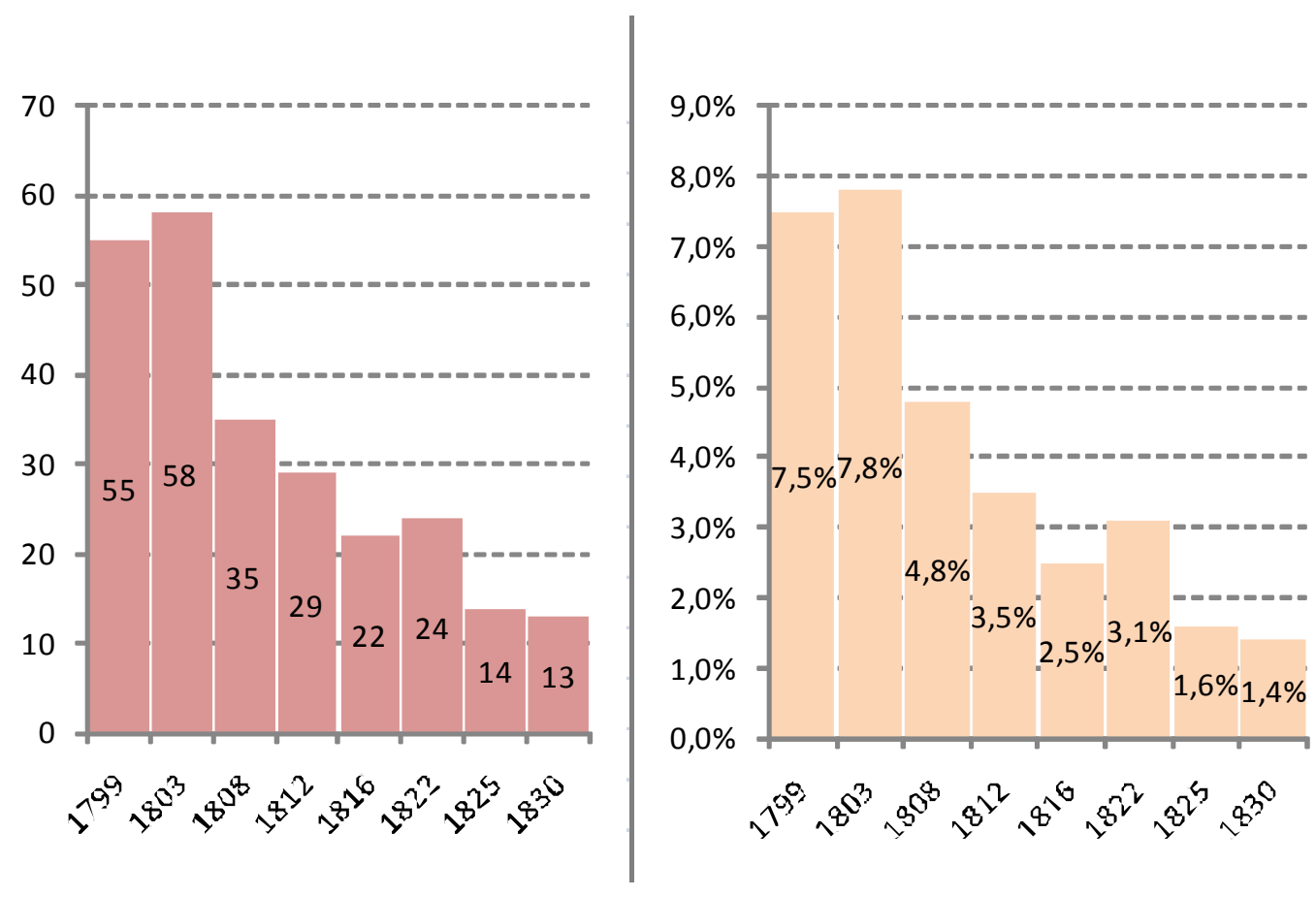

Em 1799 eram quatro fogos com chefes que "nada tem" e outros 51 que vivam de esmolas, o que representava significativos $7,5 \%$ dos fogos recenseados neste ano, um número superior a qualquer outra atividade que não aquelas agropecuárias (cf. Tabela II.2). Da mesma maneira, em 1803 eram 7,8\% (58) dos domicílios chefiados por despossuídos, com chefes declarados pobres (2), vadios (11), mendigos (15), a viver de esmolas (25) e ainda conjugações entre eles como "vadio vive de esmolas", "vive de passear e vadiar" ou "pobre e mendigo", percentual bastante significativo, mas que já não consegue ultrapassar a participação de setores como transporte e artesanato. Já a partir de 1808, o percentual devido a estes despossuídos caiu a 4,8\%, correspondente a esmolas (25), mendigos (2) e vadios (8); voltando a cair nos anos seguintes quando apenas indivíduos a viver de esmolas foram declarados em 3,5\% dos fogos em 1812, e cerca de $1,5 \%$ dos domicílios passada pouco mais de uma década.

Mesmo reconhecendo que alguns desses indivíduos tinham suas atividades produtivas dificultadas pela idade, doenças ou até mesmo pela condição cativa anterior - 
por exemplo, o preto Francisco de Oliveira, que doente vivia de esmolas em 1808 ou Domingos Rodrigues, que aos 55 anos em 1799 também era doente estava a viver de esmolas -, fato é que estes chefes de domicílio compuseram as listas nominativas de forma significativa no Setecentos, e continuaram presentes ao longo de todo o lapso oitocentista observado. Mas foi claramente decrescente a presença de indivíduos desprovidos de qualquer recurso em Jundiaí, acompanhando a anteriormente anotada ampliação do número de engenhos, atividades artesanais, de unidades comércio e pessoas envolvidas no sistema de transportes ou a viver de seus jornais, assim como com a ampliação da presença de indivíduos nascidos na própria localidade verificado em capítulo anterior.

Ademais, não anotados no Gráfico II.6 por já o terem sido nas primeiras tabelas apresentadas, encontramos em 1808 para o fogo chefiado por Maria de Jesus, solteira e com cinco filhos de 6 a 29 anos de idades a descrição "pobres vivem de fiar algodão" (cf. Lista Nominativa de Jundiaí, 1808 - AESP, Maços de População/rolo 108) e em 1812 Manoel Garcia "soldado vive de vadiar". Estas observações parecem apontar, ainda que não tenhamos podido medir e estabelecer uma classificação neste sentido, para algo que aventamos anteriormente, qual seja, as diferentes possibilidades apresentadas dentro dos setores econômicos, cujos indivíduos agrupados sob distintas ocupações dentro dos grupos em questão apresentavam situações reais distanciadas entre si, podendo existir alguns tendentes aos pobres, enquanto outros desenvolviam atividades de maior monta. 


\section{Bragança}

Como não poderia ser diferente, as listas nominativas da Vila Nova de Bragança apontam, no que respeita à distribuição dos chefes de fogo por setores de atividade econômica, para uma maioria absoluta de indivíduos ligados à agricultura e pecuária, como se vê na Tabela II.18, em que são apresentados os principais setores em que podemos classificar as atividades produtivas listadas para a localidade nos anos considerados. ${ }^{49}$ A tabela apresenta dados apenas para os chefes de fogo uma vez que, nos censos analisados, as atividades desempenhadas pelos demais membros do fogo foram bastante sub-especificadas. Ademais, chefes à margem do processo produtivo, por serem declarados pobres, vadios ou assemelhados igualmente não compõem a referida tabela, seus números são apresentados no Gráfico II.7 abaixo.

\section{Gráfico II.7}

Número absoluto de chefes despossuídos e sua participação percentual no número total de domicílios

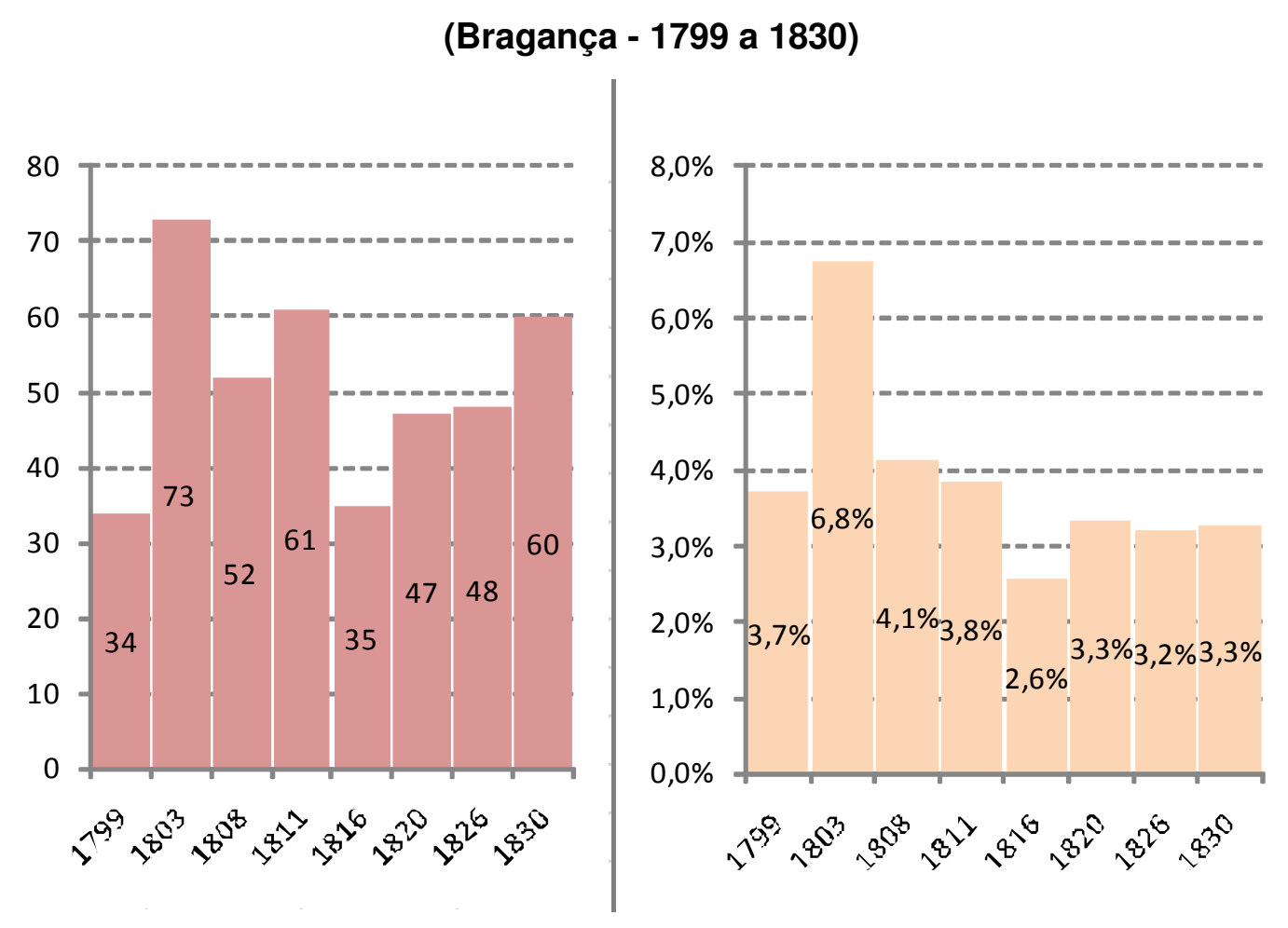

\footnotetext{
49 Para considerações acerca da definição dos setores de atividade econômica considerados, ver análise inicial da seção anterior, cujas observações se estendem a Bragança e às demais localidades estudadas.
} 
Estes indivíduos despossuídos foram contados em números variáveis. Em 1803 eram 73 chefes cujos fogos responderam por consideráveis $6,8 \%$ do total de domicílios arrolados na Vila Nova de Bragança no referido ano. Este percentual caiu a $4,1 \% \mathrm{em}$ 1808 e foi bastante constante, em pouco mais de $3 \%$, na década de 1820 , o que, nominalmente, correspondia a 47, 48 e 60 unidades domiciliares.

Entre pobres identificados alguns eram doentes ou "dementes": dois em 1799, três em 1803, dois em 1808, um em 1816, 1820 (3), 1826 (1) e 1830 (1). E alguns indivíduos apesar se declararem pobres tiveram suas ocupações descritas e foram considerados nas tabelas de setores econômicos. Este o caso de dois indivíduos em 1799 (um capitão do mato e outro que plantou para seu passar); um tropeiro em 1803; uma fiandeira em 1808; um soldado e um lavrador em 1820 e o mesmo soldado, Antonio Jose de Lima, em 1826.

\section{Tabela II.18}

\section{Distribuição dos fogos por setores de atividade econômica}

\section{(Bragança - 1799 a 1830)}

\begin{tabular}{|c|c|c|c|c|c|c|c|c|}
\hline Setor & $\begin{array}{l}1799 \\
\%(№)\end{array}$ & $\begin{array}{c}1803 \\
\% \text { (№) }\end{array}$ & $\begin{array}{r}1808 \\
\% \text { (№) }\end{array}$ & $\begin{array}{c}1811 \\
\%(№)\end{array}$ & $\begin{array}{c}1816 \\
\% \text { (№) }\end{array}$ & $\begin{array}{l}1820 \\
\%(№)\end{array}$ & $\begin{array}{l}1826 \\
\%(№)\end{array}$ & $\begin{array}{l}1830 \\
\% \text { (№) }\end{array}$ \\
\hline Agricultura & $76,0(581)$ & 74,9 (595) & $73,8(582)$ & $78,7(870)$ & $75,9(742)$ & $74,5(866)$ & 74,0 (883) & $74,4(1035)$ \\
\hline Igreja & $0,1(1)$ & $0,3(2)$ & $0,4(3)$ & $0,3(3)$ & $0,5(5)$ & $0,4(5)$ & $0,6(7)$ & $0,3(4)$ \\
\hline Magistratura & $0,4(3)$ & $0,3(2)$ & $0,5(4)$ & $0,4(4)$ & $0,4(4)$ & $0,3(3)$ & $0,1(1)$ & $0,4(6)$ \\
\hline Rentistas & $0,1(1)$ & - & - & - & - & - & $0,1(1)$ & $0,3(4)$ \\
\hline Comércio & $1,0(8)$ & $1,0(8)$ & $1,5(12)$ & $1,4(16)$ & $1,0(10)$ & 3,4 (39) & $1,9(23)$ & $5,2(73)$ \\
\hline Transporte & - & $0,4(3)$ & - & - & - & $0,2(2)$ & $0,1(1)$ & - \\
\hline Serviços em geral & - & - & - & - & - & $0,3(4)$ & $0,1(1)$ & - \\
\hline Múltiplos setores & $17,3(132)$ & $18,5(147)$ & $15,0(118)$ & $13,8(152)$ & $13,0(127)$ & $11,8(137)$ & $12,9(154)$ & $11,8(164)$ \\
\hline Total & $100,0(764)$ & $100,0(794)$ & $100,0(789)$ & $100,0(1105)$ & $100,0(978)$ & $100,0(1162)$ & $100,0(1193)$ & $100,0(1391)$ \\
\hline
\end{tabular}

Em se considerando a atividade relativa ao chefe de fogo como a atividade principal do domicilio, como o fizemos para Jundiaí - "consideramos a ocupação realizada pelo chefe como a atividade principal do fogo, mesmo sabendo que, muito provavelmente, atividades diversas eram desenvolvidas concomitantemente por outros membros do domicílio"-, verificamos estar a maioria dos domicílios/unidades produtivas bragantinas vinculadas, sem alguma conjugação aparente, a este setor cuja participação foi relativamente constante do final do século XVIII até as três primeiras décadas da centúria 
subseqüente, uma vez que as flutuações observadas são de pequena monta. O maior percentual calculamos para o ano de $1811,78,4 \%$, já nos demais anos a participação manteve-se ao redor de $74 \%$ a $76 \%$ (mínimo de 73,8\% observado em 1808). Ou seja, variou dentro de um intervalo de cinco pontos percentuais a participação devida ao setor agricultura e manufatura rural em Bragança ao longo dos anos estudados.

Dentro do setor em tela estavam anotados, em especial, indivíduos arrolados como lavradores, lavradores para seu sustento e criadores. De forma diversa aos lavradores (para seu sustento ou não), a maior parte dos criadores não aparece nestes termos nas listagens populacionais, mas o grande número de menções a capados e, mormente, à produção de toucinho - não existira toucinho sem a anterior criação de porcos - justificam, a nosso ver, a menção destes chefes de domicílio como criadores. ${ }^{50}$

Vale lembrar que os percentuais apontados são referentes apenas aos indivíduos a chefiar domicílios cujas atividades foram declaradas ou cuja leitura do documento não viu-se prejudicada pelo seu estado de conservação, e excluem chefes de fogos pobres ou indigentes, a viver de esmolas e assemelhados, o que corresponde a percentuais de $83,4 \%$ em 1799, 73,5\% em 1803, 62,8\% (1808), 69,5\% (1811), 71,7\% (1816), 82,8\% (1820), 79,5\% (1826) e 75,6\% (1830).

Os demais bragantinos, livres ou cativos, em poucas exceções tiveram suas ocupações explicitadas nos arrolamentos. Apenas em 1808 o número foi um pouco mais elevado, 72 indivíduos livres, mas que em termos percentuais respondiam por apenas 1,4\% dos mais de 5100 livres não chefes de domicilio (em que pese nesse número a presença de crianças), sendo estes indivíduos envolvidos em atividades militares. As atividades militares mereciam menção nas listas para os não chefes de domicílios, enquanto outras atividades não foram descritas. O quadro apontado estende-se também a anos em que um pequeno número de descrições foram encontradas, como aconteceu em 1799, em que 16 livres com distintas relações com o chefes tiveram suas atividades descritas, 13 deles ocupavam postos na milícia.

Em se modificando os dados apresentados na Tabela II.18, levando-se me consideração a grande presença de chefes militares que realizavam outros tipos de atividades, a dificuldade em se determinar quais desses indivíduos e respectivos fogos dependiam, principalmente, de seus soldos de tropa paga e sabendo que estes deveriam ser parcela diminuta, obtemos os dados apresentados na Tabela II.19, em que os

\footnotetext{
${ }^{50}$ Análise das características da produção de toucinho e de sua importância para a subsistência local, assim como para o comércio de gêneros da terra levado cabo por Bragança será feito mais adiante, em momento oportuno.
} 
militares em múltiplas ocupações foram considerados dentro dos setores não militares, sendo sua atividade militar "ignorada".

Tabela II.19

Distribuição dos fogos por setores de atividade econômica - exclusive militares em múltiplas ocupações -

(Bragança - 1799 a 1830)

\begin{tabular}{|c|c|c|c|c|c|c|c|c|}
\hline Setor & $\begin{array}{l}1799 \\
\% \text { (№) }\end{array}$ & $\begin{array}{c}1803 \\
\% \text { (№) }\end{array}$ & $\begin{array}{c}1808 \\
\% \text { (№) }\end{array}$ & $\begin{array}{c}1811 \\
\% \text { (№) }\end{array}$ & $\begin{array}{l}1816 \\
\% \text { (№) }\end{array}$ & $\begin{array}{l}1820 \\
\% \text { (№) }\end{array}$ & $\begin{array}{c}1826 \\
\% \text { (№) }\end{array}$ & $\begin{array}{l}1830 \\
\% \text { (№) }\end{array}$ \\
\hline Agricultura & $92,7(708)$ & $92,8(737)$ & $87,2(688)$ & $91,5(1011)$ & $87,3(854)$ & 84,3 (979) & $85,1(1015)$ & $83,5(1161)$ \\
\hline Artesanato & $3,3(25)$ & $2,9(23)$ & $5,2(41)$ & $3,4(38)$ & $5,6(55)$ & $6,9(80)$ & $4,8(57)$ & $6,1(85)$ \\
\hline Igreja & $0,1(1)$ & $0,3(2)$ & $0,4(3)$ & $0,4(4)$ & $0,5(5)$ & $0,4(5)$ & $0,6(7)$ & $0,3(4)$ \\
\hline Magistratura & $0,4(3)$ & $0,3(2)$ & $0,5(4)$ & $0,4(4)$ & $0,4(4)$ & $0,3(3)$ & $0,1(1)$ & $0,5(7)$ \\
\hline Profissões liberais & - & - & $0,1(1)$ & - & - & - & $0,1(1)$ & $0,2(3)$ \\
\hline Rentistas & $0,4(3)$ & - & - & - & - & - & $0,1(1)$ & $0,4(5)$ \\
\hline Comércio & $1,3(10)$ & $1,1(9)$ & $1,9(15)$ & $1,8(20)$ & $1,5(15)$ & $4,0(46)$ & $2,9(35)$ & 7,1 (99) \\
\hline Transporte & - & $0,4(3)$ & $0,1 \quad 1,0$ & - & - & $0,3(4)$ & $0,1(1)$ & - \\
\hline Serviços em geral & - & - & - & - & - & $0,3(4)$ & $0,1(1)$ & - \\
\hline Corpo militar & $1,2(9)$ & $1,4(11)$ & $2,8(22)$ & $1,3(14)$ & $2,4(23)$ & $0,8(9)$ & $0,8(9)$ & $1,1(15)$ \\
\hline Jornaleiros & $0,4(3)$ & $0,5(4)$ & $1,4(11)$ & $1,2(13)$ & $2,1(21)$ & $2,0(23)$ & $5,2(62)$ & $0,7(10)$ \\
\hline Outras (não-classificadas) & $0,1(1)$ & - & - & - & - & - & - & - \\
\hline Múltiplos setores & $0,1(1)$ & $0,4(3)$ & $0,4(3)$ & $0,1(1)$ & $0,1(1)$ & $0,8(9)$ & $0,3(3)$ & $0,1(2)$ \\
\hline Total & $100,0(764)$ & $100,0(794)$ & $100,0(789)$ & $100,0(1105)$ & $100,0(978)$ & $100,0(1162)$ & $100,0(1193)$ & $100,0(1391)$ \\
\hline
\end{tabular}

O já majoritário setor agricultura expande ainda mais sua participação, indicativo de que grande parcela dos militares estava ligada a este setor, o que pode ser explicitado na observação das diversas ocupações dentre os setores que podem ser observadas.

Em 1799 e 1803, a agropecuária passa a responder como atividade principal em quase $93 \%$ dos domicílios da Vila de Bragança, percentual bastante próximo ao observado em 1811: $91,5 \%$. Nos demais anos foi levemente menor, chegou a $87,2 \%$ em 1808 e ficou na casa dos $85 \%$ na década de 1820 .

Ademais, Bragança apresentou uma clara ampliação no número e participação de vendeiros e negociantes a partir de 1820 (3,4\%), chegando a se declararem ligados a atividades comerciais 5,3\% dos chefes de fogo, 73 indivíduos em 1830, contra cerca de $1 \%$ a $1,5 \%$ encontrados até 1816. Se desconsiderados os militares em múltiplas ocupações, o percentual chega a 7,1\% (1830), correspondente a 99 chefes de domicílio. Isto posto, a grande ampliação de vendeiros e negociantes em Bragança parece indicar uma diferenciação nesta vila que aponta para atividades comerciais. 
É difícil a identificação do tamanho dos empreendimentos e dos montantes comercializados por estes homens de negócio, ainda que sua ampliação seja indicativo de uma maior dinâmica nas transações da localidade. Mesmo a diferenciação entre vendeiros e negociantes mostra-se obscura (há, inclusive, a presença de negociantes e venda): em 1820 os primeiros eram maioria, já em 1830 não havia nenhum deles.

Atividades diversificadas, ligadas à vida "urbana", localizadas especialmente no "bairro da vila" foram encontradas em pequena medida, mas estavam presentes. Outra parcela dos fogos de Bragança estava ligada ao artesanato: entre 2,8\% (1803) e 6,5\% (1820) dos chefes com ocupação declarada foram assim classificados, percentual pouco afetado pela inclusão dos artesãos-militares; e que apresenta alguma elevação ao longo do tempo, apesar de flutuações diversas. Jornaleiros apresentaram participação considerável em 1826, quando eram 61 indivíduos e respondiam por 5,1\% das ocupações descritas superando, inclusive, o percentual devido ao setor comércio. Já o corpo militar, sem qualquer menção a alguma outra atividade, foi pouco representativo, chegando ao máximo de 2,4\% (23 indivíduos) em 1816.

De acordo com a Tabela II.18 parcela importante, ainda que decrescente, das unidades domiciliares/produtivas bragantinas eram chefiadas por indivíduos com mais de uma atividade declarada, classificadas sob a rubrica "múltiplos setores": a maior ocorrência deu-se em 1803, 18,5\%, e a menor foi coincidente em 11,8\% nos anos de 1820 e 1830. Como observamos anteriormente, compunham esta classificação de forma majoritária militares ligados à agricultura, ou melhor, agricultores que também possuíam vínculos militares, uma vez que consideramos em outro momento a atividade não militar como a mais representativa da realidade produtivo-econômica dos fogos da vila de Bragança. Era diminuto o número de conjugações entre outros setores.

A presença elevada de agricultores justifica observarmos mais de perto as declarações atinentes a estes fogos. No que respeita à plantação levada a cabo temos observações para pouco mais de um quarto dos fogos no setor agropecuário de 1799 , percentual que entre os anos de 1803 a 1820 variou no intervalo de 76,3\% (1808) a $87,1 \%$ (1803), superou os $90 \%$ em 1825 e foi de $96,2 \%$ em 1830; sendo a presença de alguma cultura um dos critérios para a classificação desses indivíduos como lavradores. Já a pecuária foi explicitada em ao menos 98,7\% fogos, percentual registrado em 1799 e em todo o lapso considerado apareceu acompanhada de plantações em todos os seus registros. Os bragantinos declararam a criação de suínos de forma bastante acentuada, vide o percentual considerável de indivíduos ligados, dentro do setor agricultura, à lavoura mais criação: cerca de 24-25\% em 1808 e 1830, chegando a 40,3\% em 1826 e 
respondendo por não menos de $30 \%$ de todas as atividades declaradas pelos chefes de fogo nos demais anos.

Em 1799 foram mencionados, em diferentes medidas, o cultivo do milho, feijão, algodão, arroz e cana. Entre 1803 e 1811 elas já haviam se restringido a milho, feijão, algodão e cana, esta última auferida pela declaração de aguardente, e nos anos observados de 1816 a 1830 apenas milho e feijão foram arrolados. Muito provavelmente os demais gêneros não deixaram de ser produzidos, no entanto não tinham proporções dignas de menção, ao menos na visão dos responsáveis pelos recenseamentos.

Entre os fogos com cultura listada quase a totalidade deles mencionou a produção de milho (cf. Tabela II.20), que de 1803 a 1830 teve sua menor representação em 1808 quando o cereal apareceu relacionado em $97,5 \%$ dos domicílios. Ou seja, ao longo período estudado cerca de $90 \%$ dos fogos bragantinos plantaram e colheram milho. Neste mesmo período o feijão foi colhido em um número crescente de unidades produtivas, passando de $37,2 \%$ em 1803 a $83,5 \%$ no último ano considerado. Ao final do Setecentos a participação do feijão havia superado a do milho, sendo este registrado em $59,2 \%$ dos fogos com cultura e aquele em $63,8 \%$ deles. Neste ano o algodão chegou a responder por um quinto dos fogos, para sumir das listas posteriormente.

Tabela II.20

Gêneros plantados e presença concomitante dos diferentes gêneros nos fogos (Bragança - 1799 a 1830)

\begin{tabular}{lcccccccc}
\hline \hline CULTURAS & $\mathbf{1 7 7 9}$ & $\mathbf{1 8 0 3}$ & $\mathbf{1 8 0 8}$ & $\mathbf{1 8 1 1}$ & $\mathbf{1 8 1 6}$ & $\mathbf{1 8 2 0}$ & $\mathbf{1 8 2 6}$ & $\mathbf{1 8 3 0}$ \\
\hline MILHO & $59,2 \%$ & $99,8 \%$ & $97,5 \%$ & $98,7 \%$ & $99,7 \%$ & $99,4 \%$ & $99,5 \%$ & $99,0 \%$ \\
FEIJÃO & $63,8 \%$ & $37,2 \%$ & $63,0 \%$ & $72,5 \%$ & $76,5 \%$ & $82,8 \%$ & $86,3 \%$ & $83,5 \%$ \\
ALGODÃO & $20,4 \%$ & - & $3,0 \%$ & $0,9 \%$ & - & - & - & - \\
ARROZ & $6,1 \%$ & - & - & - & - & - & - & - \\
CANA & $5,1 \%$ & $0,2 \%$ & $1,0 \%$ & $0,6 \%$ & - & - & - & - \\
TRIGO & $1,5 \%$ & - & - & - & - & - & - & - \\
FUMO & $3,1 \%$ & - & - & - & - & - & - & - \\
\hline \hline
\end{tabular}




\section{Gráfico II.8}

Percentual de fogos com presença dos diversos gêneros cultivados (Bragança - 1799 a 1830)

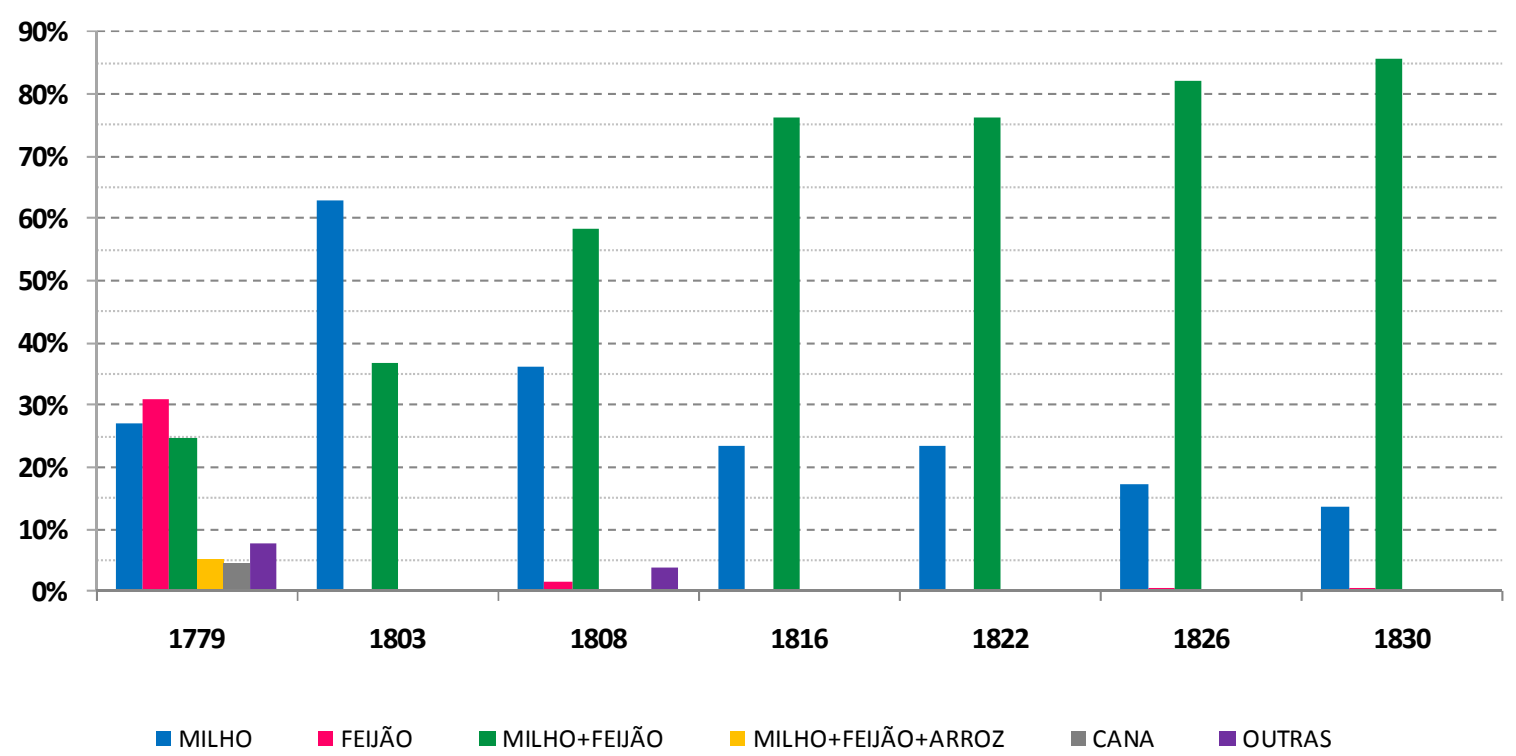

A menção elevada e concomitante de milho e feijão é devida à presença conjunta desses dois produtos nos fogos. No ano de 1808 e seguintes, maioria absoluta dos cultivos referia-se a milho mais feijão, como facilmente se observa no Gráfico II.8. Em 1808 o percentual era de $58,5 \%$ das unidades agrícolas bragantinas, superando os $70 \%$ em 1811 e os $80 \%$ em 1826. Isoladamente o feijão foi o principal cultivo em 1799 , não apresentando menção com alguma significância no Oitocentos. Já o milho, que em cultivo único teve menor representação que o feijão em 1799, cerca de $27 \%$, foi responsável por mais de $62 \%$ das declarações em 1802 , perdendo espaço para a conjugação de milho com o feijão, sendo seu percentual decrescente na medida em que a conjugação avançava.

À sua vez, paralelamente aos cultivos de milho e feijão, a pecuária esteve fortemente representada. Com exceções pontuais, a pecuária declarada resumiu-se à criação de porcos, assim explicitada ou auferida, como adiantado, através da produção do toucinho, conforme explicitado na Tabela II.21. Apenas cinco indivíduos, ao longo de mais de três décadas mencionaram a presença de gado vacum e bestas foram identificadas em fogos pontuais. 
Tabela II.21

Criações

(Bragança - 1799 a 1830)

\begin{tabular}{|c|c|c|c|c|c|c|c|c|}
\hline VACAVBEZERRO & - & $0,8(3)$ & - & $0,5(2)$ & - & $0,2(1)$ & - & - \\
\hline PORCO/CAPADO & $100,0(316)$ & $98,9(367)$ & $97,5(231)$ & $99,0(386)$ & $99,7(364)$ & $99,4(477)$ & $99,6(546)$ & $100,0(411)$ \\
\hline BESTA/BURRO/MULA & - & $0,3(1)$ & $2,5(6)$ & $0,5(2)$ & $0,3(1)$ & $0,4(2)$ & $0,4(2)$ & - \\
\hline
\end{tabular}

Nenhum fogo, em nenhum momento, declarou conjuntamente porcos e toucinho. Nos anos de 1799 e 1808 encontramos exclusivamente toucinho descrito. Os capados foram bastante listados nos anos de 1803 (284 menções a capados, 77,4\% dos fogos com porcos/capados apresentados na Tabela II.21), 1811 (55,4\%), 1816 (43,2\%) e 1820 $(50,9 \%)$, nos demais anos a presença de toucinho foi preponderante: $98,2 \%$ em 1826 e $78,8 \%$ em 1830.

Enfim, no que respeita à produção verificamos que os bragantinos (em sua grande maioria ligados ao setor agricultura) produziam no Oitocentos milho, feijão e porcos. Milho e feijão andavam juntos em grande medida, assim como o milho era insumo essencial na criação de porcos, sendo obtido nas próprias unidades produtivas em que os animais eram criados. Assim, característica marcante da produção da Vila Nova de Bragança era a presença nos diversos domicílios de milho mais feijão mais porcos (cujo objetivo final principal era o toucinho): "Bragança, que fica 3 léguas ao nordeste de Tibaia, é ainda pequena; mas seu moradores vivem abastados; criam em grande quantidade porcos; e recolhem abundancia de trigo, milho e legumes." (CASAL, 1976, p.113)

Para além das listas nominativas propriamente, os mapas de produção e comércio encontrados junto a elas podem nos dar uma idéia do que representava cada um dos gêneros típicos da economia da localidade em termos de valor - ou seja, preço multiplicado pela quantidade, o que permite a soma de bens mensurados em diferentes unidades de medida. Note-se que nos arrolamentos populacionais propriamente não foram encontrados preços que permitissem este exercício. A participação de cada bem da agricultura e da pecuária e seus derivados são apresentados na Tabela II.22.

Como haveríamos de esperar, sendo o produto mais amplamente espraiado entre os fogos da vila em tela, ao se precificar os bens o milho também aparece como responsável por maior parcela do produto gerado dentro das fronteiras de Bragança. $O$ 
cereal foi o principal gênero local em valor e teve sua participação, ainda que majoritária, flutuando ao longo dos anos, sem haver um montante ao redor do qual houvesse oscilado de maneira mais ou menos constante com o passar do tempo.

\section{Tabela II.22}

\section{Participação percentual dos diversos gêneros} no valor do produto

(Bragança - 1798 a 1829)

\begin{tabular}{lcccccccc}
\hline \hline \multicolumn{1}{c}{ Produtos } & $\mathbf{1 7 9 8}$ & $\mathbf{1 7 9 9}$ & $\mathbf{1 8 0 1}$ & $\mathbf{1 8 0 2}$ & $\mathbf{1 8 0 7}$ & $\mathbf{1 8 1 0}$ & $\mathbf{1 8 1 1}$ & $\mathbf{1 8 1 2}$ \\
\hline Milho & 69,5 & 61,9 & 58,8 & 66,2 & 62,1 & 80,8 & 66,6 & 61,8 \\
Feijão & 10,5 & 9,4 & 8,5 & 6,8 & 5,2 & 13,7 & 11,4 & 6,8 \\
Toucinho & 13,4 & 26,3 & 31,4 & 26,4 & 31,3 & 5,5 & 22,0 & 31,4 \\
Farinha & 0,2 & 0,1 & 0,4 & 0,6 & - & - & - & - \\
Algodão & 0,9 & 0,9 & - & - & 0,9 & - & - & - \\
Aguardente & 1,0 & 0,6 & 0,5 & 0,1 & 0,5 & - & - & - \\
Fumo & 0,2 & 0,2 & - & - & - & - & - & - \\
Arroz & 0,5 & 0,1 & 0,2 & - & - & - & - & - \\
Farinha de trigo & 2,9 & 0,6 & 0,3 & - & - & - & - & - \\
Amendoim & 0,1 & - & - & - & - & - & - & - \\
Potros & 0,2 & - & - & - & - & - & - & - \\
Bestas & 0,6 & - & - & - & - & - & - & - \\
\hline TOTAL & 100,0 & 100,0 & 100,0 & 100,0 & 100,0 & 100,0 & 100,0 & 100,0 \\
\hline \hline \multicolumn{1}{c}{ Produtos } & $\mathbf{1 8 1 8}$ & $\mathbf{1 8 2 0}$ & $\mathbf{1 8 2 2}$ & $\mathbf{1 8 2 5}$ & $\mathbf{1 8 2 7}$ & $\mathbf{1 8 2 8}$ & $\mathbf{1 8 2 9}$ & \\
\cline { 1 - 6 } Milho & 26,6 & 49,6 & 85,9 & 60,4 & 55,6 & 60,2 & 60,8 & \\
Feijão & 58,1 & 10,9 & 14,1 & 12,4 & 11,6 & 9,8 & 10,2 & \\
Toucinho & 15,3 & 39,5 & - & 27,2 & 32,8 & 30,0 & 29,0 & \\
\hline TOTAL & 100,0 & 100,0 & 100,0 & 100,0 & 100,0 & 100,0 & 100,0 \\
\hline \hline
\end{tabular}

Fonte: AESP, Maços de População - Mapas de produção e comércio, Bragança

Ao que parece, até a primeira década do século XIX sua participação oscilou entre $59 \%$ e 70\%. Já em 1810 a participação do milho atingiu um dos picos encontrados para a participação do bem na composição do valor dos bens produzidos em Bragança, 80,8\%, sendo $85,9 \%$ em 1822. Nos intervalos entre os anos citados a parcela devida ao milho flutuou bastante: 61,8\% em 1812, 26,6\% em 1818 e 49,6\% em 1820. Ao final da década de 1820 o percentual devido ao milho estava na casa de $60 \%$. Esses percentuais certamente são devidos à produção do milho, uma vez que não correspondem aos maiores preços do gênero no mercado local ou regional.

O feijão, também bastante espraiado entre os fogos, não repetiu a participação no que respeita ao valor da produção bragantina e, assim como o milho, não apresentou tendência identificável no longo prazo. Sua participação foi de 10,5\% em 1798. Uma 
década depois (1807), a participação do feijão havia sido reduzida a 5,2\% para subir a 13,7\% em 1810. Em 1818, o feijão foi o produto mais representativo da produção bragantina: 58,1\%. Percentual que não se manteve nos anos seguintes, quando sua maior representação chegou a 14,1\% (1822), ano em que não foi registrado o toucinho.

O toucinho foi listado entre os produtos locais em todo o período analisado (só desapareceu do mapa de produção de 1822). Foram devidas a ele participações que variaram de um mínimo de 5,5\% em 1810 a 39,5\% em 1820. Assim, os dados dos arrolamentos populacionais apontam uma constante produção do toucinho que ao longo das três primeiras décadas do Oitocentos, ao lado de feijão e milho foi, como se observa nos mapas de comércio apresentados junto aos mapas de produção, um dos principais gêneros da terras comercializados pela vila.

Como mencionamos anteriormente, decerto estas não eram as únicas produções levadas a cabo na localidade no século XIX, mas aquelas que mais provavelmente tinham alguma importância. Esta importância e a "seleção" feita no arrolamento pode estar ligada ao mercado externo à vila. Milho feijão e toucinho foram enviados por Bragança à cidade de São Paulo durante todo o período estudo, conforme aponta o "Mapa comparativo das exportações da paróquia desta Vila Nova de Bragança” para diferentes anos (Tabela II.23).

O toucinho e a plantação de milho e feijão, além de permitirem o autoconsumo, permitiam o comércio local, onde deveriam ser transacionados nos vários "negócios de vendas" anteriormente referidos - e ao que parece, espraiados pela vila e seu termo. Possibilitava, ainda, ingressar no mercado local/regional com produtos facilmente comercializáveis, afinal eram parte importante da dieta não somente daqueles que os produziam, mas de toda a população, inclusive aquela parcela ligada à prestação de serviços nos "centros urbanos" da própria vila ou em outros mais distantes, que para a Bragança do Oitocentos resumia-se a São Paulo, de acordo com os mapas encontrados. 
Tabela II.23

Gêneros exportados de acordo com o destino

(Bragança - 1798 a 1818)

\begin{tabular}{|c|c|c|c|c|c|}
\hline \multicolumn{6}{|c|}{ São Paulo } \\
\hline 1798 & 1799 & 1801 & 1802 & 1807 & 1810 \\
\hline $\begin{array}{c}\text { milho, feijão, } \\
\text { farinha, toucinho, } \\
\text { arroz, amendoim, } \\
\text { fumo, aguardente, } \\
\text { potros, bestas }\end{array}$ & $\begin{array}{l}\text { milho, feijão, } \\
\text { arroz, farinha, } \\
\text { algodão, fumo, } \\
\text { toucinho, } \\
\text { aguardente }\end{array}$ & $\begin{array}{c}\text { milho, feijão, } \\
\text { arroz, farinha, } \\
\text { toucinho, } \\
\text { aguardente }\end{array}$ & $\begin{array}{l}\text { milho, feijão, } \\
\text { farinha, toucinho, } \\
\text { aguardente }\end{array}$ & farinha, toucinho & $\begin{array}{l}\text { milho, feijão, } \\
\text { farinha, toucinho, } \\
\text { aguardente }\end{array}$ \\
\hline 1811 & 1812 & 1818 & 1820 & 1822 & 1825 \\
\hline $\begin{array}{l}\text { milho, feijão, } \\
\text { toucinho }\end{array}$ & $\begin{array}{l}\text { milho, feijão, } \\
\text { toucinho, farinha }\end{array}$ & $\begin{array}{l}\text { milho, feijão, } \\
\text { toucinho }\end{array}$ & $\begin{array}{l}\text { milho, feijão, } \\
\text { toucinho }\end{array}$ & $\begin{array}{l}\text { milho, feijão, } \\
\text { toucinho }\end{array}$ & $\begin{array}{l}\text { milho, feijão, } \\
\text { toucinho }\end{array}$ \\
\hline 1827 & 1828 & 1829 & 1830 & & \\
\hline $\begin{array}{l}\text { milho, feijão, } \\
\text { toucinho }\end{array}$ & $\begin{array}{l}\text { milho, feijão, } \\
\text { toucinho }\end{array}$ & $\begin{array}{l}\text { milho, feijão, } \\
\text { toucinho }\end{array}$ & $\begin{array}{l}\text { milho, feijão, } \\
\text { toucinho }\end{array}$ & & \\
\hline
\end{tabular}

Ainda que não apareça como destino da produção bragantina no século XIX, Minas Gerais, dadas as características históricas da província paulista, em que pese a importância do comércio com a região mineira, pode estar ligada ao impulso inicial para a comercialização dos diferentes gêneros de produção da localidade em foco, impulso este dado no século XVIII, com a necessidade de abastecimento requerida por Minas Gerais em decorrência do grande afluxo populacional, ligado à exploração aurífera, direcionado àquela região.

Bragança está situada (vide Figura II.1) onde, nos idos dos Setecentos, passava um dos três caminhos paulistas seguindo rumo às Minas; o referido caminho seguia por Atibaia, Bragança, Extrema e transpunha a serra da Mantiqueira pelo Vale do Camanducaia. (cf. Zemella, 1990, pp.115-116)

Ao fim do Setecentos e início da centúria seguinte os demais gêneros encontrados nos arrolamentos populacionais deste período, quais sejam, algodão, arroz e cana (aguardente) também foram enviados a São Paulo, assim como a farinha - dada a grande presença de milho, provavelmente a farinha referida seja produzida a partir deste grão. Sérgio Buarque de Holanda afirmou que em São Paulo, a região de serra-acima, correspondia tradicionalmente à área da farinha de milho. $\mathrm{E}$, de acordo com o viajante D’orbigny "A principal cultura é o milho, vendo-se, em compensação, poucas plantações 
de mandioca. Os habitantes dessa província [São Paulo - DOMR] consideram a farinha de mandioca como malsã, ao passo que, nas províncias do Norte, é a farinha de milho que assim é considerada." (D'ORBIGNY, 1976, p. 178).

Amendoim, ausente das listas populacionais - ainda que mencionado muito discretamente no mapa de produção (vide Tabela II.22) -, também apareceu listado entre os gêneros exportados por Bragança ao fim do Setecentos. Da mesma maneira, as bestas, praticamente ausentes das listas compunham a pauta comercial de Bragança rumo a São Paulo, o que não surpreende posto termos identificado a intermediação destes animais em Jundiaí e, como será apresentado em seções seguintes, também em Atibaia e Nazaré, indicando que esta poderia ser uma possibilidade aberta também a Bragança no século XVIII (não foram encontrados mapas de importação para Bragança, o que impediu a verificação desta hipótese para a localidade).

A se considerar os dados levantados, toucinho, farinha, aguardente e fumo seriam produzidos exclusivamente para serem enviados a São Paulo, posto aparecem com 100\% de sua produção exportada, ou valor próximo a este, conforme se nota na Tabela II.24. Tal especificidade leva-nos a considerar que nesses casos registrou-se apenas 0 comércio tendo a produção efetiva superado os volumes identificados nas listas. De fato, mesmo na listagem nominal, as características próprias dos arrolamentos em algum momento dificultam o entendimento, pois havia declarações indicando apenas "toucinho 10 arrobas”, por exemplo, sem qualquer menção à produção, consumo e/ou venda.

De maneira diversa, os mesmos documentos apontam o caráter majoritariamente de autoconsumo ou de comercialização e/ou trocas locais do milho e do feijão. Produtos mais espraiados e, especialmente milho, principal responsável pelo volume e conseqüentemente pelo valor do que foi produzido em Bragança, fizeram parte da pauta exportacionista local durante todo o lapso estudado, mas em pequena medida se considerada a parcela do montante declarado efetivamente levada ao mercado externo à vila. Na virada do século XVIII para o XIX o milho teve em 1798 a maior parcela de sua produção exportada, 4,2\%, percentual calculado em 2,6\% em 1801, 2,4\% em 1828 e em $1,3 \%$ ou menos considerados os demais anos com fonte de dados disponível. O feijão apresentou percentuais um pouco mais elevados e também bastante flutuantes, com $25,2 \%$ em 1799, entre 8-10\% já nos anos seguintes, cerca de 4-5\% em 1810-11, entre $1,5 \%$ (1825) e 4,7\% (1828) na década de 1820, após ser enviado a São Paulo em 8,8\% do total de sua produção declarada em 1820. 
Tabela II.24

Percentual exportado e participação percentual dos diversos gêneros

no valor do produto exportado

(Bragança - 1798 a 1829)

\begin{tabular}{|c|c|c|c|c|c|c|c|c|c|c|}
\hline \multirow[b]{2}{*}{ Produtos } & \multicolumn{2}{|c|}{1798} & \multicolumn{2}{|c|}{1799} & \multicolumn{2}{|c|}{1801} & \multicolumn{2}{|c|}{1802} & \multicolumn{2}{|c|}{1807} \\
\hline & $\begin{array}{c}\text { \% da } \\
\text { produção } \\
\text { do bem } \\
\text { exportada }\end{array}$ & $\begin{array}{c}\% \text { do valor } \\
\text { total } \\
\text { exportado }\end{array}$ & $\begin{array}{c}\text { \% da } \\
\text { produção } \\
\text { do bem } \\
\text { exportada }\end{array}$ & $\begin{array}{c}\% \text { do valor } \\
\text { total } \\
\text { exportado }\end{array}$ & $\begin{array}{c}\text { \% da } \\
\text { produção } \\
\text { do bem } \\
\text { exportada }\end{array}$ & $\begin{array}{c}\% \text { do valor } \\
\text { total } \\
\text { exportado }\end{array}$ & $\begin{array}{c}\text { \% da } \\
\text { produção } \\
\text { do bem } \\
\text { exportada }\end{array}$ & $\begin{array}{c}\% \text { do valor } \\
\text { total } \\
\text { exportado }\end{array}$ & $\begin{array}{c}\text { \% da } \\
\text { produção } \\
\text { do bem } \\
\text { exportada }\end{array}$ & $\begin{array}{c}\% \text { do valor } \\
\text { total } \\
\text { exportado }\end{array}$ \\
\hline Milho & 4,2 & 9,0 & 1,6 & 6,0 & 2,6 & 7,5 & 1,2 & 4,5 & - & - \\
\hline Feijão & 4,4 & 1,8 & 25,2 & 8,7 & 8,6 & 2,4 & 10,1 & 2,6 & - & - \\
\hline Toucinho & 100,0 & 82,2 & 60,0 & 80,1 & 80,0 & 87,0 & 80,0 & 90,6 & 85,7 & 99,9 \\
\hline Farinha & 100,0 & 0,7 & 75,0 & 0,3 & 85,7 & 1,0 & 85,7 & 2,0 & 80,0 & 0,1 \\
\hline Algodão & 42,7 & 1,5 & 27,9 & 0,9 & - & - & - & - & - & - \\
\hline Aguardente & 100,0 & 3,8 & 80,0 & 1,8 & 83,3 & 1,3 & 83,3 & 0,2 & - & - \\
\hline Fumo & 71,4 & 0,4 & 66,7 & 0,4 & - & - & - & - & - & - \\
\hline Arroz & 14,6 & 0,3 & 9,7 & - & 2,1 & - & - & - & - & - \\
\hline Farinha de trigo & - & - & 80,0 & 1,8 & 78,1 & 0,8 & - & - & - & - \\
\hline Potros & 11,8 & 0,1 & - & - & - & - & - & - & - & - \\
\hline Bestas & 12,5 & 0,3 & - & - & - & - & - & - & - & - \\
\hline \multirow[t]{2}{*}{ TOTAL } & 27,9 & 100,0 & 18,0 & 100,0 & 23,5 & 100,0 & 19,1 & 100,0 & 21,2 & 100,0 \\
\hline & \multicolumn{2}{|c|}{1810} & \multicolumn{2}{|c|}{1811} & \multicolumn{2}{|c|}{1812} & \multicolumn{2}{|c|}{1818} & \multicolumn{2}{|c|}{1820} \\
\hline Produtos & $\begin{array}{c}\text { \% da } \\
\text { produção } \\
\text { do bem } \\
\text { exportada }\end{array}$ & $\begin{array}{c}\% \text { do valor } \\
\text { total } \\
\text { exportado }\end{array}$ & $\begin{array}{c}\% \text { da } \\
\text { produção } \\
\text { do bem } \\
\text { exportada }\end{array}$ & $\begin{array}{c}\% \text { do valor } \\
\text { total } \\
\text { exportado }\end{array}$ & $\begin{array}{c}\% \text { da } \\
\text { produção } \\
\text { do bem } \\
\text { exportada }\end{array}$ & $\begin{array}{c}\% \text { do valor } \\
\text { total } \\
\text { exportado }\end{array}$ & $\begin{array}{c}\% \text { da } \\
\text { produção } \\
\text { do bem } \\
\text { exportada }\end{array}$ & $\begin{array}{c}\% \text { do valor } \\
\text { total } \\
\text { exportado }\end{array}$ & $\begin{array}{c}\% \text { da } \\
\text { produção } \\
\text { do bem } \\
\text { exportada }\end{array}$ & $\begin{array}{c}\% \text { do valor } \\
\text { total } \\
\text { exportado }\end{array}$ \\
\hline Milho & 0,3 & 5,5 & 0,4 & 1,6 & 0,2 & 0,6 & - & - & 3,2 & 3,4 \\
\hline Feijão & 5,3 & 12,9 & 4,4 & 2,6 & 2,4 & 0,6 & - & - & 8,8 & 3,2 \\
\hline Toucinho & 80,0 & 79,6 & 80,0 & 95,7 & 85,7 & 98,6 & 83,3 & 100,0 & 71,4 & 93,4 \\
\hline Farinha & 75,0 & 0,3 & - & - & 80,0 & 0,1 & - & - & - & - \\
\hline Aguardente & 82,1 & 1,7 & - & - & - & - & - & - & - & - \\
\hline \multirow[t]{2}{*}{ TOTAL } & 4,9 & 100,0 & 16,6 & 100,0 & 24,3 & 100,0 & 14,6 & 100,0 & 36,5 & 100,0 \\
\hline & \multicolumn{2}{|c|}{1822} & \multicolumn{2}{|c|}{1825} & \multicolumn{2}{|c|}{1827} & \multicolumn{2}{|c|}{1828} & \multicolumn{2}{|c|}{1829} \\
\hline Produtos & $\begin{array}{c}\% \text { da } \\
\text { produção } \\
\text { do bem } \\
\text { exportada }\end{array}$ & $\begin{array}{c}\% \text { do valor } \\
\text { total } \\
\text { exportado }\end{array}$ & $\begin{array}{c}\text { \% da } \\
\text { produção } \\
\text { do bem } \\
\text { exportada }\end{array}$ & $\begin{array}{c}\% \text { do valor } \\
\text { total } \\
\text { exportado }\end{array}$ & $\begin{array}{c}\text { \% da } \\
\text { produção } \\
\text { do bem } \\
\text { exportada }\end{array}$ & $\begin{array}{c}\% \text { do valor } \\
\text { total } \\
\text { exportado }\end{array}$ & $\begin{array}{c}\% \text { da } \\
\text { produção } \\
\text { do bem } \\
\text { exportada }\end{array}$ & $\begin{array}{c}\% \text { do valor } \\
\text { total } \\
\text { exportado }\end{array}$ & $\begin{array}{c}\text { \% da } \\
\text { produção } \\
\text { do bem } \\
\text { exportada }\end{array}$ & $\begin{array}{c}\% \text { do valor } \\
\text { total } \\
\text { exportado }\end{array}$ \\
\hline Milho & 0,4 & 56,4 & 1,3 & 2,4 & 1,0 & 1,2 & 2,4 & 3,5 & 1,9 & 3,3 \\
\hline Feijão & 1,9 & 43,6 & 1,5 & 0,6 & 3,7 & 1,1 & 4,7 & 1,3 & 3,6 & 1,4 \\
\hline Toucinho & - & - & 100,0 & 97,1 & 100,0 & 97,7 & 100,0 & 95,2 & 100,0 & 95,3 \\
\hline TOTAL & 0,6 & 100,0 & 33,6 & 100,0 & 43,2 & 100,0 & 38,3 & 100,0 & 32,5 & 100,0 \\
\hline
\end{tabular}

O reduzido percentual de comercialização do milho fez com que sua participação no valor total exportado pela vila fosse reduzida comparativamente a verificada para o toucinho - a quase totalidade de sua produção foi exportada (mínimo de 60\% em 1799 e acima de $80 \%$ nos demais anos, chegando a $100 \%$ a partir de 1825) - cuja menor participação foi de $79,6 \%$ em 1810 , levando o toucinho ao posto de principal produto responsável pelas divisas auferidas por Bragança e seu termo. ${ }^{51} \mathrm{Na}$ presença do

${ }^{51}$ Os mapas de produção e comércio encontrados para Bragança não continham nenhum tipo de informação atinente às importações, o que não permite uma análise da capacidade de consumo desses recursos. 
toucinho, o milho teve sua maior participação em 1798, quando o valor devido do grão exportado chegou a $9 \%$ do total verificado. O feijão teve o maior percentual a ele devido em $1799,8,7 \%$, superando o milho (6\%).

Assim, o coeficiente de exportação, que mensura a parcela da "receita" da produção da vila proveniente das exportações, foi bastante variável ao longo do tempo, chegando a valores máximos em $1820(0,37)$ e $1828(0,38)$, sendo o mínimo desprezíveis 0,01, devido à ausência do toucinho nos cálculos.

Tabela II.25

Coeficientes de exportação

(Bragança - 1798 a 1829)

\begin{tabular}{cc|cc}
\hline \hline Anos & $\begin{array}{c}\text { Coeficiente de } \\
\text { exportação* }\end{array}$ & Anos & $\begin{array}{c}\text { Coeficiente de } \\
\text { exportação* }\end{array}$ \\
\hline 1798 & 0,28 & $\mathbf{1 8 1 8}$ & 0,15 \\
1799 & 0,18 & $\mathbf{1 8 2 0}$ & 0,37 \\
1801 & 0,23 & $\mathbf{1 8 2 2}$ & 0,01 \\
1802 & 0,19 & $\mathbf{1 8 2 5}$ & 0,34 \\
1807 & 0,21 & $\mathbf{1 8 2 7}$ & 0,43 \\
1810 & 0,05 & $\mathbf{1 8 2 8}$ & 0,38 \\
$\mathbf{1 8 1 1}$ & 0,17 & $\mathbf{1 8 2 9}$ & 0,32 \\
$\mathbf{1 8 1 2}$ & 0,24 & & \\
\hline \hline & *valor das exportaçães/valor da produção \\
Fonte: AESP, Maços de População - Mapas de produção e comércio, Bragança: anos \\
selecionados
\end{tabular}

Quando levados ao mercado, estes produtos apresentaram preços diversos entre a localidade e São Paulo. O milho bragantino teve sua maior avaliação no mercado local e da capital entre 1799 e 1802, quando os preços reais de exportação do produto variaram em torno de $\$ 500$ e os preços "para consumo na paróquia" estiveram entre $\$ 240$ e $\$ 310$. A variação foi no mesmo sentido, mas a diferença entre os preços foi de até $100 \%$ nestes anos iniciais do século XIX. Estes maiores preços são coincidentes com os menores volumes totais produzidos, no limite 72416 alqueires em 1802. A diferença, provavelmente, se deve ao custo de intermediação e transporte do bem. A partir de 1807 o preço do milho, em ambos os mercados, foi decrescente, sendo a queda ocorrida em maior monta nos preços de exportação que, em três momentos (1818, 1820 e 1825), foi quase o mesmo praticado na própria localidade. A redução do preço foi coincidente com o 
aumento do montante total de alqueires produzidos. Em 1825, encontramos o maior volume, 234294 alqueires, e o menor preço real, \$093. (Gráfico II.9)

Como se pode auferir da leitura das Tabelas II.26 e II.27, ainda que com valores diversos, os dados obtidos nas listas nominativas propriamente apontam também para 0 crescimento do volume produzido de milho: 2140 alqueires em 1799, 82451 alqueires em 1816, 128220 alqueires em 1830. Esse aumento corresponde a uma variação positiva considerável no número de plantadores com montante explicitado: eram 77 em 1799, 724 já em 1803, chegando a 513 em 1811 e ao final do período podiam ser contados em número de 1216.

\section{Gráfico II.9}

\section{Evolução do volume total produzido} e do preço real médio do milho (Bragança - 1798 a 1829)

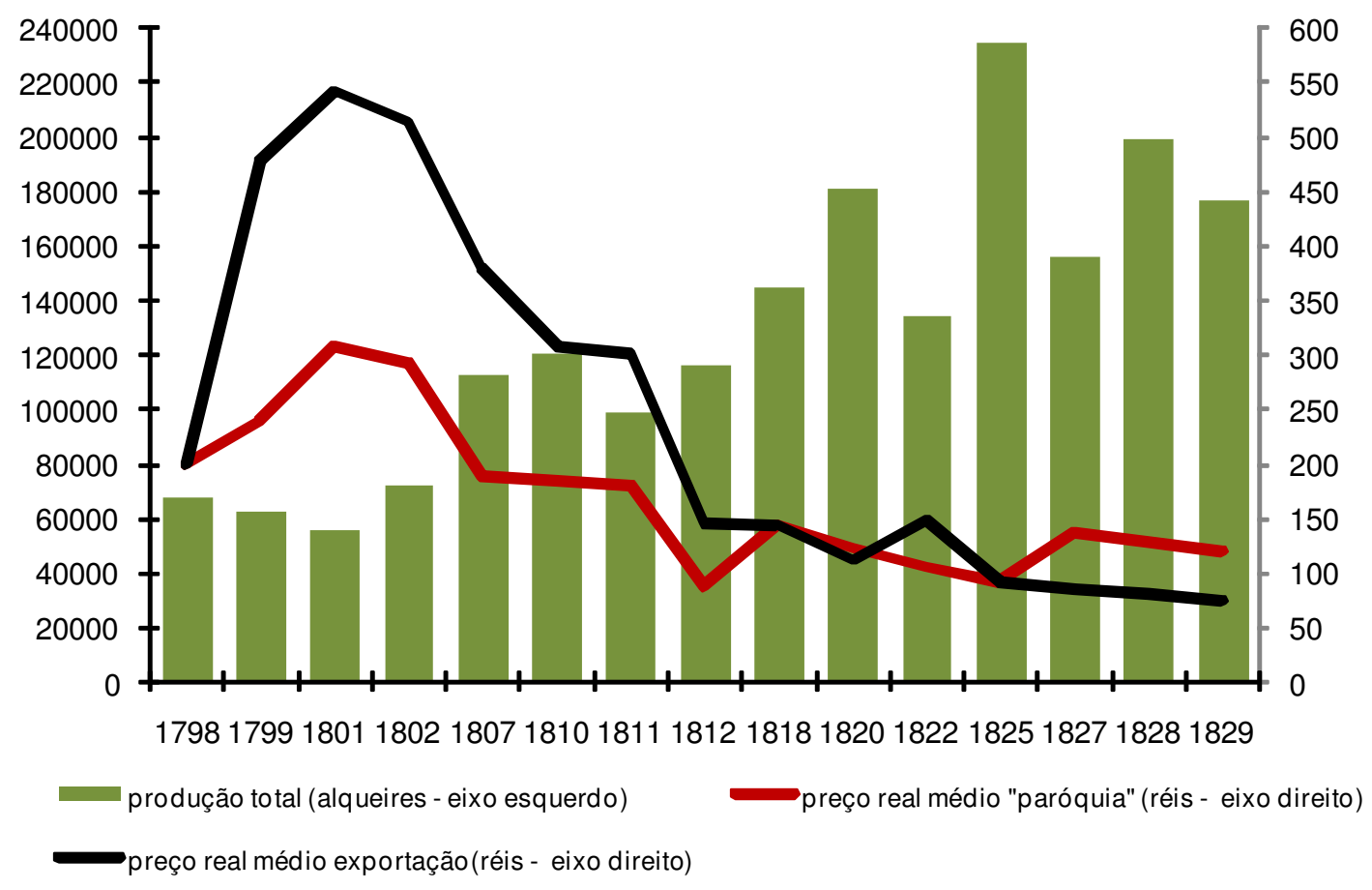

Esse aumento do número de produtores, como adiantado, levou a um aumento do volume total de milho produzido, o que, não necessariamente, refletiu-se nas médias produzidas. À exceção de 1799 quando a produção média de milho foi de apenas 27,8 alqueires por produtor, nos demais anos esteve próxima ou superou os 100 alqueires por unidade produtiva. Em 1820, a produção média foi de 159,3 alqueires, com média e mediana iguais a 100 - neste ano João Bueno da Cunha produziu 5000 alqueires de milho, o maior montante verificado nos oitos anos estudados. 
Tabela II.26

Distribuição de produtores e produção de milho de acordo com faixas de alqueires (Bragança - 1799 a 1830)

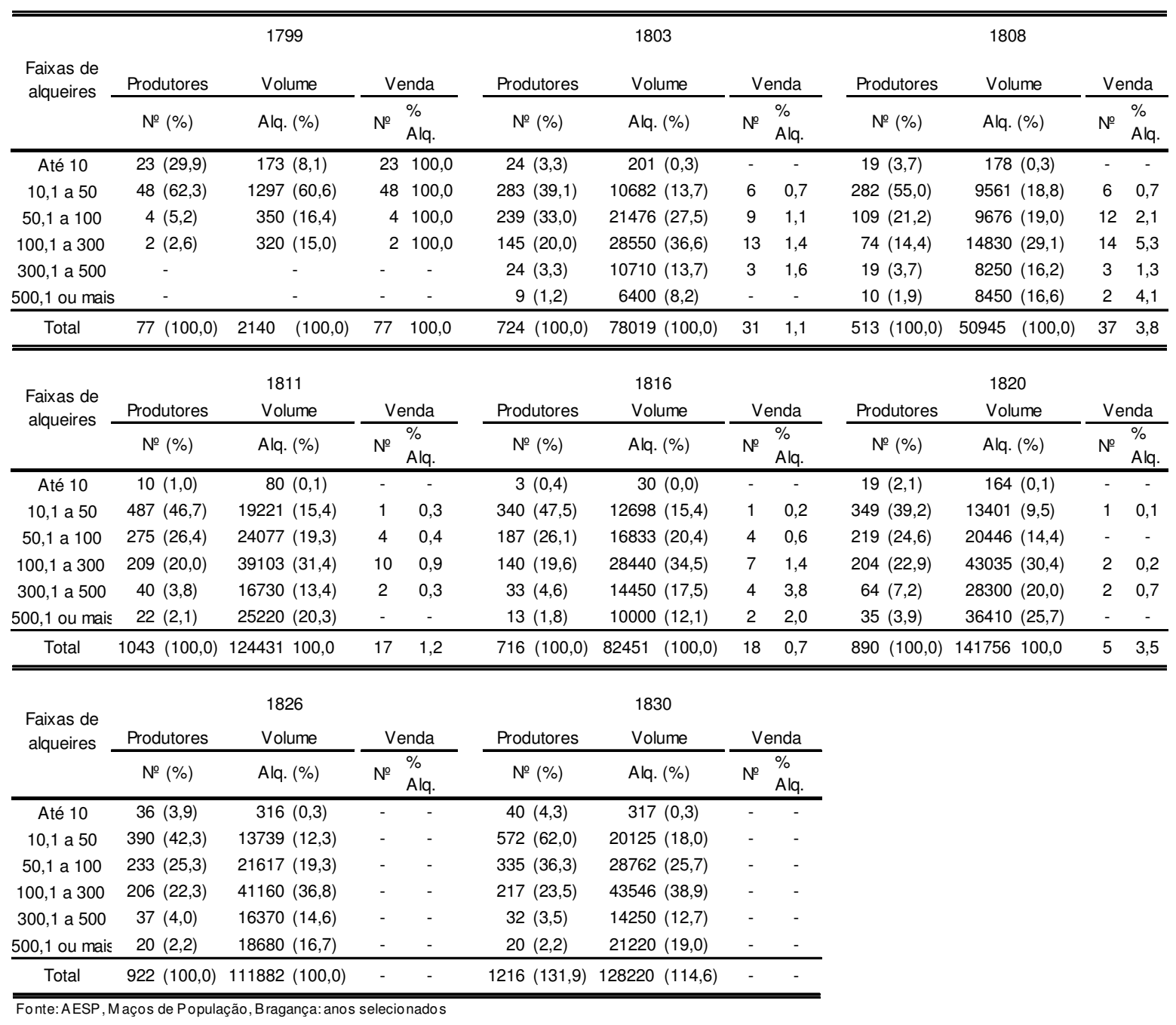

Em se considerando o total de domicílios, o volume de milho produzido ainda era, em média, bastante elevado (novamente à exceção de 1799, quando foi de apenas 2,3 alqueires), atingiu o máximo em 1820, 101 alqueires por fogo, e o menor em 1808, 40,6 alqueires; nos demais anos esteve entre 60 e 80 alqueires. Entre 1803 e 1830 a moda foi de 50 ou 100 alqueires de milho, sendo a mediana mais variável, flutuando entre 50 (1808) e 100 alqueires (1825).

Certamente os montantes apontados eram mais do que suficientes para as necessidades dos fogos - alguns produziram e consumiram volumes diminutos, pois 0 
mínimo em alguns anos foi de um ou dois alqueires, o que não jogou a concentração para cima, posto ter permanecido o índice de Gini calculado entre 0,47 e 0,56, uma concentração média -, sendo parte enviada a São Paulo.

Como notamos anteriormente, a parcela da produção de milho comercializada fora das fronteiras da vila era muito reduzida. O mesmo acontece com os dados observados nas listas nominativas, pois ali pouco se declarou de maneira explícita transações envolvendo milho. Em 1799 o que chamamos de produção foi, na realidade, a parcela dela enviada a outros mercados, sendo 100\% comercializada. Em 1818 apenas 31 (4,3\%) dos 724 domicílios com produção declarada mencionaram a venda do cereal, cujo volume vendido foi $1,1 \%$ do total descrito. Valores bastante próximos foram verificados para a década de 1810 e para a década seguinte dados de comércio foram inexistentes para 1825 e 29.

Tabela II.27

Estatísticas para a produção de milho (Bragança - 1799 a 1830)

\begin{tabular}{|c|c|c|c|c|c|c|c|c|}
\hline \multirow[b]{2}{*}{ Estatísticas } & \multicolumn{2}{|c|}{1799} & \multicolumn{2}{|c|}{1803} & \multicolumn{2}{|c|}{1808} & \multicolumn{2}{|c|}{1811} \\
\hline & $\begin{array}{c}\text { Total de } \\
\text { fogos }\end{array}$ & $\begin{array}{c}\text { Fogos com } \\
\text { milho }\end{array}$ & $\begin{array}{c}\text { Total de } \\
\text { fogos }\end{array}$ & $\begin{array}{c}\text { Fogos com } \\
\text { milho }\end{array}$ & $\begin{array}{c}\text { Total de } \\
\text { fogos }\end{array}$ & $\begin{array}{l}\text { Fogos com } \\
\text { milho }\end{array}$ & $\begin{array}{l}\text { Total de } \\
\text { fogos }\end{array}$ & $\begin{array}{l}\text { Fogos com } \\
\text { milho }\end{array}$ \\
\hline Média & 2,3 & 27,8 & 72,2 & 107,8 & 40,6 & 99,3 & 78,3 & 119,3 \\
\hline Moda & 0,0 & 20,0 & 0,0 & 100,0 & 0,0 & 50,0 & 0,0 & 50,0 \\
\hline Mediana & 0,0 & 20,0 & 0,0 & 75,0 & 0,0 & 50,0 & 0,0 & 60,0 \\
\hline Índice de Gini & 0,956 & 0,472 & 0,645 & 0,469 & 0,820 & 0,560 & 0,689 & 0,526 \\
\hline Mínimo & 0,0 & 4,0 & 0,0 & 1,0 & 0,0 & 4,0 & 0,0 & 2,0 \\
\hline \multirow[t]{2}{*}{ Máximo } & \multicolumn{2}{|c|}{200,0} & \multicolumn{2}{|c|}{1000,0} & \multicolumn{2}{|c|}{1500,0} & \multicolumn{2}{|c|}{4000,0} \\
\hline & \multicolumn{2}{|c|}{1816} & \multicolumn{2}{|c|}{1820} & \multicolumn{2}{|c|}{1826} & \multicolumn{2}{|c|}{1830} \\
\hline Estatísticas & $\begin{array}{c}\text { Total de } \\
\text { fogos }\end{array}$ & $\begin{array}{l}\text { Fogos com } \\
\text { milho }\end{array}$ & $\begin{array}{l}\text { Total de } \\
\text { fogos }\end{array}$ & $\begin{array}{c}\text { Fogos com } \\
\text { milho }\end{array}$ & $\begin{array}{c}\text { Total de } \\
\text { fogos }\end{array}$ & $\begin{array}{c}\text { Fogos com } \\
\text { milho }\end{array}$ & $\begin{array}{c}\text { Total de } \\
\text { fogos }\end{array}$ & $\begin{array}{l}\text { Fogos com } \\
\text { milho }\end{array}$ \\
\hline Média & 60,4 & 115,2 & 101,0 & 159,3 & 74,6 & 121,3 & 69,6 & 105,4 \\
\hline Moda & 0,0 & 50,0 & 0,0 & 100,0 & 0,0 & 100,0 & 0,0 & 50,0 \\
\hline Mediana & 0,0 & 60,0 & 0,0 & 100,0 & 0,0 & 75,0 & 0,0 & 50,0 \\
\hline Índice de Gini & 0,741 & 0,506 & 0,722 & 0,561 & 0,714 & 0,535 & 0,694 & 0,535 \\
\hline Mínimo & 0,0 & 10,0 & 0,0 & 2,0 & 0,0 & 2,0 & 0,0 & 2,0 \\
\hline Máximo & \multicolumn{2}{|c|}{1200,0} & \multicolumn{2}{|c|}{5000,0} & \multicolumn{2}{|c|}{1700,0} & \multicolumn{2}{|c|}{3000,0} \\
\hline
\end{tabular}

Fonte: AESP, M aços de População, Bragança: anos selecionados

Ainda que tenhamos pequeno número de observações, arriscamo-nos a observar a participação das diferentes faixas de produção no montante total de milho vendido, conforme apresentado na Tabela II.28. 
Tabela II.28

Participação das faixas de alqueires

no volume de milho vendido

(Bragança - 1799 a 1830)

\begin{tabular}{ccccccc}
\hline \hline $\begin{array}{c}\text { Faixas de } \\
\text { arrobas }\end{array}$ & 1799 & 1803 & 1808 & 1811 & 1816 & 1820 \\
\hline Até 10 & 8,1 & - & - & - & - & - \\
10,1 a 50 & 60,6 & 8,4 & 4,4 & 9,0 & 2,0 & 3,6 \\
50,1 a 100 & 16,4 & 25,9 & 13,7 & 17,1 & 7,8 & - \\
100,1 a 300 & 15,0 & 46,5 & 51,6 & 64,4 & 31,4 & 25,0 \\
300,1 a 500 & - & 19,1 & 7,3 & 9,4 & 43,1 & 71,4 \\
500,1 ou mais & - & - & 23,1 & - & 15,7 & - \\
\hline Total & 100,0 & 100,0 & 100,0 & 100,0 & 100,0 & 100,0 \\
\hline \hline
\end{tabular}

Fonte: AESP, M aços de População, Jundiaí: anos selecionados

Desconsiderando os problemas relativos ao pequeno número de observações disponíveis, verificamos uma participação passando, cada vez mais, às mãos dos indivíduos em faixas de produção superiores ao longo do tempo. Em 1799, 60,6\% do volume de vendas era devido àqueles que mencionaram de 10,1 a 50 alqueires de milho. Entre 1803 e 1811 a faixa de 50,1 a 100 alqueires era majoritária, mas apresentando crescimento entre os anos, de 46,5\% em 1803 a $64,4 \%$ em 1811 . No ano seguinte considerado, 1816, a faixa de 300,1 a 500 alqueires era a responsável por negociar maiores quantidades de milho, $43,1 \%$, mesma faixa principal em 1820 , mas com $71,4 \%$ da vendas neste último ano com dados disponíveis.

O grande consumo local de milho estava diretamente ligado à produção de toucinho, ou seja, à criação de porcos, posto que particularmente, na alimentação desses animais, o milho teve papel fundamental, era o principal alimento dado a essa criação e, portanto, era insumo utilizado indiretamente na produção do toucinho, base da alimentação no Brasil Oitocentista. Assim, milho e capados ou toucinho aparecem juntos em grande número de domicílios bragantinos, especialmente a partir de 1816, foi grande o percentual de fogos em que foram descritos tanto milho quanto porcos ou toucinho. Em 1820 e 1830 foi de $100 \%$ o montante de criadores que também plantavam milho, em 1816 esse percentual foi de $99,5 \%$, e no ano de 1826 o percentual de plantadores entre os criadores de suínos chegou a 96,5\%. Até a década de 1810 o percentual foi bem menos representativo, máximo de 21,9\% em 1816. 
Sendo o toucinho, no mais das vezes, mais presente nos recenseamentos que os porcos, e dada sua importância para o comércio da localidade, observemos mais de perto alguma das características de sua produção no que respeita, mormente, a caracteres atinentes aos diferentes volumes produzidos, sua concentração e participação das diferentes unidades produtivas no mercado deste gênero local. Estes dados vão apresentados nas Tabelas II.29 a II.31 e no Gráfico II.10.

O gráfico, cujas fontes são os mapas de produção e comércio da vila em diferentes anos, aponta distintos momentos para a produção do toucinho. Entre 1798 e 1802 a produção manteve-se em patamar mais modesto, em torno 7000 arrobas. Um lustro depois a produção superou as 17000 arrobas, caindo posteriormente (1810) a seu menor volume 3522 arrobas; sendo crescente até 1820 quando atingiu seu máximo, 35897 arrobas, para manter-se na segunda metade da década de 1820 entre 24000 e 28000 arrobas.

\section{Gráfico II.10 \\ Evolução do volume total produzido \\ e do preço real médio do toucinho}

(Bragança - 1798 a 1830)

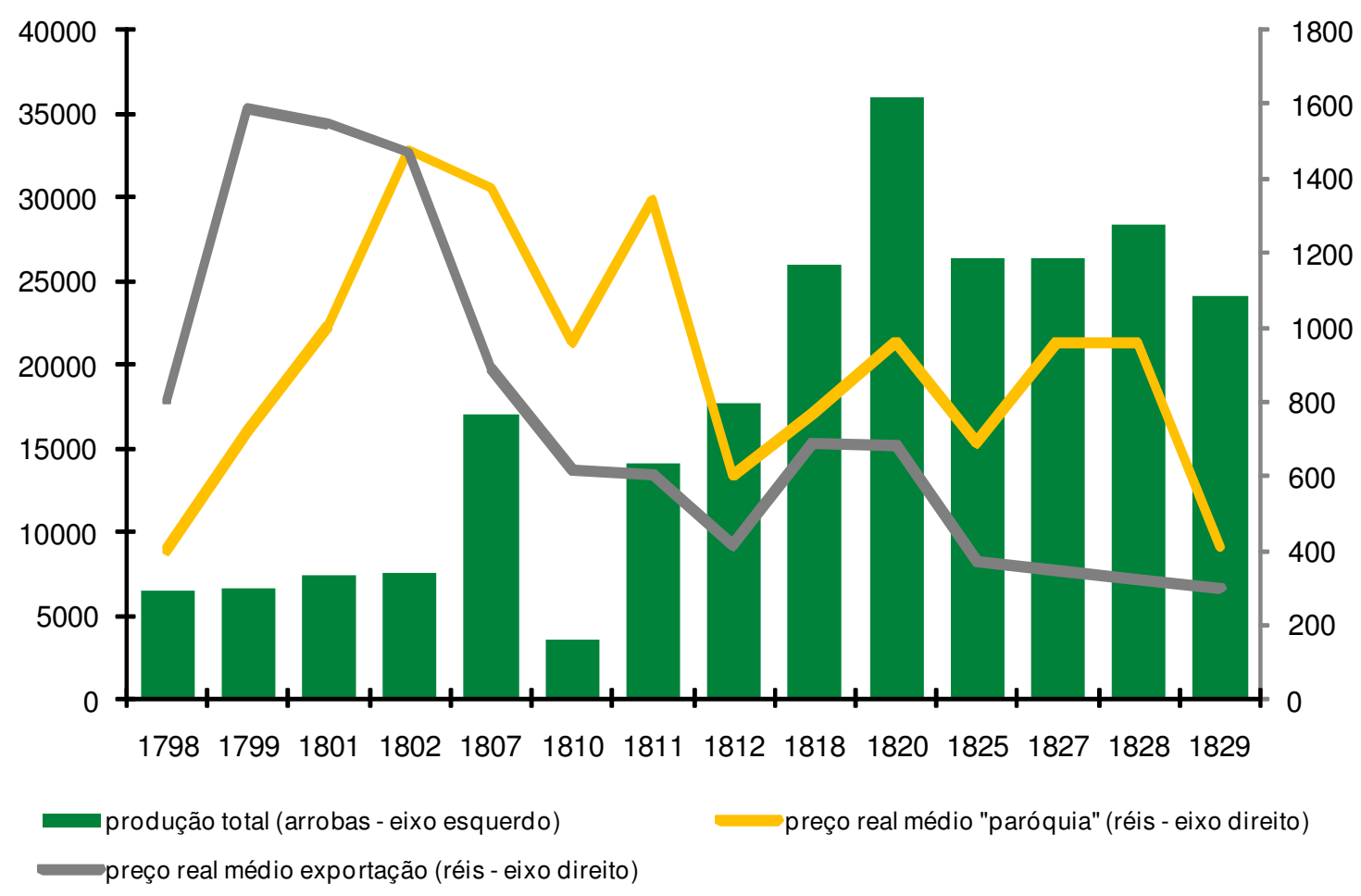


Tabela II.29

Estatística para a produção de toucinho

(Bragança - 1799 a 1830)

\begin{tabular}{|c|c|c|c|c|c|c|c|c|}
\hline \multirow[b]{2}{*}{ Estatísticas } & \multicolumn{2}{|c|}{1799} & \multicolumn{2}{|c|}{1803} & \multicolumn{2}{|c|}{1808} & \multicolumn{2}{|c|}{1811} \\
\hline & $\begin{array}{c}\text { Total de } \\
\text { fogos }\end{array}$ & $\begin{array}{c}\text { Fogos com } \\
\text { toucinho }\end{array}$ & $\begin{array}{c}\text { Total de } \\
\text { fogos }\end{array}$ & $\begin{array}{l}\text { Fogos com } \\
\text { toucinho }\end{array}$ & $\begin{array}{c}\text { Total de } \\
\text { fogos }\end{array}$ & $\begin{array}{l}\text { Fogos com } \\
\text { toucinho }\end{array}$ & $\begin{array}{c}\text { Total de } \\
\text { fogos }\end{array}$ & $\begin{array}{l}\text { Fogos com } \\
\text { toucinho }\end{array}$ \\
\hline Média & 6,3 & 18,4 & 1,8 & 24,3 & 5,5 & 30,1 & 2,4 & 22,3 \\
\hline Moda & 0,0 & 8,0 & 0,0 & 20,0 & 0,0 & 12,0 & 0,0 & 12,0 \\
\hline Mediana & 0,0 & 12,0 & 0,0 & 18,0 & 0,0 & 20,0 & 0,0 & 14,0 \\
\hline Desvio padrão & 15,6 & 22,1 & 8,6 & 21,2 & 19,0 & 35,1 & 10,4 & 23,5 \\
\hline Índice de Gini & 0,820 & 0,478 & 0,956 & 0,478 & 0,900 & 0,456 & 0,940 & 0,428 \\
\hline Mínimo & 0,0 & 2,0 & 0,0 & 6,0 & 0,0 & 1,0 & 0,0 & 4,0 \\
\hline \multirow[t]{2}{*}{ Máximo } & \multicolumn{2}{|c|}{200,0} & \multicolumn{2}{|c|}{100,0} & \multicolumn{2}{|c|}{340,0} & \multicolumn{2}{|c|}{200,0} \\
\hline & \multicolumn{2}{|c|}{1816} & \multicolumn{2}{|c|}{1820} & \multicolumn{2}{|c|}{1826} & \multicolumn{2}{|c|}{1830} \\
\hline Estatísticas & $\begin{array}{c}\text { Total de } \\
\text { fogos }\end{array}$ & $\begin{array}{c}\text { Fogos com } \\
\text { toucinho }\end{array}$ & $\begin{array}{c}\text { Total de } \\
\text { fogos }\end{array}$ & $\begin{array}{l}\text { Fogos com } \\
\text { toucinho }\end{array}$ & $\begin{array}{c}\text { Total de } \\
\text { fogos }\end{array}$ & $\begin{array}{c}\text { Fogos com } \\
\text { toucinho }\end{array}$ & $\begin{array}{c}\text { Total de } \\
\text { fogos }\end{array}$ & $\begin{array}{c}\text { Fogos com } \\
\text { toucinho }\end{array}$ \\
\hline Média & 3,9 & 25,4 & 5,4 & 32,4 & 12,4 & 34,7 & 6,2 & 35,4 \\
\hline Moda & 0,0 & 12,0 & 0,0 & 8,0 & 0,0 & 40,0 & 0,0 & 40,0 \\
\hline Mediana & 0,0 & 18,0 & 0,0 & 20,0 & 0,0 & 20,0 & 0,0 & 22,0 \\
\hline Desvio padrão & 13,0 & 23,8 & 18,9 & 35,8 & 32,5 & 46,7 & 27,1 & 56,2 \\
\hline Índice de Gini & 0,915 & 0,446 & 0,919 & 0,515 & 0,838 & 0,545 & 0,911 & 0,490 \\
\hline Mínimo & 0,0 & 1,0 & 0,0 & 1,0 & 0,0 & 1,0 & 0,0 & 2,0 \\
\hline Máximo & \multicolumn{2}{|c|}{30,0} & \multicolumn{2}{|c|}{214,0} & \multicolumn{2}{|c|}{500,0} & \multicolumn{2}{|c|}{800,0} \\
\hline
\end{tabular}

Fonte: AESP, M aços de População, Bragança: anos selecionados

Os números encontrados para as observações por fogos, à exceção de 1799 , apontam valores bastante inferiores aos citados, mas deixa transparecer o salto na produção ocorrido, especialmente, na década de 1820. As pouco mais de 5300 arrobas arroladas em 1816 foram transformadas em 18614 arrobas em 1826, ano em que registramos o maior número de fogos explicitamente com menção a toucinho: 536 . Essa ampliação simultânea de número de produtores e produção total fez com que a média por produtor em 1826 fosse equivalente àquela encontrada para os demais anos observados nesta década; 32,4 arrobas foi a produção média verificada para 1820 e 35,4 arrobas aquela atinente ao ano de 1830.

As medianas eram em boa medida inferiores às médias indicando que, presentes em menor número, produtores de quantidades mais elevadas puxavam para cima a média observada. Os grandes produtores, indivíduos a declarar 100,1 ou mais arrobas de toucinho, apareceram em pequena medida ainda que com ampliação do seu número com o passar dos anos, ampliação esta que levou à modificação da sua parcela a compor o montante total produzido. A ampliação da produção total e da presença de maiores produtores levou ao aumento da concentração da produção medida pelo índice de Gini, ainda que pequeno o salto havido. Essa mudança não implicou em uma grande 
concentração: o gini até 1816 foi o mesmo $(0,428$ a 0,478), em 1820 foi calculado em 0,515 e, em 1826, 0,545.

Tabela II.30

Distribuição de produtores e produção de toucinho

de acordo com faixas de arrobas

(Bragança - 1799 a 1830)

\begin{tabular}{|c|c|c|c|c|c|c|c|c|c|c|c|}
\hline \multirow{3}{*}{$\begin{array}{l}\text { Faixas de } \\
\text { alqueires }\end{array}$} & \multicolumn{4}{|c|}{1799} & \multicolumn{3}{|c|}{1803} & \multicolumn{4}{|c|}{1808} \\
\hline & Produtores & Volume & \multicolumn{2}{|c|}{ Venda } & Produtores & \multirow{2}{*}{$\frac{\text { Volume }}{\text { Arr. (\%) }}$} & Venda & \multicolumn{2}{|l|}{ Produtores } & \multicolumn{2}{|c|}{ Venda } \\
\hline & № (\%) & Arr. (\%) & № & $\begin{array}{l}\% \\
\text { Arr. }\end{array}$ & № (\%) & & № $\begin{array}{l}\% \\
\text { Arr. }\end{array}$ & № (\%) & Arr. (\%) & № & $\begin{array}{l}\% \\
\text { Arr. }\end{array}$ \\
\hline Até 10 & $157(42,9)$ & $1059(15,7)$ & 142 & 88,8 & $36(26,9)$ & $306(9,5)$ & $24 \quad 66,7$ & $38(16,5)$ & $261(3,8)$ & 38 & 100,0 \\
\hline 10,1 a 50 & $189(51,6)$ & $3894(57,6)$ & 158 & 85,6 & $88(65,7)$ & $2151(66,7)$ & $51 \quad 54,8$ & $163(70,6)$ & $3785(54,5)$ & 163 & 100,0 \\
\hline 50,1 a 100 & $17(4,6)$ & $1340(19,8)$ & 13 & 79,6 & $10(7,5)$ & $770(23,9)$ & $8 \quad 81,8$ & $24(10,4)$ & $1739(25,0)$ & 24 & 100,0 \\
\hline 100,1 a 300 & $3(0,8)$ & $470(6,9)$ & 3 & 100,0 & - & - & - & $5(2,2)$ & $820(11,8)$ & 5 & 100,0 \\
\hline 300,1 ou mais & - & - & - & - & - & - & - & $1(0,4)$ & $340(4,9)$ & 1 & 100,0 \\
\hline Total & $366(100,0)$ & $6763 \quad(100,0)$ & 316 & 85,9 & $134(100,0)$ & $3227(100,0)$ & $59 \quad 62,4$ & $231(100,0)$ & $6945 \quad(100,0)$ & 231 & 100,0 \\
\hline \multirow{2}{*}{$\begin{array}{l}\text { Faixas de } \\
\text { alqueires }\end{array}$} & \multicolumn{4}{|c|}{1811} & \multicolumn{3}{|c|}{1816} & \multicolumn{4}{|c|}{1820} \\
\hline & № (\%) & Arr. (\%) & № & $\begin{array}{l}\% \\
\text { Arr. }\end{array}$ & № (\%) & Arr. (\%) & $\begin{array}{ll}№ & \% \\
& \text { Arr. }\end{array}$ & № (\%) & Arr. (\%) & № & $\begin{array}{l}\% \% \\
\text { Arr. }\end{array}$ \\
\hline Até 10 & $73(25,7)$ & $581(7,3)$ & 58 & 76,6 & $57(27,1)$ & $406(7,6)$ & $57 \quad 100,0$ & $74(28,8)$ & $502(6,0)$ & 71 & 96,6 \\
\hline 10,1 a 50 & $175(61,6)$ & $4101(51,9)$ & 99 & 53,2 & $134(63,8)$ & $3260(61,1)$ & 134100,0 & $143(55,6)$ & $3750(44,8)$ & 127 & 91,6 \\
\hline 50,1 a 100 & $31(10,9)$ & $2277(28,8)$ & 14 & 44,6 & $17(8,1)$ & $1418(26,6)$ & 17100,0 & $30(11,7)$ & $2560(30,6)$ & 27 & 89,5 \\
\hline 100,1 a 300 & $4(1,4)$ & $640(8,1)$ & 1 & 31,3 & $2(1,0)$ & $250(4,7)$ & 2100,0 & $10(3,9)$ & $1564(18,7)$ & 9 & 87,2 \\
\hline 300,1 ou mais & $1(0,4)$ & $306(3,9)$ & - & - & - & - & - & - & - & - & - \\
\hline Total & $284(100,0)$ & 7905100,0 & 172 & 48,6 & $210(100,0)$ & 5334100,0 & 210100,0 & $257(100,0)$ & $8376 \quad(100,0)$ & 234 & 90,4 \\
\hline \multirow{3}{*}{$\begin{array}{l}\text { Faixas de } \\
\text { alqueires }\end{array}$} & \multicolumn{4}{|c|}{1826} & \multicolumn{3}{|c|}{1830} & & & & \\
\hline & Produtores & Volume & \multicolumn{2}{|c|}{ Venda } & Produtores & Volume & Venda & & & & \\
\hline & № (\%) & Arr. (\%) & № & $\begin{array}{l}\% \\
\text { Arr. }\end{array}$ & № (\%) & Arr. (\%) & № $\begin{array}{l}\% \\
\text { Arr. }\end{array}$ & & & & \\
\hline Até 10 & $160(29,9)$ & $952(5,1)$ & 160 & 100,0 & $63(11,8)$ & $502(2,7)$ & 63100,0 & & & & \\
\hline 10,1 a 50 & $281(52,4)$ & $7473(40,1)$ & 281 & 100,0 & $216(40,3)$ & $5706(30,7)$ & 216100,0 & & & & \\
\hline 50,1 a 100 & $68(12,7)$ & $5019(27,0)$ & 68 & 100,0 & $33(6,2)$ & $2359(12,7)$ & 33100,0 & & & & \\
\hline 100,1 a 300 & $25(4,7)$ & $4350(23,4)$ & 25 & 100,0 & $11(2,1)$ & $2110(11,3)$ & 11100,0 & & & & \\
\hline 300,1 ou mais & $2(0,4)$ & $820(4,4)$ & 2 & 100,0 & $1(0,2)$ & $800(4,3)$ & 1100,0 & & & & \\
\hline Total & $536(100,0)$ & $18614(100,0)$ & 536 & 100,0 & $324(60,4)$ & 1147761,7 & 324100,0 & & & & \\
\hline
\end{tabular}

Em 1799 três indivíduos haviam produzido entre 100 e 300 arrobas, e a soma de suas produções respondia por tão somente $6,9 \%$ da produção total, sendo a maior declaração correspondente 200 arrobas; por abranger $51,6 \%$ dos produtores de toucinho e $57,6 \%$ do que foi produzido, neste ano merece menção a faixa de produção das 10,1 as 50 arrobas. No ano de maior destaque da produção, 1826, os 27 indivíduos a produzir mais de 100 arrobas correspondiam a $5,1 \%$ dos fogos com declaração, mas a $27,8 \%$ da quantidade total do bem descrita; todavia também merece consideração a faixa de 10 a 50 alqueires, ainda a empregar maior parcela dos produtores de toucinho $(52,4 \%)$ e percentual importante da produção encontrada nos documentos (40,1\%). De fato, 
característica marcante da produção era a sua maior presença em fogos com 10,1 a 50 arrobas de toucinho mencionadas, sempre responsável pelo maior percentual encontrado para a participação na produção das distintas faixas de volume.

Parcela importante da produção, como notamos em outro momento, era enviada ao mercado. Em se tratando das listagens populacionais, os percentuais chegaram a $100 \%$ nos anos de 1808, 1816, 1826 e 1830. Difícil crer no não consumo local do toucinho, assim, resta-nos fazer uma observação a posteriore: é possível que a produção descrita nos fogos seja somente aquela efetivamente levada ao mercado, em não sendo a produção para consumo próprio arrolada a produção total deveria ser ainda superior àquela por nós levantada e analisada.

Tabela II.31

Participação das faixas de arrobas

no volume de toucinho vendido

(Bragança - 1799 a 1829)

\begin{tabular}{ccccccccc}
\hline \hline $\begin{array}{c}\text { Faixas de } \\
\text { arrobas }\end{array}$ & 1799 & 1803 & 1808 & 1811 & 1816 & 1820 & 1826 & 1830 \\
\hline Até 10 & 16,2 & 10,1 & 3,8 & 11,6 & 7,6 & 6,4 & 5,1 & 4,4 \\
10,1 a 50 & 57,4 & 58,6 & 54,5 & 56,8 & 61,1 & 45,3 & 40,1 & 49,7 \\
50,1 a 100 & 18,3 & 31,3 & 25,0 & 26,4 & 26,6 & 30,2 & 27,0 & 20,6 \\
100,1 a 300 & 8,1 & 0,0 & 11,8 & 5,2 & 4,7 & 18,0 & 23,4 & 18,4 \\
300,1 ou mais & 0,0 & 0,0 & 4,9 & 0,0 & 0,0 & 0,0 & 4,4 & 7,0 \\
\hline Total & 100,0 & 100,0 & 100,0 & 100,0 & 100,0 & 100,0 & 100,0 & 100,0 \\
\hline \hline
\end{tabular}

Fonte: AESP, M aços de População, Bragança: anos selecionados

Isto posto, a composição das vendas do toucinho por faixas de arrobas levam a resultados muito próximos à própria caracterização dos produtores por estas distintas faixas, com destaque para a faixa de 10,1 a 50 arrobas.

A produção daqueles que podemos chamar de grandes produtores teve seu máximo não em 1826 (ano de maior volume produzido, como vimos), mas em 1830, quando o português Francisco Jose de Souza produziu 800 arrobas, quantidade bastante elevada - retomando os cálculos levados a cabo em seção anterior, para um período de oito meses a um ano cada capado consumiria em média 6,6 a 8,3 alqueires de milho, sendo gerados 44 quilos de toucinho quando do seu abatimento. Considerada a relação 1 arroba equivalente a aproximadamente 14,7 quilos, para a referida produção e venda seria necessário o sacrifício a algo próximo a 270 porcos, responsáveis elo consumo de 
ao menos 1780 alqueires de milho. Diferente do ocorrido com grande parte dos produtores de milho, inclusive grandes, domicílios criavam porcos e obtinham deles toucinho com vistas ao mercado.

Considerada toda a produção de toucinho arrolada em 1803 e 1826, respectivamente, anos de menor e maior montante encontrado nas listas populacionais, teríamos sendo abatidos aproximadamente 1080 e 6220 capados. O número de porcos necessário para a produção e exportação bragantina estava totalmente dentro daquilo que foi a produção de suínos na Bragança do Setecentos e décadas iniciais do Oitocentos, de acordo com a mesma documentação.

Tabela II.32

Estatística de posição para fogos com capados (Bragança - 1803 a 1830)

\begin{tabular}{ccccccc}
\hline \hline Es tatísticas & $\mathbf{1 8 0 3}$ & $\mathbf{1 8 1 1}$ & $\mathbf{1 8 1 6}$ & $\mathbf{1 8 2 0}$ & $\mathbf{1 8 2 6}$ & $\mathbf{1 8 3 0}$ \\
\hline № de observações & 284 & 214 & 154 & 243 & 10 & 87 \\
Média & 12,2 & 19,9 & 24,0 & 40,4 & 26,6 & 40,4 \\
Moda & 4 & 12 & 20 & 8 & 16 & 20 \\
Mediana & 8 & 12 & 15 & 22 & 17 & 30 \\
Mínimo & 1 & 2 & 2 & 2 & 6 & 6 \\
Máximo & 140 & 200 & 300 & 400 & 80 & 220 \\
Soma & 3455 & 4260 & 3698 & 9811 & 262 & 3518 \\
\hline \hline
\end{tabular}

Fonte: AESP, M aços de População, Bragança: anos selecionados, exclusive 1799 e 1808

Se considerados os porcos mencionados, encontramos indivíduos como José Miguel de Santana que em 1820 declarou a criação de 400 destes animais, 4,1\% dos 9811 animais arrolados que, sabemos, eram em número bem maior posta a descrição do toucinho. Ou Francisco Jose de Oliveira que quatro anos antes possuía 300 destes animais - e havia sido, junto a outros quatro indivíduos, o terceiro maior plantador de milho no ano, com 800 alqueires colhidos. Ainda que o mínimo encontrado fosse bastante pequeno, um ou dois até 1820 , as modas eram mais elevadas, o número de animais mais comumente encontrado esteve entre 4 (1799) e 20 (1816 e 1830), o que corresponderia a cerca de 12 arrobas e 60 arrobas de toucinho, em sequência, valores que vão de encontro à identificação anterior de concentração dos produtores/vendedores de toucinho mormente na faixa de 10,1 a 50 arrobas do bem. 


\section{Atibaia}

Os maços de população de 1799 a 1829 deixam transparecer para Atibaia o grande contingente populacional ligado ao setor agricultura. Na Tabela II.33, são mostrados os principais setores em que podemos classificar as atividades econômicas arroladas para os chefes de fogo da localidade ao longo dos anos, excluídos aqueles indivíduos declarados como "pobre", "indigente" ou "vive de esmolas". Assim como anotado anteriormente para Jundiaí e Bragança, nos censos analisados as atividades desempenhadas pelos demais membros do fogo foram bastante sub-especificadas. Nenhum cônjuge ou escravo teve sua atividade descrita. A quase totalidade das poucas descrições encontradas refere-se a algum agregado, parente (irmão, sobrinho, neto) e, majoritariamente, filho, ligado às forças militares, fortemente presentes na localidade.

\section{Tabela II.33}

\section{Distribuição dos fogos por setores de atividade econômica}

\section{(Atibaia - 1799 a 1829)}

\begin{tabular}{ccccccccc}
\hline \hline Setor & $\mathbf{1 7 7 9}$ & $\mathbf{1 8 0 3}$ & $\mathbf{1 8 0 8}$ & $\mathbf{1 8 1 2}$ & $\mathbf{1 8 1 6}$ & $\mathbf{1 8 2 0}$ & $\mathbf{1 8 2 6}$ & $\mathbf{1 8 2 9}$ \\
$\%$ & $\%(№)$ & $\%(№)$ & $\%(№)$ & $\%(№)$ & $\%(\mathbf{N})$ & \%(№) & $\begin{array}{c}\text { \%(№) } \\
\%(№)\end{array}$ \\
\hline Agricultura & $70,3(370)$ & $53,8(264)$ & $52,7(256)$ & $62,0(335)$ & $58,9(348)$ & $54,4(318)$ & $56,7(238)$ & $54,9(256)$ \\
Artesanato & $1,7(9)$ & $10,0(49)$ & $10,5(51)$ & $7,4(40)$ & $7,3(43)$ & $9,2(54)$ & $10,5(44)$ & $11,4(53)$ \\
Igreja & $0,2(1)$ & $0,4(2)$ & $0,8(4)$ & $0,6(3)$ & $0,5(3)$ & $0,3(2)$ & $0,5(2)$ & $0,2(1)$ \\
Magistratura & - & $0,4(2)$ & $0,4(2)$ & $0,2(1)$ & $0,3(2)$ & $0,5(3)$ & $0,5(2)$ & $0,2(1)$ \\
Profissões liberais & - & $0,2(1)$ & - & - & $0,3(2)$ & $0,7(4)$ & $0,5(2)$ & $0,2(1)$ \\
Rentistas & - & $0,4(2)$ & $0,2(1)$ & - & - & $0,2(1)$ & $0,2(1)$ & $0,2(1)$ \\
Comércio & $1,5(8)$ & $1,0(5)$ & $2,1(10)$ & $2,8(15)$ & $1,5(9)$ & $1,5(9)$ & $3,3(14)$ & $2,6(12)$ \\
Transporte & $0,2(1)$ & $1,8(9)$ & $1,2(6)$ & $0,4(2)$ & $0,8(5)$ & $1,2(7)$ & $0,5(2)$ & $3,0(14)$ \\
Corpo militar & $2,3(12)$ & $2,4(12)$ & $2,9(14)$ & $0,7(4)$ & $1,2(7)$ & $1,4(8)$ & $0,7(3)$ & $0,2(1)$ \\
Jornaleiros & $1,9(10)$ & $11,2(55)$ & $8,0(39)$ & $6,9(37)$ & $3,4(20)$ & $11,8(69)$ & $9,3(39)$ & $9,9(46)$ \\
Outras (não-classificadas) & $1,3(7)$ & - & - & - & $2,0(12)$ & - & - & - \\
Múltiplos setores & $20,6(108)$ & $18,5(91)$ & $21,2(103)$ & $19,1(103)$ & $23,7(140)$ & $18,8(110)$ & $17,6(74)$ & $17,2(80)$ \\
\hline Total & $100,0(526)$ & $100,0(492)$ & $100,0(486)$ & $100,0(540)$ & $100,0(591)$ & $100,0(585)$ & $100,0(420)$ & $100(466)$ \\
\hline \hline
\end{tabular}

Exclusive pobres, indigentes e chefes de fogo sem ocupação declarada

Fonte: AESP, M aços de População, A tibaia: anos selecionados

Destaca-se, entre os anos considerados, 1799, por apresentar distribuição de ocupações bastante afastada daquelas encontradas nas três primeiras décadas da centúria posterior, principalmente no que tange às atividades diversificadas, ligadas ao núcleo urbano como magistratura, profissões liberais e artesanais. Cerca de $70 \%$ dos fogos estavam vinculados, como atividade principal, ao setor agricultura, em que encontramos, em especial, as atividades de criação e/ou cultivos diversos, sendo diminuta 
a participação de outras atividades, que não atividades distintas, sob a denominação "múltiplos setores".

Nos demais anos, a grande preponderância foi também de fogos ligados à agricultura, mais da metade dos domicílios ao longo das décadas, tendo estes acentuado sua participação particularmente nos anos de 1812 e 1816: 62\% e 58,9\%, respectivamente. Sob a rubrica Agricultura encontramos lavradores, criadores e indivíduos ligados à pesca e à administração dos empreendimentos agrícolas. Dentre aqueles ligados a diferentes cultivos, destacam-se os identificados como lavradores ou lavradores para seu sustento. Os lavradores anotados como "para seu sustento" declararam-se nesses termos nas listas, enquanto os demais declaram suas produções e/ou produtos negociados, não sendo possível identificarmos uma tendência clara ao longo dos anos para a relação entre esses lavradores, que poderiam aparecer oscilando entre as duas classificações ao longo dos anos.

Apesar de empregarem reduzida parcela dos atibaienses, entre 1803 e 1829 as atividades vinculadas diretamente à vida urbana, indispensáveis ao funcionamento da localidade, decorrentes ou não da agricultura, eram diversificadas: pessoas ligadas aos setores igreja, magistratura profissionais liberais. Conjuntamente essas atividades representavam 0,6\% dos fogos em 1829 e o máximo de 1,5\% nos anos 1820 e 1826 . Ou seja, nas três primeiras décadas do Oitocentos, em pouco modificou-se o peso relativo do núcleo "urbano" da vila de Atibaia, que continuou intimamente ligada à agropecuária.

O percentual apresentado é expandido se considerado o setor comercial. Negociantes, vendeiros e taberneiros - e ainda negociantes de animais, certamente a mais itinerante dentre as atividades de comércio -, respondiam por $1 \%$ das ocupações principais dos domicílios em 1803, percentual elevado a 2,1\% em 1808 e 2,8\% em 1812; variando nos demais anos entre 1,5\% (1816 e 1820), 2,6\% (1829) e 3,3\% em 1826.

Já o artesanato - diversas atividades realizadas por trabalhadores especializados, ligados à fiação e tecelagem, à carpintaria, à confecção de vestimentas e sapatos, a construção, entre outros -, consolidou-se a partir de 1803: 10\% dos fogos. Em 1808 a ocorrência de artesãos foi de 10,5\%, percentual que reduziu-se a cerca de 7,5\% em 1812 e 1816, concomitantemente com uma elevação no percentual de fogos vinculados à agricultura e um decréscimo daqueles domicílios chefiados por jornaleiros.

Nos três anos posteriores os chefes artesãos eram encontrados em 9,2\%, 10,5\% e $11,4 \%$ dos fogos, respectivamente. Merecem destaque as fiadeiras, cuja ocorrência variou de $32,1 \%$ (1829) a 65,3\% (1803) daqueles domicílios vinculados às atividades artesanais. Note-se que anos finais da década de 1820 corresponderam àqueles em que 
as razões de sexo da população livre, assim como dos chefes de fogos viu-se ainda mais favorável às mulheres, conforme observamos no capítulo anterior.

Encontramos em Atibaia importante participação de jornaleiros, indivíduos assalariados, diaristas sem especialização ou profissão definida. Em 1803 e 1820 essas pessoas compunham o segundo setor único mais importante, respondendo por mais de $11 \%$ dos fogos, percentual bastante considerável. Em 1816, no entanto, esse percentual foi de apenas $2,3 \%$.

Parcela importante dos fogos atibaienses estava vinculada ao que chamamos de múltiplos setores, ou seja, mais de uma atividade principal foi relacionada a esses fogos. Devido à própria estrutura econômica, parcela considerável dos habitantes da localidade tinha alguma ocupação para além da tradicional agropecuária de mantimentos. A maior ocorrência deu-se em 1816 (23,7\%) e a menor em 1829 (17,2\%).

As diferentes ocupações encontradas para um mesmo fogo nem sempre seguiam uma seqüência lógica, havia uma complexidade de relações entre diferentes tipos de ocupação. Havia tabelião que administrava fazenda, dono de negócio que era também alfaiate e plantava cana, fiandeira-negociante, músico-vendeiro, soldado que se dedicava à criação de porcos, alferes-sapateiro, entre inúmeras outras situações. A agropecuária, dado seu caráter de autoconsumo e/ou mercado, representou uma das atividades mais propensas à conjugação com outras. Ainda que esse setor tenha apresentado uma tendência decrescente ao longo dos anos. Em 1799 eram 97,2\% dos 108 fogos em múltiplas ocupações. E não menos de 70\% (1829) dos fogos com ocupação múltipla tinha como uma dessas ocupações a criação de animais ou cultivos diversos. O autoconsumo deveria predominar, funcionando de forma subsidiária, a complementar as demais atividades desenvolvidas, tais como negociantes, jornaleiros, alfaiates, fiadeiras, pressupondo o abastecimento da família com sua própria produção.

Assim como a agropecuária, o corpo militar apresentou participação significativa na conjugação com outros setores (percentual mínimo de 65,7\% referente aos 140 fogos com múltiplas ocupações em 1816).

Mesmo não podendo identificar para a maior parte dos chefes atibaienses a qual linha pertenciam, decerto havia na vila indivíduos ligados a todas elas, ao longo dos anos, como ilustram os Josés Antonio, Deziderio Pinto e José da Silva Toledo. O primeiro encontramos em 1816 como "soldado pago" e o segundo, era "sargento de ordenança" em 1803. O mineiro José da Silva tinha 30 anos em 1826 e, além de plantar para seu gasto era "soldado de $2^{2}$ linha". 
Em 1767 localizava-se em Atibaia uma das 15 companhias do Terceiro Corpo da Infantaria de São Paulo e Vilas do Sul de Serra Acima, companhia então composta por um capitão, um tenente, um alferes, dois sargentos e 54 soldados transformada, anos mais tarde, em dez a fazer parte do Segundo Terço de Auxiliares a pé da Capitania de São Paulo, como $3^{\text {a }}$ companhia. Várias décadas depois (1821), já às vésperas de emancipação brasileira, a já vila de Atibaia possuía duas companhias de fuzileiros que compunham o $2^{\circ}$ Regimento de Infantaria Miliciana da cidade de São Paulo, e um que compunha o Regimento de Infantaria Miliciana dos úteis da cidade de São Paulo.

Por estarem em grande medida ligados aos múltiplos setores, em se considerando para estes indivíduos a atividade não militar como a representativa da realidade produtiva dos seus domicílios, os percentuais apresentados apresentam-se modificados, com intensificação do setor agricultura, conforme exposto na Tabela II.34.

\section{Tabela II.34}

\section{Distribuição dos fogos por setores de atividade econômica} - exclusive militares em múltiplas ocupações -

(Atibaia - 1799 a 1829)

\begin{tabular}{|c|c|c|c|c|c|c|c|c|}
\hline Setor & $\begin{array}{l}1799 \\
\% \text { (№) }\end{array}$ & $\begin{array}{l}1803 \\
\% \text { (№) }\end{array}$ & $\begin{array}{l}1808 \\
\% \text { (№) }\end{array}$ & $\begin{array}{c}1812 \\
\% \text { (№) }\end{array}$ & $\begin{array}{l}1816 \\
\% \text { (№) }\end{array}$ & $\begin{array}{l}1820 \\
\% \text { (№) }\end{array}$ & $\begin{array}{l}1826 \\
\% \text { (№) }\end{array}$ & $\begin{array}{l}1829 \\
\% \text { (№) }\end{array}$ \\
\hline Agricultura & $89,7(472)$ & $68,7(338)$ & $68,7(334)$ & $77,8(420)$ & $69,9(409)$ & $66,2(387)$ & $67,9(285)$ & $63,1(294)$ \\
\hline Artesanato & $1,9(10)$ & $10,2(50)$ & $10,9(53)$ & $8,0(43)$ & $7,7(45)$ & $9,9(58)$ & $11,4(48)$ & $12,2(57)$ \\
\hline Igreja & $0,2(1)$ & $0,4(2)$ & $0,8(4)$ & $0,6(3)$ & $0,7(4)$ & $0,3(2)$ & $0,5(2)$ & $0,2(1)$ \\
\hline Magistratura & - & $0,4(2)$ & $0,4(2)$ & $0,2(1)$ & $0,5(3)$ & $0,5(3)$ & $0,5(2)$ & $0,2(1)$ \\
\hline Profissões liberais & - & $0,2(1)$ & - & - & $0,3(2)$ & $0,9(5)$ & $0,5(2)$ & $0,2(1)$ \\
\hline Rentistas & - & $0,4(2)$ & $0,2(1)$ & - & - & $0,2(1)$ & $0,2(1)$ & $0,2(1)$ \\
\hline Comércio & $1,9(10)$ & $1,8(9)$ & $2,9(14)$ & $3,5(19)$ & $2,6(15)$ & $2,6(15)$ & $3,6(15)$ & $4,9(23)$ \\
\hline Transporte & $0,2(1)$ & $2,2(11)$ & $2,1(10)$ & $0,7(4)$ & $1,2(7)$ & $1,5(9)$ & $1,0(4)$ & $4,3(20)$ \\
\hline Corpo militar & $2,3(12)$ & $2,4(12)$ & $2,9(14)$ & $0,7(4)$ & $1,2(7)$ & $1,4(8)$ & $0,7(3)$ & $0,2(1)$ \\
\hline Jornaleiros & $1,9(10)$ & $11,2(55)$ & $8,6(42)$ & $7,0(38)$ & $3,4(20)$ & $13,0(76)$ & $10,5(44)$ & $10,5(49)$ \\
\hline Não classificadas & $1,3(7)$ & - & - & - & $2,1(12)$ & - & - & - \\
\hline Múltiplos setores & $0,6(3)$ & $2,0(10)$ & $2,5(12)$ & $1,5(8)$ & $11,5(67)$ & $3,6(21)$ & $3,3(14)$ & $3,9(18)$ \\
\hline Total & $100,0(526)$ & $100,0(492)$ & $100,0(486)$ & $100,0(540)$ & $101,0(591)$ & $100,0(585)$ & $100,0(420)$ & $100,0(466)$ \\
\hline
\end{tabular}

A tabela apresenta clara redução do número de indivíduos envolvidos em múltiplos setores em todos os anos observados. Já em 1799, passa de $108(20,6 \%)$ a somente três $(0,6 \%)$ os indivíduos com mais de uma atividade declarada, ou seja, 105 fogos eram chefiados por militares ligados a outros setores, com grande destaque para o setor agricultura que com a reclassificação viu sua participação elevada a $89,7 \%$ ao findar do 
século XVIII. Por outro lado, permanece o destaque para este ano por apresentar distribuição de ocupações bastante afastada daquelas encontradas nas três primeiras décadas da centúria posterior, principalmente no que tange às atividades diversificadas, ligadas ao núcleo urbano, que tiveram participação bastante diminuta.

À exceção de 1812, em que $77,8 \%$ dos indivíduos a chefiar domicílios eram ligados a agricultura, nas demais observações levantadas para o período 1803 a 1829 encontramos percentual entre $60-70 \%$ para este setor. Interessante observar, também, que apenas em 1816 os múltiplos setores mantiveram percentual considerável, 11,5\%, devido, especialmente à presença da conjugação agricultura e comércio, com 36 indivíduos (6,1\% do total).

Como adiantado, entre aqueles indivíduos ligados a diferentes cultivos, destacamse os identificados como lavradores ou lavradores para seu sustento. O percentual dos chefes de fogo que declararam plantar (para seu sustento ou não somente, ou que plantavam e realizavam algum outro tipo de atividade econômica) e que mencionaram o tipo de cultura realizada foi de no mínimo 48,6\% (1829), chegando a 79,5\% em 1808 e 100\% em 1803.

Tabela II.35

Gêneros plantados e presença concomitante dos diferentes gêneros nos fogos

(Atibaia - 1799 a 1829)

\begin{tabular}{lcccccccc}
\hline \hline \multicolumn{1}{c}{ CULTURAS } & $\mathbf{1 7 9 9}$ & $\mathbf{1 8 0 3}$ & $\mathbf{1 8 0 8}$ & $\mathbf{1 8 1 2}$ & $\mathbf{1 8 1 6}$ & $\mathbf{1 8 2 0}$ & $\mathbf{1 8 2 6}$ & $\mathbf{1 8 2 9}$ \\
\hline MILHO & $79,5 \%$ & $96,8 \%$ & $95,6 \%$ & $95,5 \%$ & $98,2 \%$ & $99,3 \%$ & $99,5 \%$ & $98,7 \%$ \\
FEIJÃO & $52,3 \%$ & $68,1 \%$ & $73,5 \%$ & $74,3 \%$ & $75,5 \%$ & $81,1 \%$ & $85,0 \%$ & $84,8 \%$ \\
ALGODÃO & $29,5 \%$ & $13,5 \%$ & $18,4 \%$ & $3,4 \%$ & $10,9 \%$ & $4,3 \%$ & $7,2 \%$ & $11,9 \%$ \\
ARROZ & $6,4 \%$ & $2,3 \%$ & $7,0 \%$ & $6,7 \%$ & $2,1 \%$ & $4,3 \%$ & $10,1 \%$ & $11,9 \%$ \\
AMENDOIM & $0,5 \%$ & $2,0 \%$ & $4,0 \%$ & $6,1 \%$ & $6,4 \%$ & $2,0 \%$ & $1,9 \%$ & $4,0 \%$ \\
TRIGO & $1,4 \%$ & $0,9 \%$ & - & $4,5 \%$ & $1,2 \%$ & - & - & - \\
CANA & $4,5 \%$ & $0,9 \%$ & $0,7 \%$ & - & $0,3 \%$ & $0,7 \%$ & - & $0,7 \%$ \\
MANDIOCA & - & - & $0,4 \%$ & $1,1 \%$ & - & - & - & - \\
CAFÉ & - & - & - & - & - & - & $0,5 \%$ & $0,7 \%$ \\
MAMONA & - & - & $0,7 \%$ & - & - & $0,7 \%$ & $0,5 \%$ & $1,3 \%$ \\
FUMO & $0,9 \%$ & $0,6 \%$ & $0,4 \%$ & - & $0,3 \%$ & - & $0,5 \%$ & - \\
\hline \hline
\end{tabular}

Fonte: AESP, M aços de População, Atibaia: anos selecionados

Como plantação característica desses lavradores (Tabela II.35) identificamos feijão e, principalmente, milho - facilmente comercializável e crucial na alimentação humana e de animais. Considerada sua presença nos domicílios, o milho foi a principal cultura durante os 30 anos considerados, era o produto de cultivo mais constante e generalizado: desde 1803 a quase totalidade dos fogos que declararam a produção realizada 
mencionaram milho, na forma do cereal propriamente ou como produção de farinha, alimento usual em São Paulo (e em parte de Minas Gerais). Os percentuais atingiram, a partir deste ano, um mínimo de 95,5\% (1812) em Atibaia.

Em proporção pouco menor, e também bastante importante, aparece o feijão, cuja variação temporal foi claramente positiva. Em 1799 foi identificado em 52,3\% dos fogos com algum tipo de cultura, percentual elevado a $68 \%$ em 1803 , cerca de $74-75 \%$ nos anos seguintes, sendo mencionado em mais de $81 \%$ dos fogos com produção declarada a partir de 1820. Juntamente com o milho foi, provavelmente, o feijão o alimento mais consumido em São Paulo desde o início da colonização.

Milho e feijão caminhavam juntos facilmente, sendo a conjugação mais comumente encontrada: mínimo de $23 \%$ das declarações em 1779 , cerca de $50 \%$ em 1803-1808 e acima de $60 \%$ nos anos.

\section{Gráfico II.11}

Percentual de fogos com presença dos diversos gêneros cultivados

(Atibaia - 1799 a 1829)

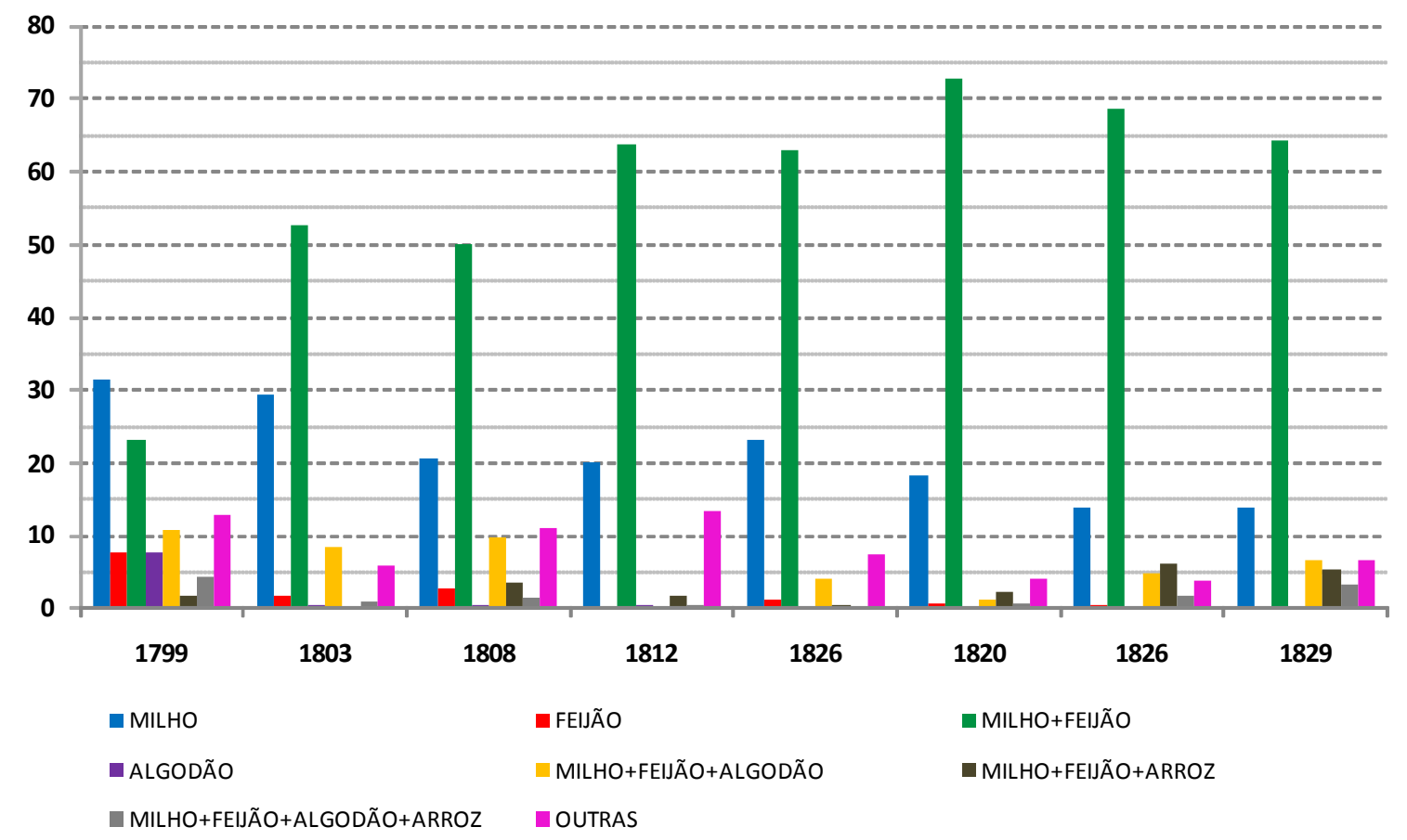

O padrão era, em diferentes medidas, a policultura (cf. Gráfico II.11). O arrolamento de milho, se considerado como cultura única, apareceu em apenas 31,4\% dos fogos com menção a cultura (39,4\% daqueles com menção a milho) em 1799 percentual que, em declínio constante ao longo dos anos, chega a $13,9 \%$ no fim do 
período (14,1\% daqueles fogos com descrição de milho). Os chefes de fogo declarantes exclusivamente do plantio e colheita de feijão, da mesma maneira viram-se reduzidos ao longo dos anos, chegando a desaparecer do recenseamento ao final da década de 1820.

Pontualmente e de maneira intermitente ao longo do tempo foram encontradas conjugações e menções a amendoim, arroz, trigo, cana (também na forma de aguardente e açúcar), mandioca (também na forma de farinha), café (somente anos finais de 1820), tipicamente mantimentos, além de fumo, mamona e algodão, cujos subprodutos têm usos diversos (ver tabela no apêndice estatístico). A mamona como óleo (conhecido atualmente como óleo de rícino), foi utilizada no Oitocentos para fins medicinais, combustível para lamparinas domésticas e de iluminação pública e ainda como lubrificante para carros de bois. O algodão, mais essencial, para a produção de tecidos, mais ou menos grosseiros, que vestiam livres e principalmente escravos, e o fumo cujas folhas poderiam ser fumadas ou mascadas.

Entre os produtos mencionados merece certo destaque o algodão, em especial conjugado com milho e o feijão. De forma diversa aos grãos mencionados o algodão teve sua participação entre a produção realizada nos fogos instável e tendente à queda ao longo dos anos. Em 1799 sua produção foi declarada em 29,5\% dos fogos em cultura, percentual que chegou a apenas 3,4\% menos de quinze anos depois, e ao final do período analisado foi calculado em $11,9 \%$ dos fogos com produção mencionada.

Para além das conjugações referidas, que em alguns casos deveriam omitir produtos cultivados em menores proporções, não pudemos identificar nenhum critério para a composição da produção ao longo do tempo ou pontualmente em um determinado momento.

Além da plantação, encontramos a descrição de animais nas listas nominativas, especialmente até o começo da década de 1820. Em 1799 26,2\% dos fogos descreveram animais, percentuais que estiveram entre 13,9\% (1816) e 18,3\% (1803) durante período 1803 a 1822, para posteriormente serem as criações mencionadas em 9,3\% dos fogos em 1826 e apenas $3,8 \%$ em 1829. Se considerados domicílios com animais mais plantações com tipo explicitado encontramos ao menos até 1822 percentuais de fogos que atingiram o máximo de 17,5\% (1822 e 1799) e o mínimo de 13,5\% em 1816, ano em que apenas três fogos mencionaram animais sem descrever de forma concomitante a presença de diferentes culturas. A Tabela II.36 apresenta o levantamento das unidades produtivas com animais arrolados nos maços de população de São João Batista de Atibaia. 
Tabela II.36

Criações e presença concomitante

dos diferentes animais nos fogos

(Atibaia - 1799 a 1829)

\begin{tabular}{|c|c|c|c|c|c|c|c|c|}
\hline CRIAÇÕES & $\begin{array}{l}1799 \\
\% \text { (№) }\end{array}$ & $\begin{array}{l}1803 \\
\% \text { (№) }\end{array}$ & $\begin{array}{l}1808 \\
\% \text { (№) }\end{array}$ & $\begin{array}{l}1812 \\
\% \text { (№) }\end{array}$ & $\begin{array}{l}1816 \\
\% \text { (№) }\end{array}$ & $\begin{array}{l}1820 \\
\% \text { (№) }\end{array}$ & $\begin{array}{l}1826 \\
\% \text { (№) }\end{array}$ & $\begin{array}{l}1829 \\
\% \text { (№) }\end{array}$ \\
\hline VACAIBEZERRO & $16,6(27)$ & $8,6(9)$ & $29,8(28)$ & $14,5(16)$ & $9,7(9)$ & $5,1(6)$ & $32,6(15)$ & $25,0(5)$ \\
\hline PORCO/CAPADO & $62,6(102)$ & $76,2(80)$ & $61,7(58)$ & $68,2(75)$ & $79,6(74)$ & $80,5(95)$ & $37,0(17)$ & $55,0(11)$ \\
\hline BESTA/BURRO/MULA & $1,23(2)$ & - & - & $0,91(1)$ & $1,1(1)$ & $1,7(2)$ & - & $10,0(2)$ \\
\hline VACA+CAPADO & $12,9(21)$ & $5,7(6)$ & $4,3(4)$ & $12,7(14)$ & $5,4(5)$ & $3,4(4)$ & $6,5(3)$ & - \\
\hline VACA+BESTA & $0,61(1)$ & $4,8(5)$ & - & $2,73(3)$ & $2,2(2)$ & $4,2(5)$ & $10,9(5)$ & - \\
\hline VACA+CAPADO+BESTA & $2,45(4)$ & - & - & - & $1,1(1)$ & $0,8(1)$ & $2,2(1)$ & $5,0(1)$ \\
\hline CAPADO+CAVALO & $1,84(3)$ & $1,0(1)$ & $3,2(3)$ & $0,9(1)$ & $1,1(1)$ & $2,5(3)$ & $4,3(2)$ & $5,0(1)$ \\
\hline CAVALO & $1,84(3)$ & $3,8(4)$ & $1,1(1)$ & - & - & $1,7(2)$ & $6,5(3)$ & - \\
\hline TOTAL & $100,0(163)$ & $100,0(105)$ & $100,0(94)$ & $100,0(110)$ & $100,0(93)$ & $100,0(118)$ & $100,0(46)$ & $100,0(20)$ \\
\hline
\end{tabular}

Basicamente os animais correspondiam a porcos (identificados através da presença de toucinho nas descrições de 1799 e 1803) e a gado vacum. Bem mais disseminada que a criação de vacuns, os capados sem alguma outra conjugação corresponderam a $62,6 \%$ das criações em 1799 , percentual que variou consideravelmente ao longo do tempo chegando a 76,2\% em 1803, voltando a 61,7\% em 1808 e já passados mais de dez anos (1816), sua participação havia subido a $80,5 \%$ dos fogos com menção a animais. Poucos fogos mencionaram haver criado algum bezerro, foram no máximo 27 em 1799 , o que correspondia a $16,6 \%$ das criações declaradas naquele ano e 28 (29,8\%), em 1808, à exceção de 1826, quando o número de observações foi reduzido e capados e bezerros tiveram participação próxima e em 1829, quando apenas 20 domicílios foram relacionados a animais, sendo em cinco deles feita menção a bezerros.

Assim como apareceram citados nas listas nominativas em diferentes medidas, o montante total produzido foi também muito distinto entre os diferentes produtos, como se pode notar na Tabela II.37, na qual aparecem os percentuais devidos aos valores totais produzidos de cada bem no valor total da produção atibaiense. Os valores considerados são os montantes totais assim apresentados nos mapas de produção e comércio ou calculados pela precificação dos produtos arrolados nas listas nominativas. 
Tabela II.37

Participação percentual dos diversos gêneros

no valor da produção

(Atibaia - 1798 a 1829)

\begin{tabular}{|c|c|c|c|c|c|c|c|c|c|c|c|}
\hline Produtos & $1798^{*}$ & $1799^{\star}$ & $1799^{\star \star}$ & $1803^{\star}$ & $1803^{\star \star}$ & $1804^{\star}$ & $1805^{\star}$ & $1806^{*}$ & $1808^{\star \star}$ & $1814^{*}$ & $1815^{\star}$ \\
\hline Milho & 46,0 & 25,8 & 86,7 & 27,1 & 69,9 & 28,5 & 21,8 & 26,2 & 61,3 & 23,2 & 25,5 \\
\hline Feijão & 23,9 & 9,9 & 1,5 & 9,0 & 8,0 & 2,6 & 13,1 & 8,7 & 10,1 & 3,1 & 3,3 \\
\hline Algodão & 8,6 & 3,1 & 1,2 & 3,9 & 2,2 & 0,6 & 4,2 & 3,8 & 3,8 & - & - \\
\hline Arroz & 1,0 & 1,0 & - & 0,6 & 0,2 & 0,2 & 0,5 & 0,6 & 0,4 & 0,3 & 0,6 \\
\hline Trigo & 0,2 & 0,5 & 0,1 & - & 0,4 & - & - & - & - & - & - \\
\hline Amendoim & - & - & 0,1 & - & 0,6 & - & - & - & 0,3 & - & - \\
\hline Fumo & 0,3 & - & - & - & 0,1 & - & - & - & 0,1 & - & - \\
\hline Farinha & 3,7 & 25,9 & 0,1 & 23,8 & 0,2 & 45,1 & 21,7 & 26,4 & 1,1 & 25,8 & 30,3 \\
\hline Panos de algodão & 1,0 & - & - & - & - & - & - & - & - & 25,1 & 19,6 \\
\hline Azeite de Mamona & 1,5 & 1,3 & - & 1,1 & - & 0,4 & 0,8 & 1,1 & - & 0,8 & 0,9 \\
\hline Açúcar & 2,3 & - & - & - & - & - & - & - & - & - & - \\
\hline Aguardente & 6,0 & 3,0 & 1,5 & 7,0 & 2,5 & 4,1 & 7,7 & 6,8 & 5,2 & 6,2 & 2,6 \\
\hline Melado & 0,4 & - & - & - & - & - & - & - & - & - & - \\
\hline Anil & 0,2 & - & - & - & - & - & - & - & - & - & - \\
\hline Capados & - & - & 4,3 & - & 13,3 & - & - & - & 17,7 & - & - \\
\hline Toucinho & 0,1 & 27,4 & 3,4 & 25,4 & 1,3 & 15,7 & 28,6 & 24,5 & - & 12,2 & 15,2 \\
\hline Potros & 2,1 & 0,8 & - & 0,4 & - & 0,5 & 0,5 & 0,4 & - & - & - \\
\hline Bois & 0,4 & 1,2 & 1,2 & 1,7 & 0,9 & 1,7 & 1,0 & 1,6 & - & 3,3 & 2,1 \\
\hline Bestas & 2,3 & - & - & - & 0,3 & 0,6 & - & - & - & - & - \\
\hline TOTAL & 100,0 & 100,0 & 100,0 & 100,0 & 100,0 & 100,0 & 100,0 & 100,0 & 100,0 & 100,0 & 100,0 \\
\hline Produtos & $1816^{\star}$ & $1816^{\star \star}$ & $1818^{\star}$ & $1820^{*}$ & $1820^{\star \star}$ & $1822^{\star}$ & $1825^{\star}$ & $1826^{\star}$ & $1826^{\star \star}$ & $1829^{\star \star \star}$ & $1829^{\star \star}$ \\
\hline Milho & 40,7 & 75,5 & 49,7 & 48,7 & 64,8 & 27,1 & 33,4 & 48,6 & 57,1 & 36,3 & 60,7 \\
\hline Feijão & 6,2 & 6,6 & 10,8 & 11,1 & 14,5 & 8,6 & 19,8 & 10,5 & 22,0 & 13,8 & 21,6 \\
\hline Algodão & - & $* \star \star *$ & - & - & 0,5 & - & - & - & 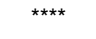 & - & $\star \star \star \star *$ \\
\hline Arroz & 0,2 & - & 11,9 & 0,3 & 0,6 & 0,3 & 0,4 & 0,1 & 1,2 & 0,2 & 0,6 \\
\hline Trigo & - & $* \star * *$ & - & - & - & - & - & - & - & - & - \\
\hline Amendoim & - & $* \star \star *$ & - & - & 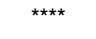 & - & - & - & 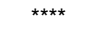 & - & 0,4 \\
\hline Fumo & - & - & - & - & - & - & - & - & - & - & - \\
\hline Farinha & 26,1 & 2,9 & 21,6 & 4,3 & 1,8 & 26,4 & 13,5 & 17,1 & 0,2 & 14,7 & - \\
\hline Panos de algodão & 3,5 & - & 1,6 & 0,7 & - & 14,0 & 3,7 & 0,4 & - & 3,4 & - \\
\hline Azeite de Mamona & 1,1 & - & 0,6 & 0,6 & - & 0,5 & 0,3 & 0,4 & - & 0,4 & - \\
\hline Açúcar & - & - & - & - & - & - & - & - & - & - & - \\
\hline Aguardente & 1,8 & 0,5 & 1,5 & 2,5 & 3,1 & 1,4 & 2,0 & 1,5 & 3,6 & 2,9 & 0,5 \\
\hline Melado & - & - & - & - & - & - & - & - & - & - & - \\
\hline Anil & - & - & - & - & - & - & - & - & - & - & - \\
\hline Capdos & - & 14,4 & - & - & 14,7 & - & - & - & 16,0 & - & 16,2 \\
\hline Toucinho & 17,4 & - & - & 28,3 & - & 18,0 & 19,8 & 18,8 & - & 23,6 & - \\
\hline Potros & - & - & - & - & - & - & - & - & - & - & - \\
\hline Bois & 2,8 & - & 2,2 & 3,5 & - & 3,8 & 7,1 & 2,5 & - & 4,8 & - \\
\hline Bestas & - & - & - & - & - & - & - & - & - & - & - \\
\hline TOTAL & 100,0 & 100,0 & 100,0 & 100,0 & 100,0 & 100,0 & 100,0 & 100,0 & 100,0 & 100,0 & 100,0 \\
\hline
\end{tabular}

"Fonte: AESP, M aços de População - M apas de produção e comércio, Atibaia

${ }^{* *}$ Fonte: AESP, M aços de População, A tibaia: anos selecionados

${ }^{\star * \star}$ Fonte: AESP, M aços de P opulação - M apas de produção e comércio, A tibaia. Inclui Nazaré

${ }^{\star * \star \star}$ Produção e/ou volume mencio nados, mas sem preço que permitisse verificar participação 
Os dados obtidos através dos mapas de produção e comércio são distintos daqueles obtidos nos arrolamentos populacionais. Parte desta diferença se deve ao fato de que os arrolamentos nominativos em muito descreveram milho, enquanto nos mapas de comércio também foi considerável a produção de farinha, que tinha no milho a sua matéria prima principal. Da mesma forma aconteceu com o algodão, citado em boa medida nas listas populacionais propriamente ditas, apareceram nos mapas de produção já na forma de tecidos; e com o toucinho, que um dos principais gêneros nos mapas, é obtido através da criação de porcos, bastante presente nas listas nominativas, especialmente a partir de 1808 quando a omissão ao tocinho é total. Farinha, toucinho e tecidos eram produtos que, por serem manufaturados a partir da cultura ou criação primárias, possuíam maiores valores adicionados.

Os dados das listas nominativas apontam uma grande produção de milho em Atibaia. Apesar de ser, juntamente com o milho, a cultura mais disseminada na localidade, o feijão comparativamente ao milho pouco representou em termos de valor. Ainda que considerável sua participação, assim como tem sido característica de todos os produtos locais, apresentou grandes variações ao longo do tempo e após se destacar em 1798, com $23,9 \%$, a segunda principal produção (os demais bens foram nada significativos neste ano), teve suas maiores participações em 1805 quando os mapas apontam seu valor compondo $13 \%$ do total e em 1825, quando atingiu quase $20 \%$. As listas nominativas foram mais generosas com o grão, que encerrou o período estudado responsável por cerca de $2 \%$ da produção arrolada.

Os panos de algodão apareceram com destaque nos mapas de 1814 e 1815, respectivamente $25,1 \%$ e $19,6 \%$ foram seus percentuais de participação no produto atibaiense, superando, inclusive, a importante participação do toucinho, observada na sequência. Em 1822 sua participação foi de 14\%, não tendo atingido marcas consideráveis nos demais anos, tendo Atibaia, como se verá, importado tecidos de algodão em alguns momentos.

Já o toucinho, praticamente ausente dos arrolamentos populacionais respondeu por valores próximos a 25-29\% até 1806, tendo em 1804 perdido espaço para a farinha. Nos anos de 1814 a 1816 sua participação viu-se diminuída, chegando a 12,2\% naquele primeiro ano mencionado, voltando a ter participação considerável em 1820, 28,3\% (superado apenas pelo milho) e 1829, 23,6\%, após manter-se na casa dos $19 \%$ no primeiro lustro da década de 1820.

Ademais, acerca da composição do valor produzido temos em $179986,7 \%$ do valor dos gêneros declarados devido ao milho, tendo caído a $69,9 \%$ em 1803, sendo de $75,5 \%$ 
em 1816 e 57,1\% em 1826. Em se considerando os mapas de comércio, estes valores eram bastante inferiores: em 1799 o percentual devido ao milho era de 25,8\%, subindo pouco até 1803 quando chegou a $27,1 \%$, percentual que varia pouco até 1815 . Já em $181640,7 \%$ do valor da produção dos mapas eram devidos ao milho, tendo esta participação subido a 48,6\% passados dez anos.

Em 1799 e 1803 essa produção de milho descrita nos mapas era bastante próxima àquela verificada para a farinha $(25,9 \%$ e $23,8 \%$, respectivamente) e o toucinho $(27,4 \%$ em 1799 e 25,4\% em 1803). Até 1822, tipicamente o percentual devido à farinha esteve variando entre $21 \%$ e $26 \%$, com dois anos em que teve maior destaque, 30,3\% em 1815 e, especialmente, 1804: 45\%. Por outro lado, chama a atenção o ano de 1820, quando o percentual devido à farinha era de apenas 4,3\%. A partir de 1826 sua participação foi diminuída e esteve entre $13-17 \%$. Nas listas nominativas a farinha não chegou a superar a participação de 2,9\% verificada em 1816.

Observados os montantes em alqueires produzidos de milho (sem ter se tornado farinha) e farinha (Gráfico II.12) citados nos mapas de produção temos, em regra, a produção de milho sempre superior à de farinha, em diferentes medidas, mas apresentando o mesmo sentido de variação até meados da década de 1810. As flutuações da produção de farinha apresentaram menor amplitude comparativamente ao milho, que chegou em 1805 e 1818 a montantes próximos a 90 mil arrobas produzidas. A partir de 1816 a produção de milho apresentou grande mudança, partindo de sua produção máxima (1818) ao menor volume encontrado nos 30 anos observados em um lapso de cerca de sete anos (1825). A seu turno, a farinha após passar de 11 mil a 20 mil alqueires produzidos entre 1816 e 1818, apresentou produção constante ao redor de 10 a 11 mil alqueires.

Contudo, estes anos não correspondem àqueles de maior participação desses bens no valor do produto atibaiense. Na composição do volume produzido em Atibaia, entre 1799 e 1803 as participações do milho e da farinha, seu derivado, variaram aproximadamente como espelhos (vide Gráfico II.13). Ao aumento de um correspondia um decréscimo no outro, o que parece estar ligado à dependência da farinha com relação ao milho - provavelmente o que levava preferência de um em detrimento ao outro era o preço, cuja diferença no mercado externo à vila reduziu-se com o passar dos anos, tornando mais próximos os valores do milho e da farinha eliminando parte dos benefícios de se trabalhar o milho. O preço relativo da farinha com relação ao milho caiu cerca de $40 \%$ nos primeiros lustros do Oitocentos. 


\section{Gráfico II.12}

\section{Evolução do volume total produzido da farinha}

e do milho (produto final)

(Atibaia - 1798 a 1829)

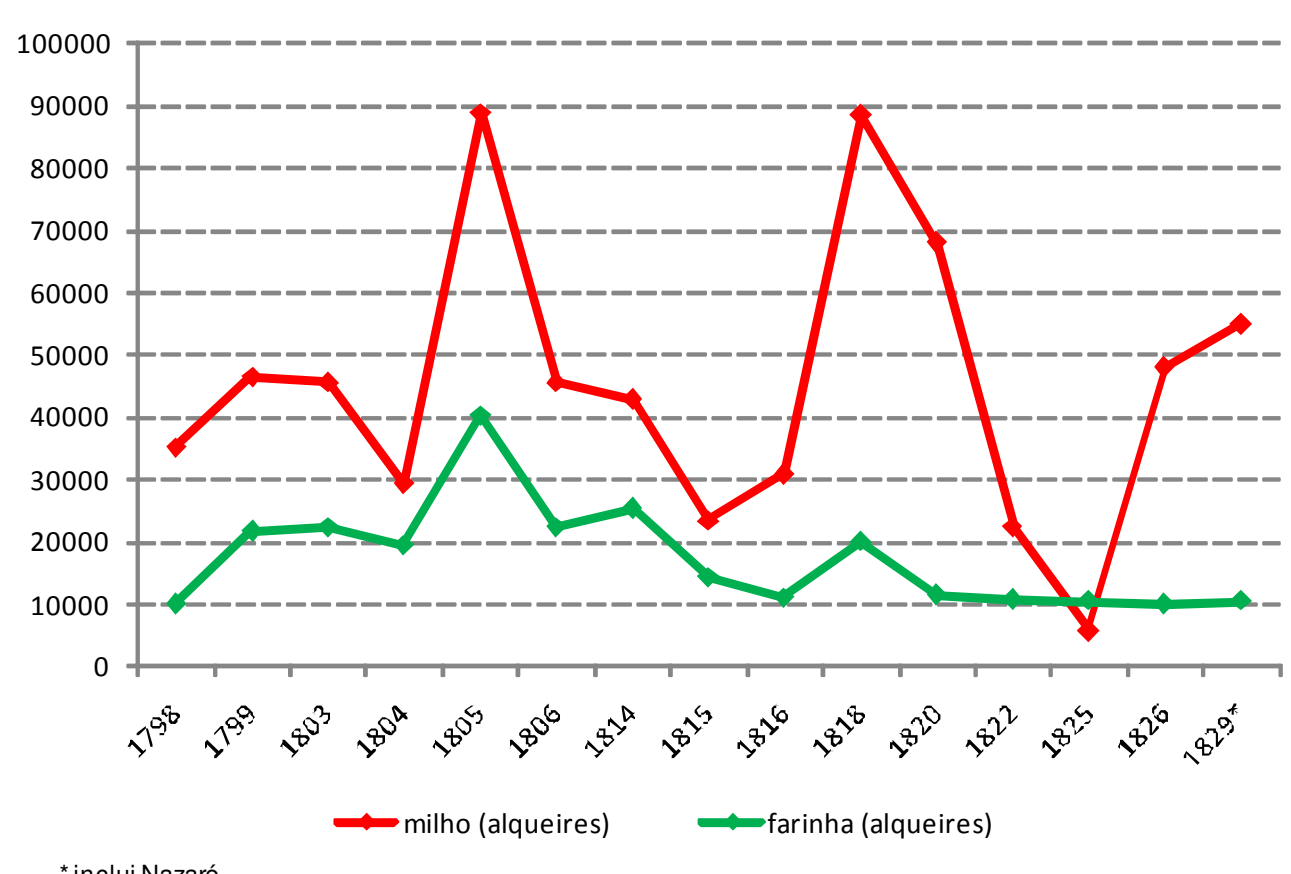

*inclui Nazaré

\section{Gráfico II.13}

Evolução da participação da farinha e do milho no produto

(Atibaia - 1798 a 1829)

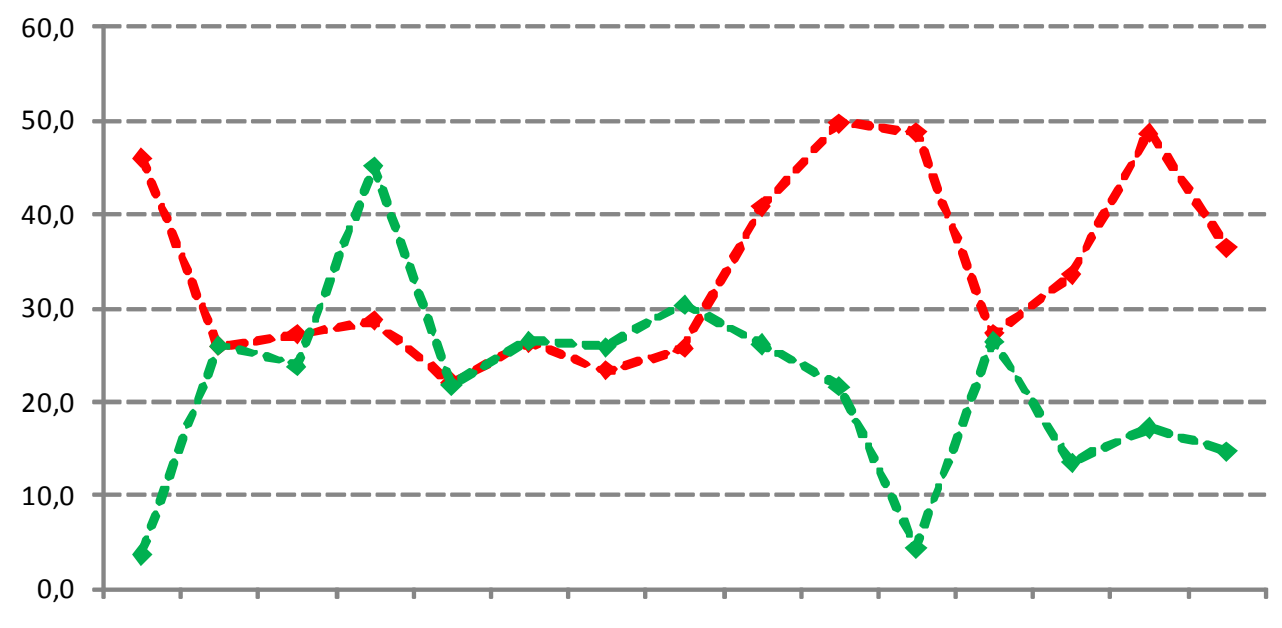

179817991803180418051806181418151816181818201822182518261829

$\rightarrow$ milho (participação \% no produto) $\quad \longrightarrow \rightarrow$ farinha (participação \% no produto) 
Apesar das diferenças indicadas entre os volumes de produção encontrados no arrolamento nominativo e nos mapas de produção e comércio, aqueles nos fornecem um bom indicativo das características da produção de milho nas unidades domiciliares nas quais era levada a cabo. Estatísticas para a produção do milho são mostradas na Tabela II.38 e a distribuição dos indivíduos envolvidos com o cultivo de acordo com faixas de volume declaradas podem ser vistas na Tabela II.39.

Os produtores do cereal apresentaram menores médias no ano inicial observado: 77,2 alqueires. A partir de 1803 produziu-se ao menos 145,1 alqueires de milho (1826), com destaque para 1812, quando a média por produtor foi calculada em 251,4 alqueires, a maior entre os anos para os quais possuímos dados. Neste ano a moda havia sido 100 alqueires e a mediana 150 alqueires de milho. Moda igual a 100 foi recorrente nos diferentes anos, sendo este valor para a moda não observado apenas em 1816 (50) e 1829 (200, sendo de 208,6 alqueires a média). Todavia, a mediana para 1812 esteve acima daquela observada em outros momentos, cujo máximo foi de 80 nos primeiros anos do século XVIII e estável em 100 alqueires de nos três últimos anos em tela.

Tabela II.38

Estatísticas para a produção de milho

(Atibaia - 1799 a 1829)

\begin{tabular}{|c|c|c|c|c|c|c|c|c|}
\hline \multirow[b]{2}{*}{ Estatísticas } & \multicolumn{2}{|c|}{ 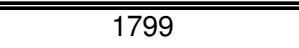 } & \multicolumn{2}{|c|}{1803} & \multicolumn{2}{|c|}{1808} & \multicolumn{2}{|c|}{ 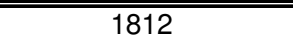 } \\
\hline & $\begin{array}{c}\text { Total de } \\
\text { fogos }\end{array}$ & $\begin{array}{c}\text { Fogos com } \\
\text { milho }\end{array}$ & $\begin{array}{c}\text { Total de } \\
\text { fogos }\end{array}$ & $\begin{array}{c}\text { Fogos com } \\
\text { milho }\end{array}$ & $\begin{array}{c}\text { Total de } \\
\text { fogos }\end{array}$ & $\begin{array}{l}\text { Fogos com } \\
\text { milho }\end{array}$ & $\begin{array}{c}\text { Total de } \\
\text { fogos }\end{array}$ & $\begin{array}{l}\text { Fogos com } \\
\text { milho }\end{array}$ \\
\hline Média & 21,1 & 77,2 & 92,4 & 152,3 & 52,3 & 117,6 & 70,5 & 251,4 \\
\hline Moda & 0,0 & 100,0 & 0,0 & 100,0 & 0,0 & 100,0 & 0,0 & 100,0 \\
\hline Mediana & 0,0 & 40,0 & 25,0 & 80,0 & 0,0 & 50,0 & 0,0 & 150,0 \\
\hline Índice de Gini & 0,883 & 0,571 & 0,760 & 0,604 & 0,828 & 0,613 & 0,850 & 0,439 \\
\hline Mínimo & 0,0 & 1,0 & & 4,0 & 0,0 & 2,0 & 0,0 & 11,0 \\
\hline \multirow[t]{2}{*}{ Máximo } & \multicolumn{2}{|c|}{800,0} & \multicolumn{2}{|c|}{3000,0} & \multicolumn{2}{|c|}{1500,0} & \multicolumn{2}{|c|}{2250,0} \\
\hline & \multicolumn{2}{|c|}{1816} & \multicolumn{2}{|c|}{1820} & \multicolumn{2}{|c|}{1826} & \multicolumn{2}{|c|}{1829} \\
\hline Estatísticas & $\begin{array}{c}\text { Total de } \\
\text { fogos }\end{array}$ & $\begin{array}{c}\text { Fogos com } \\
\text { milho }\end{array}$ & $\begin{array}{c}\text { Total de } \\
\text { fogos }\end{array}$ & $\begin{array}{l}\text { Fogos com } \\
\text { milho }\end{array}$ & $\begin{array}{c}\text { Total de } \\
\text { fogos }\end{array}$ & $\begin{array}{l}\text { Fogos com } \\
\text { milho }\end{array}$ & $\begin{array}{c}\text { Total de } \\
\text { fogos }\end{array}$ & $\begin{array}{l}\text { Fogos com } \\
\text { milho }\end{array}$ \\
\hline Média & 49,1 & 150,5 & 86,8 & 191,6 & 60,9 & 145,1 & 58,4 & 208,6 \\
\hline Moda & 0,0 & 50,0 & 0,0 & 100,0 & 0,0 & 100,0 & 0,0 & 200,0 \\
\hline Mediana & 0,0 & 80,0 & 0,0 & 100,0 & 0,0 & 100,0 & 0,0 & 100,0 \\
\hline Índice de Gini & 0,855 & 0,556 & 0,804 & 0,567 & 0,786 & 0,491 & 0,884 & 0,587 \\
\hline Mínimo & 0,0 & 2,0 & 0,000 & 5,0 & 0,000 & 5,0 & 0,000 & 5,0 \\
\hline Máximo & \multicolumn{2}{|c|}{1000,0} & \multicolumn{2}{|c|}{1000,0} & \multicolumn{2}{|c|}{1000,0} & \multicolumn{2}{|c|}{2000,0} \\
\hline
\end{tabular}

Fonte: AESP, M aços de População, Atibaia: anos selecionados 
Tabela II.39

Distribuição de produtores e produção de milho

de acordo com faixas de alqueires

(Atibaia - 1799 a 1829)

\begin{tabular}{|c|c|c|c|c|c|c|c|c|c|c|c|c|}
\hline \multirow[b]{2}{*}{$\begin{array}{l}\text { Faixas de } \\
\text { alqueires }\end{array}$} & \multicolumn{4}{|c|}{1799} & \multicolumn{4}{|c|}{1803} & \multicolumn{4}{|c|}{1808} \\
\hline & Produtores & Volume & \multicolumn{2}{|c|}{ Venda } & Produtores & Volume & \multicolumn{2}{|c|}{ Venda } & Produtores & Volume & \multicolumn{2}{|c|}{ Venda } \\
\hline Até 10 & $31(18,2)$ & $211(1,6)$ & 19 & 62,6 & $10(2,9)$ & $81(0,2)$ & - & - & $34(12,9)$ & $289(0,9)$ & - & $\overline{-}$ \\
\hline 100,1 a 300 & $27(15,9)$ & $4911(37,4)$ & 3 & 10,2 & $83(23,7)$ & $15365(28,8)$ & 10 & 3,8 & $56(21,3)$ & $10771(34,8)$ & 11 & 4,9 \\
\hline 300,1 a 500 & $3(1,8)$ & $1180(9,0)$ & - & - & $16(4,6)$ & $6740(12,6)$ & 2 & 4,1 & $10(3,8)$ & $4350(14,1)$ & 2 & 6,2 \\
\hline 500,1 ou mais & $2(1,2)$ & $1500(11,4)$ & - & - & $18(5,1)$ & $19200(36,0)$ & 1 & 0,1 & $9(3,4)$ & $7900(25,5)$ & 7 & 10,5 \\
\hline Total & $170(100,0)$ & $13118(100,0)$ & 56 & 15,7 & $350(100,0)$ & $53291(100,0)$ & 30 & 2,3 & $263(100,0)$ & $30935(100,0)$ & 32 & 5,9 \\
\hline Até 10 & - & - & - & - & $3(1,4)$ & $13(0,0)$ & - & - & $2(0,7)$ & $15(0,0)$ & - & - \\
\hline 10,1 a 50 & $19(10,9)$ & $587(1,3)$ & - & - & $90(41,3)$ & $3050(9,3)$ & - & - & $98(35,9)$ & $3555(6,2)$ & 5 & 1,8 \\
\hline 50,1 a 100 & $46(26,4)$ & $4438(10,1)$ & 1 & 45,1 & $49(22,5)$ & $4220(12,9)$ & - & - & $74(27,1)$ & $6528(11,4)$ & 3 & 0,8 \\
\hline 100,1 a 300 & $66(37,9)$ & $13315(30,4)$ & 4 & 7,1 & $47(21,6)$ & $9920(30,2)$ & 3 & 1,4 & $77(28,2)$ & $16310(28,6)$ & 6 & 2,4 \\
\hline 300,1 a 500 & $27(15,5)$ & $11450(26,2)$ & 5 & 15,5 & $20(9,2)$ & $8950(27,3)$ & 2 & 2,8 & $2(0,7)$ & $11200(19,6)$ & 8 & 7,1 \\
\hline 500,1 ou mais & $\{16(9,2)$ & $13950(31,9)$ & 4 & 6,5 & $9(4,1)$ & $6650(20,3)$ & 3 & 4,3 & $20(7,3)$ & $19500(34,1)$ & 3 & 1,5 \\
\hline Total & $174(100,0)$ & $43740(100,0)$ & 14 & 12,9 & $218(100,0)$ & $32803(100,0)$ & 8 & 2,1 & $273(100,0)$ & $57108(100,0)$ & 25 & 2,8 \\
\hline 100,1 a 300 & $71(34,3)$ & $14870(49,5)$ & 11 & 6,5 & $43(20,8)$ & $8420(28,0)$ & 6 & 3,6 & & & & \\
\hline 300,1 a 500 & $8(3,9)$ & $3500(11,6)$ & 3 & 11,4 & $13(6,3)$ & $5494(18,3)$ & 4 & 5,4 & & & & \\
\hline 500,1 ou mais & $\leqslant \quad 7(3,4)$ & $5000(16,6)$ & 3 & 15,2 & $14(6,8)$ & $13060(43,5)$ & 3 & 6,2 & & & & \\
\hline Total & $207(100,0)$ & $30043(100,0)$ & 19 & 7,1 & $149(72,0)$ & $31078(103,4)$ & 14 & 4,6 & & & & \\
\hline
\end{tabular}

O índice de Gini, considerado para os fogos com milho mostrou-se, também, variável, com dois momentos de queda um pouco mais significativa: entre 1808 e 1812 foi de 0,613 a 0,439, e entre 1820 e 1826 caiu de 0,567 a 0,491, passando de patamares relativamente elevados em torno de 0,6 a concentrações pouco menos significativas. Característica diferente pode ser notada para o total das unidades produtivas, cujos Ginis evidenciaram certa rigidez, com elevado grau de concentração na produção do milho, entre 0,8 e 0,9 . 
A discrepância, entretanto, entre os maiores e menores produtores era visível: os mínimos produzidos atingiram um alqueire no Setecentos, passando ao máximo em 1812 (11 alqueires), mantendo-se em cinco em 1820, 1826 e 1829. Nestes mesmos anos temos máximo de 800 alqueires em 1799, 2225 alqueires em 1812 e 1000, 1000 e 2000 alqueires sucessivamente nos anos a partir de 1820. A maior produção declarada em todo o período correspondia aos 3000 alqueires de milho relacionado no fogo de Maria de Oliveira Preta em 1803.

Estava relativamente bem distribuída entre as três faixas, a partir daquela composta por produtores de 10,1 a 50 alqueires, os lavradores da vila de Atibaia com colheita de milho declarada; sendo devidos a elas diferentes percentuais em diferentes momentos. Entre 1799 e 1808 o destaque foi dos menores produtores (37-39\%); em 1812 a ausência de declarações de até 10 alqueires elevou o patamar da mais importante para a faixa de 100,1 a 300 alqueires, a mais representativa também em 1826 (34,3\%). Esta faixa foi importante, pois, mesmo sem mostrar constância na inclusão de número principal de indivíduos, dividiu com os chefes a produzir mais 500 alqueires o primeiro posto na composição do volume de milho descrito, estando ano sim ano não como responsável por maior quantidade de produto, ainda que esta em pouco tenha sido superior à encontrada em diferentes faixas.

Em diferentes medidas e momentos, os gêneros produzidos em Atibaia foram enviados a mercados regionais. Os mapas de comércio apontam que Atibaia manteve, ao longo do período considerado, relações comerciais com São Paulo e Santos, para onde enviava parte da produção realizada em seus domicílios (Tabela II.40). De acordo com os mapas eram enviados para fora da localidade, com pequenas variações ao longo do tempo, milho, feijão, aguardente, toucinho, arroz, farinha, algodão e vacum, mesmo que alguns deles tivessem participação diminuta na composição produtiva da vila de São João de Atibaia. Esses produtos foram identificados nas listas nominativas que, como sabemos, em menores proporções, descreviam também amendoim, trigo, cana, mandioca, café, mamona e fumo, não mencionados na pauta exportacionista atibaiense. 
Tabela II.40

Gêneros exportados de acordo com o destino

(Atibaia - 1798 a 1829)

\begin{tabular}{|c|c|c|c|c|}
\hline & São Paulo & Santos & Mogi & Atibaia \\
\hline 1798 & $\begin{array}{c}\text { milho, feijão, arroz, farinha, trigo, } \\
\text { toucinho, açucar, algodão, azeit } \\
\text { e,fumo, aguardente }\end{array}$ & - & - & \\
\hline 1799 & $\begin{array}{l}\text { farinha, milho, feijão, } \\
\text { toucinho, arroz, trigo, bois }\end{array}$ & $\begin{array}{l}\text { milho, feijão, } \\
\text { toucinho }\end{array}$ & - & \begin{tabular}{|} 
algodão, farinha, milho, feijão, \\
toucinho, aguardente, azeite \\
de mamona, potros, bois
\end{tabular} \\
\hline 1803 & $\begin{array}{c}\text { algodão, farinha, milho, feijão, } \\
\text { toucinho, arroz, azeite de } \\
\text { mamona, bois }\end{array}$ & $\begin{array}{l}\text { farinha, milho, } \\
\text { feijão, toucinho, } \\
\text { bois }\end{array}$ & $\begin{array}{l}\text { milho, feijão, } \\
\text { farinha, toucinho }\end{array}$ & $\begin{array}{c}\text { algodão, farinha, milho, feijão, } \\
\text { toucinho, arroz, aguardente, } \\
\text { azeite de mamona, potros, } \\
\text { bois }\end{array}$ \\
\hline 1804 & $\begin{array}{c}\text { milho, feijão, farinha, toucinho, ar } \\
\text { roz, azeite, bois }\end{array}$ & $\begin{array}{c}\text { milho, feijão, farinha, } \\
\text { toucinho }\end{array}$ & toucinho & \begin{tabular}{|} 
algodão, milho, feijão, farinha, to \\
ucinho, arroz, aguardente, azeit \\
e,bois,potros, bestas
\end{tabular} \\
\hline 1805 & $\begin{array}{c}\text { milho, feijão, farinha, toucinho, ar } \\
\text { roz, bois }\end{array}$ & $\begin{array}{c}\text { milho, feijão, farinha, } \\
\text { toucinho }\end{array}$ & - & \begin{tabular}{|} 
algodão, milho,feijão, farinha, to \\
ucinho, arroz, aguardente, azeit \\
e,bois, potros
\end{tabular} \\
\hline 1806 & $\begin{array}{c}\text { farinha, milho, feijão, } \\
\text { toucinho, arroz, azeite de } \\
\text { mamona, bois }\end{array}$ & $\begin{array}{l}\text { farinha, milho, } \\
\text { feijão, toucinho, } \\
\text { bois }\end{array}$ & - & $\begin{array}{c}\text { algodão, farinha, milho, feijão, } \\
\text { toucinho, arroz, aguardente, } \\
\text { azeite de mamona, potros, } \\
\text { bois }\end{array}$ \\
\hline 1814 & $\begin{array}{c}\text { farinha, milho, feijão, } \\
\text { toucinho, arroz, azeite de } \\
\text { mamona, bois }\end{array}$ & $\begin{array}{l}\text { farinha, milho, } \\
\text { feijão, toucinho, } \\
\text { arroz }\end{array}$ & - & $\begin{array}{c}\text { panos de algodão, farinha, } \\
\text { milho, feijão, toucinho, arroz, } \\
\text { aguardente, azeite de } \\
\text { mamona, bois }\end{array}$ \\
\hline 1816 & $\begin{array}{c}\text { farinha, milho, feijão, } \\
\text { toucinho, azeite de mamona, } \\
\text { bois }\end{array}$ & $\begin{array}{l}\text { farinha, milho, } \\
\text { feijão, toucinho }\end{array}$ & - & \begin{tabular}{|} 
panos de algodão, farinha, \\
milho, feijão, toucinho, arroz, \\
aguardente, azeite de \\
mamona, bois
\end{tabular} \\
\hline 1818 & $\begin{array}{c}\text { vaca, algodão, farinha, milho,feij } \\
\text { ão,toucinho, arroz, aguardente, } \\
\text { azeite }\end{array}$ & $\begin{array}{c}\text { farinha, milho, feijão, } \\
\text { toucinho }\end{array}$ & - & \begin{tabular}{|} 
vaca, algodão,farinha, milho, feij \\
ão,toucinho, arroz, aguardente, \\
azeite
\end{tabular} \\
\hline 1820 & $\begin{array}{c}\text { farinha, milho, feijão, } \\
\text { toucinho, arroz, azeite de } \\
\text { mamona, bois }\end{array}$ & - & - & $\begin{array}{c}\text { farinha, milho, feijão, toucinho, ar } \\
\text { roz, aguardente, azeite,bois }\end{array}$ \\
\hline 1822 & $\begin{array}{l}\text { farinha, milho, feijão, } \\
\text { toucinho,bois }\end{array}$ & - & - & $\begin{array}{l}\text { algodão, farinha, milho, feijão, to } \\
\text { ucinho, aguardente, azeite, bois }\end{array}$ \\
\hline 1825 & $\begin{array}{l}\text { farinha, milho, feijão, } \\
\text { toucinho,bois }\end{array}$ & $\begin{array}{c}\text { milho, feijão, farinha, } \\
\text { toucinho }\end{array}$ & - & \begin{tabular}{|c} 
panos de algodão, farinha, \\
milho, feijão, toucinho, arroz, \\
aguardente, azeite de \\
mamona, bois
\end{tabular} \\
\hline 1826 & $\begin{array}{l}\text { farinha, milho, feijão, } \\
\text { toucinho, arroz, , bois }\end{array}$ & $\begin{array}{l}\text { milho, feijão, } \\
\text { toucinho }\end{array}$ & - & $\begin{array}{c}\text { farinha, milho, feijão, } \\
\text { toucinho, arroz, aguardente, } \\
\text { azeite de mamona, bois }\end{array}$ \\
\hline 1829 & $\begin{array}{l}\text { farinha, milho, feijão, } \\
\text { toucinho, bois }\end{array}$ & feijão, toucinho & - & $\begin{array}{c}\text { farinha, milho, feijão, } \\
\text { toucinho, arroz, aguardente, } \\
\text { azeite de mamona, bois }\end{array}$ \\
\hline
\end{tabular}

Fonte: AESP, Maços de População - M apas de produção e comércio, Jundiaí 
Assim como ocorria com Bragança - que esteve administrativamente jurisdicionada a Atibaia até 1797 - Atibaia situava-se em um dos caminhos rumo às Minas e o comércio com aquele região pode ter impulsionado a produção de gêneros de subsistência realizada na localidade.

Arriscamo-nos a dizer que o início dessas relações comerciais baseou-se apenas no possível excedente gerado na produção para consumo nas unidades produtivas locais. E, ao adquirir importância, gerou retornos suficientes para justificar o sacrifício ao consumo local - senão de suas populações propriamente, de localidades dependentes e/ou limítrofes, como São Paulo, a que era administrativamente ligada até 1769 - em nome do mercado mineiro.

Enquanto na região da Minas era densa a população ligada aos centros urbanos, em Atibaia a população espalhava-se por uma miríade de propriedades - espalhadas, mas nem por isso isoladas - ligadas à produção de gêneros agropecuários de subsistência, passíveis de serem negociados em outros mercados.

Em ordem enviada em 1775 aos Juízes de Atibaia por D.Luís Antonio de Souza (Morgado de Mateus), o caráter comercial da produção de subsistência atibaiense e sua ligação com o mercado mineiro podem ser verificados:

Porquanto nesta cidade [São Paulo- DOMR] há falta de trigo para o sustento dos seus moradores e me consta que nos distritos de São João de Atibaya e Jaguary, onde se cultiva a maior abundância desse gênero, tem havido muitos atravessadores que em prejuízo dos naturais dessa capitania compram aos lavradores os trigos de suas fábricas e os estão passando para a capitania de Minas Gerais ficando esta cidade na maior consternação por não haver mais partes d'onde possa ser provida [...] (apud CONTI, 2001, vol. II, pp.29-30)

No entanto, a documentação que analisamos é datada, no limite, no ano de 1799. Nesse período o retrocesso da produção aurífera mineira já havia levado a economia daquela capitania a espraiar-se por uma miríade de atividades características de subsistência, limitando a necessidade de importação de gêneros antes comercializados em grande monta. Assim, não pudemos identificar um comércio de forma regular com as Minas Gerais. Sendo que o trigo, mencionado por Morgado de Mateus, aparece nos mapas de comércio apenas em 1799 e em listas nominativas de alguns anos e fogos, conjugada com outras atividades, como adiantado.

Ou seja, o impulso foi dado, mas esse comércio em medida considerável não se manteve no Oitocentos. As relações com Minas Gerais reaparecem de maneira efetiva na documentação censitária na segunda década do Oitocentos, com a importação do fumo, cultura que, embora conhecida nas localidade (encontrada pontualmente em alguns 
anos), foi pouco ou nada significativa para a movimentação da economia local. Atibaia acabou por se tornar, após o declínio da extração aurífera, abastecedora regional, leia-se, de São Paulo majoritariamente, e do porto de Santos.

Ainda que se possa argumentar que entre Atibaia e São Paulo exista a serra o que dificultaria o escoamento da produção no sentido da capital ainda mais sob as condições de transporte da época, fato é que o principal parceiro comercial da região em fins do século XVIII e primeiras décadas do XIX foi a cidade de São Paulo. Apesar do decréscimo na participação paulistana, esta não chega a ser inferior àquela representada pelo porto de Santos, que no limite chegou a ter a mesma importância que São Paulo, 39\% no ano de 1826.

Curiosamente encontramos nomeadas entre as localidades de exportação de Atibaia a própria localidade. Possivelmente, esses produtos eram comercializados na vila, porém tinham como destino final distintos mercados. Deveria aparecer aqui, com importância, a figura do intermediário, assim como a dos estanqueiros, figura presente nos comércios municipais até 1820, quando foi extinto o estanco:

\begin{abstract}
Estancos eram uma espécie de armazém ou mercado, onde se vendiam os gêneros da terra. Pertenciam à câmara que, anualmente os arrecadava, em arrematações públicas, ou seja, uma espécie de concorrência a quem mais oferecesse. $O$ arrematante que passava a se chamar estanqueiro, ficava sendo então, o concessionário único das vendas de gêneros da freguesia, devendo o lavrador levar os seus produtos ao estanco, onde pagaria uma taxa qualquer (apud CONTI, 2001, vol. II, p.24)
\end{abstract}

$\mathrm{Na}$ composição percentual do valor por destino dos bens saídos de Atibaia encontramos, ao longo de todo o período 1798 a 1829, a cidade de São Paulo como a responsável majoritária por esse comércio para além das fronteiras da vila. A totalidade das exportações da localidade se dirigia para lá em 1798. Nos demais anos o comércio regular com São Paulo apresentou variações que tenderam à queda no longo prazo: de 64\% em 1799 a 35,7\% em 1839. Apesar do decréscimo na participação paulistana, esta não chega a ser inferior àquela representada pelo porto de Santos, que no limite chegou a ter importância semelhante, em torno de $41 \%$ em 1826. Parcela representativa era devida à participação das exportações na própria vila, que chegou superar os $40 \%$ naquele ano de 1829 em que São Paulo apresentou uma de suas menores participações, junto ao ano de 1814, em que Atibaia manteve participação absoluta: 51,6\%.

Ademais, aparece Mogi como um receptor de gêneros provenientes de Atibaia. $\bigcirc$ comércio com Mogi foi logo suprimido, limitava-se a farinha e toucinho que teve espaço, em maior monta, em São Paulo e em Santos. Vale mencionar que nos mapas de 
comércio de Mogi das Cruzes no período (aqui apresentados em seção atinente a esta localidade), Atibaia não aprece entre os parceiros comerciais, indicando que essa importação deveria ser pouco representativa no montante transacionado ali.

\section{Gráfico II.14}

\section{Participação das diferentes localidades nas exportações}

(Atibaia - 1798 a 1829)

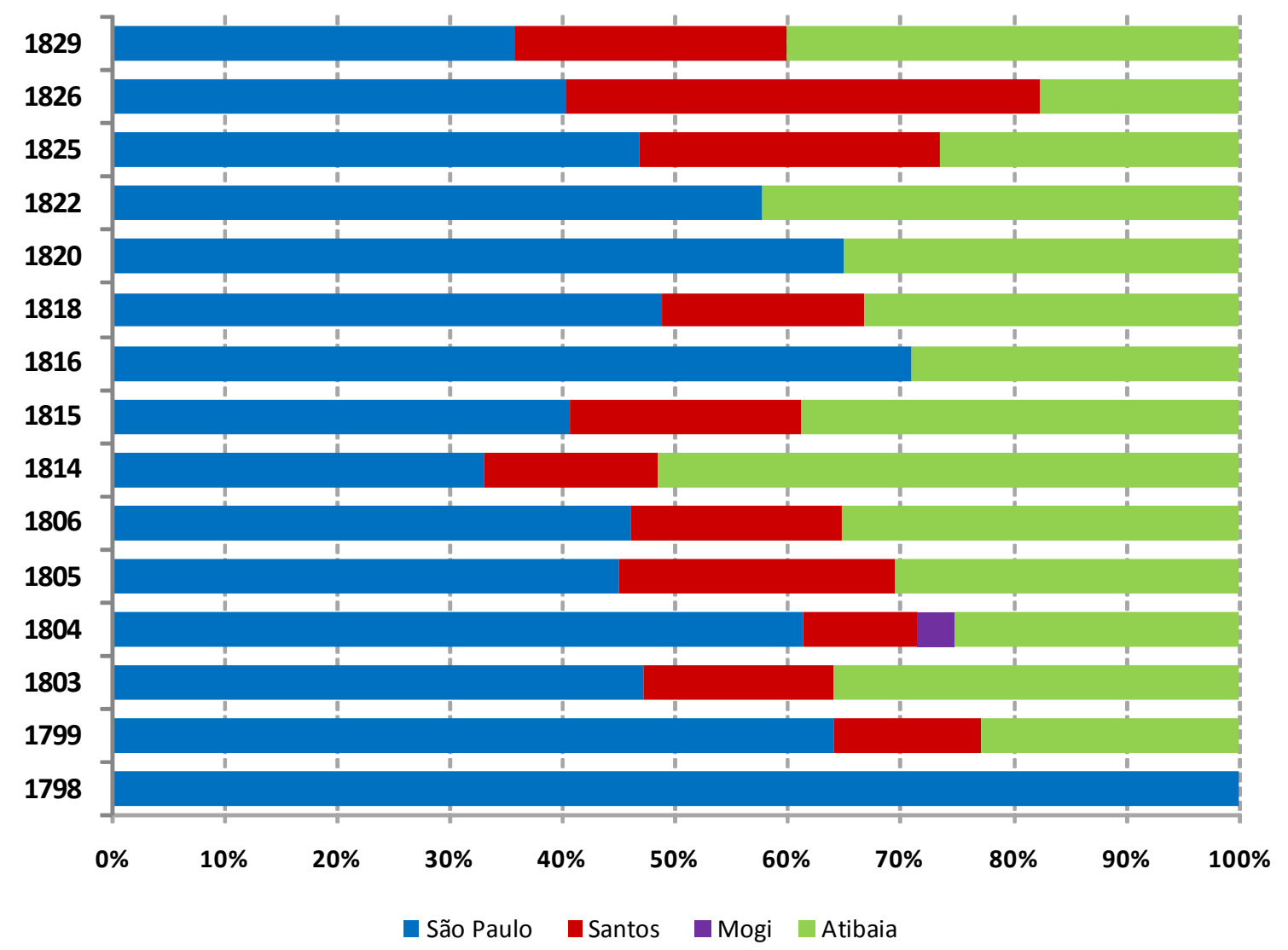

Todavia, não há uma coincidência entre os produtos mais disseminados e os mais vendidos, proporcionalmente, nos mercados regionais, de acordo com os dados da Tabela II.41. Assim, por exemplo, do montante total produzido, de acordo com os valores encontrados nos Mapas comparativos das produções com a especificação do que se consumiu na localidade e nela se exportou, a produção do arroz, pouco significativa no valor total produzido teve em $181475,6 \%$ da sua produção exportada. 
Tabela II.41

Percentual exportado e participação percentual dos diversos gêneros

no valor do produto exportado

(Atibaia- 1798 a 1830)

\begin{tabular}{|c|c|c|c|c|c|c|c|c|c|c|}
\hline \multirow[b]{2}{*}{ Produtos } & \multicolumn{2}{|c|}{1799} & \multicolumn{2}{|c|}{1803} & \multicolumn{2}{|c|}{1804} & \multicolumn{2}{|c|}{1805} & \multicolumn{2}{|c|}{1806} \\
\hline & $\begin{array}{c}\% \text { da } \\
\text { produção } \\
\text { do bem } \\
\text { exportada }\end{array}$ & $\begin{array}{c}\% \text { do valor } \\
\text { total } \\
\text { exportado }\end{array}$ & $\begin{array}{c}\% \text { da } \\
\text { produção } \\
\text { do bem } \\
\text { exportada }\end{array}$ & $\begin{array}{c}\% \text { do valor } \\
\text { total } \\
\text { exportado }\end{array}$ & $\begin{array}{c}\% \text { da } \\
\text { produção } \\
\text { do bem } \\
\text { exportada }\end{array}$ & $\begin{array}{c}\% \text { do valor } \\
\text { total } \\
\text { exportado }\end{array}$ & $\begin{array}{c}\% \text { da } \\
\text { produção } \\
\text { do bem } \\
\text { exportada }\end{array}$ & $\begin{array}{c}\% \text { do valor } \\
\text { total } \\
\text { exportado }\end{array}$ & $\begin{array}{c}\% \text { da } \\
\text { produção } \\
\text { do bem } \\
\text { exportada }\end{array}$ & $\begin{array}{c}\% \text { do valor } \\
\text { total } \\
\text { exportado }\end{array}$ \\
\hline Milho & 14,8 & 13,1 & 16,3 & 13,5 & 14,9 & 18,1 & 17,2 & 7,6 & 14,9 & 12,0 \\
\hline Feijão & 29,8 & 10,1 & 30,5 & 8,4 & 58,8 & 6,6 & 47,8 & 12,6 & 30,5 & 8,2 \\
\hline Algodão & 28,3 & 3,1 & 50,3 & 6,0 & 40,2 & 4,9 & 75,0 & 6,4 & 40,2 & 4,7 \\
\hline Arroz & 68,6 & 2,3 & 36,8 & 0,7 & 53,7 & 0,5 & 77,8 & 0,8 & 23,7 & 0,4 \\
\hline Trigo & 43,4 & 0,7 & - & - & - & - & - & - & - & - \\
\hline Farinha & 6,2 & 5,5 & 11,1 & 8,1 & 4,7 & 9,0 & 19,8 & 8,6 & 9,7 & 7,9 \\
\hline Azeite de Mamona & 84,9 & 3,8 & 15,0 & 0,5 & 40,0 & 0,6 & 23,6 & 0,4 & 15,0 & 0,5 \\
\hline Aguardente & 98,8 & 10,3 & 96,4 & 20,7 & 66,7 & 11,8 & 88,2 & 13,6 & 96,4 & 20,2 \\
\hline Toucinho & 47,7 & 45,0 & 53,7 & 41,6 & 60,9 & 40,7 & 83,2 & 47,8 & 53,7 & 40,7 \\
\hline Potros & 100,0 & 2,9 & 100,0 & 0,1 & 100,0 & 2,1 & 100,0 & 1,0 & 100,0 & 1,3 \\
\hline Bois & 76,3 & 3,2 & 8,0 & 0,4 & 44,4 & 3,2 & 63,3 & 1,3 & 81,2 & 4,0 \\
\hline Bestas & - & - & - & - & 100,0 & 2,5 & - & - & - & - \\
\hline \multirow[b]{3}{*}{ Produtos } & 29,1 & 100,0 & 32,7 & 100,0 & 25,2 & 100,0 & 51,1 & 100,0 & 32,3 & 100,0 \\
\hline & \multicolumn{2}{|c|}{1814} & \multicolumn{2}{|c|}{1815} & \multicolumn{2}{|c|}{1816} & \multicolumn{2}{|c|}{1818} & \multicolumn{2}{|c|}{1820} \\
\hline & $\begin{array}{c}\% \text { da } \\
\text { produção } \\
\text { do bem } \\
\text { exportada }\end{array}$ & $\begin{array}{c}\% \text { do valor } \\
\text { total } \\
\text { exportado }\end{array}$ & $\begin{array}{c}\% \text { da } \\
\text { produção } \\
\text { do bem } \\
\text { exportada }\end{array}$ & $\begin{array}{c}\% \text { do valor } \\
\text { total } \\
\text { exportado }\end{array}$ & $\begin{array}{c}\% \text { da } \\
\text { produção } \\
\text { do bem } \\
\text { exportada }\end{array}$ & $\begin{array}{c}\% \text { do valor } \\
\text { total } \\
\text { exportado }\end{array}$ & $\begin{array}{c}\% \text { da } \\
\text { produção } \\
\text { do bem } \\
\text { exportada }\end{array}$ & $\begin{array}{c}\% \text { do valor } \\
\text { total } \\
\text { exportado }\end{array}$ & $\begin{array}{c}\% \text { da } \\
\text { produção } \\
\text { do bem } \\
\text { exportada }\end{array}$ & $\begin{array}{c}\% \text { do valor } \\
\text { total } \\
\text { exportado }\end{array}$ \\
\hline Milho & 28,8 & 4,6 & 9,5 & 9,0 & 6,6 & 9,8 & 10,0 & 14,9 & 8,5 & 12,5 \\
\hline Feijão & 61,3 & 2,9 & 61,3 & 7,4 & 61,1 & 13,7 & 36,5 & 11,9 & 20,8 & 7,0 \\
\hline Arroz & 75,6 & 0,1 & 50,0 & 1,0 & 19,4 & 0,2 & 1,0 & 0,4 & 100,0 & 1,0 \\
\hline Farinha & 31,9 & 65,7 & 16,9 & 19,0 & 23,9 & 22,7 & 24,1 & 15,7 & 68,4 & 9,0 \\
\hline Panos de algodão & 62,5 & 10,8 & 28,6 & 20,8 & 50,0 & 6,4 & 10,0 & 0,5 & 0,0 & - \\
\hline Azeite de Mamona & 97,6 & 0,6 & 68,4 & 2,2 & 75,0 & 3,1 & 100,0 & 1,8 & 100,0 & 1,8 \\
\hline Aguardente & 98,2 & 6,2 & 96,8 & 9,4 & 50,0 & 3,3 & 100,0 & 4,6 & 100,0 & 7,6 \\
\hline Toucinho & 83,2 & 7,0 & 51,0 & 28,7 & 53,2 & 33,7 & - & 43,7 & 59,2 & 50,7 \\
\hline Bois & 96,2 & 2,2 & 33,3 & 2,6 & 68,8 & 7,1 & 100,0 & 6,5 & 100,0 & 10,5 \\
\hline \multirow[b]{3}{*}{ Produtos } & 33,2 & 100,0 & 26,9 & 100,0 & 27,5 & 100,0 & 33,2 & 100,0 & 33,0 & 100,0 \\
\hline & \multicolumn{2}{|c|}{1822} & \multicolumn{2}{|c|}{1825} & \multicolumn{2}{|c|}{1826} & \multicolumn{2}{|c|}{$1829^{*}$} & & \\
\hline & $\begin{array}{c}\% \text { da } \\
\text { produção } \\
\text { do bem } \\
\text { exportada }\end{array}$ & $\begin{array}{c}\% \text { do valor } \\
\text { total } \\
\text { exportado }\end{array}$ & $\begin{array}{c}\% \text { da } \\
\text { produção } \\
\text { do bem } \\
\text { exportada }\end{array}$ & $\begin{array}{c}\% \text { do valor } \\
\text { total } \\
\text { exportado }\end{array}$ & $\begin{array}{c}\% \text { da } \\
\text { produção } \\
\text { do bem } \\
\text { exportada }\end{array}$ & $\begin{array}{c}\% \text { do valor } \\
\text { total } \\
\text { exportado }\end{array}$ & $\begin{array}{c}\% \text { da } \\
\text { produção } \\
\text { do bem } \\
\text { exportada }\end{array}$ & $\begin{array}{c}\% \text { do valor } \\
\text { total } \\
\text { exportado }\end{array}$ & & \\
\hline Milho & 16,8 & 12,9 & 32,7 & 28,7 & 29,8 & 55,7 & 21,9 & 21,9 & & \\
\hline Feijão & 46,1 & 11,2 & 19,7 & 10,3 & 49,2 & 19,9 & 3,1 & 1,2 & & \\
\hline Arroz & 0,0 & - & 47,6 & 0,5 & 50,0 & 0,2 & 57,1 & 0,2 & & \\
\hline Farinha & 22,4 & 16,8 & 22,1 & 7,8 & 16,7 & 11,0 & 11,1 & 4,5 & & \\
\hline Panos de algodão & 30,2 & 12,0 & 11,1 & 1,1 & 0,0 & - & 0,0 & - & & \\
\hline Azeite de Mamona & 47,0 & 0,6 & 100,0 & 0,9 & 0,0 & - & 100,0 & 1,0 & & \\
\hline Aguardente & 9,5 & 0,4 & 100,0 & 5,3 & 100,0 & 5,7 & 100,0 & 8,0 & & \\
\hline Toucinho & 74,2 & 37,9 & 51,3 & 26,7 & 0,8 & 0,5 & 76,9 & 50,0 & & \\
\hline Bois & 76,7 & 8,2 & 100,0 & 18,7 & 72,4 & 6,9 & 100,0 & 13,3 & & \\
\hline TOTAL & 35,3 & 100,0 & 38,0 & 100,0 & 26,0 & 100,0 & 36,3 & 100,0 & & \\
\hline
\end{tabular}


Já o milho que, como vimos, foi bastante representativo em valor produzido, senão majoritário ao longo de todo o lapso estudo, teve percentuais de seu volume exportáveis inferiores, em regra, àqueles expostos na Tabela II.37. Bastante variável, a parcela do milho enviado para São Paulo e Santos esteve em 15-16\% na primeira década do Oitocentos, chegou a $28,8 \%$ em 1814, para não ultrapassar os $10 \%$ no restante da década; na década seguinte encontramos consideráveis 32,7\% em 1825. Para o feijão, os percentuais foram, ainda que variáveis ao longo do tempo, bem mais consideráveis que aqueles encontrados para o milho: 29,8\% em 1799, elevando-se a 61,3\% em 1815 e chegando ao término do período (1826) em 49,2\%.

Destarte, o milho teve participação de variável monta no valor do percentual exportado até 1822: mínimo de 4,6\% em 1814 e máximo de 18,1\% em 1804. Em 1825 esse percentual era de $28,7 \%$, e já no ano seguinte o milho foi a principal fonte de receitas no comércio regional atibaiense, com participação de $55,7 \%$ no valor vendido a outros mercados.

A se ter em consideração os dados para a mercantilização do milho apresentados na Tabela II.39, a venda desse gênero foi explicitada para indivíduos em todas as faixas de volume de produção, mas com especial referência a chefes de unidade domiciliares responsáveis pela colheita de 100,1 a 300 alqueires, encontrados nesse mercado em maior número a partir de 1803.

Como era de se esperar, dadas as observações acerca da Tabela II.40, as transações envolvendo milho ocorriam na localidade, em São Paulo e em Santos. Na localidade as transações incluíam as próprias unidades produtivas, onde percentual importante, por vezes majoritário, era vendido. Os atibaienses que no recenseamento explicitaram a venda do milho o haviam feito em $61,4 \%$ na "terra" em 1808, onde foram vendidos $62,1 \%$ do grão claramente levado ao mercado. O número menções a "vendeu na terra", em que pese o pequeno número de informações para alguns anos, teve um mínimo em $1826,25 \%$ por $1799,28,1 \%$ e por $1803,41,2 \%$. Os percentuais aí negociados foram de ao menos de $29,4 \%$ em 1826, e máximo de $67,7 \%$ em 1803, ano em que 34 indivíduos forneceram esta informação. (cf. Tabela II. 42)

Como mencionamos ao estudar Jundiaí, decerto parte desse comércio estava ligado a outros indivíduos da localidade não arrolados como agricultores, que recorriam os domicílios recolhendo a produção ou lavradores que, como José de Siqueira Franco que colheu 150 alqueires de milho e comprou 37 alqueires (cf. Lista Nominativa de Atibaia, 1808 - AESP, Maços de População/rolo 15), necessitavam complementar a produção em seus domicílios realizada. 
Tabela II.42

Local de venda do milho

(Atibaia - 1799 a 1829)

\begin{tabular}{|c|c|c|c|c|c|c|}
\hline \multirow{2}{*}{ Anos } & \multicolumn{2}{|c|}{ Cidade } & \multicolumn{2}{|c|}{ Terra } & \multicolumn{2}{|c|}{ Total } \\
\hline & № (\%) & Alq. (\%) & № (\%) & Alq. (\%) & № (\%) & Alq. (\%) \\
\hline 1799 & $23(71,9)$ & $852(65,2)$ & $9(28,1)$ & $455(34,8)$ & $32(100,0)$ & $1307(100,0)$ \\
\hline 1803 & $20(58,8)$ & $1815(32,3)$ & $14(41,2)$ & $3800(67,7)$ & $34(100,0)$ & $5615(100,0)$ \\
\hline 1808 & $17(38,6)$ & $4041(37,9)$ & $27(61,4)$ & $6617(62,1)$ & $44(100,0)$ & $10658(100,0)$ \\
\hline 1812 & $7(46,7)$ & $3350(57,8)$ & $8(53,3)$ & $2450(42,2)$ & $15(100,0)$ & $5800(100,0)$ \\
\hline 1816 & $3(42,9)$ & $1700(46,6)$ & $4(57,1)$ & $1950(53,4)$ & $7(100,0)$ & $3650(100,0)$ \\
\hline 1820 & $12(48,0)$ & $3760(51,2)$ & $13(52,0)$ & $3580(48,8)$ & $25(100,0)$ & $7340(100,0)$ \\
\hline 1826 & $9(75,0)$ & $2755(70,6)$ & $3(25,0)$ & $1150(29,4)$ & $12(100,0)$ & $3905(100,0)$ \\
\hline 1829 & $6(40,0)$ & $2474(41,8)$ & $9(60,0)$ & $3445(58,2)$ & $15(100,0)$ & $5919(100,0)$ \\
\hline
\end{tabular}

Fonte: AESP, M aços de População, Atibaia: anos selecionados

Se comparadas as quantidades percentuais exportadas de milho e o montante total produzido do mantimento, é possível observarmos uma relação inversa entre percentual exportado e volume produzido. Seria de se esperar, em que pese o decréscimo da população atibaiense observada no capítulo anterior, que mantida determinada média de consumo dos habitantes da vila, maior produção levaria a maiores excedentes comercializáveis, implicando, em termos percentuais, em uma relação direta entre produção e percentual do valor exportado. No entanto, nos momentos de maior produção de milho os volumes exportados foram menores, enquanto naqueles momentos em que a produção retraiu-se o percentual exportado ampliou-se. É possível supormos, então, que essa produção exportada, era produzida com essa finalidade e que vendas em outros mercados não dependiam, necessariamente, de excedentes.

Interessante notar que o pico da produção do milho em 1805 ocorreu logo após o grão atingir seu maior preço real médio no mercado externo à vila - preço deflacionado a partir daqueles apresentados nos documentos: média aritmética entre preços máximos e mínimos -, qual seja, \$614 por alqueire em 1804. Provavelmente este seria um indicativo de elevados ganhos com o produto que viu sua produção aumentada, o que por conseqüência levou a drástica redução dos preços do milho em período de tão somente um ano: em 1805 o preço médio do milho exportado foi de $\$ 229$, uma queda de $63 \%$ com relação ao ano imediatamente anterior. (vide Gráfico II.14) 


\section{Gráfico II.14}

\section{Evolução do preço real médio do milho}

(Atibaia - 1798 a 1829)

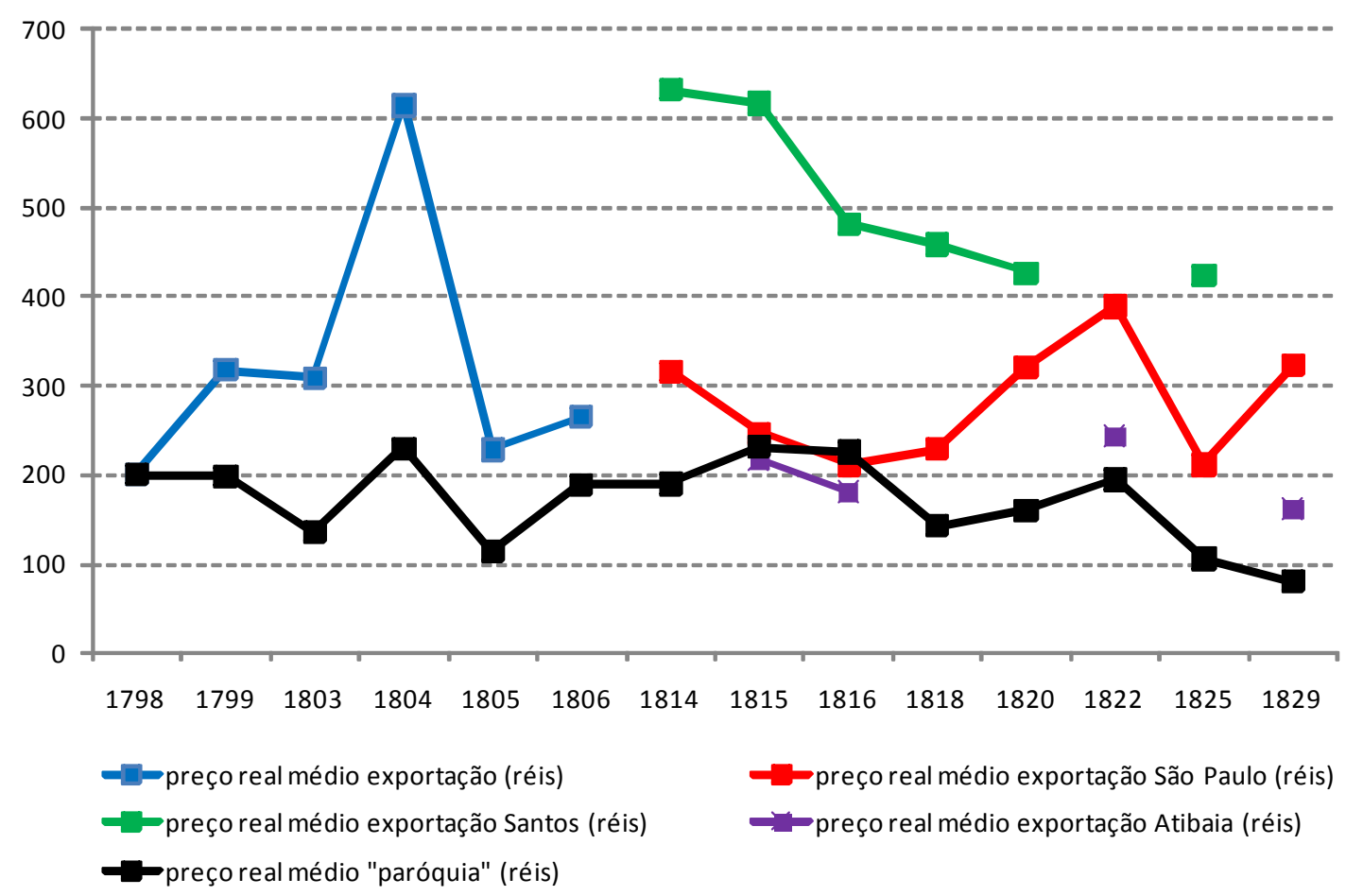

Note-se, ademais, as diferenças significativas entre os preços reais médios para consumo em Atibaia ou na localidade de destino da exportação (mormente São Paulo e Santos, como se verá), assim como entre elas. Certamente parte desta diferença era devida às margens de comércio e transporte. Apenas em 1815 e 1816 os preços do milho em Atibaia e em São Paulo foram praticamente coincidentes. Mas, salta aos olhos a diferença entre esses preços e os preços apontados para a vila de Santos, mais distante de Atibaia é certo, mas uma diferença que não justificaria discrepâncias de até $100 \%$ nos números. Possivelmente, entra aqui o fato de que grande parte do comércio com Santos tinha como destino final outros locais mais distantes, aonde o milho chegaria por transporte de cabotagem partindo daquele porto.

Também para Atibaia o toucinho, que teve seu percentual vendido a outras praças elevado e variando em amplo intervalo que esteve, em regra, entre 47,7\% (1799) e 83,2\% (1805 e 1814), foi o principal responsável pelas receitas de exportação.

Resta acrescermos aos gêneros até o momento mencionados os animais em pé e seu comércio. Poucos muares foram criados na localidade (apenas em 1804, 100\% dos animais arrolados na produção da localidade foram exportados). Todavia, era grande este 
comércio na localidade, como se nota nos mapas de produção. Ao que parece os animais eram levados a Atibaia desde o mercado de Curitiba - com possibilidades chegarem a Curitiba vindos do RS - e reexportados para São Paulo. Em alguns momentos, $100 \%$ dos animais arrolados na produção da localidade foram exportados e esse valor corresponde exatamente ao montante de animais importados de Curitiba.

Essa atividade decerto não era generalizada como ocorria com a plantação, mas pode ter gerado alguns frutos para os poucos que a praticavam, que poderiam intermediar também a venda de vacum. Entre aqueles apontados em outro momento como negociantes, encontramos negociantes de animais, esses possivelmente aqueles responsáveis por esse comércio. Foi este o caso, especialmente verificado para alguns indivíduos em 1808: Salvador Nascimento Franco declarou viver de "venda e compra de animais que rende até 100000/ano" e havia plantado milho e feijão "para seu sustento"; assim como o também produtor de milho e feijão Ignácio Alves do Amaral que "vive de compra e venda de animais que rendeu 90000 por ano"; e Joaquim Franco de Camargo que "vive de negócio de comprar e vender animais pode ter renda no ano de 10000". Ou João Gonçalves que em 1808 "tem sua tropa e vende e compra cavalo". Ou ainda, no mesmo ano, Francisco Franco que colheu 200 alqueires de milho e "tem criação de éguas e vive delas e suas crias" (Lista Nominativa de Atibaia, 1808 - AESP, Maços de População/rolo 15)

Não só muares e gado vacum eram comercializados. Como adiantado, apesar de pouco mencionar o toucinho as listas nominativas propriamente apontam importante presença dos porcos, que originavam o toucinho, mencionados quando de sua comercialização na quase totalidade das vezes em que aparece nos recenseamentos. Dados para a comercialização de capados estão dispostos nas Tabelas II.43 e II.44.

Tabela II.43

Local de venda de capados

(Atibaia - 1799 a 1829)

\begin{tabular}{|c|c|c|c|c|c|c|}
\hline \multirow{2}{*}{ Anos } & \multicolumn{2}{|c|}{ Cidade } & \multicolumn{2}{|c|}{ Terra/Casa } & \multicolumn{2}{|c|}{ Total } \\
\hline & № fogos(\%) & № animais(\%) & № fogos (\%) & № animais (\%) & № fogos(\%) & № animais (\%) \\
\hline 1799 & $3(25,0)$ & $10(2,9)$ & $9(75,0)$ & $333(97,1)$ & $12(100,0)$ & $343(100,0)$ \\
\hline 1808 & $41(77,4)$ & $619(84,9)$ & $12(22,6)$ & $110(15,1)$ & $53(100,0)$ & $729(100,0)$ \\
\hline 1820 & $32(57,1)$ & $375(46,5)$ & $24 \quad(42,9)$ & $432(53,5)$ & $56(100,0)$ & $807(100,0)$ \\
\hline 1826 & $7(77,8)$ & $89(74,8)$ & $2(22,2)$ & $30(25,2)$ & $9(100,0)$ & $119(100,0)$ \\
\hline 1829 & $2(22,2)$ & $72(39,1)$ & $7 \quad(77,8)$ & $112(60,9)$ & $9(100,0)$ & $184(100,0)$ \\
\hline
\end{tabular}

Fonte: AESP, M aços de População, A tibaia: anos selecionados, exclusive 1803, 1812 e 1816 
Tabela II.44

Estatísticas para a venda de capados

(Atibaia - 1799 a 1829)

\begin{tabular}{cccccccc}
\hline \hline Estatísticas & 1799 & 1803 & 1808 & 1816 & 1820 & 1826 & 1829 \\
\hline № de animais & 498 & 964 & 780 & 785 & 1111 & 497 & 394 \\
№ de fogos & 20 & 68 & 61 & 64 & 71 & 24 & 12 \\
Média & 24,9 & 14,2 & 12,8 & 12,3 & 16,0 & 20,7 & 32,8 \\
Moda & 4 e 40 & 4 & 4 & 5 & 4 e 10 & 4 e 14 & 100 \\
Mediana & 13 & 10 & 6 & 8 & 10 & 14 & 25 \\
Índice de Gini & 0,565 & 0,484 & 0,551 & 0,881 & 0,461 & 0,495 & 0,482 \\
Mínimo & 2 & 2 & 1 & 1 & 2 & 3 & 4 \\
Máximo & 150 & 113 & 70 & 69 & 94 & 100 & 100 \\
\hline \hline Fonte: AESP, Maços de População, A tibaia: anos selecionados, exclusive 1812 &
\end{tabular}

Fonte:AESP, M aços de População, A tibaia: anos selecionados, exclusive 1812

O maior número de animais foi registrado em 1820: 1111. Em média cada um dos 71 criadores/vendedores comercializou neste ano 16 cabeças do animal, tendo a menor negociação envolvido apenas dois porcos e a maior 94. O maior negócio de 1820 representava um número menor de animais que aquele levado ao mercado em outros anos, em especial, 1799 no qual encontramos entre os 20 criadores/produtores Angelo Franco Correa com a descrição "vendeu 150 capados a 2500 na terra" (Lista Nominativa de Atibaia, 1799 - AESP, Maços de População/rolo 13) A maior parte dos indivíduos, entretanto, levava ao comércio poucos animais, sendo a moda quatro verificada para diferentes momentos - em que foge 1820, com moda 100 (tão somente dois indivíduos) para a comercialização de animais, mas na presença de apenas 12 casos, ressalte-se. A presença dos grandes vendedores elevava a média, cuja menor valor foi calculado em 1816, 12,8, valor equivalente ao de 1816, 12,3 capados.

Para os anos com maiores informações acerca do local da comercialização, 1808 e 1820, temos resultados diferenciados. Em 1808 77,4\% das transações se deram na cidade onde foram vendidos $85 \%$ dos animais no referido ano. Já em 1820 , a maior parte dos animais havia sido vendida "na terra" ou "em casa" (53,5\%), ainda que fosse elevada a participação da cidade, tendo sido responsáveis pelas vendas 42,9\% dos chefes envolvidos, em pequena ou grande medida, na comercialização de porcos. ${ }^{52}$

\footnotetext{
${ }^{52}$ Apenas em 1829 "cidade" refere-se a Santos.
} 
Produtora e vendedora de diversos gêneros, em especial mantimentos, Atibaia ainda precisava importar grande parte daquilo que consumia. Estes bens vindos de outros locais respondiam por uma absorção de importações, mostrada na Tabela II.45, que chegou a 0,59 em 1799, tendo seu mais alto valor em 1806 quando foi de 0,76. Ou seja, quase $80 \%$ do valor de tudo aquilo que foi consumido na localidade no ano de 1808 era proveniente de outras paragens. E esse montante foi, no entanto, bastante variável tendo seus mínimos em $1825(0,19)$ e $1818(0,20)$.

Da mesma maneira, os coeficientes de exportação também apresentaram valores bastante diferentes em cada um dos anos observados, mas com amplitude de mudança um pouco inferior às observadas para o coeficiente de importações: mínimo de 0,23 em 1804 e máximo no ano subseqüente (1805), 0,50. A ampliação em alguns momentos do coeficiente de exportações deveria ser implicação de ampliação da produção para consumo local, que tornou a localidade menos dependente de importações e capaz de gerar maiores excedentes comercializáveis.

\section{Tabela II.45}

\section{Coeficientes de exportação e importação}

(Atibaia - 1799 a 1829)

\begin{tabular}{ccc}
\hline \hline Anos & $\begin{array}{c}\text { Coeficiente de } \\
\text { exportação* }\end{array}$ & $\begin{array}{c}\text { Penetração das } \\
\text { importações }\end{array}$ \\
\hline 1799 & 0,29 & 0,59 \\
1803 & 0,33 & 0,35 \\
1804 & 0,23 & 0,30 \\
1805 & 0,50 & 0,47 \\
1806 & 0,32 & 0,76 \\
1815 & 0,27 & 0,34 \\
1816 & 0,27 & 0,44 \\
1818 & 0,33 & 0,20 \\
1820 & 0,33 & 0,25 \\
1822 & 0,35 & 0,41 \\
1825 & 0,38 & 0,19 \\
1826 & 0,26 & - \\
1829 & 0,36 & - \\
\hline \hline *valor das exportações/valor da produção & \\
** valor das importações/valor do consumo & \\
Fonte: AESP, Maços de População - Mapas de produção e comércio, \\
Atibaia: anos selecionados
\end{tabular}


Eram importados por São João de Atibaia sal, vinho, tecidos diversos, chapéus, fumo, ferramentas, chegados à localidade oriundos dos portos do Rio de Janeiro e Santos, e da cidade de São Paulo. Ademais, Atibaia recebia fumo das Gerais, especialmente a partir de 1814, e bestas. (vide tabela no apêndice estatístico) Estas, como adiantado, encontravam em Atibaia (e/ou em atibaienses) intermediação comercial.

São Paulo foi, assim como Santos, o exportador mais constante, sendo relacionado em todos os anos para os quais pudemos obter informações de importações de gêneros por Atibaia. Os percentuais apresentados por estas localidades no valor das importações locais, como não surpreende, flutuaram em medida importante entre cada um dos anos. Importa notar que a importação de muares por Atibaia respondia pelo grande percentual devido a Curitiba, que no limite inferior foi de $14,3 \%$, ainda na presença marcante do comércio fluminense no Setecentos (78\% das importações em 1799), e de $36,1 \%$ ao final do período, com $36,1 \%$, com máximo de $93,4 \%$ em 1806 . A sua vez, Minas Gerais, importante importador em tempos mais antigos do Setecentos, passou a exportador de $0,8 \%$ a $15,7 \%$ do valor dos bens comprados por Atibaia na década de 1814 e 1825.

Tabela II.46

Percentual do valor importado de acordo com a origem

(Atibaia - 1799 a 1825)

\begin{tabular}{ccccccc}
\hline \hline Anos & $\begin{array}{c}\text { Rio de } \\
\text { Jane iro } \\
\%\end{array}$ & $\begin{array}{c}\text { São Paulo } \\
\%\end{array}$ & $\begin{array}{c}\text { Santos } \\
\%\end{array}$ & $\begin{array}{c}\text { Curitiba } \\
\%\end{array}$ & $\begin{array}{c}\text { Minas } \\
\text { Gerais } \\
\%\end{array}$ & $\begin{array}{c}\text { Total } \\
\%\end{array}$ \\
\hline $\mathbf{1 7 9 8}$ & 32,5 & 60,3 & 7,2 & - & - & 100,0 \\
$\mathbf{1 7 9 9}$ & 78,1 & 3,6 & 3,9 & 14,3 & - & 100,0 \\
$\mathbf{1 8 0 3}$ & 8,6 & 29,5 & 5,2 & 56,8 & - & 100,0 \\
$\mathbf{1 8 0 4}$ & - & 38,7 & 7,5 & 53,8 & - & 100,0 \\
$\mathbf{1 8 0 5}$ & - & 36,3 & 4,5 & 59,2 & - & 100,0 \\
$\mathbf{1 8 0 6}$ & 1,3 & 4,5 & 0,8 & 93,4 & - & 100,0 \\
$\mathbf{1 8 1 4}$ & - & 24,3 & 11,9 & 61,0 & 2,9 & 100,0 \\
$\mathbf{1 8 1 5}$ & - & 32,5 & 12,9 & 51,1 & 3,6 & 100,0 \\
$\mathbf{1 8 1 6}$ & - & 7,1 & 4,1 & 85,7 & 3,0 & 100,0 \\
$\mathbf{1 8 1 8}$ & - & 38,6 & 4,4 & 50,7 & 6,2 & 100,0 \\
$\mathbf{1 8 2 0}$ & - & 35,3 & 6,5 & 42,4 & 15,7 & 100,0 \\
$\mathbf{1 8 2 2}$ & - & 26,6 & 3,6 & 69,0 & 0,8 & 100,0 \\
$\mathbf{1 8 2 5}$ & - & 32,8 & 28,6 & 36,1 & 2,6 & 100,0 \\
\hline \hline Fonte:AESP,M Maços de População - Mapas de produção e comércio, Atibaia & &
\end{tabular}


Não deixam de ser notáveis, contudo, as importações provenientes da capital da capitania/província de São Paulo, certamente o principal ponto de apoio mercantil atibaiense no século XVIII, com parcelas significativas de participação tanto nas vendas como nas aquisições realizadas pela vila. Mesmo não superando o valor devido aos muares, a cidade chegou a responder por mais de $38 \%$ os gêneros comprados por Atibaia em 1804 e 1818.

Dado ser grande parte da pauta de importações da vila em estudo composta por produtos "industrializados", chegados também de regiões distantes como Portugal, suas relações comerciais para além das suas fronteiras foram bastante deficitárias. Apenas em 1798 Atibaia apresentou resultado positivo em sua balança, tão somente 594\$000. Em nenhum outro momento até 1825 esse resultado foi favorável aos gêneros locais. Chama a atenção o ano de 1806 no qual, em termos reais, a diferença entre as exportações e as importações foi de quase 52:000\$000 a favor das importações, valor bastante elevado e equivalente a duas vezes o valor do segundo maior déficit, identificado em 1799, 26:050\$000.

\section{Gráfico II.15}

\section{Saldo do balanço comercial}

(Atibaia - 1798 a 1825)

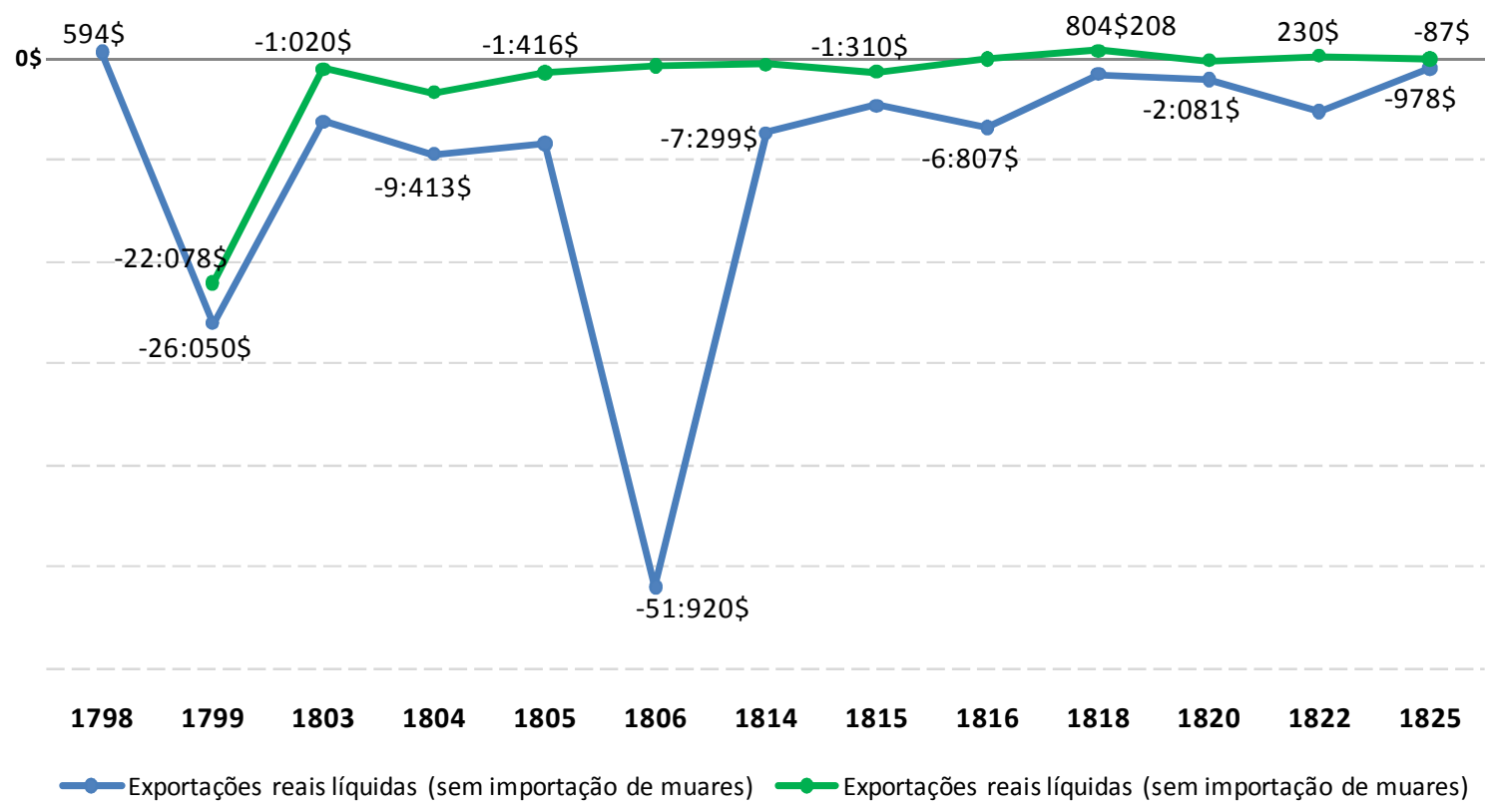


Em se desconsiderando a importação de muares para revenda, as diferenças seriam mais modestas. Em 1806, as importações bestas de Curitiba, como adiantado, superou os $93 \%$ do valor total importado por Atibaia, desconsiderado os mais de 51:000\$000 atinentes a este comércio, o déficit cairia a 757\$000.

Temos em Atibaia, então, um comércio de exportação, ainda que presente em todo o lapso estudado, incapaz de gerar divisas para financiar inteiramente seu consumo de importados. Decerto estes sucessivos déficits não eram sustentáveis, mas os dados que possuímos não permitem avançarmos na questão do crédito, que deveria explicar a possibilidade de tais balanças comerciais.

Por fim, resta-nos evidenciar a presença em Atibaia de chefes de fogo declarados pobres, indigentes ou vadios. Foi elevada a participação destes indivíduos, mormente ao final do século XVIII, quando os 76 indivíduos a chefiar domicílios assim declarados respondiam por $12,2 \%$ do total de fogos recenseados em Atibaia. Em 1808, o percentual de despossuídos era de 10,8\%, e mesmo após decréscimo em anos seguintes, chegou ao final do período com percentuais de 6,1\% em 1826 e 4,9\% em 1829.

\section{Gráfico II.16}

Número absoluto de chefes despossuídos e sua participação percentual no número total de domicílios

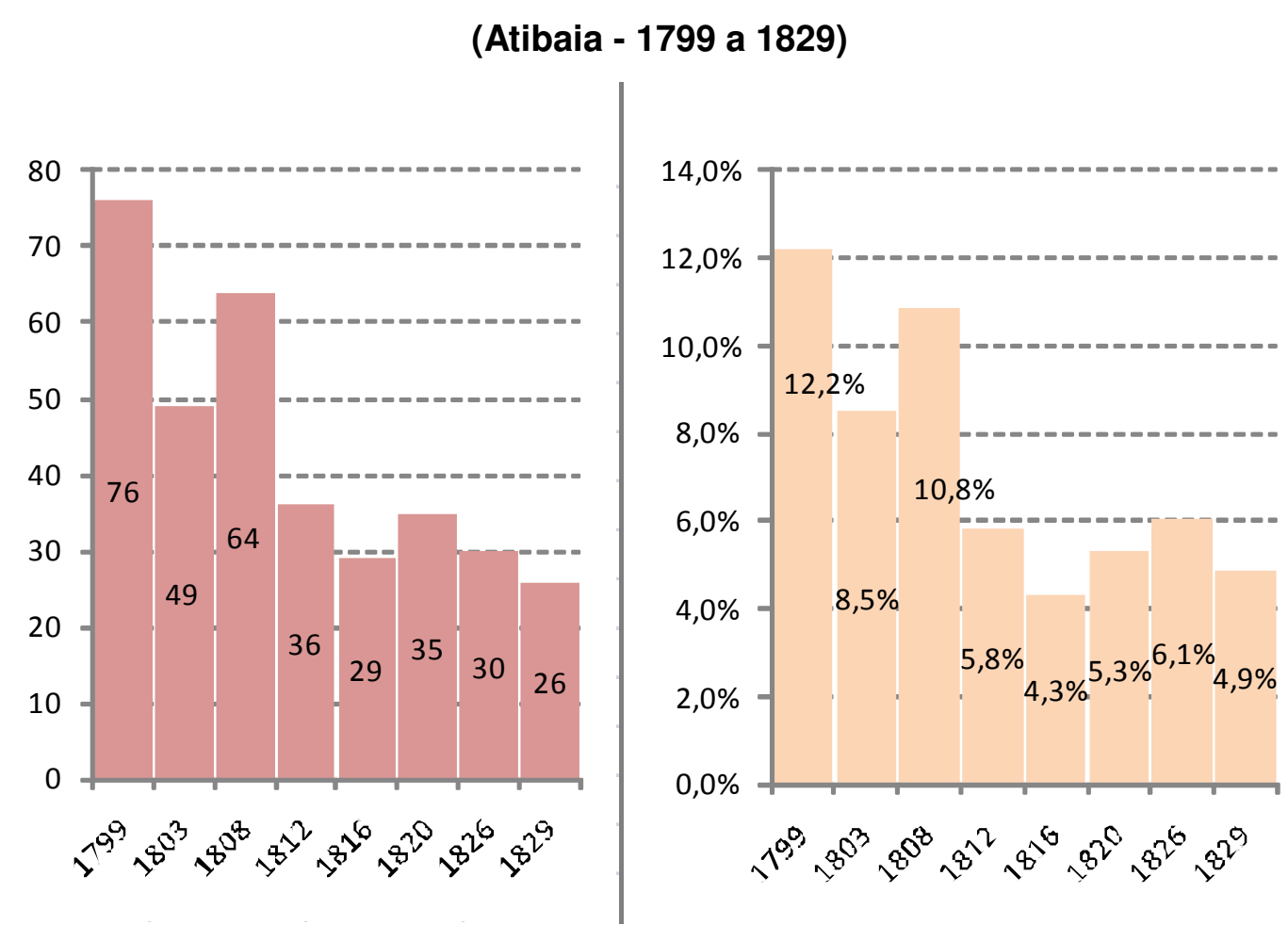




\section{$\underline{\text { Nazaré }}$}

A freguesia de Nazaré, entre 1799 e 1829, apresentou estrutura produtiva baseada, em sua quase totalidade, em atividades vinculadas ao setor agricultura e manufatura rural, conforme se nota na Tabela II.47. Os dados levantados nos arrolamentos populacionais da localidade apontam para todos os anos Oitocentistas, atividades tipicamente rurais tais como lavradores, lavradores para seu sustento e criadores, em ao menos $90 \%$ das unidades domiciliares computadas e com alguma descrição de ocupação para seu chefe - como tem sido recorrente, observações para os demais membros dos fogos e suas atividades paralelas àquela principal anotada se encontradas, o foram pontualmente.

\section{Tabela II.47}

\section{Distribuição dos fogos por setores de atividade econômica}

- exclusive militares em múltiplas ocupações -

(Nazaré - 1799 a 1829)

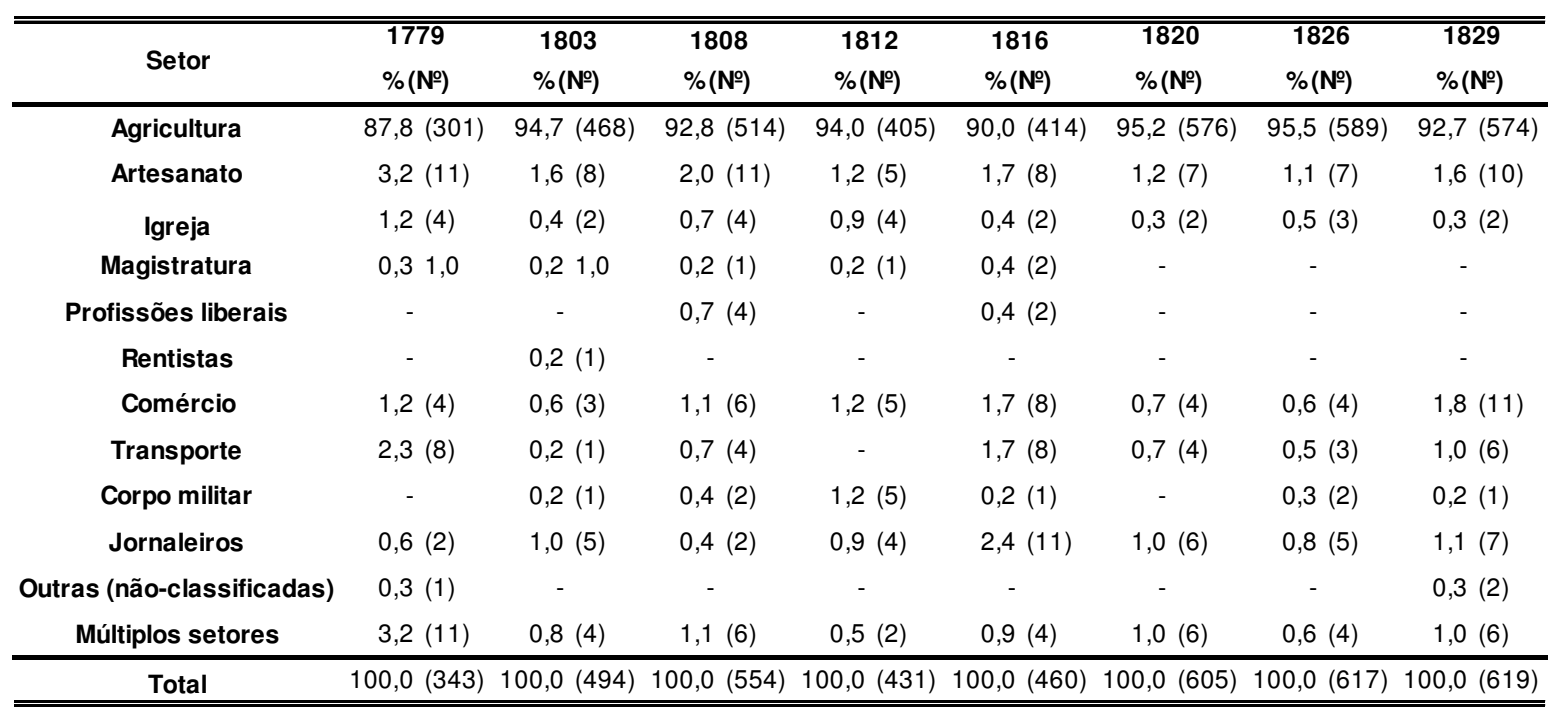

Exclusive pobres, indigentes e chefes de fogo sem ocupação declarada

Fontes: AESP, Maços de População, Nazaré: anos selecionados

O percentual apontado é devido ao ano de 1816 no qual aparece na maior proporção de todo o período a atividade de jornaleiros, indivíduos sem ocupação definida a vender sua capacidade de trabalho, representados por 11 chefes respondendo, então, por $2,4 \%$ dos domicílios em tela. Os demais percentuais a contar de 1803 foram bastante constantes e tiveram seu mínimo em 1808, 92,8\% e seus maiores valores em 1820 $(95,2 \%)$ e $1826(95,5 \%)$. Isto indica, para os demais setores considerados em seu 
conjunto, presença máxima em até $10 \%$ dos fogos. Com diferentes medidas para cada setor ao longo dos anos - à exceção da descrição pontual de um único rentista encontrado em todo o lapso observado e dos profissionais liberais resumidos a três advogados e um jornalista em 1808 e o mesmo jornalista e um professor em 1816 - todos os setores estiveram presentes nos diferentes momentos da freguesia, afinal ainda não deixavam de ser necessários ao funcionamento da localidade enquanto freguesia. Os diferentes setores não apresentaram tendências claras de longo prazo e nenhum deles chegou a ter representatividade importante.

Apenas em 1799 o percentual foi pouco inferior, 87,8\%, decorrente da participação na composição dos setores de atividade econômica do artesanato, dos múltipos setores e do transporte. O artesanato ocupava $3,2 \%$ dos chefes de domicilio naquele momento, eram cinco mulheres ligadas à fiação e tecelagem, ademais de um sapateiro, três tecelões, um alfaiate e um louceiro. Participação idêntica àquela verificada para os indivíduos em múltiplos setores que iam de um eclesiástico lavrador a um negociante sapateiro. A sua vez, os seis chefes ligados ao transporte, ou seja, tropeiros, respondiam por 2,3\% dos fogos em 1799; restando aos demais setores (igreja, magistratura, comércio, jornal e não classificadas) em seu conjunto $3,6 \%$ das unidades domiciliares nazareanas.

Note-se que os dados apresentados foram levantados a partir da exclusão, entre os múltiplos setores, daqueles indivíduos vinculados ao serviço militar em suas diversas formas. Se descrições do corpo militar, tropa paga ou não, e ao mesmo tempo de outros setores forem consideradas, encontramos os dados apresentados na Tabela II.48.

Tal procedimento amplia a participação dos múltiplos setores em todos os anos: em 1799 a participação passou a quase um quinto dos fogos, 18,4\% do total, enquanto em 1803 foi de 15,5\% e 14,3\% em 1816; mantendo-se, via de regra, ao redor de $11 \%$ nos demais documentos consultados. Da mesma maneira, é nítida a redução no setor agricultura que passa a ter a menor participação ainda em 1799, 74,9\%, seguida por 1816 $(77,6 \%)$ com os demais anos flutuando entre $80,6 \%$ (1803) e $84,8 \%$ (1826); mas indiscutivelmente percentuais elevados ainda respondendo pelas características primordiais da economia de Nazaré.

Os baixos soldos (quando existiam) somados à facilidade em levar a cabo plantações (especialmente em pequena monta) faziam dos setores agricultura e corpo militar os mais propensos à conjugação. Entre 9,2\% (1808 e 1829) e 13,9\% (1799) dos fogos com observações encontradas eram chefiados por militares dedicados também a cultivos diversos e/ou à pecuária. 
Tabela II.48

Distribuição dos fogos por setores de atividade econômica

(Nazaré - 1799 a 1829)

\begin{tabular}{|c|c|c|c|c|c|c|c|c|}
\hline Setor & $\begin{array}{l}1779 \\
\%(№)\end{array}$ & $\begin{array}{l}1803 \\
\% \text { (№) }\end{array}$ & $\begin{array}{l}1808 \\
\% \text { (№) }\end{array}$ & $\begin{array}{c}1812 \\
\% \text { (№) }\end{array}$ & $\begin{array}{l}1816 \\
\% \text { (№) }\end{array}$ & $\begin{array}{l}1820 \\
\% \text { (№) }\end{array}$ & $\begin{array}{l}1826 \\
\% \text { (№) }\end{array}$ & $\begin{array}{l}1829 \\
\% \text { (№) }\end{array}$ \\
\hline Agricultura & $74,9(256)$ & 80,6 (399) & $83,0(460)$ & $83,8(361)$ & $77,6(357)$ & $84,5(511)$ & $84,8(523)$ & $83,7(518)$ \\
\hline Artesanato & $3,2(11)$ & $1,4(7)$ & $1,8(10)$ & $0,9(4)$ & $1,7(8)$ & $1,0(6)$ & $1,1(7)$ & $1,6(10)$ \\
\hline Igreja & $1,2(4)$ & $0,4(2)$ & $0,7(4)$ & $0,9(4)$ & $0,4(2)$ & $0,3(2)$ & $0,5(3)$ & $0,3(2)$ \\
\hline Magistratura & $0,3(1)$ & $0,2(1)$ & $0,2(1)$ & - & $0,2(1)$ & - & - & - \\
\hline Profissões liberais & - & - & $0,7(4)$ & - & $0,4(2)$ & - & - & - \\
\hline Rentistas & - & $0,2(1)$ & - & - & - & - & - & - \\
\hline Comércio & $0,9(3)$ & $0,2(1)$ & $1,1(6)$ & $1,2(5)$ & $1,5(7)$ & $0,7(4)$ & $0,6(4)$ & $1,3(8)$ \\
\hline Transporte & $0,6(2)$ & $0,2(1)$ & $0,7(4)$ & - & $1,3(6)$ & $0,7(4)$ & $0,5(3)$ & $0,5(3)$ \\
\hline Corpo militar & - & $0,2(1)$ & $0,4(2)$ & $1,2(5)$ & $0,2(1)$ & - & $0,3(2)$ & $0,2(1)$ \\
\hline Jornaleiros & $0,6(2)$ & $1,0(5)$ & $0,4(2)$ & $0,9(4)$ & $2,2(10)$ & $1,0(6)$ & $0,8(5)$ & $1,1(7)$ \\
\hline Outras (não-classificadas) & - & $0,2(1)$ & - & - & - & - & - & $0,3(2)$ \\
\hline Múltiplos setores & $18,4(63)$ & $15,5(76)$ & $11,0(61)$ & $11,1(48)$ & $14,3(66)$ & $11,9(72)$ & $11,3(70)$ & $11,0(68)$ \\
\hline Total & $100,0(342)$ & $100,0(495)$ & $100,0(554)$ & $100,0(431)$ & $100,0(460)$ & $100,0(605)$ & $100,0(617)$ & $100,0(619)$ \\
\hline
\end{tabular}

Exclusive pobres, indigentes e chefes de fogo sem ocupação declarada

Fontes: AESP, Maços de População, Nazaré: anos selecionados

Os dados apresentados para os setores de atividades econômica em Nazaré são referentes a parcelas de $90 \%$ dos fogos em 1799 , $87 \%$ para os anos observados na primeira década do Oitocentos, cerca de $80 \%$ em 1820 e 25, e 87\% em 1829. Nos anos de 1812 e 1816, os percentuais foram bem mais reduzidos, respectivamente. $66,6 \%$ e 64,3\%. Esta menor participação observada é devida, em sua maior medida, não à ausência de dados acerca da atividade produtiva dos nazareanos, mas à presença dentre eles de elevado número de pobres e indigentes, como pode ser auferido da observação do Gráfico II.17. 


\section{Gráfico II.17}

Número absoluto de chefes despossuídos e sua participação percentual no número total de domicílios

(Nazaré - 1799 a 1829)
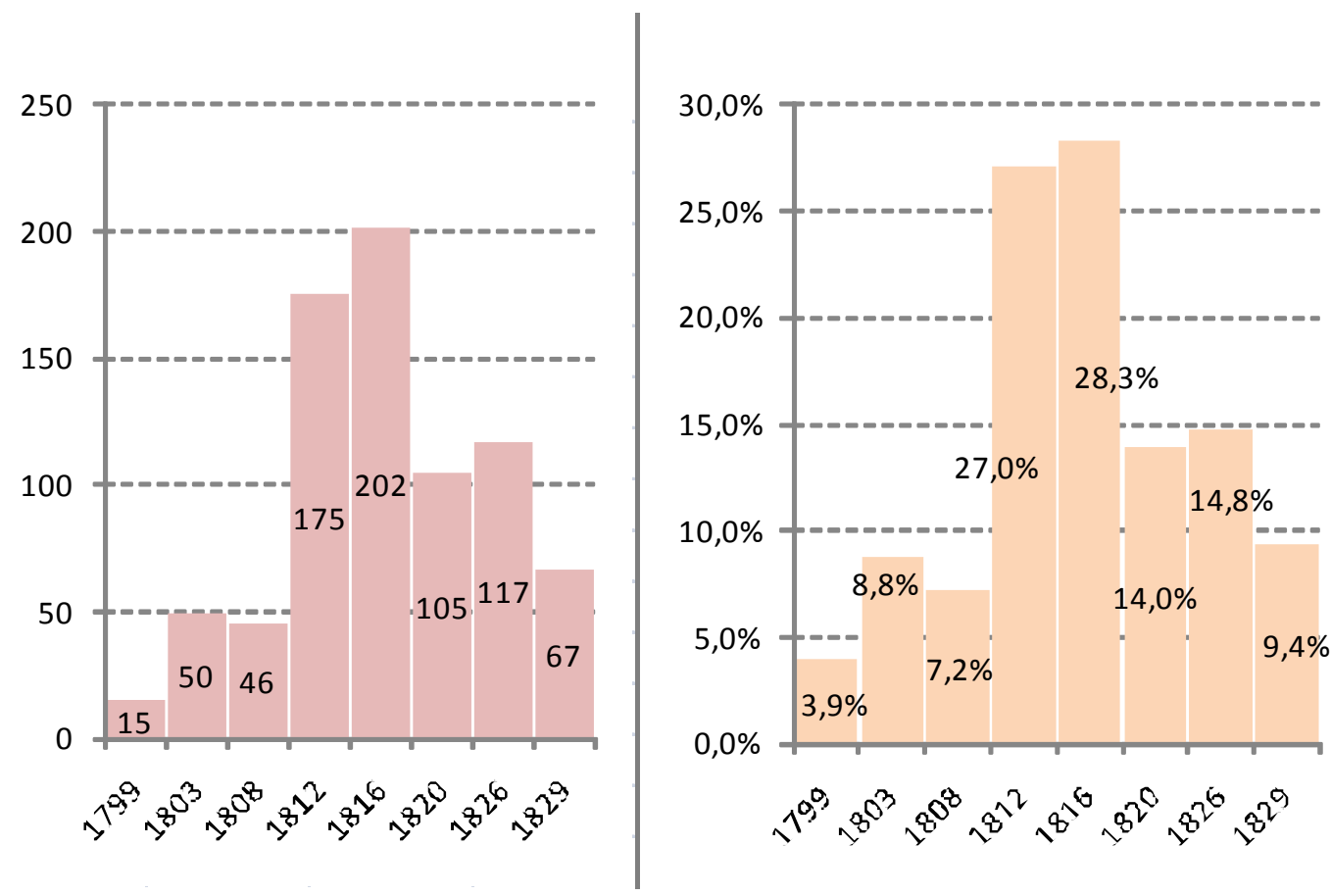

Nos anos de 1812 e 1816 encontramos, em sequência, 175 e 202 indivíduos a chefiar domicílios cujas observações os indicam como pobres, para nós entendidos como aqueles despossuídos de riquezas e à margem do processo produtivo e da relacionada geração de ganhos na freguesia (ainda que tenhamos identificado em 1812 o pobre João Rodrigues Cardoso também exercendo a função de soldado auxiliar, assim como um certo João Paulo em 1826 e Castorino Gomes "cabo pobre" em 1816). Esses números correspondem a percentuais de $27 \%$ e $28,3 \%$ de todos os fogos recenseados na freguesia. Ou seja, mais de um quarto dos fogos nazareanos na década de 1810 era pobre, correspondendo a $24 \%$ e $23 \%$ da população livre total arrolada.

O percentual havia sido baixo ainda no século XVIII, quando $3,9 \%$ dos domicílios eram pobres, para passar a patamares consideráveis nos anos seguintes: manteve-se em $7-9 \%$ em 1803 e 1808 , e entre $14-15 \%$ nos anos de 1820 e 1826, voltando a cair em 1829 $(9,4 \%)$.

Assim, temos a compor as listas nominativas da Freguesia de Nazaré no século XIX, em diferentes momentos e medidas, importante camada dos domicílios com parcas posses. 
Muito provavelmente estas oscilações na participação de fogos nazareanos despossuídos era devida à fragilidade da economia da localidade. Os lavradores locais plantavam, de acordo com os maços de população para os anos selecionados, milho, feijão, algodão, arroz, cana, mandioca e fumo. (Tabela II.49)

\section{Tabela II.49}

Gêneros plantados e presença concomitante dos diferentes gêneros nos fogos

(Nazaré - 1799 a 1829)

\begin{tabular}{lcccccccc}
\hline \hline \multicolumn{1}{c}{ CULTURAS } & $\mathbf{1 7 7 9}$ & $\mathbf{1 8 0 3}$ & $\mathbf{1 8 0 8}$ & $\mathbf{1 8 1 2}$ & $\mathbf{1 8 1 6}$ & $\mathbf{1 8 2 0}$ & $\mathbf{1 8 2 6}$ & $\mathbf{1 8 2 9}$ \\
\hline MILHO & $74,2 \%$ & $88,5 \%$ & $80,7 \%$ & $88,6 \%$ & $85,9 \%$ & $88,0 \%$ & $90,3 \%$ & $88,8 \%$ \\
FEIJÃO & $30,5 \%$ & $17,9 \%$ & $26,0 \%$ & $9,4 \%$ & $9,7 \%$ & $15,1 \%$ & $23,4 \%$ & $13,0 \%$ \\
ALGODÃO & $15,2 \%$ & $7,1 \%$ & $7,2 \%$ & $3,4 \%$ & $4,4 \%$ & $1,3 \%$ & - & $1,2 \%$ \\
ARROZ & - & - & $1,7 \%$ & $3,4 \%$ & $1,9 \%$ & $2,7 \%$ & $1,1 \%$ & $1,2 \%$ \\
CANA & - & $2,8 \%$ & $2,8 \%$ & $2,7 \%$ & $2,4 \%$ & $2,7 \%$ & $1,7 \%$ & $3,6 \%$ \\
MANDIOCA & - & - & - & - & $1,0 \%$ & $0,7 \%$ & $0,6 \%$ & $0,6 \%$ \\
FUMO & - & - & - & - & $1,0 \%$ & $0,3 \%$ & - & $1,2 \%$ \\
\hline \hline
\end{tabular}

Fontes: AESP, Maços de População, Nazaré: anos selecionados

A cana apareceu listada a partir de 1803 , o arroz desde 1808 e a mandioca e o fumo apareceram pela primeira vez em 1816. Esses gêneros surgiram de maneira tímida nos recenseamentos. Dentre as unidades produtivas com cultivares explicitados nos vários anos, não mais de $1 \%$ citaram fumo ou mandioca. O arroz apareceu em maior medida em 1812, cultivado em $3,4 \%$ dos fogos. E a cana esteve presente em aproximadamente $2,5 \%$ dos domicílios até 1820 , seguidos por 1,7\% em 1820 e 3,6\% já ao final da década de 1820 .

A sua vez, encontrado nos documentos desde o primeiro ano consultado, o algodão teve alguma importância (mesmo sendo clara a ausência em medida considerável de fogos cuja atividade principal fosse ligada à sua manufatura), identificada, em especial com este primeiro ano observado em que foi listado em 15,2\% dos fogos. Com tendência nítida à queda com o passar dos anos, encontramos o algodão em pouco mais de 7\% dos fogos em 1803 e 1808, variando a pouco mais de 1\% em 1820 e 1829.

Segundo principal produto local, o feijão foi mencionado de maneira bastante flutuante ao longo do tempo. Em 1779, seu máximo, era encontrado em 30,5\% dos domicílios, já em 1803 sua participação havia caído a 17,9\%, voltou a subir (26\%) decorrido um lustro; esteve acima de $9 \%$ na década de 1810, para encerrar o período estudado em $13 \%$ após ter sido encontrado em 23,4\% dos fogos em 1826. 
Apesar da presença dos cultivares supracitados verificamos, como produção característica dos lavrados de Nazaré, o milho. No limite, o milho chegou a ser encontrado em $90,3 \%$ dos fogos, percentual correspondente ao arrolamento de 1820. Para outros anos esteve bastante próximo a este número: 88-89\% em 1803, 1812, 1820 e 1829. Apenas em 1779 encontramos percentual para o milho cerca de 15 pontos percentuais inferior $(74,2 \%)$ ao que mais comumente pode ser observado para o grão.

De forma distinta às demais localidades até o momento estudadas cujos padrões eram, em diferentes medidas, a policultura, se agrupamos os cultivos (Gráfico II.18) encontramos o milho como única cultura em maioria absoluta das unidades produtivas. Em sua menor participação, 1799 , foi declarado por 55,6\% dos indivíduos e em sua maior participação, coincidente com o limite final do período estudado foi ao único cultivo mencionado por $82,8 \%$ dos lavradores. A conjugação milho mais feijão seguiu o milho em $1779,1808,1812$ e 1826. Nos demais anos o feijão sozinho foi a segunda principal cultura descrita, tendo atingido percentual máximo de participação em 1779: 14\%.

\section{Gráfico II.18}

Percentual de fogos com presença dos diversos gêneros cultivados

(Nazaré - 1799 a 1829)

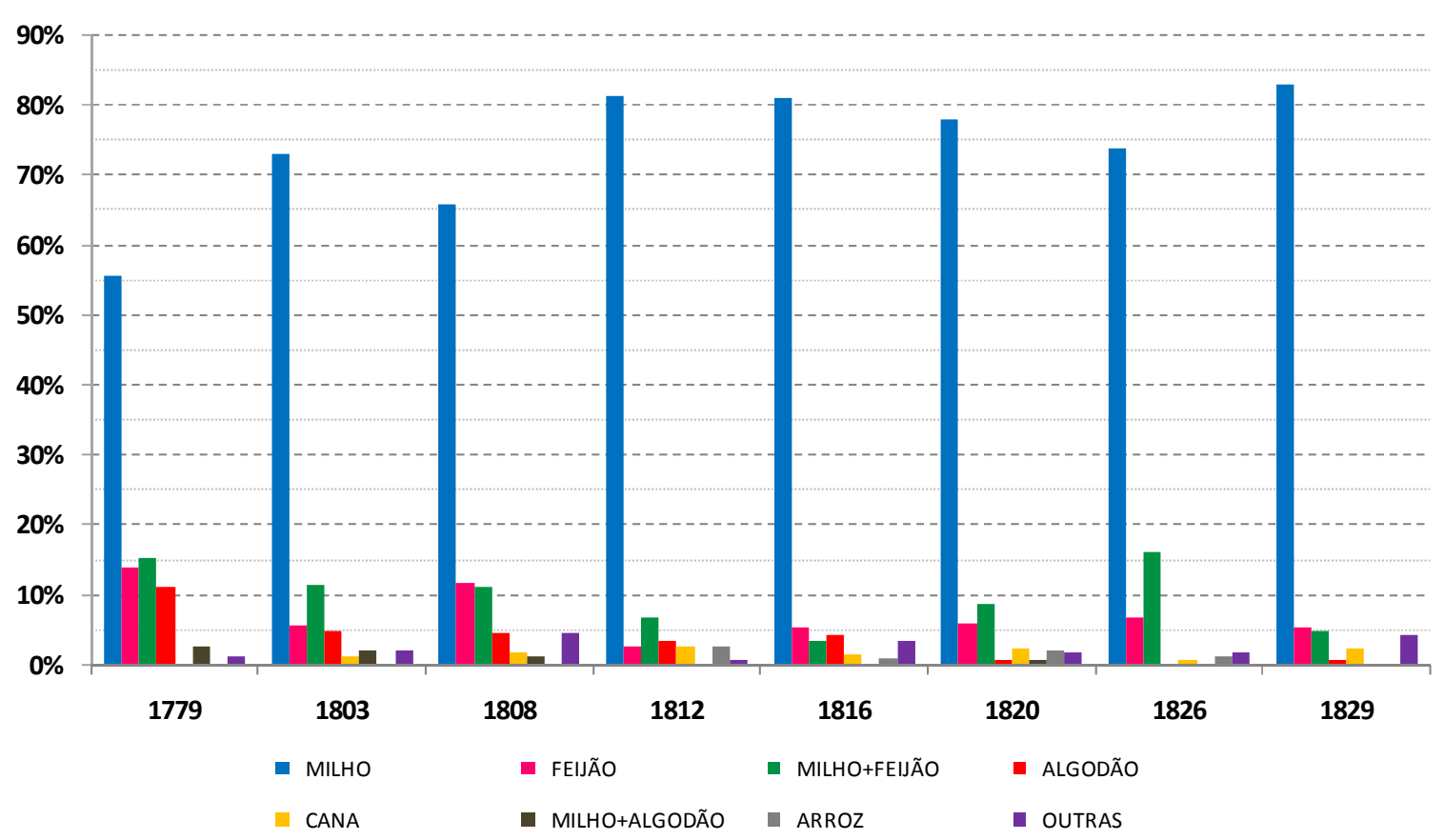

Juntem-se às plantações os animais (Tabela II.50). O tipo de criação levada a cabo foi identificada para no máximo 83 fogos em 1803 (14,6\% do total de domicílios no ano e $17,7 \%$ daqueles no setor agricultura), sendo citada em apenas 19 fogos nos anos 
de 1808,1826 e 1829. Mencionada em maior ou menor medida, característica dessas criações citadas foi ser composta quase que tão somente por capados.

\section{Tabela II.50}

\section{Criações e presença concomitante dos diferentes animais nos fogos \\ (Nazaré - 1799 a 1829)}

\begin{tabular}{|c|c|c|c|c|c|c|c|c|}
\hline CRIAÇÕES & $\begin{array}{l}1779 \\
\% \text { (№) }\end{array}$ & $\begin{array}{l}1803 \\
\% \text { (№) }\end{array}$ & $\begin{array}{c}1808 \\
\% \text { (№) }\end{array}$ & $\begin{array}{c}1812 \\
\% \text { (№) }\end{array}$ & $\begin{array}{l}1816 \\
\% \text { (№) }\end{array}$ & $\begin{array}{c}1820 \\
\% \text { (№) }\end{array}$ & $\begin{array}{l}1826 \\
\% \text { (№) }\end{array}$ & $\begin{array}{l}1829 \\
\% \text { (№) }\end{array}$ \\
\hline VACABBEZERRO & - & - & - & - & $95,8(23)$ & - & - & $5,3(1)$ \\
\hline PORCO/CAPADO & $100,0(30)$ & $96,3(77)$ & $100,0(19)$ & $100,0(43)$ & $4,2(1)$ & $100,0(49)$ & $100,0(19)$ & $94,7(18)$ \\
\hline BESTA & - & $2,5(2)$ & - & - & - & - & - & - \\
\hline $\mathrm{VACA}+\mathrm{CAPADO}$ & - & $1,3(1)$ & - & - & - & - & - & - \\
\hline TOTAL & $100,0(30)$ & $100,0(80)$ & $100,0(19)$ & $(100)(43)$ & $100,0(24)$ & $100,0(49)$ & $100,0(19)$ & $100,0(19)$ \\
\hline
\end{tabular}

O aparecer em poucos fogos está ligado à característica específica das listas nominativas de Nazaré que apresentaram as criações somente quando vendidas, ou seja, os dados apresentados são referentes unicamente à pecuária mercantil. Da mesma maneira podemos estender tal consideração aos cultivares anteriormente citados: apareceram na documentação compulsada sempre acompanhados da descrição "vendeu". Tal constatação pode justificar a presença em pequena medida da policultura, posto que plantações realizadas unicamente para autoconsumo não foram arroladas, mas sabemos presente, inclusive na figura dos chefes de domicilio declarados "lavrador para sustento", maioria dentro do setor agricultura em todos os anos, exceto 1820 (42,9\%).

A produção nazareana pode ser mais bem observada com recurso aos dados encontrados nos mapas de produção. A composição por valor do produto da localidade pode ser visto na Tabela II.51 e foi computada através dos valores da produção apresentados nos próprios mapas. A presença exclusiva de dados comerciais para os produtos nas listagens populacionais justificam sua ausência da tabela.

Assim como ocorreu com Atibaia, houve discrepância entre os dados das listas nominativas e aqueles encontrados nos mapas econômicos que as acompanhavam, mesmo relevando o viés comercial ressaltado para as listas. Como adiantamos "Parte desta diferença se deve ao fato de que os arrolamentos nominativos em muito descreveram milho, enquanto nos mapas de comércio também foi considerável a produção de farinha, que tinha no milho a sua matéria prima principal. Da mesma forma aconteceu com o algodão, citado em boa medida nas listas populacionais propriamente 
ditas, apareceram nos mapas de produção já na forma de tecidos; e com o toucinho, que um dos principais gêneros nos mapas, é obtido através da criação de porcos, bastante presente nas listas nominativas".

Tabela II.51

Participação percentual dos diversos gêneros

no valor da produção

(Nazaré - 1798 a 1829)

\begin{tabular}{|c|c|c|c|c|c|c|c|c|}
\hline Produtos & 1798 & 1799 & 1803 & 1804 & 1805 & 1806 & 1814 & 1815 \\
\hline Milho & 25,8 & 26,0 & 24,1 & 18,8 & 29,5 & 22,8 & 13,0 & 15,4 \\
\hline Feijão & 9,4 & 12,0 & 9,8 & 7,5 & 13,4 & 12,4 & 16,1 & 10,7 \\
\hline Algodão & 5,5 & 7,5 & 12,3 & 6,2 & 13,3 & 8,6 & - & - \\
\hline Arroz & 0,8 & 0,2 & 1,0 & 0,6 & 1,4 & 1,2 & 0,5 & 0,7 \\
\hline Farinha & 17,2 & 17,9 & 16,2 & 11,6 & 25,7 & 13,8 & 25,0 & 25,2 \\
\hline Panos de algodão & - & - & - & - & - & - & 0,3 & 0,4 \\
\hline Azeite de Mamona & - & - & 1,1 & 0,9 & 1,0 & 0,4 & 1,2 & - \\
\hline Aguardente & 9,3 & 18,9 & 7,9 & 11,5 & 15,6 & 16,5 & 16,8 & 18,9 \\
\hline Toucinho & 32,1 & 17,5 & 27,4 & 35,9 & - & 24,3 & 23,6 & 24,9 \\
\hline Potros & - & - & - & 1,5 & - & - & - & - \\
\hline Bois & - & - & - & 3,6 & - & - & 3,5 & 3,9 \\
\hline Bestas & - & - & - & 1,8 & - & - & - & - \\
\hline TOTAL & 100,0 & 100,0 & 100,0 & 100,0 & 100,0 & 100,0 & 100,0 & 100,0 \\
\hline Produtos & 1816 & 1818 & 1820 & 1822 & 1826 & 1829* & & \\
\hline Milho & 11,3 & 14,1 & 13,1 & 15,6 & 20,6 & 36,3 & & \\
\hline Feijão & 10,7 & 12,4 & 11,7 & 15,6 & 15,1 & 13,8 & & \\
\hline Arroz & 0,6 & 0,5 & 1,1 & 0,5 & - & 0,2 & & \\
\hline Farinha & 21,7 & 25,3 & 22,8 & 26,4 & 27,3 & 14,7 & & \\
\hline Panos de algodão & 21,7 & 21,0 & 20,8 & 13,9 & 12,5 & 3,4 & & \\
\hline Azeite de Mamona & 1,0 & 0,8 & 0,7 & 0,8 & 0,7 & 0,4 & & \\
\hline Aguardente & 12,2 & 11,0 & 10,7 & 9,8 & 8,3 & 2,9 & & \\
\hline Toucinho & 18,8 & 9,6 & 12,4 & 11,1 & 8,5 & 23,6 & & \\
\hline Bois & 2,1 & 5,2 & 6,7 & 6,4 & 7,0 & 4,8 & & \\
\hline TOTAL & 100,0 & 100,0 & 100,0 & 100,0 & 100,0 & 100,0 & & \\
\hline
\end{tabular}

O toucinho, relacionado à criação de porcos, e ausente dos arrolamentos populacionais, foi o principal responsável pelo valor dos gêneros produzidos em Nazaré em cinco dentre os oito anos para os quais possuímos os referidos mapas de produção nos três primeiros lustros do Oitocentos, com percentual mais significativo em 1804: $35,9 \%$. O bem respondeu por percentuais variáveis nos demais anos, sendo apenas o sexto gênero em valor no ano de $1818(9,6 \%)$ e o quinto em $1826(8,5 \%)$. 
Na década de 1816 a 1826 a maior parcela era devida à farinha de milho, cujos percentuais variaram dentro do intervalo $21,7 \%$ a 27,3\%. Em 1806 a farinha apresentou seu pior resultado, $13,8 \%$ do produto da freguesia, mostrando-se como quarto principal gênero. Seu correlato, o milho, sem distinguir-se dos demais produtos da terra, apresentou grande flutuação. Em 1799 foi o principal responsável pelo produto com 26\%, assim como o foi em 1805: 29\%. Já na década seguinte não ultrapassou os 15,4\% em 1815, valor equivalente aos $15,6 \%$ atribuídos ao milho em 1822, antes de apresentar-se cinco pontos percentuais acima em 1826. Somados, foram sempre atribuídos ao milho e seu derivado parcela absoluta em 1805 com 55,2\% e 1829 com 51\% (ano em que os dados foram apurados em conjunto com a vila de Atibaia, note-se); e primordial nos demais anos com um mínimo de 30,4\% em 1804.

A sua vez, os panos de algodão tiveram participação efêmera, destacada em 1816, 1818 e 1820, respectivamente, $21,7 \%, 21 \%$ e $20,8 \%$ do valor da produção registrada, em detrimento ao algodão propriamente, presente até 1806 com até $13,3 \%$ do valor total aferido, tendo inclusive, naquele primeiro ano igualado a participação do toucinho. Já o feijão, teve sua maior participação equivalente a $16,1 \%$ dos gêneros produzidos na freguesia no ano de 1814, atingindo montantes semelhantes em 1822 (15,6\%) e 1826 $(15,1 \%)$, anos em que ocupou, em sequência, posições quatro, dois (juntamente com o milho) e três entre os percentuais calculados.

O milho foi levado ao mercado externo comparativamente em pequena medida. $\mathrm{Na}$ virada do século XVIII para o subseqüente, o milho teve em 1798 uma das mais importantes parcelas de sua produção exportada, em 1798, 28,2\% do grão produzido em Nazaré foi consumido por outras localidades, percentual calculado em 10,1\% em 1801, $8,4 \%$ em 1805 e entre os anos de 1814 a 1818 aproximadamente $12 \%$ de seu volume foi exportado, após ter seu maior volume exportado em 1806: 31,6\%. Em 1820, 22 e 26 um cerca de um quinto do milho foi consumido fora da paróquia.

O milho compartiu com a farinha e o toucinho o posto de principal produto responsável pelas divisas auferidas por Nazaré entre 1798 e 1829 . Em 1799 e 1805 encontramos no milho como o principal produto; em 1798, 1803, 1804, 1806 e 1828 o posto foi devido ao milho e nos demais anos à farinha. Com destaque para os panos de algodão que, entre 1816 e 1820 responderam por cerca de $21 \%$ do comércio em análise. Apenas em 1829 os potros cumpriram este papel: 45,9\% do valor das exportações eram devidos ao seu comércio. 
Tabela II.52

Percentual exportado e participação percentual dos diversos gêneros

no valor do produto exportado

(Nazaré - 1798 a 1829)

\begin{tabular}{|c|c|c|c|c|c|c|c|c|c|c|}
\hline \multirow[b]{2}{*}{ Produtos } & \multicolumn{2}{|c|}{1798} & \multicolumn{2}{|c|}{1799} & \multicolumn{2}{|c|}{1803} & \multicolumn{2}{|c|}{1804} & \multicolumn{2}{|c|}{1805} \\
\hline & $\begin{array}{c}\% \text { da } \\
\text { produção } \\
\text { do bem } \\
\text { exportada }\end{array}$ & $\begin{array}{c}\% \text { do valor } \\
\text { total } \\
\text { exportado }\end{array}$ & $\begin{array}{c}\% \text { da } \\
\text { produção } \\
\text { do bem } \\
\text { exportada }\end{array}$ & $\begin{array}{c}\% \text { do valor } \\
\text { total } \\
\text { exportado }\end{array}$ & $\begin{array}{c}\text { \% da } \\
\text { produção } \\
\text { do bem } \\
\text { exportada }\end{array}$ & $\begin{array}{c}\% \text { do valor } \\
\text { total } \\
\text { exportado }\end{array}$ & $\begin{array}{c}\text { \% da } \\
\text { produção } \\
\text { do bem } \\
\text { exportada }\end{array}$ & $\begin{array}{c}\% \text { do valor } \\
\text { total } \\
\text { exportado }\end{array}$ & $\begin{array}{c}\% \text { da } \\
\text { produção } \\
\text { do bem } \\
\text { exportada }\end{array}$ & $\begin{array}{c}\% \text { do valor } \\
\text { total } \\
\text { exportado }\end{array}$ \\
\hline Milho & 28,2 & 25,8 & 16,4 & 26,0 & 10,1 & 24,1 & 12,1 & 18,8 & 8,4 & 29,5 \\
\hline Feijão & 100,0 & 9,4 & 35,0 & 12,0 & 28,1 & 9,8 & 43,8 & 7,5 & 65,4 & 13,4 \\
\hline Algodão & 34,5 & 5,5 & 34,4 & 7,5 & 31,7 & 12,3 & 34,2 & 6,2 & 31,5 & 13,3 \\
\hline Arroz & 52,9 & 0,8 & 7,7 & 0,2 & 28,6 & 1,0 & 42,3 & 0,6 & 6,3 & 1,4 \\
\hline Farinha & 17,9 & 17,2 & 10,8 & 17,9 & 6,0 & 16,2 & 5,6 & 11,6 & 7,4 & 25,7 \\
\hline Panos de algodão & - & - & - & - & - & - & - & - & - & - \\
\hline Azeite de Mamona & - & - & - & - & 41,9 & 1,1 & 51,1 & 0,9 & 36,2 & 1,0 \\
\hline Aguardente & 55,9 & 9,3 & 100,0 & 18,9 & 40,0 & 7,9 & 63,3 & 11,5 & 50,0 & 15,6 \\
\hline Toucinho & 62,6 & 32,1 & 27,6 & 17,5 & 35,2 & 27,4 & 54,5 & 35,9 & - & - \\
\hline Potros & - & - & - & - & - & - & 100,0 & 1,5 & - & - \\
\hline Bois & - & - & - & - & - & - & 55,9 & 3,6 & - & - \\
\hline Bestas & - & - & - & - & - & - & 100,0 & 1,8 & - & - \\
\hline \multirow[b]{3}{*}{ Produtos } & 36,1 & 100,0 & 21,4 & 100,0 & 14,6 & 100,0 & 20,2 & 100,0 & 10,7 & 100,0 \\
\hline & \multicolumn{2}{|c|}{1806} & \multicolumn{2}{|c|}{1814} & \multicolumn{2}{|c|}{1815} & \multicolumn{2}{|c|}{1816} & \multicolumn{2}{|c|}{1818} \\
\hline & $\begin{array}{c}\text { \% da } \\
\text { produção } \\
\text { do bem } \\
\text { exportada }\end{array}$ & $\begin{array}{c}\% \text { do valor } \\
\text { total } \\
\text { exportado }\end{array}$ & $\begin{array}{c}\text { \% da } \\
\text { produção } \\
\text { do bem } \\
\text { exportada }\end{array}$ & $\begin{array}{c}\% \text { do valor } \\
\text { total } \\
\text { exportado }\end{array}$ & $\begin{array}{c}\% \text { da } \\
\text { produção } \\
\text { do bem } \\
\text { exportada }\end{array}$ & $\begin{array}{c}\% \text { do valor } \\
\text { total } \\
\text { exportado }\end{array}$ & $\begin{array}{c}\text { \% da } \\
\text { produção } \\
\text { do bem } \\
\text { exportada }\end{array}$ & $\begin{array}{c}\% \text { do valor } \\
\text { total } \\
\text { exportado }\end{array}$ & $\begin{array}{c}\text { \% da } \\
\text { produção } \\
\text { do bem } \\
\text { exportada }\end{array}$ & $\begin{array}{c}\% \text { do valor } \\
\text { total } \\
\text { exportado }\end{array}$ \\
\hline Milho & 31,6 & 22,8 & 12,1 & 13,0 & 12,5 & 15,4 & 12,4 & 11,3 & 11,3 & 14,1 \\
\hline Feijão & 60,1 & 12,4 & 64,8 & 16,1 & 71,4 & 10,7 & 67,9 & 10,7 & 59,0 & 12,4 \\
\hline Algodão & 28,4 & 8,6 & - & - & - & - & - & - & - & - \\
\hline Arroz & 36,0 & 1,2 & 42,9 & 0,5 & 43,2 & 0,7 & 43,9 & 0,6 & 31,8 & 0,5 \\
\hline Farinha & 6,9 & 13,8 & 19,2 & 25,0 & 17,6 & 25,2 & 20,0 & 21,7 & 19,9 & 25,3 \\
\hline Panos de algodão & - & - & 0,3 & 0,3 & 0,3 & 0,4 & 29,4 & 21,7 & 32,9 & 21,0 \\
\hline Azeite de Mamona & 21,1 & 0,4 & 52,4 & 1,2 & - & - & 50,0 & 1,0 & 47,9 & 0,8 \\
\hline Aguardente & 85,7 & 16,5 & 98,8 & 16,8 & 98,7 & 18,9 & 98,2 & 12,2 & 97,2 & 11,0 \\
\hline Toucinho & 22,8 & 24,3 & 47,4 & 23,6 & 42,7 & 24,9 & 40,5 & 18,8 & 30,8 & 9,6 \\
\hline Potros & - & - & - & - & - & - & - & - & - & - \\
\hline Bois & - & - & 76,9 & 3,5 & 100,0 & 3,9 & 47,1 & 2,1 & 67,6 & 5,2 \\
\hline Bestas & - & - & - & - & - & - & - & - & - & - \\
\hline \multirow[t]{3}{*}{ TOTAL } & 22,1 & 100,0 & 22,6 & 100,0 & 21,6 & 100,0 & 28,1 & 100,0 & 25,6 & 100,0 \\
\hline & \multicolumn{2}{|c|}{1820} & \multicolumn{2}{|c|}{1822} & \multicolumn{2}{|c|}{1826} & \multicolumn{2}{|c|}{1828} & \multicolumn{2}{|c|}{$1829^{*}$} \\
\hline & $\begin{array}{c}\text { \% da } \\
\text { produção } \\
\text { do bem } \\
\text { exportada }\end{array}$ & $\begin{array}{c}\% \text { do valor } \\
\text { total } \\
\text { exportado }\end{array}$ & $\begin{array}{c}\text { \% da } \\
\text { produção } \\
\text { do bem } \\
\text { exportada }\end{array}$ & $\begin{array}{c}\% \text { do valor } \\
\text { total } \\
\text { exportado }\end{array}$ & $\begin{array}{c}\text { \% da } \\
\text { produção } \\
\text { do bem } \\
\text { exportada }\end{array}$ & $\begin{array}{c}\% \text { do valor } \\
\text { total } \\
\text { exportado }\end{array}$ & $\begin{array}{c}\text { \% da } \\
\text { produção } \\
\text { do bem } \\
\text { exportada }\end{array}$ & $\begin{array}{c}\% \text { do valor } \\
\text { total } \\
\text { exportado }\end{array}$ & $\begin{array}{c}\text { \% da } \\
\text { produção } \\
\text { do bem } \\
\text { exportada }\end{array}$ & $\begin{array}{c}\% \text { do valor } \\
\text { total } \\
\text { exportado }\end{array}$ \\
\hline Milho & 20,2 & 13,1 & 17,2 & 15,6 & 23,7 & 20,6 & 0,5 & 1,0 & 9,3 & 11,6 \\
\hline Feijão & 42,0 & 11,7 & 52,9 & 15,6 & 54,8 & 15,1 & 7,8 & 5,7 & 26,5 & 13,3 \\
\hline Algodão & - & - & - & - & - & - & - & - & - & - \\
\hline Arroz & 63,9 & 1,1 & 49,6 & 0,5 & 100,0 & - & 100,0 & 1,2 & 57,1 & 0,3 \\
\hline Farinha & 29,1 & 22,8 & 75,6 & 26,4 & 78,1 & 27,3 & 3,1 & 2,3 & 11,1 & 6,7 \\
\hline Panos de algodão & 37,3 & 20,8 & 30,2 & 13,9 & 30,2 & 12,5 & 12,5 & 2,3 & - & - \\
\hline Azeite de Mamona & 47,8 & 0,7 & 47,9 & 0,8 & 47,9 & 0,7 & - & 1,8 & 52,6 & 0,6 \\
\hline Aguardente & 98,0 & 10,7 & 97,8 & 9,8 & 97,7 & 8,3 & - & 11,3 & 100,0 & 11,8 \\
\hline Toucinho & 30,5 & 12,4 & 27,3 & 11,1 & 24,2 & 8,5 & 34,3 & 34,5 & 58,5 & 45,9 \\
\hline Potros & - & - & - & - & - & - & - & - & - & - \\
\hline Bois & 75,2 & 6,7 & 74,2 & 6,4 & 77,7 & 7,0 & - & 39,8 & 100,0 & 9,8 \\
\hline Bestas & - & - & - & - & - & - & - & - & - & - \\
\hline TOTAL & 34,4 & 100,0 & 38,1 & 100,0 & 40,9 & 100,0 & 21,9 & 100,0 & 28,8 & 100,0 \\
\hline
\end{tabular}

Fonte: AESP, M aços de População - M apas de produção e comércio, Nazaré

*Inclui Atibaia 
O reduzido número de informações nas listas nominativas inviabilizam análises estatísticas mais apuradas para os demais bens além do milho. Mencionado sempre quando de sua comercialização, como adiantado, o milho apresentou em suas transações os montantes característicos apresentados na Tabela II.53 a seguir:

Tabela II.53

Estatísticas para a venda de milho

(Nazaré - 1799 a 1829)

\begin{tabular}{ccccccccc}
\hline \hline Estatísticas & 1799 & 1803 & 1808 & 1812 & 1816 & 1820 & 1826 & 1829 \\
\hline Alqueires & 1979 & 2757 & 1974 & 458 & 1477 & 2643 & 1217 & 2256 \\
№ de fogos & 67 & 113 & 50 & 25 & 46 & 81 & 44 & 32 \\
Média & 29,5 & 24,4 & 39,5 & 18,3 & 32,1 & 32,6 & 27,7 & 70,5 \\
Moda & 5 e 20 & 20 & 20 & 20 & 5 e 30 & 30 & 20 & 20 \\
Mediana & 14 & 16 & 17,5 & 20 & 21 & 24 & 20 & 25 \\
Índice de Gini & 0,574 & 0,485 & 0,681 & 0,292 & 0,539 & 0,439 & 0,393 & 0,664 \\
Mínimo & 3 & 2 & 2 & 5 & 3 & 3 & 2 & 6 \\
Máximo & 300 & 200 & 800 & 50 & 200 & 200 & 100 & 1000 \\
\hline \hline Fonte: AESP, Maços de População, Nazaré: anos selecionados, exclusive 1812 & & &
\end{tabular}

O maior volume de milho levado ao mercado, de acordo com os recenseamentos, foram os 2757 alqueires vendidos em 1803 - observação que deve ser sopesada com o baixo número de observações para anos como 1812 (25) ou 1829 (32). Neste ano cada um dos 113 produtores/vendedores comercializou, em média, 24,4 alqueires do mantimento, sendo as menores negociações realizadas em pequena medida, ou seja, três alqueires, cem vezes menor que a maior transação do ano, contabilizada em 300 alqueires. Esse maior volume foi inferior ao comercializado por João de Oliveira Leme em 1808, 800 alqueires vendidos "na terra", tendo João também explicitado a venda de 100 arrobas de toucinho em Santos. (cf. Lista Nominativa de Nazaré, 1808 - AESP, Maços de População/rolo 15) E em 1829, o capitão comandante José Joaquim de Oliveira declarou a venda de 1000 alqueires de milho - e também de 70 alqueires de feijão, 34 arrobas de algodão e 40 alqueires de arroz -, o que, frente ao mencionado pequeno número de observações, elevou consideravelmente a média para este ano comparativamente aos momentos anteriores: 70,5 alqueires por negociante. (Lista Nominativa de Nazaré, 1829 AESP, Maços de População/rolo 19) 
A maior parte dos chefes de domicílios a vender milho o faziam, de maneira recorrente, em volumes de 20 alqueires, a moda para seis dentre os oito anos analisados. Fogem os anos de 1816 e 1820, com moda igual a 30 alqueires. A mediana, a seu turno, viu-se aumentada de 14 alqueires no Setecentos para 25 alqueires registrados ao final da década de 1820.

Este milho apareceu na documentação compulsada com indicação do local de comercialização conforme vai apresentado na Tabela II.54.

Tabela II.54

Local de venda do milho

(Nazaré - 1799 a 1829)

\begin{tabular}{|c|c|c|c|c|c|c|c|c|}
\hline \multirow{2}{*}{ Anos } & \multicolumn{2}{|c|}{ Cidade } & \multicolumn{2}{|c|}{ Terra } & \multicolumn{2}{|c|}{ Outros } & \multicolumn{2}{|c|}{ Total } \\
\hline & № $(\%)$ & Alqueires(\%) & № $(\%)$ & Alqueires(\%) & № $(\%)$ & Alqueires (\%) & № (\%) & Alqueires(\%) \\
\hline 1799 & $42(68,9)$ & $1042(64,6)$ & $18(29,5)$ & $515(31,9)$ & $1(1,6)$ & $57(3,5)$ & $61(100,0)$ & $1614(100,0)$ \\
\hline 1803 & $55(50,0)$ & $1240(45,2)$ & $46(41,8)$ & $1146(41,8)$ & $9(8,2)$ & $355(13,0)$ & $110(100,0)$ & $2741(100,0)$ \\
\hline 1808 & $16(33,3)$ & $384(19,6)$ & $32(66,7)$ & $1577(80,4)$ & - & - & $48(100,0)$ & $1961(100,0)$ \\
\hline 1812 & $15(62,5)$ & $217(50,7)$ & $9(37,5)$ & $211(49,3)$ & - & - & $24(100,0)$ & $428(100,0)$ \\
\hline 1816 & $21(45,7)$ & $750(50,8)$ & $23(50,0)$ & $695(47,1)$ & $2(4,3)$ & $32(2,2)$ & $46(100,0)$ & $1477(100,0)$ \\
\hline 1820 & $25(31,6)$ & $869(33,9)$ & $49(62,0)$ & $1589(62,0)$ & $5(6,3)$ & $105(4,1)$ & $79(100,0)$ & $2563(100,0)$ \\
\hline 1826 & $8(22,2)$ & $219(23,5)$ & $25(69,4)$ & $633(67,8)$ & $3(8,3)$ & $81(8,7)$ & $36(100,0)$ & $933(100,0)$ \\
\hline 1829 & $3(9,4)$ & $46(3,7)$ & $25(78,1)$ & $1104(87,9)$ & $4(12,5)$ & $106(8,4)$ & $32(100,0)$ & $1256(100,0)$ \\
\hline
\end{tabular}

Os resultados são diferenciados entre os anos quanto ao número de negociações e o volume total envolvido, mas tendente a maior montante de vendas ocorridas na "terra", ou seja, na própria unidade produtiva. Destaca-se, neste sentido, o ano de 1808, em que $66,7 \%$ das transações ocorreram sem movimento espacial do vendedor e foram responsáveis por $80,4 \%$ do volume de milho negociado, ou $1829: 78,1 \%$ das transações e $87,9 \%$ do volume. Já em 1799 , pouco mais de $62 \%$ das negociações aconteceram na "cidade" (entendida aqui como a capital da capitania), onde foram negociados $64,6 \%$ do volume do milho. Também em 1812 percentual majoritário das negociações ocorreu na cidade, mas com percentual de milho negociado, $50,7 \%$, equivalente ao transacionado na terra, $49,3 \%$. Sob a rubrica outros encontramos conjugações entre terra e cidade, e ainda menções a Santos.

Estes dados vão de encontro à relação de produtos exportados e seus destinos, encontrados nos mapas de comércio da freguesia (Tabela II.55) 
Tabela II.55

\section{Gêneros exportados de acordo com o destino}

(Nazaré - 1798 a 1829)

\begin{tabular}{|c|c|c|c|c|}
\hline & "São Paulo & Santos & Mogi & Nazaré \\
\hline 1798 & $\begin{array}{l}\text { milho, feijão, arroz, } \\
\text { farinha, toucinho, } \\
\text { algodão, aguardente }\end{array}$ & $\begin{array}{c}\text { farinha, milho, feijão, } \\
\text { toucinho }\end{array}$ & farinha, toucinho & $\begin{array}{c}\text { algodão, farinha, milho, } \\
\text { feijão, toucinho, } \\
\text { aguardente, arroz }\end{array}$ \\
\hline 1799 & $\begin{array}{l}\text { algodão, farinha, } \\
\text { milho, feijão, } \\
\text { toucinho, arroz, } \\
\text { azeite }\end{array}$ & $\begin{array}{c}\text { farinha, milho, feijão, } \\
\text { toucinho }\end{array}$ & farinha, toucinho & $\begin{array}{l}\text { algodão, farinha, milho, } \\
\text { feijão, toucinho, } \\
\text { aguardente }\end{array}$ \\
\hline 1803 & $\begin{array}{l}\text { algodão, farinha, } \\
\text { milho, feijão, } \\
\text { toucinho, arroz }\end{array}$ & $\begin{array}{c}\text { farinha, milho, feijão, } \\
\text { toucinho }\end{array}$ & $\begin{array}{l}\text { milho, feijão, } \\
\text { farinha, arroz, } \\
\text { toucinho }\end{array}$ & $\begin{array}{l}\text { algodão, milho, feijão, } \\
\text { farinha, arroz, toucinho, } \\
\text { aguardente, azeite }\end{array}$ \\
\hline 1804 & $\begin{array}{l}\text { milho, feijão, arroz, } \\
\text { farinha, toucinho, } \\
\text { azeite, bois }\end{array}$ & $\begin{array}{l}\text { farinha, milho, feijão, } \\
\text { toucinho, arroz }\end{array}$ & toucinho & $\begin{array}{l}\text { algodão, milho, feijão, } \\
\text { farinha, arroz, toucinho }\end{array}$ \\
\hline 1805 & $\begin{array}{l}\text { milho, feijão, arroz, } \\
\text { toucinho, farinha, } \\
\text { azeite }\end{array}$ & $\begin{array}{c}\text { farinha, milho, feijão, } \\
\text { toucinho }\end{array}$ & $\begin{array}{l}\text { milho, feijão, } \\
\text { farinha, toucinho }\end{array}$ & $\begin{array}{l}\text { algodão, milho, feijão, } \\
\text { farinha, arroz, toucinho, } \\
\text { aguardente, azeite }\end{array}$ \\
\hline 1806 & $\begin{array}{c}\text { milho, feijão, farinha, } \\
\text { toucinho, arroz, } \\
\text { azeite }\end{array}$ & $\begin{array}{c}\text { farinha, milho, feijão, } \\
\text { toucinho }\end{array}$ & - & $\begin{array}{l}\text { algodão, milho, feijão, } \\
\text { farinha, arroz, toucinho, } \\
\text { aguardente, azeite }\end{array}$ \\
\hline 1814 & $\begin{array}{c}\text { farinha, milho, feijão, } \\
\text { toucinho, arroz, } \\
\text { azeite }\end{array}$ & $\begin{array}{c}\text { farinha, milho, feijão, } \\
\text { toucinho }\end{array}$ & - & $\begin{array}{l}\text { pano de algodão, farinha, } \\
\text { milho, feijão, toucinho, } \\
\text { arroz, aguardente, azeite }\end{array}$ \\
\hline 1815 & $\begin{array}{c}\text { farinha, milho, } \\
\text { toucinho, arroz, } \\
\text { aguardente, azeite }\end{array}$ & $\begin{array}{c}\text { farinha, milho, feijão, } \\
\text { toucinho }\end{array}$ & - & $\begin{array}{c}\text { pano de algodão, farinha, } \\
\text { milho, feijão, toucinho, } \\
\text { arroz, aguardente, azeite, } \\
\text { bois }\end{array}$ \\
\hline 1816 & $\begin{array}{l}\text { farinha, milho, feijão, } \\
\text { toucinho, arroz, } \\
\text { aguardente, azeite }\end{array}$ & $\begin{array}{c}\text { farinha, milho, feijão, } \\
\text { toucinho }\end{array}$ & - & $\begin{array}{c}\text { vacuns, pano de algodão, } \\
\text { farinha, milho, feijão, } \\
\text { toucinho, arroz, } \\
\text { aguardente, azeite }\end{array}$ \\
\hline 1818 & $\begin{array}{c}\text { farinha, milho, feijão, } \\
\text { toucinho, arroz, } \\
\text { azeite, bois }\end{array}$ & $\begin{array}{c}\text { farinha, milho, feijão, } \\
\text { toucinho }\end{array}$ & - & $\begin{array}{l}\text { algodão, farinha, milho, } \\
\text { feijão, toucinho, arroz, } \\
\text { aguardente, azeite, bois }\end{array}$ \\
\hline 1820 & $\begin{array}{l}\text { vacuns, farinha, } \\
\text { milho, feijão, } \\
\text { toucinho, arroz, } \\
\text { azeite }\end{array}$ & $\begin{array}{c}\text { farinha, milho, feijão, } \\
\text { toucinho }\end{array}$ & - & $\begin{array}{l}\text { vacuns, pano de algodão, } \\
\text { farinha, milho, feijão, } \\
\text { toucinho, arroz, } \\
\text { aguardente, azeite }\end{array}$ \\
\hline 1822 & $\begin{array}{c}\text { farinha, milho, } \\
\text { toucinho, arroz, } \\
\text { feijão, aguardente, } \\
\text { azeite, bois }\end{array}$ & $\begin{array}{c}\text { farinha, milho, feijão, } \\
\text { toucinho }\end{array}$ & - & $\begin{array}{c}\text { pano de algodão, farinha, } \\
\text { milho, feijão, toucinho, } \\
\text { arroz, aguardente, azeite, } \\
\text { bois }\end{array}$ \\
\hline 1828 & $\begin{array}{l}\text { farinha, milho, feijão, } \\
\text { bois }\end{array}$ & milho, toucinho & - & \begin{tabular}{|c|} 
pano de \\
algodão, farinha, milho, feijã \\
o,toucinho, arroz, aguarden \\
te,bois
\end{tabular} \\
\hline 1829 & $\begin{array}{l}\text { farinha, milho, feijão, } \\
\text { toucinho, bois }\end{array}$ & feijão, toucinho & - & $\begin{array}{c}\text { farinha, milho, feijão,toucin } \\
\text { ho,arroz,aguardente, } \\
\text { azeite,bois }\end{array}$ \\
\hline
\end{tabular}


Os gêneros produzidos em Nazaré eram enviados a São Paulo, Santos, Mogi das Cruzes e comercializados na própria localidade. O principal parceiro comercial na absorção dos produtos nazareanos foi certamente a cidade de São Paulo, para onde foram enviados, de forma intermitente, entre 1798 e 1829, milho, feijão, farinha e toucinho (este exceto em 1828), por vezes acrescidos de azeite de mamona ou bois ou aguardente ou arroz, inexpressivos na composição da produção ou do valor dos gêneros exportados. Farinha, milho e toucinho (entre os principais componentes do valor exportado), foram também os bens enviados a Santos até 1822, se resumindo a milho e toucinho em 1828 e a feijão e toucinho em 1829.

O comércio com Mogi das Cruzes esteve presente até o ano de 1805. No Setecentos incluía toucinho e farinha; em 1803, ademais, encontramos milho, arroz e feijão, excluindo-se o arroz em 1806 e mantendo-se somente o toucinho no ano anterior. Apesar de identificarmos o envio de produtos para Mogi nos documentos ora considerados, nos mapas comparativos de comércio desta vila encontrados para os anos de 1798, 1799, 1802, 1803 e 1804, Nazaré aparece apenas de forma superficial: em 1798 teria enviado apenas toucinho àquela vila (cf. seção seguinte)

Ressalte-se, ainda, havermos encontrado listada entre os destinos dos bens de Nazaré a própria localidade. Possivelmente, como hipótese anteriormente levantada, esses produtos deveriam ser comercializados na freguesia - com presença de estanqueiros e intermediários, a percorrer as diversas unidades produtivas amealhando a produção, vide o milho, gênero de produção bastante generalizada e com marcante comercialização na terra -, porém, tinham como destino final outros mercados.

O percentual de participação dos citados no valor os bens saídos de Nazaré podem ser observados no Gráfico II.19. O gráfico reafirma a grande importância assumida pela cidade de São Paulo como parceira comercial de Nazaré, cujos valores de exportações chegaram a depender, em até 65\% (1798) da referida capital. O volume de comércio com Santos vai ganhando importância até 1816, em detrimento ao comércio de exportação com São Paulo. Em 1799 São Paulo respondia por 52,7\% do valor da produção exportada por Nazaré, enquanto a Santos cabia 15\%. Em 1814 esses valores eram, respectivamente, $21,7 \%$ e $32,3 \%$, sendo de $25,6 \%$ e $30,9 \%$ em 1816 . No ano final observado, 1829, as exportações para São Paulo correspondiam a 31,5\% e para Santos $32,6 \%$ do valor total transacionado por Nazaré naquele ano. 


\section{Gráfico II.19}

\section{Participação das diferentes localidades nas exportações}

(Nazaré - 1798 a 1829)

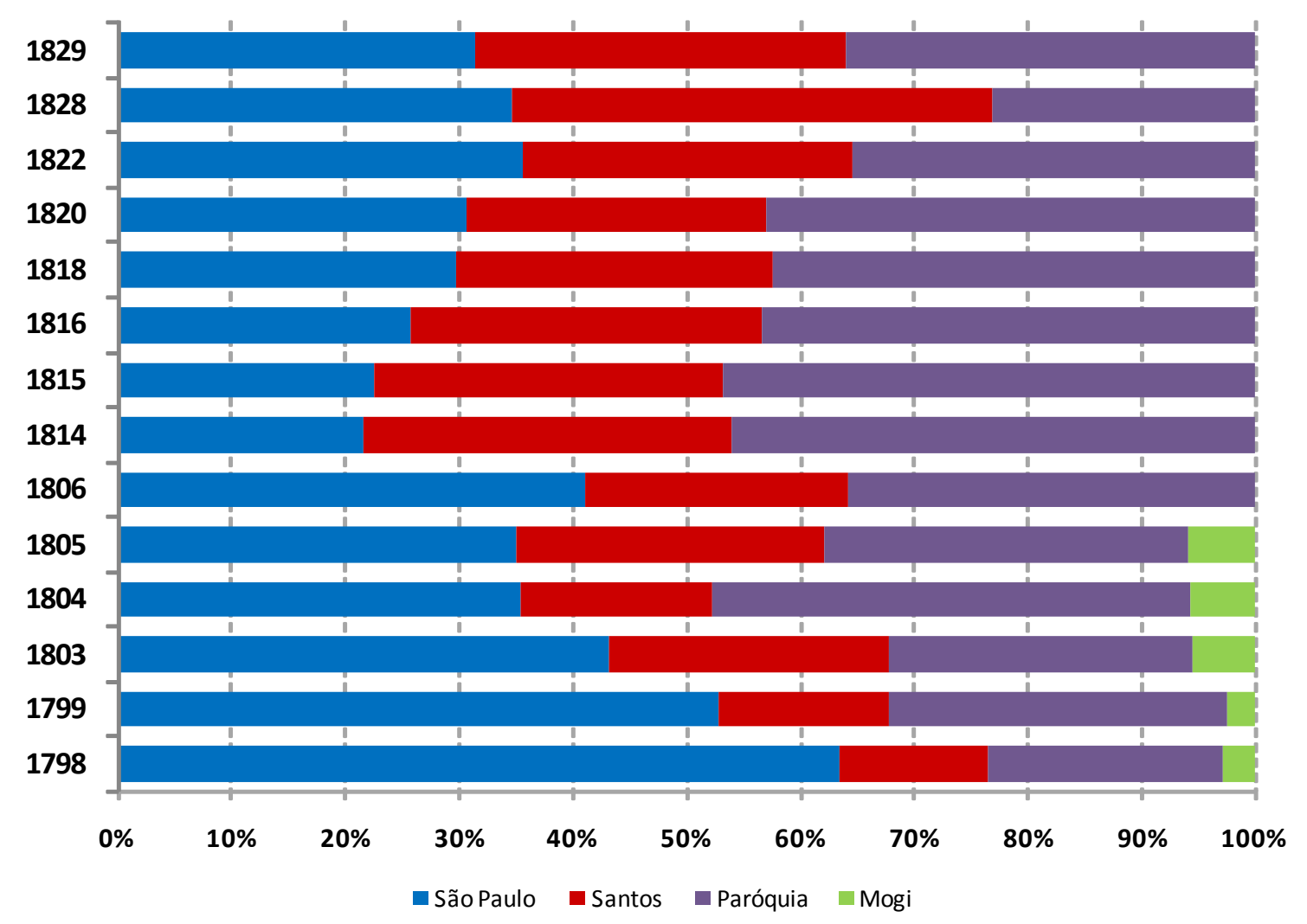

São Paulo era importante não só como receptora, mas também como responsável por fazer chegar à freguesia produtos ali não passíveis de fabricação. (Tabela II.56)

Chegavam a Nazaré, em diferentes momentos, mas ao longo dos cerca de 30 anos que separam 1798 e 1829, ferramentas, sal, vinho, tecidos diversos, chapéus, açúcar oriundos de São Paulo e, vinho, sal, ferro e enxadas vindos de Santos. Panos, chapéus, meias e sedas oriundos do Rio de Janeiro foram encontrados em 1798 e 1799. E Minas Gerais foi um exportador de fumo para a localidade, que embora tenha apresentado pequena produção do bem, importou-o a partir de 1814 .

Ademais, da pauta de importações nazareana faziam parte bestas e potros. Diferente dos demais bens chegados de outras praças comerciais, para os quais se espera consumo local, os animais saídos de Curitiba deveriam ser direcionados a outros mercados, como identificamos para as localidades até o momento observadas. 
Tabela II.56

Gêneros importados de acordo com a origem

(Nazaré - 1798 a 1829)

\begin{tabular}{|c|c|c|c|c|c|}
\hline & São Paulo & Santos & Rio de Janeiro & Curitiba & Minas Gerais \\
\hline 1798 & ferro sal & sal, vinho & $\begin{array}{l}\text { panos, chapéus, } \\
\text { meias, sedas }\end{array}$ & - & - \\
\hline 1799 & sal, ferro, aço & sal & $\begin{array}{l}\text { panos, chapéus, } \\
\text { meias, sedas }\end{array}$ & bestas, potros & - \\
\hline 1803 & $\begin{array}{l}\text { sal, fumo, açúcar, ferro, } \\
\text { panos, chapéus, meias, } \\
\text { sedas }\end{array}$ & vinho, sal & - & bestas,potros & - \\
\hline 1804 & $\begin{array}{l}\text { sal, fumo, açúcar, ferro, } \\
\text { panos, chapéus, meias, } \\
\text { sedas }\end{array}$ & vinho, sal & - & bestas, potros & - \\
\hline 1805 & $\begin{array}{l}\text { sal, fumo, açúcar, ferro, } \\
\text { panos, chapéus, meias, } \\
\text { sedas }\end{array}$ & vinho, sal & - & bestas, potros & - \\
\hline 1806 & $\begin{array}{l}\text { sal, fumo, açúcar, ferro, } \\
\text { panos, chapéus, meias, } \\
\text { sedas }\end{array}$ & vinho, sal, fumo & - & bestas, potros & - \\
\hline 1814 & $\begin{array}{c}\text { açucar, panos, chapéus, } \\
\text { enxadas, machados, } \\
\text { sedas }\end{array}$ & $\begin{array}{c}\text { vinho,sal, ferro, } \\
\text { enxada }\end{array}$ & - & bestas, potros & fumo \\
\hline 1815 & $\begin{array}{c}\text { açucar, panos, chapéus, } \\
\text { machados, sedas }\end{array}$ & $\begin{array}{c}\text { vinho, sal, ferro, } \\
\text { enxadas }\end{array}$ & - & bestas, potros & fumo \\
\hline 1816 & $\begin{array}{l}\text { sal, açucar, panos, } \\
\text { chapéus, enxadas, } \\
\text { machados, sedas }\end{array}$ & $\begin{array}{l}\text { vinho,sal,ferro, } \\
\text { enxada }\end{array}$ & - & bestas, potros & fumo \\
\hline 1818 & $\begin{array}{l}\text { sal, açucar, panos, } \\
\text { chapéus, ferro, } \\
\text { machados, sedas }\end{array}$ & vinho,sal & - & bestas, potros & fumo \\
\hline 1820 & $\begin{array}{c}\text { vinho, sal, açucar, panos, } \\
\text { chapéus, ferro, sedas }\end{array}$ & $\begin{array}{l}\text { vinho, sal, ferro, } \\
\text { enxadas }\end{array}$ & - & bestas, potros & fumo \\
\hline 1822 & $\begin{array}{c}\text { vinho, sal, açucar, panos, } \\
\text { chapéus, ferro, sedas }\end{array}$ & $\begin{array}{c}\text { vinho, sal, ferro, } \\
\text { enxadas }\end{array}$ & - & bestas, potros & fumo \\
\hline 1828 & $\begin{array}{l}\text { vinho, sal, aguardente do } \\
\text { reino, açucar, panos, } \\
\text { chapéus, enxadas, } \\
\text { machados, foices, farinha } \\
\text { de trigo, fumo da ilha }\end{array}$ & $\begin{array}{c}\text { vinho, } \\
\text { aguardente do } \\
\text { reino, sal, } \\
\text { enxada, farinha } \\
\text { de trigo, fumo } \\
\text { da ilha }\end{array}$ & - & bestas, potros & fumo \\
\hline
\end{tabular}


Esta importação de bestas e potros foi responsável pelo elevado percentual devido a Curitiba entre as localidades com produtos chegados a Nazaré, majoritário em todos os anos com dados apurados, exclusive 1818 e 1820. Em 1803 52,3\% do valor do comércio de importação nazareano era devido a Curitiba, montante equivalente ao verificado em 1815 (53\%) e inferior ao maior deles: 65,8\% em 1829. Nos anos de menor participação Curitiba apresentou percentuais de $26,4 \%$ e $21,9 \%$. (cf. Tabela II.57)

\section{Tabela II.57}

Percentual do valor importado de acordo com a origem

(Nazaré - 1799 a 1829)

\begin{tabular}{rcccccc}
\hline \hline Anos & São Paulo & $\begin{array}{c}\text { Rio de } \\
\text { Janeiro } \\
\%\end{array}$ & $\begin{array}{c}\text { Santos } \\
\%\end{array}$ & $\begin{array}{c}\text { Minas } \\
\text { Gerais } \\
\%\end{array}$ & $\begin{array}{c}\text { Curitiba } \\
\%\end{array}$ & $\begin{array}{c}\text { Total } \\
\%\end{array}$ \\
\hline $\mathbf{1 7 9 8}$ & 31,0 & 65,4 & 3,6 & - & - & 100,0 \\
$\mathbf{1 7 9 9}$ & 19,1 & 29,1 & 14,6 & - & 37,3 & 100,0 \\
$\mathbf{1 8 0 3}$ & 39,4 & - & 8,4 & - & 52,3 & 100,0 \\
$\mathbf{1 8 0 4}$ & 42,7 & - & 7,9 & - & 49,4 & 100,0 \\
$\mathbf{1 8 0 5}$ & 42,7 & - & 7,9 & - & 49,4 & 100,0 \\
$\mathbf{1 8 0 6}$ & 40,3 & - & 13,7 & - & 46,0 & 100,0 \\
$\mathbf{1 8 1 4}$ & 23,7 & - & 22,4 & 4,4 & 49,4 & 100,0 \\
$\mathbf{1 8 1 5}$ & 22,8 & - & 20,4 & 3,8 & 53,0 & 100,0 \\
$\mathbf{1 8 1 6}$ & 29,4 & - & 17,3 & 3,8 & 49,4 & 100,0 \\
$\mathbf{1 8 1 8}$ & 52,3 & - & 15,1 & 6,2 & 26,4 & 100,0 \\
$\mathbf{1 8 2 0}$ & 48,6 & - & 16,2 & 13,3 & 21,9 & 100,0 \\
$\mathbf{1 8 2 2}$ & 38,3 & - & 5,9 & 3,7 & 52,0 & 100,0 \\
$\mathbf{1 8 2 8}$ & 18,0 & - & 14,6 & 1,5 & 65,8 & 100,0 \\
\hline \hline Fonte:AESP, Maços de População - M apas de produção e comércio, Nazaré & &
\end{tabular}

Nestes anos (1818 e 1820), São Paulo aparece como o maior exportador a Nazaré, com percentuais de $52,3 \%$ e $48,6 \%$ do valor importado pela freguesia. Calculamos para a cidade percentuais elevados também em 1806, 40,3\% e nos dois anos imediatamente anteriores (1804 e 1805): 42,7\%. ${ }^{53}$ A participação do fumo de Minas era pequeno, sendo máximo em 1820 (13,3\%). Santos, assim como aconteceu com as exportações, parece ter ampliado sua participação nas importações. Passou de 3,6\% em

\footnotetext{
53 Os valores encontrados para as importações de acordo com a localidade de origem em 1804 e 1805 são curiosamente ou erroneamente iguais, indicando uma simples transcrição de dados de um ano a outro. Nominalmente, eram 1:710 $\$ 000$ relativos a São Paulo, 1:601\$400 atinentes a Santos, 3:560\$000 devidos a Curitiba e 320\$000 a Minas Gerais.
} 
1798 a 22,4\% em 1814 e 14,6\% em 1829. Quando presente o Rio de Janeiro chegou a responder por $65,4 \%$ das importações nazareanas.

Comparadas às exportações, estas importações apresentaram-se, em regra, superiores, implicando em sucessivos déficits, como resultado do balanço comercial de Nazaré (cf. Gráfico II.20), que no limite foi, em termos reais, de 6:269\$000, valor equivalente, por exemplo, a mais de 32900 alqueires de milho ou aproximadamente 10280 arrobas de toucinho. Apenas entre 1816 e 1822 as relações comerciais de Nazaré foram positivas: de 1:769\$000 em 1818 a apenas 374\$000 em 1822.

\section{Gráfico II.20}

\section{Saldo do balanço comercial}

(Nazaré - 1798 a 1825)

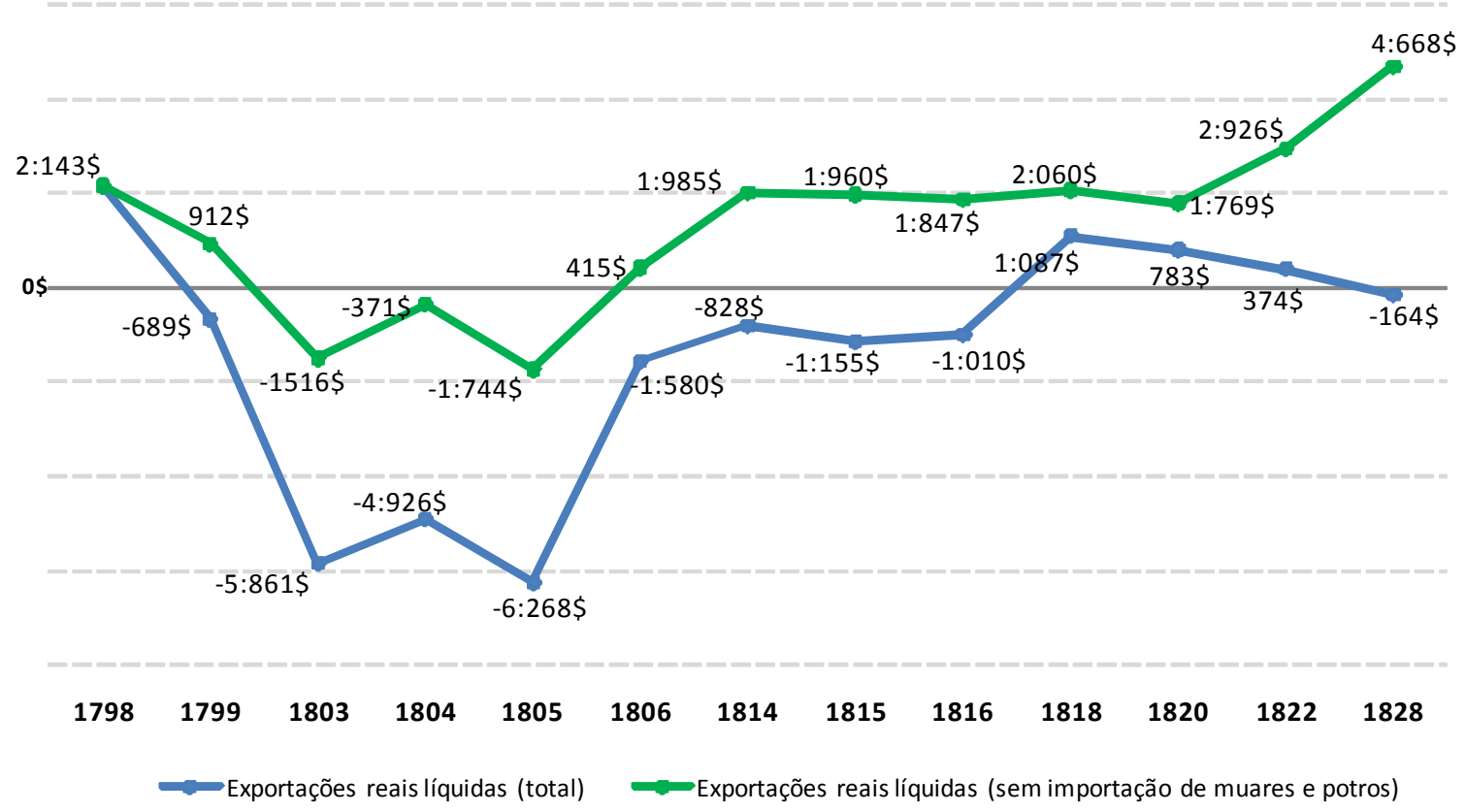

As exportação de Nazaré eram, então, insuficientes para cobrir seus gastos com importações. Certamente, mesmo não estando de posse de dados específicos nessa direção, podemos ressaltar a fundamental importância na localidade do mercado de crédito, na mão de locais ou não, a retalho ou em valores mais significativos.

As importações comparadas à produção total da vila apresentaram algum padrão entre 1805 e 1816, quando oscilaram no intervalo 0,31-0,35, somente superior àquele encontrado em 1803: 0,37. A seu turno, os coeficientes de exportação em cada um dos anos observados, apresentaram-se muito diferentes entre si, variando em intervalo de 
0,08 em 1804 a 0,70 em 1826, indicativos de diferentes níveis de dependência das vendas externas para a composição do produto/renda local.

\section{Tabela II.58}

Coeficientes de exportação e importação

(Nazaré - 1799 a 1829)

\begin{tabular}{ccc}
\hline \hline Anos & $\begin{array}{c}\text { Coeficiente de } \\
\text { exportação* }\end{array}$ & $\begin{array}{c}\text { Penetração das } \\
\text { importações }\end{array}$ \\
\hline 1798 & 0,36 & 0,24 \\
1799 & 0,21 & 0,24 \\
1803 & 0,15 & 0,37 \\
1804 & 0,08 & 0,16 \\
1805 & 0,14 & 0,35 \\
1806 & 0,22 & 0,31 \\
1814 & 0,30 & 0,34 \\
1815 & 0,30 & 0,34 \\
1816 & 0,29 & 0,33 \\
1818 & 0,26 & 0,21 \\
1820 & 0,34 & 0,31 \\
1822 & 0,38 & 0,37 \\
1826 & 0,70 & - \\
1829 & 0,29 & - \\
\hline \hline
\end{tabular}

*valor das exportações/valor da produção

** valor das importações/valor do consumo

Fonte: AESP, Maços de População - Mapas de produção e comércio,

Nazaré: anos selecionados 


\section{Mogi das Cruzes}

A vila de Mogi das Cruzes, entre 1799 e 1829, apresentou estrutura ocupacional majoritariamente rural, mas tendo entre suas atividades econômicas forte presença de fogos ligados ao artesanato, conforme Tabela II.59. Na tabela expomos a estrutura ocupacional da localidade, verificada através dos chefes de domicilio que tiveram suas atividades econômicas identificadas, posto que para os demais membros dos fogos - que deveriam desenvolver concomitantemente atividades diversas, em especial as mulheres quase não encontramos estas informações que atingiram o máximo de $1 \%$ desses indivíduos livres de 1799 a 1808, 0,7\% nos dois anos seguintes e 0,3\% na década de 1820. Para os chefes de fogo, temos $86,7 \%$ contemplados em 1799 e não menos de $91,3 \%$ a partir de então (1825), com o máximo de 96,5\% em 1820.

\section{Tabela II.59}

\section{Distribuição dos fogos por setores de atividade econômica}

(Mogi - 1799 a 1829)

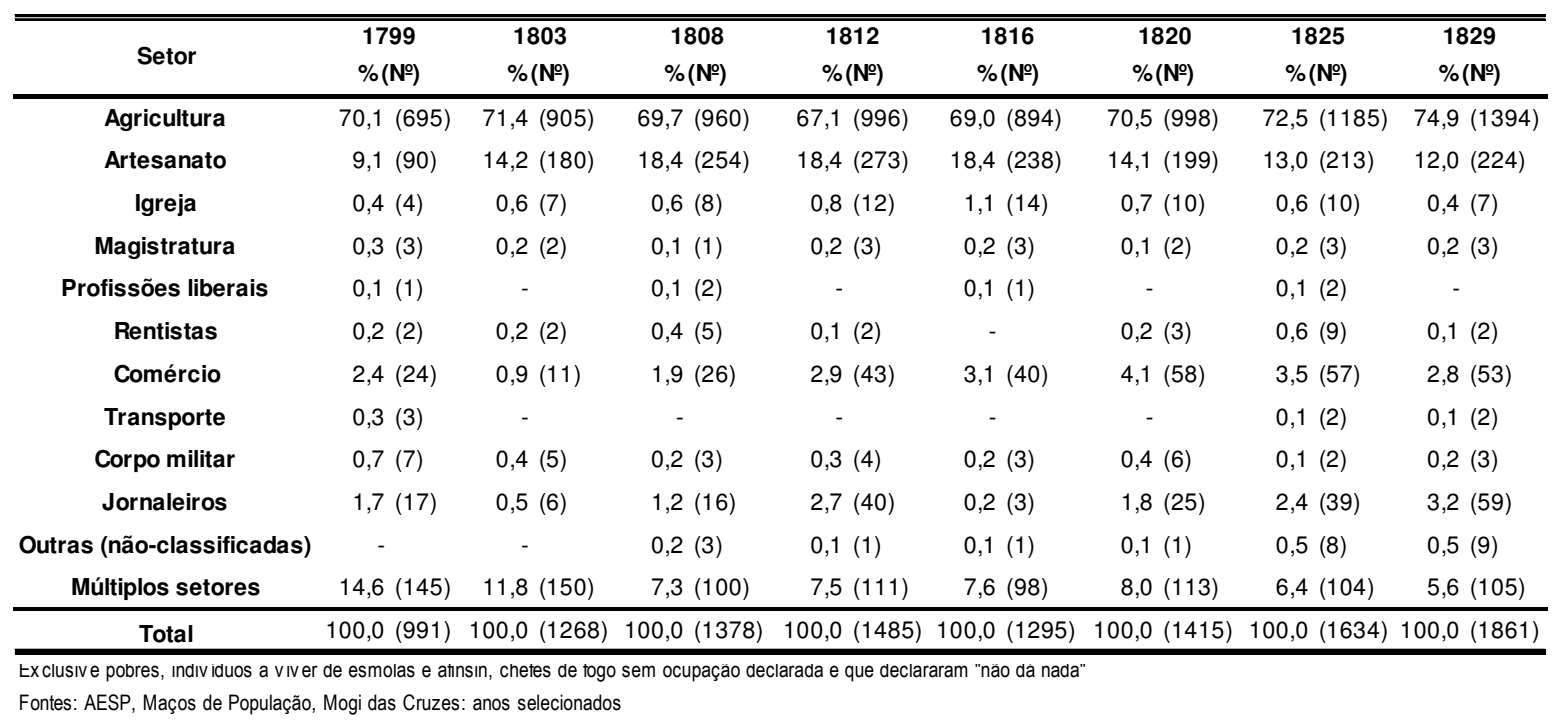

Os domicílios vinculados primordialmente a atividades do setor agricultura representavam ao longo do período estudado parcela majoritária daqueles que pudemos classificar, sem grandes variações com o passar dos anos. Em $179970 \%$ das ocupações listadas eram agrícolas, percentual que atingiu 74,9\% em 1829, após haver crescido paulatinamente desde 1812, quando respondeu por seu menor valor: 67,1\%. Indivíduos e domicílios ligados a cultivos diversos e descritos como agricultor, lavrador, roceiro ou simplesmente "planta", para seu próprio consumo ou não, são os principais componentes 
deste setor, respondendo por cerca de $85 \%$ em 1820 e 1825, quando a criação ligada aos cultivares aparece em medida importante; nos demais anos a menor participação deste grupo foi em 1816, 91,5\%.

Paralelamente à agricultura destacava-se na vila de Mogi o artesanato. O setor, composto por costureiras, louceiros, balaieiros, carpinteiros, fiadeiras, tecedeiras e tecelões, entre outras, no ano de 1799 era o terceiro mais representativo, 9,1\%, passando a segundo principal setor de atividade econômica na Mogi das Cruzes das três primeiras décadas do Oitocentos, atingindo os seus maiores percentuais em 1808, 1812 e 1816, quando chegou a responder por $18,4 \%$ das atividade econômicas encontradas. Dentro do setor destacam-se os chefes de fogo ligados à fiação e tecelagem, que respondiam por $76,7 \%$ do setor artesanato em 1799, esteve acima de 90\% entre 1803 e 1825, sendo de $87,9 \%$ em 1829. A importância da atividade na localidade justificava até a presença, registrada em 1808, de Bento José, que aos 41 anos "vive de fazer rodas de fiar" (cf. Lista Nominativa de Mogi das Cruzes, 1808 - AESP, Maços de População/rolo 128)

$\mathrm{Na}$ fiação e tecelagem, apesar da presença masculina - em 1812, por exemplo, 19 chefes de domicilio homens eram tecelões (1,3\% do total, $7 \%$ do setor, $7,5 \%$ do ramo) era contundente a predominância feminina. Essas atividades, somadas eram responsáveis por cerca de $50 \%$ das atividades declaradas pelas mulheres a chefiar fogos nos diferentes anos, e deveriam ter peso ainda maior no conjunto da sociedade, se imaginarmos que as mulheres em distintas posições nos domicílios deveriam realizar estas atividades nas mesmas ou maiores proporções. Mulheres chefiavam não mais de 23\% das unidades produtivas de Mogi até 1829 (cf. capítulo I), e a maioria delas estava nesta situação por serem viúvas (ao menos 57,5\% delas, no registro de 1799) ou, em boa medida, por serem solteiras (percentual mínimo de 20,5\% em 1825 e 1829).

Ademais da agricultura e das atividades artesanais, especialmente aquelas ligadas à fiação e tecelagem, encontramos na localidade em tela jornaleiros que de seis chefes de fogo $(0,5 \%)$ em 1803, passaram a 59 indivíduos ao final do período analisado, respondendo por $3,2 \%$ das ocupações registradas. Da mesma maneira, o comércio que teve apenas onze indivíduos $(0,9 \%)$ exclusivamente a ele vinculados em 1803 , elevou sua participação a 2,8\% o que correspondia a 53 fogos, uma variação de mais de $430 \%$ em pouco menos de 30 anos.

Os demais setores, como igreja, magistratura, rentistas e profissões liberais, ainda que anotadas, pouco representaram em termos de presença nos domicílios e mantiveram participações relativamente pouco variáveis ao longo dos anos. Apenas setores conjugados tiveram participação mais elevada. 
Para os múltiplos setores foi calculado o segundo maior percentual em 1799, 14,6\%. Sua participação foi decrescente e já a partir de 1803 havia sido superado em número pelos fogos vinculados ao artesanato, e passou de 11,8\% em 1803 (equivalentes a 150 fogos naquele momento) a 5,6\% em 1829, ou seja, 100 domicílios.

Todavia, estes percentuais vêem-se bastante afetados se desconsiderado o corpo militar caso ele aparecesse conjugado a outra atividade. Tal procedimento, com resultados apresentados na Tabela II.60, diminuiu a participação dos múltiplos setores em todos os anos: em 1799 a participação passou a 5,4\% do total, enquanto ao final do período (1829) foi de apenas $1,5 \%$.

Tabela II.60

Distribuição dos fogos por setores de atividade econômica - exclusive militares em múltiplas ocupações (Mogi - 1799 a 1829)

\begin{tabular}{|c|c|c|c|c|c|c|c|c|}
\hline Setor & $\begin{array}{l}1799 \\
\% \text { (№) }\end{array}$ & $\begin{array}{l}1803 \\
\% \text { (№) }\end{array}$ & $\begin{array}{l}1808 \\
\%\left(\mathrm{~N}^{\circ}\right)\end{array}$ & $\begin{array}{l}1812 \\
\% \text { (№) }\end{array}$ & $\begin{array}{l}1816 \\
\% \text { (№) }\end{array}$ & $\begin{array}{l}1820 \\
\% \text { (№) }\end{array}$ & $\begin{array}{l}1825 \\
\% \text { (№) }\end{array}$ & $\begin{array}{l}1829 \\
\% \text { (№) }\end{array}$ \\
\hline Agricultura & $79,3(786)$ & $80,3(1018)$ & $75,5(1040)$ & $72,9(1083)$ & $75,8(982)$ & $75,7(1071)$ & $77,7(1270)$ & $79,1(1472)$ \\
\hline Artesanato & $9,1(90)$ & $14,2(180)$ & $18,4(254)$ & $18,4(273)$ & $18,4(238)$ & 14,1 (199) & 13,0 (213) & $12,0(224)$ \\
\hline Igreja & $0,4(4)$ & $0,6(7)$ & $0,6(8)$ & $0,8(12)$ & $1,1(14)$ & $0,7(10)$ & $0,6(10)$ & $0,4(7)$ \\
\hline Magistratura & $0,3(3)$ & $0,2(2)$ & $0,1(1)$ & $0,2(3)$ & $0,2(3)$ & $0,1(2)$ & $0,2(3)$ & $0,2(3)$ \\
\hline Profissões liberais & $0,1(1)$ & - & $0,1(2)$ & - & $0,1(1)$ & - & $0,1(2)$ & - \\
\hline Rentistas & $0,2(2)$ & $0,2(2)$ & $0,4(6)$ & $0,1(2)$ & - & $0,2(3)$ & $0,6(9)$ & $0,1(2)$ \\
\hline Comércio & $2,4(24)$ & $0,9(11)$ & $1,9(26)$ & $2,9(43)$ & $3,1(40)$ & $4,1(58)$ & $3,5(57)$ & $2,8(53)$ \\
\hline Transporte & $0,3(3)$ & - & - & - & - & - & $0,1(2)$ & $0,1(2)$ \\
\hline Corpo militar & $0,7(7)$ & $0,4(5)$ & $0,2(3)$ & $0,3(4)$ & $0,2(3)$ & $0,4(6)$ & $0,1(2)$ & $0,2(3)$ \\
\hline Jornaleiros & $1,7(17)$ & $0,5(6)$ & $1,2(16)$ & $2,7(40)$ & $0,2(3)$ & $1,8(25)$ & $2,4(39)$ & $3,2(59)$ \\
\hline Outras (não-classificadas) & - & - & $0,2(3)$ & $0,1(1)$ & $0,1(1)$ & $0,1(1)$ & $0,5(8)$ & $0,5(9)$ \\
\hline Múltiplos setores & $5,4(54)$ & 2,9 (37) & $1,4(19)$ & $1,6(24)$ & $0,8(10)$ & $2,8(40)$ & $1,2(19)$ & $1,5(27)$ \\
\hline
\end{tabular}

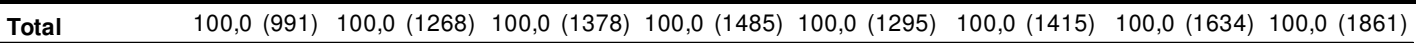

Exclusive pobres, Inaiv Iduos a viver de esmolas e annsın, cnetes de togo sem ocupaçao decıarada e que decıararam "nao da nada'

Fontes: AESP, Maços de População, Mogi das Cruzes: anos selecionados

Modificou-se também, em grande medida, o setor agricultura, incrementado em torno de nove pontos percentuais em 1799 e 1803, e seis pontos percentuais nos dois anos seguintes considerados, e entre 4-5 pontos na década de 1820. Aparece, então, agricultura (cultivos e pecuária) mais atividades militares (de diferentes patentes) como a principal conjugação entre atividades. As demais combinações eram devidas a distintas atividades, que não apresentaram características identificáveis. Havia tecelão negociante, taberneiro lavrador, negociante jornaleiro, músico carpinteiro, entre várias outras possibilidades. 
Há que se ressaltar, ademais, que havia uma parcela da sociedade mogiana ausente da classificação de ocupações apresentada por estarem à margem do processo produtivo de bens ou serviços. Eram os indivíduos cujas observações se limitavam a indicá-los como pobres ou a viver de esmolas.

Em 1799 eram 77 fogos com declarações de "esmolas" e nove pobres, e ainda Antonio das Neves, de 32 anos de idade "vive de andar" e Francisco da Cunha, aos 22 anos, casado e com uma filha ainda bebê "vive bandeando não tem lugar de morar". (Lista Nominativa de Mogi das Cruzes, 1808 - AESP, Maços de População/rolo 126). Estes indivíduos respondiam por significativos 7,7\% dos fogos anotados em Mogi no referido ano, percentual consideravelmente maior que aquele verificado no ano de 1803 , quando 38 indivíduos (2,8\% dos chefes) estavam relacionados a esmolas. Da mesma maneira, eram $2,9 \%$ os domicílios chefiados por despossuídos, com chefes declarados a viver de esmolas em 1812 (45 indivíduos) e 1816 (40 indivíduos). O menor número de informações a este respeito encontramos em 1822, 16 chefes de domicilio $(1,1 \%)$ a viver de esmolas; sendo comparativamente baixo também o percentual verificado para 1830: 1,8\% correspondente a 21 pobres, um pobre e mendigo e 13 "esmolas".

\section{Gráfico II.21}

Número absoluto de chefes despossuídos e sua participação percentual no número total de domicílios (Mogi - 1799 a 1829)

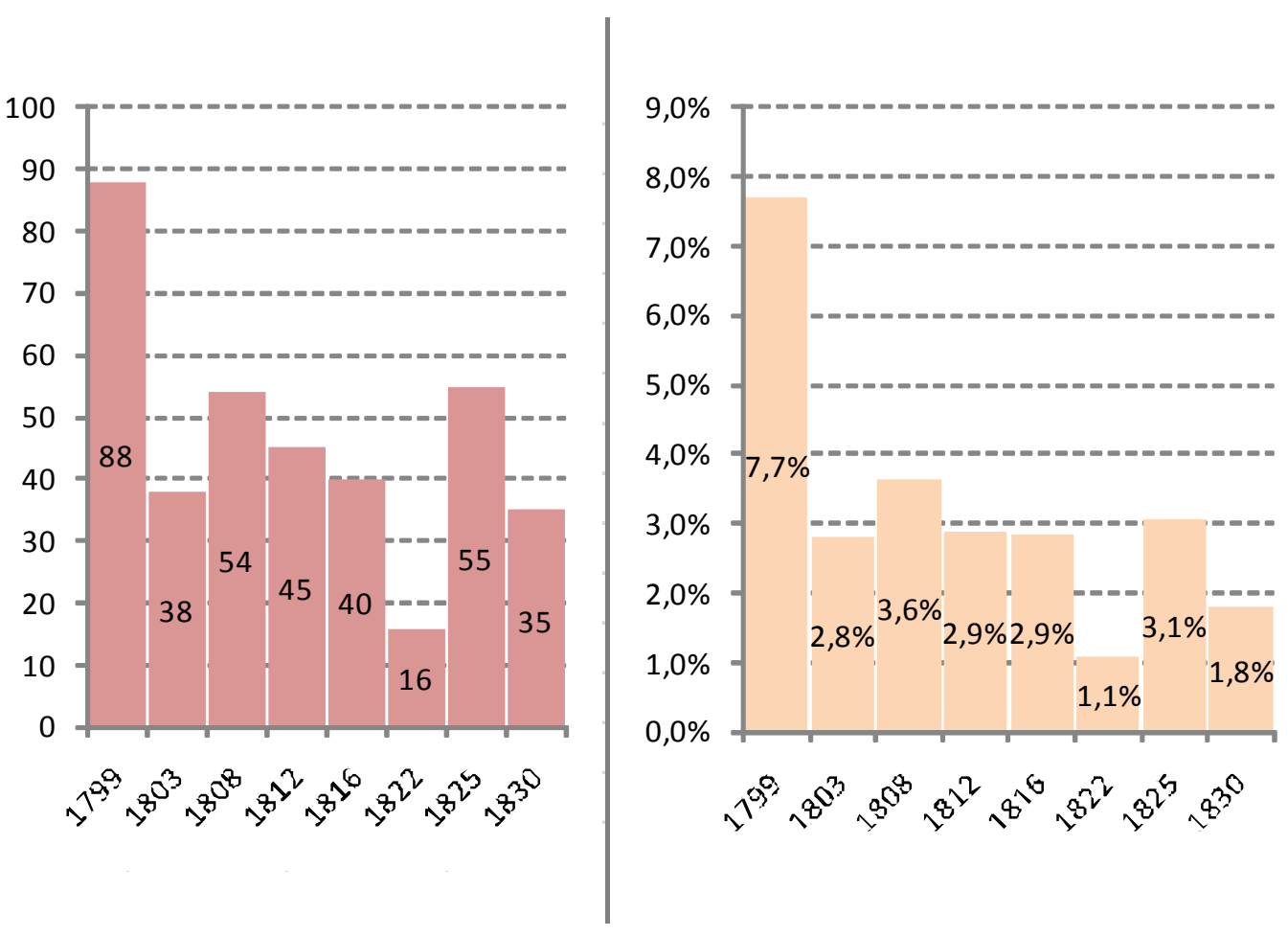


Como mencionado em outros momentos, parte desses indivíduos tinham suas atividades produtivas dificultadas pela idade ou por doenças. Em 1816 encontramos Manoel Joaquim das Neves com a esposa e o filho que "vivem de esmola doentes com mal de Lázaro", mesma doença (lepra) que acometia Joaquim Maria, também dependente de esmolas (cf. Lista Nominativa de Mogi das Cruzes, 1808 - AESP, Maços de População/rolo 129). Passada quase uma década ainda havia indivíduos nesta situação, a exemplo o "pobre lazarento" Inácio Jose Rodrigues. Contudo, os mogianos despossuídos de qualquer recurso ou capacidade que permitisse ganhos pecuniários ou em espécie, responderam por parcela considerável dos indivíduos a chefiar domicílios na localidade ao final do século XVIII. Presentes em todo o lapso estudado, foi decrescente sua participação nos maços populacionais.

A este respeito vale mencionar, por fim, a presença em 1799 de Maria Gonçalves que era "fiandeira pobre" e Angela Maria "fiandeira e esmolas", que aparecem no setor artesanato nas Tabelas II.59 e II.60, mas não no Gráfico II.21. Destarte, mesmo que não tenhamos possibilidade de estabelecer uma classificação, fato é que dentro dos setores econômicos, os diferentes indivíduos apresentavam condições econômicas distintas entre si, alguns com atividades de maior monta, outros atividades com pequena densidade que os ligava mais diretamente aos pobres.

A composição das ocupações mogianas, que aponta para agricultura e fiação como atividades predominantes, relaciona-se diretamente aos cultivos levados a cabo na localidade. Encontramos a declaração da produção realizada, ou seja, aquilo que foi arrolado na lista - em poucos casos com menção a plantou ou colheu e nenhuma referência à comercialização - para ao menos $71 \%$ dos chefes no setor agricultura ou em múltiplos setores que incluem a agricultura, percentual relativos a 1799 e 1803, com máximo em 1808 (99,4\%). Em diferentes medidas, foram importantes milho, feijão, arroz, e algodão, sendo encontrados pontualmente fumo, cana, mamona, trigo, mandioca. 
Tabela II.61

Gêneros plantados e presença concomitante dos diferentes gêneros nos fogos

(Mogi - 1799 a 1829)

\begin{tabular}{lcccccccc}
\hline \hline \multicolumn{1}{c}{ CULTURAS } & $\mathbf{1 7 9 9}$ & $\mathbf{1 8 0 3}$ & $\mathbf{1 8 0 8}$ & $\mathbf{1 8 1 2}$ & $\mathbf{1 8 1 6}$ & $\mathbf{1 8 2 0}$ & $\mathbf{1 8 2 5}$ & $\mathbf{1 8 2 9}$ \\
\hline MILHO & $97,3 \%$ & $97,9 \%$ & $89,1 \%$ & $99,9 \%$ & $99,6 \%$ & $100,0 \%$ & $98,6 \%$ & $99,7 \%$ \\
FEIJÃO & $\mathbf{8 6 , 5 \%}$ & $88,8 \%$ & $\mathbf{8 0 , 3} \%$ & $97,2 \%$ & $90,4 \%$ & $98,4 \%$ & $94,0 \%$ & $83,3 \%$ \\
ALGODÃO & $67,6 \%$ & $52,9 \%$ & $50,1 \%$ & $26,6 \%$ & $30,0 \%$ & $34,1 \%$ & $38,8 \%$ & $17,1 \%$ \\
ARROZ & $13,8 \%$ & $24,1 \%$ & $29,5 \%$ & $21,0 \%$ & $6,5 \%$ & $24,0 \%$ & $29,2 \%$ & $36,1 \%$ \\
AMENDOIM & $0,4 \%$ & $3,1 \%$ & $3,5 \%$ & $1,6 \%$ & $0,4 \%$ & $2,1 \%$ & $1,9 \%$ & $1,6 \%$ \\
CAFÉ & - & - & - & - & - & $0,4 \%$ & $4,8 \%$ & $5,6 \%$ \\
FUMO & $0,4 \%$ & $0,1 \%$ & $0,3 \%$ & $0,3 \%$ & $0,6 \%$ & $0,5 \%$ & $0,3 \%$ & $0,2 \%$ \\
CANA & - & - & - & $0,1 \%$ & - & - & - & - \\
MAMONA & - & - & - & - & - & - & $0,1 \%$ & $0,1 \%$ \\
TRIGO & - & $0,1 \%$ & - & - & - & - & - & - \\
MANDIOCA & - & - & - & - & $0,4 \%$ & - & - & - \\
\hline \hline
\end{tabular}

Fonte: AESP, Maços de População, Mogi das Cruzes: anos selecionados

O café, que se expandia pelo Vale do Paraíba, também teve presença pontual: estabeleceu-se em Mogi na década de 1820 (possivelmente suplantando parte da plantação de algodão), como se observa na documentação, e seria importante para a localidade nas décadas seguintes. Já em 1836, segundo Müller (1923, p.125) haviam sido produzidas 11237 arrobas na vila, e Santa Isabel neste anos havia sido responsável por uma produção de 2499 arrobas.

Entre os chefes das unidades domiciliares de Mogi a quase totalidade mencionou o cultivo do milho, que à exceção de 1808, em que o cereal apareceu arrolado em 89,1\% desses fogos, superou os 97\% nos demais anos: em 1799 eram 97,3\%, entre 1812 e 1820 estava em 99,5\%-100\% e em 1825 estava espraiado por 98,6\% das declarações. O feijão apresentou participação também bastante elevada, especialmente nos anos de 1812 e 1820 quando foi encontrado, respectivamente, em 97,2\% e 98,4\% dos fogos com cultivares; sua participação mínima foi de $80,3 \%$. O algodão, matéria prima da atividade de fiação e tecelagem, foi o terceiro principal produto descrito, apresentou oscilações, mas considerado todo o período claramente foi citado em número decrescente nos fogos: $67,6 \%$ em 1799, 50,1\% em 1808, 30\% em 1816 e 38,8\% em 1825. Já o arroz, variou entre $13,8 \%$ (1799) e 36,1\% em 1829. (conforme Tabela II.61)

A elevada presença de diferentes plantações implica em presença concomitante delas nos diferentes fogos em que foram descritas e mostrados no Gráfico II.22. Como cultura única, o milho foi o gênero a apresentar alguma importância em anos específicos: 
cerca de $7 \%$ dos chefes arrolaram apenas o milho em suas declarações entre 1799 e 1808, 8,5\% em 1816 e 10,3\% em 1829, correspondentes a 137 fogos neste último ano, em que estão incluídos aqueles referentes à freguesia de Santa Isabel, assim como acontecia em 1825. É dizer, parcela majoritária dos plantadores de milho (o cultivo mais espalhado) manteve algum outro cultivo que mereceu destaque; os principais deles foram o feijão e o algodão.

\section{Gráfico II.22}

Percentual de fogos com presença dos diversos gêneros cultivados (Mogi - 1799 a 1829)

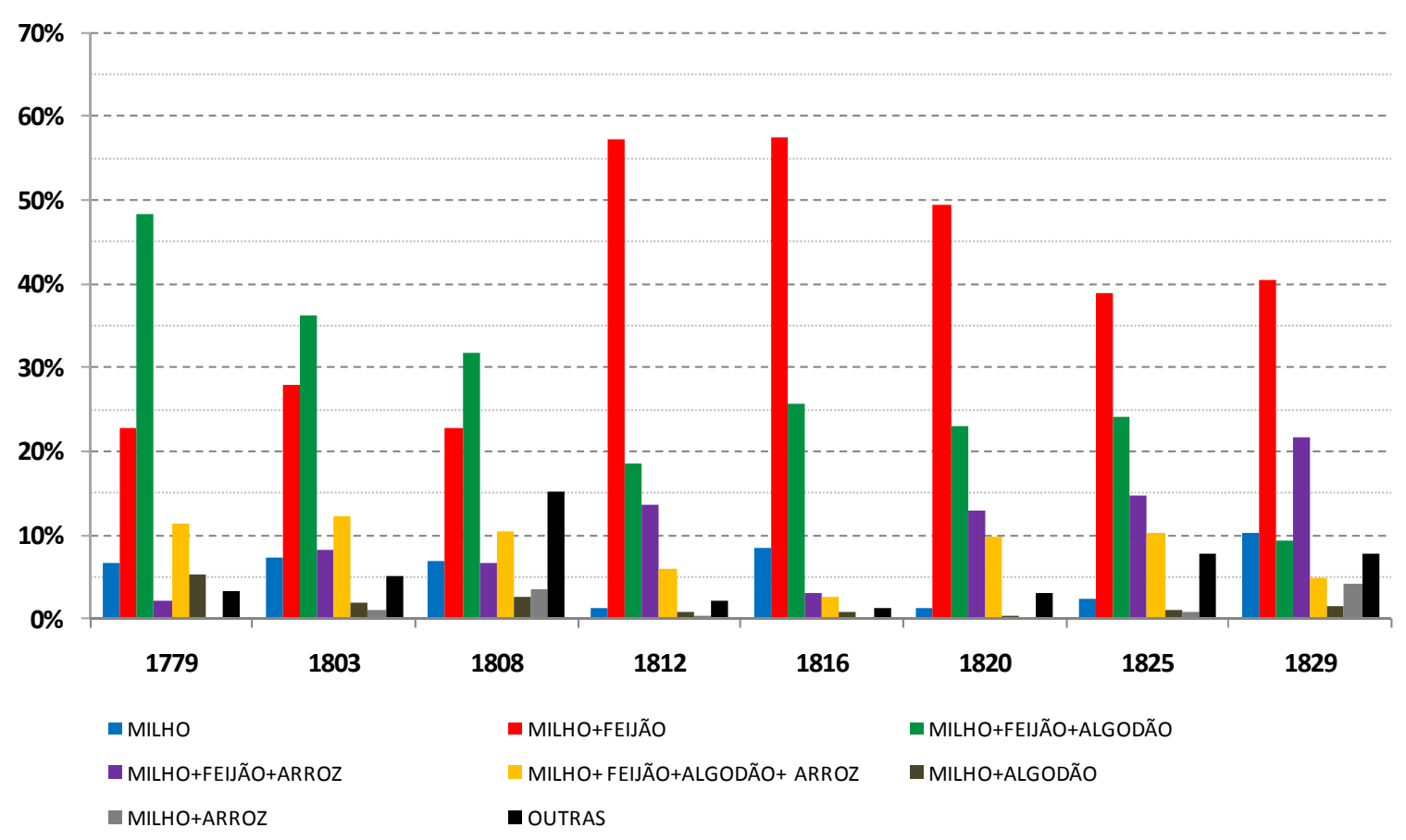

A conjugação milho mais feijão mais algodão foi traço marcante da produção mogiana, especialmente até 1808. A partir de 1812, acompanhando a redução da declaração do algodão, perdeu espaço para a conjugação mais simples entre milho e feijão. Em 1799 quase metade dos domicílios com cultivares haviam colhido milho, feijão e algodão, percentual que já havia sido reduzido a menos de $20 \%$ em 1812, ano em que milho mais feijão responderam por $57,5 \%$ dos gêneros declarados. A conjugação milho e feijão caiu a $40 \%$ em 1829, neste mesmo ano não chegavam a 10\% somados ao algodão, sendo a segunda participação mais espraiada $(21,7 \%)$ aquela relativa ao conjunto milho, feijão e arroz.

Da agricultura da vila de Mogi faziam parte também os animais, cuja presença nos fogos em que foram arrolados são mostrados na Tabela II.62. Dos indivíduos ligados ao 
setor, 3,6\% eram também criadores em 1799, 8,4\% em 1816, 15,5\% em 1820, respectivamente, $14,3 \%$ e $4 \%$ nos dois últimos anos considerados. A Tabela II.62 não apresenta dados para 1803, 1808 e 1812 pois era diminuto o número de menções a animais nestes recenseamentos. Em 1803 foram dois indivíduos a mencionar vacuns e dois com vacuns mais cavalares; depois de um lustro encontramos apenas cinco menções a animais (três referências a vacuns e duas a vacas, capados e carneiros); e em 1812 nenhuma criação foi descrita.

Tabela II.62

Criações e presença concomitante dos diferentes animais nos fogos

(Mogi - 1799 a 1829)

\begin{tabular}{|c|c|c|c|c|c|}
\hline CRIAÇÕES & $\begin{array}{l}1779 \\
\% \text { (№) }\end{array}$ & $\begin{array}{l}1816 \\
\% \text { (№) }\end{array}$ & $\begin{array}{l}1820 \\
\% \text { (№) }\end{array}$ & $\begin{array}{l}1825 \\
\% \text { (№) }\end{array}$ & $\begin{array}{l}1829 \\
\% \text { (№) }\end{array}$ \\
\hline VACAVBEZERRO & $20,0(7)$ & $26,7(27)$ & $29,6(56)$ & $23,5(40)$ & $23,9(17)$ \\
\hline PORCO/CAPADO & - & $44,6(45)$ & $38,1(72)$ & $37,1(63)$ & 46,5 (33) \\
\hline BESTAVBURRO/MULA & $48,6(17)$ & $3,0(3)$ & $4,2(8)$ & $4,1(7)$ & $4,2(3)$ \\
\hline VACA+CAPADO & - & $21,8(22)$ & $18,5(35)$ & $24,7(42)$ & $16,9(12)$ \\
\hline VACA + BESTA & $31,4(11)$ & $2,0(2)$ & $5,8(11)$ & $5,3(9)$ & $2,8(2)$ \\
\hline VACA+CAPADO+BESTA & - & - & $3,2(6)$ & $4,7(8)$ & $2,8(2)$ \\
\hline CAPADO+CAVALO & - & $2,0(2)$ & $0,5(1)$ & $0,6(1)$ & $1,4(1)$ \\
\hline CARNEIRO & - & - & - & - & $1,4(1)$ \\
\hline VACA+CAPADO+CARNEIRO & - & - & - & - & - \\
\hline TOTAL & $100,0(35)$ & $100,0(101)$ & $100,0(189)$ & $100,0(170)$ & $100,0(71)$ \\
\hline
\end{tabular}

Fontes: AESP, Maços de População, Mogi da Cruzes: anos selecionados, exclusive 1803, 1808 e 1812

Ao final do século XVIII encontramos 35 fogos com algum animal mencionado, sendo em 17 deles (48,6\%) arrolados muares. Vacas e bezerros apareceram em 17 domicílios $(20 \%)$ e os demais descreviam conjuntamente muares e vacuns. Apenas a partir de 1816 animais foram descritos em medida mais importante, 101 casos correspondentes a aproximadamente $7 \%$ dos fogos da localidade e $12 \%$ daqueles no setor agricultura. Entre eles 45 (44,6\%) eram referentes à criação de porcos, seguidos pelos vacuns e pela conjugação entre as duas criações. Tal característica reproduziu-se nos anos seguintes, em que pontualmente apareceram também uma criadora de carneiros - Clara Maria de Jesus declarou oito carneiros em 1829 -, e alguma menção a muares. 
Podemos afirmar, então, que milho, feijão e algodão eram os gêneros mais espraiados pelos domicílios em Mogi ao final do Setecentos e durante as três primeiras décadas do Oitocentos, com também representativa presença de arroz. Estes gêneros eram também aqueles mais representativos em termos de valor. (Tabela II.63).

Tabela II.63

Participação percentual dos diversos gêneros

no valor do produto

(Mogi - 1798 a 1829)

\begin{tabular}{|c|c|c|c|c|c|c|c|c|c|}
\hline Produtos & 1798 & 1799 & 1802 & 1803 & 1804 & 1808 & 1815 & 1816 & 1818 \\
\hline Milho & 27,3 & 45,2 & 41,5 & 46,3 & 36,6 & 50,8 & 42,1 & 37,5 & 33,9 \\
\hline Feijão & 6,5 & 12,6 & 27,4 & 17,9 & 23,7 & 25,1 & 15,7 & 23,5 & 20,3 \\
\hline Algodão & 24,3 & 25,9 & 16,7 & 10,3 & 24,0 & 11,5 & 23,2 & 22,7 & 24,6 \\
\hline Arroz & 1,1 & 0,9 & 3,8 & 3,3 & 2,3 & 4,7 & 4,4 & 2,0 & 1,8 \\
\hline Farinha de mandior & - & 0,9 & 2,5 & 1,8 & 3,1 & 0,5 & 0,9 & 5,2 & 0,6 \\
\hline Fumo & - & - & - & - & - & 0,2 & 0,4 & 0,2 & 0,4 \\
\hline Panos de algodão & 26,5 & 3,4 & - & - & - & 2,2 & - & - & - \\
\hline Açúcar & 1,0 & 0,1 & - & - & 0,5 & - & - & - & 0,8 \\
\hline Aguardente & 11,5 & 11,0 & 7,3 & 19,5 & 8,8 & 4,9 & 9,8 & 6,5 & 11,4 \\
\hline Farinha de pão & 1,7 & - & - & - & - & - & 0,0 & - & - \\
\hline Amendoim & - & - & 0,7 & 0,9 & 0,8 & - & 0,2 & 0,1 & 0,2 \\
\hline Café & - & - & - & - & - & - & 1,2 & 0,3 & 1,4 \\
\hline Potros & - & - & - & - & - & - & 0,4 & - & 2,1 \\
\hline Bestas/Burros & - & - & - & - & - & - & 0,8 & 0,2 & - \\
\hline Porcos & - & - & - & - & - & - & 0,9 & 0,4 & 1,3 \\
\hline Vaca & - & - & - & - & - & - & - & 0,9 & 1,2 \\
\hline TOTAL & 100,0 & 100,0 & 100,0 & 100,0 & 100,0 & 100,0 & 100,0 & 100,0 & 100,0 \\
\hline
\end{tabular}

O valor da produção, auferido a partir dos mapas de produção e comércio da localidade para anos diversos para os quais foram localizados - não encontramos preços que pudesse permitir o mesmo exercício para os arrolamentos populacionais -, apontam a majoritária participação do milho durante todo o período estudado. Milho foi em todos os anos observados o maior componente do produto mogiano: $27,3 \%$ do valor produzido em 1799 era devido ao cereal, percentual alçado a $45,2 \%$ já no ano seguinte, voltando a cair em 1804, 36,6\%, sendo de 50,8\% em 1808 e 33,9\% após uma década.

Feijão e algodão oscilaram ao longo do tempo nos segundo e terceiros postos e, assim como o milho, não houve uma tendência clara de variação ao longo dos anos ou algum nível de participação em que houvessem se estabelecido. Em 1798 o algodão respondeu por $24,3 \%$ do produto da vila e seu termo, e se considerado junto aos panos de algodão, que certamente era o objetivo final da produção algodoeira, esse percentual 
vê-se elevado em 26,5\%. Em pouco apareceram os tecidos de algodão posteriormente (2,4\% em 1799 e 2,2\% em 1808), mas o algodão foi responsável por $24 \%$ do valor dos gêneros mogianos em 1804, valor próximo àquele observado na segunda metade da década seguinte: 23,2\% em 1815 e 24,6\% em 1818.

A sua vez, o feijão respondia por 6,5\% do valor da produção de Mogi em 1798, valor que subiu a $27,4 \%$ em apenas três anos (1802), voltando a $17,9 \%$ no ano seguinte (1803). Após três lustros o feijão respondia por 20,3\% (1816) do valor do produto da localidade.

Interessante notar que apareceu, para todos os anos para os quais obtivemos informações, a produção de aguardente, que nas listas nominativas propriamente esteve ausente. Chama a atenção o valor apresentado pela aguardente em 1803, 19,5\%, a segunda maior participação entre os diferentes gêneros arrolados. Entre 1798 e 1818, não menos de 4,9\% da produção encontrada nos mapas foi devida à aguardente, que como se verá chegou a ser responsável por percentuais consideráveis das exportações da vila.

Os chefes que relacionaram o milho a seus fogos plantaram/colheram ao menos um alqueire do cereal em 1799, 1808 e 1825, dois alqueires em 1816 e três alqueires nos demais anos. A colheita média verificada para os plantadores de milho, assim como as medianas a essas colheitas relacionadas foram variáveis: em 1799 a média foi de 45,2 alqueires de milho por unidade produtiva, valor superior à mediana, 25; em 1808 a média foi menor, 28,9 alqueires em média (mediana 18 alqueires), mas o limite superior da distribuição, 1050 alqueires, foi mais de duas vezes e meia maior que o encontrado ao final do Setecentos, 400 alqueires. A partir da segunda década do Oitocentos a produção média voltou a subir, tendo atingido seu máximo em 1825: 51,7 alqueires de milho.

Apesar das diferentes médias encontradas, fato é que todas elas situaram-se na faixa de produção de 10,1 a 50 alqueires - exceção para 1825, quando o padre Francisco Bernardes produziu com seus cativos 2500 alqueires de milho, o maior volume observado ao longo dos 30 anos estudados -, ou seja, foram estes os montantes mais representativos da realidade produtiva do milho na vila de Mogi e seu termo, respondendo por percentuais que variaram entre 59\% dos chefes agricultores a plantar milho em 1799 a $85,8 \%$ deles em 1829. Dentro desta faixa de alqueires verificamos o volume mais comumente encontrado na área mogiana, 20 alqueires de milho, verificado como moda em seis dentre os oito anos para os quais obtivemos dados (em 1803 a moda foi 30, correspondente a 76 fogos e passado um lustro obtivemos moda de 10 alqueires, correspondente a 103 fogos naquele ano de 1808). Ademais, esta faixa de produção era responsável também por parcela principal da produção em todos os anos observados; 
com participação máxima em 1829: dos 62629 alqueires arrolados, 56,7\% (25055 alqueires) eram originários de unidades produtivas cuja produção situava-se entre 10,1 e 50 alqueires, correspondentes neste ano a 884 fogos, $45,7 \%$ da totalidade dos domicílios existentes naquela Mogi das Cruzes.

Tabela II.64

Estatísticas para a produção de milho (Mogi - 1799 a 1829)

\begin{tabular}{|c|c|c|c|c|c|c|c|c|}
\hline \multirow[b]{2}{*}{ Estatísticas } & \multicolumn{2}{|c|}{1799} & \multicolumn{2}{|c|}{1803} & \multicolumn{2}{|c|}{1808} & \multicolumn{2}{|c|}{1812} \\
\hline & $\begin{array}{l}\text { Total de } \\
\text { fogos }\end{array}$ & $\begin{array}{l}\text { Fogos com } \\
\text { milho }\end{array}$ & $\begin{array}{c}\text { Total de } \\
\text { fogos }\end{array}$ & $\begin{array}{l}\text { Fogos com } \\
\text { milho }\end{array}$ & $\begin{array}{c}\text { Total de } \\
\text { fogos }\end{array}$ & $\begin{array}{l}\text { Fogos com } \\
\text { milho }\end{array}$ & $\begin{array}{c}\text { Total de } \\
\text { fogos }\end{array}$ & $\begin{array}{l}\text { Fogos com } \\
\text { milho }\end{array}$ \\
\hline Média & 21,8 & 45,2 & 27,5 & 49,0 & 17,8 & 28,9 & 23,8 & 35,0 \\
\hline Moda & 0,0 & 20,0 & 0,0 & 30,0 & 0,0 & 10,0 & 0,0 & 20,0 \\
\hline Mediana & 0,0 & 25,0 & 10,0 & 30,0 & 9,0 & 18,0 & 12,0 & 20,0 \\
\hline Desvio padrão & 43,6 & 53,6 & 50,9 & 59,7 & 40,8 & 48,9 & 42,9 & 48,1 \\
\hline Índice de Gini & 0,768 & 0,527 & 0,723 & 0,506 & 0,700 & 0,511 & 0,660 & 0,501 \\
\hline Mínimo & 0,0 & 1,0 & 0,0 & 3,0 & 0,0 & & 0,0 & 3,0 \\
\hline \multirow[t]{2}{*}{ Máximo } & \multicolumn{2}{|c|}{400,0} & \multicolumn{2}{|c|}{585,0} & \multicolumn{2}{|c|}{1050,0} & \multicolumn{2}{|c|}{800,0} \\
\hline & \multicolumn{2}{|c|}{1816} & \multicolumn{2}{|c|}{1820} & \multicolumn{2}{|c|}{1825} & \multicolumn{2}{|c|}{1829} \\
\hline Estatísticas & $\begin{array}{c}\text { Total de } \\
\text { fogos }\end{array}$ & $\begin{array}{l}\text { Fogos com } \\
\text { milho }\end{array}$ & $\begin{array}{c}\text { Total de } \\
\text { fogos }\end{array}$ & $\begin{array}{c}\text { Fogos com } \\
\text { milho }\end{array}$ & $\begin{array}{c}\text { Total de } \\
\text { fogos }\end{array}$ & $\begin{array}{l}\text { Fogos com } \\
\text { milho }\end{array}$ & $\begin{array}{c}\text { Total de } \\
\text { fogos }\end{array}$ & $\begin{array}{l}\text { Fogos com } \\
\text { milho }\end{array}$ \\
\hline Média & 20,4 & 33,8 & 30,1 & 42,9 & 33,7 & 51,7 & 31,9 & 45,6 \\
\hline Moda & 0,0 & 20,0 & 0,0 & 20,0 & 0,0 & 20,0 & 0,0 & 20,0 \\
\hline Mediana & 10,0 & 20,0 & 20,0 & 27,0 & 20,0 & 30,0 & 16,0 & 30,0 \\
\hline Desvio padrão & 34,2 & 38,5 & 57,6 & 64,7 & 86,8 & 103,2 & 65,3 & 74,5 \\
\hline Índice de Gini & 0,687 & 0,484 & 0,631 & 0,474 & 0,695 & 0,532 & 0,674 & 0,523 \\
\hline Mínimo & 0,0 & 2,0 & 0,0 & 3,0 & 0,0 & 1,0 & 0,0 & 3,0 \\
\hline Máximo & \multicolumn{2}{|c|}{400,0} & \multicolumn{2}{|c|}{1500,0} & \multicolumn{2}{|c|}{2500,0} & \multicolumn{2}{|c|}{1175,0} \\
\hline
\end{tabular}

Fonte: AESP, M aços de População, Mogi das Cruzes: anos selecionados

Outra parcela importante dos produtores estava produzindo até 10 alqueires e apresentou, ao longo dos anos, percentual bastante próximo ao de unidades produtivas de 50,1 a 100 alqueires de milho. Diferença estava no volume de produto devido a cada faixa, no limite superior $7,7 \%$ (1808) para as menores colheitas e $32 \%$ (1829) para as maiores.

Na década de 1820 começam a merecer destaque os domicílios com colheitas de 300,1 ou mais alqueires, pois eram dois ou três indivíduos até 1816, não sendo mais que $0,5 \%$ dos fogos com o cereal em tela, tendo ampliado seu número a cinco em 1820 , passando a 14 indivíduos em 1825 e 16 em 1829, ainda que esta mudança pouco tenha representado em termos percentuais (subiram a 1,1\% e 1,5\%, nos dois últimos anos considerados, em seqüência). 
Tabela II.65

Distribuição de produtores e produção de milho

de acordo com faixas de alqueires

(Mogi - 1799 a 1829)

\begin{tabular}{|c|c|c|c|c|c|c|}
\hline \multirow{3}{*}{$\begin{array}{l}\text { Faixas de } \\
\text { alqueires }\end{array}$} & \multicolumn{2}{|c|}{1799} & \multicolumn{2}{|c|}{1803} & \multicolumn{2}{|c|}{1808} \\
\hline & Produtores & Volume & Produtores & Volume & Produtores & Volume \\
\hline & № (\%) & Alq. (\%) & № (\%) & Alq. (\%) & № (\%) & Alq. (\%) \\
\hline Até 10 & $105(19,0)$ & $850(3,3)$ & $89(11,6)$ & $743(2,0)$ & $278(30,2)$ & $2055(7,7)$ \\
\hline 10,1 a 50 & $327(59,0)$ & $9044(35,5)$ & $503(65,8)$ & $14094(37,3)$ & $546(59,3)$ & $13512(50,6)$ \\
\hline 50,1 a 100 & $71(12,8)$ & $5768(22,7)$ & $99(12,9)$ & $7846(20,7)$ & $71(7,7)$ & $5505(20,6)$ \\
\hline 100,1 a 300 & $48(8,7)$ & $8594(33,8)$ & $71(9,3)$ & $13812(36,5)$ & $22(2,4)$ & $3838(14,4)$ \\
\hline 300,1 a 500 & $3(0,5)$ & $1200(4,7)$ & $2(0,3)$ & $740(2,0)$ & $2(0,2)$ & $720(2,7)$ \\
\hline 500,1 ou mais & - & - & $1(0,1)$ & $585(1,5)$ & $1(0,1)$ & $1050(3,9)$ \\
\hline Total & $554(100,0)$ & $25456(100,0)$ & $765(100,0)$ & $37820(100,0)$ & $920(100,0)$ & $26680(100,0)$ \\
\hline \multirow{3}{*}{$\begin{array}{l}\text { Faixas de } \\
\text { alqueires }\end{array}$} & \multicolumn{2}{|c|}{1812} & \multicolumn{2}{|c|}{1816} & \multicolumn{2}{|c|}{1820} \\
\hline & Produtores & Volume & Produtores & Volume & Produtores & Volume \\
\hline & № (\%) & Alq. (\%) & № (\%) & Alq. (\%) & № $(\%)$ & Alq. (\%) \\
\hline Até 10 & $203(19,2)$ & $1688(4,5)$ & $193(22,7)$ & $1594(5,5)$ & $117(11,4)$ & $1058(2,4)$ \\
\hline 10,1 a 50 & $680(64,3)$ & $16373(44,0)$ & $530(62,4)$ & $13834(47,5)$ & $730(70,9)$ & $20697(46,9)$ \\
\hline 50,1 a 100 & $123(11,6)$ & $9547(25,7)$ & $91(10,7)$ & $7200(24,7)$ & $129(12,5)$ & $10354(23,4)$ \\
\hline 100,1 a 300 & $48(4,5)$ & $7801(21,0)$ & $34(4,0)$ & $5775(19,8)$ & $49(4,8)$ & $9090(20,6)$ \\
\hline 300,1 a 500 & $2(0,2)$ & $1000(2,7)$ & $2(0,2)$ & $750(2,6)$ & $4(0,4)$ & $1460(3,3)$ \\
\hline 500,1 ou mais & $1(0,1)$ & $800(2,2)$ & - & - & $1(0,1)$ & $1500(3,4)$ \\
\hline Total & $1057(100,0)$ & $37209(100,0)$ & $850(100,0)$ & 29153100,0 & $1030(100,0)$ & $44159(100,0)$ \\
\hline \multirow{3}{*}{$\begin{array}{l}\text { Faixas de } \\
\text { alqueires }\end{array}$} & \multicolumn{2}{|c|}{1825} & \multicolumn{2}{|c|}{1829} & & \\
\hline & Produtores & Volume & Produtores & Volume & & \\
\hline & № $(\%)$ & Alq. (\%) & № $(\%)$ & Alq. (\%) & & \\
\hline Até 10 & $118(10,1)$ & $1035(1,7)$ & $192(18,6)$ & $1731(3,9)$ & & \\
\hline 10,1 a 50 & $812(69,6)$ & $23234(38,5)$ & $884(85,8)$ & $25055(56,7)$ & & \\
\hline 50,1 a 100 & $151(12,9)$ & $12483(20,7)$ & $170(16,5)$ & $14145(32,0)$ & & \\
\hline 100,1 a 300 & $72(6,2)$ & $13870(23,0)$ & $64(6,2)$ & $12623(28,6)$ & & \\
\hline 300,1 a 500 & $8(0,7)$ & $3450(5,7)$ & $11(1,1)$ & $4800(10,9)$ & & \\
\hline 500,1 ou mais & $6(0,5)$ & $6225(10,3)$ & $5(0,5)$ & $4275(9,7)$ & & \\
\hline Total & $1167(100,0)$ & $60297(100,0)$ & $1326(128,7)$ & $62629(141,8)$ & & \\
\hline
\end{tabular}

Todavia, no que refere ao montante produzido, estes indivíduos que até 1816 respondiam por $2 \%$ (1803) a 5\% (1812) da produção da localidade passaram, em 1829, a ser responsáveis por $20,6 \%$ da produção. Tais caracteres levaram a certa concentração da produção do milho, observada através do índice de Gini, que pode ser considerado baixo em alguns momentos, identificados com mais reduzidos valores observados em 
1816 e 1820, respectivamente 0,484 e 0,474. Nos demais anos o índice de Gini foi praticamente coincidente, com mínimo de 0,501 (1812) e máximo de 0,532 (1825). Se expandida para os demais fogos, a concentração supera os 0,7 na virada do século XVIII para o XIX, situando-se entre 0,660 e 0,695 a partir de 1812 . Note-se que o milho foi bastante conjugado com outros cultivares, foi justamente nesses fogos que encontramos os grandes plantadores locais de milho.

O número de fogos a produzir milho variou consideravelmente (140\% entre 1799 e 1829), superando o aumento do número de fogos em Mogi, mas seguindo a direção da mudança destes, ou seja, houve uma redução no número de domicílios ligados ao cereal entre 1812 e 1816. Esse aumento do número de fogos ligados à produção refletiu-se no aumento da produção ao longo dos 30 anos observados (Gráfico II.60); de acordo com os mapas de produção eram pouco mais de 16000 alqueires em 1798, e 57303 alqueires decorridas três décadas. Durante esse período, ademais do Setecentos, o ano de 1808 apresentou as menores produções, 24736 alqueires, justamente este o ano no qual os arrolamentos nominativos apontaram os menores volumes médios colhidos do gênero.

Para além do número de fogos envolvidos, em que pese a quase total ausência de informações, a produção parece ter seguido, nos primeiros anos aqui tratados, a variação do preço real do milho. Quando este subiu depois de 1798 foi seguido pela produção, que caiu quando o preço recuou entre 1803 e 1804. Estes os únicos anos para os quais obtivemos informações sobre preços praticados na praça comercial mogiana.

O preço real médio apresentado foi o preço encontrado tanto para a "paróquia" como para as exportações, e as parcas observações obtidas para os preços também assim o foram para o comércio do cereal e de outros bens produzidos na vila. Tais informações restringem-se aos anos de 1798 a 1808 (nenhuma observação sobre venda de produção foi identificada nas listas nominativas propriamente). Neste período o milho foi em parte enviado a Santos (1798), em pequenina medida, com apenas $1,2 \%$ do volume total descrito sendo transacionado; e posteriormente a São Paulo, destino de $50 \%$ do que foi produzido em 1802 , sendo responsável por $41,5 \%$ do comércio para além vila levado a cabo no referido ano. 


\section{Gráfico II.23}

\section{Evolução do volume total produzido}

e do preço real médio do milho

(Mogi - 1798 a 1828)

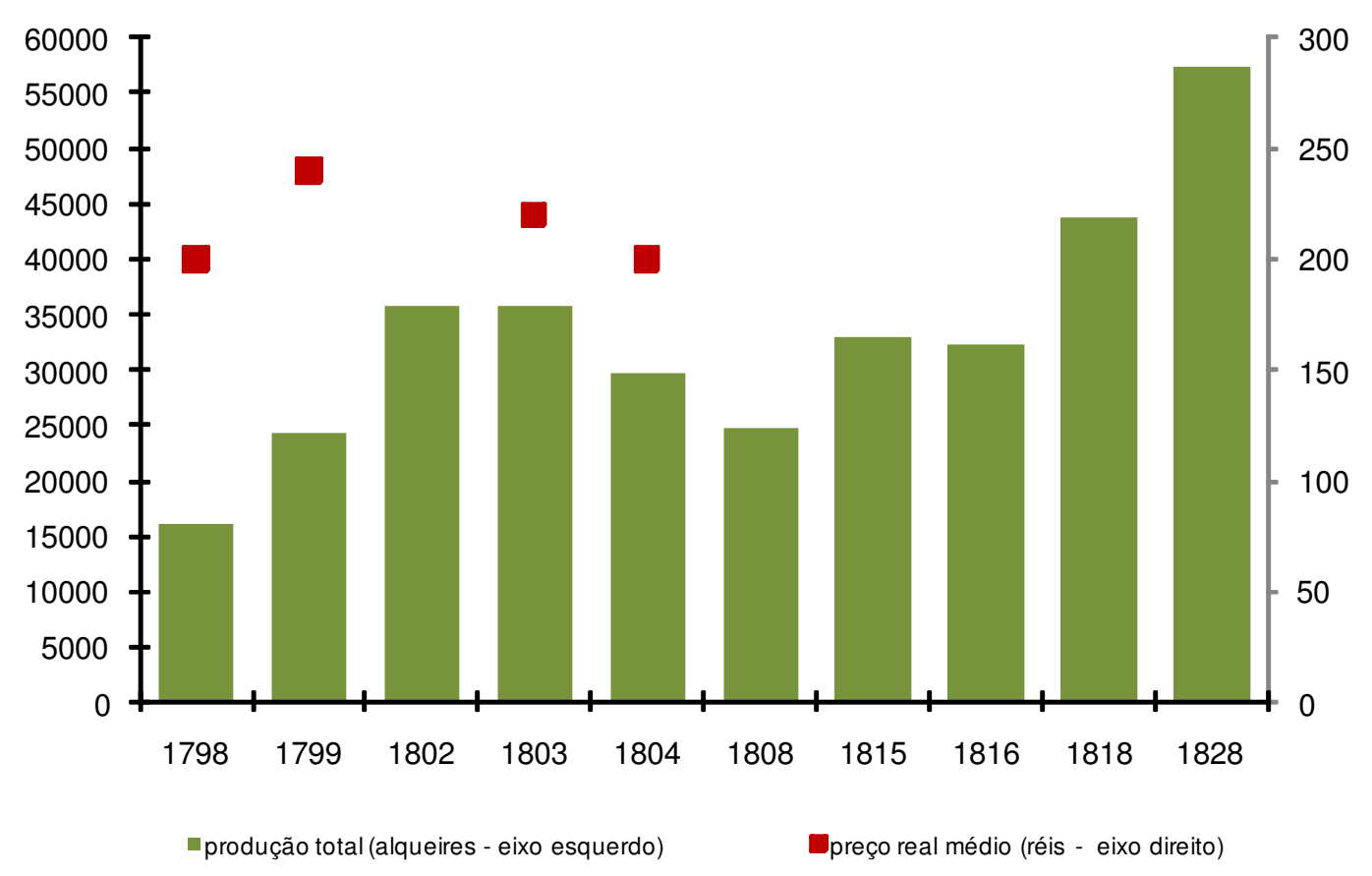

Bastante espraiado (ainda que em menores proporções que o milho), mas apresentando maior representatividade no comércio da localidade, observamos 0 algodão. Como adiantado, o algodão foi o terceiro principal produto descrito nos fogos ligados à agricultura, igualmente importante para a manutenção do artesanato de fiação e tecelagem, uma das atividades predominantes na vila: "[...] a cultura do algodão era a que mais ocupava os habitantes das redondezas. Com as fibras da Malvácea ai se faziam cobertas bem finas e bonitas redes" (SAINT-HILAIRE, 1974, p.92)

A produção algodoeira foi variável e a maior foi registrada nos mapas de 1802: 6407 arrobas, sendo $66 \%$ dela exportada, o que representou $22,3 \%$ do valor dos bens enviados para fora da localidade naquele ano (cf. Gráfico II.24 e Tabela II.69) No ano seguinte, a produção havia sido bem menor: 2390 arrobas, mas no mesmo ano as listas nominativas apontam uma produção média por produtor de 14,2 arrobas, a maior encontrada para todo o período 1799-1829, juntamente com a média calculada para 1825, 14,5 arrobas, pois se considerado o arrolamento por fogo, a soma da produção foi bastante superior, 5882 arrobas em 1803. A se considerar as produções apontadas na Tabela II.68, até 1808 o algodão estaria entre 5100 e 5900 arrobas, montante que caiu a 
3100-3500 entre 1812 e 1820, atingindo seu maior volume em 1825, 6766 arrobas aumento proporcionado pela presença em maior medida das plantações equivalentes a 50-100 arrobas, e pela presença do maior produtor individual identificado, Gabriel José Barreto de Lima, de cujo fogo saiu 165 arrobas de algodão - volume que foi de apenas 1835 arrobas em 1829, quantidade bastante próxima àquela observada para o mesmo ano nos mapas que acompanhavam os recenseamentos: 1645 arrobas de algodão.

Parcela majoritária dos algodoeiros situava-se na faixa de produção de até dez arrobas faixa que, apenas em 1829 respondeu por percentual principal da produção mogiana de algodão: 55,3\%. Anteriormente, parcela principal da produção era devida àqueles declarantes de 10,1 a 50 arrobas que responderam, aproximadamente, por $60 \%$ da produção ao longo do período 1799 a 1825, com exceção de 1820, quando 46,4\% da produção era igualmente devida aos indivíduos de cujas unidades domiciliares saíram até 10 e entre 10 e 50 arrobas de algodão, justificando a menor média encontrada neste ano, 8,8 arrobas, com moda 4 e mediana 6 .

Tabela II.66

Gêneros exportados de acordo com o destino

(Mogi - 1798 a 1808)

\begin{tabular}{|c|c|c|c|}
\hline & São Paulo & Santos & Rio de Janeiro \\
\hline 1798 & algodão, aguardente & $\begin{array}{c}\text { milho,feijão,arroz,farinha } \\
\text { de pão }\end{array}$ & panos de algodão \\
\hline 1799 & algodão, aguardente & - & panos de algodão \\
\hline 1802 & $\begin{array}{l}\text { milho, feijão, arroz, farinha } \\
\text { de mandioca, amendoim, } \\
\text { algodão, aguardente }\end{array}$ & - & - \\
\hline 1803 & algodão, aguardente & - & - \\
\hline 1804 & algodão, aguardente & - & - \\
\hline 1808 & $\begin{array}{c}\text { algodão, aguardente, panos } \\
\text { de algodão }\end{array}$ & - & - \\
\hline
\end{tabular}

Fonte: AESP, Maços de População - M apas de produção e co mércio, M ogi da Cruzes 
Tabela II.67

Percentual exportado e participação percentual dos diversos gêneros no valor do produto exportado

(Mogi - 1798 a 1808)

\begin{tabular}{|c|c|c|c|c|c|c|}
\hline \multirow[b]{2}{*}{ Produtos } & \multicolumn{2}{|c|}{1798} & \multicolumn{2}{|c|}{1799} & \multicolumn{2}{|c|}{1802} \\
\hline & $\begin{array}{c}\% \text { da } \\
\text { produção } \\
\text { do bem } \\
\text { exportada }\end{array}$ & $\begin{array}{c}\% \text { do valor } \\
\text { total } \\
\text { exportado }\end{array}$ & $\begin{array}{c}\% \text { da } \\
\text { produção } \\
\text { do bem } \\
\text { exportada }\end{array}$ & $\begin{array}{c}\% \text { do valor } \\
\text { total } \\
\text { exportado }\end{array}$ & $\begin{array}{c}\% \text { da } \\
\text { produção } \\
\text { do bem } \\
\text { exportada }\end{array}$ & $\begin{array}{c}\% \text { do valo } \\
\text { total } \\
\text { exportado }\end{array}$ \\
\hline Milho & 1,2 & 1,0 & 0,0 & - & 50,0 & 41,5 \\
\hline Feijão & 5,2 & 1,0 & 0,0 & - & 35,5 & 19,5 \\
\hline Algodão & 28,0 & 19,2 & 23,9 & 43,9 & 498,9 & 22,3 \\
\hline Arroz & 15,9 & 0,5 & 0,0 & - & 37,9 & 2,9 \\
\hline Farinha de mandioca & - & - & 0,0 & - & 34,7 & 1,7 \\
\hline Panos de algodão & 74,9 & 56,1 & 71,4 & 17,1 & - & - \\
\hline Aguardente & 64,5 & 20,9 & 50,0 & 39,0 & 80,0 & 11,6 \\
\hline Farinha de pão & 26,3 & 1,3 & - & - & - & - \\
\hline Amendoim & - & - & - & - & 32,2 & 0,5 \\
\hline \multirow[b]{3}{*}{ Produtos } & 35,4 & & 14,1 & 100,0 & 58,5 & 100,0 \\
\hline & \multicolumn{2}{|c|}{1803} & \multicolumn{2}{|c|}{1804} & \multicolumn{2}{|c|}{1808} \\
\hline & $\begin{array}{c}\% \text { da } \\
\text { produção } \\
\text { do bem } \\
\text { exportada }\end{array}$ & $\begin{array}{c}\% \text { do valor } \\
\text { total } \\
\text { exportado }\end{array}$ & $\begin{array}{c}\% \text { da } \\
\text { produção } \\
\text { do bem } \\
\text { exportada }\end{array}$ & $\begin{array}{c}\% \text { do valor } \\
\text { total } \\
\text { exportado }\end{array}$ & $\begin{array}{c}\text { \% da } \\
\text { produção } \\
\text { do bem } \\
\text { exportada }\end{array}$ & $\begin{array}{c}\% \text { do valo } \\
\text { total } \\
\text { exportado }\end{array}$ \\
\hline Algodão & 58,2 & 38,1 & 50,0 & 70,9 & 100,0 & 61,7 \\
\hline Panos de algodão & - & - & - & - & 100,0 & 11,9 \\
\hline Aguardente & 50,0 & 61,9 & 55,8 & 29,1 & 100,0 & 26,4 \\
\hline TOTAL & 15,8 & 100,0 & 16,9 & 100,0 & 18,7 & 100,0 \\
\hline
\end{tabular}

Fonte:AESP, Maços de População - Mapas de produção e co mércio, Mogi das Cruzes

Ademais, o grande número de pequenos produtores fez com que a atividade algodoeira fosse pouco concentrada entre estes indivíduos: o maior índice de Gini observado, 0,474 (1820), foi da mesma magnitude do menor índice calculado, 0,410 (1820). 


\section{Gráfico II.24}

\section{Evolução do volume total produzido}

e do preço real médio do algodão

(Mogi - 1798 a 1830)

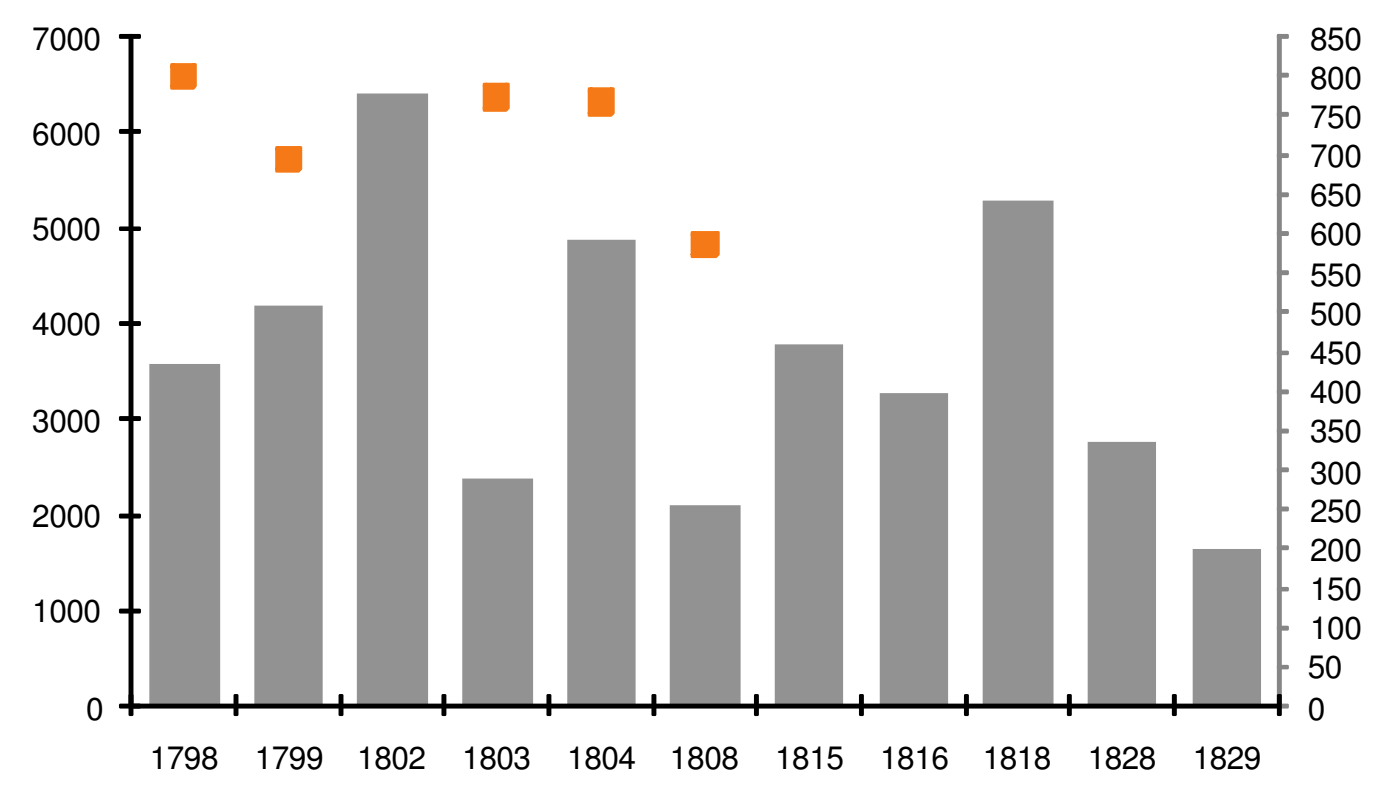

- produção total (arrobas - eixo esquerdo)

preço real médio (réis - eixo direito)

Em Mogi das Cruzes, diferente do ocorrido com o milho, o algodão participou do comércio de forma intermitente até 1808, último ano para o qual dispomos de informação a este respeito. Mas sua participação foi bastante variável, refletindo nas mudanças ocorridas na composição do valor exportado pela vila, que se viu modificada de maneira diversa ano após outro. Em 1798 o algodão era 19,2\% da exportação, já no ano seguinte o percentual era de $43,9 \%$, caindo a $22,3 \%$ após três anos (1802), sendo de $38,1 \%$ em 1803 e 70,9\% já no ano seguinte. Em 1798 a maior exportação foi de tecidos de algodão: enviados ao Rio de Janeiro foram responsáveis por $56,1 \%$ do valor dos bens saídos de Mogi naquele ano. (Tabela II.67) 
Tabela II.68

Distribuição de produtores e produção de algodão

de acordo com faixas de arrobas

(Mogi - 1799 a 1829)

\begin{tabular}{|c|c|c|c|c|c|c|}
\hline \multirow{3}{*}{$\begin{array}{c}\text { Faixas de } \\
\text { arrobas }\end{array}$} & \multicolumn{2}{|c|}{1799} & \multicolumn{2}{|c|}{1803} & \multicolumn{2}{|c|}{1808} \\
\hline & Produtores & Volume & Produtores & Volume & Produtores & Volume \\
\hline & № (\%) & Alq. (\%) & № (\%) & Alq. (\%) & № (\%) & Alq. (\%) \\
\hline Até 10 & $225(58,0)$ & $1398(26,8)$ & $236(56,9)$ & $1640(27,9)$ & $375(72,0)$ & $1928(37,7)$ \\
\hline 10,1 a 50 & $158(40,7)$ & $3393(65,1)$ & $170(41,0)$ & $3583(60,9)$ & $142(27,3)$ & $2908(56,8)$ \\
\hline 50,1 a 100 & $4(1,0)$ & $270(5,2)$ & $9(2,2)$ & $659(11,2)$ & $4(0,8)$ & $280(5,5)$ \\
\hline 100 ou mais & $1(0,3)$ & $150(2,9)$ & - & - & - & - \\
\hline Total & $388(100,0)$ & $5211(100,0)$ & $415(100,0)$ & $5882(100,0)$ & $521(100,0)$ & $5116(100,0)$ \\
\hline \multirow{3}{*}{$\begin{array}{c}\text { Faixas de } \\
\text { arrobas }\end{array}$} & \multicolumn{2}{|c|}{1812} & \multicolumn{2}{|c|}{1816} & \multicolumn{2}{|c|}{1820} \\
\hline & Produtores & Volume & Produtores & Volume & Produtores & Volume \\
\hline & № $(\%)$ & Alq. (\%) & № $(\%)$ & Alq. (\%) & № $(\%)$ & Alq. (\%) \\
\hline Até 10 & $195(66,6)$ & $1121(31,5)$ & $157(60,2)$ & $1035(30,3)$ & $292(80,0)$ & $1484(46,4)$ \\
\hline 10,1 a 50 & $93(31,7)$ & $2060(57,8)$ & $100(38,3)$ & $2121(62,2)$ & $70(19,2)$ & $1484(46,4)$ \\
\hline 50,1 a 100 & $5(1,7)$ & $380(10,7)$ & $4(1,5)$ & $255(7,5)$ & $3(0,8)$ & $230(7,2)$ \\
\hline 100,1 ou mais & - & - & - & - & - & - \\
\hline Total & $293(100,0)$ & $3561(100,0)$ & $261(100,0)$ & 3411100,0 & $365(100,0)$ & $3198(100,0)$ \\
\hline \multirow{3}{*}{$\begin{array}{c}\text { Faixas de } \\
\text { arrobas }\end{array}$} & \multicolumn{2}{|c|}{1825} & \multicolumn{2}{|c|}{1829} & & \\
\hline & Produtores & Volume & Produtores & Volume & & \\
\hline & № (\%) & Alq. (\%) & № (\%) & Alq. (\%) & & \\
\hline Até 10 & $261(55,8)$ & $1674(24,7)$ & $197(84,9)$ & $1015(55,3)$ & & \\
\hline 10,1 a 50 & $194(41,5)$ & $4057(60,0)$ & $33(14,2)$ & $665(36,2)$ & & \\
\hline 50,1 a 100 & $12(2,6)$ & $870(12,9)$ & $2(0,9)$ & $155(8,4)$ & & \\
\hline 100,1 ou mais & $1(0,2)$ & $165(2,4)$ & - & - & & \\
\hline Total & $468(100,0)$ & $6766(100,0)$ & $232(100,0)$ & $1835(100,0)$ & & \\
\hline
\end{tabular}

A importância dos tecidos não surpreende, posto termos verificado grande participação do algodão e do setor ligado a sua manufatura entre as ocupações da localidade - por exemplo, em 1799 Antonio Joaquim de Almeida e Joaquim Antonio da Cunha tinha como ocupação econômica "negócio de panos de algodão" (cf. Lista Nominativa de Mogi das Cruzes, 1799 - AESP, Maços de População/rolo 126) 


\section{Tabela II.69}

\section{Estatísticas para a produção de algodão}

(Mogi - 1799 a 1829)

\begin{tabular}{|c|c|c|c|c|c|c|c|c|}
\hline \multirow[b]{2}{*}{ Estatísticas } & \multicolumn{2}{|c|}{1799} & \multicolumn{2}{|c|}{1803} & \multicolumn{2}{|c|}{1808} & \multicolumn{2}{|c|}{1812} \\
\hline & $\begin{array}{c}\text { Total de } \\
\text { fogos }\end{array}$ & $\begin{array}{l}\text { Fogos com } \\
\text { algodão }\end{array}$ & $\begin{array}{c}\text { Total de } \\
\text { fogos }\end{array}$ & $\begin{array}{l}\text { Fogos com } \\
\text { algodão }\end{array}$ & $\begin{array}{c}\text { Total de } \\
\text { fogos }\end{array}$ & $\begin{array}{l}\text { Fogos com } \\
\text { algodão }\end{array}$ & $\begin{array}{c}\text { Total de } \\
\text { fogos }\end{array}$ & $\begin{array}{l}\text { Fogos com } \\
\text { algodão }\end{array}$ \\
\hline Média & 4,6 & 13,4 & 4,4 & 14,2 & 3,4 & 9,8 & 2,3 & 12,2 \\
\hline Moda & 0,0 & 20,0 & 0,0 & 10,0 & 0,0 & 5,0 & 0,0 & 4,0 \\
\hline Mediana & 0,0 & 10,0 & 0,0 & 10,0 & 0,0 & 6,0 & 0,0 & 8,0 \\
\hline Desvio padrão & 9,9 & 13,1 & 9,7 & 12,1 & 7,7 & 10,3 & 7,4 & 13,0 \\
\hline Índice de Gini & 0,805 & 0,428 & 0,820 & 0,413 & 0,815 & 0,470 & 0,901 & 0,473 \\
\hline Mínimo & 0,0 & 1,0 & 0,0 & 1,0 & 0,0 & 1,0 & 0,0 & 1,0 \\
\hline Máximo & \multicolumn{2}{|c|}{150,0} & \multicolumn{2}{|c|}{100,0} & \multicolumn{2}{|c|}{80,0} & \multicolumn{2}{|c|}{100,0} \\
\hline \multirow[b]{2}{*}{ Estatísticas } & \multicolumn{2}{|c|}{1816} & \multicolumn{2}{|c|}{1820} & \multicolumn{2}{|c|}{1825} & \multicolumn{2}{|c|}{1829} \\
\hline & $\begin{array}{c}\text { Total de } \\
\text { fogos }\end{array}$ & $\begin{array}{l}\text { Fogos com } \\
\text { algodão }\end{array}$ & $\begin{array}{c}\text { Total de } \\
\text { fogos }\end{array}$ & $\begin{array}{c}\text { Fogos com } \\
\text { algodão }\end{array}$ & $\begin{array}{c}\text { Total de } \\
\text { fogos }\end{array}$ & $\begin{array}{l}\text { Fogos com } \\
\text { algodão }\end{array}$ & $\begin{array}{c}\text { Total de } \\
\text { fogos }\end{array}$ & $\begin{array}{c}\text { Fogos com } \\
\text { algodão }\end{array}$ \\
\hline Média & 2,4 & 13,1 & 2,2 & 8,8 & 3,8 & 14,5 & 0,9 & 7,9 \\
\hline Moda & 0,0 & 10,0 & 0,0 & 4,0 & 0,0 & 10,0 & 0,0 & 5,0 \\
\hline Mediana & 0,0 & 10,0 & 0,0 & 6,0 & 0,0 & 10,0 & 0,0 & 5,0 \\
\hline Desvio padrão & 7,0 & 11,2 & 6,4 & 10,3 & 10,0 & 15,0 & 4,2 & 9,6 \\
\hline Índice de Gini & 0,890 & 0,410 & 0,869 & 0,474 & 0,854 & 0,442 & 0,935 & 0,457 \\
\hline Mínimo & 0,0 & 1,0 & 0,0 & 1,0 & 0,0 & 1,0 & 0,0 & 1,0 \\
\hline Máximo & \multicolumn{2}{|c|}{80,0} & \multicolumn{2}{|c|}{100,0} & \multicolumn{2}{|c|}{165,0} & \multicolumn{2}{|c|}{85,0} \\
\hline
\end{tabular}

Fonte: AESP, Maços de População, Mogi das Cruzes: anos selecionados

Todavia, mesmo acreditando ser a produção do algodão e sua fiação processos realizados em uma mesma unidade produtiva, encontramos apenas oito indivíduos em 1799 que indicaram produzir e fiar e/ou tecer o algodão, nove indivíduos em 1803 e dois em 1825, o que nos levaria a supor, em que pese a possibilidade de problemas de omissão de informações nos arrolamentos, haver parcela da população ligada à produção do algodão e outra parcela responsável por sua manufatura e transformação em tecido, sem conseguirmos ao certo identificar como se dava a relação entre eles. Certo é que tanto algodão como os tecidos dele derivados foram importantes para a economia local, para autoconsumo ou para o mercado:

Talvez devido ao clima e a qualidade do solo de Mogi das Cruzes, desenvolveu o cultivo do algodão como principal produto que era exportado, junto com os produtos de subsistência (milho, feijão,farinha e arroz). Contudo, o cultivo do algodão caracterizou por ser uma lavoura plantada em pequenas propriedades, tornando-se uma lavoura comercial de pequenos sitiantes.

Paralelamente ao cultivo do algodão desenvolveu sua manufatura. Dessa forma, as últimas décadas do século XVIII, marcaria profundas na economia da vila mogiana, pois, havia não só um produto agrícola de exportação, mas também uma atividade industrial manufatureira, cujo produto era exportado igualmente. (SANTOS, 2004). 
Entre as exportações da localidade, como adiantado, chama atenção a presença da aguardente, enviada para São Paulo. Com reduzida participação encontrada nos arrolamentos populacionais, mas com significativa presença no valor da produção local, a aguardente foi responsável por 61,9\% da produção exportada em 1803.

Conforme a Tabela II.66, Mogi comercializava seus gêneros com São Paulo e, ainda no Setecentos, com o Rio de Janeiro e Santos. Para a capital da colônia seguiam os panos de algodão; por representarem parcela majoritária das exportações foram os responsáveis pela participação marcante da localidade na composição percentual do destino dos bens saídos de Mogi: 57\% e 67\%, respectivamente em 1798 e 1799, como exposto no Gráfico II.25. Em 1798, ano em que Santos apareceu como importador de gêneros diversos (feijão, milho, arroz e farinha), respondeu por menos de $4 \%$ das exportações. São Paulo foi a única localidade a receber os produtos mogianos entre 1802 e 1808, tendo importado no século XVIII algodão e aguardente, que corresponderam a $40 \%$ e 33\% dos bens saídos de Mogi em 1798 e 1799, respectivamente.

\section{Gráfico II.25}

Participação das diferentes localidades nas exportações (Mogi - 1798 a 1808)

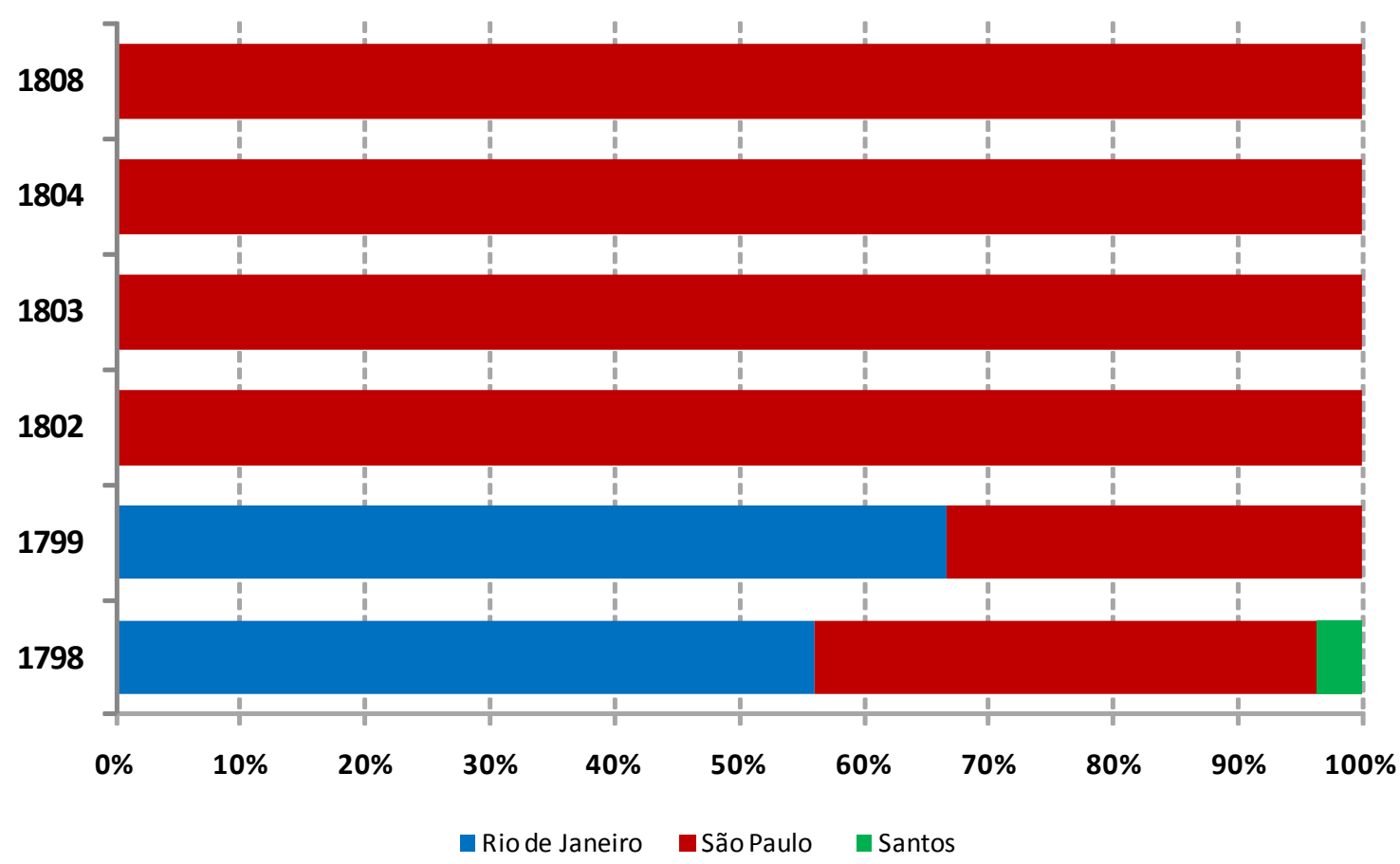


O total destas exportações, diferentes e com características distintas entre 1798 e 1808, foram responsáveis por coeficientes que variaram de 0,35 em 1798 a 0,97 em 1808 . Ou seja, a parcela da "receita" da produção da vila proveniente das exportações, foi bastante variável ao longo do tempo, passando de cerca de 35\% em 1798 à quase totalidade após dez anos.

Tabela II.70

Coeficientes de exportação e importação

(Mogi - 1798 a 1808)

\begin{tabular}{ccc}
\hline \hline Anos & $\begin{array}{c}\text { Coeficiente de } \\
\text { exportação* }\end{array}$ & $\begin{array}{c}\text { Penetração das } \\
\text { importações ** }\end{array}$ \\
\hline $\mathbf{1 7 9 8}$ & 0,35 & 0,65 \\
$\mathbf{1 7 9 9}$ & 0,37 & 0,16 \\
$\mathbf{1 8 0 2}$ & 0,58 & 0,46 \\
$\mathbf{1 8 0 3}$ & 0,39 & 0,47 \\
$\mathbf{1 8 0 4}$ & 0,40 & 0,41 \\
$\mathbf{1 8 0 8}$ & 0,97 & 0,26 \\
\hline \hline *valor das exportações/valor da produção \\
**valor das importações/valor do consumo \\
Fonte: AESP, Maços de População - Mapas de produção e comércio, \\
Mogi das Cruzes:anos selecionados
\end{tabular}

Apesar de produzir uma série de gêneros de subsistência, alguns bens chegavam à localidade vindos de locais mais distantes, como mostra a Tabela II.71. Para os anos em que identificamos a importação, 1798 a 1808, encontramos sal, azeite, aguardente do reino, vinagre e vinho chegados de Santos durante toda a década em tela; tecidos finos, chapéus e eventualmente lenços com origem no Rio de Janeiro até 1804; e toucinho importado de Nazaré - como já havíamos identificado naquela localidade em seção anterior -, corroborando a reduzida presença de animais nos recenseamentos mogianos.

O valor devido a cada localidade de onde chegaram os bens importados por Mogi das Cruzes sofreu flutuações nos anos que separam 1798 e 1808, mas apontam para a importância assumida pela praça carioca: à exceção de 1802, quando $60 \%$ do valor das importações era devida ao porto de Santos, o Rio de Janeiro foi o principal intermediário de artigos consumidos por Mogi e seu termo, especialmente tecidos, como adiantado. Especialmente no ano de 1799, 84,7\% das importações vieram do Rio, assim como $86,9 \%$ em 1803. 
Tabela II.71

Gêneros importados de acordo com a origem

(Mogi - 1798 a 1808)

\begin{tabular}{|c|c|c|c|}
\hline & Santos & Rio de Janeiro & Nazaré \\
\hline 1798 & $\begin{array}{l}\text { sal, azeite de peixe, } \\
\text { aguardente do reino, } \\
\text { vinagre, vinho }\end{array}$ & tecidos, chapéus & toucinho \\
\hline 1799 & $\begin{array}{c}\text { sal, azeite de peixe, } \\
\text { aguardente do reino, vinho }\end{array}$ & tecidos, chapéus & - \\
\hline 1802 & $\begin{array}{c}\text { sal, azeite doce, } \\
\text { aguardente do reino, vinho, } \\
\text { vinagre }\end{array}$ & $\begin{array}{c}\text { tecidos, chapéus, } \\
\text { lenços }\end{array}$ & - \\
\hline 1803 & $\begin{array}{l}\text { sal, vinho, vinagre, } \\
\text { aguardente do reino }\end{array}$ & tecidos, chapéus & - \\
\hline 1804 & sal, vinho,vinagre & $\begin{array}{l}\text { tecidos, chapéus, } \\
\text { lenços, meias }\end{array}$ & - \\
\hline 1808 & sal, vinagre, vinho & - & - \\
\hline
\end{tabular}

Fonte: AESP, M aços de População - M apas de produção e comércio, M ogi das Cruzes

Tabela II.73

Percentual do valor importado de acordo com a origem (Mogi - 1798 a 1808)

\begin{tabular}{|c|c|c|c|c|}
\hline Anos & $\begin{array}{c}\text { Rio de } \\
\text { Janeiro } \\
\%\end{array}$ & $\begin{array}{c}\text { Santos } \\
\%\end{array}$ & $\begin{array}{c}\text { Nazaré } \\
\%\end{array}$ & $\begin{array}{c}\text { Total } \\
\%\end{array}$ \\
\hline 1798 & 74,6 & 23,8 & 1,5 & 100,0 \\
\hline 1799 & 84,7 & 15,3 & - & 100,0 \\
\hline 1802 & 40,0 & 60,0 & - & 100,0 \\
\hline 1803 & 86,9 & 13,1 & - & 100,0 \\
\hline 1804 & 54,2 & 45,8 & - & 100,0 \\
\hline 1808 & 0,0 & 100,0 & - & 100,0 \\
\hline
\end{tabular}

$\overline{\text { Fonte: AESP, M aços de População - M apas de produção e co mércio, M o gi das Cruzes }}$ 
Estas importações, em 1798 e 1802-1803 representaram, de acordo com os coeficientes de importação (Tabela II.70), respectivamente 0,65 e 0,46-0,47 de tudo o que foi consumido na localidade e anotado na documentação compulsada. Em 1799 o coeficiente foi o menor identificado, 0,16 , indicando que quase menos de um quinto do consumo local foi devido a bens importados.

Comparando as importações com as exportações obtemos dados relativos à balança comercial da localidade no final do século XVIII e primeiros anos do século subseqüente de acordo com os mapas de comércio, como vai colocado no Gráfico II.26

Gráfico II.26

Saldo do balanço comercial

(Mogi - 1798 a 1808)

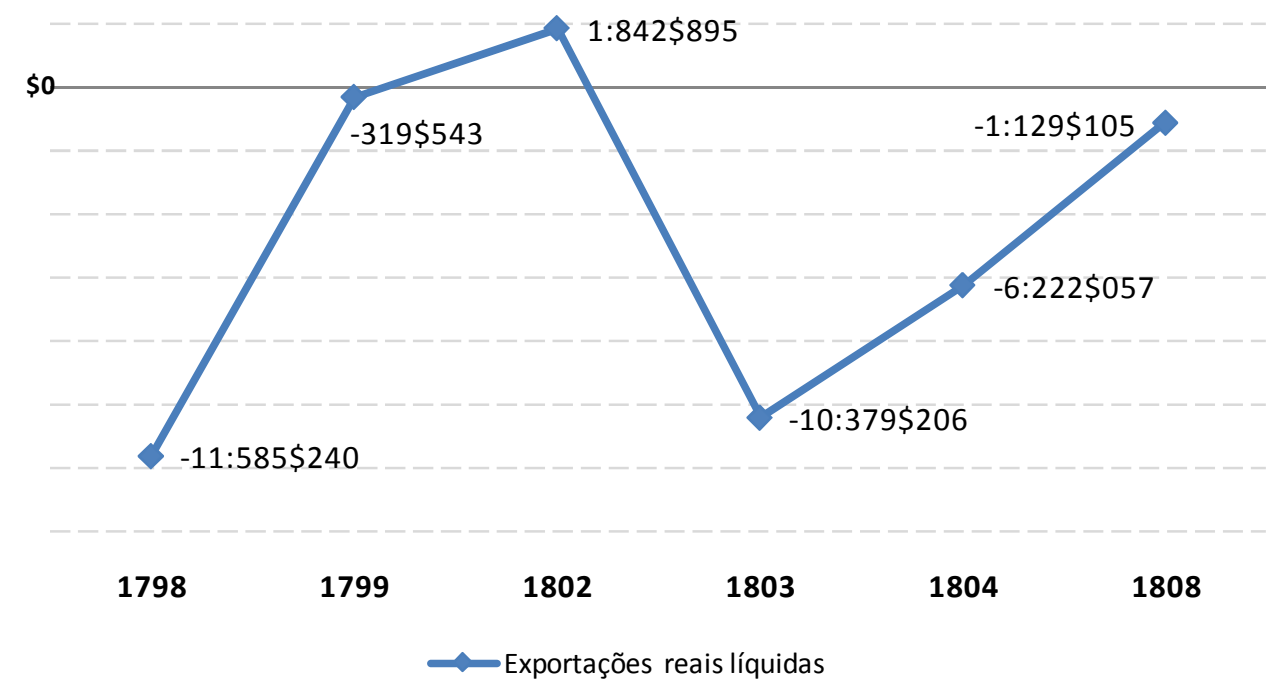

Os resultados comerciais mogianos apontam constante déficit, tendo atingido resultado positivo apenas em 1802, 1:842\$895. Os déficits variaram de valores elevados, acima de 11:500\$000 (1798) a valores menos representativos, 320\$000 (1799) em seqüência. Assim, ressalte-se, como anteriormente o fizemos para outras localidades em estudo, que saldos comerciais negativos implicam em necessidade de financiamento do consumo da vila por alguém ou alguma outra localidade, especialmente diante da restrita circulação monetária na economia do período, com um amplo comércio baseado na simples troca e a prática de pagamentos indiretos do trabalho, em gêneros ou parte da produção. 


\section{Jacareí}

Ao todo temos registrada para a vila de Jacareí e sua freguesia de Paraibuna (explicitada na documentação a partir de 1816) a atividade principal, ou seja, aquela atinente ao chefe do chefe de fogo, para $87,1 \%$ dos fogos em 1798, 80,4\% em 1803, 75,7\% em 1807, 1811 (80,9\%), 1816 (85\%), 1822 (95,1\%), 1825 (91,4\%) e 1829 (90,3\%). A distribuição dessas ocupações por setores é apresentada na Tabela II.74

\section{Tabela II.74}

Distribuição dos fogos por setores de atividade econômica (Jacareí - 1798 a 1829)

\begin{tabular}{|c|c|c|c|c|c|c|c|c|}
\hline Setor & $\begin{array}{l}1798 \\
\% \text { (№) }\end{array}$ & $\begin{array}{c}1803 \\
\% \text { (№) }\end{array}$ & $\begin{array}{c}1807 \\
\% \text { (№) }\end{array}$ & $\begin{array}{c}1811 \\
\% \text { (№) }\end{array}$ & $\begin{array}{c}1816 \\
\% \text { (№) }\end{array}$ & $\begin{array}{l}1822 \\
\% \text { (№) }\end{array}$ & $\begin{array}{l}1825 \\
\% \text { (№) }\end{array}$ & $\begin{array}{l}1829 \\
\% \text { (№) }\end{array}$ \\
\hline Agricultura & $74,6(586)$ & $68,2(513)$ & $67,4(401)$ & $70,6(566)$ & $75,3(896)$ & 72,4 (999) & $61,4(832)$ & $82,2(1014)$ \\
\hline Igreja & $0,3(2)$ & $0,4(3)$ & $0,3(2)$ & $0,4(3)$ & $0,4(5)$ & $0,3(4)$ & $0,2(3)$ & $0,3(4)$ \\
\hline Magistratura & $0,4(3)$ & $0,3(2)$ & $0,3(2)$ & $0,5(4)$ & $0,3(3)$ & $0,3(4)$ & $0,2(3)$ & $0,3(4)$ \\
\hline Rentistas & - & - & $0,2(1)$ & $0,6(5)$ & $0,6(7)$ & $0,6(8)$ & $0,4(5)$ & $0,2(2)$ \\
\hline Comércio & $1,3(10)$ & $0,5(4)$ & $4,0(24)$ & $1,9(15)$ & $1,5(18)$ & $2,1(29)$ & $2,3(31)$ & $2,0(25)$ \\
\hline Transporte & - & $0,1(1)$ & $0,5(3)$ & - & $0,2(2)$ & $0,1(1)$ & $0,7(10)$ & - \\
\hline Serviços em geral & - & - & - & - & $0,2(2)$ & $0,1(1)$ & $0,4(6)$ & - \\
\hline Não classificadas & $2,9(23)$ & $0,5(4)$ & - & $1,7(14)$ & - & - & $0,4(6)$ & - \\
\hline Múltiplos setores & $14,4(113)$ & $9,3(70)$ & $11,9(71)$ & $11,3(91)$ & $5,0(60)$ & $4,6(64)$ & $23,9(324)$ & $3,8(47)$ \\
\hline Total & $100,0(786)$ & $100,0(752)$ & $100,0(595)$ & $100,0(802)$ & $100,0(1190)$ & $100,0(1380)$ & $100,0(1355)$ & $100,0(1234)$ \\
\hline
\end{tabular}

A maioria dos domicílios jacareienses compulsados na tabela apresentou, sem algum outro vínculo aparente, ligação com atividades do setor agricultura. Para além desse setor, encontramos importante participação do artesanato nos anos de 1808 a 1822. Em 1808 o artesanato respondia por 11,9\% das ocupações arroladas, percentual ampliado a 13,5\% em 1816 e 15,9\% no ano de 1822. Neste setor, destacam-se as atividades femininas de fiação e tecelagem: em 1816 foram 110 chefes ligados a estas ocupações que respondiam por $50 \%$ dos fogos no setor artesanato e $9,2 \%$ do total de fogos registrados, todos situados na vila de Jacareí propriamente. Somente entre 1798 e 1803 encontramos estas pessoas em Paraibuna, não mais de sete indivíduos em 1803.

A participação do setor agricultura não mostrou flutuação clara ao longo do tempo, iniciou o período comportando $74,6 \%$ dos fogos, já em 1807 esse percentual havia caído 
a $67,4 \%$, voltou a valores próximos ao calculado para o Setecentos na década de 1810; em 1825 foi de $61,4 \%$ e em 1829, passados quatro anos, havia subido mais de vinte pontos percentuais: $82,2 \%$.

A participação do setor vê-se elevada se modificamos a classificação dos agricultores militares, considerando ser a primeira, a atividade principal do fogo, na medida em que a agricultura era o setor mais diretamente passível de suprir as necessidades imediatas do grupo familiar pertencente aquele fogo e/ou poderiam representar seus vínculos com o mercado.

Tabela II.75

Distribuição dos fogos por setores de atividade econômica

- exclusive militares em múltiplas ocupações (Jacareí - 1798 a 1829)

\begin{tabular}{|c|c|c|c|c|c|c|c|c|}
\hline Setor & $\begin{array}{l}1798 \\
\% \text { (№) }\end{array}$ & $\begin{array}{r}1803 \\
\% \text { (№) }\end{array}$ & $\begin{array}{r}1807 \\
\% \text { (№) }\end{array}$ & $\begin{array}{r}1811 \\
\% \text { (№) }\end{array}$ & $\begin{array}{l}1816 \\
\% \text { (№) }\end{array}$ & $\begin{array}{c}1822 \\
\% \text { (№) }\end{array}$ & $\begin{array}{l}1825 \\
\% \text { (№) }\end{array}$ & $\begin{array}{l}1829 \\
\% \text { (№) }\end{array}$ \\
\hline Agricultura & $83,7(658)$ & $76,5(575)$ & $79,2(471)$ & $80,8(648)$ & $79,7(948)$ & $76,2(1051)$ & $83,8(1135)$ & $85,3(1053)$ \\
\hline Igreja & $0,3(2)$ & $0,4(3)$ & $0,3(2)$ & $0,4(3)$ & $0,4(5)$ & $0,3(4)$ & $0,2(3)$ & $0,3(4)$ \\
\hline Magistratura & $0,4(3)$ & $0,4(3)$ & $0,3(2)$ & $0,5(4)$ & $0,3(3)$ & $0,3(4)$ & $0,2(3)$ & $0,3(4)$ \\
\hline Rentistas & - & $0,1(1)$ & $0,2(1)$ & $0,6(5)$ & $0,6(7)$ & $0,6(8)$ & $0,4(5)$ & $0,2(2)$ \\
\hline Comércio & $1,3(10)$ & $0,5(4)$ & $4,0(24)$ & $1,9(15)$ & $1,9(23)$ & $2,1(29)$ & $2,4(33)$ & $2,2(27)$ \\
\hline Transporte & - & $0,1(1)$ & $0,5(3)$ & - & $0,2(2)$ & $0,2(3)$ & $0,8(11)$ & - \\
\hline Serviços em geral & - & - & - & - & $0,2(2)$ & $0,1(1)$ & $0,4(6)$ & - \\
\hline Não classificadas & $2,9(23)$ & $0,5(4)$ & - & $2,0(16)$ & - & - & $0,4(6)$ & - \\
\hline Múltiplos setores & $5,1(40)$ & $0,7(5)$ & - & $0,2(2)$ & $0,3(3)$ & $0,7(10)$ & $1,1(15)$ & $0,2(2)$ \\
\hline Total & $100,0(786)$ & $100,0(752)$ & $100,0(595)$ & $100,0(802)$ & $100,0(1190)$ & $100,0(1380)$ & $100,0(1355)$ & 100,0 \\
\hline
\end{tabular}

$\mathrm{Na}$ Tabela II.74, homens com diferentes patentes militares e que realizaram alguma outra atividade paralela foram relacionados sob a rubrica "múltiplos setores", como exposto em seções anteriores. Os militares raras vezes foram unicamente assim descritos; encontramos, no máximo, cinco indivíduos nessa situação em 1803, quatro nos demais anos observados até 1812, e esteve ausente tal denominação nos anos de 1816 e 1822. Os demais militares estavam ligados a outras atividades que, consideradas isoladamente, reduziram a participação dos múltiplos setores a 5,1\% em 1799 (havia sido de $14,4 \%$ na classificação anterior), e valores pouco significativos de até $1,1 \%$ no século XIX. 
A agricultura passa a responder por percentuais ampliados, com destaque para o ano de 1825 , no qual dentre os $23,9 \%$ de unidades produtivas em múltiplos setores, 95,5\% (309 fogos) correspondiam ao arrolamento conjunto de militares e lavradores e/ou criadores, o que alçou a participação da agricultura a $83,8 \%$, a segunda participação mais representativa em todo o lapso 1798-1829 (a maior era pouco superior: 85,3\% em 1829). Neste mesmo ano de 1825 ela havia sido bastante inferior às demais em nossa primeira análise.

Dentro do setor agricultura foram anotados, em especial, chefes declarados lavradores e lavradores para seu sustento ("planta para gasto", "planta para comer"). Estes indivíduos realizavam cultivos diversos, em alguns fogos identificados. (Tabela II.76)

\section{Tabela II.76}

Gêneros plantados e presença concomitante dos diferentes gêneros nos fogos

(Jacareí - 1798 a 1829)

\begin{tabular}{lcccccccc}
\hline \hline \multicolumn{1}{c}{ CULTURAS } & $\mathbf{1 7 9 8}$ & $\mathbf{1 8 0 3}$ & $\mathbf{1 8 0 7}$ & $\mathbf{1 8 1 1}$ & $\mathbf{1 8 1 6}$ & $\mathbf{1 8 2 2}$ & $\mathbf{1 8 2 5}$ & $\mathbf{1 8 2 9}$ \\
\hline MILHO & $94,8 \%$ & $100,0 \%$ & $99,3 \%$ & $100,0 \%$ & $99,5 \%$ & $99,8 \%$ & $98,6 \%$ & $98,0 \%$ \\
FEIJÃO & $73,6 \%$ & $92,7 \%$ & $87,9 \%$ & $91,8 \%$ & $79,4 \%$ & $91,5 \%$ & $93,5 \%$ & $91,2 \%$ \\
ALGODÃO & $48,8 \%$ & $37,0 \%$ & $57,7 \%$ & $11,6 \%$ & $47,8 \%$ & $25,2 \%$ & $26,2 \%$ & $14,3 \%$ \\
ARROZ & $3,9 \%$ & $20,4 \%$ & $17,8 \%$ & $31,7 \%$ & $14,6 \%$ & $50,7 \%$ & $55,7 \%$ & $59,5 \%$ \\
CANA & $5,5 \%$ & $5,5 \%$ & $3,5 \%$ & $2,3 \%$ & $2,2 \%$ & $2,4 \%$ & $2,0 \%$ & $2,0 \%$ \\
FUMO & $0,3 \%$ & $1,4 \%$ & $0,5 \%$ & $1,9 \%$ & $7,3 \%$ & $11,1 \%$ & $8,6 \%$ & $3,8 \%$ \\
MANDIOCA & $1,2 \%$ & $0,2 \%$ & - & - & - & - & - & - \\
AMENDOIM & - & $0,2 \%$ & $0,5 \%$ & $4,7 \%$ & $0,8 \%$ & $0,4 \%$ & $0,4 \%$ & $0,4 \%$ \\
CAFÉ & - & $0,5 \%$ & - & $0,3 \%$ & $0,5 \%$ & $3,1 \%$ & $11,2 \%$ & $12,7 \%$ \\
TRIGO & - & - & - & - & $0,1 \%$ & - & - & - \\
MAMONA & - & $0,2 \%$ & - & - & - & - & - & - \\
\hline \hline
\end{tabular}

Fonte: AESP, M aços de População, Jacareí: anos selecionados

Sem dúvidas, a plantação mais espraiada entre os fogos era o milho, encontrado praticamente na totalidade daqueles domicílios em que algum tipo de cultura foi declarado. Apenas em 1799 este percentual havia sido pouco inferior, 94,8\%, ainda assim próximo aos valores observados nos demais anos, cujo percentual mínimo foi de $98 \%$ (1829).

Presença marcante também encontramos para o feijão, o algodão e o arroz. 0 feijão esteve em $73,6 \%$ dos domicílios em 1799, 79,4\% em 1816, partindo de $80 \%$ nos demais anos. O arroz esteve em não menos de $14,6 \%$ das declarações no século XIX, e 
ampliou consideravelmente sua participação na década de 1820 quando esteve entre $50 \%$ e $60 \%$ das unidades produtivas. O algodão, em sentido inverso ao arroz foi encontrado em menor percentual de fogos na década de 1820, partindo nesse período de 25,2\% em 1822 a 14,3\% em 1829; três décadas antes, o algodão estava em 48,8\% das declarações em 1799 e 57,7\% em 1807.

Note-se também, a presença do café, que ausente ou pontualmente encontrado ao inicio do período observado, foi encontrado em $12,7 \%$ dos fogos jacareienses com alguma plantação declarada em 1829: "Antigamente [...], ninguém se ocupava, nos arredores de Jacareí, senão com a cultura do algodão e da criação de porcos. De algum tempo para cá começou-se a plantar muito café." (SAINT-HILAIRE, 1974, p. 93)

Apesar da menção de Saint-Hilaire, feita na década de 1830, à produção de porcos, estes só apareceram na documentação a partir de 1816 (a presença desses animais foi também utilizada na classificação destes indivíduos como criadores). A Tabela II.77 mostra a quantidade de fogos em que aparecem estas criações. Os 398 chefes de domicílio ligados a pecuária e apresentados na tabela eram também lavradores.

Tabela II.77

Criações e presença concomitante

dos diferentes animais nos fogos

(Jacareí - 1798 a 1829)

\begin{tabular}{|c|c|c|c|c|}
\hline CRIAÇÕES & $\begin{array}{l}1816 \\
\% \text { (№) }\end{array}$ & $\begin{array}{l}1822 \\
\% \text { (№) }\end{array}$ & $\begin{array}{l}1825 \\
\% \text { (№) }\end{array}$ & $\begin{array}{c}1829 \\
\% \text { (№) }\end{array}$ \\
\hline VACAVBEZERRO & $15,6(22)$ & $17,3(19)$ & $6,1(7)$ & - \\
\hline PORCO/CAPADO & $51,1(72)$ & $42,7(47)$ & $65,8(75)$ & $90,9(30)$ \\
\hline BESTAVBURO/MULA & - & $0,9(1)$ & - & $6,1(2)$ \\
\hline $\mathrm{VACA}+\mathrm{CAPADO}$ & $31,2(44)$ & $27,3(30)$ & $17,5(20)$ & - \\
\hline VACA+CAVALO & $0,7(1)$ & $5,5(6)$ & $0,9(1)$ & $3,0(1)$ \\
\hline VACA+BESTA & - & - & - & - \\
\hline VACA+CAPADO+BESTA & - & $4,5(5)$ & $8,8(10)$ & - \\
\hline CAPADO+CAVALO & - & $1,8(2)$ & $0,9(1)$ & - \\
\hline VACA+CAPADO+CARNEIRO & $0,7(1)$ & - & - & - \\
\hline VACA+CAPADO+CABRITO & $0,7(1)$ & - & - & - \\
\hline TOTAL & $100,0(141)$ & $100,0(110)$ & $100,0(114)$ & $100,0(33)$ \\
\hline
\end{tabular}

Fontes: AESP, Maços de População, Jacareí: anos selecionados, ex clusive 1798,1803, 1807 e 1811

Criações, ainda que certamente presentes na vila de Jacareí e seu termo ao longo de todo o lapso considerado, foram descritas apenas a partir de 1816 e, em especial, 
resumiam-se basicamente a gado vacum e suínos. Os porcos apareceram em maior medida, eram os únicos animais em 51,1\% das declarações em 1816, 42,7\% em 1822 e $65,8 \%$ em 1825; sua conjugação com vacas e bezerros foi também importante, ao responder por $31,2 \%$ dos fogos nos quais a presença de algum animal foi identificada em 1826, 27,3\% em 1822, caindo a 17,5\% em 1829.

O elevado percentual em que foram encontrados os diferente produtos implicam em sua coexistência; explicitamente foi encontrada majoritariamente a policultura (Gráfico II.27)

\section{Gráfico II.27}

Percentual de fogos com presença dos diversos gêneros cultivados (Jacareí - 1798 a 1829)

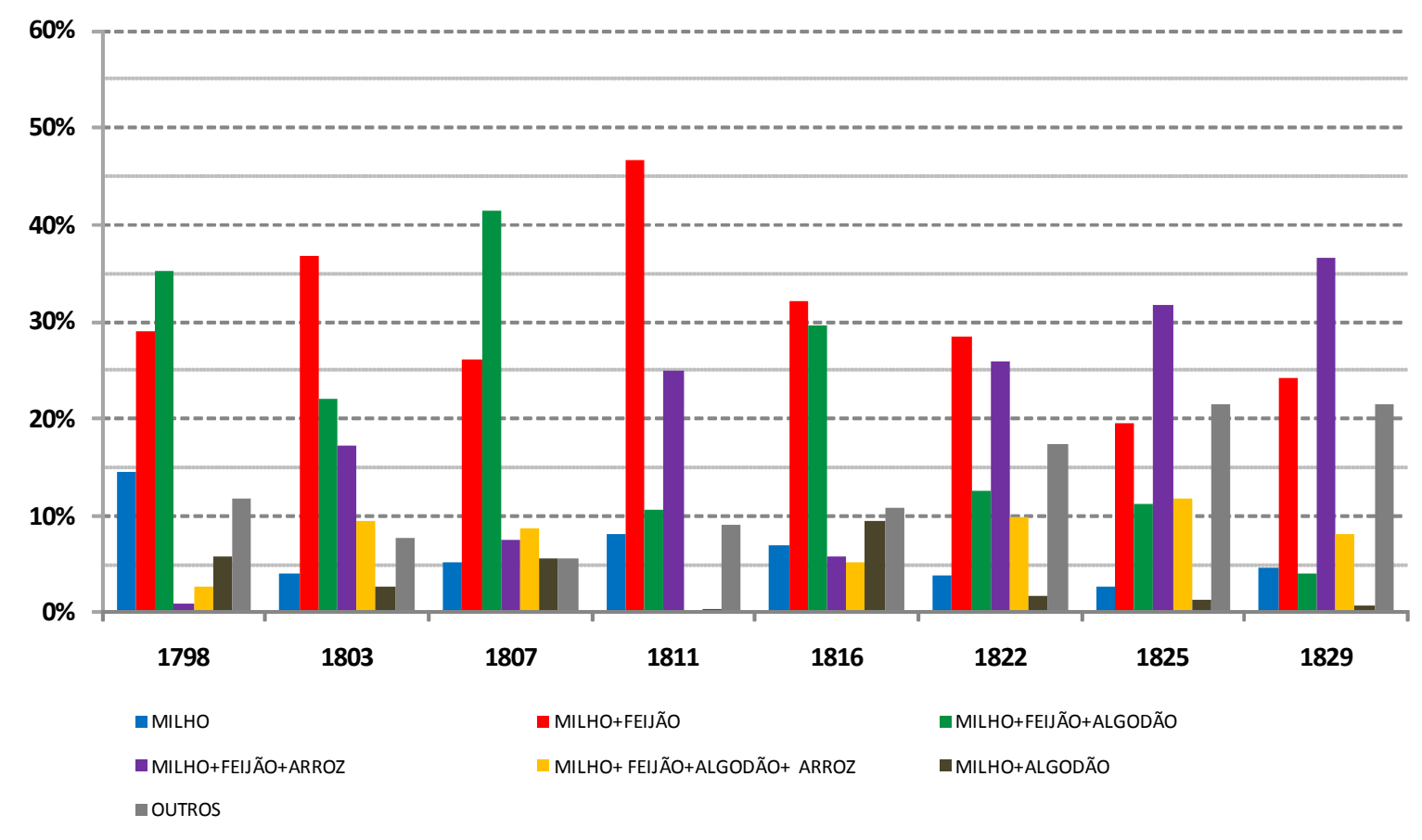

O milho foi a única plantação a apresentar alguma importância isoladamente: pouco menos de $15 \%$ das declarações de produção de 1799 , correspondente a 48 fogos naquele ano (cf. Tabela no apêndice estatístico). A conjugação milho mais feijão junto à conjugação milho mais feijão mais algodão foram comumente encontradas até 1816, sendo a conjugação com o algodão majoritária em 1799 (35\%) e em 1807 (41\%). A partir de 1822 a ampliação da cultura do arroz em detrimento à cultura do algodão levou à maior participação da conjugação entre milho, feijão e arroz que foi mais comumente encontrada em 1825 e 1829, 31,7\% e 36,5\%, respectivamente. 
Para além do setor agrícola e do artesanato anteriormente referidos, encontramos presença relativamente importante do comércio, que em 1824, ao empregar 24 chefes domicílio, respondeu por 4\% das ocupações declaradas na lista nominativa. Em 1825 este número havia subido a 33 indivíduos, mas correspondeu a um percentual menor, 2,4\% entre as 1355 descrições (cf. Tabela II.75).

Ademais, especialmente em 1803, destacam-se os jornaleiros. Neste ano eram 79 indivíduos, ou seja, $10,5 \%$ do total, percentual que supera a participação do artesanato $(9,3 \%)$. O número de jornaleiros caiu a 15 indivíduos passados menos de cinco anos (2,5\% em 1807), e atingiu sua maior presença a partir daí em 1822: 3,5\% (22 pessoas). As mudanças na economia podem ser sentidas nas flutuações desta variável, que seguia as possibilidades abertas ou fechadas pelos diferentes setores. Essas atividades foram acompanhadas por atividades típicas de núcleos urbanos, necessárias ao funcionamento das localidades que representaram pouco em termos de ocupação dos indivíduos.

Os jornaleiros, indivíduos sem ocupação específica, que auferiam ganhos de trabalhos a retalho eram "pobres que trabalhavam [...] claramente o elemento mais pobre da população." (LUNA \& KLEIN, 2006, p.235). Ou, quase tão pobres quanto aqueles que se encontravam a parte do processo produtivo da localidade, ou seja, aqueles declarados pobres nos arrolamentos populacionais. (Gráfico II.28).

Em 1798 foram encontrados nesta situação 78 indivíduos, correspondentes ao percentual de $8,6 \%$ dos fogos arrolados naquele ano. No inicio do Oitocentos (1803) este percentual havia sido de 10,8\%, correspondente a 101 chefes de domicilio; número que superava o verificado para artesãos (70) e jornaleiros (79), e equivalia a 17,6\% dos indivíduos envolvidos com a agricultura. A presença destes indivíduos permanece constante, nos patamares de 1798, também em 1808 e 1811. Já a partir de 1808, o percentual devido a estes despossuídos caiu a 2,1\% (29 indivíduos) e entre 1822 e 1829 caiu a $0,8 \%$. 


\section{Gráfico II.28}

Número absoluto de chefes despossuídos e sua participação percentual no número total de domicílios

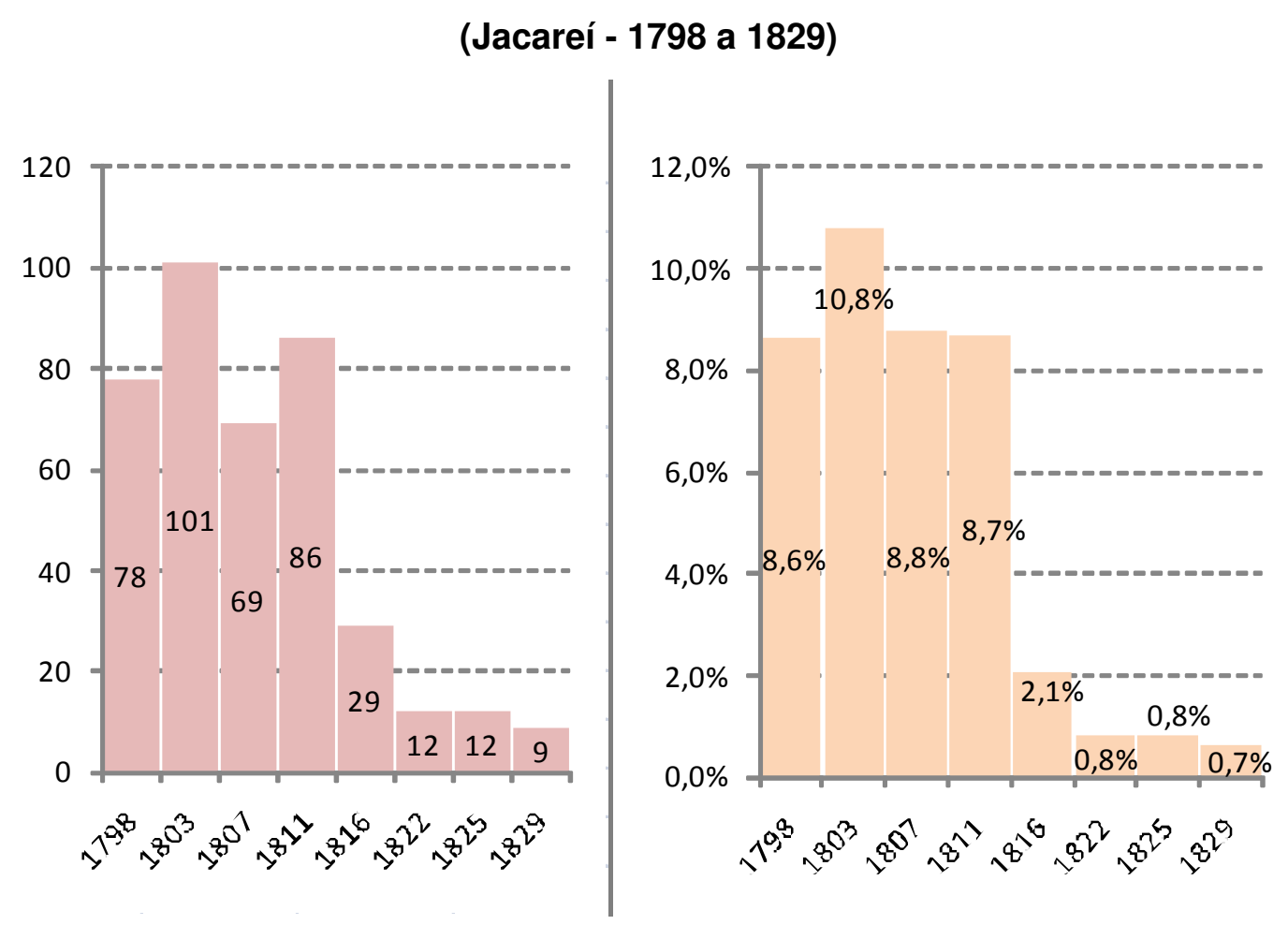

O período de menor participação de pobres em Jacareí com sua freguesia de Paraibuna coincide com aquele para o qual identificamos a presença do café e seu espraiamento na vila de Jundiaí e seu termo que, como adiantado, de 0,5\% dos fogos com alguma cultura em 1816, passou a 12,7\% desses fogos em 1829.

Ao penetrar na localidade, paralelamente aos cultivos anteriormente levados a cabo, o café apareceu como importante partícipe da produção da localidade. Do valor do produto da localidade em 1811 e 1816 , cerca de 1,5\% era devido ao café, percentuais alçados a 10,8\%, 15,9\% e 31,1\%, respectivamente nos anos de 1822, 25 e 29.

É possível que o café tenha sido origem de um importante efeito multiplicador como anteriormente anotado, especialmente para a localidade de Jundiaí a partir do açúcar - que, movimentava em ao seu redor uma vasta gama de atividades, dinamizando a economia e possibilitando a inclusão de novos grupos no processo produtivo.

Os percentuais apresentados para a importância do valor do café estão apresentados na Tabela II.78 e foram calculados de acordo com os dados que pudemos anotar a partir dos arrolamentos nominativos. Não existia, como mencionamos no apêndice metodológico, nenhum mapa econômico para a vila de Jacareí com sua 
freguesia de Paraibuna. Ou seja, não possuímos informações para de volume total produzido, consumido na própria vila ou exportado. Assim como não sabemos ao certo o destino de sua exportação, ou de onde vieram sua importações, e também ignoramos os preços médios efetivamente envolvidos nesse processo. Em suma, os dados para Jacareí e Paraibuna resumem-se às informações encontradas nas observações relativas aos diferentes fogos na lista nominativa propriamente que, em muitas situações, não mencionavam quantidades, objetivo (mercado ou consumo próprio) ou até mesmo preço para o bem. Assim, os dados da Tabela II.78 são estimativas bastante aproximadas.

Tabela II.78

Participação percentual dos diversos gêneros no valor do produto (Jacareí - 1798 a 1829)

\begin{tabular}{lcccccccc}
\hline \hline & $\mathbf{1 7 9 8}$ & $\mathbf{1 8 0 3}$ & $\mathbf{1 8 0 7}$ & $\mathbf{1 8 1 1}$ & $\mathbf{1 8 1 6}$ & $\mathbf{1 8 2 2}$ & $\mathbf{1 8 2 5}$ & $\mathbf{1 8 2 9}$ \\
\hline milho & 66,1 & 45,7 & 59,7 & 58,6 & 45,6 & 36,6 & 33,0 & 38,9 \\
feijão & 6,6 & 18,4 & 16,0 & 18,8 & 8,7 & 11,1 & 10,1 & 10,5 \\
algodão & 15,1 & 16,4 & - & - & 14,4 & 8,5 & 5,8 & 2,5 \\
arroz & 0,5 & 4,5 & 3,8 & 8,2 & 1,5 & 4,6 & 4,6 & 7,6 \\
fumo & - & 1,4 & 0,5 & 6,0 & 13,2 & 9,0 & 6,2 & 4,5 \\
aguardente & 6,7 & 9,1 & 3,3 & 3,4 & 3,6 & 3,8 & 2,9 & 1,4 \\
capado & 2,2 & 2,4 & 5,8 & 3,6 & 11,6 & 15,5 & 21,5 & 3,5 \\
toucinho & 2,7 & 0,3 & - & - & - & - & - & - \\
café & - & - & - & 1,4 & 1,3 & 10,8 & 15,9 & 31,1 \\
panos & $*$ & 1,8 & 10,9 & $*$ & $*$ & - & - & - \\
rapadura & - & - & $*$ & $*$ & - & - & - & - \\
mandioca & $*$ & - & - & - & - & - & - & - \\
amendoim & - & - & - & - & $*$ & $*$ & $*$ & $*$ \\
farinha & - & $*$ & - & - & $*$ & $*$ & - & - \\
açúcar & - & - & - & - & $*$ & - & $*$ & $*$ \\
bois & - & - & - & $*$ & $*$ & $*$ & - & - \\
cavalos/potros & - & - & - & - & $*$ & $*$ & $*$ & - \\
carneiros/cabritos & - & - & - & - & $*$ & - & - & - \\
\hline TOTAL & 100,0 & 100,0 & 100,0 & 100,0 & 100,0 & 100,0 & 100,0 & 100,0 \\
\hline \hline Fon & $-10,0$ & & & & & &
\end{tabular}

Fonte: AESP, Maços de População, Jacareí: anos selecionados

*Produtos mencionados, mas sem preço que permitisse verificar participação, e/ou sem volume e/ou menção pontual

Destacam-se na tabela, além do café, milho, algodão e capados. Capados (mesmo se somados a toucinho) foram pouco mais de $2 \%$ do produto anotado nos dois primeiros anos, chegou a $11,6 \%$ em 1816 e após uma década, encontrados em 1825 respondendo por $21,5 \%$ do valor dos bens produzidos em Jacareí/Paraibuna.

O milho, ao contrário, apresentou participação nitidamente decrescente na composição do produto jundiaense: de $66,1 \%$ do valor dos gêneros descritos em 1798 , 
passou a 58-59\% em 1807 e 1811, chegou a 36,6\% após uma década, patamar próximo ao verificado no encerramento do período, 38,9\% em 1829.

O algodão, assim como milho, viu sua cultura declarada fortemente reduzida de 15-16\% em 1798 e 1803 a 8,5\% em 1822 e 2,5\% em 1829. Ao que parece, o café expandiu-se suprimindo, em parte, a produção comercial do algodão. Ainda que não tenhamos dados para comercialização do bem e especialmente de seus derivados, como tecidos, certo é que foram importante naqueles primeiros anos em que, como adiantado encontramos bom percentual de indivíduos ligados ao setor que comportava atividades artesanais, como fiação e tecelagem.

O café "[...] era uma cultura que podia ser iniciada juntamente com o plantio de gêneros alimentícios usuais, e assim os custos iniciais do ingresso eram muito menores [que o açúcar - DOMR]. Mas em razão do tempo que os cafeeiros demoravam para começar a produzir, a disponibilidade de fontes de renda alternativas com a venda de gêneros alimentícios foi fundamental para a sobrevivência do novo cultivo." (LUNA \& KLEIN, 2006, pp.250-251) Vide por exemplo, o lavrador João de Souza que em 1825 "tem 3000 pés de café novos apurou com o feijão 70 000" (Lista Nominativa de Jacareí, 1825 AESP, Maços de População/rolo 101)

O café foi encontrado em apenas três fogos em 1811; 4 fogos em 1816 e já em 1822 eram 29 domicílios com plantações de café. Em 1829, 106 chefes declararam a plantação, número correspondente a $10 \%$ dos domicílios ligados à agricultura. Os dados apontam, então, para o rápido avanço do café em Jacareí com sua freguesia de Paraibuna. Números para o café são apresentados na Tabela II.79.

O salto para o número de produtores poderia ser esperado pela própria leitura da lista da vila propriamente em 1825, que indicava: 12 indivíduos com "pés de café novos", outros 18 fogos com "café em primeira fruta" e ainda "café começando a dar", "pés de café ainda sem frutos", "tem plantado pés de café". (Lista Nominativa de Jacareí, 1825 AESP, Maços de População/rolo 101)

A expansão do café deu-se tanto na área atinente a vila de Jacareí propriamente, como na Freguesia de Paraibuna - a posição no caminho do Rio de Janeiro de onde vinha se expandido a cultura cafeeira e a presença de terras passíveis de ocupação (cf. capítulo III), devem ter sido fatores a impulsionar esta expansão.

Sabendo da ausência da segunda companhia para Paraibuna em 1829, estes números certamente eram superiores. Era nesta companhia "perdida" que se encontrava o padre Valério Alvarenga: anotado como maior proprietário de escravos no capítulo anterior, era Valério grande produtor de café, com 1000 arrobas anotadas em 1825, 
provenientes de seus 60 mil pés de café, foi o maior produtor daquele ano. Com a venda da sua produção no Rio de Janeiro auferiu 2:500\$000 nominais. No ano anterior observado, 1822, o padre em questão apareceu como cafeicultor, sem produção arrolada, mas com a indicação de que "ainda não vendeu o café"; em 1811 contava-se em 105 o número de seus escravos, que assim como Valério, não aparecem na tabela.

\section{Tabela II.79}

\section{Características da produção de café}

(Jacareí - 1822 a 1829)

\begin{tabular}{|c|c|c|c|c|c|c|}
\hline \multirow{2}{*}{$\begin{array}{c}\text { Estatísticas } \\
\text { (Fogos com } \\
\text { café) }\end{array}$} & \multicolumn{2}{|c|}{1822} & \multicolumn{2}{|c|}{1825} & \multicolumn{2}{|c|}{1829} \\
\hline & Vila & Freguesia & Vila & Freguesia & Vila & Freguesia \\
\hline № de fogos & 12 & 16 & 25 & 32 & 72 & 34 \\
\hline Arrobas & 2188 & 1973 & 4060 & 5194 & 12828 & 3308 \\
\hline Média & 182,3 & 123,3 & 162,4 & 162,3 & 178,2 & 97,3 \\
\hline Minimo & 13 & 2 & 12 & 6 & 5 & 5 \\
\hline Máximo & 850 & 500 & 800 & 1000 & 2500 & 600 \\
\hline № de escravos & 217 & 210 & 358 & 432 & 650 & 160 \\
\hline Média & 18,1 & 6,9 & 4,0 & 13,5 & 9,0 & 4,7 \\
\hline Minimo & 4 & 0 & 1 & 0 & 0 & 0 \\
\hline Máximo & 29 & 55 & 61 & 121 & 65 & 66 \\
\hline$\%$ do total & 27,4 & 21,7 & 37,3 & 63,5 & 61,4 & 67,8 \\
\hline
\end{tabular}

As produções médias não foram muito variáveis e estiveram nesta década de 1820 entre 120 e 180 arrobas (exceção de Paraibuna em 1829, dada a referida ausência do padre Valério e de outros grandes produtores da segunda companhia, como Marcelino Carvalho, que em 1825 produziu 900 arrobas com o trabalho de 94 escravos). Em decorrência do aumento do número de produtores, o volume total foi expandido com o passar dos anos. E na década seguinte chegaria a produção da vila a 54004 arrobas e a produção de Paraibuna (já vila independente de Jacareí) a 23322 arrobas de café, conforme dados apresentados por Müller (1923, p. 125) para o ano de 1836. Os máximo e mínimo produzidos eram bastante apartados. A produção máxima anotada atingiu 2500 arrobas em 1829; enquanto o mínimo esteve entre duas e 13 arrobas ao longo do período 1822-1829, montante bastante restrito. ${ }^{54}$

Contudo, era no café que se encontravam os maiores plantéis de Jacareí/Paraibuna, setor cuja expansão levou à crescente participação no número de

\footnotetext{
${ }^{54}$ Para trabalhas que apresentam dados características pra a produção cafeeira ver, entre outros, Nozoe \& Motta (1999), Motta \& Nozoe (1994), Oliveira (2004), Marcondes (1998).
} 
escravos na população já apresentada. Para a vila de Jacareí propriamente temos percentuais de $27,4 \%$ dos cativos descritos em fogos com café em 1822 , percentual que foi de 37,3\% em 1825; em 1829 havia sido alçado a 61,4\%, Paraibuna que tinha 21,7\% dos cativos vinculados ao café em 1822 (42,5\% se considerados os escravos do Padre Valério), teve o percentual aumentado a $67,8 \%$, ou seja, dois terços dos escravos arrolados encontravam-se nas lides do café.

A produção cafeeira era em parte utilizada para consumo próprio, mas especialmente as maiores plantações foram feitas com vistas ao mercado. $O$ café era vendido especialmente no Rio de Janeiro, para onde foi levada $84,4 \%$ da produção cujo destino pudemos identificar em 1825, percentual que havia sido de 70,4\% em 1822 e foi de 57,2\% em 1829. Importante participação entre o local encontramos a "terra"; mas esta foi menor proporcionalmente àquele verificada para o volume, apontando para as menores quantidades negociada no própria unidade produtiva

"As exportações fazem-se, ou diretamente pela estrada do Rio de Janeiro ou, mais freqüentemente, via Santos; e então passam as tropas neste caso por S. Paulo, porque de Nhazinha parte uma estrada que encontra a do Cubatão." (SAINT-HILAIRE, 1974, p. 93)

Tabela II.80

Local de venda do café

(Jacareí - 1822 a 1829)

\begin{tabular}{|c|c|c|c|c|c|c|c|c|}
\hline \multirow{2}{*}{ Anos } & \multicolumn{2}{|c|}{ Terra } & \multicolumn{2}{|c|}{ Rio de Janeiro } & \multicolumn{2}{|c|}{ Outros } & \multicolumn{2}{|c|}{ Total } \\
\hline & № (\%) & Arrobas(\%) & № (\%) & Arrobas(\%) & № (\%) & Arrobas (\%) & № (\%) & Arrobas(\%) \\
\hline $1822^{*}$ & $4(30,8)$ & $620(25,9)$ & $7(53,8)$ & $1688(70,4)$ & $2(15,4)$ & $90(3,8)$ & $13(100,0)$ & $2398(100,0)$ \\
\hline $1825^{*}$ & $15(38,5)$ & $932(14,8)$ & $23(59,0)$ & $5320(84,4)$ & $1(2,6)$ & $50(0,8)$ & $39(100,0)$ & $6302(100,0)$ \\
\hline $1829^{* *}$ & $21(52,5)$ & $1858(34,8)$ & $14(35,0)$ & $3056(57,2)$ & $5(12,5)$ & $430(8,0)$ & $40(100,0)$ & $5344(100,0)$ \\
\hline
\end{tabular}

Fonte: AESP, M aços de População, Jacareí: anos selecionados

${ }^{*}$ Outros $=$ Santos

${ }^{* *}$ Outros $=$ Santos (2), vila (3)

Ademais do café, não pudemos identificar o comércio de nenhum outro gênero, à exceção já apontada negociação de panos de algodão, devido à ausência dos mapas comerciais. Mas para o milho podemos considerar a produção, com vai exposto nas Tabelas II.81 e II.82.

Ainda que apresentando valores variáveis, os dados para o volume total de milho produzido apontam para o crescimento da produção, que mais do que dobrou em 30 anos: 28186 alqueires em 1798, 82451 alqueires em 1816, 56348 alqueires em 1816 e 
76746 alqueires em 1825. Esse aumento corresponde a uma variação positiva considerável no número de plantadores com montante explicitado: eram 206 em 1798, 645 em 1811, chegando a 992 em 1830.

Tabela II.81

\section{Distribuição de produtores e produção de milho}

\section{de acordo com faixas de alqueires}

(Jacareí - 1798 a 1829)

\begin{tabular}{|c|c|c|c|c|c|c|c|c|c|c|c|c|}
\hline \multirow{3}{*}{$\begin{array}{l}\text { Faixas de } \\
\text { alqueires }\end{array}$} & \multicolumn{4}{|c|}{1798} & \multicolumn{4}{|c|}{1803} & \multicolumn{4}{|c|}{1807} \\
\hline & \multicolumn{2}{|c|}{ Produtores } & \multicolumn{2}{|c|}{ Volume } & \multicolumn{2}{|c|}{ Produtores } & \multicolumn{2}{|c|}{ Volume } & \multicolumn{2}{|c|}{ Produtores } & \multicolumn{2}{|c|}{ Volume } \\
\hline & № & $\%$ & Alq. & $\%$ & № & $\%$ & Alq. & $\%$ & № & $\%$ & Alq. & $\%$ \\
\hline Até 10 & 14 & 6,8 & 133 & 0,5 & 70 & 12,5 & 613 & 3,0 & 44 & 10,3 & 431 & 2,0 \\
\hline 10,1 a 50 & 61 & 29,6 & 1710 & 6,1 & 409 & 73,2 & 9964 & 49,5 & 285 & 66,7 & 8042 & 36,8 \\
\hline 50,1 a 100 & 41 & 19,9 & 3495 & 12,4 & 54 & 9,7 & 4595 & 22,8 & 62 & 14,5 & 5165 & 23,7 \\
\hline 100,1 a 300 & 75 & 36,4 & 15148 & 53,7 & 26 & 4,7 & 4965 & 24,7 & 31 & 7,3 & 5870 & 26,9 \\
\hline 300,1 a 500 & 9 & 4,4 & 3700 & 13,1 & - & - & & 0,0 & 4 & 0,9 & 1526 & 7,0 \\
\hline 500,1 ou mais & 6 & 2,9 & 4000 & 14,2 & - & - & & 0,0 & 1 & 0,2 & 800 & 3,7 \\
\hline Total & 206 & 100,0 & 28186 & 100,0 & 559 & 100,0 & 20137 & 100,0 & 427 & 100,0 & 21834 & 100,0 \\
\hline \multirow{3}{*}{$\begin{array}{l}\text { Faixas de } \\
\text { alqueires }\end{array}$} & \multicolumn{4}{|c|}{1811} & \multicolumn{4}{|c|}{1816} & \multicolumn{4}{|c|}{1822} \\
\hline & \multicolumn{2}{|c|}{ Produtores } & \multicolumn{2}{|c|}{ Volume } & \multicolumn{2}{|c|}{ Produtores } & \multicolumn{2}{|c|}{ Volume } & \multicolumn{2}{|c|}{ Produtores } & \multicolumn{2}{|c|}{ Volume } \\
\hline & № & $\%$ & Alq. & $\%$ & № & $\%$ & Alq. & $\%$ & № & $\%$ & Alq. & $\%$ \\
\hline Até 10 & 45 & 7,0 & 397 & 1,2 & 120 & 12,4 & 1070 & 1,9 & 63 & 6,1 & 530 & 0,9 \\
\hline 10,1 a 50 & 473 & 73,3 & 13949 & 42,4 & 652 & 67,4 & 18788 & 33,3 & 748 & 72,5 & 22340 & 36,9 \\
\hline 50,1 a 100 & 91 & 14,1 & 7260 & 22,0 & 120 & 12,4 & 9790 & 17,4 & 142 & 13,8 & 11250 & 18,6 \\
\hline 100,1 a 300 & 28 & 4,3 & 5128 & 15,6 & 58 & 6,0 & 10790 & 19,1 & 58 & 5,6 & 10317 & 17,1 \\
\hline 300,1 a 500 & 4 & 0,6 & 1900 & 5,8 & 5 & 0,5 & 2100 & 3,7 & 9 & 0,9 & 3750 & 6,2 \\
\hline 500,1 ou mais & 4 & 0,6 & 4300 & 13,1 & 13 & 1,3 & 13810 & 24,5 & 12 & 1,2 & 12300 & 20,3 \\
\hline Total & 645 & 100,0 & 32934 & 100,0 & 968 & 100,0 & 56348 & 100,0 & 1032 & 100,0 & 60487 & 100,0 \\
\hline \multirow{3}{*}{$\begin{array}{l}\text { Faixas de } \\
\text { alqueires }\end{array}$} & \multicolumn{4}{|c|}{1825} & \multicolumn{4}{|c|}{1829} & & & & \\
\hline & \multicolumn{2}{|c|}{ Produtores } & \multicolumn{2}{|c|}{ Volume } & \multicolumn{2}{|c|}{ Produtores } & \multicolumn{2}{|c|}{ Volume } & & & & \\
\hline & № & $\%$ & Alq. & $\%$ & № & $\%$ & Alq. & $\%$ & & & & \\
\hline Até 10 & 84 & 7,5 & 703 & 0,9 & 73 & 7,4 & 525 & 0,8 & & & & \\
\hline 10,1 a 50 & 729 & 65,4 & 22535 & 29,4 & 629 & 63,4 & 19630 & 31,2 & & & & \\
\hline 50,1 a 100 & 180 & 16,1 & 14183 & 18,5 & 194 & 19,6 & 15019 & 23,9 & & & & \\
\hline 100,1 a 300 & 99 & 8,9 & 18425 & 24,0 & 74 & 7,5 & 13824 & 22,0 & & & & \\
\hline 300,1 a 500 & 11 & 1,0 & 4500 & 5,9 & 12 & 1,2 & 5320 & 8,5 & & & & \\
\hline 500,1 ou mais & 12 & 1,1 & 16400 & 21,4 & 10 & 1,0 & 8500 & 13,5 & & & & \\
\hline Total & 1115 & 100,0 & 76746 & 100,0 & 992 & 100,0 & 62818 & 100,0 & & & & \\
\hline
\end{tabular}




\section{Tabela II.82}

\section{Estatísticas para a produção de milho}

(Jacareí - 1798 a 1829)

\begin{tabular}{|c|c|c|c|c|c|c|c|c|}
\hline \multirow[b]{2}{*}{ Estatísticas } & \multicolumn{2}{|c|}{1798} & \multicolumn{2}{|c|}{1803} & \multicolumn{2}{|c|}{1807} & \multicolumn{2}{|c|}{1811} \\
\hline & $\begin{array}{c}\text { Total de } \\
\text { fogos }\end{array}$ & $\begin{array}{c}\text { Fogos com } \\
\text { milho }\end{array}$ & $\begin{array}{c}\text { Total de } \\
\text { fogos }\end{array}$ & $\begin{array}{c}\text { Fogos com } \\
\text { milho }\end{array}$ & $\begin{array}{c}\text { Total de } \\
\text { fogos }\end{array}$ & $\begin{array}{c}\text { Fogos com } \\
\text { milho }\end{array}$ & $\begin{array}{c}\text { Total de } \\
\text { fogos }\end{array}$ & $\begin{array}{l}\text { Fogos com } \\
\text { milho }\end{array}$ \\
\hline Média & 31,2 & 136,0 & 21,6 & 36,1 & 27,8 & 51,1 & 33,2 & 51,0 \\
\hline Moda & 0,0 & 200,0 & 0,0 & 20,0 & 0,0 & 20,0 & 40,2 & 20,0 \\
\hline Mediana & 0,0 & 99,0 & 12,0 & 20,0 & 10,0 & 30,0 & 20,0 & 30,0 \\
\hline Índice de Gini & 0,887 & 0,512 & 0,684 & 0,473 & 0,733 & 0,508 & 0,677 & 0,504 \\
\hline Mínimo & 0,0 & 8,0 & 0,0 & 4,0 & 0,0 & 6,0 & 0,0 & 4,0 \\
\hline \multirow[t]{2}{*}{ Máximo } & \multicolumn{2}{|c|}{800,0} & \multicolumn{2}{|c|}{300,0} & \multicolumn{2}{|c|}{800,0} & \multicolumn{2}{|c|}{1500,0} \\
\hline & \multicolumn{2}{|c|}{$\overline{1816}$} & \multicolumn{2}{|c|}{1822} & \multicolumn{2}{|c|}{1825} & \multicolumn{2}{|c|}{1829} \\
\hline Estatísticas & $\begin{array}{c}\text { Total de } \\
\text { fogos }\end{array}$ & $\begin{array}{c}\text { Fogos com } \\
\text { milho }\end{array}$ & $\begin{array}{l}\text { Total de } \\
\text { fogos }\end{array}$ & $\begin{array}{c}\text { Fogos com } \\
\text { milho }\end{array}$ & $\begin{array}{c}\text { Total de } \\
\text { fogos }\end{array}$ & $\begin{array}{l}\text { Fogos com } \\
\text { milho }\end{array}$ & $\begin{array}{c}\text { Total de } \\
\text { fogos }\end{array}$ & $\begin{array}{c}\text { Fogos com } \\
\text { milho }\end{array}$ \\
\hline Média & 40,2 & 58,1 & 41,7 & 59,2 & 51,8 & 69,0 & 46,1 & 69,0 \\
\hline Moda & 0,0 & 20,0 & 0,0 & 30 & 0,0 & 20,0 & 0,0 & 20,0 \\
\hline Mediana & 20,0 & 30,0 & 20,0 & 30 & 25,0 & 40,0 & 30,0 & 40,0 \\
\hline Índice de Gini & 0,716 & 0,589 & 0,675 & 0,544 & 0,679 & 0,573 & 0,656 & 0,527 \\
\hline Mínimo & 0,0 & 2,0 & 0,0 & 2,0 & 0,0 & 1,0 & 0,0 & 1,000 \\
\hline Máximo & \multicolumn{2}{|c|}{2000,0} & \multicolumn{2}{|c|}{1600,0} & \multicolumn{2}{|c|}{3000,0} & \multicolumn{2}{|c|}{3000,0} \\
\hline
\end{tabular}

Fonte: AESP, M aços de População, Jacareí: anos selecionados

Esse aumento do número de produtores, como adiantado, levou a um aumento do volume total de milho produzido, o que, não necessariamente, refletiu-se nas médias produzidas. Em 1799 a produção média de milho foi de 137 alqueires, a mais alta encontrada em todo o período 1798-1830. Em 1803 a média caiu a 36,1 e entre 1807 e 1825 manteve-se em 50-60 alqueires por produtor.

No entanto, o limite superior da produção em 1825, 3000 alqueires produzidos por José Munhoz, era quase quatro vezes superior ao que foi produzido por Maria Leme e por José Pedro em 1798: 800 alqueires. A principal faixa de produção em que se encontravam estes chefes de fogo era aquela dos 10,1 aos 50 alqueires produzidos, que chegou a representar, em seu máximo, 73,3\% dos produtores em 1811 e ao menos 30\% deles em 1798.

Jose Munhoz era produtor de café (tinha 12 mil pés e declarou 300 arrobas de produção) e outros mantimentos, e ainda havia produzido e/ou vendido 280 porcos; possuía 61 escravos. Assim como ele, foi comum encontrar a combinação milho e café e/ou milho e porcos. Dos indivíduos criadores de porcos e assim anotados na Tabela II.77 haviam plantado milho, respectivamente, entre 1816 e $1829,55,3 \%, 76,4 \%, 100 \%$ e $100 \%$ 
deles. O volume médio do cereal anotado para estes fogos, entre 1816 e 1829, foi 172,5; 222,9; 224,8 e 178,6 alqueires por declarante.

Percentual elevado dos produtores de café cultivava também o milho: 78,6\%, $91,2 \%$ e 89,6\%, respectivamente em 1822, 1825 e 1829. Para estes indivíduos encontramos médias bastante superiores àquelas verificadas para os declarantes de milho em sua totalidade: 307,5 em 1822, 301,3 em 1825 e 190,7 alqueires por produtor em 1829. As medianas foram, respectivamente nos três anos em tela, 180, 155 e 100 alqueires de milho.

Não sabemos ao certo se foi e quanto foi vendido desta produção, mas, percebemos que as grandes colheitas do cereal estavam ligadas a fogos com café - que a sua vez empregava os maiores plantéis de escravos da Vila de Jacareí com sua freguesia de Paraibuna - e/ou capados. Ou seja, grande número de indivíduos e/ou animais indicativo de que haveria tendência ao consumo nas próprias unidades produtivas em se tratando desses maiores produtores. 


\section{Economia e seus padrões}

Os maços de população apresentam, entre outras características, observações que dizem respeito à ocupação ou atividade produtiva em que os chefes dos diferentes domicílios estavam envolvidos e estas refletem, como não poderia ser diferente, a essência agropecuária de subsistência ${ }^{55}$ das economias de Jundiaí, Bragança, Atibaia, Nazaré, Mogi das Cruzes (com a freguesia de Santa Isabel) e Jacareí (com a freguesia de Paraibuna). De fato, os maços de população de 1798/1799 a 1829/1830 evidenciam para as localidades consideradas grande contingente populacional ligado ao setor agricultura e manufatura rural.

Ao lado da agricultura encontramos, com certo destaque, o setor artesanato. "Esses não agricultores dedicavam-se me tempo integral a atividades especializadas, e apenas alguns deles também se ocupavam da agricultura e outras atividades." (LUNA, 2006, p.225)

Atividades diversificadas, ligadas à vida "urbana", encontradas especialmente nos respectivos "bairro da vila" e indispensáveis ao funcionamento administrativo das localidades, foram encontradas em pequena medida, mas estavam presentes. Ocupações do setor magistratura e empregos civis foram pontualmente arroladas, posto serem atividades como tabelião, alcaide, porteiro ou carcereiro levadas a cabo por um único indivíduo, capaz de suprir as relativamente poucas necessidades municipais no que tange às responsabilidades de seus cargos. Assim como, poucos religiosos eram suficientes para suprir as demandas de centenas ou milhares de fiéis. É dizer, o peso relativo dos "núcleos urbanos", medido por atividades administrativas e eclesiásticas viu-se em quase nada alterado até 1830 .

Do mesmo modo, diferentemente de atividades agrícolas e artesanais que facilmente espraiavam-se pelas diferentes companhias que conformavam as diferentes vilas, e assim como as atividades diversificadas anteriormente citadas, as casas de comércio predominavam na área mais "urbana" das localidades, mormente na primeira companhia, em especial ao bairro da vila, ou seja, a área mais "urbanizada" dos municípios. É possível que as casas comerciais fossem, em sua maioria, pequenos e médios estabelecimentos, voltados para a venda de produtos da terra e responsáveis por intermediar o consumo de produtos importados de outras regiões. Para algumas das

\footnotetext{
${ }^{55}$ Importante relembrar "que entendemos por atividade ou produção de subsistência aquela cujo resultado final característico tem como finalidade o suprimento de necessidades básicas de sobrevivência da população internamente à colônia; em seu âmbito há convivência de atividades para suprir as necessidades diretas das próprias unidades domiciliares/produtivas, o autoconsumo, e de atividades de mais amplo espectro, voltadas, em diferentes medidas, ao suprimento de mercados regionais"
} 
localidades foi pequeno o número de unidades comerciais ao longo dos 30 anos contemplados, afinal, uma unidade comercial poderia atender a grande número de famílias e parte importante do comércio local era realizada nas próprias unidades produtivas, as fazendas e sítios, como se viu na constante menção à venda de produtos na terra, além de ser bastante comum à época o comércio itinerante, sendo sempre encontrado entre negociantes e comerciantes aquele que "vive de mascatear".

Como acontecia em outras localidades brasileiras, conforme apontaram diversos viajantes que passaram pelo nosso território, os moradores das vilas deveriam passar a maior parte de seu tempo em seus sítios e fazendas, onde desenvolviam suas atividades produtivas, dirigindo-se ao núcleo da vila para assistirem à missa ou para atividades festivas. Corrobora-se tal colocação com a observação das terras, posta no capítulo III, em que verificamos que quase a totalidades dos moradores viviam em suas propriedades rurais. $^{56}$

Como adiantado, consideramos a ocupação realizada pelo chefe como a atividade principal do fogo, mesmo sabendo que, muito provavelmente, atividades diversas eram desenvolvidas concomitantemente por outros membros dos domicílios, livres e cativos, homens e mulheres, agregados ou não.

Destaquem-se as mulheres: bastante ligadas ao artesanato, em atividades como fiação e costura e ainda outros serviços domésticos diversos, em sendo parcela minoritária dos chefes de domicílio e ao estar entre eles, em grande medida, apresentavam condição de viúvas, eram estas parcela majoritária das mulheres cujas atividades produtivas foram declaradas. Isso subestima consideravelmente a importância de fiadeiras, tecedeiras, rendeiras, costureiras na divisão do trabalho nas diferentes localidades, sendo essas produções tipicamente femininas, com grandes possibilidades de comercialização (como se viu especialmente em Mogi e Jacareí), ademais de, primordialmente, serem capazes de suprir necessidades domésticas. ${ }^{57}$

Essa característica de omissão de atividades econômicas femininas se estendia, para todas as localidades em tela, também para homens não vinculados ao corpo militar.

\footnotetext{
${ }^{56}$ Por exemplo, Auguste de Saint-Hilaire, que passou pela localidade mineira de Araxá em finais da década de 1810 observou por ocasião de sua viagem : "[...] Durante a semana a maioria das casas de Araxá fica fechada. Seus donos só ali aparecem aos domingos, para assistirem à missa, passando o resto do tempo em suas fazendas. (SAINT-HILAIRE,1975, pp.129-130)

57 "[...] a população feminina tanto livre quanto escrava, representava um segmento subutilizado da força de trabalho, que poderia ser alocado à produção têxtil destinada ao atendimento das necessidades da subsistência ou ao aproveitamento das oportunidades de mercado que emergiam. Esta noção de que as mulheres eram fonte relativamente subutilizada de mão-de-obra, ou um segmento da força de trabalho mais direcionado ao suprimento de necessidades imediatas, empresta uma certa flexibilidade à mulher trabalhadora e não equivale à marginalidade. [...] É obvio que, ao ocupar os braços ociosos de mulheres e ao eliminar a necessidade de comprar tecidos no mercado, a produção doméstica era bastante compatível com o esquema da chamada agricultura de subsistência." (LIBBY, 1997, p.120-121)
} 
Militares de distintas patentes eram, em diferentes posições dentre das unidades domiciliares/produtivas no entorno paulistano, descritos. É dizer, atividades militares foram as mais bem apresentadas nos arrolamentos populacionais compulsados, por abrangeram não somente os chefes de domicilio, mas também os demais indivíduos com alguma patente. Entre os indivíduos a chefiar fogos, militares respondiam por parcela importante. As constantes investidas militares portuguesas, especialmente ao sul da colônia, justificam a presença intermitente destes indivíduos - a própria confecção das listas nominativas, em seus primórdios e ao longo do tempo, esteve diretamente ligada a interesses militares que levaram à necessidade de levantamentos populacionais (vide apêndice metodológico); assim, para se conhecer a parcela da população passível de ser recrutada, era necessário saber quais indivíduos já o haviam sido.

Como característica marcante do corpo militar, reproduzida em todas as vilas ou freguesias observadas, encontramos a conjugação do setor com outros setores, e considerada as patentes de uma maneira ampla, temos militares - capitães, sargentos, alferes, cabos, soldados, ajudantes, milicianos ${ }^{58}$ - ligados à totalidade dos demais setores. Entre os setores, marcadamente, agricultura: o estar ligado às forças militares não representava a atividade principal e efetivamente responsável pelos ganhos pecuniários ou a subsistência do domicílio, que deveria ser representada pela atividade a ele conjugada.

Fogos em que foram identificadas atividades múltiplas, aqueles fogos em que o chefe declarou realizar duas ou mais atividades econômicas, apresentaram uma composição ocupacional mais próxima do que deveria ser a realidade da maioria dos domicílios, pois certamente essas atividades não eram realizadas ao mesmo tempo por uma só pessoa, apesar de descreverem o chefe de fogo, e representam a necessidade dos fogos em manter diferentes atividades produtivas para consumo do próprio núcleo familiar. Havia uma relação estreita entre o que se produzia e o que se consumia: os produtos agrícolas, assim como seus derivados, como tecidos de algodão, correspondiam

\footnotetext{
${ }^{58}$ Havia três linhas (níveis) de organização para o corpo militar no Brasil: O primeiro, a Tropa Regular, ou Tropa Paga, teoricamente, ao menos, destinada a proteger o território contra ataques de inimigos externos, podendo ser deslocada para o exterior em caso de guerra. Os auxiliares, a segunda linha, que depois de 1796 eram chamados de Milicianos, deveriam zelar pela segurança interna, e funcionavam como reserva para as tropas de primeira linha, quando mobilizadas para a guerra. Estas duas divididas entre fuzileiros (tropa a pé) e cavalaria. Por fim, havia a terceira linha, as Ordenanças, que não deveriam ser deslocadas, destinadas que estavam a cuidar da segurança local. Os corpos de Ordenança e os corpos auxiliares/milicianos eram as organizações encarregadas das prestações de serviços gratuitos às Capitanias. Essa disposição das 3 linhas foi constante no Brasil até 1824, quando foi alterada: as tropas de primeira linha foram absorvidas pelo Exército Nacional, estruturado por decreto de D. Pedro I. Já o declínio das ordenanças tornou-se efetivo a partir da lei de 15 de agosto de 1827, quando foi extinto o cargo de capitão-mor das Ordenanças, substituído pelo juiz de paz, misto de autoridade policial e judicial, que contava com o auxilio de uma guarda municipal, formada através de alistamento compulsório de cidadãos. (cf. MELO, 1982)
} 
às necessidades dos fogos e assim, dos grupos domésticos ali encontrados e de suas demandas.

Quanto ao corpo militar, apresentou participação significativa na conjugação com outros setores. A proximidade das vilas/freguesia observadas com São Paulo deveria facilitar o alistamento na tropa paga e na milícia ligada àquela cidade, uma vez que todos os moradores deveriam alistar-se, independente se "nobres, plebeus, brancos, mestiços, pretos, ingênuos e libertos, que deveriam fadar-se às próprias custas e possuir armas de idêntico calibre e a manter um escravo para cuidar do animal, caso fosse da cavalaria" (MELO, 1982, p.78)

Assim, a obrigatoriedade do trabalho militar elevava a representação dos indivíduos com declaração de outras ocupações já que, na prática, a maioria dos componentes do corpo militar contava com rendas provenientes de outros serviços, pois eram raros aqueles que podiam viver com seus soldos de tropa paga, em regra, tidos como baixos. (cf. SILVA, 2005) ${ }^{59}$ Isso explica a presença de soldados pagos que exerciam outras atividades, o que certamente deveria ser facilitado em tempos de paz.

Podemos dizer, então, que os militares que não se vinculavam a ocupações diversas como o comércio ou a agricultura (como sabemos, predominante nas localidades), haveriam de "viver na indigência", pois os militares pagos passavam "mediocremente com os seus soldos", sendo reputados como "homens sem estabelecimento". (cf. SILVA, 2005, p.236)

Ao "ignorarmos" a ligação com o corpo militar na presença de outra ocupação declarada, ampliamos em boa medida o já robusto setor agricultura. Para as seis localidades consideradas parte majoritária dos fogos estava ligada primordialmente a atividades agropecuárias, situação mantida ao longo do tempo. A agricultura, em sua menor participação, foi encontrada em 55\% dos fogos em Jundiaí em 1830. Assim, justifica-se termos ressaltado haver nas localidades consideradas grande contingente populacional ligado ao setor agricultura e manufatura rural. Este, o setor responsável pela dinâmica econômica das localidades.

O mercado agropecuário apresentava, comparativamente a outros setores, menores barreiras à entrada - a maior delas seria a terra, mas esta não precisava ser

\footnotetext{
59 Os contemporâneos já notavam a necessidade dessa duplicidade de funções, em que, se tratando de serviço não remunerado, as outras atividades econômicas desenvolvidas eram a principal, como comentou Lobo Saldanha em 1776: "O serem os capitães de Auxiliares negociantes é assim forçoso em quase todo o Brasil, especialmente nesta capitania (São Paulo - DOMR), onde uns são mercadores, outros traficantes, outros tropeiros, outros condutores, e poucos serão os isentos desses manejos." (SALDANHA, apud SILVA, 2005, p.241) Ou décadas depois, já no século XIX (1815), encontramos: "[...] Mas de qualquer modo que se arranjem as Tropas Milicianas, seja qual for a sua organização é da maior necessidade que elas tenham alguma disciplina, aquela que se pode exigir de Milicianos que não tem soldo e que devem não ser muito distraídos de suas lavouras e de seus negócios [...]" (TOLEDO, apud MELO, 1982)
} 
própria, havendo no Oitocentos, como sabemos, importante parcela de agregados ou outros indivíduos, que deveriam produzir em terras alheias posto, inclusive, como se verá no capítulo III, ser relativamente pouco disseminada a posse de terrenos -, ademais de ser o responsável por gêneros básicos de consumo: mantimentos, que foram em importante medida produzidos para consumo próprio.

As vilas/freguesia apresentaram evolução diversa para os setores de atividade econômica: não houve um sentido de flutuação único e claro entre as localidades. Em Jundiaí o setor agricultura foi majoritário, em todos os anos, mas com participação percentual no número de fogos decrescente. A queda de participação do setor ocorreu paralelamente ao incremento do artesanato, sempre o segundo setor mais representativo e, mais especialmente, pela ampliação do número de chefes ligados ao comércio e indivíduos ocupados no transporte, em muito ligados ao escoamento da produção dos engenhos e da intermediação na venda de muares.

Muares, senão presença constante na produção do entorno paulistano, foram importantes no processo de circulação de bens, sendo o transporte uma das atividades básicas na citada Jundiaí. E ainda, a intermediação na venda desses animais, importados das feiras do sul ou de Sorocaba, foi importante gerador de divisas para aqueles que praticavam tal negociação, como ocorrido, mormente em Jundiaí e também em grande medida em Atibaia.

Tal constatação não surpreende por já ser anteriormente reconhecido este comércio que, como aponta Morgado de Mateus (1769) "[...] o negócio mais limpo que tem esta Capitania de São Paulo, é o animais que se vão buscar à fronteira de Viamão", ou Mello Castro e Mendonça (1798): "[...] uma parte do Povo desta Capitania vive de negócios, ou seja de bestas que vão buscar a São Pedro do Sul [...]" (apud RANGEL, 1990, p.9)

Para Atibaia verificamos destacar-se o ano de 1799, apartado dos demais pela mais elevada participação da agricultura, que se manteve no Oitocentos em menores patamares, mas com flutuações pouco marcadas. A partir de 1803 consolidou-se o artesanato e os demais setores sofreram bruscas variações. A sua vez, Nazaré apresentou no século XIX ao menos $90 \%$ de fogos essencialmente agrícolas, não havendo participação importante de algum outro setor em todo o lapso observado.

Em Bragança foi de pequena monta a flutuação da participação do setor majoritário (agricultura), mas a vila apresentou uma clara ampliação no número e participação de vendeiros e negociantes na década de 1820 e um pico para a participação de jornaleiros (1826). 
Mogi, ao lado de seu majoritário setor agrícola, para o qual não encontramos grandes variações no tempo, apresentou importante setor artesanal, com destaque para indivíduos ligados à fiação e tecelagem. Importante setor artesanal encontramos também em Jacareí, onde não mostrou flutuação clara ao longo do tempo a agricultura, sempre majoritária, e com participação crescente do café dentre seus gêneros.

Reorganizando geograficamente (vide mapa no apêndice 1) estas observações, encontramos uma característica comum atinente à localização como determinante das atividades realizadas. Parte das características econômicas das localidades estava ligada ao fator geográfico, uma vez que na multiplicidade atividades e/ou produtos encontrados verificamos influências diversas também atinentes a povoações vizinhas.

Assim, Jundiaí apresentava crescente produção de cana-de-açúcar característica e expandida desde a vizinha Campinas, assim como se utilizou da posição privilegiada em estrada rumo ao centro do país e da proximidade com Sorocaba para desenvolver um rendoso comércio de muares.

Vizinha a Jundiaí, Atibaia também em posição privilegiada rumo a Minas Gerais teve seus negociantes de animais, e foi destacado em seu comércio o toucinho e seu setor artesanato. Situada entre Jundiaí e Atibaia, Bragança, apresentou as mesmas característica e ainda um importante comércio em detrimento ao setor artesanal. As características de Nazaré eram próximas às de Atibaia.

E Mogi, assim como a fronteiriça Atibaia, apresentou importante setor artesanato, refletido principalmente na manufatura do algodão. Assim como Jacareí, que manteve importante produção e comercialização de tecidos de algodão, mas viu chegar em boa medida seus limites a cultura do café, que invadia o vale Paraíba desde o Rio de Janeiro, caminho no qual se encontrava.

Decerto as migrações (como sabemos, em regra, realizadas entre localidades próximas) e o frágil sistema de comunicação daquele tempo (dificultando a distribuição de informações para lugares mais distantes) deveriam ser fatores a determinar tais características. Difícil mostra-se pois, estudar tais localidades dentre regiões comumente observadas para São Paulo: Oeste, Capital, Vale do Paraíba. ${ }^{60}$

Invariavelmente, como produção característica das localidades, em dispersão pelos fogos e volume produzido, identificamos o milho. "De todos os gêneros alimentícios

\footnotetext{
60 Assim justifica termos observado em outro momento, por exemplo, para Jundiaí alguns autores que a estudam vinculada à região da capital, a exemplo Canabrava (1972), Marcílio (2000) e Nozoe (2008 e outros que a entendem como pertencente à região açucareira do Oeste Paulista, como Bacellar (1997) e Luna (2009b). O mesmo ocorrendo com as demais localidades, especialmente Mogi, associada ora à capital, ora ao Vale do Paraíba.
} 
consumidos e produzidos para o mercado local, nenhum foi mais onipresente ou importante que o milho." (LUNA, 2005, p. 120) O milho foi a principal cultura, para todo o entorno paulistano observado, durante os cerca de 30 anos considerados. Não a toa Sergio Buarque de Holanda referiu-se a São Paulo como Uma civilização do milho.

De fácil cultivo, a ponto de ter sua cultura descrita como "vulgar" por Taunay em seu Manual do Agricultor Brasileiro, baseado em escritos iniciados por ele na década de 1820, a produção do milho, legado indígena note-se, estava espraiada por todo o território brasileiro, como apontam, de maneira mais ou menos detalhada, inúmeros autores e ainda viajantes Oitocentistas. Apesar da diferença de produtividade, é plausível cultivá-lo em diferentes tipos de solo. A priori uma cultura anual, era possível a ocorrência de até duas colheitas ao ano, sendo o milho uma cultura que se desenvolve rapidamente, começando a produzir em até cinco ou seis meses depois de semeado; e suas sementes, que ocupavam relativamente pouco espaço, podiam ser transportadas a distâncias consideráveis, assim "Quando os sertanistas verificavam que sua viagem se prolongaria por alguns anos levavam grãos de milho e os semeavam no caminho, continuando a marcha. Meses depois voltavam para fazer a colheita." (SAINT-HILAIRE, 1976, p.27)

O milho fazia, indubitavelmente, parte do sustento da população, livre e cativa. É inegável a importância desse cereal na alimentação da população brasileira nos séculos anteriores, incluindo-se aí em grande medida São Paulo, seja na forma do grão propriamente dito, seja na forma de seu principal derivado, a farinha, ingrediente principal de diversas receitas do período.

[...] ora em grãos, depois despido da casca e fervido até ficar mole debaixo do nome de canjica, ora em pirão depois de reduzido a farinha, chamada fubá, pela socagem ou moagem; o cuscuz é outra preparação do milho grosseiramente socado e cozido dentro de um pano à moda de África. Preparam muitas outras iguarias quando temperam a farinha de milho com leite, ovos, açúcar, \&c. (TAUNAY, 2001, p.154)

E, para além das necessidades humanas, o milho cumpria importante papel na criação e engorda de animais. Entre os animais alimentados com o cereal, destacam-se as bestas e burros, galinhas e porcos. Aos animais de carga dava-se, "depois de aliviá-los da carga, uma ração de milho [...] Esse alimento é muito substancial, e necessário sobretudo nas viagens fatigantes" (WIED-NEWIED, 1958, p.491, apud RODRIGUES JR, 1996) Particularmente, na alimentação dos porcos, o milho teve papel fundamental, era o principal alimento dado a essa criação e, portanto, era insumo utilizado indiretamente na produção do toucinho, base da alimentação no Brasil Oitocentista. 
As localidades do entorno paulistano compunham-se de grande número de "fazendeiros" que se prestam tanto para agricultura quanto para a criação. A criação de animais encontrada resumia-se, basicamente, aos porcos, constatação verificada em muito através do elevado arrolamento de toucinho.

O porco tem na economia colonial um grande papel, particularmente nas capitanias do Centro-Sul, incluindo o Rio de Janeiro e São Paulo. A sua carne, neste setor da colônia, entra em grande proporção para a dieta dos habitantes. Mas a principal atividade do suíno é o toucinho com que se condimentam os alimentos, sobretudo o feijão; e do qual se extrai a banha, a universal matéria graxa da cozinha brasileira. (PRADO Jr, 1996, p.202)

A opção pelo milho teve, portanto, valor estratégico, pois se tratava de um produto de fácil e rápido cultivo, crucial na alimentação humana e de animais.

A plantação de milho, além de permitir o autoconsumo, permitia o comércio local, onde deveria ser transacionado nos "negócios de vendas" ou ainda, diante da restrita circulação monetária na economia do período, utilizado em um amplo comércio baseado na simples troca e a prática de pagamentos indiretos do trabalho, em gêneros ou parte da produção e possibilitava, ademais, ingressar no mercado regional com produto facilmente comercializável. Afinal, era parte importante da dieta não somente daqueles que os produziam, mas de toda a população, inclusive aquela parcela ligada à prestação de serviços nos "centros urbanos", seja aquele atinente à própria vila ou outros mais distantes.

Responsável por alimentar humanos e animais, as grandes colheitas do cereal estavam ligadas a fogos com grande número de indivíduos e/ou animais, que apesar do elevado montante produzido tendiam a consumi-los na própria unidade produtiva não sendo, de forma considerável, transacionados por esses produtores.

Produtores típicos, independente do momento ou local, eram aqueles produzindo entre 10,1 e 50 alqueires do grão. Ainda que a presença em grande medida desta faixa possa ser considerada padrão, os volumes totais produzidos e as estatísticas observadas para os produtores, explicitadas em especial através da média, eram diferenciadas entre as localidades: Na Jundiaí de 1829, por exemplo,chegou a 144,2 alqueires por produtor, em Mogi não ultrapassou os 48 alqueires (1803).

E mesmo frente aos grandes volumes totais observados, com indivíduos declarando montantes elevados de produção e/ou comercialização - parcela 
proporcionalmente pequena do milho era levada ao mercado para além das fronteiras das vilas. $^{61}$

São Paulo recebia milho de todas as localidades em tela (para Jacareí a ausência de dados nos impede de fazer de forma contundente esta afirmação), sendo o principal ponto de venda do grão, juntamente com as próprias localidades e ali as unidades produtivas em si - para Atibaia volume importante do total levado ao mercado era vendido na própria vila apontando, possivelmente, para importante participação de intermediários na comercialização da produção.

Além de ser o produto com produção mais disseminada encontrada, como sabemos, em percentual considerável dos fogos o milho estava, na maior parte das vezes, ligado à produção de outros gêneros. O padrão foi, em diferentes medidas, a policultura. Um maior número de plantações deveria indicar, para aqueles as praticavam, maior autoconsumo, ou seja, produção em quantidades limitadas que atendessem às necessidades das próprias unidades produtivas.

Junto o ao milho aparece primordialmente o feijão, cuja presença foi uma constante, apresentando ora maior, ora menor participação entre os cultivos anotados nas listas nominativas. Juntamente com o milho foi, provavelmente, o feijão o alimento mais consumido em São Paulo desde o início da colonização. "O feijão é por assim dizer, o companheiro obrigado do toucinho e da carne-seca; é alimento de que gostam tanto o senhor como o escravo, e que faz a fartura da casa e da senzala." (TAUNAY, 2001, p.158) E assim como o milho, a cultura do feijão é bastante simples; sua colheita pode realizar-se em apenas três meses e tem o feijão, ademais, a característica de melhorar as áreas onde é plantado.

Milho e feijão caminhavam juntos e indubitavelmente eram traço marcante da produção do entorno paulistano. Em alguns casos milho e feijão estavam associados a outros diferentes cultivos e/ou criações - em Bragança foi expressiva a conjugação milho mais feijão mais porcos e em Mogi, milho e feijão unidos ao algodão, chegaram a ser traço majoritário em alguns momentos. Relembrando, pontualmente foram encontradas menções a amendoim, arroz, café, trigo, cana, mandioca, café, tipicamente mantimentos, além de fumo, mamona (Atibaia e Nazaré) e algodão, cujos subprodutos têm usos diversos. A mamona como óleo (conhecido atualmente como óleo de rícino), foi utilizada no Oitocentos para fins medicinais, combustível para lamparinas domésticas e de

\footnotetext{
${ }^{61}$ Vale notar, todavia, que certamente os mapas de produção subestimavam a produção, posto que grande número de indivíduos produzia para consumo próprio, não sendo este contabilizado nas contas apresentadas, ou nas próprias listas nominativas. Assim, podemos considerar que a produção apresentada é, em grande medida, a produção comercializada, seja diretamente para consumo local, seja para consumo em outros mercados.
} 
iluminação pública e ainda como lubrificante para carros de bois (encontrado especialmente em Atibaia e Nazaré); o fumo cujas folhas poderiam ser fumadas ou mascadas; o algodão, mais essencial, para a produção de tecidos, mais ou menos grosseiros, que vestiam livres e principalmente escravos.

Presente em todas as localidades, mas de forma destacada em Mogi e Jacareí, merece consideração, entre produtos mencionados, o algodão, em especial, conjugado com milho e/ou feijão. "Pode-se com o algodão, plantar milho e feijão, porém, no primeiro ano somente; mais tarde, esses vegetais seriam absorvidos pelos novedios vigorosos dos algodoeiros [...]" (SAINT-HILAIRE, 1976)

Para além do milho que cumpriu papel similar em todo o entorno paulistano, os demais gêneros mostraram diferenciações. Capados e, por conseguinte, toucinho foram gênero de destaque em Atibaia e Bragança; o algodão viu-se destacado, com adiantado, em Mogi e Jacareí, onde o setor têxtil tinha marcante presença. Jundiaí distinguiu-se pela produção canavieira de açúcar; e Jacareí viu florescer uma promissora produção de café, não deixando de lado negócios envolvendo algodão.

A partir do exposto, observamos a ausência de padrões levando a outro padrão, qual seja, a manutenção de uma estrutura econômica de base rural fincada na agricultura de gêneros de subsistência, cuja característica mais marcante foi o grande espraiamento do milho, em muito unido ao feijão, cujo montante principal era utilizado na satisfação de necessidades próprias dos fogos, com parcela minoritária de seu volume respondendo por uma agricultura mercantil de subsistência, com fortes vínculos com a capital da capitania, depois província de São Paulo. Mas, com destaque de um setor de atividade econômica e/ou outro produto a ela vinculado, levando ao que podemos considerar uma certa especialização, que em não sendo destacada para algumas localidades nas ocupações, o foram na identificação dos diversos cultivares a compor as produções locais.

A especialização a que nos referimos não implica em produção de único produto, mas em havermos observado a existência de alguma atividade e/ou gênero produzido responsável por ocupar parcela considerável dos domicílios e que, em proporções significativas, ultrapassavam o âmbito local ou o autoconsumo.

Em sendo padronizada a base produtiva para as localidades, a especialização era responsável por uma diferenciação que se dava, especialmente, em suas relações comerciais, sendo importantes na geração de divisas para as localidades.

Todo o entorno paulistano esteve envolvido no comércio regional de gêneros produzidos localmente. Sem articulação comercial entre si identificada - exceção do toucinho enviado por Nazaré (e Atibaia) a Mogi no Setecentos -, como sabido, era São 
Paulo o principal destino da produção de gêneros diversos. São Paulo absorvia uma vasta gama de bens e, na ausência de produtos com valor no mercado externo à colônia, era o principal comprador em valor dos gêneros da terra originários de seu entorno - para Bragança chegou a ser o único destino encontrado, para as demais localidades Santos apareceu com alguma regularidade, e outros destinos específicos como Rio de Janeiro e Goiás, foram parceiros comercias pontuais de algumas vilas -, centro de uma rede de trocas que, certamente, ligava seu interior ao litoral e outras áreas. No núcleo urbano desta cidade residiam 9806 pessoas em 1829:

De todos os lugares que abrigavam trabalhadores não-agrícolas, era a região da própria capital que apresentava a maior percentagem de não-agricultores na província. Além de seu papel como centro de comércio e comunicações entre o litoral e o interior em desenvolvimento, a capital e sua periferia constituía uma área única em razão de suas funções político-administrativas exclusivas." (LUNA, 2005, p.236)

A circulação de bens foi bastante ativa e refletiu o grande mercado "urbano" e rural para produtos básicos, existente a partir do entorno paulistano entre os últimos anos do século XVIII e primeiras décadas do século XIX. A dinamicidade das atividades econômicas exportacionistas incentivava 0 desenvolvimento de atividades complementares. A venda de seus produtos em outras regiões, é, portanto, a força motriz da economia. ${ }^{62}$

As diferentes "especialidades" levaram a dinâmicas diferentes entre as localidades, consideradas ao lado das exportações também as importações, ou seja, seu saldo comercial. Algumas atividades "possuíam taxas de acumulação empresarial compatíveis com o comércio externo [...] Tal é o caso dos negócios de gado bovino e muar feitos a grande distância que uniam a Corte a São Paulo e Rio Grande do Sul" (FRAGOSO, 1990, p.35)

A importância do resultado da balança comercial reside no fato de as localidades em tela apresentarem dependência considerável de importações. Eram importados, entre

\footnotetext{
${ }^{62}$ As atividades ligadas ao comércio de gêneros de abastecimento interno tem sido freqüentemente observadas para diversas regiões e sob diferentes contextos. A exemplo, citamos observação de Bert Barickman: "[...] a produção e comércio de víveres para o mercado interno, tão freqüentemente desprezados como atividades "marginais", "periféricas", ou apenas "subsidiárias", revelam-se como indispensáveis e até fundamentais na economia regional mais ampla, cominada pela agricultura de exportação. A expansão da produção de açúcar da Bahia a partir do final do século XVIII dependeu de uma oferta local crescente e geralmente confiável de mantimentos. (BARICKMAN, 2003, p. 307). Ou ainda Cláudia Chaves (1999), acerca dos mercadores nas minas setecentistas, afirmou: "[...] levando em consideração a extrema diversificação da economia mineira e sua baixa especialização durante o Setecentos, podemos concluir que a atividade comercial era uma atividade bastante difundida entre os mineiros. [...] De uma certa maneira, boa parte dos sitiantes e roceiros tinham uma parcela de sua produção desviada para abastecer o mercado das grandes vilas e arraiais como forma de atividade econômica básica." (CHAVES, 1999, p.163)
} 
outros, tecidos finos, sal, metais, azeites, e para tanto seria necessário um mínimo de monetarização destas economias e, em alguns casos, de um mercado de crédito ativo. ${ }^{63}$ A ausência de dados completos de comércio para Bragança e Mogi, e a total ausência deles para Jacareí inviabilizam avançarmos em qualquer comparação que possa levar a similitudes ou diferenças neste sentido. Todavia, nos arriscamos a afirmar que as contas comerciais das localidades, ao que parece, foram negativas quando da especialização em grãos e positivas para gêneros manufaturados, que apresentavam maiores valores adicionados.

Ademais, vale mencionar, todas as localidade apresentaram pobres em seu arrolamento, mas para sua presença nenhum padrão pode ser identificado.

\footnotetext{
${ }^{63}$ Certamente havia na região a presença de um sistema de crédito que, além de ser necessário para o financiamento da economia local, poderia mostrar-se lucrativo: "Na sua ausência, ou dado seu pequeno desenvolvimento, algumas pessoas deveriam funcionar como emprestadores particulares de quantias significativas, possibilitando o giro de dinheiro necessário numa economia em mudança, com constantes inovações." (MELLO, 1990, p.92) Maurício Alves observou para a localidade de Taubaté no Oitocentos que "A forte presença das dívidas (tanto ativas quanto passivas) aliada à quase ausência de numerário [...] mostram um sistema de trocas que se confunde com o pagamento de juros. Somando-se as dívidas ativas e passivas, verifica-se que a rede de adiantamento/endividamento (crédito) representa o segundo maior setor econômico, e o crescimento contínuo deste setor mostra que as atividades econômicas desenvolvidas na vila de Taubaté dependem cada vez mais de financiamento (crédito)." (ALVES, 1999, p.40) E Renato Marcondes, por exemplo, estudando a localidade de Lorena (SP) no século XIX, através de inventários e de maços de população observou que "Os indivíduos da amostra atuavam em três tipos de comércio. O primeiro consistia na taberna ou venda de molhados, principalmente da terra. Estas pessoas mantinham relações comerciais e de crédito restritas à localidade. Eles tomavam recursos dos mercadores locais mais abastados e concediam empréstimos aos seus fregueses (contas de livro ou rol). O segundo tipo compreendia os lojistas de fazendas secas, os quais recebiam seus produtos de atacadistas do Rio de Janeiro. O porte deles atingiu patamares mais elevados do que o do primeiro grupo e seus laços mercantis alcançavam a praça carioca onde se financiavam. O segmento mais rico foi o dos usurários, que se favoreceram da pequena oferta de crédito local para atuar nesta ocupação, cobrando taxas de juros elevadas. A atividade usurária representou uma forma de acumulação de riqueza que permitiu aos capitalistas as maiores fortunas inventariadas entre os indivíduos da amostra." (MARCONDES, 1998, p.263).
} 


\section{Capítulo III ESTRUTURA FUNDIÁRIA: FORMAÇÃO E CARACTERÍSTICAS EM 1818}

O inicio da colonização do território brasileiro, por conseguinte o de São Paulo, foi baseado na transferência para a colônia de instituições portuguesas. No que respeita ao modelo de apropriação das terras ligado às primeiras tentativas de povoação do Brasil, adotou-se o sistema de capitanias hereditárias, que, na prática foram doações de grandes lotes de terras a serem explorados e ocupados pelos recebedores destas glebas, os capitães-donatários (grupo diversificado em alguma medida ligado à Coroa).

A posse não dava aos donatários o direito de dividir ou negociar a área recebida, todavia autorizava, entre as atribuições dos recebedores, a doação de sesmarias. As capitanias hereditárias não obtiveram êxito, mas as sesmarias espraiaram-se, seguindo a dinâmica demográfica brasileira, e foram meio legal para aquisição de terras públicas no Brasil até 1822 .

O sistema de distribuição de sesmarias havia sido criado em Portugal ao final do Quatrocentos (1375), como uma maneira de organizar a produção de alimentos, evitar terras incultas e assim solucionar problemas de abastecimento. Logo, fazia parte de seu instituto jurídico a necessidade de ocupação produtiva da terra (ou seja, de cultivo do solo) recebida em sesmaria dentro de prazos estabelecidos, sob a pena de cassação de direito à propriedade. As sesmarias eram, portanto, concessões administrativas sobre o domínio público com o encargo de cultivo.

Esse sistema foi transferido para o Brasil e, em que pesem as diversidades entre o aparelho administrativo português e o de sua colônia de além mar, o teor das disposições legais portuguesas regiam a instituição das sesmarias no Brasil. Mas aqui o sistema sesmarial teria se estabelecido mais como um meio de se assegurar e regularizar a própria colonização do que para solucionar problemas relativos à posse produtiva da terra. (cf. LIMA, 2002; MOTTA, 2004)

A legislação fundiária aplicada no decorrer do nosso período colonial foi baixada de modo descontínuo, dispersa em um amplo número de avisos, resoluções administrativas, cartas de doação, forais e textos das Ordenações. Essa gama de dispositivos legais ensejou uma legislação fragmentada, nem sempre coesa, revogada e reafirmada de tempos em tempos. Apesar disso, nela é possível verificar que as sesmarias constituem o regime jurídico básico acerca da terra. (NOZOE, 2006, p.588) 
Ocorreu, então, que ao longo dos séculos a Coroa fez várias tentativas de regularização do sistema de sesmarias instituído em terras brasileiras. Em especial, a partir do século XVII, com determinações acerca da extensão máxima dos terrenos a serem doados, demarcação dos limites das áreas concedidas e obrigatoriedades no cultivo que, ao que parece, não surtiram o efeito esperado. (cf. MOTTA, 2004)

Assim, por exemplo, as resoluções de 11 de abril e de 2 de agosto de 1753 determinavam que 'as terras dadas de sesmaria em que houvesse colonos cultivando solo e pagando foro aos sesmeiros deveriam ser dadas [em sesmaria] aos reais cultivadores'. Da mesma forma, o Alvará de 1795 preocupava-se com a necessidade de não doar as terras já ocupadas por colonos, desejando com isso que se evitasse conflitos de terras. Segundo o mesmo, as irregularidades e desordens na doação de sesmarias no Brasil provocaram a necessidade de elaborar um regimento próprio, capaz de obrigar a regularização e demarcação das sesmarias. O alvará não deixava de salientar os abusos e desordens resultantes da ausência de um regimento a ser aplicado em 'todo o Estado do Brasil' (MOTTA, 2004, p.65)

Provavelmente em função de leis como estas, encontramos determinação, passada à Câmara de Jundiaí em 1786, para que fosse legalizadas terras em que

[...] se acham arranchados mais de nove casais, os quais devem tirar sesmaria, cada um da posse dos seus cultivados pelo que me parece deve ser ouvidos aqueles possuidores para declararem se querem tirar cada um sesmaria da posse dos seus cultivados ou se querem entrar pro rata na sesmaria (AESP, Escrituras/C05570)

Apesar de toda a legislação, fato foi que a posse de partes de terras, independente do seu reconhecimento como sesmaria, tornou-se recorrente - o excerto acima, assim como as leis supracitadas, o exemplificam e, mesmo as sesmarias, muitas das vezes, eram requeridas mediante alegação de posse anterior. São expressões comuns nos documentos relativos a sesmarias (cf. AESP, Sesmarias, patentes e provisões, Livros diversos): "uma posse feita em", "no lugar onde tem seu sítio", "delas fez posses" e até mesmo "reservando qualquer cultivado de outras pessoas" etc.

A posse pura e simples passou a aparecer em grande medida e acabou por fugir ao controle das autoridades passando, naturalmente, a ser um caminho presumível de fixação e direito de exploração das novas terras.

Apoderar-se de terras devolutas e cultivá-las tornou-se cousa corrente entre os nossos colonizadores, e tais proporções essa prática atingiu que pôde, com o correr dos anos, vir a ser considerada como modo legítimo de aquisição do domínio, paralelamente a princípio, e, após, em substituição ao nosso tão desvirtuado regime das sesmarias. (LIMA, 2002, p.51) 
A ocupação de terrenos por posse foi decorrência direta do fato de o sistema de sesmarial privilegiar os indivíduos mais abastados e/ou "de qualidade". Era necessária a comprovação da condição de se cultivar a terra para ter direito a ela, sendo a sesmaria "o latifúndio, inacessível ao lavrador sem recursos" (LIMA, 2002) - mesmo nem sempre tendo a posse servido somente à pequena propriedade, algumas grandes glebas também formaram-se através delas - :"achando-se com bastante escravos", "tendo cabedais", "na posse de suficientes escravos" são algumas das alegações encontradas em pedidos de sesmaria para a área do entorno paulistano. (cf. AESP, Sesmarias, patentes e provisões, Livros diversos)

Ademais, tomar posse e cultivar terras deveria ser preferível e bem menos custoso que enfrentar toda a burocracia envolvida no processo de concessão de sesmarias, cujo pedido deveria ser feito ao capitão geral e a concessão confirmada pelo poder real, sendo, inclusive, a câmara local ouvida durante o processo.

Na prática, o fato é que todo o processo de ocupação do território brasileiro "[...] pressupôs em tese a institucionalização de um documento de propriedade - as sesmarias - sem comprovação alguma em relação à medição e demarcação das terras e da existência do cultivo, exigências basilares da própria lei." (MOTTA, 2009) Sesmarias ou posses, as propriedades rurais não tinham demarcações precisas "são novas fronteiras de então, não têm divisas reais, elas existem até onde o poder do dono, ou do que se diz dono, pode alcançar." (MESSIAS, 2003, p.66)

Os limites das propriedades eram dados por marcos geográficos e de acordo com terras de outros, demarcados segundo a capacidade do declarante em descrevê-la. Por exemplo, "[...] meia légua de terras em quadra na paragem denominada Itaquy, fazendo pião no dito Ribeirão seguindo rumo de um quarto de légua pelo caminho das Minas para a banda do povoado pelo meio do caminho [..]" (AESP, Sesmarias, patentes e provisões/C00362, Livro 06) foi a descrição encontrada para a sesmaria de Domingos Viera Cardoso no termo da Vila de Jundiaí; e a carta de sesmaria passada em Mogi das Cruzes,a vários sesmeiros na década de 1760, em que lê-se "[...] na paragem chamada Paratium Guassu, do termo da vila de Mogi das Cruzes, principiando das terras dos religiosos de Nossa Senhora do Monte do Carmo desta cidade de São Paulo, cortando de Oeste para Leste metendo de dentro um rio por nome Paratium Guassu e um campo chamado do Cemitério, onde os suplicantes tem os seus sítios e cultivados [...]" (AESP, Sesmarias, patentes e provisões/C00365, Livro 15) Ou ainda, a declaração nazareana de que "Manoel de Lima tem um sítio no Bairro do Rio do Peixe onde mora que possuir por posse [...] que partem com o tenente coronel João de Castro Ambrosio de Moraes Manoel 
Dias Benta Cardosa." (Relação da primeira companhia da Freguesia de Nazaré e dos habitantes que possuem seus terrenos no ano de 1818. 1818 - AESP, Tombamento/C09868)

Embora houvesse uma grande extensão territorial passível de ser ocupada (decerto variável com o passar do tempo) e o acesso a terra fosse aparentemente fácil, pois a terra em si pouco custava aos que a recebiam em doação, certo é que, no período colonial, somente uma minoria se beneficiou do sistema de sesmarial. "A propriedade de terras no Brasil escravista não pode ser considerada com latitude indefinida. Cada complexo regional ou local engendrava seu próprio mercado e quase estabelecia regras próprias para seu funcionamento." (MATTOS, 2009, p.90)

E uma das características desses mercados foi o aparecimento de transações de compras e vendas das posses, assim como de partes de sesmarias, ao que parece, multiplicadas ao longo dos anos. Paralelamente às formas tradicionais de acesso à propriedade rural existia um mercado fundiário que independia da legislação corrente e parece ter sido incorporado por ela na medida em que é possível encontrar, entre os pedidos de sesmarias, alguns com menção à compra da gleba requerida feita anteriormente pelo requisitante.

No século XIX, o duradouro sistema de doação de sesmarias agonizava e por lei de 17 de julho de 1822 foi abolida. Desde então, de forma ainda mais marcante, conseguia-se acesso à terra "[...] pela entrada simples de sua posse para a exploração, por um grupo doméstico. A partir daí, algumas famílias mais esclarecidas procuravam obter um título legal, público e registrado, que legitimasse sua posse. Mas poucos foram os que procuraram essa via." (MARCÍLIO, 2006, p.75) Outra lei que regulasse a questão agrária no Brasil, a "lei de terras", surgiu apenas em 1850.

Entre as formas "tradicionais" de acesso à propriedade encontramos também, e em grande monta, as heranças. Heranças - sejam de porções tiradas em sesmaria, posse ou negociadas no mercado fundiário - ocorreram ao longo dos séculos e de forma diversa às demais formas aquisição de terras, independia da ação pessoal, uma vez que estava relacionada à transmissão da propriedade pela morte do proprietário.

A legislação portuguesa reconhecia duas formas de herança, válidas também para as terras: o morgadio que, com o intuito de manutenção do patrimônio familiar, estabelecia o filho mais velho como herdeiro e valia, em regra, para a nobreza, e a divisão igualitária dos bens, entre elas as propriedades rurais, normalmente válida para os não nobres. Apesar dessa distinção parece ter havido no Brasil maior número de divisões igualitárias, sendo os morgados raros em terras brasileiras. (cf. MARCÌLIO, 2006) 
Ao lado desses sistemas, havia "[...] uma intrincada legislação que procurava privilegiar a manutenção dentro da família legitimamente constituída, através de herdeiros necessários e em linha patrilinear direta, descendente e depois ascendente. Paralelamente, a esposa entrava quase sempre na posse da terça, senão da metade dos bem do casal, em caso de viuvez." (MARCÍLIO, 2006, p.97), refletida no processo de acesso às propriedades rurais e, por conseguinte, nas características apresentadas pelas estruturas fundiárias.

Nosso objeto de observação, o inventário de bens rústicos de 1818, ainda que registre pontualmente aquele determinado momento, foi resultado do ocorrido em décadas e até séculos de ocupação e de conseqüente grande movimentação fundiária. Não só pelas leis, mas por toda uma ordem, de fatores econômicos e sociais. 


\title{
Jundiaí
}

Ao todo temos registradas 312 propriedades, sendo $311 \mathrm{com}$ áreas identificadas no Cadastramento de terras de Jundiaí que, em conjunto, conformam uma área total de 28514,810 alqueires paulistas. Estas terras estavam nas mãos de 275 proprietários, com razão de sexo 426,8. Nenhuma propriedade era possuída por entidades, 24 declarantes possuíam patente militar, sendo 14 delas de capitão/capitão-mor, e dois declarantes eram eclesiásticos.

Dez propriedades possuíam mais de um dono, sendo para oito delas o número de proprietários não identificado, todas herdadas, apontadas como "possui por herança onde entram mais herdeiros", inviabilizando qualquer análise mais aprofundada nesse sentido. Joaquim Antonio Barbosa morava em suas terras "e declarou, que a metade deste terreno pertence a Francisco Garcia, e este reside na Vila de Parnaíba". E Maria Inácia Lemes sobre sua gleba "declarou que a metade deste terreno pertence a Francisca de Lima, nele residem, e possuem por compra". (Relação dos proprietários que possuem terrenos no distrito, e freguesia da vila de Jundiaí. 1818 - AESP, Tombamento/ C09868)

Entre os 275 donos de terrenos rurais, 21 indivíduos eram detentores de duas propriedades, seis pessoas possuidoras de três sortes de terras e João Ferreira Alvarez, com quatro propriedades

\begin{abstract}
declarou possuir um terreno denominado Roseirinha em que compreende 250 braças de testada e 1500 de fundo [75 alqueires - DOMR], e assim mais 75 braças de testada e 500 de fundo [7,5 alqueires - DOMR], declarou mais possuir 50 braças de testada e 1300 de fundo [13 alqueires - DOMR]. Declarou possuir mais 200 braças de testada e 500 de fundo [20 alqueires - DOMR]. (Relação dos proprietários que possuem terrenos no distrito, e freguesia da vila de Jundiaí. 1818 - AESP, Tombamento/ C09868)
\end{abstract}

Como se pode notar, todas as terras de propriedade de João Ferreira podem ser consideradas pequenas ou, no limite, médias propriedades. Imaginadas em conjunto, as quatro glebas conformavam uma área de 115,5 alqueires, ainda que fossem anexas, corresponderiam a uma extensão que não pode ser considerada realmente grande, em especial se confrontada com as maiores extensões locais.

O mesmo acontecia com os demais declarantes de duas ou mais glebas, cujas conjugações de propriedades incluíam, em regra, ao menos uma pequena propriedade (ver Tabela III.1) 
Tabela III.1

Indivíduos com mais de uma propriedade

(Jundiaí - 1818)

\begin{tabular}{|c|c|c|c|c|c|c|c|}
\hline Proprietário & $\begin{array}{l}\text { Número de } \\
\text { propriedades }\end{array}$ & Denom inação & Área & Área total & Aquisição & Uso & Escravos \\
\hline \multirow{2}{*}{ JOAQUIM ANTONIO GUIMARAES } & \multirow{2}{*}{2} & Jundiaí mirim & 360,000 & \multirow{2}{*}{410,000} & compra e herança & \multirow{2}{*}{$\begin{array}{c}\text { em pasto de animais } \\
\text { cultivando }\end{array}$} & \\
\hline & & Carmo & 50,000 & & herança & & 20 \\
\hline \multirow{2}{*}{ JOAQUIM MANOEL } & \multirow{2}{*}{2} & Munhurusu & 12,500 & \multirow{2}{*}{14,500} & & & \\
\hline & & & 2,000 & & compra & cultivando & \\
\hline \multirow{2}{*}{ MANOE RODRIGUES DA SIQUEIRA } & \multirow{2}{*}{2} & Paiol & 60,000 & \multirow{2}{*}{72,000} & compra e herança & cultivando com mais herdeiros & \\
\hline & & Vargem & 12,000 & & compra & cultivando & \\
\hline \multirow{2}{*}{ ANNA MARIA DO ROSARIO } & \multirow{2}{*}{2} & Campo Limpo & 168,750 & \multirow{2}{*}{281,250} & compra & cultivando & \\
\hline & & & 112,500 & & compra & em pasto de animais & \\
\hline & & Santa Barbara & 100,000 & & herança & comfábrica de açúcar & 26 \\
\hline ANIONIO DE QUEROS IELES & 2 & Loveira & 6,500 & 106,500 & herança & em crias de animais & \\
\hline & & Boa Vista & 225,000 & & compra & cultivando & 16 \\
\hline DIONIZIA VIEIRA DE OLIVEIRA & 2 & Tapera & 112,500 & 337,500 & compra & cultiva & \\
\hline & & Pau grande & 9,000 & & & & \\
\hline ESCOLASTICA SOARES & 2 & Campinho & 4,800 & 13,800 & herança & cultivando & \\
\hline & & S. João Batista & 120,000 & & compra & comfábrica de açúcar & 70 \\
\hline FRANCISCO DA COSTA ALVARES & 2 & Guapeva & 9,000 & 129,000 & compra & com cirações de animais & \\
\hline & & Boa Vista & 18,600 & 30600 & & cultivando & \\
\hline FRANCISCO DE PAULA AFONSO & 2 & & 12,000 & 30,600 & compra & & \\
\hline ERANCISCO DEPAIUA IETF & 2 & Mansa morte & 106,200 & 114200 & compra & comfábrica de açúcar & 32 \\
\hline FRANCISCO DE PAULA LEIIE & 2 & & 8,000 & 114,200 & compra & & \\
\hline FRANCISCO JOZE DE OLIVERA & & Ponte & 112,500 & & compra & cultivando & \\
\hline FRANCISCO JOZE DE OLIVEIRA & 2 & Paiol & 28,125 & 140,625 & compra & cultiva & \\
\hline IGNACIO BUFNO DF CAMABGO & 2 & Capela & 67,500 & 75,500 & & & \\
\hline IGINACIO BUENU DE CAIVARGT & 2 & & 8,000 & 75,500 & compra & fábrica de açúcar & 6 \\
\hline IGNACO PEDROZO DFARBEI & 2 & Cururu & 75,000 & 76625 & & & \\
\hline IGIVACIU PEDROZU DE ABREU & 2 & & 1,625 & 76,625 & compra e herança & cultivando & \\
\hline & 2 & Laranjeira & 210,000 & 214000 & & & \\
\hline JUAQUIVI ANIONIO DE GODOIS & 2 & & 4,000 & 214,000 & compra & cultivando & \\
\hline & 2 & Engordador & 56,000 & 60000 & herança & em crias de animais & \\
\hline JOAQUIM JOZE DE MORAES & 2 & Rosario & 4,000 & 60,000 & compra & comfábrica de açúcar & 26 \\
\hline JOZE ANTONIO DA CBUZ & 2 & Campos & 4,000 & 9280 & & & \\
\hline JULE AIVIUINIU DA CRUL & 2 & & 5,280 & 9,280 & compra & cultivando & \\
\hline JOZE ANTONIO DE OLIVEIRA & 2 & Chapada & 30,000 & 51.000 & & & \\
\hline JOZE AINIONIO DE OLIVEIRA & 2 & Varginha & 21,000 & 51,000 & compra & cultivando & 20 \\
\hline JOZEMANOE TAYARES & 2 & Maleta & 36,000 & 68.000 & & & \\
\hline JOLE MANOEL IAVARES & 2 & Chácara de São José & 32,000 & 68,000 & compra & comfábrica de açúcar & 14 \\
\hline LUIZ FERRAZ DE ALMEIDA & & Bom jardim & 112,500 & & herança & em pasto de animais & \\
\hline LUIZ FERRAL UE ALMIEUDA & 2 & & & 112,500 & sesmaria & comfábrica de açúcar & 34 \\
\hline & & Caimirim & 12,500 & 24.500 & & & \\
\hline MANOEL RODRIGUES DA COSTA & 2 & & 12,000 & 24,500 & posse e herança & cultivando & \\
\hline & & Minguita & 11,250 & 15250 & & & \\
\hline THEREZA MARIA DEJESUS & 2 & & 4,000 & 15,250 & compra & cultivando & \\
\hline & & Vargem & 112,500 & & posse & em pastagem de animais & \\
\hline DOMINGOS LETE DE MORAES & 3 & Posse & 60,000 & 178,500 & compra & 'ando com plantações por si e seus filho & \\
\hline & & Parreira & 6,000 & & compra & & \\
\hline & & Monte alegre & 450,000 & & compra & com fábrica de açúcar & 50 \\
\hline ELEUTERIO DA SILVA PRADO & 3 & Capivari & 450,000 & 1125,000 & sesmaria & cultiva & \\
\hline & & Aterrado & 225,000 & & compra & em pastagem de animais vacum & \\
\hline & & Quilombo & 1122,000 & & compra & $\begin{array}{l}\text { cultivando herdeiros com fábrica } \\
\text { de açúcar ( } 30+16 \text { escravos) }\end{array}$ & \\
\hline GERTRUDES MARIA JACINTHA & 3 & & 40,000 & 1174,000 & compra & em pasto de animais & \\
\hline & & Bento Pereira & 12,000 & & compra & & \\
\hline & & Santa Ana & 105,000 & & compra & comfábrica de açúcar & 18 \\
\hline LUIZ JOZE PEREIRA & 3 & S. Jeronimo & 400,000 & 531,000 & sesmaria & cultivando & \\
\hline & & Loveira & 26,000 & & herança & crias de animais & \\
\hline & & Rio Acima & 0,320 & & compra & cultivando & \\
\hline RAIMUNDO DA SILVA BERNARDES & 3 & Catingueiro & 0,320 & 0,960 & compra & cultiva & \\
\hline & & Monjolinho & 0,320 & & compra & pasto de animais & \\
\hline & & Barreiro & 143,000 & & & & \\
\hline VICENTE DE SAMPAIO GOIZ & 3 & & 112,5 (litígio) & 173,000 & & & \\
\hline & & & 30,000 & & dote & comfábrica de açúcar & 19 \\
\hline & & Roseirinha & 75,000 & & & & \\
\hline & & & 7,500 & & & & \\
\hline JOAO FERREIRA ALVARES & 4 & & 13,000 & 115,500 & & & \\
\hline & & & 20,000 & & compra & cultivando & 1 \\
\hline
\end{tabular}


Entre os 28 proprietários, 24 (85,7\%) possuíam ao menos um terreno com até 50 alqueires paulistas - para 7 deles o somatório das áreas não alçava aos 50 alqueires, para outros 6 estava entre 50,1 e 100 alqueires - e um deles teve apenas uma das propriedades com área identificada. Entre esses proprietários a área média possuída era de 205,97 alqueires, enquanto a área média por propriedade era de 91,54 alqueires.

A menor conjugação entre as glebas foi possuída por Raimunda da Silva Bernardes, cujos três terrenos conjuntamente conformavam uma área de tão somente 0,96 alqueires. As duas terras de Jose Antonio da Cruz somavam 9,28 alqueires e as de Escolástica Soares 13,8 alqueires paulistas.

Entre os três proprietários de áreas rurais acima de 50 alqueires, que somavam 281,25, 337,5 e 1125 alqueires, a maior conjugação foi declarada pelo nosso conhecido capitão-mor Eleutério da Silva Prado (vide capítulos I e II) 1125 alqueires distribuídos em duas propriedades de 250 e 450 alqueires que comprou e uma sesmaria de 450 alqueires.

Maior extensão que Eleutério, 1174 alqueires, estava nas mãos de Gertrudes Maria Jacinta, que não deixava de possuir pequenas extensões. Eram 1122 alqueires paulistas, aos quais se acresciam propriedades de 12 e 40 alqueires.

Como grande parte dos detentores de múltiplas propriedades tinha ao menos uma pequena entre elas, a concentração e distribuição viram-se muito pouco distanciadas em se tratando de dados baseados em proprietários ou em propriedades, motivo pelo qual continuamos nossa análise pensando em propriedades.

A Tabela III.2 apresenta a distribuição das propriedades jundiaenses de acordo com faixas de tamanho das propriedades.

\section{Tabela III.2}

Distribuição das propriedades de acordo com faixas de tamanho (Jundiaí - 1818)

\begin{tabular}{|c|c|c|c|c|c|}
\hline $\begin{array}{l}\text { Tamanho das } \\
\text { propriedades * }\end{array}$ & \% (Número) & $\begin{array}{c}\text { Área* }^{*} \\
\% \text { (total) }\end{array}$ & Área média* & Área modal* & I. Gini ${ }^{\star}$ \\
\hline $0-50$ & $59,5(185)$ & $10,9(3120,435)$ & 16,8 & 30,0 & 0,462 \\
\hline $50,1-100$ & $16,7(52)$ & $12,5(3556,425)$ & 63,4 & 60,0 & 0,107 \\
\hline $100,1-300$ & $16,7(52)$ & $28,2(8042,450)$ & 154,7 & 112,5 & 0,170 \\
\hline $300,1-500$ & $4,5(14)$ & $20,2(5748,000)$ & 410,6 & 450,0 & 0,062 \\
\hline $500,1-1000$ & $1,6(5)$ & $14,5(4125,000)$ & 900,0 & 900,0 & 0,058 \\
\hline 1000,1 ou mais & $1,0(3)$ & $13,8(3934,500)$ & 1311,5 & - & 0,400 \\
\hline Total & $100,0(311)$ & $100,0(28526,810)$ & 91,7 & 112,5 & 0,695 \\
\hline
\end{tabular}


Entre as terras declaradas a qualquer título, 59,5\% eram pequenas, de 16,8 alqueires em média, e tinham até 50 alqueires paulistas. Por outro lado, apenas oito propriedades $(2,6 \%)$ eram grandes extensões rurais de mais de 500 alqueires paulistas. As três maiores delas, acima de 1000 alqueires, estavam nas mãos de três mulheres e tinham, respectivamente, áreas de 1012, 1122 e 1800 alqueires paulistas, 13,8\% da área jundiaense.

Naturalmente, conclui-se que a estrutura fundiária local era bastante desigual, sendo a maioria daqueles que tiveram acesso à posse da terra em 1818 possuidora de uma parcela diminuta. As referidas grandes propriedades ocupavam em conjunto $28,3 \%$ da extensão descrita no tombamento, quase três vezes a área ocupada conjuntamente pelas 185 menores propriedades. Essa desigualdade pode ser visualizada no índice de gini que, calculado para propriedades ou proprietários foi de 0,695.

No cômputo geral, entre as 294 propriedades cuja forma de aquisição identificamos, 65,6\% foram obtidas por compra. Proporção que se mantém elevada considerando-se a área como referência: $66,4 \%$ da extensão jundiaense chegou às mãos de seus detentores através do mercado fundiário, conforme apresentado na Tabela III.3. O comércio de terras era prática levada a cabo há séculos na localidade, cuja primeira escritura, registrada em 20 de outubro de 1660, cinco anos após sua elevação à condição de vila, foi a venda de 100 braças de terras que fez Manoel Gil a Miguel Costa pelo valor de 8\$000. (cf. MAZZUIA, 1976, p.55)

Tabela III.3

Formas de aquisição das propriedades de acordo com faixas de tamanho (Jundiaí - 1818)

\begin{tabular}{|c|c|c|c|c|c|c|c|c|}
\hline \multirow{2}{*}{$\begin{array}{l}\text { Tamanho das } \\
\text { propriedades * }\end{array}$} & \multicolumn{8}{|c|}{$\begin{array}{l}\text { Formas de aquisição** } \\
\qquad \% \text { (Número) }\end{array}$} \\
\hline & Compra & Herança & $\begin{array}{l}\text { Compra e } \\
\text { herança }\end{array}$ & Doação & Posse & Sesmaria & Outras & Total \\
\hline $0-50$ & $64,9(113)$ & $20,7(36)$ & $2,3(4)$ & $1,7(3)$ & $5,7(10)$ & - & $4,6(8)$ & $100,0(174)$ \\
\hline $50,1-100$ & $53,1(26)$ & $28,6(14)$ & $2,0(1)$ & 4,1 (2) & $8,2(4)$ & - & 4,1 (2) & 100,0 (49) \\
\hline $100,1-300$ & 83,7 (41) & 10,2 (5) & $2,0(1)$ & - & 2,0 (1) & - & $2,0(1)$ & 100,0 (49) \\
\hline $300,1-500$ & $57,1(8)$ & $14,3(2)$ & $7,1 \quad(1)$ & - & 7,1 (1) & $14,3(2)$ & - & $100,0(14)$ \\
\hline $500,1-1000$ & $60,0(3)$ & $20,0(1)$ & - & - & 20,0 (1) & - & - & 100,0 \\
\hline 1000,1 ou mais & $66,7(2)$ & - & - & - & $33,3(1)$ & - & - & 100,0 \\
\hline Total & 65,6 (193) & $19,7(58)$ & $2,4(7)$ & 1,7 (5) & 6,1 (18) & $0,7(2)$ & 3,7 (11) & 100,0 (294) \\
\hline
\end{tabular}


Tabela III.4

Indicadores estatísticos de propriedades adquiridas por compra, herança e posse (Jundiaí - 1818)

\begin{tabular}{lcccccccc}
\hline \hline & Número & Área média & $\begin{array}{c}\text { Desvio } \\
\text { padrão }\end{array}$ & Moda & Mediana & $\begin{array}{c}\text { Índice de } \\
\text { Gini }\end{array}$ & $\begin{array}{c}\text { Menor } \\
\text { propriedade }\end{array}$ & $\begin{array}{c}\text { Maior } \\
\text { propriedade }\end{array}$ \\
\hline Compra & 193 & 95,2 & 192,9 & 112,5 & 32,0 & 0,692 & 0,12 & 1800,0 \\
Herança & 58 & 74,1 & 141,8 & 60,0 & 29,1 & 0,660 & 0,64 & 900,0 \\
Posse & 18 & 157,7 & 304,2 & 30 e 56,25 & 37,5 & 0,738 & 0,60 & 1012,5 \\
Total & 269 & 94,9 & 192,7 & 112,5 & 30,0 & 0,697 & 0,12 & 1800,0 \\
\hline \hline Em alqueires paulistas
\end{tabular}

Fonte: AESP, Inventário de Bens Rústicos, Jundiaí:1818

A segunda forma de acesso à terra mais representativa, as heranças, respondiam por $19,7 \%$ das propriedades e a uma extensão de $15,5 \%$ do território arrolado para Jundiaí. Declaradas conjuntamente, compras mais heranças encontramos em 7 declarações $(2,4 \%)$. A área média das terras possuídas por compra era de 95,2 alqueires, enquanto entre aquelas provenientes de heranças era de 74,1 alqueires paulistas. Em regra, as propriedades negociadas tinham 112,5 alqueires, sendo de 60 alqueires a moda para a área das propriedades herdadas.

A menor propriedade adquirida por compra, 0,12 alqueires, era pouco menor à mais exígua propriedade herdada: 0,64 alqueires, ambas pequeníssimas extensões. Por outro lado, a maior propriedade adquirida por compra, 1800 alqueires, equivalia a duas da maior propriedade herdada, 900 alqueires.

As propriedades adquiridas pela simples posse ocupavam uma área de 2837,85 alqueires paulistas, dos quais 35,7\% (1012,5 alqueires) pertenciam a uma única posseira, Thereza de Jesus, ao passo que a propriedade de Antonio Rodrigues do Prado ocupava apenas 0,6 alqueires paulistas de área. $O$ índice de Gini para as terras adquiridas por posses foi de 0,738 , superior ao encontrado para a totalidade das propriedades declaradas.

Ademais, havia duas sesmarias remanescentes na Jundiaí de 1818: o capitão Luis Jose Pereira de Queirós declarou "possuir um terreno denominado São Jerônimo em que compreende 1000 braças de testada e 2000 de fundo [400 alqueires - DOMR] em cujo está cultivando e possui por sesmaria" e o já referido capitão-mor Eleutério da Silva Prado, que vivia na cidade de São Paulo, declarou "possuir um terreno denominado Capivari em que compreende em 1500 braças em quadra [450 alqueires - DOMR] em cujo cultiva, e possui por sesmaria". (Relação dos proprietários que possuem terrenos no distrito, e freguesia da vila de Jundiaí. 1818 - AESP, Tombamento/ C09868) 
As cartas e/ou confirmações das ditas sesmarias não foram localizadas. É possível que não tenham sido requisitadas pelos referidos capitães, mas herdadas, embora originalmente sesmarias, como ficou claro em outra situação, em que descreveu suas propriedades Luiz Ferraz de Almeida, entre elas "duas partes em uma sesmaria e ignora o número de braças, e está cultivando com fábrica de açúcar, e ocupa 34 escravos, nela reside e possui por herança." (Relação dos proprietários que possuem terrenos no distrito, e freguesia da vila de Jundiaí. 1818 - AESP, Tombamento/ C09868)

Pudemos identificar outra propriedade originária de uma sesmaria, mas cuja transmissão foi feita por compra. O capitão-mor reformado Luiz Castanho de Moraes, era possuidor em 1818 de terras que ocupavam 450 alqueires paulistas, em que produzia açúcar, como já vimos em capitulo anterior, ocupando, segundo o arrolamento de terras, o trabalho de 14 escravos - seriam 30 cativos segundo o mapa populacional de 1816 . Originalmente correspondente a 900 alqueires, em 1818 metade da propriedade havia "se perdido" em partilha pela meação de sua mulher, Gertrudes Maria Ferreira.

As ditas terras haviam sido cedidas a Luiz Castanho pelo seu cunhado Antonio Dias do Prado, "com outorga de sua mulher". Em 13 de julho de 1778, foi concedida a Antonio Dias carta de sesmaria de meia légua de testada e uma de sertão (900 alqueires paulistas) "na paragem chamada Barreiro", após sua requisição, na qual alegava

que ele achando-se com bastantes escravos, e com todas as sortes de criações, se via sem terras próprias para trabalhar e acomodar sua família e escravatura; e porque na paragem chamada do Barreiro, se achavam terras devolutas, que contestam com as de Domingos Dias Leme, e as de Manoel Afonso. (AESP, Sesmarias, patentes e provisões/C00368, Livro21)

No entanto, o sesmeiro não confirmou a dita carta de sesmaria e menos de uma década depois de concedidas tais terras, Luiz Castanho de Moraes pediu carta de retificação dessa propriedade com nova sesmaria, que the foi dada em abril de 1786, sem qualquer menção à transação envolvida na cessão de tais terras. Luiz Castanho apresentava-se então "com possibilidade para poder cultivar as terras na dita sesmaria e medidas, e que querendo agora medi-las e demarcá-las para tomar posse, e requerer confirmação." (AESP, Sesmarias, patentes e provisões/C00368, Livro22) Decerto, deveria possuir tais condições, tendo aparecido na lista nominativa jundiaense pouco mais de uma década após requerer a sesmaria já com engenho estalado e 25 escravos.

Dada a razão de sexo entre os donos das áreas rurais jundiaenses, torna-se inviável uma análise que considere a participação de cada sexo na composição das faixas de tamanho das propriedades ou entre as distintas formas de apropriação das terras 
rurais. É possível, porém, observamos as características encontradas para cada gênero, como apresentado na Tabela III.5.

Homens e mulheres tiveram o acesso a terra mormente através do mercado fundiário, tendo as compras sido declaradas por $75 \%$ das mulheres e $63,4 \%$ dos homens. Entre as mulheres 14,3\% das propriedades foram adquiridas por herança e 7,1\% por posse, enquanto entre os homens esses percentuais foram de $21 \%$ e $5,5 \%$, respectivamente para heranças e posses.

Ainda que compras e posses apareçam de forma marcante entre as mulheres, vale considerar a possibilidade de que grande parte dos terrenos "comprados" ou "apossados" por mulheres tenham sido adquiridos em momento anterior por maridos falecidos, então cabeças do casal. Basta lembrar que, na lista nominativa de 1816 , mais de $60 \%$ das mulheres chefes de fogo eram viúvas (cf. capitulo I). Por outro lado, as heranças poderiam ser originárias da família da mulher, sendo esta, neste caso, responsável pela parte do patrimônio de seu domicílio representado pelas propriedades rurais descritas e nas quais eram realizadas as atividades produtivas do casal.

Tabela III.5

Formas de aquisição das propriedades e estatísticas para o tamanho de acordo com o sexo do proprietário (Jundiaí - 1818)

\begin{tabular}{ccc|ccc}
\hline \hline $\begin{array}{c}\text { Formas de } \\
\text { aquisição }\end{array}$ & Homens* & Muheres ** & Estatísticas & Homens** & Muheres \\
\hline Compra & $63,4(151)$ & $75,0(42)$ & Área média & 79,2 & 146,1 \\
Herança & $21,0(50)$ & $14,3(8)$ & Desvio padrão & 133,8 & 319,1 \\
Compra e herança & $2,9(7)$ & - & Moda & 112,5 & 112,5 \\
Doação & $2,1(5)$ & - & Mediana & 30 & 0,763 \\
Posse & $5,5(13)$ & $7,1(4)$ & I. Gini & 0,658 & 0,3 \\
Sesmaria & $1,3(3)$ & $1,8(1)$ & Menor propriedade & 0,12 & 1800,0 \\
Outras & $4,2(10)$ & $1,8(1)$ & Maior propriedade & 900,0 & \\
Total & $100,4(239)$ & $100,0(56)$ & & \\
\hline \hline
\end{tabular}

${ }^{* \star}$ Exclusive 2 propriedades com forma de aquisição não especificada

*** Exclusive 1propriedade com área não especificada

Fonte: AESP, Inventário de Bens Rústicos, Jundiaí:1818 
Ademais, pudemos notar que para homens e mulheres considerados separadamente, ainda persiste relevante concentração do tamanho das propriedades. $O$ índice de concentração (Gini) para homens e mulheres foi respectivamente 0,658 e 0,763. $\mathrm{O}$ índice para as mulheres foi em boa medida superior ao dos declarantes do sexo masculino devido ao fato já identificado de estarem nas mãos de três mulheres as maiores propriedades da localidade que, como adiantado ocupavam $13,8 \%$ do território descrito no documento em tela. Tal realidade foi determinante do valor calculado para as áreas médias, que foi de 133,8 entre os indivíduos do sexo masculino e 319,1 entre aqueles do sexo oposto - com área mínima de 0,3 alqueires para as mulheres e 0,12 alqueires para os homens. Contudo, a moda foi a mesma, 112,5 alqueires paulistas e a mediana praticamente coincidente entre mulheres (30 alqueires) e homens (29 alqueires).

Entre as glebas jundiaense, a 21 (6,8\%) não estavam relacionadas descrições de cultura e/ou criação. Na localidade, apenas duas propriedades foram explicitamente declaradas como não sendo produtivamente utilizadas. Maria Antonia Lacerda, moradora na vila de Parnaíba tinha 112,5 alqueires comprados "em cujo terreno não tem cultura alguma". E Jose Garcia do Prado possuía dois alqueires paulistas em terras "e não as cultiva por impossibilidades", por nós desconhecidas. (Relação dos proprietários que possuem terrenos no distrito, e freguesia da vila de Jundiaí. 1818 - AESP, Tombamento/ C09868)

As demais propriedades, que correspondem a $92,6 \%$ do total, apresentam de forma evidente produção agropecuária. Dezoito delas $(5,8 \%)$ estavam ligadas a atividades criatórias, e outras 86,8\% mencionaram estar em cultura. A Tabela III.6 apresenta o uso da terra de acordo com faixas de tamanho das propriedades. Note-se, entretanto, que há possibilidade de que parte dessas propriedades, ligadas exclusivamente à cultura, pudessem também ser criatórios de animais, em vista do característico das declarações que apontam, no caso dos animais: "cultivados em crias de animais", "cultivadas com criações de animais" ou "cultivando em pasto de animais vacum". Assim, não há nenhuma garantia de que declarações "em cujo está cultivando" ou "está em cultura", referiam-se somente a plantações; assim como já havíamos identificado no capítulo anterior a ligação entre cultura e criação na localidade. 
Tabela III.6

Uso da terra de acordo com faixas de tamanho das propriedades

(Jundiaí - 1818)

\begin{tabular}{|c|c|c|c|c|c|}
\hline \multirow{2}{*}{$\begin{array}{l}\text { Tamanho das } \\
\text { propriedades * }\end{array}$} & \multicolumn{5}{|c|}{$\begin{array}{l}\text { Uso da terra } \\
\% \text { (Número) }\end{array}$} \\
\hline & Cultura & Sem cultura & Criação & $\begin{array}{c}\text { Não } \\
\text { mencionado }\end{array}$ & Total \\
\hline $0-50$ & $86,5(160)$ & $0,5(1)$ & $4,9(9)$ & $8,1(15)$ & $100,0(185)$ \\
\hline $50,1-100$ & $88,5(46)$ & - & $5,8(3)$ & $5,8(3)$ & $100,0(52)$ \\
\hline $100,1-300$ & $82,7(43)$ & $1,9(1)$ & $9,6(5)$ & $5,8(3)$ & $100,0(52)$ \\
\hline $300,1-500$ & $92,9(13)$ & - & $7,1(1)$ & - & $100,0(14)$ \\
\hline $500,1-1000$ & 100,0 & - & - & - & $100,0(5)$ \\
\hline 1000,1 ou mais & $100,0(3)$ & - & - & - & $100,0(3)$ \\
\hline Todas as propriedades & $86,8(270)$ & $0,6(2)$ & $5,8(18)$ & $6,8(21)$ & $100,0(311)$ \\
\hline
\end{tabular}

Localizamos uma única propriedade em que foi descrita a cultura: algodão. "Ignacia de Lima declarou possuir um terreno denominado Feital em que compreende 60 braças de testada e 100 de fundo [40 alqueires - DOMR] em cujo está cultivando em plantações de algodões, nele reside e possui por compra." (Relação dos proprietários que possuem terrenos no distrito, e freguesia da vila de Jundiaí. 1818 - AESP, Tombamento/C09868) Em 1816 o censo populacional aponta Ignacia como fiandeira, atestando o encadeamento dos processos produtivos na vila em tela.

Ademais pudemos aventar, como esperado, a produção de cana, pois 29 declarações mencionaram o fabrico do açúcar - número superior ao verificado nos arrolamentos populacionais de 1816 (22) e inferior aos 33 engenhos com produção registrada no recenseamento de 1822, como vimos no capítulo II -, o que, dadas as já conhecidas observações sobre o açúcar, observamos ser esta cultura praticada, de maneira típica em terras próprias. Em 1818, além de próprias estas propriedades foram adquiridas, majoritariamente, por compra: $68 \%$. As propriedades açucareiras respondem por $9,3 \%$ do total e $10,7 \%$ daquelas declaradas em cultura, sendo $26,3 \%$ da área declarada no inventário de bens rústicos da localidade em tela.

Nos primeiros recenseamentos feitos na Capitania, há relativamente muitas referências às fazendas de cana 'em terras de Sesmaria' ou em terras 'de Posse', mas, com o correr do tempo, predominam as que se obtiveram por compra. Em 1818, quando a lavoura do açúcar já tinha alcançado um desenvolvimento apreciável em São Paulo [...] a maioria das fazendas canavieiras de Jundiaí eram propriedades obtidas por compra, uma ou outra por herança ou dote [...] Em áreas 
mais próximas, onde a cultura da cana era mais antiga, predominavam certamente as fazendas obtidas por compra, ao passo que nas mais remotas e mais recentemente abertas eram mais numerosas as obtidas por sesmarias ou posses. [...] A rede fundiária ligada à lavoura canavieira, como outra qualquer, estava em constantes transformações. Heranças, dotes e vendas de parcelas era, responsáveis pela fragmentação da fazenda de cana. [...] $\mathrm{O}$ fato de se verificar no começo da cultua de cana maior número de fazendas obtidas por posse e sesmaria, para depois serem mais freqüentes as obtidas por compra, permite tirar algumas conclusões quanto à origem dos capitais do ciclo do açúcar paulista. Parece que a maioria dos capitais necessários para o desenvolvimento da lavoura canavieira teria tido origem nessa mesma atividade. Tudo parece indicar que a lavoura canavieira teria autofinanciado seu desenvolvimento (PETRONE, 1968, pp.56-58)

De fato, ainda que não saibamos os preços de comercialização das terras locais, decerto as características da exportação açucareira (cap. II) apontam significativamente para o autofinaciamento do seu desenvolvimento. E como bem apresentou Petrone, em 1818, além de próprias estas propriedades haviam sido adquiridas, majoritariamente, por compra, sendo de $68 \%$ o percentual devido a essas transações.

As glebas ligadas à produção do açúcar possuíam características em boa medida apartadas daquelas estatísticas consideradas para as propriedades em conjunto, e/ou não açucareiras, em especial, no que tange à extensão das terras e à utilização da mão-deobra cativa na produção como já havíamos identificado em capitulo anterior. Afinal, sabemos que o açúcar modificou o panorama local, desenvolvendo o comércio e criando uma elite agrária mais pronunciada e decerto justificando formarem os donos de engenho a principal classe da terra, ainda que a produção de açúcar jundiaense não fosse comparável, como sabido, às das principais localidades produtoras da região oeste paulista (Itu, Porto Feliz, Campinas), onde podemos situar a própria Jundiaí.

Contudo, as diferenças verificadas para o conjunto de propriedades açucareiras não implicam que a diferenciação tenha alcançado um patamar em que nenhuma propriedade não-açucareira possa se enquadrar. A título de exemplo, citamos a maior propriedade local, 1800 alqueires paulistas, onde não foi mencionada a produção do gênero em tela.

Excluindo-se aquela única propriedade arrendada ${ }^{64}$, todas as glebas açucareiras possuíam cativos como esperado: compunham o menor plantel cinco escravos e o maior 70 indivíduos. A média foi de 19,9 e moda de 16,5 escravos. A área, a sua vez, estendeuse por 259,143 alqueires em média, valor superior à mediana, 105 alqueires paulistas. As

\footnotetext{
${ }^{64}$ Maria Thereza Petrone (1968, p.56) ao observar a presença de foreiros que plantavam cana e erigiam engenhos no oeste paulista de 1818 argumentou que "o aforamento de terras para a formação de uma fazenda de cana era quase exceção em São Paulo", afirmação baseada na presença de abundância de terras na Capitania que seriam um desincentivo ao arrendamento de terrenos.
} 
pequenas propriedades, de até 50 alqueires, eram apenas 20,7\%, com área mínima de 8 alqueires, valores comparáveis ao obtidos através das listas nominativas.

\section{Tabela III.7}

Indicadores estatísticos de área e cativos em propriedades produtoras e não produtoras de açúcar

$$
\text { (Jundiaí - 1818) }
$$

\begin{tabular}{|c|c|c|c|c|}
\hline \multirow[b]{2}{*}{ Estatísticas } & \multicolumn{2}{|c|}{ Propriedades açucareiras } & \multicolumn{2}{|c|}{ Propriedades não açucareiras } \\
\hline & Áreas & Escravos & Áreas & Escravos \\
\hline Média & 258,729 & 19,8 & 74,509 & 1,1 \\
\hline Desvio padrão & 317,970 & 15,9 & 154,868 & 3,2 \\
\hline Moda & 450,000 & 34,0 & 112,300 & 0,0 \\
\hline Mediana & 105,000 & 16,5 & 30,000 & 0,0 \\
\hline I. Gini & 0,582 & 0,4 & 0,680 & 0,891 \\
\hline Mínimo & 4,000 & 0,0 & 0,120 & 0,0 \\
\hline Máximo & 1122,000 & 70,0 & 1800,000 & 20,0 \\
\hline Soma & 7503,150 & 596 & 21023,660 & 308 \\
\hline
\end{tabular}

Consideradas isoladamente as propriedades sem engenho de açúcar, $23 \%$ delas tinham até 8 alqueires, tamanho da menor gleba açucareira, percentual alçado a 63,5\% consideradas aqueles terrenos de até 50 alqueires. A média encontrada foi de 74,52 alqueires paulistas, consideravelmente menor que aquela verificada para os terrenos onde a produção do açúcar era levada a cabo. Diferença considerável encontramos nos índices de Gini calculados, que apontam para o grupo ligado a engenhos bem mais homogêneo que aquele representado pelas demais propriedades.

Já considerados em seu conjunto, $28,5 \%$ dos terrenos de Jundiaí contavam com o trabalho compulsório que estava ligado a $49,2 \%$ da extensão rural da vila. Uma vez comparados ao total de domicílios - dados esses considerados para 1816, ano mais próximo ao tombamento para o qual possuímos informações censitárias - essas glebas que contavam com trabalho escravo respondiam por $10,3 \%$ deles, sendo esse praticamente o mesmo percentual daquele considerado para chefes de fogo senhores exclusivamente de escravos $(10,8 \%)$. 
As propriedades arroladas no tombamento representam tão somente $36,2 \%$ do total de fogos listados na lista nominativa de 1816 , sendo de $25,8 \%$ o percentual dos cabeças de domicílio que não contavam com trabalho cativo. Contudo, grande parte dos fogos, $53,1 \%$, não possuía nenhum dos dois principais fatores produtivos do Oitocentos: terra e trabalho escravo. A situação dessas pessoas, em especial daqueles que tinham possibilidades de manter suas atividades produtivas principais ligadas à agropecuária, ainda que em terras de outrem, não deveria ser muito diferente daquela enfrentada pelos proprietários de pequenas extensões, em sua maioria não proprietários de cativos ou, se proprietários, apenas de poucos indivíduos. Esses dados são apresentados na Tabela III.8. ${ }^{65}$

Entre as pequenas glebas, de até 50 alqueires paulistas, 15,1\% contava com 0 trabalho de escravos encontrados nessas propriedades em número de 170 (19,5\% da escravaria arrolada), em que chegaram a atingir o máximo de 26 indivíduos (15,3\%) em um único plantel, sendo a moda igual a 1, encontrada em 8 propriedades (28,6\%).

"O capitão Joaquim José de Morais declarou possuir um terreno denominado o Rosario em que compreende 200 braças de testada e 400 de fundo [16 alqueires DOMR] em cujo está cultivando com fábrica de açúcar e ocupa 26 escravos, e possui por compra, e nele reside". (Relação dos proprietários que possuem terrenos no distrito, e freguesia da vila de Jundiaí. 1818 - AESP, Tombamento/C09868) Além deste terreno, o capitão Joaquim possuía uma outra propriedade, ainda maior, 60 alqueires, em que criava animais e a qual não foi relacionado nenhum escravo.

\footnotetext{
${ }^{65} \mathrm{O}$ dados apresentados na tabela III.8, assim como as tabelas correspondes elaboradas para as demais localidades consideradas, foram calculados de acordo com metodologia apresentada em Gutiérrez (2006) em trabalho sobre donos de terras e escravos no Paraná. Também estudando localidade no Paraná, freguesia de São José dos Pinhais, no referido ano de 1818, Machado (2008, p.65) encontra grande discrepância entre as propriedades arroladas, um total de 215, e o número de domicílios recenseados no mesmo ano, 494. A autora deduziu, então "[...] que muitos desses domicílios seriam de negros e pardos livres que nelas habitavam, embora certamente existissem inúmeras propriedades em nome de uma só pessoa, porém habitadas e cultivadas por sua família ampliada, organizada em domicílios nucleares, ou ainda por agregados que mantinham domicílios independente na propriedade."
} 
Tabela III.8

Fogos de acordo com a posse de terras e escravos

(Jundiaí - 1816, 1818, 1822)

\begin{tabular}{|c|c|c|c|}
\hline & 1816 & 1818 & 1822 \\
\hline Número total de propriedades rurais* & & 312 & \\
\hline Número (\%) de propriedades rurais com escravos & & $89(28,5 \%)$ & \\
\hline Número total de escravos no tombamento de terras* & & 904 & \\
\hline Número total de fogos & 863 & & 765 \\
\hline Número (\%) de fogos com escravos & $182(21,1 \%)$ & & $183(23,9 \%)$ \\
\hline Número total de escravos na lista nominativa & 1205 & & 1252 \\
\hline$\%$ de fogos com terras & $36,2 \%$ & & $40,8 \%$ \\
\hline$\%$ de chefes de fogo com terras e escravos & $10,3 \%$ & & $11,6 \%$ \\
\hline$\%$ de chefes de fogo sem terras e com escravos & $10,8 \%$ & & $12,8 \%$ \\
\hline$\%$ de chefes de fogo com terra e sem escravos & $25,8 \%$ & & $29,2 \%$ \\
\hline$\%$ de chefes de fogo sem terras e sem escravos & $53,1 \%$ & & $46,4 \%$ \\
\hline
\end{tabular}

*Inclusive propriedade com 34 escravos, sem área explicitada

Fontes: AESP, Inventário de Bens Rústicos, Jundiaí:1818 e AESP, Maços de População, Jundiaí: 1816, 1822

A observação do número médio de escravos ligados a distintas faixas de tamanho das propriedades aponta crescimento de acordo com o aumento da área considerada, iniciando em 6 para as menores propriedades, atingindo 19 entre as propriedades de 300,1 a 500 alqueires e 30 para as propriedades de 500,1 a 1000 alqueires de extensão.

Esse aumento no tamanho dos plantéis é acompanhado também pela elevação do percentual de propriedades escravistas, que chega a 65,5\% na faixa dos 500,1 aos 1000 alqueires, em que pese a pequena amostra consideradas propriedades mais extensas. Por outro lado, a correlação entre o tamanho dos terrenos e número de escravos foi baixa, 0,32, mas, é importante notar, foi positiva.

Chama a atenção encontrarmos duas dentre as três maiores glebas locais, sem a presença de cativos possuídos por suas proprietárias, sendo a única senhora de cativos Antonia Dias Ferreira, com o plantel composto por 8 escravos que trabalhavam em seus 1800 alqueires. Entretanto, as três declarantes eram viúvas, ou seja, o mais provável é que esses terrenos tenham sido negociados ou apossados em momento anterior pelos falecidos maridos, então cabeças do casal, conforme hipótese aventada anteriormente. 
Tabela III.9

Distribuição das faixas de tamanho das propriedades

entre propriedades com e sem escravos

(Jundiaí - 1818)

\begin{tabular}{|c|c|c|c|c|c|}
\hline \multirow{2}{*}{$\begin{array}{l}\text { Tamanho das } \\
\text { propriedades * }\end{array}$} & \multicolumn{3}{|c|}{ Propriedades com escravos ${ }^{\star \star}$} & \multicolumn{2}{|c|}{ Propriedades sem escravos } \\
\hline & \% (Número) & $\begin{array}{c}\text { Área* }^{*} \\
\% \text { (total) }\end{array}$ & $\begin{array}{l}\text { Média de } \\
\text { escravos }\end{array}$ & \% (Número) & $\begin{array}{c}\text { Área* }^{*} \\
\% \text { (total) }\end{array}$ \\
\hline $0-50$ & $15,6(29)$ & $20,1(626,0)$ & 6,0 & $84,4(157,0)$ & $79,9(2482,4)$ \\
\hline $50,1-100$ & $44,2(23)$ & $46,1(1638,2)$ & 6,26 & $55,8(29,0)$ & $53,9(1918,3)$ \\
\hline $100,1-300$ & $46,2(24)$ & $47,1(3788,7)$ & 12,8 & $53,8(28,0)$ & $52,9(4253,8)$ \\
\hline $300,1-500$ & $57,1(8)$ & $60,4(3471,0)$ & 19,0 & $42,9(6,0)$ & $39,6(2277,0)$ \\
\hline $500,1-1000$ & $60,0(3)$ & $65,5(2700,0)$ & 30,0 & $40,0(2,0)$ & $34,5(1425,0)$ \\
\hline 1000,1 ou mais & $33,3(1)$ & $45,7(1800,0)$ & 8,0 & $66,7(2,0)$ & $54,3(2134,5)$ \\
\hline Total & $28,2(88)$ & $49,2(14023,9)$ & 10,0 & $71,8(224)$ & $50,8(14490,9)$ \\
\hline
\end{tabular}

Tabela III.10

Distribuição das propriedades com e sem escravos de acordo com faixas de tamanho das propriedades

(Jundiaí - 1818)

\begin{tabular}{|c|c|c|c|c|}
\hline \multirow{2}{*}{$\begin{array}{l}\text { Tamanho das } \\
\text { propriedades * }\end{array}$} & \multicolumn{2}{|c|}{ Propriedades com escravos ${ }^{\star \star}$} & \multicolumn{2}{|c|}{ Propriedades sem escravos } \\
\hline & \% (Número) & $\begin{array}{c}\text { Área }^{*} \\
\% \text { (total) }\end{array}$ & \% (Número) & $\begin{array}{c}\text { Área* }^{*} \\
\% \text { (total) }\end{array}$ \\
\hline $0-50$ & $33,0(29)$ & $4,5(626,0)$ & $70,1(157,0)$ & $17,1(2482,4)$ \\
\hline $50,1-100$ & 26,1 (23) & $11,7(1638,2)$ & $12,9(29,0)$ & $13,2(1918,3)$ \\
\hline $100,1-300$ & $27,3(24)$ & $27,0(3788,7)$ & $12,5(28,0)$ & $29,4(4253,8)$ \\
\hline $300,1-500$ & $9,1(8)$ & $24,8(3471,0)$ & $2,7(6,0)$ & $15,7(2277,0)$ \\
\hline $500,1-1000$ & $3,4(3)$ & $19,3(2700,0)$ & $0,9(2,0)$ & $9,8(1425,0)$ \\
\hline 1000,1 ou mais & $1,1(1)$ & $12,8(1800,0)$ & $0,9(2,0)$ & $14,7(2134,5)$ \\
\hline Total & $100,0(88)$ & $100,0(14023,9)$ & $100,0(224)$ & $100,0(14490,9$ \\
\hline
\end{tabular}

Ainda que Gertrudes, residente em Itu, não possuísse nenhum escravo ali naquelas terras denominadas o Quilombo, "neste terreno está cultivando um herdeiro Modesto Antonio Correia com fábrica de açúcar e ocupa 30 escravos também cultiva outro herdeiro o capitão José Castanho no lugar denominado Bom Sucesso com fábrica de açúcar e ocupa 16 escravos". (Relação dos proprietários que possuem terrenos no 
distrito, e freguesia da vila de Jundiaí. 1818 - AESP, Tombamento/C09868) Anexas a estas terras Gertrudes possuía terras de 40 alqueires "cultivadas em pastos de animais".

Modesto Antonio Correa de Lemos era filho de Gertrudes Maria Jacinta e do capitão Manoel Correa de Lemos, falecido em 1807. José Castanho de Moraes foi casado (1804) com Matilda Maria Jacinta, também filha de Manoel e Gertrudes. (cf. LEME, 1903, vol.5).

José Castanho, como referido em capítulo anterior, era filho de Luiz Castanho que, como adiantado, era detentor de 450 alqueires em Jundiaí. Luiz Castanho faleceu viúvo em 1824, sendo José um dos seus herdeiros. Herança dos pais e do sogro, eis a origem das terras em que estavam empregados os escravos que compunham o maior plantel de Jundiaí até 1825, 88 cativos (vide capítulo I). Esses escravos estavam diretamente envolvidos na produção da cana (uma vez que ao longo dos anos José Castanho destacou-se como senhor de engenho), assim como outros indivíduos mencionados no inventário de bens rústicos.

O número de escravos eleva-se a 904 se acrescemos aos 870 antes considerados os 34 a trabalhar nas referida sesmaria de Luiz Ferraz de Almeida, sem extensões explicitadas. Todos os escravos descritos estavam em propriedades em cultivo e entre eles $596(65,9 \%)$ explicitamente naquelas em que foi declarada a produção de açúcar (cf. Tabela III.7)

$\mathrm{Na}$ realidade, escravos, ainda que em número bastante reduzido, poderiam estar sendo (re)alocados nas atividades pecuárias, que sabemos serem realizadas por alguns senhores de engenho e outros agricultores e serem demandantes de reduzido volume de mão-de-obra, dado seu caráter extensivo. Assim como havíamos identificado em outro momento, havia também a necessidade de produção de animais para gasto na própria fazenda e/ou engenho.

Proprietários de terras ligados a culturas diversas, entre elas o cultivo da cana para açúcar, e a animais não eram incomuns, como pode ser observado na Tabela III.1 em que apresentamos informações para as glebas de proprietários de duas ou mais delas. Ao menos dez senhores de terras e escravos, declarantes das atividades realizadas em todas as suas terras possuídas, tinham um terreno ligado à cultura e outro à criação. Houve casos em que a criação ocupava a maior área - a exemplo, Joaquim Jose de Moraes. Compreensível, em especial no caso do açúcar, visto ser esta atividade intensiva em mão de obra e a atividade criatória em área.

Ademais das terras de Gertrudes, em que a produção de açúcar era realizada por terceiros sendo a proprietária moradora fora da vila de Jundiaí e seu termo, outros dez 
proprietários de terras na localidade eram residentes em outras freguesias ou vilas, sendo: Itu (1), Bonfim de Goiás (1), Atibaia (1), Piracicaba (1), São Paulo (2), Parnaíba (2), Porto Feliz (1) e São Carlos (1).

A exemplo, junto à propriedade do tenente Jose Joaquim de Sampaio não havia nenhum escravo por ele declarado, ainda que a existência deles em seu terreno seja quase certa, afinal, todas as propriedades produtoras de açúcar no tombamento e todos os fogos dedicados a esta atividade nas listas nominativas de 1816 contavam com trabalho compulsório. No terreno "denominado Nossa Senhora da Penha em que compreende 1500 braças de testada e 3000 de fundo [900 alqueires - DOMR] em cujo tem fabricado açúcar, este terreno é ocupado pelo arrendatário Alexandre Cavalheiro". (Relação dos proprietários que possuem terrenos no distrito, e freguesia da vila de Jundiaí. 1818 - AESP, Tombamento/C09868). O proprietário, Jose Joaquim, residia no termo de Piracicaba.

E ainda o sempre presente capitão-mor Eleutério da Silva Prado, um dos maiores proprietários de terras em Jundiaí, era residente em São Paulo e, recobrando a memória, em 1822 foi declarado o fogo referente ao seu engenho, em que existiam, sem menção a qualquer administrador, 30 escravos. Este fogo encontrava-se, possivelmente, nas terras de 450 alqueires, denominadas Monte Alegre. E outro produtor de açúcar, Ricardo Jose Rodrigues, tinha seu fabrico nos 56,25 alqueires que herdou, com o trabalho de nove cativos, mas vivia em Bonfim de Goiás. 


\section{Bragança}

O cadastramento de bens rústicos aponta para Bragança em 1818 um total de 530 propriedades que juntas conformavam uma área de 73185,143 alqueires paulistas. Essas propriedades estavam nas mãos de 523 indivíduos (excluindo-se os casos em que havia mais de um proprietário para o mesmo terreno).

O perfil da repartição da terra em Bragança caracterizava-se por uma forte concentração, uma vez que o índice de Gini para as propriedades da localidade foi calculado em 0,688 , implicando na presença de inúmeras pequenas propriedades ao lado de um número reduzido de propriedades de extensas áreas.

Cerca de $45 \%$ das propriedades que correspondiam a terras de até 50 alqueires paulistas, com uma área média de 18,1 alqueires, apropriavam-se de tão somente 5,9\% da área total declarada. Em contrapartida, as 5 maiores propriedades $(0,9 \%)$, com áreas acima de 1000 alqueires, média de 2517 alqueires, respondiam por 17,2\% das terras bragantinas, ou seja, a uma área de 12585 alqueires. Somadas àquelas as propriedades a partir de 500 alqueires, ao percentual acrescemos 18,2 pontos percentuais. Grande parte das propriedades estava nas faixas intermediárias de tamanho, que respondiam por parcela considerável de área e número, 42958,2 alqueires e 268 terras. (cf. Tabela III.11)

\section{Tabela III.11}

Distribuição das propriedades de acordo com faixas de tamanho (Bragança -1818)

\begin{tabular}{|c|c|c|c|c|c|}
\hline $\begin{array}{l}\text { Tamanho das } \\
\text { propriedades * }\end{array}$ & $\%$ (Número) & $\begin{array}{c}\text { Área* }^{*} \\
\% \text { (total) }\end{array}$ & Área média* & Área modal* & I. Gini* \\
\hline $0-50$ & $45,3(240)$ & $5,9(4347,635)$ & $\overline{18,1}$ & 24 & 0,441 \\
\hline $50,1-100$ & $16,8(89)$ & $8,0(5886,510)$ & 66,1 & 56,3 & 0,176 \\
\hline $100,1-300$ & $28,3(150)$ & $34,8(25459,480)$ & 169,7 & 112,5 & 0,112 \\
\hline $300,1-500$ & $5,5(29)$ & $15,9(11612,700)$ & 400,4 & 450,0 & 0,085 \\
\hline $500,1-1000$ & $3,2(17)$ & $18,2(13293,818)$ & 782,0 & 900,0 & 0,090 \\
\hline 1000,1 ou mais & $0,9(5)$ & $17,2(12585,000)$ & 2517,0 & 1013 & 0,418 \\
\hline Total & $100,0(530)$ & $100,0(73185,143)$ & 138,1 & 112,5 & 0,668 \\
\hline
\end{tabular}


A menor propriedade tinha apenas 0,03 alqueires e a maior 7200 alqueires, ou seja, a maior propriedade era inimagináveis 240 mil vezes maior que a menor extensão de terras registrada. ${ }^{66}$

Essa grande diferença entre as propriedades reflete as distintas realidades de seus proprietários. Enquanto os 0,03 alqueires pertenciam a Domingos da Silva, um negro forro de origem Mina que vivia de seus jornais, detinha direitos sobre a maior propriedade Jacinto Rodrigues, como sabemos, capitão-mor da vila.

Note-se também que algumas pessoas possuíam mais de uma propriedade, ${ }^{67}$ enquanto outras propriedades eram possuídas por mais de 1 indivíduo. Estudar a distribuição das terras por proprietários em praticamente nada altera as características encontradas - o índice de gini calculado para proprietários, por exemplo, é praticamente o mesmo daquele encontrado para propriedades: 0,670.

Tabela III.12

Indivíduos com mais de uma propriedade

(Bragança - 1818)

\begin{tabular}{|c|c|c|c|c|}
\hline Proprietário & $\begin{array}{c}\text { Número de } \\
\text { propriedades }\end{array}$ & Localização & Área & Área total \\
\hline \multirow[t]{2}{*}{ ANNA GABRIELA } & \multirow{2}{*}{2} & Rio abaixo & 225,000 & \multirow{2}{*}{450,000} \\
\hline & & Camanducaia & 225,000 & \\
\hline \multirow[t]{2}{*}{ ANTONIO DIAS PAES } & \multirow[t]{2}{*}{2} & Curralinho & 98,000 & \multirow{2}{*}{130,000} \\
\hline & & Curralinho & 32,000 & \\
\hline \multirow{2}{*}{ ANTONIO RODRIGUES DE SIQUEIRA } & \multirow{2}{*}{2} & Curralinho & 18,000 & \multirow{2}{*}{42,000} \\
\hline & & Curralinho & 24,000 & \\
\hline \multirow{2}{*}{ JACINTO RODRIGUES BUENO } & \multirow{2}{*}{2} & Curralinho & 600,000 & \multirow{2}{*}{7800,000} \\
\hline & & Curralinho & 7200,000 & \\
\hline \multirow{2}{*}{ JOÃO DA ROCHA LIMA } & \multirow{2}{*}{2} & Campo novo & 330,000 & \multirow{2}{*}{555,000} \\
\hline & & Campo novo & 225,000 & \\
\hline \multirow{2}{*}{ JOÃO PIRES DE SOUZA } & \multirow{2}{*}{2} & Curralinho & 16,000 & \multirow{2}{*}{40,000} \\
\hline & & Curralinho & 24,000 & \\
\hline \multirow{2}{*}{ MANOEL GOMES DA SILVA } & \multirow{2}{*}{2} & Curralinho & 28,125 & \multirow{2}{*}{46,125} \\
\hline & & Curralinho & 18,000 & \\
\hline
\end{tabular}

Fonte: AESP, Inventário de Bens Rústicos, Bragança:1818

\footnotetext{
${ }^{66}$ Essas propriedades eram também a menor e a maior propriedades encontradas se consideramos todas as localidades observadas.

${ }^{67}$ Encontramos no documento bragantino 31 nomes encontrados em mais de uma propriedade. Entre eles, sete correspondem, com certeza, ao mesmo indivíduo, portanto são estes os proprietários de mais de uma gleba que consideramos. Outros 13 nomes são certamente homonímias e 11 despertaram considerável grau de incerteza.
} 
Dificilmente o fato de possuir mais de uma propriedade modificava em medida considerável a faixa de tamanho das terras dos indivíduos. Temos em Bragança sete indivíduos com 14 propriedades (2,6\%), como apresentado na Tabela III.12. Todos os referidos indivíduos possuíam duas propriedades e unindo-as, a menor conjugação pertencia a Antonio Rodrigues de Siqueira, 42 alqueires e a maior área estava na mãos de nosso conhecido capitão-mor Jacinto Rodrigues Bueno, que além dos 7200 alqueires anteriormente citados possuía outro propriedades de 600 alqueires paulistas, totalizando uma extensa área de 7800 alqueires.

Nos idos de 1818 a forma primordial de acesso a terra havia sido a compra (como mostra a Tabela III.13), sendo 73,8\% o percentual daquelas terras possuídas por esse meio, entre as 527 propriedades que apresentaram a forma de aquisição em sua descrição. Esse percentual manteve-se relativamente constante entre $71 \%$ e $80 \%$ nas distintas faixas de extensão das propriedades. Ou seja, independentemente do tamanho dos terrenos, estes poderiam ser negociados. Enquanto algumas propriedades assim adquiridas chegavam a 1800 alqueires, a menor propriedade era de apenas 0,06 alqueires (pertencia a Escolástica Pinheira que a comprou de Francisco Cardozo), bastante reduzida e inferior à moda e à média das terras compradas, que foram de 112,5 alqueires e 144,5 alqueires, respectivamente. Isto posto, havia também grande concentração entre as terras negociadas, sendo o Gini calculado em 0,684 (como mostra a Tabela III.14).

Tabela III.13

Formas de aquisição das propriedades de acordo com faixas de tamanho (Bragança - 1818)

\begin{tabular}{|c|c|c|c|c|c|c|c|c|}
\hline \multirow{2}{*}{$\begin{array}{l}\text { Tam anho das } \\
\text { propriedades * }\end{array}$} & \multicolumn{8}{|c|}{$\begin{array}{l}\text { Formas de aquisição** } \\
\% \text { (Número) }\end{array}$} \\
\hline & Compra & Herança & $\begin{array}{l}\text { Compra e } \\
\text { herança }\end{array}$ & Doação & Posse & Sesmaria & Outras & Total \\
\hline $0-50$ & $74,5(178)$ & $18,0(43)$ & $4,2(10)$ & $0,4(1)$ & $2,9(7)$ & - & - & $100,0(239)$ \\
\hline $50,1-100$ & $76,1 \quad(67)$ & $14,8(13)$ & $1,1(1)$ & $2,3(2)$ & $3,4(3)$ & - & $2,3(2)$ & $100,0(88)$ \\
\hline $500,1-1000$ & $76,5(13)$ & $5,9(1)$ & $5,9(1)$ & - & $5,9(1)$ & - & $5,9(1)$ & $100,0(17)$ \\
\hline 1000,1 ou mais & $80,0(4)$ & $20,0(1)$ & - & - & - & - & - & $100,0(5)$ \\
\hline Total & 73,8 (389) & $17,1(90)$ & $3,0(16)$ & $0,6(3)$ & $4,4(23)$ & $0,2(1)$ & $0,9(5)$ & 100,0 \\
\hline
\end{tabular}


Tabela III.14

Indicadores estatísticos de propriedades adquiridas por compra, herança e posse

(Bragança - 1818)

\begin{tabular}{lcccccccc}
\hline \hline & Número & Área média & $\begin{array}{c}\text { Desvio } \\
\text { padrão }\end{array}$ & Moda & Mediana & $\begin{array}{c}\text { Índice de } \\
\text { Gini }\end{array}$ & $\begin{array}{c}\text { Menor } \\
\text { propriedade }\end{array}$ & $\begin{array}{c}\text { Maior } \\
\text { propriedade }\end{array}$ \\
\hline Compra & 389 & 144,490 & 413,709 & 112,500 & 56,250 & 0,684 & 0,030 & 7200,000 \\
Herança & 90 & 106,586 & 152,468 & 112,500 & 54,370 & 0,631 & 0,250 & 1012,500 \\
Posse & 23 & 163,776 & 158,657 & 225,000 & 127,000 & 0,483 & 0,180 & 675,000 \\
\hline \hline Em alqueires paulistas & & & & & & & &
\end{tabular}

Em alqueires paulistas
Fonte: AESP, Inventário de Bens Rústicos, Bragança:1818

Ademais, pudemos identificar que a compra era realizada por homens e mulheres, ainda que transações envolvendo terras fossem mais marcantes entre os homens (que detinham $92,2 \%$ da área total descrita): $75,9 \%$ de suas terras foram compradas. Entre as mulheres 58,6\% das propriedades foram adquiridas por compra, merecendo destaque aquelas adquiridas por herança que respondiam por $29,3 \%$ das extensões rurais em mãos femininas.

Tabela III.15

Formas de aquisição das propriedades e estatísticas para o tamanho de acordo com o sexo do proprietário (Bragança - 1818)

\begin{tabular}{ccc|cc}
\hline $\begin{array}{c}\text { Formas de } \\
\text { aquisição }\end{array}$ & Homens* & Muheres** & Estatísticas & Homens \\
\hline Compra & $75,9(353)$ & $58,6(34)$ & Área média & 141,3 \\
Herança & $15,1(70)$ & $29,3(17)$ & Des vio padrão & 383,4 \\
Compra e herança & $3,2(15)$ & $1,7(1)$ & Moda & 112,5 \\
Doação & $0,4(2)$ & $1,7(1)$ & Mediana & 56,3 \\
Sesmaria/Posse & $4,3(20)$ & $6,9(4)$ & I. Gini & 0,614 \\
Outras & $0,6(3)$ & $1,7(1)$ & Menor propriedade & 0,03 \\
Total & $99,6(463)$ & $100,0(58)$ & Maior propriedade & 7200,0 \\
\hline \hline
\end{tabular}


Entre as áreas pertencentes a homens, aquelas herdadas atingiram um percentual menor, $15 \%$, podendo, inclusive, ser parte delas herdadas do sogro, ou seja, herança feminina que passa ao chefe do casal, como ocorreu, a exemplo, com Joaquim Manoel Floriano, cujos 2,4 alqueires recebeu por herança da sogra, ou o capitão Roque de Oliveira Dorta, para cujas terras "os seus títulos são por herança que houveram de seu sogro" (Relação dos habitantes que possuem seus terrenos na vila Nova de Bragança. 1818 - AESP, Tombamento/C09868)

Os diferentes pesos na forma de acesso a terra implicaram em características afastadas no que respeita aos seus tamanhos. Enquanto a propriedade média nas mãos de mulheres era de 94,7 alqueires, aquelas pertencentes a indivíduos do sexo masculino alçavam-se a 141,3 alqueires paulistas.

As heranças foram, entre todas as propriedades, a segunda forma de aquisição mais comum. Foi declarada para 90 delas $(17,1 \%)$, sendo que $43(47,8 \%)$ estendiam-se por 50 alqueires ou menos, o que é compreensível uma vez que heranças, em regra, implicam em sucessivas divisões das propriedades. No limite, estas divisões poderiam tornar-se inviáveis, posto o já diminuto tamanho alcançado por esses terrenos.

Algumas das propriedades herdadas possuíam no próprio tombamento vários herdeiros, como apresentamos na tabela III.16, onde fizemos um exercício calculando a área média por proprietário herdeiro caso as glebas tivessem sido efetivamente partilhadas. Os dados apresentados são uma aproximação, uma vez que não levamos em consideração a possibilidade de os distintos herdeiros possuírem partes diferentes nas terras, como deveria acontecer no caso de meação entre cônjuge e filhos herdeiros ou como ficou claro na descrição do terreno de João Paulo de Moraes que declarou, sobre os demais herdeiros "estes dois têm menores partes". Assim como apontado por Alcântara Machado (1980) para a São Paulo dos séculos XVII e XVIII, podemos supor que algumas das vezes "Avaliadas ou não, as terras não se partilham. Mesmas, em ser, comum, ficam em conformidade para os herdeiros, ou correndo por conta da viúva e dos mais herdeiros conteúdos na herança, que lavrarão nelas igualmente e a todo tempo se comporão." 
Tabela III.16

Propriedades adquiridas por herança e pertencentes a vários herdeiros (Bragança - 1818)

\begin{tabular}{|c|c|c|c|c|}
\hline Proprietário declarante & $\begin{array}{l}\text { Localização } \\
\text { (bairro) }\end{array}$ & Área & $\begin{array}{l}\text { Número de } \\
\text { outros } \\
\text { herdeiros }\end{array}$ & Área média \\
\hline ANNA BUENA & & 55,500 & 10 & 5,045 \\
\hline ANNA FRANCA & Couto & 112,500 & $\begin{array}{l}\text { Indeterminado } \\
\text { (filhos) }\end{array}$ & - \\
\hline ANTONIO DA SILVA & Jacareí & 9,600 & 4 & 1,920 \\
\hline BALDUINO ANTONIO & & 7,200 & 5 & 1,200 \\
\hline BENZIDA MARIA VIEIRA & Couto & 1012,500 & $\begin{array}{l}\text { Indeterminado } \\
\text { (filhos) }\end{array}$ & - \\
\hline ESCOLASTICA MARIA & Capim & 112,500 & $\begin{array}{l}\text { Indeterminado } \\
\text { (filhos e genros) }\end{array}$ & - \\
\hline IGNACIO CORREA DE LIMA & Couto & 450,000 & 1 & 225,000 \\
\hline IGNACIO FRANCISCO & & 22,500 & 5 & 3,750 \\
\hline IGNACIO RODRIGUES & Couto & 75,000 & 4 & 15,000 \\
\hline JOÃO GOMES CARDOZO & Campina & 20,000 & 12 & 1,538 \\
\hline JOÃO PAULO DE MORAIS & Jacareí & 10,800 & 2 & 3,600 \\
\hline JOAQUIM JOZE PIRES & Cascalho & 450,000 & 3 & 112,500 \\
\hline JOAQUIM MANOEL & Canivete & 1,280 & 5 & 0,213 \\
\hline JOZE GOMES NOGUEIRA & Curralinho & 90,000 & $\begin{array}{l}\text { Indeterminado } \\
\text { (filhos) }\end{array}$ & - \\
\hline JOZE MARIANO GONÇALVES & & 405,000 & 12 & 31,154 \\
\hline JOZE PEDROZO DE MORAIS & Jacareí & 24,300 & 11 & 2,025 \\
\hline JOZE PIRES BARBOZA & Canivete & 225,000 & 14 & 15,000 \\
\hline JOZE PRETO CARDOZO & & 105,000 & 8 & 11,667 \\
\hline LIBERATA RODRIGUES & & 120,000 & 4 & 24,000 \\
\hline LOURENÇO CORREA BUENO & Jacareí & 112,500 & 3 & 28,125 \\
\hline LOURENÇO RODRIGUES XAVIER & Paca & 238,000 & 4 & 47,600 \\
\hline MARIA DE SANTA ANNA & & 168,750 & 5 & 28,125 \\
\hline MARIA RIBEIRA VIEIRA & Couto & 225,000 & $\begin{array}{l}\text { Indeterminado } \\
\text { (filhos) }\end{array}$ & - \\
\hline PEDRO ALEXANDRINO & Curralinho & 4,500 & 2 & 1,500 \\
\hline RAFAEL PINTO & Sertaozinho & 64,000 & 2 & 21,333 \\
\hline ROQUE DE OLIV EIRA HORTA & Pinhal & 180,000 & 5 & 30,000 \\
\hline THEREZA DE MENDONÇA & Boca da mata & 242,000 & 17 & 13,444 \\
\hline
\end{tabular}

Fonte: AESP, Inventário de Bens Rústicos, Bragança:1818 
Entre as propriedades adquiridas por herança 27 delas, 30\%, foram declaradas como pertencentes a outros herdeiros, muitos deles com nomes não explicitados. À exceção das glebas declaradas por Inácio Correia de Lima e Joaquim José Pires, que após divididas ainda teriam extensões acima de 100 alqueires paulistas (225 e 112,5 alqueires respectivamente), as demais propriedades teriam extensões bastante reduzidas, que não chegam a atingir os 50 alqueires. As menores delas seriam aquelas provenientes do terreno "em nome" de Joaquim Manoel, cujas áreas seriam de tão somente 0,213 alqueires paulistas, praticamente a mesma área da menor propriedade declarada com "título de herança": 0,250 alqueires.

As demais formas de aquisição foram pouco representativas em termos de propriedades, as posses chegaram a $4,4 \%$, ainda que em um primeiro momento da história das propriedades esta deve ter sido a forma de acesso a parte considerável delas. E assim como as compras e heranças, englobava terras de todas as faixas de tamanho.

A conjugação entre compra e herança foi a forma de composição de 3\% (16) das extensões rurais bragantinas. Apenas Joze Luis de Morais, declarou uma propriedade que "possui 1125 braças de frente e de fundo 750 [168,75 alqueires - DOMR] este terreno é todo cultivado e tem seus títulos folhas de partilha que comprou de seus irmãos" (Relação dos habitantes que possuem seus terrenos na vila Nova de Bragança. 1818 - AESP, Tombamento/C09868), mas provavelmente a compra aos demais herdeiros era o mais comum entre essas propriedades adquiridas por compra e herança.

Apesar de responder por parcela reduzida do número de propriedades as sesmarias representam parte importante do território declarado. Voltamos à referida propriedade de nosso conhecido Jacinto Rodrigues Bueno - anotada na Tabela III.13 como outras: compra e sesmaria -, que foi composta originalmente desta forma. $\mathrm{O}$ capitão-mor era senhor de 7200 alqueires localizados no Curralinho, onde possuía também uma outra propriedade anexa que se estendia por 600 alqueires, ambas tinham como vizinho Lourenço Justiniano Freire. Ou seja, na prática havia uma única propriedade de 7800 alqueires, referidas como sesmaria e adquiridas por compra.

A maior propriedade divisava a leste e a norte com a capitania de Minas Gerais e ao sul "com outra sesmaria dos moradores da Freguesia de Nazaré", situada que estava no Morro do Lopo, que ainda hoje é marco divisório entre São Paulo e Minas Gerais. ${ }^{68}$

\footnotetext{
68 "O morro do Lopo aparece em relatos de viajantes e na cartografia desde o século XVI, mas torna-se fundamental no final do século XVII, quando as 'Bandeiras' paulistas seguem de São Paulo a Minas passando por esta região.

Este morro transformou-se em uma espécie de bússola natural da expedição, por um caminho que margeava a zona geológica cristalina do norte com a serra da Mantiqueira ocidental.

O caminho que passava pelo Lopo era conhecido como 'Caminho de Atibaia' ou também como 'Caminho que Vae para o Rio das Mortes'. (VILLANUEVA, 2006)
} 
Figura III.1

Localização do Morro do Lopo

(projeção sobre mapa atual)

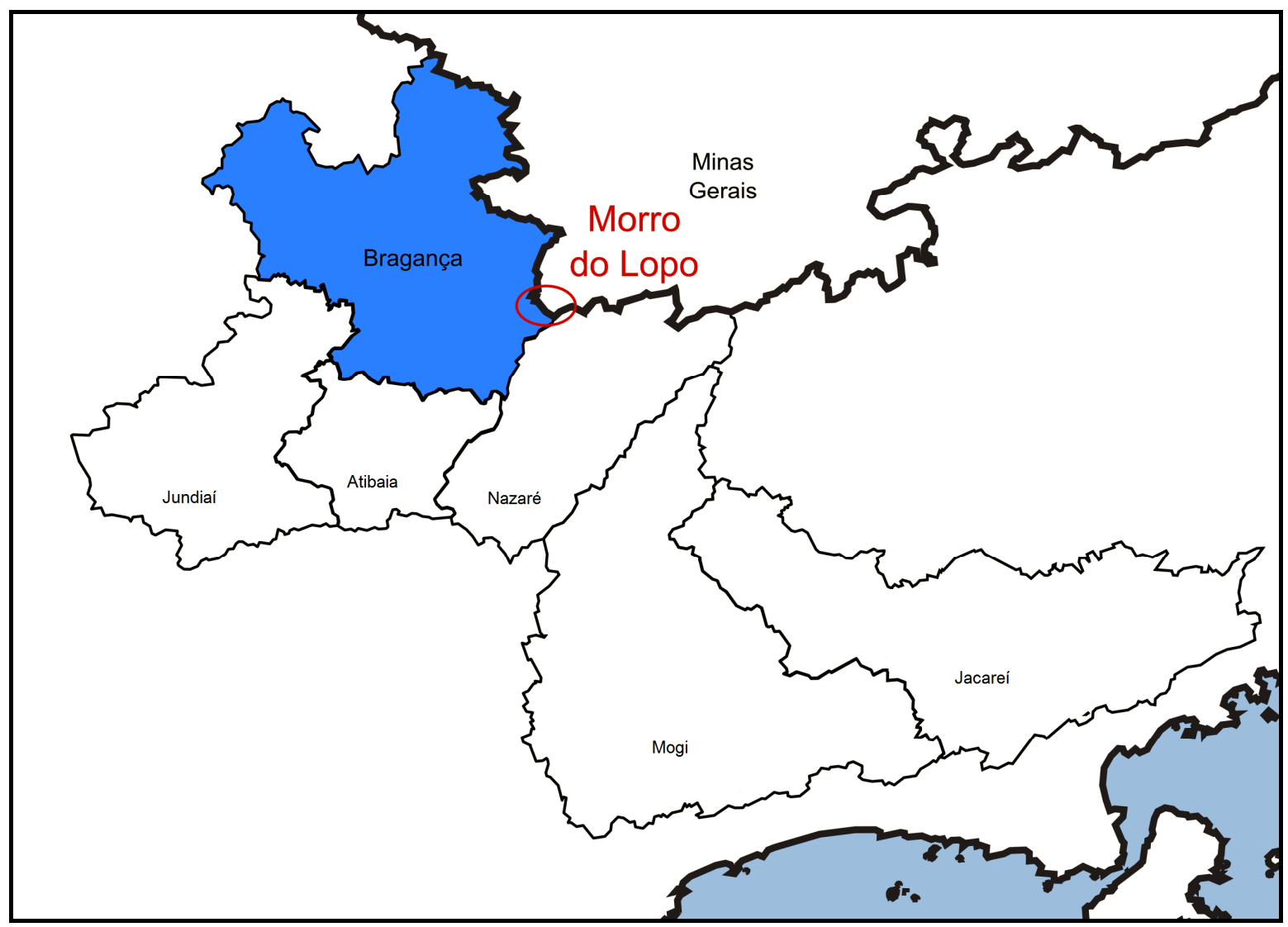

A menor sesmaria foi comprada a João Rodrigues Antunes "no lugar denominado fazenda do Lopo" e a maior das propriedades tinha "2000 braças e por compra que fez do capitão Antonio Leme da Silva e João Francisco de Oliveira tem mais 4000 braças que por todo preenche todo o terreno desta sesmaria em 6000 braças de frente, e 6000 de fundo [7200 alqueires - DOMR]" (Relação dos habitantes que possuem seus terrenos na vila Nova de Bragança. 1818 - AESP, Tombamento/C09868)

Juntos, Jacinto, Antonio e João Francisco, moradores em Atibaia (que àquele tempo compreendia Bragança, então denominada Jaguari) - foram sesmeiros, após apossarem-se, de sertão ao pé do Morro do Lopo contíguo às terras de João Rodrigues Antunes - total ou parcialmente foram os 600 alqueires supracitados a ele adquiridas por Jacinto -, cuja carta de sesmaria foi passada em 12 de novembro de 1789. 
[...] achando-se com seus escravos sem terras suficientes em que os pudesse ocupar, se apossaram de um sertão ao pé do morro denominado Lopo, contíguo as terras de João Rodrigues Antunes, cujo sertão estão possuindo os suplicantes sem contradição de pessoa alguma, fazendo pião as mesmas terras onde findam do Sr. João Rodrigues Antunes, correndo duas léguas de testada, uma para sul e outra para o Norte, e duas de sertão para leste e oeste. Pelo que me pediam Ihes concedesse por sesmaria as ditas terras em que se acham de posse [...] com a declaração que as cultivarão, e mandarão confirmar esta carta de sesmaria por Sua Majestade dentro em dois anos. (AESP, Sesmarias, patentes e provisões/C00369, Livro 25)

Ainda que o prazo para confirmação fosse de dois anos, a "Carta de sesmaria confirmada por Sua Alteza Real a Jacinto Rodrigues Bueno, Antonio Leme da Silva e João Francisco de Oliveira de 3 léguas de testada e 2 de sertão para o leste no distrito da Vila Nova de Bragança" foi passada aos 8 de agosto de 1806. (cf. AESP, Sesmarias, patentes e provisões/C00373, Livro 33)

Decerto tal situação não surpreende posto ser notório

[...] que a maioria das concessões de sesmarias não foi acompanhada dos procedimentos para sua regularização. Neste sentido, ao longo do Oitocentos era fato que as sesmarias estavam majoritariamente em comisso, pois os sesmeiros não haviam cumprido a determinação legal de medir e demarcar sua terra [...] não era importante o cumprimento dos procedimentos legais para regularizar a ocupação, posto que a carta por si só traduzia simbolicamente a expressão do poder do sesmeiro. (MOTTA, 2004, p.62)

Regularização à parte, em suma, o maior proprietário de terras em Bragança, Jacinto Rodrigues Bueno, tinha 7800 alqueires paulistas, parte adquirida por sesmaria solicitada por ele conjuntamente com outros dois sesmeiros, cujas participações na sesmaria foram compradas, e parte comprada ao sesmeiro do terreno contíguo a essas terras.

Já Antonio Leme da Silva, sesmeiro de quem parte das terras foram compradas, era Capitão no bairro do Rio Abaixo onde possuía uma propriedade que ocupava 132 alqueires paulistas. A propriedade foi adquirida por compra, todavia originou-se igualmente de uma sesmaria, desta feita que recebeu o sargento mor Jose Garcia, cujos títulos não pudemos localizar. As terras estavam todas em cultura e existiam ali 24 escravos.

A propriedade de Jacinto, em 1818, contava com o trabalho de 18 escravos, dele mesmo e agregados - o que corrobora-se com os dados apresentados no censo populacional, que aponta o dito Jacinto com 19 escravos em 1820; e Salvador Bueno de Oliveira: "Reside em uma gleba de terras que the conferira seu sogro o capitão mor Jacinto Rodrigues Bueno para trabalhar nas mesmas terras; esta dentro de sua mesma 
fazenda. Tem ali 18 escravos entre alguns pupilos." (Relação dos habitantes que possuem seus terrenos na vila Nova de Bragança. 1818 - AESP, Tombamento/C09868)

No entanto, seus escravos: "[...] vários pertencem a sua família pelo inventário a que procedeu por morte de sua mulher." (Relação dos habitantes que possuem seus terrenos na vila Nova de Bragança. 1818 - AESP, Tombamento/C09868) Salvador, anteriormente ao matrimônio com a filha de Jacinto, Gertrudes, foi casado com Jacinta que faleceu aos 31 anos em 1808. Com ela Salvador teve três filhos, o mais velho tinha, quando falecida a mãe, três anos, ou seja, a partilha não foi efetivamente levada a cabo e os filhos tem participação nos escravos que possui desde aquele tempo, mas que, na lide agrícola compunham um único plantel sob as ordens do capitão Jacinto.

Além dos supracitados outros proprietários detinham cativos, declarados em cerca de $36 \%$ das propriedades em 1818 , sendo de apenas $22,5 \%$ o percentual de propriedades de até 50 alqueires nessa condição (24\% delas com até 5 alqueires e 57,4\% até 20 alqueires) e $88,2 \%$ as propriedades escravistas entre aquelas com 500,1 a 1000 alqueires.

Como mostram as Tabelas III.17 e III.18, o número médio de escravos elevou-se ao longo das faixas de tamanho das propriedades, considerando-se as propriedades com escravos. Entre aquelas propriedades de até 50 alqueires a média de cativos relacionada ficou em 3,9, elevando-se a 6,5 entre as terras de 300,1 a 500 alqueires e a 16,3 entre as propriedades com mais de 1000 alqueires.

Tabela III.17

Distribuição das faixas de tamanho das propriedades entre propriedades com e sem escravos

(Bragança - 1818)

\begin{tabular}{|c|c|c|c|c|c|}
\hline \multirow{2}{*}{$\begin{array}{l}\text { Tamanho das } \\
\text { propriedades * }\end{array}$} & \multicolumn{3}{|c|}{ Propriedades com escravos ${ }^{\star \star}$} & \multicolumn{2}{|c|}{ Propriedades sem escravos } \\
\hline & $\%$ (Número) & $\begin{array}{c}\text { Área* }^{*} \\
\% \text { (total) }\end{array}$ & $\begin{array}{l}\text { Média de } \\
\text { escravos }\end{array}$ & $\%$ (Número) & $\begin{array}{c}\text { Área* } \\
\% \text { (total) }\end{array}$ \\
\hline $0-50$ & $22,5(54)$ & $23,9(1037,9)$ & 3,9 & $77,5(186)$ & $76,1(3309,8)$ \\
\hline $50,1-100$ & $42,7(38)$ & $44,4(2613,3)$ & 4,4 & $57,3(51)$ & $55,6(3273,3)$ \\
\hline $100,1-300$ & $38,7(58)$ & $40,7(10350,4)$ & 5,0 & $61,3(92)$ & $59,3(15109,1)$ \\
\hline $300,1-500$ & $72,4(21)$ & $74,1(8609,0)$ & 6,5 & $27,6(8)$ & $25,9(3003,7)$ \\
\hline $500,1-1000$ & $88,2(15)$ & $85,9(11425,8)$ & 12,1 & $11,8(2)$ & $14,1(1868,0)$ \\
\hline 1000,1 ou mais & $60,0(3)$ & $28,5(3585,0)$ & 16,3 & $40,0(2)$ & $71,5(9000,0)$ \\
\hline Total & $35,7(189)$ & $51,4(37621,3)$ & 5,5 & $64,3(341)$ & $48,6(35563,8)$ \\
\hline
\end{tabular}


Tabela III.18

Distribuição das propriedades com e sem escravos de acordo com faixas de tamanho das propriedades

(Bragança - 1818)

\begin{tabular}{|c|c|c|c|c|}
\hline \multirow{2}{*}{$\begin{array}{l}\text { Tamanho das } \\
\text { propriedades * }\end{array}$} & \multicolumn{2}{|c|}{ Propriedades com escravos ${ }^{\star \star}$} & \multicolumn{2}{|c|}{ Propriedades sem escravos } \\
\hline & \%(Número) & $\begin{array}{c}\text { Área* } \\
\% \text { (total) }\end{array}$ & \%(Número) & $\begin{array}{c}\text { Área* }^{*} \\
\% \text { (total) }\end{array}$ \\
\hline $0-50$ & $28,6(54)$ & $2,8(1037,9)$ & $54,5(186)$ & $9,3(3309,8)$ \\
\hline $50,1-100$ & $20,1(38)$ & $6,9(2613,3)$ & $15,0(51)$ & $9,2(3273,3)$ \\
\hline $100,1-300$ & $30,7(58)$ & $27,5(10350,4)$ & $27,0(92)$ & $42,5(15109,1)$ \\
\hline $300,1-500$ & $11,1(21)$ & $22,9(8609,0)$ & $2,3(8)$ & $8,4(3003,7)$ \\
\hline $500,1-1000$ & $7,9(15)$ & $30,4(11425,8)$ & $0,6(2)$ & $5,3(1868,0)$ \\
\hline 1000,1 ou mais & $1,6(3)$ & $9,5(3585,0)$ & $0,6(2)$ & $25,3(9000,0)$ \\
\hline Total & $100,0(189)$ & $100,0(37621,3)$ & $100,0(341)$ & $100,0(35563,8)$ \\
\hline
\end{tabular}

No entanto, a correlação entre número de cativos e área foi reduzida: 0,23. Apesar de as grandes extensões possuídas, a duas daquelas cinco maiores propriedades não correspondia nenhuma escravaria. Se consideradas em conjunto as duas propriedades de Jacinto Rodrigues Bueno, essa correlação seria de 0,36. É dizer, as grandes propriedades nem sempre estavam ligadas à posse de cativos, entretanto, quando o vinculo existia, o plantel correspondente era, em regra, composto por vários indivíduos. Ademais, havia propriedades realmente pequenas com menção à presença de cativos.

A menor propriedade com escravos tinha apenas 0,25 alqueires e Florentino Paes "emprega nesta fazenda 3 escravos este terreno é cultivado". Assim como chama atenção a quantidade de cativos na gleba de Antonio Alves de Oliveira que "possui 185 braças de frente e de fundo 400 [14,8 alqueires - DOMR] emprega nesta fazenda 13 escravos no lugar chamado Lopo este terreno é todo cultivado tem seus títulos de carta de venda e comprou do coronel Luis Antonio". (Relação dos habitantes que possuem seus terrenos na vila Nova de Bragança. 1818 - AESP, Tombamento/C09868)

No outro extremo de extensão das propriedades escravistas estavam os dois maiores plantéis declarados no tombamento de bens rústicos: 37 escravos pertencentes ao sargento-mor Fernando Dias Paes Leme e 35 deles compondo a escravaria de Francisco de Lima Bueno, que foi identificado no capítulo I como o segundo maior escravista da vila de Bragança em 1816, com 31 cativos. Fernando possuía terras com 
900 alqueires de área, e Francisco mantinha seu plantel cultivando em seus 1560 alqueires.

A faixa de 100,1 a 300 alqueires concentrou maior menção absoluta a cativos, foram 58 propriedades $(30,7 \%$ entre o total de 189 terras ligadas ao trabalho compulsório), que juntas empregavam 250 escravos, numa extensão rural correspondente a $27,5 \%$ da área arrolada com escravos. As menores glebas escravistas, ainda que em número próximo, 54 propriedades, respondiam por apenas $2,8 \%$ da área onde foram identificados cativos.

As propriedades com escravos tinham, em média 199,1 alqueires de área, sendo a moda 225 e mediana 112,5; a sua vez área média para as propriedades sem escravos foi calculada em 104,3 alqueires, a moda em 112,5 e a mediana encontrada foi de apenas 40 alqueires.

Essas propriedades, em média mais diminutas, eram 341 das 530 propriedades descritas. Logo, em sua imensa maioria os proprietários dos terrenos bragantinos não possuíam escravos. Dada a ligação entre as duas formas de riqueza/fatores produtivos, havia uma camada "mais humilde" entre os proprietários de terras, que correspondia àquela parcela sem escravos e com glebas bastante pequenas. Há que destacar, que provavelmente esse segmento constituía um dos mais pobres dentre os bragantinos do Oitocentos, somente se diferenciando daqueles mais pobres a viver em terras alheias devido ao acesso à propriedade fundiária.

Se comparados ao total de fogos declarados e à presença ou ausência de cativos nesses domicílios (Tabela III.19), temos que mais de metade dos chefes de fogo não possuíam terras tampouco escravos, sendo cerca de $25 \%$ dos domicílios constituídos em terras próprias, contudo sem a presença de cativos. O menor percentual era devido àqueles chefes de fogo sem terras e sem escravos: 5,6\% como base de comparação 1816 e 8,3\% se observamos os domicílios da Vila Nova de Bragança em 1820.

A parcela mais abastada da população, possuidora de terras e escravos respondia por pouco menos de $14 \%$ dos fogos bragantinos. Mas, se em tese esses seriam os mais abastados por possuírem riquezas na forma de capacidade produtiva, vale lembrar que anteriormente identificamos propriedades realmente pequenas onde foi mencionado 0 trabalho de cativos e, o número de cativos encontrado nessas terras era, mais comumente, bastante reduzido, com moda 1 e mediana 2. 
Tabela III.19

Fogos de acordo com a posse de terras e escravos

(Bragança - 1816, 1818, 1820)

\begin{tabular}{|c|c|c|c|}
\hline & 1816 & 1818 & 1820 \\
\hline Número total de propriedades rurais & & 531 & \\
\hline Número (\%) de propriedades rurais com escravos & & $190(35,8 \%)$ & \\
\hline Número total de escravos no tombamento de terras & & 1053 & \\
\hline Número total de fogos & 1364 & & 1404 \\
\hline Número (\%) de fogos com escravos & $265(19,4 \%)$ & & $306(21,8 \%)$ \\
\hline Número total de escravos na lista nominativa & 1072 & & 1337 \\
\hline$\%$ de fogos com terras & $38,9 \%$ & & $37,8 \%$ \\
\hline$\%$ de chefes de fogo com terras e escravos & $13,9 \%$ & & $13,5 \%$ \\
\hline$\%$ de chefes de fogo sem terras e com escravos & $5,6 \%$ & & $8,3 \%$ \\
\hline$\%$ de chefes de fogo com terra e sem escravos & $25,0 \%$ & & $24,3 \%$ \\
\hline$\%$ de chefes de fogo sem terras e sem escravos & $55,6 \%$ & & $53,9 \%$ \\
\hline
\end{tabular}

Fontes: AESP, Inventário de Bens Rústicos, Bragança:1818 e AESP, Maços de População, Bragança: 1816, 1820

Assim como identificamos em outro momento, muitos desses minúsculos plantéis possuíam escravos em idades não tão produtivas e/ou com problemas de saúde, implicando que não necessariamente, por possuir um cativo, esses indivíduos estavam em melhores condições que aqueles não escravistas, porém em domicílios com número maior de livres que possam representar, na prática, maior potencial produtivo. Apesar dessa possibilidade, o trabalho escravo ainda era essencial em grande parte das terras que declararam estar em cultura.

Considerando-se todas as propriedades para apenas $13(2,5 \%)$ delas foram omitidas a situação de uso. João de Oliveira Preto tinha "um sítio que disse comprara de novo" e foi o único a declarar terras que "não estão em culturas por não serem próprias para o efeito". E somente em uma das propriedades de Manoel Gomes da Silva havia explicitamente criação de animais, eram 28,125 alqueires paulistas e "conserva este sítio para pastagens de suas criações e tem 2 escravos nesta fazenda" (Relação dos habitantes que possuem seus terrenos na vila Nova de Bragança. 1818 - AESP, Tombamento/C09868).

As demais propriedades $(97,2 \%)$ estavam todas em cultura - tal constatação invalida análise mais detalhada como a distribuição da área das propriedades ou estatísticas para estas mesmas áreas e suas relações com o trabalho escravos de acordo com o uso da terra - e seguiram, portanto, aquelas características encontradas para o total dos terrenos bragantinos. 
Ainda que apenas Manoel Gomes da Silva mencionasse criação, chama atenção o fato de que identificamos para Bragança um elevado número de indivíduos ligados à criação de porcos (vide capítulo II), especialmente para a produção de toucinho, que nos arriscamos naquele momento a apontar como "especialização" local. Decerto cultura e criação caminhavam juntas, afinal a criação de suínos era dependente da cultura, pois, como sabido, o milho era o principal alimento desses animais e diferentemente da criação de vacuns, a atividade criatória de suínos demanda áreas bem menores, possibilitando que o terreno seja alocado em cultivos diversos. 


\section{Atibaia}

Foram descritas no tombamento atibaiense 246 propriedades, sendo que para duas delas não foi mencionada a área. Todas as propriedades foram arroladas por indivíduos, a nenhuma correspondia entidades, ainda que houvesse "Campos pertencentes aos moradores que se acham situados juntos a capela de N. Senhora do Carmo"

O perfil de repartição da terra em Atibaia (Tabela III.20) aponta para uma elevada concentração, representada por um índice de Gini de 0,645, revelando pequenos proprietários ao lado de poucos proprietários com propriedades mais extensas. Cerca de 49\% das propriedades tinham até 50 alqueires, mas conjuntamente não alçavam a $8 \%$ do total da área rural da localidade, enquanto três propriedades dividiam uma área 0,6 vezes maior: 3375 alqueires paulistas, equivalentes a 12,4\% de toda a área apresentada no tombamento. O tamanho de área mais comumente encontrado foi de 113 alqueires, sendo a área média total de 111,3 alqueires paulistas.

\section{Tabela III.20}

Distribuição das propriedades de acordo com faixas de tamanho (Atibaia -1818)

\begin{tabular}{lcccccc}
\hline \hline $\begin{array}{c}\text { Tamanho das } \\
\text { propriedades * }\end{array}$ & $\%$ (Número) & $\begin{array}{c}\text { Área* } \\
\text { \% (total) }\end{array}$ & & Área média & Área modal & I. Gini \\
\hline $0-50$ & $48,8(119)$ & $7,7(2089,35)$ & & 17,6 & 30 & 0,454 \\
\cline { 6 - 7 } \cline { 5 - 6 } $1-100$ & $18,0(44)$ & $10,6(2885,53)$ & & 65,6 & 60 & 0,092 \\
$100,1-300$ & $24,2(59)$ & $35,8(9718,05)$ & 164,7 & 113 & 0,169 \\
$300,1-500$ & $5,3(13)$ & $17,9(4855,50)$ & & 373,5 & 337,5 & 0,072 \\
$500,1-1000$ & $2,5(6)$ & $15,6(4230,00)$ & & 705,0 & 600 & 0,080 \\
1000,1 ou mais & $1,2(3)$ & $12,4(3375,00)$ & 1125,0 & 1012,5 & 0,067 \\
Total & $100,0(244)$ & $100,0(27153,40)$ & 111,3 & 113 & 0,645 \\
\hline \hline
\end{tabular}

*Em alqueires paulistas, exclusive 2 pro priedades com áreas não explicitadas

Fonte: AESP, Inventário de Bens Rústicos, Atibaia:1818

Essas propriedades com área explicitada estavam nas mãos de 220 indivíduos, com destaque para Nicolau Soares de Pugas Duque, com 10 propriedades, espraiadas pelo território atibaiense. Em 1817-1818 Nicolau seria um dos maiores proprietários de terras, em número de propriedades, da capitania de São Paulo, segundo Nozoe (2008). 
O índice de Gini calculado para os proprietários foi praticamente o mesmo daquele apresentado para as propriedades, 0,643. Da mesma forma ocorreu com a distribuição das terras por faixas de tamanho cuja maior modificação ocorreu na faixa de até 50 alqueires, que passou a responder por $46,4 \%$ dos donos de terra.

Em regra, os proprietários de duas ou mais terras possuíam, em ao menos uma das propriedades, pequenas áreas. Em Atibaia 14 indivíduos possuíam duas propriedades (totalizando 28 porções de terras), dentre elas 10 tinham mais de 100 alqueires, e estavam nas mãos de 7 proprietários. Joze Soares de Oliveira era um dos 3 proprietários com duas terras acima de 100 alqueires, uma porção com 112,5 e outra com 337,5 alqueires. Ademais, Francisco Cordeiro do Amaral tinha 112,5 e 330 alqueires no bairro do Rio Abaixo, onde o capitão mor Jose de Siqueira Franco tinha 148,2 alqueires paulistas além outros 111 alqueires em Caioçara-Caetetuba. A maior dessas propriedades, 675 alqueires no bairro Caioçara-Caetetuba, pertencia a Jeronimo Godois Moreira que ali vivia e além dessa área era proprietário também de outros 56,25 alqueires que comprou no Campo Largo, como segue:

[...] sorte de terras no Bairro do Campo Largo desta vila, de nome Boçoroca. São campos que servem para pasto de animais, e possui por compra; com comprimento pouco mais ou menos de um quarto, e meio de légua por ser terras de fronteiras, com largura de um quarto mais ou menos [56,25 alqueires - DOMR], confrontandose com o Capitão Lourenço Franco da Rocha, com João Gonçalves, com os moradores da capela de Nossa Senhora do Carmo, e com Miguel Ribeiro donde fecha, e não tem situação nelas. (Relações dos Sítios e terras de Atibaia. 1818 AESP, Tombamento/ C09868)

No entanto, grande parte daqueles indivíduos com duas propriedades possuíam porções realmente pequenas, ainda que as propriedades fossem anexas. É o caso de Francisca de Paula Pedrosa, possuidora de duas terras com apenas 4 e 9 alqueires, Francisco Pires Pimentel, com 1,6 e 7,5 alqueires ou Maria Leite de Araujo com 0,5 e 4 alqueires em Itapetinga. 
Tabela III.21

Indivíduos com mais de uma propriedade

(Atibaia - 1818)

\begin{tabular}{|c|c|c|c|c|}
\hline Proprietário & $\begin{array}{l}\text { Número de } \\
\text { propriedades }\end{array}$ & Localização & Área & Área total \\
\hline \multirow{2}{*}{ Antonio Franco Penteado } & \multirow{2}{*}{2} & Campo Largo & 6,000 & \multirow{2}{*}{54,000} \\
\hline & & Campo Largo & 48,000 & \\
\hline \multirow{2}{*}{$\begin{array}{c}\text { Daniel da Rocha Franco (e mais dois } \\
\text { herdeiros) }\end{array}$} & \multirow{2}{*}{2} & Mato Dentro & 18,000 & \multirow{2}{*}{42,500} \\
\hline & & Mato Dentro & 24,500 & \\
\hline \multirow[t]{2}{*}{ Feliciano da Cunha Ramos } & \multirow[t]{2}{*}{2} & Campo Largo & 9,000 & \multirow{2}{*}{46,500} \\
\hline & & Campo Largo & 37,500 & \\
\hline \multirow{2}{*}{ Felix Manoel Cintra } & \multirow{2}{*}{2} & Mato Dentro & 72,000 & \multirow{2}{*}{297,000} \\
\hline & & Mato Dentro & 225,000 & \\
\hline \multirow{2}{*}{ Francisca de Paula Pedrosa } & \multirow{2}{*}{2} & Campo Largo & 4,000 & \multirow{2}{*}{13,000} \\
\hline & & Campo Largo & 9,000 & \\
\hline \multirow{2}{*}{ Francisco Cordeiro do Amaral } & \multirow{2}{*}{2} & Rio Abaixo & 112,500 & \multirow{2}{*}{442,500} \\
\hline & & Rio Abaixo & 330,000 & \\
\hline \multirow{2}{*}{ Francisco Pires Pimentel } & \multirow{2}{*}{2} & Campo Largo & 1,600 & \multirow{2}{*}{9,100} \\
\hline & & Campo Largo & 7,500 & \\
\hline \multirow{2}{*}{ Francisco Soares de Lima } & \multirow{2}{*}{2} & Campo Largo & 15,000 & \multirow{2}{*}{127,500} \\
\hline & & Campo Largo & 112,500 & \\
\hline \multirow{2}{*}{ Jeronimo Godois Moreira } & \multirow{2}{*}{2} & Campo Largo & 675,000 & \multirow{2}{*}{731,300} \\
\hline & & Caioçara-Caetetuba & 56,250 & \\
\hline José de Siqueira Franco & 2 & Caioçara-Caetetuba & 111,000 & 259,200 \\
\hline & & Rio Abaixo & 148,200 & \\
\hline José Joaquim de Godois Lima & 2 & Campo Largo & 28,000 & 138,000 \\
\hline & & Campo Largo & 120,000 & \\
\hline Joze de Araujo Chaves & 2 & Mato Dentro & 16,000 & 40,000 \\
\hline & & Mato Dentro & 24,000 & \\
\hline Joze Soares de Oliveira & 2 & Rio de Maracanã & 112,500 & 450000 \\
\hline & & Rio de Maracanã abaixo & 337,500 & \\
\hline Maria Leite de Araujo & 2 & Itapetinga & 0,500 & 4,500 \\
\hline & & Itapetinga & 4,000 & \\
\hline & & Boa Vista & 0,320 & \\
\hline & & Campo largo & 8,000 & \\
\hline & & Itapetinga & 28,130 & \\
\hline & & Suburbio da vila & 28,130 & \\
\hline & & Itapetinga & 30,000 & \\
\hline Nicolau Soares de Pugas Duque & 10 & Estrada de Bragança & 30,000 & 590,330 \\
\hline & & Caetetuba & 56,250 & \\
\hline & & Ao pé do rio Atibaia & 72,000 & \\
\hline & & Mato Dentro & 112,500 & \\
\hline & & Mato Dentro & 224,000 & \\
\hline
\end{tabular}


O próprio capitão Nicolau tinha pequenas propriedades entra suas diversas glebas. A maior delas, onde residia e mantinha em cultura com 22 escravos, estendia-se por 225 alqueires de área no bairro do Mato Dentro e a menor de suas propriedades eram apenas 0,320 alqueires arrematados em praça. Havia ainda, entre a menores propriedades, uma propriedade de 8 alqueires, duas de 28,130 e duas de 30 alqueires. Conjuntamente, suas propriedades somavam 590,330 alqueires paulistas.

Os indicadores de concentração da terra não deixam dúvidas no que respeita à desigualdade na apropriação, mas ela era diferenciada também segundo o número de escravos possuídos, é dizer, existia uma ligação evidente entre a presença ou não de cativos no arrolamento e o tamanho das propriedades, conforme mostram as Tabelas III.22 e III.23.

Assim como aconteceu com as demais localidades, não foi possível identificar com exatidão se os escravos arrolados no tombamento eram a totalidade dos escravos possuídos, ou apenas aqueles alocados na lide agrícola. Na comparação com a lista nominativa de 1816, a maior fração dos plantéis possuía igual número de cativos ou número bastante próximo. Assim, consideramos os escravos encontrados no tombamento como a totalidade destes possuídos pelos proprietários de terras.

Ademais, havia situações em que os proprietários de duas glebas as tinham anexas em uma mesma região, outras estavam em locais distintos do município, sendo os escravos arrolados, algumas das vezes, em uma única propriedade, ainda que pudessem trabalhar em ambas as propriedades.

Tabela III.22

Distribuição das faixas de tamanho das propriedades entre propriedades com e sem escravos

(Atibaia - 1818)

\begin{tabular}{|c|c|c|c|c|c|}
\hline \multirow{2}{*}{$\begin{array}{l}\text { Tamanho das } \\
\text { propriedades * }\end{array}$} & \multicolumn{3}{|c|}{ Propriedades com escravos ${ }^{\star \star}$} & \multicolumn{2}{|c|}{ Propriedades sem escravos* } \\
\hline & \%(Número) & $\begin{array}{c}\text { Área* }^{*} \\
\% \text { (total) }\end{array}$ & Média & \% (Número) & $\begin{array}{c}\text { Área* } \\
\% \text { (total) }\end{array}$ \\
\hline $0-50$ & $23,5(28)$ & $36,1(753,5)$ & 4,5 & $76,5(91)$ & $63,9(1335,85)$ \\
\hline $50,1-100$ & $52,3(23)$ & $51,9(1496,98)$ & 4,5 & $47,7(21)$ & $48,1(1388,55)$ \\
\hline $100,1-300$ & $64,4(38)$ & $69,3(6734,6)$ & 6,8 & $35,6(21)$ & $30,7(2983,45)$ \\
\hline $300,1-500$ & $76,9(10)$ & $76,8(3730,5)$ & 9,8 & $23,1(3)$ & $23,2(1125)$ \\
\hline $500,1-1000$ & $83,3(5)$ & $85,8(3630)$ & 21,2 & $16,7(1)$ & $14,2(600)$ \\
\hline 1000,1 ou mais & $66,7(2)$ & $60,0(2025)$ & 11,0 & $33,3(1)$ & $40,0(1350)$ \\
\hline Total & $43,4(106)$ & $67,7(18370,58)$ & 6,7 & $56,6(138)$ & $32,3(8782,85)$ \\
\hline $\begin{array}{l}\text { Para número e área to ta } \\
{ }^{\star} \text { Em alqueires paulistas } \\
{ }^{\star \star} \text { Exclusive } 1 \text { propriedad }\end{array}$ & $\begin{array}{l}\text { ma-se } 100 \% \text { em ca } \\
\text { m área não explici }\end{array}$ & linha & & & \\
\hline Fonte: AESP, Inventário & Rústicos, $\mathrm{A}$ & :1818 & & & \\
\hline
\end{tabular}


Tabela III.23

Distribuição das propriedades com e sem escravos de acordo com faixas de tamanho das propriedades

(Atibaia - 1818)

\begin{tabular}{|c|c|c|c|c|}
\hline \multirow{2}{*}{$\begin{array}{l}\text { Tamanho das } \\
\text { propriedades * }\end{array}$} & \multicolumn{2}{|c|}{ "Propriedades com escravos ${ }^{\star \star}$} & \multicolumn{2}{|c|}{ Propriedades sem escravos *夫 } \\
\hline & $\%$ (Número) & $\begin{array}{c}\text { Área* }^{*} \\
\% \text { (total) }\end{array}$ & $\%$ (Número) & $\begin{array}{c}\text { Área* }^{*} \\
\% \text { (total) }\end{array}$ \\
\hline $0-50$ & $26,4(28)$ & $4,1(753,5)$ & $65,9(91)$ & $15,2(1335,85)$ \\
\hline $50,1-100$ & $21,7(23)$ & $8,1(1496,98)$ & $15,2(21)$ & $15,8(1388,55)$ \\
\hline $100,1-300$ & $35,8(38)$ & $36,7(6734,6)$ & $15,2(21)$ & $34,0(2983,45)$ \\
\hline $300,1-500$ & $9,4(10)$ & $20,3(3730,5)$ & $2,2(3)$ & $12,8(1125)$ \\
\hline $500,1-1000$ & $4,7(5)$ & $19,8(3630)$ & $0,7(1)$ & $6,8(600)$ \\
\hline 1000,1 ou mais & $1,9(2)$ & $11,0(2025)$ & $0,7(1)$ & $15,4(1350)$ \\
\hline Total & $100,0(106)$ & $100,0(18370,58)$ & $100,0(138)$ & $100,0(8782,85)$ \\
\hline
\end{tabular}

As propriedades de menores dimensões quase não empregavam escravos, quadro que modifica-se na medida em que observamos propriedades de maior vulto. Entre as propriedades de até 50 alqueires $76,5 \%$ não empregavam cativos. Já nos estratos de 100,1 a 300 e 300,1 a 500 alqueires considerados conjuntamente $66,7 \%$ contavam com essa mão-de-obra, restando $33,3 \%$ de propriedades sem a presença desses indivíduos. A média de escravos listados também crescia com o aumento da área considerada. Encontramos correlação positiva entre área e plantel, 050. Passando de 4,5 para as menores propriedades a 11 para as propriedades de pelo menos 1000 alqueires. Chama a atenção a média de 21,2 escravos na faixa de 500,1 a 1000 alqueires, valor devido à presença de uma propriedade de 900 alqueires pertencente a Lucas de Siqueira Franco, em que estão empregados 35 escravos. E duas propriedades com 675 alqueires que empregavam 22 e 21 cativos. A primeira pertencia ao já citado Jerônimo Godois Moreira, e a segunda, localizada no bairro de Itapetinga pertencia a Josefa Rodrigues da Cunha e seus herdeiros.

Josefa e seus herdeiros receberam as terras por herança. Em 1816 localizamos na lista nominativa Josefa, então com 59 anos, casada com Angelo Franco Correa, então com 71 anos e possuidor naquela ocasião de 36 escravos. Entre 1816 e 1818 Angelo deve ter falecido, legando terras e escravos à mulher e aos filhos José (15 anos) e Gertrudes (19), possivelmente os herdeiros referidos no tombamento. 
Claramente desigual era a distribuição da terra entre propriedades com e sem escravos. As 106 propriedades que empregavam trabalho compulsório detinham 67,7\% da área rural atibaiense, as 138 propriedades restantes ocupavam uma área de apenas 8782,85 alqueires paulistas (32,3\%). Dos proprietários sem escravos, quase $66 \%$ detinham terras de até 50 alqueires, enquanto para as terras com cativos esse percentual baixava a $26,4 \%$, sendo considerável os $35,8 \%$ relativos ao número de propriedades com 100,1 a 300 alqueires, que entre aquelas terras sem escravos era de 15,2\%.

Mas em Atibaia nem todos os indivíduos proprietários de escravos e/ou ligados à agropecuária possuíam terras. Observando todas as propriedades registradas no tombamento de 1818 (no total de 246), verificamos para cerca de 44\% delas menção à presença de cativos, ou seja, cujos proprietários declararam recorrer à lide escrava para a sua produção agrícola. O total de 715 escravos arrolados, no entanto, é bastante inferior à quantidade encontrada nas listas nominativas. Considerando os anos 1816 e 1820, anos para os quais possuímos dados mais próximos à realização do censo de terras, o número total de cativos foi de 1025 e 989, respectivamente (cf. capítulo I), indicando a presença de muitos donos de escravos não proprietários de terras.

Da mesma maneira, as propriedades arroladas no tombamento representam tão somente $36,9 \%$ do total de fogos listados na lista nominativa de 1816 e $37,4 \%$ na lista de 1820. Se considerarmos apenas aqueles fogos ligados exclusivamente ao setor agricultura, esses percentuais elevam-se a $70,7 \%$ e $77,4 \%$, mas ainda assim indicam importante presença de lavradores sem terras próprias. Estamos diante, então, de um grande contingente populacional que vivia e mantinha sua atividades produtiva principal em terras de outrem, havendo imóveis rurais com vários domicílios em seus domínios.

Podemos supor que alguns desses indivíduos chegaram a tornar-se proprietários dessas terras que cultivavam. Isto pode ter ocorrido com os sítios situados na propriedade do Sargento mor Lucas de Siqueira Franco dono de terras "que em parte há mais largura, e em parte muito menos de largura; pois tem três sítios pequenos no meio das terras, que vem a ser um de Antonio Rodrigues Tibaia, outro de Maria Francisca, e outro de Salvador Preto." (Relações dos Sítios e terras de Atibaia. 1818 - AESP, Tombamento/ C09868) Maria Francisca e Salvador Preto Cubas têm, cada um seu "sitio e terras de nome Pinha que houve por herança de seus pais", onde moram. A sua vez, Antonio tinha um "pedaço de terras" que foi herdada por sua mulher. 
Olhando mais de perto os dados, conforme apresentado na Tabela III.24, podemos unir as informações do tombamento com a lista nominativa e estabelecer uma aproximação para a composição dos fogos de Atibaia no que respeita à posse de terras e de escravos. Havia indivíduos sem terras e sem escravos, sem terras e com escravos, sem escravos mas proprietários de terras e alguns atibaienses detinham terras e escravos.

Tabela III.24

Fogos de acordo com a posse de terras e escravos

(Atibaia - 1816, 1818, 1820)

\begin{tabular}{|c|c|c|c|}
\hline & 1816 & 1818 & 1820 \\
\hline Número total de propriedades rurais & & 246 & \\
\hline Número (\%) de propriedades rurais com escravos & & $107(43,9 \%)$ & \\
\hline Número total de escravos no tombamento de terras & & 715 & \\
\hline Número total de fogos & 667 & & 658 \\
\hline Número (\%) de fogos com escravos & $175(26,2 \%)$ & & $166(25,2 \%)$ \\
\hline Número total de escravos na lista nominativa & 1025 & & 989 \\
\hline$\%$ de fogos com terras & $36,90 \%$ & & $37,40 \%$ \\
\hline$\%$ de chefes de fogo com terras e escravos & $16,0 \%$ & & $16,3 \%$ \\
\hline$\%$ de chefes de fogo sem terras e com escravos & $10,2 \%$ & & $9,0 \%$ \\
\hline$\%$ de chefes de fogo com terra e sem escravos & $20,8 \%$ & & $21,1 \%$ \\
\hline$\%$ de chefes de fogo sem terras e sem escravos & $52,9 \%$ & & $53,6 \%$ \\
\hline
\end{tabular}

Fontes: AESP, Inventário de Bens Rústicos, Atibaia:1818 e AESP, Maços de População, Atibaia: 1816,1820

O maior percentual era devido àquela parcela de chefes de fogo sem terras e sem escravos, em torno de 53\%. É dizer, parcela majoritária da população da localidade em tela contava com trabalho familiar, eventualmente de agregados, para produzir, e o fazia em terras que não eram de sua propriedade, como anotado anteriormente. Conjuntamente com outros cerca de $21 \%$ dos fogos, situados em terras próprias, mas que também utilizavam trabalho familiar, esses domicílios deveriam responder por grande parte daqueles arrolados nas listas nominativas como pobres e lavradores para seu sustento. Os chefes de fogo com terras e escravos, eram $16 \%$ do total e possivelmente representavam a parcela mais abastada da sociedade local.

Havia em Atibaia um representativo mercado de terras. O inventário de bens rústicos revela que $63,6 \%$ das propriedades cuja forma de apropriação pudemos identificar (174 ao todo) foram adquiridas por compra, ou seja, transações mediante pagamento. Por exemplo, "José dos Santos tem um sitio donde mora de nome Taipa, e 
possui por compra [...]" (Relações dos Sítios e terras de Atibaia. 1818 - AESP, Tombamento/ C09868) Essa proporção se mantém elevada considerando-se a área como referência: 72,4\%. Esses dados são apresentados na Tabela III.25.

As compras foram seguidas pelas heranças $(28,9 \%)$, e as demais formas de apropriação da terra - doações, combinações entre duas ou mais formas - foram pouco representativas.

Tabela III.25

Formas de aquisição das propriedades de acordo com faixas de tamanho

(Atibaia - 1818)

\begin{tabular}{lcccccc}
\hline \hline \multirow{2}{*}{$\begin{array}{l}\text { Tamanho das } \\
\text { propriedades }\end{array}$} & Compra & Herança & $\begin{array}{c}\text { Compra e } \\
\text { herança }\end{array}$ & Doação & Outras & Total \\
\cline { 2 - 7 } & $53,7(44)$ & $40,2(33)$ & $3,7(3)$ & $1,2(1)$ & $1,2(1)$ & $100,0(82)$ \\
\hline $\mathbf{0}-\mathbf{5 0}$ & $70,0(21)$ & $23,2(7)$ & $3,3(1)$ & $3,3(1)$ & - & $100,0(30)$ \\
$\mathbf{5 0 , 1}-\mathbf{1 0 0}$ & $75,0(33)$ & $15,9(7)$ & $6,8(3)$ & $2,3(1)$ & - & $100,0(44)$ \\
$\mathbf{1 0 0 , 1}-\mathbf{3 0 0}$ & $70,0(7)$ & $20,0(2)$ & - & - & $10,0(1)$ & $100,0(10)$ \\
$\mathbf{3 0 0 , 1}-\mathbf{5 0 0}$ & $50,0(2)$ & $25,0(1)$ & $25,0(1)$ & - & - & $100,0(4)$ \\
$\mathbf{5 0 0 , 1}-\mathbf{1 0 0 0}$ & $100,0(3)$ & & - & - & - & $100,0(3)$ \\
$\mathbf{1 0 0 0 , 1}$ ou mais & $63,6(110)$ & $28,9(50)$ & $4,6(8)$ & $1,7(3)$ & $1,2(2)$ & $100,0(173)$ \\
Total & & & & & &
\end{tabular}

Fonte: AESP, Inventário de Bens Rústicos, Atibaia:1818

Entre as combinações, a mais comum foi entre compra e herança, que respondia por apenas oito casos, sete deles envolvendo propriedades de até 300 alqueires. É possível que sendo legadas a distintos indivíduos estes nem sempre mantinham a propriedades desses pedaços de terra, vendendo-os, inclusive a outros herdeiros, como ficou claro na declaração de José Pereira Padilha que explicitamente mencionou possuir seus 112,5 alqueires "por herança e compra de outros herdeiros".

Ademais, havia a possibilidade de que as terras adquiridas por compra em algum momento modificassem a característica de sua apropriação. Manoel de Souza Bueno possuía por compra 60 alqueires, todavia, metade das terras pertencia a seus 4 filhos, todos residentes nelas. Não localizamos Manoel e seu fogo nas listas nominativas, porém é possível imaginar ter o dito Manoel comprado terras que passaram a pertencer a seu casal. Com o falecimento da esposa, metade das terras foram herdadas por seus filhos, que (eventualmente menores) não tomaram posse delas. Assim, em 1818 as terras compradas ainda constituíam uma única propriedade comandada por Manoel. 
Embora importantes, as heranças respondiam por 15,5\% da área atibaiense descrita, resultado relacionado com o tamanho médio das propriedades adquiridas. (Tabela III.26) A área média das terras possuídas por compra era de 135,9 alqueires, enquanto entre aquelas provenientes de heranças era de apenas 75,7 alqueires paulistas. Em regra, as propriedades negociadas tinham 112,5 alqueires, sendo de 3 e 18 alqueires a moda para a área das propriedades herdadas. Em ambos os casos as menores propriedades tinham 0,2 alqueires, um tamanho bastante reduzido.

\section{Tabela III.26}

Indicadores estatísticos de propriedades adquiridas por compra e herança (Atibaia - 1818)

\begin{tabular}{lcccccccc}
\hline \hline & Número & Área média & $\begin{array}{c}\text { Desvio } \\
\text { padrão }\end{array}$ & Moda & Mediana & $\begin{array}{c}\text { Índice de } \\
\text { Ginini }\end{array}$ & $\begin{array}{c}\text { Menor } \\
\text { propriedade }\end{array}$ & $\begin{array}{c}\text { Maior } \\
\text { propriedade }\end{array}$ \\
\hline Compra & 110 & 135,896 & 216,14 & 112,50 & 60,00 & 0,631 & 0,20 & 1350,00 \\
Herança & 50 & 75,672 & 105,09 & 3 e 18 & 31,00 & 0,668 & 0,20 & 675,00 \\
Total & 160 & 114,98 & 193,67 & 112,50 & 56,00 & 0,652 & 0,20 & 1350,00 \\
\hline \hline
\end{tabular}

Fonte: AESP, Inventário de Bens Rústicos, A tibaia:1818

As diferenças no tamanho médio das propriedades eram dadas, então, pelo extremo superior da distribuição. Francisco Manoel do Espírito Santo possuía 1350 alqueires por compra, enquanto a já referida Josefa Rodrigues da Cunha, juntamente com seus filhos, herdou 675 alqueires - comprados pelo seu falecido marido -, que quando efetivamente partilhados reduziria ainda mais as propriedade. Quando da conclusão da partilha, deveria haver (em caso de divisão igualitária das terras), duas propriedades de 168,8 alqueires, 4 vezes menor que a original, e uma de 337,5 - ainda que a terra não fosse efetivamente dividida e todos continuassem a compor um mesmo domicílio/unidade produtiva.

A não divisão efetiva das terras parecia ser recorrente e justificaria a quase ausência nos arrolamento da menção completa de todos os herdeiros. A exemplo, as irmãs Anna Maria e Gertrudes Maria, juntamente com outros herdeiros, declararam possuir terras e "estar o bolo inteiro, e morarem todos estes herdeiros dentro do dito sitio, sem haver divisão de repartições" ou ainda Francisco Soares de Moura declarou 168,75 alqueires paulistas, em um sitio onde morava, juntamente com dois irmãos, possuidores de parte nas terras.

Não havia nenhum sesmeiro na Atibaia de 1818, assim como não foi declarada nenhuma propriedade adquirida exclusivamente por posse. Há que notar, no entanto, que 
estamos analisando um período muito posterior à chegada dos primeiros povoadores. Como sabido, as terras atibaienses começaram a ser ocupadas nos idos das décadas finais do Seiscentos. Ao longo do tempo a vila foi perdendo parte do sue território e, nas décadas iniciais do Oitocentos, encontrava-se cercada por outras localidades. Estava, portanto, em uma região onde a disponibilidade de terras devolutas era reduzida, senão inexistente.

A ocupação das terras atibaienses teria sido iniciada com Jeronimo de Camargo, que chegou à região na segunda metade do século XVII. ${ }^{69} \mathrm{~A}$ carta de sesmaria onde provavelmente fixou-se o "desbravador" foi dada a seus herdeiros em 1707:

Faço saber aos que esta minha carta de sesmaria virem que havendo respeito ao que por sua petição me enviou a dizer Antonio do Prado da Cunha e seu filho João do Prado Batista [Camargo - DOMR] moradores na vila de São Paulo, que no termo dela no bairro de Guatibaia, freguesia de São João, na paragem denominada Cogoassu da outra banda do dito rio Guatibaia está uma légua de terras de testada com o sertão que lhe pertence em que eles suplicantes tem suas lavras e casas de vivenda nas quais lavrou e cultivou seu sogro e avô Jerônimo de Camargo há mais de quarenta anos sem impedimento nem contradição de pessoa alguma e por seu falecimento as logram e possuem eles suplicantes. Dada a passada na cidade de São Sebastião do Rio de Janeiro em os dez dias do mês de julho de mil setecentos e sete (apud MARTINS, 1940, pp. 36-37)

Mas, cerca de 4 décadas depois de expedido o documento (1741) as terras ainda não estavam totalmente legalizadas, sendo passada uma nova carta de sesmaria a João do Prado e seu filho Jeronimo de Camargo Bueno que alegavam ser possuidores das referidas terras há mais de 80 anos, não sendo a dita sesmaria até aquele momento confirmada por ter havido confusão nas "medições e confrontações" ${ }^{70}$ Requeriam, por conseguinte, nova sesmaria. Foi então passada a carta e posteriormente, em 1745, confirmada a sesmaria (cf. AESP, Sesmarias, patentes e provisões/C00364, Livro 12)

de três quartos de légua de testada, que principiam no Rio de Atibaia onde acabam as terras de Joana de Siqueira que fica abaixo do Ribeirão chamado Poti e daí correndo o rio Atibaia abaixo até perfazer os ditos três quartos de légua e pelo sertão adiante duas léguas [...] aí estavam os suplicantes cultivando, e desfrutando e pagando dízimos delas há tantos anos (AESP, Sesmarias, patentes e provisões/C00364, Livro 13)

\footnotetext{
${ }^{69}$ Ver apêndice 1.

70 De acordo com Silveira (1950, p.94) "pelos termos desta petição [sesmaria de 1707 - DOMR], as terras em questão não se situavam no planalto onde está a cidade, ficavam muito abaixo e do lado direito do rio, enquanto o burgo está ao lado esquerdo e muito acima do local indicado [...] conclue-se pois com a maior segurança, não serem as terras dessa sesmaria, o ponto onde primitivamente se localizou Jeronimo de Camargo pelos anos 1653 ou 54, quando se refugiara na região."
} 
Ao ano 18 do Oitocentos, essa sesmaria estava dispersa em várias propriedades de menor vulto que conformavam, em especial, o bairro de Mato Dentro. Herdeira direta, D. Maria Buena do Prado declarou possuir "meia légua de comprido e quarto e meio de largo" (450 alqueires paulistas), onde "existia" e tinha empregados, junto a seu sobrinho Antonio da Cunha Prado que ali também residia, nove escravos de serviço (outros três eram menores). As terras "possui por uma sesmaria que tirou e confirmou o falecido seu pai João do Prado de Camargo." (Relações dos Sítios e terras de Atibaia. 1818 - AESP, Tombamento/C09868)

Também herdou parte da sesmaria D. Ana Gertrudes, casada que foi com o capitão Francisco Xavier de Oliveira Bueno, irmão de Maria e Jeronimo ${ }^{71}$. Possuía Ana Gertrudes, em 1818, 450 alqueires paulistas.

A sua vez, Jeronimo, falecido no primeiro lustro do século XIX (1806), vendeu ou doou parte de suas terras. Francisco de Paula Bueno recebeu em doação 225 alqueires onde vivia e empregava 1 escravo -, cujas divisas eram dadas pelas glebas da dita Maria Buena, de Nicolau Soares, Felix Manoel e Manoel Caetano.

Duas das muitas propriedades do capitão Nicolau Soares foram originalmente parte da sesmaria em tela. Eram 112,5 mais 225 alqueires paulistas comprados, a menor extensão a João e a maior ao padre Jerônimo. Provavelmente contíguas (conformando um área total de 337,5 alqueires de extensão) estas eram as maiores entre todas as propriedades do capitão; aí estava estabelecido seu fogo (além de residir também na Vila de Atibaia) e trabalhavam na cultura 22 cativos.

O alferes Felix Manoel Cintra possuía 225 alqueires cuja origem foi "uma sesmaria que tirou e confirmou o falecido João do Prado de Camargo" a qual se encontrava em sua maior parte em "terreno pela antiguidade de sua ocupação". (Relações dos Sítios e terras de Atibaia. 1818 - AESP, Tombamento/ C09868)

Da mesma forma, o alferes Manoel Caetano de Mello possuía títulos de compra de 50 alqueires paulistas antes pertencentes a Jeronimo, assim como também os possuía Leonardo Mendes do Amaral para suas terras de 56,25 alqueires.

Identificamos, pois, reafirmando as hipóteses anteriormente levantadas, a partir da ocupação original do solo atibaiense terras devolutas sendo ocupadas e cultivadas, oficialmente demarcadas num moroso processo, e posteriormente fragmentadas via

\footnotetext{
71 Jerônimo de Camargo e sua mulher Ana de Cerqueira tiveram 5 filhas. A mais velha delas, Maria Pires de Camargo casou-se com o Marechal Antonio do Prado da Cunha e tiveram como único filho João do Prado de Camargo (requerente, juntamente com o pai, da sesmaria em 1707). A sua vez, João casou-se com Mariana Bueno de Camargo e teve, entre outros filhos, o padre Jeronimo (com quem novamente requereu a dita sesmaria em 1741), Maria Buena e Francisco, pai de Antonio da Cunha do Prado, que residia nas terras da tia Maria Buena. (cf. LEME, 1903, pp. 374-375)
} 
espólio e retransmissão por transações de compra e venda - concatenação que, ligada à constante utilização produtiva da terra, mais das vezes, levava à queda na qualidade do solo, como trataremos mais adiante.

De fato, as antigas sesmarias chegaram ao século XIX fragmentadas:

D. Joanna Mendes Pimentel tem quarto e meio de comprido e meio quarto de largo [168,75 alqueires - DOMR]. Existe nelas tem empregados na mesma 8 escravos de serviço sendo a metade deste terreno de seus filhos herdeiros onde se acham 2 morando com 2 escravos possui por compra tem títulos delas emanam de uma sesmaria que tirou Narciso de Oliveira Cardoso (Relações dos Sítios e terras de Atibaia. 1818 - AESP, Tombamento/ C09868)

No ano de 1770 Narciso recebeu carta da sesmaria de "uma légua de sertão em quadra [1800 alqueires - DOMR] pelo sertão adentro do rio Atibaia". As terras de Narciso "partem por um lado com João do Prado de Camargo" (cf. AESP, Sesmarias, patentes e provisões/C00366, Livro 17), cujas terras foram originalmente ocupadas décadas antes. Assim, entre os vizinhos dos quase 200 alqueires de Joana encontramos Manoel Caetano e Leonardo Mendes.

Como se pode observar, a compra de terras era prerrogativa de ambos os sexos. Ainda que tenhamos que sopesar a presença dos homens como chefes de domicílio. Homens e mulheres adquiriram áreas rurais via mercado. Cerca de 65\% das terras possuídas por indivíduos do sexo masculino foram compradas, enquanto entre aquelas declaradas por mulheres $58,6 \%$ foram assim adquiridas.(Tabela III.27)

E, mesmo com uma separação de sexos, havia concentração das terras, cujos Gini para homens e mulheres foram calculados em 0,644 e 0,654, sendo próxima também a área média das propriedades que foram, em sequência, 109,69 alqueires paulistas para indivíduos do sexo masculino e 116,65 alqueires para o sexo oposto.

No entanto, enquanto a moda para os homens foi de 112,5 , para as mulheres era de apenas 3 alqueires, e a diferença entre a menor e a maior propriedade, era mais significativa entre os homens (devido também ao número de indivíduos em cada grupo de sexo, o que certamente invalida a análise do percentual da área total possuído por homens e por mulheres). Enquanto para os homens o intervalo variava de 0,20 a 1350 alqueires, para as mulheres iniciava-se em 0,5 alqueires chegando, no limite, a 675 alqueires paulistas. 
Tabela II.27

Formas de aquisição das propriedades e estatísticas para o tamanho de acordo com o sexo do proprietário

(Atibaia - 1818)

\begin{tabular}{ccc|ccc}
\hline \hline $\begin{array}{c}\text { Formas de } \\
\text { aquisição }\end{array}$ & Homens & Muheres & Estatísticas & Homens & Muheres \\
\hline Compra & $64,8(94)$ & $58,6(17)$ & Área média & 109,69 & 116,65 \\
Herança & $26,9(39)$ & $31(9)$ & Desvio padrão & 183,00 & 161,06 \\
$\begin{array}{c}\text { Compra e } \\
\text { herança } \\
\text { Doação }\end{array}$ & $5,5(8)$ & - & Moda & 112,50 & 3,00 \\
Sesmaria & $1,4(2)$ & $3,4(1)$ & Mediana & 56,00 & 49,00 \\
Outras & - & $6,9(2)$ & I. Gini & 0,644 & 0,654 \\
Total & $1,4(2)$ & - & Menor propriedade & 0,20 & 0,50 \\
\hline \hline
\end{tabular}

Fonte: AESP, Inventário de Bens Rústicos, Atibaia:1818

Independentemente do sexo do proprietário e, como esperado, dadas as características da estrutura produtiva local expostas no capítulo anterior, quase metade das propriedades dedicavam-se a algum tipo de cultura. As pequenas propriedades, de até 50 alqueires eram aquelas que tendiam a ser mais improdutivas, com referência a ausência de cultura em 14,3\% delas. Ao mesmo tempo, essas propriedades apresentavam, em alguma medida uma tendência à criação de animais. (Tabela III.28)

Em regra, recorria-se à qualidade do solo e/ou à antiguidade de sua ocupação para justificar a ausência de atividades produtivas nas terras, o que poderia efetivamente ocorrer, como já mencionamos ao listar as várias terras originárias da primitiva ocupação do solo atibaiense.

Como exemplo, encontramos na propriedade comprada por Bento Franco "quase todas as terras são inúteis por estarem em samambaia". Jose Joaquim Ribeiro declarou possuir terras que "não estão em cultura por serem tão cansadas, e safadas que só servem para pasto de animais". As terras de Lucas Jose Leme dividiam-se "entre campos, feitais, cultivados, e terras cansadas pela antiguidade de seus possuidores, estão quase em capim, incapazes de cultura" e na propriedade de Salvador Dias da Silva "a metade das terras estão em capoeira, e a outra metade em capim, e sapezal, que não servem para cultura". (cf. Relações dos Sítios e terras de Atibaia. 1818 - AESP, Tombamento/ C09868) 
Tabela III.28

Uso da terra de acordo com faixas de tamanho das propriedades

(Atibaia - 1818)

\begin{tabular}{|c|c|c|c|c|c|c|}
\hline \multirow{2}{*}{$\begin{array}{l}\text { Tamanho das } \\
\text { propriedades * }\end{array}$} & \multicolumn{6}{|c|}{$\begin{array}{l}\text { Uso da terra }{ }^{\star \star} \\
\% \text { (Número) }\end{array}$} \\
\hline & Cultura & Criação & $\begin{array}{l}\text { Cultura } \\
\text { e criação }\end{array}$ & $\begin{array}{c}\text { Sem cultura } \\
\text { e criação }\end{array}$ & $\begin{array}{c}\text { Não } \\
\text { mencionado }\end{array}$ & Total \\
\hline $0-50$ & $37,0(44)$ & $7,6(9)$ & $2,5(3)$ & $14,3(17)$ & $38,7(46)$ & $100,0(119)$ \\
\hline $50,1-100$ & $52,3(23)$ & $4,5(2)$ & $2,3(1)$ & $2,3(1)$ & $38,6(17)$ & $100,0(44)$ \\
\hline $100,1-300$ & $54,2(32)$ & $1,7(1)$ & $1,7(1)$ & $1,7(1)$ & $40,7(24)$ & $100,0(59)$ \\
\hline $300,1-500$ & $69,2(9)$ & - & - & - & $30,8(4)$ & $100,0(13)$ \\
\hline $500,1-1000$ & $50,0(3)$ & - & $33,3(2)$ & - & $16,7(1)$ & $100,0(6)$ \\
\hline 1000,1 ou mais & $33,3(1)$ & - & - & - & $66,7(2)$ & $100,0(3)$ \\
\hline Todas as propriedades & $45,9(112)$ & $4,9(12)$ & $2,9(7)$ & $7,8(19)$ & $38,5(94)$ & $100,0(244)$ \\
\hline
\end{tabular}

O bairro em que mais se mencionou a improdutividade das terras, $15,8 \%$ das declarações, foi Mato Dentro, justamente aquele supracitado em que as propriedades originaram-se, em grande monta, da sesmaria de Jeronimo de Camargo, seguido de Caioçara, 13,3\% das propriedades e Rio Abaixo, 10\%.

Se somarmos a esse percentual aquele relativo à criação, temos $20 \%$ no bairro do Rio Abaixo, 21,1\% no Mato Dentro e destaque para Caetetuba, com 22,3\%. Se consideradas apenas as propriedades para as quais foram arroladas cultura e/ou criação os percentuais seriam, respectivamente, de $40 \%, 28,6 \%$ e $35,3 \%$, em que pese o número reduzido de observações. A baixa produtividade do solo para agricultura levava muitas vezes à opção pela criação: atividade intensiva no período colonial, necessitava apenas de pastos, nos quais podia-se transformar as terras improdutivas.

Para além das condições do solo, um dos grandes fatores a impulsionar a utilização da terra era a presença de mão-de-obra que, como vimos em outro momento, era caracterizada pelo trabalho familiar e pela conjugação deste com a força de trabalho cativa. Como mostra a Tabela III.29, entre as propriedades com escravos $77 \%$ explicitaram estar em cultura. 
Tabela III.29

Distribuição da área das propriedades de acordo com o uso da terra e presença de cativos

(Atibaia - 1818)

\begin{tabular}{|c|c|c|c|c|c|}
\hline \multirow[b]{2}{*}{ Uso da terra } & \multicolumn{5}{|c|}{ Propriedades com escravos } \\
\hline & $\%$ (Número) & $\begin{array}{c}\text { Área* } \\
\% \text { (total) }\end{array}$ & Área média* & $\begin{array}{c}\text { Escravos } \\
\% \text { (Número) }\end{array}$ & $\begin{array}{l}\text { Média de } \\
\text { escravos }\end{array}$ \\
\hline Cultura & $77(72,0)$ & $67,6(12420,45)$ & 161,30 & $70,1(501)$ & 6,5 \\
\hline Criação & - & - & - & - & - \\
\hline Cultura e criação & $5,6(6)$ & $9,6(1755,75)$ & 351,15 & $11,5(82)$ & 13,7 \\
\hline Sem cultura e criação & $1,9(2)$ & $1,5(281,25)$ & 140,63 & $2,4(17)$ & 8,5 \\
\hline Não mencionado & $20,6(22)$ & $21,3(3913,13)$ & 117,87 & $16,1(115)$ & 5,2 \\
\hline \multirow[t]{2}{*}{ Total } & $100,0(107)$ & $100,0(18370,58)$ & 171,48 & $100,0(715)$ & 6,7 \\
\hline & \multicolumn{5}{|c|}{ Propriedades sem escravos } \\
\hline Uso da terra & $\%$ (Número) & $\begin{array}{c}\text { Área* }^{*} \\
\% \text { (total) }\end{array}$ & Área média* & & \\
\hline Cultura & $25,2(35)$ & $21,6(1898,93)$ & 54,26 & & \\
\hline Criação & $8,6(12)$ & $5,3(462,78)$ & 38,57 & & \\
\hline Cultura e criação & $1,4(2)$ & $0,7(58,13)$ & 29,07 & & \\
\hline Sem cultura e criação & $12,2(17)$ & $2,6(231,88)$ & 13,64 & & \\
\hline Não mencionado & $52,5(73)$ & $69,8(6131,13)$ & 85,15 & & \\
\hline Total & $100,0(139)$ & $100,0(8782,85)$ & 63,19 & & \\
\hline
\end{tabular}

* Em alqueires paulistas, exclusive 1propriedade com área não explicitada

Fonte: AESP, Inventário de Bens Rústicos, A tibaia:1818

As propriedades escravistas explicitamente dedicadas à cultura correspondiam a $67,6 \%$ da área onde residiam escravos e eram três vezes maiores que aquelas dedicadas ao mesmo tipo de atividade, porém com mão-de-obra exclusivamente livre. Sendo a média de escravos na cultura de 6,5 é necessário que se tenha uma área suficiente para que esses indivíduos exerçam atividades, posto que aumentar o trabalho, mantendo constantes os outros fatores produtivos leva a reduções na produtividade marginal do trabalho, não justificando, então, a manutenção dessa mão-de-obra. O percentual de propriedades em que foi identificada cultura era de apenas $25,2 \%$ nas propriedades sem cativos. Por outro lado, apenas dois fogos escravistas $(1,9 \%)$ não realizavam nenhuma atividade ligada à agropecuária, número que se elevava a $17(12,2 \%)$ entre aqueles sem cativos. 
Tabela III.30

Proprietários absenteístas

(Atibaia - 1818)

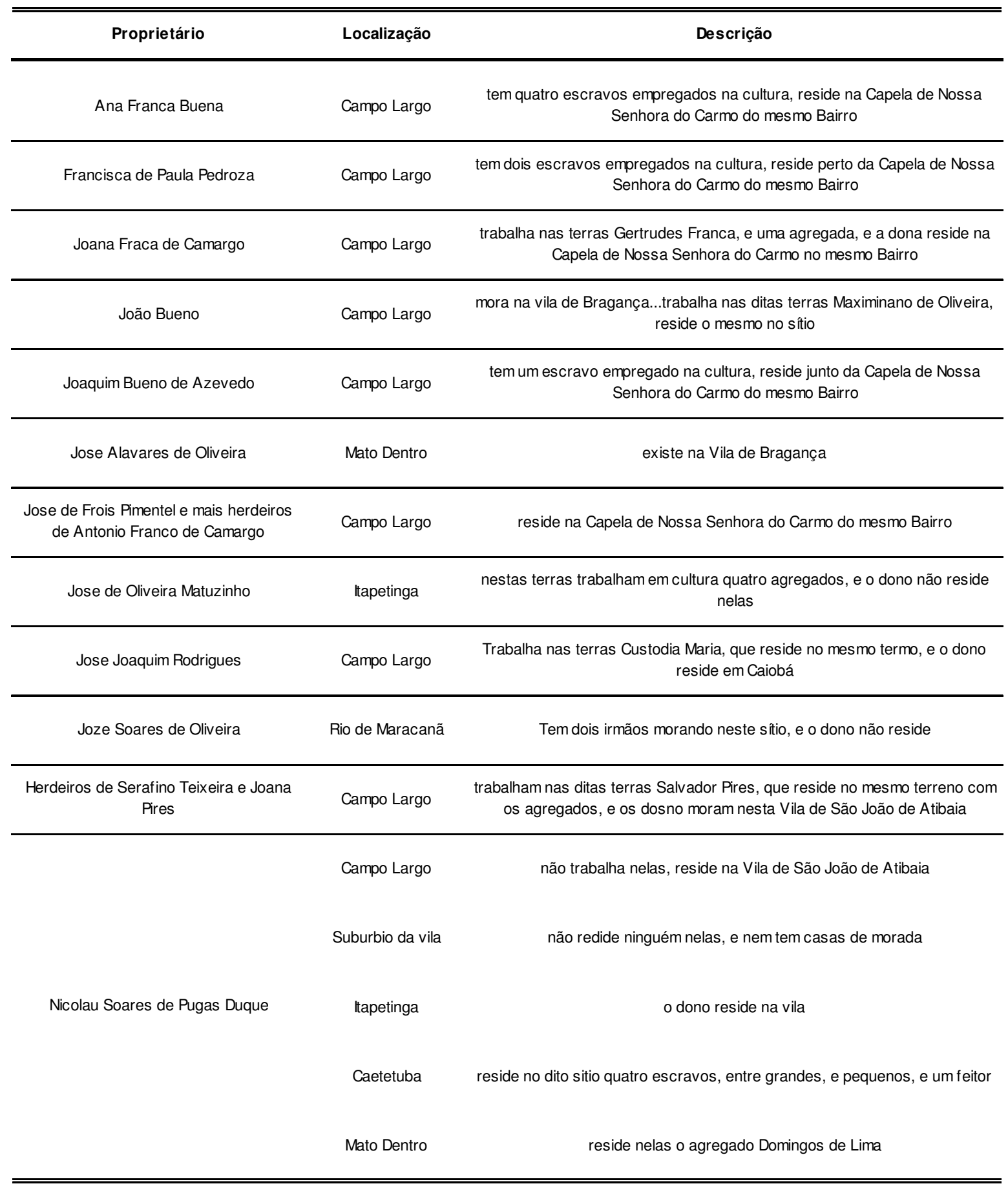

Fonte: AESP, Inventário de Bens Rústicos, A tibaia:1818 
Parece claro, novamente, que a mão-de-obra escrava impulsionava a produção. Da mesma maneira, as propriedades sem escravos apresentaram maior percentual de omissão na declaração, 52,5\% mencionaram estar as terras com algum tipo de cultivo ou incultas, provavelmente por serem estas propriedades produtoras apenas para seu próprio consumo. $^{72}$

Menção a criação localizamos em apenas 12 propriedades, com até 300 alqueires paulistas. Nenhuma delas contava com o trabalho de cativos, o que é compreensível visto ser essa atividade menos intensiva em mão-de-obra.

Algumas das propriedades, ainda que estivessem em cultura, explicitamente não eram trabalhadas por seus proprietários. (Tabela III.30) Percebe-se que alguns proprietários não precisavam cultivar seu(s) terreno(s) com trabalho familiar, utilizavam-se de arrendatários, escravos ou até mesmo ambas as formas de mão-de-obra ao mesmo tempo. Dos proprietários arrolados que mencionaram residir ou não nas terras descritas, $91,7 \%$ (187) viviam em suas terras. Das propriedades com donos explicitamente absenteístas, 16 ao todo, nove situavam-se no bairro do Campo Largo e cinco pertenciam ao capitão Nicolau, que, como adiantado, residia em suas terras no Mato Dentro e na Vila de Atibaia, ou seja, explorava diretamente uma de suas propriedades.

\footnotetext{
${ }^{72} \mathrm{Na}$ comparação do arrolamento de terras com o arrolamento populacional de 1816, em que pese a grande dificuldade na identificação dos indivíduos, Foram localizados 153 proprietários de terras, que respondiam por 174 propriedades, $70,7 \%$ das propriedades arroladas. As ocupações foram declaradas para 143 indivíduos e, como esperado, esses proprietários de terras estavam majoritariamente ligados ao setor agricultura: 62,9\%. Havia considerável percentual de chefes de fogo ligados a múltiplos setores, 32,9\% (47 pessoas), mas destes 35 tinham o setor agricultura como uma das atividades desenvolvidas, conjugada, em especial com cargos militares, conforme anotado em capítulo anterior. Quatro indivíduos declaram-se apenas como "pobre".

Entre aqueles arrolados no setor agricultura, 26 (28,9\%) declararam ser lavradores para seu sustento. Entre eles, 19 proprietários tinham terras de até 100 alqueires, 18 não possuíam escravos e 13 eram proprietários de terras até 100 alqueires e não possuíam escravos. Logo, 50\% dos lavradores "para seu passar" enquadram-se no padrão de proprietários de pequenas áreas de terra, não escravistas.
} 


\section{Nazaré}

Em Nazaré, localidade cujo inventário de bens rústicos apresentou descrição para 271 propriedades, o marcante contraste na distribuição do território rural se coloca logo como característico: o Índice de Gini foi de 0,776, o que consideramos como representativo de uma forte concentração. O contingente das propriedades de até 50 alqueires era bastante significativo, as quais sendo $69,5 \%$ das glebas arroladas $-42,8 \%$ delas com até 10 alqueires -, respondiam por pouco mais da décima parte $(11,6 \%)$ da superfície nazareana. Podemos notar, por outro lado, que três propriedades, entre as 269 declaradas, dominavam, conjuntamente, $37,9 \%$ de toda a área descrita.

O número de propriedades de até 50 alqueires era tão significativo, que determina a moda para o total de propriedades, bastante inferior à média; evidentemente a presença de poucas propriedades com grandes áreas eleva o valor da média, que atingiu 105,9 alqueires paulistas. A propriedade típica tinha oito alqueires, demonstrando a importante presença dos proprietários de terras bastante pequenas na economia do período.

Podemos considerar que um grande número de pequenas propriedades é um estímulo à ampliação da produção de autoconsumo, necessária ao menos para o sustento da unidade familiar, visto que diminui a possibilidade de áreas não cultivadas dentro das propriedades. Por outro lado, consideradas as condições de produção extensivas da época, deveria haver dificuldades no próprio sustento da família e menos excedentes gerados - excedentes eram necessários ainda que utilizado no escambo, para aquisição de gêneros obtidos necessariamente no mercado, a exemplo do sal.

\section{Tabela III.31}

Distribuição das propriedades de acordo com faixas de tamanho (Nazaré - 1818)

\begin{tabular}{|c|c|c|c|c|c|}
\hline $\begin{array}{l}\text { Tamanho das } \\
\text { propriedades * }\end{array}$ & $\%$ (Número) & $\begin{array}{c}\text { Área* }^{*} \\
\% \text { (total) }\end{array}$ & Área média* & Área modal* & I. Gini* \\
\hline $0-50$ & $69,5(187,0)$ & $11,6(3313,125)$ & 20,6 & 8,0 & 0,449 \\
\hline $50,1-100$ & $8,6(23,0)$ & $6,1(1740,875)$ & 76,7 & 60,0 & 0,117 \\
\hline $100,1-300$ & $16,0(43,0)$ & $24,0(6846,750)$ & 169,5 & 112,5 & 0,188 \\
\hline $300,1-500$ & $12,0(4,5)$ & $17,9(5102,500)$ & 423,6 & 450,0 & 0,046 \\
\hline $500,1-1000$ & $0,4(1,0)$ & $2,4(675,000)$ & 675,0 & 675,0 & - \\
\hline 1000,1 ou mais & $1,1(3,0)$ & $37,9(10800,000)$ & 4500,0 & - & 0,222 \\
\hline Total & $100,0(269,0)$ & $100,0(28478,250)$ & 105,9 & 8,0 & 0,776 \\
\hline
\end{tabular}

"Em alqueires paulistas, exclusive 2 propriedades com áreas não explicitadas 
As propriedades arroladas somavam 28478,25 alqueires paulistas (área 4,7\% maior à área arrolada em Atibaia, a que Nazaré, enquanto freguesia, era jurisdicionada). $\mathrm{A}$ menor propriedade tinha 0,08 alqueires e a maior 5400 alqueires paulistas de extensão, 0 equivalente a $19 \%$ da área total arrolada no tombamento em tela. Havia ainda outra propriedade bastante grande na freguesia: 3600 alqueires, 12,6\% das terras rurais descritas. A terceira maior propriedade, 6,3\% da área total, eram 1800 alqueires pertencentes a Bento Dias Paes. Excluindo-se tais propriedades, o índice de gini passa a 0,664 , ainda representativo de uma importante concentração, mas menos acentuada.

Ainda que consideradas em conjunto as glebas com proprietários detentores de mais de uma extensão rural, a grande concentração se mantém.

Tabela III.32

Indivíduos com mais de uma propriedade

(Nazaré - 1818)

\begin{tabular}{|c|c|c|c|c|}
\hline Proprietário & $\begin{array}{c}\text { Número de } \\
\text { propriedades }\end{array}$ & Localização & Área & Área total \\
\hline \multirow{2}{*}{ Escolastica Rodrigues } & \multirow{2}{*}{2} & Atibaia Acima & 18,000 & \multirow{2}{*}{58,000} \\
\hline & & Moinho & 40,000 & \\
\hline \multirow{2}{*}{ Francisco Buenno da Silva } & \multirow{2}{*}{2} & Mascate & 21,125 & \multirow{2}{*}{91,000} \\
\hline & & Mascate & 69,875 & \\
\hline \multirow{3}{*}{ Francisco de Paulla de Oliveira } & \multirow{3}{*}{3} & Goianiduva & 32,000 & \multirow{3}{*}{258,000} \\
\hline & & Atibaia Acima & 128,000 & \\
\hline & & Capoeira & 98,000 & \\
\hline \multirow{2}{*}{ Francisco Rodrigues } & \multirow{2}{*}{2} & Atibaia Acima & 8,000 & \multirow{2}{*}{53,000} \\
\hline & & Atibaia Acima & 45,000 & \\
\hline \multirow{3}{*}{$\begin{array}{l}\text { João Carvalho,Jose da Cunha,Jose } \\
\text { Ramos,Francisco da Cunha, Pedro de } \\
\text { Souza, Ignacio da Cunha }\end{array}$} & \multirow{3}{*}{2} & Ribeirão & 32,000 & \multirow{3}{*}{44,000} \\
\hline & & & & \\
\hline & & Ribeirão & 12,000 & \\
\hline \multirow{2}{*}{ Joze Francisco Cardozo } & \multirow{2}{*}{2} & Goianiduva & 36,000 & \multirow{2}{*}{54,000} \\
\hline & & Estrada & 18,000 & \\
\hline \multirow{2}{*}{ Luis Manoel de Souza Freire } & \multirow{2}{*}{2} & & 48,750 & \multirow{2}{*}{5448,750} \\
\hline & & Ribeirão S. Agostinho & 5400,000 & \\
\hline \multirow{2}{*}{$\begin{array}{l}\text { Manoel Jose de Almeida e João Manoel de } \\
\text { Almeida }\end{array}$} & \multirow{2}{*}{2} & Atibaia Acima & 112,500 & \multirow{2}{*}{140,625} \\
\hline & & Atibaia Acima & 28,125 & \\
\hline \multirow{2}{*}{ Margarida Corea } & \multirow{2}{*}{2} & Estrada & 3,000 & \multirow{2}{*}{21,000} \\
\hline & & Cachoeira Acima & 18,000 & \\
\hline
\end{tabular}


$\mathrm{Na}$ freguesia de Nazaré 258 alqueires paulistas dividiam-se entre as 3 propriedades de Francisco de Paula, espraiadas pelos bairros de Atibaia Acima, Ribeirão e Capoeira. E ainda Manoel Jose de Almeida mais João Manoel de Almeida possuíam 2 propriedades cujas áreas somavam 140,635 alqueires. Estes, entre os 9 possuidores de mais de uma propriedade que identificamos com certa segurança,à exceção do padre Luis Manoel, aqueles que detinham a maior área. (Tabela III.32)

Os 3600 alqueires anteriormente referidos eram de propriedade de Marianno Antonio e estavam localizados no bairro do Cuiabá, em que constavam área para 23 propriedades e onde, excetuando-se as terras de Marianno, o tamanho médio das glebas era de tão somente 55,5 alqueires paulistas.

A maior das propriedades, única situada no Ribeirão de Santo Agostinho, pertencia ao já conhecido "reverendo padre vigário colado"73 Luis Manoel de Souza Freire, natural de São Paulo, cujas terras foram obtidas por carta de sesmaria.

Como sabido, a possibilidade de adquirir uma sesmaria estava ligada à capacidade de cultivá-la. Luis Manoel em 1799 já se encontrava em Nazaré e, naquele ano, possuía um único cativo. Nos anos seguintes mencionou nas listas nominativas três escravos, e em 1812 este número já era de 18, chegando ao limite de 24 em 1816, que acrescidos em um indivíduo correspondem àqueles declarados como trabalhando em suas extensões, que ademais da sesmaria incluía 48,75 alqueires de terras comprados pelo padre e onde "é sua chácara".

A maior propriedade descrita no arrolamento de bens rústicos corresponde exatamente à sesmaria de 1 légua de testada e 3 léguas de fundo registrada em 06 de julho de 1807 - ainda que a porção de terras originalmente requisitada tenha sido maior:

Faço saber aos que esta minha carta de sesmaria virem, que atendendo a me representar o Reverendo Luiz Manoel de Souza Freire Vigário Colado da Freguesia de Nazaré termo da vila de Atibaia, que ele precisava de terras para cultura, e como no termo da mesma vila em o sertão que vai para o Selado se achavam muitas devolutas me pedia lhe concedesse a si por sesmaria uma légua de terra de testada com 4 de fundo, começando a testada na ponte da extremidade da serra que vai para o Selado, e seguindo para o Rio de Santo Agostinho, e o sertão da mesma extremidade da referida serra indo pelo cume dela adiante a baixar o Selado: e visto o seu requerimento [...], o qual somente impugnou a quantidade das terras pedidas por exceder o mais de três léguas de sertão, que unicamente se podem conceder na forma determinada pelas Reais ordens, em observância delas conformando-me com o seu parecer: Hei por bem dar de Sesmaria em nome de Sua Alteza Real em virtude de sua Real ordem de 15 de junho de 1711 ao dito reverendo Vigário Colado Luiz Manoel de Souza Freire uma légua de terra de testada, e três de fundo na

\footnotetext{
${ }^{73}$ Ademais das terras do referido padre localizamos em Nazaré, declarada por eclesiástico, a propriedade em que o "Reverendo padre Camilo Jose de Moraes Lelis tem sua chácara no bairro da freguesia cujas são parte de seu patrimônio". Tal propriedade confrontava com o vigário Pedro Pereira e com o quintal do padre Antonio Passos, que não tinham terras declaradas no tombamento de 1818.
} 
paragem mencionada com as confrontações acima indicadas, e sem prejuízo de terceiros, ou do Distrito que alguma pessoa tenha delas com a declaração que as cultivará, e mandará confirmar esta carta de Sesmaria por Sua Alteza Real dentro em 2 anos (AESP, Sesmarias, patentes e provisões/C00372, Livro 32)

A Serra do Selado era um dos marcos divisórios entre São Paulo e Minas Gerais $^{74}$. Ou seja, Nazaré, nos anos iniciais do Oitocentos possuía terras devolutas ao norte de seu território, que naquele momento ainda poderiam ser apossadas e/ou requisitadas como sesmaria. No entanto, essa possibilidade era limitada, pois a extensão de tais terras ultrapassava as fronteiras nazareanas e paulistas.

Luiz Manoel foi o único a declarar a aquisição de terras por sesmaria em Nazaré. Encontramos ademais 10 propriedades adquiridas por posse, 3,8\%. Entre essas propriedades, a menor possuía 1 alqueire, havia ainda duas propriedades com 4,5 alqueires, uma com 30 alqueires de extensão e as demais possuíam 100 ou mais alqueires paulistas. Com destaque para as terras de Bento Dias Paes com 1800 alqueires paulistas de área, a terceira maior da localidade, como adiantado.

Ou seja, posses correspondiam a pequenas e grandes propriedades, e mostravam-se, possivelmente, como uma forma de apropriação alternativa para aqueles com recursos insuficientes para compra de glebas ou a requisição de sesmarias (ou para enfrentar as dificuldades nos demorados trâmites para sua legalização). Era, então, possível que grandes extensões deixassem de ser registradas como sesmaria, como as terras de Bento Paes, que em sua extensa área não contava com o trabalho de nenhum cativo e havia declarado produzir para seu passar nas listas nominativa de 1816 e 1820.

A propriedade de Bento D. Paes estava no bairro da Cachoeira Acima, no centronorte do território nazareano - a Figura III.2 mostra a localização da serra do Selado e do Bairro da Cachoeira dentro do território da freguesia de Nazaré -, e "parte do norte com o sertão devoluto e do sul com Brizida Fernandes e do leste com o dito sertão e do oeste com o padre Policarpio". (Relação da primeira companhia da Freguesia de Nazaré e dos habitantes que possuem seus terrenos no ano de 1818. 1818 - AESP, Tombamento/C09868)

\footnotetext{
${ }^{74}$ Atualmente, a Serra do Selado é o marco divisório entre o município paulista de Joanópolis, e o mineiro de Camanducaia. Seu cume, o Pico do Selado com 2082 metros é considerado ponto turístico pelas duas cidades.
} 
Figura III.2

\section{Localização da Serra do Selado e do Bairro da Cachoeira \\ (projeção sobre mapa atual)}

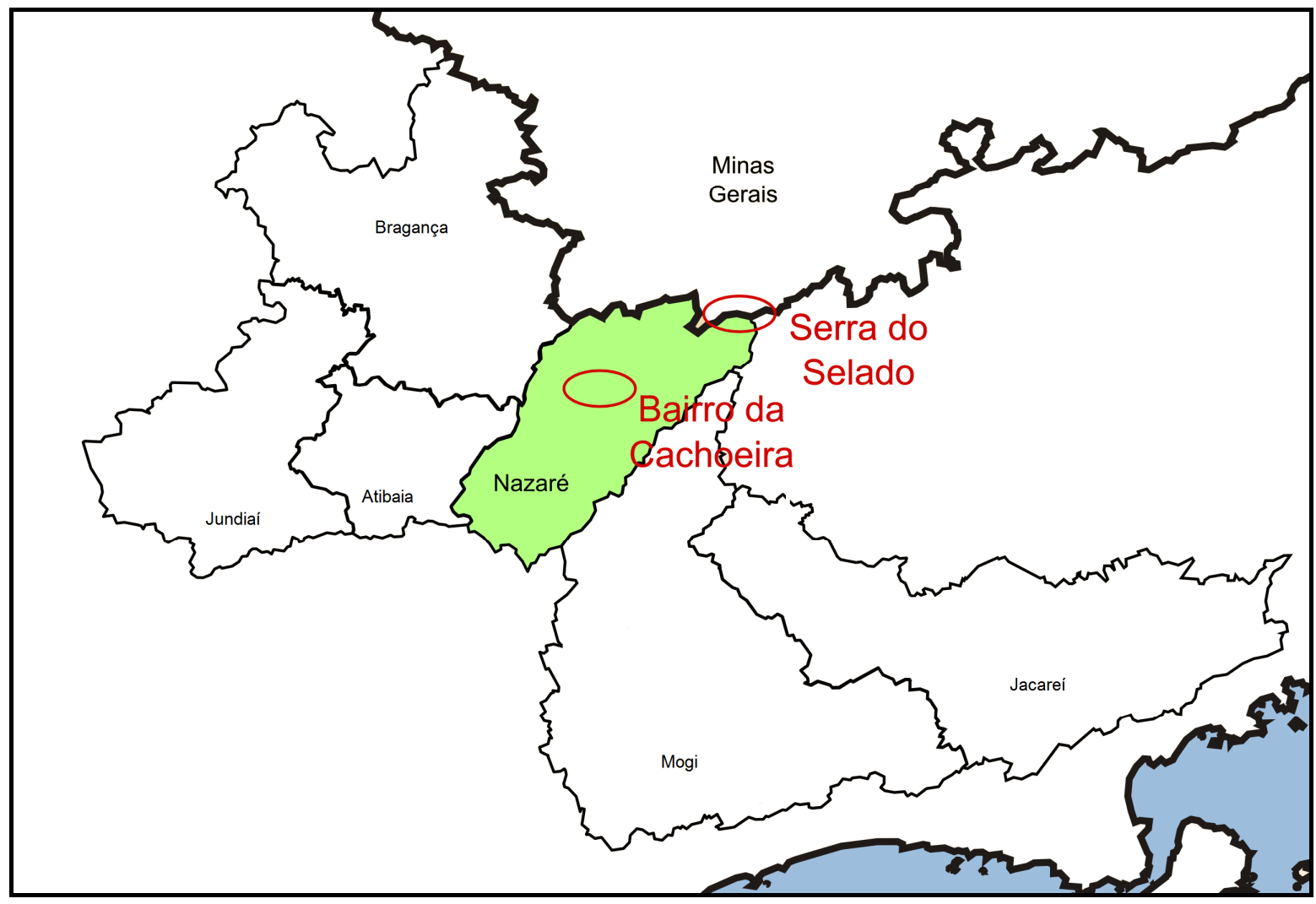

Brizida Fernandes possuía 900 alqueires paulistas adquiridos por compra que também divisava a "leste com um sertão devoluto". Assim como divisava a "leste com um sertão que se acha devoluto" a propriedade de 450 alqueires de Antonio Gonçalves da Cunha, no mesmo bairro da Cachoeira Acima. Corrobora-se, pois, a identificação de parte do território nazareano como ainda devoluto, o que possibilitava sua apropriação em grandes terrenos. E, em se transferindo as terras via compra ou herança, essas movimentações não representaram, até 1818, uma grande fragmentação de parte destas glebas, por estas estarem em área de ocupação mais recente. Quase 21\% dos terrenos do bairro estavam acima dos 300 alqueires paulistas.

Parte majoritária das propriedades, acima de $70 \%$, foi adquirida, exclusivamente, por compra, indicando um significativo mercado fundiário, como pode ser notado na Tabela III.33. 
Tabela III.33

Formas de aquisição das propriedades de acordo com faixas de tamanho

(Nazaré - 1818)

\begin{tabular}{|c|c|c|c|c|c|c|c|c|}
\hline \multirow{2}{*}{$\begin{array}{l}\text { Tamanho das } \\
\text { propriedades * }\end{array}$} & \multicolumn{8}{|c|}{$\begin{array}{l}\text { Formas de aquisição** } \\
\text { \% (Número) }\end{array}$} \\
\hline & Compra & Herança & $\begin{array}{c}\text { Compra e } \\
\text { herança }\end{array}$ & Doação & Posse & Sesmaria & Outras & Total \\
\hline $0-50$ & $68,7(125)$ & $26,4(48)$ & $\overline{-}$ & $1,1(2)$ & $2,2(4)$ & - & $1,6(3)$ & $100,0(182)$ \\
\hline $300,1-500$ & $83,3(10)$ & 16,7 (2) & - & - & - & - & - & $100,0(12)$ \\
\hline $500,1-1000$ & $100,0(1)$ & - & - & - & - & - & - & $100,0(1)$ \\
\hline 1000,1 ou mais & 33,3 (1) & - & - & - & $33,3(1)$ & 33,1 (1) & - & $100,0(3)$ \\
\hline Total & $70,6(185)$ & $21,4(56)$ & $1,5(4)$ & 1,1 (3) & $3,8(10)$ & $0,4(1)$ & 1,1 (3) & $100,0(262)$ \\
\hline
\end{tabular}

${ }^{*}$ Em alqueires paulistas

** Exclusive 9 propriedades: 2 com áreas não explicitada e 7 com forma de aquisição não especificada

Fonte: AESP, Inventário de Bens Rústicos, Nazaré:1818

Tabela III.34

Indicadores estatísticos de propriedades adquiridas por compra, herança e posse

(Nazaré - 1818)

\begin{tabular}{lcccccccc}
\hline \hline & Número & Área média & $\begin{array}{c}\text { Desvio } \\
\text { padrão }\end{array}$ & Moda & Mediana & $\begin{array}{c}\text { Índice de } \\
\text { Ginin }\end{array}$ & $\begin{array}{c}\text { Menor } \\
\text { propriedade }\end{array}$ & $\begin{array}{c}\text { Maior } \\
\text { propriedade }\end{array}$ \\
\hline Compra & 185 & 91,213 & 282,474 & 8,000 & 28,125 & 0,721 & 0,080 & 3600,000 \\
Herança & 56 & 44,480 & 90,378 & 8,000 & 13,000 & 0,698 & 0,800 & 450,000 \\
Posse & 10 & 261,500 & 547,081 & - & 106,250 & 0,635 & 1,000 & 1800,000 \\
\hline \hline
\end{tabular}

“Em alqueires paulistas

O mercado de terras movimentava negócios envolvendo em sua maior parte pequenas extensões rurais. Entre as poucas grandes propriedades, acima de 500 alqueires, duas foram adquiridas através do mercado, sendo $67,6 \%$ das propriedades obtidas por esse meio com áreas de até 50 alqueires. E 68,7\% das menores propriedades foram compradas. $O$ acesso a terra deveria ser, então, uma possibilidade aberta a pessoas pobres, mas não totalmente despossuídas. O que não surpreende visto que as terras tinham pouco valor monetário (apesar de terem algum valor de mercado, pois o comércio implica em transações mediante pagamento), sendo decerto importante para esses pequenos proprietários o mercado de crédito. A área modal negociada ficou em 8 alqueires paulistas, refletindo os valores encontrados para as propriedades conjuntamente (cf. Tabela III.35) 
Tabela III.35

Formas de aquisição das propriedades e estatísticas para o tamanho de acordo com o sexo do proprietário (Nazaré - 1818)

\begin{tabular}{ccc|ccc}
\hline \hline $\begin{array}{c}\text { Formas de } \\
\text { aquisição }\end{array}$ & Homens $^{*}$ & Muheres & Estatísticas & Homens* & Muheres \\
\hline Compra & $70,7(157)$ & $77,8(28)$ & Área média & 115,4 & 55,6 \\
Herança & $21,2(47)$ & $16,7(6)$ & Desvio padrão & 451,5 & 85,5 \\
Compra e herança & $1,4(3)$ & $2,8(1)$ & Moda & 8,0 & 8,0 \\
Doação & $1,4(3)$ & - & Mediana & 28,1 & 18,0 \\
Posses & $0,5(9)$ & $2,8(1)$ & I. Gini & 0,788 & 0,635 \\
Sesmaria & $4,1(1)$ & - & Menor propriedade & 0,080 & 0,300 \\
Outras & $0,5(2)$ & - & Maior propriedade & 5400,000 & 450,000 \\
Total & $100,0(22)$ & $100,0(36)$ & & & \\
\hline \hline
\end{tabular}

As propriedades adquiridas estavam nas mãos de homens e mulheres, sendo que para cada um dos sexos a participação das compras era de 70,7\% e 77,8\%, respectivamente. E, conforme já identificamos para outras localidades, possivelmente foram negociadas pelo chefe de casal e na sua ausência a mulheres assumiram essas propriedades, que em média, eram bastante inferiores àquelas em mãos masculinas. (Tabela III.35)

A apropriação das terras via compra convivia, em especial, com heranças $(21,4 \%)$, sendo as demais formas de acesso às glebas pouco representativas. Ainda que as propriedades negociadas fossem pequenas, as heranças eram, em regra, consideravelmente menores, sendo $85,7 \%$ delas de até 50 alqueires, moda 8 e mediana 13.

Outras quatro propriedades foram explicitamente adquiridas por herança mais compra. Entre elas "O alferes Jose Joaquim de Oliveira tem um sítio no bairro Cuiabá, onde mora, e possui por herança por cabeça de sua mulher e por compra a outros herdeiros" que ocupa área de 90 alqueires e o alferes Joaquim de Almeida "tem um sitio no bairro Atibaia Acima onde mora, e possui por herança e compra dos herdeiros de que tem títulos", cuja extensão era de 225 alqueires. (cf. Relação da primeira companhia da 
Freguesia de Nazaré e dos habitantes que possuem seus terrenos no ano de 1818. 1818 - AESP, Tombamento/C09868)

E ainda que seis indivíduos tenham sido declarantes de um terreno de 98 alqueires paulistas no bairro Atibaia Acima adquirido por herança, entre eles José Rodrigues de Souza era proprietário também "por compra de outros herdeiros de que tem título".

Os imóveis herdados, assim como acontecia com os terrenos adquiridos no mercado fundiário, eram privilégio de ambos os sexos, tendo participação pouco mais importante entre os homens que tiveram $21,2 \%$ de suas propriedades herdadas,enquanto entre as mulheres este valor foi de $16,7 \%$.

Entre as propriedades, para 187 (69\%) encontramos afirmação de trabalharem nelas seus donos. Oitenta dessas propriedades estavam explicitamente em cultura, nenhum menção à criação foi encontrada. Alguns proprietários contavam com a ajuda de escravos, de herdeiros e/ou de agregados. Os agregados foram encontrados, sem maiores especificações, na descrição de 14 terrenos. Os herdeiros foram referidos em 17 glebas e em quatro propriedades apareceram listados entre os proprietários. Com destaque "Antonio de Souza Furtado possui uma propriedade de terras em o bairro denominado Vicente Nunes que terão de extensão três quartos e de fundo e testada trezentas braças cujas possuiu por herança de onde existe em cultura com vinte e oito herdeiros e sete escravos" (Relação da primeira companhia da Freguesia de Nazaré e dos habitantes que possuem seus terrenos no ano de 1818. 1818 - AESP, Tombamento/C09868). Quando as terras eram suficientemente grandes para manutenção de todos os herdeiros, é provável que em muitos casos eles ali permanecessem.

A maior diferenciação no uso da terra e conseqüentemente na produção era devida à presença de cativos, pois ainda que tenhamos identificado em capítulo anterior a grande importância do trabalho familiar, a presença de cativos incrementava de maneira considerável a produção e justificava a ocupação de áreas mais extensas.

Em Nazaré os escravos, em número de 319, eram ocupados em 63 propriedades, que correspondem a 23,4\% dos 269 terrenos declarados no inventário de bens rústicos da freguesia e $56,7 \%$ da área rural anotada. Estes valores podem ser observados na Tabela III.36. Em média, estas propriedades escravistas contavam com o trabalho de 5,1 indivíduos, sendo a concentração de cativos muito elevada, posto que o índice de Gini para estes estabelecimentos foi de 0,863 . Enquanto $9,2 \%$ dos plantéis declarados eram unitários ou com dois indivíduos, o padre Luiz Manoel possuía 25 deles em suas terras. Essa concentração verifica-se também em se considerando as diferentes faixas de tamanho das propriedades. 
O tamanho médio atinente às propriedades com presença de cativos foi de 256,4 alqueires paulistas. A sua vez, as propriedades sem cativos ocupavam, em média, espaço mais de quatro vezes menor: 59,8 alqueires. $E$ ainda que $52,4 \%$ das propriedades com escravos fossem pequenas, com até 50 alqueires, esse percentual é bastante inferior àquele verificado para as propriedades em que o trabalho compulsório não estava presente, $74,8 \%$ e para o total das propriedades, em que as menores delas respondiam por $69,5 \%$ dos imóveis listados (Tabela III.37). Todavia, eram nessas pequenas propriedades que viviam a maior parte dos cativos, $45,8 \%{ }^{75}$

A quantidade de escravos encontrada no Tombamento de bens rústicos é muito inferior aos 624 indivíduos assim declarados na lista nominativa de 1816 e aos 751 mencionados no censo de 1820 , encontrados em cerca de $20 \%$ dos domić́lios dos referidos anos e cujas características foram apresentadas no capítulo anterior. Assim como mencionamos para outras localidades, acreditamos ser essa diferença indicativa da presença de muitos donos de escravos não proprietários de terras, ou seja, de indivíduos que viviam e mantinha suas atividades produtivas em terras de terceiros. Esses senhores de escravos sem terras seriam cerca de $11 \%$ dos chefes de fogo nazareanos.

Tabela III.36

Distribuição das faixas de tamanho das propriedades entre propriedades com e sem escravos

(Nazaré - 1818)

\begin{tabular}{|c|c|c|c|c|c|}
\hline \multirow{2}{*}{$\begin{array}{l}\text { Tamanho das } \\
\text { propriedades * }\end{array}$} & \multicolumn{3}{|c|}{ Propriedades com escravos ${ }^{\star *}$} & \multicolumn{2}{|c|}{ Propriedades sem escravos } \\
\hline & \% (Número) & $\begin{array}{c}\text { Área* } \\
\% \text { (total) }\end{array}$ & $\begin{array}{l}\text { Média de } \\
\text { escravos }\end{array}$ & \% (Número) & $\begin{array}{c}\text { Área* }^{*} \\
\% \text { (total) }\end{array}$ \\
\hline $0-50$ & $17,6(33)$ & $20,5(680,6)$ & 4,4 & $82,4(154,0)$ & $79,5(2632,5)$ \\
\hline $50,1-100$ & $26,1(6)$ & $26,4(460,0)$ & 3,2 & $73,9(17,0)$ & $73,6(1280,9)$ \\
\hline $100,1-300$ & $32,6(14)$ & $34,7(2373,0)$ & 5,1 & $67,4(29,0)$ & $65,3(4473,8)$ \\
\hline $300,1-500$ & $58,3(7)$ & $58,1(2965,0)$ & 6,6 & $41,7(5,0)$ & $41,9(2137,5)$ \\
\hline $500,1-1000$ & $100,0(1)$ & $100,0(675,0)$ & 9,0 & - & - \\
\hline 1000,1 ou mais & $66,7(2)$ & $83,3(9000,0)$ & 13,5 & $33,3(1,0)$ & $16,7(1800,0)$ \\
\hline Total & $23,4(63)$ & $56,7(16153,6)$ & 5,1 & $76,6(206,0)$ & $43,3(12324,6)$ \\
\hline
\end{tabular}

\footnotetext{
${ }^{75}$ A correlação entre escravos e área das propriedades foi positiva e igual 0,44 , valor pouco elevado.
} 
Tabela III.37

Distribuição das propriedades com e sem escravos de acordo com faixas de tamanho das propriedades

(Nazaré - 1818)

\begin{tabular}{|c|c|c|c|c|}
\hline \multirow[b]{2}{*}{$\begin{array}{l}\text { Tamanho das } \\
\text { propriedades * }\end{array}$} & \multicolumn{2}{|c|}{ Propriedades com escravos ${ }^{\star \star}$} & \multicolumn{2}{|c|}{ Propriedades sem escravos } \\
\hline & \% (Número) & $\begin{array}{c}\text { Área* }^{*} \\
\% \text { (total) }\end{array}$ & \% (Número) & $\begin{array}{c}\text { Área* }^{*} \\
\% \text { (total) }\end{array}$ \\
\hline $0-50$ & $52,4(33)$ & $4,2(680,6)$ & $74,8(154,0)$ & $21,4(2632,5)$ \\
\hline $50,1-100$ & $9,5(6)$ & $2,8(460,0)$ & $8,3(17,0)$ & $10,4(1280,9)$ \\
\hline $100,1-300$ & $22,2(14)$ & $14,7(2373,0)$ & $14,1(29,0)$ & $36,3(4473,8)$ \\
\hline $300,1-500$ & $11,1(7)$ & $18,4(2965,0)$ & $2,4(5,0)$ & $17,3(2137,5)$ \\
\hline $500,1-1000$ & $1,6(1)$ & $4,2(675,0)$ & - & - \\
\hline 1000,1 ou mais & $3,2(2)$ & $55,7(9000,0)$ & $0,5(1,0)$ & $14,6(1800,0)$ \\
\hline Total & $100,0(63)$ & $100,0(16153,6)$ & $100,0(206,0)$ & $100,0(12324,6)$ \\
\hline
\end{tabular}

${ }^{*}$ Em alqueires paulistas

${ }^{\star *}$ Exclusive 2 propriedades com áreas não explicitadas

Fonte: AESP, Inventário de Bens Rústicos, Nazaré:1818

Tabela III.38

Fogos de acordo com a posse de terras e escravos

(Nazaré - 1816, 1818, 1820)

\begin{tabular}{|c|c|c|c|}
\hline & 1816 & 1818 & 1820 \\
\hline Número total de propriedades rurais & & 271 & \\
\hline Número $(\%)$ de propriedades rurais com escravos & & $65(24,0 \%)$ & \\
\hline Número total de escravos no tombamento de terras & & 323 & \\
\hline Número total de fogos & 715 & & 751 \\
\hline Número (\%) de fogos com escravos & $141(19,7 \%)$ & & $149(19,8 \%)$ \\
\hline Número total de escravos na lista nominativa & 624 & & 724 \\
\hline$\%$ de fogos com terras & $37,90 \%$ & & $36,10 \%$ \\
\hline$\%$ de chefes de fogo com terras e escravos & $9,1 \%$ & & $8,7 \%$ \\
\hline$\%$ de chefes de fogo sem terras e com escravos & $10,6 \%$ & & $11,2 \%$ \\
\hline$\%$ de chefes de fogo com terra e sem escravos & $28,8 \%$ & & $27,4 \%$ \\
\hline$\%$ de chefes de fogo sem terras e sem escravos & $51,5 \%$ & & $52,7 \%$ \\
\hline
\end{tabular}

Fontes: AESP, Inventário de Bens Rústicos, Nazaré:1818 e AESP, Maços de População, Nazaré: 1816,1820 
Este grupo era, todavia, bastante inferior àquele predominante: os chefes de fogo sem terras e sem escravos eram majoritários, 51,5\% e 52,7\% considerando, respectivamente 1816 e 1820. Grupo este que só poderia contar com trabalho familiar e, eventualmente, de agregados para manter suas atividades produtivas. O segundo principal grupo era formado por 27,4\% (1816) - 27,4\% (1820) dos domicílios, estabelecidos em glebas próprias, mas que também utilizavam trabalho familiar.

Os chefes de fogo com terras e escravos, eram apenas em torno de $9 \%$ do total e possivelmente representavam a parcela mais abastada da sociedade local. Possuíam escravos, o bem mais valioso naquele tempo e terras, que embora apresentassem, $a$ priori, baixo valor monetário, este poderia ser aumentado em função da presença de benfeitorias ou de uma possível expansão da produção comercial. 


\section{Mogi das Cruzes}

No registro de bens rústicos de Mogi das Cruzes encontramos 636 declarações que correspondem a igual número de propriedades, incluindo 30 declarações concernentes à freguesia de Santa Isabel. A quase totalidade das glebas pertencia a proprietários individuais, sendo única exceção a propriedade de 142,5 alqueires que Angelo Joaquim e Inácio Jose Ribeiro possuíam em conjunto na "fazenda" Paraitinga. Doze propriedades $(1,9 \%)$ tinham donos ausentes - os locais de moradia são ignorados. O absenteísmo, portanto, era de muito pouca significação em Santa Ana das Cruzes de Mogi, assim como foi nas localidades anteriormente assinaladas.

Mantinham, todavia, esses donos de terras em suas propriedades, cativos. Apenas Jeronimo Francisco de Morais não vivia em suas terras e não mantinha nelas um escravo sequer, tendo declarado não estar a referida propriedade em cultura, única em Mogi com esta condição. ${ }^{76}$ Onze propriedades tinham até 24 alqueires paulistas e uma única, pertencente a João Mariano Franco era mais extensa, 240 alqueires. $^{77}$

Entre as 636 propriedades arroladas temos $628 \mathrm{com}$ a área explicitada que, em conjunto conformam uma área total de 11325,2 alqueires paulistas. A Tabela III.39 apresenta o padrão de distribuição das propriedades mogianas de acordo com faixas de tamanho das glebas e a área para o tamanho desses terrenos.

Ao verificar o peso dos diferentes segmentos de área percebemos o predomínio, na Mogi das Cruzes de 1818, de uma estrutura fundiária de pequenas propriedades, com o inventário de bens rústicos apontando $91,2 \%$ das terras com até 50 alqueires paulistas de extensão e outras 5,9\% ocupando áreas entre 50 e 100 alqueires. A média calculada para o total das propriedades foi de 18 alqueires, sendo a mediana 7,5 e o tamanho de propriedade mais comumente encontrado, a moda, de apenas 2 alqueires, correspondente a um total de 49 propriedades (7,8\% das 628 declarações com área), número bastante próximo daquelas propriedades com 4 alqueires, $47 .^{78}$

\footnotetext{
${ }^{76}$ Essas características inviabilizam qualquer análise pretendida acerca da utilização das terras e/ou da comparação entre senhores de terras com e sem cativos.

77 Encontramos 25 nomes que correspondem a duas ou três propriedades, somando 59 glebas. Em nenhum caso podemos afirmar com total segurança tratar-se de um mesmo proprietário, ainda que a existência de donos de mais de uma gleba devesse ocorrer. Nenhum dos casos corresponde a terrenos situados no mesmo bairro e à exceção de Angelo Rodrigues e Antonio Jose Fernandes, cujos nomes apareceram três vezes e um dos casos foi declarado não residência na respectiva propriedade, todos os demais declarantes apontaram viver nas suas terras.

78 Aparecem também em número considerável as propriedades de meio alqueire que responderam por 26 casos, 1 alqueire (30 casos), 3 alqueires (25), 4 (47), 6 (26), 7,5 (35), 12 (23), 15 (31) e 30 (26).
} 
Tabela III.39

Distribuição das propriedades de acordo com faixas de tamanho

(Mogi - 1818)

\begin{tabular}{|c|c|c|c|c|c|}
\hline $\begin{array}{l}\text { Tamanho das } \\
\text { propriedades * }\end{array}$ & $\%$ (Número) & $\begin{array}{c}\text { Área* } \\
\% \text { (total) }\end{array}$ & Área média* & Área modal ${ }^{\star}$ & I. Gini ${ }^{*}$ \\
\hline $0-50$ & $91,2(573)$ & $52,2(5913,600)$ & 10,3 & 2,0 & 0,557 \\
\hline $50,1-100$ & 5,9 (37) & $21,9(2475,450)$ & 66,9 & 60,0 & 0,103 \\
\hline $100,1-300$ & $2,5(16)$ & $19,9(2259,150)$ & 141,2 & 120,0 & 0,116 \\
\hline $300,1-500$ & $0,3(2)$ & $6,0(677,000)$ & 338,5 & - & 0,027 \\
\hline Total & $100,0(628)$ & $100,0(11325,200)$ & 18,0 & 2,0 & 0,667 \\
\hline
\end{tabular}

Ainda que representem a maioria absoluta das propriedades, conjuntamente a área ocupada por esses pequenos terrenos de até 50 alqueires correspondia a tão somente 52,2\% dos mais de 11 mil alqueires paulistas arrolados para a vila. As propriedades com 50 a 100 alqueires ocupavam $21,9 \%$ da área enquanto as propriedades acima de 100 alqueires, em número de 18 sendo a maior delas de 338,5 alqueires, consumiam praticamente $26 \%$ da extensão de Mogi, refletindo em um Índice de Gini elevado, 0,667.

Pudemos identificar no inventário de bens rústicos 635 propriedades com forma de aquisição explicitada para Mogi das Cruzes com sua freguesia de Santa Isabel; eram 606 glebas na própria vila e 29 na freguesia, sendo que para oito delas a área não foi arrolada (Tabelas III.40 e III.41).

Desconsiderando aquelas propriedades cuja área não pôde ser identificada, pouco menos de $68 \%$ das propriedades foram adquiridas com recurso ao mercado fundiário, que abarcou $93,3 \%$ da extensão total mogiana. As posses foram a segunda maneira mais considerável de se ascender à condição de senhor de terras rurais tendo sido encontrada em $18,3 \%$ das declarações, percentual cinco pontos superior àquele calculado para os terrenos herdados $(13,1 \%)$. Tiveram representação diminuta as demais maneiras de apropriação: uma gleba apontada como "patrimônio" e duas propriedades doadas, sendo identificada uma como esmola - 0,120 alqueires paulistas no bairro da Capela pertencentes a Jacinto da Silva -, e outra como dádiva - Joaquim Joze de Santana possuía 15 alqueires nessa condição. 
Tabela III.40

Formas de aquisição das propriedades de acordo com faixas de tamanho (Mogi - 1818)

\begin{tabular}{|c|c|c|c|c|c|c|}
\hline \multirow{2}{*}{$\begin{array}{l}\text { Tamanho das } \\
\text { propriedades * }\end{array}$} & \multicolumn{6}{|c|}{$\begin{array}{l}\text { Formas de aquisição** } \\
\% \text { (Número) }\end{array}$} \\
\hline & Compra & Herança & Doação & Posse & Outras & Total \\
\hline $0-50$ & 65,1 (373) & $13,6(78)$ & $0,3(2)$ & $19,9(114)$ & $0,9(6)$ & $100,0(573)$ \\
\hline $50,1-100$ & 86,5 (32) & $10,8(4)$ & - & 2,7 (1) & - & $100,0(37)$ \\
\hline $100,1-300$ & $100,0(16)$ & - & - & - & - & $100,0(16)$ \\
\hline $300,1-500$ & 100,0 & - & - & - & - & 100,0 \\
\hline Total & $67,3(422)$ & 13,1 (82) & $0,3(2)$ & $18,3(115)$ & $1,0(6)$ & 100,0 \\
\hline
\end{tabular}

Tabela III.41

Indicadores estatísticos de propriedades adquiridas por compra, herança e posse

(Mogi - 1818)

\begin{tabular}{lcccccccc}
\hline \hline & Número & Área média & $\begin{array}{c}\text { Desvio } \\
\text { padrão }\end{array}$ & Moda & Mediana & $\begin{array}{c}\text { Índice de } \\
\text { Gini }\end{array}$ & $\begin{array}{c}\text { Menor } \\
\text { propriedade }\end{array}$ & $\begin{array}{c}\text { Maior } \\
\text { propriedade }\end{array}$ \\
\hline Compra & 422 & 22,5 & 38,0 & 7,5 & 8,0 & 0,655 & 0,08 & 357,0 \\
Herança & 82 & 9,8 & 15,0 & 4,0 & 4,0 & 0,632 & 0,20 & 75,0 \\
Posse & 115 & 7,6 & 8,9 & 2,0 & 4,0 & 0,546 & 0,18 & 52,5 \\
\hline \hline
\end{tabular}

Em alqueires paulistas

Fonte: AESP, Inventário de Bens Rústicos, Mogi das Cruzes:1818

Interessante notar que dentre as propriedades sem área explicitada, sete estavam em Santa Isabel e ainda que cinco delas, sob a rubrica "títulos por que possuem" tenham indicado escritura, que aqui consideramos como compra, todas apresentaram sob a rubrica "braças de testada", que para as demais localidades indicava o valor de uma das faces do terreno, simplesmente a referência "posses", sendo três delas pertencentes a senhores de escravos. É possível que essas terras tivessem sido adquiridas por posse em período relativamente recente, não sendo suas medidas conhecidas com exatidão.

A única propriedade pra a qual não pudemos verificar a área e que estava arrolada entre as propriedades de Mogi propriamente foi declarada por Bento de Souza Brito, que possuía por "escritura" (compra) 200 braças de testada "com o sertão que se achar" na "fazenda" Taboão (cf. Mapa das terras que possuem os habitantes da Vila de Mogi das Cruzes. 1818 - AESP, Tombamento/ C09868 ), bairro limite a Santa Isabel. 
Uma única menção a sesmaria foi encontrada, o que não surpreende posto ser Mogi das Cruzes localidade de ocupação mais antiga entre aquelas que observamos e uma das mais antigas do planalto paulista (cf. apêndice 1), sendo suas terras ocupadas no início do século XVII, quando foram doadas as primeiras sesmarias e possivelmente em maior número, dada a grande disponibilidade de terras devolutas e certamente disponíveis naquele momento. Para o Seiscentos

Temos trinta e quatro registros de cartas de doações de sesmarias nos arredores de Mogi, sendo a primeira datada de 1608, e a última, de 1641. Desse total, quinze foram dadas antes de se fundar a vila, e o restante depois. Parece que a partir de 1641 não foram doadas mais terras nesta região até 1700, quando surgem outras poucas cartas registradas. [...] A maioria dos registros atesta a cessão de meia a uma légua e meia em quadra de terras. (DIAS, 2001, p.74)

A antiga ocupação da área mogiana pode justificar as pequenas propriedades encontradas na primeira década do século XIX, resultado de sucessivos desmembramentos que naturalmente ocorriam via transmissão por espólio ou venda, ou até mesmo, na ausência de efetivo aproveitamento econômico da área, a posse em frações bem mais reduzidas das mesmas terras por outrem.

Acha-se entre essas pequenas propriedades, inclusive, a sesmaria a que nos referimos, situada em Biritiba, era pertencente ao capitão Manoel Barbosa de Melo que ali não residia e ocupava uma área de apenas 12 alqueires paulistas - muito inferior ao que se imagina para uma sesmaria -, em cultura com dois escravos.

A área média das terras possuídas por compra era de 22,5 alqueires paulistas, enquanto entre aquelas provenientes de posses era de apenas 7,6 e de heranças era de 9,8 alqueires paulistas. Em regra, as propriedades transacionadas, em sua maior parte ocupavam 7,5 alqueires, sendo de 8 alqueires a mediana, pouco superior aos 4 alqueires paulistas encontrados para a moda que iguala a medida das glebas herdadas. Para as posses as estatísticas indicam moda igual a 2 e mediana 4.

Diferença considerável encontramos, todavia, nas áreas das maiores propriedades para cada uma dos formas de acesso á terra: 52,5 para posses, 75 para heranças e 357 para compras. Assim, os índices de gini para compras e heranças foi superior ao calculado para as posses, 0,545, uma concentração média tendendo levemente a forte, que considerada conjuntamente como o menor desvio padrão, também encontrado para as posses, indica as propriedades assim adquiridas tinham características mais próximas.

Sendo mais de $96 \%$ das propriedades com tamanho identificado localizadas em Mogi propriamente, o total delas (Mogi mais Santa Isabel) corresponde aos valores 
encontrados para a vila. Considerando separadamente a vila de Santa Ana das Cruzes e sua freguesia de Santa Isabel, encontramos áreas comparativamente maiores na freguesia, conforme se observa nas estatísticas expostas na Tabela III.42. Ainda que a maior propriedade de Santa Isabel (162 alqueires) tenha menos da metade da extensão compreendida pela maior propriedade de Mogi, seus terrenos tinham em média 42,4 alqueires paulistas, com moda e mediana 30 alqueires. A menor gleba registradas em Santa Isabel tinha 7,5 alqueires paulistas, equivalente a quase quatro vezes a área mais comumente encontrada para Mogi propriamente, 2 alqueires.

Tabela III.42

Indicadores estatísticos de propriedades de Mogi das Cruzes e Santa Isabel

(1818)

\begin{tabular}{|c|c|c|c|c|c|c|c|c|}
\hline & Número* & Área média & $\begin{array}{l}\text { Desvio } \\
\text { padrão }\end{array}$ & Moda & Mediana & $\begin{array}{c}\text { Índice de } \\
\text { Gini }\end{array}$ & $\begin{array}{c}\text { Menor } \\
\text { propriedade }\end{array}$ & $\begin{array}{c}\text { Maior } \\
\text { propriedade }\end{array}$ \\
\hline MOGI & 605 & 17,1 & 31,8 & 2,0 & 6,5 & 0,670 & 0,08 & 357,0 \\
\hline SANTA ISABEL & 23 & 42,4 & 45,4 & 30,0 & 30,0 & 0,502 & 7,50 & 162,0 \\
\hline
\end{tabular}

Observando a forma de aquisição das áreas rurais de acordo com o sexo do declarante, como exposto na Tabela III.43, podemos considerar que homens e mulheres tinham acesso aos terrenos via mercado fundiário. Entre os indivíduos do sexo masculino $66,1 \%$ mencionaram possuir escritura, entendidas aqui como compras, percentual que foi ainda mais elevado entre as mulheres, cerca de $77 \%$ delas tinham propriedades compradas. Diferença considerável entre os sexos encontramos nas heranças, responsáveis por $14,4 \%$ das terras sob responsabilidade masculina e $3,5 \%$ daquelas 86 propriedades em mãos femininas.

Os índices de Gini, considerados os sexos separadamente, eram próximos aos verificados para o termo da vila como um todo: 0,608 para as terras pertencentes a homens e 0,652 para as terras pertencentes a mulheres. Enquanto a área média calculada para os homens foi de 16,9 alqueires paulistas, para as mulheres esteve em 23,9 alqueires, sendo as modas iguais a 2 e as medianas ( 7 e 10,6 para homens e mulheres, respectivamente) bastante próximas, assim como observado para os limites 
das distribuições, cujo valor superior foi de 457 alqueires entre os senhores de terras homens e 320 alqueires para o sexo oposto.

\section{Tabela III.43}

Formas de aquisição das propriedades e estatísticas para o tamanho de acordo com o sexo do proprietário

(Mogi - 1818)

\begin{tabular}{|c|c|c|c|c|c|}
\hline $\begin{array}{c}\text { Formas de } \\
\text { aquisição }\end{array}$ & Homens* & Muheres & Estatísticas & Homens ${ }^{\star \star}$ & Muheres \\
\hline Compra & $66,1(362)$ & $76,7(66)$ & Área média & 16,9 & 23,9 \\
\hline Herança & $14,4(79)$ & $3,5(3)$ & Desvio padrão & 30,2 & 43 \\
\hline Doação & $0,4(2)$ & - & Moda & 2,0 & 2,0 \\
\hline Sesmaria & $0,2(1)$ & - & Mediana & 7,0 & 10,6 \\
\hline Posse & $18,1(99)$ & $19,8(17)$ & I. Gini & 0,608 & 0,654 \\
\hline Outras & $0,9(5)$ & - & Menor propriedade & 0,12 & 0,08 \\
\hline Total & $100,0(548)$ & $100,0(86)$ & Maior propriedade & 320,0 & 320,0 \\
\hline \multicolumn{6}{|c|}{ Exclusive 1 pro priedade pertencente a mais de 1indivíduo } \\
\hline $\begin{array}{l}\text { Exclusive } 1 \text { pro prieda } \\
\text { Exclusive } 8 \text { propriec } \\
\text { onte: AESP, Inventá }\end{array}$ & $\begin{array}{l}\text { forma de aquisiç } \\
\text { m áreas não exp } \\
\text { ens Rústicos, } M\end{array}$ & $\begin{array}{l}\text { âo especificada } \\
\text { das } \\
\text { as Cruzes:1818 }\end{array}$ & & & \\
\hline
\end{tabular}

Em Mogi/Santa Isabel praticamente 30\% (188) dos terrenos contavam com a mãode-obra de escravos. Essas propriedades relacionadas em que cativos foram listados ocupavam uma área de 6549,045 alqueires paulistas, ou seja, 57,8\% da área arrolada no tombamento em tela, já indicando serem os terrenos com escravos, em média mais extensos que aqueles que utilizam trabalho livre. As dominantes pequenas propriedades apresentaram distribuição próxima ao total, sendo encontrados cativos em $26 \%$ delas, onde foram contados em número de 424. Comparados ao número total de escravos arrolados, estavam nas mãos dos pequenos senhores rurais $70,3 \%$ dos mancípios, percentual que acompanhava em certa medida o representado por estas propriedades entre as propriedades com trabalho compulsório, 79,3\%. O maior plantel relacionado aos 
menores terrenos rurais era composto por 15 indivíduos, sendo a moda igual a 1 , encontrada em 57 glebas.

A observação do número médio de escravos ligados a distintas faixas de tamanho das propriedades aponta crescimento de acordo com o aumento da área considerada, sendo de 2,9 para as menores propriedades, atingindo 4,1 entre as propriedades de 50,1 a 100 alqueires e 5,9 na faixa seguinte. Ana de Godoi foi a única proprietária com terras acima de 300 alqueires com escravos, eram dois. A maior propriedade local, 357 alqueires pertencentes a Pedro Jose da Cunha, não era trabalhada por cativos. A correlação escravos-áreas das propriedades foi positiva, mas baixa: 0,36.

Se comparados o total de fogos declarados e a presença de cativos nesses domicílios, verificamos que as propriedades arroladas no inventário de bens rústicos correspondem a $45,4 \%$ dos fogos encontrados no arrolamento populacional se a comparação for levada a cabo com dados de 1820, e 43,3\% se considerado o ano 1816, para o qual o percentual dos chefes de fogo que não possuíam escravos e também não terras era pouco acima do mencionado: $46,8 \%$. Ou seja, grande parte dos fogos não possuía nenhum dos dois principais fatores produtivos do Oitocentos: terra e trabalho escravo.

Tabela III.44

Distribuição das faixas de tamanho das propriedades entre propriedades com e sem escravos

(Mogi - 1818)

\begin{tabular}{|c|c|c|c|c|c|}
\hline \multirow{2}{*}{$\begin{array}{l}\text { Tamanho das } \\
\text { propriedades * }\end{array}$} & \multicolumn{3}{|c|}{ Propriedades com escravos $^{\star \star}$} & \multicolumn{2}{|c|}{ Propriedades sem escravos ${ }^{* \star}$} \\
\hline & \% (Número) & $\begin{array}{c}\text { Área }^{*} \\
\% \text { (total) }\end{array}$ & $\begin{array}{l}\text { Média de } \\
\text { escravos }\end{array}$ & \% (Número) & $\begin{array}{c}\text { Área }^{*} \\
\% \text { (total) }\end{array}$ \\
\hline $0-50$ & $26,0(149)$ & $46,0(2718,895)$ & 2,9 & $74,0(424)$ & $54,0(3194,7)$ \\
\hline $50,1-100$ & $70,3(26)$ & $71,9(1780,500)$ & 4,1 & $29,7(11)$ & $28,1 \quad(695,0)$ \\
\hline $100,1-300$ & $75,0(12)$ & $76,6(1729,650)$ & 5,9 & $25,0(4)$ & $23,4(529,5)$ \\
\hline $300,1-500$ & $50,0(1)$ & $47,3(320,000)$ & 2,0 & $50,0(1)$ & $52,7(357,0)$ \\
\hline Total & $29,9(188)$ & $57,8(6549,045)$ & 3,2 & $70,1(440)$ & $42,2(4776,2)$ \\
\hline
\end{tabular}


Tabela III.45

Distribuição das propriedades com e sem escravos de acordo com faixas de tamanho das propriedades

(Mogi - 1818)

\begin{tabular}{|c|c|c|c|c|}
\hline \multirow{2}{*}{$\begin{array}{l}\text { Tamanho das } \\
\text { propriedades * }\end{array}$} & \multicolumn{2}{|c|}{ Propriedades com escravos ${ }^{\star \star}$} & \multicolumn{2}{|c|}{ Propriedades sem escravos $^{\star \star}$} \\
\hline & \% (Número) & $\begin{array}{c}\text { Área* }^{*} \\
\% \text { (total) }\end{array}$ & \% (Número) & $\begin{array}{c}\text { Área* }^{*} \\
\% \text { (total) }\end{array}$ \\
\hline $0-50$ & $79,3(149)$ & $41,5(2718,9)$ & $96,4(424)$ & $66,9(3194,7)$ \\
\hline $50,1-100$ & $13,8(26)$ & $27,2(1780,5)$ & $2,5(11)$ & $14,6(695,0)$ \\
\hline $100,1-300$ & $6,4(12)$ & $26,4(1729,7)$ & $0,9(4)$ & $11,1(529,5)$ \\
\hline $300,1-500$ & $0,5(1)$ & $4,9(320,0)$ & $0,2(1)$ & $7,5(357,0)$ \\
\hline Total & $100,0(188)$ & $100,0(6549,0)$ & $100,0(440)$ & $100,0(4776,2)$ \\
\hline
\end{tabular}

Mais de $30 \%$ dos domicílios eram constituídos em terras próprias, mas sem a posse de cativos. Estes domicílios e a parcela da população a eles diretamente vinculados não deveriam ser, na realidade, mais despossuídos comparativamente aos não detentores de glebas rurais, cujo trabalho em tais terras era exclusivamente livre, sabendo quase $75 \%$ dos proprietários de terras sem cativos tinham pequenas propriedades, que em média ocupavam, como sabido, pouco menos de 11 alqueires paulistas, o que não permitiria grandes culturas, especialmente na ausência de farta mãode-obra.

O menor percentual era devido àqueles domicílios sem terras e com escravos: 9,9\% com base de comparação em 1816 e 10,8\% se observamos os domicílios da Vila de Mogi das Cruzes com sua freguesia de Santa Isabel em 1820. A parcela mais abastada da população, em se tendo terras e cativos como proxy, correspondia a $13-14 \%$ dos chefes de fogo e seus respectivos domicílios. 
Tabela III.46

Fogos de acordo com a posse de terras e escravos

(Mogi - 1816, 1818, 1820)

\begin{tabular}{|c|c|c|c|}
\hline & 1816 & 1818 & 1820 \\
\hline Número total de propriedades rurais & & 636 & \\
\hline Número (\%) de propriedades rurais com escravos & & $192(30,2 \%)$ & \\
\hline Número total de escravos no tombamento de terras & & 616 & \\
\hline Número total de fogos & 1402 & & 1467 \\
\hline Número (\%) de fogos com escravos & $337(24 \%)$ & & $343(23,4 \%)$ \\
\hline Número total de escravos na lista nominativa & 1617 & & 1497 \\
\hline$\%$ de fogos com terras & $43,3 \%$ & & $45,4 \%$ \\
\hline$\%$ de chefes de fogo com terras e escravos & $13,7 \%$ & & $13,1 \%$ \\
\hline$\%$ de chefes de fogo sem terras e com escravos & $10,3 \%$ & & $10,3 \%$ \\
\hline$\%$ de chefes de fogo com terra e sem escravos & $31,7 \%$ & & $30,3 \%$ \\
\hline$\%$ de chefes de fogo sem terras e sem escravos & $44,3 \%$ & & $46,4 \%$ \\
\hline
\end{tabular}

Fontes: AESP, Inventário de Bens Rústicos, Mogi das Cruzes:1818 e AESP, Maços de População, Mogi das Cruzes: 1816.1820 


\section{Jacareí}

Encontramos listadas na "Relação dos habitantes do termo da vila de Jacareí, que possuem terras, e que vai declarado o lugar, e a extensão das terras que possuem, tanto de testada como de fundo, e os seus títulos se esta ou não em cultura, escravos que possuem, e onde reside" 577 propriedades - 75 localizadas na freguesia de Paraibuna -, ${ }^{79}$ uma com área não identificada, e as demais somando 34583,075 alqueires paulistas. Para todas as glebas havia descrito "está em cultura", o que deveria incluir também a criação.

Cinco entre os proprietários mencionaram residir na Vila. Entre eles estava, de acordo com o recenseamento de 1816, um tecelão, João Leite dos Santos, com 9,88 alqueires; Salvador Machado de Lima que tinha "seu negócio de contrato de dízimo" e os três capitães apontados nos capítulos anteriores como os maiores escravistas de Jundiaí (excluída Paraibuna) - posição que mantêm também no arrolamento de terras -, e produtores de milho, feijão, algodão, fumo, arroz e porcos nas suas terras que tinham ao menos 112,5 alqueires paulistas. Para os demais proprietários, na coluna "onde reside" foi mencionado "no mesmo sítio".

Com $83,2 \%$ de suas propriedades com tamanhos que não ultrapassavam os 50 alqueires paulistas respondendo conjuntamente por $15,2 \%$ da área total arrolada no município e outras seis grandes propriedades, não mais de $1 \%$ daquelas com dimensões encontradas, estendendo-se por mais de $38 \%$ de sua área, Jacareí apresenta uma concentração realmente forte no que tange à extensão das várias propriedades no interior de suas fronteiras. Merecem destaque também, corroborando tal concentração, aquelas glebas entre 100 e 500 alqueires paulistas, ocupantes de $36,1 \%$ da área jacareiense, ainda que não chegassem a $11 \%$ do número total das terras.(cf. Tabela III.47) Assim, o índice de Gini calculado para a localidade foi bastante elevado, 0,836. ${ }^{80}$

Note-se, todavia, que as cinco maiores propriedades de Jacareí, localizavam-se, na realidade, na freguesia de Paraibuna e representavam $6,7 \%$ das propriedades com áreas identificadas naquela localidade, restando apenas uma, dentre as 501 propriedades de Jacareí propriamente dita, com extensão acima de 1000 alqueires paulistas.

\footnotetext{
${ }^{79}$ Uma análise pensada em proprietários não se apresenta viável pois, mesmo na presença de 26 nomes que apareceram entre duas e quatro vezes, não foi possível confirmar tratarem-se dos mesmos indivíduos. Esses nomes correspondem a 57 propriedades.

${ }^{80} \mathrm{~A}$ concentração encontrada em Jacareí é bastante próxima àquela verificada para o município de Taubaté, limítrofe a Jacareí."Cerca de 66,3\% dos proprietários, que possuíam imóveis de até 48,4 há, com uma área média de 12,4 ha, apropriavam-se de 4,7\% da área total. Em contrapartida, os 34 maiores proprietários, com imóveis acima de 500 há, controlavam $72,5 \%$ da área total. O índice de concentração de Gini atingia 0,86." (RANGEL, 1998, p.359)
} 
Observada separadamente, a freguesia de Paraibuna apresenta Gini de 0,787 e, excluída esta, temos praticamente o mesmo índice para Jacareí, 0,793.

Tabela III.47

Distribuição das propriedades de acordo com faixas de tamanho (Jacareí - 1818)

\begin{tabular}{|c|c|c|c|c|c|}
\hline $\begin{array}{l}\text { Tamanho das } \\
\text { propriedades * }\end{array}$ & $\%$ (Número)* $^{*}$ & $\begin{array}{c}\text { Área* } \\
\% \text { (total) }\end{array}$ & Área média* & Área modal* & I.Gini ${ }^{\star \star}$ \\
\hline $0-50$ & $83,2(479)$ & $15,2(5269,3)$ & 11,0 & 2,0 & 0,571 \\
\hline $50,1-100$ & $4,7(27)$ & $5,7(1962,8)$ & 72,7 & 60,0 & 0,182 \\
\hline $100,1-300$ & $9,2(53)$ & $24,5(8478,0)$ & 160,0 & 112,5 & 0,109 \\
\hline $300,1-500$ & $1,6(9)$ & $11,6(4020,0)$ & 446,7 & 450,0 & 0,007 \\
\hline $500,1-1000$ & $0,3(2)$ & $4,7(1620,0)$ & 810,0 & - & 0,056 \\
\hline 1000,1 ou mais & $1,0(6)$ & $38,3(13233,0)$ & 2205,5 & 1188 & 0,260 \\
\hline Total & $100,0(576)$ & $100,0(34583,1)$ & 60,0 & 2,0 & 0,836 \\
\hline
\end{tabular}

"Em alqueires paulistas, exclusive 1pro priedade com área não explicitada

Fonte: AESP, Inventário de Bens Rústicos, Jacareí:1818

As menores propriedades encontradas em Jacareí/Paraibuna - em número de sete, sendo seis no Bairro do Mato Dentro - tinham cerca de 0,08 alqueires, valor abaixo da moda, calculada em apenas 2 alqueires (coincidente com a menor propriedade de Paraibuna) e da mediana que situou-se em 8 alqueires. A média, dada a presença de terrenos extensos, alçou-se a 60 alqueires, com desvio padrão de 261,4. Excluindo-se as propriedades de Paraibuna a média cai a 33,9 alqueires, sendo que para a referida freguesia a área média alcançou 234,8 alqueires, com moda em 32 e 225 alqueires, e mediana de 45 alqueires.

Pertencia ao "reverendo padre" Valério de Alvarenga Ferreira e sua comp ${ }^{a}$ Jacinta Maria a maior propriedade de Paraibuna, com 4050 alqueires paulistas, 23\% da extensão de terras descritas na freguesia - $11,7 \%$ se consideradas também as terras jacareienses. Terras estas, como sabemos, dedicada à plantação em larga escala o café.

As 501 propriedades jacareienses ocupavam uma área correspondente a 96,3\% da área ocupada pelas 75 propriedades paraibunenses com tamanho descrito. Senão todas, ao menos algumas propriedades eram realmente maiores em Paraibuna que em Jacareí, e a presença dessas grandes propriedades só era possível na existência de áreas disponíveis. Ademais, Paraibuna apresentava propriedades mais espraiadas, declaradas em 12 "bairros" distintos, que Jacareí a quem estava ligada administrativamente. 
De ocupação efetiva comparativamente recente, somente nas décadas finais do século XVIII buscou-se uma forma de povoar mais intensamente a região, que possuía, ainda, terras devolutas, "suficientes para estabelecer uma boa povoação". Em junho de 1773 o Capitão Geral de São Paulo, Morgado de Mateus, expediu ordem para que se povoasse a área da paragem chamada Santo Antônio da Barra do Paraibuna. Manoel Antonio de Carvalho, então sargento-mor e juiz de demarcações de Guaratinguetá ${ }^{81}$, tornou-se responsável pela administração da nova povoação e, conseqüentemente, pela organização e distribuição das terras. (ver apêndice 1)

Ainda que a historiografia local aponte que nenhum "morador" mostrou-se interessado em apresentar-se para ocupar a pretendida povoação, em 1775 foi concedida sesmaria nas "terras que lhe tinha demarcado o fundador da mesma Manoel Antonio Carvalho". Receberam-na

João Simões Tavares, Manoel Garcia Rosa, Manuel da Mota e José Pereira povoadores da nova povoação de Santo Antonio da Barra de Paraibuna a eles the determinou o fundador da mesma povoação uma légua de terras em quadra no fim das terras de Mariana Cardoza de Camargo seguindo os rumos das terras de sua confinante para cada um dos quatro sócios setecentas e cinquenta braças de testada uma légua de sertão como consta do despacho que junto vão do dito fundador e como os suplicantes na mesma petição possuir [sic!] as ditas terras sem títulos de sesmaria me pediam lhe mandasse passar sua carta de sesmaria das referidas terras na forma da confrontação dos mesmos autos de medições e sendo visto seu requerimento em que se não ofereceu dúvida alguma [...] (AESP, Sesmarias, patentes e provisões/C00367, Livro 19, grifo nosso)

Ademais, no mesmo ano, receberam terras na forma de sesmaria, o padre José Gonçalves da Cunha, Mariana Cardoza de Camargo "e outros", todos

povoadores da nova povoação de Santo Antonio da Barra de Paraibuna que a eles suplicantes lhe demarcou o fundador da mesma povoação légua e meia de terras de testada principiando no Rio de Paraitinga aonde se acham as terras de Antonio Ferram de Carvalho seguindo a sua testada pelo rio abaixo para a parte de Paraibuna com suas léguas de sertão e uma para cada parte do rio [...] não oferece dúvida alguma aos confrontantes por se acharem as ditas terras repartidas medidas e demarcadas pelo sobredito fundador da dita povoação(AESP, Sesmarias, patentes e provisões/C00367, Livro 19, grifo nosso)

\footnotetext{
${ }^{81}$ O cargo de o juiz de sesmarias ou de demarcação foi criado para evitar problema e abusos no processo de demarcação de terras, o ocupante do posto era responsável legal pela medição e demarcação das terras.
} 
Em 1818, estas sesmarias não estavam entre as terras descritas no arrolamento de bens rústicos, onde identificamos sesmarias em número de quatro ao todo - duas em Paraibuna - e mais as terras de 1800 alqueires na região do Pouso Alto em Paraibuna, adquiridas por sesmaria e compra pelo coronel Manoel da Cunha. A menor dessas glebas tinha 26,4 alqueires e pertencia a Ana Clara Vieira, havia ainda uma propriedade de 112,5 alqueires nas mãos de Joze Antunes de Gusmão, 225 pertencentes a Francisco Xavier de Siqueira e 450 alqueires pertencentes a Thereza Maria de Jesus Vieira. Não pudemos encontrar os registros dessas quatro sesmarias, que apresentam extensões bastante inferiores àquelas comumente verificadas em cartas de sesmaria. Possivelmente sesmaria não havia sido a forma de aquisição dessas terras pelos seus detentores no momento da feitura do documento, cuja acesso a terra pode ter-se dado por herança.

Já o coronel Manoel da Cunha Azevedo Coutinho Souza Chichorro, Fidalgo cavalheiro da casa real, teve uma sesmaria registrada em 1808, posteriormente declarada sem efeito, pois quando se tentou realizar sua demarcação foi verificada a concessão na referida sesmaria de "outras a diversos sesmeiros", não sendo possível realizar a demarcação destas terras que correspondiam a "uma sesmaria de terras de duas léguas em quadra [...] e de outra mística que comprara ao cirurgião mor Tomás Gonçalves Gomide de uma légua em quadra" (cf. AESP, Sesmarias, patentes e provisões/C00373, Livro 34 e C00376, Livro 39).

Em conseqüência, o coronel requereu nova sesmaria, concedida em dezembro de 1815 na mesma região da "estrada que vai de serra acima para o porto de Santo Antonio de Caraguatatuba", cuja área passou a ser entrando para os sertões devolutos a partir do lado direito da estrada, correspondentes ao

terreno que vai desde o marco que o divide com o capitão mor Jose Ferreira de Castilho, e com o capitão mor de São Luiz Jose Gomes de Govea e Silva da parte esquerda da estrada, rumo direto para a parte do mar, até encontrar-se com o rio Negro, e que a distância achada se quadra sobre o lado direito para os sertões incultos, ficando este terreno assim quadrado somente pertencendo ao supra, com as voltas dos rios para seus logradouros. (AESP, Sesmarias, patentes e provisões/C00376, Livro 39)

Ainda que houvesse terras a serem ocupadas no território de Jacareí com seu distrito de Paraibuna, com possibilidades de requisição de sesmarias, nota-se de imediato o grande predomínio das compras entre as formas de aquisição das propriedades, conforme aponta a Tabela III.48 e seguinte. Foram $79 \%$ das propriedades e $84,1 \%$ da área total descrita no inventário de bens rústicos. Desconsiderada a freguesia os percentuais alçam-se, respectivamente, a $83,5 \%$ e $86,4 \%$; enquanto o número 
paraibunense de terrenos adquiridos por compra foi de 37 propriedades, $49,3 \%$ das terras que conjuntamente conformavam uma área de 14411,500 alqueires paulistas, $81,8 \%$ do total arrolado. A sua vez, os $9,9 \%$ correspondentes à participação das posses em Jacareí/Paraibuna atinge a cifra de $40 \%$ em Paraibuna e de apenas 5,4\% em Jacareí propriamente.

Tabela III.48

Formas de aquisição das propriedades de acordo com faixas de tamanho (Jacareí - 1818)

\begin{tabular}{|c|c|c|c|c|c|c|}
\hline \multirow{3}{*}{$\begin{array}{l}\text { Tamanho das } \\
\text { propriedades * }\end{array}$} & \multicolumn{6}{|c|}{ "Formas de aquisição** } \\
\hline & \multicolumn{6}{|c|}{ \%(Número) } \\
\hline & Compra & Herança & Posse & Sesmaria & Outras & Total \\
\hline $0-50$ & $77,9(373)$ & $11,9(57)$ & $84,2(48)$ & $0,2(1)$ & - & $90,0(479)$ \\
\hline $50,1-100$ & $81,5(22)$ & $3,7(1)$ & $7,0(4)$ & - & - & $85,2(27)$ \\
\hline $100,1-300$ & $86,8(46)$ & - & $8,8(5)$ & $3,8(2)$ & - & $90,6(53)$ \\
\hline $300,1-500$ & $88,9(8)$ & - & - & $11,1(1)$ & - & $100,0(9)$ \\
\hline $500,1-1000$ & $50,0(1)$ & $50,0(1)$ & - & - & - & $100,0(2)$ \\
\hline 1000,1 ou mais & $83,3(5)$ & - & - & - & $16,7(1)$ & $100,0(6)$ \\
\hline Total & $79,0(455)$ & $10,2(59)$ & $5700,0(57)$ & $0,7(4)$ & $0,2(1)$ & $90,1(576)$ \\
\hline
\end{tabular}

${ }^{*}$ Em alqueires paulistas

${ }^{\star \star}$ Exclusive 1propriedade com área não explicitada, adquirida por herança

Fonte: AESP, Inventário de Bens Rústicos, Jacareí:1818

Tabela III.49

Indicadores estatísticos de propriedades adquiridas por compra, herança e posse (Jacareí - 1818)

\begin{tabular}{lcccccccc}
\hline \hline & Número & Área média & $\begin{array}{c}\text { Desvio } \\
\text { padrão }\end{array}$ & Moda & Mediana & $\begin{array}{c}\text { Índice de } \\
\text { Gini }\end{array}$ & $\begin{array}{c}\text { Menor } \\
\text { propriedade }\end{array}$ & $\begin{array}{c}\text { Maior } \\
\text { propriedade }\end{array}$ \\
\hline Compra & 455 & 64,000 & 279,000 & 2,0 & 8,0 & 0,840 & 0,08 & 4050,0 \\
Herança & 59 & 20,810 & 93,228 & 8,0 & 7,50 & 0,803 & 0,08 & 720,0 \\
Posse & 57 & 29,218 & 33,116 & 32,0 & 16,0 & 0,552 & 0,08 & 120,0 \\
\hline \hline
\end{tabular}

Em alqueires paulistas

Fonte: AESP, Inventário de Bens Rústicos, Jacareí:1818

Desta maneira, verificamos que em Paraibuna, localidade com grandes áreas ainda devolutas, como adiantamos, parcela bastante elevada das propriedades havia sido adquirida por posse, sendo essas propriedades de menor extensão comparativamente àquelas negociadas, ocupavam proporcionalmente parcela menor das áreas povoadas na 
freguesia, enquanto na vila de Jacareí, era relativamente pequena a quantidade de terras assim possuídas, sobressaindo-se sobremaneira o mercado fundiário.

As terras comercializadas em Jacareí/Jundiaí perfaziam em média 64 alqueires, com moda 2, mediana 8 e desvio padrão de 279. Em Jacareí os valores são, em ordem, 35,08, 8 e 2. E para Paraibuna temos como área média 389,5 alqueires paulistas - acima do valor encontrado para o total dos terrenos da freguesia -, com 112,5 de mediana e 225,00 de área modal. A propriedade do padre foi adquirida por compra e, por corresponder a elevado percentual das terras da freguesa influenciou consideravelmente a média, que seria de 287,19 eliminando-se tal gleba. O índice de Gini para as propriedades compradas em Paraibuna foi de 0,73 , bastante elevado, o que não surpreende posto que $5(13,5 \%)$ das propriedades adquiridas por compra estavam acima dos 1000 alqueires e ocupavam $81,8 \%$ das glebas obtidas no mercado.

Para além de compra e posse, as heranças cobriam 3,5\% do território em tela com $10,2 \%$ das propriedades, percentual relacionado ao tamanho médio dos imóveis herdados que não ultrapassou os 720 alqueires paulistas, como área modal de 8 alqueires e média de 20,8 . Mais uma vez, encontramos diferenciação entre os valores verificados para a vila e sua freguesia separadamente. Em Jacareí, a participação de heranças foi de 10,8\%, em Paraibuna esse percentual foi de $6,7 \%$.

Assim, em Jacareí temos, de maneira quase absoluta a presença de compras seguida por heranças e depois posses como as principais formas de aquisição e em Paraibuna compra, posses (com percentual comparativamente próximo às compras) e heranças, respectivamente.

Para proprietários e proprietárias o percentual das heranças equivalia àquele encontrado para todos os detentores de terrenos em Jacareí/Paraibuna: 10,3\% para eles e $10,5 \%$ para elas, que respondiam por apenas 6,6\% das terras arroladas. Entre as 38 propriedades nas mãos de mulheres, 31 (81,6\%) haviam sido adquiridas por compra, percentual pouco menor aos $78,7 \%$ cujas haviam sido compradas por homens; essa pequena diferença corresponde aos respectivos percentuais encontrados para sesmarias mais posses, 10,8\% e 7,9\%, para homens e mulheres. Uma única mulher havia declarado possuir terras por posse, Tomazia Rodrigues havia se apossado de 8 alqueires em Jaguari, onde residia.

Os indicadores estatísticos apontam como moda propriedades pouco maiores para mulheres, 8 alqueires, sendo 2 alqueires área mais comumente encontrada entre os homens, cuja mediana de 8 alqueires também manteve-se abaixo daquela verificada para o sexo oposto, 10 alqueires paulistas. A maior área encontrada para o homens 207,8 
alqueires justifica-se pelo seu índice de Gini bastante elevado, 0,822, e superior ao encontrado para mulheres, 0,751 , reflexo do extremos superior da distribuição que alçouse a 3375 alqueires entre os proprietários do sexo masculino, o equivalente a 7,5 terrenos, considerado o maior deles possuído por uma mulher. (cf. Tabela III.50)

\section{Tabela III.50}

Formas de aquisição das propriedades e estatísticas para o tamanho de acordo com o sexo do proprietário

(Jacareí - 1818)

\begin{tabular}{|c|c|c|c|c|c|}
\hline $\begin{array}{l}\text { Formas de } \\
\text { aquisição }\end{array}$ & Homens & Muheres & Estatísticas & Homens & Muheres \\
\hline Compra & 78,7 (422) & $81,6(31)$ & Área média & 54,00 & 37,40 \\
\hline Herança & $10,3(55)$ & $10,5(4)$ & Desvio padrão & 207,80 & 81,10 \\
\hline Posse & $10,4(56)$ & $2,6(1)$ & Moda & 2,00 & 8,00 \\
\hline Sesmaria & $0,4(2)$ & $5,3(2)$ & Mediana & 8,00 & 10,00 \\
\hline Outras & $0,2(1)$ & - & I. Gini & 0,822 & 0,751 \\
\hline \multirow[t]{2}{*}{ Total } & $100,0(536)$ & 100,0 & Menor propriedade & 0,08 & 0,08 \\
\hline & & & Maior propriedade & 3375,00 & 450,00 \\
\hline
\end{tabular}

Exclusive 3 propriedades pertencentes a mais de 1indivíduo

Fonte: AESP, Inventário de Bens Rústicos, Jacareí:1818

Entre as propriedades jacareienses cuja informação acerca do número de cativos não foi omitida, $80,3 \%$ não mencionaram escravos, encontrados em outros 19,7\% (113) dos terrenos em tela, sendo 21 deles localizados em Paraibuna. Os indicadores estatísticos apontam uma grande diferença entre as terras explicitamente ligadas à presença de cativos e aquelas cujo trabalho empregado era exclusivamente familiar. Enquanto a área média para aquelas foi calculada em 185,67 alqueires, para as demais foi de apenas 22,14 alqueires paulistas, justificada pelo fato de que apesar de terem em suas mãos quatro quintos das propriedades, essas glebas em conjunto estendiam-se por $32,8 \%$ do território computado.

De acordo com os dados das Tabelas III.51 e III.52, o número médio de escravos elevou-se ao longo das faixas de tamanho das propriedades, considerando-se as glebas 
ligadas a cativos, ainda que para as propriedades com 500,1 a 1000 alqueires a média de 6 escravos tenha sido inferior ao número médio de cativos verificado para os terrenos com áreas na faixa imediatamente anterior: 11,7 indivíduos. As duas propriedades escravistas na faixa em questão eram 900 alqueires pertencentes a Manuel Rodrigues, detentor de um plantel com 8 mancípios e os 720 alqueire do capitão Libiano José Nogueira onde mantinha 4 escravos. E o capitão-mor da vila, Cláudio José Machado possuía 29 escravos (terceiro maior plantel local) e 225 alqueires, elevando a média na faixa em que se encaixa.

Uma grande gleba, 3375 alqueires em Paraibuna, pertencente ao capitão da primeira companhia local, Antonio de Souza de Carvalho não teve o número de escravos mencionado. Todavia, de acordo com os dados dos maços de população sabemos que o capitão possuía 43 cativos em 1816, número que já atingia 57 indivíduos em 1822.

\section{Tabela III.51}

Distribuição das faixas de tamanho das propriedades entre propriedades com e sem escravos

(Jacareí - 1818)

\begin{tabular}{|c|c|c|c|c|c|}
\hline \multirow[b]{2}{*}{$\begin{array}{l}\text { Tamanho das } \\
\text { propriedades * }\end{array}$} & \multicolumn{3}{|c|}{ Propriedades com escravos } & \multicolumn{2}{|c|}{ Propriedades sem escravos $^{\star \star \star}$} \\
\hline & \%(Número) & $\begin{array}{c}\text { Área }^{*} \\
\% \text { (total) }\end{array}$ & $\begin{array}{l}\text { Média de } \\
\text { escravos }\end{array}$ & \% (Número) & $\begin{array}{c}\text { Área }^{*} \\
\% \text { (total) }\end{array}$ \\
\hline $0-50$ & $11,9(57)$ & $19,4(1020,630)$ & 3,1 & $88,1(422)$ & $80,6(4248,695)$ \\
\hline $50,1-100$ & $37,0(10)$ & $37,4(734,250)$ & 3,4 & $63,0(17)$ & $62,6(1228,500)$ \\
\hline $100,1-300$ & $62,3(33)$ & $68,6(5815,500)$ & 6,8 & $37,7(20)$ & $31,4(2662,500)$ \\
\hline $300,1-500$ & $77,8(7)$ & $77,6(3120,000)$ & 11,7 & $22,2(2)$ & $22,4(900,000)$ \\
\hline $500,1-1000$ & $100,0(2)$ & $100,0(1620,000)$ & 6,0 & - & - \\
\hline 1000,1 ou mais ${ }^{* *}$ & $80,0(4)$ & $87,9(8670,000)$ & 41,0 & $20,0(1)$ & $12,1(1188,000)$ \\
\hline Total & $19,7(113)$ & $67,2(20980,380)$ & 6,1 & $80,3(462)$ & $32,8(10227,695)$ \\
\hline
\end{tabular}

Para número e área total so ma-se $100 \%$ em cada linha

${ }^{\star}$ Em alqueires paulistas

** Exclusive 1 propriedade sem menção à presença ou não de escravos

*** Exclusive 1propriedade com área não explicitada

Fonte: AESP, Inventário de Bens Rústicos, Jacareí:1818 
Tabela III.52

Distribuição das propriedades com e sem escravos de acordo com faixas de tamanho das propriedades

(Jacareí - 1818)

\begin{tabular}{|c|c|c|c|c|}
\hline \multirow{2}{*}{$\begin{array}{l}\text { Tamanho das } \\
\text { propriedades * }\end{array}$} & \multicolumn{2}{|c|}{ Propriedades com escravos } & \multicolumn{2}{|c|}{$\bar{P}$ Propriedades sem escravos ${ }^{\star \star \star}$} \\
\hline & \% (Número) & $\begin{array}{c}\text { Área* }^{*} \\
\% \text { (total) }\end{array}$ & \% (Número) & $\begin{array}{c}\text { Área* } \\
\% \text { (total) }\end{array}$ \\
\hline $0-50$ & $50,4(57)$ & $4,9(1020,630)$ & $91,3(422)$ & $31,2(4248,695)$ \\
\hline $50,1-100$ & $8,8(10)$ & $3,5(734,250)$ & $3,7(17)$ & $9,0(1228,500)$ \\
\hline $100,1-300$ & $29,2(33)$ & $27,7(5815,500)$ & $4,3(20)$ & $19,6(2662,500)$ \\
\hline $300,1-500$ & $6,2(7)$ & $14,9(3120,000)$ & $0,4(2)$ & $6,6(900,000)$ \\
\hline $500,1-1000$ & $1,8(2)$ & $7,7(1620,000)$ & - & - \\
\hline 1000,1 ou mais ${ }^{\star *}$ & $3,5(4)$ & $41,3(8670,000)$ & $0,2(1)$ & $33,5(1188,000)$ \\
\hline Total & $100,0(113)$ & $100,0(20980,380)$ & $100,0(462)$ & $100,0(10227,695)$ \\
\hline
\end{tabular}

A menor faixa de área, até 50 alqueires, concentrou maior menção absoluta a cativos, foram 57 propriedades, mas que contabilizadas em seu conjunto empregavam 174 escravos, 25,2\% deles. Entre essas pequenas glebas, 10,1\% contavam com o trabalho de escravos, percentual que ultrapassa os $60 \%$ para as propriedades de 100,1 ou mais alqueires, em que pese o reduzido número de observações em algumas faixas de tamanho das propriedades.

Ao que parece, a ocupação de novas áreas, como Paraibuna, atraía tanto indivíduos com recursos que adquiriam grandes propriedades e detinham considerável escravaria para trabalhá-las, assim como pessoas sem grandes recursos que tomavam a posse pura e simples de determinada área, e as trabalhavam sem a presença de cativos.

Por fim, note-se que a principal conjugação entre terras e escravos encontramos para o nosso conhecido padre Valério de Alvarenga, além da maior propriedade descrita no tombamento de bens rústicos possuía, com grande distanciamento, a maior escravaria registrada na documentação em questão - consideradas inclusive as demais localidades estudadas -, eram 111 escravos, mais de três vezes a segunda maior escavaria com 31 indivíduos. Relembrando, o padre Valério, natural de Taubaté, apareceu na lista nominativa de 1822 como o maior escravista de Jacareí/Paraibuna; juntamente com seu sócio Luiz era produtor de milho, arroz, café, porcos, bois e cavalares. Seus cabedais vieram, a priori, de acumulação anterior à aquisição de sua propriedade, e que, inclusive, devem ter proporcionado a capacidade de compra de tamanha gleba. 
Valério foi um outlier, e sua presença entre os proprietários de terras e escravos fez com que a correlação entre tamanho das propriedades e o número de cativos fosse extremamente alta: 0,82 considerando-se Jacareí com Paraibuna, sendo 0,91 a correlação calculada somente com as variáveis atinentes à freguesia, ainda que também elevado esse valor foi reduzido a 0,64 excluindo-se da conta o padre em questão. Sozinha, Jacareí apresentou uma correlação entre terras e escravos de 0,45.

Sem sombra de dúvidas, era o padre Valério parte do diminuto grupo dos mais abastados habitantes de Jacareí com sua freguesia de Paraibuna em 1818. Grupo este a que podemos acrescer os demais senhores de terras e cativos, que respondiam cerca de $8 \%$ dos chefes de domicilio considerados dados do registro de terras comparados aos das listas nominativas com datas mais próximas a ele, 1816 e 1822, mostrados na Tabela III.43 - ressalte-se, todavia, que essa parcela era significativamente maior considerada, em 1816, a freguesia de Paraibuna separadamente, onde os chefes de fogo detentores de terras e cativos, os principais recursos produtivos de então, eram $16,3 \%{ }^{82}$

\section{Tabela III.43}

\section{Fogos de acordo com a posse de terras e escravos}

(Jacareí - 1816, 1818, 1822)

\begin{tabular}{|c|c|c|c|}
\hline & 1816 & 1818 & 1822 \\
\hline Número total de propriedades rurais & & 576 & \\
\hline Número (\%) de propriedades rurais com escravos & & $113(19,6 \%)$ & \\
\hline Número total de escravos no tombamento de terras & & 690 & \\
\hline Número total de fogos & 1400 & & 1451 \\
\hline Número (\%) de fogos com escravos & $191(13,6 \%)$ & & $221(15,2 \%)$ \\
\hline Número total de escravos na lista nominativa & 921 & & 1298 \\
\hline$\%$ de fogos com terras & $41,1 \%$ & & $39,7 \%$ \\
\hline$\%$ de chefes de fogo com terras e escravos & $8,1 \%$ & & $7,8 \%$ \\
\hline$\%$ de chefes de fogo sem terras e com escravos & $5,5 \%$ & & $7,4 \%$ \\
\hline$\%$ de chefes de fogo com terra e sem escravos & $27,5 \%$ & & $31,9 \%$ \\
\hline$\%$ de chefes de fogo sem terras e sem escravos & $58,9 \%$ & & $52,9 \%$ \\
\hline
\end{tabular}

\footnotetext{
82 Jacareí propriamente, por responde por $85 \%$ e $78,6 \%$ dos fogos nos arrolamentos populacionais e $87,2 \%$ das glebas no arrolamento de terras tem seus valores refletidos, em elevada medida, nos valores apresentados para vila e freguesia considerados em seu conjunto.
} 
Os escravos possuídos por esses senhores de glebas e mancípios somavam 690 indivíduos, número inferior àquele verificado no arrolamento populacional: 1400 em 1816 e 1451 cinco anos mais tarde. Ou seja, havia uma parcela da população no termo da vila de Jacareí que contava com o trabalho de cativos, mas não era proprietária de terras. Esses indivíduos estavam distribuídos em apenas 5,5\% dos fogos comparando-se os bens rústicos com a lista nominativa de 1816. E assim como mencionamos para outras localidades, estamos diante de contingente populacional que vivia e mantinha sua atividades produtiva principal em terras de outrem, havendo imóveis rurais com vários domicílios em seus domínios, mesmo sendo este o menor percentual apresentado dentre as possibilidades de associação de posse de terras e escravos na localidade em tela.

O maior percentual foi verificado para os chefes de domicilio despossuídos de terras e de escravos, que respondiam por 59\% e 53\% dos domicílios, respectivamente nos anos da lista nominativa considerados. Ou seja, eram aqueles fogos que ocupavam na lida a família e eventuais agregados e em sendo ligados à agropecuária, esta seria realizada em terras de outrem - uma vez mais, note-se que Paraibuna sozinha não segue a característica verificada para o município de Jundiaí como um todo, posto ser a participação desses indivíduos mais representativa ali, não mais de $60 \%$ em 1816 . O restante dos fogos, outros cerca de $27,5 \%$ ou $32 \%$ eram situados em terras próprias, mas também utilizavam trabalho familiar, percentual que decresce em Paraibuna. 


\section{Estrutura fundiária e seus padrões}

No início do século XIX, mostra o cadastramento de bens rústicos, a estrutura fundiária da Capitania de São Paulo era bastante concentrada. Seja no conjunto da área Gini igual a 0,86 , com $70,23 \%$ das propriedades nas mãos de $5 \%$ dos proprietários com as maiores porções de terra - seja considerando diferenciações regionais: 0,69 na região da Capital, 0,92 na região fortemente vinculada à pecuária, 0,82 no Vale do Paraíba, 0,88 a 0,90 ao longo do litoral e 0,82 na região açucareira. (cf. CANABRAVA, 1972b).

Tal concentração fundiária reflete o que ocorre com as localidades que observamos. Se comparadas às regiões utilizadas por Canabrava, temos Jacareí e Mogi das Cruzes no Vale do Paraíba e as demais localidades - Atibaia, Nazaré, Bragança, Jundiaí - na Região da Capital. Ao todo temos registradas 2558 propriedades com áreas identificadas que, em conjunto, conformavam uma área total de 203240 alqueires paulistas.

Para fins de padronização utilizamos o mesma convenção apresentada no capítulo I para os escravos, lembre-se: Gini de 0,000 a 0,100 apresenta uma concentração considerada nula, de 0,101 a 0,250 uma concentração de nula a fraca, de 0,251 a 0,500 concentração fraca a média, de 0,501 a 0,700 concentração média a forte, de 0,701 a 0,900 concentração forte a muito forte e de 0,901 a 1,000 concentração muito forte a absoluta.

Tal índice para as propriedades de Atibaia, Bragança, Mogi e Jundiaí eram praticamente os mesmos, variaram entre 0,65 e 0,70, como adiantado. Nazaré apresentou um Gini mais elevado, 0,78, padrão de concentração mais próximo ao de Jacareí, onde houve uma maior concentração $(0,84 ; 0,79$ se consideradas em separado vila e freguesia), sendo essas duas localidades as que podemos indicar como apresentando uma concentração fundiária realmente forte. Ainda que haja alguma variação, em regra, a propriedade das áreas rurais do entorno de São Paulo era bastante concentrada em 1818. 
Gráfico III.1

Número de propriedades e área declarada por localidade

(1818)
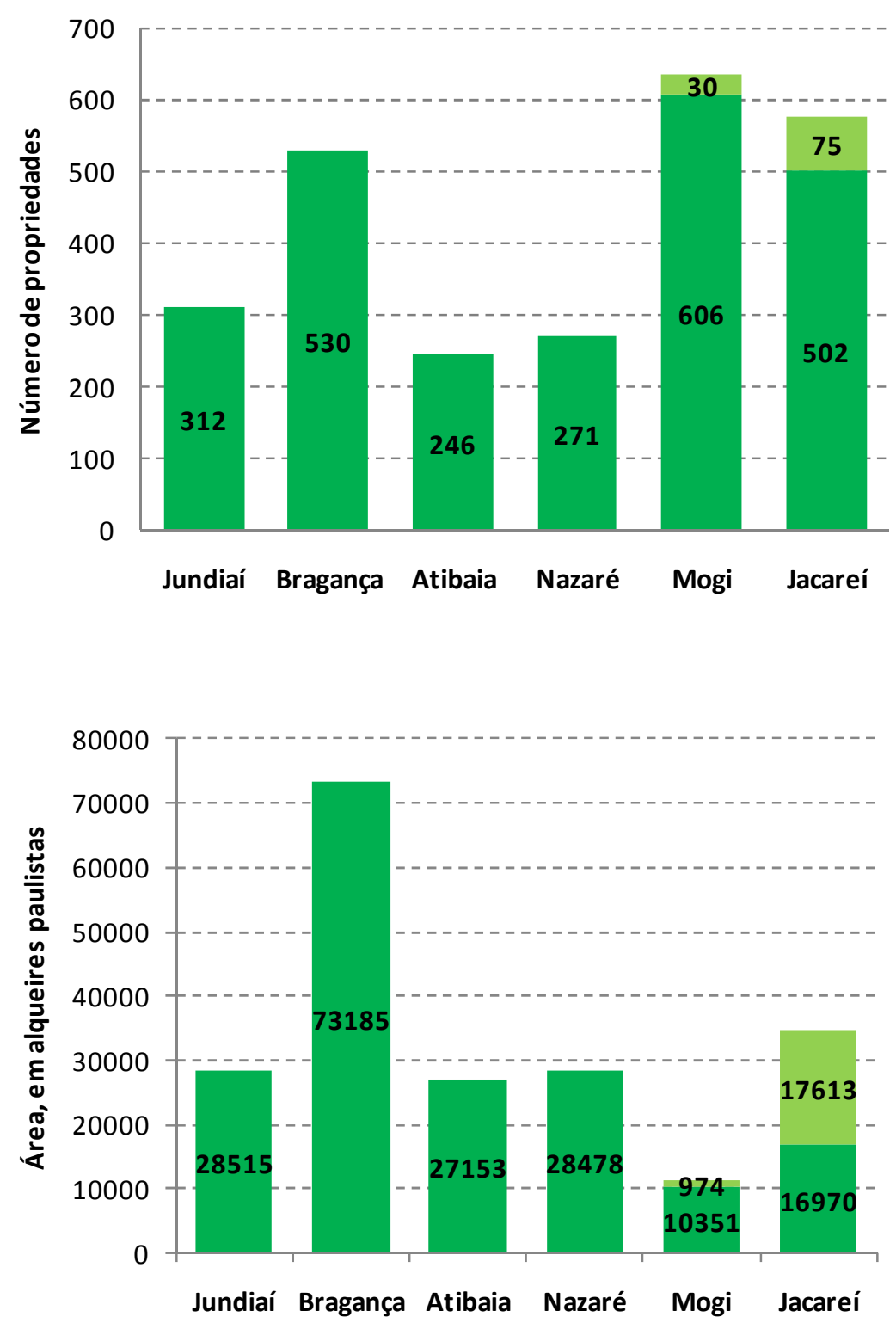

Ademais de Canabrava, os valores por nós calculados, no que tange à considerável concentração das terras, são bastante próximos àqueles apresentados para as propriedades paulistas por Nozoe (2008), que explicitou a recorrente concentração encontrada: 
O índice de Gini de 0,87 evidencia uma estrutura fundiária marcada por uma concentração elevada em São Paulo. É importante ressaltar que, apesar das ligeiras variacões, altos níveis de concentração foram observados em regiões com diferenças bastante nítidas, tanto do ponto de vista econômico como da antiguidade do povoamento. Índices abaixo daquele apurado para o conjunto da Capitania foram encontrados na periferia da grande São Paulo $(0,70)$ e nas regiões Açucareira $(0,82)$ e Vale do Paraíba $(0,83)$. Observamos os maiores níveis de concentração no Litoral Centro-Norte $(0,88)$, no Litoral Sul $(0,90)$ e na região da pecuária $(0,94)$. (grifo nosso)

Ou seja, não fugiu ao modelo concentrador de terras nenhuma das localidades estudadas, ${ }^{83}$ independentemente da dinâmica de sua economia e das conseqüentes possibilidades de acesso ao mercado de terras que estas poderiam gerar, posto ser a aquisição de terrenos via compra aquela predominante no entorno paulistano.

Ainda que a concentração possa ser considerada padrão, o tamanho das propriedades explicitadas, em especial através de estatísticas descritivas, mostrou-se bastante diferenciado entre as localidades - as áreas médias, a exemplo, variaram entre 18 alqueires (Mogi) e 138,1 alqueires (Bragança), sendo as modas calculadas entre 2 alqueires (Mogi e Jacareí) e 113 alqueires (Atibaia). Em que pese o extremo superior da distribuição das áreas, justificativa, inclusive, para os maiores índices de Gini encontrados para Nazaré e Jacareí e o menor verificado para Mogi das Cruzes.

À exceção de Mogi das Cruzes/Santa Isabel em que a maior propriedade ocupava uma área de 357 alqueires paulistas, nas demais localidades grandes extensões rurais, acima de 1000 alqueires, representavam, habitualmente, cerca de $1 \%$ das propriedades

\footnotetext{
${ }^{83}$ Entre outros autores que se depararam com concentração fundiária, temos Rangel (1998, p. 359) , que considerando especificamente o município de Taubaté no Vale do Paraíba paulista, aponta que "Cerca de $66,3 \%$ dos proprietários, que possuíam imóveis de até 48,4 ha, com uma área média de 12,4ha, apropriavamse de $4,7 \%$ da área total. Em contrapartida, os 34 maiores proprietários, com imóveis acima de 500 há, controlavam 72,5\% da área total. O índice de concentração de Gini atingia 0,86." Para o Paraná em 1817, tratando especialmente da região de São José dos Pinhais as observações de Cacilda Machado mostram que : "[...] 115 propriedades com até 100 ha compunham $56 \%$ do total de 205 propriedades e ocupavam pouco menos de $4 \%$ da área total. Já as propriedades com mais de 4.000 ha (não foram registradas propriedades com mais de 5.000 ha) eram apenas quatro (perfazendo cerca de $2 \%$ do total das propriedades), ocupando $70 \%$ da área total na freguesia." (MACHADO, 2008, p.64) Para além da Capitania de São Paulo, o modelo concentrador de terras foi encontrado por outros autores para diferentes localidades, e outros períodos que chegam ao final do século XIX. "Ao longo do Cordão Mapendipe-Pinaré [na Comarca de Ilhéus na Bahia DOMR] foram identificados somente nove indivíduos $(4,7 \%)$ que se enquadram na faixa dos grandes detentores de terra. Na faixa mediana, encontram-se $24(12,5 \%)$, sendo que destes, somente 11 possuíam mais de 250 hectares. A maior parcela ficava na faixa dos pequenos detentores de terra, que englobava 160 indivíduos (83\%), possuidores de datas de até 150 hectares. Cada um nessa faixa detinha em média 70,7 hectares e, em conjunto, controlavam menos da metade (48\%) das terras de todo o cordão." (DIAS, 2007, p.94) Já em Capivary (RJ), os registros paroquiais realizados entre 1855 e 1857 "apontam para uma impressionante concentração fundiária.Considerando como grandes proprietários os declarantes de extensões de terra de dimensões maiores ou similares à área média de uma fazenda de café no Vale do Paraíba (400 a 800 há), percebemos que os declarantes de mais de 400 ha em Capivary detinham $75 \%$ da área total dos registros e que, se acrescermos a esta área as extensões menores declaradas por seus familiares, chegavam a controlar $88 \%$ dos terrenos [áreas - DOMR] registrados." (MATTOS, 2009, p.19), sendo esses grandes proprietários responsáveis por $15,17 \%$ dos registros.
} 
arroladas. Todavia somente em Jacareí com Paraibuna essas gebas ocupavam um percentual alçado a 38,3\% do território arrolado, assim como em Nazaré 37,9\% da área descrita dividia-se entre as propriedades realmente grandes.

Soma-se a isso ser recorrente, ou seja, podermos igualmente considerar um padrão, a existência em quantidade majoritária, em todos os casos, de menores propriedades ocupando uma área realmente diminuta. Ocupavam, cada uma delas, uma extensão entre 0,03 e 0,2 alqueires paulistas da área arrolada, como mencionado um tamanho bastante reduzido que, consideradas as condições de produção extensivas da época, deveria ser insuficiente para prover todo o sustento de uma unidade familiar, especialmente se mais numerosa. Warren Dean (1977, apud RANGEL, 1998, p.359) aponta que para uma família de seis pessoas - próximo a médias para os fogos das diversas localidades verificada em capítulo anterior - prover adequadamente a sua subsistência seria necessária uma área de 40 ha, o equivalente a cerca de 16,5 alqueires paulistas.

Se por um lado alguns não detinham terrenos suficientes para levar a cabo cultivos consideráveis, a concentração das terras permitia a outros possuírem reservas em suas propriedades, ou seja, extensões de terras virgens. Decerto, mesmo na presença de grande contingente de mão-de-obra, as maiores propriedades não eram de todo exploradas. Em um momento em que a agropecuária sabidamente caracteriza-se por seu caráter extensivo, itinerante e muitas das vezes destruidor da qualidade solo, como bem reclamaram alguns declarantes atibaienses, essas áreas ainda não exploradas das propriedades eram essenciais.

As áreas de terras virgens para a expansão das culturas, fornecimento de madeira $e$ pastos constituíam parte integrante das fazendas rigorosamente preservadas e defendidas. A apropriação de uma extensão de terras muito maior que as necessidades imediatas da lavoura constituía condição indispensável à possibilidade de reprodução ampliada da grande fazenda. Muito difícil é determinar até que limite vão as necessidades de terra de cada fazendeiro. (MATTOS, 2009, p.88)

Para além das necessidades características da tecnologia produtiva Oitocentista a concentração do tamanho das propriedades e, especialmente, a presença de glebas relativamente extensas e/ou ocupantes de menores áreas estavam mais diretamente vinculadas ao momento e conseqüentemente à idade do povoamento e ocupação produtiva das localidades cotejadas e ao seu posicionamento geográfico dentro da direção da expansão paulista rumo ao sertão "desconhecido", do que propriamente ao grau de mercantilização (ou seja, atividades econômicas principais) verificado para as agropecuárias locais - ainda que elas não tenham apresentado características 
extremamente díspares, quando da sua análise no que respeita ao volume e à comercialização da produção (cf. capítulo II) -, mesmo tendo a historiografia recorrentemente apontado que "Os indicadores de concentração da terra não deixam dúvidas quanto à desigualdade na apropriação, mas ela era diferenciada segunda a atividade econômica principal da vila e dos donos da terra." (GUTIÉRREZ, 2001, p.209) ${ }^{84}$ As novas fronteiras abririam possibilidades de aquisição de propriedades de tamanhos variados.

A concentração do tamanho dos terrenos, mesmo que padrão presente em todas as localidades em estudo tende a ser mais acentuado quanto mais recente a ocupação da região considerada, pois a "pouca idade" estava diretamente ligada à existência de terras disponíveis e, por conseguinte, à possibilidade de apossar-se de maneira primária de maiores áreas, implicando em possibilidade de um máximo mais elevado na distribuição. Assim como, estava essa possibilidade ligada ao caminho seguido pelo avanço populacional: a presença de posses e sesmarias deveria indicar a ocupação relativamente recente do solo. ${ }^{85}$

Mas, mais do que estabelecer a possibilidade da presença de terras passíveis de serem tomadas por posse ou sesmaria, a antiguidade da ocupação das terras implicava em sucessivas fragmentações dos terrenos por herança ou transações comerciais, sendo esperada, passadas sucessivas gerações desde a ocupação original do território considerado, uma redução nas extensões verificadas para as propriedades, o que, para nosso estudo fundiário pontual, datado em 1818, configura-se na presença majoritária das referidas pequenas propriedades. Observação válida para todas as localidades, sendo, em toda a região estudada, as propriedades adquiridas por herança de menores extensões que aquelas negociadas no mercado. Foi característico encontramos áreas médias mais elevadas entre as propriedades compradas comparativamente àquelas adquiridas por herança.

Eram poucas as possibilidades de área devolutas sendo ocupadas dentro do território paulista nas décadas finais do Setecentos e primeiras décadas do século subseqüente, especialmente daquele território aqui considerado. Entre essas possibilidades encontramos a região limítrofe ao sul das Minas Gerais como pudemos verificar nas observações acerca da Serra do Selado em Nazaré e do Morro do Lopo em

\footnotetext{
${ }^{84}$ Ver, entre outros, Nozoe (2008) que, recorrendo à mesma fonte por nós utilizada, apresenta análise acerca da distribuição, uso e formação da estrutura fundiária de São Paulo, a partir de regiões econômicas. Ver também o trabalho clássico de Canabrava (1972b): A repartição da terra na capitania de São Paulo.

${ }^{85} \mathrm{Em}$ estudo sobre o vale do Ribeira, Agnaldo Valentin (2006) verificou a presença de áreas com elevado número de propriedades e predominância de glebas adquiridas por compra e herança, características das quais se utilizou para referência à "antiguidade da ocupação daqueles territórios". Da mesma maneira,
} 
Bragança - ainda que conhecido desde antigas expedições que por ali transitaram no Seiscentos, seu povoamento efetivo data dos anos finais do século XVIII - onde encontramos algumas das pouquíssimas sesmarias arroladas. E a parte que segue para 0 litoral norte, situada ao sul da área hoje correspondente aos municípios de Biritiba Mirim e Salesópolis, componentes da nossa vila de Mogi das Cruzes e seu termo, que a sua vez são limítrofes à área onde verificamos a expansão da freguesia de Paraibuna, cujos registros apontam áreas de sertão "na estrada de Caraguatatuba", onde encontramos quantidade de posses comparativamente elevada e ainda algumas sesmarias.

Essa característica causal pode ser considerada um padrão, mesmo sendo este observado a partir das diferenças e não das similitudes entre as localidades. Assim, Mogi das Cruzes, localidade de ocupação mais antiga, tendo sido erigida vila em 1611, e situada em área circundada por outros importantes núcleos populacionais (vide figura 1.1 no primeiro apêndice) apresenta elevado número de propriedades, em sua quase totalidade não ultrapassando os 50 alqueires paulistas, e o menor índice de concentração, mesmo tendo parte de seu território ocupado por várias posses. Essas posses, como sabido, estavam em sua maioria na área de Mogi mais próxima ao litoral, ou seja, fora das grandes rotas de comércio dos principais caminhos que cortavam a Capitania e última parte do território da vila a ser ocupada, com povoado efetivamente erigido a partir de 1820.

A sua vez, o maior índice de Gini foi encontrado para Jacareí, onde grande parte do território - correspondente a Paraibuna (quase metade da área total descrita) -, havia sido efetivamente ocupado e, conseqüentemente, as primeiras sesmarias doadas nas décadas finais do século XVIII, tendo as posses ocupado lugar de destaque naquele povoamento.

A forma de aquisição de propriedades predominante em todas as localidades foi a compra, sendo terrenos em todas as faixas de extensão sido comercializados em todas as seis localidades e seus termos. Quem possuía poucos recursos comprava uma pequena parte de terras, os detentores de maiores cabedais adquiriam grandes fazendas - certamente a capacidade produtiva e conseqüente inserção no mercado regional de gêneros era determinante das distintas possibilidades enquanto demandantes de terras.

O mercado fundiário respondeu pelo menor percentual entre as distintas possibilidades na vila de Atibaia (63,3\%) e o maior no termo da vila de Jacareí $(79 \%)$. Mesmo encontrando uma diferença de quase 16 pontos percentuais entre os dois montantes apresentados, aí também temos um padrão e podemos confirmá-lo lançando 
mão do teorema de Tchebychev, ${ }^{86}$ que aponta para as localidades consideradas um intervalo de $58,6 \%$ a $81,5 \%$ como padrão.

Ou seja, entre as localidades, por possuírem composição da forma de aquisição por compra estabelecidas dentro desse intervalo, nenhuma fugiu àquela característica encontrada para o conjunto da área estudada. Apenas se observamos Paraibuna separadamente encontramos localidade fora desta característica mais marcante para o território considerado, uma vez que $49,3 \%$ das 75 propriedades da localidade foram adquiridas com recurso ao mercado fundiário e outros $40 \%$ por posse, o que facilmente se entende posto termos discutido anteriormente a questão da idade da ocupação do território. Na realidade, é bem provável que com o passar do tempo "Sua exploração e continuidade de uso acabavam por legalizar, na prática e mesmo em direito, a propriedade particular da mesma" (MARCÍLIO, 2006, p. 77), verificada na forte presença de compras nas demais localidades.

A presença marcante do mercado fundiário pode ser um indicativo de que os próprios donos de terras "[...] construíram seus patrimônios, de forma gradativa, sem grande auxílio de seus pais, já que poucos receberam terras por herança”, (SCOTT, 1987, p.229), ainda que teoricamente todos os filhos herdassem as terras dos pais, possivelmente apenas alguns deles nelas permaneciam e exploravam. ${ }^{87}$ "Por outro lado, percebe-se que representava um valor cobiçado, pois a compra em si, demonstra que havia mais interessados do que terras disponíveis [...]". (SCOTT, 1987, p.229)

É consenso que, apesar de ter algum valor de mercado, em termos monetários a terra valia pouco - especialmente frente à ausência de "produção comercial", entenda-se, ligada ao comércio exterior à colônia, que tendia a valorizá-la, e como sabido pouco presente no contexto do entorno paulistano -, "[...] numa região de economia camponesa dentro do sistema agrícola da roça itinerante se [sic!] subsistência, a propriedade da terra

\footnotetext{
dessas características inferiu o sentido da expansão agrícola na região, centrado na produção do arroz.

${ }^{86}$ Como não sabemos se nossa distribuição segue uma normal, utilizamos o teorema de Tchebychev que fornece elementos para compreender como a variância mede a variabilidade em relação ao valor esperado de uma variável. Esse teorema diz que considerando uma variável aleatória $x$ com média $\mu$ e desvio e desviopadrão $\sigma$, "a probabilidade de essa variável estar acima ou abaixo da média, no máximo, $k$ desvios-padrão ( $k$ é uma constante positiva) é, no mínimo igual a $1-1 / k^{2}$ "(SARTORIS, 2003, pp.20-21). Ou seja, uma variável aleatória qualquer (no nosso caso o percentual de terras compradas) tem $75 \%$ pelo menos de probabilidade de estar entre dois devios-padrão acima ou abaixo da média.

87 Especificamente para um conjunto de grandes proprietários de localidades do Oeste Paulista, inclusive Jundiaí, sabemos que "Para salvaguardar o processo sucessório de desmembramentos indesejáveis, apelava-se para um concentração da propriedade nas mãos de poucos sucessores e para o encaminhamento dos demais rumo à Frente Pioneira. Assim evitava-se os mecanismos seja de herança igualitária, seja do morgadio." (BACELLAR, 1997, p.187)
} 
tem valor intrínseco e contábil relativo." (MARCíLIO, 2006, p. 81). ${ }^{88}$ A terra, obviamente, não deixa de ser um fator básico em uma economia de base agropecuária.

A identificação do mercado fundiário como principal meio de acesso à terra tem sido recorrente nos trabalhos que tomam por base o tombamento de bens rústicos, considerando-se distintas regiões da capitania paulista (assim como para o Paraná, então a ela submetido). Entre eles, Nozoe (2008) apresenta tabela bastante completa, para as localidades da área paulista da Capitania para as quais existe tal registro, também subdivididas em regiões (conforme feito por Canabrava em trabalho já citado). Nela podemos observar compras como meio primordial de acesso à propriedade rural para mais de $70 \%$ das localidades.

Eventualmente, adquirir uma propriedade já constituída poderia ser mais interessante que empenhar-se em desbravar nova área ou a simples ausência de terras devolutas e/ou apropriáveis (em se não considerando a possibilidade de aquisição de terras via divisão de espólio) tornava necessário dirigir-se ao mercado fundiário como meio de acesso a terra ou de ampliação das glebas já adquiridas. ${ }^{89}$

Recorrer ao mercado com sucesso implicaria em coincidência de interesses, o que muitas das vezes não deveria ocorrer, mormente em se tratando de áreas mais específicas, quais sejam, aquelas anexas aos terrenos já possuídos, que parece ter sido característica comum àqueles detentores de dois ou mais imóveis, como pudemos observar em especial para a região de Bragança, Atibaia e Nazaré (Tabelas III.12, III.21 e III.30). ${ }^{90}$

\footnotetext{
${ }^{88}$ Alguns autores apontam a expansão da produção comercial, entenda-se, voltada a mercados externos, como um determinante na valorização comercial da terra. Ver, entre outros, Lucila Hermann (1986), Mattos (2009), Marcílio (2006).

89 Tratando das freguesias de Boipeba e Cairu na Bahia, menciona Marcelo Dias "[...] que o mercado de terras, movimentava negócios envolvendo, na maior parte, pequenas propriedades, As maiores posses permaneceram à margem do mercado de terras e, nestas condições, a expansão de uma unidade produtiva, nos moldes do sistema agrário extensivo, requeria a compra de pequenas datas contíguas ou, pelo menos, vizinhas umas às outras." (DIAS, 2007, p.101)

90 Relembrando, à exceção de Mogi e Jacareí, pudemos identificar nas demais povoações indivíduos certamente detentores de duas ou mais propriedades. Em Jundiaí as propriedades foram declaradas de acordo com seu nome, que dadas as diferentes denominações encontradas à época dificultam uma perfeita identificação de sua localização. Em Bragança, seis entre os sete proprietários com mais de uma gleba as tinham anexas, em Atibaia foram 12 em 15 e em Nazaré cinco entre os nove terrenos.
} 
Talvez por isso tenhamos encontrado marcante presença de pequenas glebas entre aqueles detentores de ao menos duas propriedades. ${ }^{91}$

Assim, o simples fato de ser um indivíduo aquinhoado não implicaria em plena facilidade de acesso a grandes extensões, especialmente em áreas de ocupação mais antiga, onde o território estava mais fracionado. Diversos aspectos poderiam estar envolvidos no interesse e no processo de comercialização dos terrenos rurais por parte de ofertantes e demandantes. Entre eles, possivelmente, alguns ligados ao desejo de manutenção da propriedade ou ausência de expectativa quanto ao apossamento de outra propriedade: a venda poderia não ser assim tão bom negócio, posta a dificuldade em se conseguir bons novos terrenos cultiváveis.

Segundo as colocações e o entendimento de Antonil, que no raiar do século XVIII escreveu a respeito da comercialização de terras, cujas impressões parecem válidas ainda na centúria seguinte:

Muitos vendem as terras que têm por cansadas, ou faltas de lenha; outros, porque se não atrevem a ouvir tantos recados, semelhantes aos que se davam a Jó, do partido queimado, dois bois atolados, dos escravos mortos, e do açúcar perdido. Outros, obrigados a vender contra vontade por causa dos acredores que o apertam, bem pode ser que ofereçam terras novas e fortes; porém, o comprador corre então outro risco de comprar demandas eternas, pelas obrigações e hipotecas a que estão por repetidas vezes sujeitas. Portanto, nesse caso, fale o comprador com letrados, pergunte ao acredores que é o que pretendem; e, se for necessário, com autoridades do juiz, cite a todos, para saber o que na verdade se deve; nem conclua a compra, antes de ver com seus olhos que é o que compra, que títulos de domínio tem o vendedor, e se os ditos bens são vinculados ou livres, e se tem partes neles órfãos, mosteiros ou igrejas, para que se não falte ao fazer da escritura a alguma condição ou solenidade necessária. Veja também as demarcações da terras, se foram medidas por justiça, e se os marcos estão em ser, ou se há mister aviventálos, que tais são os co-heréus a saber, se amigos de justiça, de verdade e de paz, ou, pelo contrário, trapaceiros desinquietos e violentos; porque não há pior peste que um mal vizinho.

Feita a compra, não falte à seu tempo à palavra que deu, pague e seja pontual nesta parte. (ANTONIL, 1997, pp.78-79)

\footnotetext{
${ }^{91}$ Para a localidade de Capivary (RJ), Hebe Mattos (2009, p.90) apontou que em se considerando que a terras incultas faziam parte dos empreendimentos, seu esgotamento implicaria em necessidade de novas terras, nesse caso "[...] a tendência seria de ampliar as áreas ocupadas pelos grandes fazendeiros à custa de vizinhos menores." Já Lucila Hermann em estudo acerca da evolução social de Guaratinguetá aponta uma relação entre o "ciclo" de atividade econômica da localidade e a necessidade/tendência de anexação de terras para alargamento dos suas propriedades: "Os latifúndios e grandes propriedades nos primeiros anos de vida da Colônia não exprimiam uma tendência anexadora, não representavam um esforço por parte dos proprietários para alargarem seus domínios. [...] No ciclo dos engenhos [1775 a 1836 - DOMR] encontramos grande propriedades quer na área fluminense, quer em Guaratinguetá, mas não exprimiam uma tendência anexadora.[...] No clico do café as condições se alteram [...] Os proprietários, enriquecidos durante o período curto mas rendoso do ciclo dos engenhos, aumentando sua renda nos primeiros anos do ciclo do café, com larga escravaria e fortes fundos em prata, ouro e cobre, encontrando, em seu redor, cada vaz [sic!] mais feridos pela Lei das Partilhas, aumentam seus domínios por meio da compra da terras circundantes à fazenda, comprando ou formando sítios mais distantes, cuja direção entregam aos filhos." (Hermann, 1986, p.124)
} 
Gutiérrez (2001, p.228), utilizando-se igualmente do inventário de bens rústicos para estudar o Paraná, aponta que o mercado de terras "Foi talvez o canal encontrado por quem não tinha os meios nem o acesso necessário para requerer sesmarias e, de quem tinha os meios, a forma encontrada de angariar um capital loteando a sesmaria recebida graciosamente e solicitando outra em seguida."

Podemos acrescer a estas proposições, considerações que remetem ao já conhecido fato de que grande parte das sesmarias das localidades em tela foram distribuídas ainda no Seiscentos ou Setecentos, sendo legadas em parte menores a distintos herdeiros que nem sempre mantinham a propriedade desses pedaços de terra, vendendo-as, inclusive a outros herdeiros, como conseguimos exemplificar com o caso do bragantino Joze Luis de Morais cuja propriedade parte era possuída por compra que fez aos seus irmãos - uma possível exceção em que a divisão igualitária de terras entre herdeiros poderia não ter efeito tão efetivo de segmentação da propriedade.

Em economias cujos produtos principais são típicos de subsistência ter onde produzir e não necessariamente ser o proprietário das terras onde se está produzindo era o mais importante. E, ainda mais importante, era ter braços para que essa terra pudesse ser trabalhada.

Em comparação do tombamento de bens rústicos com a lista nominativa de habitantes para os anos 1816 e 1820/1822 encontramos, para todas as localidades, uma maioria de chefes de fogo sem terras e sem escravos (48\% a 56\%), padrão que aponta a necessidade, para a maioria dos domicílios do entorno paulistano, de recorrer ao trabalho familiar e, eventualmente, de agregados para se trabalhar e isto, em terras alheias.

Há que considerar também haver grande número de propriedades onde viviam e trabalhavam famílias ampliadas, que acabavam por representar fogo independente dentro de determinada propriedade. Isso implica que trabalhar em terras alheias não era prerrogativa apenas daqueles totalmente despossuídos, pois verificamos ser pequena a parcela, igualmente encontrada em todas as localidades (em comparação com o ano de 1816, o maior percentual não ultrapassou os 10,6\% encontrados para Nazaré) devida aos chefes de fogo sem terras, mas senhores de escravos.

Vide, por exemplo, termos encontrado em Bragança Salvador Bueno de Oliveira que trabalhava com seus 18 cativos nas terras de seu sogro, o capitão mor Jacinto Rodrigues Bueno. Assim, podemos aventar também, a idéia de que produzir em terras alheias não era prerrogativa exclusiva dos detentores de pequenas escravarias, ainda que os maiores escravistas, provavelmente, produzissem em terras de parentes que, em algum momento, herdariam. Vide o caso supracitado, de Salvador Bueno, ou ainda o do 
capitão-mor de Jundiaí, José Castanho, que possuía 16 escravos e produzia açúcar juntamente com o cunhado nas terras denominadas o Quilombo, de propriedade de sua mãe, Gertrudes Maria Jacinta, residente em Itu.

Ademais do acima exposto, a presença de proprietários de escravos e sem terras deveria ser situação especialmente válida para aqueles possuidores de uma menor escravaria. "arrendatários, agregados, casais jovens que receberam de seus pais cativos como dote e que residiam em casas cedidas pela família" (GUTIÈRREZ, 1998, p.108)

Os escravos adquiridos pelos pequenos proprietários, em muitos casos, possivelmente objetivavam complementar a mão-de-obra doméstica. Possuir escravos poderia estar relacionado à ação conjunta de necessidades econômicas e demandas sociais. Uma parte dos escravos adquiridos seria destinada às atividades agropastoris das localidades, mas outra atenderia a tipos distintos de atividades, como serviços pessoais, por exemplo. De uma maneira geral, possivelmente nas atividades artesanais os escravos poderiam estar ligados à própria produção; no comércio urbano, poderiam ser utilizados em diversos tipos de atividades como carregamento de mercadorias ou atendimento nas lojas, o que não os liga necessariamente à terra.

Concordamos com a afirmação posta por Rangel para a vila de Taubaté em 1798, e ousamos estendê-la, como padrão, às seis localidades por nós consideradas:

[...] parcela substantiva da população - denominada de agregados - era destituída de propriedade imobiliária e vivia em terras alheias ou casas alheias, contraindo, portanto, algum tipo de relação de dependência e subordinação com relação aos proprietários de imóveis urbanos e/ou rurais. [...] Os agregados constituíam os elementos mais humildes da população livre, pois além de viver a favor, em sua maioria não possuíam escravos [...] No entanto, os agregados não envolviam somente estranhos e pobres, mas, também, parentes e amigos. [...] Nesse segmento, os que viviam em terras de parentes pareciam compor um segmento mais favorecido pela riqueza 'com padrões semelhantes aos estratos mais altos' (RANGEL, 1998, pp.356-357)

Os chefes de fogo com terras e escravos - entre 8,1\% (Jacareí) e 16\% (Atibaia) do total considerando-se 1816 para comparação -, possivelmente representavam a parcela mais abastada da sociedade local o que, por consequência, deveria ser representativo de elevada posição social. Como bem mencionou Maria Luiza Marcílio, a terra 
é ao mesmo tempo um meio de produção e um meio de definição social, o suporte do status'. Aumentando a superfície possuída, o grupo doméstico tem aumentada sua capacidade de produção que só será conseguida com o aumento da força de trabalho. Assim, ele tem necessidade de aumentar o número de seus membros, agregando novos braços, comprando escravos, ou então recorrendo ao sistema de arrendamento de porções de suas terras que ele não tem condições de cultivar. À medida que a extensão de suas terras aumenta, o chefe do fogo aumenta concomitantemente sua superfície social, seu status, sua segurança e a de seus herdeiros. (MARCÍLIO, 2006, p.65)

Mas, se não os mais abastados e topo das elites locais, em muito ligadas a patentes militares e ao clero, decerto esses proprietários de terras e de escravos eram aqueles que tinham maiores chances de ligação com o mercado. A posse de escravos representava uma evidente vantagem nas possibilidades de produção para os senhores comparativamente aos indivíduos sem cativos - a mão-de-obra era fator determinante na produção tendo em vista ser reduzida a presença de maquinários e ferramentas mecanizadas.

Essa possibilidade fazia com que esses proprietários partissem de uma dotação inicial mais favorável à acumulação via mercado e, portanto, de maiores facilidades na compra principalmente de escravos e ainda, em algum momento, de terras adicionais ou eventualmente mais extensas, implicando em um fluxo circular: possuir terras e escravos possibilitava produção em maior escala e conseqüente participação em mercados regionais dos quais se auferiam ganhos que poderiam financiar a compra de mais escravos e, na ausência de área disponível dentro de suas propriedade, terras levando a conseqüente aumento da capacidade produtiva.

O autofinanciamento, recorrente na historiografia açucareira ${ }^{92}$, mantidas as devidas proporções, acreditamos, pode ser estendido à produção comercial de gêneros de subsistência (ainda que não tenhamos dados concretos para valores de terras e escravos a serem comparados com as receitas geradas no mercado dos diversos gêneros anteriormente identificados para o cinturão paulistano, merecedores de uma análise mais aprofundada).

Como temos considerado, as características econômicas mais marcantes de cada localidade não implicaram, ainda que importantes, como fator preponderante na determinação do tamanho das propriedades, frente à idade da ocupação do solo. Não obstante, como anteriormente o fizemos, podemos considerar que implicaram nas diferenças consideráveis entre as características dos plantéis; arranjo este que possibilitou diferentes possibilidades quando da observação conjunta de número de escravos e tamanho das propriedades. 
A observação do número médio de escravos ligados a distintas faixas de tamanho das terras rurais aponta como padrão um crescimento de acordo com o aumento da área considerada para as propriedades ligadas ao trabalho compulsório, mas sendo a correlação calculada diretamente para área das propriedades contra número de escravos baixa, ainda que positiva, ou seja, estatisticamente significante. Apenas na freguesia de Paraibuna essa correlação foi extremamente elevada, $(0,91)$ reflexo da presença na localidade da propriedade pertencente ao padre Valério Bueno, com 4050 alqueires de extensão (terceira maior entre as 2558 propriedades com área explicitada que analisamos) e nada menos que 111 escravos. As demais localidades apresentaram correlação próxima $^{93}$ : 0,32 pra Jundiaí, 0,36 para Mogi, Bragança, 0,44 para Nazaré, 0,45 para Jacareí (sem Paraibuna), sendo a correlação mais alta verificada para Atibaia, 0,50.

O fato é que as grandes propriedades nem sempre estavam ligadas à posse de escravos, entretanto, na presença de vínculo, o plantel correspondente era, comumente, composto por vários indivíduos. Ademais, havia propriedades realmente pequenas com menção à presença de cativos, ainda que o percentual de pequenos imóveis em que foram declarados mancípios fosse comparativamente reduzido, posto havermos identificado ser o aumento no tamanho dos plantéis acompanhado também pela elevação do percentual de propriedades escravistas ao longo de faixas. ${ }^{94}$

Esse padrão foi encontrado especialmente levando-se em consideração as quatro primeiras faixas de tamanho das propriedades (até 500 alqueires), cujo número de observações permite afirmações mais seguras. A menor diferença entre o percentual de propriedades de até 50 alqueires paulistas com cativos e aquelas entre 300,1 e 500 alqueires também ligada a mão-de-obra escrava foi de encontrada em Nazaré, 40,7\% e em Mogi, 24\%, sendo que aí a observação deve ser feita considerando-se o limite a faixa de até 330 alqueires, pois somente duas propriedades ocupavam áreas acima dessa metragem.$^{95}$

\footnotetext{
92 Ver, por exemplo, Furtado (1998) e Petrone (1968).

93 Usualmente só se considera uma correlação alta quando esta atinge valores acima de 0,50.

${ }^{94}$ Esses fatores, observados para o Vale do Ribeira por Agnaldo Valentin (2006), levaram o autor a concluir que na região analisada não havia uma correlação clara entre área possuída e número de escravos. Já a concentração foi considerada por Rangel (1998) para Taubaté,

95 Apenas em Bragança a distribuição percentual entre as faixas de tamanho foi levemente errática, sendo a participação de terrenos com escravos respectivamente de $22,5 \%, 42,7 \%, 38,7 \%$ e $72,4 \%$ ao longo das quatro primeiras faixas de extensão estabelecidas para as propriedades; o que não invalida nossa conclusões; posto serem os extremos da observação bastante distintos (diferença de praticamente 50 pontos percentuais), indicando uma tendência de crescimento da série.
} 
Como resultado das características apontadas identificamos, em todas as localidades, áreas médias superiores entre propriedades com escravos comparativamente àquelas sem escravos. Mas, assim como verificamos na análise do tamanho das glebas, uma comparação das estatísticas descritivas encontradas, feita de maneira absoluta, aponta para dissimilitudes entre as localidades. Por exemplo, as área médias das propriedades escravistas em Nazaré e Santa Ana de Mogi foram, respectivamente, de 256,4 e 34,8 alqueires paulistas, enquanto a média de área pra aqueles terrenos não ligados diretamente ao escravismo, variaram de 10,85 alqueires em Mogi (primeira faixa de tamanho), passando por cerca de 64 em Atibaia e Jundiaí (segunda faixa) e atingindo 104,3 em Bragança (terceira faixa). 


\section{CONSIDERAÇÕES FINAIS}

Neste trabalho observamos características demográficas, econômicas e fundiárias, no período compreendido dos anos finais do século XVIII até as três primeiras décadas da centúria subseqüente, para seis localidades (Jundiaí, Bragança, Atibaia, Nazaré, Mogi das Cruzes e Jacareí) situadas no entorno paulistano. Buscou-se, a partir da análise levada a cabo para cada vila ou freguesia em tela, a observação de algumas características comuns entre elas, os referidos padrões.

Parece-nos supérfluo nos estendermos aqui no balanço e nas conclusões que nortearam a busca por padrões, regularidades e tendências, objeto deste estudo, que já vão anotados na seção final de cada capítulo. O maior padrão, afinal, é ser cada localidade única em seus detalhes, mas próxima ao conjunto em seus caracteres mais gerais e amplos.

De maneira sintética, seguem alguns dos padrões e tendências encontrados:

- Entre os extremos do lapso estudado houve crescimento generalizado nas populações totais específicas, mas em períodos mais curtos todas as localidades passaram por momentos, não coincidentes, de expansão e declínio de sua população;

- Foi grande a movimentação de indivíduos, sendo grosso da mobilidade, capaz de afetar os caracteres demográficos das localidades - e por conseguinte econômicos -, devido a fluxos em menores distâncias, entre vilas vizinhas, que acabavam por ter suas fronteiras fluidas, que tanto recebiam quanto enviavam indivíduos a outras áreas;

- Como padrão temos populações livres com elevada taxa de natalidade, grande proporção de jovens, baixa participação de idosos e em crescimento, conforme apontam as pirâmides etárias, sempre figuras do tipo crescente com alguns períodos em que foram identificadas faixas etárias podendo ser classificadas como classes ocas;

- Entre os livres houve sistemática superioridade numérica feminina, encontrada em pequena medida (população feminina manteve-se entre $51 \%$ e $55 \%$ ) e com pequenas variações ao longo do tempo, decorrentes de flutuações em montantes diferentes do número de indivíduos de cada um dos sexos, ainda que, em regra, homens e mulheres 
tivessem suas populações variando no mesmo sentido e em proporções relativamente próximas;

- Na parcela da população livre com ao menos 15 anos de idade parte majoritária era casada, seguida por solteiros(as) e com pequena representatividade de viúvos(as), sendo o percentual devido aos homens sempre superior aquele verificado para as mulheres entre os solteiros. As mulheres, em maior proporção que os homens, eram viúvas e, atingindo os 50 ou mais anos de idade, as mulheres, mais que os homens, eram solteiras;

- Foi característico haver ao redor de seis indivíduos, entre livres e cativos, por unidade domiciliar, com variação em torno de um para mais ou para menos, indicativos de que a distribuição dos mancípios pelos domicílios era bem dispersa, à parte de alguns fogos com elevados plantéis;

- Houve predominância numérica de proprietários de pequenos plantéis entre o total de senhores. As modas (o tamanho de plantel mais comumente encontrado), foi bastante reduzida: igual a dois ou, majoritariamente, igual a um;

- Foram comuns mudanças nas razões de sexo observadas para diferentes tamanhos de plantéis: a razão muda favoravelmente aos homens na medida em que se amplia a faixa de tamanho de plantel considerada. Em plantéis muito grandes a razão de sexos foi sempre superior àquela encontrada nos menores grupos de cativos;

- Os cativos concentravam-se em faixas etárias mais jovens (não crianças): 15-19, 20-24 e 25-30 anos de idade, faixa em que em maior medida eram homens, tipicamente resultado de efeitos migratórios;

- A composição por setores de atividade econômica das diferentes localidades apresentou evolução diversa para cada uma delas, não sendo identificado sentido único e claro de flutuação, a não ser aquele que aponta para número absoluto de fogos e, por conseguinte, elevado contingente populacional encontrado no setor agricultura e manufatura rural; 
- Atividades militares foram as mais bem apresentadas nos arrolamentos populacionais, por abrangeram não somente os chefes de domicilio, mas também os demais indivíduos com alguma patente. Característica marcante do corpo militar era a sua necessária conjugação com outros setores, especialmente a agricultura, a atividade principal e efetivamente responsável pelos ganhos pecuniários ou a subsistência do domicílio;

- Dentro do setor agricultura o padrão foi, em diferentes medidas, a policultura. Mas invariavelmente como produção característica, em dispersão pelos fogos e volume produzido, identificamos o milho, que teve valor estratégico e cumpriu papel similar em toda a área estudada - tratava- se de um produto de fácil e rápido cultivo, crucial na alimentação humana e de animais. Junto o ao milho aparece primordialmente o feijão. Milho e feijão caminhavam juntos e indubitavelmente eram traço marcante da produção do entorno paulistano;

- Produtores de milho típicos eram aqueles produzindo entre 10 e 50 alqueires do grão, sendo as grandes colheitas do cereal ligadas a fogos com grande número de indivíduos e/ou animais (ou seja, grande demanda) que apesar do elevado montante produzido tendiam a consumi-los na própria unidade produtiva não sendo o milho, de forma considerável, transacionados por esses produtores;

- Houve destaque de um setor de atividade econômica e/ou outro produto a ela vinculado em cada localidade, apontando para certa especialização, que em não sendo destacada para algumas localidades nas ocupações, o foram na identificação de cultivares para além dos tradicionais milho e feijão, a compor cada uma de suas produções locais;

- Em sendo padronizada a base produtiva para as localidades, a especialização era responsável por uma diferenciação que se dava, especialmente, em suas relações comerciais, importantes na geração de recursos monetários e na dinamização das economias. As contas comerciais, ao que parece, foram negativas quando da especialização em grãos e positivas para gêneros manufaturados, que apresentavam maiores valores adicionados; 
- Parte importante das características econômicas das localidades estava ligada ao fator geográfico, uma vez que na multiplicidade atividades e/ou produtos encontrados verificamos influências diversas também atinentes a povoações vizinhas;

- Na década de 1810, a estrutura fundiária da capitania de São Paulo era bastante concentrada. Não fugiu ao modelo concentrador de terras nenhuma das localidades estudadas, independentemente da dinâmica de sua economia e das conseqüentes possibilidades de acesso ao mercado de terras que estas poderiam gerar;

- Existiam em quantidade majoritária menores propriedades ocupando uma área realmente diminuta e grandes extensões rurais, acima de 1000 alqueires, representavam, habitualmente, cerca de $1 \%$ das propriedades arroladas;

- A concentração do tamanho das propriedades e a presença de glebas de diferentes tamanhos, estavam mais diretamente vinculadas ao momento e conseqüentemente à idade do povoamento e ocupação produtiva de cada localidade, do que ao grau de mercantilização verificado para as agropecuárias locais. A concentração do tamanho dos terrenos tendia a ser mais acentuado quanto mais recente a ocupação;

- O mercado fundiário teve presença marcante, sendo a forma de aquisição de propriedades predominante a compra, com terrenos em todas as faixas de extensão tendo sido comercializados. Foram características áreas médias mais elevadas entre as propriedades compradas comparativamente àquelas adquiridas por herança;

- Os detentores de dois ou mais imóveis possuíam, em regra, terras anexas, com marcante presença de pequenas glebas;

- Em comparação do tombamento de bens rústicos com a lista nominativa de habitantes encontramos uma maioria de chefes de fogo sem terras e sem escravos, padrão que aponta a necessidade de recorrer à mão-de-obra familiar e, eventualmente, de agregados para se trabalhar e isto, em terras alheias;

- Houve aumento de número de escravos de acordo com o aumento da área considerada para as propriedades ligadas ao trabalho compulsório, mas sendo a correlação calculada diretamente para área das propriedades contra número de 
escravos baixa, ainda que positiva. As grandes propriedades nem sempre estavam ligadas à posse de escravos, entretanto, na presença de vínculo, o plantel correspondente era, comumente, composto por vários indivíduos. 


\section{Apêndice 1}

\section{EVOLUÇÃO ADMINISTRATIVA E TERRITORIAL: BREVE HISTÓRICO}

O que hoje conhecemos como o estado de São Paulo, nos séculos XVI e XVII era a então capitania de São Vicente, e compreendia as atuais áreas de Minas Gerais, Goiás, Mato Grosso, Paraná, Santa Catarina e parte do Rio Grande do Sul, pertencentes em seu momento inicial ao donatário Martim Afonso de Sousa.

Em 1720 criou-se um governo para Minas separando-a de São Paulo, que passou por sucessivos desmembramentos com a criação dos territórios do Rio Grande do Sul e Santa Catarina (1738), chegando mesmo a própria Capitania a ser extinta sob a subordinação do Rio de Janeiro por alvará de 1748, quando também desmembraram-se Goiás e Mato Grosso. Pouco menos de duas décadas depois, em 1765, restaurou-se novamente a Capitania, tendo como primeiro governador enviado por Portugal D. Luis Antonio de Sousa Botelho Mourão, o Morgado de Mateus. (cf. PRADO, 2004, pp. 157158).

Iniciado o povoamento paulista pelo litoral (Santos e São Vicente), colonizou-se a área Planaltina, ainda no Seiscentos. Santo Andre e depois São Paulo de Piratininga foram as primeiras áreas planaltinas colonizadas, tendo o povoamento da primeira se redirecionado para a segunda. ${ }^{96}$ Os jesuítas, com seus objetivos escolares e religiosos, têm seu nome ligado à organização primitiva da vila, especialmente nas personagens de José de Anchieta e Manuel da Nóbrega.

Instalado o núcleo populacional paulistano, ele deu origem às conhecidas bandeiras de exploração do território mais adentro até meados do século XVIII, inicialmente na captura do gentio da terra e posteriormente na busca de metais preciosos.

As expedições com finalidades de buscar os índios para vendê-los como escravos tornaram-se então freqüentes. Nelas está a origem das Bandeiras.[...] Durante todo o século XVII e parte do XVIII, a vila de São Paulo foi o ponto de partida das Bandeiras. Tirando proveito da situação geográfica privilegiada da vila, os bandeirantes percorreram distâncias consideráveis. [...] Pela metade do século XVII,

\footnotetext{
96 "Apesar do relativo contingente populacional, Santo André não chega a prosperar, devido às dificuldades enfrentadas por seus moradores, desde a carência no abastecimento de víveres até a ameaça de ataques indígenas. Paralelamente outra povoação no planalto paulista começa a se desenvolver.[...]Situada em condições naturais favoráveis à sua proteção e contra eventuais ataques indígenas e contando com a assistência da Igreja Católica, esta povoação conhece rápido progresso, atraindo, de forma paulatina, os moradores da vila de Santo André. É assim que [...] o então governador geral Mem de Sá [...]ordenou a extinção desta e erigiu a vila de São Paulo [...]" (IGC, 1995, pp.66-67)
} 
o movimento paulista de perseguição aos índios estava em declínio, pois o número destes começava a diminuir. Mas as bandeiras voltaram-se para outros objetivos: a busca do ouro e pedras preciosas. (MARCÍLIO, 1973, pp. 17-18) ${ }^{97}$

Durante todo esse processo houve, ao longo dos caminhos rumo ao sertão, a formação de aglomerados humanos - foi recorrente a radicalização de pessoas ou grupos ao terreno virgem, os quais destruíam sua vegetação primária, e iniciavam ali sua cultura - e o conseqüente espraiamento das vilas, que foi sucessivamente alargando a faixa colonizada, na medida em que a "colonização do território paulista se desenvolve por estrias que acompanham as vias de comunicação que levam do litoral para o interior do continente" (PRADO Jr., 1996, p.67).

A população, a priori concentrada no entorno do núcleo central paulistano, dava origem a bairros e localidades cada vez mais distantes, que a sua vez dava origem a bairros e localidades cada vez mais distantes, em um povoamento descontínuo e disperso.

Parece certo que cada nova extensão da área assim assenhoreada se faz à custa do núcleo primitivo ou, em menor escala, dos secundários, que vão recebendo desfalques às vezes consideráveis em sua população. E não é menos exato dizer ainda que essas sangrias, como de ordinário sucede nos movimentos colonizadores, costumam verificar-se depois de saturados aqueles núcleos. [...] o fato é que, o multiplicar-se, entre nós, de vilarejos novos, não exprime forçosamente um aumento no número de habitantes de toda a região.

O nascimento de um novo povoado pode, em realidade, originar-se da simples escassez, no termo da vila madre, de espaço disponível e acessível para a abertura de roçados [...]

A outra causa e mais freqüente desse alastrar-se da população associa-se ao próprio regime de trabalho rural que adota [...] sempre é dispersivo e perdulário" (HOLANDA, 1966, pp.55-56)

Assim, o aumento ou a simples transferência da população de determinadas localidades transformou-as em novas povoações, bairros, freguesias e vilas, desmembrando-as dos municípios a que pertenceram, processo iniciado nos tempos dos donatários e intensificado nos séculos posteriores, respondendo, então, por um processo ininterrupto realizado através dos tempos até os anos mais recentes.

São Paulo de Piratininga propriamente deu origem a três dentre as localidades que conformam o território por nós estudado: Atibaia, Nazaré Paulista e Bragança Paulista, submetidas que foram à municipalidade paulistana até as décadas finais do Setecentos. Os movimentos de expansão paulista para leste da vila de São Paulo levaram ao

\footnotetext{
${ }^{97}$ As descobertas auríferas, assim como, em menor medida, o declínio do apresamento indígena, forneceram subsídios para a dispersão da população por que passaram, então, as populações seiscentistas paulistas rumo àquelas áreas, que já apontavam o sentido das novas regiões a serem exploradas.
} 
povoamento da região de Mogi das Cruzes (um dos municípios paulistas originários) e Jacareí, no Vale do Paraíba, e para oeste acarretaram na povoação de Jundiaí. As localidades em tela são mostradas na Figura 1.1.

[...] longe de movimentar apenas famílias isoladas, muitas das migrações responsáveis pela formação desses núcleos chegam a assumir o caráter de deslocamentos maciços, capazes de afetar fundamente a estrutura demográfica de áreas já caracterizadas por seu notável índice de mobilidade e dispersão. (HOLANDA, 1966, p.95)

Seguindo o mesmo e característico processo, todas as referidas localidades sofreram sucessivos desdobramentos, implicando em várias modificações em suas unidades territoriais e administrativas. $\mathrm{Na}$ extensão correspondente a elas quando do período por nós analisados, qual seja, os anos finais do século XVIII e as décadas iniciais do século seguinte (mostrada na Figura 1.1) encontramos hoje quase 40 municípios, mostrados na Figura 1.2. A figura seguinte apresenta os desdobramentos territoriaisadministrativos por que passaram estas localidades. 
Figura 1.1

Aproximação do território estudado (projeção sobre mapa atual)

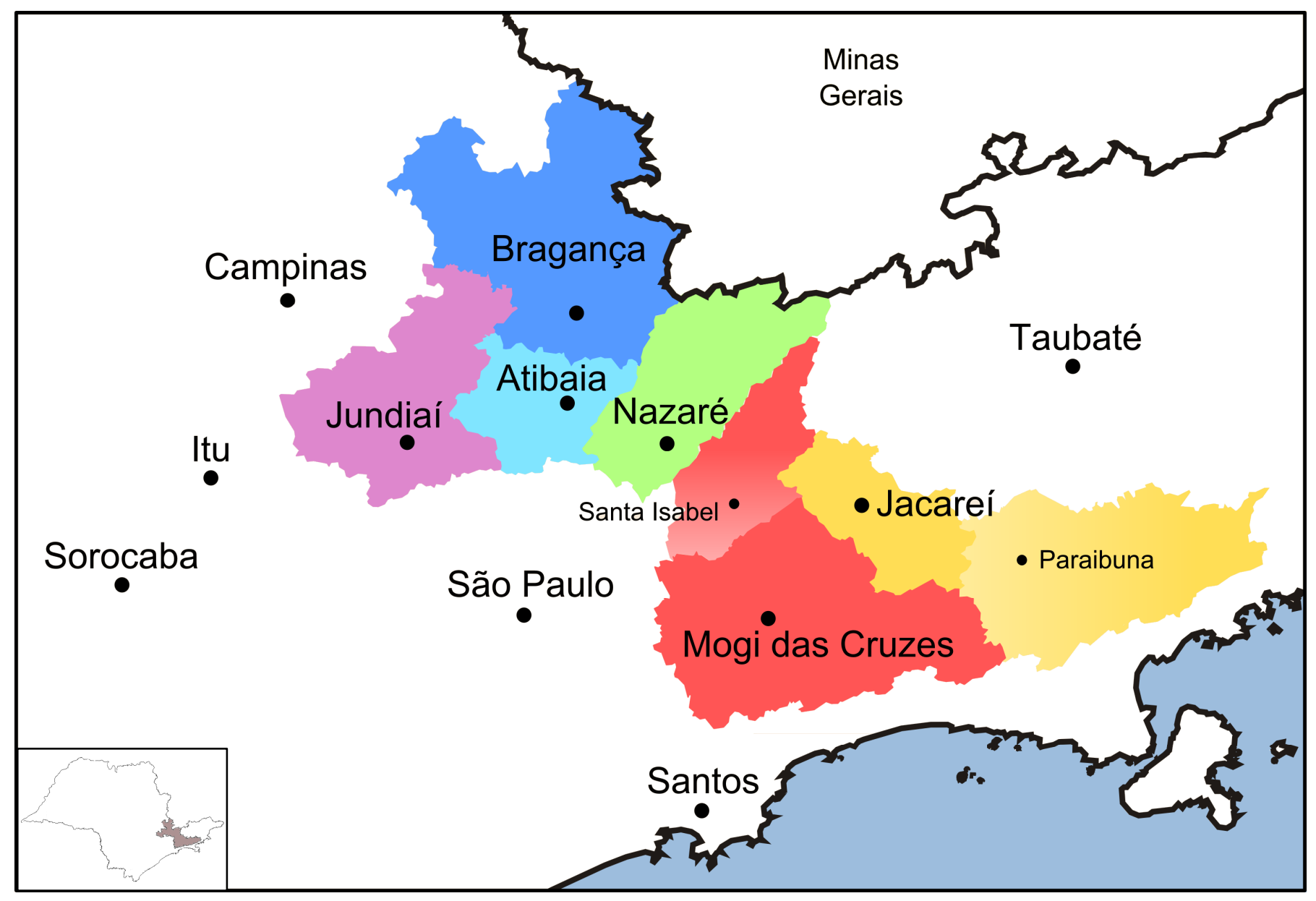


Figura 1.2

Divisão atual dos municípios localizados no território estudado

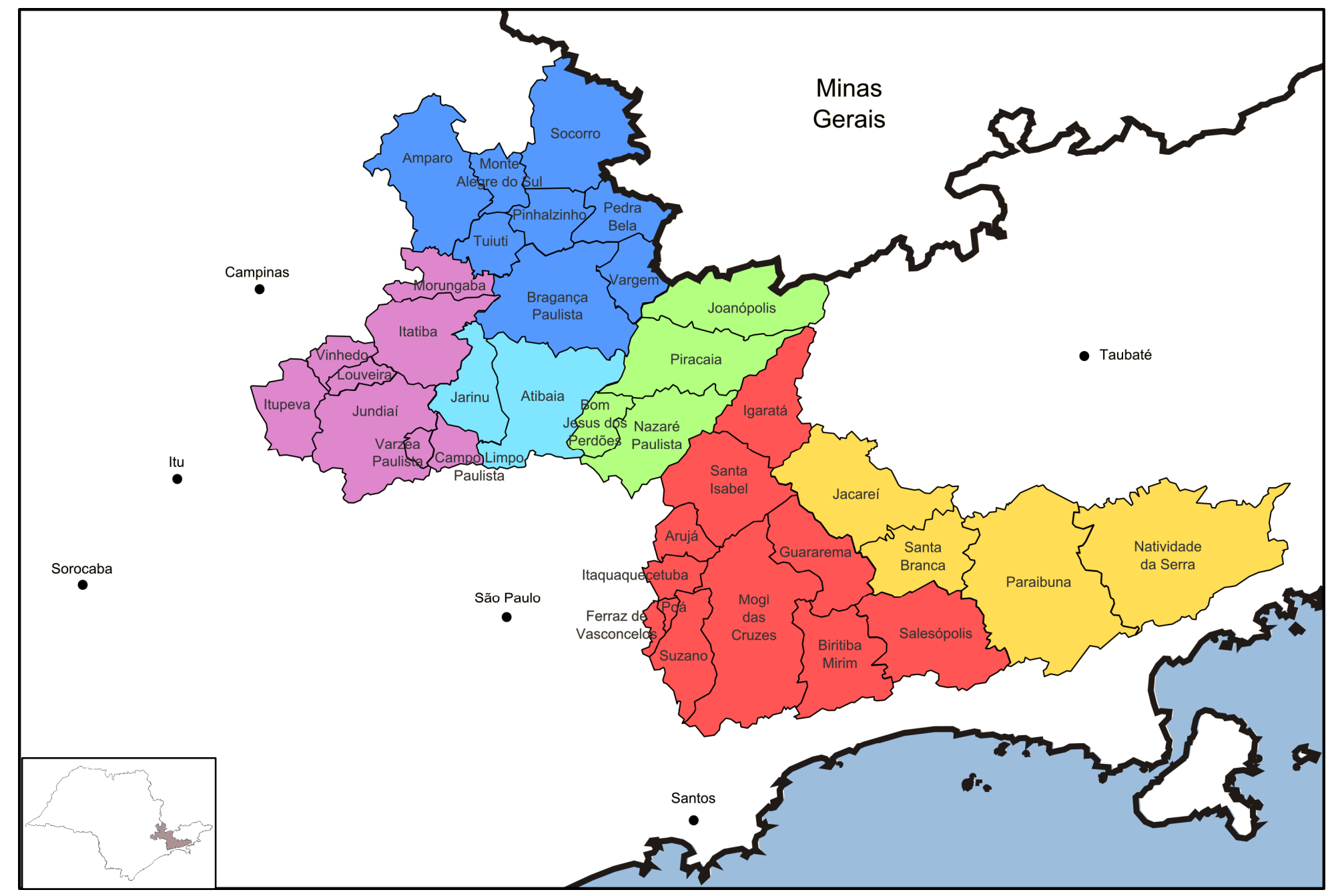


Figura 1.3

\section{Desmembramentos do território estudado}

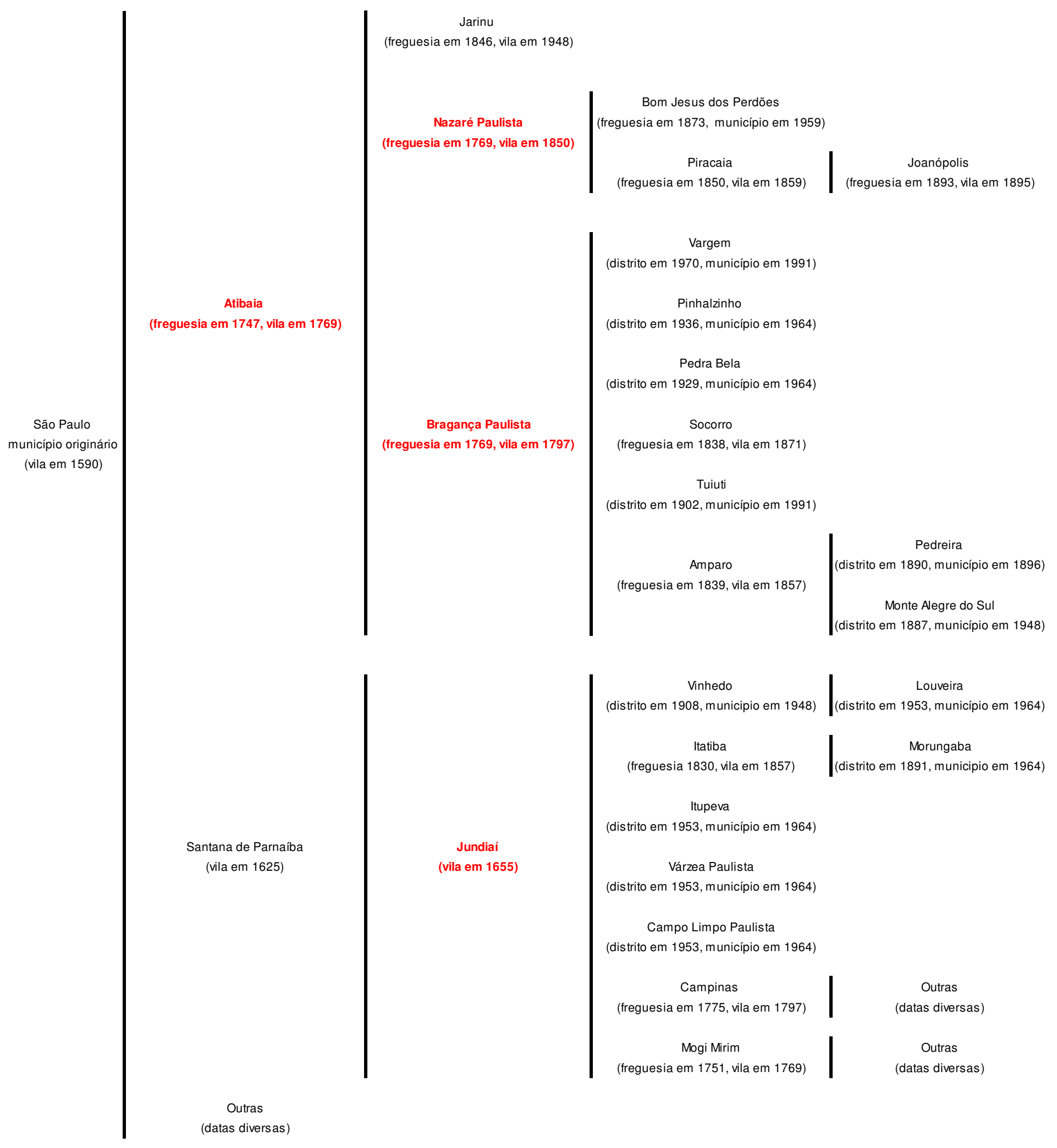




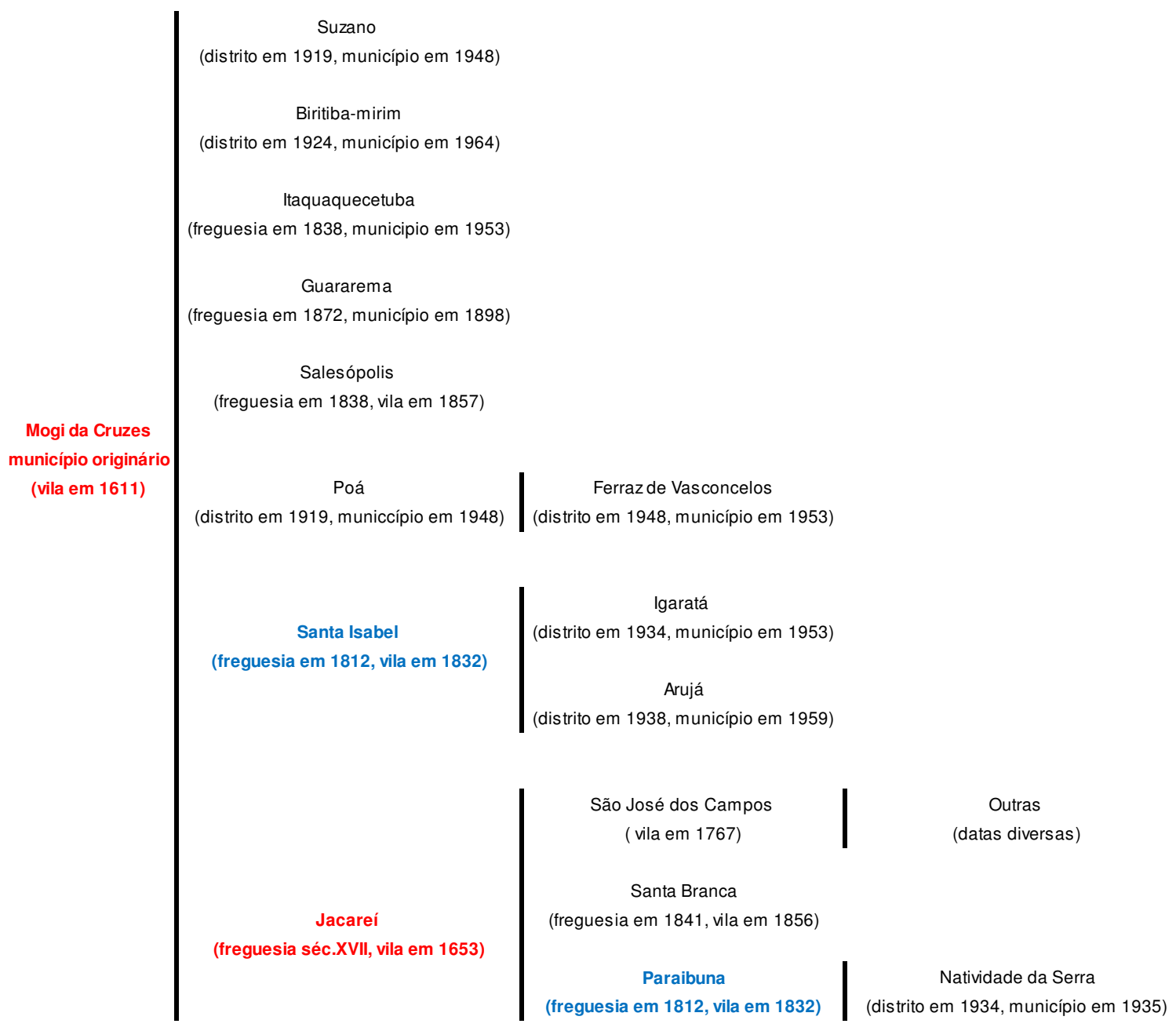

Fonte: IGC (1995)

\section{$\underline{\text { Jundiaí }}$}

Seguindo o referido processo de interiorização de São Paulo, em que "[...] os bandeirantes acabaram por criar, durante suas andanças pelas matas para a captura de índios, pontos para o descanso nas beiradas de várias trilhas originalmente abertas pelos próprios indígenas" (JUNDIAÍ (município), 2002, p.29), temos os primórdios de Jundiaí. Conhecida como "Porta do Sertão", início do caminho de muitas entradas e bandeiras local à frente da expansão territorial colonial - Jundiaí compreendia originalmente a área 
que se estendia desde o Rio Grande - atualmente marco divisório entre os estados de São Paulo e Minas Gerais - até as vilas de Santana de Parnaíba e de São Paulo.

Não se sabe se este povoado, em algum momento, é elevado à categoria de freguesia, mas há provas documentais que atestam ter Jundiaí se desmembrado de Santana de Paranaíba, pois que seu território encontrava-se no termo desta vila. Entre estes documentos, destaca-se o inventário de Afonso Dias: 'aos 30 dias do mês de agosto de 1654 anos nesta paragem de Jundiaí, sítio do defunto Rafael de Oliveira, termo da vila de Santana de Parnaíba'

Acredita-se ter Jundiaí passado a termo de Santana de Parnaíba quando da criação desta vila, desmembrada de São Paulo em 14 de novembro de 1625, tendo permanecido subordinada a ela até o momento de sua emancipação, em 14 de dezembro de 1655. (IGC, 1995, pp.83-84)

O povoamento da região de Jundiaí deu-se em época ignorada e de forma dispersa, mas de acordo com o Quadro do desmembramento territorial e administrativo dos municípios paulistas por volta de 1625 é provável que já houvesse moradores na região. E, somente a partir dos anos finais da década seguinte esse povoamento se intensificou.

Azevedo Marques (1953, p.66) aponta a fuga para o sertão de Rafael de Oliveira e Petronilha Antunes em data anterior, 1615, após terem cometido crime passional em São Paulo, como o início da povoação jundiaense. ${ }^{98}$ Versão que tem sido contestada, uma vez que a esse tempo havia em São Paulo duas pessoas com o nome Rafael de Oliveira em São Paulo, pai e filho, e este último, nascido em 1602, teria apenas 13 anos quando da data mencionada por Azevedo Marques, ou seja, ao que tudo indica seria demasiado jovem para cometer crime amoroso, se embrenhar e sobreviver no sertão desconhecido. E o pai, seria sertanista e estaria no sertão entre 1614 e 1615, quando retornou a São Paulo envolvendo-se, então, com o inventário de sua mulher, falecida quando de sua ausência e contraindo segundas núpcias em 1816. (cf. CAMPANHOLE, 1994)

Parece, todavia, ter havido uma confusão na transcrição das datas por Azevedo Marques, pois certo é que Rafael e Petronilha foram os doadores dos recursos para a edificação da primeira capela devotada a Nossa Senhora do Desterro, no ano de 1851. (cf. CAMPANHOLE, 1994)

\footnotetext{
98“[...] Assim, a migração inicial, anterior possivelmente ao ano de 1620 e provinda, ao que consta, do estabelecimento de pessoas criminosas que para aqueles lugares se deslocaram com as famílias e apaniguados, fugindo à perseguição das justiças, filia-se claramente ao tipo de povoamento por homízio e couto. Importado de Portugal, onde tem raízes medievais, alcançou importantes repercussões na colonização do Brasil." (HOLANDA, 1966, p.97)
} 


\begin{abstract}
A igreja desta freguesia é da invocação de Nossa Senhora do Desterro; teve seu principio no ano de 1651 anos, como melhor consta de um letreiro que os antigos fundadores dela puseram em visíveis letras na lumieira de cima da porta principal da Matriz que ainda hoje se conserva nova, anos depois de descoberta esta povoação, foi alta a Igreja por duas famílias poderosas e vindas que foram, Petronilha Reis Antunes, Dona viúva com seus filhos e genros e Rafael de Oliveira com sua mulher e filhos e genros, que por criminosos e fugindo da Justiça vieram rompendo os sertões, ou sertão de matos virgens até chegar a esta altura onde se acha e fez-se vila, situada no Rio Chamado Jundiaí, estes tais fundadores eram natuaris (sic!) e fregueses da Vila de São Paulo, cidade que é hoje por mercê de Deus e se S. Majestade, que Deus guarde. (Traslado do tombo da Igreja matriz da Vila de Jundiaí. 1747 - apud MAZZUIA, 1976, p.24)
\end{abstract}

Em se considerando 1651, provavelmente teria chegado a Jundiaí "o Moço". É sabido que Rafael, com sua família, instalou-se em Jundiaí em 1649 "acompanhado por cerca de 250 índios, alguns escravos e muito forros e homens de armas, que somados, formavam um aglomerado de cerca de 300 almas" - o que remete ao menos a esse ano um povoamento regular -, ali falecendo em 1654. "De Petronilha, até o presente momento, por falta de documentação, nada, absolutamente nada, se pode afirmar, não se conhece ascendentes nem antecedentes." (MAZZUIA, 1976, p.36)

"O primeiro lugar a ser ocupado foi a Serra do Japi, onde o fundador formou sua fazenda e, em seguida, os homens de armas que o acompanhavam estabeleceram-se em outras terras, serra abaixo, onde atualmente se localiza o centro da cidade" (CAMPANHOLE, 1994)

Para além da questão Rafael-Petronilha fato é que desde a décadas anteriores a 1850 sesmarias já haviam sido doadas na região, como atesta a sesmaria recebida em 1642 por Sebastião Fernandes Correa - que não deixava de fazer referencia à dita Petronilha, aliás, segundo Holanda (1966), único documento existente a fazê-lo:

(...) nas cabeceiras de Petronilha Antunes cortando a ponta de terras de Hibiturucaia partindo de uma banda com terras de Amador Bueno e da outra banda com uma (...) de Pedro Madeira e confronta da banda de Amador Bueno de uma taperas que foram de um índio chamado Marafana rio arriba chamado Jundiahi que seriam duas léguas pouco mais ou menos em quadra pedindo me nome do dito senhor conde donatário desta dita Capitania (...). (apud JUNDIAì (município), 2002, p.24)

Em 14 de dezembro de 1655, por provisão do Capitão-Mor de São Vicente, Gonçalo Couraça de Mesquita, a povoação, fundada às margens do rio Jundiaí, foi elevada á condição de Vila, tendo recebido o nome de Vila Formosa de Nossa Senhora do Desterro de Jundiaí, em homenagem à padroeira da igreja local e ao rio, conhecido pela abundância de peixe e cujo topônimo decorre do tupi "Yundiá-y" que significa "rio dos Jundiás", tipo de peixe ali existente. 
Figura 1.4

Provável planta da vila de Jundiaí em 1657

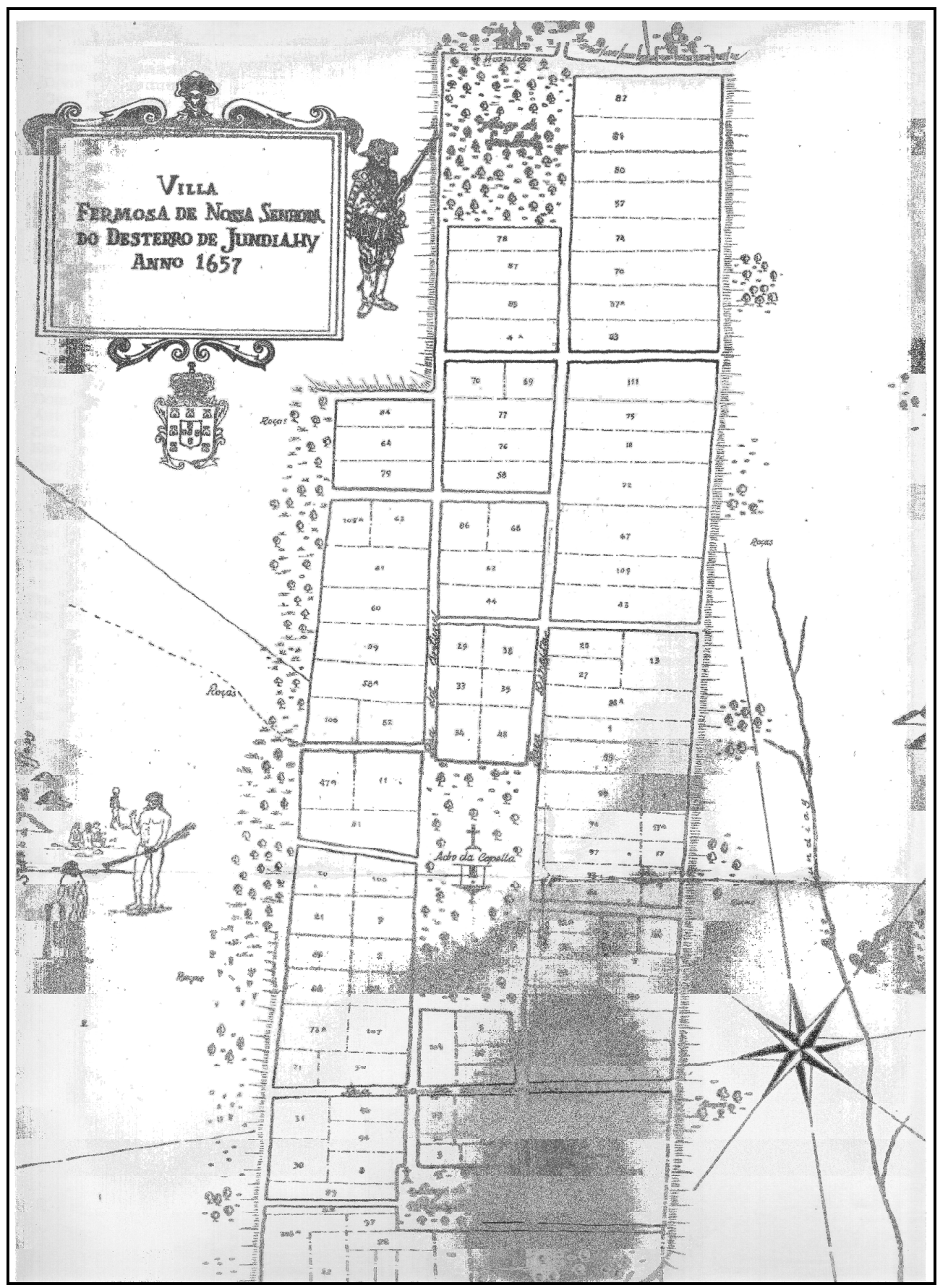

Fonte: MAZZUIA, 1976

Ressalte-se que apenas dois anos depois de ser elevada à condição de vila, as cartas de datas para casas e quintais da localidade naquele ano apontam, a existência no entorno da capela de mais de 110 lotes de terra, onde "diversos interessados" já 
possuíam seus ranchos (Figura 1.4). Eram 85 concessionários, em grande parte vindos de São Paulo. Como bem explorou Sergio Buarque de Holanda (1966, pp.96-97):

Entre os peticionários de datas na vila de Jundiaí, em 1657, há quem alegue estar lavrando na mesma paragem há doze anos, como Estácio Ferreira, ou mesmo há dezesseis anos, como Antonio Alvares Bezerra, e quer isto dizer que ali assistiriam desde 1645 e 1641 respectivamente. Nem por isso são os 'primeiros povoadores' do lugar. Os primeiros povoadores são expressamente Francisco de Gaia e Manoel Antunes Preto, os quais alegam notoriedade do fato e invocam testemunho dos moradores antigos. Mas não seriam os únicos. Igual título é invocado por Manoel Madeira e sua mãe Isabel Bicudo. Além disso, Maria Jorge e Agostinha Rodrigues se dizem 'donas viúvas dos primeiros povoadores'. Dos 85 habitantes do local que receberam datas entre fins de 1656 e março de 57, nada menos de 11 se diziam povoadores ou 'dos primeiros povoadores'; 18, netos e filhos de povoador, e 4 casados com filha de povoador. Com exceção de 2, que viviam em S. Paulo, mas queriam mudar-se para o lugar, todos os mais eram moradores no antigo bairro, agora vila, do Desterro de Jundiaí. ${ }^{99}$

Jundiaí prosperou desde o início de sua formação por constituir um ponto de parada natural, um "porto seco" de apoio para as expedições que se dirigiam aos sertões, que aí se abasteciam de gêneros produzidos pelos seus habitantes. Mais de dois séculos depois, em 28 de março de 1865, lei provincial eleva Jundiaí à categoria de cidade.

\section{Bragança}

Com nome que remete à tradição portuguesa, tendo a "Casa de Bragança" durante séculos governado Portugal e o Brasil, a hoje cidade de Bragança Paulista nasceu no topo de uma colina, à margem direita do ribeirão Canivete (hoje Lavapés), pequeno afluente do rio Jaguari.

As primeiras notícias acerca do território bragantino são datadas do início do século XVII, quando expedição colonizadora chefiada por Francisco de Souza seguindo rumo a Goiás e Minas em busca de ouro, "fez ponto no morro do Lopo". Mais tarde, já no

\footnotetext{
99 "Ao Preto não se referem outros textos, além da sua carta de data, e nem sequer os escritos genealógicos conhecidos, mas seu apelido sugere que pertença à numerosa parentela dos Antunes, dos Rodrigues, dos Hortas e assim, possivelmente, de Petronilha Rodrigues Antunes, a mesma que segundo versão publicada por Azevedo Marques, teria feito com Rafael de Oliveira - o Moço, por volta de 1615, a capela da invocação de Nossa Senhora do Desterro, que dará seu nome à vila futura. Ė significativo como outro que alega, a 27 de janeiro de 57, ser povoador da vila e mais, 'casado com filha do primeiro povoador dela', é João Leme do Prado, provavelmente o filho de Pedro Leme, aparentado, assim, pela linhagem materna, aos Pretos, além de genro de Gaspar de Louveira, um dos primeiros moradores da vila, que recebe sua data em frente ao pelourinho." (HOLANDA, 1966, p.97)
} 
século XVIII, Bartolomeu Bueno da Silva abriu a estrada que "depois de atravessar o território de Atibaia penetrava em Bragança, em direção ao norte da Capitania, passando pela zonas onde hoje estão Amparo, Mogi-mirim, Casa Branca, Batatais, até chegar ao porto de Anhanguera nas barrancas do Rio Grande" (SILVEIRA \& LAURITO, 1943, pp.2526), já se iam duas décadas do Setecentos.

Mas os primeiros povoadores chegaram efetivamente à região na segunda metade o século XVII estabelecendo-se então as primeiras fazendas na região bragantina. No bairro do Jaguari, pertencente à freguesia de Atibaia, ocorreram as primeiras demarcações de terras, em local de passagem e descanso de tropeiros. Até que em 15 de dezembro de 1763 foi doado por Antonio Pires Pimentel e sua mulher Inácia da Silva um terreno para que fosse construída capela em homenagem à Nossa Senhora da Conceição, ao que consta, como pagamento de uma promessa religiosa, por feito realizado pela santa ${ }^{100}$. Foi tal a afluência de pessoas de outras localidades que em 13 de fevereiro de 1765 foi criada a Freguesia da Conceição do Jaguari - nome que homenageia a Santa padroeira da primeira capela - sendo nomeado o primeiro vigário, Jeronimo de Camargo Bueno, que àquele ano já havia realizado "o primeiro batizado na nova paróquia" (cf. SILVEIRA \& LAURITO, 1943)

A então freguesia era judiciária e administrativamente ligada a Atibaia, o que provavelmente não agradava aos habitantes locais pois poucos anos depois os residentes na localidade dirigiram-se ao governador geral da capitania por meio de um abaixo assinado em que os moradores da Freguesia de Jaguari pedem a ereção do mesmo em Vila. No documento os moradores de Bragança sugeriam a transformação da freguesia em vila, argumentando que ao estarem subordinados à Atibaia estavam bastante longe da justiça, especialmente por estar a freguesia na divisa com as Minas Gerais e pra lá seguirem os criminosos antes que se possa dar notícia a Atibaia, ademais das custosas dependências judiciais "pelas muitas léguas que contam de caminho os respectivos oficiais". Consta também no requerimento

Que os moradores da dita freguesia são obrigados a exercerem os cargos da República da Vila de Atibaia com notável detrimento, deixando suas casas, lavouras, mulheres e filhos pelo ano de sua ocupação, alugando casas para suas residências, porque na dita vila os não tem, além das demais despesas, o que comodamente podem fazer na dita freguesa onde tem suas casas e necessários (apud SILVEIRA \& LAURITO, 1943, p.64)

\footnotetext{
${ }^{100}$ Ao que consta, a promessa era pela recuperação de Antonio Pires Pimentel, "doente e desenganado".
} 
Decerto tal desmembramento não era de interesse para Atibaia, pois sobre a "pretensão" bragantina, assim manifestou-se à época a Câmara de Atibaia:

[...] Naquela freguesia de Jaguari não há outra coisa em que se estabeleçam as rendas senão aquele único estanco, no Talho, na aferição e entradas se nesta vila compreendendo três freguesias (Atibaia, Jaguari e Nazaré - DOMR) se arremata por tão limitados preços, pior há de ser lá, que só compreende uma; e por isso quer parecer que estes rendimentos não são bastantes para se formar casa de Câmara, cadeira com os necessários ferros, despesas anuais, e o mais que um Conselho deve depender" (apud MARTINS, 1940, p.87)

Contudo, em portaria de 17 de outubro de 1797, a Freguesia de Conceição do Jaguari foi elevada à condição de Vila, sob a nova denominação de Vila Nova de Bragança, sendo erigida a vila com seu pelourinho, cadeia e paço do conselho no mês seguinte:

Atendendo a justa representação, que fizeram os moradores da Freguesia de Jaguari, termo da Vila de São João de Atibaia, para que a mesma freguesia fosse criada, e ereta vila, e isto não só pelo fundamento de haver nela quatro mil, quatrocentas, quarenta, e seis pessoas de confissão; mas também povoação freqüentada de comerciantes para a Capitania de Minas Gerais, tendo por isso toda capacidade e disposição para vir a ser, em poucos anos uma das vilas opulentas desta Capitania [...]Tendo consideração de que os expressados motivos expostos pelos referidos habitantes, se acharam identicamente verdadeiros; e atentando principalmente, que a criação da mesma freguesia em vila é em tudo conforme as régias instruções de vinte, e seis de janeiro de mil setecentos, e sessenta, e cinco, e outras ordens posteriormente dirigidas aos Governadores e Capitães Generais desta Capitania. Hei por bem ordenar no Real Nome de Sua Majestade, e por serviço da mesma Senhora, ao Doutor Ouvidor Geral desta Cidade, e Comarca Caetano Luiz de Barros Monteiro que passando in continenti a mencionada Freguesia de Jaguari, faça erigir a sua nova povoação em Vila, cuja se denominará - Nova Bragança [...] (apud SILVEIRA \& LAURITO, 1943, pp.76-77)

Em dezembro do referido ano foram eleitos e nomeados juiz, corpo de vereadores, e demais oficiais da câmara: "[...] para Juízes, o capitão Lourenço Franco Bueno, e o Capitão Antonio Lemes da Silva; Para vereadores o alferes José Paes da Silva, Lourenço Justiniano Freire de Figueiredo e Christovão Xavier do Prado: Para Procurador João Gomes Ferreira [...] (apud SILVEIRA \& LAURITO, 1943, p.79).

Pouco antes de sua elevação à vila, o "arraial e freguesia de Jaguari” estava

[...] formado em um lugar muito aprazível,e alegre a formação dele há um espigão de campo com bastante planície em cima, de maneira que tem uma grande praça em cujo meio está situada a igreja matriz, pelo lado esquerdo está cercado de casas, e acaba de fazer uns muros feitos de Taipa com capacidade para neles se 
formarem casas; e pela banda que faz frente a igreja tem de um e de outro lado casas e pelo meio delas o alinhamento da porta principal da lgreja tem rua larga do cumprimento de duzentos passos mais ou menos, cujas casas são fabricadas de taipa de pilão, algumas de madeira e quase todas cobertas de telhas

Tem o distrito de Jaguari quatro mil, e quatrocentas e tantas almas; destas as pessoas que tem cabedais são o Capitão Jacinto Rodrigues Bueno, o Alferes Aleixo Corrêa da Cunha e Manoel Rodrigues Pereira, os quais conforme o estado daquela Freguesia, nela se tem por muito ricos, o Capitão Antonio Leme, José Xavier e Francisco de Lima que tem seu modo de viver; e fora destas são raras as casas onde nelas se procure a quantia de $12 \$ 000$ que se achem (apud SILVEIRA \& LAURITO, 1943, p.71)

A lei $n^{\circ} 21$ de 24 de abril de 1856 transformou a então vila em cidade com o nome de Bragança que continuou mantendo as características de seu assentamento inicial. A partir daí a evolução administrativa-territorial de Bragança foi marcada por modificações com o surgimento de diversas localidades no território bragantino que, em alguns casos, vieram a desmembrar-se (ver figura 1.3).

Em que pesem esses desmembramentos para conformação do território bragantino, vale mencionar que a localidade enfrentou problemas com sua unidade territorial desde as primeiras décadas do Setecentos, quando após a separação da capitania de Minas Gerais da capitania de São Paulo, surgiram com aquela capitania conflitos pelos marcos divisórios, ou seja, parte do território. O primeiro deles, em 1731, quando "[...] os marcos foram mudados furtivamente, havendo protesto do governador paulista, Antonio da Silva Caldeira."

Nova questão envolvendo tais limites ocorreu, por exemplo, ano depois quando, referindo-se a ocorrência de 1745, em 1765 recebeu Morgado de Mateus a informação de que:

Quando descobriram as Minas da Campanha do Rio Verde que estão na outra banda do Rio Sapucaí, para as partes da Minas Gerais, e por estar esta parte neste tempo na divisão de São Paulo, por se dizer e na Paragem chamada Caxambu, mandou o Governador de São Paulo (D. Luiz de Mascarenhas) para Intendente da capitação das ditas minas ao Capitão Bartolomeu Correa Bueno, morador na Freguesia de Atibaia; este lá chegando, veio do Rio das Mortes o Ouvidor cujo nome não me lembra, e botou-o fora daquelas minas, dizendo-lhe que o distrito de São Paulo era daquele Rio (o Sapucaí) para esta parte.(apud SILVEIRA, 1950, pp.166167)

Ou ainda décadas depois, em 1804, quando alguns moradores reconhecidamente antigos, são chamados a testemunhar acerca das fronteiras conhecidas, em um processo que se estende por longos anos. 


\section{Atibaia e Nazaré}

Localizada a cerca de $60 \mathrm{~km}$ ao norte da cidade de São Paulo, na atual zona fisiográfica da Mantiqueira, a hoje cidade de Atibaia tem como limites, ao norte Bragança Paulista, ao sul Mairiporã, a leste Piracaia e a oeste Jarinu e Jundiaí.

Spix e Martius (1981) passaram pela região em 1817 em sua descrição mencionaram que

Mais para o Norte se estende um campo montanhoso (Campo Largo) que nos apresentou rica florescência de belas plantas alpestres [...] Suas serras mais altas que vão paralelamente do Norte para o Sul, de contornos pitorescos algo semelhantes ao nossos Pro-alpes, em parte cobertas de selvas e capoeiras limitam a planície. O ponto mais alto, sobre o caminho, é o morro de Catetuva, de onde desce para um largo vale coberto de alguma mata nova, e limitada a Leste pela Parapizinga, montanha selvosa, bastante alta e de contornos escarpados.

Figura 1.5

Provável planta da vila de Atibaia em 1800

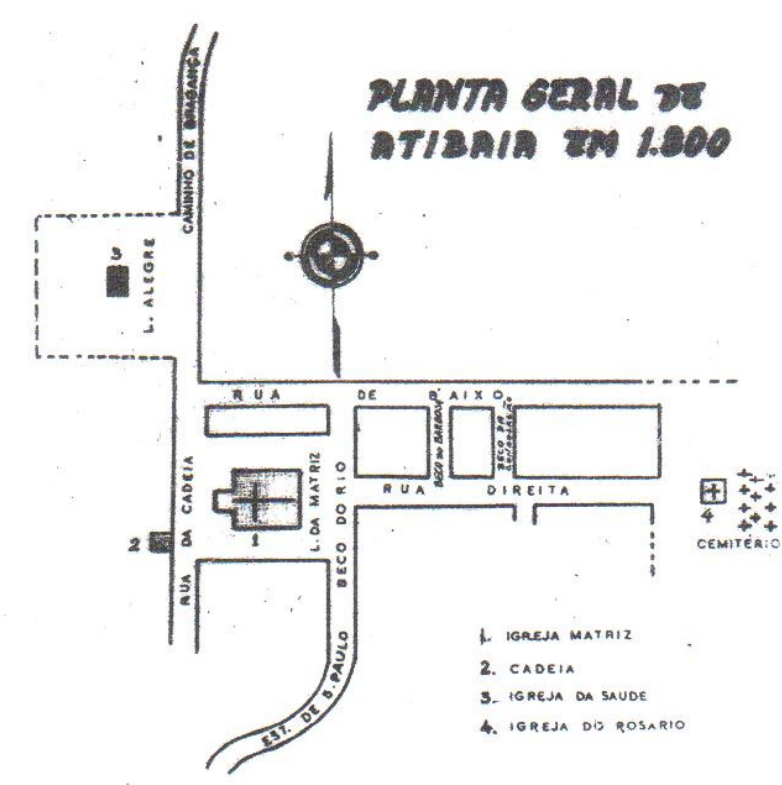

PLANTA GERAL DE ATIBALA EM 1800

RUA DE BALXo, atual Rua José Alvim

RUA DIRETTA, atual Rua José Lucas

BECO DO BARBOSA, atual Rua José Bim

BECO DA CONSOLAÇÁo, atual RUa José Inácio

RUA DA CADELA, atual Visconde do Rio Branco

BECO Do Ro, atual Rua Olimpto da Paíxão

EST. DE S. PAULO, atual "Escadão"

CEMTTÉRIO E CAPELA DO ROSARIO, atUal Igreja do Rosárto

LARGO ALEGTE ONDE SE ENCONTRAVA A IGREJA DA SAÚDE, atual praça Bento Paes

CAMINHO DE BRAGANĢ, atual Av. São João

Fonte: CONTI, 2001, p.29 
A localidade começou a receber população na segunda metade do século XVII. Segundo diferentes autores - Martins (1940), Silveira (1950), Marques (1953), Marcílio (1973), Conti (2001) - Jerônimo de Camargo fundou a localidade nesse período (décadas de 1650-60), tendo construído ali capela dedicada a São João Batista.

De acordo com a vertente tradicional (diga-se, a mais amplamente difundida) acerca da história local, descendente de uma das mais conhecidas famílias da época, ${ }^{101}$ Jerônimo de Camargo destacou-se entre os bandeirantes que, àquele tempo, abriam caminhos no sertão em expedições à procura de índios e metais preciosos. Junto ao rio conhecido pelos nativos como "Tubaia" ou "Atubaia" - cujo significado, do tupi-guarani, é "água agradável ao paladar" ou "manancial saudável" -, acabou por fixar-se, fundando a primeira fazenda da localidade, provavelmente criadora de gado, e que deu origem ao povoado. $^{102}$

Em 1665, teria chegado à região, por ordem da Câmara Municipal de São Paulo datada de 3 de julho daquele ano, o padre Mateus Nunes de Siqueira, responsável por catequizar os índios guarulhos, "descidos do sertão", que ali localizou. ${ }^{103}$ De acordo com Martins (1940, p.24), a região onde encontra-se Atibaia foi, originalmente, habitada exclusivamente pela tribo dos guarus (ou guarulhos) que "eram os que mais se prestavam ao aldeamento, pela sua índole dócil.". Foi ainda, segundo o autor, com esses elementos que contou Jerônimo de Camargo na sua empreitada para desbravar a região.

Contudo, há que notar haver contestação, por parte de outro historiador local, Afonso de Freitas, da fundação de Atibaia por Jeronimo de Camargo, atribuindo-a ao padre Mateus:

\begin{abstract}
A generalidade dos historiadores e cronistas afirma ter sido a povoação originária da atual cidade de Atibaia, fundada na segunda metade do século XVII pelo paulista Jerônimo de Camargo; entretanto, a documentação que conseguimos compulsar relativamente ao pródomos da cidade atibaiana nos leva a divergir daquela afirmativa, em relação à pessoa do fundador da povoação, que entendemos ter sido o padre Mateus Nunes de Siqueira, vigário da vara paroquial de São Paulo. Foi o
\end{abstract}

\footnotetext{
101 Jerônimo Camargo pertencia à importante família Camargo, uma das mais importantes de São Paulo, ocupando cargos de destaque na capital no Seiscentos. Jerônimo chegou a tomar parte na vida política paulistana, exercendo cargos de almotacé e juiz ordinário, integrando uma câmara sob o domínio dos Camargos.

102 Antes, todavia, algumas sesmarias haviam sido distribuídas na vasta área compreendida por Atibaia naquele tempo. Silveira (1950, pp. 85-95), levantou algumas delas, de acordo com o autor considerando que "é sempre o rio Juqueri" a melhor referência para esse levantamento, pois "as primeiras notícias sobre um rio denominado Ibiatibaia datam oficialmente de 1638, mas com a simples denominação de lbiatibaia não é possível fazer localização exata desta ou daquela sesmaria, porquanto o rio Atibaia começa na Serra do Mato Mole, passa por Nazaré, atravessa o município todo de Atibaia, e entra no de Campinas em grande extensão, sempre conservando o nome".

103 "Em 1665 andava o padre Mateus, então ouvidor da vara eclesiástica de São Paulo, em missão de catequizar os índios. Numa expedição que fez na vertente oposta da serra da Mantiqueira, desta desceu com grande número de gentios já reduzidos ao grêmio católico e, por ordem da câmara de São Paulo localizou-os na paragem denominada Atibaia."
} 
padre Mateus Nunes quem colocou na margem chamada Atibaia certa quantidade de aborígines da nação guarulho, descido do sertão com o intuito único de os chamar ao grêmio da igreja e da civilização [...] Não conhecemos documento algum pelo qual se possa, com segurança, atribuir a iniciativa de fundação de Atibaia Jerônimo de Camargo; a dar-se crédito às alegações dos seus herdeiros, ${ }^{104}$ foi ele, contemporâneo da fixação do gentio Guarulho na margem esquerda de Atibaia, em cuja margem direita, na paragem chamada Caaguaçú, cultivava grande trato de terra, mas a ata da vereança de 3 de julho de 1665 é clara bastante para que se não possa atribuir a parte capital na fundação da aldeia de Atibaia senão ao padre Mateus Nunes. (FREITAS, apud MARTINS,1940, pp.30-31)

O fato é que alguns anos depois da chegada desses primeiro povoadores, 1679, a então capela de São João Batista passou a capela curada, contando com padre próprio.

A partir daí, a evolução administrativa da localidade foi marcada pela elevação à condição de freguesia em 13 de agosto de 1747, com o nome de distrito de São João de Atibaia, pertencente ao bispado de Paratininga; e à condição de vila em junho de 1769 sendo o novo município instalado em 5 de novembro do dito ano -, quando se desmembrou do município de São Paulo, ao qual estava submetida até então. Consta, que tal elevação ocorreu em face de queixas acerca do "maléfico poderio de Jerônimo de Camargo, que, na ausência de autoridades criminais e dispondo de um corpo de mais de 500 índios, tinha nociva preponderância sobre a freguesia, impondo-lhe seus desarrazoados alvedrios e levando-a a desatinos" (apud CONTI, 2001, p.19). ${ }^{105}$

Alguns anos antes (1761), a Câmara Municipal de São Paulo já havia manifestado sua intenção de elevar Atibaia à condição de vila. Não o fez, atendendo aos membros da sociedade atibaiense que, em carta enviada àquela Câmara, alegaram ser tal feito prejudicial à localidade, tamanha a pobreza e indigência dos moradores locais, e isto posto por não haver meios com que "[...] fazer casa de Câmara e cadeia, e de que rendas se hão de pagar as rubricas dos livros, correições anuais despesas precisas do conselho [...]" (apud MARTINS, 1940, p.43).

Já havia em 1761 um termo de vereança, anexado ao auto de criação da nova vila em 1769, pois a elevação ocorreu "[...] na forma que mais largamente consta do termo que se lavrou na Câmara desta cidade aos quinze de fevereiro de 1761 [...]" (apud MARTINS, 1940, p.50). Tal termo menciona, caso os rendimentos de Atibaia (e seus distritos) não fossem suficientes para as despesas anuais:

[...] se lançaria uma imposição por entrada em todos os gêneros que viessem para a dita Freguesia, criada de novo em Vila, e seu Termo por negócio, e que nas terras

\footnotetext{
${ }_{104}^{104}$ A referida alegação dos herdeiros foi feita em pedido da sesmaria que apresentamos no capítulo IV.

${ }^{105} \mathrm{O}$ referido Jerônimo Camargo tinha como último nome Pimentel e era sobrinho-neto do fundador da localidade, que faleceu em Jundiaí, no princípio de 1707, sendo que "seus descendentes deram continuidade ao trabalho nas fazendas de gado".
} 
devolutas mais próximas à vila se lhe desse de rocio meia légua em quadra, que vinha ser um quarto para cada lado para a Câmara poder aforar as ditas terras, unicamente para casas e quintais correspondentes às grandezas das casas que se edificassem nas terras, todo em rocio à dita vila para a parte desta cidade até onde compreendia o distrito da freguesia de Nazaré e todo o distrito de S. João de Atibaia, e para a parte de Jundiaí chegaria o termo até onde acabava o da vila do dito Jundiaí [...] (apud MARTINS, 1940, p.54)

Construíram-se ou alugaram-se, então, prédios para abrigar cadeia, câmara municipal, pelourinho, e foi nomeado por Morgado de Mateus, então governador da Capitania de São Paulo, juiz, corpo de vereadores, e demais oficiais da câmara: "[...] para juízes Antonio Gonçalves da Cunha e o Capitão Domingos Leme do Prado, e para vereadores João Franco Viegas, Francisco Xavier Cezar e o Capitão André Pereira de Meireles, e para procurador do Conselho Manoel de Barcellos [...]" (apud MARTINS, 1940, p.59)

A nova vila e município, além do distrito próprio de Atibaia, possuía os distritos de Nazaré (atual Nazaré Paulista) e Jaguari (atual Bragança Paulista), igualmente povoados primitivamente em fins do século XVII, e também desmembrados de São Paulo. Jaguari tornou-se vila independente já em 1797, quando passou a chamar-se Vila Nova de Bragança (vide seção correspondente) e Nazaré permaneceu sob a jurisdição de Atibaia até 1850:

[...] servindo de divisa com a cidade a mesma das Freguesias de Nazaré e desta vila, e com Jundiaí, ficando também para esta Vila a Freguesia Nova de Jaguari por esta desmembrada da de Nazaré, que no dito termo de Vereança se assentou ficasse servindo de distrito a esta nova Vila de São João de Atibaia, e que os juízes que entrarem a servir mandassem logo por marcos nas partes convenientes nos distritos das freguesias acima ditas para evitarem dúvidas para o futuro... (apud SILVEIRA, 1950, p.188)

O foro de cidade foi dado a Atibaia em 22 de abril de 1864 (lei provincial $n^{\circ} 26$ ), sendo a cidade reconhecida simplesmente como Atibaia desde dezembro de 1905 (lei estadual $\left.n^{\circ} 975\right)$.

Como adiantado, Nazaré surgiu como freguesia jurisdicionada a Atibaia e assim permaneceu até 1850. A localidade foi um dos antigos povoados da era seiscentista e uma das primeiras freguesias da então Província de São Paulo. Sobre uma elevação à margem direita do Rio Atibaia, ao norte da cidade de São Paulo e dela distante cerca de 11 e meia léguas $(64 \mathrm{~km})$ teria surgido, nas décadas finais do Setecentos, "Nazareth".

Em 1676 Matias Lopes - Marques (1953) aponta também a figura de Gonçalo Simões - ali teria edificado uma capela em homenagem a Nossa Senhora de Nazaré, 
fundando o povoamento que daria origem a atual cidade de Nazaré Paulista, (cf. MARQUES, 1953;CARMO, 2006) de cuja capela herdou o nome.

O primeiro livro tombo daquela capela, manuscrito em 1688 pelo Padre Manoel Cardoso de Lima aponta que "Esta Igreja é de invocação de nossa Senhora de Nazareth, foi feita na era de mil seiscentos e setenta e seis e mandou-a fazer Mathias Lopes e seu Zuzarte Lopes, e não foi desmembrada de parte alguma, não consta petição nem alvará de consentimento dela." (apud CARMO, 2006, pp.149-150)

No entanto, Silveira (1950, pp.130-131) deduziu

[...] que o núcleo primitivo que deu nascimento à atual cidade de Nazaré, já estava formado muito antes de 1676, porquanto nesse ano foi a capela interditada; restabelecido o Curato em 1682 só teve pároco efetivo em 1688, data em que se procediam batizados; em 1686 já se faziam casamentos naquela capela [...]

Nazaré estava então no território pertencente à vila de Atibaia. Para a data de sua elevação à condição de freguesia, cuja criação implicaria em uma série de modificações no que tange ao crescimento do povoado e suas necessidades, encontramos diferentes referências. Merino (1976, p.34) aponta que "Não sabemos, ao certo, a data da elevação do núcleo à freguesia.", o Quadro do desmembramento territorial-administrativo dos municípios paulistas aponta 1769, e em Carmo (2006, p.152) encontramos:

"Freguesia de Nazareth (1731): A comunidade eclesiástica, tendo e mantendo o padre por conta de seus paroquianos, foi elevada à condição de "freguezia", como sendo uma instituição oficial, com administração eclesiástica e civil, subordinada administrativamente a uma vila, inicialmente a "Villa de São Paulo", e depois, em 1769, à "Villa de Atibaia".

Nazaré apenas desmembrou-se de Atibaia em 1850, quando por lei municipal de 10 de junho criou-se o novo município, constituído por dois distritos: o distrito próprio da vila e o da freguesia de Santo Antonio da Cachoeira, hoje Piracaia (desmembrado em março de 1859). Sua instalação verificou-se no dia 21 de outubro de 1850.

Esta vila possui casa de Câmara e cadeia em edifício acanhado, além da matriz as capelas do Senhor Bom Jesus Achado, e do Senhor Bom Jesus dos Perdões na estrada para Atibaia; esta última foi fundada por D. Bárbara Cardoso em terras de sua fazenda, com permissão do Ordinário, dada a 22 de maio de 1706. (MARQUES,1953, p.134) 
A Lei Estadual número 1038, de 19 de dezembro de 1906, criou a cidade de Nazaré. E em 30 de novembro de 1944 (decreto lei estadual numero 14334), sua denominação foi mudada para Nazaré Paulista.

\section{Mogi das Cruzes}

A localidade de Mogi das Cruzes teve origem indígena, sendo suas terras ocupadas originalmente pelos índios "Boigy" que no início do século XVII já estavam, segundo consta, extintos.

De acordo com Leopoldo e Silva (apud Grinberg, 1961) dessa origem indígena Mogi herdou parte de seu primitivo nome Santa Ana das Cruzes de Boigi Mirim, sendo Mogi uma alteração daquele nome original que significa "rio das Cobras", denominação dada pelo gentio a um trecho do Rio Tietê; menciona também que, de acordo com documentos oficiais, é possível verificar que os oficiais costumavam demarcar divisas de terrenos e demais marcos divisórios da vila com cruzes, de onde vem parte da denominação da localidade. Já Marques (1953) havia anteriormente anotado "[..] que no adro da primeira igreja matriz existiram plantados três cruzeiros e daí resultou aquela qualificação de Mogi das Cruzes."

Localizada "em uma lomba (plateau) formada pelos vales do Rio Tietê ao Norte, do ribeirão chamado de cima ao Sul e do Ipiranga a O." (MARQUES, 1953, vol.2, p.120), Mogi foi povoada nos derradeiros anos do século XVI e iniciais do século XVII, como um dos primeiros núcleos de população da região do entorno paulistano, sendo a terceira vila mais antiga do planalto paulista (Santo André da Borda do Campo e São Paulo de Piratininga tiveram povoamentos anteriores). Os primeiros moradores chegaram à localidade na virada do século XVI para o XVII. Vindos em sua maioria de Santos e São Paulo - grande centro de irradiação de bandeiras e de povoamento naquele período, como adiantado -, estabeleceram as primeiras Fazendas na região.

As primeiras demarcações de terras que se tem notícia ocorreram nesse período, sendo que há interessante "disputa" entre aqueles que versaram sobre a história local acerca daquele que efetivamente primeiro se estabeleceu em terras mogianas: Braz Cubas, em 1560 ou Gaspar Vaz, nos primeiros anos do Seiscentos. 
Tal situação ganhou tanto interesse público, que culminou com a designação de uma comissão de pesquisadores pelo prefeito da cidade, em 1980, a fim de provar 'quem era, afinal, o fundador de Mogi das Cruzes.'[...] Tendo, por fim, a comissão concluído por Gaspar Vaz, que o povoado era surgido em meados de 1601, e que a data crucial de seu reconhecimento era mesmo o primeiro dia de setembro de 1611 [...]" (DIAS, 2001, p.9)

De acordo com os partidários de Braz Cubas o bandeirante embrenhou-se pelo sertão e descobriu ouro "em uma vasta sesmaria que chega quase à margem esquerda do Rio Anhembi (Tietê) - o que comunica ao Rei depois em carta datada de 25 de abril de 1562." (GRINBERG, 1961, p.15). Aí teria, então, fundado uma fazenda de cultura, ponto a partir do qual teriam se aglomerados moradores emigrados especialmente da vila de São Paulo, iniciando o incremento da povoação.

Todavia, argumenta Grinberg (1992), os índios que habitavam a região onde hoje encontra-se Mogi das Cruzes eram bastante agressivos tendo, em combate, matado certo número de bandeirantes e ameaçado a vila paulistana a ponto de, em 1694, a Câmara dar ordens "para que se organizasse uma guerra contra o gentio de Mogi, dizimando-os a todos." (GRINBERG, 1992, p.14). Até então, não haveria condições para a manutenção de brancos na região, situação que viu-se modificada com a extinção do referido gentio no último lustro do século XVII. ${ }^{106}$

Em 1601 Gaspar Vaz, que havia sido juiz em São Paulo, recebeu de Dom Francisco de Souza, então governador-geral do Brasil, a incumbência de abrir estrada que ligasse São Paulo a Mogi, onde decidiu fixar-se após a empreitada. Ademais, a abertura de melhores caminhos serviu de impulso ao trânsito de paulistanos e à fixação deles na região mogiana. Assim, dentro dos limites da sesmaria concedida a Gaspar Vaz em 1608, teria surgido o primitivo povoado de Santa Ana.

Gaspar Vaz encabeçou, posteriormente, aos 8 de abril de 1611, o requerimento dos moradores e povoadores pedindo a elevação a vila:

Gaspar Vaz morador em Mogi mirim, faz a saber a Vossa Senhoria com os mais moradores abaixo assinados, em como Gaspar Vaz, com eles ditos moradores, povoaram ali por mandado de Vossa Senhoria, e lá assistem e tem suas plantas e benfeitorias por ser terra boa, e terem muitos filhos, e cá não terem terras por este respeito se passaram para a dita povoação, e porquanto eles suplicantes passam muito deterimento para poderem vir a esta vila por terem muitos filhos, e serem pobres, e ser pelo Rio acima mais vinte léguas desta vila, e serem moradores bastantes (apud GRINBERG, 1961, p.337)

\footnotetext{
106 Segundo Grinberg (1992), "Ainda no início de 1601 o quadro deveria ser o mesmo. Nesse ano a bandeira de André de Leão partiu de São Paulo e passou pela região de Mogi rumo às minas. E segundo o engenheiro holandês Wilhem Glimmer que acompanhou aquela entrada como seu escrivão, os bandeirantes não encontraram viva alma no longo caminho percorrido."
} 
O fato é que, naquele mesmo ano, a localidade foi elevada à condição de vila, como atesta foral passado várias décadas depois.

Certifico eu Manuel Rodrigues de Alvarenga, tabelião do público nesta via de Sant'ana das Cruzes de Mogi-mirim, em como é verdade que no cartório desta vila está o foral e a fundação dela, e que foi fundada por uma provisão do Sr. D. Luiz de Souza seu governador, e o capitão-mor Gaspar Coqueiro levantou pelourinho, aos três dias do mês de Setembro de 1611, havendo dez anos que na dita terras estavam moradores, e no dia, mês e ano que se lhe levantou the assinalou por limite a paragem chamada Embiacica, que é uma légua que fica na fazenda dos reverendos padres de Nossa Senhora do Carmo, a qual foi de Lopo Dias, e da banda do mar outra tanta terra e do Paraíba outra tanta, e para o sertão outro tanto, o qual termo foi dado com o consentimento das câmaras das vilas de S. Paulo, Santos e S. Vicente; e o dito capitão-mor logo no dito dia constituiu oficiais e justiças para reger e governar a vila. E por ser mandado passei a presente pelos oficiais da Câmara aos três dias de Outubro de 1672. (apud MARQUES, 1953, vol.2, p.120)

A figura abaixo apresenta a provável planta de Mogi em meados do Setecentos, pouco após a criação da vila. Nela é possível observar a "chácara de Gaspar Vaz".

Figura 1.6

Provável planta da vila de Mogi no século XVII

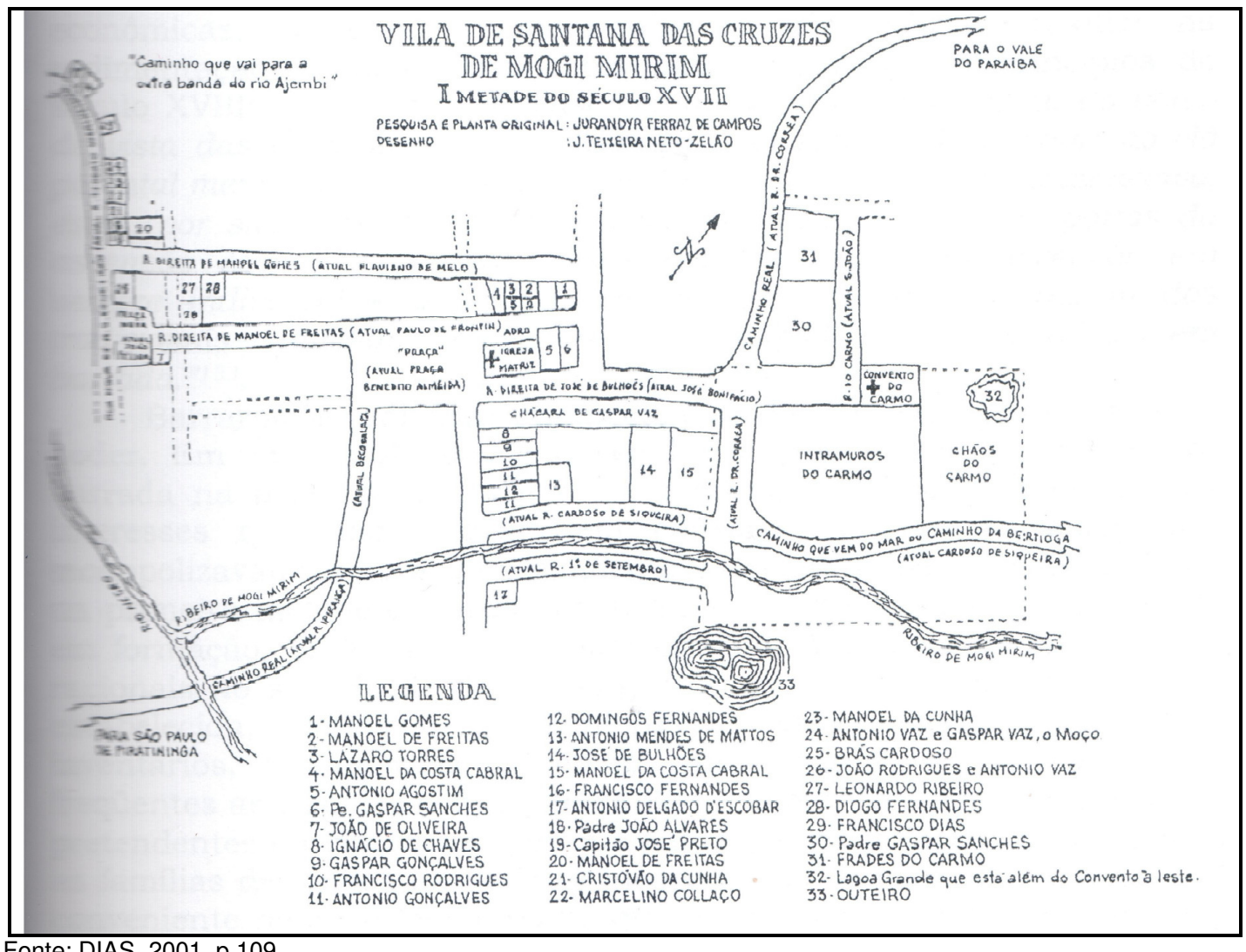

Fonte: DIAS, 2001, p.109 
Praticamente duas décadas depois,1822, já no período abarcado pelo nosso estudo, o naturalista Saint-Hilaire passou por ali e registrou:

"[...] Mogi das Cruzes fica situada num vale largo e pantanoso, limitado de um lado por colinas e do outro pela serra do Tapeti, que não é provavelmente senão um contraforte da Mantiqueira. Esta vilazinha apresenta mais ou menos a forma de um paralelogramo, as ruas são bem largas, mas de casario pequeno e bem feio. No largo principal, que é quadrado, contam-se diversos sobrados, mas não mais bonitos do que os outros prédios. A igreja paroquial ocupa um dos lados da praça. É bastante grande, mas mal ornamentada." (SAINT-HILAIRE, 1974, p.84)

Só em 1855 Mogi das Cruzes recebeu o foro de cidade, pela Lei Provincial número 5 de 3 de março, sendo elevada à condição de Comarca, pela lei provincial número 29, em 10 de abril de 1874. Ao longo desses séculos duas modificações em sua estrutura territorial administrativa merecem destaque: em 1653 a área correspondente a Jacareí, então pertencente a Santa Ana foi erigida em vila, desmembrando-se da povoação originária, (cf. primeira seção e seção seguinte, acerca de Jacareí). Já no Oitocentos, criou-se no território mogiano, "nas cabeceiras dos Ribeirão Manduí", a freguesia de Santa Isabel.

Consta que havia na região de Santa Isabel, desde o século XVIII uma fazenda denominada Morro Grande "concentrando-se nessa fazenda um pequeno número de índios e escravos que instalados no local, formaram um povoado". Este povoado viu-se aumentado pelo afluxo de pessoas que abandonaram as minas nas Gerais, já no período de declínio da exploração aurífera, dando início ali a um pequeno entreposto comercial.

Por determinação do Império, o Município de Mogi das Cruzes, passou a ter responsabilidade de administrar alguns povoados que ao seu redor se espalhavam, o que resultou na inclusão da Fazenda Morro Grande à jurisdição de Mogi das Cruzes (não obstante sua eqüidistância com o município de Jacareí).

A localidade foi erigida em freguesia por resolução de 25 de junho de 1812 com o nome de Santa Isabel - em decorrência da capela ali existente, homenagem à "rainhasanta" de Portugal de mesmo nome -, tornando-se vila e tendo sido criado o município, desmembrado de Mogi das Cruzes, 20 anos depois por decreto de primeiro de julho de 1832. As primeiras eleições municipais, assim como a posse dos eleitos, ocorreram em julho do ano seguinte, caracterizando a instalação do município. 


\section{Jacareí}

Localizada a cerca de $70 \mathrm{~km}$ a nordeste da cidade de São Paulo, na zona do Vale do Paraíba paulista, a hoje cidade de Jacareí, assim como as demais localidades estudadas, formou-se durante o período colonial, quando os paulistas foram ocupando o interior. Neste caso, a povoação deu-se ao longo da estrada geral de São Paulo para o Rio de Janeiro, às margens do Rio Paraíba:

Ao sul de Taubaté, a estrada continua a atravessar o vale do Paraíba, margeando colinas cobertas de matos [...] Passa-se pelas vendas de Campo Grande, Saída do Campo, Paranangaba e pela aldeia de São José, para se chegar à cidadezinha de Jacareí. Ali reencontramos o Paraíba, que faz uma ampla curva. Naquele ponto, o rio já é menos importante, por causa das numerosas corredeiras que barram seu curso. (SAINT-HILAIRE, 1976, p.174)

A região, anteriormente habitada e percorrida pelos índios Tamoios, constituía um ponto de união entre o litoral e o interior do Brasil, como outras Vilas do Vale do Paraíba e era ponto de apoio dos comboios que buscavam os locais de embarque no litoral, ao mesmo tempo que se transformou em centro de suprimento de gêneros.

Azevedo Marques (1953, vol.2, p.8) aponta ter sido a ocupação da área jacareiense realizada em 1852 quando Antonio Afonso e seus filhos - Francisco Afonso, Bartolomeu Afonso, Estevão Afonso e Antonio Afonso - com suas respectivas famílias e ainda agregados estabeleceram-se junto ao referido rio, fato reproduzido por outros historiadores locais. (LENCIONE, 1994; JACAREí (município), 1990)

Surpreende, portanto, já no ano seguinte ter-se elevado tal povoação à condição de vila, denominada Vila de Nossa Senhora da Conceição do Paraíba. Jacareí encontrava-se, então, em território pertencente à vila de Mogi das Cruzes, que daquela povoação distava 7 léguas (cerca de $40 \mathrm{~km}$ ).

Aos vinte e um dias do mês de Novembro de mil seiscentos e cinquenta e três anos, em casas do Capitão Diogo de Fontes, todos juntos os moradores da Paraíba, apareceram com o dito Capitão Diogo de Fontes, diante do Capitão mor Bento Ferrão Castelo Branco, que presente estava, e por ele foi dito e requerido ao dito senhor que sua Mercê Ihe mandasse fazer uma Vila, e levantar Pelourinhos em nome de sua Majestade, pois eram bastante para o poder fazer, visto serem pobres e suas mulheres e filhos não poderem acudir à Vila de Mogy- Mirim, por ser 0 caminho muito longe e não terem passagem para poderem levar suas mulheres $e$ filhos a ouvirem a Missa juntamente por carecerem seus filhos de Água de Batismo, e que da parte de Sua Majestade, Ihe requeriam, o que visto pelo dito senhor seus requerimentos serem justos, Ihe respondeu que se o Sitio fosse capaz e suficiente para se poder fazer Vila e levantar Pelourinho o faria, e de como assim requereram fiz este termo que todos assinaram com o dito senhor, e eu Jorge de Sousa Pereira, 
Tabelião do Publico Judicial e Notas da Vila de Santa Anna das Cruzes de MogyMirim, o escrevi por mandado do dito senhor Bento Ferrão Castelo Branco - Antonio Agostin - Domingos Afonço - Diogo de Fontes [...], e logo pelo dito capitão mor em os vinte e dois dias do mês de novembro do dito ano, se pôs a caminho com os ditos moradores e veio ver o Sítio e paragem que os tais pediram se levantasse a dita Vila na forma atrás nomeada [...]. E logo vindo o dito Capitão mor desta Capitania dito Bento Ferrão Castelo Branco de donde alevantou a Vila de Nossa Senhora da Conceição da Paraíba em pousada de Antonio Agostín, onde todos se achavam presentes ali morando, ele Capitão mor a eleição na conformidade que sua Majestade ordena, para que na dita Vila se celebrassem Justiça de Sua Majestade, e aí procederam a eleição de Juiz Ordinário, Vereadores e Procurador da Câmara, que prestaram juramento e prometeram obediência ao Marquês de Cascais, Donatário, e ao Alcaide mor desta Capitania de São Vicente [...]”. (apud JACAREÍ (município), 1990)

Todavia, não se sabe ao certo a data da constituição da paróquia de Jacareí, estima-se que tal criação deu-se entre 1700 e 1730, quando foi erigida a Capela do Avareí, datada provavelmente de 1728 pois "esta data está gravada no Cruzeiro de madeira de seu pátio e segundo consta é a igreja mais antiga da cidade". Por ser área alagadiça constituiu-se uma nova área de aglomeração populacional em torno da Matriz dedicada a Nossa Senhora da Conceição e cuja data de construção é desconhecida.

A invocação a Nossa Senhora da Conceição, assim como a referencia à sua localização determinaram o nome recebido pela vila, que se alterou na medida em que decorria o tempo. Do nome recebido na ocasião em que a povoação foi elevada a Vila acresceu-se Jacareí, como era conhecida e a forma a ela referida por alguns autores como Antonil ou Conde de Assumar, passando a aparecer em alguns documentos como Vila de Nossa Senhora da Conceição da Paraíba do Jacareí, que se reduziu a Vila de Jacareí (cf. LENCIONE, 1994).

A denominação oficialmente mudada para "Jacarehy" ocorreu em 03 de abril de 1849, quando a Lei Provincial no 17 elevou a Vila à categoria de cidade. O significado etimológico de Jacareí é rio de jacarés (cf. LENCIONE, 1994). Porém, no Dicionário Geográfico da Província de São Paulo, etimologicamente Y-aqûa-yerê-eí significa esquina e volta desnecessárias, referente à volta do Rio Paraíba em Jacareí.

Durante o período que se manteve na condição de vila (1653 -1849) surgiu no território jundiaense, entre outras, e tornou-se freguesia (1812) e vila (1832) a localidade de Paraibuna (cf. figura 1.3).

Freguesia criada com a denominação de Santo Antonio da Paraibuna, por Resolução Régia de 28 de agosto de 1812, e Alvará de 07 de dezembro de 1812, no Município de Jacareí, a localidade teve suas origens com a chegada, às imediações do Rio Paraibuna, de algumas famílias vindas de Taubaté no ano de 1666. "O início do povoamento se formou seguramente no mesmo local onde outrora estava estabelecido 
um aldeamento de índios Tamoios à margem do antigo caminho dos Guaianases, que ligava o Rio de Janeiro a São Paulo, unindo as tribos de serra acima às do litoral.”

Teria se iniciado então o pequeno povoado, conhecido primeiramente como Santo Antônio da Caraguatatuba, cujos primeiros moradores, segundo a historiografia local, migraram para o litoral em função de uma epidemia. Com o abandono das terras daqueles primeiros mineradores ainda no mesmo ano de 1666, o extinto povoado passou a receber, aos poucos, novos habitantes que denominaram o local Paraibuna - que significa água escura.

Um desses povoadores, Manoel Antônio de Carvalho, que ocupava o cargo de Juiz de Demarcações em Guaratinguetá, apresentou, então, requerimentos

que Ihe tem feito muitos moradores desta Villa e alguns da Capitania das Minas [...] para [...] fazerem uma nova Povoação entre o rio chamado de Paraitinga e Paraibuna, a qual povoação querem fazer [...] gozando tão somente dos privilégios que Sua Majestade concede aos povoadores das novas povoações ; e assim mais quer os suplicantes que Vossa Excelência. seja servido conceder Ihes a faculdade para levantar as ditas povoações e a tombar duas léguas de terras em quadra para acomodação da pobreza, que não podem tirar Sesmaria e as mais serão dadas aos povoadores a Cada um, as que Ihe forem necessárias, conforme as famílias na forma que Vossa Excelência determinar (apud CALDEIRA, 1932)

E, assim o fez em 1773 o capitão geral de São Paulo, Morgado de Mateus:

Ordem para ser fundada a Povoação de Paraibuna - Porquanto tenho determinado em virtude das ordens de Sua Majestade de aumentar as povoações desta Capitania e tenho notícia que na paragem chamada Santo Antônio da Barra do Paraibuna, entre as Vilas de Sam Sebastião, Jacareí e Sam Luiz de Paraitinga há terras suficientes para estabelecer uma boa povoação, sou servido nomear o juiz de Demarcações de Guaratinguetá, o Sargento- Mor Manoel Antônio de Carvalho para fundador, administrador e diretor da povoação, enquanto Eu não mandar o contrário e concorrer na sua pessoa, cristandade capacidade e justiça para dirigir os povos dela conforme Sua Majestade manda e que ordeno convoque para o dito efeito todos os Forros, vadios e vagabundos de que se tiver notícia andam dispersos e não tem casa, nem domicílio certo,nem são úteis a República e os obrigue a ir povoar as ditas terras do Paraibuna, estabelecendo nelas a referida povoação e elegendo sitio proporcionado para ela e fazendo guardar aos moradores todos os privilégios que Sua Majestade tem concedido aos que se estabelecem colônias de novo, como também todos os mais que Eu, além deles, Ihes concedo pelo bando de 10 de Fevereiro de 1766 [...] (apud CALDEIRA, 1932)

O próprio Manoel de Carvalho foi, haja visto, nomeado fundador do núcleo populacional, que segundo consta passados alguns anos não havia atraído interessados em ocupá-lo: "Mesmo sendo concedido aos cidadãos o privilégio da dispensa do recrutamento militar, isenção de impostos e o perdão de dívidas passadas, tais facilidades 
não despertaram de imediato o interesse de moradores de vilas vizinhas."(CAMPOS, 1909)

Contudo, fato é que, poucas décadas depois, a localidade erigiu-se em freguesia e por Decreto de 10 de julho de 1832, tornou-se vila de Santo Antonio da Paraibuna, com município estabelecido em 1833 independente de Jacareí. 


\section{APÊNDICE 2 FONTES E MÉTODOS}

Para a consecução dos objetivos propostos para nosso trabalho apoiamo-nos em fontes documentais primárias de naturezas distintas, visto ser o cruzamento de fontes, como sabido, bastante profícuo. Diferentes fontes proporcionam uma noção de interrelação entre as diversas faces da reconstrução histórica colocada, quais sejam: população, mão-de-obra (estrutura domiciliar, trabalho livre e posse de escravos), mercado (possibilidade e/ou necessidade e/ou interesse na produção e comercialização dos frutos dela) e estrutura fundiária.

Para tal, foi necessária a busca, a seleção e a análise das fontes que aqui se apresenta. Faz-se mister conhecer e entender as fontes documentais com que se trabalha, na medida em que traduzem um recorte da realidade mediadas por um informante e em dado momento do tempo, assim como são também produções das épocas sucessivas durante as quais continuou a viver até os nossos dias.

[...] fontes documentais não podem ser utilizadas sem um arsenal crítico consistente. Não se trata, claro, de preconizar o tal uso de tais fontes, de resto profundamente ricas e únicas em sua diversidade informativa. Mas sim de fazer a análise dessas fontes no contexto em que foram produzidas. E não aceitar de antemão as informações prestadas como verdade absoluta, pois podiam ser imprecisas ou deliberadamente deturpadas. (BACELLAR, 2008, p.117)

O caráter do documento e as características dos dados nele colocados, a sua razão de ser, sua história, por quem e atendendo a quem foi elaborado, a percepção daqueles que foram do mesmo tempo podem ajudar a conhecer o que o documento traz de explicito e implícito, como mediação para as diferentes possibilidades de análise que se apresentam. Afinal, essa documentação primária manuscrita que tomamos como fonte acaba por influenciar nosso modo de proceder, trabalhar e pensar.

\section{$\underline{\text { Tombamento de bens rústicos }}$}

No período que consideramos, o único documento a arrolar as propriedades e os proprietários de terra foi o Cadastramento de terras - ou Inventário de bens rústicos, como é conhecido -, com a "relação dos sítios e terras" para os anos 1817-1818. 
Arquivados no AESP com o título de Tombamento, esses documentos correspondem a um cadastramento dos terrenos rurais encontrado para 40 localidades da Capitania de São Paulo, incluindo as localidades estudadas nesse trabalho, quais sejam, Atibaia, Nazaré, Bragança, Jundiaí, Jacareí (e sua freguesia de Paraibuna), Mogi das Cruzes (e sua freguesia de Santa Isabel); para todas elas levado a cabo em 1818, justificando a menção deste ano ao longo do texto.

Realizado em cumprimento à carta régia de 21 de outubro de 1817, foi ordenado em caráter claramente administrativo e inseria-se no rol das medidas destinadas à promoção do desenvolvimento agrícola. (cf. CANABRAVA, 1972b) Esse levantamento

[...] permitiria conhecer os limites geográficos da ocupação e a extensão das terras devolutas, a existência de lavouras e o uso do solo em geral, bem como o emprego de escravos o que pôde vincular-se ao interesse de conhecer o cumprimento ou não dos requisitos para a manutenção das sesmarias. Propiciava também quantificar a extensão da pequena propriedade que se queria implantar, e aferir as possibilidades de formação de núcleos coloniais de imigrantes. (GUTIÉRREZ, 2001, p.212)

O manuscrito em tela mapeou de forma interessante a estrutura agrária vigente, ainda que tenha sido feito através da declaração compulsória da propriedade de terras adquiridas legal ou ilegalmente e não fosse exigida nenhuma medição que confirmasse as áreas declaradas.

É um registro de depoimentos orais, mas fidedignos, tendo-se em conta interesse dos próprios declarantes, desde que, nos assentamentos das autoridades, consubstanciava-se uma forma de oficialização, decorrente do foro de legalidade que implicitamente outorgava aos diversos modos de ocupação ou domínio. (CANABRAVA, 1972b, p.79)

Grosso modo - pois o grau de detalhamento e complexidade das informações contidas no documento diferem entre as várias localidades -, encontramos descritos no tombamento a relação das propriedades existentes nas localidades, seus proprietários e medidas. Em boa monta aparecia também a forma de aquisição do quinhão declarado, assim como, em alguns casos, a utilização das terras e suas divisas. São mencionadas também se os proprietários ali residem ou, eventualmente, as outras pessoas que vivem e/ou trabalham nas terras descritas, ademais era mencionada a quantidade, sem qualquer menção a idade ou sexo, o número de escravos possuídos, empregados ou não na produção realizada na propriedade. ${ }^{107}$

\footnotetext{
107 Poderíamos supor também que os escravos referidos nesse tombamento não são o total possuído, mas sim aqueles efetivamente empregados na lide agropecuária, porém, as divergências com relação ao número de escravos encontrados na listas e no tombamento, quando observados casos específicos são pequenas e não apontam nesse sentido.
} 
Em Atibaia, Bragança, Nazaré e Jundiaí temos a descrição por extenso, a exemplo: "Felipe Pires declarou possuir um terreno denominado Laranjal em que compreende 200 braças de testada e 300 de fundo em cujo esta cultivando, nele reside e possui por compra." (Relação dos proprietários que possuem terrenos no Distrito, e Freguesia da vila de Jundiaí. 1818 - AESP, Tombamento/C09869)

No entanto, as propriedades de Jundiaí não mencionavam as divisas e foram as únicas apresentadas pelo nome da propriedade, dificultando a identificação de sua localização. As outras 3 povoações realizaram o arrolamento apresentando as terras por bairros e a descrição mencionava ainda as divisas: "[...] parte do nascente com o Rio de Atibaia e do poente com Rita de Moraes e das outras bandas parte com a dita Rita" (Relação da primeira companhia da Freguesia de Nazaré e dos habitantes que possuem seus terrenos no ano de 1818. 1818 - AESP, Tombamento/C09868)

A sua vez, Jacareí e Mogi das Cruzes ilustram a situação em que os dados foram apresentados de forma mais reduzida. As informações foram dispostas segundo colunas, como apresentado na Figura 2.1.

Figura 2.1

Registro de terras de Mogi das Cruzes

(excerto)

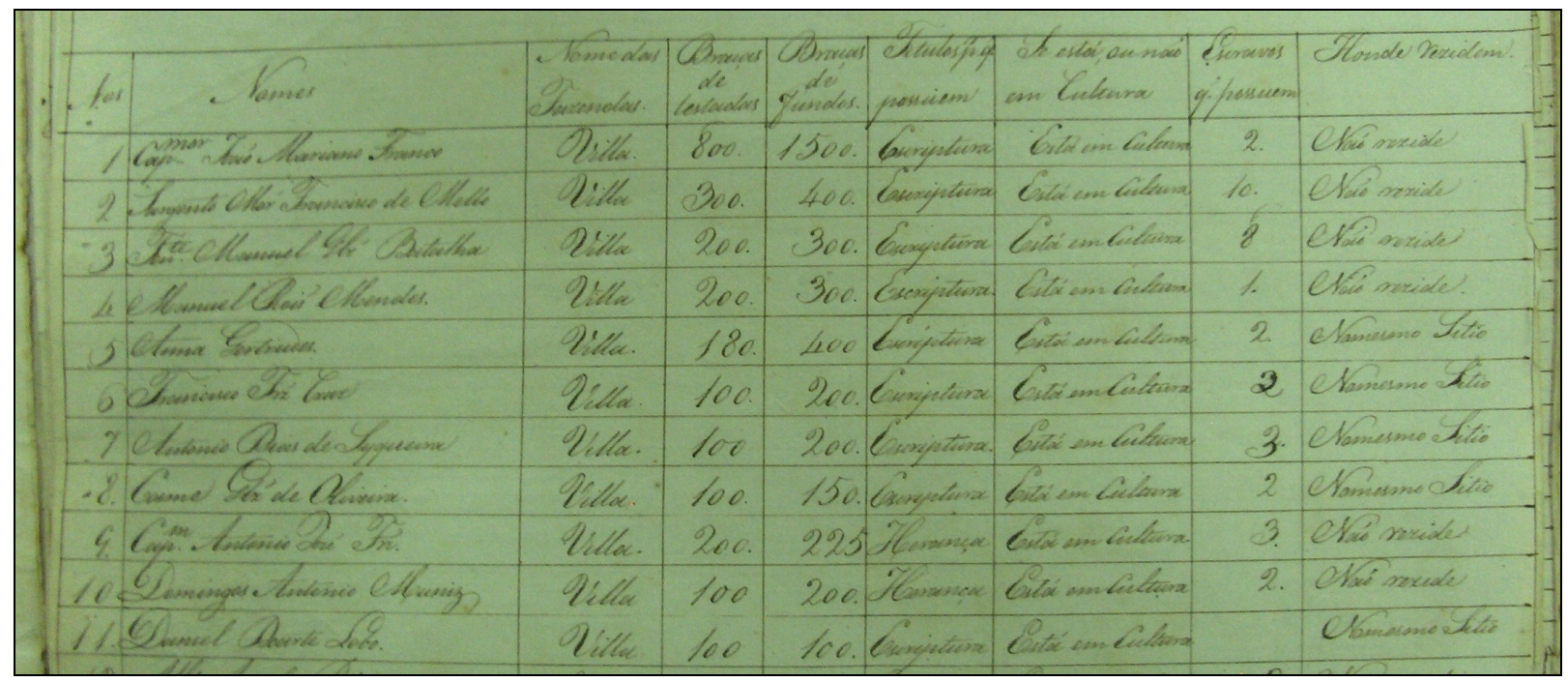

Fonte: Mapa das terras que possuem os habitantes da Vila de Mogi das Cruzes. 1818 - AESP, Tombamento/ C09868 
Note-se ademais que para Jacareí foi encontrado também um registro para o ano de 1919, bastante próximo aquele de 1818 que utilizamos.

Essas diferenças - encontradas também em outras fontes e cujo entendimento é extensivo a elas - implicam maior ou menor qualidade de informações entre as distintas localidades consideradas, ou ainda, para determinadas localidades em que o arrolamento teve mais de um responsável, é visível bairros e/ou companhias com grau de detalhamento distinto no que tange às informações apresentadas.

O que é compreensível, afinal, poderia haver maior ou menor dedicação, preocupação e paciência daqueles que efetuaram e/ou transcreveram as informações contidas na documentação. "Vilas como territórios bastante alargados, com vias de comunicação precárias e segmentos da população internados em áreas ermas do sertão não constituíam exatamente um panorama facilitador da atividade." (BACELLAR, 2008, p.117)

E as feituras desses arrolamentos fundiários envolviam não só os capitães-mores, mas também a população, o responsável por fornecer as informações ou que as copiava em sua versão final. Por ser resultado de ação de várias pessoas o Inventário de bens rústicos não apresentavam uniformidade entre si havendo, por exemplo, tipos de informações presentes em uma lista e em outras não. Nesse caso, pudemos apresentar dados para algumas localidades e anos pouco mais detalhados que aqueles mencionados para outras localidades e datas.

A apresentação das propriedades reflete a estrutura das companhias de ordenanças e/ou os bairros sob sua responsabilidade, uma vez que foram realizadas pelo capitão mor ou, mormente, a mando dele pelos capitães comandantes de cada uma dessas companhias.

As medidas, em regra, eram apresentadas por braças, de testada e fundo. Em alguns casos espraiados pelas localidades as medidas foram postas por léguas. Essas medidas, para apresentação ao longo do trabalho, foram transformadas em alqueires paulistas que, ao longo do texto, muitas vezes foram mencionados apenas como alqueires. Uma braça quadrada equivale a 5 mil alqueires paulistas; cada alqueire paulista, se em metros quadrados corresponderiam a $24200 \mathrm{~m}^{2}$ de área. ${ }^{108}$

Por fim, é notório que alguns indivíduos possuíam mais de uma propriedade, enquanto outras propriedades eram possuídas por mais de 1 indivíduo. Ao identificar os proprietários de mais de uma porção de terras nos defrontamos com a questão dos homônimos, bastante comum àquele tempo. Em alguns casos essa tarefa apresentou-se

\footnotetext{
${ }^{108}$ Para uma correspondência entre medidas ver SIMONSEN, 2005, pp.585-586.
} 
menos árdua, como a identificação das dez propriedades pertencentes ao capitão Nicolau Soares de Pugas Duque, citado ao longo do texto. Ou quando as terras eram declaradas em conjunto:

O capitão-mor Jose de Siqueira Franco, morador nesta Vila de S. João Batista de Atibaia tem um sitio no Bairro do Rio Abaixo termo desta mesma Vila e possui por compra, e te títulos delas. [...]Tem outro pedaço, e possui por compra, tem títulos delas [...] existe seu filho José de Siqueira Franco nelas com cinco escravos e dois criados. (Relações dos Sítios e terras de Atibaia. 1818 - AESP, Tombamento/ C09868)

Em outros momentos a coincidência de nomes foi checada com recurso à lista nominativa, assim identificamos no mesmo documento atibaiense, as viúvas Maria Cardosa de Oliveira e Maria Cardosa de Oliveira. A primeira possuía "um sítio e terras que tem de largura um quarto de légua, de comprimento um quarto e mais de légua" onde morava no bairro de Itapetinga. A outra, vivia nas terras que possuía entre aquelas arroladas nos bairros Mato Dentro, Itajoapira e Boa Vista e que também pertenciam a 8 filhos, seus herdeiros. (cf. Relações dos Sítios e terras de Atibaia. 1818 - AESP, Tombamento/C09868 e Lista Nominativa de Atibaia - AESP, Maços de População/rolo 17)

\section{Maços de População}

Para o desenvolvimento de grande parte de nosso trabalho apoiamo-nos em um conjunto Listas Nominativas de Habitantes, arquivadas no Arquivo Público do Estado de São Paulo sob a rubrica Maços de População.

A amostra com a qual trabalhamos compreende documentos dos derradeiros anos do século XVIII e das três primeiras décadas do século XIX. Para a região considerada Atibaia, Nazaré, Bragança, Jundiaí, Jacareí, Mogi das Cruzes -, localizamos no AESP listas nominativas microfilmadas datadas de 1765 a 1850. Selecionamos para nossa pesquisa, após um levantamento qualitativo dos documentos - o grau de detalhamento e complexidade das informações, assim como o estado de conservação em que se encontram, variam ao longo do tempo -, um total de 40 listas, datadas de 1798 a 1830, que se apresentam, em boa medida, completas em termos de abrangência (bairros arrolados) e volume/qualidade de dados.

O critério adotado foi privilegiar, dentro do período considerado em nossa análise, documentos realizados entre intervalos aproximados de 5 anos, iniciando-se em 1799 . 
Quando, para determinada localidade, nos anos escolhidos a lista nominativa não foi localizada, as listas encontravam-se muito deterioradas impossibilitando a leitura ou a quantidade/qualidade das informações mostrou-se insatisfatória, incorporaram-se também os manuscritos de um ou mais anos antecedentes e/ou subseqüentes. A tabela 2.1 mostra a composição da amostra de acordo com as diferentes localidades. As listas selecionadas foram transcritas integralmente, primeiro foram fotografadas, e então, foram criados bancos de dados em excel e spss.

Tabela 2.1

\section{Localidades e anos das listas nominativas selecionadas}

\begin{tabular}{ccccc}
\hline \hline Jundiaí & Bragança & Atibaia e Nazaré $^{*}$ & Mogi das Cruzes & Jacareí \\
\hline 1799 & 1799 & 1799 & 1799 & 1798 \\
1803 & 1803 & 1803 & 1803 & 1803 \\
1807 & 1808 & 1808 & 1808 & 1807 \\
1811 & 1811 & 1812 & 1812 & 1811 \\
1816 & 1816 & 1816 & 1816 & 1816 \\
1820 & 1820 & 1820 & 1820 & 1822 \\
1825 & 1826 & 1826 & 1825 & 1825 \\
1829 & 1830 & 1829 & 1829 & 1829 \\
\hline \hline
\end{tabular}

*Durante o perío do considerado Nazaré foi distrito de A tibaia. Assim, a relação do s habitantes de Nazaré aparece entremeada entre aquelas do distrito pró prio da vila de A tibaia.

Os mapas populacionais são documentos manuscritos, em tese anuais, que contêm a relação nominal dos habitantes de diversos municípios da capitania/província de São Paulo.

Esse censo foi realizado por determinação governamental e, como bem anotou Maria Luiza Marcílio (1998), a confecção das listas teve motivações distintas ao longo do período em que foram levadas a cabo. A autora aponta três momentos na evolução da prática censitária nos séculos XVIII e XIX: entre 1765 e 1797, possuíam objetivos econômicos e, especialmente, militares, uma vez que havia grandes problemas nas fronteiras do sul e a capitania de São Paulo era a mais próxima à região disputada sendo, então, solicitada com freqüência a "oferecer suas forças vivas para lutar nas fronteiras", que poderiam ter seu número conhecido através dos levantamentos encontrados nos maços de população. ${ }^{109}$

\footnotetext{
109 "Esses objetivos vêm claramente expressos em numerosos documentos oficiais expedidos pela Metrópole, como, a título de ilustração, [...] 'que hoje façam formar relações exatas de todas as famílias dos seus respectivos Distritos e que as remetam a mim, declarando nelas os Moços que há capazes de pegarem em armas e se empregarem no Serviço de Sua Majestade [...]'" (MARCÍLIO, 1998, p. 34)
} 
Nos anos seguintes, 1797 a 1830, em que se encontram todos os maços de população que fundamentam nosso estudo, a preocupação em aumentar a população e desenvolver a agricultura e o comércio coloniais nortearam a elaboração das listas nominativas, ou seja, seus objetivos passaram a ser menos militares (ainda que essa necessidade não tenha sido totalmente abandonada) e mais focados na política populacional e econômica, passando a documentação a apresentar, inclusive, tabelas econômicas contendo informações sobre consumo, preços, exportação e importação de diferentes produtos, como detalharemos mais adiante.

No período 1830-1872 a feitura das listas foi quase abandonada por não se apresentarem mais, com peso, os objetivos militares e econômicos que justificavam a sua necessidade até então, sendo encontradas para anos espraiados e com volume menor de informações.

A operação de tabulação das informações colhidas das listas de habitantes, para o período que mais nos interessa, era realizada em etapas:

\begin{abstract}
Cada capitão de companhia dividindo os moradores pelas suas classes igualmente pelas idades e sexos de cada um, encherá cinco mapas iguais aos primeiros que vão, resumindo afinal, debaixo de um ponto de vista, o número total de seus moradores. Desse (sic!) mapas particulares das companhias, formará V.M. ${ }^{\text {ê̂ }}$ pelo mesmo método, o geral do seu distrito, que enviará por duas vias a esta Secretaria. Segue-se outro mapa, em que descreverá as ocupações dos habitantes, acrescendo-as ou diminuindo-as segundo os empregos em que se ocupar esse povo. Nos três mapas imediatos se descreverão os casamentos, nascimentos e mortes anualmente acontecidos; e porque há distritos, que compreendem mais de uma paróquia, os capitães das primeiras companhias recorrerão aos párocos delas para lhes darem, como thes é determinado, uma relação exata dos assentos dos seus livros. (apud MARCÍLIO, 1998, pp. 39-40)
\end{abstract}

Assim, encontramos nessa fonte a relação nominal dos moradores das localidades em tela, arrolados por companhias de ordenança e/ou bairros, onde eram descritos por fogos (domicílios). Cada companhia - subdividida em esquadras - respondia, em regra, por determinada área geográfica, especialmente bairros.

Em algumas localidades consideradas predominou a descrição dos bairros, não sendo possível identificar as companhias, assim como, para outras predominaram as companhias, sendo dificilmente encontradas referências aos bairros. Apenas em Jundiaí, para algumas companhias de anos determinados, encontramos a subdivisão por esquadras. Como houve modificações ao longo do tempo, procuramos estabelecer um espaço que se mantivesse ao longo de todo o período estudado, 1798/99 a 1829/30, possibilitando a comparação de informações. 
Seria de esperar uma ampliação do número de companhias ou bairros, com o crescimento das localidades ao longo dos 30 anos considerados, o que de fato ocorreu. $O$ que se percebe é que, a partir de 1820, há desmembramento das companhias e dos respectivos bairros, que passam a ter, cada uma, número menor de habitantes listados . Tendo em mente as modificações e a efetiva descrição encontrada nas listas nominativas, consideramos o seguinte:

- Jundiaí: As listas apresentaram-se subdivididas por companhias de ordenanças e dentro delas foram indicados bairros na medida em que os fogos avançavam dentro das companhias. Até 1816 eram 3 as companhias ali existentes, passando a 5 em 1822. Inicialmente a primeira correspondia aos bairros da vila, Cururu, Itupeva e Rio abaixo; a segunda aos bairros Atibaia, Capivari, Jundiai-mirim e Cachoeirinha; a terceira incluía Japi, Rio das Pedras, Vuturucaia e Capão. Esta terceira companhia manteve-se assim composta até 1830. As demais, juntadas a novos bairros se reorganizaram em diferentes companhias sendo que a quinta, assim como a primeira, a partir daquele momento não teve mencionado o nome do bairro a ela vinculado (no caso da primeira provavelmente a própria vila); a segunda compreendia Rio Abaixo, Cachoeira, Capivari; a quarta Itupeva e Cururu.

- Bragança: Os domicílios foram dispostos por bairros. O bairro da vila, Curralinho, Jacareí, Rio abaixo e Couto estavam presentes desde 1799. Em 1803 surge o bairro do Campo Novo e em 1820 os citados bairros subdividem-se também em bairro do Canivete, Anhumas, Araras, Pântano e Guarapuava. O bairro da Campanha de Toledo (correspondente a parte do território de Socorro), assim como o bairro do Cascalho, não foram considerados em nosso trabalho, pois o primeiro apareceu apenas em 1803 e 1811 e o segundo em 1799,1820 e 1830.

- Atibaia: Não foram mencionadas companhias, foram nomeados apenas bairros. Posto que houve variações consideráveis entre os documentos consultados - a exemplo encontramos no ano de 1820 descritos conjuntamente os bairros de Campo Largo e Caetetuba, sob responsabilidade do alferes Jose Desiderio Pinto e o bairro da vila juntamente com o de Caioçara cujo capitão era Jeronimo de Godois Moreira; alguns anos depois, 1826, Campo Largo apareceu ao lado de Caioçara em que era capitão Francisco Rodrigues Bueno, enquanto o alferes Joze de Siqueira Franco respondeu pelo bairro próprio da vila juntamente com Caetetuba - criamos para a vila "grupos" que correspondem a um ou mais bairros, como forma de organizá-los.

A organização é apresentada da seguinte maneira: 1) Vila + Caioçara + Caetetuba + Campo Largo; 2) Itapetinga + Rio Acima +Cachoeira; 3) Rio Abaixo; 4) Mato Dentro + 
Itajoapira + Boa Vista. É importante mencionar que em 1826 não há o grupo 2 e em 1829 não há o grupo 4.

- Nazaré: Assim como Atibaia os fogos foram dispostos por bairros. Eram eles, em 1799, o bairro da Vila e o bairro Cachoeira, aos quais se acresce o bairro do Rio do Peixe a partir de 1803. Desde 1820 surgem os bairros da Capela, Mascate, Cuiabá, Vicente Nunes, e ainda uma "6" companhia de ordenança", cuja área a que se refere não foi dado nome. Vale observar que em 1829 aparece o bairro do Moinho em detrimento ao Rio do Peixe, que, considero, sejam o mesmo bairro com nome distinto uma vez que há coincidência de habitantes e o mesmo capitão, Joze Joaquim de Oliveira, cabeceava o Rio do Peixe em 1820 e 1826 e o referido Moinho em 1829. Ademais, na lista de 1816 o bairro da Cachoeira aparece anexado, mas há referência ao atraso na lista do bairro, concluída em 1817.

- Mogi das Cruzes: Durante todo o período o recenseamento foi feito por companhias sem qualquer referência a bairros ou áreas a que se referiam. Até 1816 foram quatro companhias, em 1820 elas apareceram desmembradas sendo dez o número de companhias arroladas, em 1825 eram doze companhias sendo que a $11^{\text {a }}$ e a $12^{\text {a }}$ correspondem à Santa Isabel, assim como a $11^{\underline{a}}, 12^{\mathrm{a}}$ e $13^{\mathrm{a}}$ entre as treze companhias encontradas em 1829. Os arrolamentos relativos a Santa Isabel são utilizados com devidas ressalvas ao longo do texto.

- Jacareí: Também arrolados por companhias, sem menção a bairros ou áreas correspondentes a cada companhia. Eram quatro companhias até 1811; sendo transformadas em oito a partir de 1816. Ademais são consideradas, a partir de 1816 duas companhias referentes à freguesia de Paraibuna. Em, 1807 o arrolamento correspondente à primeira companhia de ordenanças de Jacareí não foi localizado, assim como aquele relativo à segunda companhia de Paraibuna para o ano de 1829, o que pode acarretar, em análises específicas, problemas de comparação para localidade.

Como adiantado, dentro dos bairros e/ou companhias de ordenança a população era descrita por fogos. Ao longo do trabalho utilizamos fogo como sinônimo de domicílio. Se para os padrões atuais a tendência é entendermos domicílio como lugar em que mora uma unidade familiar, consideramos, em nosso trabalho, quando nos referimos a fogos ou domicílios, uma unidade econômico-familiar, onde os ali residentes trabalhavam lado a lado, em torno de atividades específicas e organizadas, para manutenção do grupo doméstico em questão. Grupo doméstico este que, muitas vezes, era composto não somente por familiares próximos, mas também por escravos e agregados (indivíduos que 
não apresentavam nenhuma relação de parentesco com o núcleo familiar principal), e suas eventuais famílias, todos contabilizados como pertencentes ao fogo.

A documentação que utilizamos, portanto, registra uma miríade de fogos/domicílios. Podemos encontrar indivíduos que viviam solitários como é o caso da viúva Margarida Pedrosa, de 50 anos que trabalhava como fiandeira em Jundiaí em 1812 (cf. Lista Nominativa de Jundiaí - AESP, Maços de População/rolo 108); até grandes famílias como a mogiana chefiada por Ignacio Fernandez da Silva, 58 anos, que em 1820 "vive de suas curiosidades" na companhia de sua mulher Maria Magdalena e de seus 8 filhos (cf. Lista Nominativa de Mogi das Cruzes - AESP, Maços de População/rolo 130) ou ainda famílias acompanhadas de escravos, como ocorreu em Nazaré (1799) com o casal Reginaldo Jose da Silva e Esmeria, pais de Antonio, então com 2 anos, que mantinham em seu fogo quatro escravos; entre várias outras possibilidades. ${ }^{110}$ (cf. Lista Nominativa de Nazaré - AESP, Maços de População/rolo 13)

Os moradores de cada domicílio, eram descritos de acordo com sua relação com o "chefe de fogo" (cônjuge, filhos, agregados, escravos), que encabeçava a lista e para quem, via de regra, apareciam as informações mais completas.

\begin{abstract}
O critério que define uma pessoa como chefe nem sempre resulta transparente. O caso em que estes critérios não deixam lugar para dúvidas é o de uma família nuclear, onde o marido é considerado chefe. No caso em que homens ou mulheres (viúvos ou solteiros) moram sozinhos ou unicamente com filhos menores, eles também são, sem dúvida, considerados como chefes. Configurações familiares mais atípicas não parecem ter uma regra fixa dada pela estrutura da família, mas provavelmente sua gênese defina essas diferenças: explicar-se-ia assim que algumas vezes homens solteiros apareçam como chefes de fogo e suas mães viúvas como agregadas, enquanto que outras vezes a mãe viúva encabeça a relação do fogo e o homem consta como 'seu filho'. (FERNÁNDEZ, 1989, P.480)
\end{abstract}

Para cada um dos indivíduos eram anotadas suas características. Encontramos, geralmente, essa divisão de forma explícita: nomes dos indivíduos residentes no fogo (completo para o chefe e seu eventual cônjuge e apenas o primeiro nome nos demais casos), condição, naturalidade, estado conjugal, cor e idade.

Foram poucas as menções a condição que não livres ou escravos, ou seja, forros. E a naturalidade foi mais encontrada no caso dos chefes de fogo, ainda que muitos deles tenham omitido tal informação. A declaração de cor, a sua vez, foi sempre colocada, porém com certas variações nas indicações de negros, pretos, pardos e mulatos.

\footnotetext{
${ }^{110}$ Tal fato levou a historiografia a buscar padronizações no que se refere às distintas possibilidades ligadas à composição dos fogos. Ver discussão apresentada no capítulo 2.
} 
Idade e estado conjugal foram raramente omitidos. No entanto, no passado, a preocupação com a contagem da idade era pequena apontando, então, para evidências de incorreções na estrutura etária como bem notaram Bacellar (2008) e Nozoe \& Costa (1991), pois as listas de determinados anos apresentavam-se como mera transcrição de lista de anos anteriores, por vezes com o acréscimo de um anos às idades declaradas. Assim, entre as possibilidades de ação dos responsáveis pelas listas temos

a) Por ocasião da feitura do levantamento, ou da inclusão de moradores na lista, explicitava-se uma visível preferência por idades com terminação 0

b) Para os anos de não realização de coleta original deste dado (idade), dava-se a atualização das idades das pessoas figurantes da lista do ano imediatamente anterior mediante o acréscimo da unidade. (NOZOE \& COSTA, 1991, pp.)

Os cativos tiveram na quase totalidade dos casos a descrição "escravo" dada com relação ao chefe de fogo, fazendo com que as análises de plantel fossem feitas com relação ao fogo (e seu chefe), em detrimento de uma distribuição, eventualmente preferível, de cativos ao nível de proprietários, o que pode estar distorcendo um pouco a realidade e superestimando o tamanho das posses consideradas. Houve exceções pontuais como ocorrido em Bragança no ano de 1830. Jozé Marianno Ferreira de 56 anos chefiava o fogo em que vivia na companhia de sua mulher e 8 escravos seus e ainda 4 escravos explicitamente pertencentes a seu neto Joze, de apenas 12 anos. (cf. Lista Nominativa de Bragança - AESP, Maços de População/rolo 30)

Provavelmente na ausência de seus pais teve os escravos legados e vivia na companhia do avô que deveria ser, na prática, senão o proprietário, o responsável por aqueles cativos.

Por serem poucos casos, salvo menção contrária, esses escravos foram considerados como um único plantel, pois, além de viverem no mesmo domicílio, pensados como mão-de-obra, trabalhavam e conformavam uma mesma unidade produtiva.

Ademais, para os chefes de domicílio eram apontadas as ocupações econômicas realizadas (atividade principal do fogo) incluindo, em certos anos, dados sobre a produção levada a cabo, sendo mencionados tipo de produto, quantidade e destino dado à produção (consumo próprio ou mercado, inclusive valores): em 1799 encontramos o atibaiense Ignacio Joaquim "Lavrador planta para seu sustento vendeu 4 arrobas de algodão a 9608 alqueires de feijão a 960 na cidade" (cf. Lista Nominativa de Atibaia AESP, Maços de População/rolo13) 
Em regra, as atividades econômicas/produtivas foram apresentadas de forma bastante genérica, nos fornecendo indícios mais dos setores em que a pessoa estava envolvida do que das suas condições e sua função exata, como no caso dos lavradores, por exemplo. "Como definir as diferenças ou similaridades entre lavradores, agricultores, roceiros, planta para o gasto, planta para viver?" (BACELLAR, 2008, p.121) Também as ocupações foram bastante omitidas: a totalidade dos escravos, grande parte dos livres não-chefes de fogo e até alguns chefes de domicílio não tiveram suas atividades econômicas/produtivas declaradas. Para além dos chefes de fogo, a quase totalidade das poucas descrições encontradas refere-se a algum agregado, parente (irmão, sobrinho, neto) e, majoritariamente, filho, ligado às forças militares.

Isto posto, as análises que se valeram dessa variável entendem a atividade realizada pelo chefe do domicílio como principal e característica do fogo, mesmo sabendo que, muito provavelmente, atividades diversas eram desenvolvidas concomitantemente por outros membros do domicílio, em especial mulheres, bastante ligadas ao artesanato, em atividades como fiação e costura e ainda outros serviços domésticos diversos.

Também é possível encontrar, em alguns casos, observações sobre baixas e aquisições de escravos e variações no número de pessoas no fogo no ano a que se refere o arrolamento, dados estes utilizados apenas de forma a complementar alguma análise específica. Uma ilustração do alcance dessas informações adicionais encontramos nos arrolamento mogiano de 1816, em que apareceram com certa freqüência: "comprou o escravo João", "casou a filha Joana e faleceu o escravo Manoel", "nasceram e faleceram João e Joana gêmeos", "filho Lourenço mudou para o Rio de Janeiro" (cf. Lista Nominativa de Nazaré - AESP, Maços de População/rolo 120)

Como parte das listas nominativas, encontramos quadros-resumo denominados Mapas de população, uma série de quadros estatísticos inicialmente de caráter demográfico, que passaram a apresentar também, a partir da década de 1790, estatísticas econômicas. Estes últimos, que denominamos Mapas de comércio nos interessam aqui e são comentados na sequência.

\section{Mapas de produção e comércio}

Informações econômicas que abrangem produção e comércio (compra e venda de distintos produtos), as quantidades produzidas e negociadas, seus destinos/origens, assim como os preços levados a cabo em diferentes mercados são observados nos 
mapas de comércio, como adiantado, encontrados junto aos maços de população no AESP. Assim, o processo de leitura e organização das informações seguiu àquele adotado para o arrolamento populacional.

A priori, checamos as informações para anos correspondentes às listas utilizadas, ainda que nem sempre presentes. Com o intuito de montarmos séries de dados completas o mais possível e de alguma forma consistentes para importações, exportações, preços e contas correntes - permitindo que lançássemos mão de diferentes modelos estatísticos em nossa análise - foram utilizados todos os quadros localizados. Eventualmente havia um ou outro mapa ausente ou os mapas encontrados apresentavam-se incompletos. Esses mapas em muitos anos não foram anexados às listas.

A ausência dos dados econômicos podem ser devidas aos motivos anteriormente apontados, quais sejam: dificuldades, empenho, preocupação, paciência, vontade daqueles responsáveis pela feitura de tal documento no caso não terem sido elaborados, ou até mesmo a não sobrevivência desses documentos.

Para Jacareí, em especial, nenhum mapa foi localizado. Para as demais localidades foram localizados e tiveram os dados levantados conforme os anos apresentados a seguir:

- Atibaia: 1798 e 1799, 1803 e 1804, 1814 a 1818, 1820, 1822, 1824 a 1826, 1828 e 1829

- Nazaré: 1798 e 1799, 1803 e 1804, 1814 a 1818, 1820, 1822, 1824 a 1826, 1828 e 1829

- Bragança: 1798 a 1801, 1803 e 1804, 1808 a 1811, 1816 a 1819, 1829 e 1830

- Mogi das Cruzes: 1798 e 1799, 1802 a 1804, 1808, 1810, 1815 a 1818, 1828 e 1829

- Jundiaí: 1798 a 1802, 1809 e 1810, 1816 a 1818, 1827 a 1830

Foram encontrados, especialmente, quatro mapas com diferentes informações. Os Mapas da importação dos produtos e manufaturas de outros reinos e portos do Brasil em que são encontradas informações acerca do tipo de produto importado (vinho, sal, pano etc.), as quantidades totais transacionadas, os valores de cada produto por unidade de medida (peças, alqueires, arrobas, entre outros) e os valores totais importados, apresentados de acordo com os locais de onde vieram os produtos listados.

Nos mesmos moldes dos mapas de importação, os Mapas da exportação dos produtos da Vila apresentam informações acerca do tipo de produto exportado (em geral agrícolas), as quantidades totais transacionadas, os valores de cada produto por unidade de medida (número, alqueires, arrobas, entre outros) e os valores totais enviados para 
outras localidades, sendo apresentados de acordo com os locais para onde foram enviados os produtos listados.

Com a especificação do que se consumiu na localidade e nela se exportou os Mapas comparativos das produções da Vila listam, separados por "produções da paróquia", "consumo na paróquia" e "exportação da paróquia" os tipos de produtos, quantidades totais de cada um deles, valores de cada produto pela sua unidade de medida específica, valores totais de cada produto e do somatório dos produtos referidos.

Os Mapas dos preços correntes na Vila incluem o preço mínimo, médio e máximo (de acordo com a respectiva unidade de medida) atingido por cada um dos principais gêneros de exportação, importação e aqueles consumidos na própria localidade.

É preciso ressaltar que tais mapas, muitas vezes, apresentam problemas de tabulação, com cálculos e totalizações errôneos. Diante desta situação optamos por recalcular esses valores.

Problemas de critério também foram encontrados, tais como aqueles relativos ao cálculo dos preços médios apresentados. Não foi possível identificar se, em regra, esses preços foram calculados com base em uma media simples ou ponderada.

A comparação dos totais apresentados nos diferentes mapas com os totais das respectivas listas nominativas apontam para montantes bastante divergentes. Em regra, com informações de menor monta encontradas na listagem por fogos. Ademais, existem informações nos mapas que não constam dos recenseamentos, mormente naqueles mapas relativos à importação e exportação, como as sedas, chapéus, vinhos, pólvora, ferro, entre outros que em nenhum momento foram mencionados no arrolamento populacional propriamente. Isto implica a existência de fontes de informações que vão além das próprias listas nominativas e do nosso conhecimento.

Por fim, e talvez a mais importante consideração com relação a essa fonte diz respeito às séries de preços. Os preços são expressão monetária dos gêneros produzidos, consumidos localmente e/ou comercializados e, por conseguinte, suscetíveis de embutir efeitos inflacionários ou deflacionários. Uma vez que os preços nominais apresentados nos mapas de comércio (e também nas listas nominativas propriamente) podem embutir os efeitos da inflação, temos, ao considerá-los, a dificuldade de comparação dos valores ao longo do período estudado, 1798/99 a 1829/30, em não sendo a própria variação de preços objeto de análise.

Para contornar o problema, em alguns momentos, poderíamos trabalhar com valores porcentuais, ou seja, com a participação relativa do valor (definido como preço multiplicado pela quantidade) dos distintos produtos encontrados, pois os valores 
nominais não são comparáveis ano a ano, mas as participações percentuais desses valores em um determinado montante total o são.

Fez-se necessário, todavia, o uso de valores absolutos para o desenvolvimento de algumas análises. Nesse caso, a questão da variação de preços causada pela distribuição temporal dos documentos pode ser superada com deflacionamento. A princípio, defrontamo-nos com dois métodos possíveis de conversão: a taxa de câmbio (libras/réis) e algum índice de preços.

A taxa de câmbio, por definição, representa a relação de trocas entre produtos medidos em moedas diferentes. Na possibilidade de sua aplicação, poderíamos obtê-la com base em fontes distintas, apresentadas por COSTA et alli. (2004). Nesta nota intitulada Brasil: breves comentários sobre algumas séries referentes à taxa de câmbio os autores indicam algumas séries relativas ao câmbio no Brasil nos séculos XIX e XX, apontando as que lhes parecem ser mais confiáveis, de um total de 16 comentadas. Entre aquelas apresentadas destacam-se, em coleções do IBGE, a série encontrada nas Séries Estatísticas Retrospectivas, que se inicia em 1808 e a série publicada no Anuário Estatístico do Brasil, apresentada para o período 1812-1912, em termos de pence por milréis. Em ambas os valores praticamente coincidem.

No que respeita aos índices de preços temos, entre outros, os índices de preços calculados por Eulália Lobo et alli (1971), Mircea Buescu (1973) e Luis Catão (1992), ambos bastante difundidos e referentes ao mercado do Rio de Janeiro. Ademais das fontes disponíveis, justifica-se a opção pela cidade do Rio de Janeiro por ser seu mercado representativo do mercado nacional na medida em que a localidade foi, no Oitocentos, o principal centro econômico brasileiro e, grande parte do bens ali circulantes serem, de fato, importados de outras regiões.

Os índices de custo de vida de Eulália Lobo compreendem dados para a alimentação no período 1820 a 1930 e foi elaborado através de dados obtidos para o mercado do Rio de Janeiro no Jornal do Commercio, nos livros de contabilidade da Ordem Terceira de São Francisco da Penitência e nos livros de contabilidade da Santa Casa de Misericórdia daquela localidade, em que foram observados preços, a saber, de feijão preto, arroz, carne seca do Prata, farinha de mandioca, farinha de trigo, açúcar mascavinho, café, bacalhau em tina e manteiga. A ponderação considerada foi obtida em estudos sobre a composição do regime alimentar - alimentação para a cesta de consumo de escravos em 1856, alimentação para a cesta de consumo de famílias de mais alta renda de Affonseca Jr. para 1919, cesta de consumo da FGV para 1947. 
Utilizando a ponderação de 1856, encontramos uma variação no custo da alimentação carioca de 58,86\% entre 1820 e 1829 e 40,99\% entre 1820 e 1830. Considerando todo o período escravista o valor bastante elevado de cerca de $2173 \%$.

A sua vez, Mircea Buescu criticou os valores elevados apresentados por Lobo:

Quanto aos índices de custo de alimentação, calculados por Eulália lobo, talvez tenham sido muito distorcidos por causa do emprego de um peso muito elevado para os produtos nacionais de consumo interno [...] Nenhuma informação da época, nem as mais pessimistas observações de Ferreira Soares permitem entrever altas de tal ordem de grandeza. (BUESCU, 1973, pp. 175-176)

O autor estudou as flutuações de preços por subperíodos. Para o período 1760 a 1822 - fim do "ciclo" da mineração até a independência - e 1822 a 1889 - independência até a república - observou os preços de diferentes produtos, em grande medida gêneros alimentícios, no Rio de Janeiro e para o cálculo do índice considerou terem maior importância econômica os produtos que mais aparecem, ou seja, para o autor o número de observações reflete sua importância no orçamento dos consumidores. $O$ índice foi, então, construído através da média aritmética dos preços.

O mais recente entre os índices consultados foi aquele apresentado por Luis Catão para o período 1870-1913. Tendo como fonte dados apresentados no Jornal do Commercio, o autor utilizou cerca de 30 produtos no atacado, que subdividiu entre agricultura e indústria para criar seu índice, que tem como ano base o ano de 1913. Para proceder à ponderação o autor recorreu aos dados do Censo Industrial de 1907 e 1919. Segundo o autor The proposed index is superior to the existing ones in two important respects: first, it consists of a much more representative sample of commodities; secondly, it employs a weighting system based on the national censuses of production. (CATÃO, 1992, p. 520)

Após levantamento das características dos deflatores pudemos compará-los. A escolha de um método de conversão pode interferir nas distribuições levadas a cabo ao longo do trabalho, ainda que, como adiantado, há semelhanças entre as distintas séries, entenda-se, elevada correlação entre a taxa de câmbio e os índices de preço e, como observado por Buescu:

Pode-se admitir que, dada a importância das importações na pauta de consumo, a taxa cambial influenciava o nível geral de preços, mas também que a taxa cambial equiparava o nível de preços internos com os estrangeiros. De fato, verifica-se uma forte coincidência entre o sentido da variação dos preços, tal como foi calculada no que precede [índice de preços - DOMR] e o da taxa de câmbio. A ordem de grandeza é diferente e em vários casos a flutuação do câmbio é maior - o que sugere que esta constituía, tanto causa inflacionária, como deflacionária. (BUESCU, 1973, p.153) 
Para proceder a uma escolha que melhor atenda a nosso objetivo, a principal questão que se coloca diz respeito aos gêneros a serem deflacionados encontrados em nossas fontes. Como salientamos anteriormente, eram três os mapas econômicos encontrados. O mapa de importações, em regra, apresenta produtos, a exemplo de vinhos e tecidos finos, cuja origem está reconhecidamente fora das fronteiras brasileiras. Assim ainda que alguns produtos pontuais tenham sido importados de outras regiões do país ou sua produção tenha sido internalizada ao longo do tempo - arriscamo-nos a utilizar a taxa de câmbio implícita para o deflacionamento desses bens importados, à exceção daqueles certamente produzidos internamente como o gado importado dos campos do Sul.

Há que notar, no entanto, que a taxa de câmbio apresenta variação de preços de bens escassos em nossos mapas de produção e exportação, afinal alguns gêneros agropecuários essenciais, tais como o milho ou a farinha, não eram objeto de intercâmbio internacional. Tal situação aponta, então, para a utilização de um índice de preços. Como conceitualmente produção, exportação e importação são diferentes, pode-se deflacionálos com recurso a fontes distintas.

A priori, para se deflacionar a produção agropecuária a melhor alternativa corresponderia à utilização de um índice de preços no atacado, já que os índices de preços no varejo (ou índices de custo de vida) embutem margens de comercialização e transporte dos produtos.

Mas, dadas as características das economias estudadas - parte considerável da produção destina-se ao autoconsumo e, muitas das vezes, o produtor vendia sua produção diretamente aos consumidores -; o fato de encontramos nos documentos preços para produtos locais praticados em outros mercados; e sendo os índices de custo de vida uma combinação de preços de bens produzidos dentro e fora da colônia/império, logo medindo efetivamente o poder de compra da produção local; optamos por converter os preços encontrados para produção e comércio através dessa possibilidade (excluindo, portando, o índice de Catão).

Nesse caso, a questão que se coloca é o fato de que as séries apresentadas por Mattoso somente se iniciam em períodos posteriores ao de nossa análise. Isto posto, a escolha recaiu no índice de Buescu.

Buescu indica que a tendência dos preços foi moderadamente ascendente no período 1771-1819, sendo mais acentuada ao final do século XVIII e afrouxando-se nos primeiros anos do século seguinte. Para o período 1771-1807 foi encontrada uma taxa de inflação acumulada de 47,2\%, no período $1807-1819$ houve uma variação de $34,5 \%$. No período 1771-1819 a taxa acumulada foi de 98\%. Para períodos posteriores Buescu indica 
que de 1836 a 1838 a taxa de variação acumulada foi de 49,6\%. Para o período entre 1838-1842 foi calculada uma taxa de $-7,2 \%$ e para os anos posteriores de 1842-1847 a taxa de inflação encontrada foi de 12,6\%. Entre 1847-1850 houve uma modificação nos preços de -4,2\%. Entre 1850 e 1856 houve uma variação acumulada nos preços de 42,9\%; a inflação entre 1856 e 1862 foi de 2,4\% e entre $1862-1870,25,8 \%$. Os preços caíram $0,4 \%$ entre 1870 e 1875 , elevando-se $6,7 \%$ até $1880,4,5 \%$ até 1883 , voltando a sofrer variação negativa (-7,9\%) no período 1883-1887.

Como exposto, o referido índice apresenta valores por períodos. Transformamos, então, as taxas médias anuais por períodos por ele apresentadas em um índice de preços, base 100 em 1798, a ser utilizado. O índice é apresentado no gráfico a seguir.

\section{Gráfico 2.1}

\section{Índice de preços}

\section{$(1798=100)$}

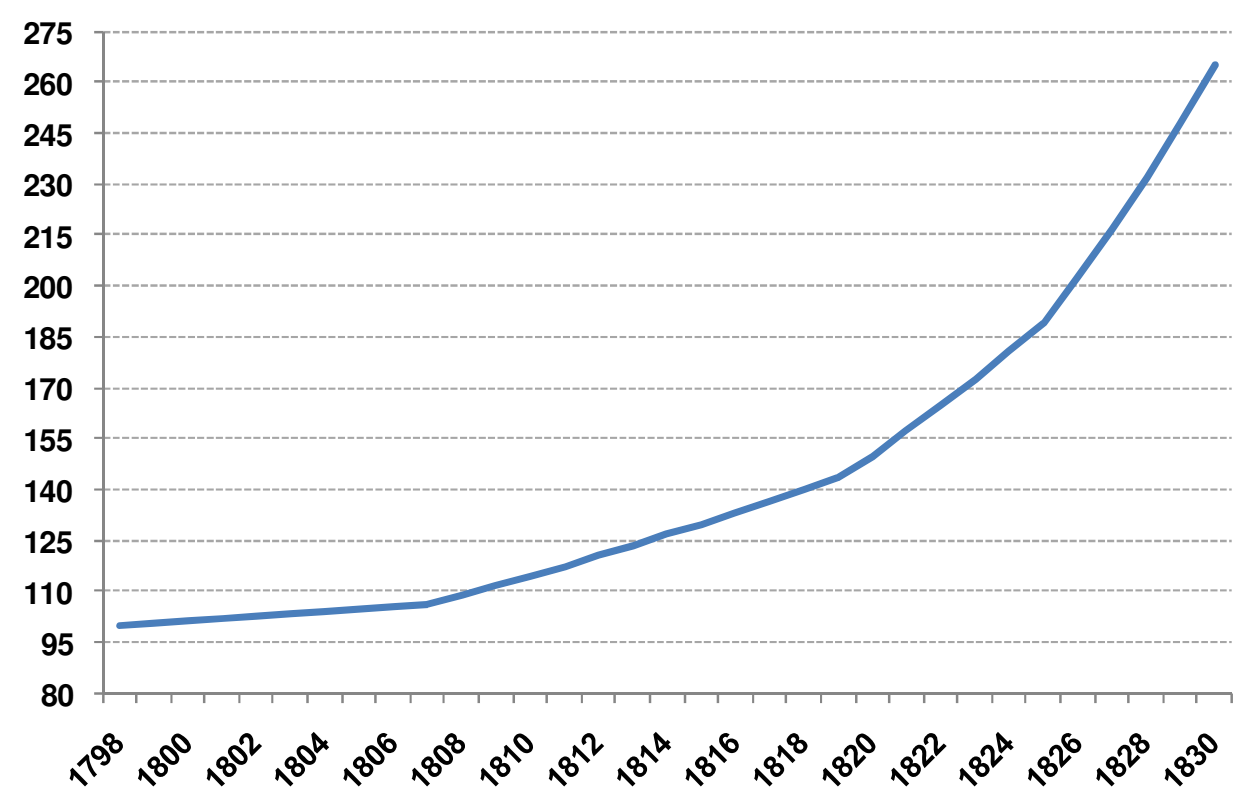

Elaborado a partir de dados de Buescu (1973) 


\section{APÊNDICE 3 \\ APÊNDICE ESTATÍSTICO}

Tabela 3.1

Sexo e idade dos chefes de fogo com escravos Bragança

(1799 a 1830)

\begin{tabular}{ccccccccc}
\hline \hline & $\mathbf{1 7 9 9}$ & $\mathbf{1 8 0 3}$ & $\mathbf{1 8 0 8}$ & $\mathbf{1 8 1 2}$ & $\mathbf{1 8 1 6}$ & $\mathbf{1 8 2 2}$ & $\mathbf{1 8 2 5}$ & $\mathbf{1 8 3 0}$ \\
\hline Homens (\%) & 79,6 & 82,3 & 79,4 & 80,7 & 77,8 & 82,2 & 78,0 & 80,7 \\
Mulheres (\%) & 20,4 & 17,7 & 20,6 & 19,3 & 22,2 & 17,8 & 22,0 & 17,8 \\
Razão de sexo & 389,2 & 464,0 & 385,4 & 418,8 & 352,8 & 424,1 & 354,5 & 461,3 \\
\hline Idade média & 41,5 & 46,6 & 42,0 & 46,1 & 41,6 & 45,6 & 40,6 & 45,1 \\
Idade mínima & 13 & 19 & 16 & 19 & 15 & 21 & 14 & 19 \\
Idade máxima & 96 & 79 & 90 & 84 & 92 & 89 & 90 & 100 \\
\hline \hline
\end{tabular}

Fonte: AESP, M aços de População, Jundiaí: anos selecionados

Tabela 3.2

Sexo e idade dos chefes de fogo com escravos Bragança

(1799 a 1830)

\begin{tabular}{ccccccccc}
\hline \hline & $\mathbf{1 7 9 9}$ & $\mathbf{1 8 0 3}$ & $\mathbf{1 8 0 8}$ & $\mathbf{1 8 1 1}$ & $\mathbf{1 8 1 6}$ & $\mathbf{1 8 2 0}$ & $\mathbf{1 8 2 6}$ & $\mathbf{1 8 3 0}$ \\
\hline Homens (\%) & 91,9 & 87,9 & 88,1 & 89,1 & 88,3 & 89,2 & 88,1 & 85,3 \\
Mulheres (\%) & 8,1 & 12,1 & 11,9 & 10,9 & 11,7 & 10,8 & 11,9 & 14,7 \\
Razão de sexo & 1130,0 & 728,6 & 741,7 & 815,4 & 754,8 & 827,3 & 737,2 & 579,7 \\
\hline Idade média & 43,8 & 45,9 & 44,9 & 45,8 & 43,8 & 44,0 & 42,7 & 43,4 \\
Idade mínima & 21 & 21 & 20 & 17 & 17 & 15 & 18 & 15 \\
Idade máxima & 80 & 101 & 89 & 81 & 85 & 89 & 100 & 85 \\
\hline \hline
\end{tabular}

Fonte: AESP, M aços de População, Bragança: anos selecionados 
Tabela 3.3

\section{Composição da população livre de acordo com estado conjugal} (Jundiaí - 1799 a 1830)

\begin{tabular}{ccccc}
\hline \hline Anos & $\begin{array}{c}\text { Casados } \\
\text { \% (№) }\end{array}$ & $\begin{array}{c}\text { Solteiros } \\
\% \text { (№) }\end{array}$ & $\begin{array}{c}\text { Viúvos } \\
\%(\text { (№) }\end{array}$ & $\begin{array}{c}\text { Total } \\
\% \text { (№) }\end{array}$ \\
\hline $\mathbf{1 7 9 9}$ & $32,7(1013,0)$ & $61,9(1917,0)$ & $5,4(167,0)$ & $100,0(3097,0)$ \\
$\mathbf{1 8 0 3}$ & $29,5(1102,0)$ & $65,2(2438,0)$ & $5,3(197,0)$ & $100,0(3737,0)$ \\
$\mathbf{1 8 0 8}$ & $32,6(1092,0)$ & $61,9(2073,0)$ & $5,5(183,0)$ & $100,0(3348,0)$ \\
$\mathbf{1 8 1 2}$ & $34,5(1310,0)$ & $61,2(2325,0)$ & $4,4(166,0)$ & $100,0(3801,0)$ \\
$\mathbf{1 8 1 6}$ & $35,0(1321,0)$ & $59,8(2258,0)$ & $5,2(195,0)$ & $100,0(3774,0)$ \\
$\mathbf{1 8 2 2}$ & $34,8(1109,0)$ & $60,2(1918,0)$ & $5,0(159,0)$ & $100,0(3186,0)$ \\
$\mathbf{1 8 2 5}$ & $33,6(1265,0)$ & $61,9(2330,0)$ & $4,5(169,0)$ & $100,0(3764,0)$ \\
$\mathbf{1 8 3 0}$ & $36,0(1323,0)$ & $59,1(2173,0)$ & $4,9(182,0)$ & $100,0(3678,0)$ \\
\hline \hline Fonte: AESP, Maços de População, Jundiaí: anos selecionados & & \\
Exclusive indivíduos com estado conjugal não identificado & & \\
Inclui crianças & &
\end{tabular}

Tabela 3.4

Composição da população livre de acordo com estado conjugal (Bragança - 1799 a 1830)

\begin{tabular}{clllc}
\hline \hline Anos & $\begin{array}{c}\text { Casados } \\
\text { \% (№) }\end{array}$ & $\begin{array}{c}\text { Solteiros } \\
\% \text { (№) }\end{array}$ & $\begin{array}{c}\text { Viúvos } \\
\% \text { (№) }\end{array}$ & $\begin{array}{c}\text { Total } \\
\% \text { (№) }\end{array}$ \\
\hline $\mathbf{1 7 9 9}$ & $29,1(1489,0)$ & $67,8(3473,0)$ & $3,1(157,0)$ & $100,0(5119,0)$ \\
$\mathbf{1 8 0 3}$ & $28,6(1701,0)$ & $68,4(4065,0)$ & $2,9(174,0)$ & $100,0(5940,0)$ \\
$\mathbf{1 8 0 8}$ & $31,5(2018,0)$ & $65,3(4177,0)$ & $3,2(205,0)$ & $100,0(6400,0)$ \\
$\mathbf{1 8 1 1}$ & $32,9(2573,0)$ & $63,9(4996,0)$ & $3,1(244,0)$ & $100,0(7813,0)$ \\
$\mathbf{1 8 1 6}$ & $33,2(2216,0)$ & $63,6(4244,0)$ & $3,2(215,0)$ & $100,0(6675,0)$ \\
$\mathbf{1 8 2 0}$ & $33,8(2266,0)$ & $63,6(4270,0)$ & $2,6(174,0)$ & $100,0(6710,0)$ \\
$\mathbf{1 8 2 6}$ & $35,7(2480,0)$ & $61,4(4268,0)$ & $2,9(204,0)$ & $100,0(6952,0)$ \\
$\mathbf{1 8 3 0}$ & $36,4(2965,0)$ & $60,2(4900,0)$ & $3,4(276,0)$ & $100,0(8141,0)$ \\
\hline \hline
\end{tabular}

Fonte: AESP, M aços de População, Bragança: anos selecionado $s$

Exclusive indivíduos com estado conjugal não identificado

Inclui crianças 
Tabela 3.5

Composição da população livre de acordo com estado conjugal (Atibaia - 1799 a 1830)

\begin{tabular}{ccccc}
\hline \hline Anos & $\begin{array}{c}\text { Casados } \\
\% \text { (№) }\end{array}$ & $\begin{array}{c}\text { Solteiros } \\
\% \text { (№) }\end{array}$ & $\begin{array}{c}\text { Viúvos } \\
\% \text { (№) }\end{array}$ & $\begin{array}{c}\text { Total } \\
\% \text { (№) }\end{array}$ \\
\hline $\mathbf{1 7 9 9}$ & $30,2(876,0)$ & $65,5(1903,0)$ & $4,3(125,0)$ & $100,0(2904,0)$ \\
$\mathbf{1 8 0 3}$ & $29,0(898,0)$ & $67,0(2077,0)$ & $4,0(123,0)$ & $100,0(3098,0)$ \\
$\mathbf{1 8 0 8}$ & $30,6(902,0)$ & $65,3(1926,0)$ & $4,1(121,0)$ & $100,0(2949,0)$ \\
$\mathbf{1 8 1 2}$ & $32,4(968,0)$ & $63,6(1903,0)$ & $4,0(120,0)$ & $100,0(2991,0)$ \\
$\mathbf{1 8 1 6}$ & $32,0(1010,0)$ & $63,5(2004,0)$ & $4,5(142,0)$ & $100,0(3156,0)$ \\
$\mathbf{1 8 2 0}$ & $33,7(1005,0)$ & $61,5(1831,0)$ & $4,8(142,0)$ & $100,0(2978,0)$ \\
$\mathbf{1 8 2 6}$ & $33,7(758,0)$ & $62,1(1396,0)$ & $4,2(95,0)$ & $100,0(2249,0)$ \\
$\mathbf{1 8 2 9}$ & $35,1(803,0)$ & $60,3(1377,0)$ & $4,6(105,0)$ & $100,0(2285,0)$ \\
\hline \hline Fonte: A ESP, Maços de População, Atibaia: anos selecionados & & \\
Exclusive indivíduos com estado conjugal não identificado & & \\
Inclui crianças & & &
\end{tabular}

Tabela 3.6

Composição dos chefes de fogo de acordo com estado conjugal e sexo (Nazaré - 1799 a 1830)

\begin{tabular}{ccccc}
\hline \hline Anos & $\begin{array}{c}\text { Casados } \\
\text { \% (№) }\end{array}$ & $\begin{array}{c}\text { Solteiros } \\
\text { \% (№) }\end{array}$ & $\begin{array}{c}\text { Viúvos } \\
\% \text { (№) }\end{array}$ & $\begin{array}{c}\text { Total } \\
\% \text { (№) }\end{array}$ \\
\hline $\mathbf{1 7 9 9}$ & $32,4(613)$ & $63,5(1203)$ & $4,1(78)$ & $100,0(1894)$ \\
$\mathbf{1 8 0 3}$ & $30,3(870)$ & $65,8(1889)$ & $4,0(114)$ & $100,0(2873)$ \\
$\mathbf{1 8 0 8}$ & $33,3(1031)$ & $62,9(1950)$ & $3,8(118)$ & $100,0(3099)$ \\
$\mathbf{1 8 1 2}$ & $33,1(1004)$ & $63,4(1922)$ & $3,5(105)$ & $100,0(3031)$ \\
$\mathbf{1 8 1 6}$ & $33,9(1089)$ & $61,8(1988)$ & $4,3(139)$ & $100,0(3216)$ \\
$\mathbf{1 8 2 0}$ & $33,2(1182)$ & $62,3(2217)$ & $4,5(160)$ & $100,0(3559)$ \\
$\mathbf{1 8 2 6}$ & $33,7(1246)$ & $62,0(2291)$ & $4,2(156)$ & $100,0(3693)$ \\
$\mathbf{1 8 2 9}$ & $34,8(1112)$ & $60,7(1938)$ & $4,5(143)$ & $100,0(3193)$ \\
\hline \hline
\end{tabular}

Fonte:AESP, M aços de População, Nazaré: anos selecionados

Exclusive indivíduos com estado conjugal não identificado

Inclui crianças 
Tabela 3.7

Composição dos chefes de fogo de acordo com estado conjugal e sexo

(Mogi - 1799 a 1829)

\begin{tabular}{ccccc}
\hline \hline Anos & $\begin{array}{c}\text { Casados } \\
\text { \% (№) }\end{array}$ & $\begin{array}{c}\text { Solteiros } \\
\% \text { (№) }\end{array}$ & $\begin{array}{c}\text { Viúvos } \\
\% \text { (№) }\end{array}$ & $\begin{array}{c}\text { Total } \\
\% \text { (№) }\end{array}$ \\
\hline $\mathbf{1 7 9 9}$ & $31,9(1693)$ & $64,2(3413)$ & $3,9(208)$ & $100,0(5314,0)$ \\
1803 & $30,8(1990)$ & $64,2(4151)$ & $5,0(324)$ & $100,0(6465,0)$ \\
1808 & $32,2(2130)$ & $62,2(4108)$ & $5,6(370)$ & $100,0(6608,0)$ \\
1812 & $33,9(2313)$ & $60,8(4145)$ & $5,3(361)$ & $100,0(6819,0)$ \\
1816 & $35,4(2320)$ & $60,0(3929)$ & $4,6(304)$ & $100,0(6553,0)$ \\
1820 & $34,8(2284)$ & $60,8(3985)$ & $4,4(288)$ & $100,0(6557,0)$ \\
1825 & $35,4(2842)$ & $59,8(4795)$ & $4,8(387)$ & $100,0(8024,0)$ \\
1829 & $35,8(3090)$ & $59,3(5122)$ & $4,9(422)$ & $100,0(8634,0)$ \\
\hline \hline
\end{tabular}

Fonte: AESP, Maços de População, M ogi das Cruzes: anos selecio nados

Exclusive indivíduos com estado conjugal não identificado

Inclui crianças

Tabela 3.8

Composição dos chefes de fogo de acordo com estado conjugal e sexo (Jacareí - 1798 a 1829)

\begin{tabular}{ccccc}
\hline \hline Anos & $\begin{array}{c}\text { Casados } \\
\% \text { (№) }\end{array}$ & $\begin{array}{c}\text { Solteiros } \\
\% \text { (№) }\end{array}$ & $\begin{array}{c}\text { Viúvos } \\
\% \text { (№) }\end{array}$ & $\begin{array}{c}\text { Total } \\
\% \text { (№) }\end{array}$ \\
\hline $\mathbf{1 7 9 9}$ & $33,5(1421)$ & $63,5(2690)$ & $3,0(127)$ & $100,0(4238,0)$ \\
$\mathbf{1 8 0 3}$ & $33,5(1491)$ & $62,7(2790)$ & $3,9(172)$ & $100,0(4453,0)$ \\
$\mathbf{1 8 0 8}$ & $31,9(1115)$ & $63,8(2233)$ & $4,3(150)$ & $100,0(3498,0)$ \\
$\mathbf{1 8 1 2}$ & $37,9(1648)$ & $58,7(2553)$ & $3,3(145)$ & $100,0(4346,0)$ \\
$\mathbf{1 8 1 6}$ & $38,9(2316)$ & $57,7(3435)$ & $3,3(199)$ & $100,0(5950,0)$ \\
$\mathbf{1 8 2 0}$ & $37,8(2360)$ & $59,0(3680)$ & $3,1(196)$ & $100,0(6236,0)$ \\
$\mathbf{1 8 2 5}$ & $38,8(2458)$ & $58,2(3680)$ & $3,0(189)$ & $100,0(6327,0)$ \\
$\mathbf{1 8 2 9}$ & $39,8(2257)$ & $56,7(3214)$ & $3,5(200)$ & $100,0(5671,0)$ \\
\hline \hline
\end{tabular}

Fonte:AESP, M aços de População, Jacareí: anos selecionados

Exclusive indivíduos com estado conjugal não identificado

Inclui crianças 
Tabela 3.9

Razão de sexo dos escravos por faixa de tamanho de plantel

$$
\text { (Jundiaí - } 1799 \text { a 1830) }
$$

\begin{tabular}{ccccc}
\hline \hline & \multicolumn{4}{c}{ FTP } \\
\cline { 2 - 5 } & $\mathbf{1}$ a $\mathbf{1 1}$ & $\mathbf{6}$ a 10 & $\mathbf{1 1} \mathbf{~ 0}$ & Acima 20 \\
\hline $\mathbf{1 7 9 9}$ & 120,8 & 137,7 & 169,6 & 228,9 \\
$\mathbf{1 8 0 3}$ & 123,4 & 124,6 & 175,0 & 190,5 \\
$\mathbf{1 8 0 8}$ & 107,3 & 133,3 & 201,3 & 212,8 \\
$\mathbf{1 8 1 2}$ & 108,8 & 153,6 & 181,5 & 213,6 \\
$\mathbf{1 8 1 6}$ & 114,9 & 126,6 & 194,7 & 232,2 \\
$\mathbf{1 8 2 2}$ & 147,7 & 185,1 & 239,3 & 219,9 \\
$\mathbf{1 8 2 5}$ & 136,9 & 175,4 & 241,8 & 211,6 \\
$\mathbf{1 8 3 0}$ & 140,5 & 154,9 & 207,2 & 181,7 \\
\hline \hline
\end{tabular}

Exclusive escravos com sexo não identificado

Fonte: AESP, M aços de População, Jundiaí: anos selecionados

Tabela 3.10

Razão de sexo dos escravos por faixa de tamanho de plantel (Bragança - 1799 a 1830)

\begin{tabular}{ccccc}
\hline \hline & \multicolumn{4}{c}{ FTP } \\
\cline { 2 - 5 } & $\mathbf{1}$ a $\mathbf{5}$ & $\mathbf{6}$ a 10 & $\mathbf{1 1}$ a 20 & Acima 20 \\
\hline $\mathbf{1 7 9 9}$ & 87,1 & 90,9 & 139,5 & 140,0 \\
$\mathbf{1 8 0 3}$ & 94,9 & 89,0 & 113,2 & 138,5 \\
$\mathbf{1 8 0 8}$ & 88,3 & 103,2 & 121,5 & 103,6 \\
$\mathbf{1 8 1 1}$ & 112,1 & 128,0 & 137,9 & 121,1 \\
$\mathbf{1 8 1 6}$ & 90,2 & 126,8 & 144,6 & 150,0 \\
$\mathbf{1 8 2 0}$ & 109,8 & 141,4 & 162,7 & 129,7 \\
$\mathbf{1 8 2 6}$ & 111,3 & 136,4 & 130,0 & 161,5 \\
$\mathbf{1 8 3 0}$ & 114,2 & 132,2 & 143,4 & 156,0 \\
\hline \hline
\end{tabular}

Exclusive escravos com sexo não identificado

Fonte: AESP, M aços de População, B ragança: anos selecionados

Tabela 3.11

Razão de sexo dos escravos por faixa de tamanho de plantel (Atibaia - 1799 a 1829)

\begin{tabular}{ccccc}
\hline \hline & \multicolumn{4}{c}{ FTP } \\
\cline { 2 - 5 } & $\mathbf{1}$ a 5 & $\mathbf{6}$ a 10 & $\mathbf{1 1}$ a 20 & Acima 20 \\
\hline $\mathbf{1 7 9 9}$ & 84,6 & 102,0 & 124,3 & 105,0 \\
$\mathbf{1 8 0 3}$ & 72,0 & 122,3 & 123,3 & 113,0 \\
$\mathbf{1 8 0 8}$ & 85,0 & 107,8 & 123,0 & 114,9 \\
$\mathbf{1 8 1 2}$ & 73,5 & 100,7 & 108,0 & 142,3 \\
$\mathbf{1 8 1 6}$ & 98,6 & 94,0 & 138,8 & 128,4 \\
$\mathbf{1 8 2 0}$ & 99,3 & 112,0 & 118,0 & 134,2 \\
$\mathbf{1 8 2 6}$ & 83,7 & 133,0 & 126,0 & 155,0 \\
$\mathbf{1 8 2 9}$ & 83,9 & 125,6 & 127,8 & 140,6 \\
\hline \hline
\end{tabular}

Exclusive escravos com sexo não identificado

Fonte: AESP, M aços de População, Atibaia: anos selecionados 
Tabela 3.12

Razão de sexo dos escravos por faixa de tamanho de plantel

(Nazaré - 1799 a 1829)

\begin{tabular}{ccccc}
\hline \hline & \multicolumn{4}{c}{ FTP } \\
\cline { 2 - 5 } & $\mathbf{1}$ a 5 & $\mathbf{6}$ a 10 & $\mathbf{1 1}$ a 20 & Acima 20 \\
\hline $\mathbf{1 7 9 9}$ & 90,1 & 80,3 & 162,5 & 110,0 \\
$\mathbf{1 8 0 3}$ & 107,0 & 77,5 & 130,9 & 153,6 \\
$\mathbf{1 8 0 8}$ & 78,0 & 94,7 & 120,3 & 111,8 \\
$\mathbf{1 8 1 2}$ & 72,2 & 111,9 & 87,6 & 91,3 \\
$\mathbf{1 8 1 6}$ & 88,7 & 128,0 & 108,5 & 84,6 \\
$\mathbf{1 8 2 0}$ & 86,5 & 126,4 & 112,5 & 117,7 \\
$\mathbf{1 8 2 6}$ & 85,2 & 124,5 & 105,7 & 110,0 \\
$\mathbf{1 8 2 9}$ & 78,6 & 137,9 & 95,2 & 110,7 \\
\hline \hline
\end{tabular}

Fonte: AESP, M aços de População, Nazaré: anos selecionados

Exclusive escravos com sexo não identificado

Tabela 3.13

Razão de sexo dos escravos por faixa de tamanho de plantel

(Mogi - 1799 a 1829)

\begin{tabular}{ccccc}
\hline \hline & \multicolumn{4}{c}{ FTP } \\
\cline { 2 - 5 } & $\mathbf{1}$ a $\mathbf{5}$ & $\mathbf{6}$ a 10 & $\mathbf{1 1}$ a 20 & Acima 20 \\
\hline $\mathbf{1 7 9 9}$ & 79,4 & 100,0 & 112,9 & 91,6 \\
$\mathbf{1 8 0 3}$ & 80,2 & 85,8 & 96,0 & 83,5 \\
$\mathbf{1 8 0 8}$ & 86,5 & 74,5 & 104,7 & 105,3 \\
$\mathbf{1 8 1 2}$ & 79,8 & 97,8 & 102,5 & 77,5 \\
$\mathbf{1 8 1 6}$ & 81,3 & 101,8 & 111,8 & 98,4 \\
$\mathbf{1 8 2 0}$ & 89,1 & 96,9 & 105,3 & 97,2 \\
$\mathbf{1 8 2 5}$ & 91,5 & 101,8 & 111,8 & 133,0 \\
$\mathbf{1 8 2 9}$ & 98,7 & 113,8 & 124,0 & 153,2 \\
\hline \hline
\end{tabular}

Exclusive escravos com sexo não identificado

Fonte: AESP, M aços de População, M ogi das Cruzes: anos selecionados

Tabela 3.14

Razão de sexo dos escravos por faixa de tamanho de plantel

(Jacareí - 1798 a 1829)

\begin{tabular}{ccccc}
\hline \hline & \multicolumn{4}{c}{ FTP } \\
\cline { 2 - 5 } & $\mathbf{1}$ a $\mathbf{5}$ & $\mathbf{6}$ a 10 & $\mathbf{1 1}$ a 20 & Acima 20 \\
\hline $\mathbf{1 7 9 8}$ & 65,1 & 93,0 & 152,2 & \\
$\mathbf{1 8 0 3}$ & 81,5 & 97,9 & 105,0 & 112,5 \\
$\mathbf{1 8 0 7}$ & 76,5 & 91,7 & 117,4 & 130,8 \\
$\mathbf{1 8 1 1}$ & 79,4 & 98,8 & 135,7 & 212,5 \\
$\mathbf{1 8 1 6}$ & 105,6 & 101,0 & 140,5 & 143,2 \\
$\mathbf{1 8 2 2}$ & 87,0 & 116,1 & 184,6 & 172,3 \\
$\mathbf{1 8 2 5}$ & 118,8 & 142,3 & 221,6 & 202,7 \\
$\mathbf{1 8 2 9}$ & 110,8 & 127,2 & 224,6 & 206,7 \\
\hline \hline
\end{tabular}

Exclusive escravos com sexo não identificado

Fonte: AESP, M aços de População, Jacareí: anos selecionados 
Tabela 3.15

\section{Estatística para a posse de escravos em fogos com açúcar}

(Jundiaí - 1799 a 1830)

\begin{tabular}{ccccccccc}
\hline \hline $\begin{array}{c}\text { Estatísticas (Fogos com } \\
\text { açúcar) }\end{array}$ & 1799 & 1803 & 1808 & 1812 & 1816 & 1822 & 1825 & 1830 \\
\hline № de fogos & 16 & 14 & 17 & 10 & 22 & 33 & 33 & 29 \\
№ de escravos & 223 & 238 & 383 & 284 & 582 & 722 & 962 & 1082 \\
\% do total de escravos & 32,8 & 28,1 & 42,7 & 28,1 & 48,3 & 57,7 & 56,5 & 53,2 \\
Média & 13,9 & 17,0 & 22,5 & 28,4 & 17,5 & 21,9 & 29,2 & 37,3 \\
Moda & - & - & - & - & - & - & - & - \\
Mediana & 14,0 & 18,0 & 19,0 & 22,5 & 25,0 & 20,0 & 23,0 & 25,0 \\
Índice de Gini & 0,292 & 0,258 & 0,215 & 0,219 & 0,322 & 0,345 & 0,352 & 0,379 \\
Mínimo & 2,0 & 4,0 & 9,0 & 16,0 & 5,0 & 8,0 & 8,0 & 7,0 \\
Máximo & 29,0 & 29,0 & 50,0 & 60,0 & 72,0 & 78,0 & 88,0 & 89,0 \\
\hline \hline
\end{tabular}

Fonte: AESP, M aços de População, Jundiaí: anos selecionados

Tabela 3.16

Gêneros cultivados

(Bragança - 1799 a 1830)

\begin{tabular}{|c|c|c|c|c|c|c|c|c|}
\hline CULTURAS & $\begin{array}{l}1779 \\
\% \text { (№) }\end{array}$ & $\begin{array}{r}1803 \\
\%\left(\mathfrak{N}^{\circ}\right)\end{array}$ & $\begin{array}{l}1808 \\
\%\left(^{\circ}\right)\end{array}$ & $\begin{array}{l}1811 \\
\%\left(\mathbf{N}^{\circ}\right)\end{array}$ & $\begin{array}{l}1816 \\
\%\left(^{\circ}\right)\end{array}$ & $\begin{array}{r}1820 \\
\%\left(^{\circ}\right)\end{array}$ & $\begin{array}{l}1826 \\
\%\left(^{\circ}\right)\end{array}$ & $\begin{array}{l}1830 \\
\% \text { (№ })\end{array}$ \\
\hline MLHO & $27,2(53)$ & $62,8(403)$ & 36,0 (189) & 27,5 (240) & 23,5 (169) & $17,2(137)$ & 13,7 (128) & 16,5 (184) \\
\hline FEIJÃO & $30,8(60)$ & $0,2(1)$ & $1,7(9)$ & $0,8(7)$ & $0,3(2)$ & $0,6(5)$ & $0,5(5)$ & $1,0(11)$ \\
\hline MLLHO+FEIJÃO & $24,6(48)$ & $36,9(237)$ & $58,5(307)$ & $70,2(613)$ & $76,2(548)$ & $82,1(653)$ & $85,7(799)$ & $82,5(922)$ \\
\hline MLLHO+FEIJÃO+ALGODÃO & $0,5(1)$ & - & $1,3(7)$ & $0,5(4)$ & - & - & - & - \\
\hline FEIJÃO+ALGODÃO & $1,5(3)$ & - & $0,8(4)$ & $0,5(4)$ & - & - & - & - \\
\hline MILHO+FEIJÃO+ARROZ & $5,1(10)$ & - & - & - & - & - & - & - \\
\hline MILHO+FEIJÃO+ALGODÃO+CANA & - & - & $0,2(1)$ & - & - & - & - & - \\
\hline MLLHO+CANA & $0,5(1)$ & - & $0,2(1)$ & - & - & - & - & - \\
\hline FEIJÃO+TRIGO & $1,0(2)$ & - & - & - & - & - & - & - \\
\hline CANA & $4,6(9)$ & - & - & - & - & - & - & - \\
\hline MILHO+FEIJÃO+CANA & - & $0,2(1)$ & $0,6(3)$ & $0,6(5)$ & - & - & - & - \\
\hline FUMO & $2,6(5)$ & - & - & - & - & - & - & - \\
\hline MILHO+ALGODÃO & - & - & $0,8(4)$ & - & - & - & - & - \\
\hline MILHO+ARROZ & $0,5(1)$ & - & - & - & - & - & - & - \\
\hline ARROZ & $0,5(1)$ & - & - & - & - & - & - & - \\
\hline TRIGO & $0,5(1)$ & - & - & - & - & - & - & - \\
\hline MILHO+FEIJÃO+FUMO & $0,5(1)$ & - & - & - & - & - & - & - \\
\hline TOTAL & 100,5 (196) & 100,0 (642) & $100,0(525)$ & $100,0(873)$ & $100,0(719)$ & 100,0 (795) & 100,0 (932) & $100,0(1117)$ \\
\hline
\end{tabular}


Tabela 3.17

Gêneros cultivados

(Jundiaí - 1799 a 1830)

\begin{tabular}{|c|c|c|c|c|c|c|c|c|}
\hline CULTURAS & $\begin{array}{c}1779 \\
\%(\mathbb{N})\end{array}$ & $\begin{array}{c}1803 \\
\%(\mathrm{NP})\end{array}$ & $\begin{array}{c}1808 \\
\%(\mathbf{N})\end{array}$ & $\begin{array}{c}1812 \\
\%(\mathbf{N})\end{array}$ & $\begin{array}{c}1816 \\
\%(\mathbf{N})\end{array}$ & $\begin{array}{c}1822 \\
\%(\mathrm{NP})\end{array}$ & $\begin{array}{c}1825 \\
\%(\mathrm{NP})\end{array}$ & $\begin{array}{c}1830 \\
\%(\mathrm{NP})\end{array}$ \\
\hline MLHO & $39,5(134)$ & $24,9(107)$ & $13,3(31)$ & - & $28,9(144)$ & $34,8(149)$ & $21,3(114)$ & $32,7(130)$ \\
\hline 田颌 & $6,8(23)$ & - & $0,4(1)$ & - & $0,2(1)$ & - & $0,4(2)$ & $0,3(1)$ \\
\hline MLHO+F日コÃO & 29,2 (99) & 42,4 (182) & $45,1(105)$ & $14,3(3)$ & $42,3(211)$ & $41,8(179)$ & $61,7(330)$ & $47,6(189)$ \\
\hline ALGODÃO & $1,2(4)$ & $0,2(1)$ & - & $4,8(1)$ & $0,2(1)$ & - & - & - \\
\hline MLHO+FEJÃO+ALGODÃO & $9,4(32)$ & $6,3(27)$ & $16,7(39)$ & - & $7,8(39)$ & $4,2(18)$ & $1,9(10)$ & $1,5(6)$ \\
\hline MLHO+F日JÃO+ALGODÃO+AMENDOIM & - & $0,2(1)$ & - & - & $1,0(5)$ & - & - & - \\
\hline MLHO+F日JÃO+AMENDOM & - & $0,7(3)$ & - & - & $2,0(10)$ & - & $0,2(1)$ & - \\
\hline MLHO + AMENDOIM & - & - & - & - & $0,6(3)$ & - & - & - \\
\hline 円コÃO+ALGODÃO & $0,6(2)$ & - & $0,4(1)$ & - & - & - & - & - \\
\hline MLHO+FEJÃO+ARROZ & $2,7(9)$ & $12,8(55)$ & $8,6(20)$ & - & $7,0(35)$ & $7,9(34)$ & $7,5(40)$ & $11,8(47)$ \\
\hline MLHO+ F曰JÃO+ALGODÃO+ ARROZ & $1,5(5)$ & $3,3(14)$ & $4,7(11)$ & - & $1,2(6)$ & $1,2(5)$ & $0,2(1)$ & $1,3(5)$ \\
\hline 円コJ̃̃O+AMENDOIM & - & - & $0,4(1)$ & - & - & - & - & - \\
\hline MLHO+F日JÃO+ALGODÃO+CANA & $0,3(1)$ & - & $0,9(2)$ & - & - & - & - & - \\
\hline MLHO+CANA & $0,3(1)$ & $0,5(2)$ & - & - & - & $0,2(1)$ & - & - \\
\hline MLHO+F四O+AMENDOIM+ARROZ & - & $1,4(6)$ & - & - & $0,6(3)$ & $0,2(1)$ & - & - \\
\hline 田JÃO+TRIGO & - & - & - & - & - & - & - & - \\
\hline CANA & $1,2(4)$ & - & $4,3(10)$ & $81,0(17)$ & $0,2(1)$ & $0,2(1)$ & - & $0,3(1)$ \\
\hline MLHO+FEJÃO+CANA & $4,1(14)$ & $0,9(4)$ & $2,6(6)$ & - & $2,2(11)$ & $5,1(22)$ & $2,6(14)$ & $1,5(6)$ \\
\hline MLHO+ALGODÃO & $2,4(8)$ & $1,4(6)$ & $1,3(3)$ & - & $1,2(6)$ & $0,7(3)$ & $0,2(1)$ & $0,3(1)$ \\
\hline MLHO+ARROZ & $0,3(1)$ & $1,9(8)$ & - & - & $0,8(4)$ & $1,6(7)$ & $0,6(3)$ & $0,3(1)$ \\
\hline MLHO+F日Ũ̃O+ALGODÃO+ARROZ+AMENDOM & - & $0,2(1)$ & - & - & $0,4(2)$ & $0,2(1)$ & - & - \\
\hline MLHO+ F曰JÃO+ ARROZ + CANA & $0,3(1)$ & $1,6(7)$ & $0,4(1)$ & - & $1,0(5)$ & $1,6(7)$ & $3,4(18)$ & $2,0(8)$ \\
\hline MLHO+F日JÃO+MANDIOCA+ALGODÃO & - & - & $0,4(1)$ & - & - & - & - & - \\
\hline MLHO+ALGODÃO+ARROZ & - & $0,7(3)$ & - & - & $0,2(1)$ & - & - & - \\
\hline MLHO+F日JÃO+ARROZ+ALGODÃO+CANA & - & $0,2(1)$ & $0,4(1)$ & - & - & - & - & - \\
\hline MLHO+ALGODÃO+CANA & - & $0,2(1)$ & - & - & - & - & - & - \\
\hline MLHO+F日JÃO+FUMD+ARROZ & - & - & - & - & $0,2(1)$ & - & $0,2(1)$ & - \\
\hline MLHO+F日Ũ̃O+ARROZ+TRIGO & - & - & - & - & $0,2(1)$ & - & - & - \\
\hline FUMO+ALGODÃO & $0,3(1)$ & - & - & - & - & - & - & - \\
\hline MLHO+ALGODÃO+AMENDOM & - & - & - & - & $0,2(1)$ & - & - & - \\
\hline MLHO+ARROZ+AMENDOM+TRIGO & - & - & - & - & $0,2(1)$ & - & - & - \\
\hline ARROZ + ALGODÃO & - & - & - & - & $0,2(1)$ & - & - & - \\
\hline MLHO+ARAOZ+AMENDOM & - & - & - & - & $0,2(1)$ & - & - & - \\
\hline MLHO+FEJÃO+ARROZ+ALGODÃO+TRIGO+CANA & - & - & - & - & $0,2(1)$ & - & - & - \\
\hline MLHO+FUMD & - & - & - & - & $0,2(1)$ & - & - & - \\
\hline MLHO+F日J̃̃O+MAMONA & - & - & - & - & $0,2(1)$ & - & - & - \\
\hline MANDIOCA + ALGODÃO & - & - & - & - & $0,2(1)$ & - & - & - \\
\hline MLHO+F日ÃO+ARROZ+CANA+CAF́ & - & - & - & - & - & - & - & $0,3(1)$ \\
\hline MLHO+FEÃO+MANDIOCA+CANA+ARROZ & - & - & - & - & $0,2(1)$ & - & - & $0,3(1)$ \\
\hline TOTAL & $100,0(339)$ & $100,0(429)$ & $100,0(233)$ & $100,0(21)$ & $100,0(499)$ & $100,0(428)$ & $100,0(535)$ & $100,0(397)$ \\
\hline
\end{tabular}

Fontes: AESP, Maços de População, Jundiaí: anos selecionados 
Tabela 3.18

\section{Gêneros cultivados}

\section{(Atibaia - 1799 a 1829)}

\begin{tabular}{|c|c|c|c|c|c|c|c|c|}
\hline \multirow{2}{*}{ CULTURAS } & 1779 & 1803 & 1808 & 1812 & 1816 & 1820 & 1826 & 1829 \\
\hline & $\%(\mathbb{N})$ & $\%(\mathrm{NP})$ & $\%(\mathbb{N})$ & $\%(\mathbb{N})$ & $\%(\mathbb{N})$ & $\%\left(N^{P}\right)$ & $\%(\mathrm{~N})$ & $\%\left(N^{P}\right)$ \\
\hline MபD & $31,4(69)$ & $29,3(102)$ & $20,6(56)$ & $20,1(36)$ & $23,3(77)$ & $18,2(55)$ & $14,0(29)$ & $13,9(21)$ \\
\hline 円却O & $7,7(17)$ & $1,7(6)$ & $2,9(8)$ & - & $1,2(4)$ & $0,7(2)$ & $0,5(1)$ & - \\
\hline MUH+田ÃO & $23,2(51)$ & $52,6(183)$ & $50,0(136)$ & $63,7(114)$ & ๔,0(२०८) & $72,8(220)$ & $68,6(142)$ & $64,2(97)$ \\
\hline ALGODÃO & $7,7(17)$ & $0,6(2)$ & $0,4(1)$ & $0,6(1)$ & - & - & - & - \\
\hline MபHOA田ÃOAALGODÃO & $10,9(24)$ & $8,6(30)$ & $9,9(27)$ & - & $4,2(14)$ & $1,3(4)$ & $4,8(10)$ & $6,6(10)$ \\
\hline MLHO+田Ũ̃O+ALGODÃO+AMENDOM & - & $0,3(1)$ & $1,5(4)$ & - & $1,8(6)$ & $1,0(3)$ & - & $0,7(1)$ \\
\hline MLH+田ÃO+AMEDDOM & - & $0,6(2)$ & $1,5(4)$ & $1,1(2)$ & $2,1(7)$ & $0,7(2)$ & $1,4(3)$ & - \\
\hline MU-D田JÃO+AMENDOM & - & $0,3(1)$ & - & $0,6(1)$ & $0,9(3)$ & - & $0,5(1)$ & - \\
\hline 円UÃO+ALGODÃO & $0,9(2)$ & $0,9(3)$ & $0,7(2)$ & - & $0,3(1)$ & - & - & - \\
\hline 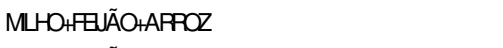 & $1,8(4)$ & $0,3(1)$ & $3,7(10)$ & $1,7(3)$ & $0,6(2)$ & $2,3(7)$ & $6,3(13)$ & $5,3(8)$ \\
\hline MU-D田UÃO+AMENDOMM+UMD & - & - & - & - & $0,3(1)$ & - & - & - \\
\hline 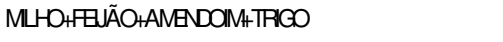 & - & $0,3(1)$ & - & $0,6(1)$ & $0,3(1)$ & - & - & - \\
\hline MLHO+⿴囗ÃO+TRGOAAMENDOMMAPFOZ & - & - & - & $1,1(2)$ & $0,6(2)$ & - & - & - \\
\hline MLHO+⿴囗ÃOAALGODÃOAARROZ & $4,5(10)$ & $0,9(3)$ & $1,5(4)$ & $0,6(1)$ & $0,3(1)$ & $0,7(2)$ & $1,9(4)$ & $3,3(5)$ \\
\hline 円UÃOAAMENDOM & $0,5(1)$ & - & - & - & $0,3(1)$ & - & - & $0,7(1)$ \\
\hline MLHOCANA & $0,9(2)$ & - & $0,4(1)$ & - & $0,3(1)$ & - & - & - \\
\hline 凡JÃO+TRGO & $0,5(1)$ & - & - & - & - & - & - & - \\
\hline ALGODÃO+CANA & $0,5(1)$ & - & - & - & - & - & - & - \\
\hline CANA & $1,8(4)$ & - & $0,4(1)$ & - & - & - & - & $0,7(1)$ \\
\hline MU-D田JÃO+CANA & $0,9(2)$ & $0,3(1)$ & - & - & - & $0,3(1)$ & - & - \\
\hline TRGO & $0,9(2)$ & - & - & - & - & - & - & - \\
\hline MUHOAALGODÃO & $4,5(10)$ & $1,4(5)$ & $3,3(9)$ & $0,6(1)$ & - & $0,3(1)$ & - & - \\
\hline MU-D田JÃO+ALGODÃO+CANA & $0,5(1)$ & $0,6(2)$ & - & - & - & $0,3(1)$ & - & - \\
\hline MLH+田JÃO+AFAOZ+MAMONA+ALGODÃO & - & - & - & - & - & $0,7(2)$ & $0,5(1)$ & - \\
\hline 円JÃO+MLHO+TRGO & - & - & - & $1,1(2)$ & $0,3(1)$ & - & - & - \\
\hline MU-OAAPAOZ & - & $0,3(1)$ & $0,4(1)$ & - & - & $0,3(1)$ & $0,5(1)$ & $0,7(1)$ \\
\hline ML-D+⿴囗ÃOAAMENDOMAAPROZ & - & $0,3(1)$ & $1,1(3)$ & $1,7(3)$ & - & $0,3(1)$ & - & $0,7(1)$ \\
\hline MLHO田ÃOAAMENDOMAMAMONA & - & - & - & - & - & - & - & $0,7(1)$ \\
\hline MU-D+⿴囗Ã̃O+AFAOZ+MAMONA & - & - & - & - & - & - & - & $0,7(1)$ \\
\hline MU-D田JÃO+CAґ́tALGODÃO & - & - & - & - & - & - & - & $0,7(1)$ \\
\hline MLHD+田Ũ̃O+ALGODÃO+ARROZ+AMENDOM & - & $0,3(1)$ & - & $0,6(1)$ & - & - & - & $1,3(2)$ \\
\hline 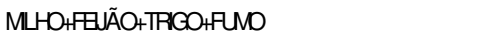 & - & $0,3(1)$ & - & - & - & - & - & - \\
\hline MபHO+⿴囗ÃO+AFAOZ+FUMD+TRGO & - & $0,3(1)$ & - & - & - & - & - & - \\
\hline Mப-O+田ÃOAMANDIOCA+ALGODÃO & - & - & $0,4(1)$ & - & - & - & - & - \\
\hline MLH+田ÃO+FUM & $0,9(2)$ & - & $0,4(1)$ & - & - & - & - & - \\
\hline MUHO+ALGOAÃO+ARPOZ & - & - & $0,4(1)$ & - & - & - & - & - \\
\hline ML-DAALGODÃOAMAMONA & - & - & $0,4(1)$ & - & - & - & - & - \\
\hline MLOHMAMONA & - & - & $0,4(1)$ & - & - & - & - & - \\
\hline MLHO田Ũ̃O+AFAOZ+CA民́ & - & - & - & - & - & - & $0,5(1)$ & - \\
\hline MLHO田Ã̃O+FUM+APROZ & - & - & - & - & - & - & $0,5(1)$ & - \\
\hline MLHO+⿴囗十ÃO+TRGO+MANDOCA+ALGODÃO+ARPOZ & - & - & - & $0,6(1)$ & - & - & - & - \\
\hline MLHO田UÃOAMANDIOCA & - & - & - & $0,6(1)$ & - & - & - & - \\
\hline MLHO+田UÃO+APAOZ+TRGO & - & - & - & $0,6(1)$ & - & - & - & - \\
\hline MU-D+田ÃO+ALGODÃO+TRGOAAMENDOM & - & - & - & $0,6(1)$ & - & - & - & - \\
\hline TOTAL & $100,0(220)$ & $100,0(348)$ & 100,0 (272) & $100,0(179)$ & 100,0 (330) & $100,0(302)$ & $100,0(207)$ & $100,0(151)$ \\
\hline
\end{tabular}

Fonte: AESP, Maços de População, Atibaia: anos selecionados 
Tabela 3.19

\section{Gêneros cultivados}

(Nazaré - 1799 a 1830)

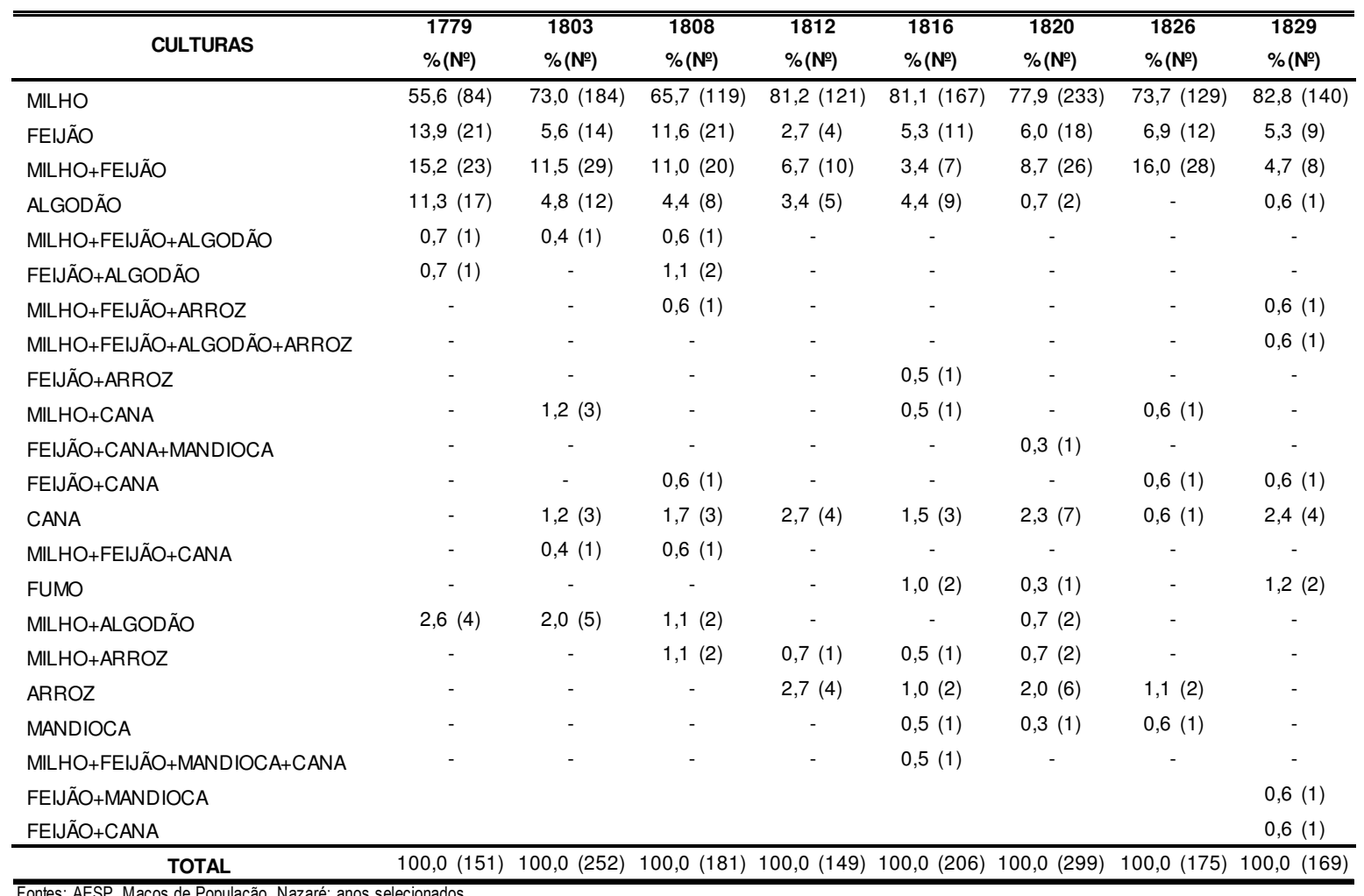


Tabela 3.20

Gêneros importados de acordo com a origem

(Atibaia - 1798 a 1825)

\begin{tabular}{|c|c|c|c|c|c|}
\hline & São Paulo & Santos & Rio de Janeiro & Curitiba & Minas Gerais \\
\hline 1798 & sal & vinho,sal & $\begin{array}{c}\text { panos (lã,linhos), } \\
\text { chapéus }\end{array}$ & - & - \\
\hline 1799 & sal, aço, ferro & sal, vinho & $\begin{array}{l}\text { panos (lã, linho, } \\
\text { algodão), sedas, } \\
\text { chapéus, meias }\end{array}$ & bestas, potros & - \\
\hline 1803 & $\begin{array}{l}\text { sal, ferro, vinho, fumo, } \\
\text { açúcar, panos (lã, linho, } \\
\text { algodão), sedas, chapéus, }\end{array}$ & sal, vinho & $\begin{array}{l}\text { panos (lã, linho, } \\
\text { algodão), sedas, } \\
\text { chapéus, meias }\end{array}$ & bestas, potros & - \\
\hline 1804 & $\begin{array}{c}\text { sal,fumo, açucar,ferro, panos } \\
\text { (lino,lã,algodão) } \\
\text { sedas, meias,chapéus, } \\
\text { açucar }\end{array}$ & vinho,sal,fumo & - & bestas, potros & - \\
\hline 1805 & $\begin{array}{c}\text { sal,fumo, açucar, ferro, panos } \\
\text { (linho,lã, algodão) } \\
\text { sedas, meias,chapéus }\end{array}$ & vinho,sal & - & bestas, potros & - \\
\hline 1806 & $\begin{array}{c}\text { sal, ferro, vinho, açúcar, } \\
\text { panos (lã, linho, algodão), } \\
\text { fumo,sedas,meias, } \\
\text { chapéus }\end{array}$ & sal, vinho, fumo & $\begin{array}{l}\text { panos (lã, linho, } \\
\text { algodão), sedas, } \\
\text { chapéus }\end{array}$ & bestas, potros & - \\
\hline 1814 & $\begin{array}{c}\text { açúcar, panos (lã, linho, } \\
\text { algodão), sedas, chapéus, } \\
\text { meias }\end{array}$ & $\begin{array}{l}\text { sal, vinho, ferro, } \\
\text { enxadas }\end{array}$ & - & bestas, potros & fumo \\
\hline 1815 & $\begin{array}{l}\text { vinho,sal,açucar,enxada, } \\
\text { panos (lã,linho,algodão) } \\
\text { chapeus,maxado,sedas }\end{array}$ & vinho,sal,ferro,enxada & - & bestas, potros & fumo \\
\hline 1816 & $\begin{array}{l}\text { sal, vinho, açúcar, } \\
\text { machados, enxadas }\end{array}$ & $\begin{array}{l}\text { sal, vinho, ferro, } \\
\text { enxadas }\end{array}$ & - & bestas, potros & fumo \\
\hline 1818 & $\begin{array}{l}\text { vinho,sal,enxada, } \\
\text { machado, foice }\end{array}$ & vinho,sal,ferro,enxada & - & bestas, potros & fumo \\
\hline 1820 & $\begin{array}{l}\text { sal, vinho, açúcar, panos } \\
\text { de algodão, chapéus } \\
\text { machados, foices }\end{array}$ & sal, vinho,, enxadas & - & bestas, potros & fumo \\
\hline 1822 & $\begin{array}{l}\text { vinho,sal, açucar,enxada, } \\
\text { panos(lã,linho,algodão) } \\
\text { chapéus,machados }\end{array}$ & $\begin{array}{c}\text { vinho,sal,ferro, } \\
\text { enxada, farinha de } \\
\text { trigo,fumo, aguardente }\end{array}$ & - & bestas, potros & fumo \\
\hline 1825 & $\begin{array}{l}\text { vinho, aguardente,sal, } \\
\text { enxada,machado,meias, } \\
\text { açúcar,farinha trigo,fumo }\end{array}$ & $\begin{array}{l}\text { vinho aguardente,sal, } \\
\text { enxada, farinha de } \\
\text { trigo,fumo }\end{array}$ & - & bestas, potros & fumo \\
\hline 1826 & $\begin{array}{c}\text { sal, vinho, açúcar, panos } \\
\text { (lã, linho, algodão), sedas, } \\
\text { chapéus, machados, } \\
\text { enxadas }\end{array}$ & $\begin{array}{c}\text { sal, vinho, machados, } \\
\text { enxadas }\end{array}$ & - & bestas, potros & fumo \\
\hline
\end{tabular}




\section{REFERÊNCIAS BIBLIOGRÁFICAS}

\section{$\underline{\text { Fontes manuscritas }}$}

\section{AESP - Arquivo Público do Estado de São Paulo}

Maços de população - completos

- Atibaia e Nazaré: 1799 (rolo 13); 1803 (rolo 13); 1808 (rolo 15); 1812 (rolo 16); 1816 (rolo 17); 1820 (rolo 17); 1826 (rolo 19); 1829 (rolo 19)

- Bragança Paulista: 1799 (rolo 21); 1803 (rolo 22); 1811 (rolo 25); 1816 (rolo 26); 1820 (rolo27); 1826 (rolo29); 1830 (rolo 30)

- Mogi da Cruzes: 1799 (rolo 126); 1803 (rolo 127); 1812 (rolo 128); 1816 (rolo 129); 1820 (rolo 130);1825 (rolo 130); 1829 (rolo131)

- Jacareí: 1798 (rolo 97); 1803 (rolo 98); 1807 (rolo 99); 1816 (rolo 100); 1822 (rolo 100); 1825 (rolo 101), 1829 (rolo 101)

- Jundiaí: 1799 (rolo 106); 1803 (rolo 107); 1808 (rolo 108); 1812 (rolo 109); 1816 (rolo109); 1822 (rolo 110); 1825 (rolo 110); 1830 (rolo 111).

Maços de população - resumos e mapas de produção e comércio

- Atibaia e Nazaré: anos diversos (rolos 13 a 20)

- Bragança Paulista: anos diversos (rolos 20 a 30)

- Mogi da Cruzes: anos diversos (rolos 126 a 132)

- Jacareí: anos diversos (rolos 97 a 101 - somente resumos)

- Jundiaí: anos diversos (rolos 105 a 111)

Tombamento de bens rústicos

- Atibaia: 1818 (C09868 - Relações dos Sítios e terras de Atibaia. 1818)

- Bragança Paulista: 1818 (C09868 - Relação dos habitantes que possuem seus terrenos na vila Nova de Bragança)

- Mogi das Cruzes: 1818 (C09868 - Mapa das terras que possuem os habitantes da Vila de Mogi das Cruzes)

- Nazaré: 1818 (C0968 - Relação da primeira companhia da Freguesia de Nazaré e dos habitantes que possuem seus terrenos no ano de 1818)

- Jacareí: (C09669 - Relação dos habitantes do termo da vila de Jacareí que possuem terras) 
- Jundiaí: 1818 (C09869 - Relação dos proprietários que possuem terrenos no distrito, e freguesia da vila de Jundiaí)

Sesmarias, patentes e provisões

- documentos e anos diversos: C00362 - livro 6; C364 - livros 12 e 13; C00365 - livro15; C00366 - livro 17; C0067 - livro 19; C00368 - livros 21 e 22; C00369; C00372 - livro 32; C00373 - livros 33 e 34; C00376 - livro 39

\section{Fontes impressas}

ALVES, Maurício Martins. Caminhos da pobreza: a manutenção da diferença em Taubaté (16801729). Dissertação de Mestrado. Rio de Janeiro: IFCS/UFRJ, 1995.

ANTONIL, André João. Cultura e opulência do Brasil. Belo Horizonte: Itatiaia/São Paulo:Edusp, 1997.

BACELLAR, C. de A. P. Viver e sobreviver em uma vila colonial: Sorocaba, séculos XVIII e XIX. São Paulo: Annablume/Fapesp, 2001.

BACELLAR, C. de A. P. Os senhores da terra - família e sistema sucessório entre os senhores de engenho do oeste paulista, 1765-1855. Campinas: CMU/Unicamp, 1997.

BACELLAR, Carlos de A. P., SCOTT, Ana Silvia V. \& BASSANEZI, Maria Silvia C. B.Quarenta anos de demografia histórica. Revista Brasileira de Estudos de População 22 (2): 339-350, jul/dez, 2005.

BACELLAR, Carlos de . A. P. . Arrolando os habitantes no passado: as listas nominativas sob um olhar crítico. Locus 14: 107-124, 2008.

BARICKMAN, B. J. Um contraponto baiano: açúcar, fumo, mandioca e escravidão no Recôncavo, 1780-1860. Rio de Janeiro: Civilização Brasileira, 2003.

BERGARD, Laird. W. Escravidão e História Econômica: demografia de Minas Gerais, 1720-1888. Bauru: EDUSC, 2004.

BERGAD, Laird W. Depois do boom: aspectos demográficos e econômicos da escravidão em Mariana, 1750-1808. Estudos Econômicos 24 (3): 495-525, set./dez. 1994.

BLAJ, Ilana. A trama das tensões. O processo de mercantilização de São Paulo colonial (16811721). Tese de doutoramento. São Paulo: FFLCH-USP, 1995.

BUESCU, Mircea. 300 anos de inflação. APEC. Rio de Janeiro: 1973

CALDEIRA, João Netto. História de Paraibuna São Paulo: Org. Cruzeiro do Sul, 1933.

CAMPANHOLE, Adriano; SANTOS, Wanderey \& GICOVATE, Moisés. Aditamento à história da fundação de Jundiaí. Jundiaí: Ed. Literarte, 1994. 
CAMPOS, Francisco. Almanack de Parahybuna. 1909

CAMPOS, Jurandir F. Santa Anna das Cruzes de Mogy: Huma vila de serra asima. São Paulo: Global editora/Univ. de Mogi das Cruzes, 1978.

CANABRAVA, Alice Piffer. Uma Economia de decadência: os níveis de riqueza na capitania de São Paulo, 1765/67. Revista Brasileira de Economia 26 (4): 95-123, out.dez., 1972a.

CANABRAVA, Alice Piffer. A Repartição da terra na capitania de São Paulo, 1818. Estudos Econômicos 6(2):77-129. 1972b.

CARMO, Oscar T. Pinheiro. Nazaré Paulista: paraíso das águas e da fé. In: SILVA, Jailson (org). I Concurso literário história do meu bairro história do meu município. São Paulo, Arte e Ciência, 2006.

CATÂO, Luis A. V. A new holesale price índex for Brazil during the period 1870-1913. Revista Brasileira de Economia 46(4):519-33, out-dez, 1992.

CHAVES, Cláudia Maria das G. Perfeitos negociantes: mercadores das minas setecentistas. São Paulo: Annablume, 1999.

CONTI, João Batista. História de Atibaia. 2 vol. Prefeitura da Estância de Atibaia. Conselho Municipal do Patrimônio Cultural de Atibaia/ Editora Grosse: 2001.

COSTA, I. del N. Minas Colonial: Características básicas de quatro estruturas demo-econômicas. In: LUNA, F. V.; COSTA, Iraci del N. da \& KLEIN, Herbert. Escravismo em São Paulo e Minas Gerais. São Paulo: Edusp/imprensa oficial do Estado de São Paulo, 2009.

COSTA, I. del N. da. Arraia-miúda: um estudo sobre os não-proprietários de escravos no Brasil. São Paulo: MGSP, 1992.

COSTA, Iraci del Nero da. Por uma definição de demografia histórica. Boletim de História Demográfica. São Paulo, FEA-USP, 1 (2), 1994.

COSTA, Iraci del Nero da. Demografia Histórica no Brasil: contribuição para o estabelecimento de um dossiê sobre avanços e desafios. Boletim de História Demográfica. São Paulo, FEA-USP, 1 (3), 1994

COSTA, Iraci del Nero da \& GUTIÉRREZ, Horacio.Nota sobre casamentos de escravos em São Paulo e no Paraná. In: LUNA, F. V.; COSTA, Iraci del N. da \& KLEIN, Herbert. Escravismo em São Paulo e Minas Gerais. São Paulo: Edusp/imprensa oficial do Estado de São Paulo, 2009.

COSTA, Iraci del N.da \& NOZOE, N. H Economia Colonial Brasileira: Classificação das ocupações segundo ramos e setores. Estudos Econômicos 17 (1):69-87, 1987.

COSTA, Iraci del Nero da \& SLENES, Robert \& SCHWARTZ, Stuart B. A Família Escrava em Lorena (1801). In: LUNA, F. V.; COSTA, Iraci del N. da \& KLEIN, Herbert. Escravismo em São Paulo e Minas Gerais. São Paulo: Edusp/imprensa oficial do Estado de São Paulo, 2009.

COSTA et alli. Brasil: breves comentários sobre algumas séries referentes à taxa de câmbio, 2004.

DIAS, Madalena M. A formação das elite numa vila colonial paulista: Mogi das Cruzes (1608-1646). Dissertação de Mestrado. São Paulo: FFLCH/USP, 2001.

DIAS, Marcelo Henrique. Estruturas fundiárias nas freguesias de Cairu e Boipeba na Comarca de Ilhéus (BA), 1786-1800. In:GUIMARÂES, Elione S. \& MOTTA, Márcia M. M.(orgs.) Campos em 
disputa: história agrária e companhia. São Paulo: Annablume; Núcleo de Referência Agrária, 2007.

D'ORBIGNY, Alcide. Viagem pitoresca através do Brasil. Belo Horizonte:Itatiaia/São Paulo: Edusp, 1976.

FARIA, Sheila de Castro. A colônia em movimento: fortuna e família no cotidiano colonial. Rio de Janeiro: Nova Fronteira, 1998

FAUSTO, Boris. História do Brasil. São Paulo: Edusp, 2009.

FERNANDEZ, Ramon V. Garcia. A consistência das listas nominativas de habitantes da capitania de São Paulo: um estudo de caso. Estudos Econômicos 19 (3): 477-496, 1989.

FRAGOSO, João Luís R. Homens de grossa aventura: acumulação e hierarquia na praça mercantil do Rio de Janeiro (1790-1830). Rio de Janeiro: Civilização Brasileira, 1990.

FRAGOSO, João Luís R. \& FLORENTINO, Manolo G. O arcaísmo como projeto: mercado atlântico, sociedade agrária e elite mercantil no Rio de Janeiro, c.1790-c.1840. Rio de Janeiro: Civilização Brasileira, 2001. 4º edição, revista e ampliada.

FURTADO, Celso. Formação econômica do Brasil. $27^{a}$ ed. São Paulo: Nacional, 1998

GODOY, Marcelo M. No País das minas de ouro a paisagem vertia engenhos de cana e casas de negócio. Tese de doutoramento. São Paulo: FFLCH/USP, 2004.

GORENDER, J. O escravismo colonial. 6.ed. São Paulo: Ática, 1992.

GRINBERG, Isaac. História de Mogi das Cruzes: do começo até 1954. São Paulo: Saraiva, 1961.

GRINBERG, Isaac. Viajantes ilustres em Mogi das Cruzes. São Paulo, 1992.

GUTIÉRREZ, Horacio. Demografia escrava numa economia não- exportadora: Paraná, 1800-1830. Estudos Econômicos 17 (2): 297-314, mai./ago. 1987.

GUTIÉRREZ, Horacio. A Estrutura fundiária no Paraná antes da imigração. Estudos de História. Franca, 8(2): 209-231, 2001.

GUTIÉRREZ, Horacio. Donos de terras e escravos no Paraná: padrões e hierarquias nas primeiras décadas do século XIX. História (UNESP) 25: 100-122, 2006.

HERMANN, Lucila. Evolução da estrutura social de Guaratinguetá num período de 300 anos. São Paulo: IPE/USP, 1986.

HOLANDA, Sérgio Buarque de. Caminhos e fronteiras. Rio de Janeiro: Livraria José Olympio Editora, 1957.

HOLANDA. Movimentos da população em São Paulo no século XVIII. Revista do IEB 1: 55-111, 1966.

IBGE. Estatísticas históricas do Brasil: séries econômicas, demográficas e sociais de 1550 a 1998.2 $2^{\text {a }}$ ed. Rio de Janeiro: IBGE, 1990.

IGC. Quadro do desmembramento territorial - administrativo dos municípios paulistas. São Paulo: IGC, 1995.

JACAREÌ (município). Nossa Senhora da Conceição de Jacarehy. Jacareí: Indústrias de papel Simão, 1990.

JUNDIAì (município). Secretaria Municipal de Planejamento e meio ambiente. Índios e africanos na Jundiaí colonial. Série memórias, vol 3. Jundiaí, 2002. 
KLEIN, Herbert S. A demografia do tráfico atlântico de escravos para o Brasil. Estudos Econômicos 17 (2): 129-149, mai./ago. 1987.

KLEIN, Herbert. Novas interpretações do tráfico de escravos do atlântico. Revista de História 120: 3-25, jan./jul. 1989.

LEME, Luiz Gonzaga da Silva. Genealogia Paulistana. Vários volumes. São Paulo: Duprat \& cia, 1903.

LIBBY, Douglas C. Notas sobre a produção têxtil brasileira no final dos século XVIII: Novas evidências de Minas Gerais. Estudos Econômicos 27 (1): 97-125, jan/abr. 1997

LIMA, Ruy Cirne. Pequena história territorial do Brasil: sesmarias e terras devolutas.

LINHARES, M. Y. L. \& SILVA, F. C. T. da. História da agricultura brasileira: combates e controvérsias. São Paulo: Brasiliense, 1981.

LOBO, Eulália Maria L. et alii. Evolução dos preços e do padrão de vida no Rio de Janeiro, 18201930. Rio de Janeiro: RBE, 1971.

LUNA, Francisco V. População e atividade econômicas em Areias (1817-1836). In: LUNA, F. V.; COSTA, Iraci del N. da \& KLEIN, Herbert. Escravismo em São Paulo e Minas Gerais. São Paulo: Edusp/imprensa oficial do Estado de São Paulo, 2009a.

LUNA, Francisco V. São Paulo: população, atividades e posse de escravos em vinte e cinco localidades (1777-1829). In: LUNA, F. V.; COSTA, Iraci del N. da \& KLEIN, Herbert. Escravismo em São Paulo e Minas Gerais. São Paulo: Edusp/imprensa oficial do Estado de São Paulo, 2009b.

LUNA, Francisco V. Características demográficas dos escravos de São Paulo (1777-1829) In: LUNA, F. V.; COSTA, Iraci del N. da \& KLEIN, Herbert. Escravismo em São Paulo e Minas Gerais. São Paulo: Edusp/imprensa oficial do Estado de São Paulo, 2009c.

LUNA, Francisco V. Estrutura de posse de escravos e atividades produtivas em Jacareí (1777 a 1829). Revista do Instituto de Estudos Brasileiros 28: 23-35, 1988.

LUNA, Francisco V, COSTA, Iraci del N. da. Profissões, atividades produtivas e posse de escravos em Vila Rica ao alvorecer do sécuo XIX In: LUNA, F. V.; COSTA, Iraci del N. da \& KLEIN, Herbert. Escravismo em São Paulo e Minas Gerais. São Paulo: Edusp/imprensa oficial do Estado de São Paulo, 2009.

LUNA, Francisco V. \& KLEIN, Herbert. Pessoas livres de core $m$ uma sociedade escravocrata. In: LUNA, F. V.; COSTA, Iraci del N. da \& KLEIN, Herbert. Escravismo em São Paulo e Minas Gerais. São Paulo: Edusp/imprensa oficial do Estado de São Paulo, 2009.

LUNA, Francisco V. \& KLEIN, Herbert. Evolução da Sociedade e Economia Escravista de São Paulo, de 1750 a 1850. São Paulo: Edusp, 2006.

MACHADO, Cacilda. A trama da vontades: negros, pardos e brancos na produção da hierarquia social do Brasil escravista. Rio de Janeiro: Apicuri, 2008.

MACHADO, J. de. A. Vida e morte do bandeirante. 2.ed. Belo Horizonte: Itatiaia; São Paulo: Edusp, 1980.

MARCÍLIO, Maria Luiza. Caiçara, terra e população: estudo de demografia histórica e da história 
social de Ubatuba. São Paulo: Edusp, 2006.

MARCÍLIO, Maria Luiza. Crescimento Demográfico e evolução agrária paulista: 1700-1836. São Paulo: Hucitec/Edusp, 2000.

MARCÍLIO, Maria Luiza. A cidade de São Paulo: povoamento e população, 1750-1850, com base nos registros paroquiais e nos recenseamentos antigos. São Paulo: Pioneira/ Edusp, 1973.

MARCONDES, Renato Leite. A arte de acumular na economia cafeeira: Vale do Paraíba, século XIX. Lorena: Editora Stiliano,1998.

MARCONDES, Renato Leite \& GARAVAZO, Juliana. A propriedade escrava e a hipótese de crescimento vegetativo em Batatais: a classificação dos escravos (1875). Anais XIII Encontro da ABEP. Disponível em: <http:www.abep.org.br>

MARQUES, Manoel E. Azevedo. Apontamentos históricos, geográficos, biográficos, estatísticos e noticiosos da província de São Paulo. 2 vol. São Paulo: Comissão do IV Centenário da Cidade de São Paulo, 1953.

MARTINS, Nelson Silveira. Atibaia: o paraíso possível na terra. São Paulo: Mario M Ponzini, 1940.

MARTINS, V. Nem senhores, nem escravos - os pequenos agricultores em Campinas (1800 1850). Campinas: Área de Publicações / Centro de Memória, 1996. (Coleção Campiniana, 10).

MATTOS, Hebe M. Ao Sul da História. São Paulo: Editora FGV, 2009.

MAZZUIA, Mario. Jundiaí através dos documentos. IHGSP, 1976.

MELO, Edilberto de Oliveira. Raízes do militarismo paulista. São Paulo: Imprensa. Oficial do Estado, 1982.

MELLO, Zélia Maria Cardoso de. Metamorfose da riqueza: São Paulo, 1845-1888. São Paulo: Hucitec/Prefeitura do Município de São Paulo/ Secretaria Municipal de Cultura,1985.

MESSIAS, Rosane C. M. O cultivo de café nas bocas de sertão paulista: mercado interno e mãode-obra no período de transição - 1830-1888. São Paulo, Editora Unesp, 2003.

METCALF, A. C. A família e a sociedade rural paulista: Santana de Parnaíba (1750-1850). Estudos Econômicos, São Paulo, 20 (2): 283-304, maio/ago. 1990.

MOTTA, José Flávio. A demografia histórica no Brasil: contribuições à historiografia. Revista Brasileira de Estudos de População. Campinas: ABEP, 12 (1-2): 133-149, jan./dez. 1995.

MOTTA, José Flávio \& COSTA, Iraci del Nero da. Demografia histórica: da semeadura à colheita. Revista Brasileira de Estudos de População. Brasília: ABEP, 14 (1-2): 151-158, jan./dez. 1997. MOTTA, José Flávio. The historical demography of Brazil at the $\mathrm{V}$ centenary of its discovery. Ciência e Cultura: Journal of the Brazilian Association for the Advancement of Science. São Paulo: SBPC, 51 (5-6): 446-456, September/December 1999.

MOTTA, José Flávio, NOZOE, Nelson \& COSTA, Iraci del N. da. Às vésperas da abolição - um estudo sobre a estrutura da posse de escravos em São Cristóvão (RJ), 1870. Estudos Econômicos 34: 157-213, jan./mar. 2004.

MOTTA, Márcia M. M. Sesmarias e o mito da primeira ocupação. Rio Grande s Sul: Justiça e história 4(7): 61-83, 2004.

MÜLLER, Daniel. P. Ensaio d'um quadro estatístico da província de São Paulo. 1923. 
NADALIN, Sérgio O. História e Demografia: elementos para um diálogo. Campinas: Abep, 2004.

NOVAIS, F. A. Portugal e Brasil na crise do antigo sistema colonial (1777-1808). São Paulo: Hucitec, 2001

NOZOE, N. A apropriação de terras rurais na Capitania de São Paulo. Livre docência. São Paulo: FEA/USP, 2008.

NOZOE, N. H. Sesmaria e apossamento de terras no Brasil colônia. Revista ANPEC, 7, 587-605, 2006

NOZOE, N. \& COSTA, Iraci del Nero da. Achegas para a qualificação das listas nominativas. Estudos Econômicos 21 (2)::271-284, maio/ago. 1991

NOZOE, N. \& MOTTA, J. F. Os produtores eventuais de café: nota sobre os primórdios da cafeicultura paulista (Bananal, 1799-1829). LOCUS: revista de história 5 (1): 51-84, 1999.

OLIVEIRA, Lelio Luiz de. Ao lado do café: produção de exportação e de abastecimento em Franca:1890-1920. Tese de doutoramento. São Paulo: FFLCH/USP, 2004.

PAIVA, Clotilde Andrade \& KLEIN, Herbert S. Escravos e livres nas Minas Gerais do século XIX: Campanha em 1831. Estudos Econômicos 22 (1): 129-151, jan./abr. 1992.

PAIVA, Clotilde Andrade \& LIBBY, Douglas Cole. Caminhos alternativos: escravidão e reprodução em Minas Gerais no século XIX. Estudos Econômicos 25 (2): 203-233, maio/ago. 1995.

PETRONE, Maria Thereza Schorer. A lavoura canavieira em São Paulo: expansão e declínio (1765-1851). São Paulo: Difusão Européia do Livro, 1968.

PRADO, Paulo. Paulística etc. 4ed. revista e ampliada por Carlos Augusto Calil. São Paulo: Cia da Letras, 2004.

PRADO Jr., Caio Prado. Formação do Brasil Contemporâneo: colônia. 24.ed. Brasiliense, 1996.

RANGEL, Armênio de Souza. Dilemas da Historiografia paulista: a repartição da riqueza no município de Taubaté no início do século XIX. Estudos Econômicos 28(2): 351-368, abr./jun, 1998.

RANGEL, Armênio de Souza. Escravismo e Riqueza: formação da economia cafeeira no município de Taubaté. Tese de doutoramento. São Paulo: FEA/USP, 1990.

ROCHA, Ilana P. A Demografia Escrava em São Paulo em 1829: análise Comparativa de estudos demográficos. Ciência et Praxis v. 2, n. 3, 2009.

RODRIGUES Jr., Mauro. A agricultura de subsistência colonial: aspectos diversos dos cultivo do milho. Relatório de iniciação científica, PIB/CNPq. São Paulo: FEA/USP, 2006.

SAINT-HILAIRE, Auguste de. Segunda viagem ao interior do Brasil. Belo Horizonte: Itatiaia/ São Paulo: Edusp, 1974

SAINT-HILAIRE, Auguste de. Viagem à província de São Paulo. Belo Horizonte: Itatiaia/ São Paulo: Edusp, 1976.

SAMARA, Eni de M. Mulheres chefes de família e domicilio no Brasil: séculos XIX e XX. In: MOURA, Esmeralda \& FERLINI, Vera L. Amaral. (orgs.) História econômica: agricultura, história e populações. São Paulo: Alameda, 2006. 
SAMARA, Eni de M. Lavoura canavieira, trabalho livre e cotidiano: Itu,1780-1830. São Paulo: Edusp, 2005.

SANTOS, Jonas R. dos. Senhores e escravos: a estrutura da posse de escravos em Mogi das Cruzes no início do Século XIX. Anais XIV Encontro da ABEP. Disponível em: <http: www.abep.org.br>

SÃO PAULO (ESTADO). Secretaria da Cultura. Departamento de Museus e Arquivos do Estado. Divisão de Arquivo do Estado. Repertório das sesmarias - concedidas pelos capitães generais da Capitania de São Paulo, no período de 1721 a 1821. São Paulo, 1994.

SARTORIS, Alexandre. Estatística e introdução à econometria. São Paulo: Saraiva, 2003.

SCHWARTZ, Stuart B. Escravos, roceiros e rebeldes. Bauru, SP: EDUSC, 2001.

SCOTT, Ana Silvia V. Dinâmica familiar da elite paulista (1765-1836): estudo diferencial de demografia histórica das famílias dos proprietários de grandes escravarias do Vale do Paraiba e região da capital de São Paulo. Dissertação de Mestrado. São Paulo: FFLCH/USP, 1987.

SILVA, Maria Beatriz Nizza da. Ser nobre na colônia. Imprenta São Paulo: UNESP, 2005

SIVEIRA, Nelson M. \& LAURITO, Domingo. Bragança, 1763-1942. São Paulo: M M Ponzini, 1943.

SILVEIRA, Waldomiro Franco da. História de Atibaia.São Paulo: [s.n.], 1950.

SIMONSEN, Roberto C. História econômica do Brasil: 1500-1820. Brasília: Senado Federal, Conselho editorial, 2005.

SPIX, Johann B. \& MARTIUS, Carl F. von. Viagem pelo Brasil: 1817-1820. Belo Horizonte: Itatiaia/São Paulo: Edusp, 1981.

SIQUEIRA, Lucília. Bens e costumes na Mantiqueira: o município de Socorro no prelúdio da cafeicultura paulista (1840-1895). São Paulo: Editora CLA, 2005.

SLENES, Robert W. Os múltiplos de porcos e diamantes: a economia escrava de Minas Gerais no século XIX. Estudos Econômicos 18 (3): 449-495, set./dez. 1988.

TAUNAY, Carlos Augusto. Manual do agricultor brasileiro. São Paulo: Cia das Letras, 2001.

TAUNAY, Afonso de E. História da cidade de São Paulo. Brasília: Edições do Senado Federal, 2004.

TEIXEIRA, Paulo Eduardo. O processo migratório na formação de Campinas: 1765-1830. Revista Brasileira de Estudos de População 19(1):75-93, jan./jun. 2002.

TEIXEIRA, Paulo Eduardo. A formação da famílias livres em Campinas, 1774-1850. In: MOURA, Esmeralda \& FERLINI, Vera L. Amaral. (orgs.) História econômica: agricultura , história e populações. São Paulo: Alameda, 2006.

VALENTIN, Agnaldo. Uma civilização do arroz: agricultura, comércio e subsistência no Vale do Ribeira (1800-1880). Tese de doutoramento. São Paulo: FFLCH/USP, 2006.

VILLANUEVA, Ana. Os marcos geográficos como referência na ocupação do território paulista: o caso do morro do Lopo e os núcleos urbanos no "caminho de Atibaia, no século XVII. Revista Eletrônica do CIEC/UNICAMP 1(1), set-dez, 2006.

ZEMELLA, Mafalda P. O abastecimento da capitania das Minas Gerais no século XVIII. 2. ed. São Paulo: Hucitec/Edusp, 1990. 